\title{
BELAJAR OLAH DATA dengan SPSS, MINITAB, R, MICROSOFT EXCEL, EVIEWS, LISREL, AMOS, dan SMARTPLS
}

(disertai beberapa contoh perhitungan manual)

Prana Ugiana Gio Elly Rosmaini 


\section{USU Press}

Art Design, Publishing \& Printing

Gedung F

Jl. Universitas No. 9, Kampus USU

Medan, Indonesia

Telp. 061-8213737; Fax 061-8213737

Kunjungi kami di:

http://usupress.usu.ac.id

(c) USU Press 2016

Hak cipta dilindungi oleh undang-undang; dilarang memperbanyak, menyalin, merekam sebagian atau seluruh bagian buku ini dalam bahasa atau bentuk apapun tanpa izin tertulis dari penerbit.

ISBN 979458

Perpustakaan Nasional: Katalog Dalam Terbitan (KDT)

BELAJAR OLAH DATA dengan SPSS, MINITAB, R, MICROSOFT EXCEL, EVIEWS, LISREL, AMOS, dan SMARTPLS / Prana Ugiana Gio dan Elly Rosmaini. - Medan: USU Press, 2016

v, 112 p.; ilus.: $24 \mathrm{~cm}$

Bibliografi

ISBN:

Dicetak di Medan, Indonesia 


\section{$\mathcal{K} \mathcal{A} \mathcal{T A}$ PENGAJNTAR}

Alhamdulillah, puji syukur atas kehadirat Allah SWT, karena atas izin-Nya, penulis dapat terus mempertahankan semangat untuk menulis, dan akhirnya dapat menyelesaikan buku ini. Hadirnya buku ini, tidak semata-mata atas usaha penulis sendiri, melainkan atas izin-Nya. Sungguh suatu kebahagiaan bagi penulis bisa berbagi sebagian kecil ilmu pengetahuan milik-Nya melalui buku yang berjudul "Belajar Olah Data dengan SPSS, MINITAB, R, MICROSOFT EXCEL, EVIEWS, LISREL, AMOS, dan SMARTPLS".

Ucapan terima kasih penulis sampaikan kepada semua pihak yang telah membantu dalam rangka penyelesaian buku ini. Penulis menyadari bahwa buku ini tentunya masih perlu perbaikan, sehingga penulis mengharapkan kritik dan saran yang membangun dari para pembaca agar buku ini dapat menjadi lebih baik. Kritik dan saran dapat ditujukan ke alamat email gioprana89@gmail.com atau website www.olahdatamedan.com.

Medan, 4 Januari 2016

Prana Ugiana Gio

Elly Rosmaini 


\section{DAFTAR ISI}

\section{BAB 1}

PERNAK-PERNIK STATISTIK

$\Rightarrow$ Contoh Sampel-Sampel Berhubungan (Dependent Samples)

$\Rightarrow$ Contoh Sampel-Sampel Independen (Independent Samples)

$\Rightarrow$ Pendekatan Nilai Probabilitas (P-Value) dan Nilai Kritis (Critical Value) dalam

Pengambilan Keputusan terhadap Hipotesis

$\Rightarrow$ Distribusi Populasi (Population Distribution)

$\Rightarrow$ Distribusi Sampling Rata-Rata Sampel $\bar{X}$ (Sampling Distribution of $\bar{X})$

$\Rightarrow$ Rata-Rata dari Distribusi Sampling $\bar{X}$

$\Rightarrow$ Standar Deviasi dari Distribusi Sampling $\bar{X}$

$\Rightarrow$ Bentuk Distribusi Sampling dari Rata-Rata $\bar{X}$.

\section{BAB 2}

MEMBANGUN DAN MEMODIFIKASI DATA DALAM SPSS
$\Rightarrow$ Data View dan Variable View
$\Rightarrow$ Value Labels
$\Rightarrow$ Menyisipkan Data (Insert Cases)
$\Rightarrow$ Menyisipkan Variabel (Insert Variable)
$\Rightarrow$ Menghapus Data dan Variabel (Clear)
$\Rightarrow$ Select Cases.
$\Rightarrow$ Compute Variable
$\Rightarrow$ Compute Variable Bersyarat
$\Rightarrow$ Menyimpan dan Membuka Data

\section{BAB 3}

MENYAJIKAN DATA MENGGUNAKAN GRAFIK DAN TABEL

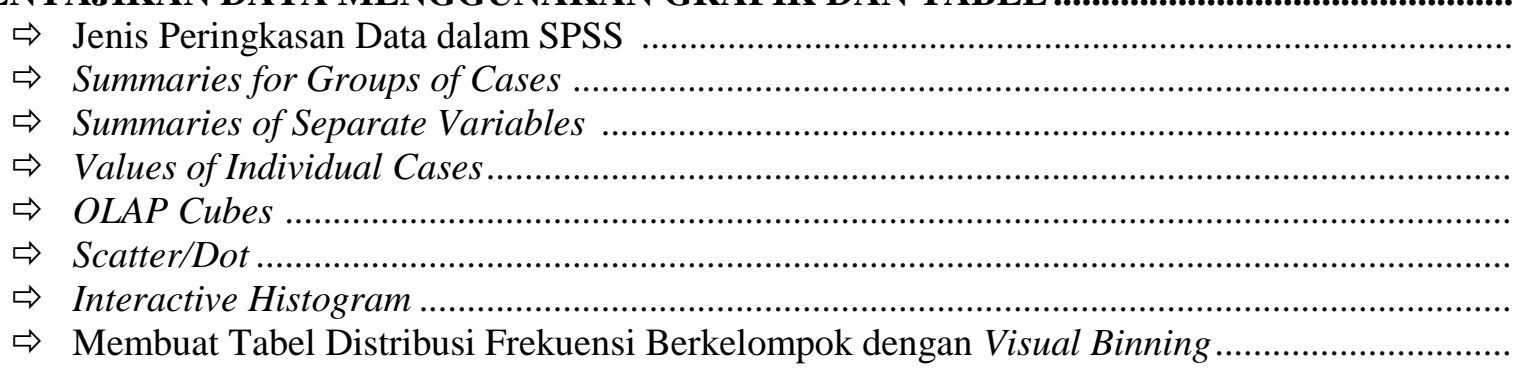

\section{BAB 4}

\section{UKURAN GEJALA PUSAT, LETAK, PENCARAN, KEMIRINGAN DAN} KERUNCINGAN

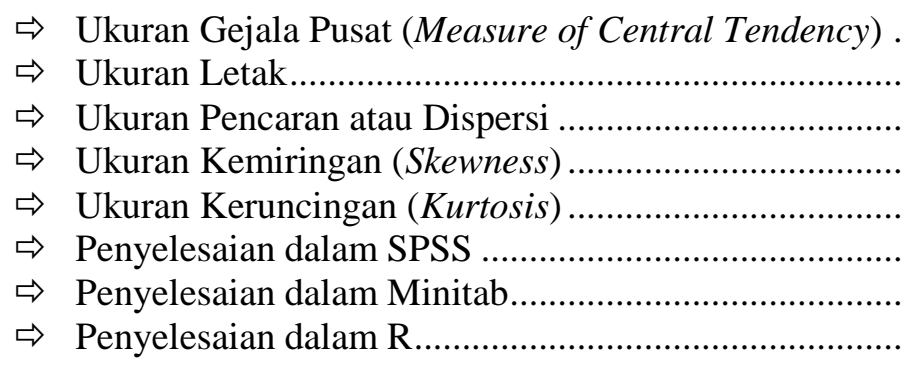

\section{BAB 5}

MEMBUAT TABEL DISTRIBUSI DALAM SPSS \& MICROSOFT EXCEL
$\Rightarrow$ Membuat Tabel Distribusi Normal Standar dalam SPSS dan Microsoft Excel
$\Rightarrow$ Membuat Tabel Distribusi $t$ Student dalam SPSS dan Microsoft Excel.
$\Rightarrow$ Membuat Tabel Distribusi F dalam SPSS dan Microsoft Excel
$\Rightarrow$ Membuat Tabel Distribusi Chi-Square dalam SPSS dan Microsoft Excel 


\section{BAB 6}

\section{UJI NORMALITAS POPULASI}

$\Rightarrow$ Uji Normalitas dengan Uji Kolmogorov-Smirnov

$\Rightarrow$ Penyelesaian dalam SPSS

$\Rightarrow$ Penyelesaian dalam Minitab.

$\Rightarrow$ Penyelesaian dalam R

$\Rightarrow$ Share.

\section{BAB 7}

\section{UJI KESAMAAN VARIANS POPULASI}

$\Rightarrow$ Sekilas Uji Kesaman Varians Populasi dengan Uji Levene

$\Rightarrow$ Contoh Kasus dalam Uji Levene.

$\Rightarrow$ Penyelesaian dalam SPPSS

$\Rightarrow$ Penyelesaian dalam Minitab.

$\Rightarrow$ Penyelesaian dalam R

$\Rightarrow$ Share.

\section{BAB 8}

UJI RATA-RATA POPULASI (UJI t).

$\Rightarrow$ Sekilas Uji Rata-Rata Populasi (Uji t)

$\Rightarrow$ Uji Asumsi Normalitas

$\Rightarrow$ Contoh Kasus dalam Uji Rata-Rata Populasi

$\Rightarrow$ Penyelesaian dalam SPSS

$\Rightarrow$ Penyelesaian dalam Minitab.

$\Rightarrow$ Penyelesaian dalam R

$\Rightarrow$ Share.

\section{BAB 9}

\section{UJI KESAMAAN RATA-RATA DARI DUA POPULASI (UJI t)}

$\Rightarrow$ Sekilas Uji Kesamaan Rata-Rata dari Dua Populasi

$\Rightarrow$ Uji Kesamaan Rata-Rata dari Dua Populasi untuk Data Berpasangan dan Saling Berhubungan dengan Uji t (Paired t Test for Dependent Populations)

$\Rightarrow$ Uji Asumsi Normalitas

$\Rightarrow$ Contoh Kasus dalam Uji Kesamaan Rata-Rata dari Dua Populasi untuk Data Berpasangan dan Saling Berhubungan dengan Uji t

$\Rightarrow$ Uji Kesamaan Rata-Rata dari Dua Populasi yang Tidak Berhubungan dengan Asumsi Varians yang Sama.

$\Rightarrow$ Uji Asumsi Normalitas

$\Rightarrow$ Uji Asumsi Kesamaan Varians

$\Rightarrow$ Uji Kesamaan Rata-Rata dari Dua Populasi yang Tidak Berhubungan dengan Asumsi Varians yang Tidak Sama

$\Rightarrow$ Uji Asumsi Normalitas.

$\Rightarrow$ Uji Asumsi Ketidaksamaan Varians

$\Rightarrow$ Contoh Kasus dalam Uji Kesamaan Rata-Rata dari Dua Populasi Tidak Berhubungan dengan Uji t

$\Rightarrow$ Penyelesaian dalam SPSS

$\Rightarrow$ Penyelesaian dalam Minitab.

$\Rightarrow$ Penyelesaian dalam R

$\Rightarrow$ Share.

\section{BAB 10}

\section{REGRESI LINEAR BERGANDA}

$\Rightarrow$ Sekilas Regresi Linear Berganda

$\Rightarrow$ Mengukur Kecocokkan Model Regresi Linear Berganda terhadap Data dengan Koefisien Determinasi $\left(\mathrm{r}^{2}\right)$ 
$\Rightarrow$ Menguji Kecocokkan Model Regresi Linear Berganda terhadap Data dengan Uji F ...

$\Rightarrow$ Korelasi Parsial (Partial Correlation).

$\Rightarrow$ Uji Signifikansi Koefisien Regresi Secara Individu dengan Uji t

$\Rightarrow$ Contoh Kasus dalam Regresi Linear Berganda.

$\Rightarrow$ Asumsi-Asumsi dalam Regresi Linear Berganda.

$\Rightarrow$ Asumsi Normalitas

$\Rightarrow$ Asumsi Tidak Terjadi Multikolinearitas

$\Rightarrow$ Asumsi Non-Autokorelasi.

$\Rightarrow$ Asumsi Homoskedastisitas

$\Rightarrow$ Penyelesaian dalam SPSS

$\Rightarrow$ Penyelesaian dalam EViews

$\Rightarrow$ Share

\section{BAB 11}

REGRESI LOGISTIK

$\Rightarrow$ Sekilas Regresi Logistik.

$\Rightarrow$ Mengukur Kecocokkan Model Regresi Logistik terhadap Data dengan Nagelkerke's $R_{N}^{2}$

$\Rightarrow$ Menguji Kecocokkan Model Regresi Logistik terhadap Data dengan -2log-likelihood,

Hosmer-Lemeshow, dan Pearson Chi-Square

$\Rightarrow$ Uji Signifikansi Koefisien Regresi Logistik Secara Individu (Uji Wald)

$\Rightarrow$ Contoh Kasus dalam Regresi Logistik

$\Rightarrow$ Penyelesaian dalam SPSS

$\Rightarrow$ Share

\section{BAB 12}

ANALISIS DISKRIMINAN

$\Rightarrow$ Sekilas Analisis Diskriminan

$\Rightarrow$ Uji Beda Rata-Rata berdasarkan Kategori-Kategori pada Variabel Tak Bebas dari Masing-Masing Variabel Bebas

$\Rightarrow$ Mengukur Kemampuan Variabel-Variabel Bebas yang Digunakan pada Persamaan Diskriminan dalam Menjelaskan Varians (Variance) dari Variabel Tak Bebas

$\Rightarrow$ Mengukur Kemampuan dan Menguji Signifikansi Persamaan Diskriminan dalam

Pengelompokkan

$\Rightarrow$ Contoh Kasus dalam Analisis Diskriminan.

$\Rightarrow$ Asumsi-Asumsi dalam Analisis Diskriminan

$\Rightarrow$ Asumsi Normalitas Multivariat (Multivariate Normality Assumption).....

$\Rightarrow$ Asumsi Kesamaan Matriks-Matriks Kovarian (Assumption of Equal Covariance Matrices)

$\Rightarrow$ Penyelesaian dalam SPSS

$\Rightarrow$ Share......

\section{BAB 13}

ANALISIS VARIANS SATU ARAH

$\Rightarrow$ Sekilas Analisis Varians Satu Arah.

$\Rightarrow$ Contoh Kasus dalam Analisis Varians Satu Arah

$\Rightarrow$ Asumsi-Asumsi dalam Analisis Varians Satu Arah

$\Rightarrow$ Asumsi Normalitas

$\Rightarrow$ Asumsi Kesamaan Varians

$\Rightarrow$ Asumsi Sampel-Sampel Acak Independen (Independent Random Samples)

$\Rightarrow$ Penyelesaian dalam SPSS

\section{BAB 14}

ANALISIS VARIANS DUA ARAH

$\Rightarrow$ Sekilas Analisis Varians Dua Arah

$\Rightarrow$ Contoh Kasus dalam Analisis Varians Dua Arah.

$\Rightarrow$ Asumsi-Asumsi dalam Analisis Varians Dua Arah 
$\Rightarrow$ Asumsi Normalitas

$\Rightarrow$ Asumsi Kesamaan Varians

$\Rightarrow$ Asumsi Sampel-Sampel Acak Independen (Independent Random Samples)

$\Rightarrow$ Penyelesaian dalam SPSS

\section{BAB 15}

ANALISIS KOVARIAN

$\Rightarrow$ Sekilas Analisis Kovarian

$\Rightarrow$ Contoh Kasus dalam Analisis Kovarian

$\Rightarrow$ Asumsi-Asumsi dalam Analisis Kovarian

$\Rightarrow$ Asumsi Linearitas dari Regresi (Linearity of Regression)

$\Rightarrow$ Asumsi Homogenitas dari Regresi (Homogeneity of Regression)

$\Rightarrow$ Penyelesaian dalam SPSS

$\Rightarrow$ Share.

\section{BAB 16}

\section{UJI INDEPENDENSI UNTUK VARIABEL-VARIABEL KATEGORI}

$\Rightarrow$ Sekilas Uji Independensi untuk Variabel-Variabel Kategori

$\Rightarrow$ Tabel Kontingensi (Contingency Table)

$\Rightarrow$ Uji Chi Kuadrat Pearson (Pearson's Chi-Square Test) dan Contoh Perhitungan

$\Rightarrow$ Uji Eksak Fisher (Fisher's Exact Test)

$\Rightarrow$ Uji Likelihood Ratio dan Contoh Perhitungan

$\Rightarrow$ Penyelesaian dalam SPSS

\section{BAB 17}

ANALISIS VARIANS MULTIVARIAT (MANOVA)

$\Rightarrow$ Sekilas MANOVA

$\Rightarrow$ Contoh Kasus dalam MANOVA.

$\Rightarrow$ Asumsi-Asumsi dalam Analisis MANOVA

$\Rightarrow$ Asumsi Normalitas Multivariat (Multivariate Normality Assumption)

$\Rightarrow$ Asumsi Kesamaan Matriks-Matriks Kovarian (Assumption of Equal Covariance Matrices)

$\Rightarrow$ Penyelesaian dalam SPSS

\section{BAB 18}

\section{DISTRIBUSI PROBABILITAS}

$\Rightarrow$ Distribusi Binomial, Contoh Perhitungan, dan Penyelesaian dalam Microsoft Excel dan R

$\Rightarrow$ Distribusi Poisson, Contoh Perhitungan, dan Penyelesaian dalam Microsoft Excel dan $\mathrm{R}$

$\Rightarrow$ Distribusi Normal, Contoh Perhitungan, dan Penyelesaian dalam Microsoft Excel dan $\mathrm{R}$

$\Rightarrow$ Distribusi Geometri, Contoh Perhitungan, dan Penyelesaian dalam R

$\Rightarrow$ Distribusi Binomial Negatif, Contoh Perhitungan, dan Penyelesaian dalam R

$\Rightarrow$ Distribusi Hipergeometri, Contoh Perhitungan, dan Penyelesaian dalam R

\section{BAB 19}

\section{REGRESI NONLINEAR SEDERHANA}

$\Rightarrow$ Sekilas Regresi Nonlinear Sederhana

$\Rightarrow$ Regresi Nonlinear Sederhana Kuadratik dan Contoh Perhitungan

$\Rightarrow$ Regresi Nonlinear Sederhana Power dan Contoh Perhitungan

$\Rightarrow$ Regresi Nonlinear Sederhana Eksponensial dan Contoh Perhitungan

$\Rightarrow$ Regresi Nonlinear Sederhana Inverse dan Contoh Perhitungan

$\Rightarrow$ Regresi Nonlinear Sederhana Logaritma dan Contoh Perhitungan

$\Rightarrow$ Regresi Nonlinear Sederhana Compound dan Contoh Perhitungan

$\Rightarrow$ Regresi Nonlinear Sederhana Kubik dan Contoh Perhitungan 
$\Rightarrow$ Penyelesaian dalam SPSS

$\Rightarrow$ Regresi Nonlinear Sederhana Kuadratik dalam SPSS

$\Rightarrow$ Regresi Nonlinear Sederhana Power dalam SPSS

$\Rightarrow$ Regresi Nonlinear Sederhana Eksponensial dalam SPSS

$\Rightarrow$ Regresi Nonlinear Sederhana Inverse dalam SPSS.

$\Rightarrow$ Regresi Nonlinear Sederhana Logaritma dalam SPSS

BAB 20

STATISTIKA NONPARAMETRIK

$\Rightarrow$ Uji Tanda dan Contoh Perhitungan

$\Rightarrow$ Uji Wilcoxon dan Contoh Perhitungan

$\Rightarrow$ Uji Mann-Whitney dan Contoh Perhitungan

$\Rightarrow$ Uji McNemar dan Contoh Perhitungan

$\Rightarrow$ Korelasi Berperingkat Spearman dan Contoh Perhitungan

$\Rightarrow$ Uji Kruskal-Wallis dan Contoh Perhitungan.

$\Rightarrow$ Uji Cochran dan Contoh Perhitungan

$\Rightarrow$ Uji Friedman dan Contoh Perhitungan....

$\Rightarrow$ Uji Chi-Kuadrat dan Contoh Perhitungan

$\Rightarrow$ Penyelesaian dalam SPSS (Uji Tanda).

$\Rightarrow$ Penyelesaian dalam Minitab (Uji Tanda)

$\Rightarrow$ Penyelesaian dalam R (Uji Tanda)

$\Rightarrow$ Penyelesaian dalam SPSS (Uji Wilcoxon)

$\Rightarrow$ Penyelesaian dalam Minitab (Uji Wilcoxon)

$\Rightarrow$ Penyelesaian dalam R (Uji Wilcoxon)....

$\Rightarrow$ Penyelesaian dalam SPSS (Uji Mann-Whitney)

$\Rightarrow$ Penyelesaian dalam Minitab (Uji Mann-Whitney)

$\Rightarrow$ Penyelesaian dalam R (Uji Mann-Whitney)

$\Rightarrow$ Penyelesaian dalam SPSS (Uji McNemar)

$\Rightarrow$ Penyelesaian dalam Minitab (Uji McNemar)

$\Rightarrow$ Penyelesaian dalam R (Uji McNemar)

$\Rightarrow$ Penyelesaian dalam SPSS (Korelasi Spearman)

$\Rightarrow$ Penyelesaian dalam R (Korelasi Spearman)

$\Rightarrow$ Penyelesaian dalam SPSS (Uji Kruskal-Wallis)

$\Rightarrow$ Penyelesaian dalam Minitab (Uji Kruskal-Wallis)

$\Rightarrow$ Penyelesaian dalam R (Uji Kruskal-Wallis)

$\Rightarrow$ Penyelesaian dalam SPSS (Uji Cochran)

$\Rightarrow$ Penyelesaian dalam R (Uji Cochran)

$\Rightarrow$ Penyelesaian dalam SPSS (Uji Friedman)

$\Rightarrow$ Penyelesaian dalam Minitab (Uji Friedman)

$\Rightarrow$ Penyelesaian dalam R (Uji Friedman)

$\Rightarrow$ Penyelesaian dalam SPSS (Uji Chi-Kuadrat 1)

$\Rightarrow$ Penyelesaian dalam SPSS (Uji Chi-Kuadrat 2)

$\Rightarrow$ Penyelesaian dalam Minitab (Uji Chi-Kuadrat 1)

$\Rightarrow$ Penyelesaian dalam Minitab (Uji Chi-Kuadrat 2)

$\Rightarrow$ Penyelesaian dalam R (Uji Chi-Kuadrat 1)

$\Rightarrow$ Penyelesaian dalam R (Uji Chi-Kuadrat 2)

\section{BAB 21}

ANALISIS FAKTOR

$\Rightarrow$ Sekilas Analisis Faktor

$\Rightarrow$ Ukuran Kaiser-Meyer-Olkin of Measure of Sampling Adequacy (KMO MSA)

$\Rightarrow$ Bartlett's Test of Sphericity.

$\Rightarrow$ Ukuran Kaiser-Meyer-Olkin of Measure of Sampling Adequacy (KMO MSA) untuk

Tiap-Tiap Variabel (KMO Values for Individual Variables)

$\Rightarrow$ Ekstraksi Faktor (Factor Extraction): Eigenvalues.

$\Rightarrow$ Communalities

$\Rightarrow$ Component Matrix (Before Rotation) 
$\Rightarrow$ Rotated Component Matrix (After Rotation)

$\Rightarrow$ Penyelesaian dalam SPSS

$\Rightarrow$ Share.

BAB 22

ANALISIS KLASTER.

$\Rightarrow$ Sekilas Analisis Klaster.

$\Rightarrow$ Ukuran Kemiripan (Measure of Similarity)

$\Rightarrow$ Mendeteksi Outlier (Multivariate Outlier)

$\Rightarrow$ Prosedur Pengklasteran

$\Rightarrow$ Contoh Perhitungan Average Linkage.

$\Rightarrow$ Contoh Perhitungan Single Linkage.

$\Rightarrow$ Contoh Perhitungan Metode Ward

$\Rightarrow$ Penyelesaian dalam SPSS

BAB 23

ANALISIS KONJOIN

$\Rightarrow$ Sekilas Analisis Konjoin

$\Rightarrow$ Contoh Jenis Data Metrik dan Nonmetrik

$\Rightarrow$ Pairwise Approach dan Full-Profile Approach

$\Rightarrow$ Penyelesaian dalam SPSS

$\Rightarrow$ Share.

\section{BAB 24}

MULTIDIMENSIONAL SCALING (MDS)

$\Rightarrow$ Sekilas Multidimensional Scaling (MDS)

$\Rightarrow$ Pengumpulan Data Langsung (Direct Data Collection)

$\Rightarrow$ Pengumpulan Data Tak Langsung (Indirect Data Collection)

$\Rightarrow$ Penyelesaian dalam SPSS

\section{BAB 25}

ANALISIS JALUR (PATH ANALYSIS)

$\Rightarrow$ Sekilas Analisis Jalur

$\Rightarrow$ Model Mediasi dengan Satu Variabel Mediator

$\Rightarrow$ Uji Signifikansi Pengaruh Mediasi untuk Model Mediasi dengan Satu Variabel Mediator (Significance Tests of Indirect Effect) dengan Pendekatan Baron dan Kenny.....

$\Rightarrow$ Uji Signifikansi Pengaruh Mediasi untuk Model Mediasi dengan Satu Variabel Mediator (Significance Tests of Indirect Effect) dengan Pendekatan Uji Sobel dan Bootstrapping

$\Rightarrow$ Analisis Jalur: Dalam Mengestimasi Koefisien Jalur (Path Coefficient), Dapat Menggunakan Software (AMOS, LISREL) atau software (SPSS, SAS, EViews, Minitab). Di mana Letak Perbedaannya?

$\Rightarrow$ Penyelesaian dalam SPSS, Minitab, R, LISREL, Amos, dan SmartPLS

$\Rightarrow$ Uji Signifikansi Pengaruh Mediasi untuk Model Mediasi dengan Satu Variabel Mediator (Significance Tests of Indirect Effect) dengan Pendekatan Baron dan Kenny (Output: SPSS, Minitab, R, LISREL, Amos, dan SmartPLS)....

$\Rightarrow$ Uji Signifikansi Pengaruh Mediasi untuk Model Mediasi dengan Satu Variabel Mediator (Significance Tests of Indirect Effect) dengan Pendekatan Uji Sobel dan Bootstrapping dengan Macro PROCESS oleh Andrew F. Hayes (dengan SPSS) 



\section{BAB 1}

\section{PERNAK-PERNIK STATISTIK}

\section{Contoh Sampel-Sampel Berhubungan (Dependent Samples)}

Misalkan diberikan data mengenai berat badan sebelum dan sesudah mengkonsumsi obat penambah berat badan merek X selama satu minggu.

Tabel 1.1 (Data Fiktif)

\begin{tabular}{|c|c|c|c|c|c|c|c|c|c|}
\hline Nama & A & B & C & D & E & F & G & H & I \\
\hline $\mathrm{P}$ & $45 \mathrm{~kg}$ & $50 \mathrm{~kg}$ & $35 \mathrm{~kg}$ & $45 \mathrm{~kg}$ & $54 \mathrm{~kg}$ & $44 \mathrm{~kg}$ & $41 \mathrm{~kg}$ & $44 \mathrm{~kg}$ & $35 \mathrm{~kg}$ \\
\hline $\mathrm{Q}$ & $44 \mathrm{~kg}$ & $50 \mathrm{~kg}$ & $37 \mathrm{gk}$ & $50 \mathrm{~kg}$ & $57 \mathrm{~kg}$ & $48 \mathrm{~kg}$ & $45 \mathrm{~kg}$ & $44 \mathrm{~kg}$ & $35 \mathrm{~kg}$ \\
\hline
\end{tabular}

Berdasarkan data pada Tabel 1.1, perhatikan bahwa terdapat dua sampel, yakni sampel $P$ dan sampel $Q$. Sampel $P$ merupakan sampel mengenai data berat badan sebelum mengkonsumsi obat penambah berat badan merek X, sedangkan sampel Q menyatakan sampel mengenai data berat badan setelah mengkonsumsi obat penambah berat badan merek X selama satu minggu.

Perhatikan bahwa data dari kedua sampel tersebut berasal dari subjek yang sama. Data dari sampel $P$ berasal dari subjek A, B, C, . . . I. Begitu juga data dari sampel $Q$ berasal dari subjek A, B, C, ...,I. Subjek tersebut mendapat dua perlakuan, yakni perlakuan sebelum mengkonsumsi obat penambah berat badan merek $X$, dan perlakuan setelah mengkonsumsi obat penambah berat badan merek $X$ selama satu minggu. Dua sampel tersebut, yakni sampel $\boldsymbol{P}$ dan $\boldsymbol{Q}$ disebut sampel-sampel berhubungan (dependent samples). Atau istilah lainnya adalah sampel-sampel berpasangan (paired samples).

Contoh lain, andaikan seorang produsen kerupuk ingin memasarkan kerupuk dengan empat rasa, yakni rasa ayam, daging, ikan, dan udang ke Kota $B$. Sebelum memasarkan kerupukkerupuk tersebut ke Kota $B$, produsen tersebut ingin mengetahui respon atau penilaian dari masyarakat yang tinggal di sekitar rumahnya terhadap keempat rasa kerupuk tersebut. Misalkan respon yang digunakan berupa "suka" atau "tidak suka". Untuk keperluan penelitian, produsen tersebut mempersilahkan 11 orang untuk mencicipi keempat rasa kerupuk tersebut dan memberikan penilaian atau respon terhadap keempat rasa kerupuk tersebut. Data yang telah dikumpulkan oleh produsen kerupuk tersebut disajikan pada Tabel 1.2 .

Berdasarkan data pada Tabel 1.2, respon 0 menyatakan tidak suka, sedangkan respon 1 menyatakan suka. Diketahui seorang subjek yang bernama A hanya menyukai kerupuk rasa ayam. Subjek yang bernama B menyukai keempat rasa kerupuk. Subjek yang bernama F hanya menyukai kerupuk rasa ayam dan udang. Perhatikan bahwa terdapat empat sampel, yakni:

$\Rightarrow$ Sampel data penilaian mengenai kerupupuk rasa ayam (sampel pertama).

$\Rightarrow$ Sampel data penilaian mengenai kerupuk rasa daging (sampel kedua).

$\Rightarrow$ Sampel data penilaian mengenai kerupuk rasa ikan (sampel ketiga).

$\Rightarrow$ Sampel data penilaian mengenai kerupuk rasa udang (sampel keempat). 
Perhatikan bahwa keempat sampel tersebut berasal dari subjek yang sama, yakni A, B, C, dan seterusnya. Keempat sampel tersebut merupakan sampel-sampel berhubungan (dependent samples) atau several related samples.

Tabel 1.2 (Data Fiktif)

\begin{tabular}{|c|c|c|c|c|c|}
\hline \multirow{2}{*}{ No } & \multirow{2}{*}{ Nama } & \multicolumn{5}{|c|}{ Rasa Kerupuk } \\
\cline { 3 - 6 } & & Ayam & Daging & Ikan & Udang \\
\hline 1 & A & 1 & 0 & 0 & 0 \\
\hline 2 & B & 1 & 1 & 1 & 1 \\
\hline 3 & C & 0 & 0 & 0 & 0 \\
\hline 4 & D & 0 & 1 & 1 & 1 \\
\hline 5 & E & 1 & 1 & 1 & 1 \\
\hline 6 & F & 1 & 0 & 0 & 1 \\
\hline 7 & G & 1 & 0 & 1 & 1 \\
\hline 8 & H & 1 & 0 & 0 & 1 \\
\hline 9 & I & 1 & 0 & 0 & 0 \\
\hline 10 & J & 1 & 0 & 0 & 0 \\
\hline 11 & K & 1 & 1 & 1 & 1 \\
\hline
\end{tabular}

\section{Contoh Sampel-Sampel Tídak Berhubungan (Independent Samples)}

Andaikan seorang dosen ingin meneliti mengenai ada tidaknya perbedaan yang signifikan secara statistika (statistically significant) pada nilai ujian matakuliah kalkulus antara mahasiswa jurusan matematika dan mahasiswa jurusan statistika. Untuk keperluan penelitian, dosen tersebut meneliti 20 nilai ujian matakuliah kalkulus yang terdiri dari 10 nilai ujian matakuliah kalkulus mahasiswa jurusan matematika dan 10 nilai ujian matakuliah kalkulus mahasiswa jurusan statistika. Berikut data yang telah diperoleh.

Tabel 1.3 (Data Fiktif)

\begin{tabular}{|c|c|c|c|}
\hline Nama Mahasiswa Jurusan Matemaika & X & Nama Mahasiswa Jurusan Statistika & Y \\
\hline A & 65 & K & 85 \\
\hline B & 68 & L & 75 \\
\hline C & 70 & M & 75 \\
\hline D & 80 & N & 80 \\
\hline E & 75 & O & 75 \\
\hline F & 72 & P & 75 \\
\hline G & 65 & Q & 75 \\
\hline H & 60 & R & 80 \\
\hline I & 88 & S & 90 \\
\hline J & 70 & T & 85 \\
\hline
\end{tabular}

Berdasarkan data pada Tabel 1.3, terdapat dua sampel, yakni sampel $X$ dan $Y$. Data pada sampel $X$ dan $Y$ berasal dari orang atau subjek yang berbeda-beda. Kedua sampel tersebut disebut juga dengan sampel-sampel tidak berhubungan (independent samples). 


\section{Pendekatan Nilai Probabilitas (P-Value) dan Nilai Kritís (Critícal Value) dalam Pengambilan Keputusan terhadap Hipotesís}

Penentuan dalam pengambilan keputusan terhadap hipotesis dapat digunakan pendekatan nilai kritis (critical value approach) atau pendekatan nilai probabilitas (probability value approach). Perlu diperhatikan bahwa pendekatan nilai kritis dan pendekatan nilai probabilitas tidak saling berbeda. Mann dan Lacke (2011:391) menyatakan sebagai berikut.

"Note that two approaches-the p-value approach and the critical-value approach-are not mutually exclusive."

Dalam pendekatan nilai probabilitas ( $p$-value), jika nilai probabilitas ( $p$-value) lebih besar atau sama dengan tingkat signifikansi $(\alpha)$, maka hipotesis nol $\left(H_{0}\right)$ diterima. Namun jika nilai probabilitas ( $p$-value) lebih kecil dibandingkan tingkat signifikansi, maka hipotesis nol ditolak. Mann dan Lacke (2011:391) menyatakan sebagai berikut.

"Using p-value approach, we reject the null hypothesis if

$$
\text { p-value }<\alpha \text { or } \alpha>p \text {-value, }
$$

and we do not reject the null hypothesis if

$$
\text { p-value } \geq \alpha \text { or } \alpha \leq p \text {-value”. }
$$

Untuk uji satu sisi (one-tailed test), nilai probabilitas ( $p$-value) dapat direpresentasikan sebagai luas pada sisi (tail) dari kurva distribusi sampling di luar (beyond) dari nilai statistik sampel (value of statistic sample). Pada Gambar 1.1, nilai probabilitas (p-value) menunjukkan luas pada sisi dari kurva distribusi sampling di sebelah kanan dari nilai rata-rata sampel teramati $(\bar{X})$.

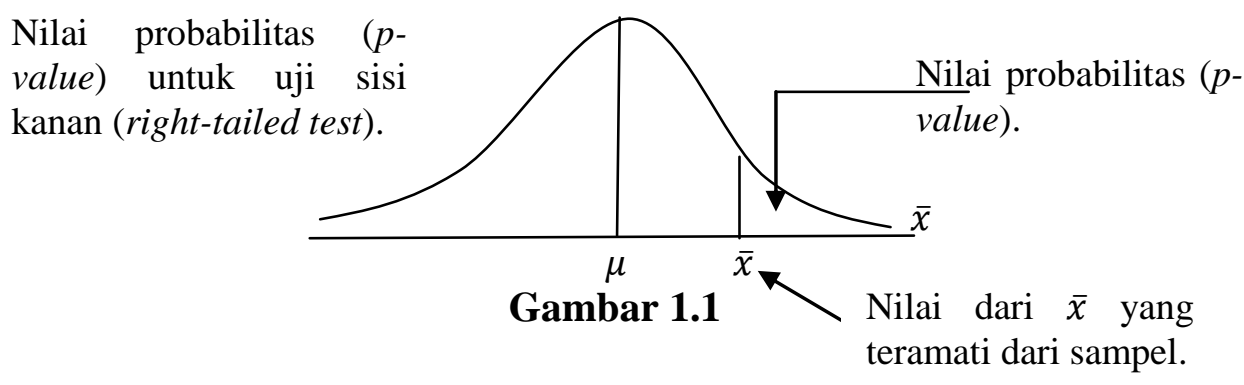

Untuk uji dua sisi (two-tailed test), nilai probabilitas ( $p$-value) dapat direpresentasikan sebagai dua kali luas pada bagian sisi (tail) dari kurva distribusi sampling di luar (beyond) dari nilai statistik sampel (value of statistic sample). Pada Gambar 1.2 menunjukkan nilai probabilitas ( $p$-value) untuk uji dua sisi (two-tailed test).

Dalam pendekatan nilai kritis (critical-value approach), nilai tingkat signifikansi $(\alpha)$ ditentukan lebih dahulu sebelum menghitung nilai kritis. Nilai dari tingkat signifikansi dapat direpresentasikan sebagai luas total daerah penolakkan hipotesis nol (Mann dan Lacke, 2011:394). Pada kasus distribusi normal standar, nilai kritis normal (standar) $\left(Z_{\text {kritis }}\right)$ dihitung berdasarkan tabel distribusi normal standar pada suatu tingkat signifikan tertentu. Selanjutnya 
menghitung nilai statistik dari uji $Z$ atau $Z_{\text {hitung }}$ berdasarkan nilai rata-rata sampel $\bar{X}$ yang diamati.

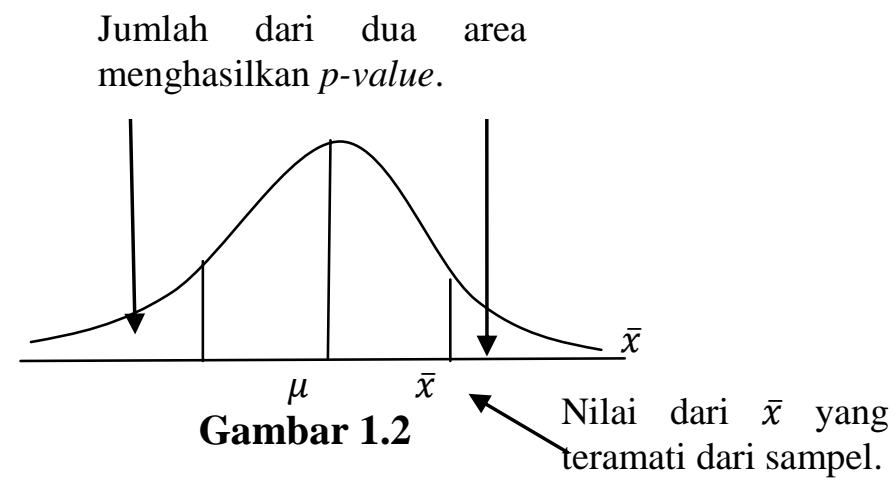

Untuk uji dua sisi (two-tailed test), daerah penerimaan dan penolakkan hipotesis nol digambarkan sebagai berikut.

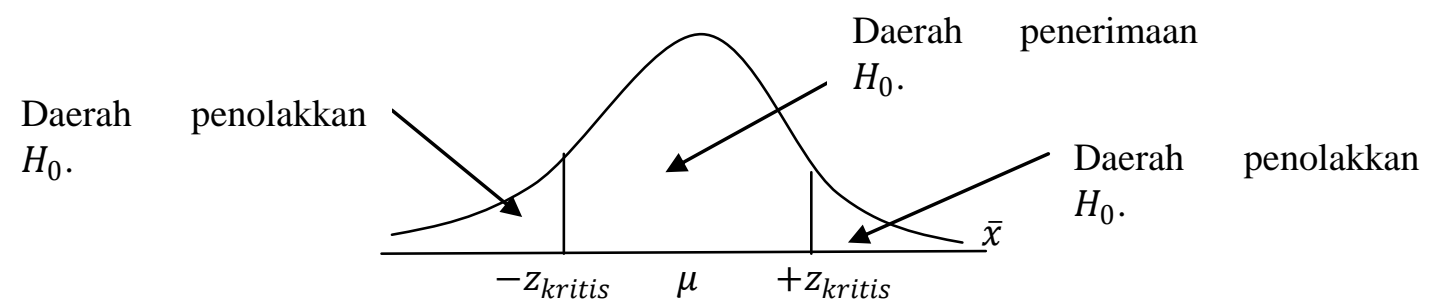

Gambar 1.3

Jika $+Z_{\text {hitung }}>+Z_{\text {kritis }}$, maka hipotesis nol ditolak dan hipotesis alternatif diterima atau jika $-Z_{\text {hitung }}<-Z_{\text {kritis }}$, maka hipotesis nol ditolak dan hipotesis alternatif diterima. Namun jika $-Z_{\text {kritis }} \leq Z_{\text {hitung }} \leq+Z_{\text {kritis }}$, maka hipotesis nol diterma dan hipotesis alternatif ditolak. Atau dapat juga dinyatakan sebagai berikut.

$$
\begin{aligned}
& \text { Jika }\left|Z_{\text {hitung }}\right| \leq\left|Z_{\text {kritis }}\right| \text {, maka } H_{0} \text { diterima, } H_{1} \text { ditolak. } . \\
& \text { Jika }\left|Z_{\text {hitung }}\right|>\left|Z_{\text {kritis }}\right| \text {, maka } H_{0} \text { ditolak, } H_{1} \text { diterima. }
\end{aligned}
$$

Berikut disajikan output SPSS yang menyajikan nilai $\boldsymbol{Z}_{\text {hitung }}$ dan nilai probabilitasnya (Tabel 1.4).

\section{Tabel 1.4}

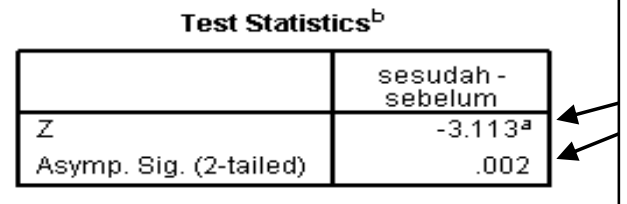

$Z=-3,113$ merupakan nilai statistik dari uji $Z$ ( $\left.Z_{\text {hitung }}\right)$, sedangkan Asymp. Sig. (2tailed $)=0,002$ merupakan nilai probabilitas ( $p$-value).

Berdasarkan Tabel 1.4 diketahui nilai probabilitas (Asymp. Sig. (2-tailed)) adalah 0,002. Perhatikan Gambar 1.4. Probabilitas untuk $Z=-3,113$ berdasarkan tabel distribusi normal kumulatif adalah 0,0009. Karena uji dua sisi maka $2 \times 0,0009=0,0018 \cong 0,002$. 


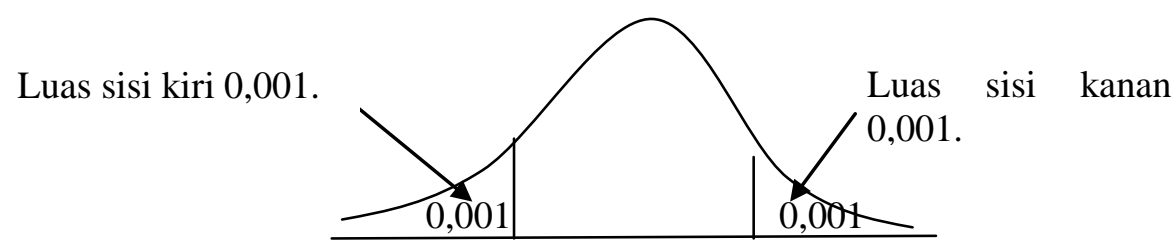

Gambar 1.4

\section{Distríbusi Populasí (Population Dístríbution)}

Distribusi populasi dapat diartikan sebagai distribusi probabilitas dari data populasi. Andaikan dalam suatu kelas hanya terdiri lima mahasiswa jurusan matematika. Berikut disajikan nilai ujian matakuliah kalkulus dari lima mahasiswa tersebut.

$$
70,75,80,80,90
$$

Andaikan $X$ menyatakan nilai ujian matakuliah kalkulus dan $P(X=x)$ atau $f(x)$ menyatakan probabilitas dari suatu nilai ujian matakuliah kalkulus. Berikut disajikan distribusi probabilitas dari data populasi nilai ujian matakuliah kalkulus (Tabel 1.5).

Tabel 1.5 Distribusi Probabilitas dari Data Populasi Nilai Ujian Kalkulus

\begin{tabular}{|c|c|}
\hline$X$ & $P(X=x)$ \\
\hline 70 & 0.2 \\
\hline 75 & 0.2 \\
\hline 80 & 0.4 \\
\hline 90 & 0.2 \\
\hline$\sum P(X=x)=\sum f(x)=1$ \\
\hline
\end{tabular}

Nilai rata-rata dan standar deviasi berdasarkan data pada Tabel 1.5 dihitung sebagai berikut.

$$
\begin{gathered}
\mu=\frac{70+75+80+80+90}{5}=79 \\
\sigma=\sqrt{\frac{(70-79)^{2}+(75-79)^{2}+\cdots+(90-79)^{2}}{5}}=6,633 .
\end{gathered}
$$

Perhatikan bahwa $\mu$ dan $\sigma$ merupakan nilai-nilai parameter populasi. Parameter dapat diartikan sebagai suatu nilai atau ukuran yang dihitung berdasarkan populasi.

\section{Distribusi Sampling Rata-Rata Sampel $\overline{\mathrm{x}}$ (Sampling Distribution of $\overline{\mathrm{x}}$ )}

Berbeda dengan statistika deskriptif yang rangkaian pengerjaannya meliputi mengorganisasi (organizing), menampilkan (displaying), dan menjelaskan data dengan menggunakan tabel, grafik, serta ukuran-ukuran seperti rata-rata, median, serta modus, pada statistika inferensi sampai pada tahap pengambilan keputusan atau prediksi mengenai populasi berdasarkan sampel yang diteliti. Konsep mengenai distribusi sampling memberikan teori yang penting 
untuk membuat prosedur-prosedur statistik inferensi. Daniel (2005:129) menyatakan sebagai berikut.

"Sampling distributions serve two purposes: (1) they allow us to answer probability questions about sample statistics, and (2) they provide the necessary theory for making statistical inference procedures valid".

Nilai dari parameter suatu populasi bersifat konstan. Dalam hal ini, untuk setiap data populasi hanya memiliki satu nilai rata-rata populasi $\mu$. Namun hal ini belum tentu berlaku untuk ratarata sampel $\bar{X}$. Sampel-sampel yang ditarik dari populasi yang sama dan dengan ukuran yang sama dapat menghasilkan nilai rata-rata sampel yang berbeda-beda. Jadi, nilai rata-rata sampel bergantung pada nilai-nilai yang berada dalam sampel tersebut. Oleh karena itu, ratarata sampel $\bar{X}$ merupakan variabel acak (random variable). Sebagaimana pada variabel acak, maka rata-rata sampel $\bar{X}$ memiliki distribusi probabilitas. Distribusi probabilitas $\bar{X}$ sering disebut dengan istilah distribusi sampling dari $\bar{X}$. Ukuran-ukuran statistik lainnya seperti median, modus, dan standar deviasi juga memiliki distribusi sampling (Mann dan Lacke, 2011:302).

Pada pembahasan sebelumnya mengenai "Distribusi Probabilitas", diketahui data populasi

$$
70,75,80,80,90 \text {. }
$$

Andaikan masing-masing nilai diberi kode huruf sebagai berikut.

$$
\mathrm{V}=70, \mathrm{~W}=75, \mathrm{X}=80, \mathrm{Y}=80 \text {, dan } \mathrm{Z}=90 \text {. }
$$

Maka, V, W, X, Y, dan Z merupakan kode-kode huruf yang menyatakan kelima nilai ujian matakuliah kalkulus. Kemudian misalkan akan diambil sampel yang terdiri tiga nilai tanpa pengembalian (without replacement). Maka banyaknya kemungkinan sampel yang terambil sebagai berikut.

$$
C_{3}^{5}=\frac{5 !}{(5-3) ! 3 !}=\frac{5.4 .3 .2 .1}{(2.1)(3.2 .1)}=10 \text { kemungkinan sampel }
$$

VWX, VWY, VWZ, VXY, VXZ, VYZ, WXY, WXZ, WYZ, XYZ

\section{Tabel 1.6 Sampel-Sampel yang Mungkin Terambil beserta Nilai Rata-Rata}

\begin{tabular}{|c|c|c|c|c|}
\hline Sampel & \multicolumn{3}{|c|}{ Nilai-Nilai dalam Sampel } & $\bar{X}$ \\
\hline VWX & 70 & 75 & 80 & 75 \\
\hline VWY & 70 & 75 & 80 & 75 \\
\hline VWZ & 70 & 75 & 90 & 78.33 \\
\hline VXY & 70 & 80 & 80 & 76.67 \\
\hline VXZ & 70 & 80 & 90 & 80 \\
\hline VYZ & 70 & 80 & 90 & 80 \\
\hline WXY & 75 & 80 & 80 & 78.33 \\
\hline WXZ & 75 & 80 & 90 & 81.67 \\
\hline WYZ & 75 & 80 & 90 & 81.67 \\
\hline XYZ & 80 & 80 & 90 & 83.33 \\
\hline
\end{tabular}


Perhatikan bahwa terdapat 10 kemungkinan sampel. Sampel VWX berarti mengandung nilai 70,75 , dan 80, sampel WYZ berarti mengandung nilai 75, 80, dan 90, dan seterusnya. Tabel 1.6 menyajikan sampel-sampel yang mungkin terambil beserta penghitungan nilai rata-rata. Berdasarkan Tabel 1.6, selanjutnya dibentuk tabel distribusi frekuensi dan frekuensi relatif berdasarkan nilai rata-rata sampel (Tabel 1.7). Tabel 1.8 menyajikan distribusi sampling dari rata-rata sampel $\bar{X}$ berdasarkan data pada Tabel 1.6.

\section{Tabel 1.7 Distribusi Frekuensi dan Frekuensi Relatif} Berdasarkan Nilai Rata-Rata Sampel

\begin{tabular}{|c|c|c|}
\hline $\bar{X}$ & Frekuensi & Frekuensi Relatif \\
\hline 75 & 2 & 0.2 \\
\hline 76.67 & 1 & 0.1 \\
\hline 78.33 & 2 & 0.2 \\
\hline 80 & 2 & 0.2 \\
\hline 81.67 & 2 & 0.2 \\
\hline 83.33 & 1 & 0.1 \\
\hline Jumlah & 10 & 1 \\
\hline
\end{tabular}

Tabel 1.8 Distribusi Sampling dari $\bar{X}$ dengan Ukuran Sampel sebanyak 3

\begin{tabular}{|c|c|}
\hline $\bar{X}$ & $P(\bar{X}=\bar{x})=f(\bar{x})$ \\
\hline 75 & 0.2 \\
\hline 76.67 & 0.1 \\
\hline 78.33 & 0.2 \\
\hline 80 & 0.2 \\
\hline 81.67 & 0.2 \\
\hline 83.33 & 0.1 \\
\hline \multicolumn{2}{|c|}{$\sum P(\bar{X}=\bar{x})=1$} \\
\hline
\end{tabular}

Tabel 1.8 menyajikan distribusi probabilitas dari rata-rata sampel $\bar{X}$. Sebagai contoh probabilitas untuk memperoleh sampel yang memiliki nilai rata-rata 76,67 sebesar 0,2. Atau dapat dinyatakan

$$
P(\bar{X}=81.67)=0.20 \text {. }
$$

\section{Rata-Rata dari Dístríbusí Sampling $\bar{X}$}

Rata-rata dari distribusi sampling $\bar{X}$ (mean of the sampling distribution of $\bar{X}$ ) atau rata-rata dari $\bar{X}$ dilambangkan dengan $\mu_{\bar{X}}$. Berdasarkan Tabel 1.6, berikut akan dihitung rata-rata dari distribusi sampling $\bar{X}$ serta rata-rata populasinya.

$$
\begin{gathered}
\mu_{\bar{X}}=\frac{75+75+78,33+\cdots+83,33}{10}=79 \\
\mu=\frac{70+75+80+80+90}{5}=79 .
\end{gathered}
$$


Perhatikan bahwa bedasarkan perhitungan diperoleh $\mu_{\bar{X}}=79$ dan $\mu=79$. Mann dan Lacke (2011:307) menyatakan sebagai berikut.

"The mean of the sampling distribution of $\bar{X}$ is always equal to the mean of the population. Thus, $\mu_{\bar{X}}=\mu$ ".

Rata-rata sampel $\bar{X}$ disebut juga sebagai estimator atau penduga terhadap rata-rata populasi $\mu$. Suatu statistik dikatakan sebagai estimator tak-bias atau unbiased estimator jika nilai rata-rata dari distribusi sampling statistik tersebut sama dengan nilai parameter tertentu. Perhatikan bahwa statistik rata-rata sampel $\bar{X}$ merupakan estimator tak-bias dari parameter rata-rata populasi $(\mu)$, karena nilai rata-rata dari distribusi sampling rata-rata $\bar{X}$ selalu sama dengan rata-rata populasi, yakni

$$
\mu_{\bar{X}}=\mu
$$

\section{Standar Devíasi dari Dístríbusi Sampling $\bar{X}$}

Diketahui pada pembahasan sebelumnya bahwa rata-rata dari distribusi sampling rata-rata $\bar{X}$ dilambangkan dengan simbol $\mu_{\bar{X}}$, sedangkan rata-rata populasi dilambangkan dengan simbol $\mu$. Standar deviasi dari distribusi sampling rata-rata $\bar{X}$ dilambangkan dengan simbol $\sigma_{\bar{X}}$, sedangkan standar deviasi populasi dilambangkan dengan simbol $\sigma$. Pada pembahasan sebelumnya diketahui bahwa rata-rata dari distribusi sampling rata-rata $\bar{X}$ sama dengan ratarata populasi $\mu$, yakni

$$
\mu_{\bar{X}}=\mu
$$

Namun pada standar deviasi dari distribusi sampling rata-rata $\bar{X}$ tidak sama dengan standar deviasi populasi (kecuali jika $n=1$ ). Sebagai contoh untuk kasus $n=1$, misalkan suatu populasi terdiri dari tiga angka, yakni 1,2, 3. Misalkan dari populasi yang terdiri dari tiga angka tersebut, akan diambil sampel yang terdiri atas satu angka. Maka sampel-sampel yang mungkin adalah

$$
123 .
$$

Diketahui rata-rata dari setiap sampel tersebut adalah

$$
123 .
$$

Maka rata-rata dari distribusi sampling rata-rata $\bar{X}$ tersebut adalah

$$
\mu_{\bar{X}}=\frac{1+2+3}{3}=2 .
$$

Sedangkan standar deviasi dari distribusi sampling rata-rata $\bar{X}$ tersebut adalah

$$
\sigma_{\bar{X}}=\sqrt{\frac{(1-2)^{2}+(2-2)^{2}+(3-2)^{2}}{3}}=0,8165 \text {, }
$$


yang mana

$$
\sigma_{\bar{X}}=\sigma \quad(\text { ketikan }=1) \text {. }
$$

Mann dan Lacke (2011:307) menyatakan rumus

$$
\sigma_{\bar{X}}=\frac{\sigma}{\sqrt{n}}
$$

berlaku ketika paling tidak memenuhi salah satu dari kriteria sebagai berikut.

$\Rightarrow$ Jumlah elemen dalam populasi berhingga (finite) dan pengambilan elemen untuk sampel dari suatu populasi dengan pengembalian (with replacement).

$\Rightarrow$ Jumlah elemen dalam populasi tak berhingga (infinite) dan pengambilan elemen untuk sampel dari suatu populasi tanpa pengembalian (without replacement).

Namun kriteria-kriteria tersebut dapat diganti ketika ukuran sampel kecil (sample size is small) dalam perbandingannya terhadap ukuran populasi (in comparison to the population size). Ukuran sampel dapat dipandang (is considered) kecil dalam perbandingannya terhadap ukuran populasi ketika ukuran sampel lebih kecil atau sama dengan 5\% dari ukuran populasi, yakni

$$
\frac{n}{N} \leq 0,05
$$

dengan $n$ merupakan ukuran sampel dan $N$ ukuran populasi. Namun ketika tidak terpenuhi, maka penghitungan $\sigma_{\bar{X}}$ dihitung dengan rumus

$$
\sigma_{\bar{X}}=\frac{\sigma}{\sqrt{n}} \sqrt{\frac{N-n}{N-1}}
$$

di mana

$$
\sqrt{\frac{N-n}{N-1}}
$$

merupakan faktor koreksi populasi berhingga (Mann dan Lacke, 2011:307).

Berikut diberikan contoh kasus untuk perhitungan standar deviasi dari distribusi sampling $\bar{X}$ dengan rumus $\sigma_{\bar{X}}=\frac{\sigma}{\sqrt{n}}$. Misalkan suatu populasi terdiri dari tiga angka, yakni 1, 2, 3 . Misalkan dari populasi yang terdiri dari tiga angka tersebut, akan diambil sampel yang terdiri atas dua angka dengan pengembalian (with replacement). Maka sampel-sampel yang mungkin adalah sebagai berikut.
$(1,1) \quad(1,2)$
$(3,1) \quad(3,2) \quad(3,3)$ 
Perhatikan bahwa karena jumlah elemen dalam populasi berhingga, yakni tiga, dan pengambilan elemen sampel dengan pengembalian, maka standar deviasi dari distribusi sampling rata-rata $\bar{X}$ dihitung dengan rumus sebagai berikut.

$$
\sigma_{\bar{X}}=\frac{\sigma}{\sqrt{n}}
$$

Hasil perhitungan rata-rata untuk setiap sampel sebagai berikut.

$\begin{array}{ccc}1 & 1,5 & 2 \\ 1,5 & 2 & 2,5 \\ 2 & 2,5 & 3\end{array}$

Maka rata-rata dari distribusi sampling rata-rata $\bar{X}$ tersebut adalah

$$
\mu_{\bar{X}}=\frac{1+1,5+2+1,5+2+2,5+2+2,5+3}{9}=\frac{18}{9}=2 .
$$

Berikut perhitungan standar deviasi dari distribusi sampling rata-rata $\bar{X}$.

$$
\begin{array}{ccc}
(1-2)^{2} & (1,5-2)^{2} & (2-2)^{2} \\
(1,5-2)^{2} & (2-2)^{2} & (2,5-2)^{2} \\
(2-2)^{2} & (2,5-2)^{2} & (3-2)^{2}
\end{array}
$$

Maka diperoleh hasil sebagai berikut.

$$
\begin{array}{ccc}
1 & 0,25 & 0 \\
0,25 & 0 & 0,25 \\
0 & 0,25 & 1
\end{array}
$$

Sehingga

$$
\begin{gathered}
\sigma_{\bar{X}}=\sqrt{\frac{(1-2)^{2}+(1,5-2)^{2}+(2-2)^{2}+\cdots+(3-2)^{2}}{9}} \\
\sigma_{\bar{X}}=\sqrt{\frac{1+0,25+0+0,25+0+0,25+0+0,25+1}{9}} \\
\sigma_{\bar{X}}=\sqrt{\frac{3}{9}}=\sqrt{0,3333333}=0,57735
\end{gathered}
$$

Perhatikan bahwa berdasarkan perhitungan sebelumnya diperoleh

$$
\begin{gathered}
\mu_{\bar{X}}=2 \\
\sigma_{\bar{X}}=0,57735 .
\end{gathered}
$$

Diketahui 


$$
\begin{gathered}
\mu=\frac{1+2+3}{3}=2 \\
\sigma=\sqrt{\frac{(1-2)^{2}+(2-2)^{2}+(3-2)^{2}}{3}}=\sqrt{0,6666666}=0,81649658 .
\end{gathered}
$$

Perhatikan bahwa

$$
\sigma_{\bar{X}} \neq \sigma
$$

namun

$$
\begin{gathered}
\sigma_{\bar{X}}=\frac{\sigma}{\sqrt{n}} \\
0,57735=\frac{0,81649658}{\sqrt{2}} \\
0,57735=0,57735 .
\end{gathered}
$$

Berikut diberikan contoh kasus untuk perhitungan standar deviasi dari distribusi sampling $\bar{X}$ dengan rumus $\sigma_{\bar{X}}=\frac{\sigma}{\sqrt{n}} \sqrt{\frac{N-n}{N-1}}$. Misalkan suatu populasi terdiri dari tiga angka, yakni 1, 2, 3 . Misalkan dari populasi yang terdiri dari tiga angka tersebut, akan diambil sampel yang terdiri atas dua angka tanpa pengembalian (without replacement). Maka sampel-sampel yang mungkin adalah

$$
(1,2) \quad(1,3) \quad(2,3)
$$

Perhatikan bahwa karena jumlah elemen dalam populasi berhingga, yakni tiga, namun pengambilan elemen sampel tanpa pengembalian, maka standar deviasi dari distribusi sampling rata-rata $\bar{X}$ dihitung dengan rumus sebagai berikut.

$$
\sigma_{\bar{X}}=\frac{\sigma}{\sqrt{n}} \sqrt{\frac{N-n}{N-1}}
$$

Diketahui rata-rata dari setiap sampel tersebut adalah

$$
1,5 \quad 2 \quad 2,5
$$

sehingga rata-rata dari distribusi sampling rata-rata $(\bar{X})$ tersebut adalah

$$
\mu_{\bar{X}}=\frac{1,5+2+2,5}{3}=\frac{6}{3}=2 \text {. }
$$

Standar deviasi dari distribusi sampling rata-rata $\bar{X}$ tersebut adalah 


$$
\begin{gathered}
\sigma_{\bar{X}}=\sqrt{\frac{(1,5-2)^{2}+(2-2)^{2}+(2,5-2)^{2}}{3}} \\
\sigma_{\bar{X}}=\sqrt{\frac{0,25+0+0,25}{3}} \\
\sigma_{\bar{X}}=\sqrt{\frac{0,5}{3}}=\sqrt{0,16666667}=0,408248 .
\end{gathered}
$$

Perhatikan bahwa berdasarkan perhitungan sebelumnya diperoleh

$$
\begin{gathered}
\mu_{\bar{X}}=2 \\
\sigma_{\bar{X}}=0,408248 .
\end{gathered}
$$

Diketahui

$$
\begin{gathered}
\mu=\frac{1+2+3}{3}=2 \\
\sigma=\sqrt{\frac{(1-2)^{2}+(2-2)^{2}+(3-2)^{2}}{3}}=\sqrt{0,6666666}=0,81649658 .
\end{gathered}
$$

Perhatikan bahwa

$$
\sigma_{\bar{X}} \neq \sigma
$$

Namun

$$
\begin{gathered}
\sigma_{\bar{X}}=\frac{\sigma}{\sqrt{n}} \sqrt{\frac{N-n}{N-1}} \\
0,408248=\frac{0,81649658}{\sqrt{2}} \sqrt{\frac{3-2}{3-1}} \\
0,408248=\frac{0,81649658}{\sqrt{2}} \sqrt{\frac{1}{2}} \\
0,408248=\frac{0,81649658}{2} \\
0,408248=0,408248
\end{gathered}
$$

Beberapa hal penting mengenai distribusi sampling rata-rata $\bar{X}$, yakni: 
$\Rightarrow$ Nilai standar deviasi dari distribusi sampling rata-rata $\bar{X}$ lebih kecil dibandingkan nilai standar deviasi populasi, yakni $\sigma_{\bar{X}}<\sigma$ ketika $n$ lebih besar dari 1 . Hal ini terlihat jelas dari rumus

$$
\sigma_{\bar{X}}=\frac{\sigma}{\sqrt{n}} .
$$

Sebagai contoh misalkan $\sigma=20$ dan $n=4$, maka

$$
\sigma_{\bar{X}}=\frac{\sigma}{\sqrt{n}}=\frac{20}{\sqrt{4}}=10 .
$$

Perhatikan bahwa

$$
\begin{gathered}
\sigma_{\bar{X}}<\sigma \\
10<20 .
\end{gathered}
$$

$\Rightarrow$ Nilai dari standar deviasi dari distribusi sampling rata-rata $\bar{X}$ akan semakin mengecil ketika ukuran sampel $n$ semakin besar.

$$
\text { ketika } n \uparrow_{\text {maka }} \sigma_{\bar{X}}=\frac{\sigma}{\sqrt{n}} \downarrow
$$

Sebagai contoh misalkan $\sigma=20$ dan $n=4$, maka

$$
\sigma_{\bar{X}}=\frac{\sigma}{\sqrt{n}}=\frac{20}{\sqrt{4}}=10 .
$$

Untuk $n=20$ maka

$$
\sigma_{\bar{X}}=\frac{\sigma}{\sqrt{n}}=\frac{20}{\sqrt{20}}=4,4721
$$

Untuk $n=50$ maka

$$
\sigma_{\bar{X}}=\frac{\sigma}{\sqrt{n}}=\frac{20}{\sqrt{50}}=2,828 .
$$

Untuk $n=100$ maka

$$
\sigma_{\bar{X}}=\frac{\sigma}{\sqrt{n}}=\frac{20}{\sqrt{100}}=2 .
$$

Perhatikan bahwa nilai $\sigma_{\bar{X}}$ semakin mengecil ketika ukuran sampel $n$ semakin besar. Suatu statistik dikatakan estimator konsisten jika nilai standar deviasi dari distribusi sampling statistik tersebut semakin mengecil ketika ukuran sampel $n$ semakin besar, sehingga statistik rata-rata $\bar{X}$ merupakan estimator konsisten dari parameter rata-rata $\mu$ (Mann dan Lacke, 2011:307) 
Standar deviasi dari distribusi sampling rata-rata $\bar{X}$ merupakan suatu nilai yang mengukur pencaran atau sebaran dari rata-rata sampel dari distribusi sampling rata-rata $\bar{X}$ terhadap ratarata populasinya $\mu$. Semakin kecil nilai standar deviasi dari distribusi sampling rata-rata $\bar{X}$, maka rata-rata sampel dari distribusi sampling rata-rata $\bar{X}$ semakin mengumpul atau lebih dekat terhadap rata-rata populasinya $\mu$. Pada pembahasan sebelumnya, diketahui untuk untuk $n=20$ diperoleh $\sigma_{\bar{X}}=4,4721$, untuk $n=50$ diperoleh $\sigma_{\bar{X}}=2,828$, dan untuk $n=100$ diperoleh $\sigma_{\bar{X}}=2$. Perhatikan ilustrasi gambar berikut ini (Gambar 1.5).

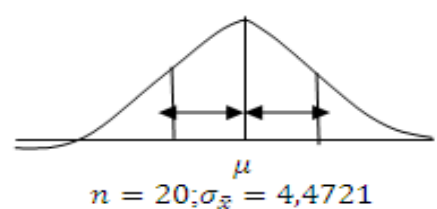

$n=20 ; \sigma_{\bar{x}}=4,4721$

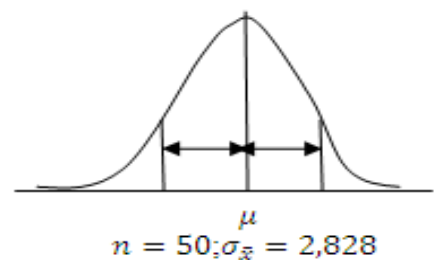

Gambar 1.5

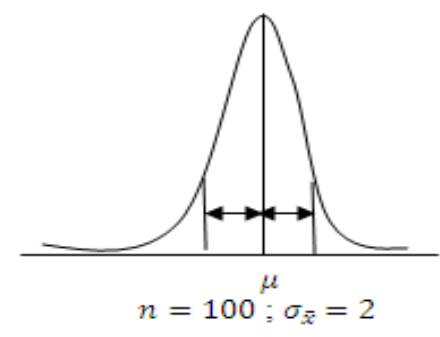

\section{Bentuk Dístríbusí Sampling darí Rata-Rata $\bar{X}$}

Mann dan Lacke (2011:310) menyatakan bentuk distribusi sampling dari rata-rata $\bar{X}$ berkenaan (relates) atas dua hal, yakni:

$\Rightarrow$ Sampel yang ditarik dari populasi yang berdistribusi normal.

$\Rightarrow$ Sampel yang ditarik dari populasi yang tidak berdistribusi normal.

Jika sampel-sampel yang ditarik berasal dari populasi yang berdistribusi normal dengan ratarata dan standar deviasi masing-masing $\mu$ dan $\sigma$, maka:

$\Rightarrow$ Rata-rata distribusi sampling rata-rata $\bar{X}$ sama dengan rata-rata populasi, yakni

$$
\mu_{\bar{X}}=\mu
$$

$\Rightarrow$ Standar deviasi distribusi sampling rata-rata $\bar{X}$ sama dengan $\frac{\sigma}{\sqrt{n}}$, dengan asumsi (assuming) $n / N \leq 0,05$.

$\Rightarrow$ Bentuk dari distribusi sampling rata-rata $\bar{X}$ berbentuk normal, untuk berapapun ukuran sampel $n$.

Jadi, jika sampel-sampel yang ditarik berasal dari populasi yang berdistribusi normal dengan rata-rata adalah $\mu$ dan standar deviasi adalah $\sigma$, maka distribusi sampling dari rata-rata $\bar{X}$ juga terdistribusi secara normal, dengan rata-rata dan standar deviasi

$$
\begin{gathered}
\mu_{\bar{X}}=\mu \\
\sigma_{\bar{X}}=\frac{\sigma}{\sqrt{n}} \quad ; \frac{n}{N} \leq 0,05 .
\end{gathered}
$$

Perhatikan Gambar 1.6 hingga Gambar 1.9. 


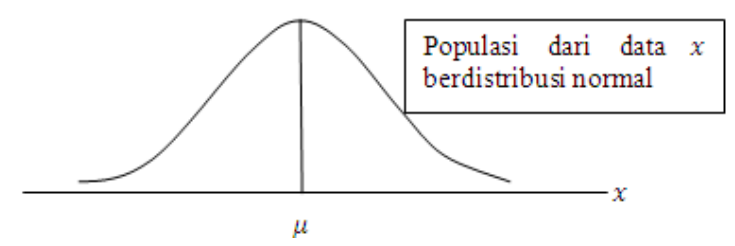

Gambar 1.6

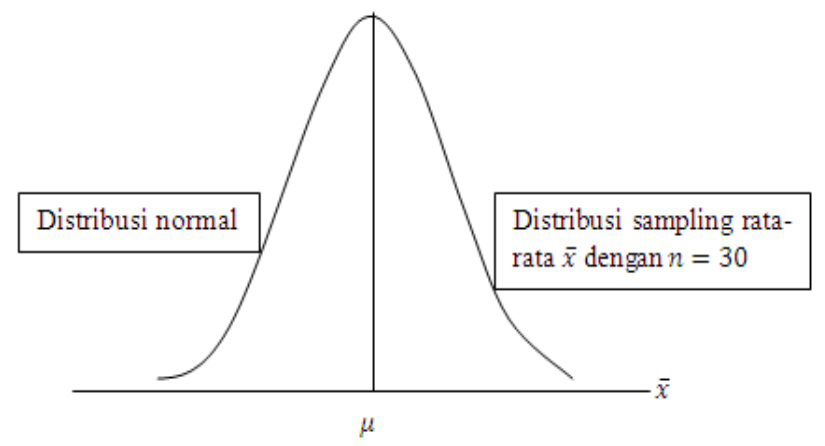

Gambar 1.8

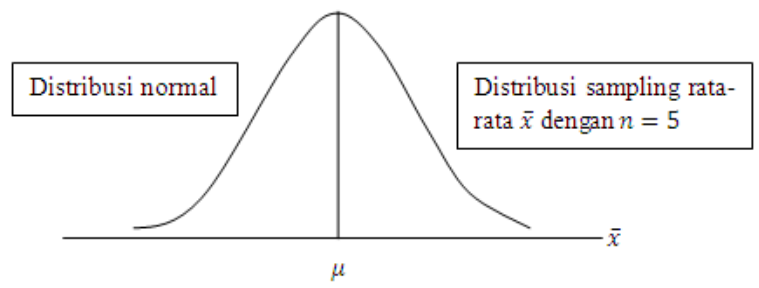

Gambar 1.7

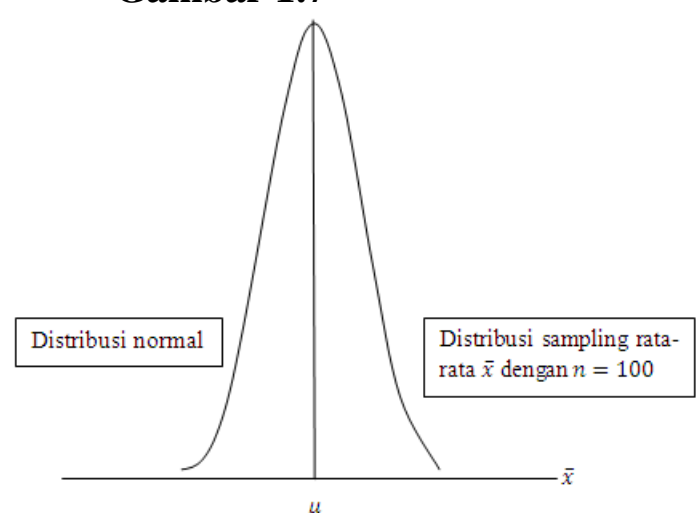

Gambar 1.9

Perhatikan bahwa pada Gambar 1.6 menjelaskan data $X$ berasal dari populasi berdistribusi normal. Pada Gambar 1.7 merupakan kurva dari distribusi sampling rata-rata $\bar{X}$ dengan $n=5$. Pada Gambar 1.8 merupakan kurva dari distribusi sampling rata-rata $\bar{X}$ dengan $n=30$. Pada Gambar 1.9 merupakan kurva dari distribusi sampling rata-rata $\bar{X}$ dengan $n=100$. Perhatikan bahwa karena sampel-sampel ditarik dari populasi yang berdistribusi normal, maka kurva dari distribusi sampling rata-rata $\bar{X}$ membentuk kurva normal (Gambar 1.7 sampai Gambar 1.9). Perhatikan bahwa standar deviasi dari distribusi sampling rata-rata $\bar{X}$ pada Gambar 1.8 lebih kecil daripada Gambar 1.7, standar deviasi dari distribusi sampling rata-rata $\bar{X}$ pada Gambar 1.9 lebih kecil daripada Gambar 1.8. Perhatikan bahwa semakin besar ukuran sampel, maka akan semakin kecil nilai standar deviasi dari distribusi sampling rata-rata $\bar{X}$. Dalam prakteknya, seringkali populasi yang diteliti tidak berdistribusi normal. Teorema yang sangat penting untuk menyimpulkan bentuk dari distribusi sampling rata-rata $\bar{X}$ adalah Teorema Limit Sentral (Central Limit Theorem).

Teorema limit sentral menyatakan bahwa untuk sampel berukuran besar, distribusi sampling rata-rata $\bar{X}$ akan mendekati normal, tidak peduli apakah sampel-sampel tersebut ditarik dari populasi yang berdistribusi normal atau tidak, dengan rata-rata dan standar deviasi dari distribusi sampling rata-rata $\bar{X}$ sebagai berikut.

$$
\mu_{\bar{X}}=\mu \quad \text { dan } \quad \sigma_{\bar{X}}=\frac{\sigma}{\sqrt{n}}
$$

Ukuran sampel $n$ dipertimbangkan cukup besar, yakni $n \geq 30$. Berdasarkan teorema limit sentral, perlu diperhatikan bahwa, jika populasi tidak berdistribusi normal, bentuk dari distribusi sampling rata-rata $\bar{X}$ tidak secara tepat normal, namun mendekati normal, ketika sampel berukuran besar. Semakin besar ukuran sampel, maka bentuk dari distribusi sampling rata-rata $(\bar{X})$ akan semakin mendekati normal. Berdasarkan teori limit sentral (Mann dan Lacke, 2011:313), 
$\Rightarrow$ Ketika ukuran sampel $n \geq 30$, maka bentuk dari distribusi sampling rata-rata $(\bar{X})$ mendekati normal, tidak peduli apakah sampel-sampel tersebut ditarik dari populasi berdistribusi normal atau tidak.

$\Rightarrow$ Rata-rata dari distribusi sampling rata-rata $(\bar{X})$, yakni $\mu_{\bar{X}}$ sama dengan rata-rata populasi, yakni $\mu$.

$\Rightarrow$ Standar deviasi dari distribusi sampling rata-rata $(\bar{X})$, yakni $\sigma_{\bar{X}}$ sama dengan $\sigma / \sqrt{n}$ dengan syarat $n / N \leq 0,05$.

Perhatikan ilustrasi gambar berikut.
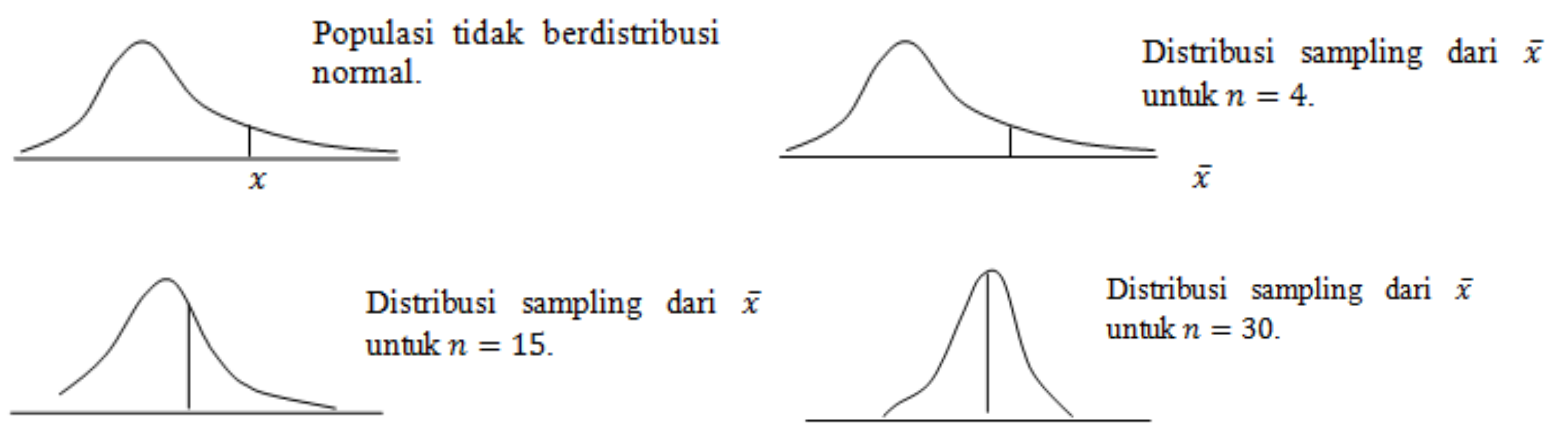

\section{Gambar 1.10}

Berdasarkan gambar tersebut, populasi tidak berdistribusi normal. Semakin meningkat ukuran sampel, maka distribusi sampling rata-rata $\bar{X}$ semakin berbentuk distribusi normal. Semakin meningkat ukuran sampel, semakin kecil nilai standar deviasi dari distribusi sampling ratarata $\bar{X}$.

\section{Referensi}

1. Agresti, A. dan B. Finlay. 2009. Statistical Methods for the Social Sciences, $4^{\text {th }}$ Edition. United States of America: Prentice Hall.

2. Field, A. 2009. Discovering Statistics Using SPSS, $3^{\text {rd }}$ Edition. London: Sage.

3. Johnson, R.A. dan G.K. Bhattacharyya. 2011. Statistics, Principles and Methods, $6^{\text {th }}$ Edition. John Wiley and Sons, Inc.

4. Mann, P. S. dan C.J. Lacke. 2011. Introductory Statistics, International Student Version, $7^{\text {th }}$ Edition. Asia: John Wiley \& Sons, Inc.

5. Montgomery, D. C. dan G. C. Runger. 2011. Applied Statistics and Probability for Engineers, $5^{\text {th }}$ Edition. United States of America: John Wiley \& Sons, Inc.

6. Ott, R.L. dan M. Longnecker. 2001. An Introduction to Statistical Methods and Data Analysis, $5^{\text {th }}$ Edition. United States of America: Duxbury.

7. Smidth, R. K. dan D. H. Sanders. 2000. Statistics a First Course, $6^{\text {th }}$ Edition. United States of America: McGraw-Hill Companies. 


\section{MEMBANGUN DAN MEMODIFIKASI DATA DALAM SPSS}

\section{Data View dan Varíable View}

Area atau wilayah kerja dalam SPSS terbagi menjadi dua, yakni Data View dan Variable View. Data View merupakan suatu area untuk mengisi atau menginput data, sedangkan Variable View merupakan suatu area untuk mendefinisikan atau membuat variabel. Perhatikan Gambar 2.1.

\begin{tabular}{|c|c|c|c|c|}
\hline & nama & pendapatan & tinggi_badan & var \\
\hline 1 & Ugi & $100,000,000$ & 170.20 & \\
\hline 2 & Egi & $250,000,000$ & 175.65 & \\
\hline 3 & Faisal & $50,000,000$ & 171.14 & \multirow{7}{*}{$\begin{array}{l}\text { Ugi, Egi, 100,000,000, } \\
250,000,000,170.20,175.65, \\
171.14, \text { dan seterusnya } \\
\text { merupakan suatu data yang } \\
\text { diisi pada area Data View. }\end{array}$} \\
\hline 4 & Alvi & $15,000,000$ & 170.00 & \\
\hline 5 & Suci & $200,000,000$ & 180.04 & \\
\hline 6 & lqbal & $90,000,000$ & 169.80 & \\
\hline 7 & Ridho & $19,000,000$ & 175.78 & \\
\hline 8 & Mifdhal & $75,000,000$ & 167.45 & \\
\hline 9 & Fitri & $25,000,000$ & T85.66 & \\
\hline 10 & Febri & 0,008000 & 185.66 & \\
\hline 11 & & & & \\
\hline Data View & Variable Viem & & & \\
\hline
\end{tabular}

\section{Gambar 2.1}

Berdasarkan Gambar 2.1, Ugi, Egi, 100,000,000, 250,000,000, 170.20, 175.65, 171.14, dan seterusnya merupakan suatu data yang diisi pada area Data View, sedangkan nama, pendapatan, dan tinggi_badan merupakan nama variabel yang dibuat atau didefinisikan pada area Variable View. Sebelum mengisi data pada area Data View, terlebih dahulu membuat atau mendefinisikan variabel di area Variable View. Pada Gambar 2.2, variabel nama, pendapatan, dan tinggi_badan dibuat pada area Variable View.

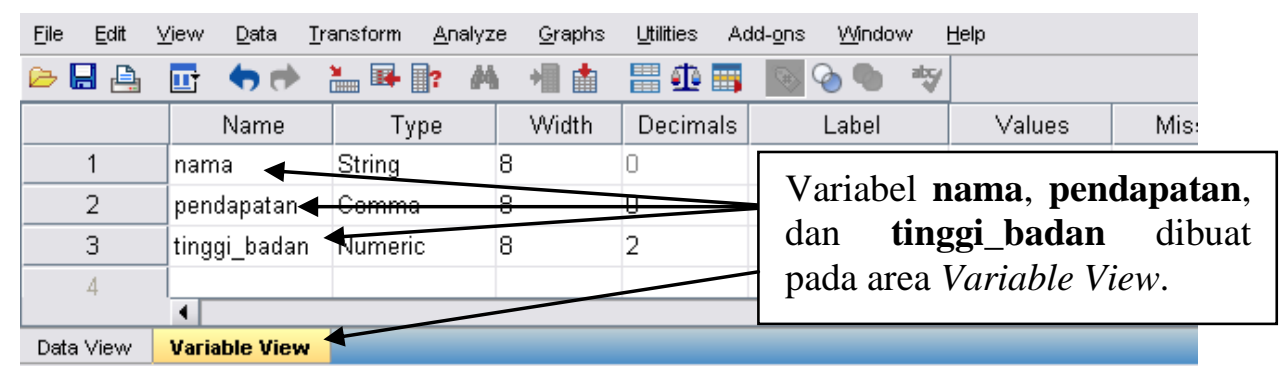

Gambar 2.2 
Misalkan diberikan data seperti pada Tabel 2.1.

Tabel 2.1

\begin{tabular}{|c|c|c|}
\hline nama & pendapatan & tinggi_badan \\
\hline Ugi & $100,000,000$ & 170.2 \\
\hline Egi & $250,000,000$ & 175.65 \\
\hline Faisal & $50,000,000$ & 171.14 \\
\hline Alvi & $15,000,000$ & 170 \\
\hline Suci & $200,000,000$ & 180.04 \\
\hline Iqbal & $90,000,000$ & 169.8 \\
\hline Ridho & $19,000,000$ & 175.78 \\
\hline Mifdhal & $75,000,000$ & 167.45 \\
\hline Fitri & $25,000,000$ & 185.66 \\
\hline Febri & $70,000,000$ & 185.66 \\
\hline
\end{tabular}

Jika data pada Tabel 2.1 disajikan dalam SPSS, maka hasilnya seperti pada Gambar 2.1. Berikut akan dipaparkan tahapan-tahapan untuk menyajikan data pada Tabel 2.1 dalam SPSS. Aktifkan program SPSS (program SPSS yang digunakan dalam buku ini adalah SPSS 17). Icon SPSS terlihat pada Gambar 2.3. Setelah program SPSS diaktifkan, maka akan muncul kotak dialog SPSS Statistics 17.0 (Gambar 2.4). Pilih Cancel untuk masuk ke SPSS Statistics Data Editor (Gambar 2.5).

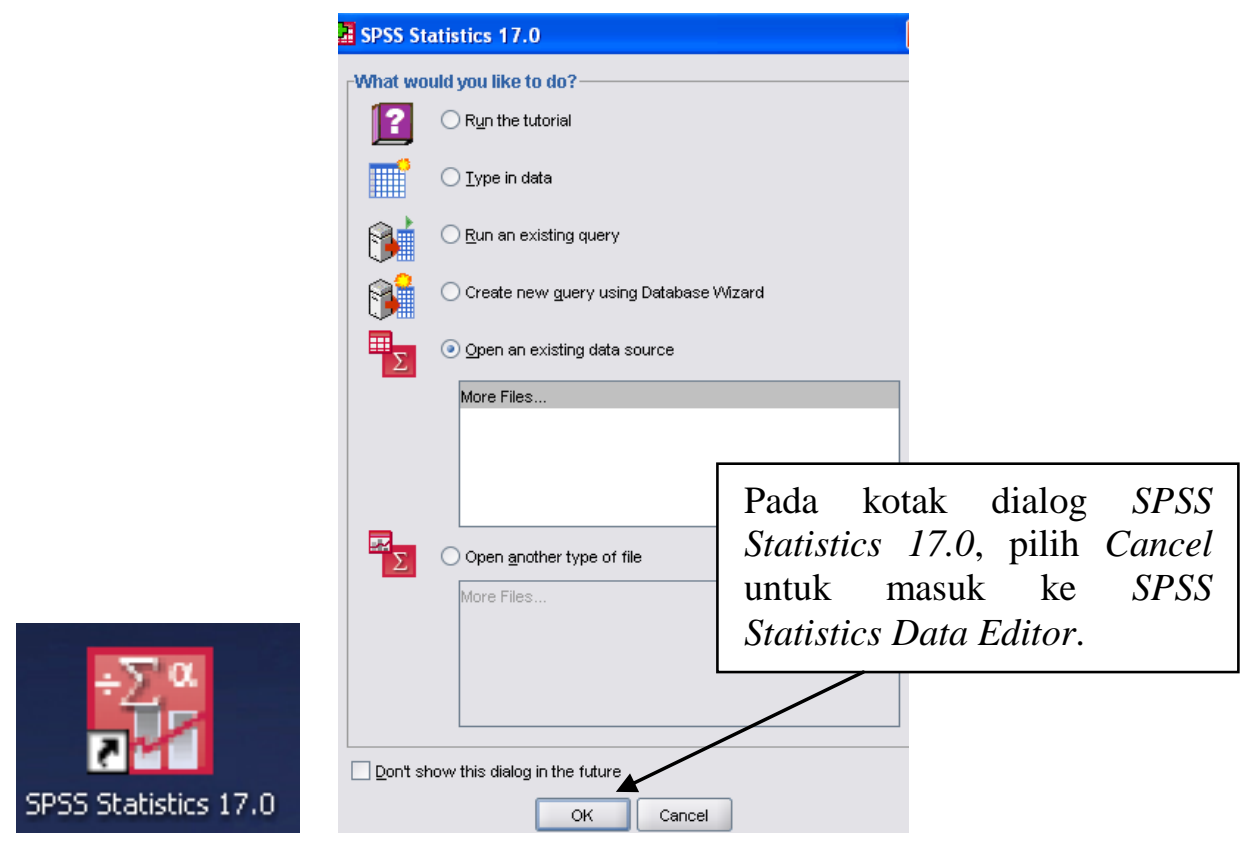

Gambar 2.3

Gambar 2.4

Selanjutnya aktifkan Variable View dan buat variabel nama seperti pada Gambar 2.6. Berdasarkan Gambar 2.6, untuk baris pertama, pada kolom Name ketik nama, pada kolom Type atur menjadi String, dan pada kolom Width atur menjadi 8. Perhatikan bahwa String digunakan untuk data yang tidak ditujukan untuk perhitungan, seperti seperti nama manusia, nama perusahaan, nama sekolah, nama buah, nama planet, dan sebagainya. Nilai Width menyatakan jumlah maksimal karakter yang diperkenankan untuk ditampilkan dalam suatu cell. Nilai Width 8 berarti jumlah maksimal karakter yang akan ditampilkan dalam suatu cell sebanyak 8 karakter. 


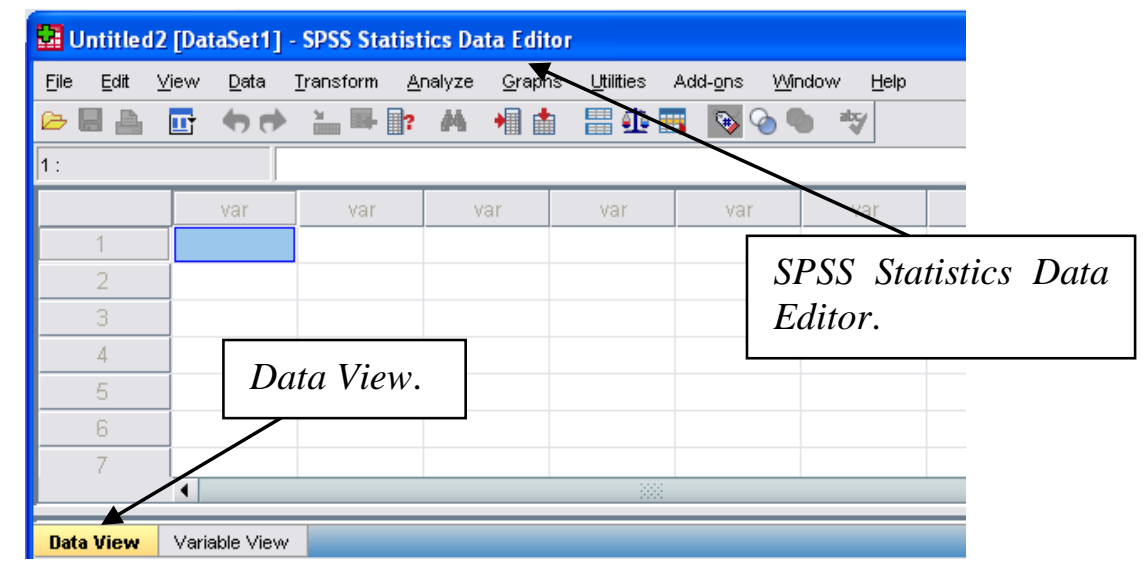

Gambar 2.5

\begin{tabular}{|c|c|c|c|c|c|c|c|c|}
\hline 的回曷 & 世 & 音圆圈? & 憎細 & 畕进 & \multirow{5}{*}{$\begin{array}{l}\text { Area Variable View } \\
\text { untuk mendefinisikan } \\
\text { variabel. Dalam hal ini } \\
\text { mendefinisikan variabel } \\
\text { nama. }\end{array}$} & \multirow{2}{*}{\multicolumn{3}{|c|}{ Fing }} \\
\hline & Name & Type & Width & Decimals & & & & \\
\hline 1 & nama & String & 8 & & & & 8 & 豆 Left \\
\hline$?$ & & & & & & & & \\
\hline Data View & Variable View & & & & & & & \\
\hline
\end{tabular}

\section{Gambar 2.6}

Setelah membuat variabel nama pada Variable View, aktifkan Data View. Pada Data View telah terbentuk sebuah variabel yang bernama nama (Gambar 2.7).

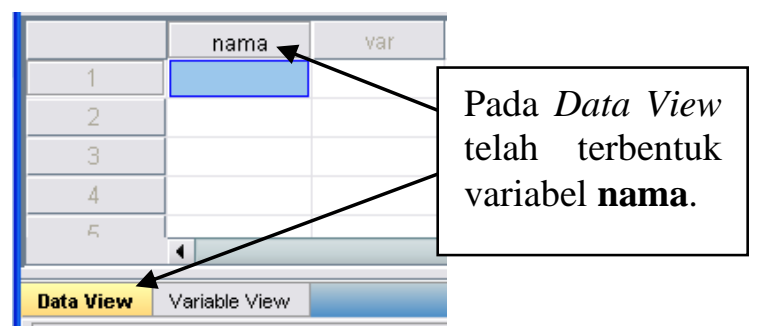

\section{Gambar 2.7}

Setelah membuat variabel nama, isi data nama pada Data View (Gambar 2.8).

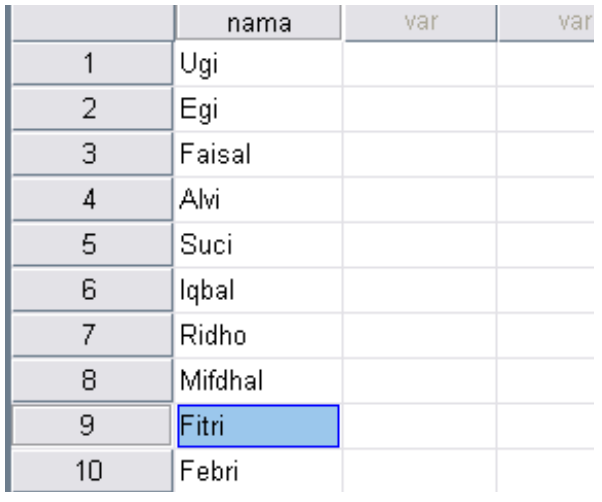

Gambar 2.8

\begin{tabular}{|c|c|c|c|c|c|}
\hline \multirow[t]{2}{*}{ 厚回 } & 画 & \multicolumn{4}{|c|}{ 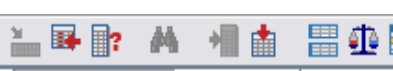 } \\
\hline & Name & Type & & Width & Decimz \\
\hline 1 & nama & String & 8 & & 0 \\
\hline 2 & pendapatan & Comma & ... 12 & & 0 \\
\hline ? & 4 & & & & \\
\hline Data View & Variable View & & & & \\
\hline
\end{tabular}

Gambar 2.9 
Perhatikan bahwa pada Gambar 2.8 telah dibuat sebuah variabel bernama nama dengan data Ugi, Egi, Faisal dan seterusnya. Selanjutnya akan dibuat variabel bernama pendapatan. Aktifkan kembali Variable View dan buat variabel pendapatan (Gambar 2.9). Berdasarkan Gambar 2.9 untuk baris kedua, pada kolom Name ketik/isi pendapatan, pada kolom Type atur menjadi Comma, pada kolom Width atur menjadi 12, dan pada kolom Decimal atur menjadi 0. Perhatikan bahwa Comma digunakan untuk data seperti, 1,000 (seribu), 500,000,000 (lima ratus juta), 10,000 (sepuluh ribu), dan sebagainya. Perhatikan bahwa Decimal diatur menjadi 0 karena data berupa bilangan bulat. Jika data berbentuk seperti 12,23, 12,11, 100,01, maka atur Decimal menjadi 2 (dua angka di belakang koma).

\begin{tabular}{|c|c|c|c|c|c|c|c|}
\hline & nama & pendapatan & var & & nama & pendapatan & var \\
\hline 1 & Ugi & & & 1 & Ugi & $100,000,000$ & \\
\hline 2 & Egi & \multirow{5}{*}{\multicolumn{2}{|c|}{$\begin{array}{l}\text { Pada Data View telah } \\
\text { terbentuk variabel } \\
\text { pendapatan. }\end{array}$}} & 2 & Egi & $250,000,000$ & \\
\hline 3 & Faisal & & & 3 & Faisal & $50,000,000$ & \\
\hline 4 & Alvi & & & 4 & Alvi & $15,000,000$ & \\
\hline 5 & Suci & & & 5 & Suci & $200,000,000$ & \\
\hline \multirow{4}{*}{6} & Iqbal & & & 6 & lqbal & $90,000,000$ & \\
\hline & 4 & & & 7 & Ridho & $19,000,000$ & \\
\hline & & & & 8 & Mifdhal & $75,000,000$ & \\
\hline & Variable View & & & 9 & Fitri & $25,000,000$ & \\
\hline
\end{tabular}

Gambar 2.10

Gambar 2.11

Setelah membuat variabel pendapatan pada Variable View, aktifkan Data View. Pada Data View telah terbentuk sebuah variabel yang bernama pendapatan seperti pada Gambar 2.10. Setelah membuat variabel pendapatan, isi data pendapatan pada Data View seperti pada Gambar 2.11. Perhatikan bahwa pada Gambar 2.11 telah dibuat sebuah variabel baru bernama pendapatan dengan data 100,000,000, 250,000,000, 50,000,000, dan seterusnya.

Selanjutnya akan dibuat variabel bernama tinggi_badan. Aktifkan kembali Variable View dan buat variabel tinggi_badan seperti pada Gambar 2.12.

\begin{tabular}{|c|c|c|c|c|c|c|c|}
\hline & Name & Type & Width & Decimals & Label & Values & $\mathrm{M}$ \\
\hline 1 & nama & String & 8 & 0 & & None & None \\
\hline 2 & pendapatan & Comma & 12 & 0 & & None & None \\
\hline 3 & tinggi_badan & Numeric & 8 & $\div$ & & None & None \\
\hline & \multicolumn{7}{|l|}{4} \\
\hline Data View & Variable View & & & & & & \\
\hline
\end{tabular}

\section{Gambar 2.12}

Berdasarkan Gambar 2.12 untuk baris ketiga, pada kolom Name ketik/isi tinggi_badan, pada kolom Type atur menjadi Numeric, pada kolom Width atur menjadi 8, dan pada kolom Decimal atur menjadi 2. Perhatikan bahwa Numeric digunakan untuk data berupa angka yang dapat digunakan untuk penghitungan. Perhatikan bahwa Decimal diatur menjadi 2 karena di belakang koma melibatkan dua angka.

Setelah membuat variabel tinggi_badan pada Variable View, aktifkan kembali Data View. Pada Data View telah terbentuk sebuah variabel yang bernama tinggi_badan seperti pada Gambar 2.13. Setelah membuat variabel tinggi_badan, isi data tinggi_badan pada Data View seperti pada Gambar 2.14. 


\section{Penting!!}

Penulisan nama variabel pada Variable View tidak diperkenankan menggunakan spasi.

Sebagai contoh :

$\Rightarrow$ tinggi badan (penulisan nama variabel tidak diperbolehkan karena mengandung spasi).

$\Rightarrow$ tinggi_badan (penulisan nama variabel diperbolehkan).

$\Rightarrow$ tinggibadan (penulisan nama variabel diperbolehkan).

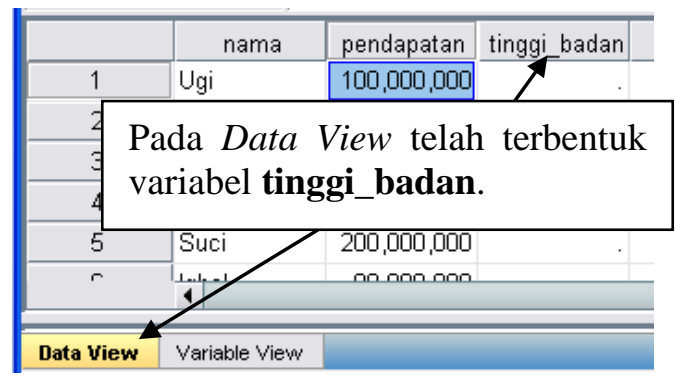

Gambar 2.13

\begin{tabular}{|c|c|c|c|}
\hline & nama & pendapatan & tinggi_badan \\
\hline 1 & Ugi & $100,000,000$ & 170.20 \\
\hline 2 & Egi & $250,000,000$ & 175.65 \\
\hline 3 & Faisal & $50,000,000$ & 171.14 \\
\hline 4 & Alvi & $15,000,000$ & 170.00 \\
\hline 5 & Suci & $200,000,000$ & 180.04 \\
\hline 6 & Iqbal & $90,000,000$ & 169.80 \\
\hline 7 & Ridho & $19,000,000$ & 175.78 \\
\hline$\circ$ & A Mifdbal & 75 חחה חחר & 157 A \\
\hline Data View & Variable View & & \\
\hline
\end{tabular}

Gambar 2.14

\section{Value Labels}

Misalkan diberikan data dengan variabel nama, jenis_kelamin, dan pekerjaan seperti pada Tabel 2.2.

\section{Tabel 2.2}

\begin{tabular}{|c|c|c|}
\hline nama & jenis_kelamin & pekerjaan \\
\hline Ugi & Laki-Laki & Dosen \\
\hline Egi & Laki-Laki & Karyawan \\
\hline Faisal & Laki-Laki & Karyawan \\
\hline Alvi & Perempuan & Karyawan \\
\hline Suci & Perempuan & Pengusaha \\
\hline Iqbal & Laki-Laki & Dosen \\
\hline Ridho & Laki-Laki & Pengusaha \\
\hline Mifdhal & Laki-Laki & Dosen \\
\hline Fitri & Perempuan & Karyawan \\
\hline Febri & Perempuan & Pengusaha \\
\hline
\end{tabular}

Data pada Tabel 2.2 melibatkan variabel jenis_kelamin dan pekerjaan. Variabel jenis_kelamin mempunyai dua kategori, yakni laki-laki dan perempuan, sedangkan variabel pekerjaan mempunyai tiga kategori, yakni dosen, pengusaha, dan karyawan. 
Misalkan untuk variabel jenis_kelamin ingin diberi kode angka untuk masing-masing kategori, yakni angka (Value) 1 untuk kategori laki-laki (Label) dan angka (Value) 0 untuk kategori perempuan (Label). Perhatikan bahwa 0 dan 1 merupakan Value (nilai atau angka), sedangkan laki-laki dan perempuan merupakan Label (kategori). Pengkodean tersebut dibuat dalam area Variable View pada menu Values. Jika kategori laki-laki akan diberi kode angka 1, sedangkan perempuan diberi kode angka 0, maka tipe data pada variabel jenis_kelamin adalah numeric.

Berikut tahapan-tahapan dalam penggunaan Value Labels. Aktifkan Variable View dan buat variabel nama (Gambar 2.15). Setelah variabel nama dibuat, aktifkan Data View untuk mengisi data variabel nama. Hasilnya seperti pada Gambar 2.16.

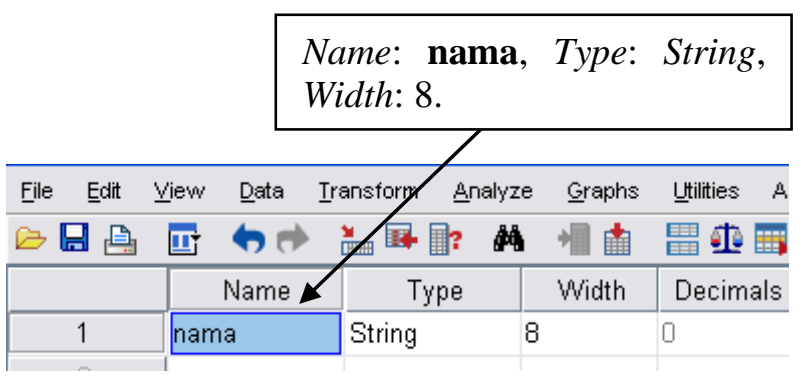

Gambar 2.15

\begin{tabular}{|c|l|}
\hline & \multicolumn{1}{|c|}{ nama } \\
\cline { 1 - 2 } 1 & Ugi \\
\hline 2 & Egi \\
\hline 3 & Faisal \\
\hline 4 & Alvi \\
\hline 5 & Suci \\
\hline 6 & Iqbal \\
\hline 7 & Ridho \\
\hline 8 & Mifdhal \\
\hline 9 & Fitri \\
\hline 10 & Febri \\
\hline
\end{tabular}

Gambar 2.16

Selanjutnya aktifkan Variable View dan buat variabel jenis_kelamin seperti pada Gambar 2.17 .

\begin{tabular}{|c|c|c|c|c|c|}
\hline & Name & Type & Width & Decimals & Name: jenis_kelamin, Type: \\
\hline 1 & nama & String & 8 & 0 & Numeric, Width: 8, dan \\
\hline 2 & jenis_kelamin & Numeric & 8 & 0 & Decimal: 0 . \\
\hline
\end{tabular}

\section{Gambar 2.17}

Pada Gambar 2.18, isi Name dengan nama jenis_kelamin dan Type diatur menjadi Numeric. Pada kolom Values dan baris kedua aktifkan atau pilih (...) (Gambar 2.18).

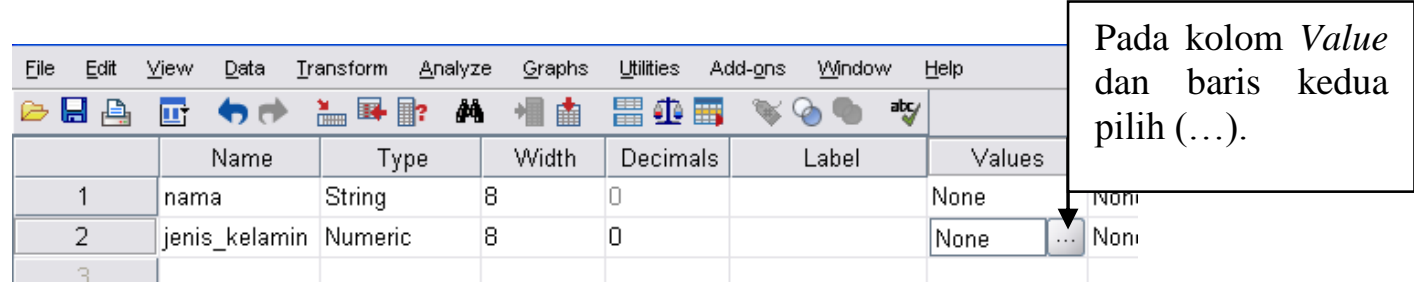

\section{Gambar 2.18}

Setelah (...) diaktifkan, maka akan muncul kotak dialog Value Labels seperti pada Gambar 2.19. Pada kotak Value Labels, isi Value dengan angka 1 dan Label dengan laki-laki (Gambar 2.20). Kemudian pilih Add. 


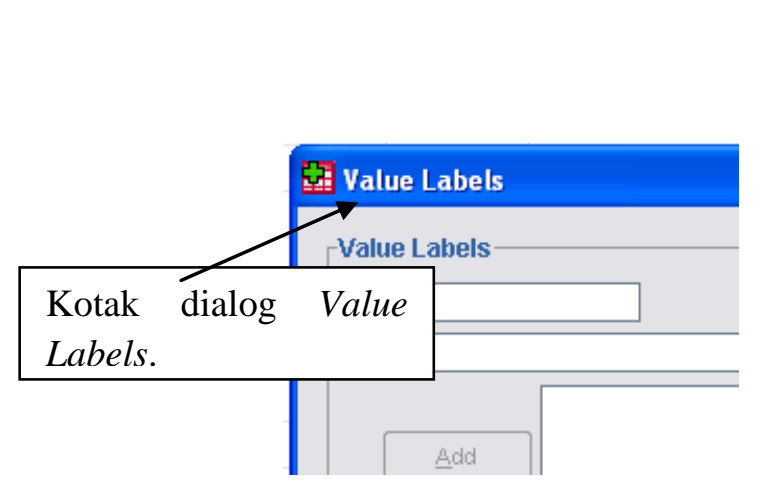

Gambar 2.19

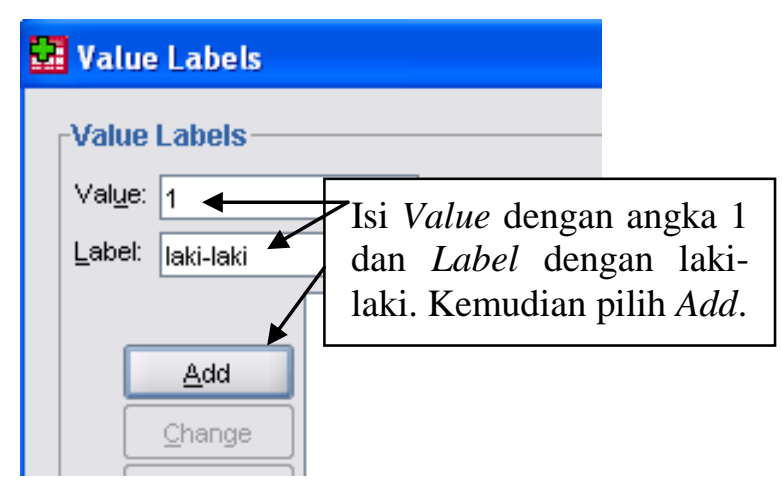

Gambar 2.20

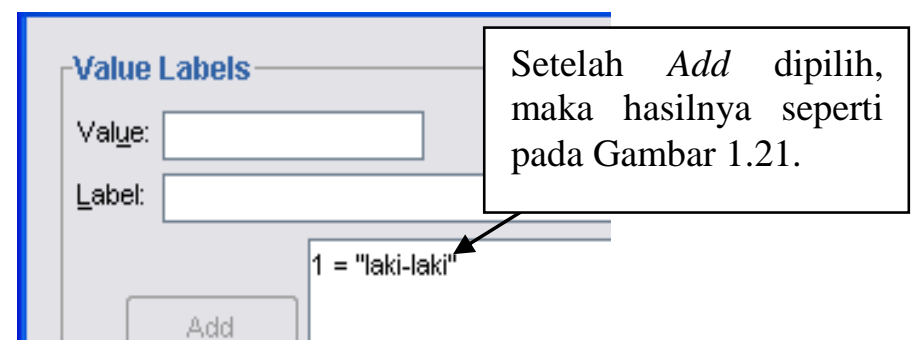

Gambar 2.21

Selanjutnya pada kotak Value Labels isi Value dengan angka 0 dan Label dengan perempuan (Gambar 2.22). Kemudian pilih Add (Gambar 2.23).

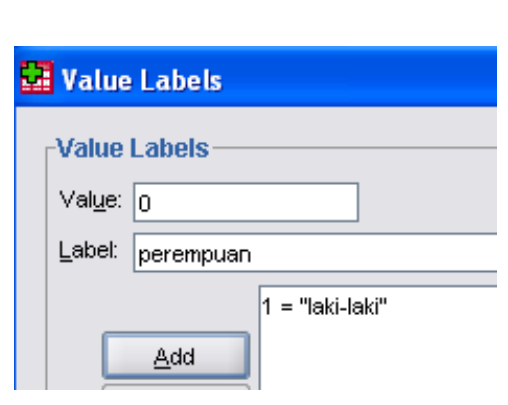

Gambar 2.22

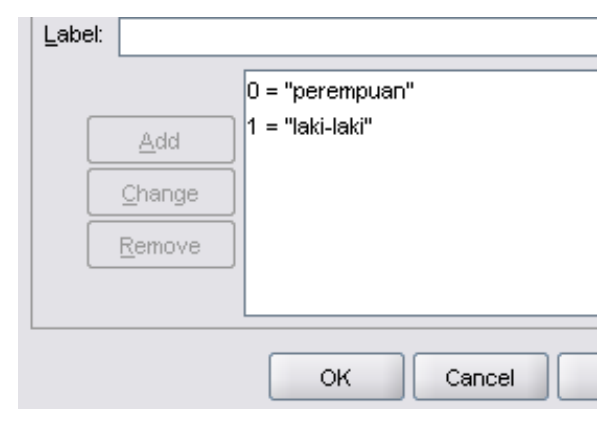

Gambar 2.23

Pada Gambar 2.23 telah berhasil untuk memberi kode angka 1 untuk laki-laki dan kode angka 0 untuk perempuan. Selanjutnya pilih $O K$. Perhatikan bahwa tampilan akan kembali pada Variable View seperti pada Gambar 2.24.

\begin{tabular}{|c|c|c|c|c|c|}
\hline \multirow{3}{*}{$\begin{array}{l}\text { Telah berhasil untuk memberi kode } \\
\text { angka } 1 \text { untuk laki-laki dan kode } \\
\text { angka } 0 \text { untuk perempuan. }\end{array}$} & Width & Decimals & Label & Values & \\
\hline & 8 & 0 & & None & None \\
\hline & & & & & None \\
\hline
\end{tabular}

\section{Gambar 2.24}

Setelah berhasil memberi kode angka untuk kategori-kategori pada variabel jenis_kelamin, maka kembali ke Data View dan isi data variabel jenis_kelamin seperti pada Gambar 2.25. Pada Gambar 2.25 perhatikan bahwa data yang dimasukkan pada variabel jenis_kelamin berupa angka 1 dan 0 . Angka 1 untuk laki-laki dan angka 0 untuk perempuan. 


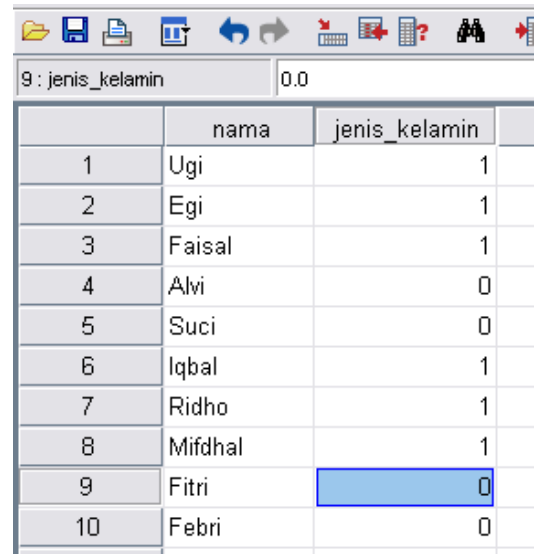

Gambar 2.25

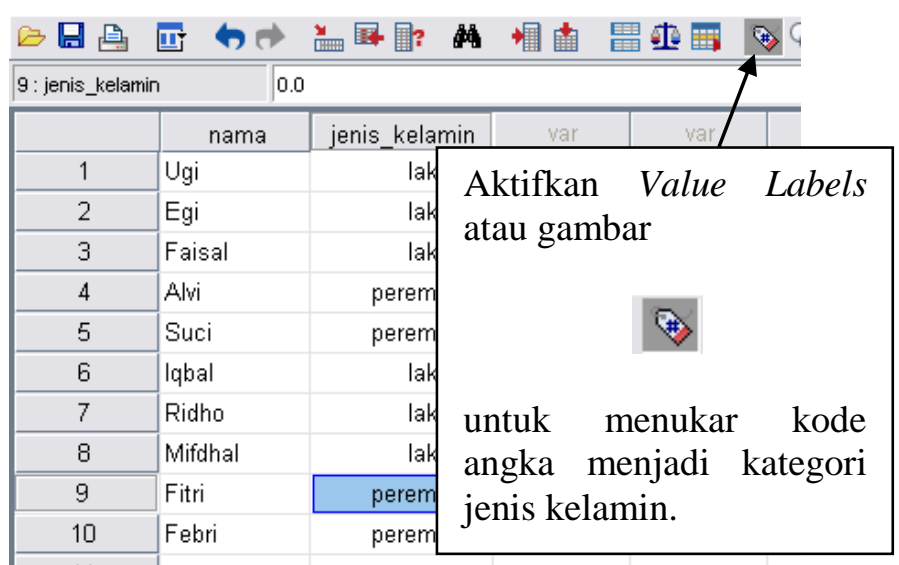

Gambar 2.26

Selanjutnya akan dibuat variabel pekerjaan dengan kategori dosen, karyawan dan pengusaha. Misalkan angka 1 sebagai kode untuk dosen, angka 2 sebagai kode untuk karyawan, dan angka 3 sebagai kode untuk pengusaha (Gambar 2.27). Setelah berhasil memberi kode untuk kategori-kategori pada variabel pekerjaan, maka kembali ke Data View dan masukkan data variabel pekerjaan seperti pada Gambar 2.28.

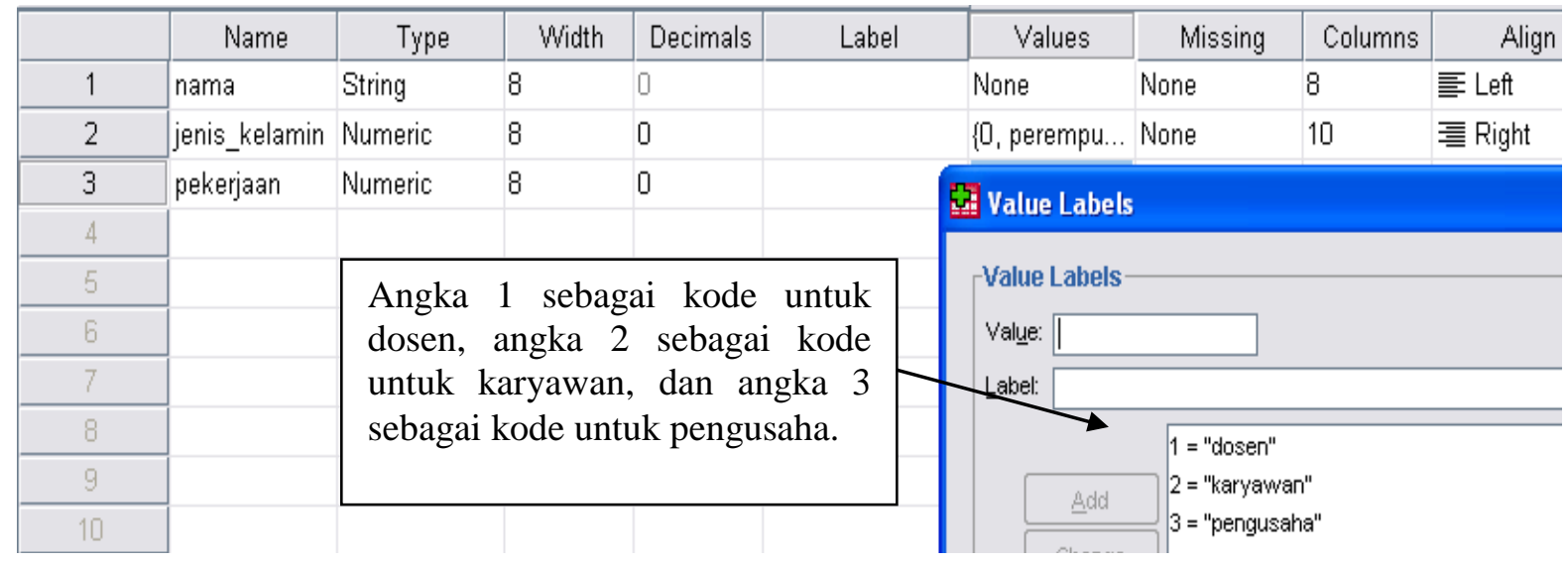

Gambar 2.27

\begin{tabular}{|c|c|c|c|c|}
\hline & nama & jenis_kelamin & pekerjaan & \\
\hline 1 & Ugi & 1 & 1 & \multirow{7}{*}{$\begin{array}{l}\text { Perhatikan bahwa data yang } \\
\text { dimasukkan pada variabel } \\
\text { pekerjaan berupa angka } 1,2 \text {, } \\
\text { dan 3. Angka } 1 \text { untuk dosen, } \\
\text { angka } 2 \text { untuk karyawan, dan } \\
\text { angka } 3 \text { untuk pengusaha. }\end{array}$} \\
\hline 2 & Egi & 1 & 2 & \\
\hline 3 & Faisal & 1 & 2 & \\
\hline 4 & Alvi & 0 & 2 & \\
\hline 5 & Suci & 0 & 3 & \\
\hline 6 & Iqbal & 1 & 1 & \\
\hline 7 & Ridho & 1 & 3 & \\
\hline 8 & Mifdhal & 1 & 1 & \\
\hline 9 & Fitri & 0 & 2 & \\
\hline 10 & Febri & 0 & 3 & \\
\hline
\end{tabular}

Gambar 2.28

Kemudian klik icon Value Labels untuk menukar angka menjadi kategori-kategori pada variabel pekerjaan (Gambar 2.29). 


\begin{tabular}{l}
\hline 1 : pekerjaan \\
\hline
\end{tabular}

Gambar 2.29

\section{Menyísipkan Data (Insert Cases)}

Fasilitas Insert Cases pada SPSS digunakan untuk menyisipkan data di antara baris. Pada Gambar 2.31 diberikan ilustrasi mengenai penyisipan suatu data. Misalkan ingin disisipkan sebuah nilai 100 di antara nilai 89.50 dan 82.00. Aktifkan sel data nilai dengan nilai 82.00 (Gambar 2.32). Kemudian klik icon Insert Cases (Gambar 2.32).
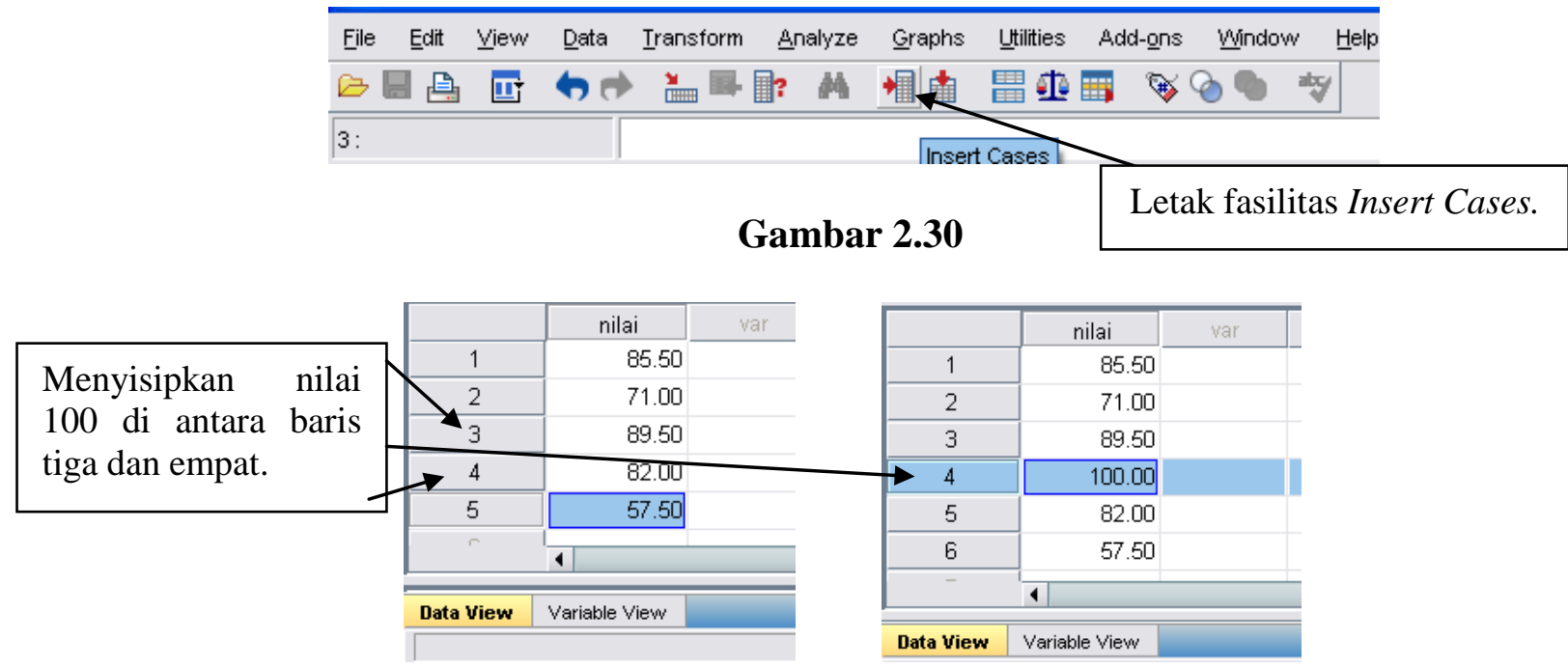

Gambar 2.31

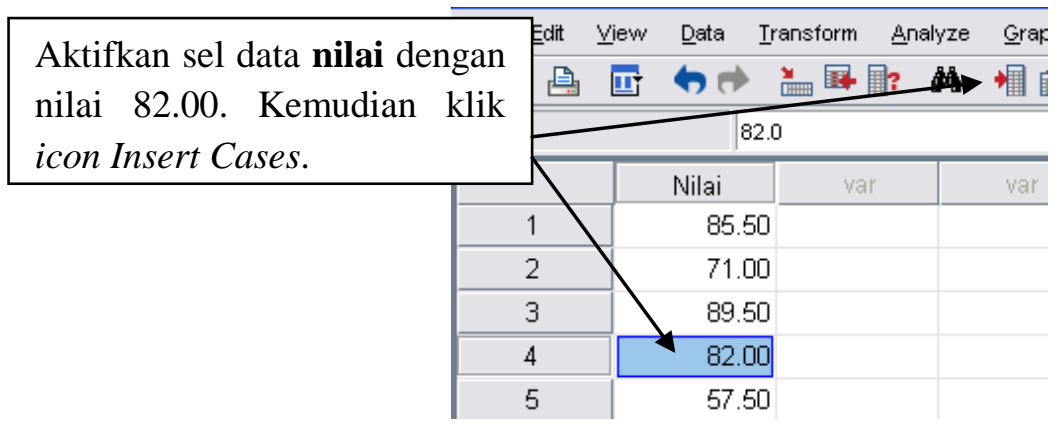

Gambar 2.32 
Isi cell kosong tersebut dengan nilai 100.00 (Gambar 2.33).

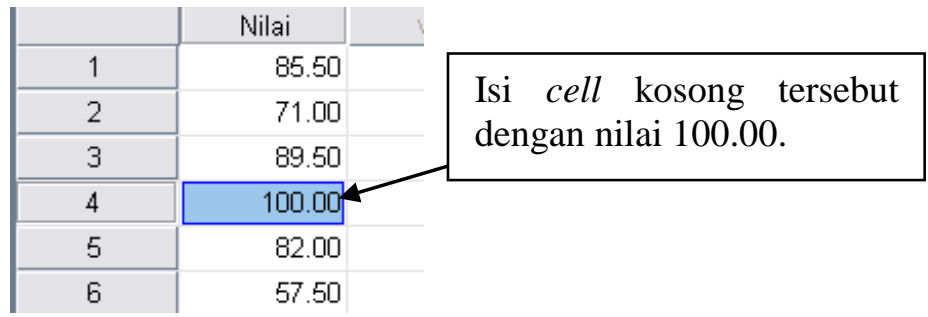

Gambar 2.33

\section{Menyisipkan Variabel (Insert Variable)}

Fasilitas Insert Variable dalam SPSS digunakan untuk menyisipkan variabel.

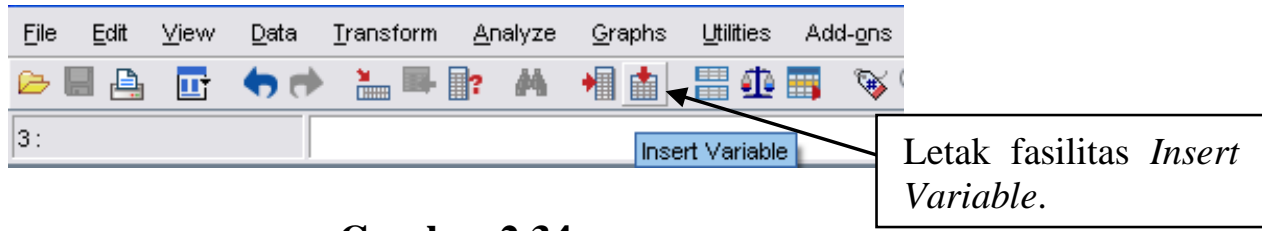

\section{Gambar 2.34}

Pada Gambar 2.35, misalkan ingin disisipkan variabel nama di sebelah kiri variabel nilai. Aktifkan sel nilai 85.50. Kemudian pilih/klik icon Insert Variable, maka akan terbentuk sebuah variabel baru dengan nama VAR00002 (Gambar 2.36).

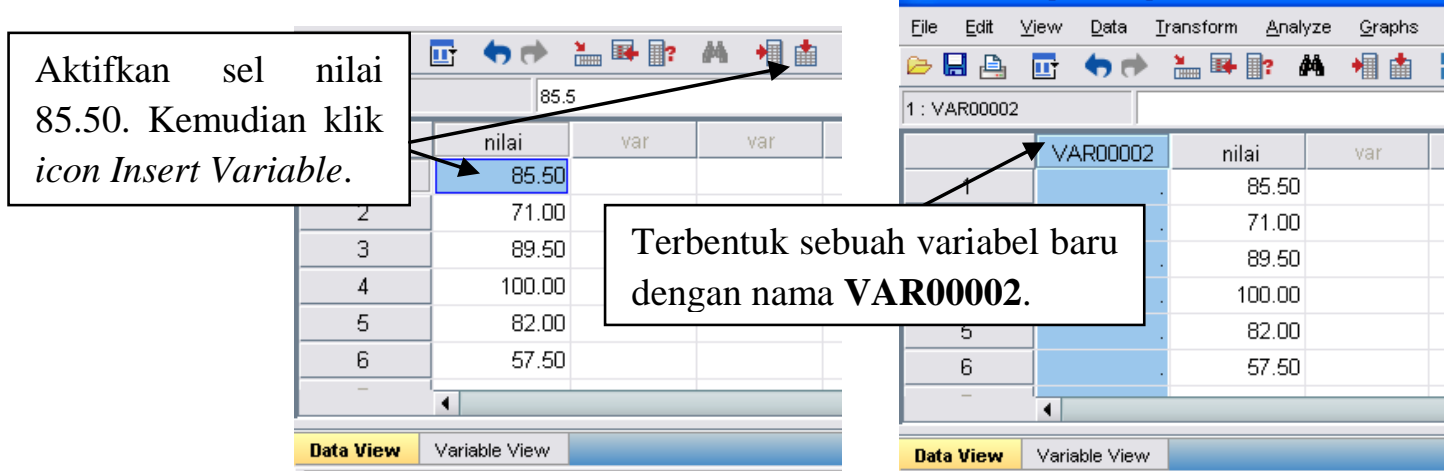

Gambar 2.35

Gambar 2.36

Selanjutnya aktifkan Variable View dan ubah nama VAR00001 menjadi nama. Kemudian atur jenis data menjadi String (Gambar 2.37).

\begin{tabular}{|c|l|l|l|l}
\hline & \multicolumn{1}{|c|}{ Name } & \multicolumn{1}{c|}{ Type } & Width & Decimal \\
\hline 1 & VAR00002 & Numeric & 8 & 2 \\
\hline 2 & nilai & Numeric & 8 & 2 \\
\hline & Variable View & & \\
\hline
\end{tabular}

\begin{tabular}{|c|l|l|l|l|l}
\hline & \multicolumn{1}{|c|}{ Name } & \multicolumn{2}{|c|}{ Type } & Width & Decim \\
\hline 1 & nama & String & $\ldots$ & 8 & 0 \\
\hline 2 & nilai & Numeric & 8 & 2 \\
\hline & & & & & \\
\hline
\end{tabular}

\section{Gambar 2.37}

Aktifkan Data View dan isi data pada variabel nama seperti pada Gambar 2.38. 


\begin{tabular}{|c|l|r|r}
\hline & & nama & \multicolumn{1}{c|}{ nilai } \\
& A & 85.50 \\
\hline 2 & B & 71.00 \\
\hline 3 & C & 89.50 \\
\hline 4 & D & 100.00 \\
\hline 5 & E & 82.00 \\
\hline 6 & F & 57.50 \\
\hline 7 & & \\
\hline \hline Data View & Variable View & \\
\hline \hline
\end{tabular}

Gambar 2.38

\section{Menghapus Data dan Variabel (Clear)}

Fasilitas Clear dapat digunakan untuk menghapus data atau variabel. Pada Gambar 2.39, andaikan data pada baris 4, yakni nama: D dan nilai: 100.00 akan dihapus. Arahkan kursor ke nomor 4, kemudian klik kanan pada mouse dan pilih Clear. Hal ini berarti menghapus data pada baris keempat. Hasilnya terlihat pada Gambar 2.40.

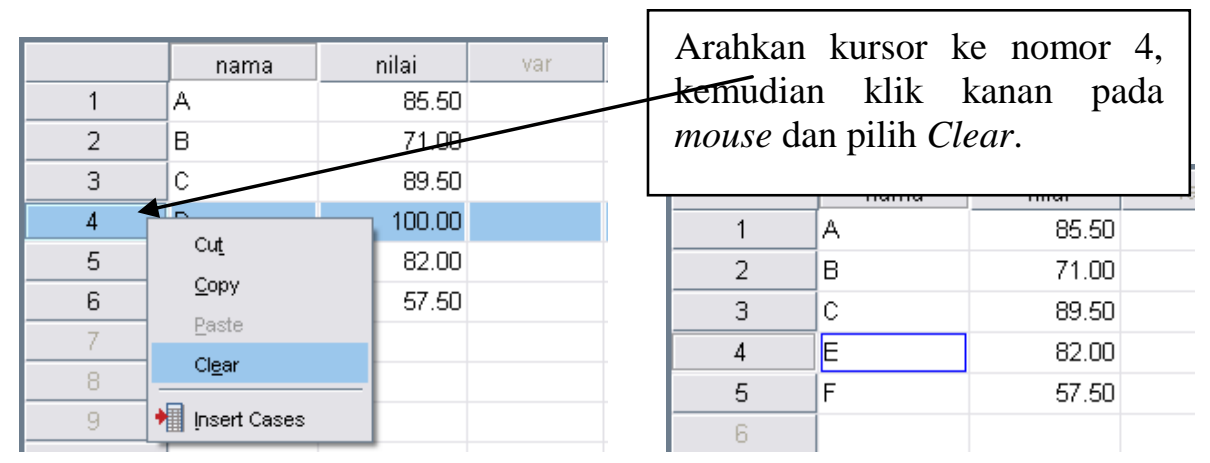

Gambar 2.39

Gambar 2.40

Andaikan ingin dihapus variabel nilai. Arahkan kursor pada nilai. Kemudian klik kanan pada mouse dan pilih Clear (Gambar 2.41). Hasilnya seperti pada Gambar 2.42.

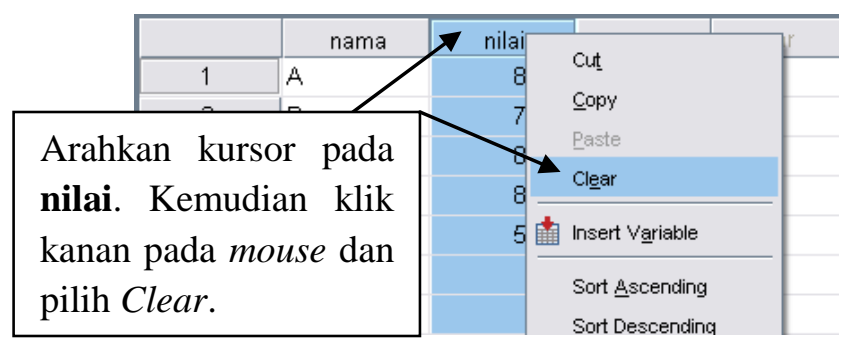

Gambar 2.41

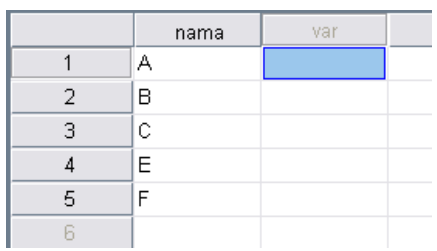

Gambar 2.42

\section{Select Cases}

Metode Select Cases berfungsi untuk memilih data berdasarkan suatu syarat tertentu. Seperti pada Gambar 2.43, metode Select Cases digunakan untuk memilih data dengan syarat uang_jajan lebih besar atau sama dengan 10000. Jika suatu data tidak memenuhi suatu persyaratan, maka akan diberi garis silang dari kanan atas ke kiri bawah pada nomor data. 
Selain itu, terbentuk variabel bernama filter_\$ dengan nilai data 0 dan 1 . Nilai 0 untuk data yang tidak memenuhi persyaratan, sedangkan nilai 1 untuk data yang memenuhi persyaratan (Gambar 2.43).

\begin{tabular}{|r|l|r|}
\hline \hline 1: nama & \multicolumn{2}{|l}{ Andi } \\
\hline & nama & uang_jajan \\
& Andi & 10000 \\
\hline 1 & Udin & 7500 \\
\hline 3 & Anggi & 9000 \\
\hline 4 & Ulan & 10000 \\
\hline 5 & Ugi & 20000 \\
\hline
\end{tabular}

sebelum penggunaan Select Casess

\begin{tabular}{|c|c|c|c|}
\hline \multicolumn{2}{|l|}{ 1: nama } & \multicolumn{2}{|l|}{ Andi } \\
\hline & nama & uang_jajan & filter_\$ \\
\hline 1 & Andi & 10000 & 1 \\
\hline $2-$ & Udin & 7500 & 0 \\
\hline - & Anggi & 9000 & 0 \\
\hline 4 & Ulan & 10000 & 1 \\
\hline 5 & Ugi & 20000 & 1 \\
\hline f & & & \\
\hline
\end{tabular}

setelah penggunaan Select Cases

\section{Gambar 2.43}

Pada Gambar 2.43, data nomor 2 dan 3 disilang. Hal ini karena tidak memenuhi persyaratan, yakni uang_jajan tidak lebih besar atau sama dengan 10000. Sebagai contoh implementasi dari metode Select Cases, bangun data pada Gambar 2.44 dalam SPSS. Setelah data pada Gambar 2.44 dibangun dalam SPSS, kemudian pilih Data => Select Cases (Gambar 2.45), sehingga muncul kotak dialog Select Cases (Gambar 2.46).

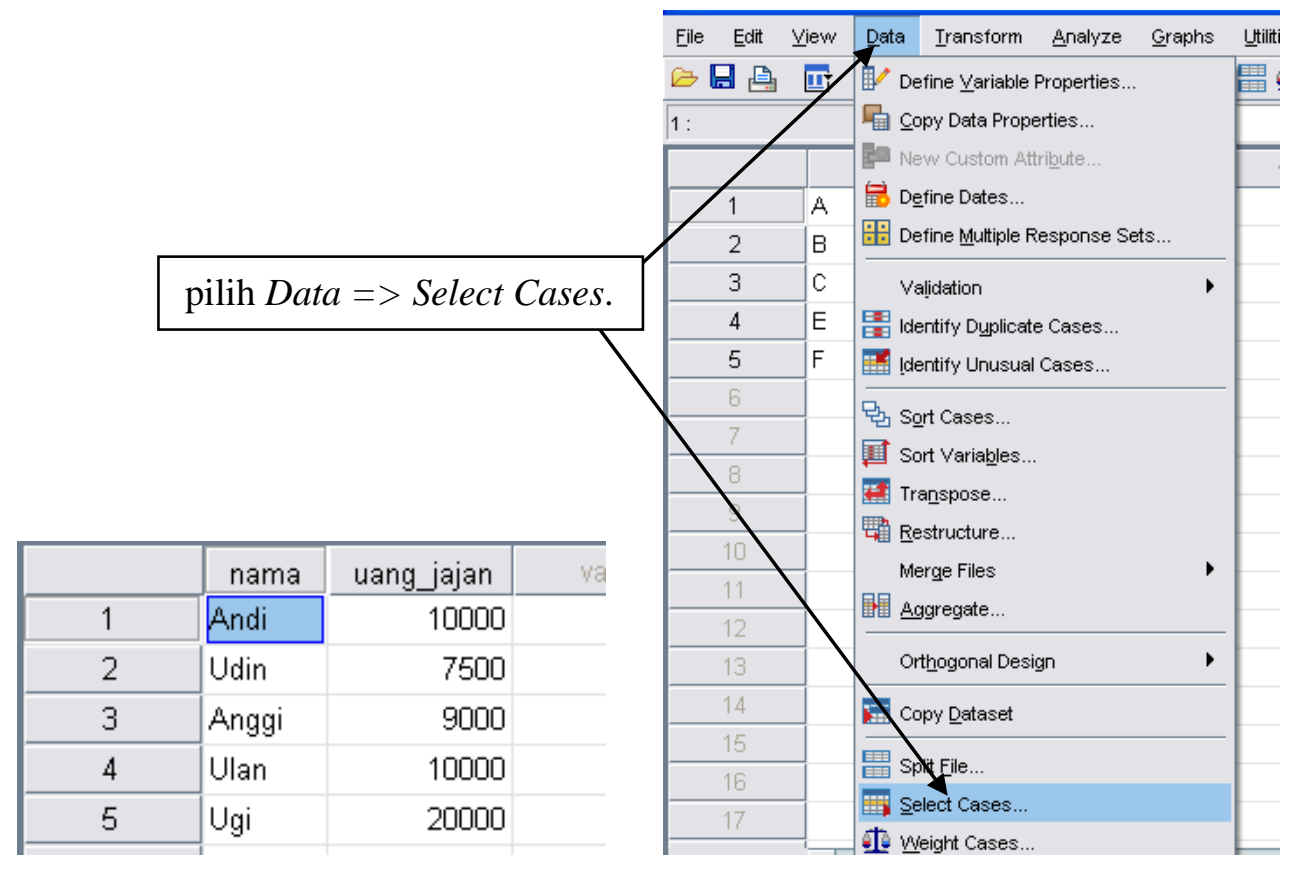

Gambar 2.44

Gambar 2.45

Pada kotak dialog Select Cases, pilih If condition is satisfied dan pilih If... (Gambar 2.46), sehingga muncul kotak dialog Select Cases: If (Gambar 2.47). Pada Gambar 2.47, karena syarat yang digunakan adalah uang_jajan harus lebih besar atau sama dengan 10000, maka pada kotak sisi kanan diisi dengan rumus

\section{uang_jajan $>=10000$.}

Setelah syarat dibuat seperti pada Gambar 2.47, kemudian pilih Continue dan OK. Hasilnya seperti pada Gambar 2.48 . 


\section{Felect Cases}

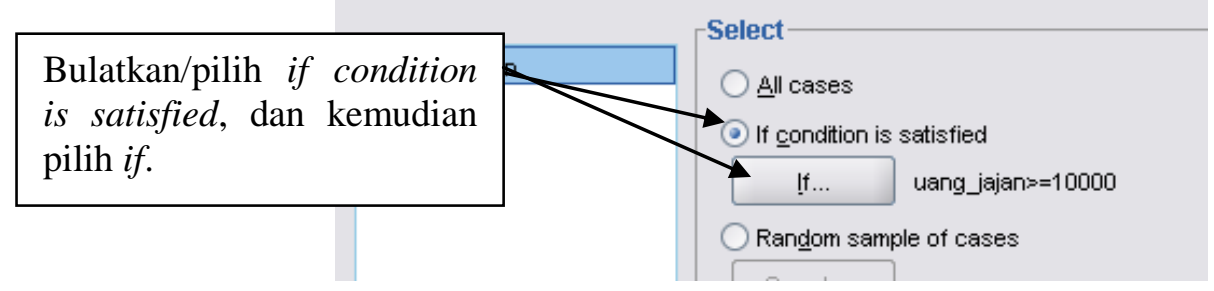

Gambar 2.46

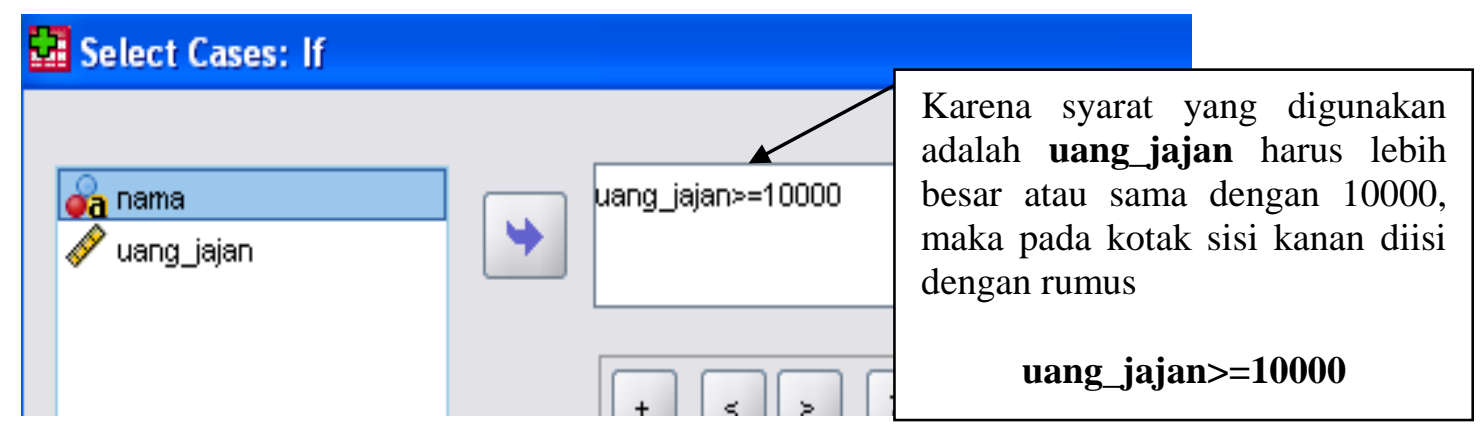

Gambar 2.47

\begin{tabular}{|c|c|c|c|}
\hline & nama & uang_jajan & filter_\$ \\
\hline 1 & Andi & 10000 & 1 \\
\hline-2 & Udin & 7500 & 0 \\
\hline 3 & Anggi & 9000 & 0 \\
\hline 4 & Ulan & 10000 & 1 \\
\hline 5 & Ugi & 20000 & 1 \\
\hline 6 & & & \\
\hline
\end{tabular}

Gambar 2.48

Perhatikan bahwa pada Gambar 2.48, data pada nomor 2 dan 3 tidak memenuhi persyaratan. Hal ini karena uang_jajan pada data nomor 2 dan 3 tidak lebih besar atau sama dengan 10000.

\section{Compute Variable}

Compute Variable dapat digunakan untuk membuat variabel baru berdasarkan suatu ekspresi atau rumus tertentu, serta dapat melibatkan variabel yang telah ada.

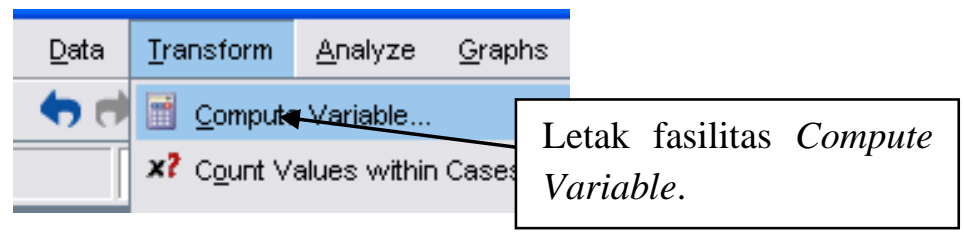

Gambar 2.49

Misalkan diberikan data seperti pada Gambar 2.50. 


\begin{tabular}{|c|l|l|l|}
\hline \hline 5: nama & \multicolumn{3}{|l|}{ Ugi } \\
\hline & nama & jumlah_jam_mengajar & \\
& Andi & 20 \\
\hline 1 & Udin & 15 \\
\hline 2 & Anggi & 12 \\
\hline 3 & Ulan & 17 \\
\hline 4 & Ugi & 10 \\
\hline 5 & & & \\
\hline \hline
\end{tabular}

\section{Gambar 2.50}

Berdasarkan data pada Gambar 2.50, Andi mempunyai jumlah jam mengajar sebanyak 20 jam dalam seminggu, Udin sebanyak 15 jam, dan seterusnya. Misalkan akan dibuat sebuah variabel bernama gaji dengan menggunakan fasilitas Compute Variable. Variabel gaji dihitung dengan rumus sebagai berikut.

$$
\text { gaji }=\text { jumlah_jam_mengajar } * R p .10000 .
$$

Bangun data pada Gambar 2.50 dalam SPSS. Kemudian pilih Transform $=>$ Compute Variable, sehingga muncul kotak dialog Compute Variable (Gambar 2.51). Pada kotak Target Variable, ketik nama variabel. Dalam hal ini nama variabel adalah gaji. Pada kotak Numeric Expression ketik rumus:

$$
\text { jumlah_jam_mengajar } * 10000 .
$$

Selanjutnya pilih OK, sehingga hasilnya seperti pada Gambar 2.52. Perhatikan bahwa pada Gambar 2.52 telah terbentuk sebuah variabel baru bernama gaji yang berasal dari penggunaan fasilitas Compute Variable.

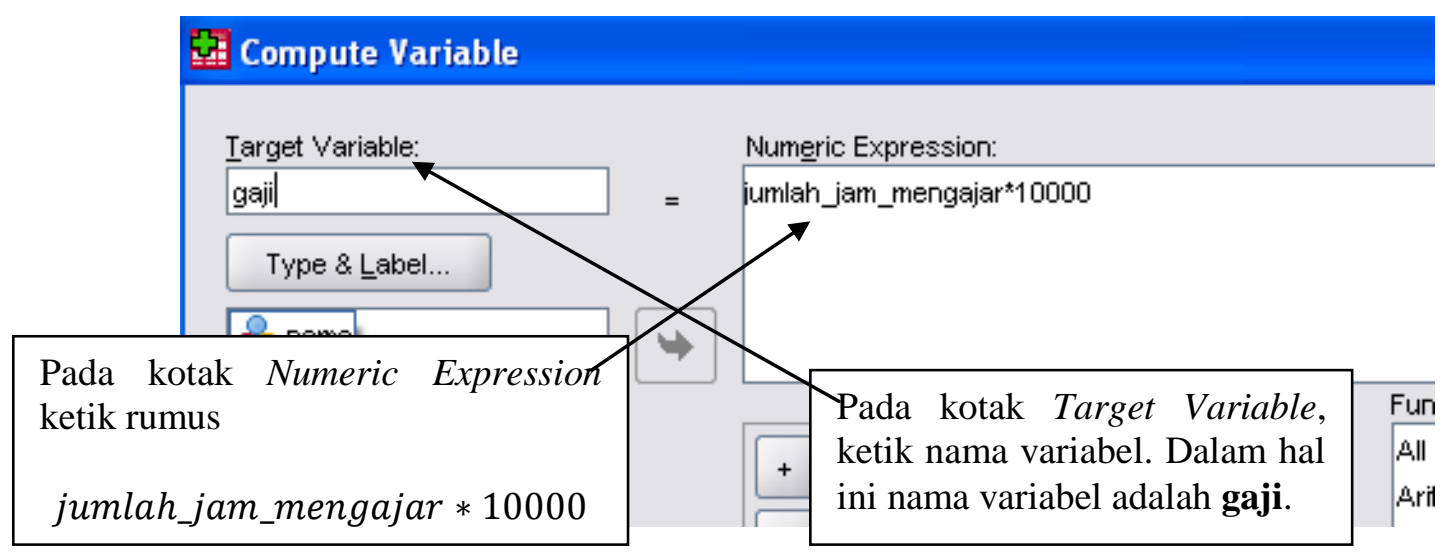

Gambar 2.51

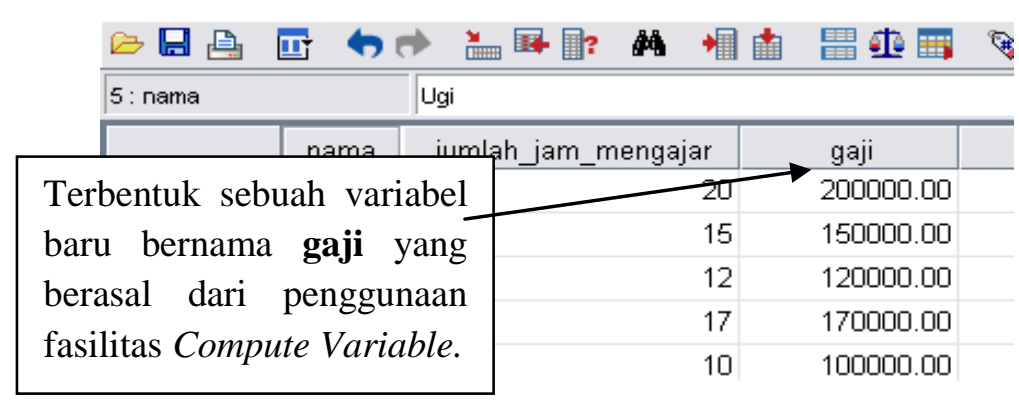

Gambar 2.52 


\section{Compute Variable Bersyarat}

Compute Variable bersyarat tidak lain hanyalah suatu metode untuk membuat variabel baru berdasarkan suatu ekspresi atau rumus tertentu, serta dapat melibatkan variabel yang telah ada dan menggunakan syarat tertentu.

\begin{tabular}{|c|l|r|r|r}
\hline & nama & jumlah_jam_mengajar & gaji & \\
\cline { 4 - 5 } & Andi & 20 & 200000.00 \\
\hline 2 & Udin & 15 & 150000.00 \\
\hline 3 & Anggi & 12 & 120000.00 \\
\hline 4 & Ulan & 17 & 170000.00 \\
\hline 5 & Ugi & 10 & 100000.00 \\
\hline \hline
\end{tabular}

Gambar 2.53

Berdasarkan data pada Gambar 2.53, misalkan akan dibuat variabel bernama bonus dengan Compute Variable bersyarat. Varibel bonus dihitung dengan syarat dan rumus sebagai berikut.

$\Rightarrow$ Jumlah jam mengajar harus lebih dari 15 jam.

○ Jika jumlah jam mengajar lebih dari 15 jam, maka bonus yang akan diterima sebesar bonus $=\left(j m l h \_j a m \_m e n g a j a r-15\right) * 1000$.

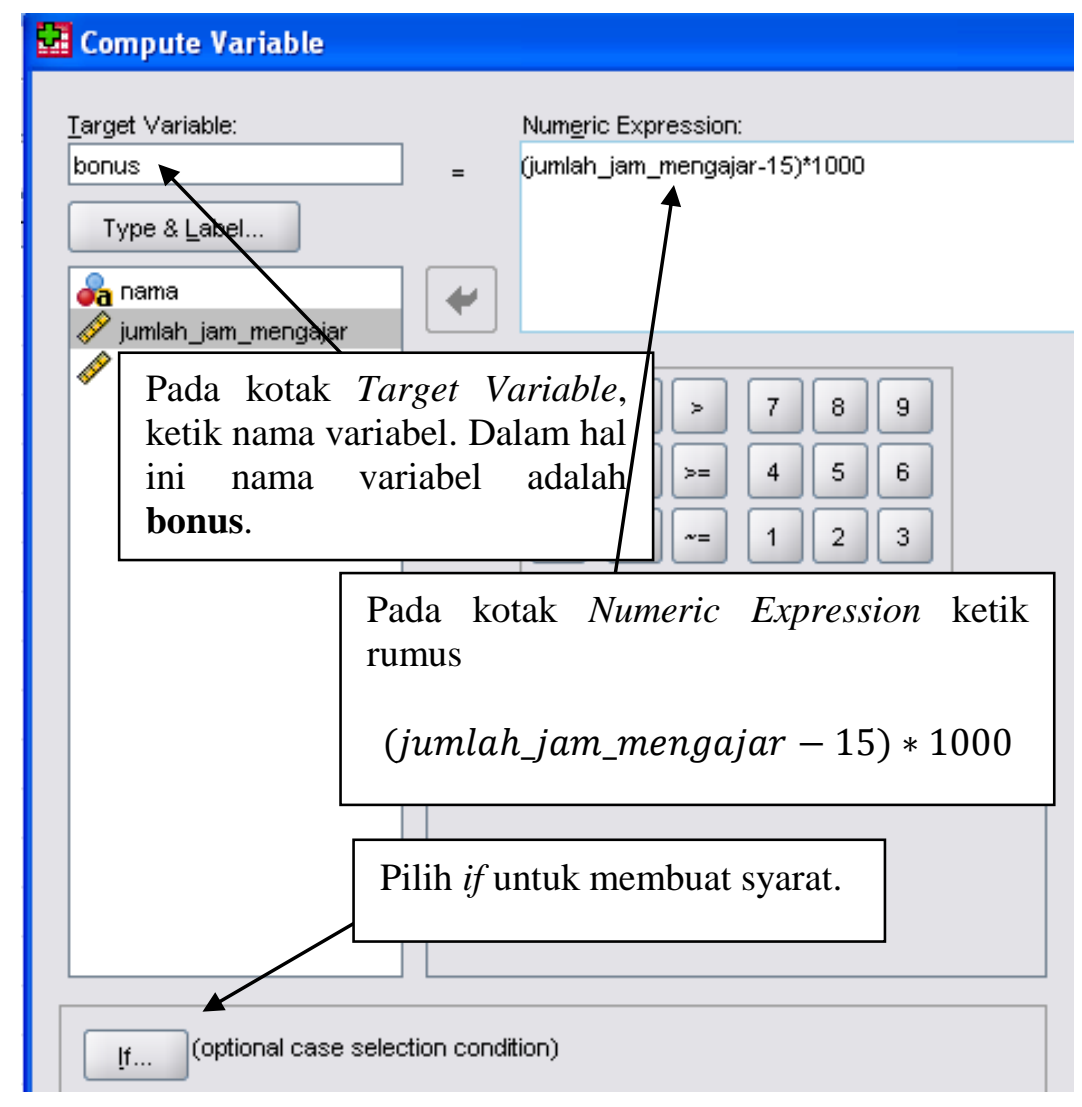

Gambar 2.54

Sebagai contoh implementasi dari Compute Variable bersyarat, bangun data dalam SPSS seperti pada Gambar 2.53. Selanjutnya pilih Transform $\Rightarrow$ Compute Variable, sehingga muncul kotak dialog Compute Variable (Gambar 2.54). Pada kotak Target Variable ketik 
nama variabel. Dalam hal ini nama variabel adalah bonus. Pada kotak Numeric Expression ketik rumus

$$
\left(j u m l a h \_j a m \_m e n g a j a r-15\right) * 1000 .
$$

Selanjutnya pilih if untuk membuat syarat. Setelah memilih if, maka akan muncul kotak dialog Compute Variable: if Cases (Gambar 2.55). Pada Gambar 2.55, pilih atau bulatkan Include if cases satisfies condition:, serta isi syarat dengan jumlah_jam_mengajar>15. Kemudian pilih Continue dan OK, sehingga hasilnya tersaji pada Gambar 2.56.

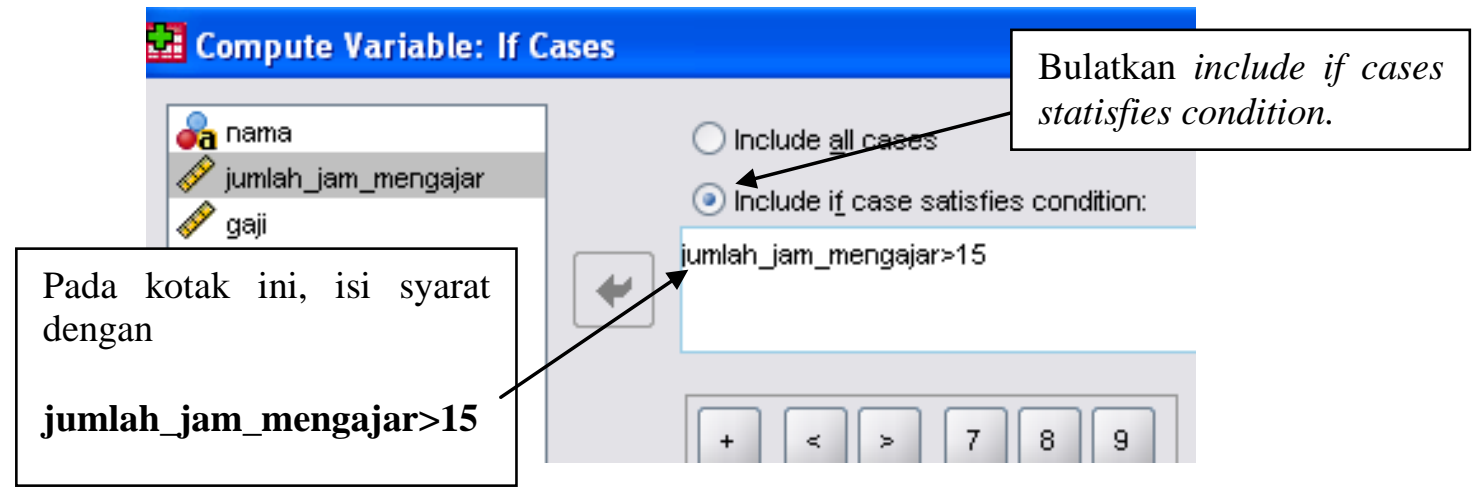

Gambar 2.55

\begin{tabular}{|r|l|r|r|r|r}
\hline & nama & jumlah_jam_mengajar & gaji & \multicolumn{1}{c|}{ bonus } & \\
\hline 1 & Andi & 20 & 200000.00 & 5000.00 \\
\hline 2 & Udin & 15 & 150000.00 & \\
\hline 3 & Anggi & 12 & 120000.00 & \\
\hline 4 & Ulan & 17 & 170000.00 & 2000.00 \\
\hline 5 & Ugi & 10 & 100000.00 & \\
\hline \hline 6 & & & & & \\
\hline \hline
\end{tabular}

Gambar 2.56

Perhatikan bahwa pada Gambar 2.56 hanya Andi dan Ulan yang mendapatkan bonus. Hal ini karena jumlah jam mengajar mereka memenuhi syarat, yakni lebih besar dari 15 .

\section{Menyímpan dan Membuka Data}

Misalkan data pada Gambar 2.57 akan disimpan. Pilih File => Save (Gambar 2.58), sehingga muncul kotak dialog Save Data As (Gambar 2.59). Pada File name, tentukan nama file yang akan disimpan. Dalam Gambar 2.59, nama file-nya adalah data simpan. Setelah menentukan nama file, pilih Save.

Untuk membuka file yang telah disimpan, dalam hal ini file yang bernama data simpan, pilih File $\Rightarrow$ Open $=>$ Data (Gambar 2.60), sehingga muncul kotak dialog Open Data (Gambar 2.61).

Selanjutnya pilih file yang akan dibuka. Dalam hal ini adalah file data simpan.sav. Kemudian pilih Open. 


\begin{tabular}{|l|l|}
\hline & nama \\
\hline 1 & Andi \\
\hline 2 & Udin \\
\hline 3 & Anggi \\
\hline 4 & Ulan \\
\hline 5 & Ugi \\
\hline
\end{tabular}

Gambar 2.57

\begin{tabular}{l}
\hline File Edit View Data Iransform Analyze \\
New \\
Open \\
Open Database \\
国 Read Text Data... \\
Close \\
Dave \\
Save As...
\end{tabular}

Gambar 2.58

Lave Data As
Lecent

Gambar 2.59

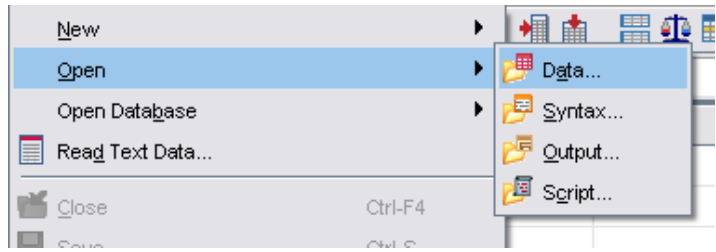

Gambar 2.60

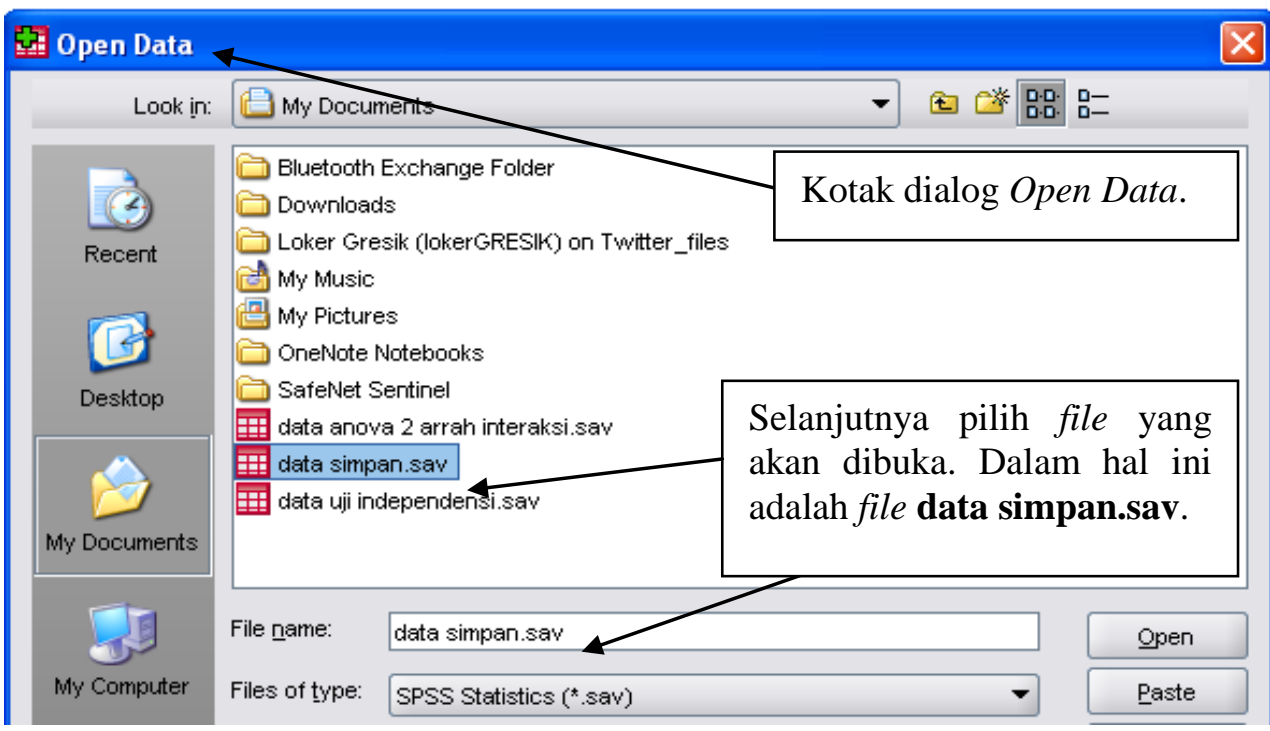

Gambar 2.61 


\section{BAB 3}

\section{MENYAJIKAN DATA MENGGUNAKAN GRAFIK DAN TABEL}

\section{Jenis Peringkasan Data dalam SPSS}

Dalam SPSS, suatu data dapat disajikan dengan menggunakan grafik batang (bar chart) atau grafik garis. Penyajian data dalam bentuk grafik bertujuan agar mendapatkan gambaran yang lebih jelas mengenai informasi dari suatu data. Berikut merupakan contoh tampilan dari grafik batang (Gambar 3.1) dan grafik garis (Gambar 3.2) dalam SPSS.

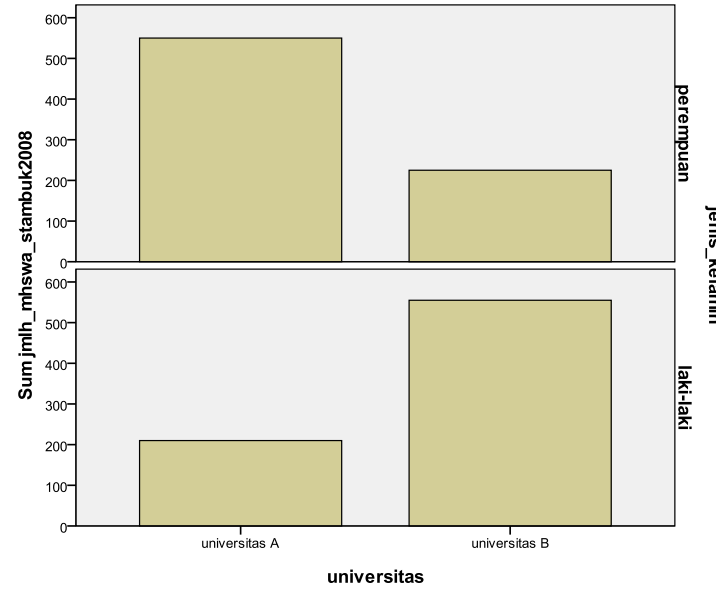

Gambar 3.1

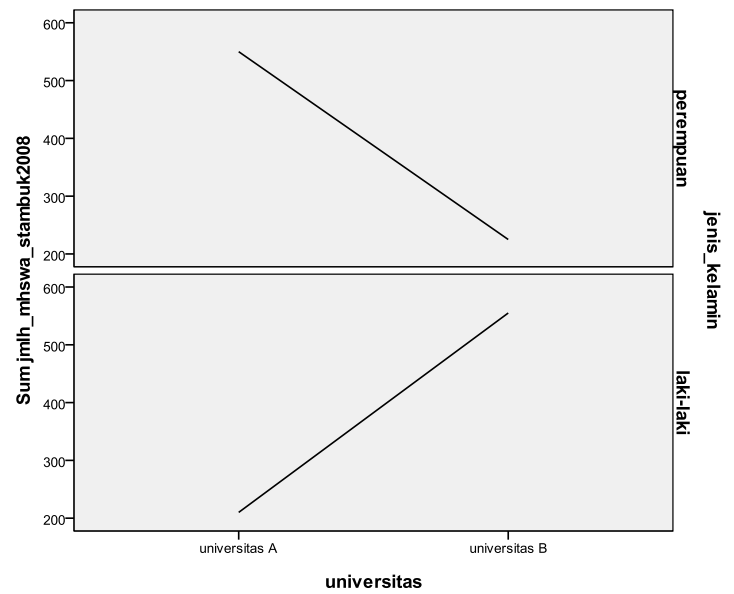

Gambar 3.2

Dalam SPSS, peringkasan (summaries) suatu data dalam grafik (grafik batang dan grafik garis) dikelompokkan atas tiga jenis, yakni Summaries for groups of cases, Summaries of separate variables, dan Values of individual cases.

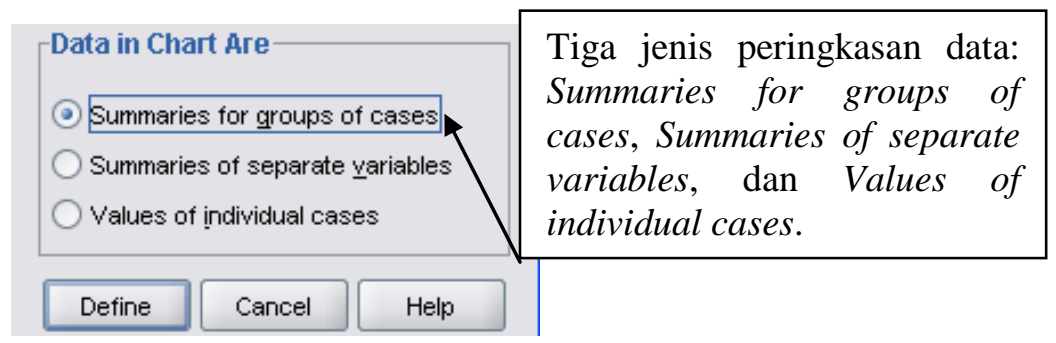

\section{Gambar 3.3}

Untuk melihat perbedaan dari ketiga jenis peringkasan data tersebut, perhatikan Gambar 3.4 sampai Gambar 3.9. Gambar 3.4 sampai Gambar 3.9 menyajikan grafik batang dan grafik garis dari ketiga jenis peringkasan data berdasarkan data pada Tabel 3.1. 
Tabel 3.1

\begin{tabular}{|c|c|c|c|c|c|}
\hline & universitas & Jurusan & jenis_kelamin & nilai_kalkulus & nilai_statistika_dasar \\
\hline 1 & universitas A & Matematika & laki laki & 100 & 10 \\
\hline 2 & universitas A & Matematika & Perempuan & 90 & 65 \\
\hline 3 & universitas $\mathrm{A}$ & Matematika & laki laki & 65 & 75 \\
\hline 4 & universitas A & Matematika & Perempuan & 80 & 60 \\
\hline 5 & universitas A & Matematika & laki laki & 70 & 70 \\
\hline 6 & universitas $\mathrm{A}$ & Matematika & Perempuan & 90 & 65 \\
\hline 7 & universitas $\mathrm{A}$ & Statistika & laki laki & 70 & 75 \\
\hline 8 & universitas $\mathrm{A}$ & Statistika & Perempuan & 85 & 60 \\
\hline 9 & universitas $\mathrm{A}$ & Statistika & laki laki & 60 & 70 \\
\hline 10 & universitas A & Statistika & Perempuan & 80 & 65 \\
\hline 11 & universitas A & Statistika & laki laki & 75 & 75 \\
\hline 12 & universitas A & Statistika & Perempuan & 100 & 60 \\
\hline 13 & universitas B & Matematika & laki laki & 90 & 80 \\
\hline 14 & universitas B & Matematika & Perempuan & 60 & 70 \\
\hline 15 & universitas B & Matematika & laki laki & 80 & 90 \\
\hline 16 & universitas B & Matematika & Perempuan & 70 & 70 \\
\hline 17 & universitas B & Matematika & laki laki & 95 & 80 \\
\hline 18 & universitas B & Matematika & Perempuan & 65 & 70 \\
\hline 19 & universitas B & Statistika & laki laki & 100 & 90 \\
\hline 20 & universitas B & Statistika & Perempuan & 75 & 70 \\
\hline 21 & universitas B & Statistika & laki laki & 80 & 80 \\
\hline 22 & universitas B & Statistika & Perempuan & 70 & 70 \\
\hline 23 & universitas B & Statistika & laki laki & 80 & 90 \\
\hline 24 & universitas B & Statistika & Perempuan & 30 & 70 \\
\hline
\end{tabular}

Gambar 3.4 dan Gambar 3.5 merupakan tampilan grafik berdasarkan jenis peringkasan Summaries for groups of cases berdasarkan data pada Tabel 3.1.

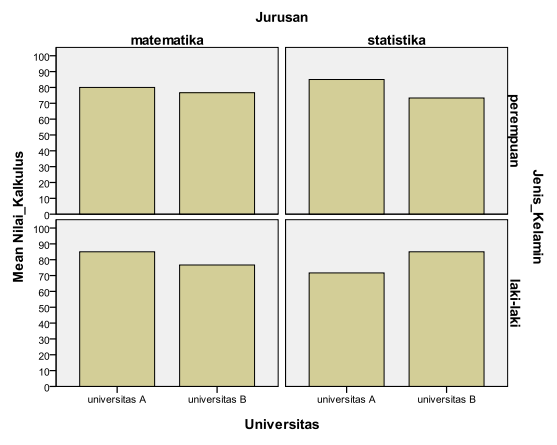

Gambar 3.4

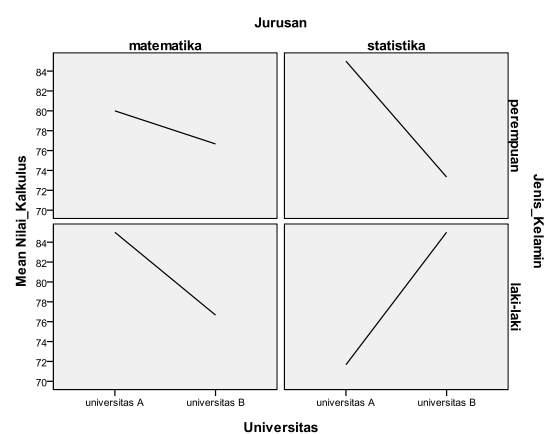

Gambar 3.5

Gambar 3.6 dan Gambar 3.7 merupakan tampilan grafik berdasarkan jenis peringkasan Summaries of separate variables berdasarkan data pada Tabel 3.1. 


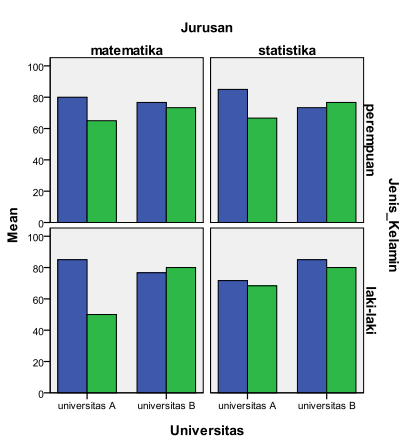

Gambar 3.6

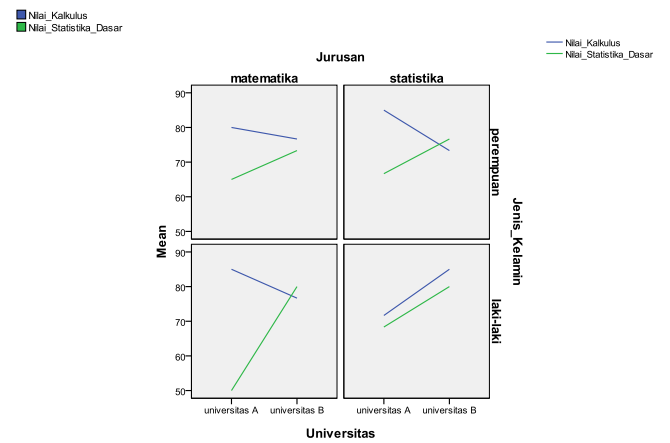

Gambar 3.7

Gambar 3.8 dan Gambar 3.9 merupakan tampilan grafik berdasarkan jenis peringkasan Values of individual cases berdasarkan data pada Tabel 3.1.

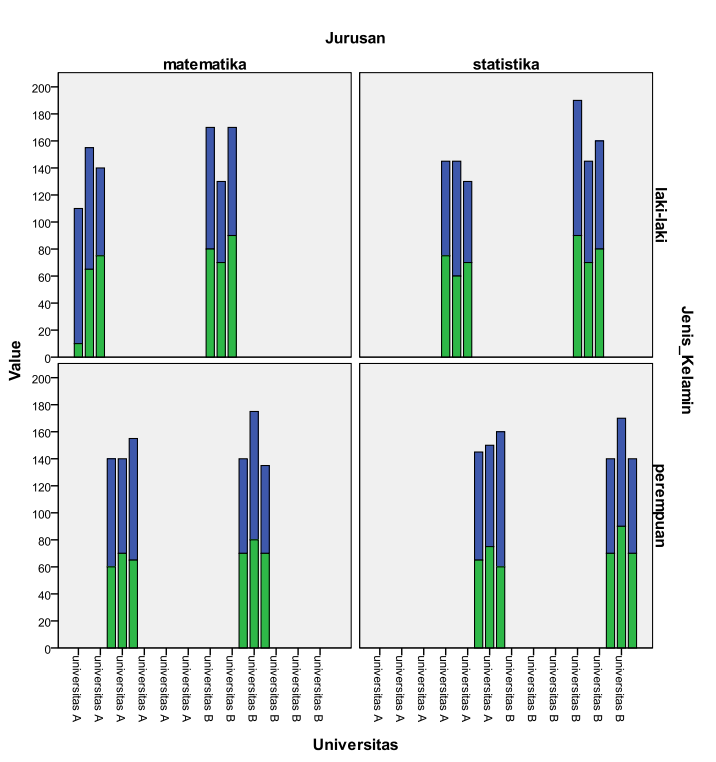

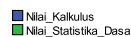

Gambar 3.8

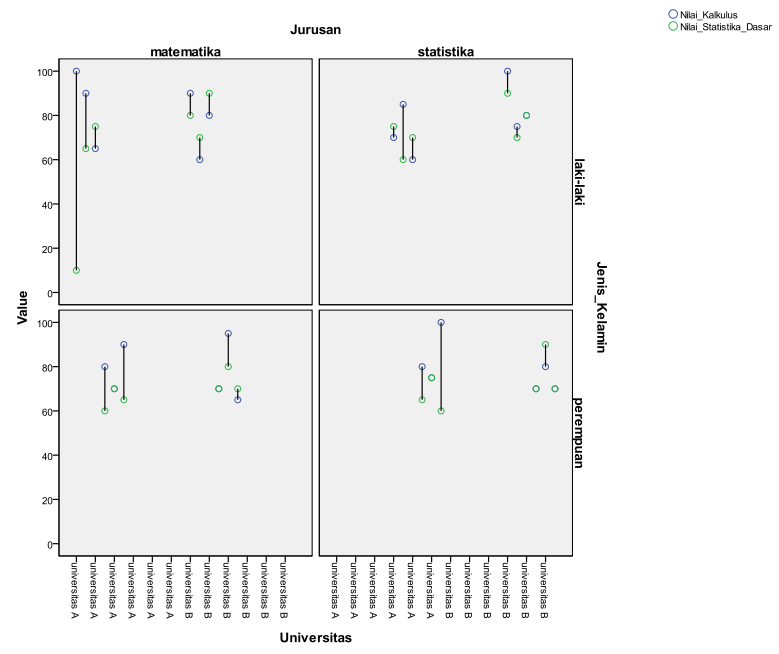

Gambar 3.9 


\section{Summaries for Groups of Cases}

Peringkasan data berdasarkan Summaries for groups of cases merupakan suatu jenis peringkasan data yang meringkas data hanya menggunakan/melibatkan satu variabel. Berikut diberikan ilustrasi penggunaan Summaries for groups of cases.

Bangun data pada Tabel 3.1 dalam SPSS (Gambar 3.10). Pada Gambar 3.10, jumlah data sebenarnya adalah 24, namun karena keterbatasan tampilan hanya tampak 17 data. Setelah data pada Tabel 3.1 dibangun dalam SPSS, pilih Graphs $=>$ Legacy Dialogs => Bar (Gambar 3.11), sehingga muncul kotak dialog Bar Charts (Gambar 3.12). Dalam hal ini, data akan disajikan dalam grafik batang terlebih dahulu.

\begin{tabular}{|c|c|c|c|c|}
\hline & universitas & jurusan & jenis_kelamin & nilai_kalkulus nilai_statistika_dasar \\
\hline 1 & universitas A & matematika & laki laki & 100 \\
\hline 2 & universitas $\mathrm{A}$ & matematika & perempuan & 65 \\
\hline 3 & universitas $\mathrm{A}$ & matematika & laki laki & 75 \\
\hline 4 & universitas A & matematika & perempuan & 60 \\
\hline 5 & universitas $\mathrm{A}$ & matematika & laki laki & 70 \\
\hline 6 & universitas A & matematika & perempuan & Untuk variabel universita \\
\hline 7 & universitas A & statistika & laki laki & kode angka 1 untuk \\
\hline 8 & universitas A & statistika & perempuan & universitas A, kode ang \\
\hline 9 & universitas $\mathrm{A}$ & statistika & laki laki & untuk label universitas B. \\
\hline 10 & universitas A & statistika & perempuan & juga untuk variabel jurus \\
\hline 11 & universitas $\mathrm{A}$ & statistika & laki laki & in heri nenok \\
\hline 12 & universitas A & statistika & perempuan & \\
\hline 13 & universitas B & matematika & \multirow{4}{*}{\multicolumn{2}{|c|}{$\begin{array}{l}\text { Untuk variabel nilai_kalkulus dan } \\
\text { nilai_statistika_dasar gunakan } \\
\text { tipe data Numeric. }\end{array}$}} \\
\hline 14 & universitas B & matematika & & \\
\hline 15 & universitas B & matematika & & \\
\hline 16 & universitas B & matematika & & \\
\hline \multirow[t]{2}{*}{17} & universitas B & matematika & laki laki & 95 \\
\hline & 4 & & & \\
\hline Data View & Variable View & & & \\
\hline
\end{tabular}

\section{Gambar 3.10}

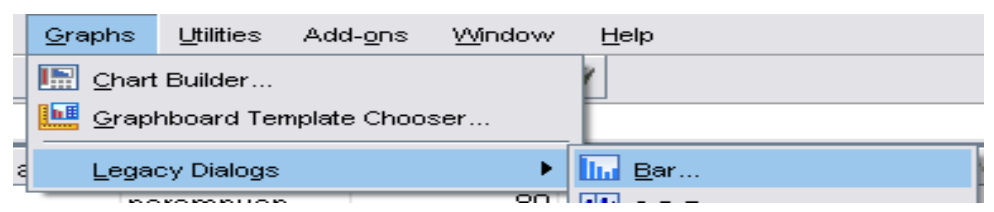

Gambar 3.11

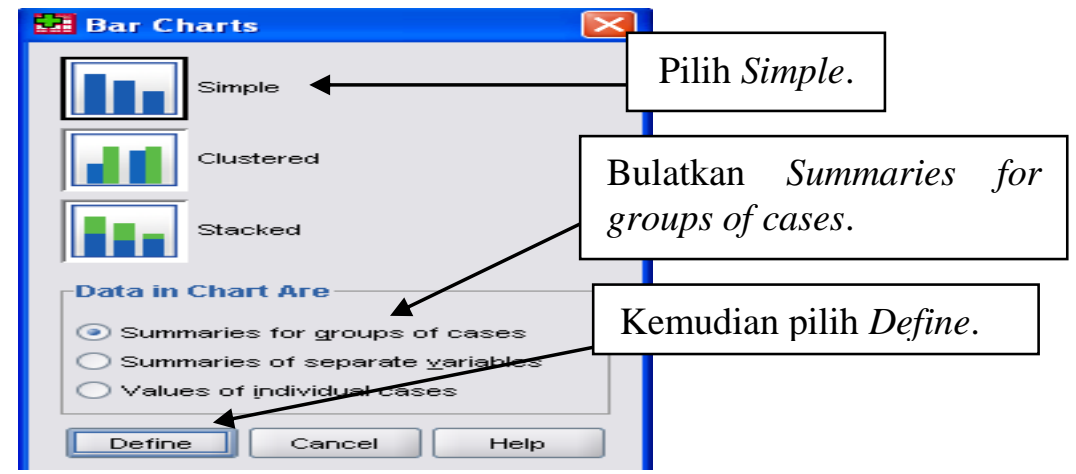

Gambar 3.12 
Pada Gambar 3.12 atau kotak Bar Charts, pilih Simple, dan bulatkan/pilih Summaries for groups of cases. Kemudian pilih Define, sehingga muncul kotak dialog Define Simple Bar: Summaries for Groups of Cases (Gambar 3.13).

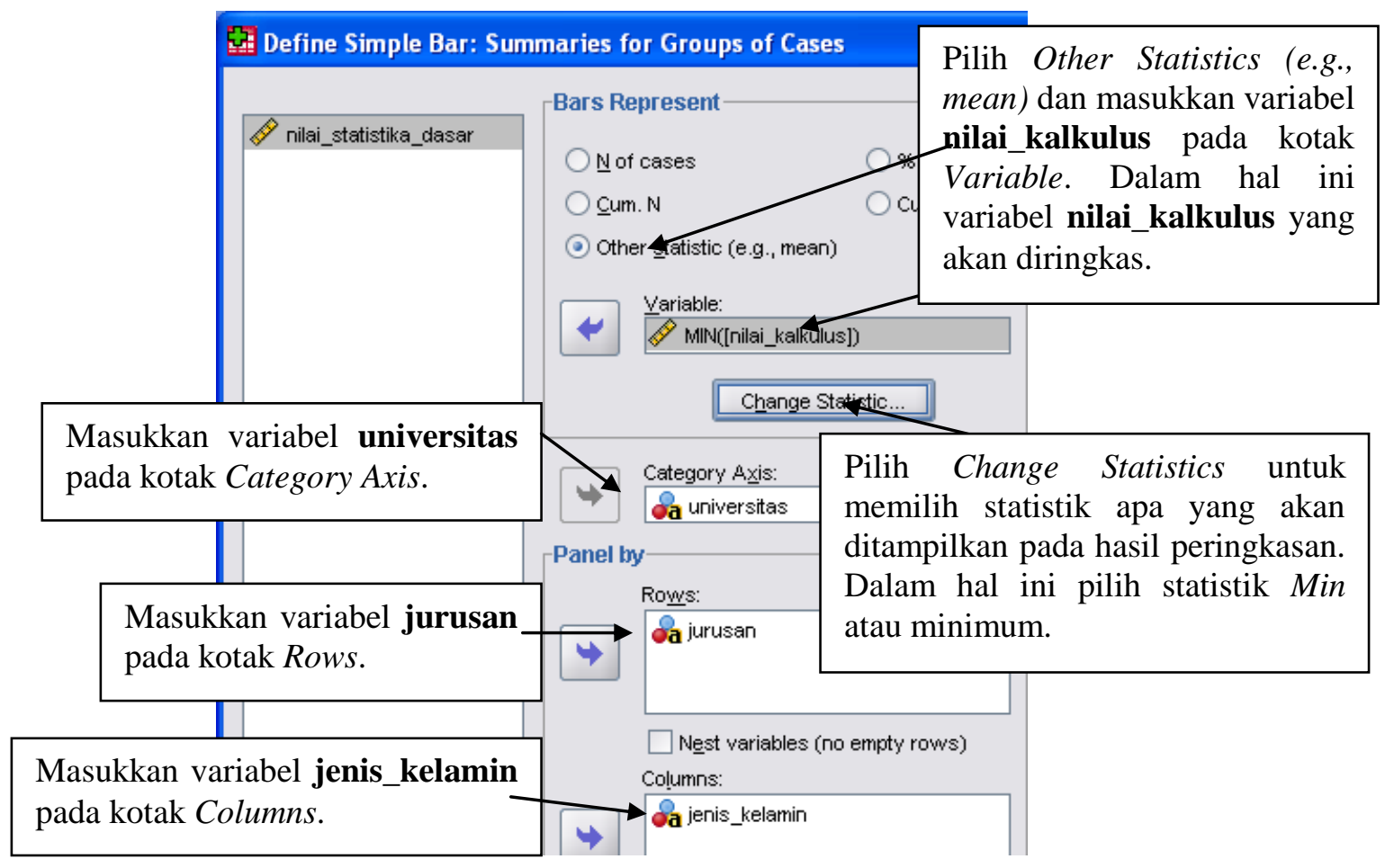

Gambar 3.13

Pada Gambar 3.13, pilih Other Statistics (e.g., mean) dan masukkan variabel nilai_kalkulus pada kotak Variable. Dalam hal ini, variabel nilai_kalkulus yang akan diringkas. Pilih Change Statistics untuk memilih statistik yang akan ditampilkan pada hasil peringkasan. Dalam hal ini, pilih statistik Min atau minimum. Masukkan variabel universitas pada kotak Category Axis, variabel jurusan pada kotak Rows, dan variabel jenis_kelamin pada kotak Column. Kemudian pilih OK, sehingga hasilnya terlihat pada Gambar 3.14.

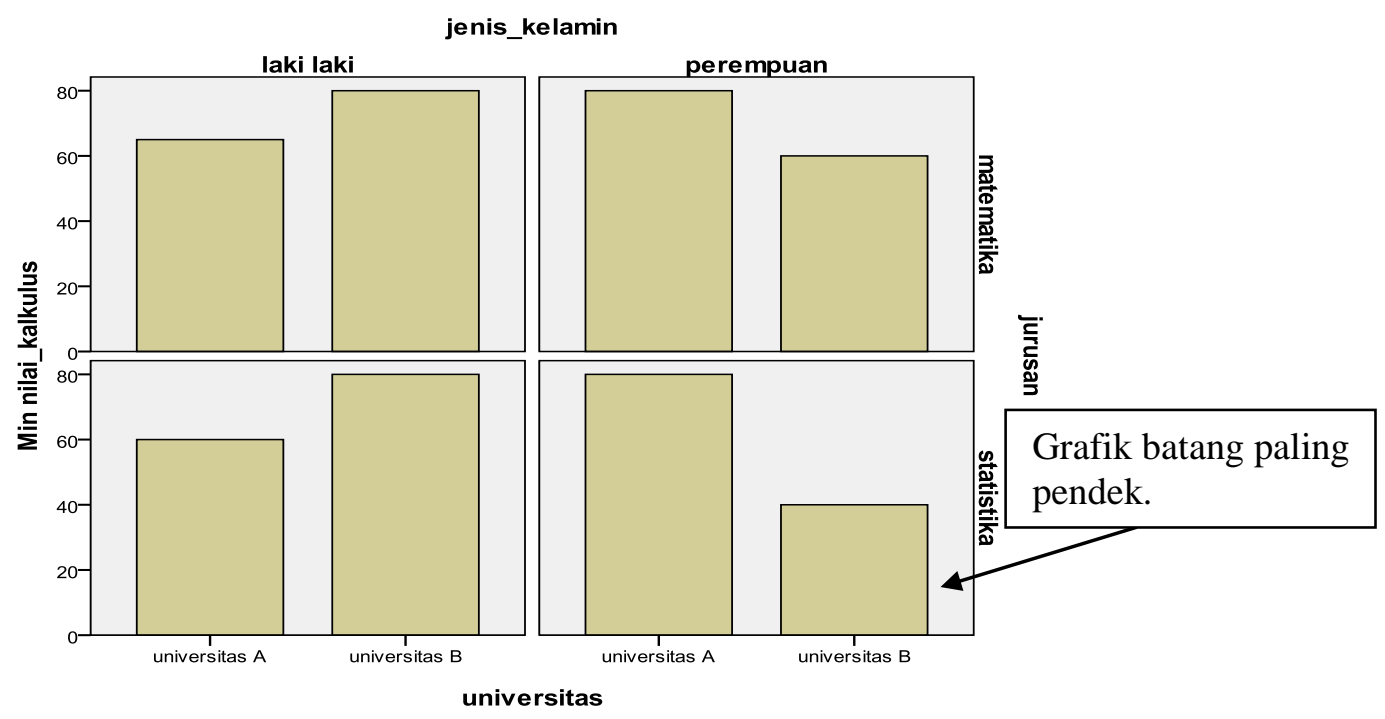

Gambar 3.14 
Berdasarkan grafik batang pada Gambar 3.14, dapat ditarik suatu informasi bahwa nilai ujian kalkulus paling rendah terletak pada Universitas B, Jurusan Statistika, dan berjenis kelamin perempuan, yakni dengan nilai 40. Perhatikan bahwa grafik batang tersebut paling pendek. Hal ini juga bisa dilihat pada data Tabel 3.1 dengan nomor 24, yakni Universitas B, Jurusan Statistika, dan jenis kelamin perempuan. Nilai ujian kalkulus tersebut adalah 40 dan nilai tersebut adalah nilai yang paling rendah (minimum).

Penyajian grafik sebelumnya disajikan dengan grafik batang. Untuk menyajikan data dengan grafik garis, pilih Graphs => Legacy Dialogs => Line (Gambar 3.15), sehingga muncul kotak dialog Line Charts. Pada kotak dialog Line Charts, pilih Simple dan bulatkan/pilih Summaries for groups of cases. Kemudian pilih Define, sehingga muncul kotak dialog Define Simple Line: Summaries for Groups of Cases. Pada kotak Line Represents, pilih Other Statistics (e.g., mean) dan masukkan variabel nilai_kalkulus pada kotak Variable. Dalam hal ini, variabel nilai_kalkulus yang akan diringkas. Pilih Change Statistics untuk memilih statistik yang akan ditampilkan pada hasil peringkasan. Dalam hal ini, pilih statistik Min atau minimum.

\begin{tabular}{|c|c|c|c|c|c|}
\hline ialyze & Graphs & Untilities & Add-gns & Window & 브elp \\
\hline 40 & \multicolumn{4}{|c|}{$\begin{array}{l}\text { 国 Chart Builder... } \\
\text { Graphboard Template Chooser... }\end{array}$} & 1 \\
\hline jurusa & LEege & Cy Dialogs & & $\bullet$ & In Ear... \\
\hline istika & & rempuan & & 80 & Hit $\underline{3}-\mathrm{D}$ Bar... \\
\hline istika & & রi laki & & 75 & $\$$ Line... \\
\hline
\end{tabular}

Gambar 3.15

Masukkan variabel universitas pada kotak Category Axis, variabel jurusan pada kotak Rows, dan variabel jenis_kelamin pada kotak Column. Kemudian pilih OK. Hasilnya diperlihatkan pada Gambar 3.16.

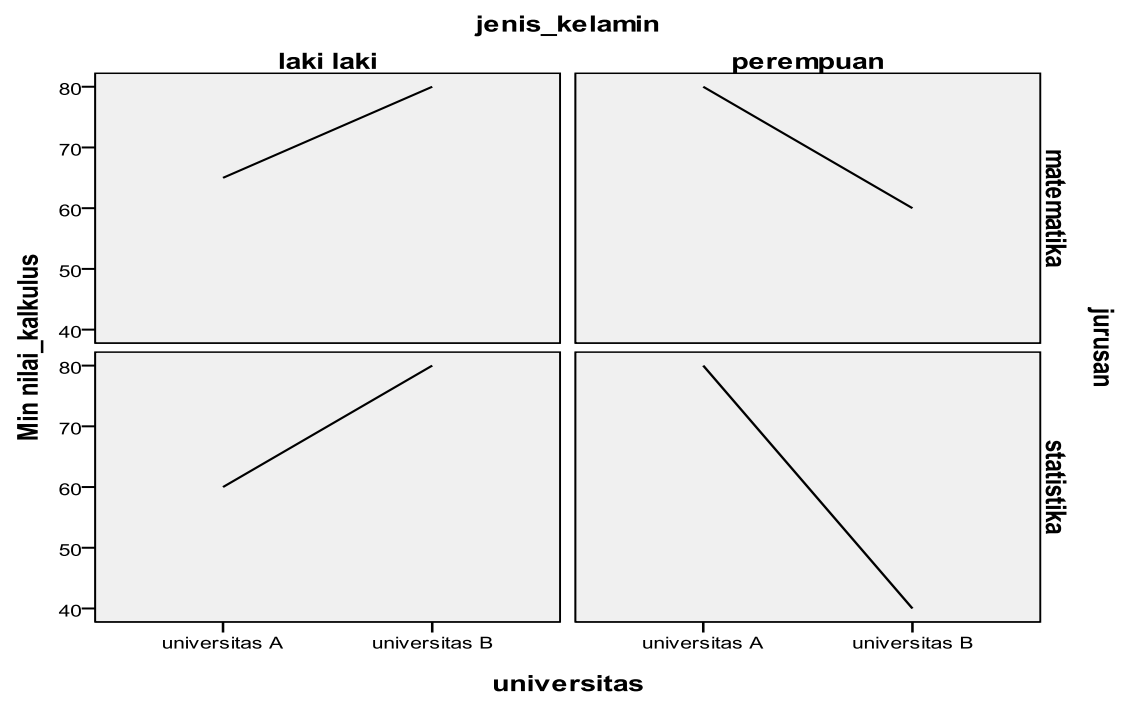

Gambar 3.16

Berdasarkan grafik garis pada Gambar 3.16, dapat ditarik suatu informasi bahwa nilai ujian kalkulus paling rendah terletak pada Universitas B, Jurusan Statistika dan berjenis kelamin perempuan, yakni dengan nilai 40 . 


\section{Summaries of Separate Variables}

Berikut diberikan ilustrasi penggunaan peringkasan Summaries of separate variables. Bangun data pada Tabel 3.1 dalam SPSS. Kemudian pilih Graphs => Legacy Dialogs => Bar, sehingga muncul kotak dialog Bar Charts (Gambar 3.17). Pada kotak dialog Bar Charts, pilih Clustered dan bulatkan Summaries of separate variables. Selanjutnya pilih Define, sehingga muncul kotak dialog Define Clustered Bar: Summaries of Separate Variables (Gambar 3.18). Pada Gambar 3.18, masukkan variabel nilai_kalkulus dan nilai_statistika_dasar. Kemudian pilih Change Statistics. Pada kotak Statistics, pilih Minimum Value. Dalam hal ini, statistik yang ditampilkan adalah nilai minimum. Masukkan variabel universitas pada kotak Category Axis, variabel jurusan pada kotak Rows, dan variabel jenis_kelamin pada kotak Columns. Kemudian pilih OK. Hasilnya terlihat pada Gambar 3.19.

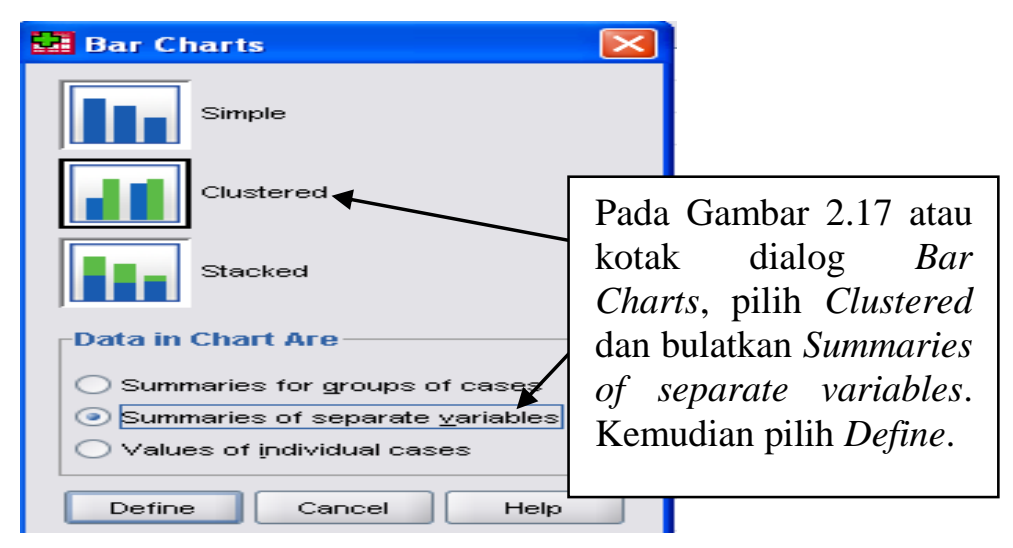

Gambar 3.17

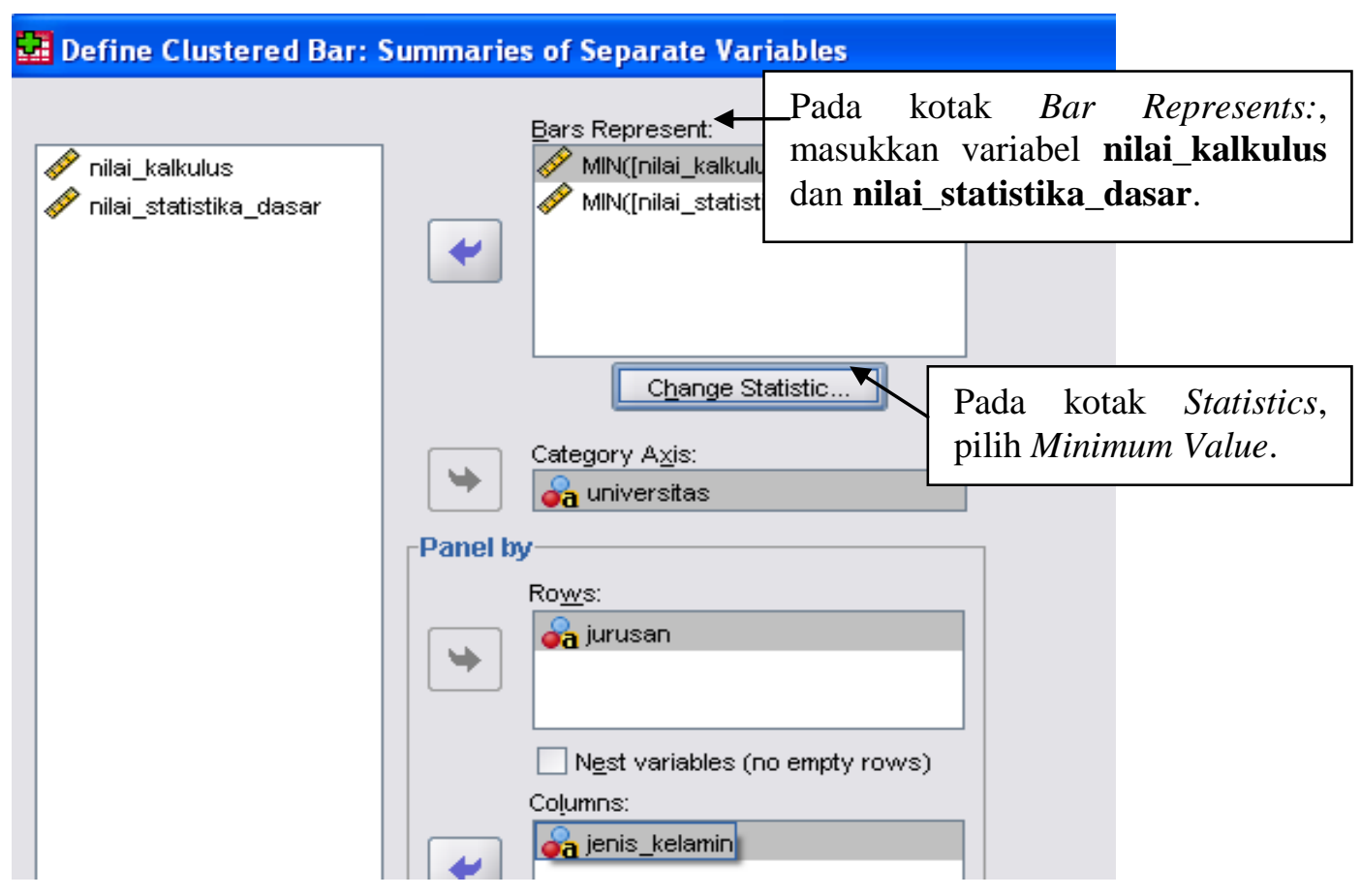

Gambar 3.18 


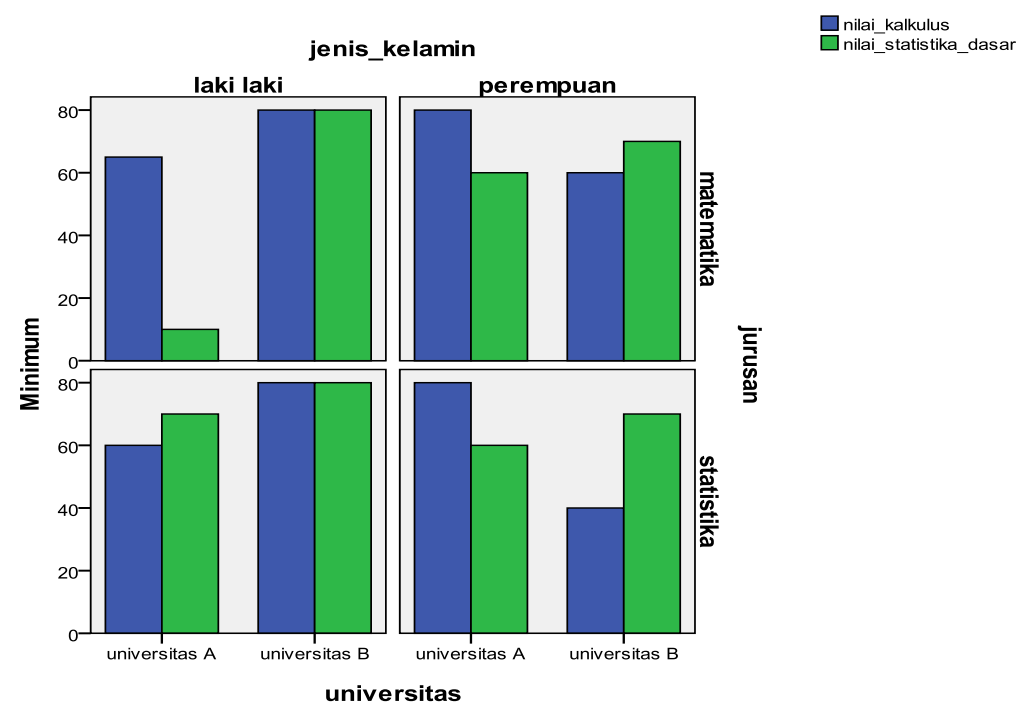

Gambar 3.19

Berdasarkan Gambar 3.19, dapat ditarik suatu informasi bahwa pada Universitas A, Jurusan Matematika, dan jenis kelamin laki-laki memiliki nilai minimum 10 pada matakuliah statistika dasar, sedangkan untuk jenis kelamin perempuan memiliki nilai minimum 60 .

Selain itu pada Universitas B, untuk Jurusan Matematika dan Statistika, berjenis kelamin lakilaki memperoleh nilai minimum 80 pada matakuliah kalkulus dan statistika dasar. Penyajian grafik sebelumnya disajikan dengan grafik batang. Untuk menyajikan data dengan grafik garis, pilih Graphs => Legacy Dialogs => Line, sehingga muncul kotak dialog Line Charts.

Pada kotak dialog Line Charts, pilih Multiple, bulatkan Summaries of separate variables, serta pilih Define, sehingga muncul kotak dialog Define Multiple Line: Summaries of Separates Variables (Gambar 3.20). Pada Gambar 3.20, yakni pada kotak Line Represents, masukkan variabel nilai_kalkulus dan nilai_statistika_dasar. Kemudian pilih Change Summary. Pada kotak Statistics, pilih Minimum Value. Dalam hal ini, statistik yang akan ditampilkan adalah nilai minimum. Pada kotak Category Axis, masukkan variabel universitas. Pada kotak Rows, masukkan variabel jurusan. Variabel jenis_kelamin dimasukkan pada kotak Columns. Kemudian pilih OK. Hasilnya terlihat pada Gambar 3.21.

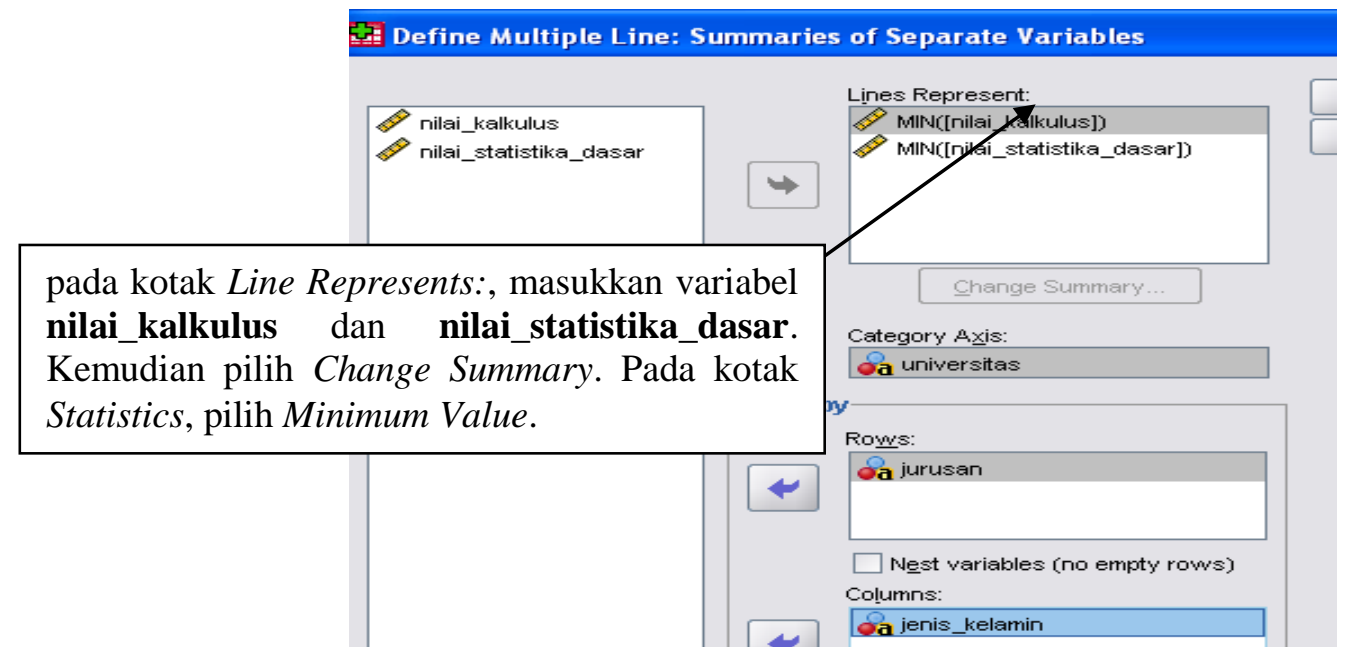

Gambar 3.20 


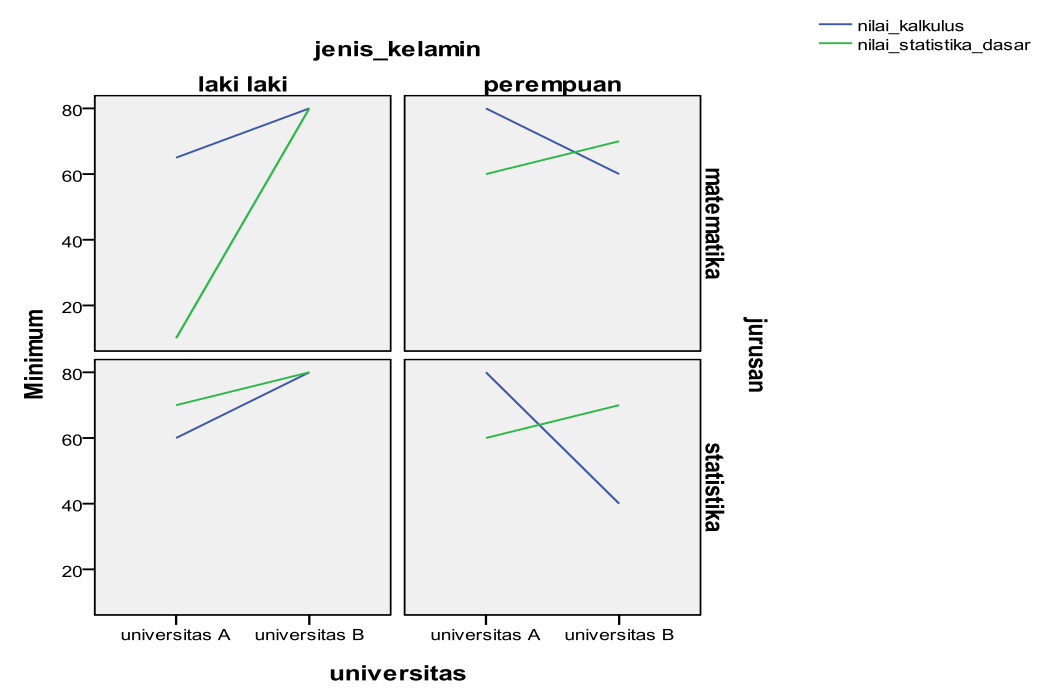

Gambar 3.21

Berdasarkan Gambar 3.21, dapat ditarik suatu informasi bahwa pada Universitas A, Jurusan Matematika, dan jenis kelamin laki-laki memperoleh nilai statistika dasar paling rendah, yakni 10. Selain itu, pada Universitas B, Jurusan Matematika dan Statistika, dan jenis kelamin laki-laki memperoleh nilai minimum 80 pada matakuliah kalkulus dan statistika dasar.

\section{Values of Individual Cases}

Berikut diberikan ilustrasi penggunaan peringkasan Values of individual cases. Bangun data pada Tabel 3.1 dalam SPSS. Kemudian pilih Graphs $=>$ Legacy Dialogs => Bar, sehingga muncul kotak dialog Bar Charts. Pada kotak dialog Bar Charts, pilih Stacked dan bulatkan Values of individual cases. Kemudian pilih Define, sehingga muncul kotak dialog Define Stacked Bar: Values of Individual Cases (Gambar 3.22).

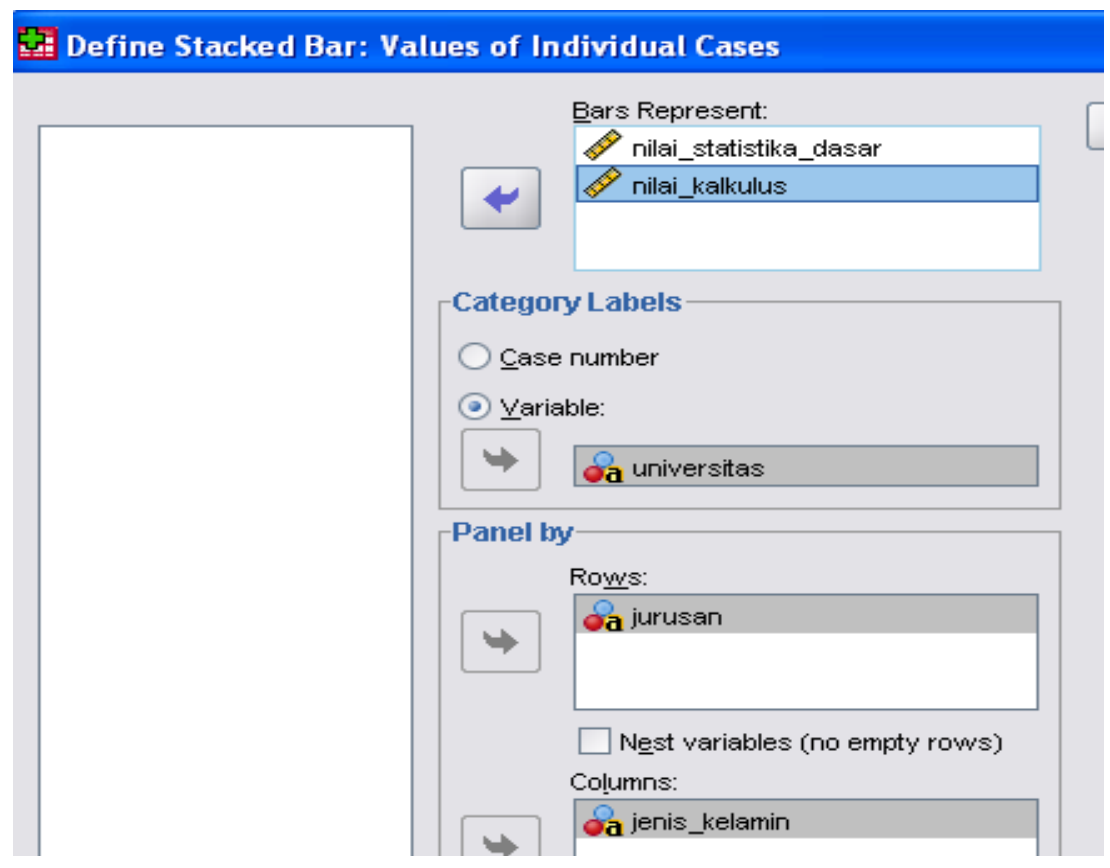

Gambar 3.22 
Pada Gambar 3.22, masukkan variabel nilai_statistika_dasar dan nilai_kalkulus pada kotak Bars Represent. Pada Category Labels, bulatkan Variable dan masukkan variabel universitas. Pada Rows, masukkan variabel jurusan. Pada Columns, masukkan variabel jenis_kelamin. Kemudian pilih OK. Hasilnya diperlihatkan pada Gambar 3.23.

Perhatikan bahwa peringkasan berdasarkan variabel nilai ujian kalkulus dan statistika dasar. Nilai-nilai dari setiap individu tersaji pada setiap batang. Karena jumlah individu sebanyak 24, maka jumlah batang juga sebanyak 24 batang. Setiap batang memberikan informasi dua buah nilai, yakni nilai ujian kalkulus dan statistika dasar. Individu pertama dari universitas A, jenis kelamin laki-laki, dan jurusan matematika memperoleh nilai ujian kalkulus 100 dan statistika dasar 10.

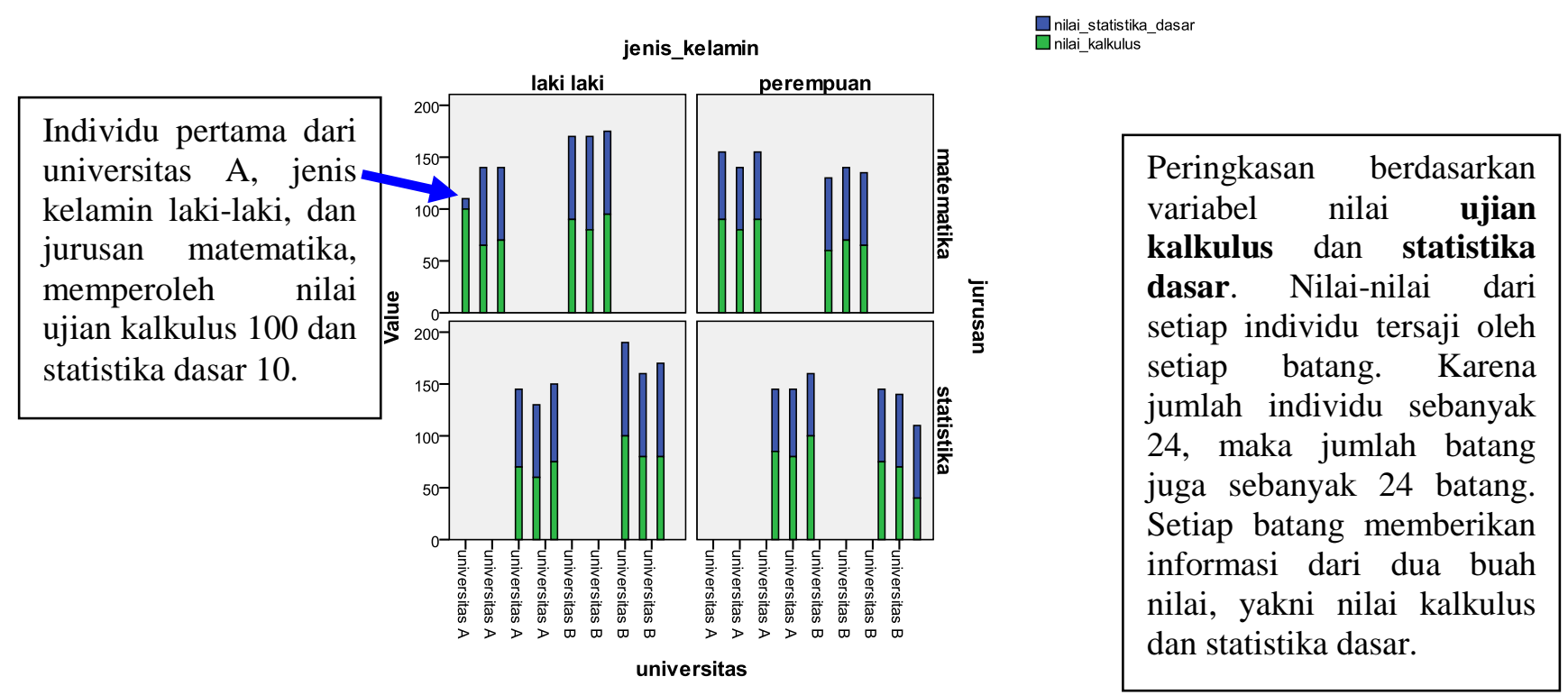

Gambar 3.23

Untuk menyajikan secara grafik garis, langkah-langkah yang dilakukan hampir sama seperti penyajian secara grafik batang. Pilih Graphs $=>$ Legacy Dialogs $=>$ Line, sehingga muncul kotak dialog Line Charts. Pada kotak dialog Line Charts, pilih Drop-Line dan bulatkan Values of individual cases. Kemudian pilih Define, sehingga muncul kotak dialog Define Drop-Line: Values of Individual Cases (Gambar 3.24).

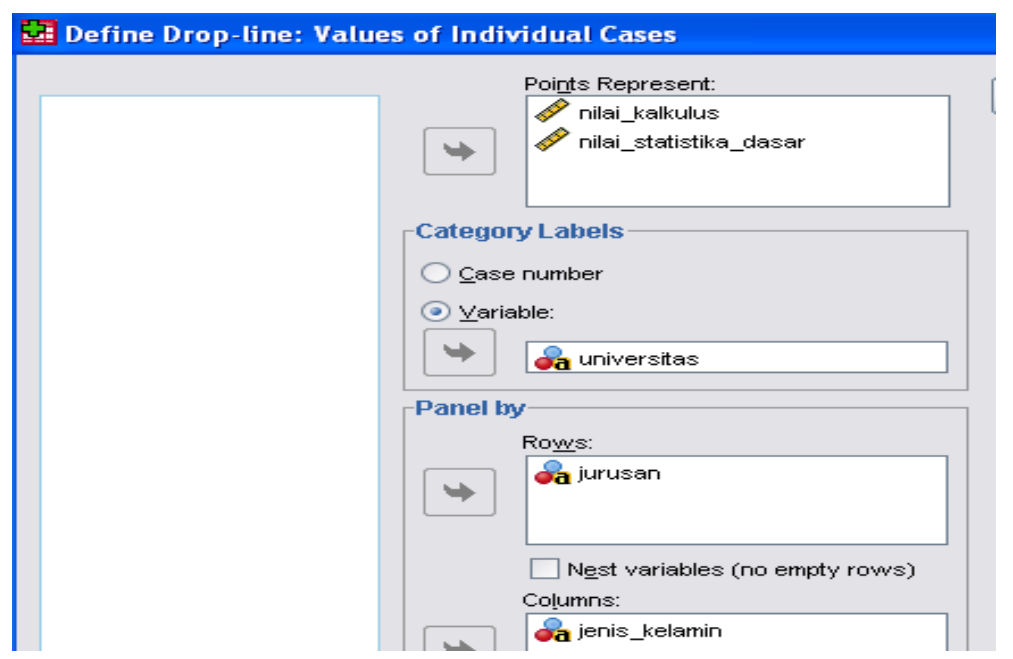

Gambar 3.24 
Pada Gambar 3,24, masukkan variabel nilai_kalkulus dan nilai_statistika_dasar pada kotak Points Represents. Pada kotak Category Labels, bulatkan Variable: dan masukkan variabel universitas. Pada kotak Rows, masukkan variabel jurusan. Pada kotak Columns, masukkan variabel jenis_kelamin. Kemudian pilih OK. Hasilnya diperlihatkan pada Gambar 3.25.

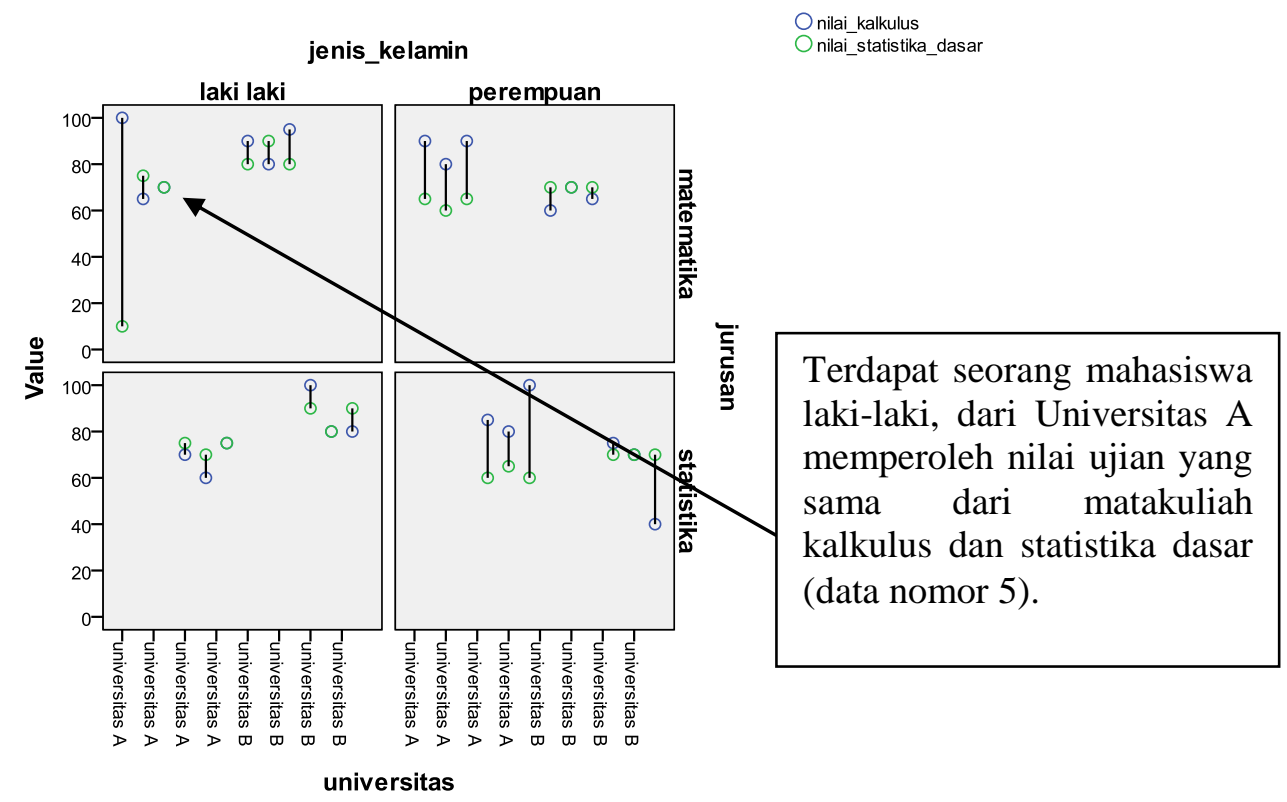

Gambar 3.25

\section{oLAPP Cubes}

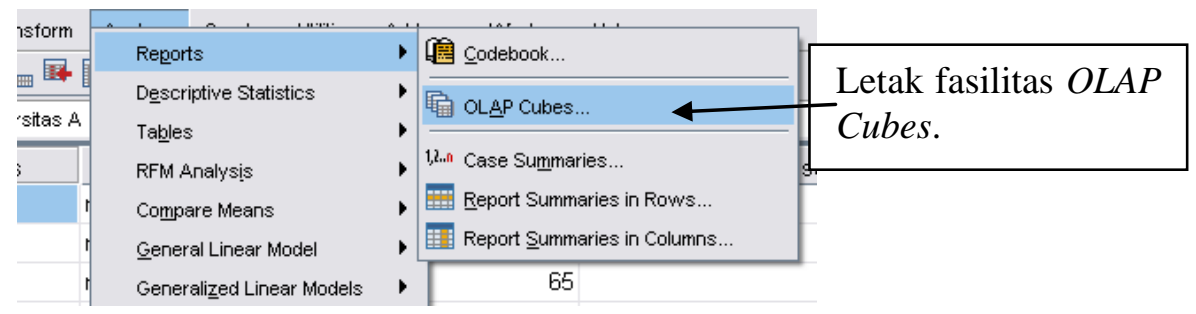

Gambar 3.26

Pada pembahasan sebelumnya, telah dipelajari bagaimana cara menyajikan data dalam bentuk grafik, baik itu grafik batang maupun grafik garis. Suatu data juga dapat disajikan dalam bentuk tabel. OLAP Cubes merupakan fasilitas yang terdapat dalam SPSS untuk menyajikan data dalam bentuk tabel.

Tabel 3.2

OLAP Cubes

universitas:universitas B

jurusan:statistika

jenis_kelamin:laki laki

\begin{tabular}{|l|r|r|r|r|r|}
\hline & \multicolumn{1}{|c|}{ Sum } & Mean & Std. Deviation & Minimum & Maximum \\
\hline nilai_kalkulus & 260 & 86.67 & 11.547 & 80 & 100 \\
nilai_statistika_dasar & 260 & 86.67 & 5.774 & 80 & 90 \\
\hline
\end{tabular}


Berbeda dengan penyajian data secara grafik yang hanya dapat menampilkan informasi dari satu ukuran statistik, pada OLAP Cubes dapat menyajikan lebih dari satu ukuran statistik, seperti mean, median, modus, minimum, dan sebagainya. Tabel 3.2 merupakan hasil dari penggunaan fasilitas OLAP Cubes. Perhatikan bahwa pada Tabel 3.2, penyajian infomasi lebih dari satu ukuran statistik, yakni sum, mean, std. deviation, minimum dan maximum. Berdasarkan Tabel 3.2, dapat ditarik suatu informasi bahwa pada Universitas B, Jurusan Statistika dan jenis kelamin laki-laki memperoleh nilai kalkulus minimum 80 dan maksimum 100 .

Tabel 3.3

\begin{tabular}{|c|c|c|c|c|c|}
\hline \multirow{2}{*}{$\begin{array}{l}\text { universitas:universitas A } \\
\text { jurusan:statistika } \\
\text { jenis_kelamin:laki laki }\end{array}$} & \multicolumn{3}{|c|}{ OLAP Cubes } & \multicolumn{2}{|c|}{$\begin{array}{l}\text { Klik dua kali secara cepat } \\
\text { untuk mengubah informasi } \\
\text { berdasarkan universtias, } \\
\text { jurusan, dan jenis kelamin. }\end{array}$} \\
\hline & sum & INean & Std. Deviation & Minımum & Maximum \\
\hline nilai_kalkulus & 205 & 68.33 & 7.638 & 60 & 75 \\
\hline nilai_statistika_dasar & 220 & 73.33 & 2.887 & 70 & 75 \\
\hline
\end{tabular}

Berdasarkan Tabel 3.3, dapat ditarik suatu informasi bahwa pada Universitas A, Jurusan Statistika dan jenis kelamin laki-laki memperoleh nilai kalkulus minimum 60 dan maksimum 75 .

Berikut akan diberikan ilustrasi penggunaan dari fasilitas OLAP Cubes dalam SPSS. Bangun data pada Tabel 3.1 dalam SPSS. Kemudian pilih Analyze $=>$ Reports $=>$ OLAP Cubes (Gambar 3.26), sehingga muncul kotak dialog OLAP Cubes (Gambar 3.27).

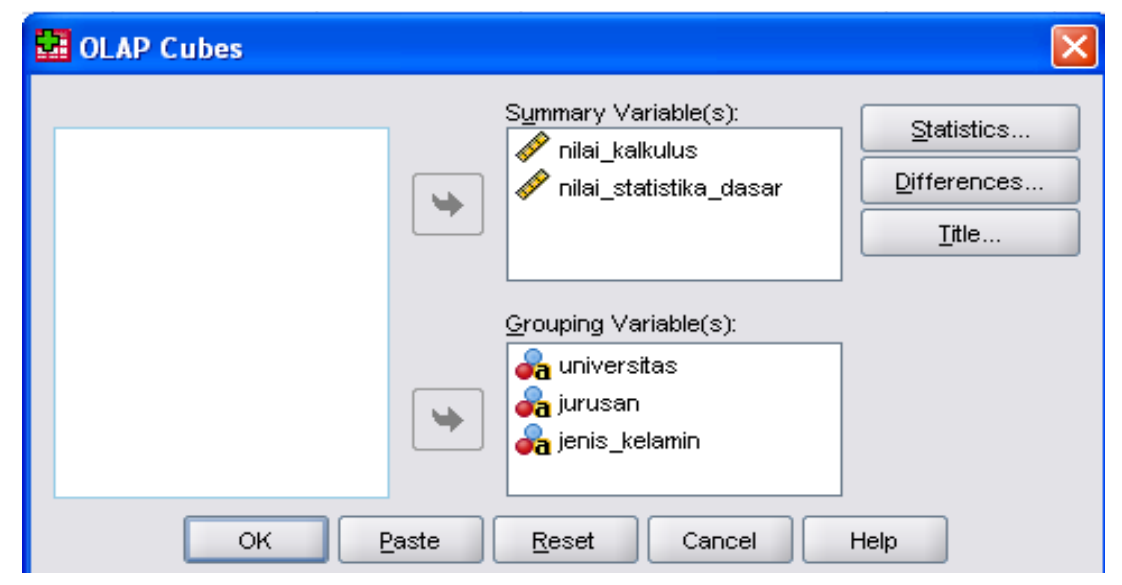

\section{Gambar 3.27}

Pada Gambar 3.27, masukkan variabel nilai_kalkulus dan nilai_statistika_dasar pada kotak Summary Variable(s). Kemudian masukkan variabel universitas, jurusan, dan jenis_kelamin pada kotak Grouping Variable(s). Selanjutnya pilih Statistics, sehingga muncul kotak dialog OLAP Cubes: Statistics (Gambar 3.28). Pada Gambar 3.28, masukkan statistik Sum, Mean, Standard Deviation, Minimum dan Maximum pada kotak Cell Statistics,. Kemudian pilih Continue dan OK. Hasilnya tersaji pada Tabel 3.4. 


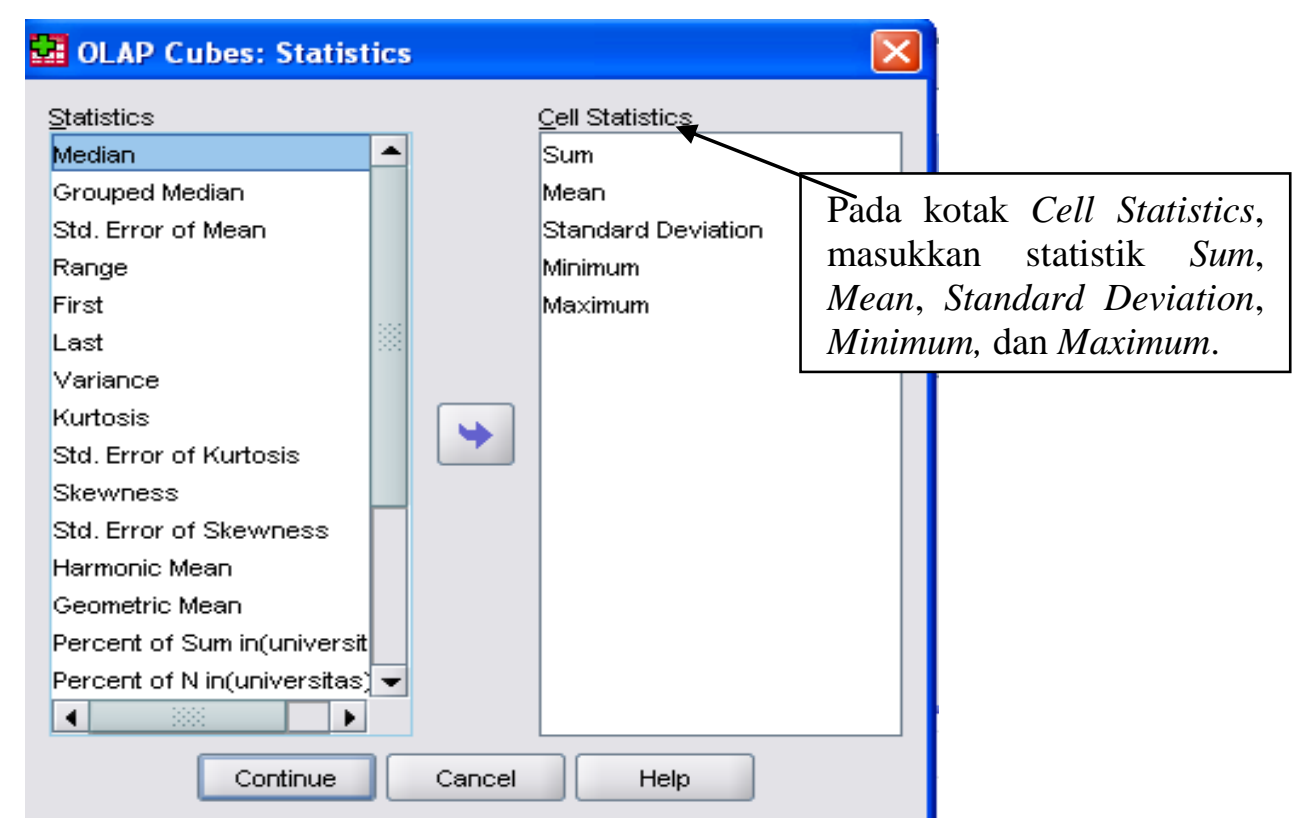

Gambar 3.28

Tabel 3.4

\begin{tabular}{|l|r|r|r|r|r|}
$\begin{array}{l}\text { universitas:Total } \\
\text { jurusan:Total } \\
\text { jenis_kelamin:Total }\end{array}$ & \multicolumn{1}{|c|}{$\begin{array}{l}\text { OLAP Cubes } \\
\text { Sum }\end{array}$} & $\begin{array}{l}\text { Klik dua kali secara cepat untuk mengubah } \\
\text { informasi berdasarkan universitas, jurusan, } \\
\text { dan jenis kelamin. }\end{array}$ \\
\hline nilai_kalkulus & 1860 & 77.50 & 15.880 & 30 & 100 \\
nilai_statistika_dasar & 1680 & 70.00 & 15.534 & 10 & 90 \\
\hline
\end{tabular}

\section{Scatter/Dot}

Misalkan diberikan data sebagai berikut (Gambar 3.29).

\begin{tabular}{|r|r|r|r}
\hline & penghasilan & pengeluaran & var \\
\hline 1 & $1,000,000$ & 500,000 & \\
\hline 2 & $1,000,000$ & 800,000 \\
\hline 3 & $1,000,000$ & 650,000 \\
\hline 4 & $1,200,000$ & 700,000 \\
\hline 5 & $1,200,000$ & 850,000 \\
\hline 6 & $1,200,000$ & $1,000,000$ \\
\hline 7 & $1,500,000$ & $1,000,000$ \\
\hline 8 & $1,500,000$ & $1,200,000$ \\
\hline 9 & $1,500,000$ & $1,350,000$ \\
\hline 10 & $1,800,000$ & $1,500,000$ \\
\hline 11 & $1,800,000$ & $1,400,000$ \\
\hline \hline 12 & & \\
\hline & & \\
\hline
\end{tabular}

Gambar 3.29 
Data pada Gambar 3.29 menyajikan informasi mengenai penghasilan dan pengeluaran perbulan dari 11 individu. Individu pertama memperoleh penghasilan per-bulan sebesar Rp. 1.000.000 dan pengeluaran per-bulan sebesar Rp. 500.000. Individu kelima memperoleh penghasilan per-bulan sebesar Rp. 1.200.000 dan pengeluaran per-bulan sebesar Rp. 850.000.

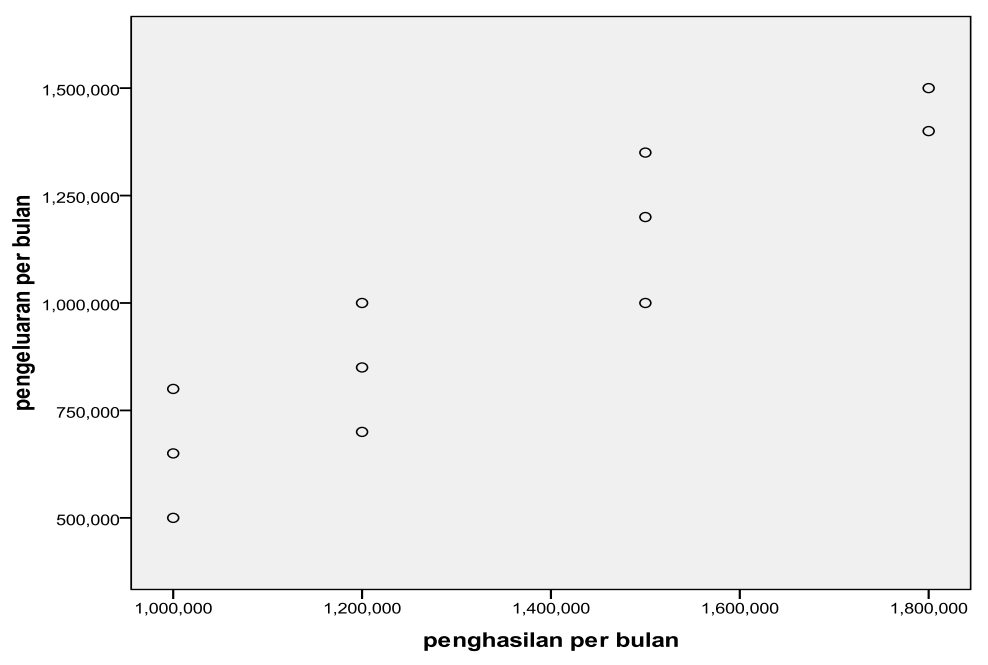

Gambar 3.30

Berdasarkan Gambar 3.30, sumbu horizontal menyatakan penghasilan per-bulan, sedangkan sumbu vertikal menyatakan pengeluaran per-bulan. Titik-titik pada Gambar 3.30 menyatakan penghasilan dan pengeluaran per-bulan. Berdasarkan Gambar 3.30 terlihat suatu pola bahwa semakin tinggi penghasilan per-bulan, maka pengeluaran per-bulan cenderung meningkat. Gambar 3.30 diperoleh dengan menggunakan fasilitas Scatter/Dot dalam SPSS.

Berikut akan diberikan ilustrasi penggunaan dari fasilitas Scatter/Dot dalam SPSS. Bangun data pada Gambar 3.29 dalam SPSS. Kemudian pilih Graphs $\Rightarrow$ Scatter/Dot (Gambar 3.31), sehingga muncul kotak dialog Scatter/Dot (Gambar 3.32). Pada Gambar 3.32, pilih Simple Scatter dan pilih Define, sehingga muncul kotak dialog Simple Scatterplot (Gambar 3.33). Pada Gambar 3.33, masukkan variabel pengeluaran pada $Y$-Axis dan masukkan penghasilan pada $X$-Axis. Kemudian pilih OK. Hasilnya tersaji pada Gambar 3.30.

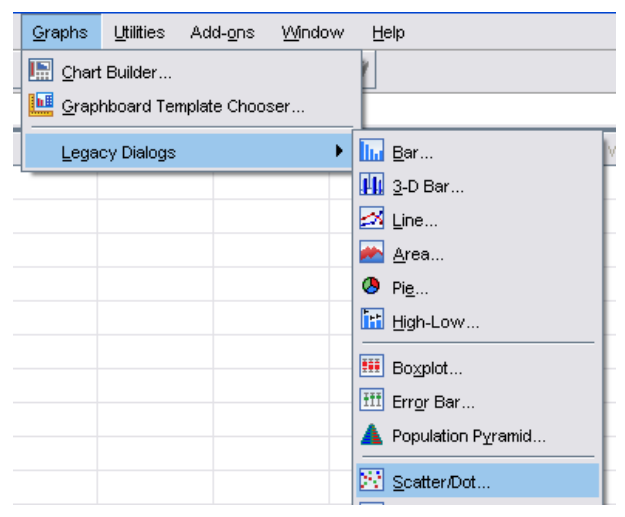

Gambar 3.31 


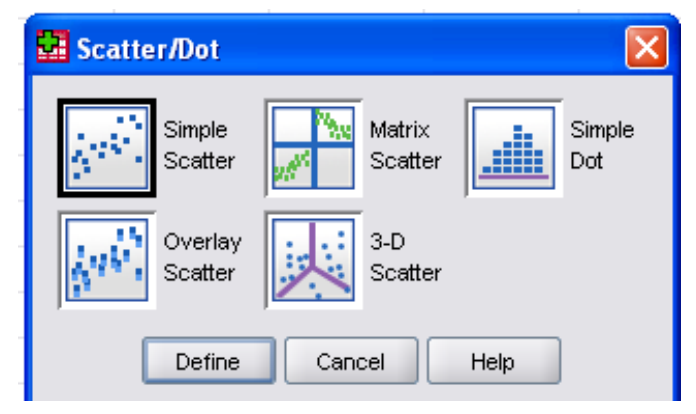

Gambar 3.32

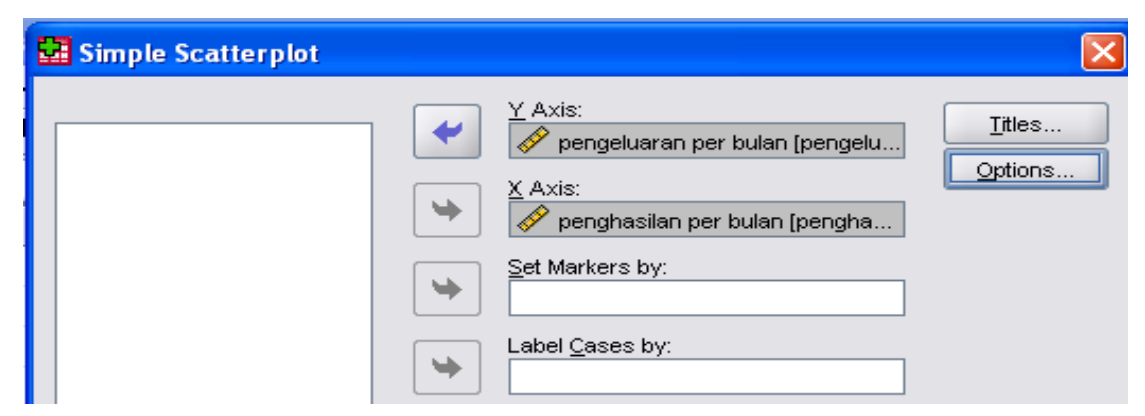

Gambar 3.33

\section{Interactive Histogram}

Misalkan diberikan data sebagai berikut (Tabel 3.5).

Tabel 3.5

\begin{tabular}{|l|l|l|l|l|l|l|l|}
\hline 2 & 2 & 2 & 3 & 3 & 3 & 4 & 4 \\
\hline 4 & 4 & 3 & 3 & 3 & 5 & 5 & 6 \\
\hline
\end{tabular}

Berdasarkan data pada Tabel 3.5, disajikan tabel distribusi frekuensi sebagai berikut (Tabel 3.6).

\section{Tabel 3.6}

\begin{tabular}{|c|c|}
\hline Interval & Frekuensi \\
\hline $1 \leq X<3$ & 3 \\
\hline $3 \leq X<5$ & 10 \\
\hline $5 \leq X<7$ & 3 \\
\hline Total & 16 \\
\hline
\end{tabular}

Andaikan akan dibuat histogram dalam SPSS berdasarkan tabel distribusi frekuensi pada Tabel 3.6 seperti pada Gambar 3.34. Berdasarkan histogram pada Gambar 3.34, diketahui frekuensi pada kelas interval $1 \leq X<3$ adalah 3 , frekuensi pada kelas interval $3 \leq X<5$ adalah 10, dan frekuensi pada kelas interval $5 \leq X<7$ adalah 3 . 


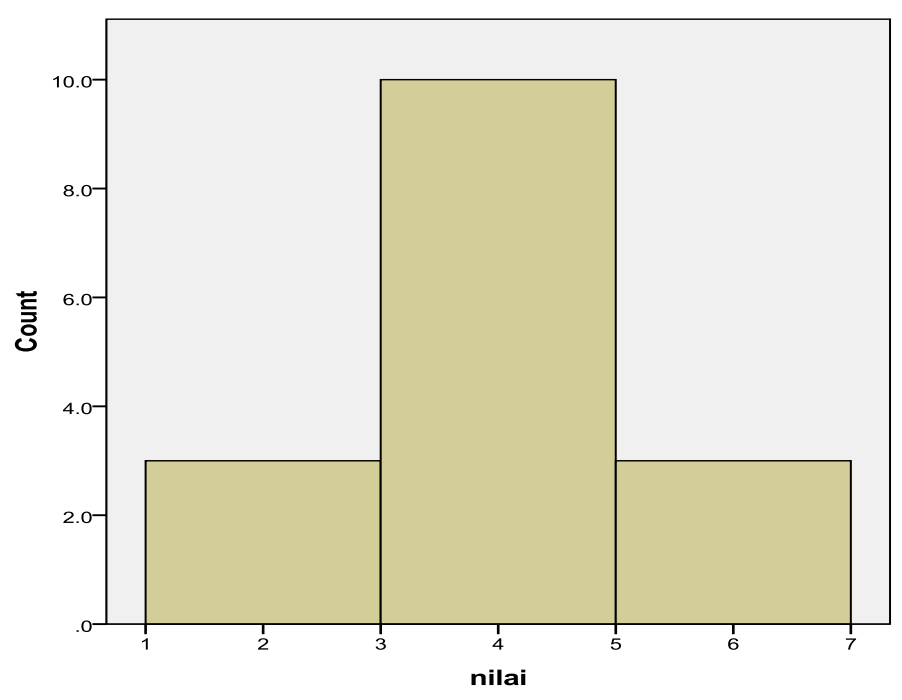

Gambar 3.34

Berikut langkah-langkah untuk membuat histogram pada Gambar 3.34. Bangun data pada Tabel 3.5 dalam SPSS (Gambar 3.35). Selanjutnya pilih Graphs => Legacy Dialogs => Interactive $=>$ Histogram (Gambar 3.36), sehingga muncul kotak dialog Create Histogram (3.37). Selanjutnya pindahkan variabel nilai pada kotak (Gambar 3.37). Kemudian pilih Histogram (Gambar 3.38). Selanjutnya atur Number of intervals menjadi 3, Width of intervals menjadi 2, dan First interval width menjadi 1\%. Kemudian pilih OK. Output histogram tersaji seperti pada Gambar 3.34.

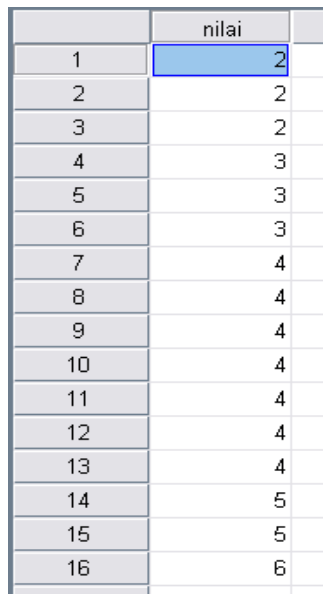

Gambar 3.35

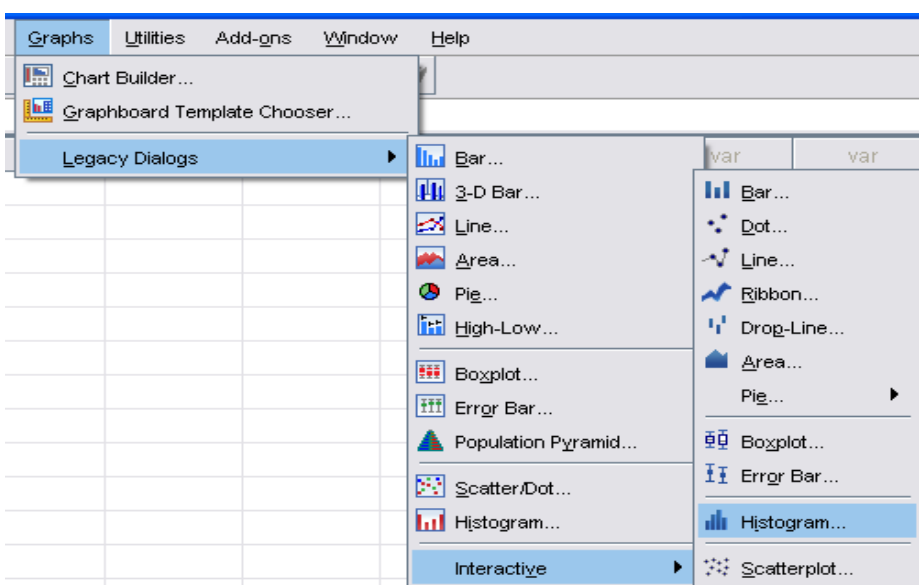

Gambar 3.36

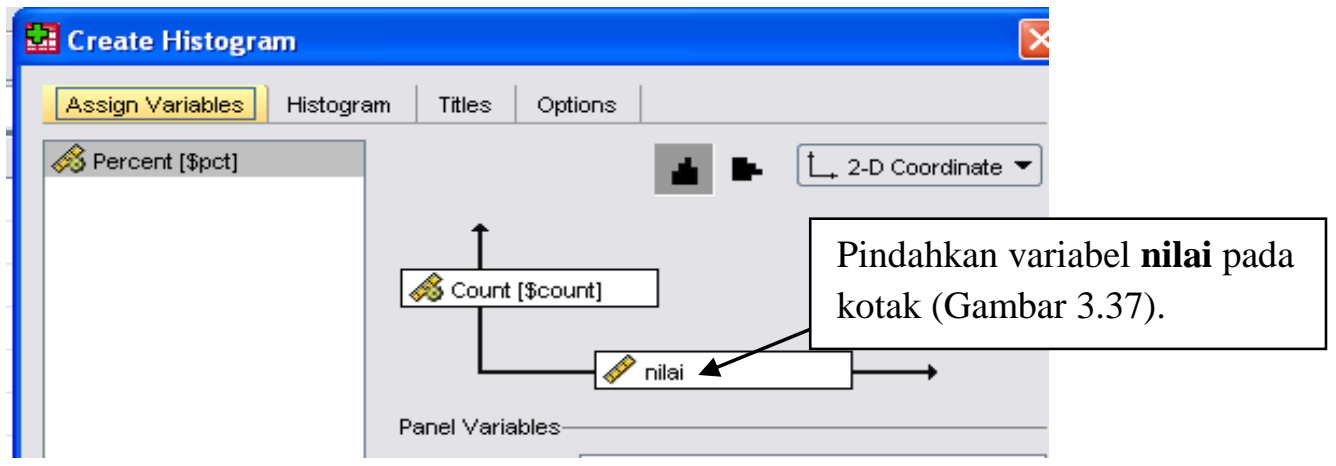

Gambar 3.37 


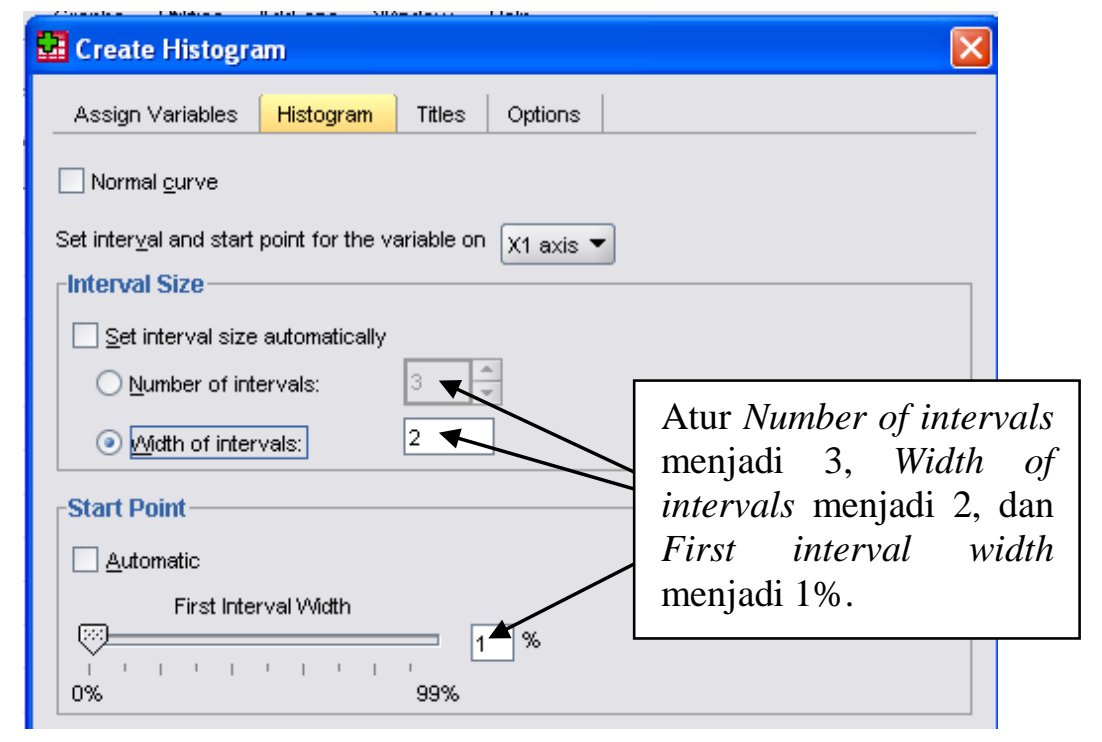

Gambar 3.38

Selanjutnya misalkan diberikan data sebagai berikut.

Tabel 3.7

\begin{tabular}{|l|l|l|l|}
\hline 4 & 7 & 6 & 9 \\
\hline 4 & 7 & 6 & 9 \\
\hline 5 & 7 & 6 & 9 \\
\hline 5 & 7 & 6 & 9 \\
\hline 5 & 8 & 7 & 9 \\
\hline
\end{tabular}

Berdasarkan data pada Tabel 3.7, berikut akan disajikan histogram dalam SPSS dengan interval $3 \leq X<6,6 \leq X<9$, dan $9 \leq X<12$. Bangun data pada Tabel 3.7 dalam SPSS (Gambar 3.39). Selanjutnya pilih Graphs $\Rightarrow$ Legacy Dialogs $\Rightarrow$ Interactive $\Rightarrow>$ Histogram, sehingga muncul kotak dialog Create Histogram (3.40). Selanjutnya pindahkan variabel data pada kotak (Gambar 3.40). Kemudian pilih Histogram (Gambar 3.41). Selanjutnya atur Number of intervals menjadi 3, Width of intervals menjadi 3, dan First interval width menjadi 3\%. Kemudian pilih OK. Output histogram tersaji seperti pada Gambar 3.42.

\begin{tabular}{|c|r|r|r|}
\hline & data & & \\
\hline 1 & 4 & & \\
\hline 2 & 4 & 11 & 7 \\
\hline 3 & 5 & 12 & 7 \\
\hline 4 & 5 & 7 \\
\hline 5 & 5 & 13 & 8 \\
\hline 6 & 6 & 15 & 9 \\
\hline 7 & 6 & 16 & 9 \\
\hline 8 & 6 & 17 & 9 \\
\hline 9 & 6 & 18 & 9 \\
\hline 10 & 7 & 20 & \\
\hline
\end{tabular}

Gambar 3.39 


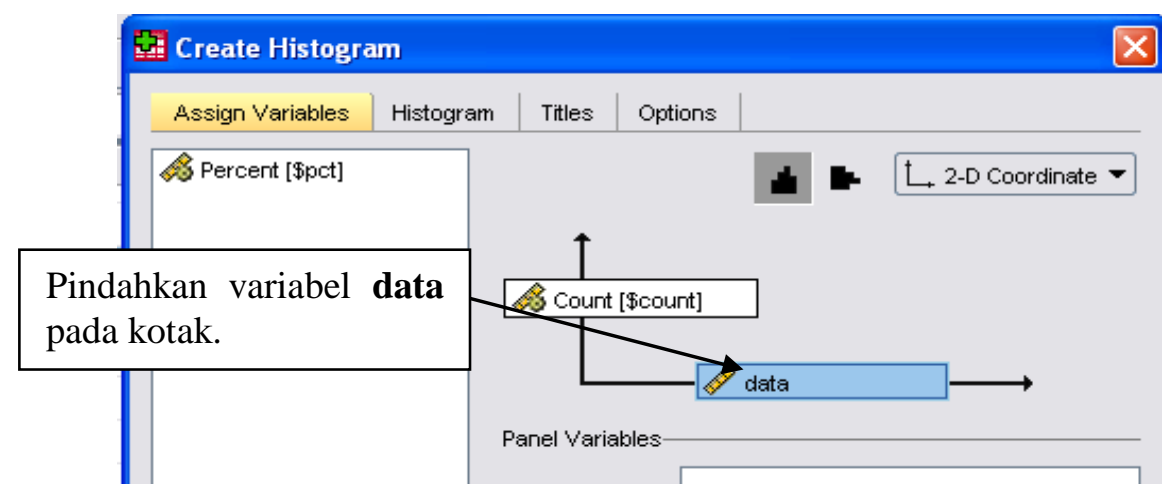

Gambar 3.40

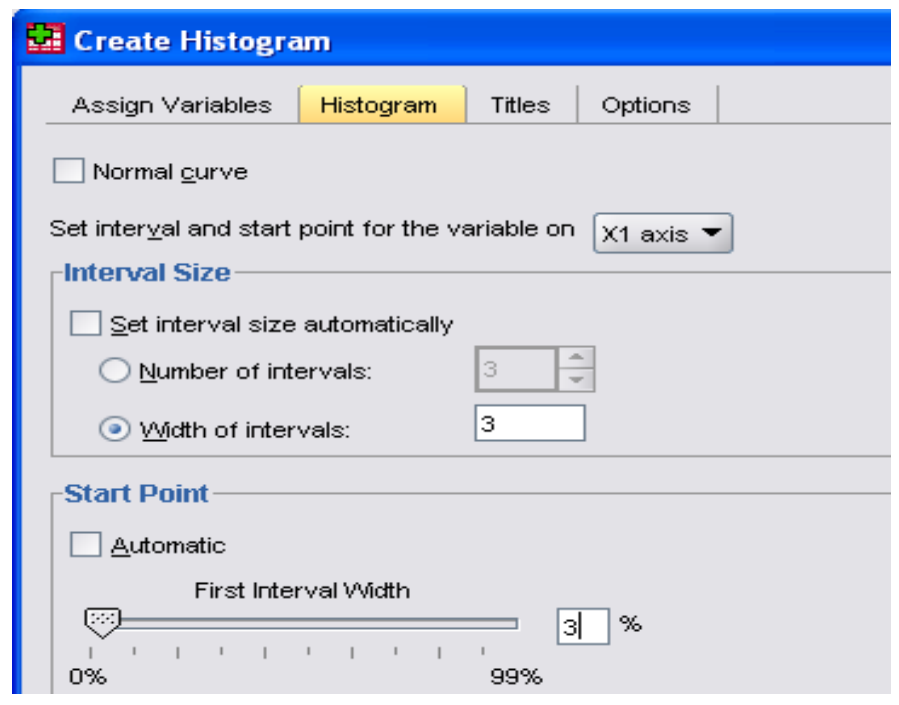

Gambar 3.41

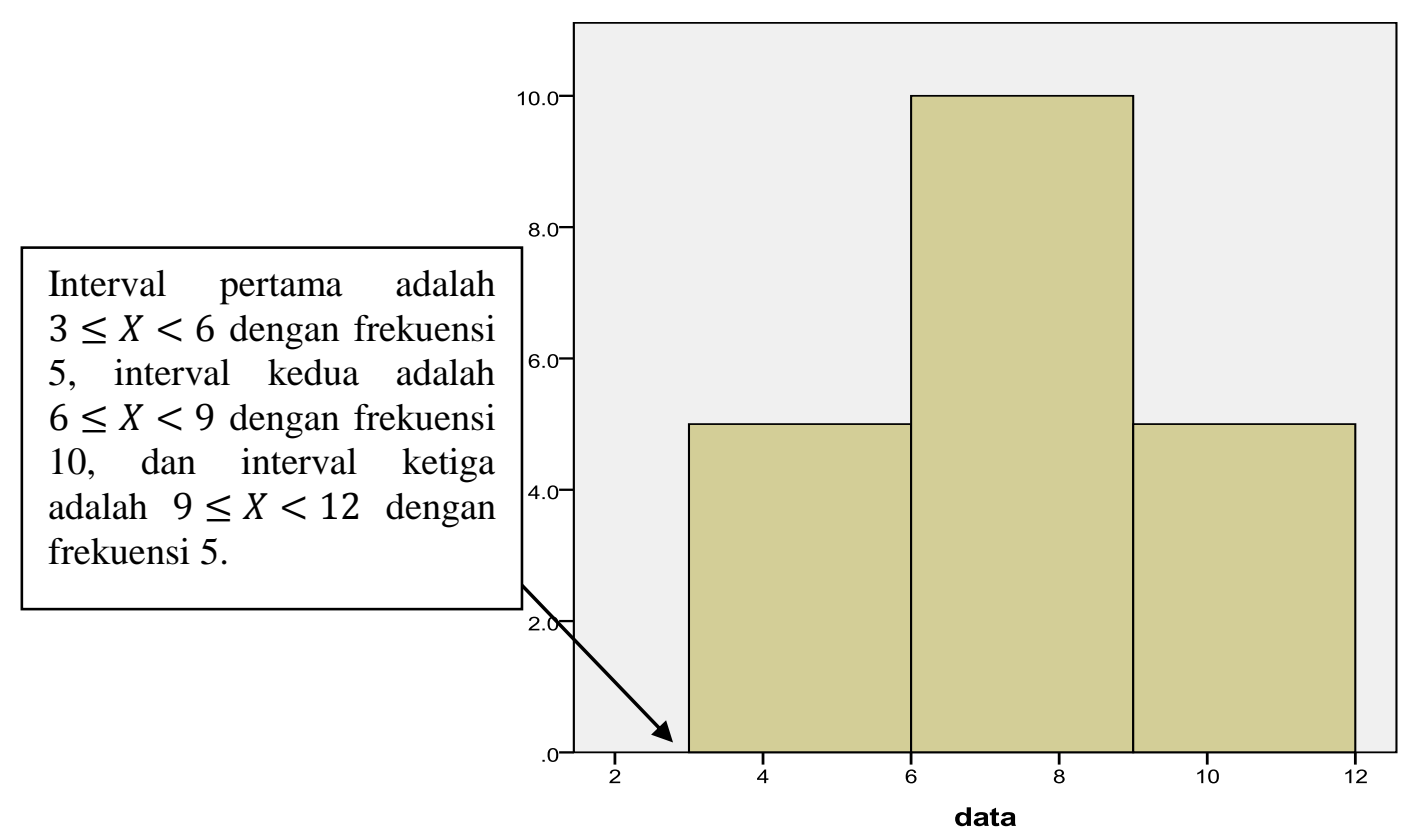

Gambar 3.42 


\section{Membuat Tabel Distríbusi Frekuensi Berkelompok dengan Visual Binning}

Berikut tahap-tahap untuk membuat tabel distribusi frekuensi berkelompok dalam SPSS berdasarkan data pada Tabel 3.7 dengan Visual Binning. Andaikan melibatkan tiga interval, dengan masing-masing interval $\leq 5,6-8$, dan $9-11$. Bangun data pada Tabel 3.7 dalam SPSS (Gambar 3.39). Selanjutnya pilih Transform $\Rightarrow$ Visual Binning, sehingga muncul kotak dialog Visual Binning (Gambar 3.43). Masukkan variabel data pada kotak Variables to Bin (Gambar 3.43), kemudian pilih Continue. Selanjutnya aktifkan atau klik variabel data (Gambar 3.44), sehingga pada kotak Minimum terisi 4 dan Maximum terisi 9. Pada kotak Binned Variable isi dengan nama data_simpan (Gambar 3.44). Pada kolom Value dan Label, atur seperti pada Gambar 3.45. Setelah dilakukan pengaturan seperti pada Gambar 3.45, kemudian pilih OK, sehingga muncul pemberitahuan seperti pada Gambar 3.46. Pada Gambar 3.46, pilih OK, sehingga terbentuk variabel data_simpan (Gambar 3.47).

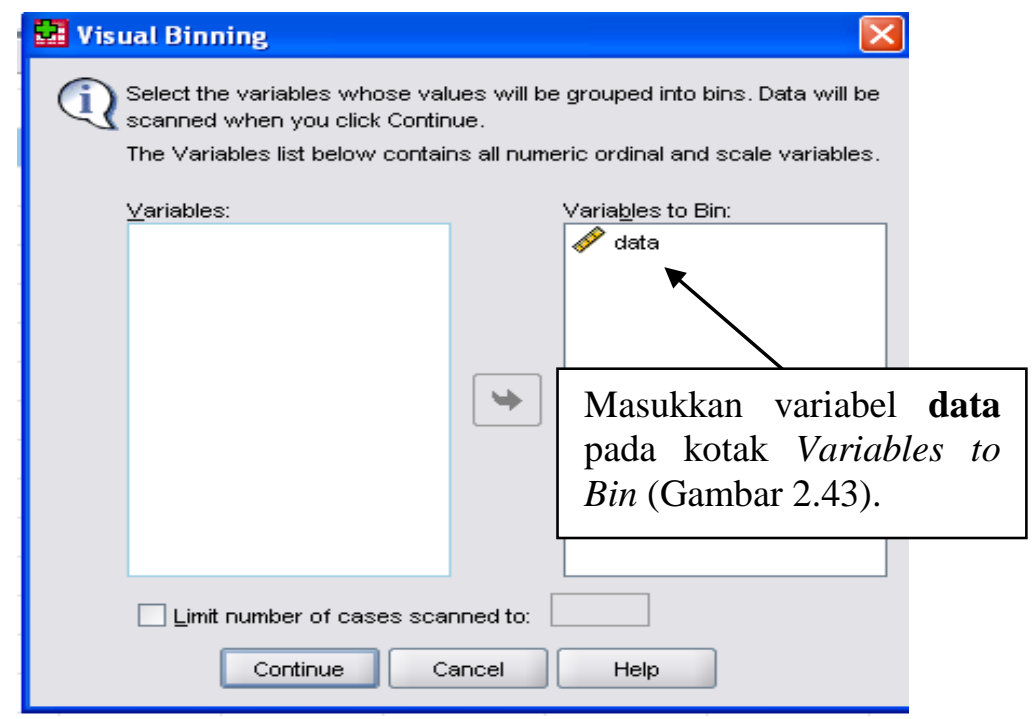

Gambar 3.43

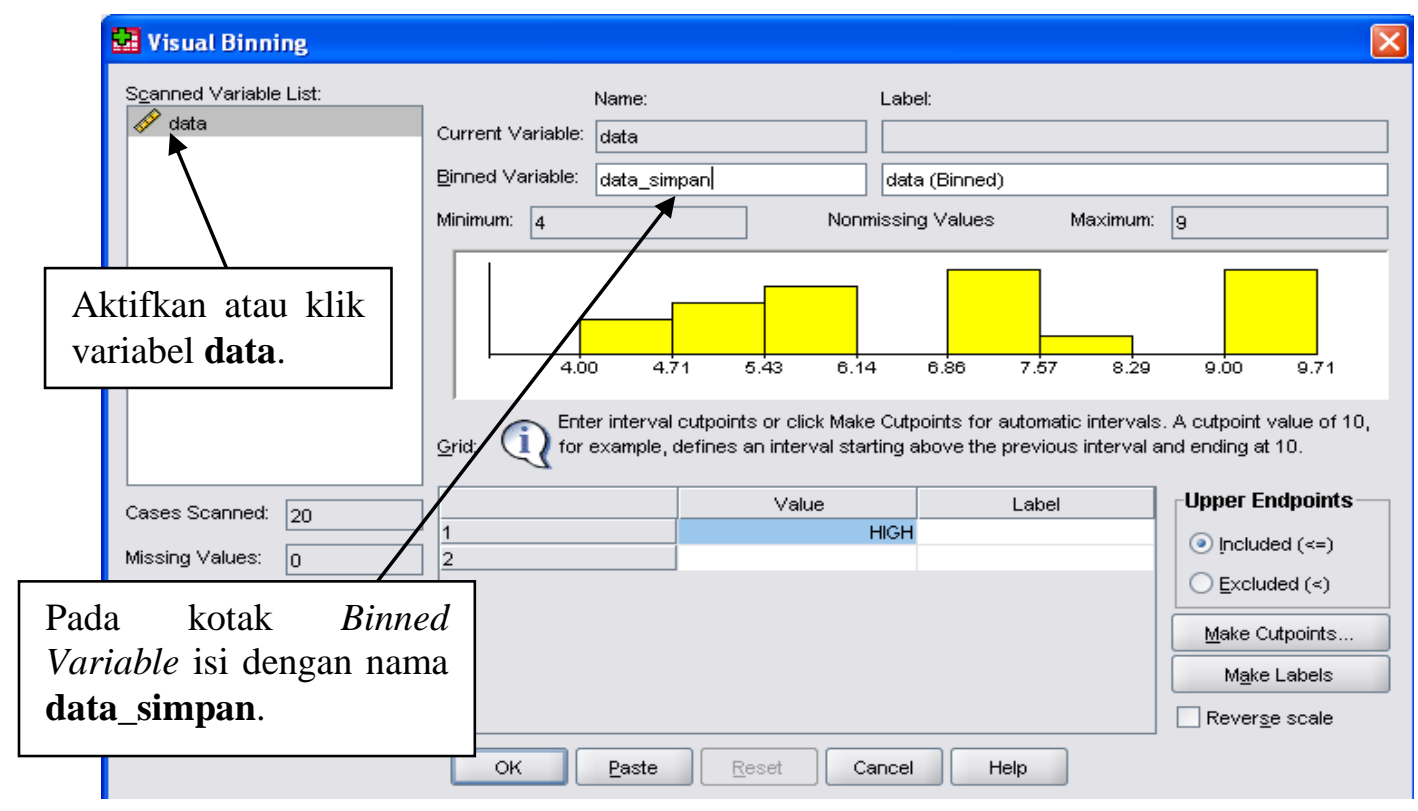

Gambar 3.44 
Selanjutnya pilih Analyze $\Rightarrow>$ Descriptive Statistics $\Rightarrow$ Frequencies, sehingga muncul kotak dialog Frequencies (3.48). Masukkan variabel data_simpan pada kotak Variable(s). Kemudian pilih OK. Hasilnya tersaji pada Tabel 3.8.

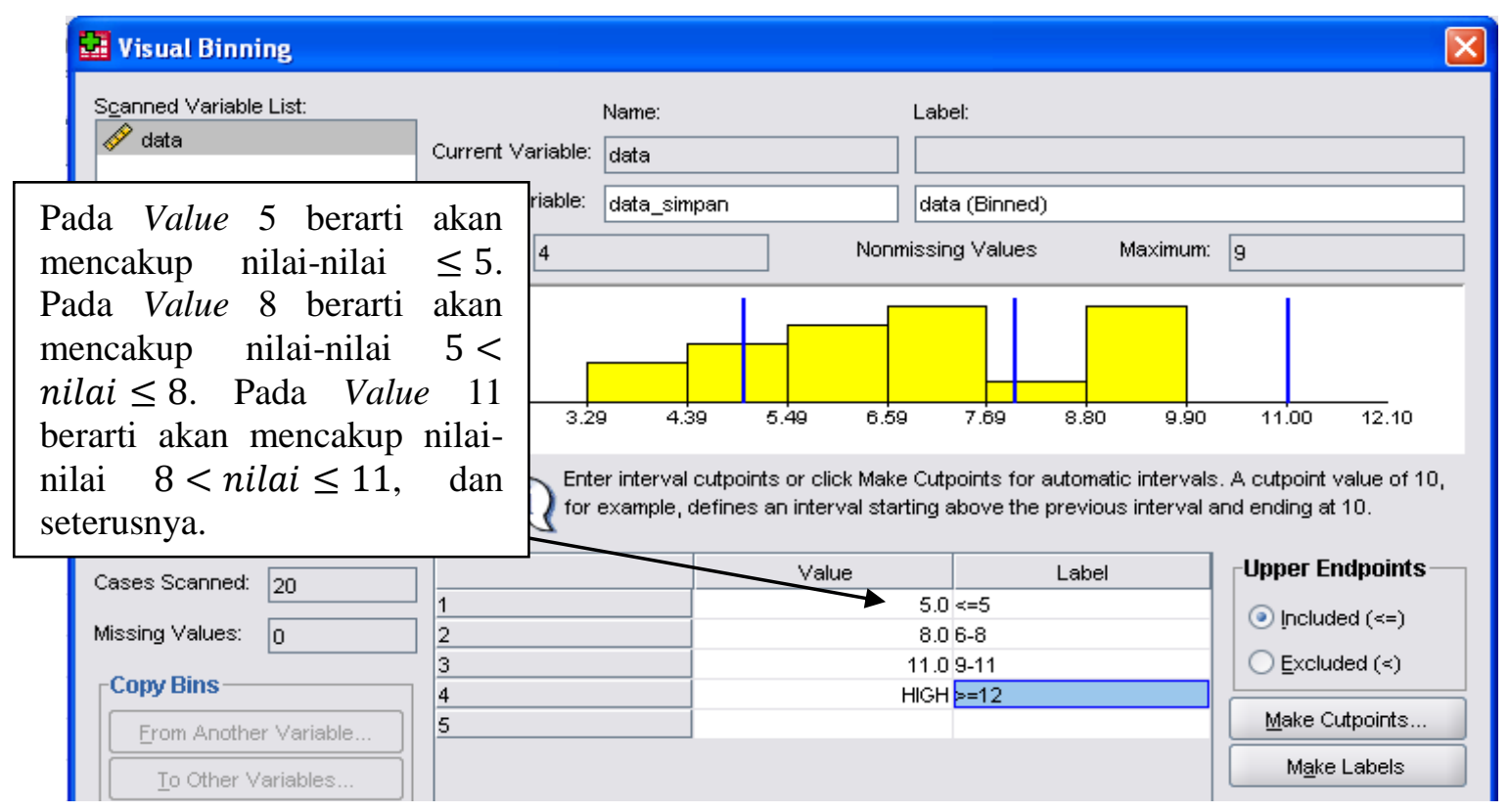

Gambar 3.45

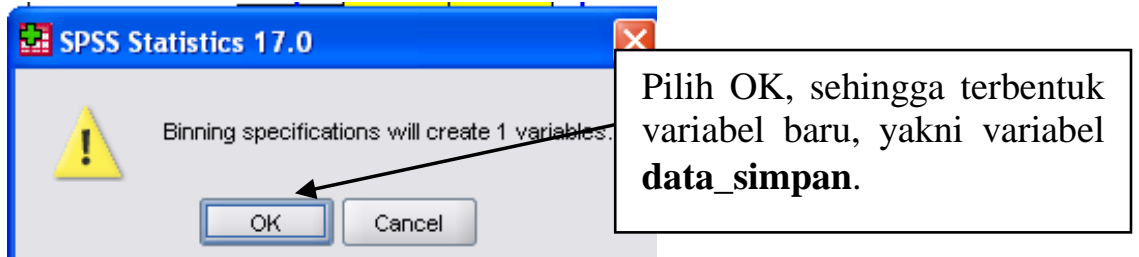

Gambar 3.46

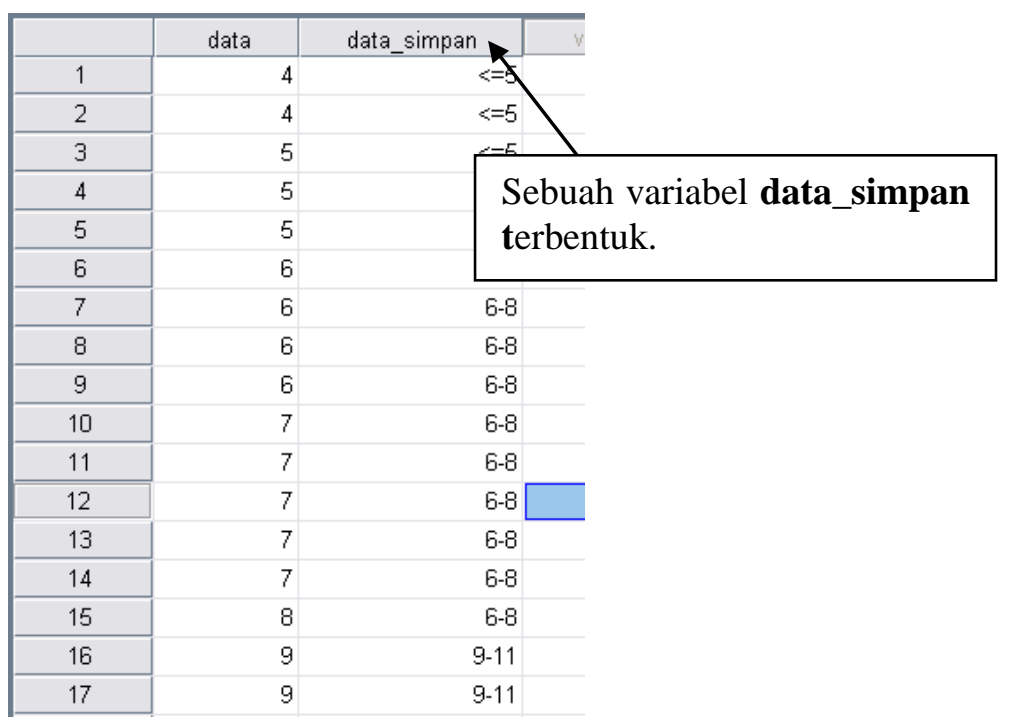

Gambar 3.47 


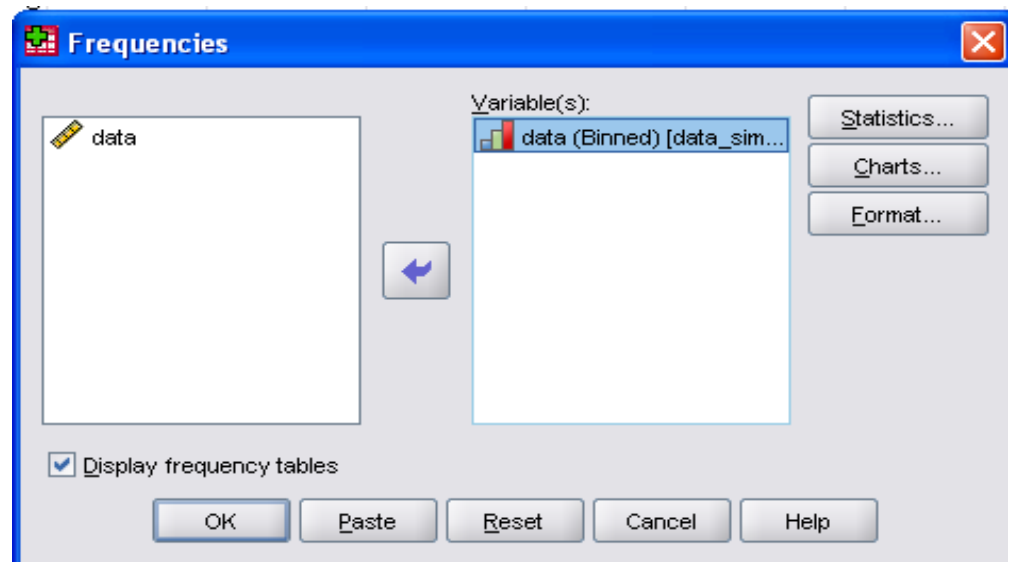

\section{Gambar 3.48}

Tabel 3.8

\begin{tabular}{|c|c|c|c|c|}
\hline \multirow{2}{*}{$\begin{array}{l}\text { Distribusi frekuensi dengan } \\
3 \text { kelas interval. }\end{array}$} & \multicolumn{4}{|c|}{ data (Binned) } \\
\hline & & & & Cumulative \\
\hline$\varepsilon=5$ & 5 & 25.0 & 25.0 & 25.0 \\
\hline $6-8$ & 10 & 50.0 & 50.0 & 75.0 \\
\hline 9-11 & 5 & 25.0 & 25.0 & 100.0 \\
\hline Total & 20 & 100.0 & 100.0 & \\
\hline
\end{tabular}




\section{BAB 4}

\section{UKURAN GEJALA PUSAT, LETAK, PENCARAN, KEMIRINGAN DAN KERUNCINGAN}

\section{Ukuran Gejala Pusat (Measure of Central Tendency)}

Ukuran gejala pusat merupakan suatu ukuran atau nilai yang letaknya cenderung terletak dipusat data. Beberapa contoh dari ukuran gelaja pusat adalah rata-rata hitung, median, dan modus. Misalkan diberikan data seperti pada Tabel 4.1.

Tabel 4.1

\begin{tabular}{|c|c|c|c|c|}
\hline Nilai & Nilai & Nilai & Nilai & Nilai \\
\hline 1 & 5 & 9 & 12 & 16 \\
\hline 2 & 6 & 10 & 13 & 17 \\
\hline 3 & 7 & 11 & 14 & 18 \\
\hline 4 & 8 & 11 & 15 & \multicolumn{1}{|c}{} \\
\cline { 1 - 4 } & &
\end{tabular}

Berdasarkan data pada Tabel 4.1, berikut akan dihitung jumlah keseluruhan nilai (sum), ratarata hitung (mean), modus (mode), dan median.

\section{Jumlah Keseluruhan Nilaí (Sum)}

Andaikan terdapat $n$ buah nilai, yakni $X_{1}, X_{2}, X_{3}, \ldots, X_{n}$. Jumlah dari keseluruhan nilai tersebut dihitung dengan rumus sebagai berikut.

$$
\begin{gathered}
\text { jumlah keseluruhan nilai }=\sum_{i=1}^{n} X_{i} \\
\sum_{i=1}^{n} X_{i}=X_{1}+X_{2}+X_{3}+\cdots+X_{n} .
\end{gathered}
$$

Jumlah keseluruhan nilai untuk data pada Tabel 4.1 adalah $1+2+3+\cdots+18=172$.

\section{Rata-Rata Hitung (Mean)}

Rata-rata hitung merupakan jumlah seluruh nilai dari data dibagi dengan banyaknya data. Berikut rumus untuk menghitung nilai rata-rata hitung.

$$
\begin{gathered}
\bar{X}=\frac{\sum_{i=1}^{n} X_{i}}{n} \\
=\frac{X_{1}+X_{2}+X_{3}+\cdots+X_{n}}{n} .
\end{gathered}
$$


Rata-rata hitung sampel secara umum dilambangkan dengan $\bar{X}$, sedangkan untuk populasi $\mu$. Andaikan data pada Tabel 4.1 merupakan data sampel. Berikut akan dihitung nilai rata-rata hitung berdasarkan data pada Tabel 4.1 .

$$
\begin{gathered}
\bar{X}=\frac{1+2+3+\cdots+18}{19} \\
\bar{X}=9,578947 .
\end{gathered}
$$

Nilai rata-rata hitung berdasarkan data pada Tabel 4.1 adalah 9,578947.

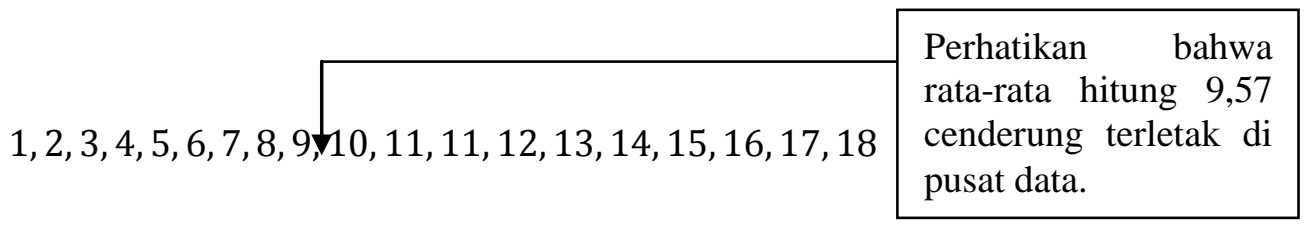

\section{Modus (Mode)}

Modus merupakan nilai data dengan frekuensi atau jumlah kemunculan paling banyak. Berdasarkan data pada Tabel 4.1, nilai dengan frekuensi kemunculan paling banyak adalah nilai 11, yakni muncul sebanyak dua kali.

\section{Median}

Median merupakan suatu nilai yang membagi data menjadi dua bagian yang sama. Sebelum menghitung nilai median, terlebih dahulu data diurutkan dari yang terkecil hingga terbesar. Berikut rumus menghitung median untuk data dengan jumlah genap.

$$
\text { Median }=\frac{X_{\frac{n}{2}}+X_{\frac{n}{2}+1}}{2} \text {. }
$$

Berikut rumus menghitung median untuk data dengan jumlah ganjil.

$$
\text { Median }=X_{\frac{n+1}{2}} .
$$

Perhatikan bahwa $X_{\frac{n}{2}}$ merupakan nilai $X$ yang terletak pada urutan ke- $\frac{n}{2}$. Sebelum menghitung nilai median, data terlebih dahulu diurutkan dari yang terkecil hingga yang terbesar. Berikut disajikan kembali data pada Tabel 4.1 setelah diurutkan dari yang terkecil hingga terbesar.

$$
1,2,3,4,5,6,7,8,9,10,11,11,12,13,14,15,16,17,18 \text {. }
$$

Diketahui banyaknya nilai $n=19$, sehingga banyaknya data adalah ganjil.

$$
\begin{aligned}
& \text { Median }=X_{\frac{n+1}{2}} \\
& \text { Median }=X_{\frac{19+1}{2}}
\end{aligned}
$$




$$
\text { Median }=X_{10}
$$

Perhatikan bahwa $X_{10}$ berarti nilai median terletak pada data dengan urutan ke-10, yakni 10 .

$1,2,3,4,5,6,7,8,9,10,11,11,12,13,14,15,16,17,18$\begin{tabular}{l|} 
Nilai median 10 \\
cenderung terletak di \\
pusat data serta nilai \\
median tersebut \\
membagi data menjadi \\
dua bagian yang sama.
\end{tabular}

Perhatikan bahwa nilai median membagi menjadi dua bagian yang sama. Masing-masing bagian terdiri dari 9 nilai.

\section{Ukuran Letak}

Kuartil dan desil merupakan jenis-jenis dari ukuran letak. Ukuran tersebut membagi data menjadi beberapa bagian yang sama. Sebagai contoh pada ukuran kuartil terdapat tiga buah nilai. Letak dari nilai-nilai kuartil tersebut membagi data menjadi empat bagian yang sama.

\section{$\mathcal{K u a r t i C}(\boldsymbol{K})$}

Ukuran kuartil terdiri dari tiga buah nilai yang membagi data menjadi empat bagian yang sama.

$$
1,2,3,4,5,6,7,8,9,10,11
$$

Nilai kuartil dikelompokkan atas tiga, yakni kuartil pertama $\left(K_{1}\right)$, kuartil kedua $\left(K_{2}\right)$, dan kuartil ketiga $\left(K_{3}\right)$. Angka 3,6, dan 9 masing-masing merupakan $K_{1}, K_{2}$, dan $K_{3}$. Berikut rumus untuk menghitung nilai kuartil.

$$
K_{i}=\frac{i(n+1)}{4} ; i=1,2,3
$$

Perhatikan bahwa $K_{i}$ merupakan nilai dari kuartil ke-i dengan $i=1,2$, dan 3 . Berikut disajikan kembali data pada Tabel 4.1.

$$
1,2,3,4(5) 6,7,8,9(10) 11,11,12,13,14,15,16,17,18
$$

Diketahui jumlah data $n=19$. Berikut akan dihitung nilai dari $K_{1}, K_{2}$, dan $K_{3}$.

$$
\begin{gathered}
K_{1}=\frac{1(19+1)}{4} \\
K_{1}=5 .
\end{gathered}
$$

$K_{1}=5$ berarti nilai $K_{1}$ terletak pada data dengan urutan ke-5, yakni 5 .

$$
K_{2}=\frac{2(19+1)}{4}
$$




$$
K_{2}=10
$$

$K_{2}=10$ berarti nilai $K_{2}$ terletak pada data dengan urutan ke-10, yakni 10 .

$$
\begin{gathered}
K_{3}=\frac{3(19+1)}{4} \\
K_{3}=15 .
\end{gathered}
$$

$K_{3}=15$ berarti nilai $K_{3}$ terletak pada data dengan urutan ke-15, yakni 14. Ketiga nilai kuartil tersebut membagi data menjadi empat bagian yang sama dengan banyaknya nilai untuk masing-masing bagian adalah 4 .

\section{$\operatorname{DesiC}(D)$}

Ukuran desil terdiri dari sembilan nilai yang membagi data menjadi sepuluh bagian yang sama.

$$
1(2,3(4) 5,6,7,8,9,10,11(11) 12,(13,14,15,16(17) 18 .
$$

Perhatikan bahwa nilai-nilai yang dilingkar merupakan nilai-nilai desil. Nilai-nilai tersebut membagi data menjadi 10 bagian yang sama. Masing-masing bagian terdiri dari 1 nilai. Terdapat sembilan nilai desil, yakni desil pertama $\left(D_{1}\right)$, desil kedua $\left(D_{2}\right)$, dan sampai dengan desil kesembilan $\left(D_{9}\right)$. Berikut rumus untuk menghitung nilai desil.

$$
D_{i}=\frac{i(n+1)}{10} ; i=1,2,3, \ldots, 9
$$

Berikut akan dihitung nilai desil pertama, kedelapan, dan kesembilan berdasarkan data pada Tabel 4.1.

$$
D_{1}=\frac{1(19+1)}{10}=2 \text {. }
$$

Nilai desil ke-1 terletak pada data dengan urutan ke-2, yakni 2.

$$
D_{8}=\frac{8(19+1)}{10}=16 \text {. }
$$

Nilai desil ke-8 terletak pada data dengan urutan ke-16, yakni 15.

$$
D_{9}=\frac{9(19+1)}{10}=18 \text {. }
$$

Nilai desil ke-9 terletak pada data dengan urutan ke-18, yakni 17. Sembilan nilai desil tersebut membagi data menjadi sepuluh bagian yang sama dengan banyaknya nilai untuk masing-masing bagian adalah 1 . 


\section{Ukuran Pencaran atau Dispersi}

Ukuran pencaran atau dispersi merupakan suatu nilai yang mengukur tingkat pencaran atau sebaran nilai-nilai data terhadap nilai rata-ratanya.

$$
\begin{aligned}
& \left.\begin{array}{l}
\text { 7,8,9 } \\
6,8,10 \\
5,8,11
\end{array}\right\} \begin{array}{l}
\begin{array}{l}
\text { Dari keempat data ini memiliki } \\
\text { nilai rata-rata yang sama, } \\
\text { namun data 4,8,12 memiliki } \\
\text { nilai pencaran data yang tinggi } \\
\text { terhadap rata-ratanya. }
\end{array} \\
\hline
\end{array} \\
& 4,8,12 \text {. }
\end{aligned}
$$

Nilai pencaran yang tinggi menunjukkan nilai-nilai data cenderung terletak cukup jauh terhadap nilai rata-rata dari data tersebut. Beberapa contoh dari ukuran pencaran adalah range, varians, dan standar deviasi. Misalkan diberikan data sebagai berikut.

Tabel 4.2

\begin{tabular}{|c|c|c|c|c|}
\hline Nilai & Nilai & Nilai & Nilai & Nilai \\
\hline 10 & 20 & 30 & 40 & 50 \\
\hline 10 & 30 & 30 & 40 & 50 \\
\hline 10 & 30 & 30 & 40 & 50 \\
\hline 20 & 30 & 30 & 50 & \multicolumn{1}{|c}{} \\
\cline { 1 - 3 }
\end{tabular}

Berdasarkan data pada Tabel 4.2, berikut akan dihitung nilai maksimum, minimum, range, varians, dan standar deviasi.

\section{Nílai Maksímum}

Nilai maksimum merupakan nilai yang paling tinggi dari suatu data. Berdasarkan data pada Tabel 4.2, nilai maksimum adalah nilai 50 .

\section{Nílai Minimum}

Nilai minimum merupakan nilai yang paling rendah dari suatu data. Berdasarkan data pada Tabel 4.2, nilai minimum adalah nilai 10 .

\section{Range}

Range merupakan selisih antara nilai maksimum dengan nilai minimum. Diketahui nilai maksimum adalah 50 dan nilai minimum adalah 10 , sehingga nilai range adalah $50-10=$ 40 . 


\section{Varíans (Variance)}

Varians (dalam hal ini varians untuk sampel) dilambangkan dengan $s^{2}$. Berikut rumus untuk menghitung nilai varians.

$$
s^{2}=\frac{|X-\bar{X}|^{2}}{n-1} \text {. }
$$

Nilai varians sampel $\left(s^{2}\right)$ berdasarkan data pada Tabel 4.2 adalah

$$
\begin{gathered}
s^{2}=\frac{3 \times|10-31,6|^{2}+2 \times|20-31,6|^{2}+\cdots+4 \times|50-31,6|^{2}}{19-1} \\
s^{2}=180,7018 .
\end{gathered}
$$

\section{Standar Deviasí}

Standar deviasi merupakan akar pangkat dua dari nilai varians $\left(\sqrt{s^{2}}=s\right)$. Diketahui nilai varians adalah 180,7018, sehingga nilai standar deviasi adalah $\sqrt{180,7018}=13,4425$.

\section{Ukuran Kemiringan (Skewness)}

Ukuran kemiringan atau skewness merupakan suatu nilai yang mengukur ketidaksimetrisan distribusi data. Suatu data dikatakan berdistribusi simetris sempurna bila nilai rata-rata, median, dan modus dalam data adalah sama.

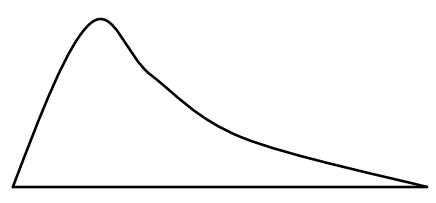

(1)

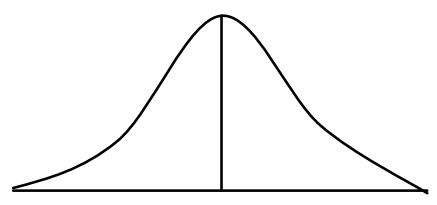

(2)

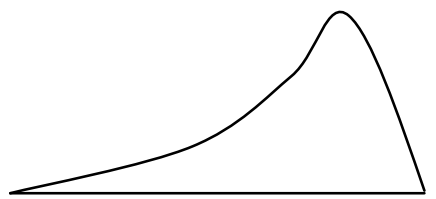

(3)

Pada Gambar (1) kurva cenderung condong ke kanan atau disebut kurva positif. Pada Gambar (2) kurva bersifat simetris. Pada Gambar (3) kurva cenderung condong ke kiri atau disebut kurva negatif. Berikut rumus untuk menghitung nilai kemiringan suatu data.

$$
\text { Kemiringan }=\frac{n}{(n-1)(n-2)}\left(\frac{\sum(X-\bar{X})^{3}}{s^{3}}\right) \text {. }
$$

Bila nilai kemiringan $<0$ atau negatif, maka kurva cenderung condong ke kiri (kurva negatif). Jika nilai kemiringan $>0$ atau positif, maka kurva cenderung condong ke kanan (kurva positif). Jika nilai kemiringan mendekati 0 atau 0 , maka kurva cenderung simetris. Misalkan diberikan data sebagai berikut (Tabel 4.3). 
Tabel 4.3

\begin{tabular}{|c|c|c|c|}
\hline Nilai $(X)$ & Nilai $(X)$ & Nilai $(X)$ & Nilai $(X)$ \\
\hline 1 & 3 & 4 & 5 \\
\hline 2 & 3 & 4 & 6 \\
\hline 2 & 3 & 4 & 6 \\
\hline 3 & 3 & 5 & \multicolumn{1}{|c}{} \\
\cline { 1 - 3 } & &
\end{tabular}

Tabel 4.4

\begin{tabular}{|c|c|c|c|c|}
\cline { 2 - 5 } \multicolumn{1}{c|}{} & $X$ & Frekuensi $(f)$ & $f X$ & $f \sum(X-\bar{X})^{3}$ \\
\cline { 2 - 5 } & 1 & 1 & 1 & $-17,576$ \\
\cline { 2 - 5 } & 2 & 2 & 4 & $-8,192$ \\
\cline { 2 - 5 } & 3 & 5 & 15 & $-1,08$ \\
\cline { 2 - 5 } & 4 & 3 & 12 & 0,192 \\
\cline { 2 - 5 } & 5 & 2 & 10 & 5,488 \\
\cline { 2 - 5 } & 6 & 2 & 12 & 27,648 \\
\hline Jumlah & & & & \multicolumn{1}{|c}{} \\
\hline Rata-rata $(\bar{X})$ & 3,6 & 15 & 54 & 6,48 \\
\hline Standar deviasi $(s)$ & 1,454058 & & & \\
\hline
\end{tabular}

Berdasarkan data pada Tabel 4.3, berikut akan dihitung nilai kemiringan. Dari Tabel 4.4, diketahui $\bar{X}=3,6$ dan $s=1,454058$, sehingga nilai kemiringan dapat dihitung sebagai berikut.

$$
\begin{gathered}
\text { kemiringan }=\frac{n}{(n-1)(n-2)}\left(\frac{\sum(X-\bar{X})^{3}}{s^{3}}\right) \\
=\frac{15}{(15-1)(15-2)}\left(\frac{6,48}{1,454058^{3}}\right) \\
=0,17372 .
\end{gathered}
$$

Nilai kemiringan berdasarkan perhitungan adalah 0,17372.

\section{Ukuran Keruncingan (Kurtosis)}

Ukuran keruncingan atau kurtosis merupakan suatu nilai yang mengukur tingkat keruncingan atau ketinggian puncak dari distribusi data. Berikut rumus untuk menghitung kurtosis.

$$
\text { Kurtosis }=\left\{\frac{(n)(n+1) \sum(X-\bar{X})^{4}}{(n-1)(n-2)(n-3) s^{4}}\right\}-\frac{3(n-1)^{2}}{(n-2)(n-3)} .
$$

Pada Gambar (1), (2), dan (3), ketinggian atau keruncingan puncak kurva berbeda-beda. Gambar (2) merupakan kurva normal atau mesokurtis. Suatu kurva normal mempunyai nilai keruncingan atau ketinggian $=3$. Pada Gambar (1), kurva cenderung datar dan puncak tidak terlalu tinggi. Kurva ini dinamakan kurva platikurtis. Pada kurva yang cenderung datar, nilai 
kurtosis < 3. Pada Gambar (3), puncak kurva terlihat lancip dan tinggi. Kurva ini dinamakan kurva leptokurtis. Pada kurva leptokurtis, nilai kurtosis > 3. Berikut akan dihitung nilai kurtosis berdasarkan data pada Tabel 4.3.

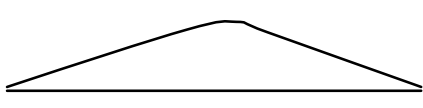

(1)

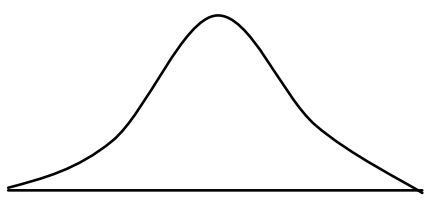

(2)

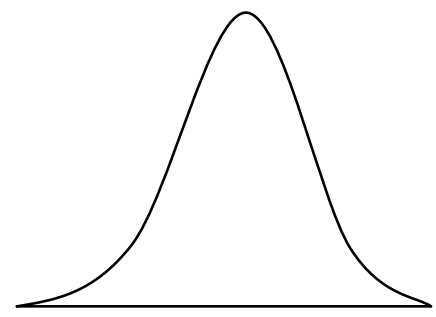

(3)

Berdasarkan data pada Tabel 4.4, diketahui nilai $\bar{X}=3,6$ dan $s=1,454058$, sehingga

$$
\begin{gathered}
\text { kurtosis }=\left\{\frac{(n)(n+1) \sum(X-\bar{X})^{4}}{(n-1)(n-2)(n-3) s^{4}}\right\}-\frac{3(n-1)^{2}}{(n-2)(n-3)} \\
\text { kurtosis }=\left\{\frac{(15)(15+1)(133,568)}{(15-1)(15-2)(15-3)\left(1,454^{3}\right)}\right\}-\frac{3(15-1)^{2}}{(15-2)(15-3)} \\
\text { kurtosis }=-0,485756 .
\end{gathered}
$$

Nilai kurtosis berdasarkan perhitungan adalah $-0,485756$. Tabel untuk perhitungan disajikan

\begin{tabular}{|c|c|c|c|c|}
\hline & $X$ & Frekuensi $(f)$ & $f X$ & $f \sum(X-\bar{X})^{4}$ \\
\hline & 1 & 1 & 1 & 45,6976 \\
\hline & 2 & 2 & 4 & 13,1072 \\
\hline & 3 & 5 & 15 & 0,648 \\
\hline & 4 & 3 & 12 & 0,0768 \\
\hline & 5 & 2 & 10 & 7,6832 \\
\hline & 6 & 2 & 12 & 66,3552 \\
\hline Jumlah & & 15 & 54 & 133,568 \\
\hline
\end{tabular}
pada Tabel 4.5.

\section{Tabel 4.5}




\section{Ukuran Gejala Pusat dan Ukuran Letak}

Bangun data pada Tabel 4.1 dalam SPSS seperti pada Gambar 4.1. Pilih Analyze => Descriptive Statistics $=>$ Frequencies (Gambar 4.2), sehingga muncul kotak dialog Frequencies (Gambar 4.3).

Tabel 4.1

\begin{tabular}{|c|c|c|c|c|}
\hline Data & Data & Data & Data & Data \\
\hline 1 & 5 & 9 & 12 & 16 \\
\hline 2 & 6 & 10 & 13 & 17 \\
\hline 3 & 7 & 11 & 14 & 18 \\
\hline 4 & 8 & 11 & 15 & \multicolumn{1}{|c}{} \\
\cline { 1 - 3 } & &
\end{tabular}

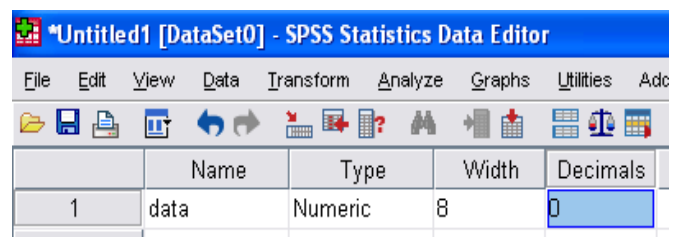

\begin{tabular}{|r|r|r}
\hline & data & \\
\hline 1 & 1 \\
\hline 2 & 2 \\
\hline 3 & 3 \\
\hline 4 & 4 \\
\hline 5 & 5 \\
\hline 6 & 6 \\
\hline 7 & 7 \\
\hline 8 & 8 \\
\hline 9 & 9 \\
\hline 10 & 10 \\
\hline
\end{tabular}

\begin{tabular}{|l|l|}
\hline 11 & 11 \\
\hline 12 & 11 \\
\hline 13 & 12 \\
\hline 14 & 13 \\
\hline 15 & 14 \\
\hline 16 & 15 \\
\hline 17 & 16 \\
\hline 18 & 17 \\
\hline 19 & 18 \\
\hline
\end{tabular}

\section{Gambar 4.1}

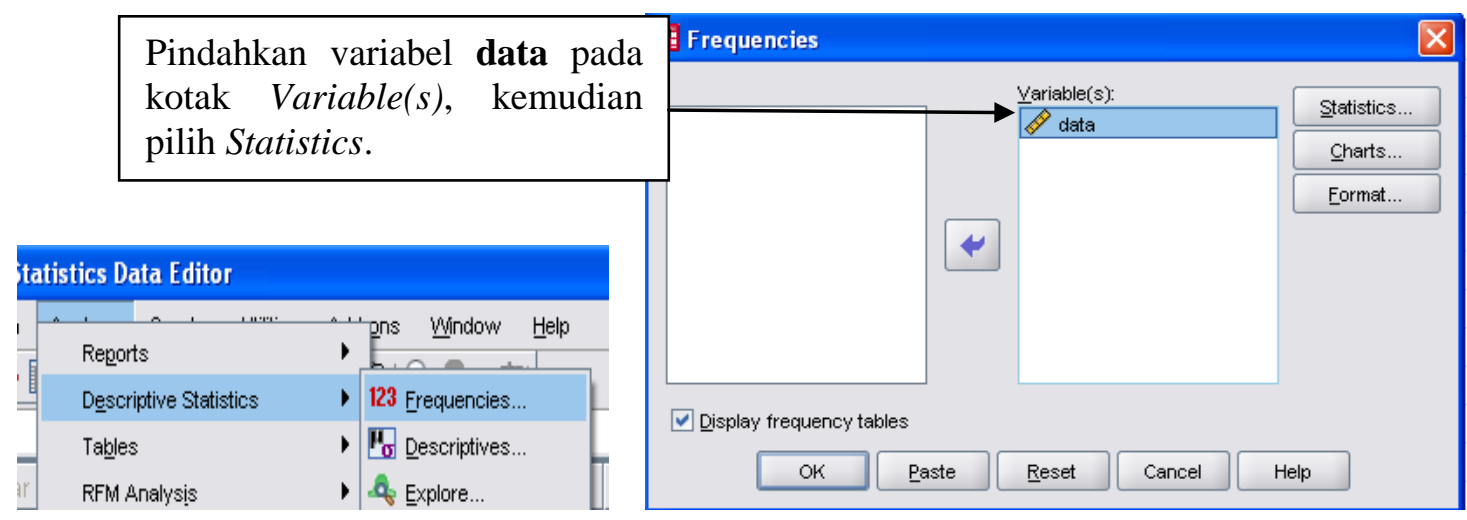

Gambar 4.2

Gambar 4.3

Pada Gambar 4.3, pindahkan variabel data pada kotak Variable(s). Selanjutnya pilih Statistics, sehingga muncul kotak Frequencies: Statistics (Gambar 4.4). Pada Central Tendency, pilih Mean, Median, Mode, dan Sum. Pada Percentile Values, pilih Quartiles, Cut points for 10 equal group. Kemudian pilih Continue dan OK. Hasilnya seperti pada Tabel 4.2. 


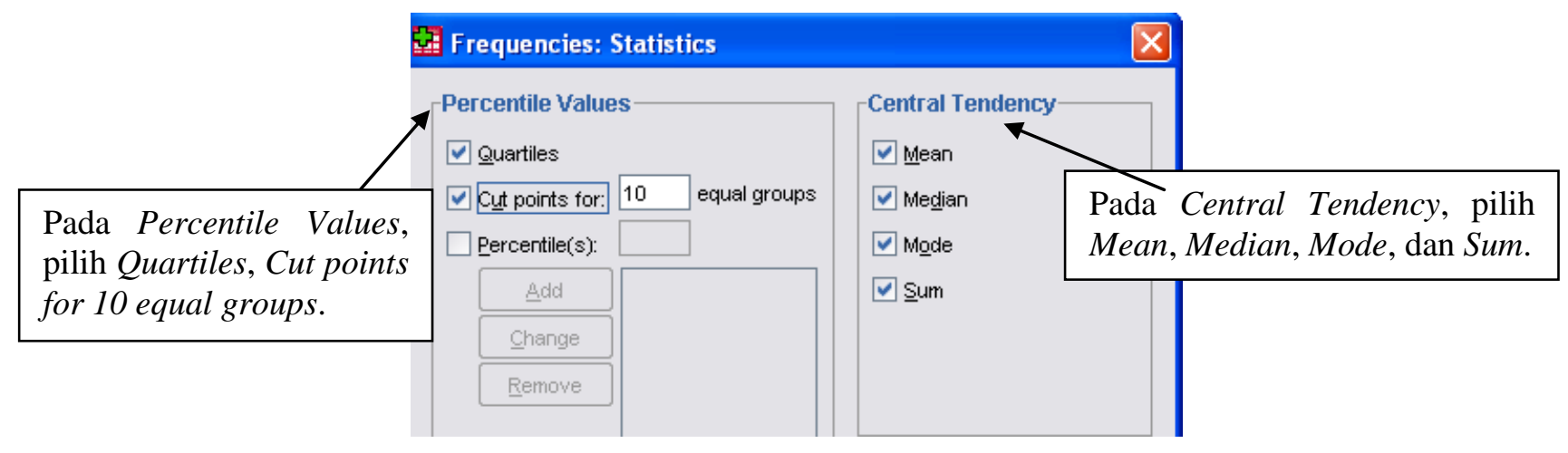

Gambar 3.4

\section{Tabel 4.2}

Statistics

\begin{tabular}{|c|c|c|}
\hline \multicolumn{3}{|l|}{ Data } \\
\hline \multirow[t]{2}{*}{$\mathrm{N}$} & Valid & 19 \\
\hline & Missing & 0 \\
\hline Mean & & 9.58 \\
\hline Median & & 10.00 \\
\hline Mode & & 11 \\
\hline Sum & & 182 \\
\hline \multirow[t]{11}{*}{ Percentiles } & 10 & 2.00 \\
\hline & 20 & 4.00 \\
\hline & 25 & 5.00 \\
\hline & 30 & 6.00 \\
\hline & 40 & 8.00 \\
\hline & 50 & 10.00 \\
\hline & 60 & 11.00 \\
\hline & 70 & 13.00 \\
\hline & 75 & 14.00 \\
\hline & 80 & 15.00 \\
\hline & 90 & 17.00 \\
\hline
\end{tabular}

Berdasarkan Tabel 4.2, yakni Tabel Statistics, diperoleh rata-rata hitung atau Mean 9,58, median 10, modus 11, jumlah keseluruhan atau Sum 182, desil pertama 2, desil kedua 4, kuartil pertama 5, desil ketiga 6, desil keempat 8, desil kelima sama dengan kuartil kedua 10, desil keenam 11, desil ketujuh 13, kuartil ketiga 14, desil kedelapan 15 dan desil kesembilan 17. Hasil ini sesuai dengan perhitungan secara manual sebelumnya.

Catatan: Perhatikan bahwa Cut points for 10 equal group berarti membagi data menjadi sepuluh bagian yang sama. Ini sama saja menentukan nilai-nilai desil. Jika Cut points for 100 equal group berarti membagi data menjadi seratus bagian yang sama. Ini sama saja mencari nilai-nilai persentil.

\section{Ukuran Pencaran atau Dispersí}

Bangun data pada Tabel 4.3 dalam SPSS seperti pada Gambar 4.5. Selanjutnya pilih Analyze $\Rightarrow$ Descriptive Statistics $=>$ Frequencies, sehingga muncul kotak dialog Frequencies. Pindahkan variabel data ke kotak Variable(s). Kemudian pilih Statistics, sehingga muncul kotak dialog Frequencies: Statistics. Pada kotak Dispersion, pilih Std. Deviation, Minimum, 
Maximum, Variance, dan Range. Kemudian pilih Continue dan OK. Hasilnya tersaji pada Tabel 4.4.

Tabel 4.3

\begin{tabular}{|c|c|c|c|c|}
\hline Data & Data & Data & Data & Data \\
\hline 10 & 20 & 30 & 40 & 50 \\
\hline 10 & 30 & 30 & 40 & 50 \\
\hline 10 & 30 & 30 & 40 & 50 \\
\hline 20 & 30 & 30 & 50 & \\
\end{tabular}

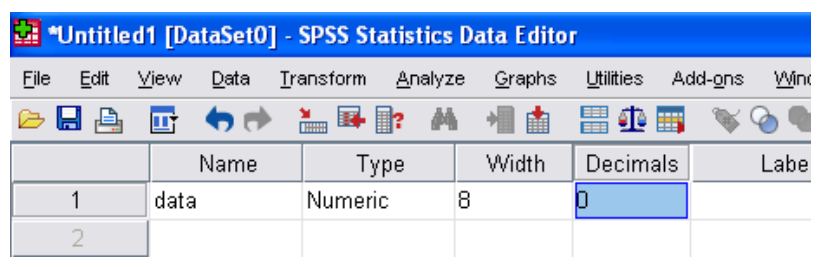

\begin{tabular}{|c|r|}
\hline & data \\
\hline 1 & 10 \\
\hline 2 & 10 \\
\hline 3 & 10 \\
\hline 4 & 20 \\
\hline 5 & 20 \\
\hline 6 & 30 \\
\hline 7 & 30 \\
\hline 8 & 30 \\
\hline 9 & 30 \\
\hline 10 & 30 \\
\hline
\end{tabular}

\begin{tabular}{|l|l|}
\hline 11 & 30 \\
\hline 12 & 30 \\
\hline 13 & 40 \\
\hline 14 & 40 \\
\hline 15 & 40 \\
\hline 16 & 50 \\
\hline 17 & 50 \\
\hline 18 & 50 \\
\hline 19 & 50 \\
\hline
\end{tabular}

\section{Gambar 4.5}

Tabel 4.4

Statistics

Data
\begin{tabular}{|l|r|}
\hline \multicolumn{1}{|c|}{$\quad$ Valid } & 19 \\
Missing & 0 \\
Std. Deviation & 13.443 \\
Variance & 180.702 \\
Range & 40 \\
Minimum & 10 \\
Maximum & 50 \\
\hline
\end{tabular}

Berdasarkan Tabel 4.4, yakni Tabel Statistics, diperoleh nilai standar deviasi atau Std. Deviation 13,443, varians atau Variance 180,702, Range 40, minimum 10 dan maksimum 50. Hasil ini sesuai dengan perhitungan sebelumnya secara manual.

Tabel 4.5

\begin{tabular}{|c|c|c|c|c|c|}
\hline \multicolumn{6}{|c|}{ Data } \\
\hline & & Frequency & Percent & Valid Percent & $\begin{array}{c}\text { Cumulative } \\
\text { Percent }\end{array}$ \\
\hline \multirow[t]{6}{*}{ Valid } & 10 & 3 & 15.8 & 15.8 & 15.8 \\
\hline & 20 & 2 & 10.5 & 10.5 & 26.3 \\
\hline & 30 & 7 & 36.8 & 36.8 & 63.2 \\
\hline & 40 & 3 & 15.8 & 15.8 & 78.9 \\
\hline & 50 & 4 & 21.1 & 21.1 & 100.0 \\
\hline & Total & 19 & 100.0 & 100.0 & \\
\hline
\end{tabular}


Perhatikan bahwa pada Tabel 4.5, yakni Tabel Data, dapat ditarik suatu informasi bahwa nilai 10 memiliki frekuensi sebanyak 3, nilai 20 memiliki frekuensi sebanyak 2, nilai 30 memiliki frekuensi sebanyak 7 , dan seterusnya.

\section{Ukuran Kemiringan dan Kurtosis}

Bangun data pada Tabel 4.6 dalam SPSS. Selanjutnya pilih Analyze $=>$ Descriptive Statistics => Frequencies, sehingga muncul kotak dialog Frequencies. Pindahkan variabel data pada kotak Variable(s). Kemudian pilih Statistics, sehingga muncul kotak dialog Frequencies: Statistics. Pada kotak Distribution pilih Skewness dan Kurtosis. Kemudian pilih Continue dan OK. Hasilnya seperti pada Tabel 4.7. Berdasarkan Tabel 4.7, yakni Tabel Statistics, diperoleh nilai Skewness sebesar 0,174 dan nilai kurtosis sebesar -0,486. Hasil perhitungan SPSS sama dengan hasil perhitungan secara manual.

Tabel 4.6

\begin{tabular}{|c|c|c|c|}
\hline Data & Data & Data & Data \\
\hline 1 & 3 & 4 & 5 \\
\hline 2 & 3 & 4 & 6 \\
\hline 2 & 3 & 4 & 6 \\
\hline 3 & 3 & 5 & \multicolumn{1}{|c|}{} \\
\cline { 1 - 3 } & &
\end{tabular}

Tabel 4.7

Statistics

\begin{tabular}{|l|r|}
\hline \multicolumn{1}{|c|}{ Valid } & 15 \\
Missing & 0 \\
Skewness & .174 \\
Std. Error of Skewness & .580 \\
Kurtosis & -.486 \\
Std. Error of Kurtosis & 1.121 \\
\hline
\end{tabular}




\section{PENYELESAIAN DALAM Minitab}

Bangun data pada Tabel 4.1 dalam Minitab seperti pada Gambar 4.6. Pilih Stat $=>$ Basic Statistics $=>$ Display Descriptive Statistics (Gambar 4.7), sehingga muncul tampilan seperti pada Gambar 4.8. Pada Gambar 4.8, masukkan variabel C1 ke dalam kotak Variables:, kemudian pilih Statistics, sehingga muncul tampilan seperti pada Gambar 4.9. Pada Gambar 4.9, pilih ukuran-ukuran yang dikehendaki, kemudian pilih OK. Selanjutnya pilih Graphs, sehingga muncul tampilan seperti pada Gambar 4.10. Pada Gambar 4.10, pilih Histogram of data dan Histogram of data, with normal curve. Kemudian pilih OK dan OK.

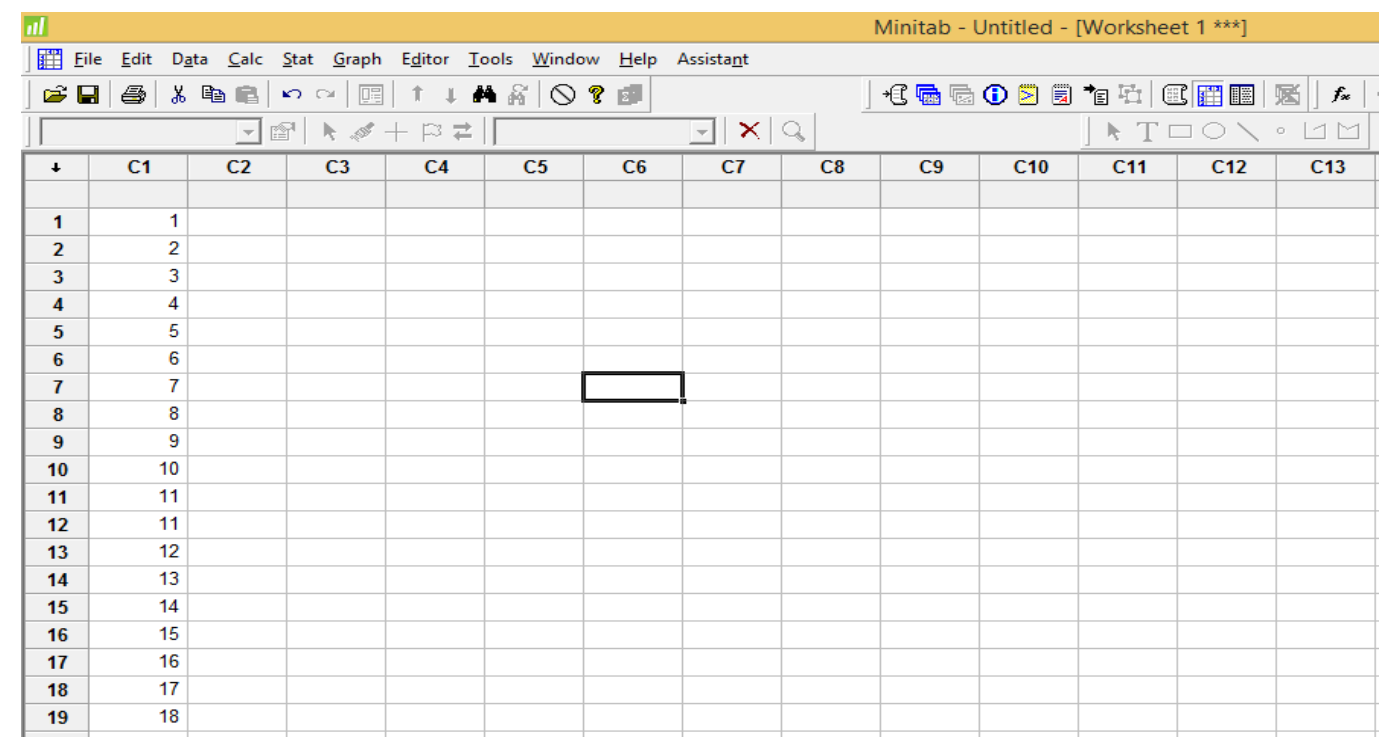

\section{Gambar 4.6}

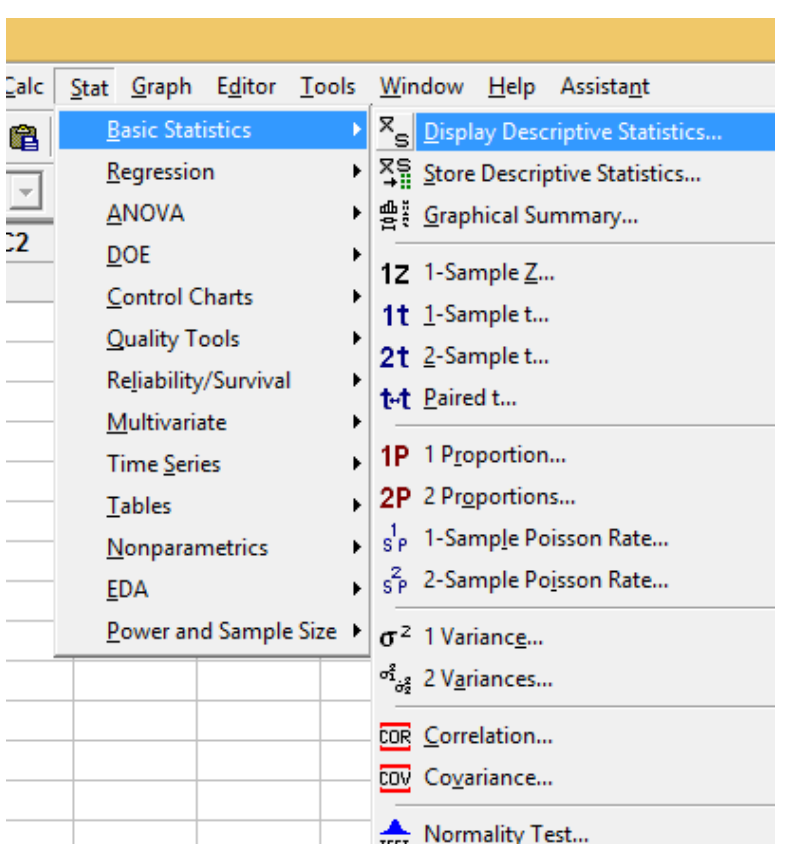

Gambar 4.7

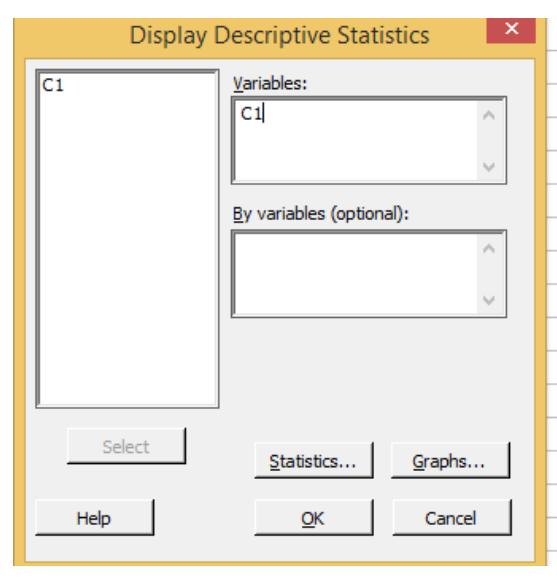

Gambar 4.8 


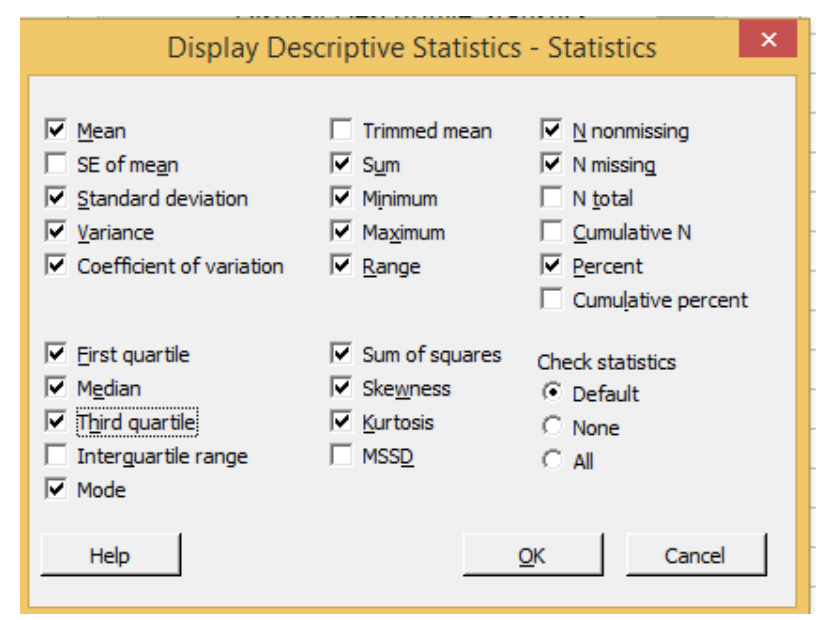

Gambar 4.9

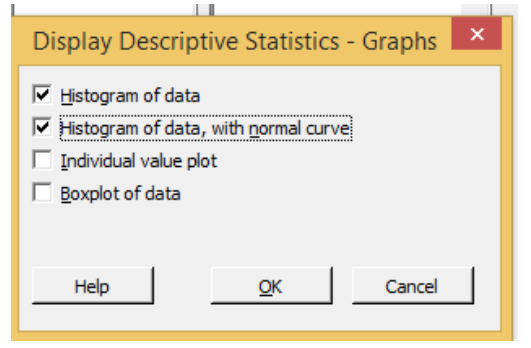

Gambar 4.10

Gambar 4.11 sampai Gambar 4.12 merupakan hasil atau output berdasarkan Minitab. Pada Gambar 4.11 menyajikan ukuran-ukuran seperti rata-rata (Mean) 9,58, standar deviasi (StDev) 5,20, dan seterusnya. Pada Gambar 4.12 menyajikan histogram tanpa dan dengan kurva normal.

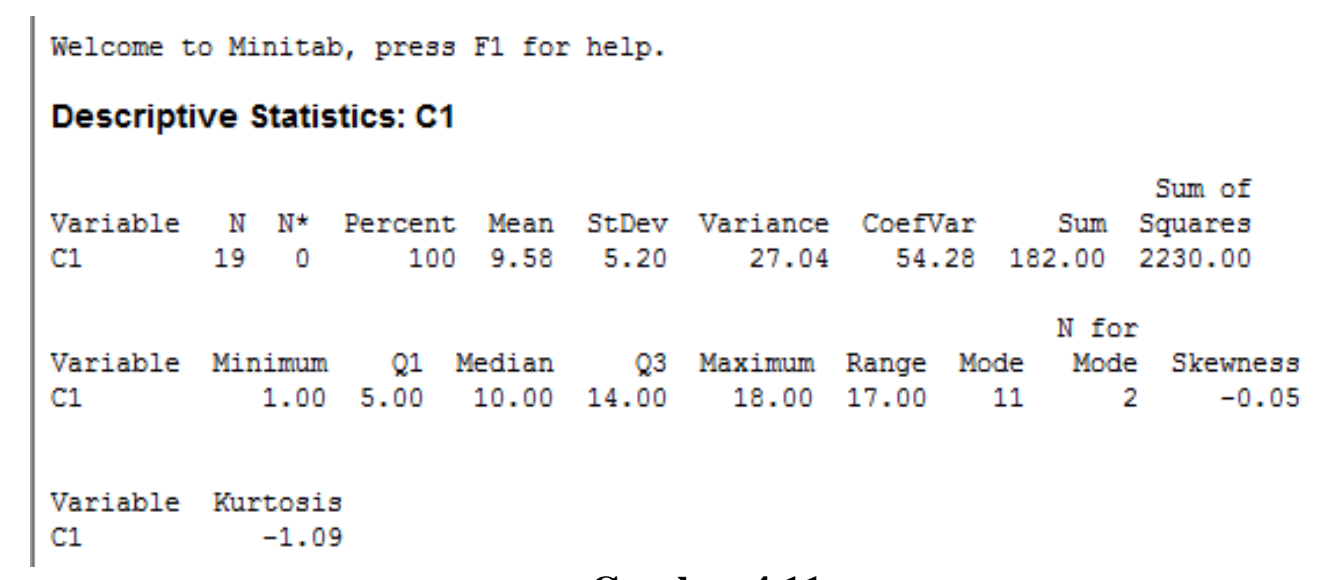

\section{Gambar 4.11}
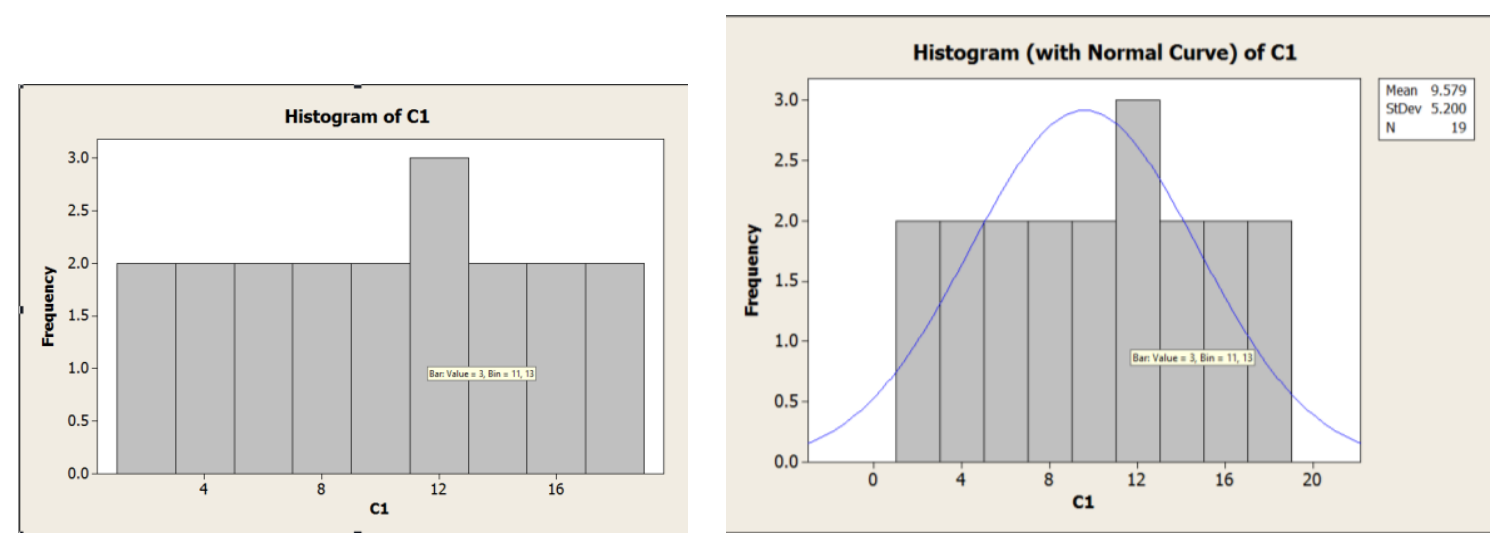

Gambar 4.12 


\section{PENYELESAIAN DALAM R}

Data terlebih dahulu dibuat dalam Microsoft Excel (Gambar 4.13) dan disimpan dengan format tipe .csv (Gambar 4.14 dan Gambar 4.15). Ketik kode R seperti pada Gambar 4.16. Kemudian Compile dan pilih HTML (Gambar 4.17). Hasilnya seperti pada Gambar 4.18.

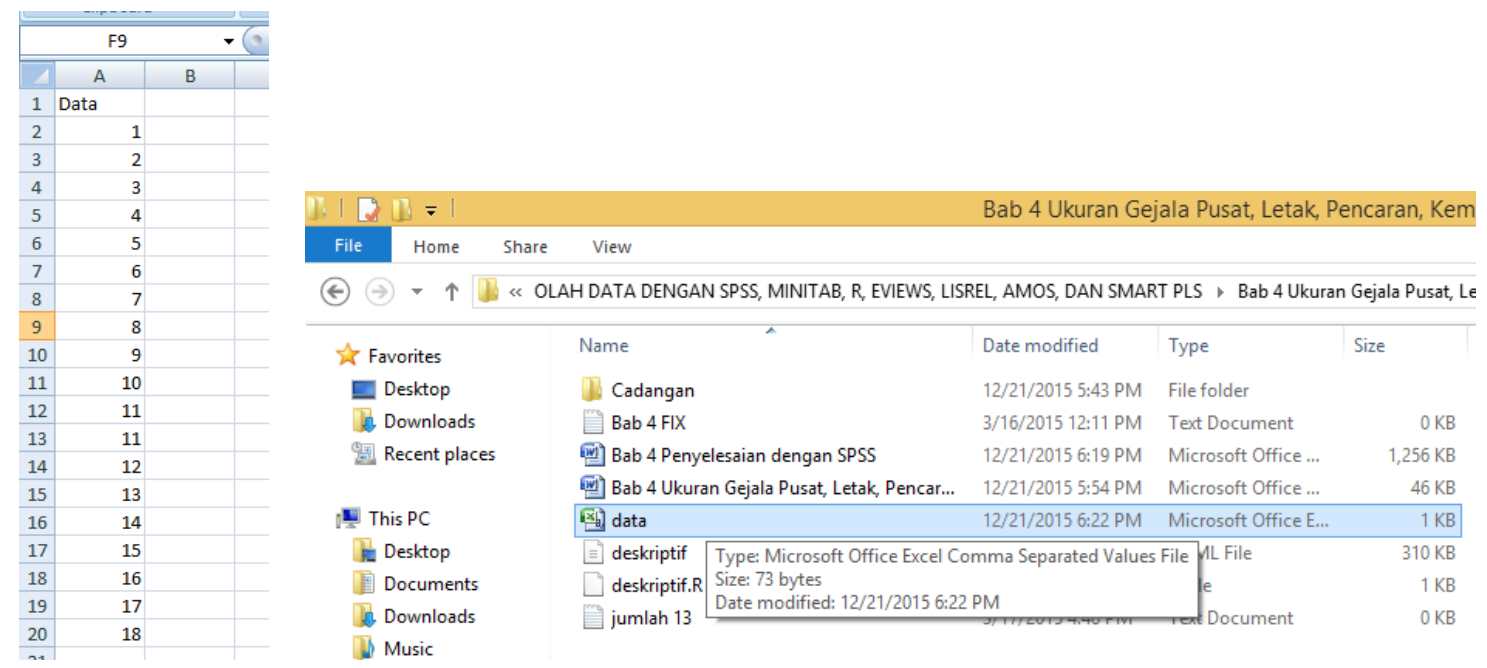

\section{Gambar 4.13}

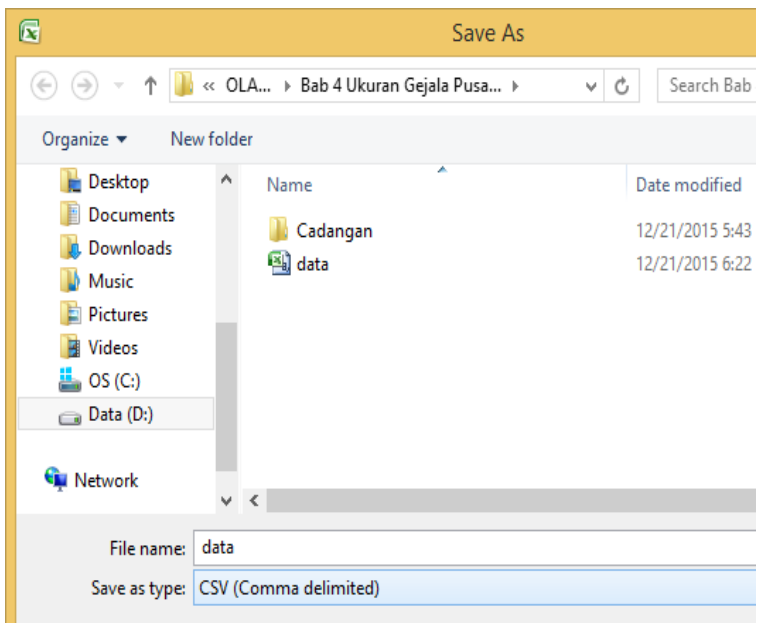

\section{Gambar 4.14}

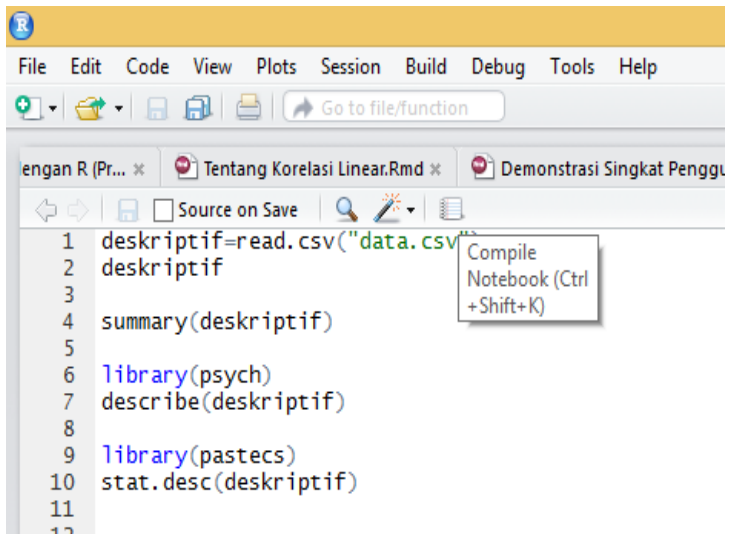

Gambar 4.15

Gambar 4.16

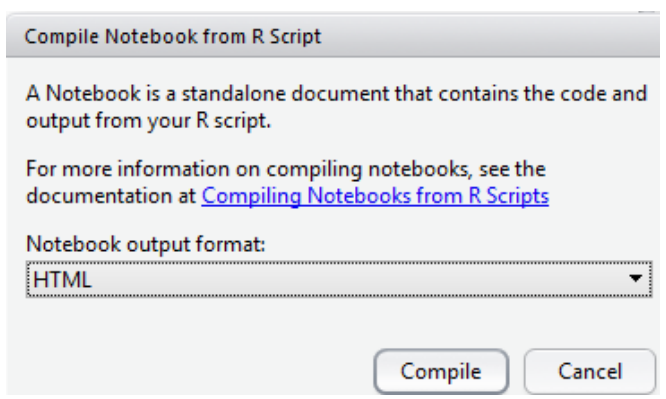

Gambar 4.17 


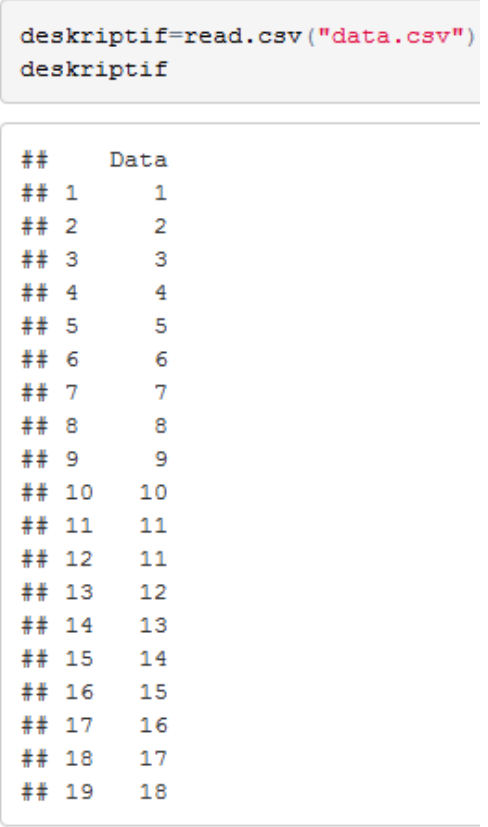

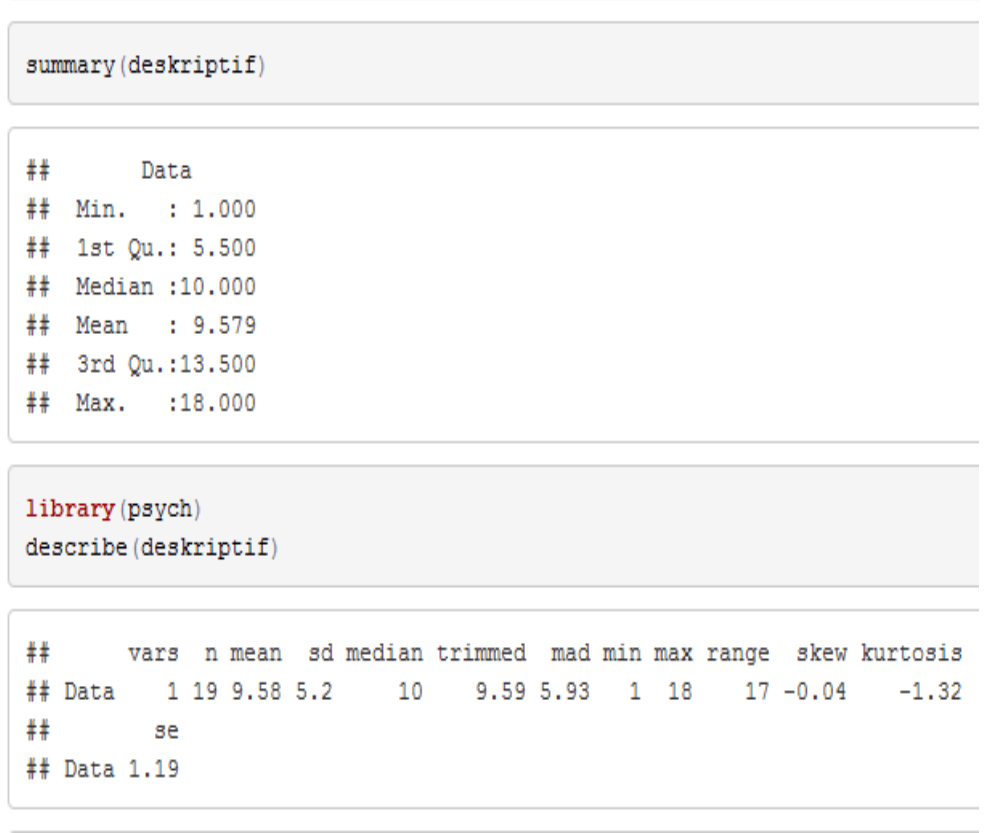

\begin{tabular}{|rr}
\hline \multicolumn{2}{|l}{ stat.desc(deskriptif) } \\
\hline \#\# & Data \\
\# nbr.val & 19.0000000 \\
\# nbr.nul1 & 0.0000000 \\
\# nbr.na & 0.0000000 \\
\# min & 1.0000000 \\
\# max & 18.0000000 \\
\# range & 17.0000000 \\
\# sum & 182.0000000 \\
\# median & 10.0000000 \\
\# mean & 9.5789474 \\
\# SE.mean & 1.1928535 \\
\# CI.mean.0.95 & 2.5060921 \\
\# var & 27.0350877 \\
\# std.dev & 5.1995276 \\
\# coef.var & 0.5428078 \\
\hline
\end{tabular}

\section{Gambar 4.18}

\section{Referensi}

1. Gio, P.U. 2013. Aplikasi Statistika dalam SPSS. Medan: USUpress.

2. Mann, P. S. dan C. J. Lacke. 2001. Introductory Statistics, International Student Version, $7^{\text {th }}$ Edition. Asia: John Wiley \& Sons, Inc.

3. Smidth, R. K. dan D. H. Sanders. 2000. Statistics a First Course, $6^{\text {th }}$ Edition. United States of America: McGraw-Hill Companies.

4. Spiegel, M.R. dan L. J. Stephens. 1999. Statistics, $3^{\text {rd }}$ Edition. United States of America: McGraw-Hill Companies. 


\section{BAB 5}

\section{MEMBUAT TABEL DISTRIBUSI DALAM SPSS \& MICROSOFT EXCEL}

\section{Membuat Tabel Distribusi Normal Standar dalam SPSS dan Mícrosoft Excel}

Berikut langkah-langkah untuk membuat tabel distribusi normal standar dalam SPSS. Bangun data dalam SPSS seperti pada Gambar 5.1 dan Gambar 5.2.

\begin{tabular}{|c|c|}
\hline & $z$ \\
\hline 1 & 0.000 \\
\hline 2 & 0.010 \\
\hline 3 & 0.020 \\
\hline 4 & 0.030 \\
\hline 5 & 0.040 \\
\hline 6 & 0.050 \\
\hline 7 & 0.060 \\
\hline 8 & 0.070 \\
\hline 9 & 0.080 \\
\hline 10 & 0.090 \\
\hline 11 & 0.100 \\
\hline 12 & 0.110 \\
\hline 13 & 0.120 \\
\hline 14 & 0.130 \\
\hline 15 & 0.140 \\
\hline 16 & 0.150 \\
\hline 17 & 0.160 \\
\hline
\end{tabular}

\begin{tabular}{|l|l|}
\hline & \multicolumn{1}{|l|}{$z$} \\
\hline 18 & 0.170 \\
\hline 19 & 0.180 \\
\hline 20 & 0.190 \\
\hline 21 & 0.200 \\
\hline 22 & 0.210 \\
\hline 23 & 0.220 \\
\hline 24 & 0.230 \\
\hline 25 & 0.240 \\
\hline 26 & 0.250 \\
\hline 27 & 0.260 \\
\hline 28 & 0.270 \\
\hline 29 & 0.280 \\
\hline 30 & 0.290 \\
\hline 31 & 0.300 \\
\hline 32 & 0.310 \\
\hline 33 & 0.320 \\
\hline 34 & 0.330 \\
\hline
\end{tabular}

\begin{tabular}{|l|l|l}
\hline & $z$ & \\
\hline 35 & 0.340 \\
\hline 36 & 0.350 \\
\hline 37 & 0.360 \\
\hline 38 & 0.370 \\
\hline 39 & 0.380 \\
\hline 40 & 0.390 \\
\hline 41 & 0.400 \\
\hline 42 & 0.410 \\
\hline 43 & 0.420 \\
\hline 44 & 0.430 \\
\hline 45 & 0.440 \\
\hline 46 & 0.450 \\
\hline 47 & 0.460 \\
\hline 48 & 0.470 \\
\hline 49 & 0.480 \\
\hline 50 & 0.490 \\
\hline 51 & 0.500 \\
\hline
\end{tabular}

Gambar 5.1

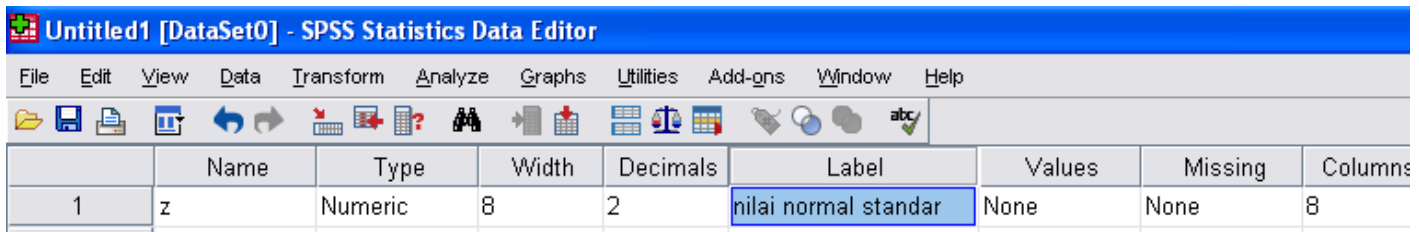

\section{Gambar 5.2}

Selanjutnya pilih Transform $\Rightarrow$ Compute Variable, sehingga muncul tampilan Compute Variable (Gambar 5.3). Pada kotak Target Variable, ketik fz, dan pada kotak Numeric Expression, ketik rumus berikut.

$$
\text { CDF.NORMAL(z,0,1)-0.5 }
$$

Kemudian pilih OK. Hasilnya seperti pada Gambar 5.4. 


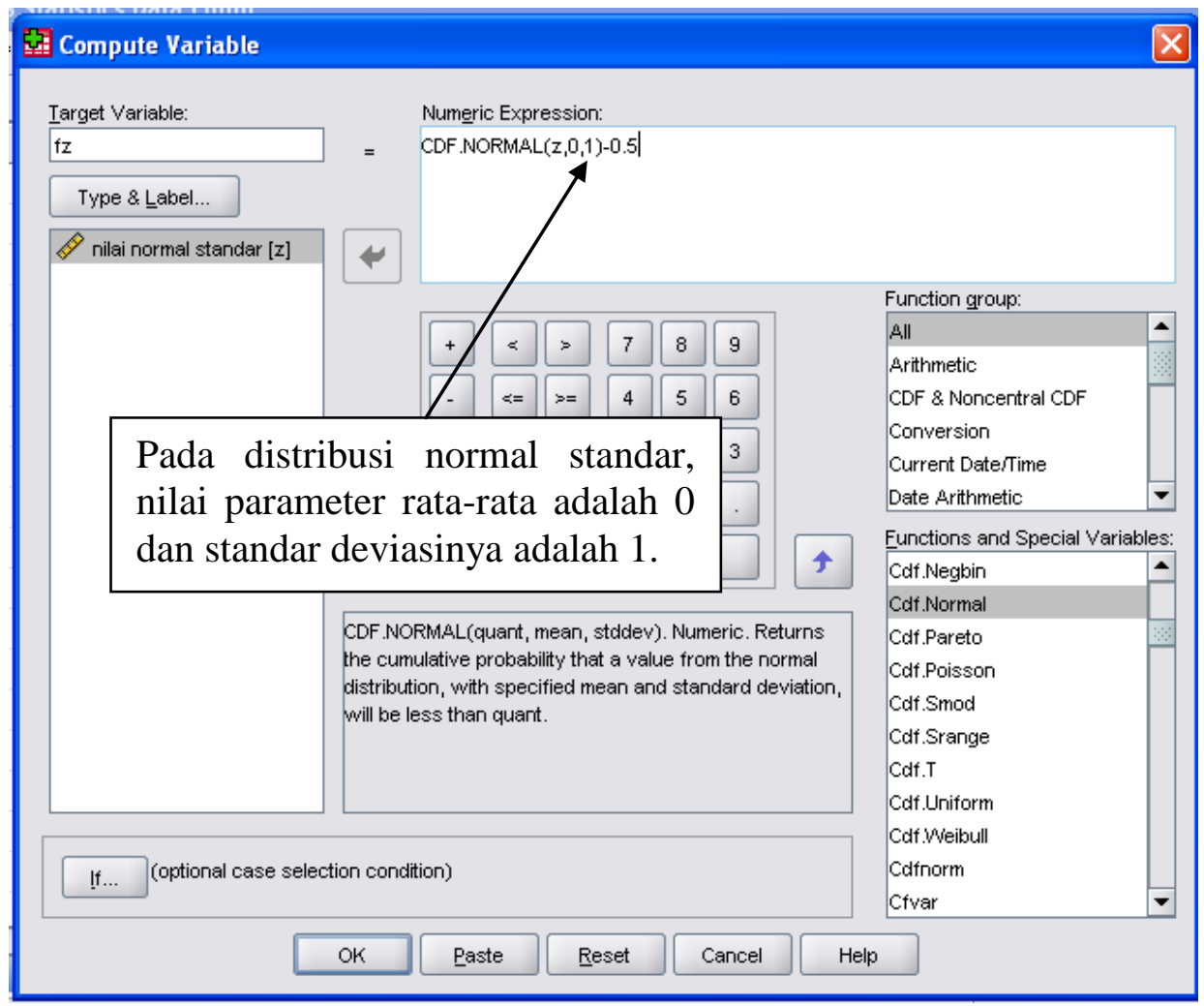

\section{Gambar 5.3}

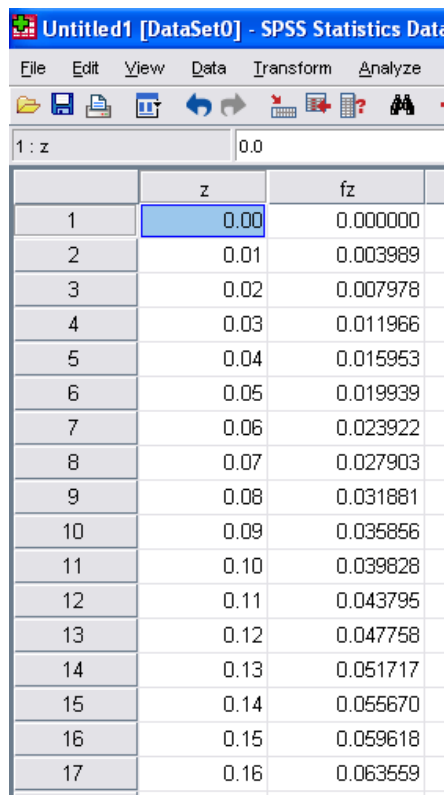

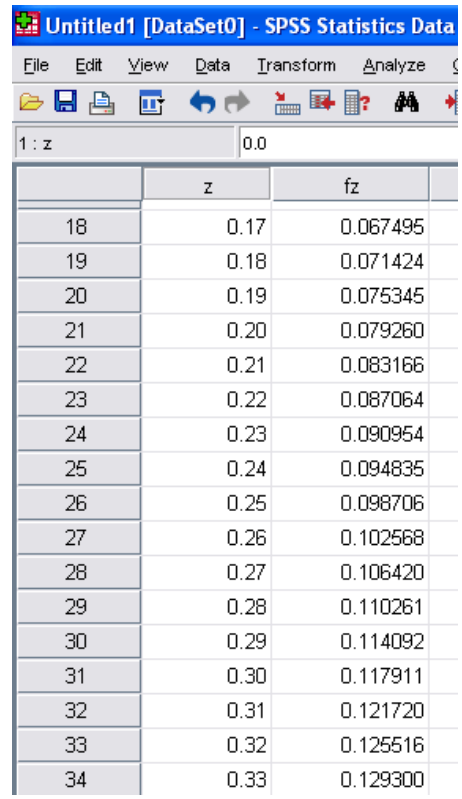

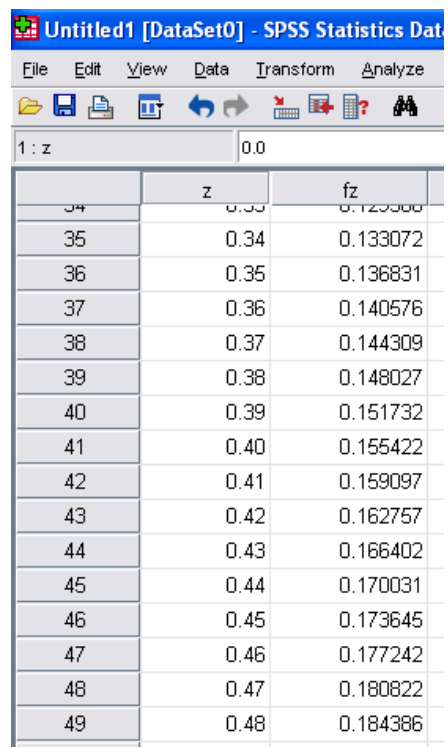

\section{Gambar 5.4}

Sebagai contoh, probabilitas di antara $Z=0$ dan $Z=0,16$ adalah

$$
P(0 \leq Z \leq 0,16)=0,063559 \text {. }
$$

Berikut langkah-langkah untuk membuat tabel distribusi normal standar dalam Microsoft Excel. Bangun data dalam Microsoft Excel, seperti pada Gambar 5.5. 


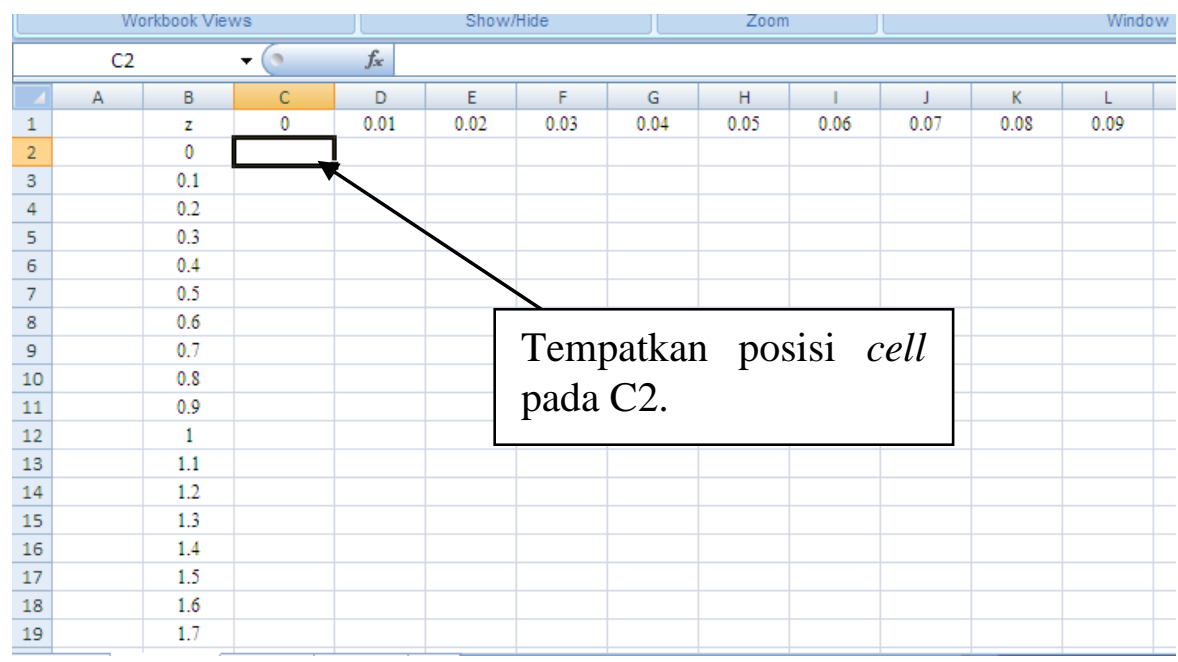

Gambar 5.5

Pada Gambar 5.5, tempatkan posisi pada cell C2. Kemudian ketik rumus pada cell C2 seperti berikut.

$=$ NORMSDIST $(\$ B \$ 2+C 1)-0.5$

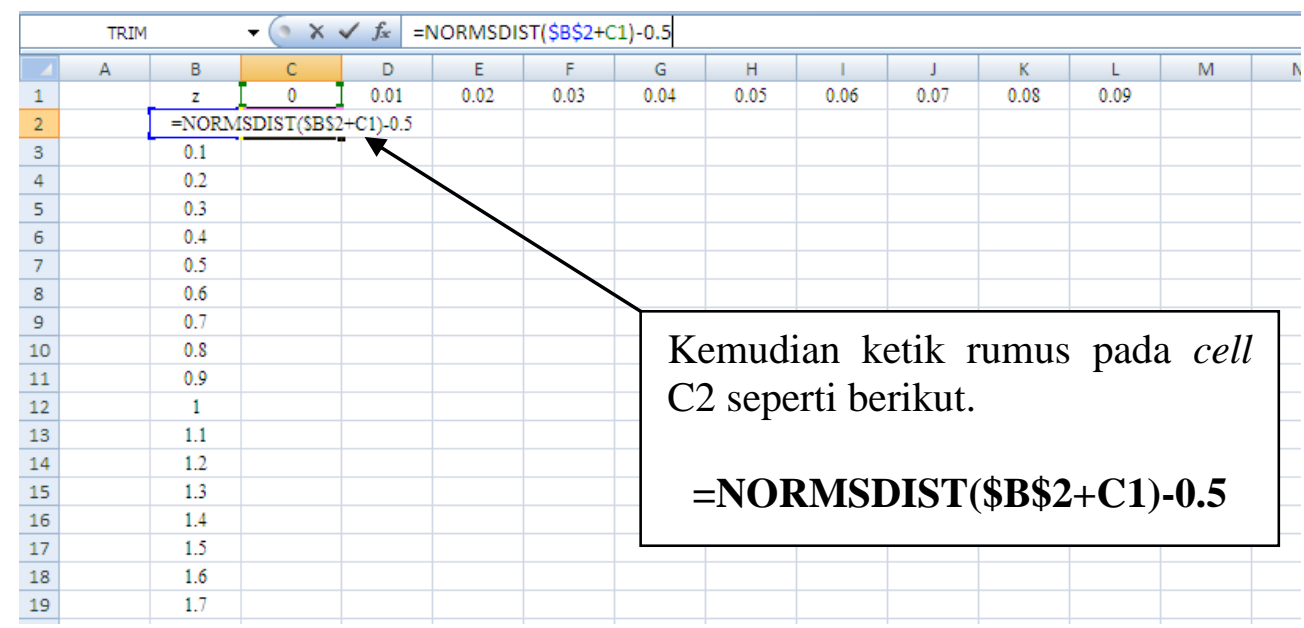

Gambar 5.6

Hasilnya seperti pada Gambar 5.7. Kemudian pada cell C2, geser ke kanan, sehingga diperoleh hasil seperti pada Gambar 5.8. Kemudian letakkan kembali pada Cell C3. Ketik rumus pada Cell $\mathrm{C} 3$ sebagai berikut.

\section{$=$ NORMSDIST $(\$ B \$ 3+C 1)-0.5$}

Hasilnya seperti pada Gambar 5.9. Kemudian pada cell C3, geser ke kanan, sehingga diperoleh hasil seperti pada Gambar 5.10. 


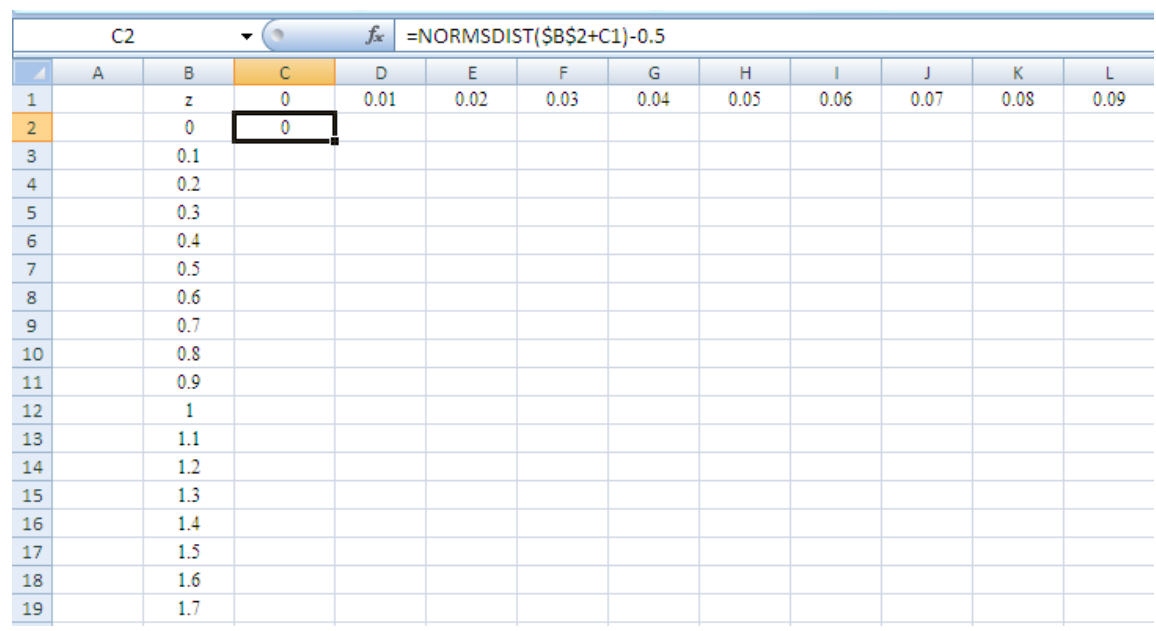

Gambar 5.7

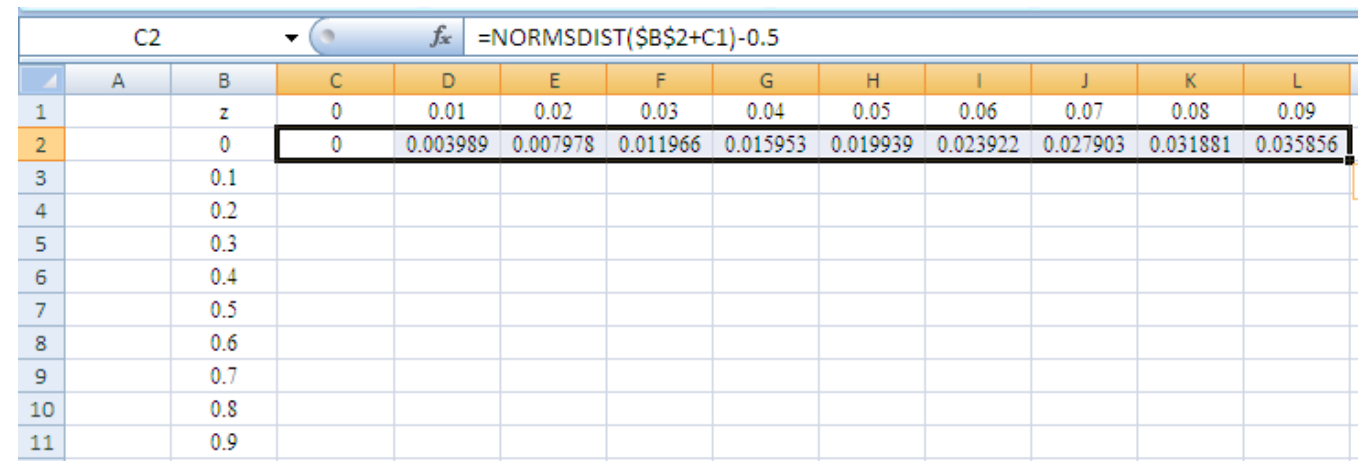

Gambar 5.8

\begin{tabular}{|c|c|c|c|c|c|c|c|c|c|c|c|c|c|}
\hline \multicolumn{3}{|c|}{$\mathrm{C} 3$} & \multicolumn{11}{|c|}{ - $\quad f_{x x}=$ NORMSDIST $(\$ B \$ 3+C 1)-0.5$} \\
\hline 4 & A & B & C & D & $E$ & $F$ & G & H & 1 & J & K & L & M \\
\hline 1 & & $z$ & 0 & 0.01 & 0.02 & 0.03 & 0.04 & 0.05 & 0.06 & 0.07 & 0.08 & 0.09 & \\
\hline 2 & & 0 & 0 & 0.003989 & 0.007978 & 0.011966 & 0.015953 & 0.019939 & 0.023922 & 0.027903 & 0.031881 & 0.035856 & \\
\hline 3 & & 0.1 & 0.0398278 & & & & & & & & & & \\
\hline 4 & & 0.2 & & & & & & & & & & & \\
\hline 5 & & 0.3 & & & & & & & & & & & \\
\hline 6 & & 0.4 & & & & & & & & & & & \\
\hline 7 & & 0.5 & & & & & & & & & & & \\
\hline 8 & & 0.6 & & & & & & & & & & & \\
\hline 9 & & 0.7 & & & & & & & & & & & \\
\hline
\end{tabular}

Gambar 5.9

\begin{tabular}{|c|c|c|c|c|c|c|c|c|c|c|c|c|c|}
\hline \multicolumn{4}{|c|}{ Workbook Views } & \multicolumn{4}{|c|}{ Show/Hide } & \multicolumn{2}{|c|}{ Zoom } & \multicolumn{4}{|c|}{ Window } \\
\hline \multicolumn{3}{|c|}{$\mathrm{C} 3$} & \multicolumn{2}{|c|}{$\rightarrow\left(f_{x}\right.$} & \multicolumn{3}{|c|}{$=$ NORMSDIST $(\$ B \$ 3+C 1)-0.5$} & & & & & & \\
\hline 4 & A & $B$ & $\mathrm{C}$ & D & $E$ & $\mathrm{~F}$ & G & $\mathrm{H}$ & 1 & J & K & L & \\
\hline 1 & & $z$ & 0 & 0.01 & 0.02 & 0.03 & 0.04 & 0.05 & 0.06 & 0.07 & 0.08 & 0.09 & \\
\hline 2 & & 0 & 0 & 0.003989 & 0.007978 & 0.011966 & 0.015953 & 0.019939 & 0.023922 & 0.027903 & 0.031881 & 0.035856 & \\
\hline 3 & & 0.1 & 0.0398278 & 0.043795 & 0.047758 & 0.051717 & 0.05567 & 0.059618 & 0.063559 & 0.067495 & 0.071424 & 0.075345 & \\
\hline 4 & & 0.2 & & & & & & & & & & & 要+ \\
\hline 5 & & 0.3 & & & & & & & & & & & \\
\hline
\end{tabular}

Gambar 5.10

Lakukan terus, sehingga diperoleh hasil seperti pada Gambar 5.11 dan Tabel 5.1. 


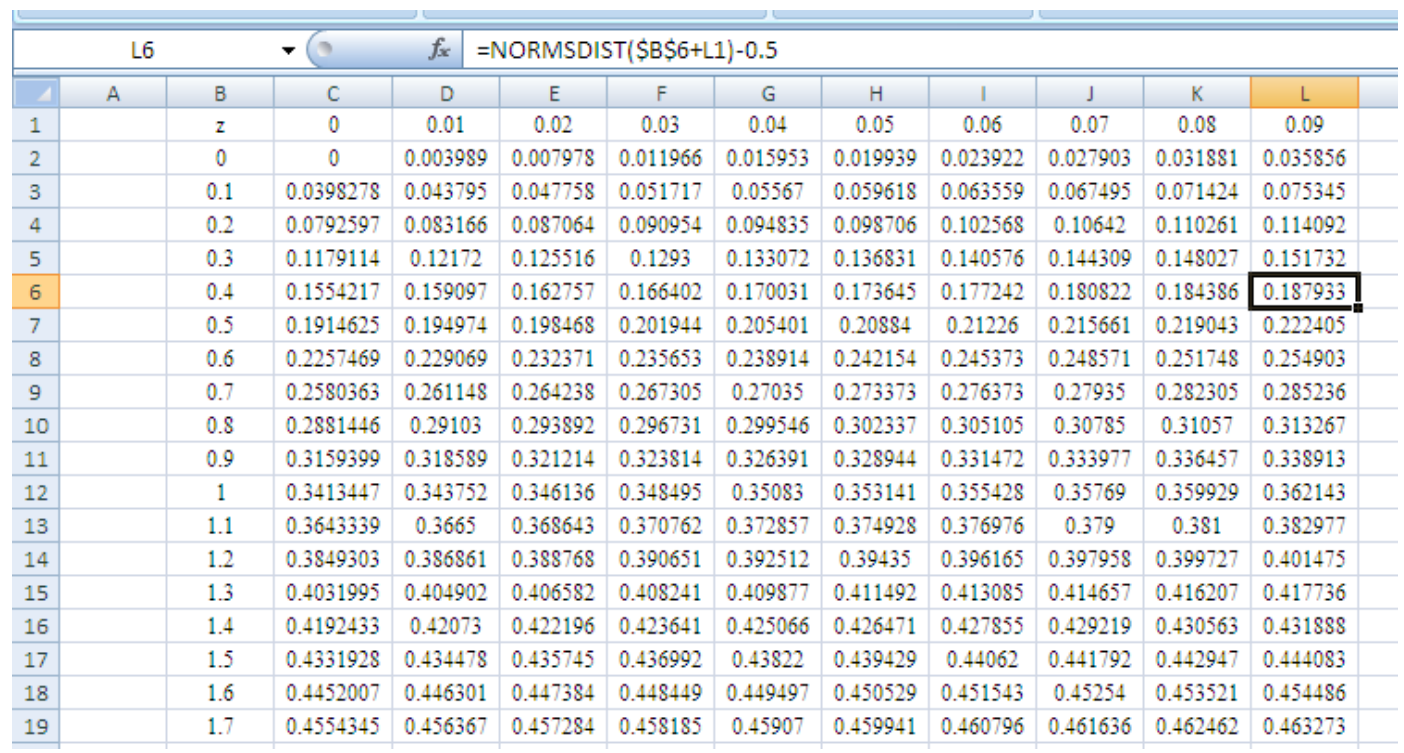

\section{Gambar 5.11}

Tabel 5.1 Distribusi Normal Standar dengan Microsoft Excel

\begin{tabular}{|c|c|c|c|c|c|c|c|c|c|c|}
\hline $\mathrm{z}$ & 0 & 0.01 & 0.02 & 0.03 & 0.04 & 0.05 & 0.06 & 0.07 & 0.08 & 0.09 \\
\hline 0 & 0 & 0.004 & 0.008 & 0.012 & 0.016 & 0.0199 & 0.0239 & 0.0279 & 0.0319 & 0.0359 \\
\hline 0.1 & 0.0398 & 0.0438 & 0.0478 & 0.0517 & 0.0557 & 0.0596 & 0.0636 & 0.0675 & 0.0714 & 0.0753 \\
\hline 0.2 & 0.0793 & 0.0832 & 0.0871 & 0.091 & 0.0948 & 0.0987 & 0.1026 & 0.1064 & 0.1103 & 0.1141 \\
\hline 0.3 & 0.1179 & 0.1217 & 0.1255 & 0.1293 & 0.1331 & 0.1368 & 0.1406 & 0.1443 & 0.148 & 0.1517 \\
\hline 0.4 & 0.1554 & 0.1591 & 0.1628 & 0.1664 & 0.17 & 0.1736 & 0.1772 & 0.1808 & 0.1844 & 0.1879 \\
\hline 0.5 & 0.1915 & 0.195 & 0.1985 & 0.2019 & 0.2054 & 0.2088 & 0.2123 & 0.2157 & 0.219 & 0.224 \\
\hline 0.6 & 0.2257 & 0.2291 & 0.2324 & 0.2357 & 0.2389 & 0.2422 & 0.2454 & 0.2486 & 0.2517 & 0.2549 \\
\hline 0.7 & 0.258 & 0.2611 & 0.2642 & 0.2673 & 0.2704 & 0.2734 & 0.2764 & 0.2794 & 0.2823 & 0.2852 \\
\hline 0.8 & 0.2881 & 0.291 & 0.2939 & 0.2967 & 0.2995 & 0.3023 & 0.3051 & 0.3078 & 0.3106 & 0.3133 \\
\hline 0.9 & 0.3159 & 0.3186 & 0.3212 & 0.3238 & 0.3264 & 0.3289 & 0.3315 & 0.334 & 0.3365 & 0.3389 \\
\hline 1 & 0.3413 & 0.3438 & 0.3461 & 0.3485 & 0.3508 & 0.3531 & 0.3554 & 0.3577 & 0.3599 & 0.3621 \\
\hline 1.1 & 0.3643 & 0.3665 & 0.3686 & 0.3708 & 0.3729 & 0.3749 & 0.377 & 0.379 & 0.381 & 0.383 \\
\hline 1.2 & 0.3849 & 0.3869 & 0.3888 & 0.3907 & 0.3925 & 0.3944 & 0.3962 & 0.398 & 0.3997 & 0.4015 \\
\hline 1.3 & 0.4032 & 0.4049 & 0.4066 & 0.4082 & 0.4099 & 0.4115 & 0.4131 & 0.4147 & 0.4162 & 0.4177 \\
\hline 1.4 & 0.4192 & 0.4207 & 0.4222 & 0.4236 & 0.4251 & 0.4265 & 0.4279 & 0.4292 & 0.4306 & 0.4319 \\
\hline 1.5 & 0.4332 & 0.4345 & 0.4357 & 0.437 & 0.4382 & 0.4394 & 0.4406 & 0.4418 & 0.4429 & 0.4441 \\
\hline 1.6 & 0.4452 & 0.4463 & 0.4474 & 0.4484 & 0.4495 & 0.4505 & 0.4515 & 0.4525 & 0.4535 & 0.4545 \\
\hline 1.7 & 0.4554 & 0.4564 & 0.4573 & 0.4582 & 0.4591 & 0.4599 & 0.4608 & 0.4616 & 0.4625 & 0.4633 \\
\hline
\end{tabular}

\section{Membuat Tabel Distribusí t Student dalam SPSS dan Mícrosoft Excel}

Berikut langkah-langkah untuk membuat tabel distribusi $t$ student dalam SPSS dengan tingkat signifikansi 5\%. Bangun data dalam SPSS seperti pada Gambar 5.12. Kemudian pilih Transform $\Rightarrow$ Compute Variable, sehingga muncul tampilan Compute Variable (Gambar 5.13). Pada kotak Target Variable, ketik Nilai_Kritis_t_0.05_uji_dua_arah, dan pada kotak Numeric Expression, ketik ABS(IDF.T(0.975,Derajat_Bebas)). Kemudian pilih OK. Hasilnya seperti pada Gambar 5.14. 


\begin{tabular}{|c|c|c|c|c|}
\hline \multicolumn{5}{|c|}{ F Untitled1 [DataSet0] - SPSS Statistics Data Editor } \\
\hline \multirow{2}{*}{\multicolumn{5}{|c|}{ 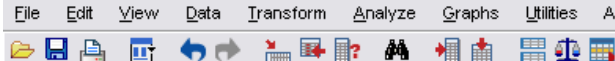 }} \\
\hline & & & & \\
\hline \multicolumn{5}{|c|}{\begin{tabular}{|l|l}
1 : Derajat_Bebas & 1.0
\end{tabular}} \\
\hline & Derajat_Bebas & var & var & var \\
\hline 1 & 1 & & & \\
\hline 2 & 2 & & & \\
\hline 3 & 3 & & & \\
\hline 4 & 4 & & & \\
\hline 5 & 5 & & & \\
\hline 6 & 6 & & & \\
\hline 7 & 7 & & & \\
\hline 8 & 8 & & & \\
\hline 9 & 9 & & & \\
\hline 10 & 10 & & & \\
\hline 11 & 11 & & & \\
\hline 12 & 12 & & & \\
\hline 13 & 13 & & & \\
\hline 14 & 14 & & & \\
\hline 15 & 15 & & & \\
\hline 16 & 16 & & & \\
\hline 17 & 17 & & & \\
\hline
\end{tabular}

Gambar 5.12

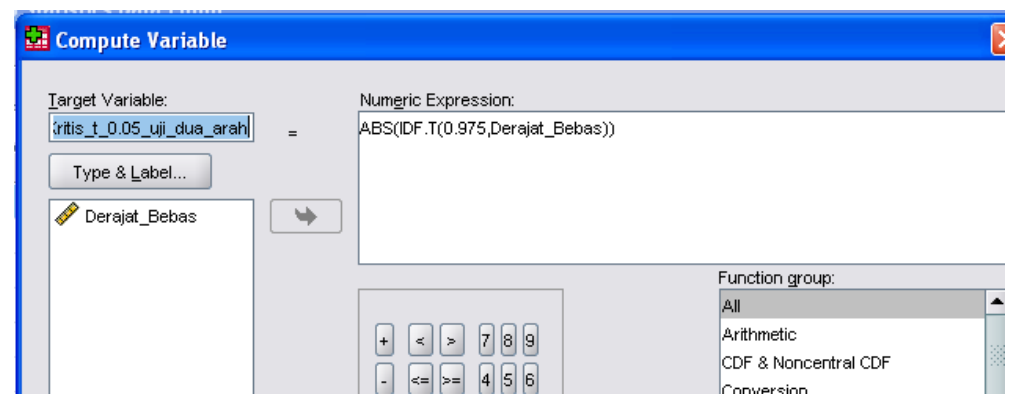

Gambar 5.13

\section{Wntitled1 [DataSet0] - SPSS Statistics Data Editor}

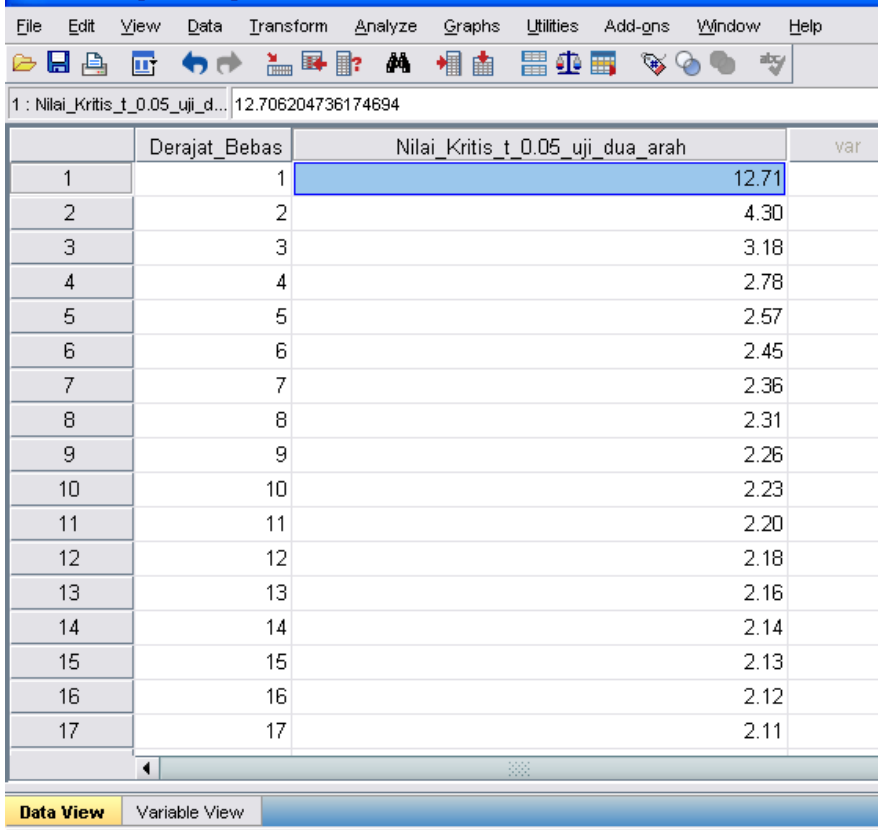

Gambar 5.14 
Sebagai contoh nilai kritis $t$, dengan derajat bebas 10 dan tingkat signifikansi $5 \%$ adalah $\pm 2,23$.

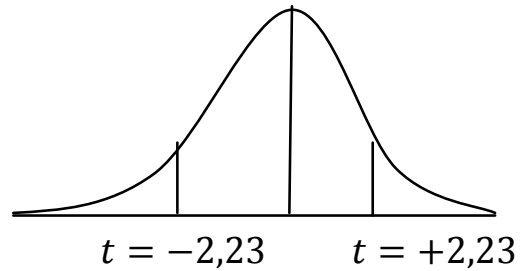

Berikut langkah-langkah untuk membuat tabel distribusi $t$ student dalam Microsoft Excel. Bangun data dalam Microsoft Excel, seperti pada Gambar 5.15. Kemudian tempatkan posisi pada cell $\mathrm{C} 2$. Pada cell $\mathrm{C} 2$, ketik rumus sebagai berikut.

\section{$=\operatorname{TINV}(\mathbf{B 2}, \mathrm{A} 2)$}

Hasilnya seperti pada Gambar 5.16. Kemudian pada cell C2, geser ke bawah, sehingga diperoleh hasil seperti pada Gambar 5.17 dan Tabel 5.2.

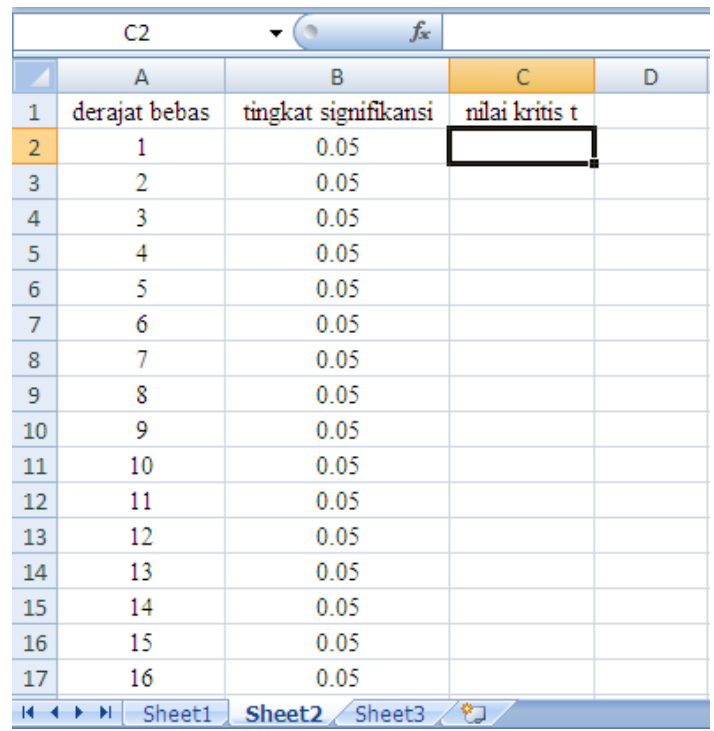

Gambar 5.15

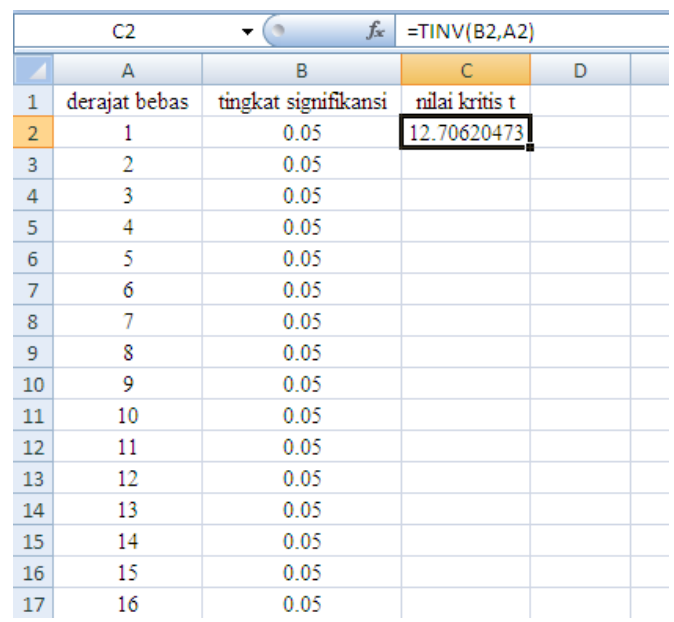

Gambar 5.16 


\begin{tabular}{|c|c|c|c|c|}
\hline \hline & C2 & $-(3$ & $f_{x}$ & $=\operatorname{TINV}(B 2, A 2)$ \\
\hline \hline 1 & A & B & C & D \\
\hline 1 & derajat bebas & tingkat signifikansi & nilai kritis t & \\
\hline 2 & 1 & 0.05 & 12.70620473 & \\
\hline 3 & 2 & 0.05 & 4.30265273 & \\
\hline 4 & 3 & 0.05 & 3.182446305 & \\
\hline 5 & 4 & 0.05 & 2.776445105 & \\
\hline 6 & 5 & 0.05 & 2.570581835 & \\
\hline 7 & 6 & 0.05 & 2.446911846 & \\
\hline 8 & 7 & 0.05 & 2.364624251 & \\
\hline 9 & 8 & 0.05 & 2.306004133 & \\
\hline 10 & 9 & 0.05 & 2.262157158 & \\
\hline 11 & 10 & 0.05 & 2.228138842 & \\
\hline 12 & 11 & 0.05 & 2.200985159 & \\
\hline 13 & 12 & 0.05 & 2.178812827 & \\
\hline 14 & 13 & 0.05 & 2.160368652 & \\
\hline 15 & 14 & 0.05 & 2.144786681 & \\
\hline 16 & 15 & 0.05 & 2.131449536 & \\
\hline 17 & 16 & 0.05 & 2.119905285 & P.+ \\
\hline \hline
\end{tabular}

Gambar 5.17

Tabel 5.2 Distribusi $t$ Student

\begin{tabular}{|c|c|c|}
\hline Derajat Bebas & Tingkat Signifikansi & Nilai Kritis t \\
\hline 1 & 0.05 & 12.70620473 \\
\hline 2 & 0.05 & 4.30265273 \\
\hline 3 & 0.05 & 3.182446305 \\
\hline 4 & 0.05 & 2.776445105 \\
\hline 5 & 0.05 & 2.570581835 \\
\hline 6 & 0.05 & 2.446911846 \\
\hline 7 & 0.05 & 2.364624251 \\
\hline 8 & 0.05 & 2.306004133 \\
\hline 9 & 0.05 & 2.262157158 \\
\hline 10 & 0.05 & 2.228138842 \\
\hline 11 & 0.05 & 2.200985159 \\
\hline 12 & 0.05 & 2.178812827 \\
\hline 13 & 0.05 & 2.160368652 \\
\hline 14 & 0.05 & 2.144786681 \\
\hline 15 & 0.05 & 2.131449536 \\
\hline 16 & 0.05 & 2.119905285 \\
\hline 17 & 0.05 & 2.109815559 \\
\hline 18 & 0.05 & 2.100922037 \\
\hline 19 & 0.05 & 2.09302405 \\
\hline 20 & 0.05 & 2.085963441 \\
\hline 21 & 0.05 & 2.079613837 \\
\hline 22 & 0.05 & 2.073873058 \\
\hline 23 & 0.05 & 2.068657599 \\
\hline 24 & 0.05 & 2.063898547 \\
\hline 25 & 0.05 & 2.059538536 \\
\hline 26 & 0.05 & 2.055529418 \\
\hline 27 & 0.05 & 2.051830493 \\
\hline 28 & 0.05 & 2.048407115 \\
\hline 29 & 0.05 & 2.045229611 \\
\hline
\end{tabular}




\begin{tabular}{|c|c|c|}
\hline 30 & 0.05 & 2.042272449 \\
\hline 31 & 0.05 & 2.039513438 \\
\hline 32 & 0.05 & 2.036933334 \\
\hline 33 & 0.05 & 2.034515287 \\
\hline 34 & 0.05 & 2.032244498 \\
\hline 35 & 0.05 & 2.030107915 \\
\hline 36 & 0.05 & 2.028093987 \\
\hline 37 & 0.05 & 2.026192447 \\
\hline 38 & 0.05 & 2.024394147 \\
\hline 39 & 0.05 & 2.022690901 \\
\hline 40 & 0.05 & 2.02107537 \\
\hline 41 & 0.05 & 2.019540948 \\
\hline 42 & 0.05 & 2.018081679 \\
\hline 43 & 0.05 & 2.016692173 \\
\hline 44 & 0.05 & 2.015367547 \\
\hline 45 & 0.05 & 2.014103359 \\
\hline 46 & 0.05 & 2.012895567 \\
\hline 47 & 0.05 & 2.01174048 \\
\hline 48 & 0.05 & 2.010634722 \\
\hline 49 & 0.05 & 2.009575199 \\
\hline 50 & 0.05 & 2.008559072 \\
\hline 51 & 0.05 & 2.007583728 \\
\hline 52 & 0.05 & 2.006646761 \\
\hline 53 & 0.05 & 2.005745949 \\
\hline 54 & 0.05 & 2.004879275 \\
\hline 55 & 0.05 & 2.004044769 \\
\hline 56 & 0.05 & 2.003240704 \\
\hline 57 & 0.05 & 2.002465444 \\
\hline 58 & 0.05 & 2.001717468 \\
\hline 59 & 0.05 & 2.000995361 \\
\hline 60 & 0.05 & 2.000297804 \\
\hline 61 & 0.05 & 1.999623567 \\
\hline 62 & 0.05 & 1.998971498 \\
\hline 63 & 0.05 & 1.998340522 \\
\hline 64 & 0.05 & 1.997729633 \\
\hline 65 & 0.05 & 1.997137887 \\
\hline 66 & 0.05 & 1.996564396 \\
\hline 67 & 0.05 & 1.996008331 \\
\hline 68 & 0.05 & 1.995468907 \\
\hline 69 & 0.05 & 1.99494539 \\
\hline 70 & 0.05 & 1.994437086 \\
\hline 71 & 0.05 & 1.993943341 \\
\hline 72 & 0.05 & 1.993463539 \\
\hline 73 & 0.05 & 1.992997097 \\
\hline 74 & 0.05 & 1.992543466 \\
\hline 75 & 0.05 & 1.992102124 \\
\hline
\end{tabular}




\begin{tabular}{|c|c|c|}
\hline 76 & 0.05 & 1.991672579 \\
\hline 77 & 0.05 & 1.991254363 \\
\hline 78 & 0.05 & 1.990847036 \\
\hline 79 & 0.05 & 1.990450177 \\
\hline 80 & 0.05 & 1.990063387 \\
\hline 81 & 0.05 & 1.989686288 \\
\hline 82 & 0.05 & 1.989318521 \\
\hline 83 & 0.05 & 1.988959743 \\
\hline 84 & 0.05 & 1.988609629 \\
\hline 85 & 0.05 & 1.988267868 \\
\hline 86 & 0.05 & 1.987934166 \\
\hline 87 & 0.05 & 1.987608241 \\
\hline 88 & 0.05 & 1.987289823 \\
\hline 89 & 0.05 & 1.986978657 \\
\hline 90 & 0.05 & 1.986674497 \\
\hline 91 & 0.05 & 1.98637711 \\
\hline 92 & 0.05 & 1.986086272 \\
\hline 93 & 0.05 & 1.985801768 \\
\hline 94 & 0.05 & 1.985523395 \\
\hline 95 & 0.05 & 1.985250956 \\
\hline 96 & 0.05 & 1.984984263 \\
\hline 97 & 0.05 & 1.984723136 \\
\hline 98 & 0.05 & 1.984467404 \\
\hline 99 & 0.05 & 1.9842169 \\
\hline 100 & 0.05 & 1.983971466 \\
\hline 101 & 0.05 & 1.98373095 \\
\hline 102 & 0.05 & 1.983495205 \\
\hline 103 & 0.05 & 1.98326409 \\
\hline 104 & 0.05 & 1.983037471 \\
\hline 105 & 0.05 & 1.982815217 \\
\hline 106 & 0.05 & 1.982597204 \\
\hline 107 & 0.05 & 1.982383312 \\
\hline
\end{tabular}

\section{Membuat Tabel Dístríbusí F dalam SPSS dan Mícrosoft Excel}

Berikut langkah-langkah untuk membuat tabel distribusi $F$, dengan tingkat signifikansi 5\% dalam SPSS. Bangun data dalam SPSS, seperti pada Gambar 5.18 dan Gambar 5.19. Selanjutnya pilih Transform $\Rightarrow$ Compute Variable, sehingga muncul tampilan Compute Variable (Gambar 5.20). Pada kotak Target Variable, ketik nilai_kritis_F, dan pada kotak Numeric Expression, ketik rumus

\section{IDF.F(0.95,db_pembilang,db_penyebut)}

Kemudian pilih OK. Hasilnya seperti pada Gambar 5.21. Sebagai contoh, berdasarkan Gambar 5.21, nilai kritis $F$ dengan derajat bebas pembilang 4, derajat bebas penyebut 15, dan tingkat signifikansi 0,05 adalah 3,0566. Nilai kritis $F$ dengan derajat bebas pembilang 4, derajat bebas penyebut 4 , dan tingkat signifikansi 0,05 adalah 6,3882 . 


\begin{tabular}{|c|c|c|c|c|}
\hline & db_pembilang & db_penyebut & tgkt_signifikansi & var \\
\hline 1 & 4 & 1 & 0.05 & \\
\hline 2 & 4 & 2 & 0.05 & \\
\hline 3 & 4 & 3 & 0.05 & \\
\hline 4 & 4 & 4 & 0.05 & \\
\hline 5 & 4 & 5 & 0.05 & \\
\hline 6 & 4 & 6 & 0.05 & \\
\hline 7 & 4 & 7 & 0.05 & \\
\hline 8 & 4 & 8 & 0.05 & \\
\hline 9 & 4 & 9 & 0.05 & \\
\hline 10 & 4 & 10 & 0.05 & \\
\hline 11 & 4 & 11 & 0.05 & \\
\hline 12 & 4 & 12 & 0.05 & \\
\hline 13 & 4 & 13 & 0.05 & \\
\hline 14 & 4 & 14 & 0.05 & \\
\hline 15 & 4 & 15 & 0.05 & \\
\hline 16 & 4 & 16 & 0.05 & \\
\hline \multirow[t]{2}{*}{17} & 4 & 17 & 0.05 & \\
\hline & 4 & & & \\
\hline
\end{tabular}

Gambar 5.18

\section{Fit Untitled1 [DataSet0] - SPSS Statistics Data Editor}

Eile Édit View Data Iransform Analyze Graphs Lutilities Add-ons Window Help

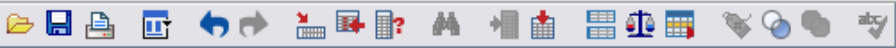

\begin{tabular}{|l|l|l|l|l|l|l|l|l|}
\hline & \multicolumn{1}{|c|}{ Name } & \multicolumn{1}{|c|}{ Type } & Width & Decimals & Label & Values & Missing & Colum \\
\hline 1 & db_pembilang & Numeric & 8 & 0 & None & None & 10 \\
\hline 2 & db_penyebut & Numeric & 8 & 0 & None & None & 9 \\
\hline 3 & tgkt_signifikansi & Numeric & 8 & 2 & None & None & 11 \\
\hline
\end{tabular}

Gambar 5.19

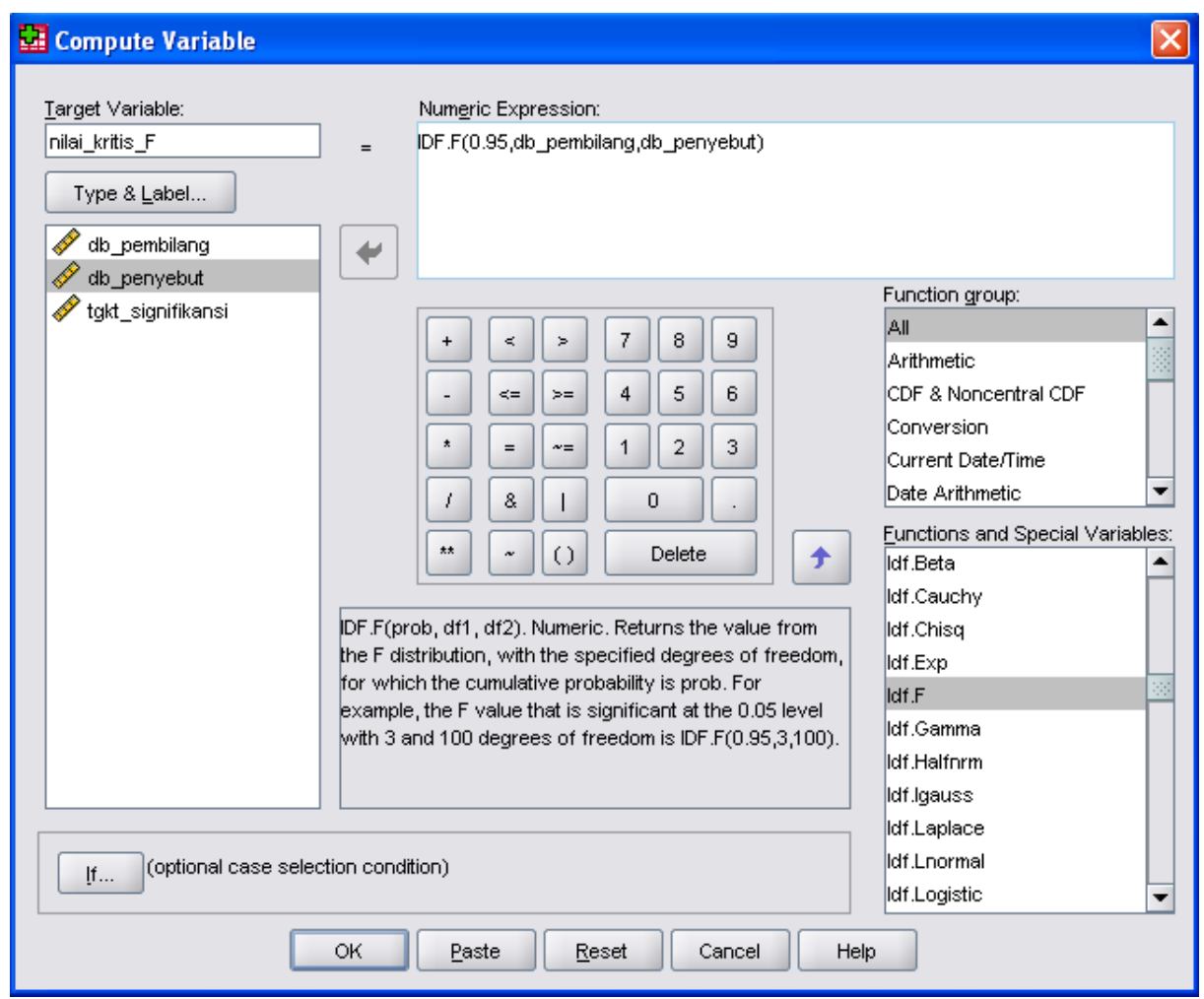

Gambar 5.20 


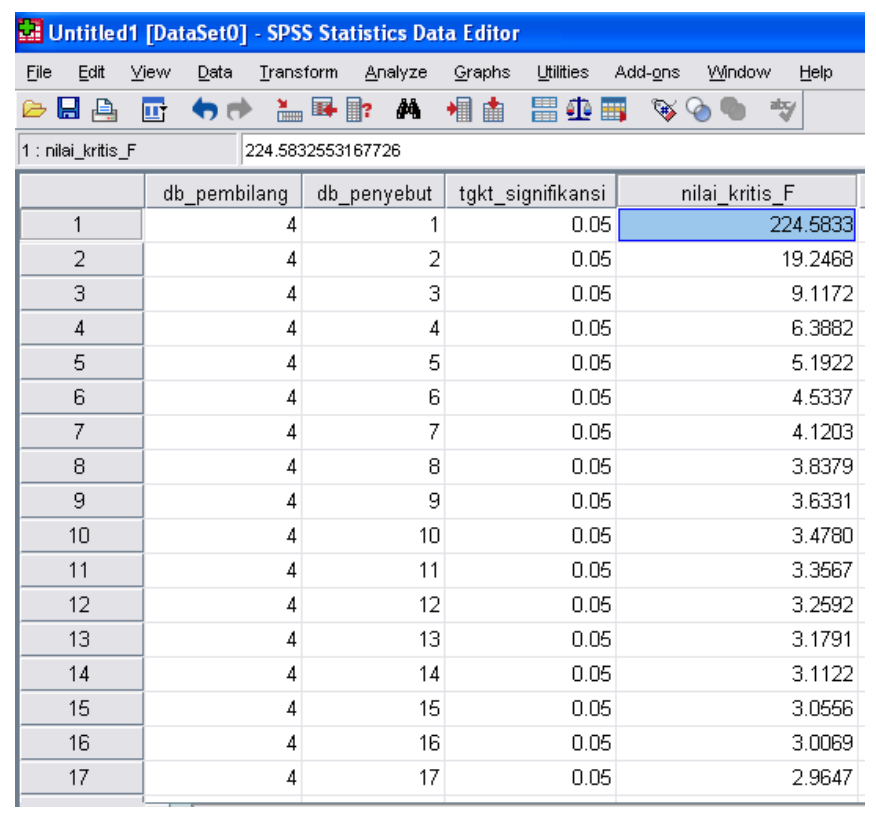

\section{Gambar 5.21}

Berikut langkah-langkah untuk membuat tabel distribusi $F$ dalam Microsoft Excel. Bangun data dalam Microsoft Excel, seperti pada Gambar 5.22. Kemudian tempatkan posisi pada cell C4. Pada cell $\mathrm{C} 4$, ketik rumus sebagai berikut.

\section{$=\operatorname{FINV}(0.05, \$ C \$ 3, B 4)$}

Hasilnya seperti pada Gambar 5.23. Kemudian pada cell C4, geser ke bawah, sehingga diperoleh hasil seperti pada Gambar 5.24.

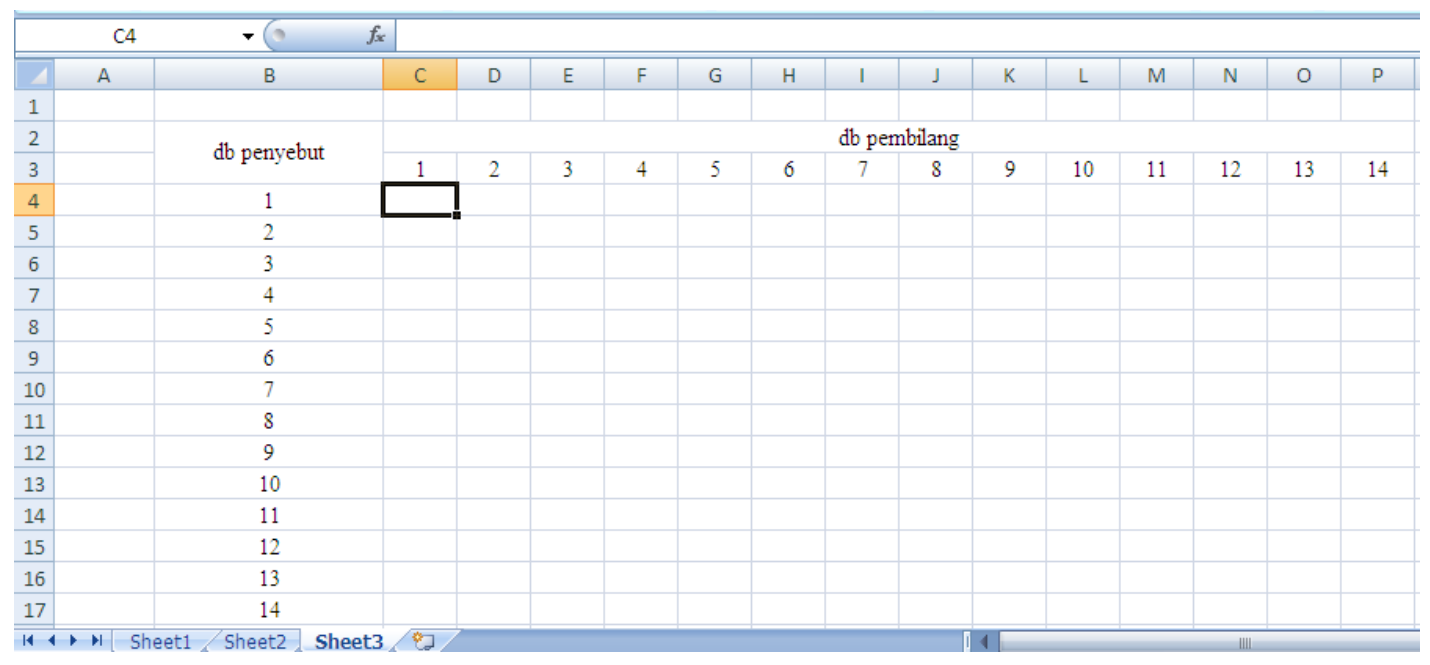

Gambar 5.22 


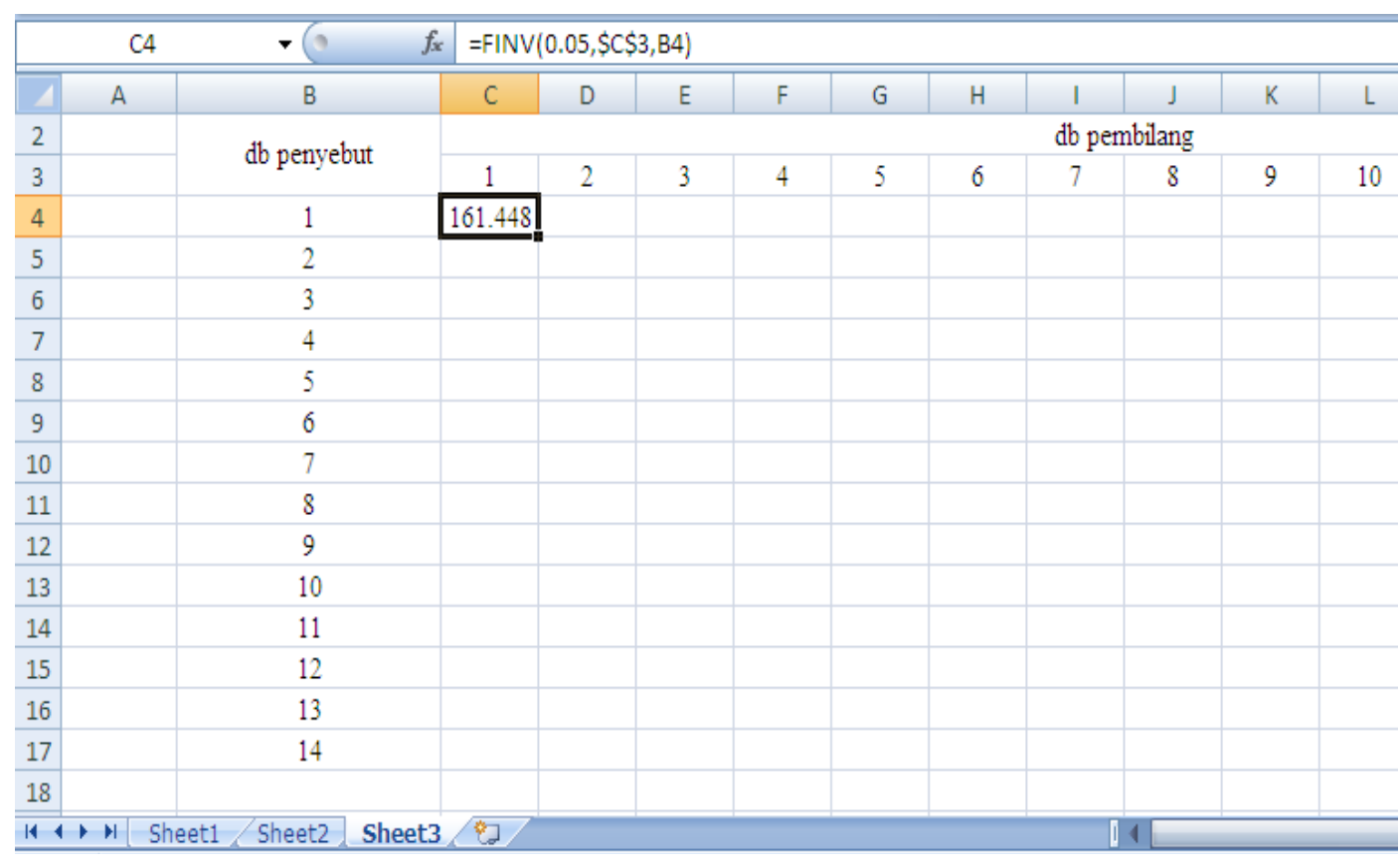

Gambar 5.23

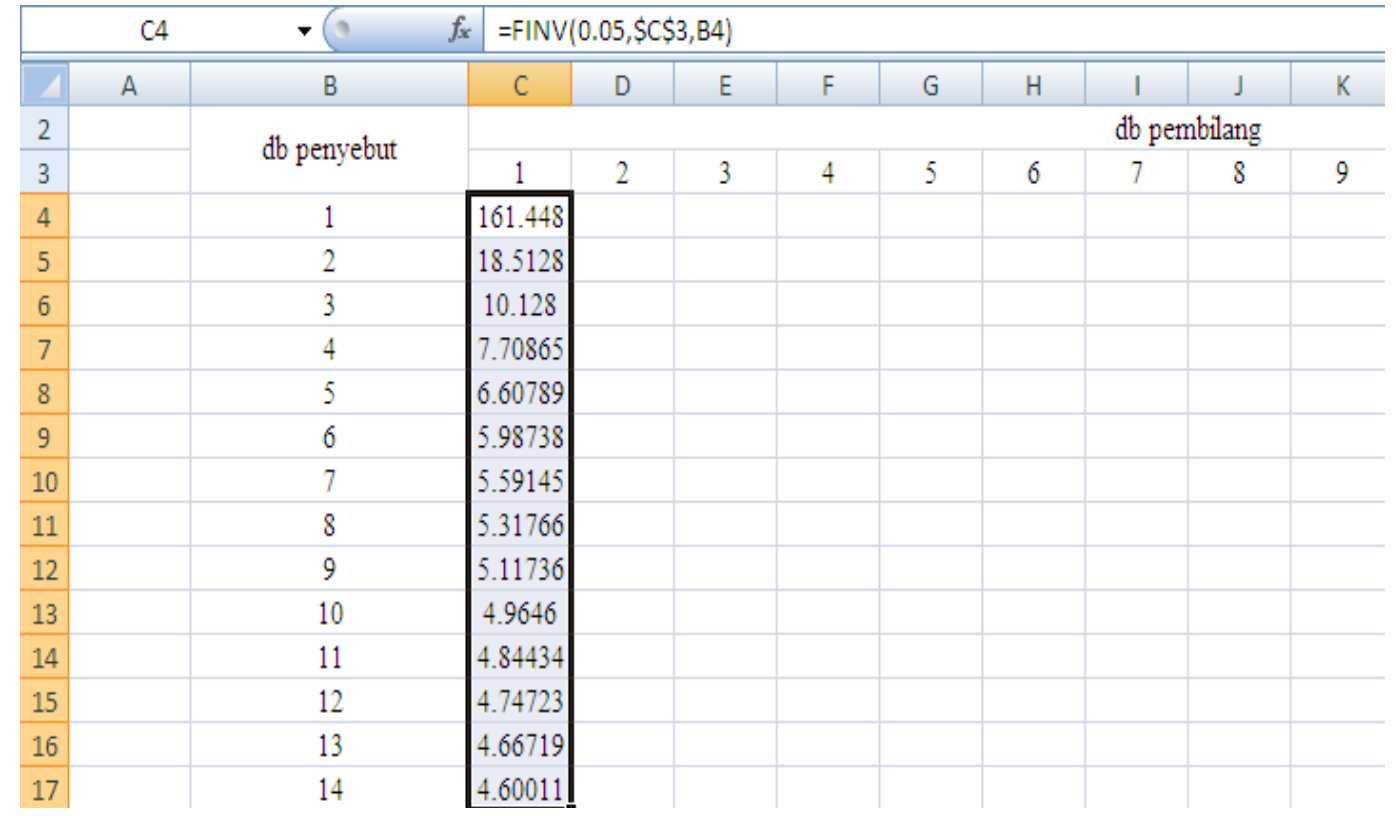

Gambar 5.24

Lakukan langkah yang sama untuk kolom-kolom selanjutnya, sehingga diperoleh tabel distribusi $F$ seperti pada Gambar 5.25 atau Tabel 5.3. 


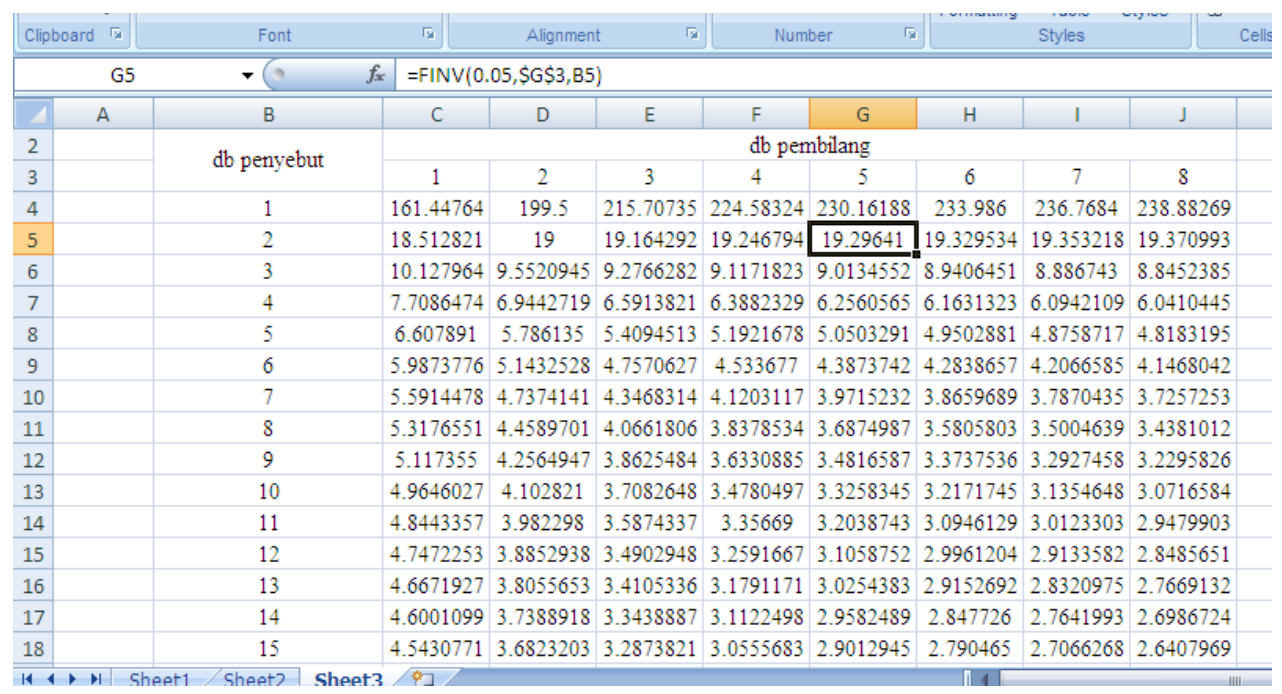

Gambar 5.25

Tabel 5.3 Distribusi $F$

\begin{tabular}{|c|c|c|c|c|c|c|c|c|}
\hline \multirow{2}{*}{ db penyebut } & \multicolumn{7}{|c|}{ db pembilang } \\
\cline { 2 - 9 } & 1 & 2 & 3 & 4 & 5 & 6 & 7 & 8 \\
\hline 1 & 161.45 & 199.5 & 215.71 & 224.58 & 230.16 & 233.99 & 236.768 & 238.88 \\
\hline 2 & 18.513 & 19 & 19.164 & 19.247 & 19.296 & 19.33 & 19.3532 & 19.371 \\
\hline 3 & 10.128 & 9.5521 & 9.2766 & 9.1172 & 9.0135 & 8.9406 & 8.88674 & 8.8452 \\
\hline 4 & 7.7086 & 6.9443 & 6.5914 & 6.3882 & 6.2561 & 6.1631 & 6.09421 & 6.041 \\
\hline 5 & 6.6079 & 5.7861 & 5.4095 & 5.1922 & 5.0503 & 4.9503 & 4.87587 & 4.8183 \\
\hline 6 & 5.9874 & 5.1433 & 4.7571 & 4.5337 & 4.3874 & 4.2839 & 4.20666 & 4.1468 \\
\hline 7 & 5.5914 & 4.7374 & 4.3468 & 4.1203 & 3.9715 & 3.866 & 3.78704 & 3.7257 \\
\hline 8 & 5.3177 & 4.459 & 4.0662 & 3.8379 & 3.6875 & 3.5806 & 3.50046 & 3.4381 \\
\hline 9 & 5.1174 & 4.2565 & 3.8625 & 3.6331 & 3.4817 & 3.3738 & 3.29275 & 3.2296 \\
\hline 10 & 4.9646 & 4.1028 & 3.7083 & 3.478 & 3.3258 & 3.2172 & 3.13546 & 3.0717 \\
\hline 11 & 4.8443 & 3.9823 & 3.5874 & 3.3567 & 3.2039 & 3.0946 & 3.01233 & 2.948 \\
\hline 12 & 4.7472 & 3.8853 & 3.4903 & 3.2592 & 3.1059 & 2.9961 & 2.91336 & 2.8486 \\
\hline 13 & 4.6672 & 3.8056 & 3.4105 & 3.1791 & 3.0254 & 2.9153 & 2.8321 & 2.7669 \\
\hline 14 & 4.6001 & 3.7389 & 3.3439 & 3.1122 & 2.9582 & 2.8477 & 2.7642 & 2.6987 \\
\hline 15 & 4.5431 & 3.6823 & 3.2874 & 3.0556 & 2.9013 & 2.7905 & 2.70663 & 2.6408 \\
\hline 16 & 4.494 & 3.6337 & 3.2389 & 3.0069 & 2.8524 & 2.7413 & 2.6572 & 2.5911 \\
\hline 17 & 4.4513 & 3.5915 & 3.1968 & 2.9647 & 2.81 & 2.6987 & 2.6143 & 2.548 \\
\hline 18 & 4.4139 & 3.5546 & 3.1599 & 2.9277 & 2.7729 & 2.6613 & 2.57672 & 2.5102 \\
\hline 19 & 4.3807 & 3.5219 & 3.1274 & 2.8951 & 2.7401 & 2.6283 & 2.54353 & 2.4768 \\
\hline 20 & 4.3512 & 3.4928 & 3.0984 & 2.8661 & 2.7109 & 2.599 & 2.51401 & 2.4471 \\
\hline 21 & 4.3248 & 3.4668 & 3.0725 & 2.8401 & 2.6848 & 2.5727 & 2.48758 & 2.4205 \\
\hline 22 & 4.3009 & 3.4434 & 3.0491 & 2.8167 & 2.6613 & 2.5491 & 2.46377 & 2.3965 \\
\hline 23 & 4.2793 & 3.4221 & 3.028 & 2.7955 & 2.64 & 2.5277 & 2.44223 & 2.3748 \\
\hline 24 & 4.2597 & 3.4028 & 3.0088 & 2.7763 & 2.6207 & 2.5082 & 2.42263 & 2.3551 \\
\hline 25 & 4.2417 & 3.3852 & 2.9912 & 2.7587 & 2.603 & 2.4904 & 2.40473 & 2.3371 \\
\hline 26 & 4.2252 & 3.369 & 2.9752 & 2.7426 & 2.5868 & 2.4741 & 2.38831 & 2.3205 \\
\hline 27 & 4.21 & 3.3541 & 2.9604 & 2.7278 & 2.5719 & 2.4591 & 2.37321 & 2.3053 \\
\hline & & & & & & & & \\
\hline
\end{tabular}




\begin{tabular}{|c|c|c|c|c|c|c|c|c|}
\hline 28 & 4.196 & 3.3404 & 2.9467 & 2.7141 & 2.5581 & 2.4453 & 2.35926 & 2.2913 \\
\hline 29 & 4.183 & 3.3277 & 2.934 & 2.7014 & 2.5454 & 2.4324 & 2.34634 & 2.2783 \\
\hline 30 & 4.1709 & 3.3158 & 2.9223 & 2.6896 & 2.5336 & 2.4205 & 2.33434 & 2.2662 \\
\hline 31 & 4.1596 & 3.3048 & 2.9113 & 2.6787 & 2.5225 & 2.4094 & 2.32317 & 2.2549 \\
\hline 32 & 4.1491 & 3.2945 & 2.9011 & 2.6684 & 2.5123 & 2.3991 & 2.31274 & 2.2444 \\
\hline 33 & 4.1393 & 3.2849 & 2.8916 & 2.6589 & 2.5026 & 2.3894 & \begin{tabular}{|l|}
2.30298 \\
\end{tabular} & 2.2346 \\
\hline 34 & 4.13 & 3.2759 & 2.8826 & 2.6499 & 2.4936 & 2.3803 & 2.29383 & 2.2253 \\
\hline 35 & 4.1213 & 3.2674 & 2.8742 & 2.6415 & 2.4851 & 2.3718 & 2.28524 & 2.2167 \\
\hline 36 & 4.1132 & 3.2594 & 2.8663 & 2.6335 & 2.4772 & 2.3638 & 2.27714 & 2.2085 \\
\hline 37 & 4.1055 & 3.2519 & 2.8588 & 2.6261 & 2.4696 & 2.3562 & 2.26951 & 2.2008 \\
\hline 38 & 4.0982 & 3.2448 & 2.8517 & 2.619 & 2.4625 & 2.349 & 2.2623 & 2.1936 \\
\hline 39 & 4.0913 & 3.2381 & 2.8451 & 2.6123 & 2.4558 & 2.3423 & 2.25549 & 2.1867 \\
\hline 40 & 4.0847 & 3.2317 & 2.8387 & 2.606 & 2.4495 & 2.3359 & 2.24902 & 2.1802 \\
\hline 41 & 4.0785 & 3.2257 & 2.8327 & 2.6 & 2.4434 & 2.3298 & 2.24289 & 2.174 \\
\hline 42 & 4.0727 & 3.2199 & 2.827 & 2.5943 & 2.4377 & 2.324 & 2.23707 & 2.1681 \\
\hline 43 & 4.067 & 3.2145 & 2.8216 & 2.5888 & 2.4322 & 2.3185 & 2.23153 & 2.1625 \\
\hline 44 & 4.0617 & 3.2093 & 2.8165 & 2.5837 & 2.427 & 2.3133 & 2.22625 & 2.1572 \\
\hline 45 & 4.0566 & 3.2043 & 2.8115 & 2.5787 & 2.4221 & 2.3083 & 2.22122 & 2.1521 \\
\hline 46 & 4.0517 & 3.1996 & 2.8068 & 2.574 & 2.4174 & 2.3035 & 2.21642 & 2.1473 \\
\hline 47 & 4.0471 & 3.1951 & 2.8024 & 2.5695 & 2.4128 & 2.299 & 2.21183 & 2.1427 \\
\hline 48 & 4.0427 & 3.1907 & 2.7981 & 2.5652 & 2.4085 & 2.2946 & 2.20744 & 2.1382 \\
\hline 49 & 4.0384 & 3.1866 & 2.7939 & 2.5611 & 2.4044 & 2.2904 & 2.20323 & 2.134 \\
\hline 50 & 4.0343 & 3.1826 & 2.79 & 2.5572 & 2.4004 & 2.2864 & 2.1992 & 2.1299 \\
\hline 51 & 4.0304 & 3.1788 & 2.7862 & 2.5534 & 2.3966 & 2.2826 & 2.19534 & 2.126 \\
\hline 52 & 4.0266 & 3.1751 & 2.7826 & 2.5498 & 2.393 & 2.2789 & 2.19163 & 2.1223 \\
\hline 53 & 4.023 & 3.1716 & 2.7791 & 2.5463 & 2.3894 & 2.2754 & 2.18806 & 2.1187 \\
\hline 54 & 4.0195 & 3.1682 & 2.7758 & 2.5429 & 2.3861 & 2.272 & 2.18463 & 2.1152 \\
\hline 55 & 4.0162 & 3.165 & 2.7725 & 2.5397 & 2.3828 & 2.2687 & 2.18133 & 2.1119 \\
\hline 56 & 4.013 & 3.1619 & 2.7694 & 2.5366 & 2.3797 & 2.2656 & 2.17816 & 2.1087 \\
\hline 57 & 4.0099 & 3.1588 & 2.7664 & 2.5336 & 2.3767 & 2.2625 & 2.17509 & 2.1056 \\
\hline 58 & 4.0069 & 3.1559 & 2.7636 & 2.5307 & 2.3738 & 2.2596 & 2.17214 & 2.1026 \\
\hline 59 & 4.004 & 3.1531 & 2.7608 & 2.5279 & 2.371 & 2.2568 & 2.16929 & 2.0997 \\
\hline 60 & 4.0012 & 3.1504 & 2.7581 & 2.5252 & 2.3683 & 2.2541 & 2.16654 & 2.097 \\
\hline 61 & 3.9985 & 3.1478 & 2.7555 & 2.5226 & 2.3657 & 2.2514 & 2.16388 & 2.0943 \\
\hline 62 & 3.9959 & 3.1453 & 2.753 & 2.5201 & 2.3631 & 2.2489 & 2.16131 & 2.0917 \\
\hline 63 & 3.9934 & 3.1428 & 2.7505 & 2.5177 & 2.3607 & 2.2464 & 2.15883 & 2.0892 \\
\hline 64 & 3.9909 & 3.1404 & 2.7482 & 2.5153 & 2.3583 & 2.244 & 2.15642 & 2.0868 \\
\hline 65 & 3.9886 & 3.1381 & 2.7459 & 2.513 & 2.356 & 2.2417 & 2.1541 & 2.0844 \\
\hline 66 & 3.9863 & 3.1359 & 2.7437 & 2.5108 & 2.3538 & 2.2395 & 2.15184 & 2.0821 \\
\hline 67 & 3.984 & 3.1338 & 2.7416 & 2.5087 & 2.3517 & 2.2373 & 2.14965 & 2.0799 \\
\hline 68 & 3.9819 & 3.1317 & 2.7395 & 2.5066 & 2.3496 & 2.2352 & 2.14753 & 2.0778 \\
\hline 69 & 3.9798 & 3.1296 & 2.7375 & 2.5046 & 2.3475 & 2.2332 & 2.14547 & 2.0757 \\
\hline 70 & 3.9778 & 3.1277 & 2.7355 & 2.5027 & 2.3456 & 2.2312 & 2.14348 & 2.0737 \\
\hline 71 & 3.9758 & 3.1258 & 2.7336 & 2.5008 & 2.3437 & 2.2293 & 2.14154 & 2.0717 \\
\hline 72 & 3.9739 & 3.1239 & 2.7318 & 2.4989 & 2.3418 & 2.2274 & 2.13966 & 2.0698 \\
\hline 73 & 3.972 & 3.1221 & 2.73 & 2.4971 & 2.34 & 2.2256 & 2.13782 & 2.068 \\
\hline
\end{tabular}




\begin{tabular}{|c|c|c|c|c|c|c|c|c|}
\hline 74 & 3.9702 & 3.1203 & 2.7283 & 2.4954 & 2.3383 & 2.2238 & 2.13605 & 2.0662 \\
\hline 75 & 3.9685 & 3.1186 & 2.7266 & 2.4937 & 2.3366 & 2.2221 & 2.13431 & 2.0644 \\
\hline 76 & 3.9668 & 3.117 & 2.7249 & 2.492 & 2.3349 & 2.2204 & 2.13263 & 2.0627 \\
\hline 77 & 3.9651 & 3.1154 & 2.7233 & 2.4904 & 2.3333 & 2.2188 & 2.13099 & 2.0611 \\
\hline 78 & 3.9635 & 3.1138 & 2.7218 & 2.4889 & 2.3317 & 2.2172 & 2.12939 & 2.0595 \\
\hline 79 & 3.9619 & 3.1123 & 2.7203 & 2.4874 & 2.3302 & 2.2157 & 2.12784 & 2.0579 \\
\hline 80 & 3.9604 & 3.1108 & 2.7188 & 2.4859 & 2.3287 & 2.2142 & 2.12632 & 2.0564 \\
\hline 81 & 3.9589 & 3.1093 & 2.7173 & 2.4844 & 2.3273 & 2.2127 & 2.12485 & 2.0549 \\
\hline 82 & 3.9574 & 3.1079 & 2.7159 & 2.483 & 2.3259 & 2.2113 & 2.12341 & 2.0534 \\
\hline 83 & 3.956 & 3.1065 & 2.7146 & 2.4817 & 2.3245 & 2.2099 & 2.122 & 2.052 \\
\hline 84 & 3.9546 & 3.1052 & 2.7132 & 2.4803 & 2.3231 & 2.2086 & 2.12063 & 2.0506 \\
\hline 85 & 3.9532 & 3.1038 & 2.7119 & 2.479 & 2.3218 & 2.2072 & 2.1193 & 2.0493 \\
\hline 86 & 3.9519 & 3.1026 & 2.7106 & 2.4777 & 2.3205 & 2.2059 & 2.11799 & 2.048 \\
\hline 87 & 3.9506 & 3.1013 & 2.7094 & 2.4765 & 2.3193 & 2.2047 & 2.11672 & 2.0467 \\
\hline 88 & 3.9493 & 3.1001 & 2.7082 & 2.4753 & 2.3181 & 2.2034 & 2.11547 & 2.0454 \\
\hline 89 & 3.9481 & 3.0989 & 2.707 & 2.4741 & 2.3169 & 2.2022 & 2.11426 & 2.0442 \\
\hline 90 & 3.9469 & 3.0977 & 2.7058 & 2.4729 & 2.3157 & 2.2011 & 2.11307 & 2.043 \\
\hline 91 & 3.9457 & 3.0966 & 2.7047 & 2.4718 & 2.3145 & 2.1999 & 2.1119 & 2.0418 \\
\hline 92 & 3.9445 & 3.0954 & 2.7036 & 2.4707 & 2.3134 & 2.1988 & 2.11077 & 2.0407 \\
\hline 93 & 3.9434 & 3.0943 & 2.7025 & 2.4696 & 2.3123 & 2.1977 & 2.10966 & 2.0395 \\
\hline 94 & 3.9423 & 3.0933 & 2.7014 & 2.4685 & 2.3113 & 2.1966 & 2.10857 & 2.0384 \\
\hline 95 & 3.9412 & 3.0922 & 2.7004 & 2.4675 & 2.3102 & 2.1955 & 2.10751 & 2.0374 \\
\hline 96 & 3.9402 & 3.0912 & 2.6994 & 2.4665 & 2.3092 & 2.1945 & 2.10647 & 2.0363 \\
\hline 97 & 3.9391 & 3.0902 & 2.6984 & 2.4655 & 2.3082 & 2.1935 & 2.10545 & 2.0353 \\
\hline 98 & 3.9381 & 3.0892 & 2.6974 & 2.4645 & 2.3072 & 2.1925 & 2.10445 & 2.0343 \\
\hline 99 & 3.9371 & 3.0882 & 2.6965 & 2.4636 & 2.3063 & 2.1915 & 2.10347 & 2.0333 \\
\hline 100 & 3.9361 & 3.0873 & 2.6955 & 2.4626 & 2.3053 & 2.1906 & 2.10251 & 2.0323 \\
\hline & & & & & & & & \\
\hline
\end{tabular}

\section{Membuat Tabel Distribusí Chi-Square dalam SPSS dan Mícrosoft Excel}

Berikut langkah-langkah untuk membuat tabel distribusi chi-square, dengan tingkat signifikansi 5\% dalam SPSS. Bangun data dalam SPSS, seperti pada Gambar 5.26 dan Gambar 5.27. Selanjutnya pilih Transform $=>$ Compute Variable, sehingga muncul tampilan Compute Variable (Gambar 5.28).

Pada kotak Target Variable, ketik nilai_kritis_chi_square_0.05, dan pada kotak Numeric Expression, ketik IDF.CHISQ(0.95,derajat_bebas). Kemudian pilih OK. Hasilnya seperti pada Gambar 5.29. Sebagai contoh, nilai kritis chi-square dengan derajat bebas 16 dan tingkat signifikansi 5\% adalah 26,2962. Nilai kritis chi-square dengan derajat bebas 10 dan tingkat signifikansi 5\% adalah 18,3070. 


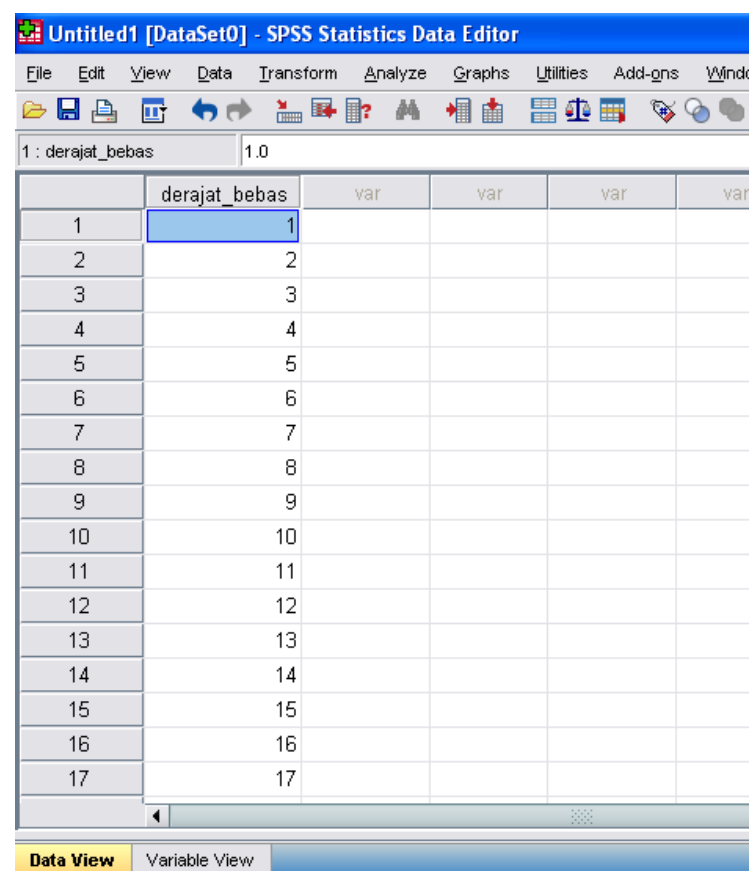

Gambar 5.26

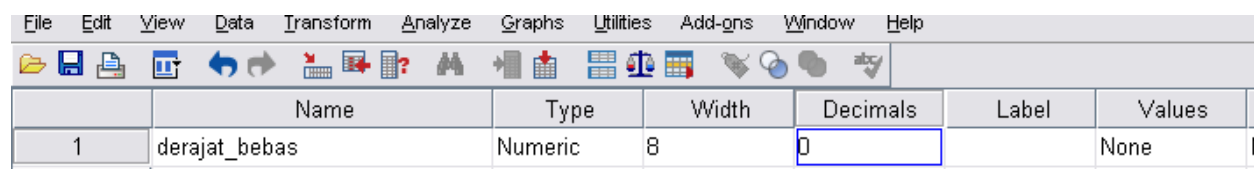

Gambar 5.27

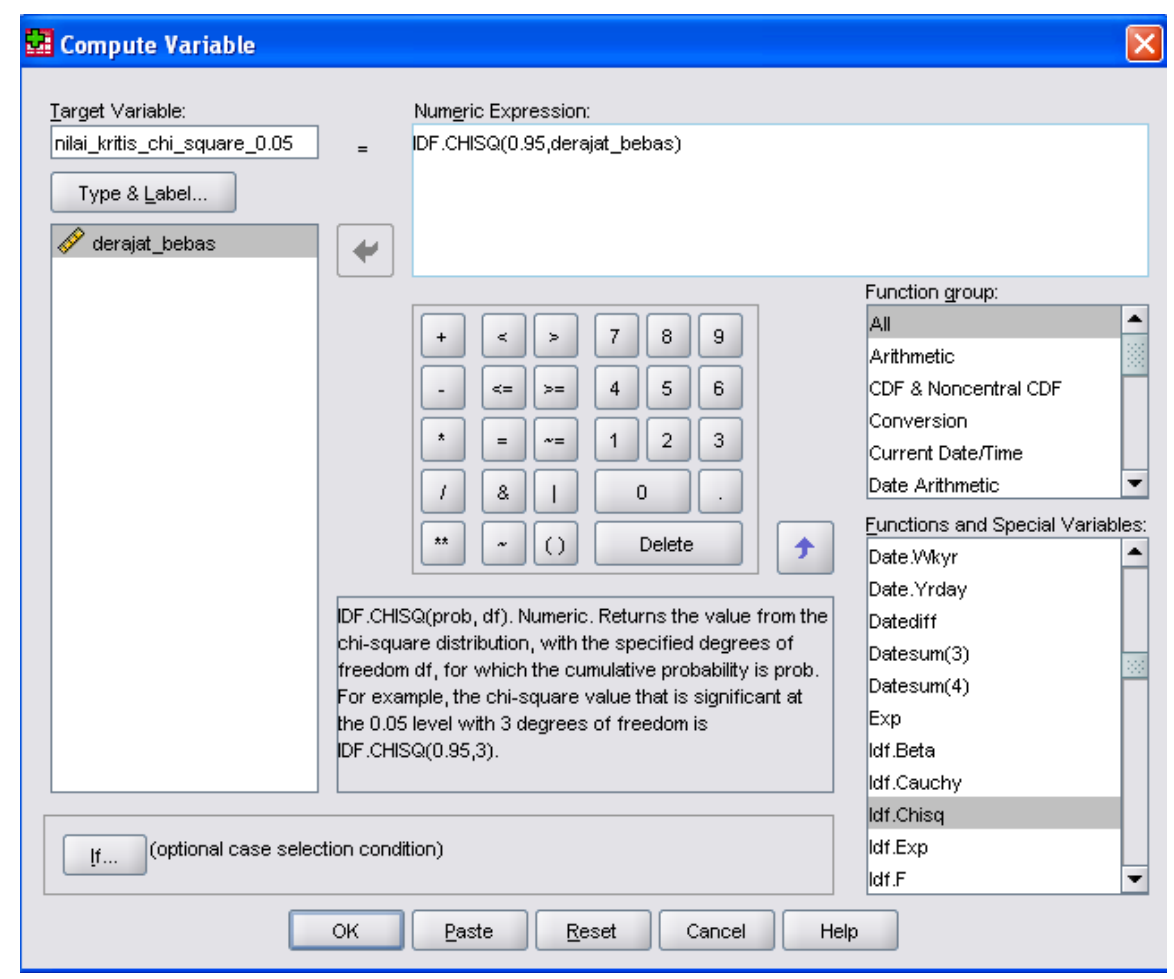

Gambar 5.28 


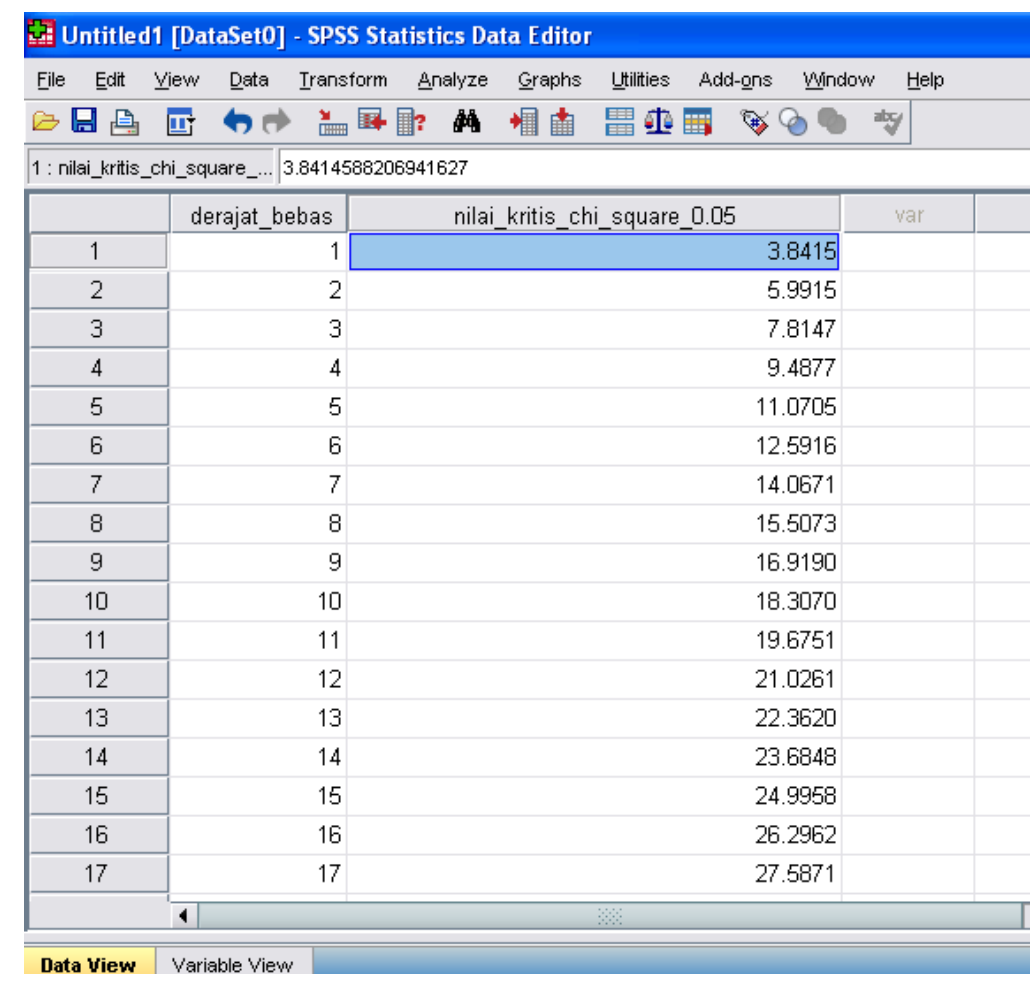

\section{Gambar 5.29}

Berikut langkah-langkah untuk membuat tabel distribusi chi-square dalam Microsoft Excel. Bangun data dalam Microsoft Excel, seperti pada Gambar 5.30. Kemudian tempatkan posisi pada cell D2. Pada cell D2, ketik rumus sebagai berikut.

\section{$=\mathrm{CHIINV}(\mathrm{C} 2, \mathrm{~B} 2)$}

Hasilnya seperti pada Gambar 5.31. Kemudian pada cell D2, geser ke bawah, sehingga diperoleh hasil seperti pada Gambar 5.32 dan Tabel 5.4.

\begin{tabular}{|c|c|c|c|c|c|}
\hline \multicolumn{3}{|c|}{ D2 } & $f_{x}$ & \multirow[b]{2}{*}{ D } & \multirow[b]{2}{*}{ E } \\
\hline 4 & A & B & C & & \\
\hline 1 & & derajat bebas & tingkat signifikansi & nilai kritis chi-square & \\
\hline 2 & & 1 & 0.05 & & \\
\hline 3 & & 2 & 0.05 & & \\
\hline 4 & & 3 & 0.05 & & \\
\hline 5 & & 4 & 0.05 & & \\
\hline 6 & & 5 & 0.05 & & \\
\hline 7 & & 6 & 0.05 & & \\
\hline 8 & & 7 & 0.05 & & \\
\hline 9 & & 8 & 0.05 & & \\
\hline 10 & & 9 & 0.05 & & \\
\hline 11 & & 10 & 0.05 & & \\
\hline 12 & & 11 & 0.05 & & \\
\hline 13 & & 12 & 0.05 & & \\
\hline 14 & & 13 & 0.05 & & \\
\hline 15 & & 14 & $n \cap \varepsilon$ & & \\
\hline
\end{tabular}

Gambar 5.30 


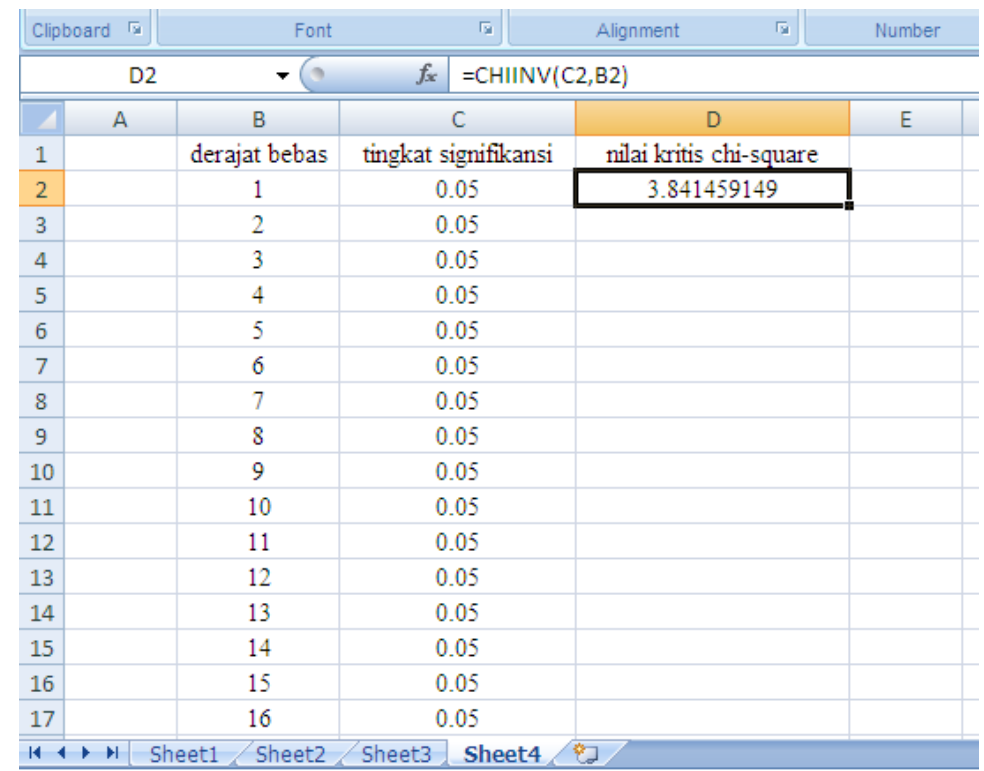

Gambar 5.31

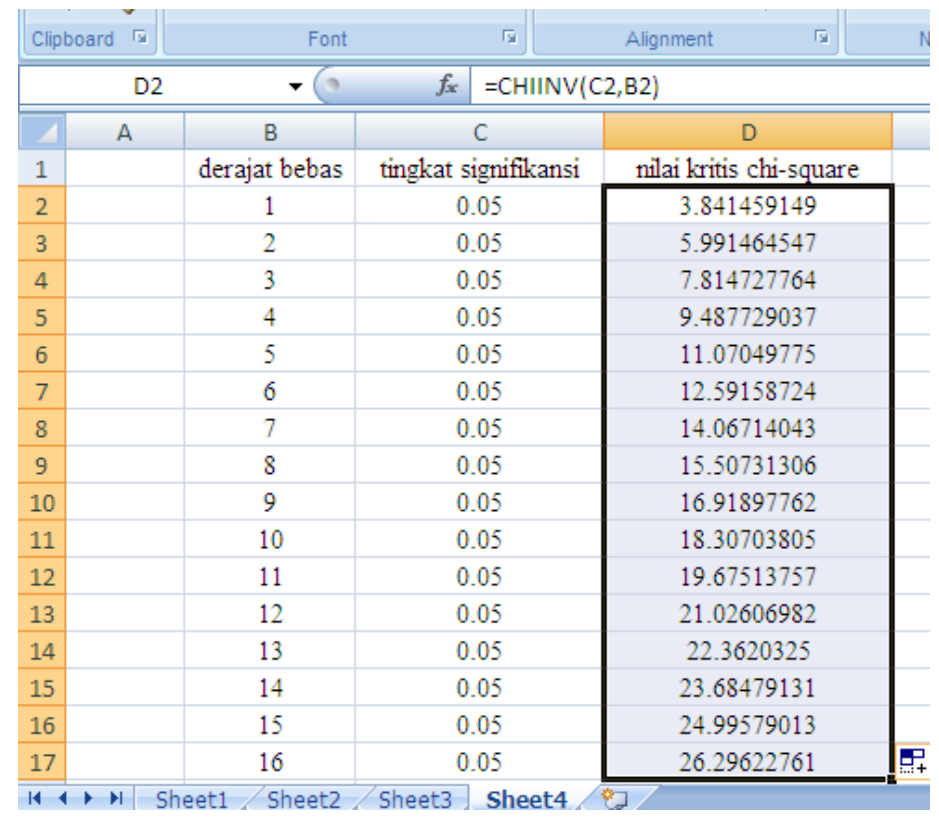

Gambar 5.32

Tabel 5.4 Distribusi Chi-Square

\begin{tabular}{|c|c|c|}
\hline derajat bebas & tingkat signifikansi & nilai kritis chi-square \\
\hline 1 & 0.05 & 3.841459149 \\
\hline 2 & 0.05 & 5.991464547 \\
\hline 3 & 0.05 & 7.814727764 \\
\hline 4 & 0.05 & 9.487729037 \\
\hline 5 & 0.05 & 11.07049775 \\
\hline 6 & 0.05 & 12.59158724 \\
\hline 7 & 0.05 & 14.06714043 \\
\hline 8 & 0.05 & 15.50731306 \\
\hline 9 & 0.05 & 16.91897762 \\
\hline
\end{tabular}




\begin{tabular}{|c|c|c|}
\hline 10 & 0.05 & 18.30703805 \\
\hline 11 & 0.05 & 19.67513757 \\
\hline 12 & 0.05 & 21.02606982 \\
\hline 13 & 0.05 & 22.3620325 \\
\hline 14 & 0.05 & 23.68479131 \\
\hline 15 & 0.05 & 24.99579013 \\
\hline 16 & 0.05 & 26.29622761 \\
\hline 17 & 0.05 & 27.58711164 \\
\hline 18 & 0.05 & 28.86929943 \\
\hline 19 & 0.05 & 30.14352721 \\
\hline 20 & 0.05 & 31.41043286 \\
\hline 21 & 0.05 & 32.67057337 \\
\hline 22 & 0.05 & 33.92443852 \\
\hline 23 & 0.05 & 35.17246163 \\
\hline 24 & 0.05 & 36.4150285 \\
\hline 25 & 0.05 & 37.65248413 \\
\hline 26 & 0.05 & 38.88513865 \\
\hline 27 & 0.05 & 40.11327205 \\
\hline 28 & 0.05 & 41.33713813 \\
\hline 29 & 0.05 & 42.55696777 \\
\hline 30 & 0.05 & 43.77297178 \\
\hline 31 & 0.05 & 44.98534322 \\
\hline 32 & 0.05 & 46.19425944 \\
\hline 33 & 0.05 & 47.39988381 \\
\hline 34 & 0.05 & 48.60236738 \\
\hline 35 & 0.05 & 49.80184958 \\
\hline 36 & 0.05 & 50.99846018 \\
\hline 37 & 0.05 & 52.19231975 \\
\hline 38 & 0.05 & 53.38354065 \\
\hline 39 & 0.05 & 54.5722278 \\
\hline 40 & 0.05 & 55.75847932 \\
\hline 41 & 0.05 & 56.9423872 \\
\hline 42 & 0.05 & 58.12403775 \\
\hline 43 & 0.05 & 59.3035121 \\
\hline 44 & 0.05 & 60.480886667 \\
\hline 45 & 0.05 & 61.65623348 \\
\hline 46 & 0.05 & 62.82962054 \\
\hline 47 & 0.05 & 64.00111212 \\
\hline 48 & 0.05 & 65.17076907 \\
\hline 49 & 0.05 & 66.33864905 \\
\hline 50 & 0.05 & 67.50480652 \\
\hline 51 & 0.05 & 68.66929388 \\
\hline 52 & 0.05 & 69.83216031 \\
\hline 53 & 0.05 & 70.99345279 \\
\hline 54 & 0.05 & 72.15321612 \\
\hline 55 & 0.05 & 73.31149298 \\
\hline
\end{tabular}




\begin{tabular}{|c|c|c|}
\hline 56 & 0.05 & 74.4683241 \\
\hline 57 & 0.05 & 75.6237484 \\
\hline 58 & 0.05 & 76.77780308 \\
\hline 59 & 0.05 & 77.93052372 \\
\hline 60 & 0.05 & 79.08194439 \\
\hline 61 & 0.05 & 80.23209774 \\
\hline 62 & 0.05 & 81.38101507 \\
\hline 63 & 0.05 & 82.52872641 \\
\hline 64 & 0.05 & 83.6752606 \\
\hline 65 & 0.05 & 84.82064534 \\
\hline 66 & 0.05 & 85.96490727 \\
\hline 67 & 0.05 & 87.108072 \\
\hline 68 & 0.05 & 88.25016421 \\
\hline 69 & 0.05 & 89.39120764 \\
\hline 70 & 0.05 & 90.53122518 \\
\hline 71 & 0.05 & 91.6702389 \\
\hline 72 & 0.05 & 92.80827009 \\
\hline 73 & 0.05 & 93.94533966 \\
\hline 74 & 0.05 & 95.08146673 \\
\hline 75 & 0.05 & 96.21667082 \\
\hline 76 & 0.05 & 97.35097045 \\
\hline 77 & 0.05 & 98.48438354 \\
\hline 78 & 0.05 & 99.61692741 \\
\hline 79 & 0.05 & 100.7486188 \\
\hline 80 & 0.05 & 101.8794741 \\
\hline 81 & 0.05 & 103.0095088 \\
\hline 82 & 0.05 & 104.1387383 \\
\hline 83 & 0.05 & 105.2671774 \\
\hline 84 & 0.05 & 106.3948404 \\
\hline 85 & 0.05 & 107.5217411 \\
\hline 86 & 0.05 & 108.6478931 \\
\hline 87 & 0.05 & 109.7733095 \\
\hline 88 & 0.05 & 110.898003 \\
\hline 89 & 0.05 & 112.0219859 \\
\hline 90 & 0.05 & 113.1452703 \\
\hline 91 & 0.05 & 114.2678679 \\
\hline 92 & 0.05 & 115.3897899 \\
\hline 93 & 0.05 & 116.5110475 \\
\hline 94 & 0.05 & 117.6316514 \\
\hline 95 & 0.05 & 118.751612 \\
\hline 96 & 0.05 & 119.8709396 \\
\hline 97 & 0.05 & 120.989644 \\
\hline 98 & 0.05 & 122.1077349 \\
\hline 99 & 0.05 & 123.2252218 \\
\hline 100 & 0.05 & 124.3421137 \\
\hline 101 & 0.05 & 125.4584198 \\
\hline
\end{tabular}




\begin{tabular}{|c|c|c|}
\hline 102 & 0.05 & 126.5741486 \\
\hline 103 & 0.05 & 127.6893087 \\
\hline 104 & 0.05 & 128.8039083 \\
\hline 105 & 0.05 & 129.9179552 \\
\hline 106 & 0.05 & 131.0314582 \\
\hline 107 & 0.05 & 132.1444244 \\
\hline 108 & 0.05 & 133.2568616 \\
\hline 109 & 0.05 & 134.368777 \\
\hline 110 & 0.05 & 135.4801778 \\
\hline 111 & 0.05 & 136.5910711 \\
\hline 112 & 0.05 & 137.7014637 \\
\hline 113 & 0.05 & 138.8113624 \\
\hline 114 & 0.05 & 139.9207738 \\
\hline 115 & 0.05 & 141.0297041 \\
\hline 116 & 0.05 & 142.1381599 \\
\hline 117 & 0.05 & 143.2461471 \\
\hline 118 & 0.05 & 144.3536719 \\
\hline 119 & 0.05 & 145.46074 \\
\hline 120 & 0.05 & 146.5673574 \\
\hline 121 & 0.05 & 147.6735296 \\
\hline 122 & 0.05 & 148.7792621 \\
\hline 123 & 0.05 & 149.8845604 \\
\hline 124 & 0.05 & 150.9894298 \\
\hline 125 & 0.05 & 152.0938755 \\
\hline
\end{tabular}

\section{Membuat Tabel Distríbusí r Product Moment dalam Mícrosoft Excel}

Berikut langkah-langkah untuk membuat tabel distribusi $r$ product moment dalam Microsoft Excel, dengan tingkat signifikansi 5\% dalam SPSS. Data pada Gambar 5.17 disajikan kembali pada Gambar 5.33 dengan penambahan kolom untuk nilai kritis $r$. Tempatkan posisi cell pada D2 dan ketik rumus $=\mathbf{C 2 / S Q R T}\left(\mathbf{A} 2+\mathbf{C 2}^{\wedge} \mathbf{2}\right)$. Maka hasilnya seperti pada Gambar 5.34

\begin{tabular}{|c|c|c|c|c|c|}
\hline \multicolumn{2}{|c|}{ Clipboard } & Font & \multicolumn{2}{|c|}{ Alignment } & $\mathrm{N}$ \\
\hline & $\mathrm{D} 2$ & - $0 \quad f_{x}$ & & & \\
\hline$\overline{4}$ & A & B & C & D & \\
\hline 1 & derajat bebas & tingkat signifikansi & nilai kritis t & nilai kritis $r$ & \\
\hline 2 & 1 & 0.05 & 12.70620473 & & \\
\hline 3 & 2 & 0.05 & 4.30265273 & & \\
\hline 4 & 3 & 0.05 & 3.182446305 & & \\
\hline 5 & 4 & 0.05 & 2.776445105 & & \\
\hline 6 & 5 & 0.05 & 2.570581835 & & \\
\hline 7 & 6 & 0.05 & 2.446911846 & & \\
\hline 8 & 7 & 0.05 & 2.364624251 & & \\
\hline 9 & 8 & 0.05 & 2.306004133 & & \\
\hline 10 & 9 & 0.05 & 2.262157158 & & \\
\hline
\end{tabular}

Gambar 5.33 


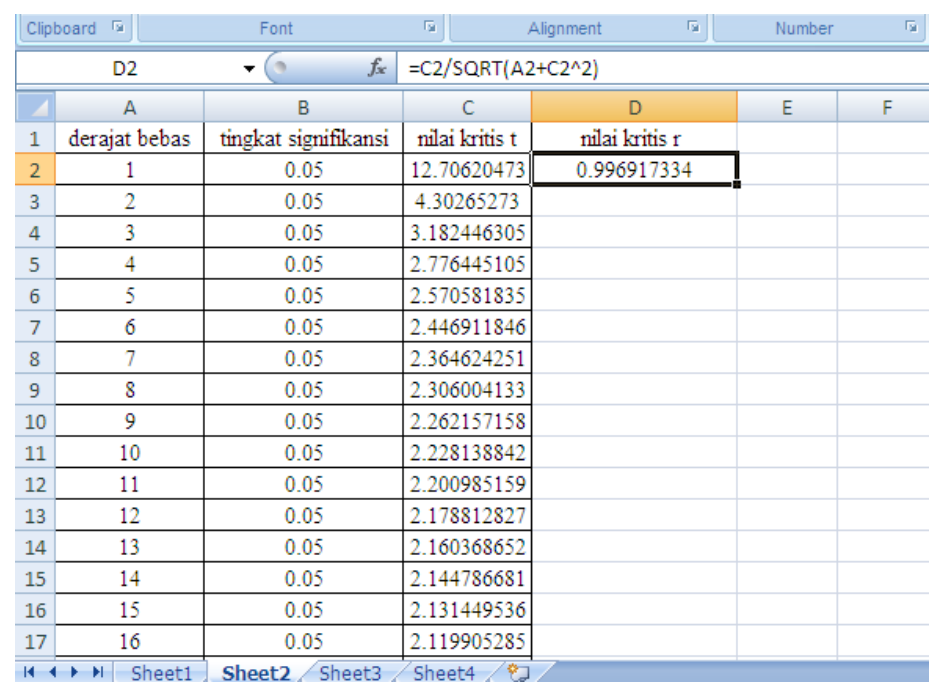

Gambar 5.34

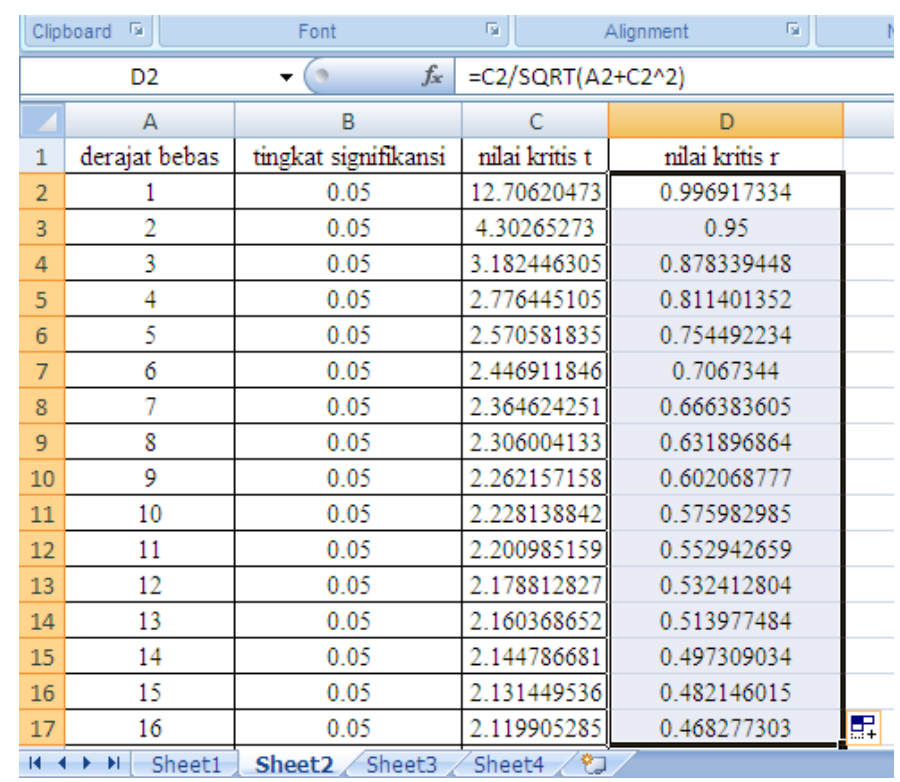

Gambar 5.35

Tabel 5.5 Distribusi $r$ Product Moment

\begin{tabular}{|c|c|c|c|}
\hline derajat bebas & tingkat signifikansi & nilai kritis t & nilai kritis $\mathrm{r}$ \\
\hline 1 & 0.05 & 12.70620473 & 0.996917334 \\
\hline 2 & 0.05 & 4.30265273 & 0.95 \\
\hline 3 & 0.05 & 3.182446305 & 0.878339448 \\
\hline 4 & 0.05 & 2.776445105 & 0.811401352 \\
\hline 5 & 0.05 & 2.570581835 & 0.754492234 \\
\hline 6 & 0.05 & 2.446911846 & 0.7067344 \\
\hline 7 & 0.05 & 2.364624251 & 0.666383605 \\
\hline 8 & 0.05 & 2.306004133 & 0.631896864 \\
\hline 9 & 0.05 & 2.262157158 & 0.602068777 \\
\hline 10 & 0.05 & 2.228138842 & 0.575982985 \\
\hline 11 & 0.05 & 2.200985159 & 0.552942659 \\
\hline
\end{tabular}




\begin{tabular}{|c|c|c|c|}
\hline 12 & 0.05 & 2.178812827 & 0.532412804 \\
\hline 13 & 0.05 & 2.160368652 & 0.513977484 \\
\hline 14 & 0.05 & 2.144786681 & 0.497309034 \\
\hline 15 & 0.05 & 2.131449536 & 0.482146015 \\
\hline 16 & 0.05 & 2.119905285 & 0.468277303 \\
\hline 17 & 0.05 & 2.109815559 & 0.455530502 \\
\hline 18 & 0.05 & 2.100922037 & 0.443763399 \\
\hline 19 & 0.05 & 2.09302405 & 0.432857556 \\
\hline 20 & 0.05 & 2.085963441 & 0.422713503 \\
\hline 21 & 0.05 & 2.079613837 & 0.413247029 \\
\hline 22 & 0.05 & 2.073873058 & 0.404386321 \\
\hline 23 & 0.05 & 2.068657599 & 0.396069727 \\
\hline 24 & 0.05 & 2.063898547 & 0.388243995 \\
\hline 25 & 0.05 & 2.059538536 & 0.380862857 \\
\hline 26 & 0.05 & 2.055529418 & 0.373885908 \\
\hline 27 & 0.05 & 2.051830493 & 0.367277681 \\
\hline 28 & 0.05 & 2.048407115 & 0.361006904 \\
\hline 29 & 0.05 & 2.045229611 & 0.355045884 \\
\hline 30 & 0.05 & 2.042272449 & 0.349370006 \\
\hline 31 & 0.05 & 2.039513438 & 0.343957288 \\
\hline 32 & 0.05 & 2.036933334 & 0.338788053 \\
\hline 33 & 0.05 & 2.034515287 & 0.333844617 \\
\hline 34 & 0.05 & 2.032244498 & 0.329111042 \\
\hline 35 & 0.05 & 2.030107915 & 0.324572913 \\
\hline 36 & 0.05 & 2.028093987 & 0.320217167 \\
\hline 37 & 0.05 & 2.026192447 & 0.316031926 \\
\hline 38 & 0.05 & 2.024394147 & 0.312006366 \\
\hline 39 & 0.05 & 2.022690901 & 0.308130601 \\
\hline 40 & 0.05 & 2.02107537 & 0.304395578 \\
\hline 41 & 0.05 & 2.019540948 & 0.300792993 \\
\hline 42 & 0.05 & 2.018081679 & 0.297315209 \\
\hline 43 & 0.05 & 2.016692173 & 0.293955192 \\
\hline 44 & 0.05 & 2.015367547 & 0.29070645 \\
\hline 45 & 0.05 & 2.014103359 & 0.287562981 \\
\hline 46 & 0.05 & 2.012895567 & 0.284519225 \\
\hline 47 & 0.05 & 2.01174048 & 0.281570024 \\
\hline 48 & 0.05 & 2.010634722 & 0.278710589 \\
\hline 49 & 0.05 & 2.009575199 & 0.275936458 \\
\hline 50 & 0.05 & 2.008559072 & 0.273243479 \\
\hline 51 & 0.05 & 2.007583728 & 0.270627772 \\
\hline 52 & 0.05 & 2.006646761 & 0.268085715 \\
\hline 53 & 0.05 & 2.005745949 & 0.265613918 \\
\hline 54 & 0.05 & 2.004879275 & 0.26320921 \\
\hline 55 & 0.05 & 2.004044769 & 0.260868604 \\
\hline 56 & 0.05 & 2.003240704 & 0.258589308 \\
\hline 57 & 0.05 & 2.002465444 & 0.256368692 \\
\hline
\end{tabular}




\begin{tabular}{|c|c|c|c|}
\hline 58 & 0.05 & 2.001717468 & 0.254204284 \\
\hline 59 & 0.05 & 2.000995361 & 0.252093751 \\
\hline 60 & 0.05 & 2.000297804 & 0.250034898 \\
\hline 61 & 0.05 & 1.999623567 & 0.248025651 \\
\hline 62 & 0.05 & 1.998971498 & 0.246064049 \\
\hline 63 & 0.05 & 1.998340522 & 0.244148241 \\
\hline 64 & 0.05 & 1.997729633 & 0.242276472 \\
\hline 65 & 0.05 & 1.997137887 & 0.240447082 \\
\hline 66 & 0.05 & 1.996564396 & 0.238658496 \\
\hline 67 & 0.05 & 1.996008331 & 0.236909221 \\
\hline 68 & 0.05 & 1.995468907 & 0.235197837 \\
\hline 69 & 0.05 & 1.99494539 & 0.233522997 \\
\hline 70 & 0.05 & 1.994437086 & 0.231883419 \\
\hline 71 & 0.05 & 1.993943341 & 0.230277884 \\
\hline 72 & 0.05 & 1.993463539 & 0.22870523 \\
\hline 73 & 0.05 & 1.992997097 & 0.227164349 \\
\hline 74 & 0.05 & 1.992543466 & 0.225654188 \\
\hline 75 & 0.05 & 1.992102124 & 0.224173738 \\
\hline 76 & 0.05 & 1.991672579 & 0.22272204 \\
\hline 77 & 0.05 & 1.991254363 & 0.221298173 \\
\hline 78 & 0.05 & 1.990847036 & 0.219901261 \\
\hline 79 & 0.05 & 1.990450177 & 0.218530464 \\
\hline 80 & 0.05 & 1.990063387 & 0.217184978 \\
\hline 81 & 0.05 & 1.989686288 & 0.215864035 \\
\hline 82 & 0.05 & 1.989318521 & 0.214566897 \\
\hline 83 & 0.05 & 1.988959743 & 0.213292858 \\
\hline 84 & 0.05 & 1.988609629 & 0.212041241 \\
\hline 85 & 0.05 & 1.988267868 & 0.210811396 \\
\hline 86 & 0.05 & \begin{tabular}{|l|l}
1.987934166 \\
\end{tabular} & 0.209602699 \\
\hline 87 & 0.05 & 1.987608241 & 0.208414551 \\
\hline 88 & 0.05 & 1.987289823 & 0.207246376 \\
\hline 89 & 0.05 & 1.986978657 & 0.206097622 \\
\hline 90 & 0.05 & \begin{tabular}{|l|}
1.986674497 \\
\end{tabular} & 0.204967756 \\
\hline 91 & 0.05 & 1.98637711 & 0.203856266 \\
\hline 92 & 0.05 & 1.986086272 & 0.20276266 \\
\hline 93 & 0.05 & 1.985801768 & 0.201686463 \\
\hline
\end{tabular}

Berdasarkan Tabel 5.5, nilai kritis $r$ product moment dengan derajat bebas 93 adalah $\pm 0,201686463$. 


\section{BAB 6}

\section{UJI NORMALITAS POPULASI}

\section{Ují Normalitas dengan Uji Kolmogorov-Smirnov}

Uji Kolmogorov-Smirnov dapat digunakan untuk menguji suatu asumsi apakah suatu data sampel berasal dari populasi yang berdistribusi normal atau tidak. Pada pembahasan pada Bab 1 telah dibahas mengenai distribusi sampling dari rata-rata $\bar{X}$. Apabila data sampel berasal dari populasi yang berdistribusi normal, maka distribusi sampling dari rata-rata $\bar{X}$ juga mengikuti distribusi normal. Asumsi normalitas memiliki peranan penting dalam uji-uji parametrik, seperti uji beda rata-rata dari dua populasi dengan uji $t$ dan analisis varians. Hal ini karena uji-uji parametrik akan bekerja dengan baik ketika asumsi normalitas dipenuhi. Conover (1999:115) menyatakan sebagai berikut.

"Most parametric methods are based on the normality assumption because the theory behind the test can be worked out with the normal population distribution. The resulting procedures are efficient and powerful procedures for normally distributed data. Other parametric procedures have been developed assuming the population has other distributions, such as the exponential, Weibull, and soon".

Pada uji Kolmogorov-Smirnov, hipotesis nol menyatakan data yang diteliti berasal dari populasi yang berdistribusi normal, sedangkan hipotesis alternatif menyatakan data yang diteliti tidak berasal dari populasi yang berdistribusi normal. Andaikan $X_{1}, X_{2}, X_{3}, \ldots, X_{k}$ merupakan nilai-nilai pada sampel acak (random sample). Misalkan $f\left(X_{i}\right)$ menyatakan probabilitas dari nilai $X_{i}$, sedangkan $F\left(X_{i}\right)=f\left(X \leq X_{i}\right)$ menyatakan probabilitas kumulatif dari nilai $X_{i}$, di mana $i=1,2,3, \ldots, k$. Selanjutnya andaikan $Z_{i}$ merupakan nilai normal (sampel) terstandarisasi dari hasil transformasi nilai $X_{i}$ dan $F\left(Z_{i}\right)=f\left(Z \leq Z_{i}\right)$ menyatakan probabilitas kumulatif dari nilai normal $Z_{i}$ terstandarisasi. Nilai normal $Z_{i}$ terstandarisasi merupakan hasil transformasi dari nilai $X_{i}$ yang dihitung dengan rumus sebagai berikut.

$$
Z_{i}=\frac{X_{i}-\bar{X}}{s}, i=1,2,3, \ldots, k
$$

Perhatikan bahwa $\bar{X}$ merupakan rata-rata sampel sebagai estimasi dari rata-rata populasi $\mu$, sedangkan $s$ merupakan standar deviasi sampel sebagai estimasi dari standar deviasi populasi $\sigma$. Misalkan $D_{i}$ menyatakan nilai mutlak dari selisih antara $F\left(Z_{i}\right)$ dan $F\left(X_{i}\right)$, yakni

$$
\mathrm{D}_{\mathrm{i}}=\left|F\left(Z_{i}\right)-F\left(X_{i}\right)\right|, i=1,2,3, \ldots, k .
$$

Nilai $D_{i}$ paling besar (maximum) atau $D_{\max }$ merupakan nilai statistik dari uji KolmogorovSmirnov. Nilai statistik dari uji Kolmogorov-Smirnov $\left(D_{\max }\right)$ kemudian dibandingkan dengan nilai kritis berdasarkan tabel distribusi Kolmogorov-Smirnov untuk pengambilan keputusan terhadap hipotesis. Berikut aturan pengambilan keputusan terhadap hipotesis berdasarkan uji Kolmogorov-Smirnov.

Jika $D_{\max } \leq$ nilai kritis, maka $H_{0}$ diterima dan $H_{1}$ ditolak. Jika $D_{\max }>$ nilai kritis, maka $H_{0}$ ditolak dan $H_{1}$ diterima. 
Tabel 6.1 merupakan tabel distribusi Kolmogorov-Smirnov. Pengambilan keputusan terhadap hipotesis juga dapat dilakukan dengan membandingkan nilai probabilitas ( $p$-value) dari uji Kolmogorov-Smirnov terhadap tingkat signifikansi $\alpha$ (significance level). Berikut aturan pengambilan keputusan berdasarkan pendekatan nilai probabilitas.

Jika nilai probabilitas $\geq$ tingkat signifikansi, maka $H_{0}$ diterima dan $H_{1}$ ditolak. Jika nilai probabilitas < tingkat signifikansi, maka $H_{0}$ ditolak dan $H_{1}$ diterima.

Tabel 6.2 menyajikan nilai statistik dan nilai probabilitas dari uji Kolmogorov-Smirnov.

\section{Tabel 6.1}

\begin{tabular}{|c|c|c|c|c|c}
\hline$n$ & $\alpha=0,2$ & $\alpha=0,1$ & $\alpha=0,05$ & $\alpha=0,02$ & $\alpha=0,01$ \\
\hline 1 & 0,900 & 0,950 & 0,975 & 0,990 & 0,995 \\
\hline 2 & 0,684 & 0,776 & 0,842 & 0,900 & 0,929 \\
\hline 3 & 0,565 & 0,636 & 0,708 & 0,785 & 0,829 \\
\hline 4 & 0,493 & 0,565 & 0,624 & 0,689 & 0,734 \\
\hline 5 & 0,447 & 0,509 & 0,563 & 0,627 & 0,669 \\
\hline 6 & 0,410 & 0,468 & 0,519 & 0,577 & 0,617 \\
\hline 7 & 0,381 & 0,436 & 0,483 & 0,538 & 0,576 \\
\hline 8 & 0,359 & 0,410 & 0,454 & 0,507 & 0,542 \\
\hline 9 & 0,339 & 0,387 & 0,430 & 0,480 & 0,513 \\
\hline 10 & 0,323 & 0,369 & 0,409 & 0,457 & 0,486 \\
\hline 11 & 0,308 & 0,352 & 0,391 & 0,437 & 0,468 \\
\hline 12 & 0,296 & 0,338 & 0,375 & 0,419 & 0,449 \\
\hline 13 & 0,285 & 0,325 & 0,361 & 0,404 & 0,432 \\
\hline 14 & 0,275 & 0,314 & 0,349 & 0,390 & 0,418 \\
\hline 15 & 0,266 & 0,304 & 0,338 & 0,377 & 0,404 \\
\hline 16 & 0,258 & 0,295 & 0,327 & 0,366 & 0,392 \\
\hline 17 & 0,250 & 0,286 & 0,318 & 0,355 & 0,381 \\
\hline 18 & 0,244 & 0,279 & 0,309 & 0,346 & 0,371
\end{tabular}

Tabel 6.2

\begin{tabular}{|c|c|c|c|}
\hline \multicolumn{3}{|c|}{ One-Sample Kolmogorov-Smirnov Test } & \multirow{2}{*}{$\begin{array}{l}\text { Nilai Absolute } 0,125 \\
\text { merupakan nilai statistik dari }\end{array}$} \\
\hline & & data & \\
\hline \multicolumn{2}{|l|}{$\bar{N}$} & 16 & uji Kolmogorov-Smirnov, \\
\hline \multirow[t]{2}{*}{ Normal Parameters ${ }^{a, b}$} & Mean & 70.00 & sedangkan nilai Asymp. Sig. \\
\hline & Std. Deviation & 16.330 & (2-tailed) merupakan nilai \\
\hline \multirow[t]{3}{*}{ Most Extreme Differences } & Absolute & .125 & probabilitas dari uji \\
\hline & Positive & .125 & Kolmogorov-Smirnov. \\
\hline & Negative & -.125 & \\
\hline \multicolumn{2}{|l|}{ Kolmogorov-Smirnov Z } & .500 & \\
\hline \multicolumn{2}{|l|}{ Asymp. Sig. (2-tailed) } & .964 & \\
\hline
\end{tabular}




\section{PENYELESAIAN DALAM SPSS}

Misalkan seorang mahasiswa semester 8 sedang menyusun tugas akhir dan baru saja mengambil sampel mengenai nilai ujian matematika kelas 6 SD sebanyak 16 siswa. Berikut data yang telah dikumpulkan oleh mahasiswa tersebut.

Tabel 6.1 (Data Fiktif)

\begin{tabular}{|c|c|c|c|c|c|c|c|c|}
\hline Nomor & Nama & Nilai & Nomor & Nama & Nilai & Nomor & Nama & Nilai \\
\hline 1 & $\mathrm{~A}$ & 40 & 7 & $\mathrm{H}$ & 70 & 13 & $\mathrm{~N}$ & 80 \\
\hline 2 & $\mathrm{~B}$ & 50 & 8 & $\mathrm{I}$ & 70 & 14 & $\mathrm{O}$ & 90 \\
\hline 3 & $\mathrm{C}$ & 50 & 9 & $\mathrm{~J}$ & 70 & 15 & $\mathrm{P}$ & 90 \\
\hline 4 & $\mathrm{D}$ & 60 & 10 & $\mathrm{~K}$ & 70 & 16 & $\mathrm{Q}$ & 100 \\
\hline 5 & $\mathrm{~F}$ & 60 & 11 & $\mathrm{~L}$ & 80 & & & \\
\hline 6 & $\mathrm{G}$ & 60 & 12 & $\mathrm{M}$ & 80 & & & \\
\hline
\end{tabular}

Berikut akan digunakan uji Kolmogorov-Smirnov dalam SPSS untuk menentukan apakah data tersebut ditarik dari populasi yang berdistribusi normal atau tidak (misalkan tingkat signifikansi yang digunakan $\alpha=5 \%$ ). Bangun data pada Tabel 6.1 dalam SPSS (Gambar 6.1). Selanjutnya pilih Analyze $\Rightarrow$ Nonparametric Statistics $\Rightarrow>1$-Sample $K$-S, sehingga muncul kotak dialog One-Sample Kolmogorov-Smirnov Test (Gambar 6.2).

\begin{tabular}{|r|r|r|r|}
\hline & data & \multicolumn{2}{|c|}{} \\
\hline 1 & 40 & 9 & 70 \\
\hline 2 & 50 & 10 & 70 \\
\hline 3 & 50 & 11 & 80 \\
\hline 4 & 60 & 12 & 80 \\
\hline 5 & 60 & 13 & 80 \\
\hline 6 & 60 & 14 & 90 \\
\hline 7 & 70 & 15 & 90 \\
\hline 8 & 70 & 16 & 100 \\
\hline & & & \\
\hline & & & \\
\hline & & & \\
\hline
\end{tabular}

Gambar 6.1

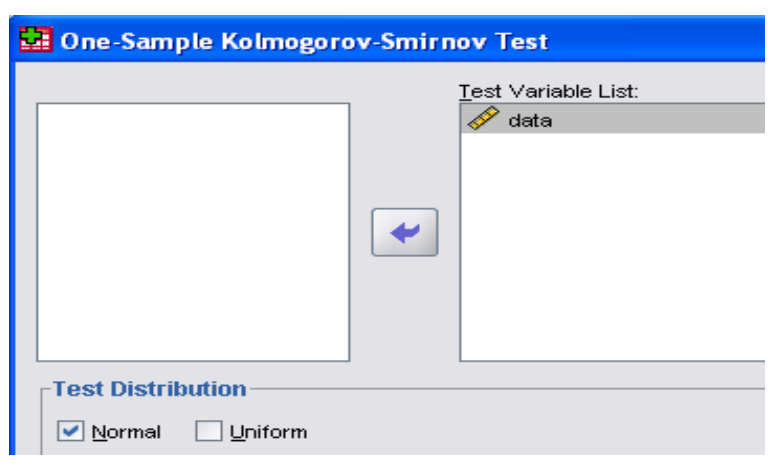

Gambar 6.2

Pada Gambar 6.2, masukkan variabel data pada kotak Test Variable List. Kemudian pilih Normal pada Test Distribution dan pilih OK. Hasil SPSS tersaji pada Tabel 6.2.

Tabel 6.2

\begin{tabular}{|ll|r|}
\hline \multicolumn{2}{|c|}{ One-Sample Kolmogorov-Smirnov Test } \\
\hline N & & \multicolumn{1}{c|}{ data } \\
Normal Parameters ${ }^{\text {a..b }}$ & Mean & 16 \\
& Std. Deviation & 70.00 \\
Most Extreme Differences & Absolute & 16.330 \\
& Positive & .125 \\
& Negative & .125 \\
Kolmogorov-Smirnov $Z$ & & -.125 \\
Asymp. Sig. (2-tailed) & & .500 \\
\end{tabular}


Berdasarkan Tabel 6,2, diketahui nilai Mean atau rata-rata adalah 70 dan nilai Std. Deviation atau standar deviasi 16,330. Diketahui nilai statistik dari uji Kolmogorov-Smirnov (Absolute) adalah 0,125. Nilai kritis Kolmogorov-Smirnov dengan jumlah elemen dalam sampel $n=16$ dan tingkat signifikansi $\alpha=5 \%$ adalah 0,327 . Berikut aturan pengambilan keputusan terhadap hipotesis berdasarkan uji Kolmogorov-Smirnov.

Jika $D_{\max } \leq$ nilai kritis, maka $H_{0}$ diterima dan $H_{1}$ ditolak. Jika $D_{\max }>$ nilai kritis, maka $H_{0}$ ditolak dan $H_{1}$ diterima.

Perhatikan bahwa karena nilai statistik dari uji Kolmogorov-Smirnov $(0,125)$ lebih kecil dibandingkan nilai kritis Kolmogorov-Smirnov (0,327), maka hipotesis nol diterima dan hipotesis alternatif ditolak, sehingga asumsi mengenai data nilai ujian matematika kelas $6 \mathrm{SD}$ ditarik dari populasi yang berdistribusi normal dapat diterima pada tingkat signifikansi $5 \%$.

Pengambilan keputusan terhadap hipotesis juga dapat dilakukan dengan membandingkan nilai probabilitas ( $p$-value) dari uji Kolmogorov-Smirnov terhadap tingkat signifikansi $\alpha$ (significance level). Berikut aturan pengambilan keputusan terhadap hipotesis berdasarkan pendekatan nilai probabilitas.

Jika nilai probabilitas $\geq$ tingkat signifikansi, maka $H_{0}$ diterima dan $H_{1}$ ditolak. Jika nilai probabilitas < tingkat signifikansi, maka $H_{0}$ ditolak dan $H_{1}$ diterima.

Berdasarkan Tabel 6.2, diketahui nilai probabilitas dari uji Kolmogorov-Smirnov (Asymp. Sig. (2-tailed)) adalah 0,964. Diketahui tingkat signifikansi yang digunakan $\alpha=5 \%$. Perhatikan bahwa karena nilai probabilitas $(0,964)$ lebih besar dibandingkan tingkat signifikansi $(0,05)$, maka hipotesis nol diterima dan hipotesis alternatif ditolak. 


\section{PENYELESAIAN DALAM Minitab}

Bangun data pada Tabel 6.1 dalam Minitab seperti pada Gambar 6.3. Pilih Stat $=>$ Basic Statistics $=>$ Normality Test (Gambar 6.4), sehingga muncul tampilan seperti pada Gambar 6.5. Pada Gambar 6.5, masukkan variabel Data ke dalam kotak Variable:, kemudian pilih Kolmogorov-Smirnov pada Tests for Normality. Selanjutnya pilih OK. Hasilnya diperlihatkan pada Gambar 6.6.

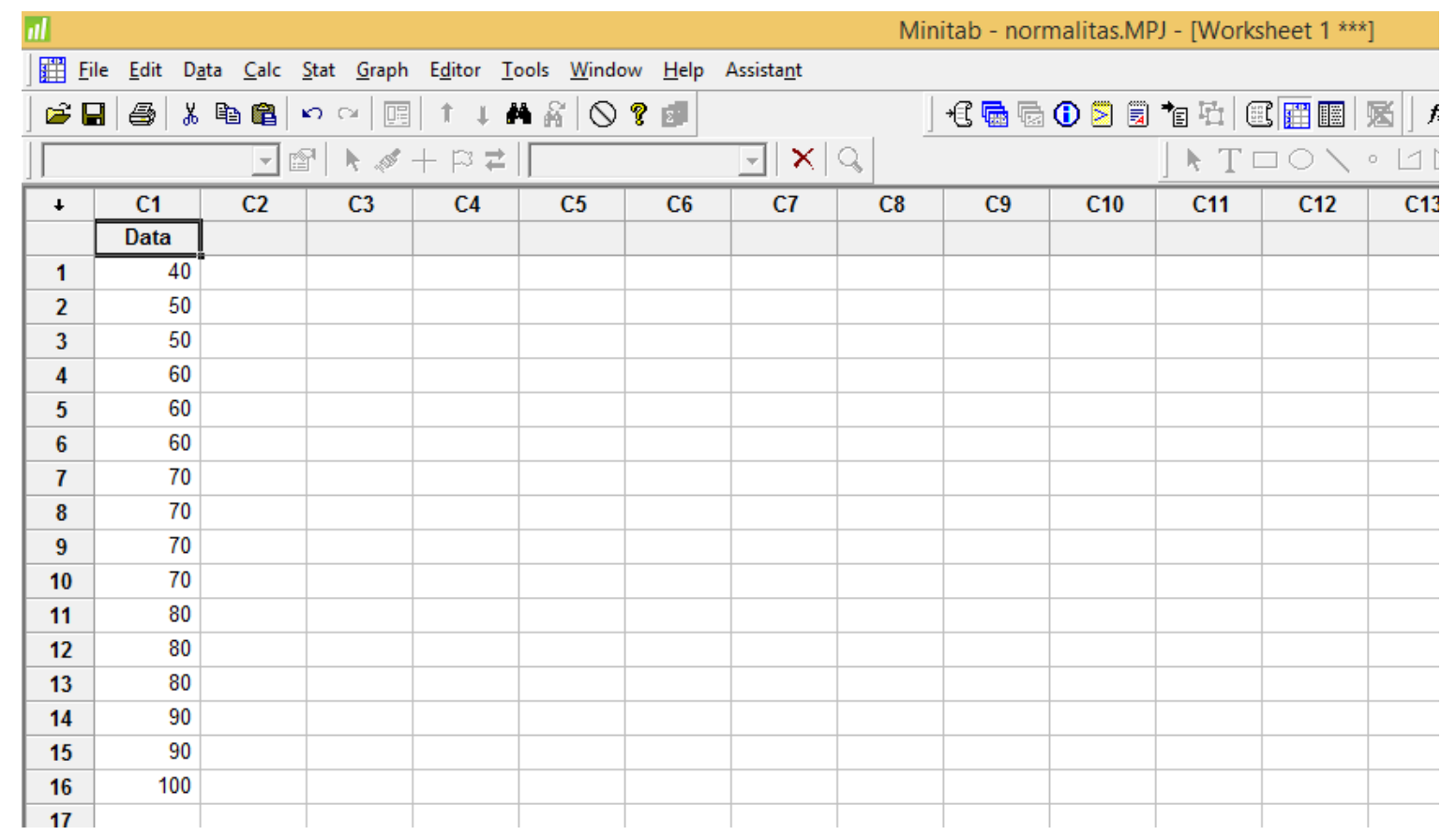

\section{Gambar 6.3}

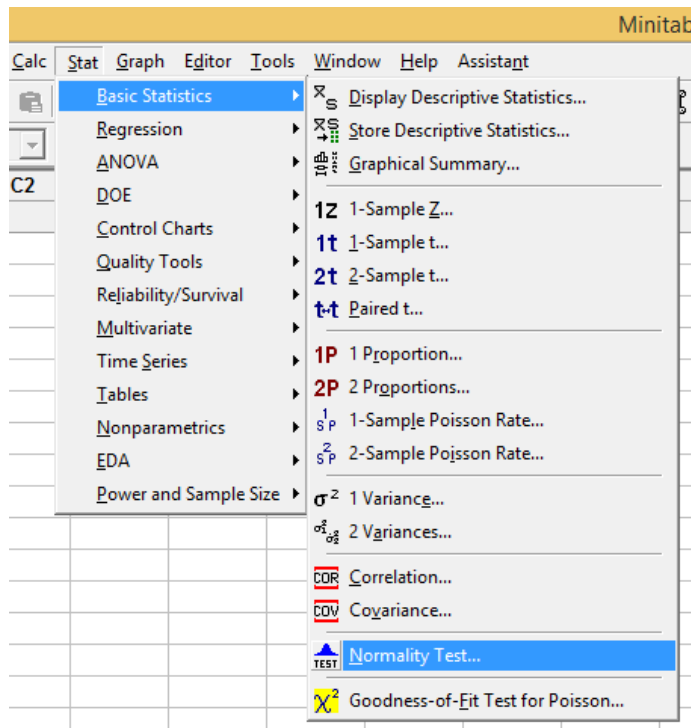

Gambar 6.4

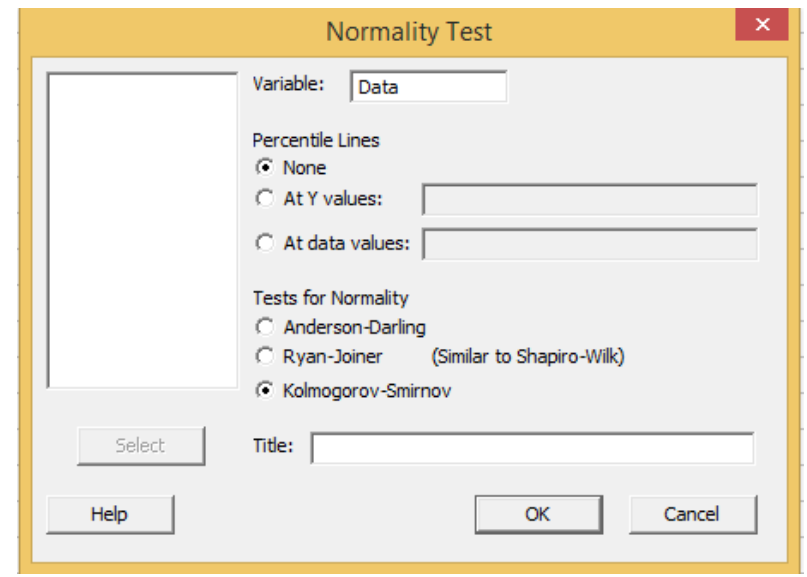

Gambar 6.5 
Pada Gambar 6.6, terlihat bahwa nilai statistik dari uji Kolmogorov-Smirnov (KS) 0,125, lebih kecil dibandingkan nilai kritis Kolmogorov-Smirnov 0,327, maka hipotesis nol diterima dan hipotesis alternatif ditolak, sehingga asumsi mengenai data nilai ujian matematika kelas 6 SD ditarik dari populasi yang berdistribusi normal dapat diterima pada tingkat signifikansi $5 \%$. Perhatikan juga bahwa nilai probabilitas ( $P$-Value) lebih besar dari 0,150 , yang artinya juga nilai probabilitas $>\alpha=0,05$.

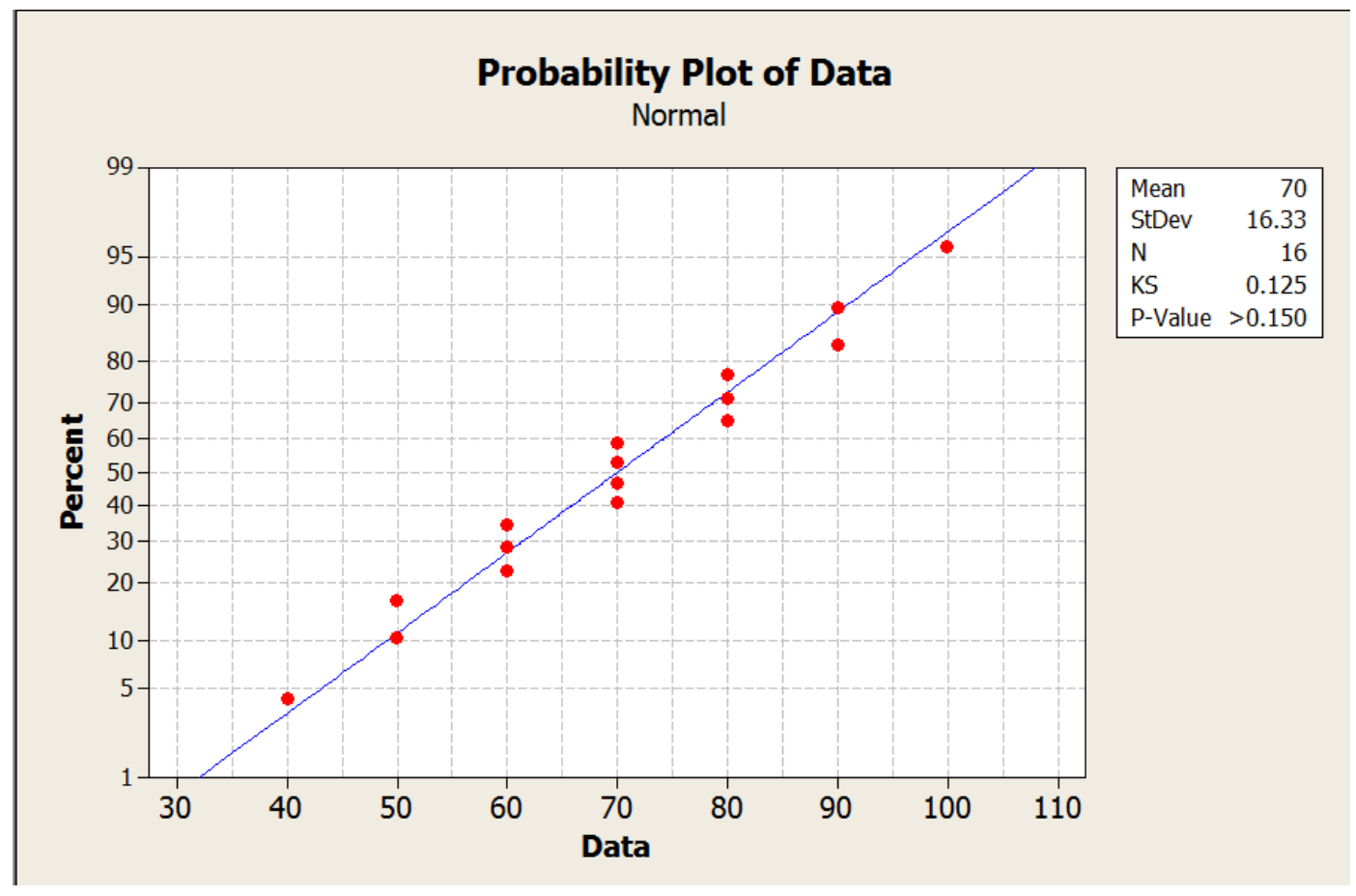

\section{Gambar 6.6}




\section{PENYELESAIAN DALAM R}

Data terlebih dahulu dibuat dalam Microsoft Excel (Gambar 6.7) dan disimpan dengan format tipe .csv (Gambar 6.8 dan Gambar 6.9). Ketik kode R seperti pada Gambar 6.10. Kemudian Compile dan pilih HTML (Gambar 6.11). Hasilnya seperti pada Gambar 6.12.

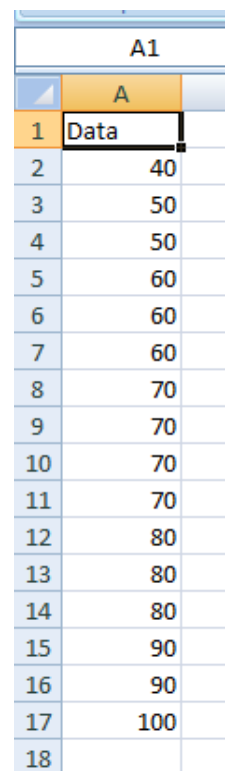

Gambar 6.7

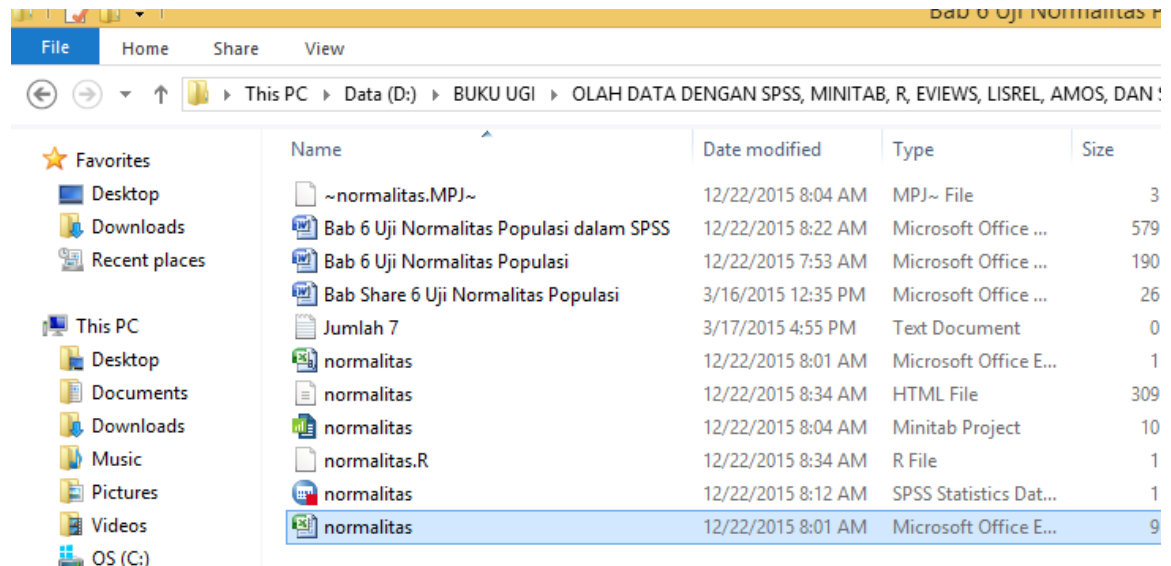

Gambar 6.8

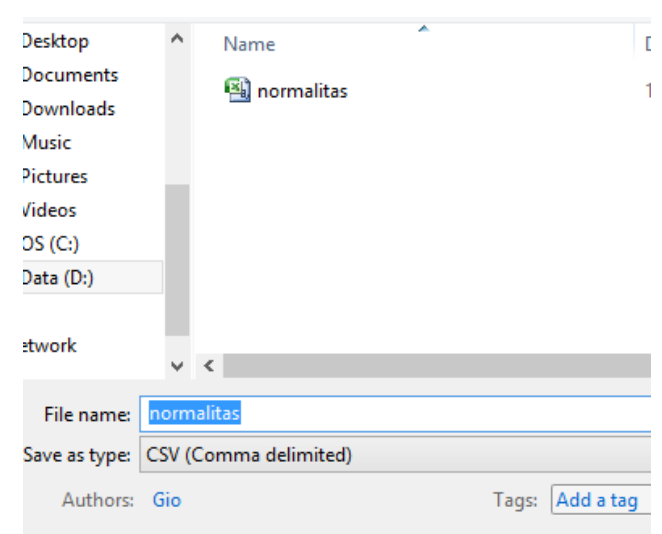

Gambar 6.9

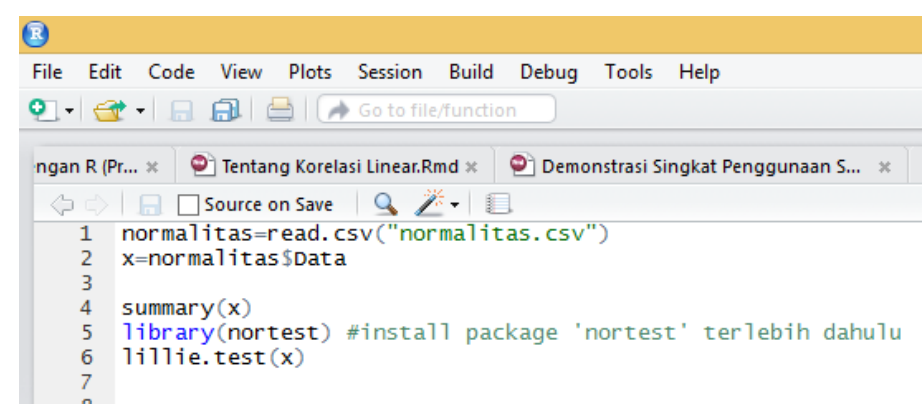

Gambar 6.10

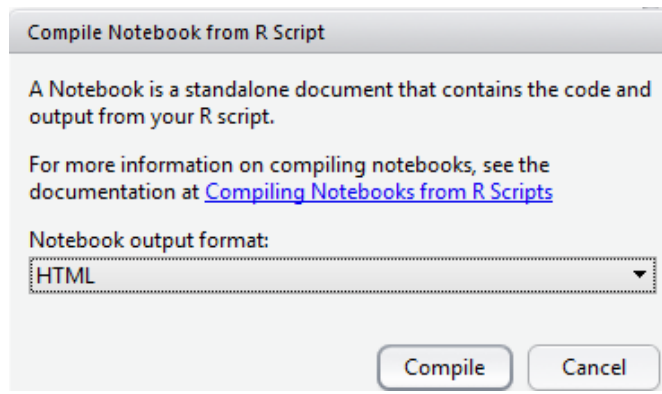

Gambar 6.11 


\section{normalitas. $R$}

Gio

Tue Dec 22 08:53:48 2015

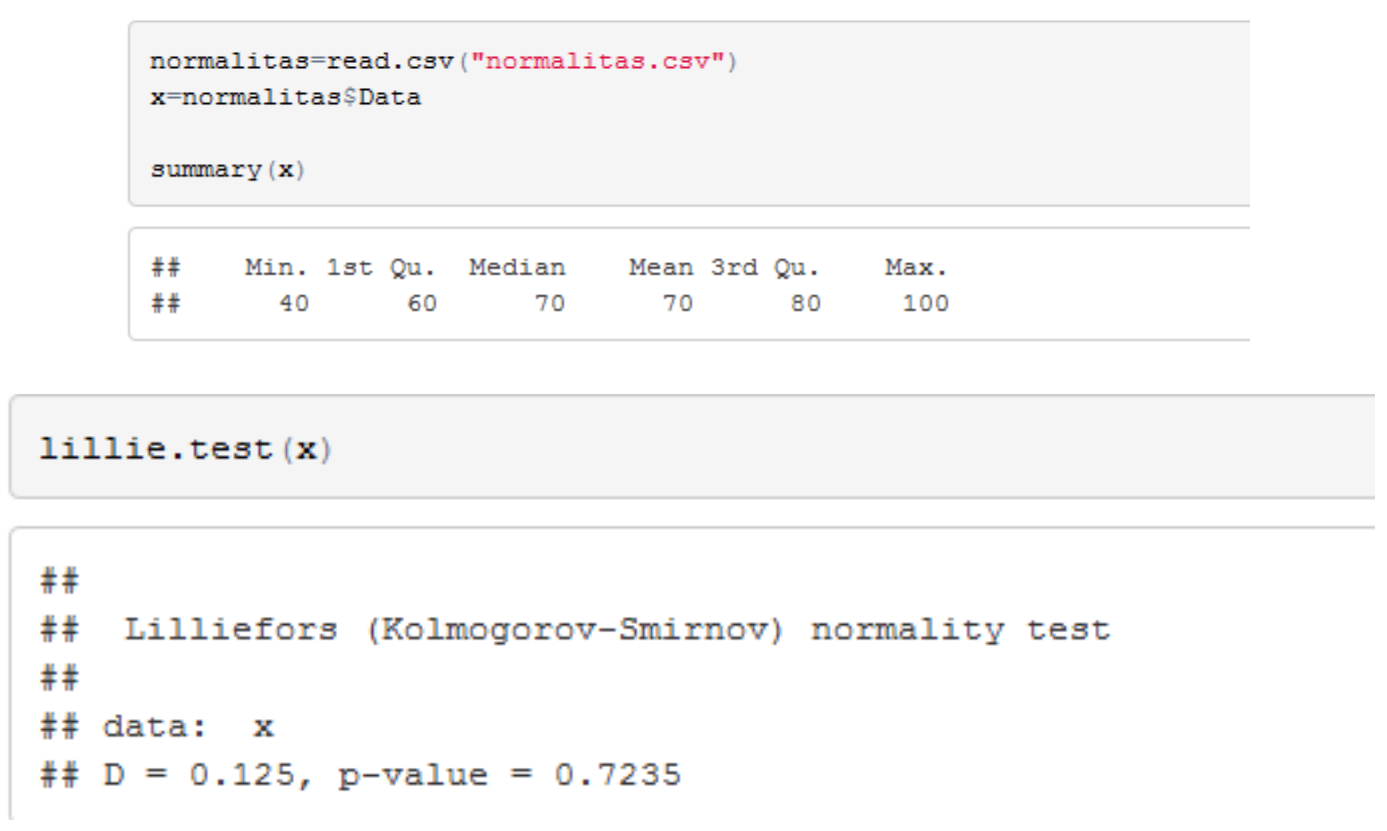

\section{Gambar 6.12}

Pada Gambar 6.12, terlihat bahwa nilai statistik dari uji Kolmogorov-Smirnov (D) 0,125, lebih kecil dibandingkan nilai kritis Kolmogorov-Smirnov 0,327, maka hipotesis nol diterima dan hipotesis alternatif ditolak, sehingga asumsi mengenai data nilai ujian matematika kelas 6 SD ditarik dari populasi yang berdistribusi normal dapat diterima pada tingkat signifikansi $5 \%$. 


\section{$S \mathcal{H A R E}$}

[1] Misalkan seorang mahasiswa semester 8 sedang menyusun tugas akhir dan baru saja mengumpulkan data sampel mengenai nilai ujian matematika kelas 6 SD sebanyak 16 siswa. Berikut data yang telah dikumpulkan oleh mahasiswa tersebut.

Tabel 6.1 (Data Fiktif)

\begin{tabular}{|c|c|c|c|c|c|c|c|c|}
\hline Nomor & Nama & Nilai & Nomor & Nama & Nilai & Nomor & Nama & Nilai \\
\hline 1 & A & 40 & 7 & H & 70 & 13 & N & 80 \\
\hline 2 & B & 50 & 8 & I & 70 & 14 & O & 90 \\
\hline 3 & C & 50 & 9 & J & 70 & 15 & P & 90 \\
\hline 4 & D & 60 & 10 & K & 70 & 16 & Q & 100 \\
\hline 5 & F & 60 & 11 & L & 80 & & & \\
\hline 6 & G & 60 & 12 & M & 80 & & & \\
\hline
\end{tabular}

Berikut akan digunakan pendekatan uji Kolmogorov-Smirnov untuk menentukan apakah data tersebut ditarik dari populasi yang berdistribusi normal atau tidak (misalkan tingkat signifikansi yang digunakan $\alpha=5 \%$ ). Perhitungan akan dilakukan secara manual.

$\rightarrow$ Menghitung nilai rata-rata $(\bar{X})$ dan standar deviasi $(s)$.

Tabel 6.2

\begin{tabular}{|c|c|c|c|c|c|c|c|}
\hline No. & $X$ & Frekuensi & $f(X)$ & $F(X)$ & $Z$ & $F(Z)$ & $D=|F(Z)-F(X)|$ \\
\hline 1 & 40 & 1 & 0,0625 & 0,0625 & $-1,83712$ & 0,033096276 & 0,029403724 \\
\hline 2 & 50 & 2 & 0,125 & 0,1875 & $-1,22474$ & 0,110335658 & 0,077164342 \\
\hline 3 & 60 & 3 & 0,1875 & 0,375 & $-0,61237$ & 0,270145667 & 0,104854333 \\
\hline 4 & 70 & 4 & 0,25 & 0,625 & 0 & 0,5 & $\mathbf{0 , 1 2 5}$ \\
\hline 5 & 80 & 3 & 0,1875 & 0,8125 & 0,612372 & 0,729854333 & 0,082645667 \\
\hline 6 & 90 & 2 & 0,125 & 0,9375 & 1,224745 & 0,889664342 & 0,047835658 \\
\hline 7 & 100 & 1 & 0,0625 & 1 & 1,837117 & 0,966903724 & 0,033096276 \\
\hline
\end{tabular}

Berdasarkan Tabel 6.2 , berikut akan dihitung nilai rata-rata hitung $(\bar{X})$ dan standar deviasi (s).

$$
\begin{gathered}
\bar{X}=\frac{\sum X}{n} \\
\bar{X}=\frac{(40 \times 1)+(50 \times 2)+(60 \times 3)+(70 \times 4)+(80 \times 3)+(90 \times 2)+(100 \times 1)}{16} \\
\bar{X}=70
\end{gathered}
$$




$$
\begin{gathered}
s=\sqrt{\frac{\sum(X-\bar{X})^{2}}{n-1}} \\
s=\sqrt{\frac{4000}{15}} \\
s=16,330 .
\end{gathered}
$$

$\rightarrow$ Menghitung probabilitas dari $X_{i}$ atau $f\left(X_{i}\right)$.

Setelah diperoleh $\bar{X}=70$ dan $s=16,330$, selanjutnya akan dihitung probabilitas dari $X_{i}$ atau $f\left(X_{i}\right)$. Probabilitas untuk nilai $X=40$ atau $f(40)$ adalah $\frac{1}{16}=0,0625$, probabilitas untuk nilai $X=50$ atau $f(50)$ adalah $\frac{2}{16}=0,125$, probabilitas untuk nilai $X=70$ atau $f(70)$ adalah $\frac{4}{16}=0,25$, dan seterusnya.

$\rightarrow$ Menghitung probabilitas kumulatif dari $X_{i}$ atau $F\left(X_{i}\right)=f\left(X \leq X_{i}\right)$.

Nilai dari $F(40)=0,0625$, nilai dari $F(50)=f(X \leq 50)=f(40)+f(50)=0,0625+$ $0,125=0,1875$, nilai dari $F(60)=f(X \leq 60)=f(40)+f(50)+f(60)=0,375$, dan seterusnya.

$\rightarrow$ Mentransformasi nilai $X_{i}$ menjadi nilai normal $Z_{i}$ terstandarisasi.

Selanjutnya mentransformasi nilai $X_{i}$ ke dalam nilai normal $Z_{i}$ terstandarisasi yang dihitung dengan rumus

$$
Z_{i}=\frac{X_{i}-\bar{X}}{S}
$$

Untuk $X=40$, maka

$$
Z(X=40)=\frac{40-70}{16,330}=-1,837
$$

Untuk $X=50$, maka

$$
Z(X=50)=\frac{50-70}{16,330}=-1,2247
$$

dan seterusnya.

$\rightarrow$ Menghitung probabilitas kumulatif dari $Z_{i}$ atau $F\left(Z_{i}\right)=f\left(Z \leq Z_{i}\right)$.

Setelah diperoleh nilai-nilai normal terstandarisasi, maka akan dihitung probabilitas kumulatif dari nilai-nilai normal terstandarisasi tersebut. Probabilitas kumulatif dari $Z=-1,837$ atau $f(Z \leq-1,837)$ berdasarkan tabel distribusi normal kumulatif adalah 0,033 , probabilitas kumulatif dari $Z=0,61$ atau $f(Z \leq 0,61)$ berdasarkan tabel distribusi normal kumulatif adalah 0,729 , dan seterusnya. 
$\rightarrow$ Menghitung nilai mutlak dari selisih antara $F\left(Z_{i}\right)$ dan $F\left(X_{i}\right)$.

Selanjutnya menghitung nilai mutlak dari selisih antara $F\left(Z_{i}\right)$ dan $F\left(X_{i}\right)$.

$$
\mathrm{D}_{\mathrm{i}}=\left|F\left(Z_{i}\right)-F\left(X_{i}\right)\right|
$$

Nilai $D$ untuk $X=40$ adalah $|0,033-0,0625|=0,0295$, nilai $D$ untuk $X=50$ adalah $|0,110-0,1875|=0,077$, dan seterusnya.

$\rightarrow$ Menghitung nilai statistik dari uji Kolmogorov-Smirnov $\left(D_{\max }\right)$.

Nilai statistik dari uji Kolmogorov-Smirnov merupakan nilai $D$ yang paling besar atau maksimum. Berdasarkan Tabel 6.2, nilai $D$ terbesar adalah 0,125, sehingga nilai statistik dari uji Kolmogorov-Smirnov adalah 0,125 atau $D_{\max }=0,125$.

$\rightarrow$ Menghitung nilai kritis Kolmogorov-Smirnov.

Nilai kritis Kolmogorov-Smirnov pada tingkat signifikansi 5\% dan jumlah elemen sampel 16 berdasarkan tabel distribusi Kolmogorov-Smirnov adalah 0,327.

$\rightarrow$ Pengambilan keputusan terhadap hipotesis.

Perhatikan bahwa karena nilai statistik dari uji Kolmogorov-Smirnov $(0,125)$ lebih kecil dibandingkan nilai kritis Kolmogorov-Smirnov (0,327), maka hipotesis nol diterima dan hipotesis alternatif ditolak, sehingga asumsi mengenai data nilai ujian matematika kelas $6 \mathrm{SD}$ ditarik dari populasi yang berdistribusi normal dapat diterima pada tingkat signifikansi 5\%.

\section{Referensi}

1. Conover, W.J. 1999. Practical Nonparametric Statistics, $3^{\text {rd }}$ Edition. New York: John Wiley \& Sons, Inc.

2. Field, A. 2009. Discovering Statistics Using SPSS, $3^{\text {rd }}$ Edition. London: Sage.

3. Gio, P.U. 2013. Aplikasi Statistika dalam SPSS. Medan: USUpress.

4. Mann, P. S. dan C.J. Lacke. 2011. Introductory Statistics, International Student Version, $7^{\text {th }}$ Edition, Asia: John Wiley \& Sons, Inc.

5. Montgomery, D.C. dan G.C. Runger. 2011. Applied Statistics and Probability for Engineers, $5^{\text {th }}$ Edition. United States of America: John Wiley \& Sons, Inc. 


\section{BAB 7}

\section{UJI KESAMAAN VARIANS POPULASI}

\section{Sekílas Uji Kesaman Varíans Populasi dengan Uji Levene}

Uji Levene merupakan salah satu uji dalam statistika yang dapat digunakan untuk menguji kesamaan varians dari dua atau lebih populasi. Selain uji Levene, dapat juga digunakan uji $F$, uji Hartley, dan uji Bartlett untuk menguji kesamaan varians populasi. Varians populasi dilambangkan dengan $\sigma^{2}$, sedangkan varians sampel dilambangkan dengan $s^{2}$.

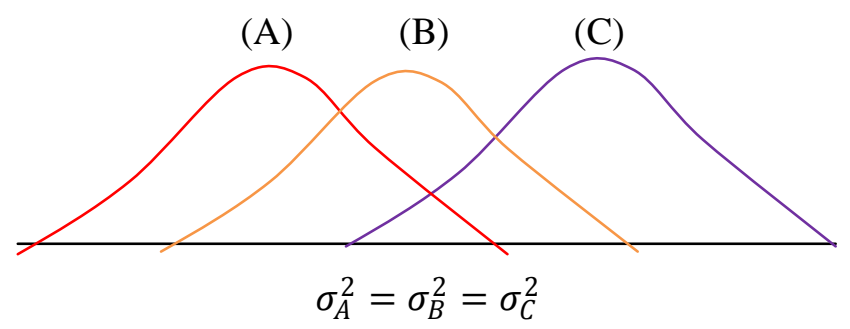

\section{Gambar 7.1}

Pada Gambar 7.1, varians dari populasi A, B, dan C adalah sama, namun rata-ratanya berbeda. Pada Gambar 7.2, varians dari populasi A dan B sama, namun berbeda dengan C.

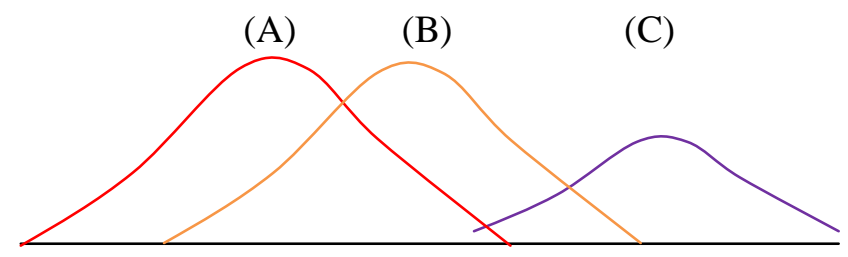

Gambar 7.2

Pada uji Levene, hipotesis nol menyatakan tidak terdapat perbedaan varians di antara populasi, sedangkan hipotesis alternatif menyatakan terdapat paling tidak sepasang varians populasi yang berbeda. Field (2009:150) menyatakan sebagai berikut.

"Levene's test tests null hypothesis that the variances in different groups are equal (i.e. the difference between the variances is zero)."

Untuk pengambilan keputusan terhadap hipotesis dapat dilakukan dengan membandingkan nilai statistik dari uji Levene $(L)$ terhadap nilai kritis dari tabel distribusi $F$ ( $\left.F_{k r i t i s}\right)$. Berikut aturan pengambilan keputusan terhadap hipotesis berdasarkan uji Levene.

Jika $L \leq$ nilai kritis $F$, maka $H_{0}$ diterima dan $H_{1}$ ditolak.

Jika $L>$ nilai kritis $F$, maka $H_{0}$ ditolak dan $H_{1}$ diterima.

Pengambilan keputusan terhadap hipotesis juga dapat dilakukan dengan membandingkan nilai probabilitas dari uji Levene terhadap tingkat signifikansi $\alpha$ (significance level). 
Jika nilai probabilitas $\geq$ tingkat signifikansi, maka $H_{0}$ diterima dan $H_{1}$ ditolak. Jika nilai probabilitas $<$ tingkat signifikansi, maka $H_{0}$ ditolak dan $H_{1}$ diterima.

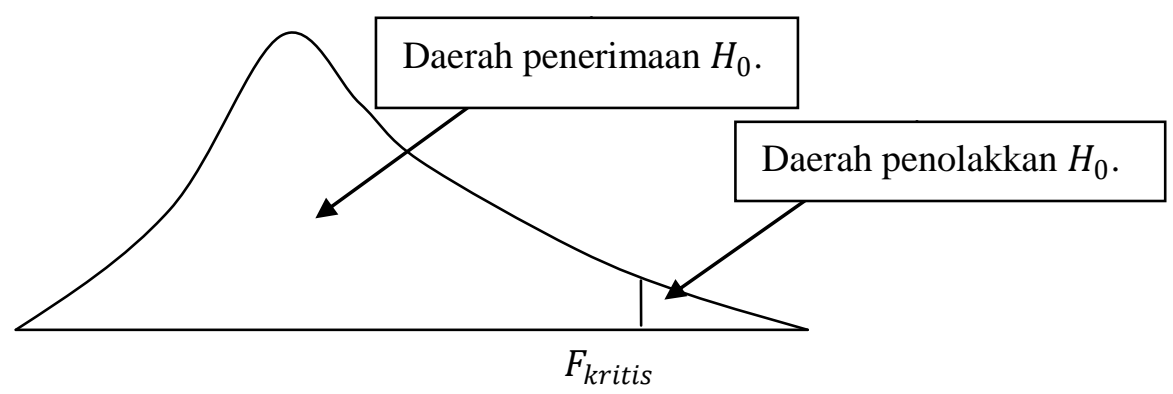

Tabel 7.1 menyajikan nilai statistik dan nilai probabilitas dari uji Levene.

Tabel 7.1

Test of Homogeneity of Variances

\begin{tabular}{|c|c|c|c|}
\hline Levene Statistic & df1 & df2 & Sig. \\
\hline .649 & 2 & 15 & .537 \\
\hline
\end{tabular}

Nilai pada kolom Levene Statistic merupakan nilai statistik dari uji Levene. Nilai pada kolom Sig merupakan nilai probabilitas dari uji Levene.

\section{Contoh Kasus dalam Uji Levene}

[1] Andaikan seorang peneliti baru saja mengumpulkan data sampel mengenai nilai ujian matematika dari 15 siswa laki-laki dan 15 siswa perempuan.

Nilai ujian matematika siswa laki-laki:

$$
61,62,63,64,65,66,67,68,69,70,71,72,73,74,75 \text {. }
$$

Nilai ujian matematika siswa perempuan:

$$
71,72,73,74,75,76,77,78,79,80,81,82,83,84,85 .
$$

Ujilah dengan menggunakan uji Levene untuk menentukan apakah varians populasi dari nilai ujian matematika siswa laki-laki dan perempuan sama pada tingkat signifikansi $5 \%$.

[2] Andaikan seorang peneliti baru saja mengumpulkan data mengenai skor IQ dari 10 mahasiswa kelompok A dan 10 mahasiswa kelompok B.

Skor IQ mahasiswa kelompok A: 99, 100, 101, 102, 103, 104, 105, 106, 107, 108.

Skor IQ mahasiswa kelompok B: 99, 105, 115, 121, 122, 127, 125, 125, 122, 122.

Ujilah dengan menggunakan uji Levene untuk menentukan apakah varians populasi dari skor IQ mahasiswa kelompok A dan kelompok B sama pada tingkat signifikansi 5\%. 


\section{PENYELESAIAN DALAM SPSS}

Misalkan diberikan data mengenai nilai ujian matematika kelas 1,2, dan 3 SMA (Tabel 7.1). Berdasarkan data pada Tabel 7.1, $X$ menyatakan nilai ujian matematika siswa kelas 1 SMA, $Y$ menyatakan nilai ujian matematika siswa kelas 2 SMA, dan $Z$ menyatakan nilai ujian siswa kelas 3 SMA. Berikut akan digunakan uji Levene dalam SPSS untuk menguji apakah $X, Y$, dan $Z$ memiliki varians populasi yang sama pada tingkat signifikansi $5 \%$. Dengan kata lain, akan di uji asumsi bahwa sampel-sampel ditarik dari populasi-populasi yang memiliki varians yang sama.

\section{Tabel 7.1 (Data Fiktif)}

\begin{tabular}{|c|c|c|}
\hline \multicolumn{3}{|c|}{ Nilai Ujian Matematika } \\
\hline$X$ & $Y$ & $Z$ \\
\hline 70 & 80 & 70 \\
\hline 80 & 85 & 87 \\
\hline 87 & 70 & 90 \\
\hline 77 & 77 & 77 \\
\hline 80 & 85 & 76 \\
\hline & 60 & 87 \\
\hline & 80 & \\
\hline
\end{tabular}

Bangun data pada Tabel 7.1 dalam SPSS (Gambar 7.1).

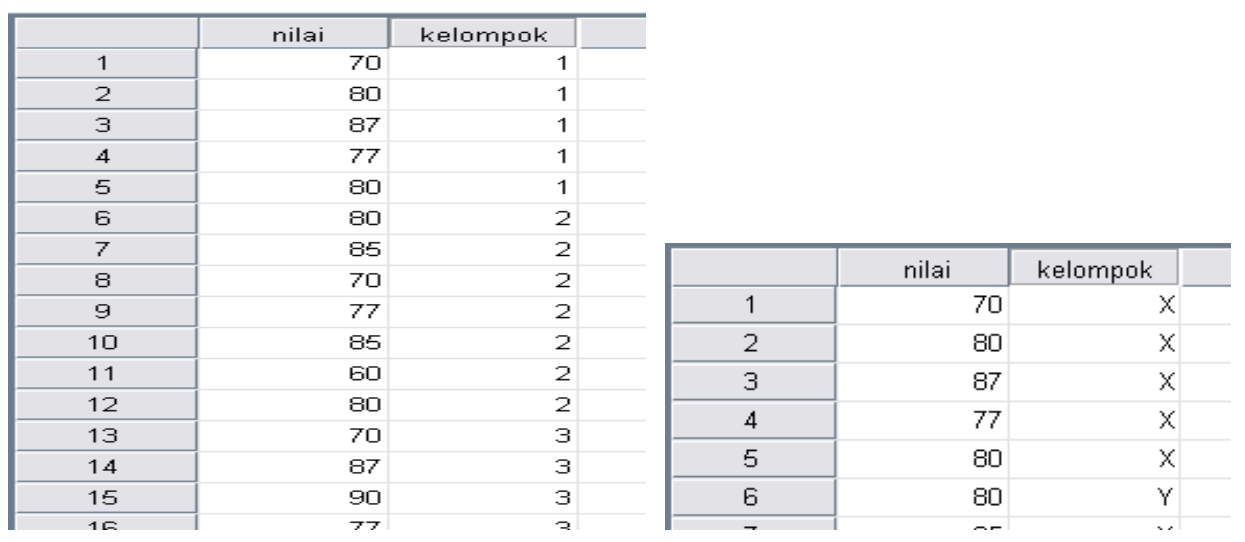

\section{Gambar 7.1}

Selanjutnya pilih Analyze $=>$ Compare Means $=>$ One-Way ANOVA, sehingga muncul kotak dialog One-Way ANOVA (Gambar 7.2).

Pada Gambar 7.2, masukan variabel nilai pada kotak Dependent List dan variabel kelompok pada kotak Factor. Kemudian pilih Options, sehingga muncul kotak dialog One-Way ANOVA: Options (Gambar 7.3). Pilih Homogeneity of Variance Test dan Continue. Selanjutnya pilih OK. Hasil SPSS tersaji pada Tabel 7.2. 


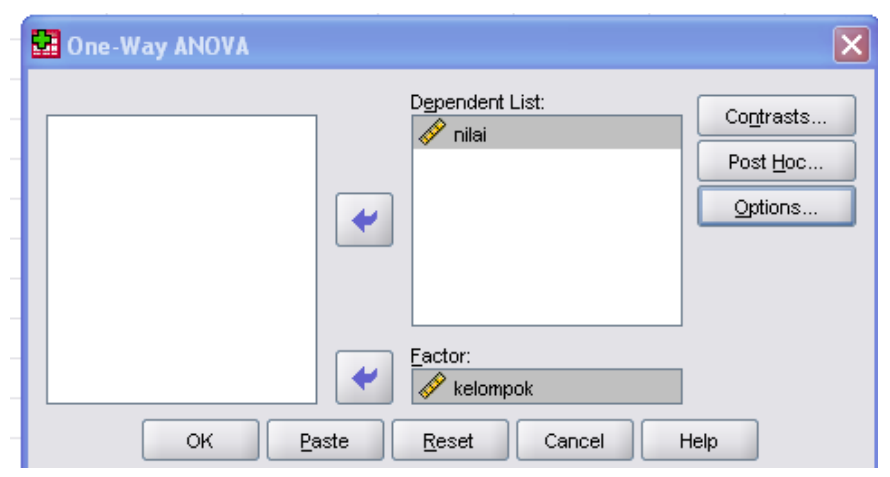

Gambar 7.2

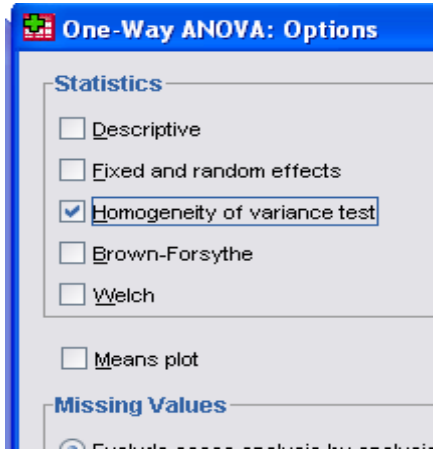

Gambar 7.3

Tabel 7.2

Test of Homogeneity of Variances

Nilai

\begin{tabular}{|c|c|c|c|}
\hline Levene Statistic & df1 & df2 & Sig. \\
\hline .649 & 2 & 15 & .537 \\
\hline
\end{tabular}

Berdasarkan Tabel 7.2, diketahui nilai statistik dari uji Levene (L) (Levene Statistic) adalah 0,649 , derajat bebas pembilang ( $d f 1$ ) adalah 2, derajat bebas penyebut ( $d f 2$ ) adalah 15 , dan nilai probabilitas dari uji Levene ( $\mathrm{Sig}$ ) adalah 0,537. Nilai kritis $F$ dengan derajat bebas pembilang 2, derajat bebas penyebut 15 , dan tingkat signifikansi 5\% adalah 3,68 (perhatikan tabel distribusi $F$ ).

Tabel 7.3 Distribusi $F$

\begin{tabular}{|c|c|c|c|c|}
\hline & \multicolumn{3}{|c|}{ luas sisi kanan $0.05, \alpha=0.05$} & \\
\hline & derajat bebas pembilang & 1 & & \\
\hline \multicolumn{5}{|l|}{ derajat bebas penyebut } \\
\hline 1 & & 161.45 & 199 & 50 \\
\hline 2 & & 18.51 & 19 & 00 \\
\hline 3 & & 10.13 & 9. & 5 \\
\hline 4 & & 7.71 & 6. & 4 \\
\hline 5 & & 6.61 & 5. & 9 \\
\hline 6 & & 5.99 & 5. & 4 \\
\hline 7 & & 5.59 & 4. & 4 \\
\hline 8 & & 5.32 & 4. & 6 \\
\hline 9 & & 5.12 & 4. & 6 \\
\hline 10 & & 4.96 & 4. & 0 \\
\hline 11 & & 4.84 & 3. & 8 \\
\hline 12 & & 4.75 & 3. & 9 \\
\hline 13 & & 4.67 & 3. & 1 \\
\hline 14 & & 4.60 & & 4 \\
\hline 13 & & & 3. & 58 \\
\hline
\end{tabular}

Berikut aturan pengambilan keputusan terhadap hipotesis berdasarkan uji Levene.

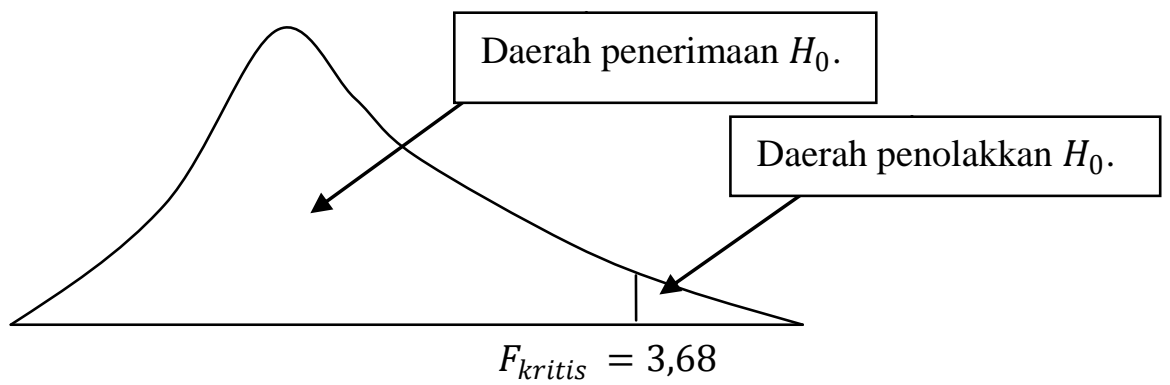


Jika $L \leq$ nilai kritis $F$, maka $H_{0}$ diterima dan $H_{1}$ ditolak. Jika $L>$ nilai kritis $F$, maka $H_{0}$ ditolak dan $H_{1}$ diterima.

Perhatikan bahwa karena nilai statistik dari uji Levene $(0,649)$ lebih kecil dibandingkan nilai kritis $F(3,68)$, maka hipotesis nol diterima dan hipotesis alternatif ditolak, sehingga asumsi mengenai kesamaan varians populasi dari $X, Y$, dan $Z$ dapat diterima pada tingkat signifikansi $5 \%$.

Pengambilan keputusan terhadap hipotesis juga dapat dilakukan dengan membandingkan nilai probabilitas ( $p$-value) dari uji Levene terhadap tingkat signifikansi $\alpha$ (significance level). Berikut aturan pengambilan keputusan terhadap hipotesis berdasarkan pendekatan nilai probabilitas.

Jika nilai probabilitas $\geq$ tingkat signifikansi, maka $H_{0}$ diterima dan $H_{1}$ ditolak. Jika nilai probabilitas < tingkat signifikansi, maka $H_{0}$ ditolak dan $H_{1}$ diterima.

Berdasarkan Tabel 7.2, diketahui nilai probabilitas dari uji Levene (Sig) adalah 0,537. Diketahui tingkat signifikansi yang digunakan $\alpha=5 \%$. Perhatikan bahwa karena nilai probabilitas $(0,537)$ lebih besar dibandingkan tingkat signifikansi $(0,05)$, maka hipotesis nol diterima dan hipotesis alternatif ditolak. 


\section{PENYELESAIAN DALAM Minitab}

Bangun data pada Tabel 7.1 dalam Minitab seperti pada Gambar 7.4. Pilih Stat $=>$ ANOVA => Test for Equal Variances (Gambar 7.5), sehingga muncul tampilan seperti pada Gambar 7.6. Pada Gambar 7.6, masukkan variabel Nilai ke dalam kotak Response:, masukkan variabel Kelas ke dalam kotak Factors. Kemudian pilih Storage, sehingga muncul tampilan Test for Equal Variances - Storage (Gambar 7.6). Pada tampilan Test for Equal Variances - Storage, pilih Variances. Kemudian pilih OK dan OK. Hasilnya diperlihatkan pada Gambar 7.7 dan Gambar 7.8.

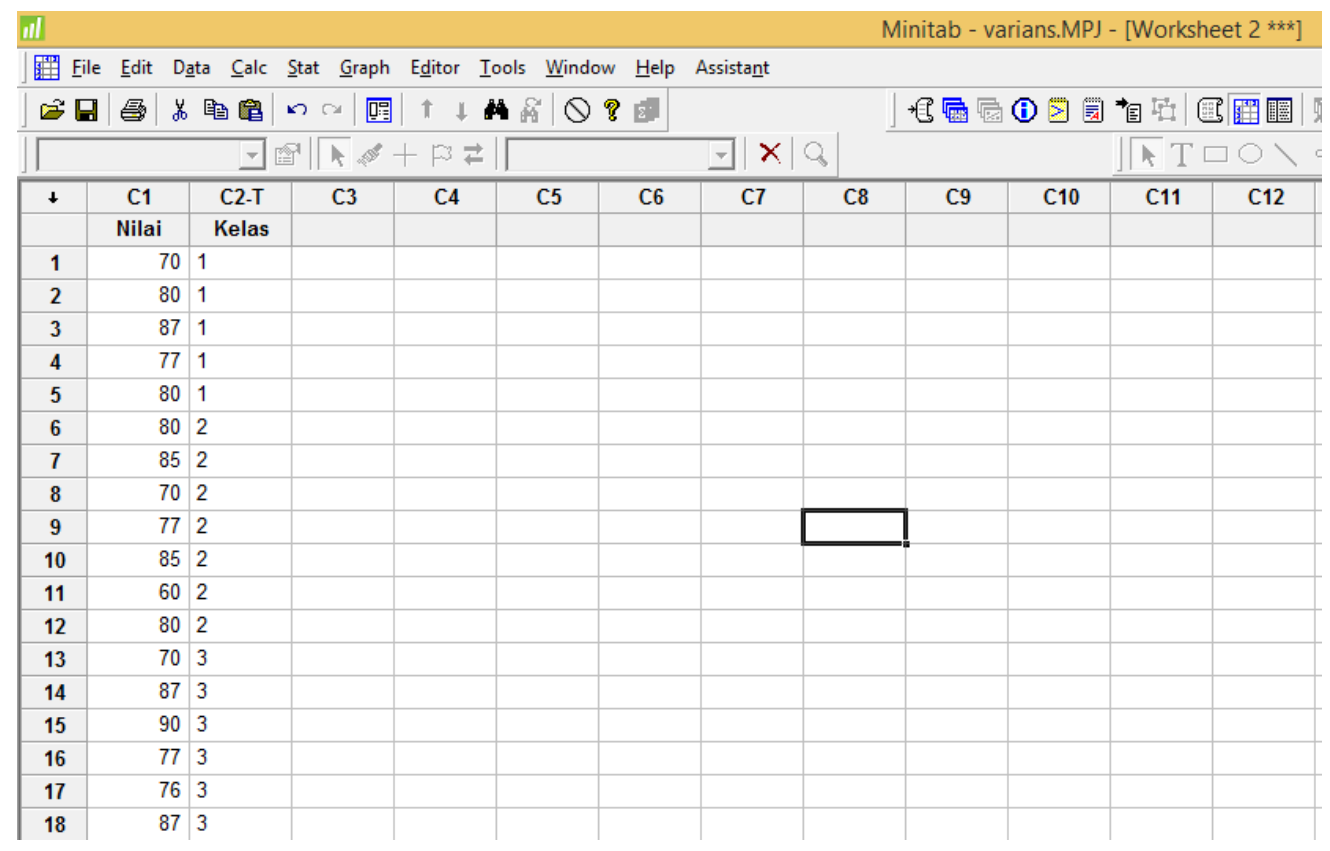

\section{Gambar 7.4}

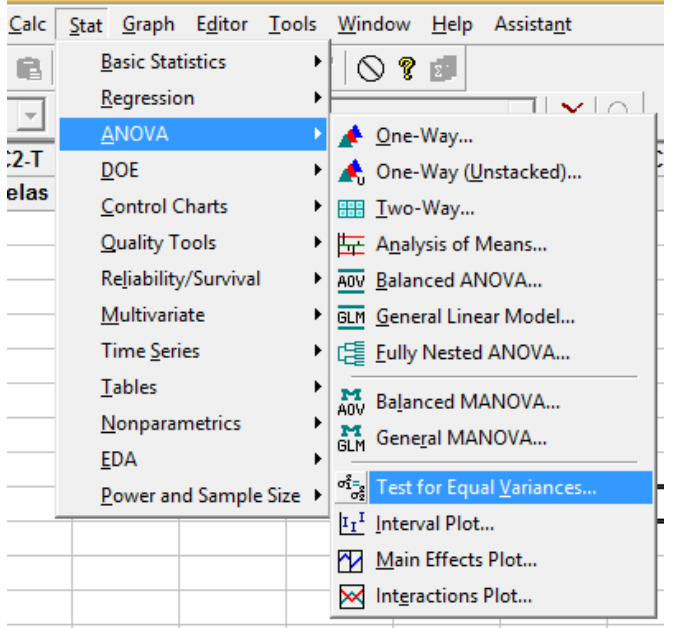

Gambar 7.5

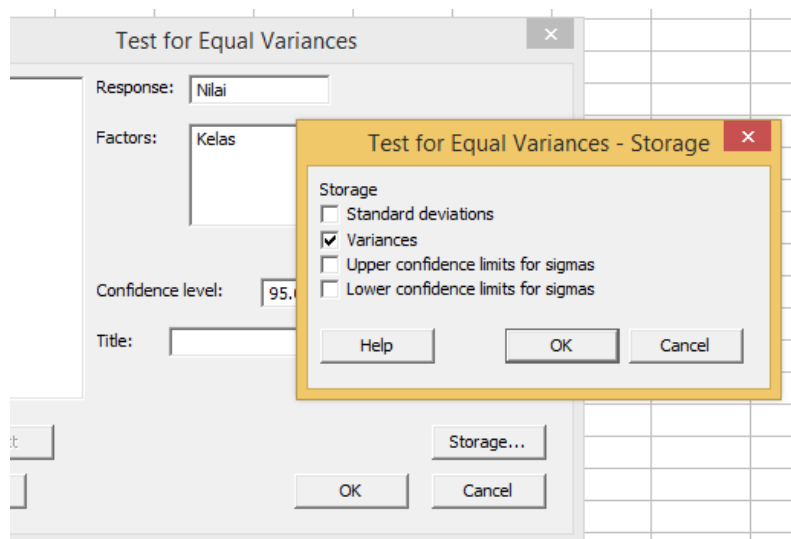

Gambar 7.6 


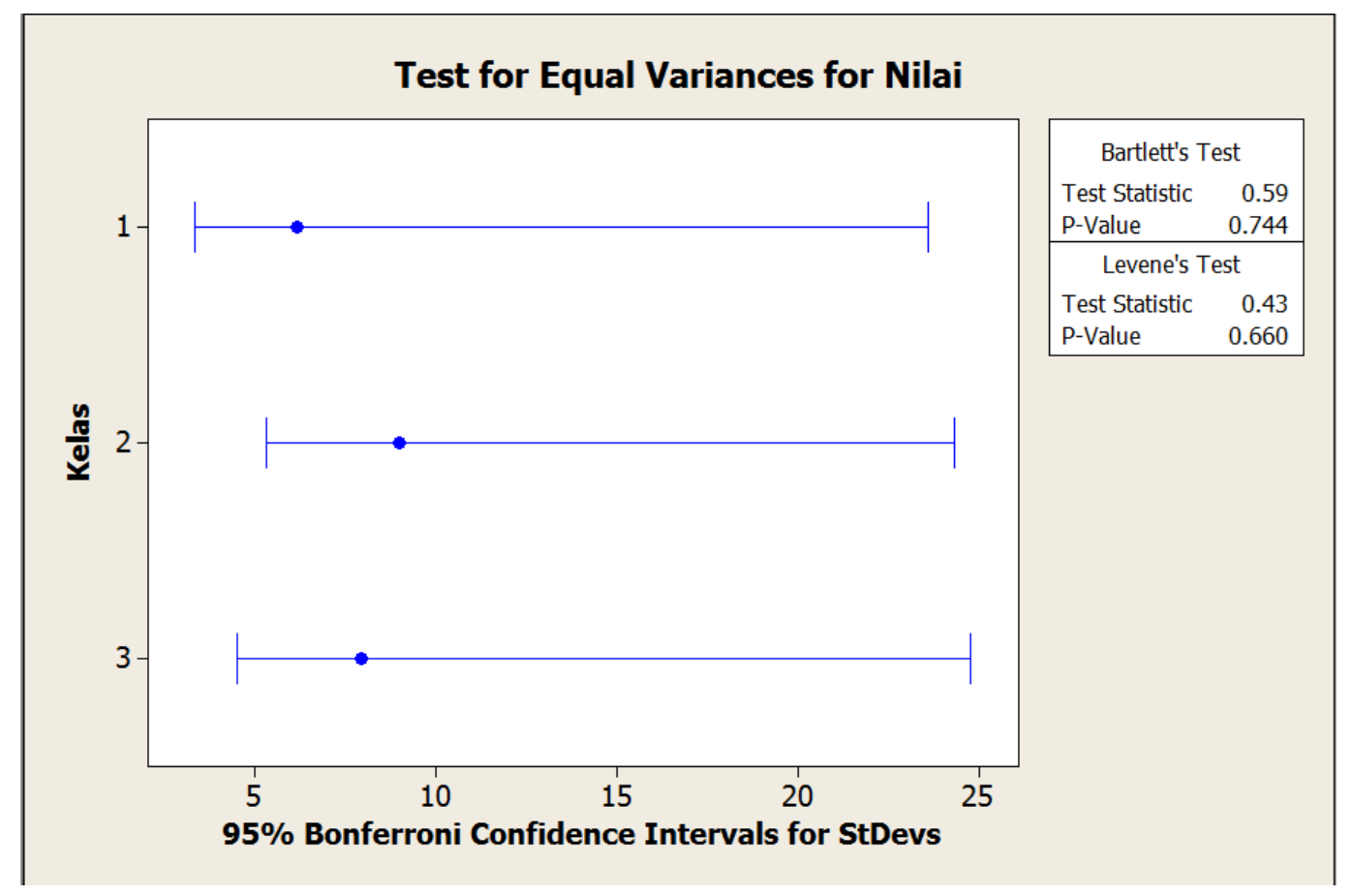

Gambar 7.7

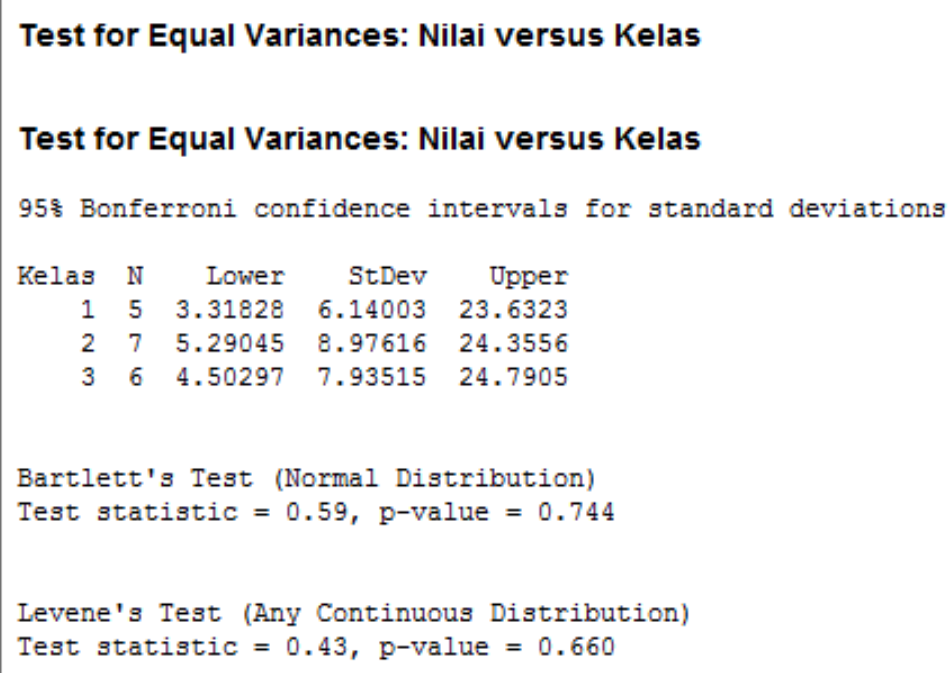

\section{Gambar 7.8}

Pada Gambar 7.7 dan Gambar 7.8, terlihat bahwa nilai statistik dari uji Levene adalah 0,43, sementara nilai probabilitas dari uji Levene adalah 0,660. Perhatikan bahwa hasil yang diperoleh berdasarkan SPSS dan Minitab berbeda. Penjelasannya dapat dilihat pada Penyelesaian dalam $\mathbf{R}$. 


\section{PENYELESAIAN DALAM R}

Data terlebih dahulu dibuat dalam Microsoft Excel (Gambar 7.9) dan disimpan dengan format tipe .csv (Gambar 7.10). Ketik kode R seperti pada Gambar 7.11. Kemudian Compile dan pilih HTML (Gambar 7.12). Hasilnya seperti pada Gambar 7.13 dan Gambar 7.14.

\begin{tabular}{|l|l|l|}
\hline \hline & A & \multicolumn{2}{|c|}{ B } \\
\hline 1 & Nilai & Kelas \\
\hline 2 & 70 & 1 \\
\cline { 2 - 3 } & 80 & 1 \\
\hline 4 & 87 & 1 \\
\hline 5 & 77 & 1 \\
\hline 6 & 80 & 1 \\
\hline 7 & 80 & 2 \\
\hline 8 & 85 & 2 \\
\hline 9 & 70 & 2 \\
\hline 10 & 77 & 2 \\
\hline 11 & 85 & 2 \\
\hline 12 & 60 & 2 \\
\hline 13 & 80 & 2 \\
\hline 14 & 70 & 3 \\
\hline 15 & 87 & 3 \\
\hline 16 & 90 & 3 \\
\hline 17 & 77 & 3 \\
\hline 18 & 76 & 3 \\
\hline 19 & 87 & 3 \\
\hline 20 & & \\
\hline & & \\
\hline & & \\
\hline
\end{tabular}

Gambar 7.9

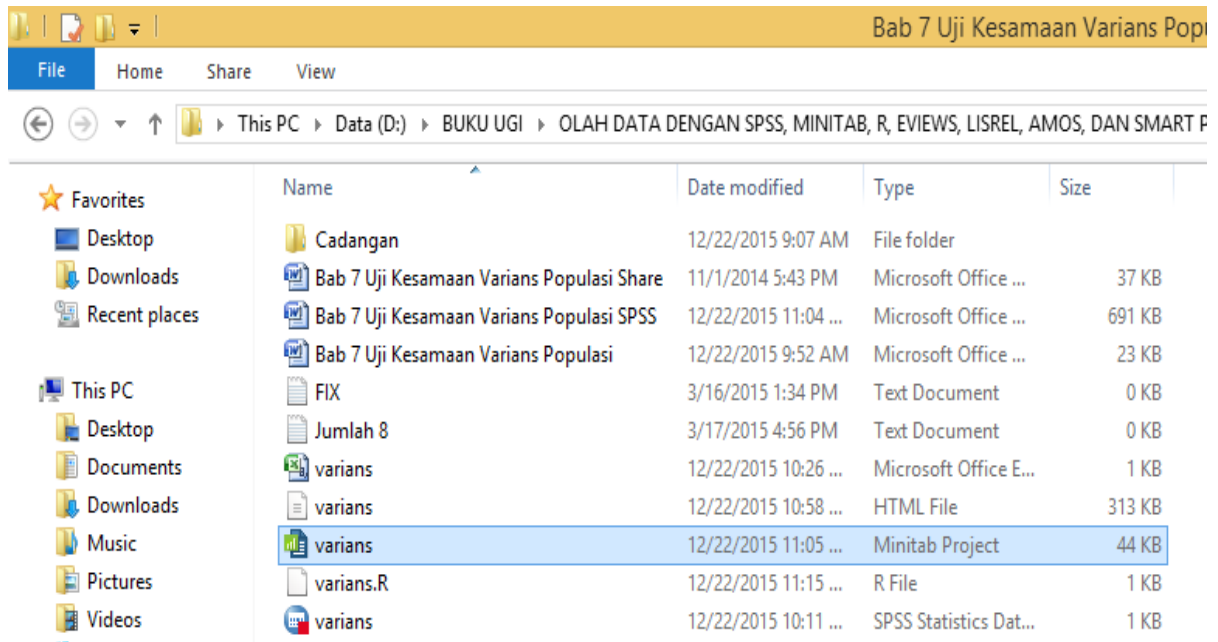

$\because$ OS $\left(C_{:}\right)$

Data (D:)

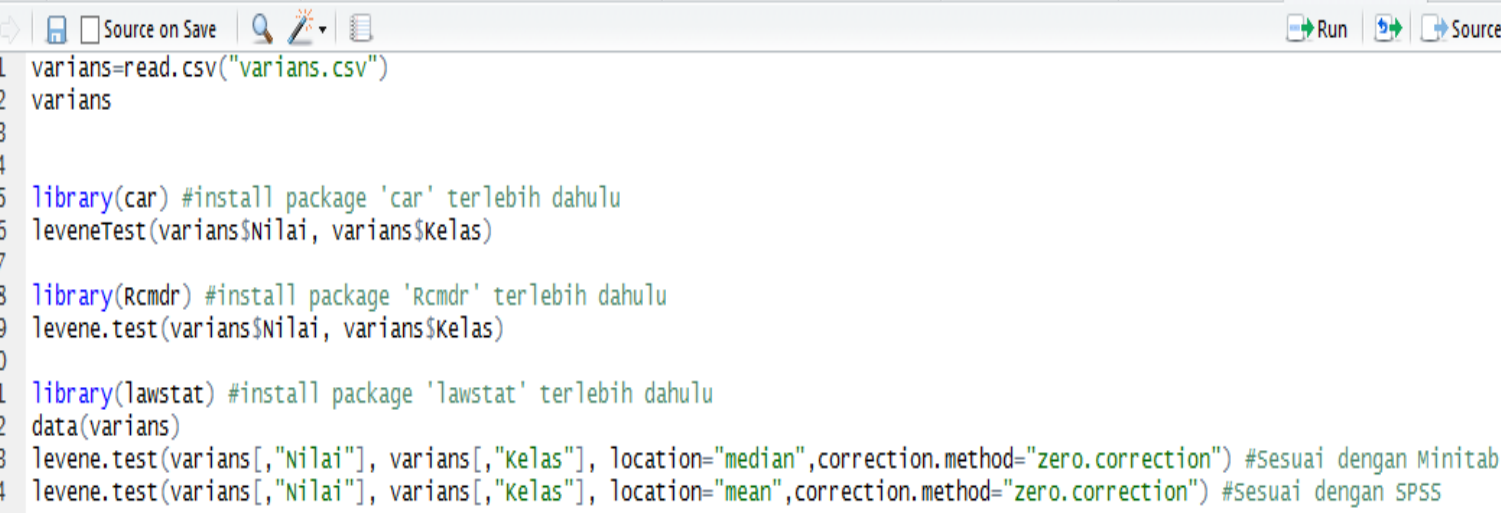

Gambar 7.10

\section{Gambar 7.11}

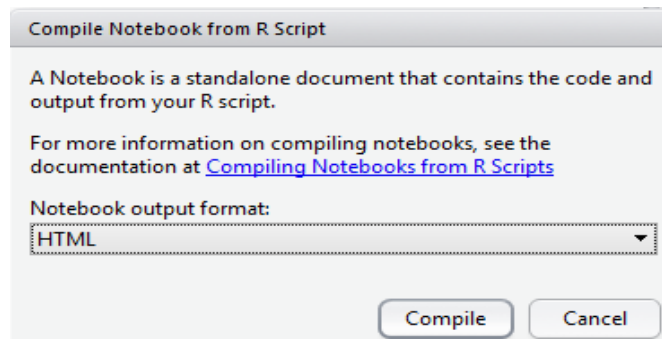

Gambar 7.12 


\section{varians. $R$}

\begin{tabular}{|c|c|c|c|}
\hline \multicolumn{4}{|c|}{$\begin{array}{l}\text { varians=read.csv ("varians. csv") } \\
\text { varians }\end{array}$} \\
\hline \# \# & & lai & Kelas \\
\hline \#\# & 1 & 70 & 1 \\
\hline$\# \#$ & 2 & 80 & 1 \\
\hline$\# \#$ & 3 & 87 & 1 \\
\hline$\# \#$ & 4 & 77 & 1 \\
\hline$\# \#$ & 5 & 80 & 1 \\
\hline$\# \#$ & 6 & 80 & 2 \\
\hline$\# \#$ & 7 & 85 & 2 \\
\hline \#\# & 8 & 70 & 2 \\
\hline \#\# & 9 & 77 & 2 \\
\hline \# \# & 10 & 85 & 2 \\
\hline \# \# & 11 & 60 & 2 \\
\hline \#\# & 12 & 80 & 2 \\
\hline$\# \#$ & 13 & 70 & 3 \\
\hline \# \# & 14 & 87 & 3 \\
\hline \# \# & 15 & 90 & 3 \\
\hline$\# \#$ & 16 & 77 & 3 \\
\hline \# \# & 17 & 76 & 3 \\
\hline \#\# & 18 & 87 & 3 \\
\hline
\end{tabular}

\# Levene's Test for Homogeneity of Variance (center = median)

\# Df $\mathrm{E}$ value $\operatorname{Pr}(>\mathrm{F})$

\#\# group $2 \quad 0.4267 \quad 0.6604$

\# 15

Gambar 7.13

levene.test (varians [,"Nilai"], varians [,"Kelas"], location="median", correction.method="zero.correction") \#Sesua i dengan Minitab

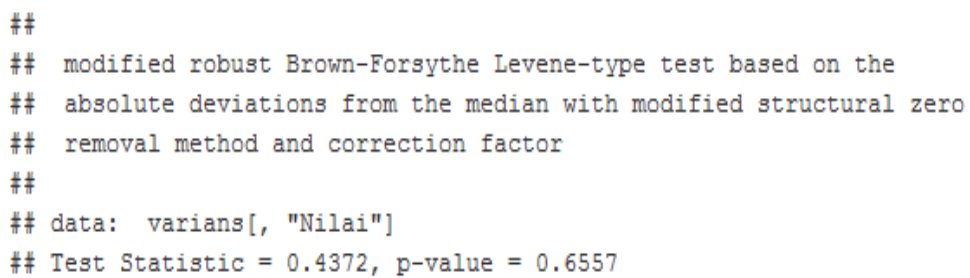

levene.test (varians [,"Nilai"], varians[,"Kelas"], location="mean", correction.method="zero.correction") \#Sesuai dengan SPSS

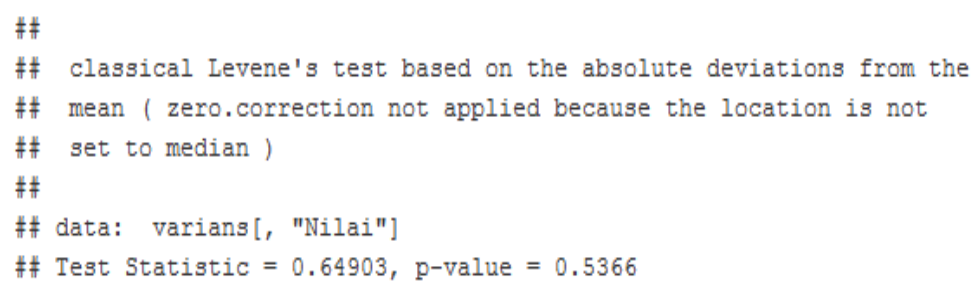

\section{Gambar 7.14}

Perhatikan Gambar 7.14. Nilai statistik dari uji Levene dengan pendekatan Location = "median" adalah 0,4372, yang mana hasil ini sama dengan hasil Minitab. Namun nilai statistik dari uji Levene dengan pendekatan Location = "mean" adalah 0,649, yang mana hasil ini sama dengan hasil SPSS. 
[1] Misalkan diberikan data mengenai nilai ujian matematika kelas 1,2, dan 3 SMA (Tabel 7.1). Berdasarkan data pada Tabel 7.1, $X$ menyatakan nilai ujian matematika siswa kelas 1 SMA, $Y$ menyatakan nilai ujian matematika siswa kelas 2 SMA, dan $Z$ menyatakan nilai ujian siswa kelas 3 SMA. Berikut akan digunakan pendekatan uji Levene untuk menguji/menentukan apakah asumsi populasi $X, Y$, dan $Z$ memiliki varians yang sama pada tingkat signifikansi 5\%. Perhitungan akan dilakukan secara manual.

Tabel 7.1 (Data Fiktif)

\begin{tabular}{|c|c|c|}
\hline \multicolumn{3}{|c|}{ Nilai Ujian Matematika } \\
\hline$X$ & $Y$ & $Z$ \\
\hline 70 & 80 & 70 \\
\hline 80 & 85 & 87 \\
\hline 87 & 70 & 90 \\
\hline 77 & 77 & 77 \\
\hline 80 & 85 & 76 \\
\hline & 60 & 87 \\
\hline & 80 & \\
\hline
\end{tabular}

Tabel 7.2

\begin{tabular}{|c|c|c|c|c|c|c|}
\cline { 2 - 7 } & $X$ & $Y$ & $Z$ & $a=|X-\bar{X}|$ & $b=|Y-\bar{Y}|$ & $c=|Z-\bar{Z}|$ \\
\cline { 2 - 7 } & 70 & 80 & 70 & 8,8 & 3,28571429 & 11,16666667 \\
\cline { 2 - 7 } & 80 & 85 & 87 & 1,2 & 8,28571429 & 5,8333333333 \\
\cline { 2 - 7 } & 87 & 70 & 90 & 8,2 & 6,71428571 & 8,8333333333 \\
\cline { 2 - 7 } & 77 & 77 & 77 & 1,8 & 0,28571429 & 4,166666667 \\
\cline { 2 - 7 } & 80 & 85 & 76 & 1,2 & 8,28571429 & 5,166666667 \\
\cline { 2 - 7 } & & 60 & 87 & & 16,7142857 & 5,8333333333 \\
\hline Jumlah & 394 & 537 & 487 & 21,2 & 46,8571429 & 41 \\
\hline Rata-rata & 78,8 & 76,71429 & 81,16667 & 4,24 & 6,69387755 & 6,8333333333 \\
\hline
\end{tabular}

\begin{tabular}{|c|c|c|c|}
\cline { 2 - 4 } \multicolumn{1}{c|}{} & $d=(a-\bar{a})^{2}$ & $e=(b-\bar{b})^{2}$ & $f=(c-\bar{c})^{2}$ \\
\cline { 2 - 4 } & 20,7936 & 11,61557684 & 18,77777778 \\
\cline { 2 - 4 } & 9,2416 & 2,53394419 & 1 \\
\cline { 2 - 4 } & 15,6816 & 0,000416493 & 4 \\
\cline { 2 - 4 } & 5,9536 & 41,06455643 & 7,111111111 \\
\cline { 2 - 4 } & 9,2416 & 2,53394419 & 2,777777778 \\
\cline { 2 - 4 } & & 100,4085798 & 1 \\
\hline Jumlah & 60,912 & 11,61557684 & \\
\hline Rata-rata & & 169,7725948 & 34,66666667 \\
\hline
\end{tabular}


$\rightarrow$ Menghitung rata-rata gabungan dari data $a, b$, dan $c$.

$$
\begin{gathered}
\bar{X}_{a, b, c}=\frac{\sum a+\sum b+\sum c}{n_{a}+n_{b}+n_{c}} \\
\bar{X}_{a, b, c}=\frac{21,2+46,8571429+41}{5+7+6} \\
\bar{X}_{a, b, c}=6,05873 .
\end{gathered}
$$

$\rightarrow$ Menghitung nilai statistik dari uji Levene $(L)$.

$$
\begin{gathered}
L=\frac{\frac{n_{a}\left(\bar{X}_{a}-\bar{X}_{a, b, c}\right)^{2}+n_{b}\left(\bar{X}_{b}-\bar{X}_{a, b, c}\right)^{2}+n_{c}\left(\bar{X}_{c}-\bar{X}_{a, b, c}\right)^{2}}{\frac{(k-1)}{\left(N+\sum e+\sum f\right)}}}{n_{a}\left(\bar{X}_{a}-\bar{X}_{a, b, c}\right)^{2}=(5)(4,24-6,05873)^{2}=16,5389} \\
n_{b}\left(\bar{X}_{b}-\bar{X}_{a, b, c}\right)^{2}=(7)(6.69387755-6,05873)^{2}=2,823885 \\
n_{c}\left(\bar{X}_{c}-\bar{X}_{a, b, c}\right)^{2}=(6)(6.833333333-6,05873)^{2}=3,60006 \\
\frac{16,5389+2,823885+3,60006}{3-1} \\
\frac{60,912+169,7725948+34,66667}{18-3} \\
L=\frac{\frac{22,96284}{2}}{265,3513}
\end{gathered}
$$

$\rightarrow$ Menghitung nilai kritis $F$.

Berikut rumus untuk menghitung nilai derajat bebas pembilang dan derajat bebas penyebut.

$$
\begin{aligned}
& \text { Derajat bebas pembilang }=k-1 \\
& \text { Derajat bebas penyebut }=N-k \text {. }
\end{aligned}
$$

Perhatikan bahwa $k$ menyatakan banyaknya sampel, sedangkan $N$ merupakan jumlah elemen/pengamatan dari seluruh sampel. Diketahui nilai $k$ adalah 3, sedangkan nilai $N$ adalah $18\left(n_{1}+n_{2}+n_{3}=5+7+6=18\right)$. Diketahui tingkat signifikansi yang digunakan adalah $5 \%$, sehingga nilai kritis berdasarkan Tabel distribusi $F$ dengan derajat bebas pembilang $3-1=2$, derajat bebas penyebut $18-3=15$, dan tingkat signifikansi $5 \%$ adalah 3,68.

$\rightarrow$ Pengambilan keputusan terhadap hipotesis.

Berikut aturan pengambilan keputusan terhadap hipotesis berdasarkan uji Levene. 
Jika $L \leq$ nilai kritis $F$, maka $H_{0}$ diterima dan $H_{1}$ ditolak. Jika $L>$ nilai kritis $F$, maka $H_{0}$ ditolak dan $H_{1}$ diterima.

Perhatikan bahwa karena nilai statistik dari uji Levene $(0,649)$ lebih kecil dibandingkan nilai kritis $F(3,68)$, maka hipotesis nol diterima dan hipotesis alternatif ditolak, sehingga asumsi mengenai kesamaan varians populasi dari $X, Y$, dan $Z$ dapat diterima pada tingkat signifikansi $5 \%$. Untuk sampel berjumlah lebih dari tiga, misalkan jumlah sampel sebanyak empat, maka tabel perhitungan nilai statistik dari Levene sebagai berikut.

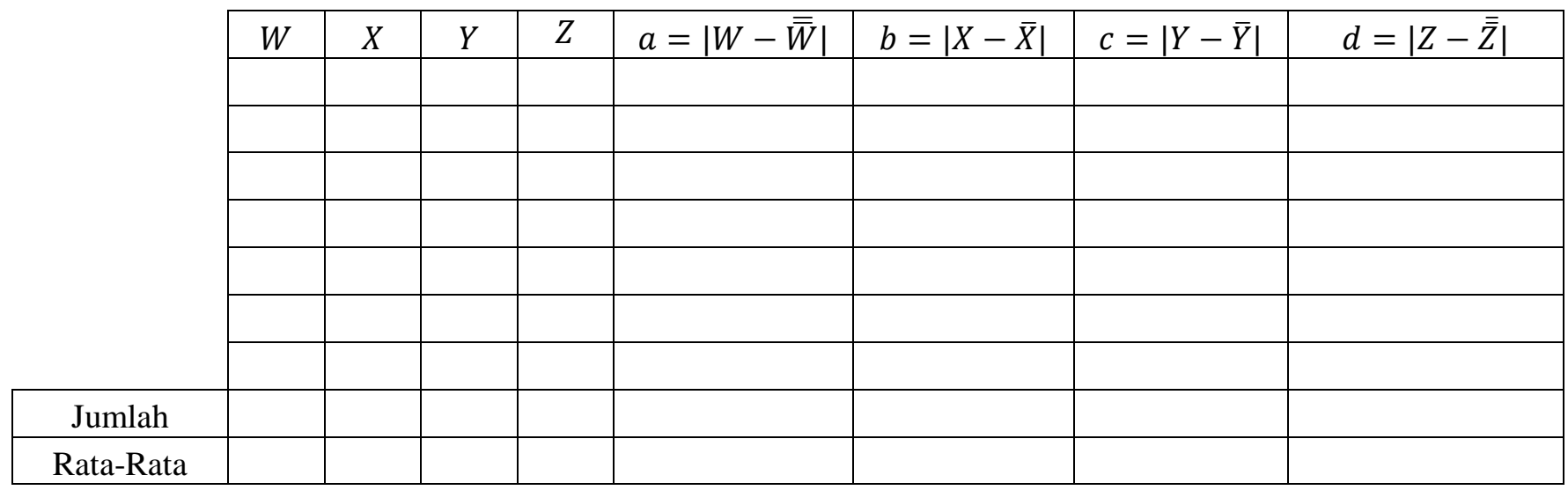

\begin{tabular}{|l|l|l|l|l|}
\cline { 2 - 5 } \multicolumn{1}{c|}{} & $e=(a-\bar{a})^{2}$ & $f=(b-\bar{b})^{2}$ & $g=(c-\bar{c})^{2}$ & $h=(d-\bar{d})^{2}$ \\
\cline { 2 - 5 } & & & & \\
\cline { 2 - 5 } & & & & \\
\cline { 2 - 5 } & & & & \\
\cline { 2 - 5 } & & & & \\
\hline Jumlah & & & & \\
\hline Rata-Rata & & & & \\
\hline
\end{tabular}

$$
L=\frac{\frac{n_{a}\left(\bar{X}_{a}-\bar{X}_{a, b, c, d}\right)^{2}+n_{b}\left(\bar{X}_{b}-\bar{X}_{a, b, c, d}\right)^{2}+n_{c}\left(\bar{X}_{c}-\bar{X}_{a, b, c, d}\right)^{2}+n_{d}\left(\bar{X}_{d}-\bar{X}_{a, b, c, d}\right)^{2}}{(k-1)}}{\frac{\left(\sum d+\sum e+\sum f++\sum h\right)}{(N-k)}} .
$$

\section{Referensi}

1. Field, A. 2009. Discovering Statistics Using SPSS, $3^{\text {rd }}$ Edition. London: Sage.

2. Gamst, G., L.S. Meyers dan A.J. Guarino. 2008. Analysis of Variance Designs. New York: Cambridge University Press.

3. Gio, P.U. 2013. Aplikasi Statistika dalam SPSS. Medan: USUpress.

4. Ott, R.L. dan M. Longnecker. 2001. An Introduction to Statistical Methods and Data Analysis, $5^{\text {th }}$ Edition. United States of America: Duxbury. 


\section{BAB 8}

\section{UJI RATA-RATA POPULASI (UJI $t)$}

\section{Sekílas Uji Rata-Rata Populasi (Ují t)}

Uji rata-rata populasi dengan uji $t$ merupakan suatu uji dalam statistika untuk menguji ratarata (mean) suatu populasi yang didasarkan pada ketidaktahuan (unknown) mengenai nilai varians dari populasi $\left(\sigma^{2}\right)$ (Montgomery dan Runger, 2011:310). Agresti dan Finlay (2009:148) menyatakan sebagai berikut.

"We use the symbol $t$ rather than $z$ because, as in forming a confidence interval, using $s$ to estimate $\sigma$ in the standard error introduces additional error. The null sampling distribution of the t test statistic is the $t$ distribution".

Ketika ukuran sampel meningkat, distribusi $t$ akan mendekati distribusi normal standar (Z). Agresti dan Finlay (2009:69) menyatakan sebagai berikut.

" $t$ distribution relative to standard normal distribution. The $t$ gets closer to the normal as the degrees of freedom (df) increase, and the two distributions are practically identical when $d f>30 "$.

Senada dengan Agresti dan Finlay, Ott dan Longkecker (2001) menyatakan sebagai berikut.

"Thus, with

$$
t=\frac{\bar{y}-\mu_{0}}{s / \sqrt{n}}
$$

we conclude that $t$ has a $t$ distribution with $d f=n-1$, and, as $n$ increases, the distribution of $t$ approaches the distribution of $z$ ".

Dalam penggunaan uji rata-rata populasi dengan uji $t$ dikenakan asumsi normalitas, yakni sampel yang diteliti diasumsikan berasal dari populasi yang berdistribusi normal. Jika asumsi normalitas tidak dipenuhi, maka alternatif lain yang dapat digunakan adalah uji nonparametrik, seperti uji tanda atau uji Wilcoxon. Dalam uji rata-rata populasi dengan uji $t$, hipotesis nol menyatakan rata-rata populasi $(\mu)$ bernilai $\mu_{0}$, sedangkan hipotesis alternatif menyatakan rata-rata populasi $(\mu)$ tidak bernilai $\mu_{0}$ (untuk pengujian dua arah).

$$
\begin{aligned}
& H_{0}: \mu=\mu_{0} \\
& H_{1}: \mu \neq \mu_{0}
\end{aligned}
$$

Nilai statistik dari uji $t$ dihitung $\left(t_{\text {hitung }}\right)$ dengan rumus sebagai berikut.

$$
t=\frac{\bar{X}-\mu_{0}}{s / \sqrt{n}} .
$$


Perhatikan bahwa $t$ merupakan nilai statistik dari uji $t\left(t_{\text {hitung }}\right), \bar{X}$ merupakan nilai rata-rata sampel, $\mu_{0}$ merupakan nilai rata-rata populasi yang akan diuji, $s$ merupakan standar deviasi sampel, dan $n$ merupakan ukuran sampel (sample size).

Berikut rumus untuk menghitung standar deviasi sampel.

$$
s=\sqrt{\frac{\sum(X-\bar{X})^{2}}{n-1}} .
$$

Untuk pengambilan keputusan terhadap hipotesis, dapat dilakukan dengan membandingkan nilai statistik dari uji $t$ terhadap nilai kritis berdasarkan tabel distribusi $t\left(t_{\text {kritis }}\right)$. Sebelum menghitung nilai kritis $t$, terlebih dahulu menghitung nilai derajat bebas. Berikut rumus untuk menghitung nilai derajat bebas.

\section{Derajat bebas $=n-1$.}

Perhatikan bahwa $n$ menyatakan jumlah pengamatan/elemen dalam sampel. Andaikan banyaknya pengamatan dalam sampel sebanyak 9 dan tingkat signifikansi yang digunakan adalah 5\%. Maka nilai kritis $t$ dengan derajat bebas $9-1=8$ dan tingkat signifikansi 5\% adalah $\pm 2,306$. Diketahui nilai kritis $t= \pm 2,306$. Berikut aturan pengambilan keputusan terhadap hipotesis berdasarkan uji $t$ (pengujian dua arah).

$$
\begin{aligned}
& \text { Jika }\left|t_{\text {hitung }}\right| \leq\left|t_{\text {kritis }}\right| \text {, maka } H_{0} \text { diterima dan } H_{1} \text { ditolak. } . \\
& \text { Jika }\left|t_{\text {hitung }}\right|>\left|t_{\text {kritis }}\right| \text {, maka } H_{0} \text { ditolak dan } H_{1} \text { diterima. }
\end{aligned}
$$

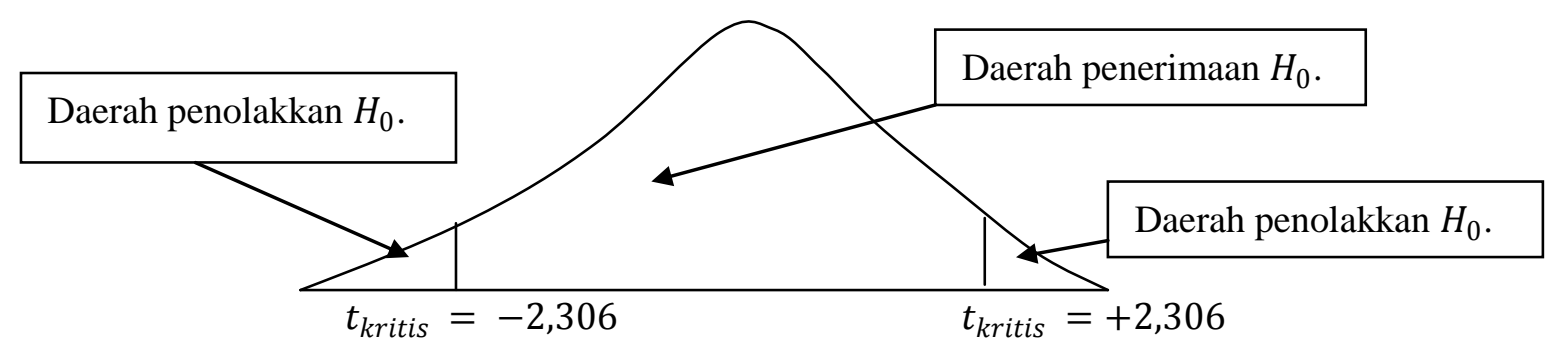

Pengambilan keputusan terhadap hipotesis juga dapat dilakukan dengan menggunakan nilai probabilitas dari uji $t$. Nilai probabilitas dari uji $t$ dibandingkan dengan tingkat signifikansi yang digunakan. Berikut aturan pengambilan keputusan terhadap hipotesis berdasarkan pendekatan nilai probabilitas.

Jika nilai probabilitas $\geq$ tingkat signifikansi, maka $H_{0}$ diterima dan $H_{1}$ ditolak. Jika nilai probabilitas < tingkat signifikansi, maka $H_{0}$ ditolak dan $H_{1}$ diterima.

\section{Uji Asumsí Normalitas}

Dalam penggunaan uji rata-rata populasi dengan uji $t$ dikenakan asumsi normalitas, yakni sampel yang diteliti berasal dari populasi yang berdistribusi normal. Untuk menguji apakah suatu sampel yang diteliti berasal dari populasi yang berdistribusi normal, dapat digunakan pendekatan grafik, yakni $P-P$ plot (probability-probability plot) dalam SPSS. Pada pendekatan $P$-P plot, jika titik-titik (dots) menyebar jauh (menyebar jauh berliku-liku pada garis diagonal seperti ular) dari garis diagonal, maka diindikasi asumsi normalitas tidak 120 
dipenuhi. Jika titik-titik menyebar sangat dekat pada garis diagonal, maka asumsi normalitas dipenuhi.

Selain itu dapat juga digunakan pendekatan uji Kolmogorov-Smirnov untuk menguji asumsi normalitas. Dalam pendekatan uji Kolmogorov-Smirnov, suatu sampel diuji, apakah sampel yang diteliti ditarik dari populasi yang berdistribusi normal atau tidak. Hipotesis nol menyatakan sampel yang diteliti berasal dari populasi yang berdistribusi normal, sedangkan hipotesis alternatif menyatakan sampel yang diteliti tidak berasal dari populasi yang berdistribusi normal.

Untuk pengambilan keputusan terhadap hipotesis, dapat dibandingkan antara nilai probabilitas dari uji Kolmogorov-Smirnov dan tingkat signifikansi yang digunakan $(\alpha)$. Berikut aturan pengambilan keputusan terhadap hipotesis.

Jika nilai probabilitas $\geq$ tingkat signifikansi, $H_{0}$ diterima dan $H_{1}$ ditolak. Jika nilai probabilitas $<$ tingkat signifikansi, $H_{0}$ ditolak dan $H_{1}$ diterima.

\section{Contoh Kasus dalam Ují Rata-Rata Populasí}

Pada bagian ini, berikut akan diberikan contoh kasus yang dapat diselesaikan dengan pendekatan uji rata-rata populasi dengan uji $t$.

[1] Misalkan seorang peneliti ingin menguji suatu hipotesis bahwa rata-rata tinggi badan anak laki-laki berusia 8 tahun adalah $100 \mathrm{~cm}$ di kota X. Untuk keperluan penelitian, peneliti tersebut mewawancarai 20 anak laki-laki berusia 8 tahun dengan maksud untuk mengetahui tinggi badan dari 20 anak tersebut. Data yang telah dikumpulkan oleh peneliti disajikan pada Tabel 8.1.

Hipotesis nol menyatakan rata-rata tinggi badan anak laki-laki berusia 8 tahun di kota $X$ adalah $100 \mathrm{~cm}$. Dengan menggunakan uji $t$, apakah hipotesis nol dapat diterima atau ditolak pada tingkat signifikansi $5 \%$.

Tabel 8.1 (Data Fiktif)

\begin{tabular}{|c|c|c|c|}
\hline Anak & Tinggi & Anak & Tinggi \\
\hline 1 & 95 & 11 & 98 \\
\hline 2 & 101 & 12 & 96 \\
\hline 3 & 99 & 13 & 102 \\
\hline 4 & 98 & 14 & 99 \\
\hline 5 & 99 & 15 & 98 \\
\hline 6 & 102 & 16 & 97 \\
\hline 7 & 100 & 17 & 100 \\
\hline 8 & 99 & 18 & 102 \\
\hline 9 & 97 & 19 & 102 \\
\hline 10 & 101 & 20 & 100 \\
\hline
\end{tabular}


[2] Misalkan seorang peneliti ingin menguji suatu hipotesis bahwa rata-rata nilai ujian nasional matematika SMA di kota $X$ adalah 85. Untuk keperluan penelitian, peneliti tersebut mewawancarai 14 siswa SMA di kota $X$ dengan maksud untuk mengetahui nilai ujian nasional matematika dari siswa tersebut. Data yang telah dikumpulkan oleh peneliti disajikan pada Tabel 8.2. Hipotesis nol menyatakan rata-rata nilai ujian nasional matematika SMA di kota $\mathrm{X}$ adalah 85 . Dengan menggunakan uji $t$, apakah hipotesis nol tersebut dapat diterima atau ditolak pada tingkat signifikansi $5 \%$.

Tabel 8.2 (Data Fiktif)

\begin{tabular}{|c|c|c|c|}
\hline Siswa & Nilai & Siswa & Nilai \\
\hline 1 & 75 & 8 & 89 \\
\hline 2 & 70 & 9 & 85 \\
\hline 3 & 78 & 10 & 7 \\
\hline 4 & 80 & 11 & 7 \\
\hline 5 & 7 & 12 & 69 \\
\hline 6 & 77 & 13 & 8 \\
\hline 7 & 85 & 14 & 7 \\
\hline
\end{tabular}

[3] Misalkan seorang peneliti ingin menguji suatu hipotesis bahwa rata-rata uang jajan mahasiswa matematika di kota X adalah Rp. 10000 per-hari. Untuk keperluan penelitian, peneliti tersebut mewawancarai 16 mahasiswa matematika di kota $X$ dengan maksud untuk mengetahui uang jajan mahasiswa matematika tersebut. Berikut data yang telah dikumpulkan oleh peneliti (Tabel 8.3).

Tabel 8.3 (Data Fiktif)

\begin{tabular}{|c|c|c|c|c|c|c|c|}
\hline Mahasiswa & Nilai & Mahasiswa & Nilai & Mahasiswa & Nilai & Mahasiswa & Nilai \\
\hline 1 & 9000 & 5 & 11000 & 9 & 10000 & 13 & 9000 \\
\hline 2 & 9500 & 6 & 10000 & 10 & 10000 & 14 & 12000 \\
\hline 3 & 9000 & 7 & 9500 & 11 & 11000 & 15 & 11000 \\
\hline 4 & 8500 & 8 & 11000 & 12 & 9500 & 16 & 8000 \\
\hline
\end{tabular}

Hipotesis nol menyatakan rata-rata uang jajan mahasiswa matematika di kota $\mathrm{X}$ adalah $\mathrm{Rp}$. 10000 per-hari. Dengan menggunakan uji $t$, apakah hipotesis nol tersebut dapat diterima atau ditolak pada tingkat signifikansi $5 \%$. 


\section{PENYELESAIAN DALAM SPSS}

Misalkan seorang peneliti ingin menguji suatu hipotesis yang menyatakan rata-rata ujian nasional matematika SMA di kota $X$ adalah 75 . Untuk keperluan penelitian, peneliti tersebut mewawancarai 15 siswa SMA di kota $X$ dengan maksud untuk mengetahui nilai ujian nasional matematika dari siswa SMA tersebut. Berikut data yang telah dikumpulkan oleh peneliti tersebut (Tabel 8.1).

Tabel 8.1 (Data Fiktif)

\begin{tabular}{|c|c|c|c|c|c|c|c|}
\hline Nama & X & Nama & X & Nama & X & Nama & X \\
\hline A & 55 & E & 66 & I & 45 & M & 50 \\
\hline B & 60 & F & 69 & J & 55 & N & 30 \\
\hline C & 54 & G & 40 & K & 80 & O & 35 \\
\hline D & 70 & H & 70 & L & 75 & & \\
\hline
\end{tabular}

Hipotesis nol menyatakan rata-rata ujian nasional matematika SMA di kota X adalah 75 . Dengan menggunakan tingkat signifikansi 5\%, peneliti akan menguji hipotesis nol, apakah dapat diterima atau ditolak.

Dalam penggunaan uji rata-rata populasi dengan uji $t$ dikenakan asumsi normalitas, yakni sampel yang diteliti diasumsikan berasal dari populasi yang berdistribusi normal. Untuk menguji asumsi apakah suatu sampel yang diteliti berasal dari populasi yang berdistribusi normal, dapat digunakan pendekatan grafik, yakni $P-P$ plot (probability-probability plot) dalam SPSS. Pada pendekatan P-P plot, jika titik-titik (dots) menyebar jauh (menyebar jauh berliku-liku pada garis diagonal seperti ular) dari garis diagonal, maka diindikasi asumsi normalitas tidak dipenuhi. Jika titik-titik menyebar sangat dekat pada garis diagonal, maka asumsi normalitas dipenuhi. Bangun data pada Tabel 8.1 dalam SPSS seperti pada Gambar 8.1. Selanjutnya pilih Analyze $=>$ Descriptive Statistics $=>P-P$ Plots, sehingga muncul kotak dialog P-P Plots (Gambar 8.2). Masukkan variabel Nilai pada kotak Variables. Pada Test Distribution, pilih Normal. kemudian pilih OK. Output SPSS disajikan dalam Gambar 8.3. Pada Gambar 8.3, titik-titik menyebar sangat dekat pada garis diagonal, maka asumsi normalitas dipenuhi.

\begin{tabular}{|r|r|r}
\hline \multicolumn{1}{|c|}{} & \multicolumn{1}{c}{ Nilai } \\
\hline 1 & 55 \\
\hline 2 & 60 \\
\hline 3 & 54 \\
\hline 4 & 70 \\
\hline 5 & 66 \\
\hline 6 & 69 \\
\hline 7 & 40 \\
\hline 8 & 70 \\
\hline 9 & 45 \\
\hline 10 & 55 \\
\hline
\end{tabular}
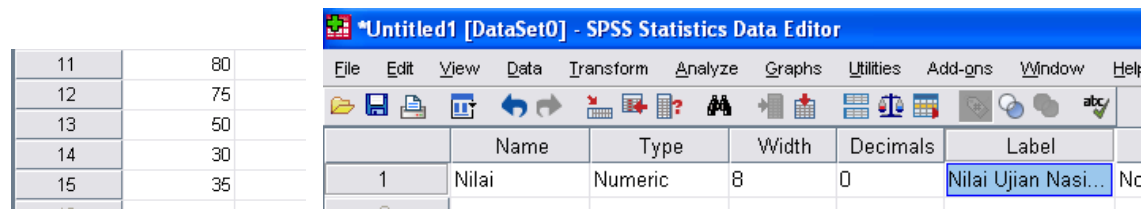

\section{Gambar 8.1}




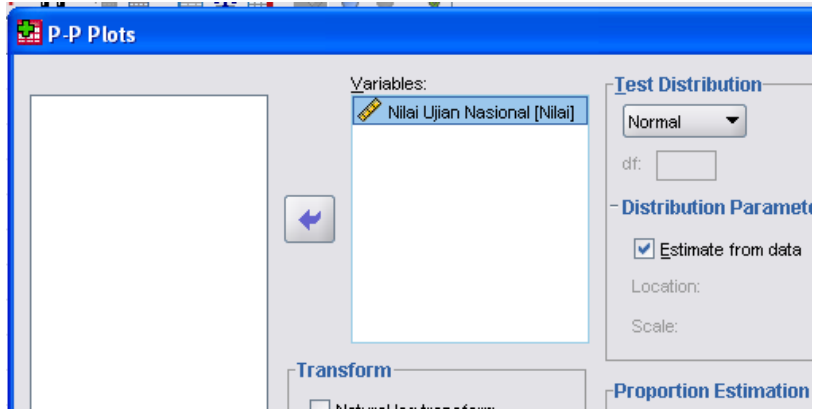

Gambar 8.2

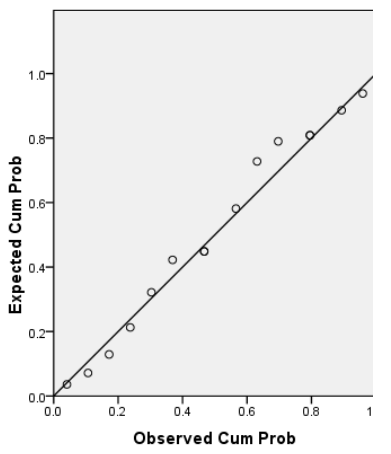

Gambar 8.3

Selain itu dapat juga digunakan pendekatan uji Kolmogorov-Smirnov untuk menguji asumsi normalitas. Dalam pendekatan uji Kolmogorov-Smirnov, suatu sampel diuji, apakah sampel yang diteliti ditarik dari populasi yang berdistribusi normal atau tidak. Hipotesis nol menyatakan sampel yang diteliti berasal dari populasi yang berdistribusi normal, sedangkan hipotesis alternatif menyatakan sampel yang diteliti tidak berasal dari populasi yang berdistribusi normal. Pilih Analyze $\Rightarrow$ Nonparametric Tests $\Rightarrow 1$-Sample K-S, sehingga muncul kotak dialog One-Sample Komogorov-Smirnov Test (Gambar 8.4).

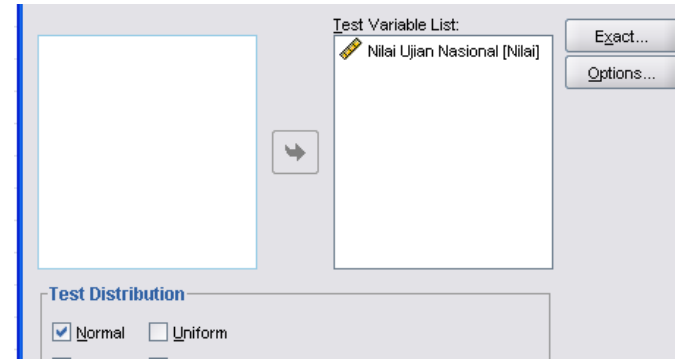

\section{Gambar 8.4}

Tabel 8.2

\begin{tabular}{|ll|r|}
\hline \multicolumn{2}{|c|}{ One-Sample Kolmogorov-Smirnov Test } \\
\hline N & $\begin{array}{c}\text { Nilai Ujian } \\
\text { Nasional }\end{array}$ \\
Normal Parameters ${ }^{\text {a.,b }}$ & Mean & 15 \\
& Std. Deviation & 56.93 \\
Most Extreme Differences & Absolute & 14.969 \\
& Positive & .128 \\
& Negative & .085 \\
Kolmogorov-Smirnov $Z$ & & -.128 \\
Asymp. Sig. (2-tailed) & & .494 \\
\end{tabular}

Masukkan variabel Nilai pada kotak Test Variable List. Pada Test Distribution, pilih Normal. Kemudian pilih OK. Output SPSS disajikan pada Tabel 8.2. Berdasarkan pada Tabel 8.2, nilai probabilitas dari uji Kolmogorov-Smirnov adalah 0,967. Karena nilai probabilitas tersebut lebih besar dibandingkan tingkat signifikansi $\alpha=0,05$, maka hipotesis nol diterima dan hipotesis alternatif ditolak. Hal ini berarti asumsi mengenai sampel yang diteliti ditarik dari populasi yang berdistribusi normal diterima. Perhatikan bahwa asumsi normalitas telah dipenuhi. 


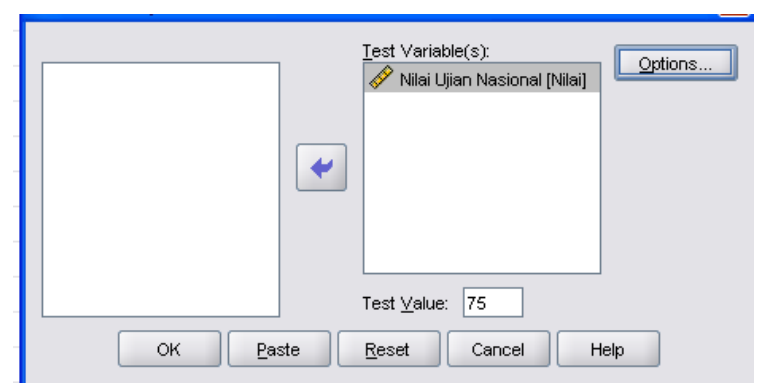

Gambar 8.5

Tabel 8.3

\section{One-Sample Statistics}

\begin{tabular}{|c|r|r|r|c|}
\hline & \multicolumn{1}{|c|}{$N$} & Mean & Std. Deviation & $\begin{array}{c}\text { Std. Error } \\
\text { Mean }\end{array}$ \\
\hline Nilai Ujian Nasional & 15 & 56.93 & 14.969 & 3.865 \\
\hline
\end{tabular}

Selanjutnya pilih Analyze => Compare Means => One-Sample T test, sehingga muncul kotak dialog One-Sample T Test (Gambar 8.5). Masukkan variabel Nilai pada kotak Test Variable(s). Pada Test Value, masukkan nilai 75. Nilai 75 merupakan nilai dari hipotesis nol. Selanjutnya pilih OK. Output SPSS disajikan pada Tabel 8.3 dan Tabel 8.4.

\section{Tabel 8.4}

One-Sample Test

\begin{tabular}{|c|c|c|c|c|c|c|}
\hline & \multicolumn{6}{|c|}{ Test Value $=75$} \\
\hline & \multirow[b]{2}{*}{$t$} & \multirow[b]{2}{*}{ df } & \multirow[b]{2}{*}{ Sia. (2-tailed) } & \multirow[b]{2}{*}{$\begin{array}{c}\text { Mean } \\
\text { Difference }\end{array}$} & \multicolumn{2}{|c|}{$\begin{array}{l}95 \% \text { Confidence Interval of the } \\
\text { Difference }\end{array}$} \\
\hline & & & & & Lower & Upper \\
\hline Nilai Ujian Nasional & -4.674 & 14 & .000 & -18.067 & -26.36 & -9.78 \\
\hline
\end{tabular}

Pada Tabel 8.3, yakni One-Sample Statistics, diketahui nilai rata-rata atau Mean adalah 56,93 dan standar deviasi atau Std. deviation adalah 14,969. Perhatikan bahwa nilai rata-rata 56,93 terlihat cukup jauh dari nilai rata-rata hipotesis, yakni 75. Hal ini mengindikasikan hipotesis nol akan ditolak. Hal ini berarti nilai rata-rata ujian nasional matematika SMA di kotak X tidak sama dengan 75 .

Pada Tabel 8.4, yakni One-Sample Test, diketahui nilai statistik dari uji $t$ adalah $-4,674$. Diketahui derajat bebas $(d f)$ bernilai $15-1=14$. Nilai kritis $t$ dengan derajat bebas 14 dan tingkat signifikansi $5 \%$ adalah $\pm 2,145$. Berikut aturan pengambilan keputusan terhadap hipotesis berdasarkan uji $t$.

$$
\begin{aligned}
& \text { Jika }\left|t_{\text {hitung }}\right| \leq\left|t_{\text {kritis }}\right| \text {, maka } H_{0} \text { diterima dan } H_{1} \text { ditolak. } \\
& \text { Jika }\left|t_{\text {hitung }}\right|>\left|t_{\text {kritis }}\right| \text {, maka } H_{0} \text { ditolak dan } H_{1} \text { diterima. }
\end{aligned}
$$

Perhatikan bahwa karena $\left|t_{\text {hitung }}\right|>\left|t_{\text {kritis }}\right|$, yakni $|-4,674|>|-2,145|$, maka disimpulkan bahwa hipotesis nol ditolak dan hipotesis alternatif diterima. Hal ini berarti pernyataan mengenai nilai rata-rata ujian nasional matematika SMA di kotak X tidak sama dengan 75 diterima pada tingkat signifikansi $5 \%$. 


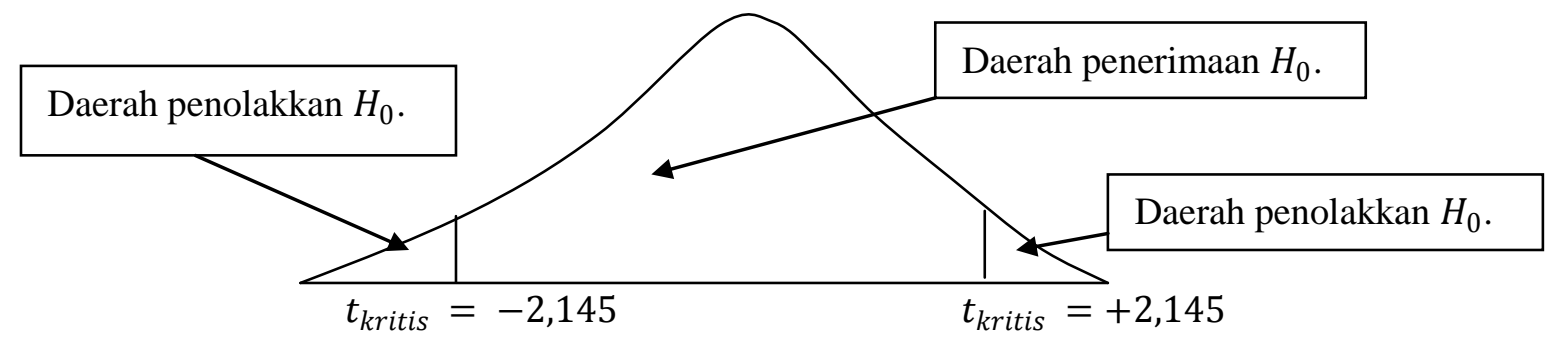

Pengambilan keputusan terhadap hipotesis juga dapat dilakukan dengan menggunakan nilai probabilitas dari uji $t$. Nilai probabilitas dari uji $t$ dibandingkan dengan tingkat signifikansi yang digunakan. Berikut aturan pengambilan keputusan terhadap hipotesis berdasarkan nilai probabilitas.

Jika nilai probabilitas $\geq$ tingkat signifikansi, maka $H_{0}$ diterima dan $H_{1}$ ditolak. Jika nilai probabilitas < tingkat signifikansi, maka $H_{0}$ ditolak dan $H_{1}$ diterima.

Diketahui nilai probabilitas (Sig. (2-tailed)) dari uji $t$ adalah 0,000. Karena nilai probabilitas tersebut lebih kecil dibandingkan tingkat signifikansi $\alpha=0,05$, maka hipotesis nol ditolak dan hipotesis alternatif diterima. Hal ini berarti pernyataan mengenai nilai rata-rata ujian nasional matematika SMA di kotak $\mathrm{X}$ tidak sama dengan 75 diterima pada tingkat signifikansi $5 \%$. 


\section{PENYELESAIAN DALAM Minitab}

Bangun data pada Tabel 8.1 dalam Minitab seperti pada Gambar 8.6. Pilih Stat $=>$ Basic Statistics $=>1$-Sample $t$ (Gambar 8.7), sehingga muncul tampilan seperti pada Gambar 8.8. Pada Gambar 8.8, masukkan variabel Nilai ke dalam kotak Samples in columns:, pada Perform hypothesis test:hypothesized test: isi dengan 75. Selanjutnya pilih OK. Hasilnya seperti pada Gambar 8.9. Diketahui nilai statistik dari uji $t(\mathrm{~T})$ adalah $-4,67$, sementara nilai probabilitas (P) adalah 0,000. Hasil Minitab sama dengan hasil SPSS.

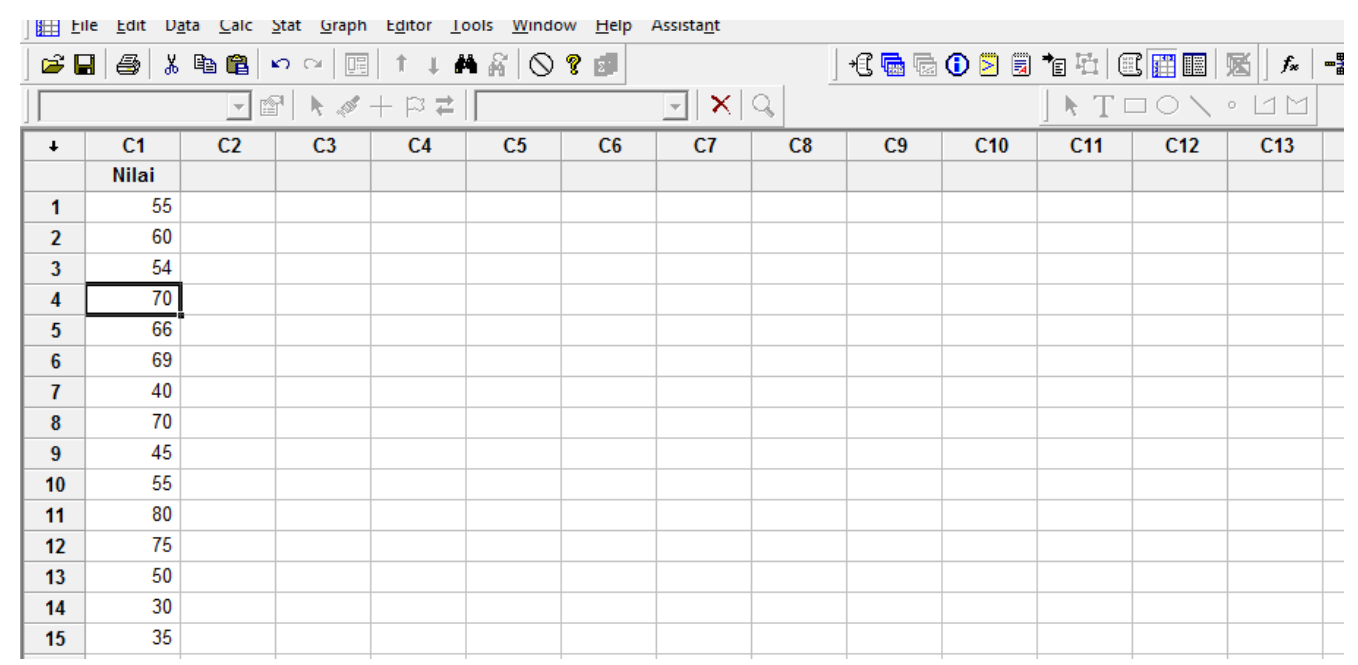

\section{Gambar 8.6}

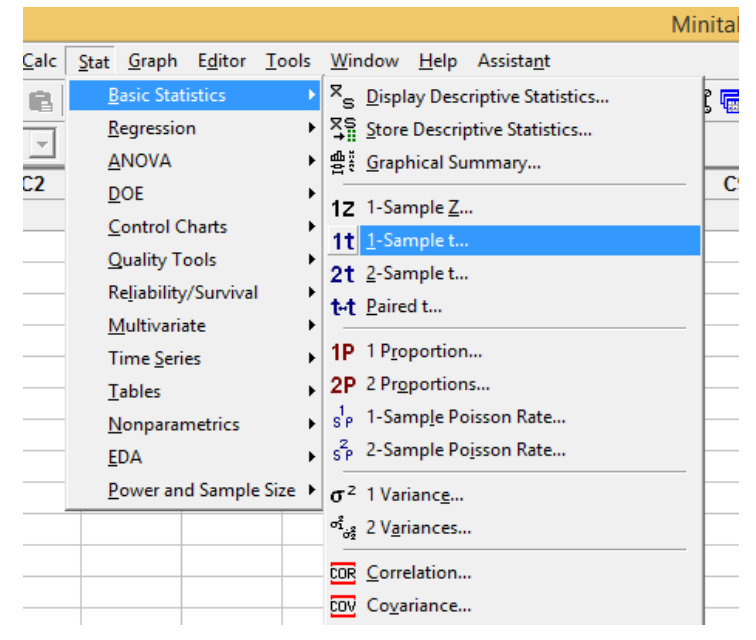

Gambar 8.7

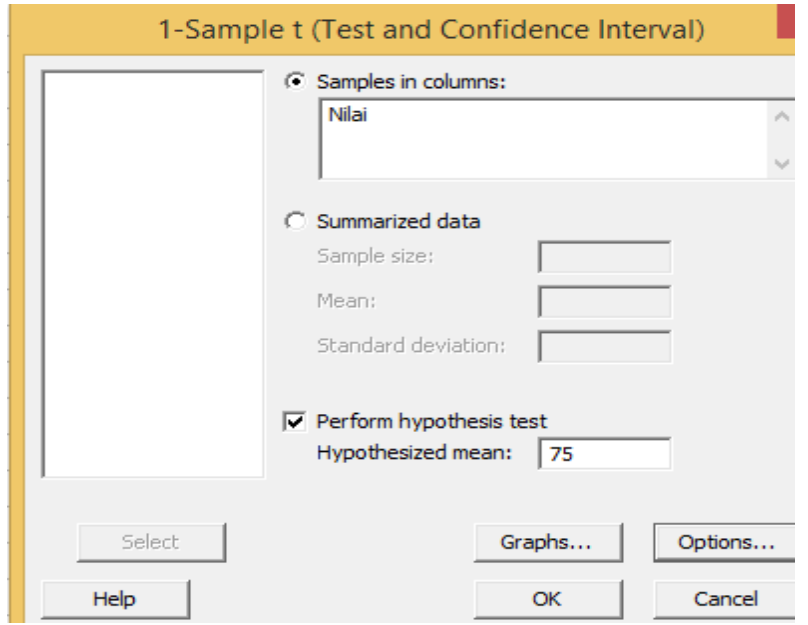

Gambar 8.8

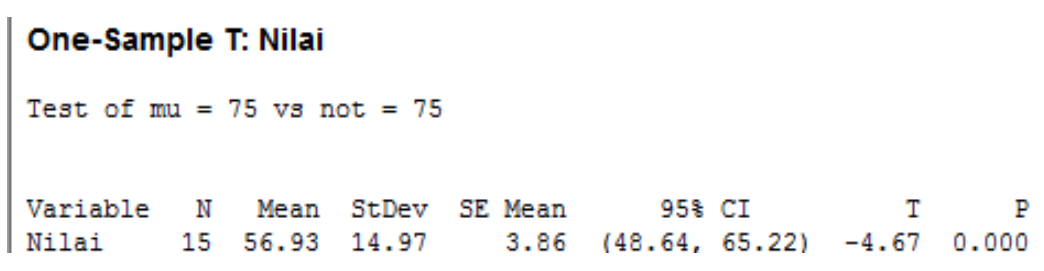

Gambar 8.9 


\section{PENYELESAIAN DALAM R}

Data terlebih dahulu dibuat dalam Microsoft Excel (Gambar 8.10) dan disimpan dengan format tipe .csv (Gambar 8.11). Ketik kode R seperti pada Gambar 8.12. Kemudian Compile dan pilih HTML (Gambar 8.13). Hasilnya seperti pada Gambar 8.14.

\begin{tabular}{|c|c|}
\hline \multicolumn{2}{|c|}{ A2 } \\
\hline \hline 1 & A \\
\hline 1 & Nilai \\
\hline 2 & 55 \\
\hline 3 & 60 \\
\hline 4 & 54 \\
\hline 5 & 70 \\
\hline 6 & 66 \\
\hline 7 & 69 \\
\hline 8 & 40 \\
\hline 9 & 70 \\
\hline 10 & 45 \\
\hline 11 & 55 \\
\hline 12 & 80 \\
\hline 13 & 75 \\
\hline 14 & 50 \\
\hline 15 & 30 \\
\hline 16 & 35 \\
\hline 17 & \\
\hline
\end{tabular}

Gambar 8.10

\begin{tabular}{|c|c|c|c|c|}
\hline \multicolumn{3}{|l|}{$1[2]=$} & \multicolumn{2}{|c|}{ Bab 8 Uji Rata-Rata Popul } \\
\hline File Home & View & & & \\
\hline \multicolumn{5}{|c|}{ 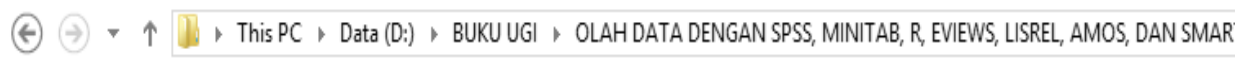 } \\
\hline Favorites & Name & Date modified & Type & Size \\
\hline Desktop & Dimpan & 12/22/2015 11:48 ... & File folder & \\
\hline Downloads & [ Nilai.MPJ & 12/22/2015 1:50 PM & $\mathrm{MPJ} \sim$ File & $3 \mathrm{~KB}$ \\
\hline \multirow[t]{2}{*}{ 國 Recent places } & 뜰 Bab 8 Share Uji Rata-Rata Populasi & 3/16/2015 3:14 PM & Microsoft Office ... & $158 \mathrm{~KB}$ \\
\hline & 띨 Bab 8 Uji Rata-Rata Populasi dalam SPSS & 12/22/2015 2:00 PM & Microsoft Office ... & $1,045 \mathrm{~KB}$ \\
\hline This $\mathrm{PC}$ & 삘 Bab 8 Uji Rata-Rata Populasi & 12/22/2015 1:38 PM & Microsoft Office ... & $28 \mathrm{~KB}$ \\
\hline Desktop & Jumlah 9 & 3/17/2015 4:58 PM & Text Document & $O K B$ \\
\hline Documents & Nilai & 12/22/2015 2:01 PM & Microsoft Office E.... & $1 \mathrm{~KB}$ \\
\hline Downloads & Nilai & 12/22/2015 1:50 PM & Minitab Project & $10 \mathrm{~KB}$ \\
\hline 18 Music & ⿶ㅐㄹ Nilai & 12/22/20152:00 PM & Microsoft Office E... & $9 \mathrm{~KB}$ \\
\hline
\end{tabular}

Gambar 8.11

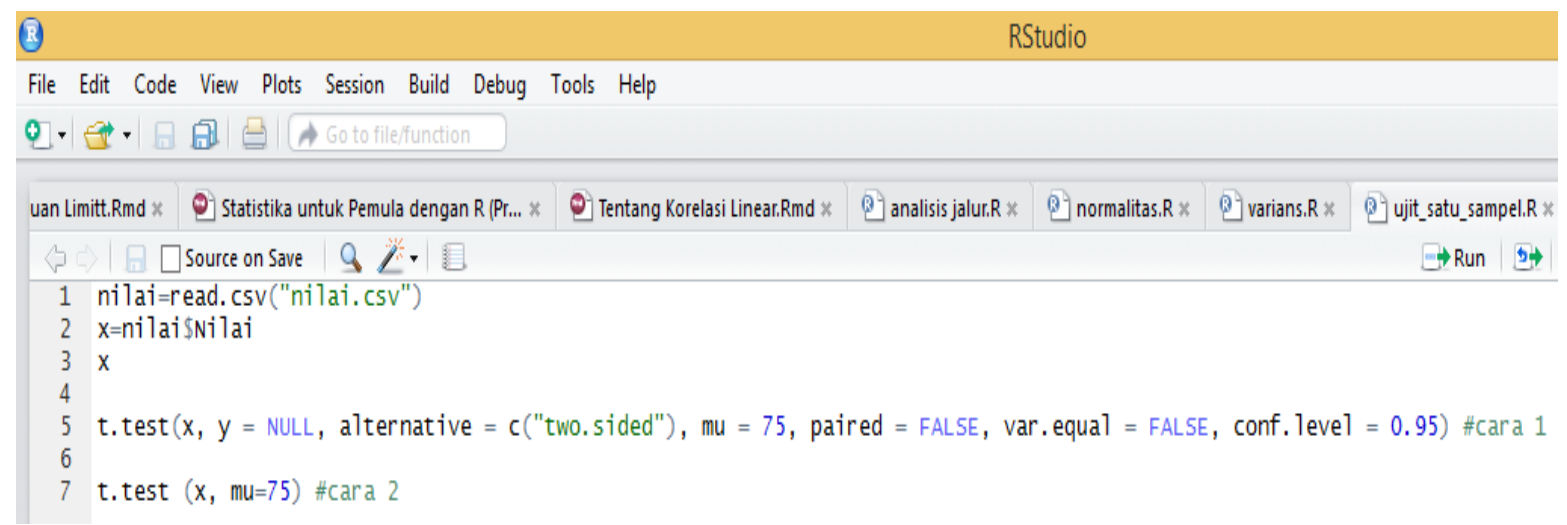

\section{Gambar 8.12}

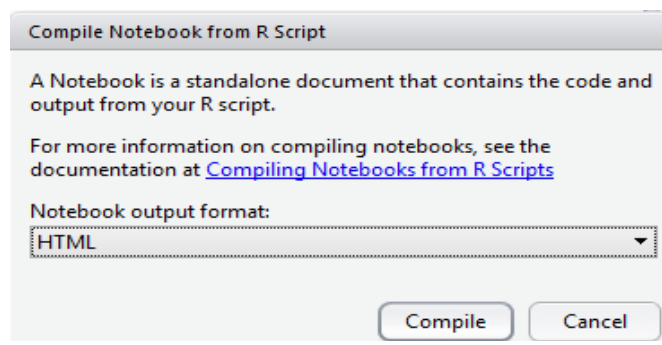

Gambar 8.13 


\section{ujit_satu_sampel.R}

\section{Gio}

\section{Tue Dec 22 14:08:13 2015}

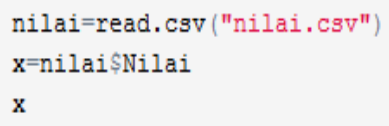

\#\# [1] $55 \begin{array}{lllllllllllllll}5 & 60 & 54 & 70 & 66 & 69 & 40 & 70 & 45 & 55 & 80 & 75 & 50 & 30 & 35\end{array}$

t. test $(x, y=$ NULL, alternative $=c("$ two.sided"), $m u=75$, paired $=$ FALSE, var. equal $=$ FALSE, conf.level $=0.95$ ) \# $\operatorname{cara} 1$

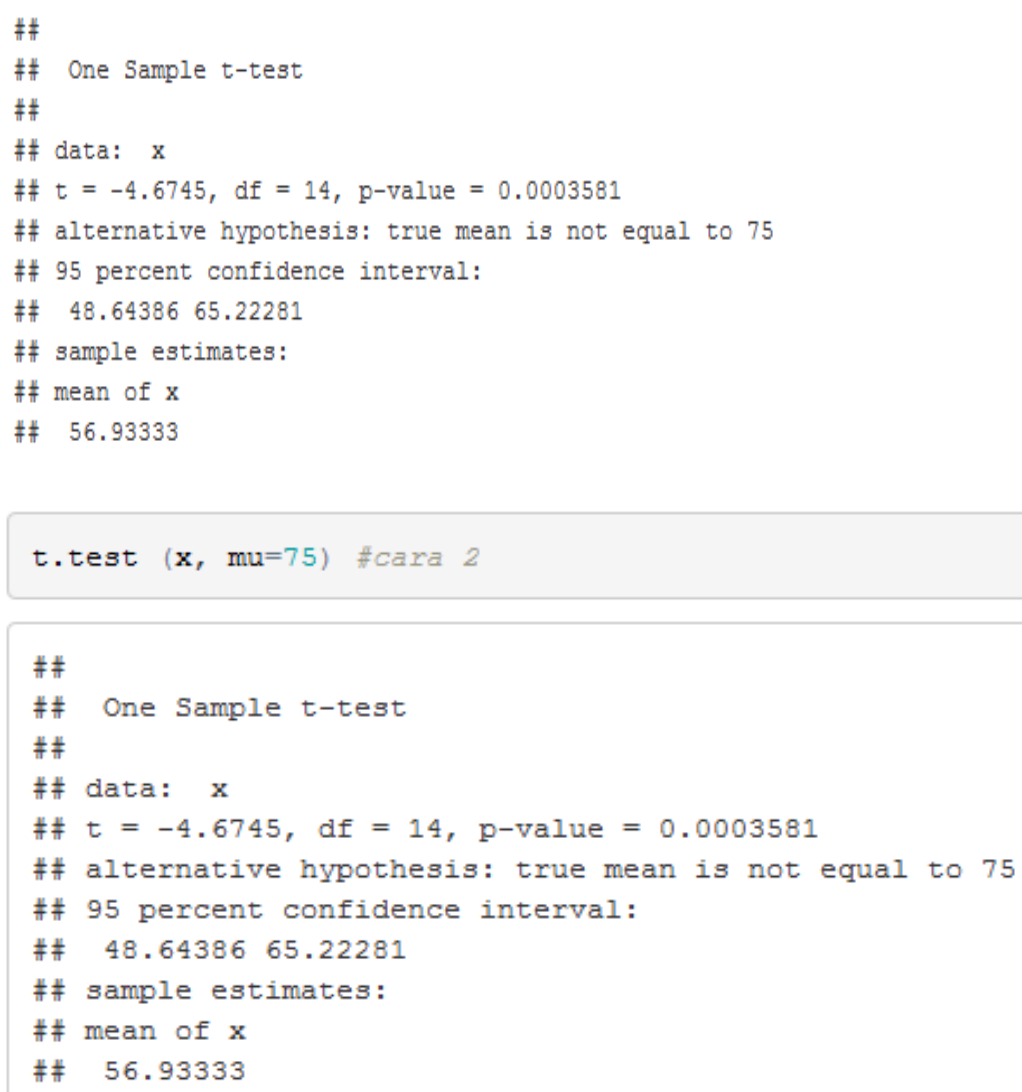

\section{Gambar 8.14}

Berdasarkan Gambar 8.14, diketahui nilai statistik dari uji $t(\mathrm{~T})$ adalah -4,67, sementara nilai probabilitas (P) adalah 0,000. Hasil yang diperoleh dengan R, Minitab, dan SPSS adalah sama. 


\section{$S \mathcal{H A R E}$}

[1] Berikut akan dipaparkan perhitungan manual pada kasus uji rata-rata populasi. Data disajikan pada Tabel 8.1.

Tabel 8.1

\begin{tabular}{|c|c|c|c|c|c|c|c|}
\hline Nama & X & Nama & X & Nama & X & Nama & X \\
\hline A & 55 & E & 66 & I & 45 & M & 50 \\
\hline B & 60 & F & 69 & J & 55 & N & 30 \\
\hline C & 54 & G & 40 & K & 80 & O & 35 \\
\hline D & 70 & H & 70 & L & 75 & & \\
\hline
\end{tabular}

Berikut akan dihitung nilai standar deviasi sampel terlebih dahulu.

Tabel 8.2

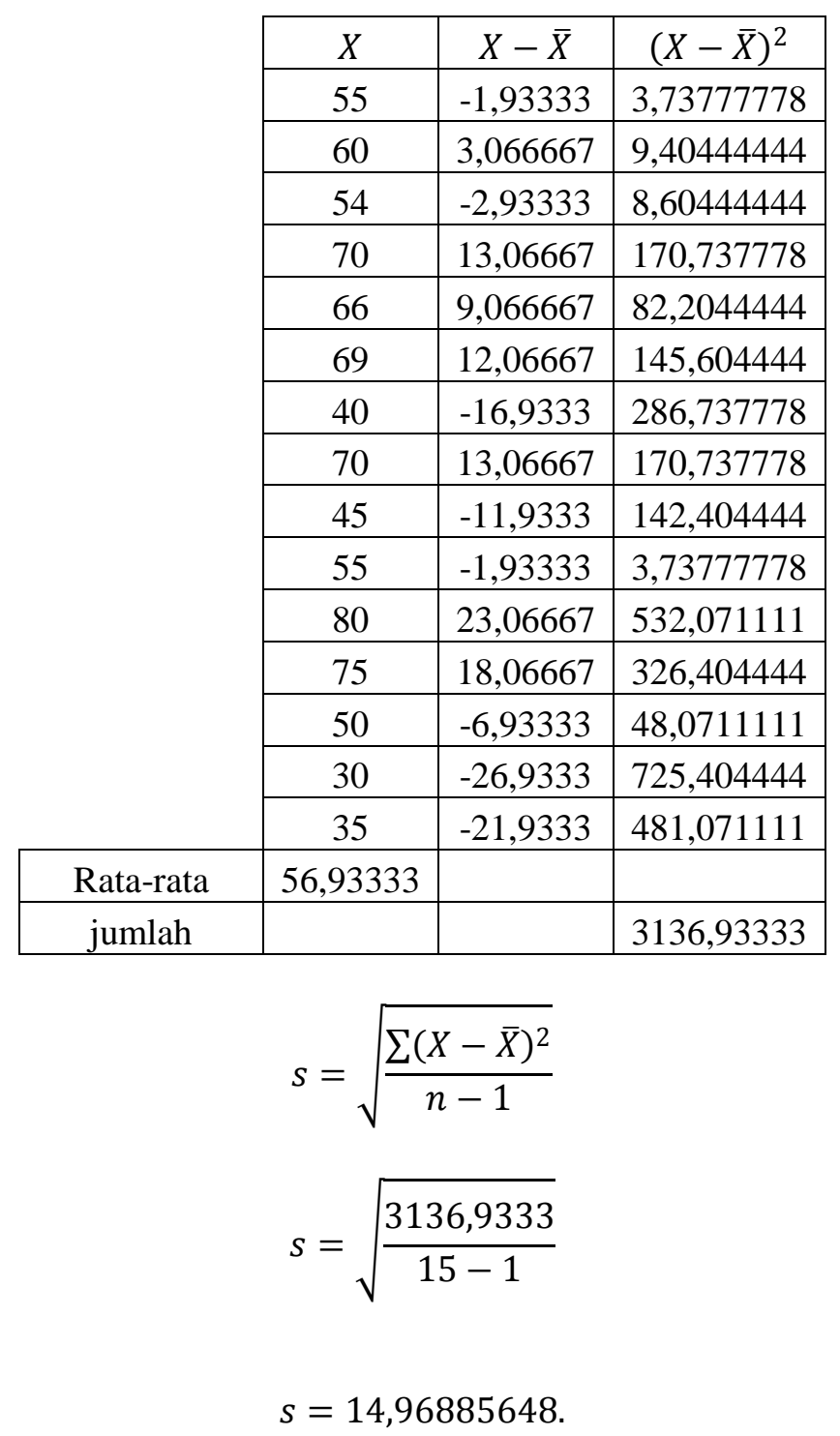


Tabel 8.3 menyajikan nilai dari standar deviasi sampel.

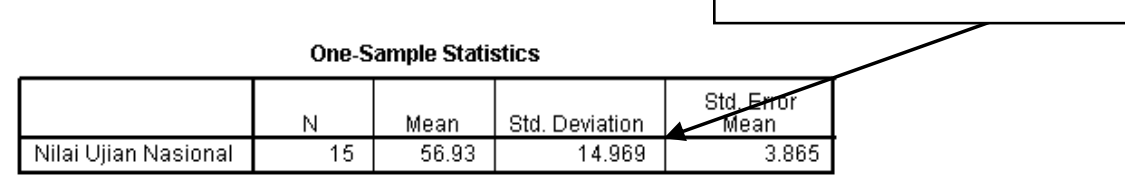

Selanjutnya menghitung nilai statistik dari uji $t$.

$$
\begin{gathered}
t=\frac{\bar{X}-\mu_{0}}{s / \sqrt{n}} \\
t=\frac{56,9333-75}{14,96885648 / \sqrt{15}} \\
t=-4,674507255
\end{gathered}
$$

\section{Tabel 8.4}

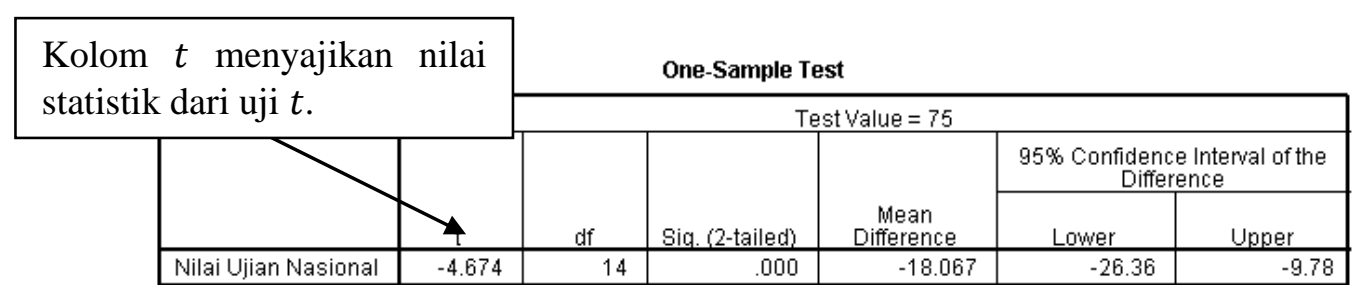

\section{Referensi}

1. Agresti, A. dan B. Finlay. 2009. Statistical Methods for the Social Sciences, $4^{\text {th }}$ Edition. United States of America: Prentice Hall.

2. Field, A. 2009. Discovering Statistics Using SPSS, $3^{\text {rd }}$ Edition. London: Sage.

3. Gio, P.U. 2013. Aplikasi Statistika dalam SPSS. Medan: USUpress.

4. Mann, P. S. dan C.J. Lacke. 2011. Introductory Statistics, International Student Version, $7^{\text {th }}$ Edition. Asia: John Wiley \& Sons, Inc.

5. Montgomery, D. C. dan G. C. Runger. 2011. Applied Statistics and Probability for Engineers, $5^{\text {th }}$ Edition. United States of America: John Wiley \& Sons, Inc.

6. Ott, R.L. dan M. Longnecker. 2001. An Introduction to Statistical Methods and Data Analysis, $5^{\text {th }}$ Edition. United States of America: Duxbury.

7. Smidth, R. K. dan D. H. Sanders. 2000. Statistics a First Course, $6^{\text {th }}$ Edition. United States of America: McGraw-Hill Companies. 


\section{BAB 9}

\section{UJI KESAMAAN RATA-RATA DARI DUA POPULASI (UJI $t)$}

\section{Sekílas Ují Kesamaan Rata-Rata dari Dua Populasí}

Uji kesamaan rata-rata dari dua populasi dengan uji $t$ yang akan dipaparkan dalam bab ini adalah sebagai berikut.

$\Rightarrow$ Uji kesamaan rata-rata dari dua populasi untuk data berpasangan dan saling berhubungan (paired t test for dependent populations).

$\Rightarrow$ Uji kesamaan rata-rata dari dua populasi yang tidak berhubungan dengan asumsi varians yang sama ( $t$ test for independent populations with assumption $\sigma_{1}^{2}=\sigma_{2}^{2}$ ).

$\Rightarrow$ Uji kesamaan rata-rata dari dua populasi yang tidak berhubungan dengan asumsi varians yang berbeda ( $t$ test for independent populations with assumption $\sigma_{1}^{2} \neq \sigma_{2}^{2}$ ).

\section{Uji Kesamaan Rata-Rata darí Dua Populasi untuk Data Berpasangan dan Saling Berhubungan dengan Uji $\mathbf{t}$ (Paired $t$ Test for Dependent Populations)}

Dalam uji kesamaan rata-rata dari dua populasi untuk data berpasangan dan saling berhubungan dengan uji $t$, pengamatan-pengamatan dari dua populasi dinyatakan dalam berpasangan. Sebagai contoh misalkan $\left(X_{1}, Y_{1}\right),\left(X_{2}, Y_{2}\right), \ldots,\left(X_{k}, Y_{k}\right)$ merupakan pengamatanpengamatan dari dua populasi, yakni populasi $X$ dan $Y$ yang dinyatakan dalam berpasangan.

Berikut beberapa contoh kasus yang dapat diselesaikan dengan pendekatan uji kesamaan ratarata dari dua populasi untuk data berpasangan dan saling berhubungan dengan uji $t$.

$\Rightarrow$ Menguji ada tidaknya pengaruh yang signifikan secara statistika penggunaan suplemen $\mathrm{X}$ terhadap berat badan, sebelum dan sesudah mengkonsumsi suplemen $\mathrm{X}$ selama satu minggu.

$\Rightarrow$ Menguji ada tidaknya pengaruh yang signifikan secara statistika penggunaan suplemen Y terhadap tinggi badan, sebelum dan sesudah mengkonsumsi suplemen $\mathrm{Y}$ selama satu bulan.

$\Rightarrow$ Menguji ada tidaknya pengaruh yang signifikan secara statistika pada program kursus matematika terhadap nilai ujian matematika siswa, sebelum dan sesudah mengikuti kursus matematika. 
Misalkan $D_{i}$ menyatakan selisih dari pasangan pengamatan ke- $i$ dari dua populasi, yakni $X$ dan $Y$, maka $D_{1}=Y_{1}-X_{1}, D_{2}=Y_{2}-X_{2}, \ldots, D_{k}=Y_{k}-X_{k}$. Dalam uji kesamaan rata-rata dari dua populasi untuk data berpasangan dan saling berhubungan dengan uji $t$, data dari selisih pasangan pengamatan $(D)$ diasumsikan berdistribusi normal, dengan rata-rata $\mu_{D}$.

Dalam uji kesamaan rata-rata dari dua populasi untuk data berpasangan dan saling berhubungan dengan uji $t$, hipotesis nol menyatakan tidak terdapat pengaruh yang signifikan secara statistika, sesudah dan sebelum perlakuan. Dengan kata lain, selisih rata-rata antara kelompok sesudah dan sebelum perlakuan sama dengan nol $\left(\mu_{2}-\mu_{1}=0\right)$. Hipotesis alternatif menyatakan terdapat pengaruh yang signifikan secara statistika, sesudah dan sebelum perlakuan. Dengan kata lain, selisih rata-rata antara kelompok sesudah dan sebelum perlakuan berbeda dari nol $\left(\mu_{2}-\mu_{1} \neq 0\right)$. Nilai statistik dari uji $t\left(t_{\text {hitung }}\right)$ dihitung dengan rumus sebagai berikut.

$$
t=\frac{\bar{d}-\mu_{D}}{s_{d} / \sqrt{n}} .
$$

Perhatikan bahwa $\bar{d}$ merupakan rata-rata dari selisih pasangan pengamatan dari dua sampel, $\mu_{D}$ merupakan rata-rata dari selisih pasangan pengamatan dari dua populasi, serta $s_{d}$ merupakan nilai standar deviasi dari selisih pasangan pengamatan dari dua sampel. Berikut rumus untuk menghitung nilai $s_{d}$.

$$
s_{d}=\sqrt{\frac{\sum(d-\bar{d})^{2}}{n-1}} .
$$

Untuk pengambilan keputusan terhadap hipotesis, dapat dilakukan dengan membandingkan nilai statistik dari uji $t$ terhadap nilai kritis berdasarkan tabel distribusi $t\left(t_{\text {kritis }}\right)$. Sebelum menghitung nilai kritis $t$, terlebih dahulu menghitung nilai derajat bebas. Berikut rumus untuk menghitung nilai derajat bebas.

$$
\text { Derajat bebas }=n-1 \text {. }
$$

Perhatikan bahwa $n$ menyatakan banyaknya pasangan pengamatan. Andaikan banyaknya pasangan pengamatan sebanyak 9, tingkat signifikansi yang digunakan adalah 5\%, sehingga nilai kritis $t$ dengan derajat bebas $9-1=8$ dan tingkat signifikansi $5 \%$ adalah $\pm 2,306$. Diketahui nilai kritis $t= \pm 2,306$. Berikut aturan pengambilan keputusan terhadap hipotesis berdasarkan uji $t$ (pengujian dua arah).

$$
\begin{gathered}
\text { Jika }\left|t_{\text {hitung }}\right| \leq\left|t_{\text {kritis }}\right| \text {, maka } H_{0} \text { diterima dan } H_{1} \text { ditolak. } \\
\text { Jika }\left|t_{\text {hitung }}\right|>\left|t_{\text {kritis }}\right| \text {, maka } H_{0} \text { ditolak dan } H_{1} \text { ditolak. }
\end{gathered}
$$

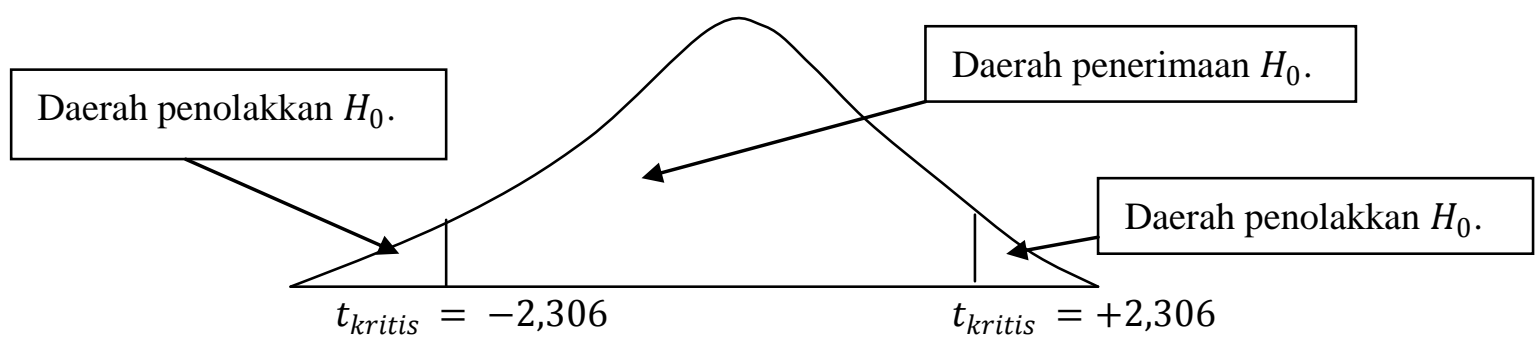


Pengambilan keputusan terhadap hipotesis juga dapat dilakukan dengan menggunakan nilai probabilitas dari uji $t$. Nilai probabilitas dari uji $t$ dibandingkan dengan tingkat signifikansi yang digunakan. Berikut aturan pengambilan keputusan terhadap hipotesis berdasarkan pendekatan nilai probabilitas.

Jika nilai probabilitas $\geq$ tingkat signifikansi, maka $H_{0}$ diterima dan $H_{1}$ ditolak. Jika nilai probabilitas < tingkat signifikansi, maka $H_{0}$ ditolak dan $H_{1}$ diterima.

Tabel 9.1 merupakan output SPSS yang menunjukkan nilai statistik dari uji $t$ dan nilai probabilitas dari uji $t$.

\section{Tabel 9.1}

\begin{tabular}{|c|c|c|c|c|c|c|}
\hline \multirow{4}{*}{$\begin{array}{l}\text { Kolom } t \text { dan Sig. (2-tailed) } \\
\text { masing-masing menyajikan nilai } \\
\text { statistik dari uji } t \text { dan nilai } \\
\text { probabilitas dari uji } t \text {. }\end{array}$} & \multicolumn{6}{|c|}{ Paired Samples Test } \\
\hline & \multicolumn{3}{|c|}{ Differences } & \multirow[b]{3}{*}{$t$} & \multirow[b]{3}{*}{$\mathrm{df}$} & \multirow{3}{*}{$\begin{array}{l}\text { Sig. (2- } \\
\text { tailed) }\end{array}$} \\
\hline & \multirow{2}{*}{$\begin{array}{l}\text { Error } \\
\text { fan }\end{array}$} & \multicolumn{2}{|c|}{$\begin{array}{c}95 \% \text { Confidence Interval of } \\
\text { the Difference }\end{array}$} & & & \\
\hline & & Lower & Upper & & & \\
\hline Pair1 $Y-X$ & 2.120 & 11.334 & 21.111 & 7.652 & & .000 \\
\hline
\end{tabular}

\section{Ujî Asumsi Normalitas}

Dalam uji kesamaan rata-rata dari dua populasi untuk data berpasangan dan saling berhubungan dengan uji $t$, data dari selisih pasangan pengamatan (D) diasumsikan berdistribusi normal, dengan rata-rata $\boldsymbol{\mu}_{\boldsymbol{D}}$. Field (2009:326) menyatakan sebagai berikut.

"The sampling distribution is normally distributed. In the dependent $t$-test this means that the sampling distribution of the differences between scores should be normal, not the scores themselves (see section 9.4.3)".

Sejalan dengan Field, Mann dan Lacke (2011:465) menyatakan sebagai berikut.

"If the sample size is small, then the population of paired differences is normally distributed".

Lebih lanjut, Mann dan Lacke (2011:465) menyatakan sebagai berikut.

"However, usually $\sigma_{d}$ is never known. Then, if the standard deviation $\sigma_{d}$ of the population paired differences is unknown and either the sample size is large (i.e., $n \geq 30$ ) or the population of paired differences is normally distributed (with $n<30$ ), then the $t$ distribution is used to make a confidence interval and test hypothesis about $\mu_{d} . "$

Namun ketika ukuran sampel cukup besar, yakni $\geq 3$, maka populasi tidak harus berdistribusi normal (Mann dan Lacke, 2011:465). Hal ini karena berdasarkan sifat teorema limit sentral (central limit theorem). Untuk menguji asumsi normalitas tersebut, dapat digunakan pendekatan grafik, yakni $P$-P plot (probability-probability plot) dalam SPSS. Pada pendekatan $P-P$ plot, jika titik-titik (dots) menyebar jauh (menyebar jauh berliku-liku pada garis diagonal seperti ular) dari garis diagonal, maka diindikasi asumsi normalitas tidak dipenuhi. Jika titik-titik menyebar sangat dekat pada garis diagonal, maka asumsi normalitas dipenuhi. 
Di samping itu dapat juga digunakan pendekatan uji Kolmogorov-Smirnov untuk menguji asumsi normalitas. Dalam pendekatan uji Kolmogorov-Smirnov, data dari selisih pasangan pengamatan diuji normalitasnya. Hipotesis nol menyatakan data dari selisih pasangan pengamatan $(D)$ berdistribusi normal, sedangkan hipotesis alternatif menyatakan data dari selisih pasangan pengamatan $(D)$ tidak berdistribusi normal. Untuk pengambilan keputusan terhadap hipotesis, dapat dibandingkan antara nilai probabilitas dari uji Kolmogorov-Smirnov dan tingkat signifikansi yang digunakan $(\alpha)$. Berikut aturan pengambilan keputusan terhadap hipotesis.

Jika nilai probabilitas $\geq$ tingkat signifikansi, $H_{0}$ diterima dan $H_{1}$ ditolak. Jika nilai probabilitas < tingkat signifikansi, $H_{0}$ ditolak dan $H_{1}$ diterima.

Tabel 9.2 merupakan output SPSS yang menunjukkan nilai probabilitas dari uji KolmogorovSmirnov.

Tabel 9.2

\begin{tabular}{|c|c|c|}
\hline \multicolumn{3}{|c|}{ One-Sample Kolmogorov-Smirnov Test } \\
\hline & & $\begin{array}{l}\text { Unstandardiz } \\
\text { ed Residual }\end{array}$ \\
\hline $\mathrm{N}$ & & 15 \\
\hline Normal Parameters ${ }^{a, \ldots}$ & Mean & .0000000 \\
\hline & Std. Deviation & .07019822 \\
\hline Most Extreme Differences & Absolute & .247 \\
\hline & Positive & .150 \\
\hline & Negative & -.247 \\
\hline Kolmogorov-Smirnov Z & & .959 \\
\hline Asymp. Sig. (2-tailed) & & .317 \\
\hline
\end{tabular}

Nilai Asyp. Sig. (2-tailed) $=0,317$ merupakan nilai probabilitas dari uji Kolmogorov-Smirnov.

\section{Contoh Kasus dalam Ují Kesamaan Rata-Rata dari Dua Populasí untuk Data Berpasangan dan Saling Berhubungan dengan Uji $\mathrm{t}$}

[1] Misalkan seorang peneliti bernama Ugi ingin meneliti ada tidaknya pengaruh mengkonsumsi suplemen $\mathrm{X}$ terhadap berat badan. Untuk keperluan penelitian, Ugi mewawancarai 10 responden untuk mengetahui berat badan sebelum dan sesudah mengkonsumsi suplemen $\mathrm{X}$ selama satu minggu. Berikut data yang telah dikumpulkan Ugi (Tabel 9.3).

Tabel 9.3 (Data Fiktif)

\begin{tabular}{|c|c|c|}
\hline \multirow{2}{*}{ Responden } & \multicolumn{2}{|c|}{ Berat Badan } \\
\cline { 2 - 3 } & Sebelum $(X)$ & Sesudah $(Y)$ \\
\hline 1 & 50 & 55 \\
\hline 2 & 49 & 56 \\
\hline 3 & 52 & 56 \\
\hline 4 & 48 & 53 \\
\hline 5 & 51 & 60 \\
\hline 6 & 49 & 52 \\
\hline 7 & 51 & 53 \\
\hline 8 & 55 & 61 \\
\hline 9 & 48 & 52 \\
\hline 10 & 47 & 56 \\
\hline
\end{tabular}


Berdasarkan data pada Tabel 9.3, responden ke-1 memiliki berat badan $50 \mathrm{~kg}$ sebelum mengkonsumsi suplemen $X$. Setelah mengkonsumsi suplemen $\mathrm{X}$ selama satu minggu, berat badannya naik menjadi $55 \mathrm{~kg}$.

[2] Misalkan seorang peneliti bernama Ugi ingin meneliti ada tidaknya pengaruh yang signifikan secara statistika pada pelaksanaan program kursus matematika terhadap nilai ujian matematika siswa kelas 6 di sekolak XYZ. Berikut data yang telah dikumpulkan Ugi (Tabel 9.4).

Tabel 9.4 (Data Fiktif)

\begin{tabular}{|c|c|c|}
\hline \multirow{2}{*}{ Siswa } & \multicolumn{2}{|c|}{ Nilai Ujian Matematika } \\
\cline { 2 - 3 } & Sebelum $(X)$ & Sesudah $(Y)$ \\
\hline 1 & 65 & 75 \\
\hline 2 & 50 & 80 \\
\hline 3 & 55 & 76 \\
\hline 4 & 48 & 65 \\
\hline 5 & 51 & 60 \\
\hline 6 & 49 & 70 \\
\hline 7 & 54 & 64 \\
\hline 8 & 55 & 78 \\
\hline 9 & 40 & 80 \\
\hline 10 & 56 & 69 \\
\hline
\end{tabular}

Berdasarkan data pada Tabel 9.4, siswa ke-1 memperoleh nilai ujian 65 sebelum mengikuti kursus matematika. Setelah mengikuti kursus matematika, nilai ujian meningkat menjadi 75.

\section{Uji Kesamaan Rata-Rata dari Dua Populasi yang Tidak} Berhubungan dengan Asumsi Varians yang Sama ( $t$ Test for Independent Populations with Assumption $\sigma_{1}^{2}=\sigma_{2}^{2}$ )

Dalam uji kesamaan rata-rata dari dua populasi yang tidak berhubungan dengan asumsi varians yang sama menguji ada tidaknya perbedaan rata-rata antara populasi pertama dan populasi kedua. Dengan kata lain, menguji apakah selisih rata-rata antara kelompok kedua dan pertama berbeda atau sama dengan nol. Dalam uji ini, pengamatan-pengamatan pada populasi pertama saling bebas/independen dengan pengamatan-pengamatan pada populasi kedua (independent populations). Uji ini didasarkan pada ketidaktahuan (unknown) mengenai nilai varians dari dua populasi, namun diasumsikan varians dari dua populasi tersebut sama.

Berikut beberapa contoh kasus yang dapat diselesaikan dengan pendekatan uji kesamaan ratarata dari dua populasi dengan asumsi varians yang sama dengan uji $t$.

$\Rightarrow$ Menguji ada tidaknya perbedaan nilai indeks prestasi (secara rata-rata) antara mahasiswa laki-laki dan perempuan.

$\Rightarrow$ Menguji ada tidaknya perbedaan harga saham antara perusahaan manufaktur dan real estate.

$\Rightarrow$ Menguji ada tidaknya perbedaan uang jajan antara mahasiswa kedokteran dan mahasiswa matematika. 
$\Rightarrow$ Menguji ada tidaknya perbedaan indeks prestasi antara mahasiswa dominan otak kanan dan dominan kotak kiri.

Dalam uji kesamaan rata-rata dari dua populasi yang tidak berhubungan dengan asumsi varians yang sama, hipotesis nol menyatakan tidak terdapat perbedaan rata-rata antara populasi pertama dan populasi kedua. Dengan kata lain, selisih rata-rata antara populasi kedua dan pertama sama dengan nol $\left(\mu_{2}-\mu_{1}=0\right)$. Hipotesis alternatif menyatakan terdapat perbedaan rata-rata antara populasi pertama dan populasi kedua. Dengan kata lain, selisih rata-rata antara populasi kedua dan pertama berbeda dari nol $\left(\mu_{2}-\mu_{1} \neq 0\right)$. Nilai statistik dari uji $t$ ( $\left.t_{\text {hitung }}\right)$ dihitung dengan rumus sebagai berikut.

$$
t=\frac{\bar{X}_{2}-\bar{X}_{1}}{s_{p} \sqrt{\frac{1}{n_{1}}+\frac{1}{n_{2}}}}
$$

Perhatikan bahwa $t$ merupakan nilai statistik dari uji $t, \bar{X}_{1}$ merupakan nilai rata-rata dari sampel pertama, $\bar{X}_{2}$ merupakan nilai rata-rata dari sampel kedua, $n_{1}$ merupakan jumlah pengamatan dalam sampel pertama, dan $n_{2}$ merupakan jumlah pengamatan dalam sampel kedua. Berikut rumus untuk menghitung $s_{p}$.

$$
s_{p}=\sqrt{\frac{s_{1}^{2}\left(n_{1}-1\right)+s_{2}^{2}\left(n_{2}-1\right)}{n_{1}+n_{2}-2}} .
$$

Perhatikan bahwa $s_{p}^{2}$ disebut pooled estimator standard deviation for two samples, yang mana merupakan estimator dari $\sigma^{2}$. Untuk pengambilan keputusan terhadap hipotesis, dapat dilakukan dengan membandingkan nilai statistik dari uji $t$ terhadap nilai kritis berdasarkan tabel distribusi $t$ ( $\left.t_{\text {kritis }}\right)$. Sebelum menghitung nilai kritis $t$, terlebih dahulu menghitung nilai derajat bebas. Berikut rumus untuk menghitung nilai derajat bebas.

$$
\text { Derajat bebas }=n_{1}+n_{2}-2 \text {. }
$$

Perhatikan bahwa $n_{1}$ menyatakan banyaknya pengamatan/elemen pada sampel pertama, $n_{2}$ menyatakan banyaknya pengamatan/elemen pada sampel kedua. Andaikan $n_{1}=n_{2}=10$ dan tingkat signifikansi yang digunakan $\alpha=5 \%$, maka nilai kritis $t$ adalah $\pm 2,101$. Berikut aturan pengambilan keputusan terhadap hipotesis berdasarkan uji $t$.

$$
\begin{aligned}
& \text { Jika }\left|t_{\text {hitung }}\right| \leq\left|t_{\text {kritis }}\right| \text {, maka } H_{0} \text { diterima dan } H_{1} \text { ditolak. } \\
& \text { Jika }\left|t_{\text {hitung }}\right|>\left|t_{\text {kritis }}\right| \text {, maka } H_{0} \text { ditolak dan } H_{1} \text { diterima. }
\end{aligned}
$$

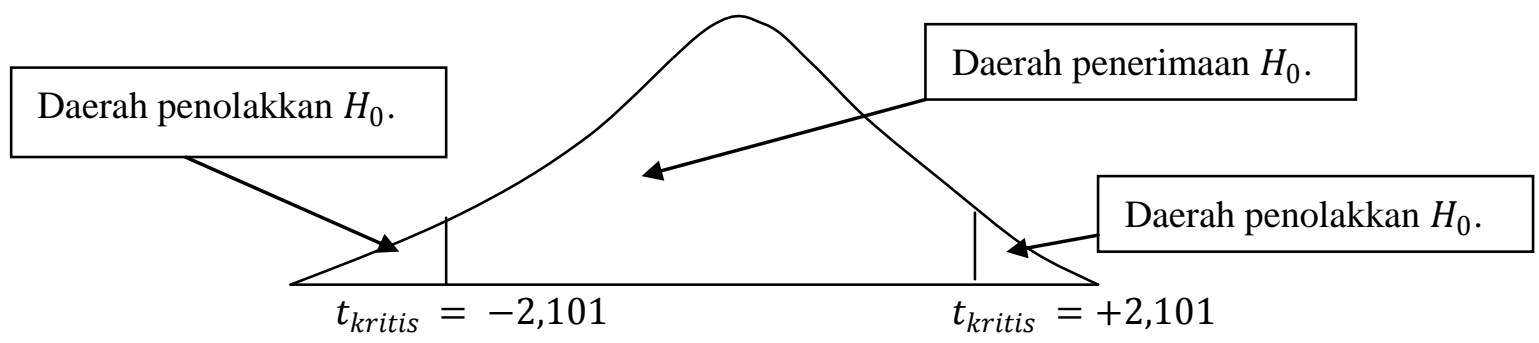


Pengambilan keputusan terhadap hipotesis juga dapat dilakukan dengan menggunakan pendekatan nilai probabilitas dari uji $t$. Nilai probabilitas dari uji $t$ dibandingkan dengan tingkat signifikansi yang digunakan. Berikut aturan pengambilan keputusan terhadap hipotesis berdasarkan nilai probabilitas.

Jika nilai probabilitas $\geq$ tingkat signifikansi, maka $H_{0}$ diterima dan $H_{1}$ ditolak. Jika nilai probabilitas < tingkat signifikansi, maka $H_{0}$ ditolak dan $H_{1}$ diterima.

\section{Uji Asumsi Normalitas}

Dalam uji kesamaan rata-rata dari dua populasi yang tidak berhubungan dengan asumsi varians yang sama, populasi pertama dan populasi kedua diasumsikan berdistribusi normal (Mann dan Lacke, 2011:448). Namun ketika ukuran sampel cukup besar, yakni masingmasing sampel berukuran $\geq 30$, maka populasi tidak harus berdistribusi normal (Mann dan Lacke, 2011:465). Untuk menguji apakah suatu sampel yang diteliti berasal dari populasi yang berdistribusi normal, dapat digunakan pendekatan grafik, yakni $P-P$ plot (probabilityprobability plot) dalam SPSS. Pada pendekatan $P$-P plot, jika titik-titik (dots) menyebar jauh (menyebar jauh berliku-liku pada garis diagonal seperti ular) dari garis diagonal, maka diindikasi asumsi normalitas tidak dipenuhi. Jika titik-titik menyebar sangat dekat pada garis diagonal, maka asumsi normalitas dipenuhi.

Di samping itu, dapat juga digunakan pendekatan uji Kolmogorov-Smirnov untuk menguji asumsi normalitas. Dalam pendekatan uji Kolmogorov-Smirnov, masing-masing sampel diuji normalitasnya. Hipotesis nol menyatakan sampel yang diteliti berasal dari populasi yang berdistribusi normal, sedangkan hipotesis alternatif menyatakan sampel yang diteliti tidak berasal dari populasi yang berdistribusi normal.

Untuk pengambilan keputusan terhadap hipotesis, dapat dibandingkan antara nilai probabilitas dari uji Kolmogorov-Smirnov dan tingkat signifikansi yang digunakan $(\alpha)$. Berikut aturan pengambilan keputusan terhadap hipotesis.

Jika nilai probabilitas $\geq$ tingkat signifikansi, $H_{0}$ diterima dan $H_{1}$ ditolak. Jika nilai probabilitas $<$ tingkat signifikansi, $H_{0}$ ditolak dan $H_{1}$ diterima.

\section{Uji Asumsi Kesamaan Varians}

Selain asumsi normalitas, asumsi lain yang dikenakan adalah asumsi kesamaan varians, yakni sampel-sampel yang diteliti berasal dari populasi-populasi yang memiliki varians yang sama. Untuk menguji apakah sampel-sampel yang diteliti berasal dari populasi-populasi yang memiliki varians yang sama, dapat digunakan uji Levene. Pada uji Levene, hipotesis nol menyatakan sampel-sampel yang diambil berasal dari populasi-populasi yang memiliki varians yang sama, sedangkan hipotesis alternatif menyatakan paling tidak terdapat sepasang populasi yang memiliki varians yang berbeda.

Pengambilan keputusan terhadap hipotesis dilakukan dengan membandingkan nilai statistik dari uji Levene $(L)$ dengan nilai kritis berdasarkan tabel distribusi $F\left(F_{\text {kritis }}\right)$. Sebelum menghitung nilai kritis $F$, terlebih dahulu menghitung nilai dari derajat bebas pembilang dan derajat bebas penyebut. Berikut rumus untuk menghitung nilai dari derajat bebas pembilang dan derajat bebas penyebut. 
Derajat bebas pembilang $=k-1$.

Derajat bebas penyebut $=N-k$.

Perhatikan bahwa $k$ menyatakan banyaknya sampel/populasi yang diteliti, sedangkan $N$ merupakan jumlah pengamatan/elemen dari seluruh sampel. Diketahui misalkan nilai $k$ adalah 2, sedangkan nilai $N$ adalah $20\left(n_{1}+n_{2}=10+10=20\right)$. Misalkan tingkat signifikansi yang digunakan adalah 5\%, sehingga nilai kritis $F$ dengan derajat bebas pembilang $2-1=1$, derajat bebas penyebut $20-2=18$, dan tingkat signifikansi $5 \%$ adalah 4,41. Berikut aturan pengambilan keputusan terhadap hipotesis berdasarkan uji Levene.

Jika nilai statistik dari uji Levene $\leq F_{\text {kritis }}$, maka $H_{0}$ diterima dan $H_{1}$ ditolak. jika nilai statistik dari uji Levene $>F_{\text {kritis }}$, maka $H_{0}$ ditolak dan $H_{1}$ diterima.

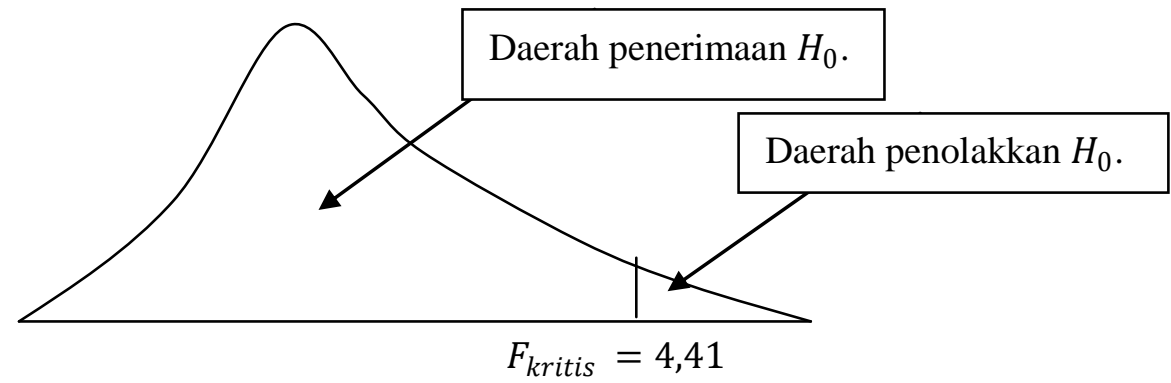

Pengambilan keputusan terhadap hipotesis dapat juga digunakan pendekatan nilai probabilitas dari uji Levene. Nilai probabilitas tersebut dibandingkan dengan tingkat signifikansi $(\alpha)$. Berikut aturan pengambilan keputusan terhadap hipotesis.

Jika nilai probabilitas $\geq \alpha$, maka $H_{0}$ diterima dan $H_{1}$ ditolak. Jika nilai probabilitas $<\alpha$, maka $H_{0}$ ditolak dan $H_{1}$ diterima.

Berikut diberikan tampilan output SPSS yang menunjukkan nilai probabilitas dari uji Levene (Tabel 9.5).

Tabel 9.5

Test of Homogeneity of Variances
\begin{tabular}{|c|r|r|r|}
\hline $\begin{array}{c}\text { nilai indeks prestasi kumulatif mahasiswa } \\
\text { Statistic }\end{array}$ & $\mathrm{df1}$ & $\mathrm{df} 2$ & $\mathrm{Sig}$. \\
\hline 2.233 & 3 & 36 & .101 \\
\hline
\end{tabular}

\section{Ují Kesamaan Rata-Rata dari Dua Populasí yang Tídak Berhubungan dengan Asumsi Varians yang Tídak Sama ( $t$ Test for Independent Populations with Assumption $\sigma_{1}^{2} \neq \sigma_{2}^{2}$ )}

Dalam uji kesamaan rata-rata dari dua populasi yang tidak berhubungan dengan asumsi varians yang tidak sama menguji ada tidaknya perbedaan rata-rata antara populasi pertama dan populasi kedua. Dengan kata lain, menguji apakah selisih rata-rata antara kelompok kedua dan pertama berbeda atau sama dengan nol. Dalam uji ini, pengamatan-pengamatan pada populasi pertama saling bebas/independen (independent) dengan pengamatan- 
pengamatan pada populasi kedua (independent populations). Uji ini didasarkan pada ketidaktahuan (unknown) mengenai nilai varians dari dua populasi, namun diasumsikan varians dari dua populasi tersebut tidak sama.

Dalam uji kesamaan rata-rata dari dua populasi yang tidak berhubungan dengan asumsi varians yang tidak sama, hipotesis nol menyatakan tidak terdapat perbedaan rata-rata antara populasi pertama dan populasi kedua. Dengan kata lain, selisih rata-rata antara populasi kedua dan pertama sama dengan nol $\left(\mu_{2}-\mu_{1}=0\right)$. Hipotesis alternatif menyatakan terdapat perbedaan rata-rata antara populasi pertama dan populasi kedua. Dengan kata lain, selisih rata-rata antara populasi kedua dan pertama berbeda dari nol $\left(\mu_{2}-\mu_{1} \neq 0\right)$. Nilai statistik dari uji $t\left(t_{\text {hitung }}\right)$ dihitung dengan rumus sebagai berikut.

$$
t=\frac{\bar{X}_{2}-\bar{X}_{1}}{\sqrt{\frac{s_{1}^{2}}{n_{1}}+\frac{s_{2}^{2}}{n_{2}}}} .
$$

Perhatikan bahwa $t$ merupakan nilai statistik dari uji $t, \bar{X}_{1}$ merupakan nilai rata-rata dari sampel pertama, $\bar{X}_{2}$ merupakan nilai rata-rata dari sampel kedua, $s_{1}$ merupakan nilai standar deviasi dari sampel pertama, $s_{2}$ merupakan nilai standar deviasi dari sampel kedua, $n_{1}$ merupakan jumlah pengamatan dalam sampel pertama, dan $n_{2}$ merupakan jumlah pengamatan dalam sampel kedua.

Untuk pengambilan keputusan terhadap hipotesis, dapat dilakukan dengan membandingkan nilai statistik dari uji $t$ terhadap nilai kritis berdasarkan tabel distribusi $t\left(t_{\text {kritis }}\right)$. Sebelum menghitung nilai kritis $t$, terlebih dahulu menghitung nilai derajat bebas. Berikut rumus untuk menghitung nilai derajat bebas.

$$
\text { Derajat bebas }=\frac{\left(\frac{s_{1}^{2}}{n_{1}}+\frac{s_{2}^{2}}{n_{2}}\right)^{2}}{\frac{\left(\frac{s_{1}^{2}}{n_{1}}\right)^{2}}{\left(n_{1}-1\right)}+\frac{\left(\frac{s_{2}^{2}}{n_{2}}\right)^{2}}{\left(n_{2}-1\right)}} .
$$

Berikut aturan pengambilan keputusan terhadap hipotesis berdasarkan uji $t$.

$$
\begin{aligned}
& \text { Jika }\left|t_{\text {hitung }}\right| \leq\left|t_{\text {kritis }}\right| \text {, maka } H_{0} \text { diterima dan } H_{1} \text { ditolak. } \\
& \text { Jika }\left|t_{\text {hitung }}\right|>\left|t_{\text {kritis }}\right| \text {, maka } H_{0} \text { ditolak dan } H_{1} \text { diterima. }
\end{aligned}
$$

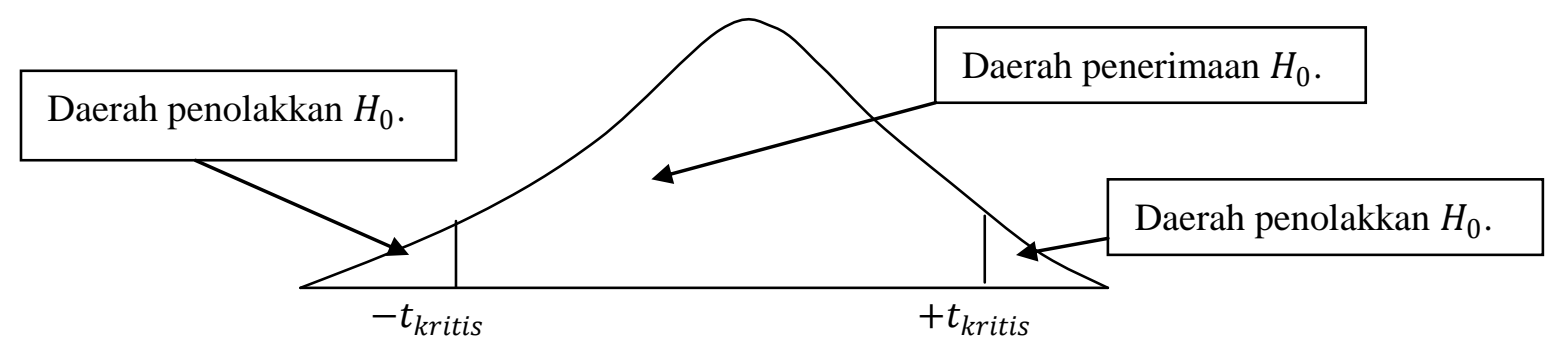

Pengambilan keputusan terhadap hipotesis juga dapat dilakukan dengan menggunakan pendekatan nilai probabilitas dari uji $t$. Nilai probabilitas dari uji $t$ dibandingkan dengan 
tingkat signifikansi yang digunakan. Berikut aturan pengambilan keputusan terhadap hipotesis berdasarkan pendekatan nilai probabilitas.

Jika nilai probabilitas $\geq$ tingkat signifikansi, maka $H_{0}$ diterima dan $H_{1}$ ditolak. Jika nilai probabilitas < tingkat signifikansi, maka $H_{0}$ ditolak dan $H_{1}$ diterima.

\section{Uji Asumsi Normalitas}

Dalam uji kesamaan rata-rata dari dua populasi yang tidak berhubungan dengan asumsi varians yang berbeda, populasi pertama dan populasi kedua diasumsikan berdistribusi normal (Mann dan Lacke, 2011:458). Namun ketika ukuran sampel cukup besar, yakni masingmasing sampel berukuran $\geq 30$, maka populasi tidak harus berdistribusi normal (Mann dan Lacke, 2011:465). Untuk menguji apakah suatu sampel yang diteliti berasal dari populasi yang berdistribusi normal, dapat digunakan pendekatan grafik, yakni $P$-P plot (probabilityprobability plot) dalam SPSS. Pada pendekatan $P$-P plot, jika titik-titik (dots) menyebar jauh (menyebar berliku-liku pada garis diagonal seperti ular) dari garis diagonal, maka diindikasi asumsi normalitas tidak dipenuhi. Jika titik-titik menyebar sangat dekat pada garis diagonal, maka asumsi normalitas dipenuhi.

Di samping itu, dapat juga digunakan pendekatan uji Kolmogorov-Smirnov untuk menguji asumsi normalitas. Dalam pendekatan uji Kolmogorov-Smirnov, masing-masing sampel diuji normalitasnya. Hipotesis nol menyatakan sampel yang diteliti berasal dari populasi yang berdistribusi normal, sedangkan hipotesis alternatif menyatakan sampel yang diteliti tidak berasal dari populasi yang berdistribusi normal.

Untuk pengambilan keputusan terhadap hipotesis, dapat dibandingkan antara nilai probabilitas dari uji Kolmogorov-Smirnov dan tingkat signifikansi yang digunakan $(\alpha)$. Berikut aturan pengambilan keputusan terhadap hipotesis.

Jika nilai probabilitas $\geq$ tingkat signifikansi, $H_{0}$ diterima dan $H_{1}$ ditolak. Jika nilai probabilitas $<$ tingkat signifikansi, $H_{0}$ ditolak dan $H_{1}$ diterima.

\section{Ují Asumsi Ketídaksamaan Varians}

Selain asumsi normalitas, asumsi lain yang dikenakan adalah asumsi ketidaksamaan varians, yakni sampel-sampel yang diteliti berasal dari populasi-populasi yang memiliki varians yang berbeda. Untuk menguji apakah sampel-sampel yang diteliti berasal dari populasi-populasi yang memiliki varians berbeda, dapat digunakan uji Levene. Pada uji Levene, hipotesis nol menyatakan sampel-sampel yang diambil berasal dari populasi-populasi yang memiliki varians yang sama, sedangkan hipotesis alternatif menyatakan paling tidak terdapat sepasang populasi yang memiliki varians yang berbeda.

Pengambilan keputusan terhadap hipotesis dilakukan dengan membandingkan nilai statistik dari uji Levene $(L)$ dengan nilai kritis berdasarkan tabel distribusi $F\left(F_{\text {kritis }}\right)$. Sebelum menghitung nilai kritis $F$, terlebih dahulu menghitung nilai dari derajat bebas pembilang dan derajat bebas penyebut. Berikut rumus untuk menghitung nilai dari derajat bebas pembilang dan derajat bebas penyebut. 
Derajat bebas pembilang $=k-1$.

Derajat bebas penyebut $=N-k$.

Perhatikan bahwa $k$ menyatakan banyaknya elemen sampel, sedangkan $N$ merupakan jumlah elemen/pengamatan dari seluruh sampel. Diketahui misalkan nilai $k$ adalah 2, sedangkan nilai $N$ adalah $20\left(n_{1}+n_{2}=10+10=20\right)$. Diketahui misalkan tingkat signifikansi yang digunakan adalah 5\%, sehingga nilai kritis $F$ dengan derajat bebas pembilang $2-1=1$, derajat bebas penyebut $20-2=18$, dan tingkat signifikansi $5 \%$ adalah 4,41 . Berikut aturan pengambilan keputusan terhadap hipotesis berdasarkan uji Levene.

Jika nilai statistik dari uji Levene $\leq F_{\text {kritis }}$, maka $H_{0}$ diterima dan $H_{1}$ ditolak. jika nilai statistik dari uji Levene $>F_{\text {kritis }}$, maka $H_{0}$ ditolak dan $H_{1}$ diterima.

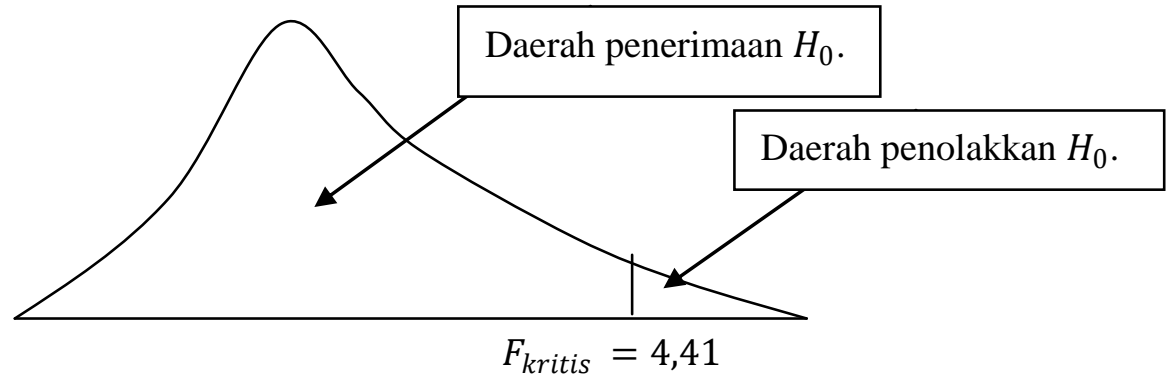

Pengambilan keputusan terhadap hipotesis juga dapat digunakan pendekatan nilai probabilitas dari uji Levene. Nilai probabilitas tersebut dibandingkan dengan tingkat signifikansi $(\alpha)$. Berikut aturan pengambilan keputusan terhadap hipotesis berdasarkan pendekatan nilai probabilitas.

Jika nilai probabilitas $\geq$ tingkat signifikansi, $H_{0}$ diterima dan $H_{1}$ ditolak. Jika nilai probabilitas $<$ tingkat signifikansi, $H_{0}$ ditolak dan $H_{1}$ diterima.

\section{Contoh Kasus dalam Ují Kesamaan Rata-Rata dari Dua Populasí Tídak Berhubungan dengan Uji t}

[1] Misalkan seorang peneliti bernama Ugi ingin meneliti ada tidaknya perbedaan indeks prestasi antara mahasiswa dominan otak kanan dan mahasiswa dominan otak kiri. Untuk keperluan penelitian, Ugi mewawancarai 20 mahasiswa, yang terdiri dari 10 mahasiswa dominan otak kanan dan 10 mahasiswa dominan otak kiri dengan maksud untuk mengetahui nilai indeks prestasi. Data yang telah dikumpulkan Ugi disajikan pada Tabel 9.6. Berdasarkan Tabel 9.6, $X$ menyatakan nilai indeks prestasi mahasiswa dominan otak kanan, sedangkan $Y$ menyatakan nilai indeks prestasi mahasiswa dominan otak kiri.

[2] Misalkan seorang peneliti bernama Ugi ingin meneliti ada tidaknya perbedaan uang jajan antara mahasiswa jurusan matematika dan kedokteran. Untuk keperluan penelitian, Ugi mewawancarai 20 mahasiswa, yang terdiri dari 10 mahasiswa matematika dan 10 mahasiswa kedokteran dengan maksud untuk mengetahui uang jajan dalam sehari. Data yang telah dikumpulkan Ugi disajikan pada Tabel 9.7. Berdasarkan Tabel 9.7, $X$ menyatakan uang jajan (dalam ribuan) mahasiswa jurusan matematika, sedangkan $Y$ menyatakan uang jajan mahasiswa jurusan kedokteran. 
[3] Misalkan seorang peneliti bernama Ugi ingin meneliti ada tidaknya perbedaan IQ antara mahasiswa jurusan matematika dan seni. Untuk keperluan penelitian, Ugi mewawancarai 14 mahasiswa, yang terdiri dari 7 mahasiswa matematika dan 7 mahasiswa seni dengan maksud untuk mengetahui IQ saat ini. Berikut data yang telah dikumpulkan Ugi (Tabel 9.8).

Tabel 9.6 (Data Fiktif)

\begin{tabular}{|c|c|c|c|}
\hline Mahasiswa & $X$ & Mahasiswa & $Y$ \\
\hline 1 & 2.9 & 11 & 3.24 \\
\hline 2 & 2.75 & 12 & 2.99 \\
\hline 3 & 3.01 & 13 & 3.3 \\
\hline 4 & 2.85 & 14 & 3.25 \\
\hline 5 & 2.99 & 15 & 3.1 \\
\hline 6 & 3.1 & 16 & 3.23 \\
\hline 7 & 3.05 & 17 & 3.6 \\
\hline 8 & 2.8 & 18 & 3.4 \\
\hline 9 & 2.94 & 19 & 3.5 \\
\hline 10 & 3 & 20 & 3.2 \\
\hline
\end{tabular}

Tabel 9.7 (Data Fiktif)

\begin{tabular}{|c|c|c|c|}
\hline Mahasiswa & $X$ & Mahasiswa & $Y$ \\
\hline 1 & 10 & 11 & 20 \\
\hline 2 & 9 & 12 & 40 \\
\hline 3 & 7 & 13 & 90 \\
\hline 4 & 12 & 14 & 50 \\
\hline 5 & 8 & 15 & 50 \\
\hline 6 & 10 & 16 & 90 \\
\hline 7 & 11 & 17 & 80 \\
\hline 8 & 10 & 18 & 60 \\
\hline 9 & 9 & 19 & 90 \\
\hline 10 & 8 & 20 & 100 \\
\hline
\end{tabular}

Tabel 9.8 (Data Fiktif)

\begin{tabular}{|c|c|c|c|}
\hline Mahasiswa & $X$ & Mahasiswa & $Y$ \\
\hline 1 & 118 & 8 & 105 \\
\hline 2 & 115 & 9 & 109 \\
\hline 3 & 110 & 10 & 112 \\
\hline 4 & 112 & 11 & 114 \\
\hline 5 & 125 & 12 & 111 \\
\hline 6 & 119 & 13 & 100 \\
\hline 7 & 109 & 14 & 101 \\
\hline
\end{tabular}

Berdasarkan Tabel 9.8, $X$ menyatakan IQ mahasiswa jurusan matematika, sedangkan $Y$ menyatakan IQ mahasiswa jurusan seni. 


\section{Uji Kesamaan Rata-Rata darí Dua Populasi untuk Data Berpasangan dan Saling Berhubungan dengan Uji $\mathrm{t}$ (Paired $t$ Test for Dependent Popu(ations)}

Misalkan seorang peneliti ingin meneliti mengenai pengaruh penggunaan obat $A$ terhadap jumlah denyut jantung per-menit pada manusia. Peneliti tersebut mengambil sampel sebanyak 9 responden. Pertama, sebelum pemberian obat $A$, peneliti mencatat jumlah denyut jantung yang terjadi dalam satu menit dari 9 responden tersebut. Kemudian, 9 responden tersebut mengkonsumsi obat $A$ dan setelah 15 menit, peneliti tersebut mencatat kembali jumlah denyut jantung yang terjadi dalam satu menit. Berikut data dari 9 responden mengenai jumlah denyut jantung yang terjadi dalam satu menit sebelum dan sesudah mengkonsumsi obat $A$ (Tabel 9.1).

Tabel 9.1 (Data Fiktif)

\begin{tabular}{|c|c|c|}
\hline Responden & $\mathrm{X}$ & $\mathrm{Y}$ \\
\hline 1 & 78 & 100 \\
\hline 2 & 75 & 95 \\
\hline 3 & 67 & 70 \\
\hline 4 & 77 & 90 \\
\hline 5 & 70 & 90 \\
\hline 6 & 72 & 90 \\
\hline 7 & 78 & 89 \\
\hline 8 & 74 & 90 \\
\hline 9 & 77 & 100 \\
\hline
\end{tabular}

Berdasarkan data pada Tabel 9.1, diketahui jumlah denyut jantung dalam satu menit dari responden ke-3 ketika belum mengkonsumsi obat $A$ sebanyak 67, dan setelah mengkonsumsi obat $A$ sebanyak 70 . Peneliti akan menguji apakah terdapat pengaruh yang signifikan secara statistika dalam hal jumlah denyut jantung yang terjadi dalam satu menit, sebelum dan sesudah mengkonsumsi obat $A$ pada tingkat signifikansi $\alpha=5 \%$.

Dalam uji kesamaan rata-rata dari dua populasi untuk data berpasangan dan saling berhubungan dengan uji $t$, data dari selisih pasangan pengamatan $(D)$ diasumsikan berdistribusi normal, dengan rata-rata $\mu_{D}$. Untuk menguji asumsi normalitas tersebut, dapat digunakan pendekatan grafik, yakni $P-P$ plot (probability-probability plot) dalam SPSS. Pada pendekatan $P$-P plot, jika titik-titik (dots) menyebar jauh (menyebar jauh berliku-liku pada garis diagonal seperti ular) dari garis diagonal, maka diindikasi asumsi normalitas tidak dipenuhi. Jika titik-titik menyebar sangat dekat pada garis diagonal, maka asumsi normalitas dipenuhi. Bangun data pada Tabel 9.1 dalam SPSS seperti pada Gambar 9.1. Pilih Transform $\Rightarrow$ Compute Variable, sehingga muncul kotak dialog Compute Variable (Gambar 9.2). Pada kotak dialog Compute Variable, ketik d pada kotak Target Variable dan ketik Y-X pada kotak Numeric Expression. Kemudian pilih Continue, sehingga terbentuk variabel baru bernama d (Gambar 9.3). 


\begin{tabular}{|r|r|r|}
\hline & $X$ & \multicolumn{1}{|r|}{$Y$} \\
\hline 1 & 78 & 100 \\
\hline 2 & 75 & 95 \\
\hline 3 & 67 & 70 \\
\hline 4 & 77 & 90 \\
\hline 5 & 70 & 90 \\
\hline 6 & 72 & 90 \\
\hline 7 & 78 & 89 \\
\hline 8 & 74 & 90 \\
\hline 9 & 77 & 100 \\
\hline
\end{tabular}

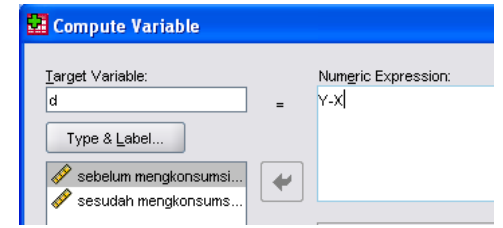

Gambar 9.2

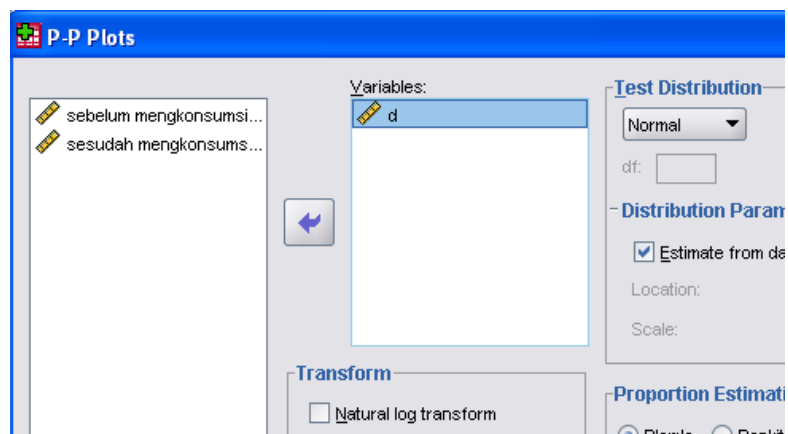

Gambar 9.4

\begin{tabular}{|c|c|c|c|c|}
\hline & $x$ & $Y$ & 7 & \\
\hline 1 & 78 & 100 & 22.00 & \\
\hline 2 & 75 & 95 & 20.00 & \\
\hline 3 & 67 & 70 & 3.00 & \\
\hline 4 & 77 & 90 & 13.00 & \multirow{6}{*}{$\begin{array}{c}\text { Terbentuk } \\
\text { variabel baru } \\
\text { bernama } \mathbf{d} .\end{array}$} \\
\hline 5 & 70 & 90 & 20.00 & \\
\hline 6 & 72 & 90 & 18.00 & \\
\hline 7 & 78 & 89 & 11.00 & \\
\hline 8 & 74 & 90 & 16.00 & \\
\hline 9 & 77 & 100 & 23.00 & \\
\hline
\end{tabular}

Gambar 9.3

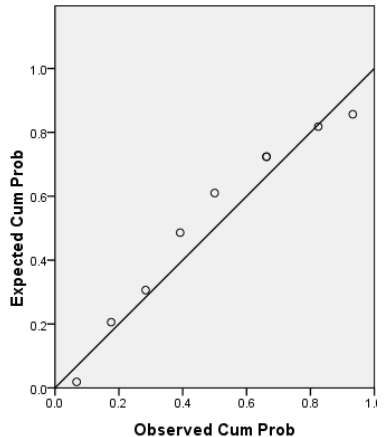

Gambar 9.5

Selanjutnya pilih Analyze $\Rightarrow$ Descriptive Statistics $\Rightarrow P-P$ Plots, sehingga muncul kotak dialog P-P Plots (Gambar 9.4). Masukkan variabel d pada kotak Variables. Kemudian pilih OK. Grafik P-P Plots diperlihatkan pada Gambar 9.5. Perhatikan bahwa titik-titik menyebar sangat dekat pada garis diagonal, maka disimpulkan bahwa asumsi normalitas data dari selisih pasangan pengamatan $(D)$ dipenuhi.

Selain pendekatan grafik, dapat juga digunakan pendekatan uji Kolmogorov-Smirnov untuk menguji asumsi normalitas data dari selisih pasangan pengamatan $(D)$. Pilih Analyze $=>$ Nonparametric Tests $\Rightarrow$ 1-Sample $K-S$, sehingga muncul kotak dialog One-Sample Kolmogorov-Smirnov Test (Gambar 9.6). Pada kotak dialog One-Sample KolmogorovSmirnov Test, masukkan variabel d pada kotak Test Variable List. Pada Test Distribution pilih Normal. Kemudian pilih OK. Hasil SPSS dari uji Kolmogorov-Smirnov diperlihatkan dalam Tabel 9.2. Berdasarkan Tabel 9.2, diketahui nilai probabilitas dari uji Kolmogorov-Smirnov adalah 0,961 . Karena nilai probabilitas tersebut lebih besar dibandingkan tingkat signifikansi $\alpha=5 \%$, maka disimpulkan bahwa asumsi normalitas data dari selisih pasangan pengamatan (D) dipenuhi.

Perhatikan bahwa asumsi normalitas telah dipenuhi, selanjutnya akan digunakan uji kesamaan rata-rata dari dua populasi untuk data berpasangan dan saling berhubungan dengan uji $t$ untuk menguji ada tidaknya pengaruh yang signifikan secara statistika pada penggunaan obat $A$ terhadap jumlah denyut jantung per-menit pada manusia. 


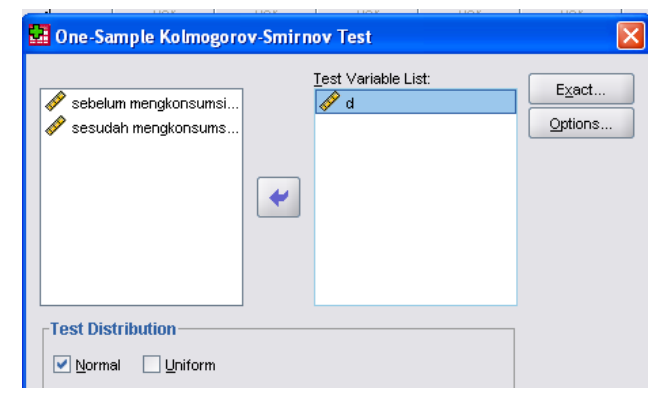

Tabel 9.2

Gambar 9.6

Pilih Analyze $=>$ Compare Means $=>$ Paired Sample T Test, sehingga muncul kotak dialog Paired-Samples T Test (Gambar 9.7). Masukkan variabel Y (sesudah) pada kotak Variable 1 dan masukkan variabel X (sebelum) pada kotak Variable2 (Gambar 9.7). Kemudian pilih OK, sehingga diperoleh hasil SPSS seperti pada Tabel 9.3 dan 9.4.

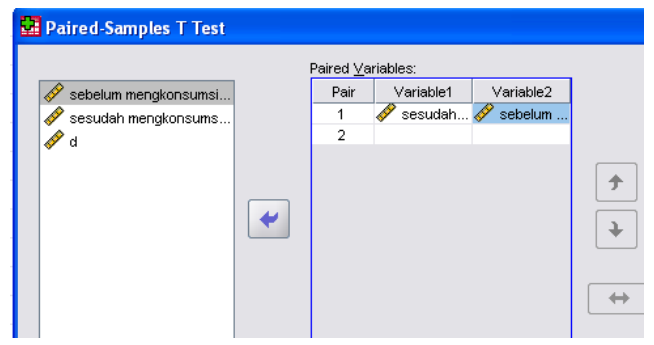

Gambar 9.7
Tabel 9.3

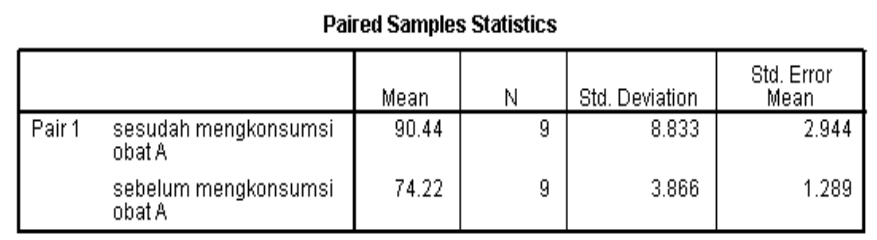

Tabel 9.4

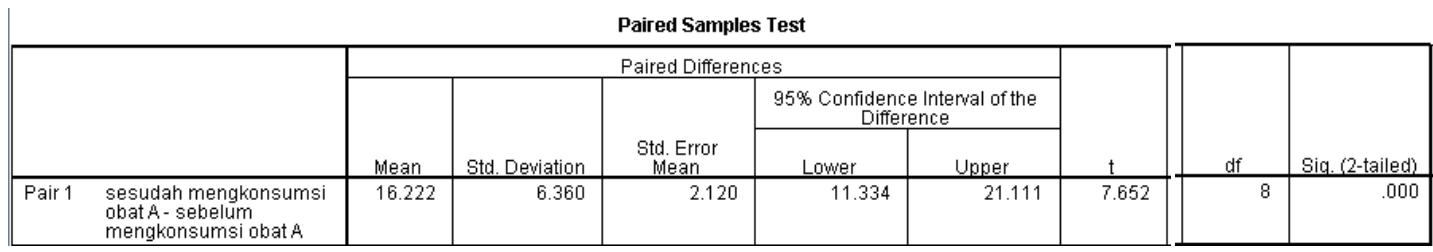

Berdasarkan Tabel 9.3, yakni Paired Samples Statistics, secara rata-rata (Mean) terjadi peningkatan terhadap jumlah denyut jantung setelah mengkonsumsi obat A. Hal ini terlihat bahwa nilai rata-rata jumlah denyut jantung sebelum mengkonsumsi obat $A$ sebanyak 74,22 kali per-menit dan setelah mengkonsumsi obat $A$ sebanyak 90,44 kali per-menit. Hal ini mengindikasikan terdapat pengaruh yang cukup signifikan dalam hal jumlah denyut jantung, sebelum dan sesudah mengkonsumsi obat $A$.

Selanjutnya perhatikan Tabel 9.4, yakni Paired Samples Test. Diketahui nilai statistik dari uji $t$ adalah 7,652. Diketahui derajat bebas $(d f)$ bernilai 8 . Nilai kritis $t$ dengan derajat bebas 8 dan tingkat signifikansi $5 \%$ adalah $\pm 2,306$. Berikut aturan pengambilan keputusan terhadap hipotesis berdasarkan uji $t$.

$$
\begin{aligned}
& \text { Jika }\left|t_{\text {hitung }}\right| \leq\left|t_{\text {kritis }}\right| \text {, maka } H_{0} \text { diterima dan } H_{1} \text { ditolak. } \\
& \text { Jika }\left|t_{\text {hitung }}\right|>\left|t_{\text {kritis }}\right| \text {, maka } H_{0} \text { ditolak dan } H_{1} \text { diterima. }
\end{aligned}
$$




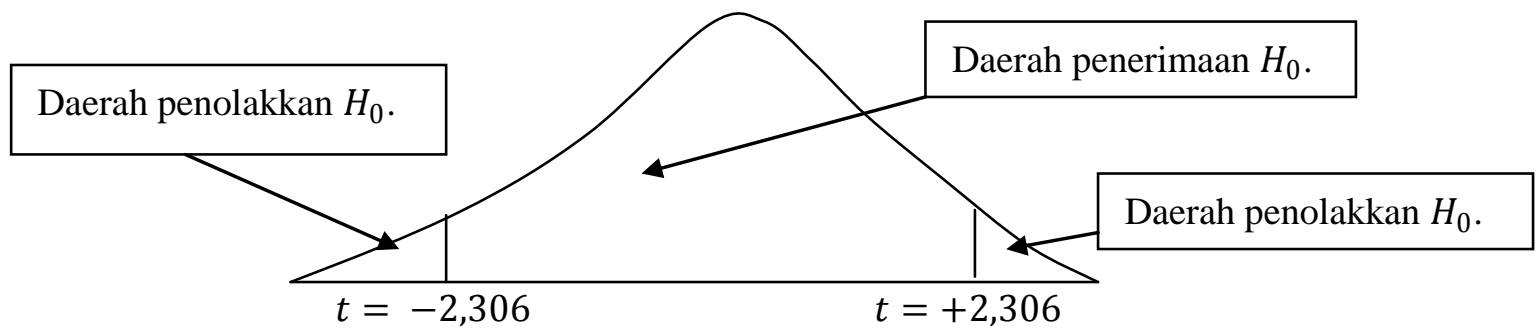

Perhatikan bahwa karena $\left|t_{\text {hitung }}\right|>\left|t_{\text {kritis }}\right|$, yakni 7,652 > 2,306, maka disimpulkan bahwa hipotesis nol ditolak dan hipotesis alternatif diterima. Hal ini berarti terdapat pengaruh yang signifikan secara statistika dalam hal jumlah denyut jantung, sebelum dan sesudah mengkonsumsi obat $A$ pada tingkat signifikansi $5 \%$.

Pengambilan keputusan terhadap hipotesis juga dapat dilakukan dengan menggunakan nilai probabilitas dari uji $t$. Nilai probabilitas dari uji $t$ dibandingkan dengan tingkat signifikansi yang digunakan. Berikut aturan pengambilan keputusan terhadap hipotesis berdasarkan pendekatan nilai probabilitas.

Jika nilai probabilitas $\geq$ tingkat signifikansi, maka $H_{0}$ diterima dan $H_{1}$ ditolak. Jika nilai probabilitas < tingkat signifikansi, maka $H_{0}$ ditolak dan $H_{1}$ diterima.

Diketahui nilai probabilitas (Sig. (2-tailed)) dari uji $t$ adalah 0,000 . Karena nilai probabilitas tersebut lebih kecil dibandingkan tingkat signifikansi $\alpha=0,05$, maka hipotesis nol ditolak dan hipotesis alternatif diterima. Hal ini berarti terdapat pengaruh yang signifikan secara statistika dalam hal jumlah denyut jantung, sebelum dan sesudah mengkonsumsi obat $A$ pada tingkat signifikansi $5 \%$.

\section{Ují Kesamaan Rata-Rata dari Dua Populasi yang Tidak Berhubungan dengan Asumsi Varians yang Sama ( $t$ Test for Independent Populations with Assumption $\sigma_{1}^{2}=\sigma_{2}^{2}$ )}

Misalkan seorang peneliti akan meneliti mengenai ada tidaknya perbedaan (secara rata-rata) nilai ujian matematika dasar antara mahasiswa laki-laki dan perempuan. Untuk keperluan penelitian, peneliti tersebut mengambil sampel sebanyak 20 nilai ujian matakuliah matematika dasar yang terdiri dari 10 nilai ujian mahasiswa laki-laki dan 10 nilai ujian mahasiswa perempuan. Data yang telah dikumpulkan disajikan dalam Tabel 9.5. Peneliti akan menguji apakah terdapat perbedaan (secara rata-rata) yang signifikan secara statistika dari nilai ujian matematika dasar antara mahasiswa laki-laki dan perempuan dengan tingkat signifikansi $5 \%$.

Dalam uji kesamaan rata-rata dari dua populasi yang tidak berhubungan dengan asumsi varians yang sama, diasumsikan populasi pertama dan populasi kedua berdistribusi normal. Untuk menguji apakah suatu sampel yang diteliti berasal dari populasi yang berdistribusi normal, dapat digunakan pendekatan grafik, yakni $P-P$ plot (probability-probability plot) dalam SPSS. Pada pendekatan P-P plot, jika titik-titik (dots) menyebar jauh (menyebar jauh berliku-liku pada garis diagonal seperti ular) dari garis diagonal, maka diindikasi asumsi normalitas tidak dipenuhi. Jika titik-titik menyebar sangat dekat pada garis diagonal, maka asumsi normalitas dipenuhi. Bangun data pada Tabel 9.5 dalam SPSS seperti pada Gambar 9.8 . 
Tabel 9.5 (Data Fiktif)

\begin{tabular}{|c|c|c|c|}
\hline Nama Mahasiswa Laki-Laki & $X$ & Nama Mahasiswa Perempuan & $Y$ \\
\hline Ugi & 65 & Ulan & 85 \\
\hline Mifdhal & 68 & Fitri & 75 \\
\hline Iqbal & 70 & Evelin & 75 \\
\hline Alan & 80 & Melda & 80 \\
\hline John & 75 & Dina & 75 \\
\hline Andre & 72 & Suci & 75 \\
\hline Ridho & 65 & Febri & 75 \\
\hline Hanafi & 60 & Oshin & 80 \\
\hline Romi & 88 & Wilya & 90 \\
\hline Hasoloan & 70 & Windy & 85 \\
\hline
\end{tabular}

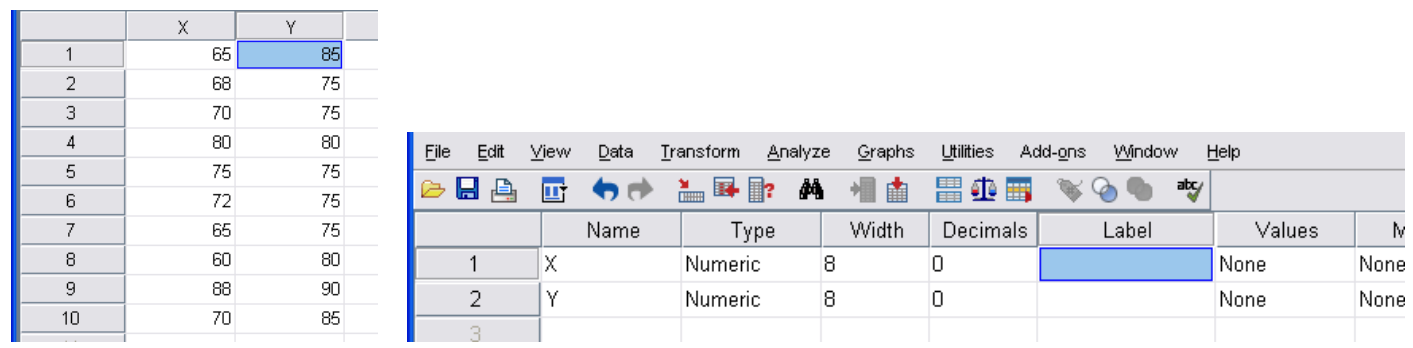

\section{Gambar 9.8}

Selanjutnya pilih Analyze $=>$ Descriptive Statistics $\Rightarrow>P-P$ Plots, sehingga muncul kotak dialog P-P Plots (Gambar 9.9). Masukkan variabel $\mathbf{X}$ dan $\mathbf{Y}$ pada kotak Variables. Pada Test Distribution pilih Normal. Kemudian pilih OK. Grafik P-P Plots diperlihatkan pada Gambar 9.10 dan Gambar 9.11. Gambar 9.10 merupakan grafik untuk variabel X, sedangkan Gambar 9.11 merupakan grafik untuk variabel Y. Perhatikan bahwa pada kedua grafik tersebut, titiktitik menyebar sangat dekat pada garis diagonal, maka disimpulkan bahwa asumsi normalitas dari kedua populasi dipenuhi.

Selain pendekatan grafik, dapat juga digunakan pendekatan uji Kolmogorov-Smirnov untuk menguji asumsi normalitas. Pilih Analyze $\Rightarrow$ Nonparametric Tests $\Rightarrow>1$-Sample $K-S$, sehingga muncul kotak dialog One-Sample Kolmogorov-Smirnov Test (Gambar 9.12). Pada kotak dialog One-Sample Kolmogorov-Smirnov Test, masukkan variabel $\mathbf{X}$ dan $\mathbf{Y}$ pada kotak Test Variable List. Pada Test Distribution pilih Normal. Kemudian pilih OK. Hasil SPSS dari uji Kolmogorov-Smirnov diperlihatkan dalam Tabel 9.6. Berdasarkan Tabel 9.6, diketahui nilai probabilitas dari uji Kolmogorov-Smirnov (Asymp. Sig. (2-tailed)) untuk variabel $\mathbf{X}$ dan Y masing-masing adalah 0,947 dan 0,356. Karena nilai-nilai probabilitas tersebut lebih besar dibandingkan tingkat signifikansi $\alpha=5 \%$, maka disimpulkan bahwa asumsi normalitas dipenuhi. Dengan kata lain, asumsi mengenai sampel $\mathbf{X}$ dan sampel $\mathbf{Y}$ berasal dari populasipopulasi yang berdistribusi normal diterima pada tingkat signifikansi 5\%. 
Normal P-P Plot of $X$

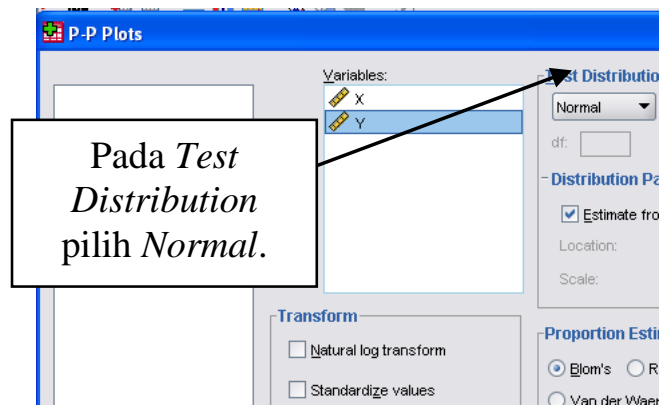

Gambar 9.9

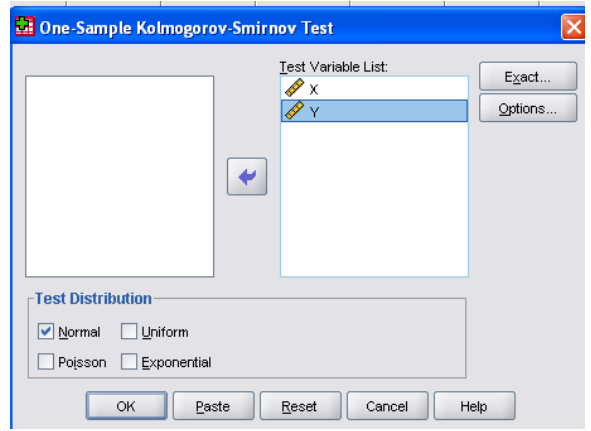

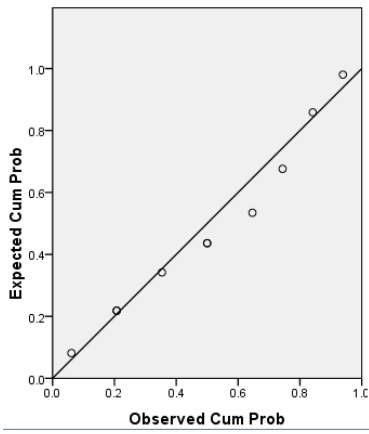

Gambar 9.10

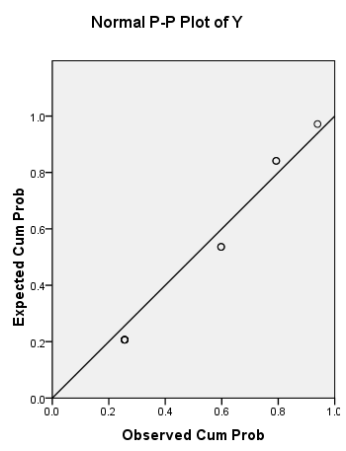

Gambar 9.11

Tabel 9.6

One-Sample Kolmogorov-Smirnow Test
\begin{tabular}{|ll|r|r|}
\hline & & \multicolumn{1}{|c|}{$\times$} & \multicolumn{1}{c|}{$Y$} \\
\hline N & & 10 & 10 \\
Normal Parameters ${ }^{\mathrm{a}, \mathrm{b}}$ & Mean & 71.30 & 79.50 \\
& Std. Deviation & 8.097 & 5.503 \\
Most Extreme Differences & Absolute & .166 & .293 \\
& Positive & .166 & .293 \\
& Negative & -.118 & -.207 \\
Kolmogorow-Smirnov Z & & .524 & .927 \\
Asymp. Sig. (2-tailed) & & .947 & .356 \\
\hline
\end{tabular}

Gambar 9.12

\begin{tabular}{|c|c|c|}
\hline & nilai & jenis_kelamin \\
\hline 1 & 65 & 0 \\
\hline 2 & 68 & 0 \\
\hline 3 & 70 & 0 \\
\hline 4 & 80 & 0 \\
\hline 5 & 75 & 0 \\
\hline 6 & 72 & 0 \\
\hline 7 & 65 & 0 \\
\hline 8 & 60 & 0 \\
\hline 9 & 88 & 0 \\
\hline 10 & 70 & 0 \\
\hline
\end{tabular}

\begin{tabular}{|r|r|r|}
\hline & nilai & jenis_kelamin \\
\hline \hline 11 & 85 & 1 \\
\hline 12 & 75 & 1 \\
\hline 13 & 75 & 1 \\
\hline 14 & 80 & 1 \\
\hline 15 & 75 & 1 \\
\hline 16 & 75 & 1 \\
\hline 17 & 75 & 1 \\
\hline 18 & 80 & 1 \\
\hline 19 & 90 & 1 \\
\hline 20 & 85 & 1 \\
\hline 21 & & \\
\hline
\end{tabular}

\begin{tabular}{|c|c|c|}
\hline & nilai & jenis_kelamin \\
\hline 1 & 65 & laki-laki \\
\hline 2 & 68 & laki-laki \\
\hline 3 & 70 & laki-laki \\
\hline 4 & 80 & laki-laki [ \\
\hline 5 & 75 & laki-laki \\
\hline 6 & 72 & laki-laki \\
\hline 7 & 65 & laki-laki \\
\hline 8 & 60 & laki-laki \\
\hline 9 & 88 & laki-laki \\
\hline 10 & 70 & laki-laki \\
\hline 11 & 85 & perempuan \\
\hline
\end{tabular}

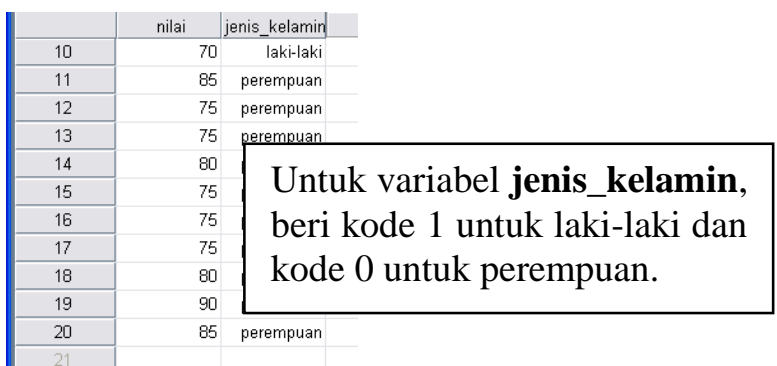

\section{Gambar 9.13}

Perhatikan bahwa asumsi normalitas dari dua populasi telah dipenuhi. Selanjutnya bangun data pada Tabel 9.5 seperti pada Gambar 9.13. Kemudian pilih Analyze $=>$ Compare Means => Independent-Samples T Test, sehingga muncul kotak dialog Independent-Sample T Test (Gambar 9.14). Masukkan variabel nilai pada kotak Test Variable(s) dan masukkan variabel jenis_kelamin pada kotak Grouping Variable (Gambar 9.14). Kemudian pilih Define Groups, sehingga muncul kotak dialog Define Groups (Gambar 9.15). Beri nilai 1 untuk Group 1 dan nilai 0 untuk Group 2. Selanjutnya pilih Continue dan OK, sehingga diperoleh hasil SPSS seperti pada Tabel 9.7 dan Tabel 9.8. 


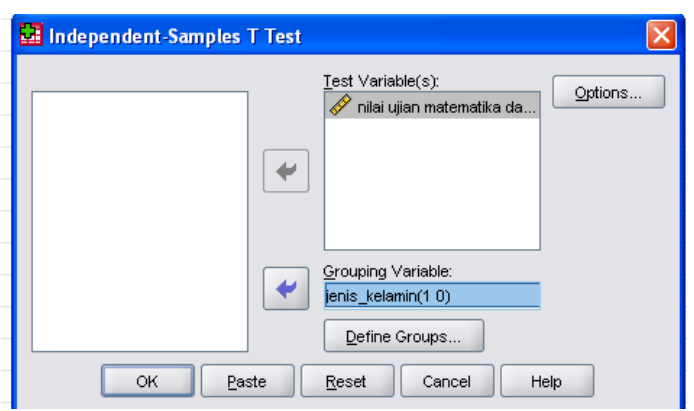

Gambar 9.14

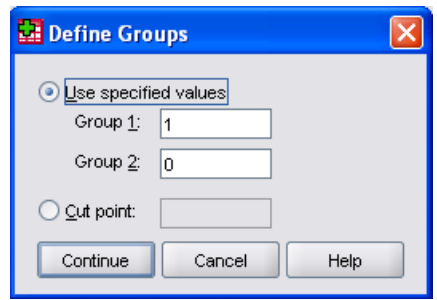

Gambar 9.15

Tabel 9.7

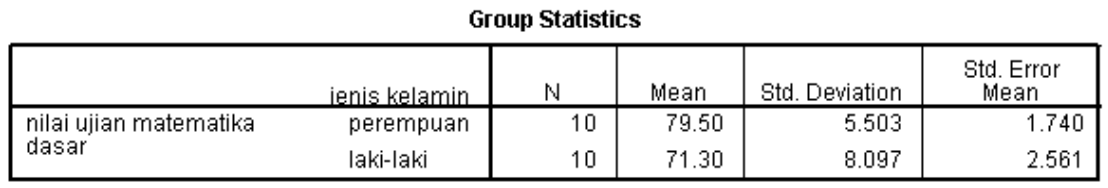

\begin{tabular}{|c|c|c|c|c|c|c|}
\hline \multirow{5}{*}{$\begin{array}{c}\text { Cukup perhatikan output } \\
\text { SPSS pada baris Equal } \\
\text { variances assumed. } \\
\text { Perhatikan nilai } \\
\text { probabilitas (Sig.) untuk } \\
\text { uji Levene } 0,438> \\
\alpha=0,05 \text {. Hal ini berarti } \\
\text { asumsi kesamaan varians } \\
\text { populasi dinenuhi. }\end{array}$} & \multicolumn{6}{|c|}{ Independent Samples Test } \\
\hline & & \multicolumn{2}{|c|}{$\begin{array}{l}\text { Levene's Test for Equality of } \\
\text { Variances }\end{array}$} & & & \\
\hline & & & & & & \\
\hline & & $\mathrm{F}$ & Siq. & $t$ & $d f$ & Siq (2-tailed) \\
\hline & $\begin{array}{l}\text { Equal variances } \\
\text { assumed } \\
\text { Equal variances not } \\
\text { assumed }\end{array}$ & .629 & .438 & & $\begin{array}{r}18 \\
15.851\end{array}$ & $\begin{array}{l}.016 \\
.018\end{array}$ \\
\hline
\end{tabular}

Berdasarkan Tabel 9.7, yakni Group Statistics, secara rata-rata (Mean) nilai ujian matematika dasar mahasiswa perempuan lebih tinggi dibandingkan mahasiswa laki-laki. Hal ini terlihat bahwa nilai rata-rata nilai ujian matematika dasar mahasiswa laki-laki adalah 71,30, sedangkan pada mahasiswa perempuan 79,50. Hal ini mengindikasikan terdapat perbedaan (secara rata-rata) nilai ujian matematika dasar antara mahasiswa laki-laki dan perempuan.

Perhatikan bahwa selain asumsi normalitas, asumsi lain yang dikenakan adalah asumsi kesamaan varians, yakni sampel-sampel yang diteliti berasal dari populasi-populasi yang memiliki varians yang sama. Uji Levene dapat digunakan untuk menguji apakah sampelsampel yang diteliti berasal dari populasi-populasi yang memiliki varians yang sama. Hipotesis nol menyatakan sampel-sampel yang diambil berasal dari populasi-populasi yang memiliki varians yang sama, sedangkan hipotesis alternatif menyatakan paling tidak terdapat sepasang populasi yang memiliki varians yang berbeda. Dengan kata lain, varians populasi pertama berbeda dengan varians populasi kedua.

Untuk itu perhatikan Tabel 9.8, yakni Independent-Samples Test. Diketahui nilai statistik dari uji Levene adalah 0,629 (Perhatikan kolom $F$ ). Nilai kritis $F$ dengan derajat bebas pembilang $2-1=1$, derajat bebas penyebut $20-2=18$, dan tingkat signifikansi $5 \%$ adalah 4,41 .

Berikut aturan pengambilan keputusan terhadap hipotesis berdasarkan uji Levene. 
Jika nilai statistik dari uji Levene $\leq F_{k r i t i s}$, maka $H_{0}$ diterima dan $H_{1}$ ditolak. jika nilai statistik dari uji Levene $>F_{\text {kritis }}$, maka $H_{0}$ ditolak dan $H_{1}$ diterima.

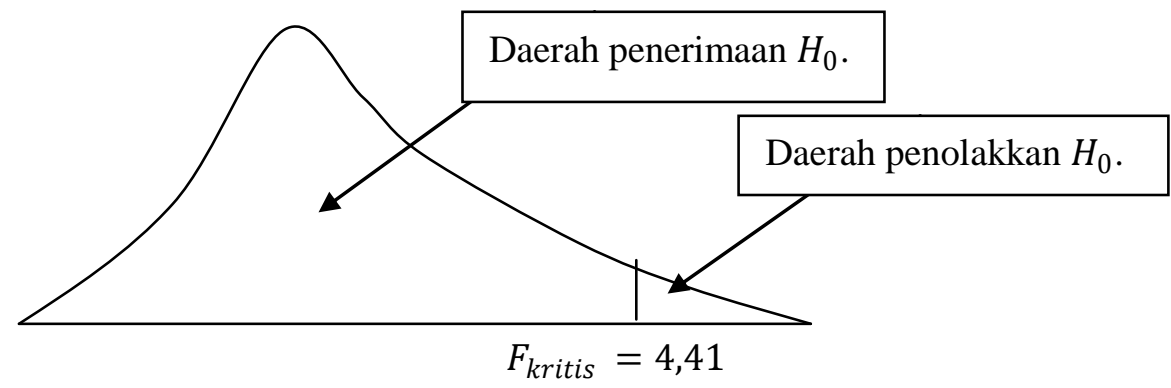

Perhatikan bahwa karena nilai statistik dari uji Levene, yakni 0,629, lebih kecil dibandingkan nilai kritis $F$, yakni 4,41, maka hipotesis nol diterima dan hipotesis alternatif ditolak. Hal ini berarti asumsi kesamaan varians populasi dipenuhi pada tingkat signifikansi $5 \%$.

Pengambilan keputusan terhadap hipotesis juga dapat digunakan pendekatan nilai probabilitas dari uji Levene. Nilai probabilitas tersebut dibandingkan dengan tingkat signifikansi $(\alpha)$. Berikut aturan pengambilan keputusan terhadap hipotesis.

Jika nilai probabilitas $\geq \alpha$, maka $H_{0}$ diterima dan $H_{1}$ ditolak. Jika nilai probabilitas $<\alpha$, maka $H_{0}$ ditolak dan $H_{1}$ diterima.

Diketahui nilai probabilitas dari uji Levene adalah 0,438. Karena nilai probabilitas tersebut lebih besar dibandingkan tingkat signifikansi $\alpha=5 \%$, maka hipotesis nol diterima dan hipotesis alternatif ditolak. Hal ini berarti asumsi kesamaan varians populasi dipenuhi pada tingkat signifikansi 5\%. Perhatikan bahwa asumsi normalitas dan kesamaan varians populasi telah dipenuhi. Selanjutnya perhatikan lagi Tabel 9.8, yakni Independent Samples Test. Diketahui nilai statistik dari uji $t$ adalah 2,649. Diketahui juga derajat bebas $(d f)$ bernilai 18 . Nilai kritis $t$ dengan derajat bebas 18 dan tingkat signifikansi $5 \%$ adalah $\pm 2,101$. Berikut aturan pengambilan keputusan terhadap hipotesis berdasarkan uji $t$.

$$
\begin{aligned}
& \text { Jika }\left|t_{\text {hitung }}\right| \leq\left|t_{\text {kritis }}\right| \text {, maka } H_{0} \text { diterima dan } H_{1} \text { ditolak. } \\
& \text { Jika }\left|t_{\text {hitung }}\right|>\left|t_{\text {kritis }}\right| \text {, maka } H_{0} \text { ditolak dan } H_{1} \text { diterima. }
\end{aligned}
$$

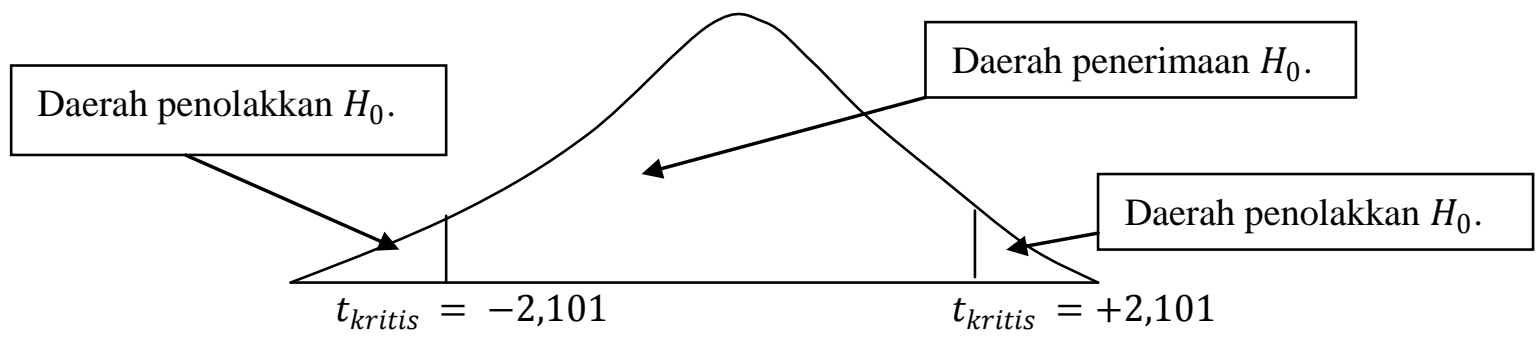

Perhatikan bahwa karena $\left|t_{\text {hitung }}\right|>\left|t_{\text {kritis }}\right|$, yakni 2,649 > 2,101, maka disimpulkan bahwa hipotesis nol ditolak dan hipotesis alternatif diterima. Hal ini berarti terdapat perbedaan (secara rata-rata) yang signifikan secara statistika dari nilai ujian matematika dasar antara mahasiswa laki-laki dan perempuan dengan tingkat signifikansi $5 \%$.

Pengambilan keputusan terhadap hipotesis juga dapat dilakukan dengan menggunakan nilai probabilitas dari uji $t$. Nilai probabilitas dari uji $t$ dibandingkan dengan tingkat signifikansi 
yang digunakan. Berikut aturan pengambilan keputusan terhadap hipotesis berdasarkan nilai probabilitas.

Jika nilai probabilitas $\geq$ tingkat signifikansi, maka $H_{0}$ diterima dan $H_{1}$ ditolak. Jika nilai probabilitas < tingkat signifikansi, maka $H_{0}$ ditolak dan $H_{1}$ diterima.

Diketahui nilai probabilitas (Sig. (2-tailed)) dari uji $t$ adalah 0,016. Karena nilai probabilitas tersebut lebih kecil dibandingkan tingkat signifikansi $\alpha=0,05$, maka hipotesis nol ditolak dan hipotesis alternatif diterima. Hal ini berarti terdapat perbedaan (secara rata-rata) yang signifikan secara statistika dari nilai ujian matematika dasar antara mahasiswa laki-laki dan perempuan dengan tingkat signifikansi $5 \%$.

\section{Uji Kesamaan Rata-Rata dari Dua Populasi yang Tidak Berhubungan dengan Asumsi Varians Berbeda (t Test for Independent Populations with Assumption $\sigma_{1}^{2} \neq \sigma_{2}^{2}$ )}

Misalkan seorang peneliti akan meneliti mengenai ada tidaknya perbedaan nilai ujian matakuliah matematika dasar antara mahasiswa laki-laki dan mahasiswa perempuan. Untuk keperluan penelitian, peneliti tersebut mengambil sampel sebanyak 20 nilai ujian matakuliah matematika dasar yang terdiri dari 10 nilai ujian mahasiswa laki-laki dan 10 nilai ujian mahasiswa perempuan. Data yang telah dikumpulkan disajikan dalam Tabel 9.9. Peneliti akan menguji apakah terdapat perbedaan (secara rata-rata) yang signifikan secara statistika dari nilai ujian matematika dasar antara mahasiswa laki-laki dan perempuan dengan tingkat signifikansi $5 \%$.

Tabel 9.9 (Data Fiktif)

\begin{tabular}{|c|c|c|c|}
\hline Nama Mahasiswa Laki-laki & Nilai $(X)$ & Nama Mahasiswa Perempuan & Nilai Ujian $(Y)$ \\
\hline Ugi & 70 & Ulan & 90 \\
\hline Mifdhal & 71 & Fitri & 91 \\
\hline Iqbal & 72 & Evelin & 92 \\
\hline Alan & 70 & Melda & 93 \\
\hline John & 71 & Dina & 94 \\
\hline Andre & 72 & Suci & 95 \\
\hline Ridho & 70 & Febri & 86 \\
\hline Hanafi & 70 & Oshin & 97 \\
\hline Romi & 71 & Wilya & 98 \\
\hline Hasoloan & 72 & Windy & 100 \\
\hline
\end{tabular}

Langkah-langkah yang dilakukan sama dengan langkah-langkah pada uji kesamaan rata-rata dari dua populasi yang tidak berhubungan dengan asumsi varians yang sama. Berikut disajikan output SPSS untuk uji normalitas dengan pendekatan P-P Plot (Gambar 9.16 dan Gambar 9.17) dan uji Kolmogorov-Smirnov (Tabel 9.10). Berdasarkan Gambar 9.16, Gambar 9.17, dan Tabel 9.10 memperlihatkan bahwa sampel $\mathbf{X}$ dan $\mathbf{Y}$ berasal dari populasi-populasi berdistribusi normal. 


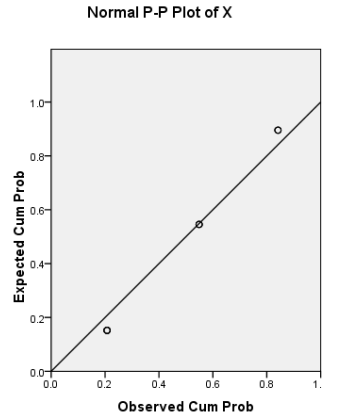

Gambar 9.16

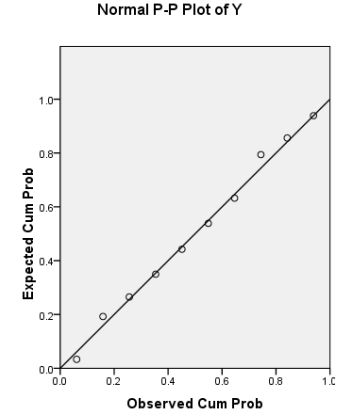

Tabel 9.10

\begin{tabular}{|c|c|c|c|}
\hline \multicolumn{4}{|c|}{ One-Sample Kolmogorov-Smirnov Test } \\
\hline & & $x$ & $\bar{Y}$ \\
\hline $\bar{N}$ & & 10 & 10 \\
\hline \multirow[t]{2}{*}{ Normal Parameters ${ }^{a, \ldots b}$} & Mean & 70.90 & 93.60 \\
\hline & Std. Deviation & .876 & 4.142 \\
\hline \multirow[t]{3}{*}{ Most Extreme Differences } & Absolute & .248 & .094 \\
\hline & Positive & .248 & .068 \\
\hline & Negative & -.195 & -.094 \\
\hline Kolmogorow-Smirnov Z & & .784 & .298 \\
\hline Asymp. Sig. (2-tailed) & & .570 & 1.000 \\
\hline
\end{tabular}

Gambar 9.17

Tabel 9.11

\begin{tabular}{|c|c|c|c|c|c|}
\hline & jenis & $N$ & Mean & Std. Deviation & $\begin{array}{l}\text { Std. Error } \\
\text { Mean }\end{array}$ \\
\hline \multirow[t]{2}{*}{ nilai } & perempuan & 10 & 93.60 & 4.142 & 1.310 \\
\hline & laki-laki & 10 & 70.90 & .876 & .277 \\
\hline
\end{tabular}

Cukup perhatikan output SPSS pada baris Equal variances not assumed. Perhatikan nilai probabilitas (Sig.) untuk uji Levene $0,005<\alpha=0,05$. Hal ini berarti asumsi ketidaksamaan varians populasi dipenuhi.

Tabel 9.12

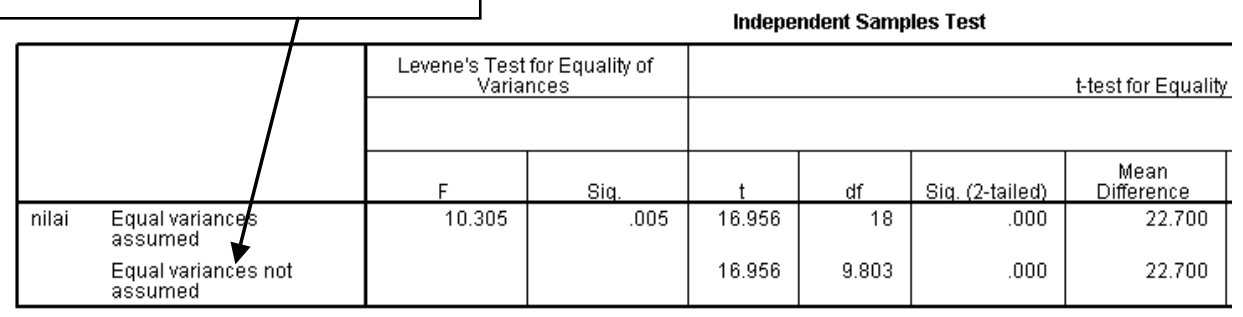

Berdasarkan Tabel 9.11, yakni Group Statistics, secara rata-rata (Mean) nilai ujian matematika dasar mahasiswa perempuan lebih tinggi dibandingkan mahasiswa laki-laki. Hal ini terlihat bahwa nilai rata-rata nilai ujian matematika dasar mahasiswa laki-laki adalah 70,90, sedangkan pada mahasiswa perempuan 93,60. Hal ini mengindikasikan terdapat perbedaan (secara rata-rata) nilai ujian matematika dasar antara mahasiswa laki-laki dan perempuan.

Perhatikan bahwa selain asumsi normalitas, asumsi lain yang dikenakan adalah asumsi ketidaksamaan varians populasi, yakni sampel-sampel yang diteliti berasal dari populasipopulasi yang memiliki varians yang berbeda. Uji Levene dapat digunakan untuk menguji apakah sampel-sampel yang diteliti berasal dari populasi-populasi yang memiliki varians yang berbeda. Hipotesis nol menyatakan sampel-sampel yang diambil berasal dari populasipopulasi yang memiliki varians yang sama, sedangkan hipotesis alternatif menyatakan paling tidak terdapat sepasang populasi yang memiliki varians yang berbeda. Dengan kata lain, varians populasi pertama berbeda dengan varians populasi kedua.

Untuk itu perhatikan Tabel 9.12, yakni Independent-Samples Test. Diketahui nilai statistik dari uji Levene adalah 10,305 (Perhatikan kolom $F$ ). Nilai kritis $F$ dengan derajat bebas pembilang $2-1=1$, derajat bebas penyebut $20-2=18$, dan tingkat signifikansi $5 \%$ 
adalah 4,41. Berikut aturan pengambilan keputusan terhadap hipotesis berdasarkan uji Levene.

Jika nilai statistik dari uji Levene $\leq F_{\text {kritis }}$, maka $H_{0}$ diterima dan $H_{1}$ ditolak. jika nilai statistik dari uji Levene $>F_{\text {kritis }}$, maka $H_{0}$ ditolak dan $H_{1}$ diterima.

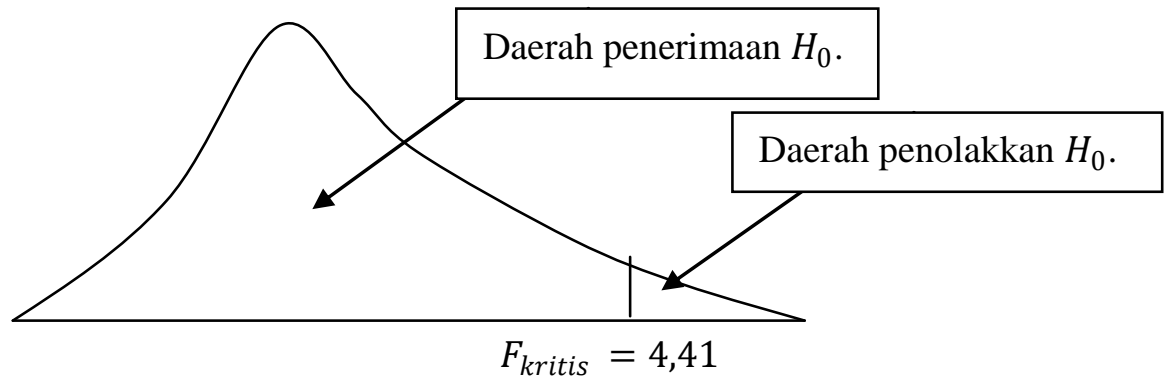

Perhatikan bahwa karena nilai statistik dari uji Levene, yakni 10,305, lebih besar dibandingkan nilai kritis $F$, yakni 4,41, maka hipotesis nol ditolak dan hipotesis alternatif diterima. Hal ini berarti asumsi ketidaksamaan varians populasi dipenuhi pada tingkat signifikansi $5 \%$.

Pengambilan keputusan terhadap hipotesis juga dapat digunakan pendekatan nilai probabilitas dari uji Levene. Nilai probabilitas tersebut dibandingkan dengan tingkat signifikansi $(\alpha)$. Berikut aturan pengambilan keputusan terhadap hipotesis.

Jika nilai probabilitas $\geq \alpha$, maka $H_{0}$ diterima dan $H_{1}$ ditolak. Jika nilai probabilitas $<\alpha$, maka $H_{0}$ ditolak dan $H_{1}$ diterima.

Diketahui nilai probabilitas dari uji Levene adalah 0,005. Karena nilai probabilitas tersebut lebih kecil dibandingkan tingkat signifikansi $\alpha=5 \%$, maka hipotesis nol ditolak dan hipotesis alternatif diterima. Hal ini berarti asumsi ketidaksamaan varians populasi dipenuhi pada tingkat signifikansi $5 \%$.

Perhatikan bahwa asumsi normalitas dan ketidaksamaan varians populasi telah dipenuhi. Selanjutnya perhatikan lagi Tabel 9.12, yakni Independent Samples Test. Diketahui nilai statistik dari uji $t$ adalah 16,956. Diketahui derajat bebas $(d f)$ bernilai $9,803 \cong 10$. Nilai kritis $t$ dengan derajat bebas 10 dan tingkat signifikansi 5\% adalah $\pm 2,228$. Berikut aturan pengambilan keputusan terhadap hipotesis berdasarkan uji $t$.

$$
\begin{aligned}
& \text { Jika }\left|t_{\text {hitung }}\right| \leq\left|t_{\text {kritis }}\right| \text {, maka } H_{0} \text { diterima dan } H_{1} \text { ditolak. } \\
& \text { Jika }\left|t_{\text {hitung }}\right|>\left|t_{\text {kritis }}\right| \text {, maka } H_{0} \text { ditolak dan } H_{1} \text { diterima. }
\end{aligned}
$$

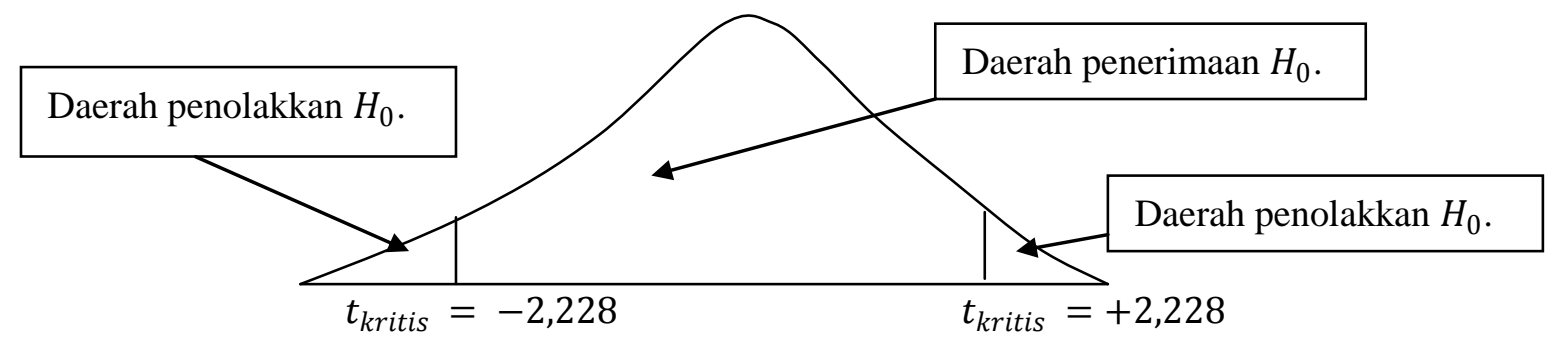


Perhatikan bahwa karena $\left|t_{\text {hitung }}\right|>\left|t_{\text {kritis }}\right|$, yakni $16,956>2,228$, maka disimpulkan bahwa hipotesis nol ditolak dan hipotesis alternatif diterima. Hal ini berarti terdapat perbedaan (secara rata-rata) yang signifikan secara statistika dari nilai ujian matematika dasar antara mahasiswa laki-laki dan perempuan dengan tingkat signifikansi 5\%. Pengambilan keputusan terhadap hipotesis juga dapat dilakukan dengan menggunakan nilai probabilitas dari uji $t$. Nilai probabilitas dari uji $t$ dibandingkan dengan tingkat signifikansi yang digunakan. Berikut aturan pengambilan keputusan terhadap hipotesis berdasarkan nilai probabilitas.

Jika nilai probabilitas $\geq$ tingkat signifikansi, maka $H_{0}$ diterima dan $H_{1}$ ditolak. Jika nilai probabilitas < tingkat signifikansi, maka $H_{0}$ ditolak dan $H_{1}$ diterima.

Diketahui nilai probabilitas (Sig. (2-tailed)) dari uji $t$ adalah 0,000. Karena nilai probabilitas tersebut lebih kecil dibandingkan tingkat signifikansi $\alpha=0,05$, maka hipotesis nol ditolak dan hipotesis alternatif diterima. Hal ini berarti terdapat perbedaan (secara rata-rata) yang signifikan secara statistika dari nilai ujian matematika dasar antara mahasiswa laki-laki dan perempuan dengan tingkat signifikansi $5 \%$. 


\section{PENYELESAIAN DALAM Minitab}

Uji Kesamaan Rata-Rata dari Dua Populasi untuk Data Berpasangan dan Saling Berhubungan dengan Uji $\mathbf{t}$ (Paired $t$ Test for Dependent Populations)

Bangun data dalam Minitab seperti pada Gambar 9.18. Pilih Stat $=>$ Basic Statistics $=>$ Paired $t$ (Gambar 9.19), sehingga muncul tampilan seperti pada Gambar 9.20. Pada Gambar 9.20, pilih/bulatkan Samples in columns, kemudian masukkan variabel Y pada First sample: dan masukkan variabel X pada Second sample:. Pilih OK, hasilnya seperti pada Gambar 9.21. Diketahui nilai statistik dari uji $t(\mathrm{~T})$ adalah 7,65 , sementara nilai probabilitas (P) adalah 0,000 .

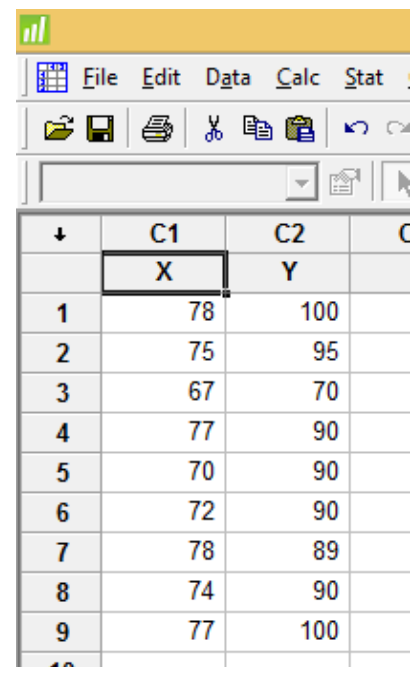

Gambar 9.18

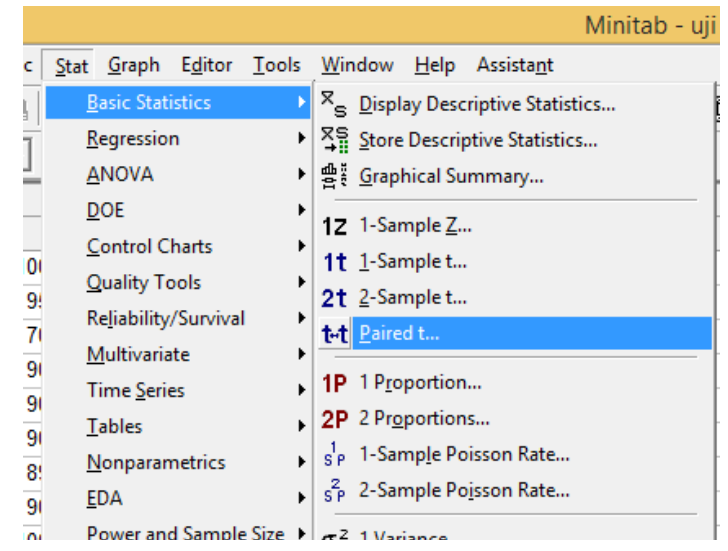

Gambar 9.19

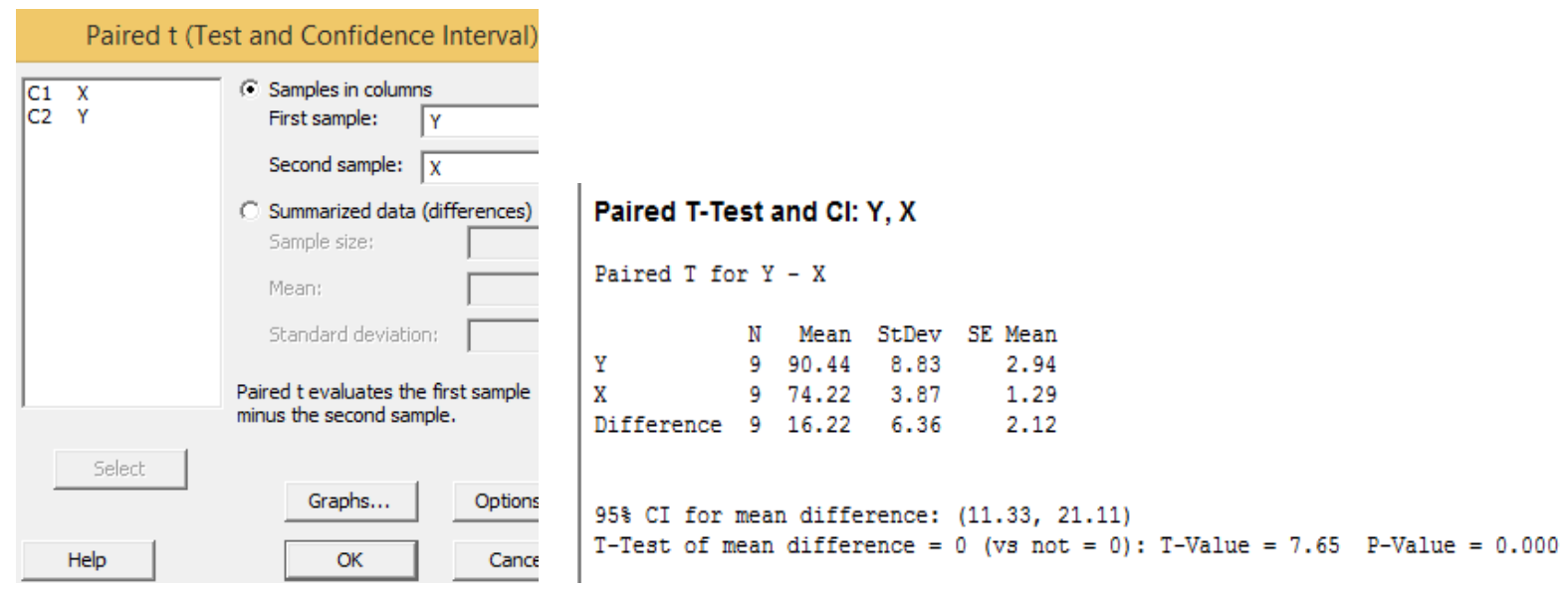

Gambar 9.20

Gambar 9.21 
Ují Kesamaan Rata-Rata dari Dua Populasi yang Tídak Berhubungan dengan Asumsi Varians yang Sama ( $t$ Test for Independent Populations with Assumption $\sigma_{1}^{2}=\sigma_{2}^{2}$ )

Bangun data dalam Minitab seperti pada Gambar 9.22. Pilih Stat $=>$ Basic Statistics $=>2$ Sample $t$ (Gambar 9.23), sehingga muncul tampilan seperti pada Gambar 9.24. Pada Gambar 9.24, pilih/bulatkan Samples in different columns, kemudian masukkan variabel Y pada First: dan masukkan variabel $\mathbf{X}$ pada Second: Pilih Assume equal variances, dan pilih OK. Hasilnya seperti pada Gambar 9.25. Diketahui nilai statistik dari uji $t$ (T) adalah 2,65, sementara nilai probabilitas (P) adalah 0,016. Diketahui juga nilai derajat bebas (DF) adalah 18.

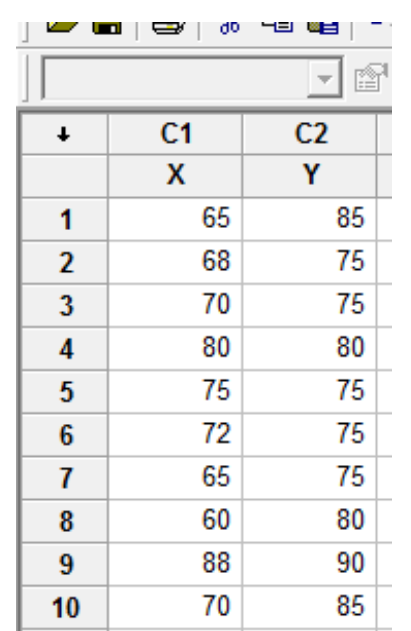

Gambar 9.22

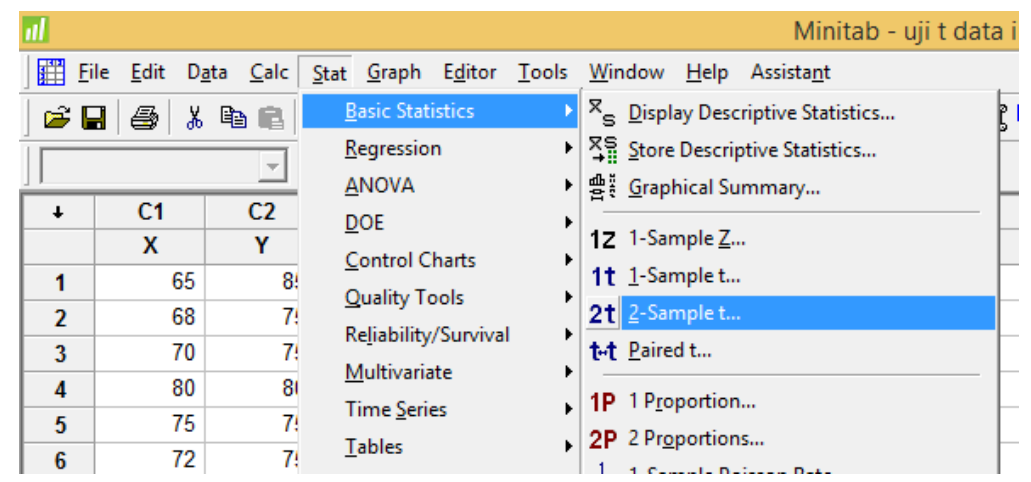

Gambar 9.23

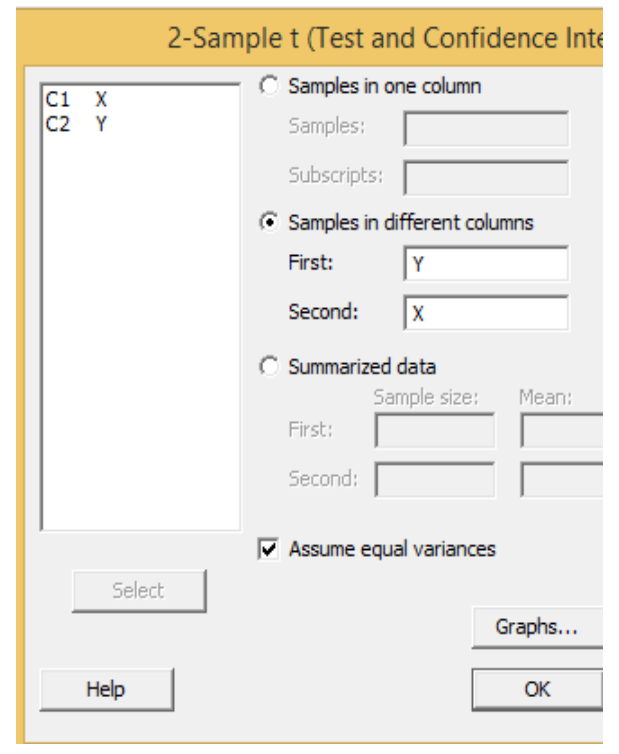

Gambar 9.24

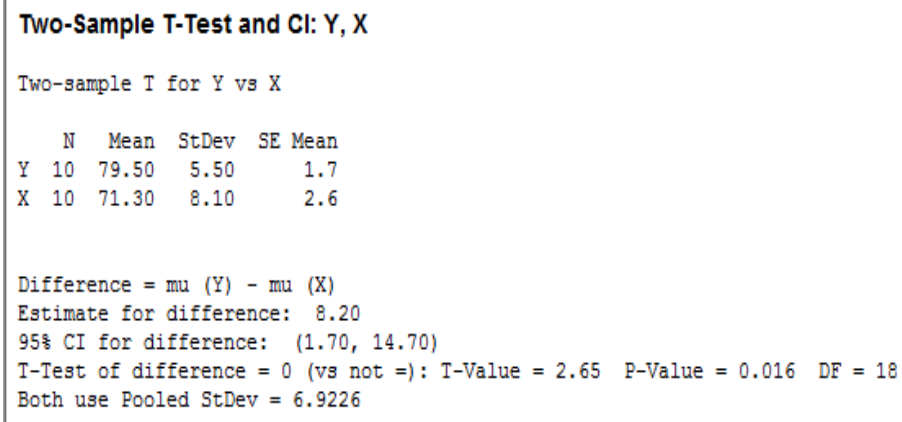

\section{Gambar 9.25}


Uji Kesamaan Rata-Rata dari Dua Populasi yang Tídak Berhubungan dengan Asumsi Varians Berbeda ( $t$ Test for Independent Populations with Assumption $\sigma_{1}^{2} \neq \sigma_{2}^{2}$ )

Bangun data dalam Minitab seperti pada Gambar 9.26. Pilih Stat $=>$ Basic Statistics $=>2$ Sample $t$ (Gambar 9.27), sehingga muncul tampilan seperti pada Gambar 9.28. Pada Gambar 9.28, pilih/bulatkan Samples in different columns, kemudian masukkan variabel Y pada First: dan masukkan variabel X pada Second: Pilih OK, hasilnya seperti pada Gambar 9.29. Diketahui nilai statistik dari uji $t(\mathrm{~T})$ adalah 16,96 , sementara nilai probabilitas (P) adalah 0,000. Diketahui juga nilai derajat bebas (DF) adalah 9 .

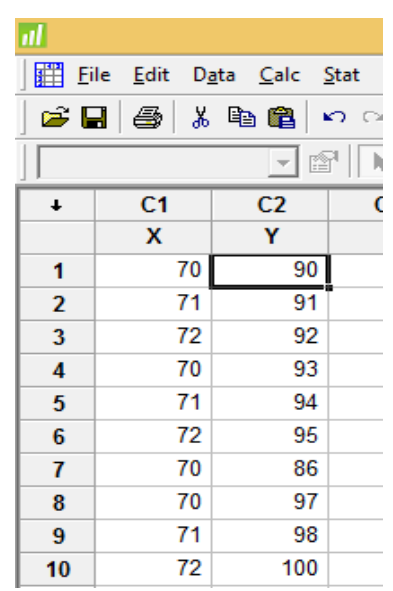

Gambar 9.26

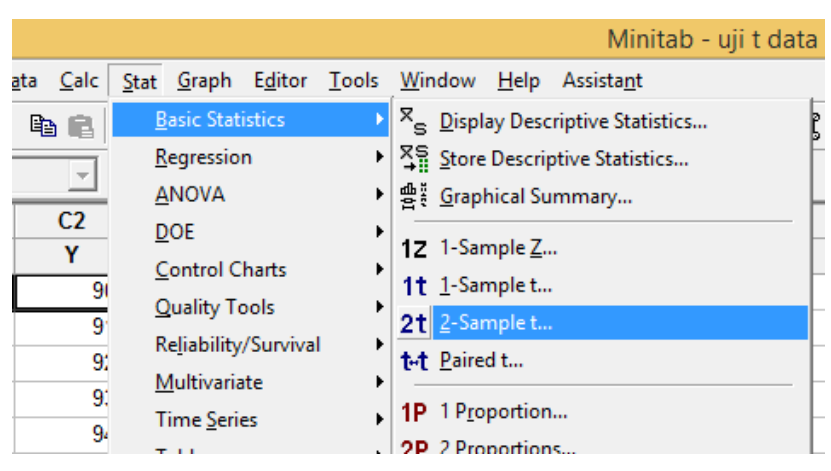

Gambar 9.27

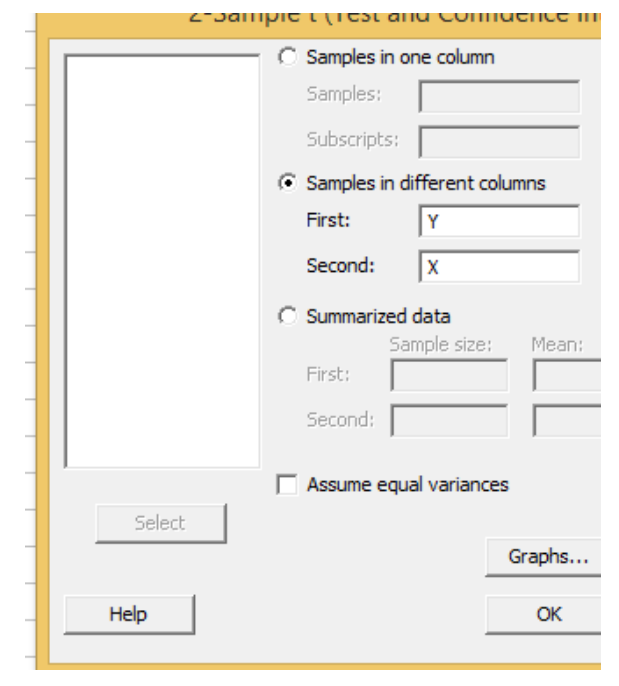

Gambar 9.28

\section{Gambar 9.29}




\section{PENYELESAIAN DALAM R}

\section{Uji Kesamaan Rata-Rata dari Dua Populasi untuk Data Berpasangan dan Saling Berhubungan dengan Uji $\mathrm{t}$ (Paired $t$ Test for Dependent Populations)}

Data terlebih dahulu dibuat dalam Microsoft Excel (Gambar 9.30) dan disimpan dengan format tipe .csv (Gambar 9.31). Ketik kode R seperti pada Gambar 9.32. Kemudian Compile dan pilih HTML. Hasilnya seperti pada Gambar 9.33 dan Gambar 9.34. Diketahui nilai statistik dari uji $t(\mathrm{~T})$ adalah 7,65, sementara nilai probabilitas $(\mathrm{P})$ adalah 0,000 . Diketahui nilai derajat bebas (DF) adalah 8. Hasil R, sama dengan hasil berdasarkan Minitab dan SPSS.

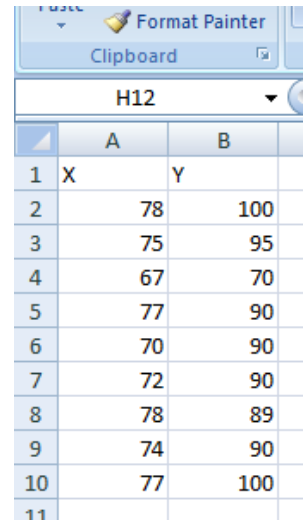

Gambar 9.30

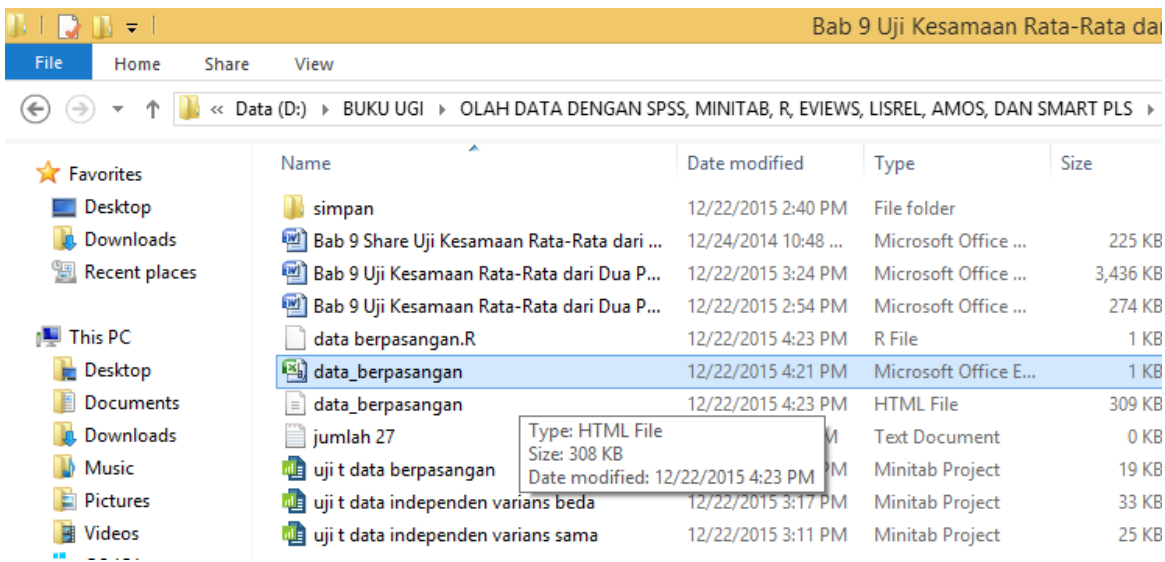

Gambar 9.31

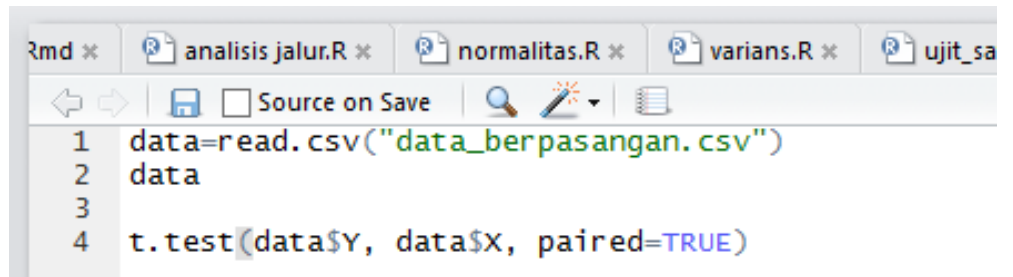

Gambar 9.32

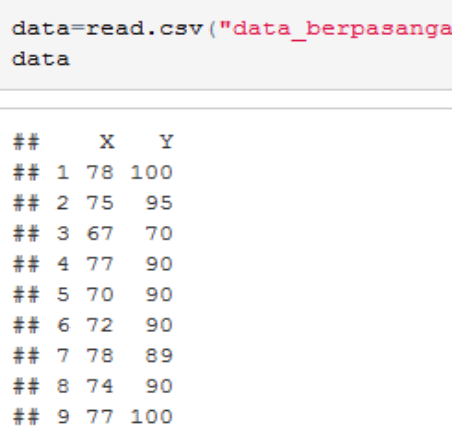

Gambar 9.33

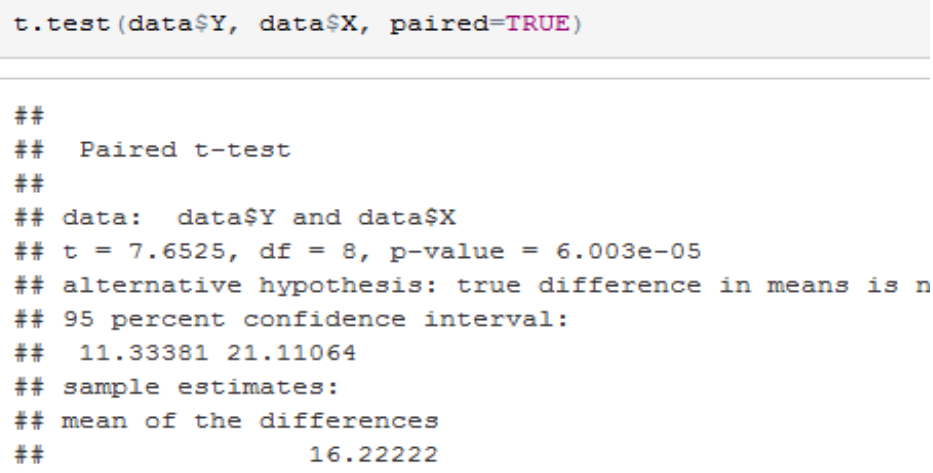


Uji Kesamaan Rata-Rata dari Dua Populasi yang Tídak Berhubungan dengan Asumsi Varians yang Sama ( $t$ Test for Independent Populations with Assumption $\sigma_{1}^{2}=\sigma_{2}^{2}$ )

Data terlebih dahulu dibuat dalam Microsoft Excel (Gambar 9.35) dan disimpan dengan format tipe .csv (Gambar 9.36). Ketik kode R seperti pada Gambar 9.37. Kemudian Compile dan pilih HTML. Hasilnya seperti pada Gambar 9.38 hingga Gambar 9.39. Diketahui nilai statistik dari uji $t(\mathrm{~T})$ adalah 2,6487, sementara nilai probabilitas (P) adalah 0,01633. Diketahui nilai derajat bebas (DF) adalah 18. Hasil R, sama dengan hasil berdasarkan Minitab dan SPSS.

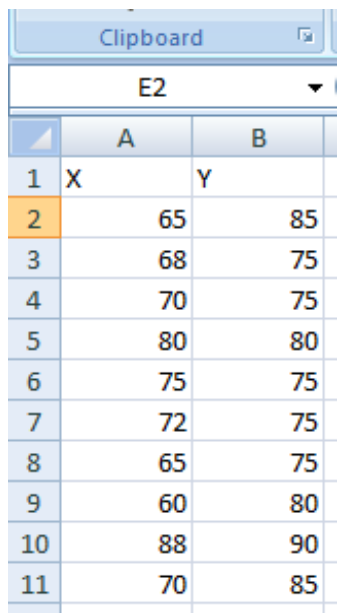

Gambar 9.35

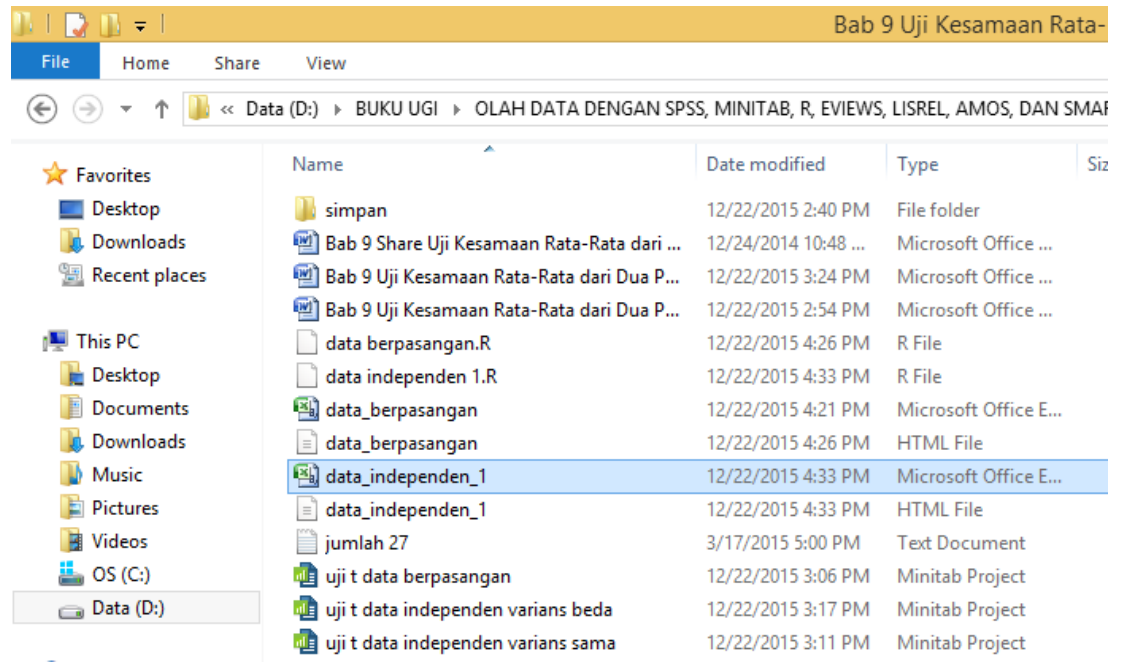

Gambar 9.36

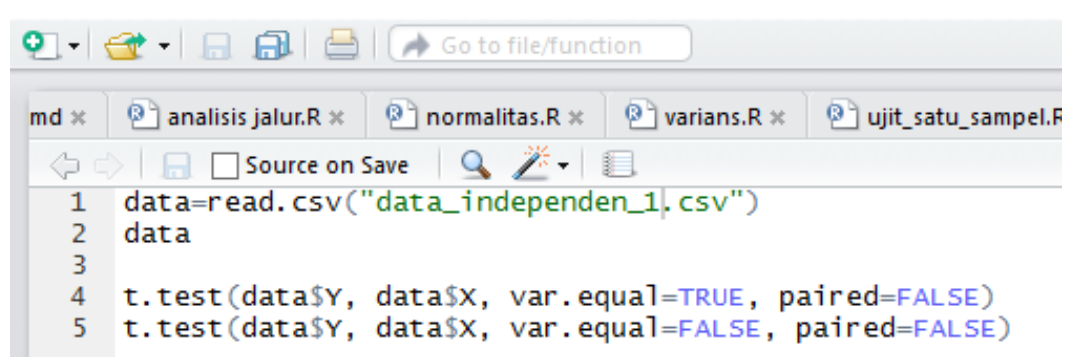

Gambar 9.37

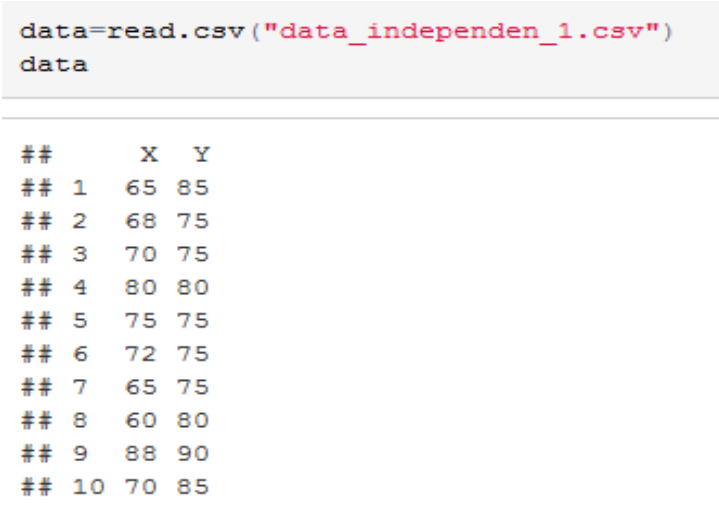

Gambar 9.38 


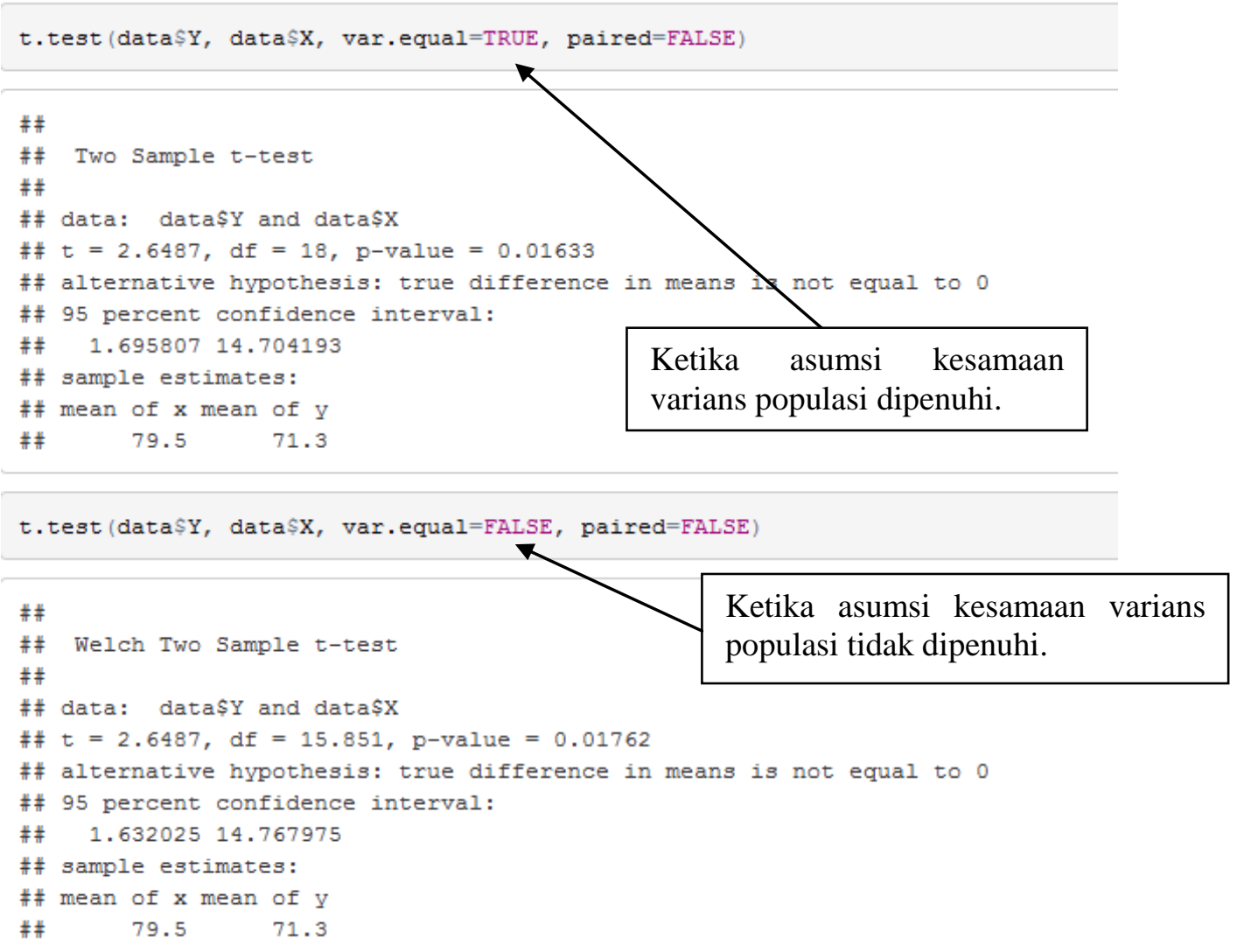

Gambar 9.39

\section{Ují Kesamaan Rata-Rata dari Dua Populasi yang Tídak Berhubungan dengan Asumsi Varians Berbeda ( $t$ Test for Independent Populations with Assumption $\sigma_{1}^{2} \neq \sigma_{2}^{2}$ )}

Data terlebih dahulu dibuat dalam Microsoft Excel (Gambar 9.40) dan disimpan dengan format tipe .csv (Gambar 9.41). Ketik kode R seperti pada Gambar 9.42. Kemudian Compile dan pilih HTML. Hasilnya seperti pada Gambar 9.43 hingga Gambar 9.44. Diketahui nilai statistik dari uji $t(\mathrm{~T})$ adalah 16,956 , sementara nilai probabilitas $(\mathrm{P})$ adalah 0,000 . Diketahui nilai derajat bebas (DF) adalah 9,8028.

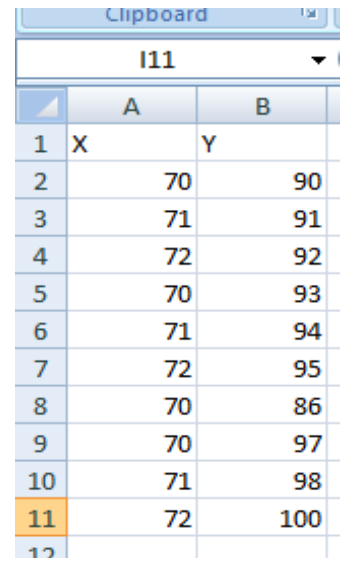

Gambar 9.40

\begin{tabular}{|c|c|c|c|}
\hline surm & 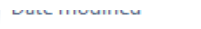 & ביבי & sac \\
\hline 13. simpan & 12/22/2015 2:40 PM & File folder & \\
\hline 띨] Bab 9 Share Uji Kesamaan Rata-Rata dari ... & $12 / 24 / 201410: 48 \ldots$ & Microsoft Office ... & $225 \mathrm{~KB}$ \\
\hline 띨] Bab 9 Uji Kesamaan Rata-Rata dari Dua P... & 12/22/2015 3:24 PM & Microsoft Office ... & $3,436 \mathrm{~KB}$ \\
\hline 漹 Bab 9 Uji Kesamaan Rata-Rata dari Dua P... & 12/22/2015 2:54 PM & Microsoft Office ... & $274 \mathrm{~KB}$ \\
\hline data berpasangan. $R$ & 12/22/2015 4:26 PM & R File & $1 \mathrm{~KB}$ \\
\hline data independen $1 . R$ & 12/22/2015 4:33 PM & R File & $1 \mathrm{~KB}$ \\
\hline$\square$ data independen $2 . R$ & 12/22/2015 4:37 PM & R File & $1 \mathrm{~KB}$ \\
\hline 㺼 data_berpasangan & 12/22/2015 4:21 PM & Microsoft Office E... & $1 \mathrm{~KB}$ \\
\hline E data_berpasangan & 12/22/2015 4:26 PM & HTML File & $309 \mathrm{~KB}$ \\
\hline 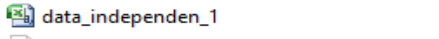 & 12/22/2015 4:33 PM & Microsoft Office E... & $1 \mathrm{~KB}$ \\
\hline E data_independen_1 & 12/22/2015 4:33 PM & HTML File & $310 \mathrm{~KB}$ \\
\hline 驲) data_independen_2 & 12/22/2015 4:37 PM & Microsoft Office E... & $1 \mathrm{~KB}$ \\
\hline jumlah 27 & 3/17/2015 5:00 PM & Text Document & $\mathrm{OKB}$ \\
\hline 贯 uji t data berpasangan & 12/22/2015 3:06 PM & Minitab Project & $19 \mathrm{~KB}$ \\
\hline uji t data independen varians beda & 12/22/2015 3:17 PM & Minitab Project & $33 \mathrm{~KB}$ \\
\hline 目 uji t data independen varians sama & 12/22/2015 3:11 PM & Minitab Project & $25 \mathrm{~KB}$ \\
\hline
\end{tabular}

Gambar 9.41 


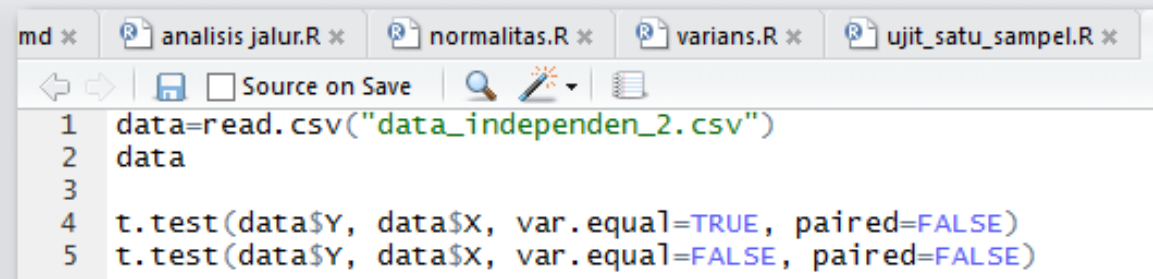

Gambar 9.42

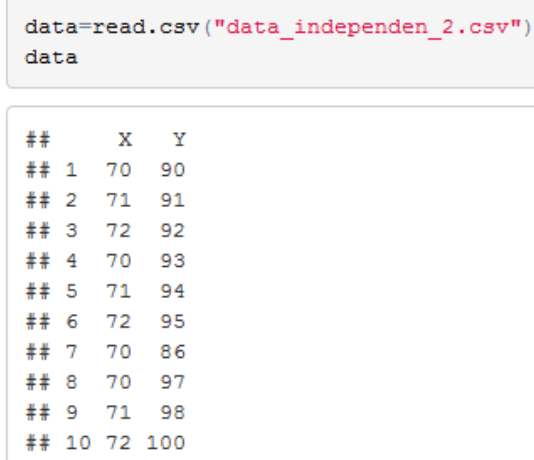

Gambar 9.43

t.test (datașY, data\$N, var.equal=TRUE, paired=FALSE)

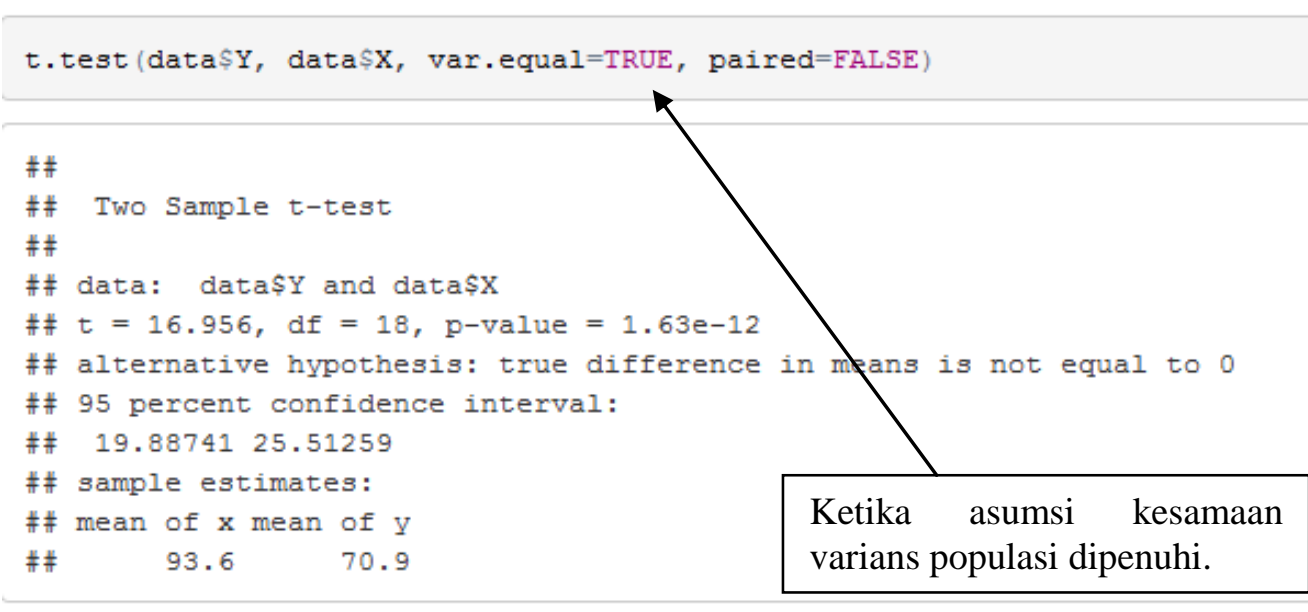

t. test (datașY, data $\$ \mathrm{X}$, var.equal=FALSE, paired=FALSE)

\#\# Welch Two Sample t-test

$\# \#$

Ketika asumsi kesamaan varians populasi tidak dipenuhi.

\#\# data: data\$Y and data\$X

$\# \# t=16.956$, df $=9.8028, p$-value $=1.374 \mathrm{e}-08$

\#\# alternative hypothesis: true difference in means is not equal to 0

\# 95 percent confidence interval:

\#\# $19.70895 \quad 25.69105$

\#\# sample estimates:

\#\# mean of $\mathrm{x}$ mean of $\mathrm{y}$

\#\# $\quad 93.6 \quad 70.9$

\section{Gambar 9.44}




\section{$S \mathcal{H A R E}$}

[1] Berikut akan dipaparkan perhitungan manual pada kasus uji kesamaan rata-rata dari dua populasi untuk data berpasangan dan saling berhubungan dengan uji $t$ (paired $t$ test for dependent populations). Data disajikan kembali pada Tabel 9.1.

\section{Tabel 9.1}

\begin{tabular}{|c|c|c|}
\hline Responden & X & Y \\
\hline 1 & 78 & 100 \\
\hline 2 & 75 & 95 \\
\hline 3 & 67 & 70 \\
\hline 4 & 77 & 90 \\
\hline 5 & 70 & 90 \\
\hline 6 & 72 & 90 \\
\hline 7 & 78 & 89 \\
\hline 8 & 74 & 90 \\
\hline 9 & 77 & 100 \\
\hline
\end{tabular}

Berikut akan dihitung standar deviasi dari data selisih pasangan pengamatan $s_{d}$.

Tabel 9.2

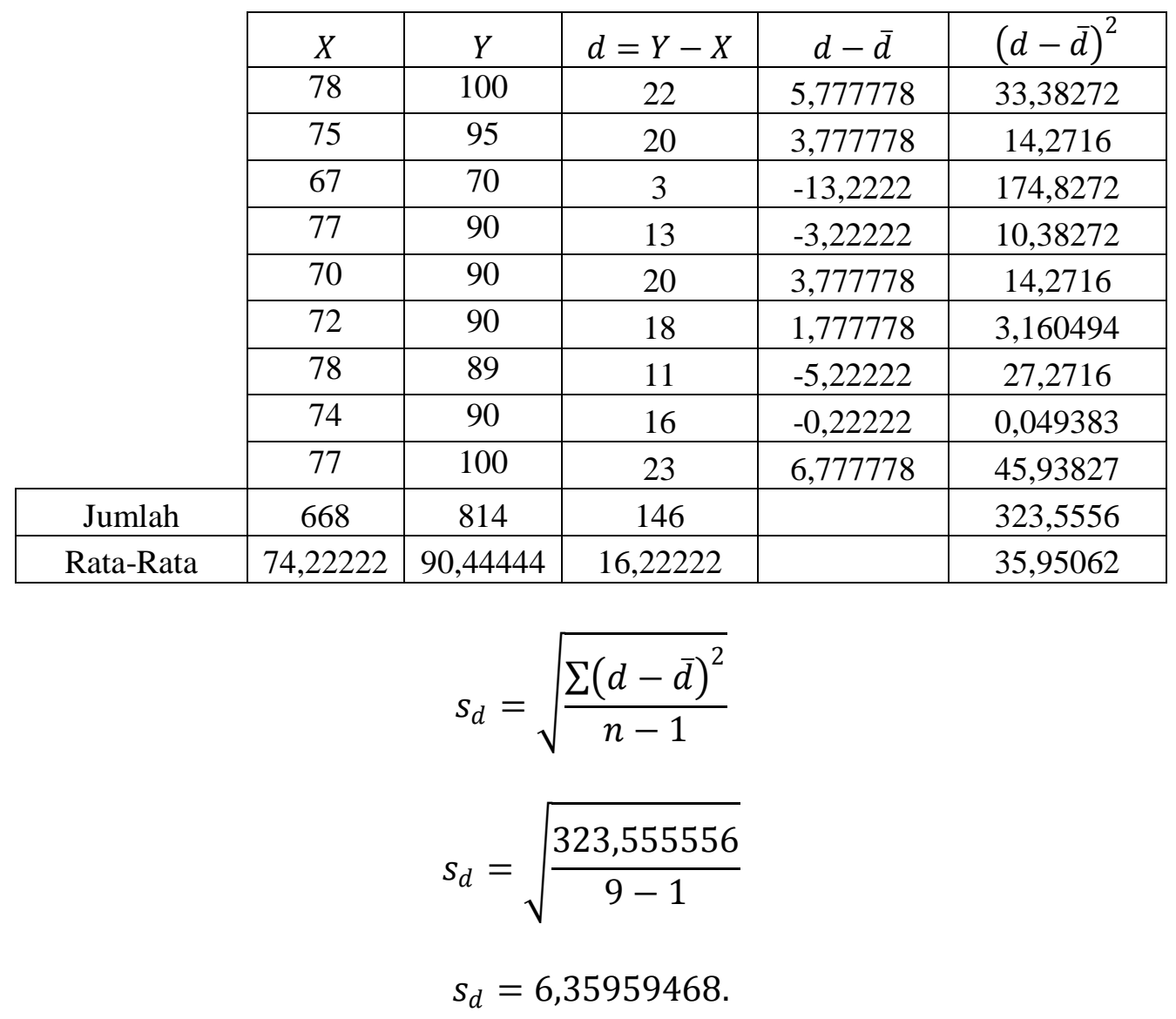


Berdasarkan perhitungan diperoleh nilai standar deviasi dari data selisih pasangan pengamatan, yakni $s_{d}=6,360$.

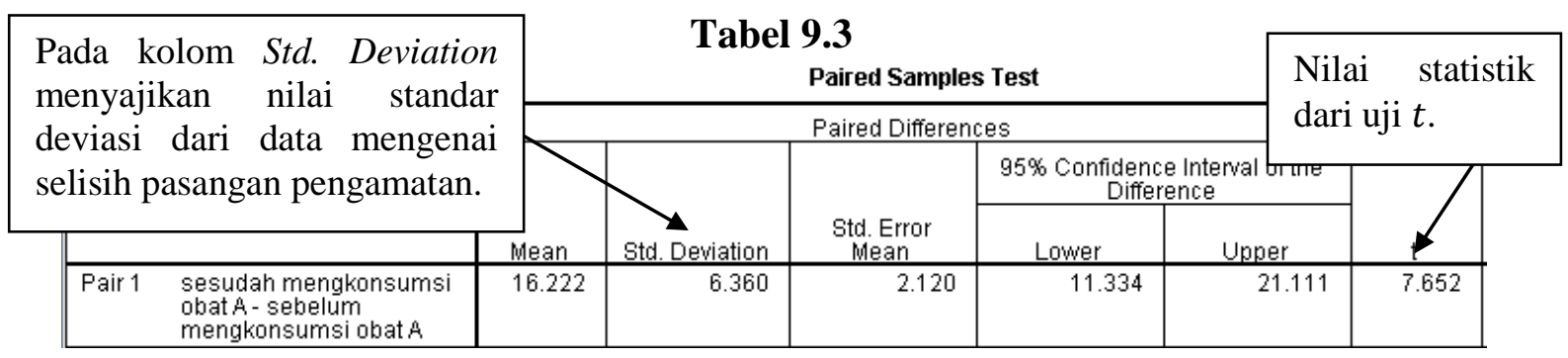

Selanjutnya akan dihitung nilai statistik dari uji $t$.

$$
\begin{gathered}
t=\frac{\bar{d}-\mu_{d}}{s_{d} / \sqrt{n}} \\
t=\frac{16,2222-0}{6,35959468 / \sqrt{9}} \\
t=7,652468821
\end{gathered}
$$

Berdasarkan perhitungan, nilai statistik dari uji $t$ adalah 7,652468821. Nilai statistik dari uji $t$ berdasarkan perhitungan SPSS dapat dilihat pada Tabel 9.3, kolom $t$.

[2] Berikut akan dipaparkan perhitungan manual pada kasus uji kesamaan rata-rata dari dua populasi yang tidak berhubungan (independent) dengan asumsi varians yang sama ( $t$ Test for independent populations with assumption $\sigma_{1}^{2}=\sigma_{2}^{2}$ ). Data disajikan kembali pada Tabel 9.4.

Tabel 9.4 (Data Fiktif)

\begin{tabular}{|c|c|c|c|}
\hline Nama Mahasiswa Laki-laki & $X$ & Nama Mahasiswa Perempuan & $Y$ \\
\hline Ugi & 65 & Ulan & 85 \\
\hline Mifdhal & 68 & Fitri & 75 \\
\hline Iqbal & 70 & Evelin & 75 \\
\hline Alan & 80 & Melda & 80 \\
\hline John & 75 & Dina & 75 \\
\hline Andre & 72 & Suci & 75 \\
\hline Ridho & 65 & Febri & 75 \\
\hline Hanafi & 60 & Oshin & 80 \\
\hline Romi & 88 & Wilya & 90 \\
\hline Hasoloan & 70 & Windy & 85 \\
\hline
\end{tabular}

Berikut akan dihitung $s_{p}^{2}$ (pooled estimator standard deviation for two samples). 


\section{Tabel 9.5}

\begin{tabular}{|c|c|c|}
\hline & $X$ & $Y$ \\
\hline & 65 & 85 \\
\hline & 68 & 75 \\
\hline & 70 & 75 \\
\hline & 80 & 80 \\
\hline & 75 & 75 \\
\hline & 72 & 75 \\
\hline & 65 & 75 \\
\hline & 60 & 80 \\
\hline & 88 & 90 \\
\hline & 70 & 85 \\
\hline Rata-Rata & 71,3 & 79,5 \\
\hline Standar Deviasi & 8,097325 & 5,502525 \\
\hline
\end{tabular}

Berdasarkan data pada Tabel 9.5, diketahui $\bar{X}=71,3 ; \bar{Y}=79,5 ; s_{X}=8,097325 ; s_{Y}=$ 5,502525, sehingga

$$
\begin{gathered}
s_{p}=\sqrt{\frac{s_{X}^{2}\left(n_{X}-1\right)+s_{Y}^{2}\left(n_{Y}-1\right)}{n_{X}+n_{Y}-2}} \\
s_{p}=\sqrt{\frac{(8,097325)^{2}(10-1)+(5,502525)^{2}(10-1)}{10+10-2}} \\
s_{p}=6,922588 .
\end{gathered}
$$

Nilai statistik dari uji $t$ dihitung sebagai berikut.

$$
\begin{gathered}
t=\frac{\bar{Y}-\bar{X}}{s_{p} \sqrt{\frac{1}{n_{X}}+\frac{1}{n_{Y}}}} \\
t=\frac{79,5-71,3}{6,922588 \sqrt{\frac{1}{10}+\frac{1}{10}}}=2,648685349 .
\end{gathered}
$$

\begin{tabular}{|c|c|c|c|c|c|c|}
\hline & & \multicolumn{2}{|c|}{$\begin{array}{c}\text { Levene's Test for Equality of } \\
\text { Variances }\end{array}$} & \multicolumn{3}{|c|}{$\begin{array}{l}\text { Kolom } t \text { menyajikan nilai } \\
\text { statistik dari uji } t \text {. }\end{array}$} \\
\hline & & E & & & df & Sig O-tailed \\
\hline $\begin{array}{l}\text { nilai ujian matematika } \\
\text { dasar }\end{array}$ & $\begin{array}{l}\text { Equal variances } \\
\text { assumed } \\
\text { Equal variances not } \\
\text { assumed }\end{array}$ & .629 & .438 & & $\begin{array}{r}18 \\
15.851\end{array}$ & $\begin{array}{l}.01 \varepsilon \\
.01 \varepsilon\end{array}$ \\
\hline
\end{tabular}

Nilai statistik dari uji $t$ berdasarkan perhitungan adalah 2,648685394.

Tabel 9.6 
[3] Berikut akan dipaparkan perhitungan manual pada kasus uji kesamaan rata-rata dari dua populasi yang tidak berhubungan dengan asumsi varians berbeda ( $t$ Test for independent populations with assumption $\sigma_{1}^{2} \neq \sigma_{2}^{2}$ ). Data disajikan kembali pada Tabel 9.7.

Tabel 9.7 (Data Fiktif)

\begin{tabular}{|c|c|c|c|}
\hline Nama Mahasiswa Laki-laki & Nilai $(X)$ & Nama Mahasiswa Perempuan & Nilai Ujian $(Y)$ \\
\hline Ugi & 70 & Ulan & 90 \\
\hline Mifdhal & 71 & Fitri & 91 \\
\hline Iqbal & 72 & Evelin & 92 \\
\hline Alan & 70 & Melda & 93 \\
\hline John & 71 & Dina & 94 \\
\hline Andre & 72 & Suci & 95 \\
\hline Ridho & 70 & Febri & 86 \\
\hline Hanafi & 70 & Oshin & 97 \\
\hline Romi & 71 & Wilya & 98 \\
\hline Hasoloan & 72 & Windy & 100 \\
\hline
\end{tabular}

Tabel 9.8

\begin{tabular}{|c|c|c|}
\cline { 2 - 3 } \multicolumn{1}{c|}{} & $X$ & $Y$ \\
\cline { 2 - 3 } & 70 & 90 \\
\cline { 2 - 3 } & 71 & 91 \\
\cline { 2 - 3 } & 72 & 92 \\
\cline { 2 - 3 } & 70 & 93 \\
\cline { 2 - 3 } & 71 & 94 \\
\cline { 2 - 3 } & 72 & 95 \\
\cline { 2 - 3 } & 70 & 86 \\
\cline { 2 - 3 } & 70 & 97 \\
\hline rata - rata & 71 & 98 \\
\hline standar deviasi & 0,875595 & 4,141927 \\
\cline { 2 - 3 } & 72 & 100 \\
\hline
\end{tabular}

Berikut akan dihitung nilai derajat bebas (degree of freedom).

$$
\begin{gathered}
\text { derajat bebas }=\frac{\left(\frac{s_{X}^{2}}{n_{X}}+\frac{s_{Y}^{2}}{n_{Y}}\right)^{2}}{\frac{\left(\frac{s_{X}^{2}}{n_{X}}\right)^{2}}{\left(n_{X}-1\right)}+\frac{\left(\frac{s_{Y}^{2}}{n_{Y}}\right)^{2}}{\left(n_{Y}-1\right)}} \\
\text { derajat bebas }=\frac{\frac{\left(\frac{0,875595^{2}}{10}+\frac{4,141927^{2}}{10}\right)^{2}}{\left(\frac{0,875595^{2}}{10}\right)^{2}}+\frac{\left(\frac{4,141927^{2}}{10}\right)^{2}}{(10-1)}}{\frac{(10-1)}{10-1)}}
\end{gathered}
$$$$
\text { derajat bebas }=9,802 \cong 10 \text {. }
$$ 
Tabel 9.9

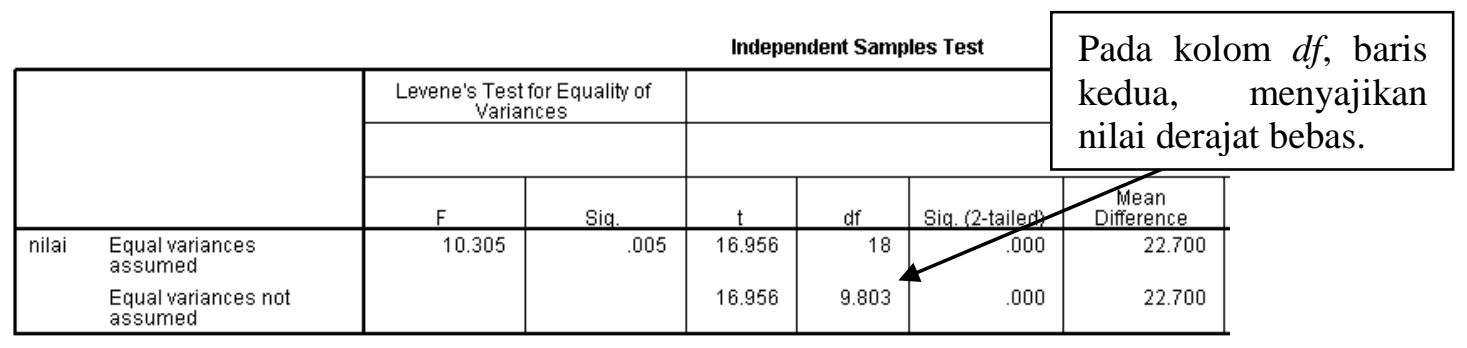

Selanjutnya akan dihitung nilai statistik dari uji $t$.

$$
\begin{gathered}
t=\frac{\bar{Y}-\bar{X}}{\sqrt{\frac{s_{X}^{2}}{n_{X}}+\frac{s_{Y}^{2}}{n_{Y}}}} \\
t=\frac{93,6-70,9}{\sqrt{\frac{(0,8755)^{2}}{10}+\frac{(4,141927)^{2}}{10}}} \\
t=16,9563 .
\end{gathered}
$$

Nilai statistik dari uji $t$ berdasarkan perhitungan adalah 16,9563. Nilai statistik dari uji $t$ berdasarkan perhitungan SPSS dapat dilihat pada Tabel 9.9, kolom $t$, dan baris kedua.

\section{Referensi}

1. Agresti, A. dan B. Finlay. 2009. Statistical Methods for the Social Sciences, $4^{\text {th }}$ Edition. United States of America: Prentice Hall.

2. Field, A. 2009. Discovering Statistics Using SPSS, $3^{\text {rd }}$ Edition. London: Sage.

3. Gio, P.U. 2013. Aplikasi Statistika dalam SPSS. Medan: USUpress.

4. Mann, P. S. dan C.J. Lacke. 2011. Introductory Statistics, International Student Version, $7^{\text {th }}$ Edition, Asia: John Wiley \& Sons, Inc.

5. Montgomery, D. C. dan G. C. Runger. 2011. Applied Statistics and Probability for Engineers, $5^{\text {th }}$ Edition. United States of America: John Wiley \& Sons, Inc.

6. Smidth, R. K. dan D. H. Sanders. 2000. Statistics a First Course, $6^{\text {th }}$ Edition, United States of America: McGraw-Hill Companies. 


\section{BAB 10}

\section{REGRESI LINEAR BERGANDA}

\section{Sekílas Regresi Linear Berganda}

Persamaan regresi merupakan suatu persamaan yang menerangkan atau menjelaskan hubungan antara variabel bebas dan variabel tak bebas. Persamaan regresi dapat digunakan untuk memprediksi atau mengestimasi nilai dari variabel tak bebas berdasarkan informasi dari variabel bebas. Persamaan regresi linear merupakan suatu persamaan yang berupa garis lurus, sedangkan persamaan regresi nonlinear bukan merupakan persamaan garis lurus (Gambar 10.1).

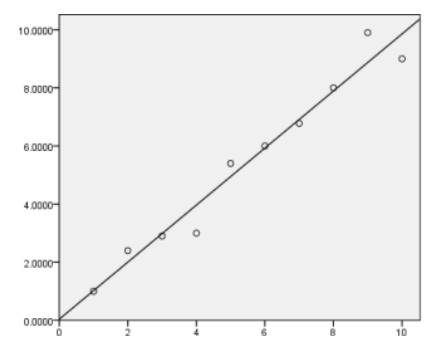

Persamaan Regresi Linear

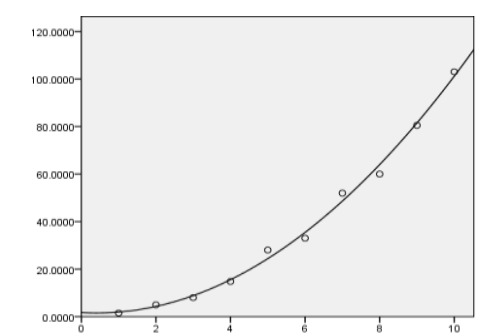

Persamaan Regresi Non-linear

\section{Gambar 10.1}

Persamaan regresi linear hanya melibatkan satu variabel tak bebas, namun jumlah variabel bebas dapat lebih dari satu. Jika persamaan regresi linear hanya menggunakan satu variabel bebas, maka persamaan regresi linear tersebut disebut persamaan regresi linear sederhana (simple linear regression). Namun, jika jumlah variabel bebas pada persamaan regresi linear lebih dari satu, maka persamaan regresi linear tersebut disebut persamaan regresi linear berganda (multiple linear regression). Dalam regresi linear sederhana atau berganda, baik variabel bebas maupun variabel tak bebas bersifat metrik (interval atau rasio) (Hair dkk., 2010:151). Sebagai contoh data bersifat metrik, seperti gaji pegawai, tinggi badan, berat badan, umur manusia, jumlah produksi beras, dan sebagainya. Berikut diberikan contoh aplikasi dari regresi linear sederhana.

$\Rightarrow$ Membuat persamaan atau model untuk memprediksi atau mengestimasi nilai indeks prestasi mahasiswa berdasarkan jumlah jam belajar dalam sehari. Di samping itu dapat diketahui seberapa besar kontribusi yang diberikan faktor jumlah jam belajar dalam sehari terhadap indeks prestasi.

$\Rightarrow$ Membuat persamaan atau model untuk memprediksi atau mengestimasi laba perusahaan berdasarkan tingkat penjualan perusahaan. Di samping itu dapat diketahui seberapa besar kontribusi yang diberikan dari faktor tingkat penjualan perusahaan terhadap naik/turunnya laba perusahaan.

$\Rightarrow$ Membuat persamaan atau model untuk memprediksi atau mengestimasi return saham suatu perusahaan berdasarkan laba kotor perusahaan. 
Dalam regresi linear sederhana hanya melibatkan satu variabel bebas dalam membuat persamaan regresi, sedangkan pada regresi linear berganda melibatkan dua atau lebih variabel bebas. Variabel bebas bersifat metrik (interval atau rasio) (Hair dkk., 2010:151). Penggunaan lebih dari satu variabel bebas dalam pembuatan persamaan regresi linear dimaksudkan agar persamaan regresi linear yang dihasilkan lebih mampu menerangkan atau menjelaskan karakteristik dari variabel tak bebas. Contoh aplikasi dari regresi linear berganda sebagai berikut.

$\Rightarrow$ Membuat persamaan untuk memprediksi atau mengestimasi nilai indeks prestasi mahasiswa berdasarkan jumlah jam belajar dalam sehari dan intelligence quotient (IQ). Di samping itu dapat diketahui faktor-faktor yang memberikan kontribusi paling besar dalam hal pengaruhnya terhadap indeks prestasi mahasiswa.

$\Rightarrow$ Membuat model untuk memprediksi atau mengestimasi laba perusahaan berdasarkan umur perusahaan, tingkat penjualan, dan besarnya perusahaan. Di samping itu, dapat diketahui seberapa besar kontribusi yang diberikan dari faktor umur perusahaan terhadap naik/turunnya laba perusahaan, dengan mengontrol pengaruh tingkat penjualan dan besarnya perusahaan. Dapat juga diketahui seberapa besar kontribusi yang diberikan dari faktor tingkat penjualan perusahaan terhadap naik/turunnya laba perusahaan, dengan mengontrol pengaruh umur perusahaan dan besarnya perusahaan.

$\Rightarrow$ Membuat persamaan untuk memprediksi atau mengestimasi harga saham suatu perusahaan berdasarkan laba per-lembar saham dan jumlah kas dividen yang diberikan. Di samping itu, dapat diketahui seberapa besar kontribusi yang diberikan dari faktor laba per-lembar saham terhadap naik/turunnya harga saham, dengan mengontrol pengaruh jumlah kas dividen yang diberikan.

\section{Mengukur Kecocokkan Model Regresi Linear Berganda terhadap Data dengan Koefisien Determinasi $\left(r^{2}\right)$}

Dalam regresi linear, baik sederhana maupun berganda, koefisien determinasi $\left(r^{2}\right)$ digunakan untuk mengukur kemampuan model regresi linear dalam mencocokkan atau menyesuaikan (fits) data. Jika koefisien determinasi dari model regresi linear bernilai 1, maka model tersebut menyesuaikan atau mencocokkan data secara sempurna (Gambar 10.2). Jika koefisien determinasi dari model regresi linear bernilai mendekati 0 , maka model tersebut kurang baik dalam menyesuaikan atau mencocokkan data (Gambar 10.3).

Pada Gambar 10.2, model regresi linear secara sempurna dalam mencocokkan atau menyesuaikan data (titik-titik). Nilai koefisien determinasi bernilai 1. Pada Gambar 10.3, model regresi linear kurang baik dalam mencocokkan atau menyesuaikan data (titik-titik). Hal ini karena titik-titik menyebar cukup jauh dari model regresi linear. Nilai koefisien determinasi yang semakin dekat dengan 1 menunjukkan semakin baik kemampuan model regresi linear dalam mencocokkan atau menyesuaikan (fits) data. Dengan kata lain kemampuan variabel-variabel bebas dalam menjelaskan variation variabel tak bebas semakin baik (Gujarati, 2993:87). 


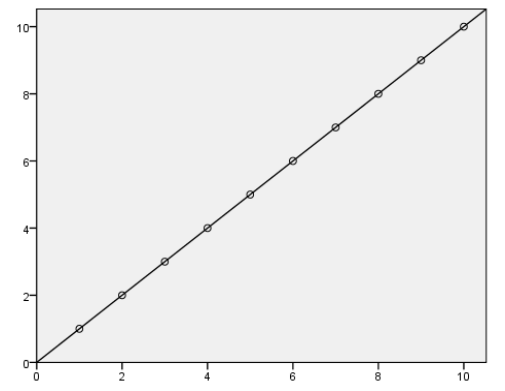

Gambar 10.2

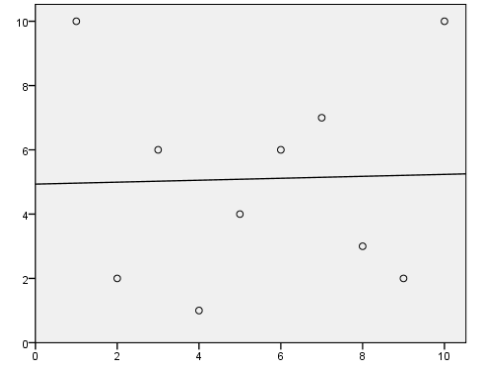

Gambar 10.3

Berikut diberikan output SPSS yang menyajikan nilai statistik dari koefisien determinasi (Tabel 10.1).

\section{Tabel 10.1}

\begin{tabular}{|c|c|c|c|c|}
\hline \multirow{2}{*}{$\begin{array}{l}\text { Tabel R Square menyajikan } \\
\text { nilai koefisien determinasi. }\end{array}$} & \multicolumn{4}{|c|}{ Model Summary } \\
\hline & $\mathrm{R}$ & R Square & $\begin{array}{l}\text { Adjusted R } \\
\text { Square }\end{array}$ & $\begin{array}{l}\text { Std. Error of the } \\
\text { Estimate }\end{array}$ \\
\hline & $.991^{3}$ & .983 & .978 & .04941 \\
\hline
\end{tabular}

\section{Mengují Kecocokkan Model Regresi Linear Berganda terhadap Data dengan Uji $F$}

Dalam regresi linear berganda, uji $F$ digunakan untuk menguji kecocokkan model regresi linear berganda terhadap data. Dengan kata lain, uji $F$ menguji signifikansi secara simultan (simultaneously) atau bersamaan seluruh koefisien regresi populasi. Berikut perumusan hipotesis untuk uji $F$.

$$
H_{0}: \beta_{1}=\beta_{2}=\cdots=\beta_{k}=0 .
$$

$H_{1}$ : Paling tidak terdapat satu koefisien regresi populasi yang tidak sama dengan nol.

Perhatikan bahwa hipotesis nol menyatakan seluruh koefisien regresi populasi bernilai nol. Dengan kata lain, seluruh variabel bebas tidak memiliki pengaruh yang signifikan secara statistika terhadap variabel tak bebas. Hipotesis alternatif menyatakan bahwa paling tidak terdapat satu koefisien regresi populasi yang tidak bernilai nol. Dengan kata lain, paling tidak terdapat satu variabel bebas yang memiliki pengaruh signifikan secara statistika terhadap variabel tak bebas.

Untuk pengambilan keputusan terhadap hipotesis, dapat dilakukan dengan membandingkan nilai statistik dari uji $F$ ( $\left.F_{\text {hitung }}\right)$ terhadap nilai kritis berdasarkan tabel distribusi $F\left(F_{\text {kritis }}\right)$. Sebelum menghitung nilai kritis $F$, terlebih dahulu menghitung nilai derajat bebas pembilang dan derajat bebas penyebut. Berikut rumus untuk menghitung nilai derajat bebas pembilang dan penyebut. 
Perhatikan bahwa $n$ menyatakan jumlah elemen dalam sampel dan $k$ menyatakan jumlah variabel. Andaikan melibatkan 2 variabel bebas, 1 variabel tak bebas, serta jumlah elemen sampel sebanyak 10 , maka derajat bebas pembilang adalah $k-1=(2+1)-1=2$ dan derajat bebas penyebut adalah $10-3=7$. Misalkan tingkat signifikansi yang digunakan adalah 5\%. Maka nilai kritis $F$ dengan derajat bebas pembilang adalah 2, derajat bebas penyebut adalah 7 , dan tingkat signifikansi $5 \%$ adalah 4,74 . Berikut aturan pengambilan keputusan terhadap hipotesis berdasarkan uji $F$.

Jika nilai statistik dari uji $F \leq$ nilai kritis $F$, maka $H_{0}$ diterima dan $H_{1}$ ditolak. jika nilai statistik dari uji $F>$ nilai kritis $F$, maka $H_{0}$ ditolak dan $H_{1}$ diterima.

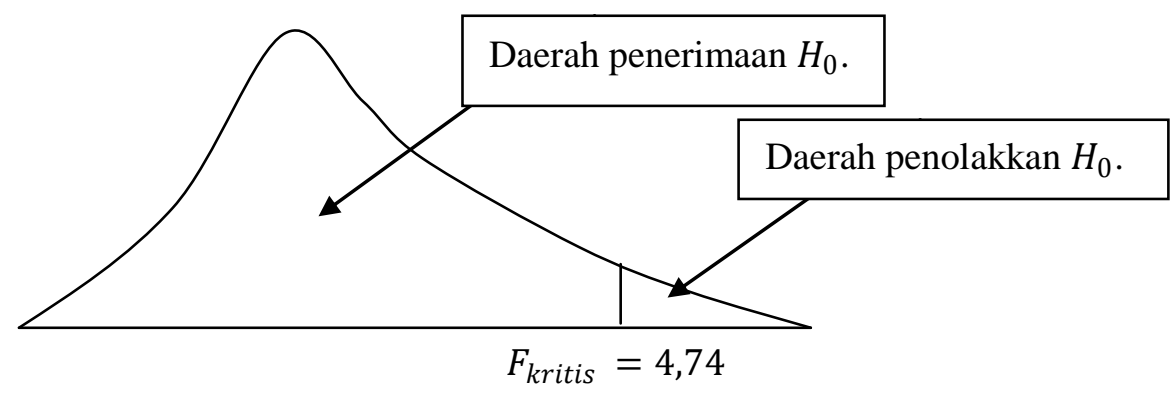

Pengambilan keputusan terhadap hipotesis juga dapat dilakukan dengan menggunakan pendekatan nilai probabilitas dari uji $F$. Nilai probabilitas dari uji $F$ dibandingkan dengan tingkat signifikansi yang digunakan. Berikut aturan pengambilan keputusan terhadap hipotesis berdasarkan pendekatan nilai probabilitas.

Jika nilai probabilitas $\geq$ tingkat signifikansi, maka $H_{0}$ diterima dan $H_{1}$ ditolak. Jika nilai probabilitas < tingkat signifikansi, maka $H_{0}$ ditolak dan $H_{1}$ diterima.

Berikut diberikan output SPSS yang menyajikan nilai statistik dari uji $F$ dan nilai probabilitas dari uji $F$ (Tabel 10.2).

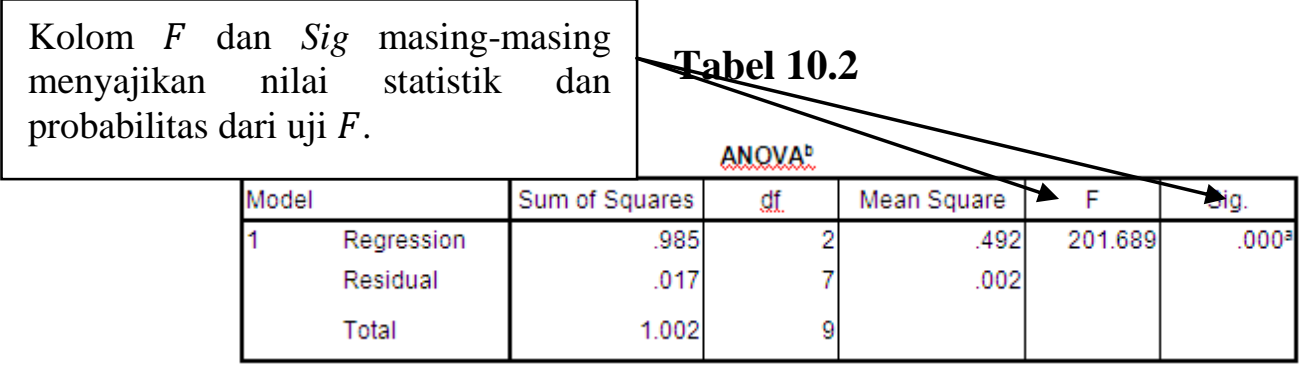

\section{Korelasi Parsial (Partíal Correlation)}

Korelasi parsial merupakan suatu nilai yang mengukur keeratan hubungan antara dua variabel dengan mengontrol pengaruh dari variabel lain. Dengan kata lain, pengaruh dari variabel lain dipertahankan konstan. Andaikan $X_{1}$ dan $X_{2}$ merupakan variabel bebas, sedangkan $Y$ merupakan variabel tak bebas. Misalkan hanya ingin diketahui korelasi antara $X_{1}$ dan $Y$, dengan pengaruh dari $X_{2}$ dikontrol atau dipertahankan konstan. Dengan kata lain, ingin diketahui korelasi atau hubungan yang murni antara $X_{1}$ dan $Y$, bebas tanpa pengaruh dari $X_{2}$. Korelasi yang demikian dinamakan korelasi parsial $X_{1}$ dan $Y$, dengan pengaruh $X_{2}$ dikontrol atau dipertahankan konstan. Berikut diberikan output SPSS yang menyajikan nilai dari korelasi parsial (Tabel 10.3). 


\section{Tabel 10.3}

\begin{tabular}{|c|c|c|c|c|c|}
\hline \multicolumn{5}{|c|}{ Correlations } & \multirow{4}{*}{$\begin{array}{l}\text { Berdasarkan Tabel } 11.3 \text {, nilai } \\
0,691 \text { merupakan korelasi } \\
\text { parsial antara } X_{1} \text { dan } Y \text {, } \\
\text { dengan pengaruh dari } X_{2} \\
\text { dikontrol atau dipertahankan } \\
\text { konstan. }\end{array}$} \\
\hline \multicolumn{3}{|c|}{ Control Variables } & $\mathrm{x}_{1}$ & $Y$ & \\
\hline \multirow[t]{3}{*}{$\times 2$} & $\mathrm{X} 1$ & $\begin{array}{l}\text { Correlation } \\
\text { Significance (2-tailed) } \\
\text { Df }\end{array}$ & 1.000 & $\begin{array}{r}.691 \\
.039 \\
7\end{array}$ & \\
\hline & $Y$ & Correlation & .691 & 1.000 & \\
\hline & & $\begin{array}{l}\text { Significance (2-tailed) } \\
\text { Df }\end{array}$ & $\begin{array}{r}.039 \\
7\end{array}$ & 0 & \\
\hline
\end{tabular}

\section{Uji Sígnífíkansi Koefisien Regresi Secara Individu dengan Uji t}

Dalam regresi linear berganda, uji $t$ digunakan untuk menguji signifikansi dari masingmasing koefisien regresi populasi. Signifikansi koefisien regresi populasi diuji berdasarkan koefisien regresi sampel. Berikut perumusan hipotesis untuk uji signifikansi koefisien regresi secara individu.

$$
\begin{aligned}
& H_{0}: \beta_{i}=0 . \\
& H_{1}: \beta_{i} \neq 0 .
\end{aligned}
$$

Perhatikan bahwa hipotesis nol menyatakan koefisien regresi populasi ke- $i\left(\beta_{i}\right)$ bernilai nol. Dengan kata lain, variabel bebas ke- $i$ memiliki pengaruh yang tidak signifikan secara statistika terhadap variabel tak bebas, dengan mengontrol pengaruh dari variabel bebas lain. Hipotesis alternatif menyatakan koefisien regresi populasi ke- $i\left(\beta_{i}\right)$ tidak bernilai nol. Dengan kata lain, variabel bebas ke-i memiliki pengaruh yang signifikan secara statistika terhadap variabel tak bebas, dengan mengontrol pengaruh dari variabel bebas lain.

Untuk pengambilan keputusan terhadap hipotesis, dapat dilakukan dengan membandingkan nilai statistik dari uji $t$ ( $\left.t_{\text {hitung }}\right)$ terhadap nilai kritis berdasarkan tabel distribusi $t\left(t_{\text {kritis }}\right)$. Sebelum menghitung nilai kritis $t$, terlebih dahulu menghitung nilai derajat. Berikut rumus untuk menghitung nilai derajat bebas.

$$
\text { Derajat bebas }=n-k \text {. }
$$

Perhatikan bahwa $n$ menyatakan jumlah elemen dalam sampel, sedangkan $k$ merupakan jumlah variabel. Andaikan jumlah elemen dalam sampel sebanyak 10 dan jumlah variabel adalah 3 (jumlah variabel bebas adalah 2 dan variabel tak bebas adalah 1), sehingga derajat bebas adalah $10-3=7$. Misalkan tingkat signifikansi yang digunakan adalah 5\%, sehingga nilai kritis $t$ dengan derajat bebas 7 dan tingkat signifikansi $5 \%$ berdasarkan tabel distribusi $t$ adalah $\pm 2,365$. Berikut aturan pengambilan keputusan terhadap hipotesis berdasarkan uji $t$.

$$
\begin{aligned}
& \text { Jika }\left|t_{\text {hitung }}\right| \leq\left|t_{\text {kritis }}\right| \text {, maka } H_{0} \text { diterima dan } H_{1} \text { ditolak. } \\
& \text { Jika }\left|t_{\text {hitung }}\right|>\left|t_{\text {kritis }}\right| \text {, maka } H_{0} \text { ditolak dan } H_{1} \text { diterima. }
\end{aligned}
$$

Pengambilan keputusan terhadap hipotesis juga dapat dilakukan dengan menggunakan pendekatan nilai probabilitas dari uji $t$. Nilai probabilitas dari uji $t$ dibandingkan dengan tingkat signifikansi yang digunakan. Berikut aturan pengambilan keputusan terhadap hipotesis berdasarkan pendekatan nilai probabilitas. 


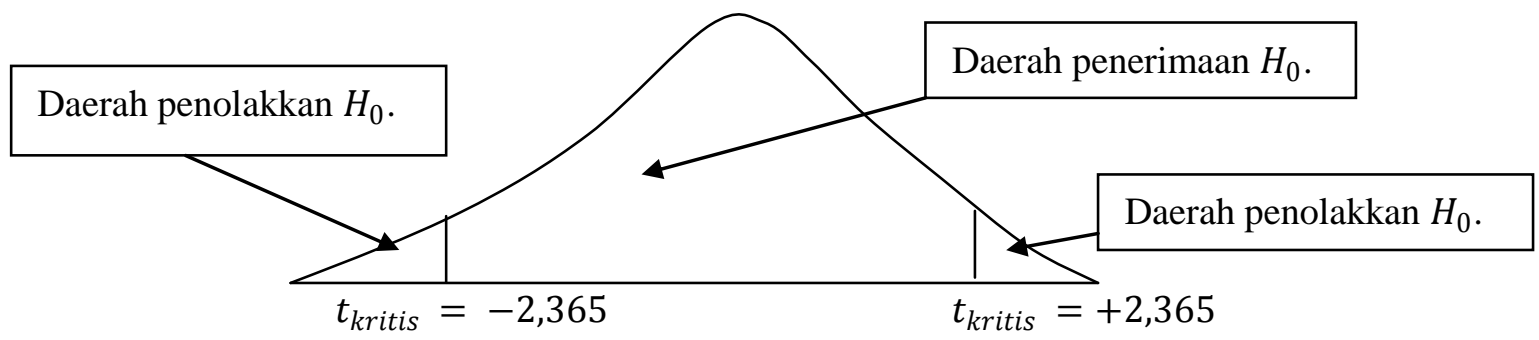

Jika nilai probabilitas $\geq$ tingkat signifikansi, maka $H_{0}$ diterima dan $H_{1}$ ditolak. Jika nilai probabilitas < tingkat signifikansi, maka $H_{0}$ ditolak dan $H_{1}$ diterima.

Berikut diberikan output SPSS yang menyajikan nilai statistik dari uji $t$ dan nilai probabilitas dari uji $t$ (Tabel 10.4).

\section{Tabel 10.4}

\begin{tabular}{|c|c|c|c|c|}
\hline \multicolumn{5}{|c|}{ Coefficientss } \\
\hline & \multirow{5}{*}{$\begin{array}{l}\text { Kolom } T \text { menyajikan nilai } \\
\text { statistik dari uji } t \text {, sedangkan } \\
\text { kolom Sig menyajikan nilai } \\
\text { probabilitas dari uji } t \text {. }\end{array}$} & $\begin{array}{l}\text { Standardized } \\
\text { Coefficients }\end{array}$ & \multirow[b]{2}{*}{$\mathrm{T}$} & \multirow[b]{2}{*}{ Sig. } \\
\hline & & Beta & & \\
\hline & & & 13.723 & .000 \\
\hline & & .372 & 2.528 & .039 \\
\hline & & .633 & 4.298 & .004 \\
\hline
\end{tabular}

\section{Contoh Kasus dalam Regresí Línear Berganda}

Berikut diberikan contoh kasus yang dapat diselesaikan dengan pendekatan regresi linear berganda.

[1] Misalkan seorang peneliti bernama Ugi ingin membuat model regresi linear berganda dengan menggunakan variabel berat badan $(Y)$ sebagai variabel tak bebas, variabel tinggi badan $\left(X_{1}\right)$ dan usia $\left(X_{2}\right)$ sebagai variabel bebas. Data yang telah dikumpulkan oleh Ugi disajikan dalam Tabel 10.5.

Berdasarkan data pada Tabel 10.5, jumlah responden yang diteliti sebanyak $n=30$ responden. Responden yang diteliti dalam hal ini adalah anak laki-laki. Diketahui responden ke-2 memiliki tinggi $130 \mathrm{~cm}$, usia 15 tahun, dan berat $52 \mathrm{~kg}$. Responden ke-28 memiliki tinggi $127 \mathrm{~cm}$, usia 14 tahun, dan berat $59 \mathrm{~kg}$.

Berikut hal-hal yang ingin dilakukan oleh peneliti.

$\Rightarrow$ Membuat persamaan regresi linear berganda yang menerangkan hubungan berat $(\mathrm{kg})$ terhadap tinggi $(\mathrm{cm})$ dan usia (tahun).

$\Rightarrow$ Menentukan seberapa besar keeratan hubungan atau korelasi antara faktor tinggi dan berat badan, dengan mengontrol pengaruh usia.

$\Rightarrow$ Menentukan seberapa besar keeratan hubungan atau korelasi antara faktor usia dan berat badan, dengan mengontrol pengaruh tinggi. 
$\Rightarrow$ Menentukan seberapa besar faktor tinggi berkontribusi dalam hal naik/turunnya berat badan, dengan mengontrol pengaruh usia.

$\Rightarrow$ Menentukan seberapa besar faktor usia berkontribusi dalam hal naik/turunnya berat badan, dengan mengontrol pengaruh tinggi.

$\Rightarrow$ Menentukan faktor yang memberikan kontribusi paling besar terhadap naik/turunnya berat badan.

$\Rightarrow$ Mengestimasi atau memprediksi berat badan seoarang anak laki-laki, ketika memiliki tinggi $135 \mathrm{~cm}$ dan usia 14 tahun.

Tabel 10.5 (Data Fiktif)

\begin{tabular}{|c|c|c|c|c|c|c|c|}
\hline Responden & $Y$ & $X_{1}$ & $X_{2}$ & Responden & $Y$ & $X_{1}$ & $X_{2}$ \\
\hline 1 & 45 & 128 & 13 & 16 & 46 & 129 & 14 \\
\hline 2 & 52 & 130 & 15 & 17 & 53 & 131 & 16 \\
\hline 3 & 34 & 120 & 10 & 18 & 35 & 121 & 11 \\
\hline 4 & 48 & 133 & 13 & 19 & 49 & 134 & 14 \\
\hline 5 & 36 & 122 & 11 & 20 & 37 & 123 & 12 \\
\hline 6 & 39 & 121 & 12 & 21 & 40 & 122 & 13 \\
\hline 7 & 58 & 126 & 16 & 22 & 59 & 127 & 17 \\
\hline 8 & 38 & 119 & 11 & 23 & 39 & 120 & 12 \\
\hline 9 & 37 & 123 & 10 & 24 & 38 & 124 & 11 \\
\hline 10 & 32 & 123 & 8 & 25 & 33 & 124 & 9 \\
\hline 11 & 57 & 132 & 14 & 26 & 58 & 133 & 15 \\
\hline 12 & 49 & 128 & 12 & 27 & 50 & 129 & 13 \\
\hline 13 & 58 & 126 & 13 & 28 & 59 & 127 & 14 \\
\hline 14 & 38 & 119 & 8 & 29 & 39 & 120 & 9 \\
\hline 15 & 37 & 123 & 11 & 30 & 38 & 124 & 12 \\
\hline & & & & & & \\
\hline
\end{tabular}

[2] Misalkan seorang peneliti bernama Ugi ingin membuat persamaan regresi linear berganda dengan menggunakan variabel indeks prestasi $(Y)$ sebagai variabel tak bebas, variabel jumlah jam belajar dalam sehari $\left(X_{1}\right)$ dan IQ $\left(X_{2}\right)$ sebagai variabel bebas. Data yang telah dikumpulkan oleh Ugi disajikan dalam Tabel 10.6.

Berdasarkan data pada Tabel 10.6, jumlah responden yang diteliti sebanyak $n=20$ responden. Responden yang diteliti dalam hal ini adalah mahasiswa matematika semester 2 . Diketahui responden ke-2 menghabiskan waktu untuk belajar dalam sehari selama 12 jam, memiliki IQ 106, dan meraih IP 3,15. Responden ke-15 menghabiskan waktu untuk belajar dalam sehari selama 9 jam, memiliki IQ 99, dan meraih IP 2,75.

Berikut hal-hal yang ingin dilakukan oleh peneliti.

$\Rightarrow$ Membuat persamaan regresi linear berganda yang menerangkan hubungan IP terhadap jumlah jam belajar dalam sehari dan IQ.

$\Rightarrow$ Menentukan seberapa besar keeratan hubungan atau korelasi antara faktor jumlah jam belajar dalam sehari dan IP, dengan mengontrol pengaruh IQ. 
$\Rightarrow$ Menentukan seberapa besar keeratan hubungan atau korelasi antara faktor IQ dan IP, dengan mengontrol pengaruh jumlah jam belajar dalam sehari.

$\Rightarrow$ Menentukan seberapa besar faktor jumlah jam belajar dalam sehari berkontribusi dalam hal naik/turunnya IP, dengan mengontrol pengaruh IQ.

$\Rightarrow$ Menentukan seberapa besar faktor IQ berkontribusi dalam hal naik/turunnya IP, dengan mengontrol pengaruh jumlah jam belajar dalam sehari.

$\Rightarrow$ Menentukan faktor yang memberikan kontribusi paling besar terhadap naik/turunnya IP.

$\Rightarrow$ Mengestimasi atau memprediksi IP mahasiswa, ketika mahasiswa menghabiskan waktu belajar dalam sehari 11 jam dan IQ 113.

Tabel 10.6 (Data Fiktif)

\begin{tabular}{|c|c|c|c|c|c|c|c|}
\hline Responden & $X_{1}$ & $X_{2}$ & $Y$ & Responden & $X_{1}$ & $X_{2}$ & $Y$ \\
\hline 1 & 10 & 103 & 3.01 & 11 & 11 & 105 & 3.06 \\
\hline 2 & 12 & 106 & 3.15 & 12 & 13 & 108 & 3.2 \\
\hline 3 & 9 & 104 & 2.9 & 13 & 10 & 106 & 2.95 \\
\hline 4 & 10 & 109 & 3.1 & 14 & 11 & 111 & 3.15 \\
\hline 5 & 8 & 97 & 2.7 & 15 & 9 & 99 & 2.75 \\
\hline 6 & 11 & 114 & 3.25 & 16 & 12 & 116 & 3.3 \\
\hline 7 & 15 & 118 & 3.6 & 17 & 16 & 120 & 3.65 \\
\hline 8 & 17 & 117 & 3.7 & 18 & 18 & 119 & 3.75 \\
\hline 9 & 16 & 112 & 3.65 & 19 & 17 & 114 & 3.7 \\
\hline 10 & 10 & 107 & 3.15 & 20 & 11 & 109 & 3.2 \\
\hline
\end{tabular}

[3] Misalkan seorang peneliti bernama Ugi ingin membuat persamaan regresi linear berganda dengan menggunakan variabel pengeluaran per-bulan $(Y)$ sebagai variabel tak bebas, variabel penghasilan per-bulan $\left(X_{1}\right)$, jumlah anggota keluarga $\left(X_{2}\right)$ dan jumlah kendaraan $\left(X_{3}\right)$ sebagai variabel bebas. Data yang telah dikumpulkan oleh Ugi disajikan dalam Tabel 10.7.

Tabel 10.7 (Data Fiktif)

\begin{tabular}{|c|c|c|c|c|c|c|c|c|c|}
\hline Keluarga & $X_{1}$ & $X_{2}$ & $X_{3}$ & $Y$ & Keluarga & $X_{1}$ & $X_{2}$ & $X_{3}$ & $Y$ \\
\hline 1 & 8 & 4 & 5 & 5.5 & 11 & 8 & 4 & 5 & 5.5 \\
\hline 2 & 8.1 & 5 & 6 & 6.5 & 12 & 8.1 & 5 & 6 & 6.5 \\
\hline 3 & 9 & 4 & 7 & 7 & 13 & 9 & 4 & 7 & 7 \\
\hline 4 & 6 & 4 & 2 & 4.5 & 14 & 6 & 4 & 2 & 4.5 \\
\hline 5 & 5.2 & 3 & 2 & 3.6 & 15 & 5.2 & 3 & 2 & 3.6 \\
\hline 6 & 5 & 4 & 3 & 3.4 & 16 & 5 & 4 & 3 & 3.4 \\
\hline 7 & 4.5 & 2 & 3 & 4 & 17 & 4.5 & 2 & 3 & 4 \\
\hline 8 & 4 & 4 & 4 & 4.5 & 18 & 4 & 4 & 4 & 4.5 \\
\hline 9 & 5 & 5 & 4 & 4 & 19 & 5 & 5 & 4 & 4 \\
\hline 10 & 4.2 & 3 & 3 & 3 & 20 & 4.2 & 3 & 3 & 3 \\
\hline
\end{tabular}

Berdasarkan data pada Tabel 10.7, jumlah responden yang diteliti sebanyak $n=20$ responden (keluarga). Diketahui keluarga ke-2 memiliki penghasilan per-bulan 8,1 juta, 
jumlah anggota keluarga sebanyak 5, jumlah kendaraan yang dimiliki sebanyak 6 kendaraan, dan pengeluaran per-bulan sebesar 6,5 juta.

Berikut hal-hal yang ingin dilakukan oleh peneliti.

$\Rightarrow$ Membuat persamaan regresi linear berganda yang menerangkan hubungan pengeluaran per-bulan terhadap penghasilan per-bulan, jumlah anggota keluarga, dan jumlah kendaraan.

$\Rightarrow$ Menentukan seberapa besar keeratan hubungan atau korelasi antara faktor penghasilan per-bulan dan pengeluaran per-bulan, dengan mengontrol pengaruh jumlah anggota keluarga dan jumlah kendaraan.

$\Rightarrow$ Menentukan seberapa besar keeratan hubungan atau korelasi antara faktor jumlah kendaraan dan pengeluaran per-bulan, dengan mengontrol pengaruh jumlah anggota keluarga dan penghasilan per-bulan.

$\Rightarrow$ Menentukan seberapa besar keeratan hubungan atau korelasi antara faktor jumlah anggota keluarga dan pengeluaran per-bulan, dengan mengontrol pengaruh jumlah kendaraan dan penghasilan per-bulan.

$\Rightarrow$ Menentukan seberapa besar faktor penghasilan per-bulan berkontribusi dalam hal naik/turunnya pengeluaran per-bulan, dengan mengontrol pengaruh jumlah anggota keluarga dan jumlah kendaraan.

$\Rightarrow$ Menentukan seberapa besar faktor jumlah kendaraan berkontribusi dalam hal naik/turunnya pengeluaran per-bulan, dengan mengontrol pengaruh jumlah anggota keluarga dan penghasilan per-bulan.

$\Rightarrow$ Menentukan faktor yang memberikan kontribusi paling besar terhadap naik/turunnya pengeluaran per-bulan.

$\Rightarrow$ Mengestimasi atau memprediksi pengeluaran per-bulan suatu keluarga, ketika memiliki pengasilan per-bulan 5 juta, jumlah anggota keluarga sebanyak 3, dan jumlah kendaraan sebanyak 2 kendaraan.

\section{Asumsi-Asumsi dalam Regresi Linear Berganda}

Terdapat beberapa asumsi yang dikenakan dalam penggunaan regresi linear berganda. Beberapa di antaranya adalah asumsi normalitas dari error, tidak terjadi multikolinearitas, non-autokorelasi, dan homoskedastisitas.

\section{Asumsi Normalitas}

Gujarati (2003:107) mengemukakan dalam penggunaan metode estimasi ordinary least squares (OLS) pada regresi linear berganda untuk tujuan pengujian hipotesis (hypothesis testing) terhadap estimasi-estimasi parameter dikenakan asumsi normalitas. Asumsi normalitas yang dimaksud adalah distribusi dari error (e) menyebar secara normal. Field (2009:221) menyatakan sebagai berikut. 
"Normally distributed errors: It is assumed that the residuals in the model are random, normally distributed variables, with mean of 0 . This assumption simply means that the differences between the model and the observed data are most frequently zero or very close to zero, and that differences much greater than zero happen only occasionally. Some people confuse this assumption with the idea that predictors have to be normally distributed. In fact, predictors do not need to be normally distributed".

Dalam hal ini, asumsi normalitas berarti distribusi dari error $(e)$ menyebar secara normal, dan variabel-variabel bebas tidak harus berdistribusi normal. Stevens (2009:90) juga menyatakan sebagai berikut.

"Recal that in linear regression model, it is assumed that the errors are independent and follow a normal distribution with constant variance. The normality assumption can be checked through use of the histogram of the standardized or studentized residuals".

Error merupakan selisih antara nilai variabel tak bebas $(Y)$ dan estimasi dari nilai variabel tak bebas $(\hat{Y})$. Nilai estimasi dari variabel tak bebas diperoleh berdasarkan persamaan regresi. Untuk menguji asumsi normalitas dapat digunakan pendekatan analisis grafik, seperti normal probability plot dan histogram, atau dapat juga digunakan uji Kolmogorov-Smirnov. Pada pendekatan normal probability plot, jika titik-titik (dots) menyebar jauh (menyebar berlikuliku pada garis diagonal seperti ular) dari garis diagonal, maka diindikasi asumsi normalitas error tidak dipenuhi. Jika titik-titik menyebar sangat dekat pada garis diagonal, maka asumsi normalitas dipenuhi. Sedangkan untuk pendekatan histogram, jika kurva berbentuk kurva normal, maka asumsi normalitas dipenuhi.

Dalam pendekatan uji Kolmogorov-Smirnov, pengujian normalitas dilakukan dengan menggunakan data residual ( $\hat{e})$. Hipotesis nol menyatakan error berdistribusi normal, sedangkan hipotesis alternatif menyatakan error tidak berdistribusi normal. Untuk pengambilan keputusan terhadap hipotesis, dapat dibandingkan antara nilai probabilitas dari uji Kolmogorov-Smirnov dan tingkat signifikansi yang digunakan $(\alpha)$. Berikut aturan pengambilan keputusan terhadap hipotesis.

Jika nilai probabilitas $\geq$ tingkat signifikansi, $H_{0}$ diterima dan $H_{1}$ ditolak. Jika nilai probabilitas < tingkat signifikansi, $H_{0}$ ditolak dan $H_{1}$ diterima.

Berikut diberikan output SPSS yang menyajikan nilai probabilitas dari uji KolmogorovSmornov (Tabel 10.8).

Tabel 10.8

\begin{tabular}{|ll|r|}
\hline & & $\begin{array}{r}\text { Unstandardiz } \\
\text { ed Residual }\end{array}$ \\
\hline Normal Parameters ${ }^{\mathrm{a} . \mathrm{b}}$ & Mean & 15 \\
& Std. Deviation & .0000000 \\
Most Extreme Differences & Absolute & .07019822 \\
& Positive & .247 \\
& Negative & .150 \\
Kolmogorow-Smirnov Z & -.247 \\
Asymp. Sig. (2-tailed) & .959 \\
a. Test distribution is Normal. & .317 \\
b. Calculated from data.
\end{tabular}

Nilai Asyp. Sig. (2-tailed) $=0,317$ merupakan nilai probabilitas dari uji Kolmogorov-Smirnov. 
Untuk menguji asumsi normalitas juga dapat digunakan pendekatan analisis grafik, yakni $Q-Q$ (quantile-quantile) plot atau dapat juga digunakan uji Jarque-Bera (JB). Pada pendekatan $Q-Q$ plot, jika titik-titik (dots) menyebar jauh (menyebar berliku-liku pada garis diagonal seperti ular) dari garis diagonal, maka diindikasi asumsi normalitas error tidak dipenuhi. Jika titiktitik menyebar sangat dekat pada garis diagonal, maka asumsi normalitas dipenuhi.

Dalam pendekatan uji Jarque-Bera, pengujian normalitas dilakukan dengan menggunakan data residual $(\hat{e})$. Hipotesis nol menyatakan error berdistribusi normal, sedangkan hipotesis alternatif menyatakan error tidak berdistribusi normal. Untuk pengambilan keputusan terhadap hipotesis, dapat dibandingkan antara nilai probabilitas dari uji Jarque-Bera dan tingkat signifikansi yang digunakan $(\alpha)$. Berikut aturan pengambilan keputusan terhadap hipotesis.

\section{Jika nilai probabilitas $\geq \alpha, H_{0}$ diterima dan $H_{1}$ ditolak.} Jika nilai probabilitas $<\alpha, H_{0}$ ditolak dan $H_{1}$ diterima.

Gambar 10.4 menunjukkan nilai probabilitas dari uji Jarque-Bera. Diketahui nilai probabilitas (Probability) dari uji Jarque-Bera adalah 0,739403.

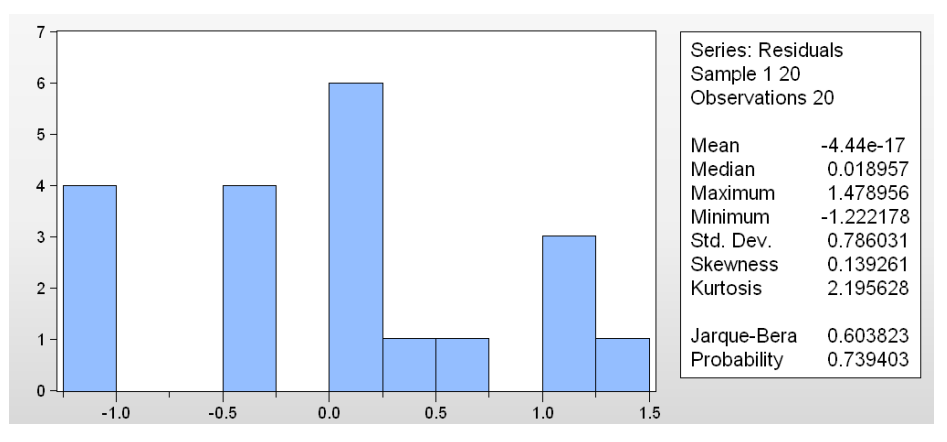

\section{Gambar 10.4}

Pengambilan keputusan terhadap hipotesis, juga dapat dilakukan dengan membandingkan nilai statisik dari uji Jarque-Bera terhadap nilai kritis chi-kuadrat $\chi_{\text {kritis }}^{2}$ (atau chi-kuadrat tabel). Statistik dari uji Jarque-Bera berdistribusi sampling chi-kuadrat dengan derajat bebas 2 untuk ukuran sampel yang besar. Gujarati (2003:148) menyatakan sebagai berikut.

"Under the null hypothesis that the residuals are normally distributed, Jarque and Bera showed that asymptotically (i.e., in large samples) the JB statistic given in (5.12.1) follows the chi-square distribution with $2 d f$ ".

Berikut aturan pengambilan keputusan terhadap hipotesis.

Jika nilai statistik $J B \leq \chi_{\text {kritis }}^{2}, H_{0}$ diterima dan $H_{1}$ ditolak. Jika nilai statistik $J B>\chi_{\text {kritis }}^{2}, H_{0}$ ditolak dan $H_{1}$ diterima.

Berdasarkan Gambar 10.4, diketahui nilai statistik dari uji Jarque-Bera adalah 0,603823. 


\section{Asumsi Tídak Terjadi Multíkolinearitas}

Multikolinearitas merupakan suatu kejadian di mana terjadi korelasi atau hubungan linear yang kuat di antara variabel-variabel bebas. Salah satu asumsi yang dikenakan pada penggunaan regresi linear berganda adalah asumsi tidak terjadi multikolinearitas. Multikolinearitas dapat membuat beberapa permasalahan, yakni koefisien-koefisien regresi tidak dapat diestimasi secara tepat, serta tanda dari koefisien regresi dapat berubah dari sampel ke sampel. Apabila terjadi multikolinearitas sempurna (perfect multicolinearity), maka koefisien-koefisien regresi tidak dapat ditentukan (indeterminate), serta nilai standard error dari koefisien-koefisien regresi tidak terhingga (infinite). Jika terjadi multikolinearitas kuat (tidak sempurna), maka koefisien-koefisien regresi dapat ditentukan (determinate), namun memiliki standard error yang besar, sehingga mengakibatkan koefisien-koefisien regresi tidak diestimasi dengan tingkat ketelitian yang akurat. Perhatikan data pada Tabel 10.9.

\section{Tabel 10.9}

\begin{tabular}{|c|c|c|c|c|c|c|c|c|}
\hline$Y$ & 1 & 2 & 4 & 5 & 6 & 8 & 10 & 12 \\
\hline$X_{1}$ & 1 & 2 & 3 & 4 & 5 & 6 & 7 & 8 \\
\hline$X_{2}$ & 3 & 5 & 7 & 9 & 11 & 13 & 15 & 17 \\
\hline
\end{tabular}

Berdasarkan data pada Tabel 10.9, misalkan $Y$ merupakan variabel tak bebas, sedangkan $X_{1}$ dan $X_{2}$ merupakan variabel bebas. Perhatikan bahwa terjadi korelasi atau hubungan linear yang sempurna antara variabel bebas $X_{1}$ dan variabel bebas $X_{2}$, yakni dapat dinyatakan dalam bentuk persamaan linear $X_{2}=2 X_{1}+1$. Jika dihitung nilai korelasi antara variabel bebas $X_{1}$ dan variabel bebas $X_{2}$, maka diperoleh nilai korelasi sebesar 1 , yang berarti terjadi korelasi linear yang sempurna antara variabel bebas $X_{1}$ dan variabel bebas $X_{2}$. Salah satu akibat dari terjadinya hubungan linear yang sempurna di antara variabel-variabel bebas adalah koefisienkoefisien regresi tidak dapat ditentukan nilainya, serta standard error dari koefisien-koefisien regresi bernilai tak terhingga (infinite). Persamaan regresi linear berganda untuk data pada Tabel 10.9 adalah sebagai berikut.

$$
\hat{Y}=\hat{\alpha}+\hat{\beta}_{1} X_{1}+\hat{\beta}_{2} X_{2}
$$

Berikut akan dihitung nilai dari koefisien regresi $\hat{\beta}_{1}$ dan $\hat{\beta}_{2}$ untuk data pada Tabel 10.9.

Tabel 10.10

\begin{tabular}{|c|c|c|c|c|c|c|c|c|c|}
\hline & & & & & & & & & Total \\
\hline$Y$ & 1 & 2 & 4 & 5 & 6 & 8 & 10 & 12 & 48 \\
\hline$X_{1}$ & 1 & 2 & 3 & 4 & 5 & 6 & 7 & 8 & 36 \\
\hline$X_{2}$ & 3 & 5 & 7 & 9 & 11 & 13 & 15 & 17 & 80 \\
\hline$X_{1} Y$ & 1 & 4 & 12 & 20 & 30 & 48 & 70 & 96 & 281 \\
\hline$X_{2} Y$ & 3 & 10 & 28 & 45 & 66 & 104 & 150 & 204 & 610 \\
\hline$X_{1} X_{2}$ & 3 & 10 & 21 & 36 & 55 & 78 & 105 & 136 & 444 \\
\hline$X_{1}^{2}$ & 1 & 4 & 9 & 16 & 25 & 36 & 49 & 64 & 204 \\
\hline$X_{2}^{2}$ & 9 & 25 & 49 & 81 & 121 & 169 & 225 & 289 & 968 \\
\hline$Y^{2}$ & 1 & 4 & 16 & 25 & 36 & 64 & 100 & 144 & 390 \\
\hline
\end{tabular}




$$
\begin{gathered}
r=n \sum X_{1} X_{2}-\sum X_{1} \sum X_{2}=(8)(444)-(36)(80)=672 \\
s=n \sum X_{2} Y-\sum X_{2} \sum Y=(8)(610)-(80)(48)=1040 \\
t=n \sum X_{1}^{2}-\left(\sum X_{1}\right)^{2}=(8)(204)-(36)^{2}=336 \\
u=t q-r^{2}=0 .
\end{gathered}
$$

Sehingga nilai $\hat{\beta}_{1}$ dan $\hat{\beta}_{2}$ adalah

$$
\begin{aligned}
& \hat{\beta}_{1}=\frac{p q-r s}{u}=\frac{(520)(1344)-(672)(1040)}{0}=\frac{0}{0} \\
& \hat{\beta}_{2}=\frac{s t-p r}{u}=\frac{(1040)(336)-(520)(672)}{0}=\frac{0}{0} .
\end{aligned}
$$

Perhatikan bahwa koefisien regresi $\hat{\beta}_{1}$ dan $\hat{\beta}_{2}$ berdasarkan perhitungan di atas tidak dapat ditentukan. Hal ini disebabkan karena terjadi hubungan linear yang sempurna antara variabel bebas $X_{1}$ dan variabel bebas $X_{2}$. Berikut akan dihitung standard error dari koefisien regresi $\hat{\beta}_{1} \operatorname{dan} \hat{\beta}_{2}$.

\section{Tabel 10.11}

\begin{tabular}{|c|c|c|c|c|c|c|c|c|c|}
\hline & & & & & & & & & \\
\hline$\left(X_{1}-\bar{X}_{1}\right)^{2}$ & 12,25 & 6,25 & 2,25 & 0,25 & 0,25 & 2,25 & 6,25 & 12,25 & 42 \\
\hline$\left(X_{2}-\bar{X}_{2}\right)^{2}$ & 49 & 25 & 9 & 1 & 1 & 9 & 25 & 49 & 168 \\
\hline$\left(X_{1}-\bar{X}_{1}\right)\left(X_{2}-\bar{X}_{2}\right)$ & 24,5 & 12,5 & 4,5 & 0,5 & 0,5 & 4,5 & 12,5 & 24,5 & 84 \\
\hline
\end{tabular}

$$
\begin{gathered}
s_{\widehat{\beta}_{1}}=\frac{s \quad \sqrt{\sum\left(X_{2}-\bar{X}_{2}\right)^{2}}}{\left[\sqrt{\left(\sum\left(X_{1}-\bar{X}_{1}\right)^{2}\right)\left(\sum\left(X_{2}-\bar{X}_{2}\right)^{2}\right)-\left(\sum\left(X_{1}-\bar{X}_{1}\right)\left(X_{2}-\bar{X}_{2}\right)\right)^{2}}\right]} \\
s_{\widehat{\beta}_{1}}=\frac{s \sqrt{\sum\left(X_{2}-\bar{X}_{2}\right)^{2}}}{\left[\sqrt{(42)(168)-(84)^{2}}\right]} \\
s_{\widehat{\beta}_{2}}=\frac{s \quad \sqrt{\sum\left(X_{2}-\bar{X}_{2}\right)^{2}}}{s_{\widehat{\beta}_{1}}=\frac{0}{\left[\sqrt{\left(\sum\left(X_{1}-\bar{X}_{1}\right)^{2}\right)\left(\sum\left(X_{2}-\bar{X}_{2}\right)^{2}\right)-\left(\sum\left(X_{1}-\bar{X}_{1}\right)\left(X_{2}-\bar{X}_{2}\right)\right)^{2}}\right]}} \\
s_{\widehat{\beta}_{2}}=\frac{s \quad \sqrt{\sum\left(X_{1}-\bar{X}_{1}\right)^{2}}}{\left[\sqrt{(42)(168)-(84)^{2}}\right]}
\end{gathered}
$$




$$
s_{\widehat{\beta}_{2}}=\frac{s \quad \sqrt{\sum\left(X_{1}-\bar{X}_{1}\right)^{2}}}{0}=\infty
$$

Perhatikan bahwa nilai standard error dari koefisien regresi $\hat{\beta}_{1}$ dan $\hat{\beta}_{2}$ adalah tak terhingga (infinite). Hal ini berarti tingkat ketelitian dalam memperkirakan parameter koefisien regresi sangat buruk. Interval keyakinan (confidence interval) dalam memperkirakan koefisien regresi populasi sangat lebar.

Untuk mendeteksi apakah terindikasi terjadi gejala multikolinearitas, dapat digunakan pendekatan nilai VIF (variance inflation factor) atau nilai tolerance. Nilai VIF dari masingmasing variabel bebas dihitung dengan maksud untuk mendeteksi apakah terindikasi terjadi gejala multikolinearitas. Nilai VIF yang lebih besar dari 10 diindikasi terjadi multikolinearitas (Myers dalam Steven, 2009).

Untuk mendeteksi apakah terindikasi terjadi gejala multikolinearitas, juga dapat digunakan pendekatan matriks korelasi dari variabel bebas. Jika terdapat nilai korelasi di atas 0,8 antar variabel bebas, maka diindikasi terjadi multikolinearitas. Gujarati (2003:359) menyatakan sebagai berikut.

"Another suggested rule of thumb is that if the pair-wise or zero-order correlation coefficient between two regressors is high, say, in excess of 0,8 , then multicolinearity is a serious problem".

\section{Asumsi Non-Autokorelasi}

Selain asumsi normalitas dari error dan tidak terjadi multikolinearitas, asumsi lain yang dikenakan pada penggunaan regresi linear berganda adalah asumsi independensi dari error (independent errors). Stevens (2009:90) menyatakan sebagai berikut.

"Recal that in linear regression model, it is assumed that the errors are independent and follow a normal distribution with constant variance".

Senada dengan Stevens, Field (2009:220) menyatakan sebagai berikut.

"Independent errors: For any two observations the residual terms should be uncorrelated (or independent). This eventually is sometimes described as a lack of autocorrelation".

Asumsi ini disebut juga dengan asumsi non-autokorelasi (non-autocorrelation). Untuk menguji asumsi independensi dari error, dapat digunakan uji Durbin-Watson. Nilai statistik dari uji Durbin-Watson berkisar di antara 0 dan 4. Field (2009:220) menyatakan sebagai berikut.

"Specifically, it (Durbin-Watson) tests whether adjacent residuals are correlated. The test statistic can vary between 0 dan 4 with a value 2 meaning that the residuals are uncorrelated".

Nilai statistik dari uji Durbin-Watson yang lebih kecil dari 1 atau lebih besar dari 3 diindikasi terjadi autokorelasi. Field (2009:220-221) menyatakan sebagai berikut. 
"The size of the Durbin-Watson statistic depends upon the number of predictors in the model and the number of observations. For accuracy, you should look up the exact acceptable values in Durbin and Watson's (1951) original paper. As very conservative rule of thumb, values less then 1 or greater than 3 are definitely cause for concern; however, values closer to 2 may stil be problematic depending on your sample and model".

Gujarati (2003) mengemukakan dalam keadaan pelanggaran asumsi independensi dari error, estimator-estimator yang dihasilkan dengan metode kuadrat terkecil (ordinary least square) masih bersifat tak bias, konsisten, secara asismtotik terdistribusi normal, namun estimatorestimator tersebut tidak lagi efisien. Sebagai akibatnya, uji signifikansi $t$ dan $F$ yang biasa tidak lagi valid, serta jika diterapkan cenderung memberikan kesimpulan yang menyesatkan (misleading) mengenai signifikansi dari koefisien-koefisien regresi estimasi (sampel).

Berikut diberikan output SPSS yang menyajikan nilai statistik dari uji Durbin-Watson (Tabel 10.12).

\section{Tabel 10.12}

\begin{tabular}{|c|c|c|}
\hline & & \\
\hline \multirow{2}{*}{$\begin{array}{l}\text { Kolom Durbin-Watson menyajikan } \\
\text { nilai statistik dari uji Durbin- } \\
\text { Watson. }\end{array}$} & $\begin{array}{l}\text { d. Error of the } \\
\text { Estimate }\end{array}$ & Durbin-Watson \\
\hline & .07582 & \\
\hline
\end{tabular}

\section{Asumsi Homoskedastísitas}

Asumsi homoskedastisitas menyatakan terjadi kesamaan varians dari error (errors with constant variance) untuk setiap tingkatan atau level dari variabel-variabel bebas. Ketika asumsi homoskedastisitas tidak dipenuhi, maka peristiwa tersebut disebut heteroskedastisitas. Untuk mendeteksi terjadinya gejala heteroskedastisitas dapat dilakukan dengan menggunakan uji Park. Berikut langkah-langkah untuk melakukan uji asumsi homoskedastisitas dengan menggunakan uji Park.

$\Rightarrow$ Tentukan persamaan regresi dari variabel tak bebas berdasarkan variabel-variabel bebas. Misalkan $Y$ sebagai variabel tak bebas, sedangkan $X_{1}$ dan $X_{2}$ merupakan variabel bebas.

$\Rightarrow$ Setelah diperoleh persamaan regresi, yakni $\hat{Y}=\hat{\alpha}+\hat{\beta}_{1} X_{1}+\hat{\beta}_{2} X_{2}$, hitung nilai residual, yakni selisih antara variabel tak bebas dan estimasi dari variabel tak bebas $(\hat{e}=Y-\hat{Y})$.

$\Rightarrow$ Kuadratkan untuk tiap-tiap nilai residual $\left(\hat{e}^{2}\right)$.

$\Rightarrow$ Hitung logaritma natural $(\ln )$ untuk kuadrat residual dan variabel bebas $X_{1}$ dan $X_{2}$, sehingga diperoleh $\ln \left(\hat{e}^{2}\right), \ln \left(X_{1}\right)$, dan $\ln \left(X_{2}\right)$.

$\Rightarrow$ Lakukan regresi dari logaritma natural kuadrat residual terhadap logaritma natural dari variabel-variabel bebas. Dalam hal ini, lakukan regresi $\ln \left(\hat{e}^{2}\right)$ terhadap $\ln \left(X_{1}\right)$ dan $\ln \left(X_{2}\right)$, sehingga diperoleh persamaan regresi sebagai berikut.

$$
\widehat{\ln \left(\hat{e}^{2}\right)}=a+b_{1} \ln X_{1}+b_{2} \ln X_{2} \quad[10.1]
$$


$\Rightarrow$ Jika terdapat koefisien regresi $b$ yang signifikan secara statistika (statistically significant), maka diindikasi terjadi heteroskedastisitas. Namun jika tidak terdapat koefisien regresi $b$ yang signifikan secara statistika (statistically significant), maka asumsi homoskedastisitas dipenuhi (Gujarati, 2003:404).

Selain uji Park, dapat juga digunakan uji Glejser. Berikut langkah-langkah untuk melakukan uji asumsi homoskedastisitas dengan menggunakan uji Glejser.

$\Rightarrow$ Tentukan persamaan regresi dari variabel tak bebas berdasarkan variabel-variabel bebas. Misalkan $Y$ sebagai variabel tak bebas, sedangkan $X_{1}$ dan $X_{2}$ merupakan variabel bebas.

$\Rightarrow$ Setelah diperoleh persamaan regresi, yakni $\hat{Y}=\hat{\alpha}+\hat{\beta}_{1} X_{1}+\hat{\beta}_{2} X_{2}$, hitung nilai residual, yakni selisih antara variabel tak bebas dan estimasi dari variabel tak bebas $(\hat{e}=Y-\hat{Y})$.

$\Rightarrow$ Absolutkan untuk tiap-tiap nilai residual $(|\hat{e}|)$.

$\Rightarrow$ Lakukan regresi dari $|\hat{e}|$ terhadap $X_{1}$ dan $X_{2}$, sehingga diperoleh persamaan regresi sebagai berikut.

$$
\widehat{\mid \hat{e}} \mid=a+b_{1} X_{1}+b_{2} X_{2} \quad[10.2]
$$

$\Rightarrow$ Jika terdapat koefisien regresi $b$ yang signifikan secara statistika, maka diindikasi terjadi heteroskedastisitas. Namun jika tidak terdapat koefisien regresi $b$ yang signifikan secara statistika, maka asumsi homoskedastisitas dipenuhi (Gujarati, 2003:406).

Selain uji Park dan uji Glejser, dapat juga digunakan uji White. Berikut langkah-langkah untuk melakukan uji asumsi homoskedastisitas dengan menggunakan uji White.

$\Rightarrow$ Tentukan persamaan regresi dari variabel tak bebas berdasarkan variabel-variabel bebas. Misalkan $Y$ sebagai variabel tak bebas, sedangkan $X_{1}$ dan $X_{2}$ merupakan variabel bebas.

$\Rightarrow$ Setelah diperoleh persamaan regresi, yakni $\hat{Y}=\hat{\alpha}+\hat{\beta}_{1} X_{1}+\hat{\beta}_{2} X_{2}$, hitung nilai residual, yakni selisih antara variabel tak bebas dan estimasi dari variabel tak bebas $(\hat{e}=Y-\hat{Y})$.

$\Rightarrow$ Kuadratkan untuk tiap-tiap nilai residual $\left(\hat{e}^{2}\right)$.

$\Rightarrow$ Peroleh pesamaan regresi sebagai berikut.

$$
\widehat{\hat{e}^{2}}=a+b_{1} X_{1}+b_{2} X_{2}+b_{3} X_{1}^{2}+b_{4} X_{2}^{2}+b_{5} X_{1} X_{2}
$$

$\Rightarrow$ Peroleh nilai koefisien determinasi $\left(r^{2}\right)$ dari persamaan regresi [10.3]. Gujarati (2003:413) mengemukakan bahwa dengan hipotesis nol menyatakan tidak terjadi heteroskedastisitas, serta nilai perkalian antara jumlah elemen sampel (sample size) dan $r^{2}$ pada persamaan regresi [10.3] secara asimtotis mengikuti distribusi chi-kuadrat dengan derajat bebas merupakan jumlah regressors (tidak termasuk konstanta) pada 
persamaan regresi [10.3]. Berdasarkan persamaan regresi [10.3], diketahui nilai derajat bebas adalah 5 .

$\Rightarrow$ Jika nilai dari hasil perkalian antara jumlah elemen sampel (sample size) dan $r^{2}$ pada persamaan regresi [10.3] lebih besar dari nilai kritis chi-kuadrat, maka disimpulkan terjadi heteroskedastisitas (Gujarati, 2003:413)

Untuk mendeteksi terjadinya gejala heteroskedastisitas dapat dilakukan dengan pendekatan analisis grafik dari residual. Dalam pendekatan analisis grafik dari residual, sumbu horizontal menyatakan nilai estimasi dari variabel tak bebas terstandarisasi (regression standardized predicted value), sedangkan sumbu vertikal menyatakan nilai residual (studentized residual). Apabila sebaran titik-titik dalam grafik analisis residual menyebar secara acak (no systematic pattern) di sekitar 0 (around zero), maka diindikasi tidak terjadi heteroskedastisitas, namun apabila titik-titik dalam grafik analisis residual tidak menyebar secara acak (membentuk suatu pola), maka diindikasi terjadi heteroskedastisitas. Berikut disajikan grafik analisis residual (Gambar 10.5).

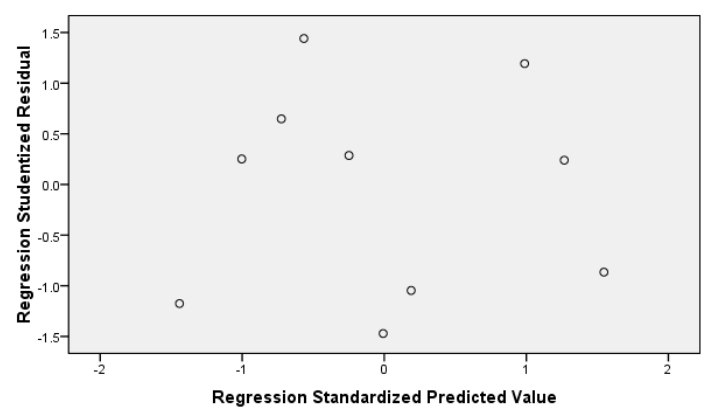

Gambar 10.5

Berdasarkan grafik pada Gambar 10.5, titik-titik menyebar secara acak di sekitar 0, sehingga diindikasi tidak terjadi heteroskedastisitas. Misalkan diberikan data populasi sebagai berikut.

Tabel 10.13

\begin{tabular}{|l|l|l|l|l|l|l|l|l|l|l|l|l|l|l|l|}
\hline$X$ & 1 & 1 & 1 & 2 & 2 & 2 & 3 & 3 & 3 & 4 & 4 & 4 & 5 & 5 & 5 \\
\hline$Y$ & 1 & 2 & 3 & 2 & 3 & 4 & 3 & 4 & 5 & 4 & 5 & 6 & 5 & 6 & 7 \\
\hline
\end{tabular}

Berdasarkan data pada Tabel 10.3, misalkan $X$ adalah variabel bebas, sedangkan $Y$ adalah variabel tak bebas. Berikut disajikan dalam grafik berdasarkan data pada Tabel 10.13 (Gambar 10.6).

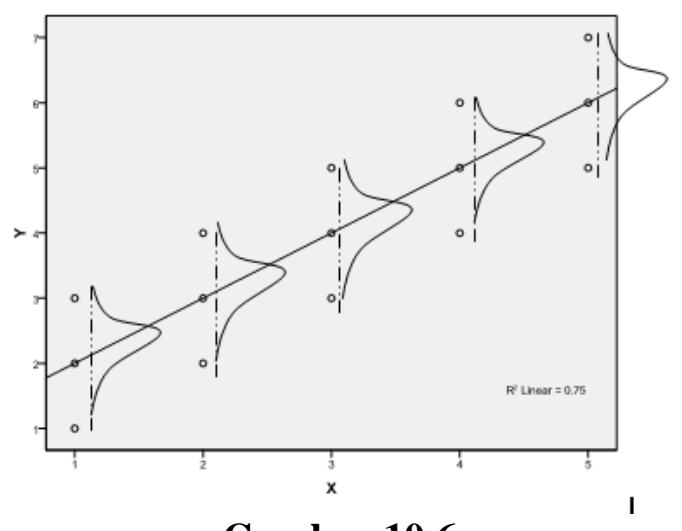

Gambar 10.6 
Berikut akan dihitung nilai varians $Y$ untuk masing-masing nilai $X$.

$\Rightarrow$ Menghitung varians $Y$ untuk $X=1$.

$$
\operatorname{Var}(Y / X=1)=\frac{(1-2)^{2}+(2-2)^{2}+(3-2)^{2}}{3}=\frac{2}{3}=0,667
$$

$\Rightarrow$ Menghitung varians $Y$ untuk $X=2$.

$$
\operatorname{Var}(Y / X=2)=\frac{(2-3)^{2}+(3-3)^{2}+(4-3)^{2}}{3}=\frac{2}{3}=0,667
$$

$\Rightarrow$ Menghitung varians $Y$ untuk $X=3$.

$$
\operatorname{Var}(Y / X=3)=\frac{(3-4)^{2}+(4-4)^{2}+(5-4)^{2}}{3}=\frac{2}{3}=0,667
$$

$\Rightarrow$ Menghitung varians $Y$ untuk $X=4$.

$$
\operatorname{Var}(Y / X=4)=\frac{(4-5)^{2}+(5-5)^{2}+(6-5)^{2}}{3}=\frac{2}{3}=0,667
$$

$\Rightarrow$ Menghitung varians $Y$ untuk $X=5$.

$$
\operatorname{Var}(Y / X=5)=\frac{(5-6)^{2}+(6-6)^{2}+(7-6)^{2}}{3}=\frac{2}{3}=0,667
$$

Perhatikan bahwa nilai varians dari $Y$ untuk setiap $X$ bersifat konstan atau dapat dinyatakan $\operatorname{Var}\left(Y_{i}\right)=\operatorname{Var}\left(e_{i}\right)=\sigma^{2}$ untuk setiap $i=1,2,3, \ldots, n$. Fenomena ini disebut dengan istilah homoskedastisitas.

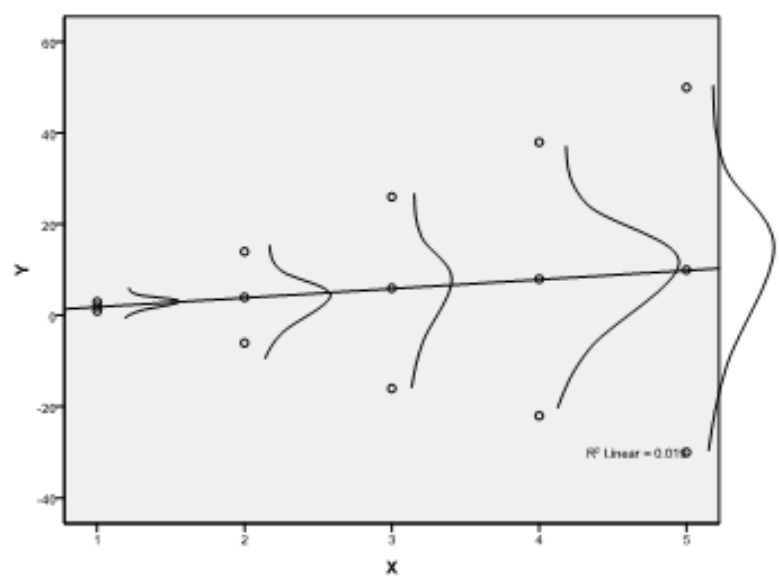

Gambar 10.7

Pada Gambar 10.7 memperlihatkan varians dari $Y$ untuk setiap $X$. Nilai-nilai varians tersebut berbeda-beda atau dapat dinyatakan dengan $\operatorname{Var}\left(Y_{i}\right)=\operatorname{Var}\left(e_{i}\right)=\sigma_{i}^{2}$. Fenomena ini disebut dengan istilah heteroskedastisitas. 


\section{PENYELESAIAN DALAM SPSS}

Misalkan seorang peneliti ingin membuat model regresi linear berganda dengan menggunakan variabel indeks prestasi $(Y)$ sebagai variabel tak bebas, variabel jumlah jam belajar dalam sehari $\left(X_{1}\right)$ dan uang jajan dalam sehari $\left(X_{2}\right)$ sebagai variabel bebas. Data yang telah dikumpulkan oleh peneliti disajikan dalam Tabel 10.1.

Berdasarkan data pada Tabel 10.1, jumlah responden yang diteliti sebanyak $n=20$ responden. Responden yang diteliti adalah mahasiswa matematika. Diketahui responden ke-1 bernama Ugi menghabiskan waktu untuk belajar dalam sehari selama 10 jam, uang jajan satu hari Rp. 7000, dan meraih IP 3,01. Responden ke-3 bernama Alvi menghabiskan waktu untuk belajar dalam sehari selama 9 jam, uang jajan dalam satu hari Rp. 11000, dan meraih IP 2,9.

Tabel 10.1 (Data Fiktif)

\begin{tabular}{|c|c|c|c|c|c|c|c|}
\hline Nama & $X_{1}$ & $X_{2}$ & $Y$ & Nama & $X_{1}$ & $X_{2}$ & $Y$ \\
\hline Ugi & 10 & 7 & 3.01 & Iqbal & 10 & 7 & 3.02 \\
\hline Niar & 10 & 7 & 3.15 & Edi & 12 & 7.2 & 3.16 \\
\hline Alvi & 9 & 11 & 2.9 & Budi & 9 & 6 & 2.95 \\
\hline Fitri & 10 & 8 & 3.1 & Indah & 10 & 8 & 3.12 \\
\hline Ridho & 8 & 7.5 & 2.7 & Tari & 8 & 12 & 2.8 \\
\hline Mifdhal & 11 & 8 & 3.25 & Maura & 11 & 11 & 3.3 \\
\hline Romi & 13 & 7 & 3.6 & Nina & 15 & 10 & 3.57 \\
\hline Wilya & 13 & 12 & 3.7 & Suci & 17 & 8 & 3.64 \\
\hline Windi & 15 & 9.5 & 3.65 & Febri & 16 & 9.5 & 3.6 \\
\hline Evelin & 10 & 10 & 3.15 & Iman & 10 & 10 & 3.15 \\
\hline
\end{tabular}

Berikut hal-hal yang ingin dilakukan oleh peneliti.

$\Rightarrow$ Membuat persamaan regresi linear berganda yang menerangkan hubungan IP terhadap jumlah jam belajar dalam sehari dan uang jajan dalam sehari.

$\Rightarrow$ Menentukan seberapa besar keeratan hubungan atau korelasi antara faktor jumlah jam belajar dalam sehari dan IP, dengan mengontrol pengaruh uang jajan dalam sehari.

$\Rightarrow$ Menentukan seberapa besar keeratan hubungan atau korelasi antara faktor uang jajan dalam sehari dan IP, dengan mengontrol pengaruh jumlah jam belajar dalam sehari.

$\Rightarrow$ Menentukan seberapa besar faktor jumlah jam belajar dalam sehari berkontribusi dalam hal naik/turunnya IP, dengan mengontrol pengaruh uang jajan dalam sehari. Kemudian menentukan apakah kontribusi tersebut signifikan secara statistika.

$\Rightarrow$ Menentukan seberapa besar faktor uang jajan dalam sehari berkontribusi dalam hal naik/turunnya IP, dengan mengontrol pengaruh jumlah jam belajar dalam sehari. Kemudian menentukan apakan kontribusi tersebut signifikan secara statistika. 
$\Rightarrow$ Menentukan faktor yang memberikan kontribusi paling besar terhadap naik/turunnya IP.

Bangun data pada Tabel 10.1 dalam SPSS seperti berikut (Gambar 10.1).

\begin{tabular}{|c|c|c|c|c|c|c|c|}
\hline & $x_{1}$ & $\times 2$ & $Y$ & & & & \\
\hline 1 & 10 & 7.00 & 3.01 & & & & \\
\hline 2 & 10 & 7.00 & 3.15 & 12 & 12 & 7.20 & 3.16 \\
\hline 3 & 9 & 11.00 & 2.90 & 13 & 9 & 6.00 & 2.95 \\
\hline 4 & 10 & 8.00 & 3.10 & 14 & 10 & 8.00 & 3.12 \\
\hline 5 & 8 & 7.50 & 2.70 & 15 & 8 & 12.00 & 2.80 \\
\hline 6 & 11 & 8.00 & 3.25 & 16 & 11 & 11.00 & 3.30 \\
\hline 7 & 13 & 7.00 & $\begin{array}{l}3.60 \\
3.70\end{array}$ & 17 & 15 & 10.00 & 3.57 \\
\hline $\begin{array}{l}8 \\
9\end{array}$ & $\begin{array}{l}13 \\
15\end{array}$ & $\begin{array}{r}12.00 \\
9.50\end{array}$ & $\begin{array}{l}3.70\lfloor \\
3.65\end{array}$ & 18 & 17 & 8.00 & 3.64 \\
\hline 10 & 10 & 10.00 & 3.15 & 19 & 16 & 9.50 & 3.60 \\
\hline 11 & 10 & 7.00 & 3.02 & 20 & 10 & 10.00 & 3.15 \\
\hline
\end{tabular}

\begin{tabular}{|c|c|c|c|c|c|c|c|}
\hline & Name & Type & Width & Decimals & Label & Values & Missing \\
\hline 1 & $x 1$ & Numeric & 8 & 0 & jumlah jam belajar dalam sehari & None & None \\
\hline 2 & $\times 2$ & Numeric & 8 & 2 & uang jajan dalam sehari & None & None \\
\hline 3 & Y & Numeric & 8 & 2 & nilai indeks prestasi $(\mathbb{P})$ & None & None \\
\hline
\end{tabular}

\section{Gambar 10.1}

Selanjutnya pilih Analyze $\Rightarrow>$ Regression $=>$ Linear, sehingga muncul kotak dialog Linear Regression (Gambar 10.2). Pada kotak dialog Linear Regression, masukkan variabel IP ke dalam kotak Dependent dan masukkan variabel X1 dan X2 ke dalam kotak Independent(s). Kemudian pilih Statistics, sehingga muncul kotak dialog Linear Regression: Statistics (Gambar 10.3). Pada kotak dialog Linear Regression: Statistics, pilih Model fit, Estimates, Colinearity diagnostics, dan Durbin-Watson. Kemudian pilih Continue.

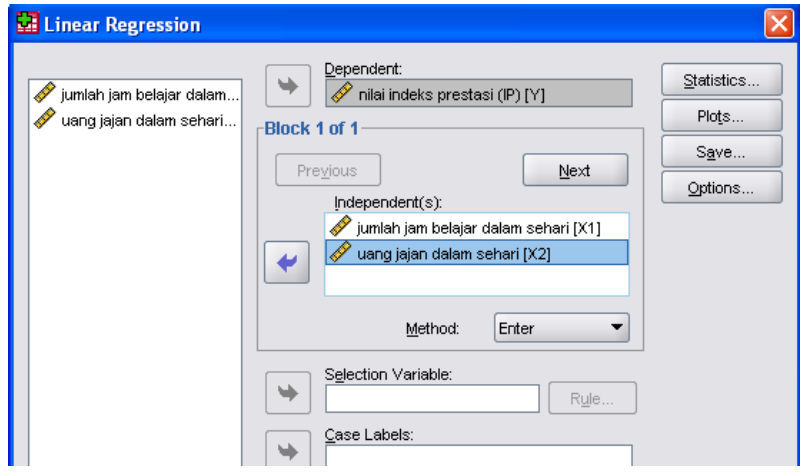

Gambar 10.2

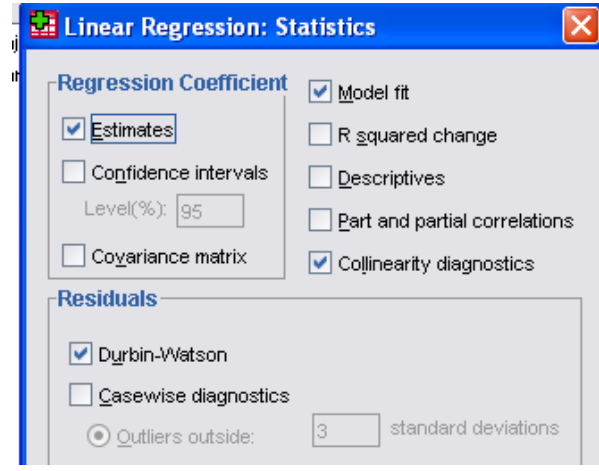

Gambar 10.3

Pilih Plots, sehingga muncul kotak dialog Linear Regression: Plots (Gambar 10.4). Pada kotak dialog Linear Regression: Plots, masukkan *ZPRED ke dalam kotak X dan masukkan *SRESID ke dalam kotak Y. selanjutnya pilih Histogram dan Normal probability plot pada Standardized Residual Plots. Pilih Continue. Selanjutnya pilih Save, sehingga muncul kotak dialog Linear Regression: Save (Gambar 10.5). Pada kotak dialog Linear Regression: Save, pilih Unstandardized pada Residual. Kemudian pilih Continue dan OK. Berikut hasil perhitungan berdasarkan SPSS. 


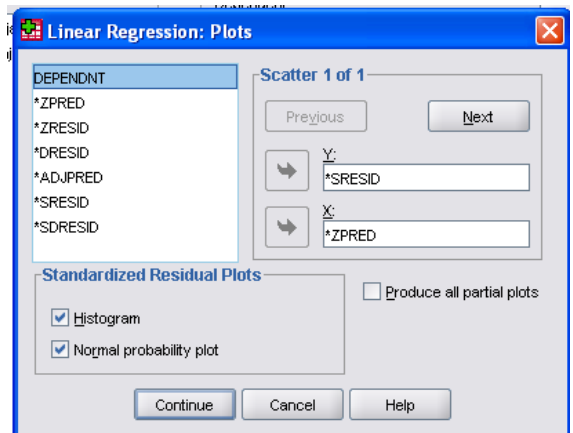

Gambar 10.4

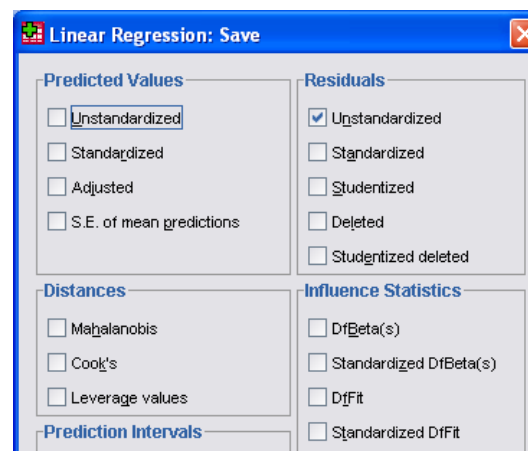

Gambar 10.5

\section{Ují Asumsi Normalitas Error}

Pengujian asumsi normalitas error akan dilakukan dengan pendekatan analisis grafik, yakni histogram (Gambar 10.6) dan normal probability plot (Gambar 10.7). Gambar 10.6 dan Gambar 10.7 merupakan output dari SPSS. Perhatikan bahwa kurva pada histogram berbentuk kurva normal, sehingga disimpulkan bahwa asumsi normalitas error dipenuhi. Di samping itu pada normal probability plot (Gambar 10.7), titik-titik menyebar cukup dekat pada garis diagonal, maka disimpulkan bahwa asumsi normalitas dipenuhi.

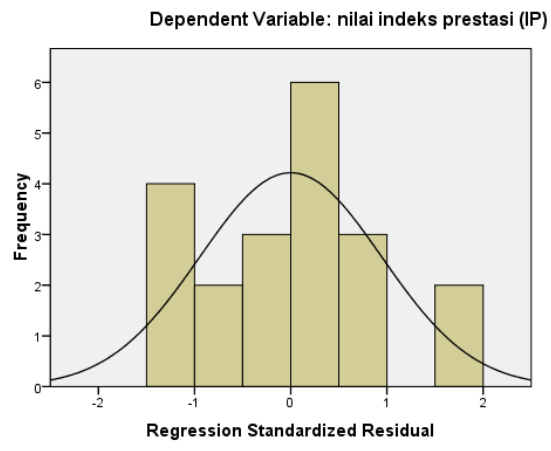

Gambar 10.6

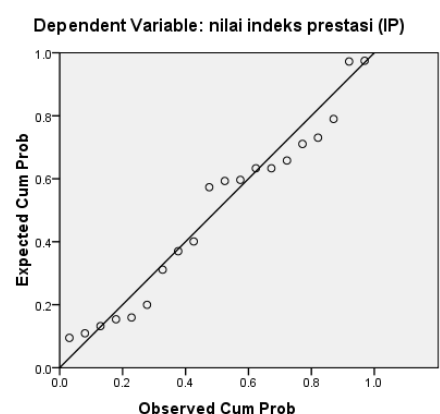

Gambar 10.7

Pada pengujian asumsi normalitas error dengan pendekatan analisis grafik, disimpulkan bahwa asumsi normalitas error dipenuhi. Berikut akan digunakan pendekatan uji Kolmogorov-Smirnov untuk menguji asumsi normalitas error. Pilih Analyze $\Rightarrow$ Nonparametric Tests $\Rightarrow 1$-Sample $K-S$, sehingga muncul kotak dialog One-Sample Kolmogorov-Smirnov Test (Gambar 10.8). Masukkan variabel RES_1 ke dalam kotak Test Variable List. Pada Test Distribution, pilih Normal. Kemudian pilih OK. Output SPSS dari uji Kolmogorov-Smirnov disajikan pada Tabel 10.2.

Dalam pendekatan uji Kolmogorov-Smirnov, pengujian normalitas dilakukan dengan menggunakan data residual ( $\hat{e})$. Hipotesis nol menyatakan error berdistribusi normal, sedangkan hipotesis alternatif menyatakan error tidak berdistribusi normal. Untuk pengambilan keputusan terhadap hipotesis, dapat dibandingkan antara nilai probabilitas dari uji Kolmogorov-Smirnov dengan tingkat signifikansi yang digunakan $(\alpha)$. Berikut aturan pengambilan keputusan terhadap hipotesis.

Jika nilai probabilitas $\geq$ tingkat signifikansi, $H_{0}$ diterima dan $H_{1}$ ditolak. Jika nilai probabilitas $<$ tingkat signifikansi, $H_{0}$ ditolak dan $H_{1}$ diterima. 
Tabel 10.2
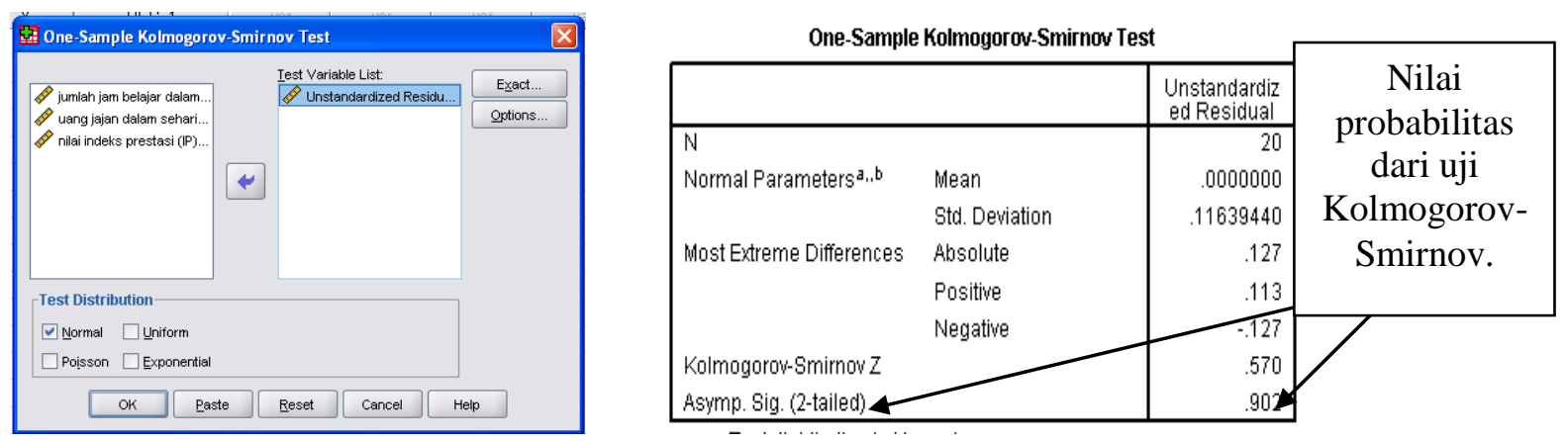

\section{Gambar 10.8}

Berdasarkan Tabel 10.2, diketahui nilai probabilitas (Asymp. Sig. (2-tailed)) adalah 0,902. Karena nilai probabilitas lebih besar dibandingkan tingkat signifikansi $\alpha=0,05$, maka disimpulkan bahwa asumsi normalitas dari error dipenuhi.

\section{Ují Asumsi Tídak Terjadi Multíkolinearitas}

Untuk mendeteksi apakah terindikasi terjadi gejala multikolinieritas atau tidak, dapat digunakan pendekatan nilai VIF (variance inflation factor) atau nilai tolerance. Nilai VIF dari masing-masing variabel bebas dihitung dengan maksud untuk mendeteksi apakah terindikasi terjadi gejala multikolinieritas atau tidak. Nilai VIF yang lebih besar dari 10 diindikasi terjadi multikolinearitas (Myers dalam Steven, 2009).

Output SPSS untuk uji asumsi tidak terjadi multikolinearitas disajikan pada Tabel 10.3. Berdasarkan Tabel 10.3, dapat dilihat bahwa nilai VIF untuk jumlah jam belajar dalam sehari (X1) dan uang jajan dalam sehari (X2) adalah 1,007. Karena nilai VIF dari kedua variabel bebas tersebut tidak lebih dari 10, maka disimpulkan tidak terjadi multikolinearitas.

\section{Tabel 10.3}

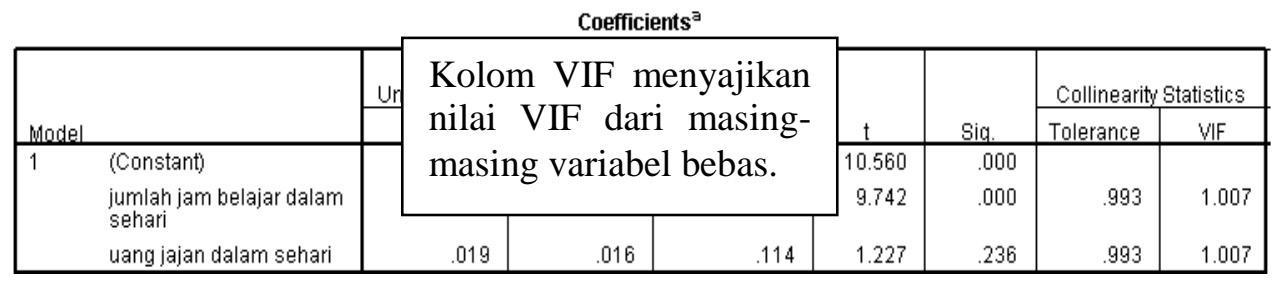

\section{Uji Asumsí Non-Autokorelasi}

Untuk menguji asumsi independensi dari error, dapat digunakan uji Durbin-Watson. Field (2009) menyatakan nilai statistik dari uji Durbin-Watson yang lebih besar dari (greater than) 2 atau lebih kecil (less than) dari -2 diindikasi terkena gejala autokorelasi. Output SPSS untuk uji asumsi non-autokorelasi disajikan pada Tabel 10.4. Berdasarkan Tabel 10.4, dapat dilihat bahwa nilai statistik dari uji Durbin-Watson adalah 1,584. Perhatikan bahwa karena nilai statistik dari uji Durbin-Watson berada di antara -2 dan 2, maka disimpulkan bahwa asumsi independensi dari error atau non-autokorelasi dipenuhi. 
Tabel 10.4

\begin{tabular}{|c|c|c|c|c|c|}
\hline \multicolumn{6}{|c|}{ Model Summary ${ }^{b}$} \\
\hline Madel & $\mathrm{R}$ & R Square & $\begin{array}{c}\text { Adjusted R } \\
\text { Square }\end{array}$ & $\begin{array}{l}\text { Std. Error of } \\
\text { the Estimate }\end{array}$ & $\begin{array}{l}\text { Durbin- } \\
\text { Watson }\end{array}$ \\
\hline 1 & $.924^{a}$ & .854 & .836 & .12305 & 1.584 \\
\hline
\end{tabular}

\section{Uji Asumsi Homoskedastísitas}

Untuk mendeteksi terjadinya gejala heteroskedastisitas dapat dilakukan dengan pendekatan analisis grafik dari residual atau dengan menggunakan uji Park. Dalam pendekatan analisis grafik dari residual, sumbu horizontal menyatakan nilai estimasi dari variabel tak bebas terstandarisasi (regression standardized predicted value), sedangkan sumbu vertikal menyatakan nilai residual (studentized residual). Apabila sebaran titik-titik dalam grafik analisis residual menyebar secara acak (no systematic pattern) di sekitar 0 (around zero), maka diindikasi tidak terjadi heteroskedastisitas, namun apabila titik-titik dalam grafik analisis residual tidak menyebar secara acak (membentuk suatu pola), maka diindikasi terjadi heteroskedastisitas. Output SPSS untuk uji asumsi homoskedastisitas dengan pendekatan analisis grafik residual disajikan pada Gambar 10.9. Berdasarkan grafik pada Gambar 10.9, titik-titik menyebar secara acak di sekitar 0 , sehingga diindikasi tidak terjadi heteroskedastisitas.

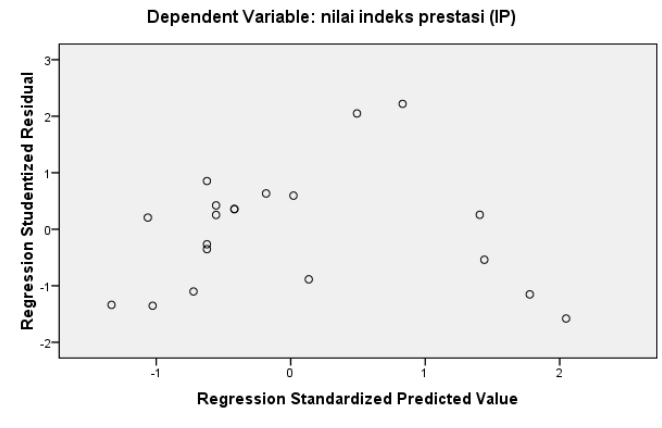

Gambar 10.9

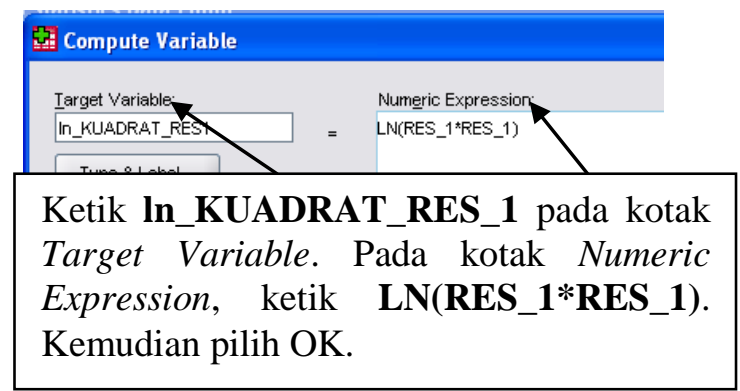

Gambar 10.10

Pada pengujian asumsi homoskedastisitas dengan pendekatan analisis grafik residual, disimpulkan bahwa diindikasi tidak terjadi heteroskedastisitas. Berikut akan digunakan pendekatan uji Park untuk menguji asumsi homoskedastisitas. Pilih Transform $=>$ Compute Variable, sehingga muncul kotak dialog Compute Variable (Gambar 10.10). Ketik In_KUADRAT_RES_1 pada kotak Target Variable dan pada kotak Numeric Expression: ketik LN(RES_1*RES_1). Kemudian pilih OK. Perhatikan bahwa telah terbentuk variabel baru bernama In_KUADRAT_RES_1 (Gambar 10.11). Selanjutnya, pilih Transform => Compute Variable, sehingga muncul kotak dialog Compute Variable. Pada kotak Target Variable ketik In_X1 dan pada kotak Numeric Expression: ketik LN(X1) (Gambar 10.12). Kemudian pilih OK, sehingga terbentuk variabel baru bernama In_X1 (Gambar 10.13). 


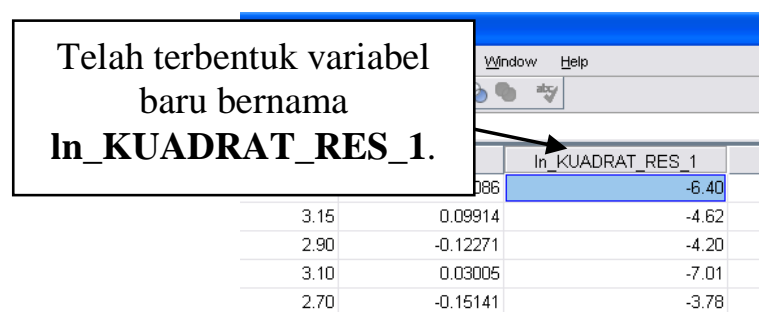

Gambar 10.11

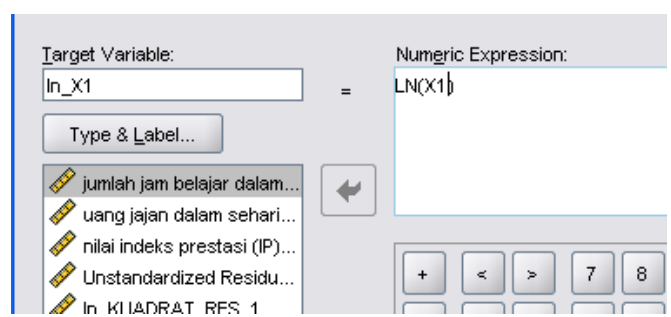

Gambar 10.12

Pilih Transform => Compute Variable, sehingga muncul kotak dialog Compute Variable. Pada kotak Target Variable ketik In_X2 dan pada kotak Numeric Expression: ketik LN(X2) (Gambar 10.14). Kemudian pilih OK, sehingga terbentuk variabel baru bernama In_X2 (Gambar 10.15).

\begin{tabular}{r|r|}
\hline UADRAT_RES_1 & \multicolumn{1}{c}{$\ln$ I X1 } \\
\hline-6.40 & 2.30 \\
\hline-4.62 & 2.30 \\
\hline-4.20 & 2.20 \\
\hline-7.01 & 2.30 \\
\hline-3.78 & 2.08 \\
\hline-5.17 & 2.40 \\
\hline-2.89 & 2.56 \\
\hline-2.85 & 2.56 \\
\hline-7.08 & 2.71 \\
\hline$r ר$ & $77 n$ \\
\hline
\end{tabular}

Gambar 10.13

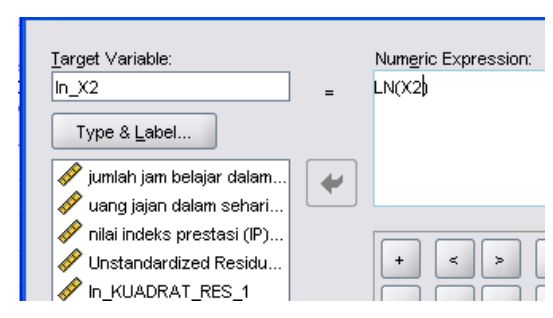

Gambar 10.14

\begin{tabular}{r|r|r|}
\hline RES_1 & In_X1 & \multicolumn{1}{c|}{$\ln$ X2 } \\
\hline \hline-6.40 & 2.30 & 1.95 \\
\hline-4.62 & 2.30 & 1.95 \\
\hline-4.20 & 2.20 & 2.40 \\
\hline-7.01 & 2.30 & 2.08 \\
\hline-3.78 & 2.08 & 2.01 \\
\hline-5.17 & 2.40 & 2.08 \\
\hline-2.89 & 2.56 & 1.95 \\
\hline-2.85 & 2.56 & 2.48 \\
\hline-7.08 & 2.71 & 2.25 \\
\hline-6.35 & 2.30 & 2.30 \\
\hline-2. & $\cdots$ & $\ldots$. \\
\hline
\end{tabular}

Gambar 10.15

Selanjutnya pilih Analyze $=>$ Regression $=>$ Linear, sehingga muncul kotak dialog Linear Regression (Gambar 10.16). Masukkan variabel In_KUADRAT_RES_1 pada kotak Dependent: dan masukkan variabel In_X1 dan In_X2 pada kotak Independet(s). Kemudian pilih OK. Output SPSS untuk uji asumsi homoskedastisitas dengan uji Park disajikan pada Tabel 10.5. Perhatikan bahwa berdasarkan Tabel 10.5, nilai probabilitas (Sig) untuk koefisien regresi dari variabel In_X1 dan In_X2 masing-masing adalah 0,424 dan 0,292. Perhatikan bahwa karena nilai-nilai probabilitas tersebut lebih besar dari tingkat signifikansi $\alpha=0,05$, maka disimpulkan bahwa tidak terjadi heteroskedastisitas. Dengan kata lain, asumsi mengenai homoskedastisitas dipenuhi.

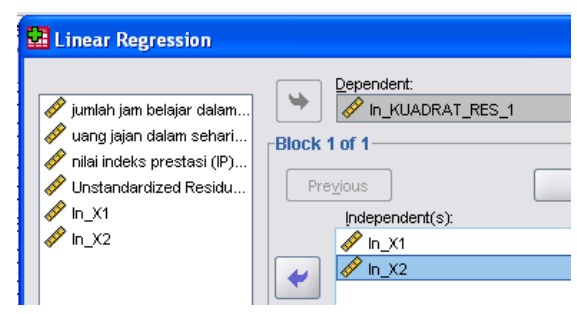

\section{Gambar 10.16}

\section{Tabel 10.5}

\begin{tabular}{|c|c|c|c|c|c|c|c|c|}
\hline \multicolumn{9}{|c|}{ Coefficients ${ }^{a}$} \\
\hline & & \multicolumn{2}{|c|}{ Unstandardized Coefficients } & $\begin{array}{l}\text { Standardized } \\
\text { Coefficients }\end{array}$ & \multirow[b]{2}{*}{$t$} & \multirow[b]{2}{*}{ Siq. } & \multicolumn{2}{|c|}{ Collinearity Statistics } \\
\hline \multicolumn{2}{|c|}{ Model } & B & Std. Error & Beta & & & Tolerance & VIF \\
\hline \multirow[t]{3}{*}{1} & (Constant) & -12.013 & 4.780 & & -2.513 & .022 & & \\
\hline & $\ln \_x 1$ & 1.239 & 1.511 & .189 & .820 & .424 & .988 & 1.012 \\
\hline & $\ln \_x 2$ & 1.769 & 1.629 & .250 & 1.086 & .292 & .988 & 1.012 \\
\hline
\end{tabular}

Perhatikan bahwa telah diperlihatkan asumsi normalitas dari error, tidak terjadi multikolinearitas, non-autokorelasi, dan homoskedastisitas telah dipenuhi. 


\section{Mengukur Kecocokkan Model Regresi Linear Berganda terhadap Data dengan Koefisien Determinasi $\left(r^{2}\right)$}

Dalam regresi linear, baik itu sederhana maupun berganda, koefisien determinasi $\left(r^{2}\right)$ digunakan untuk mengukur kemampuan model regresi linear dalam mencocokkan atau menyesuaikan (fits) data. Nilai koefisien determinasi berkisar antara 0 dan 1 . Nilai koefisien determinasi yang semakin dekat dengan 1 menunjukkan semakin baik kemampuan model regresi linear dalam mencocokkan atau menyesuaikan (fits) data. Dengan kata lain kemampuan variabel-variabel bebas dalam menjelaskan variation variabel tak bebas semakin baik. Output SPSS yang menyajikan nilai statistik dari koefisien determinasi disajikan pada Tabel 10.4. Diketahui nilai koefisien determinasi atau $R$-Square adalah 0,854 . Nilai tersebut dapat diinterpretasikan sebagai variabel jumlah jam belajar dalam sehari dan uang jajan dalam sehari mampu menjelaskan atau menerangkan variation variabel IP sebesar $85,4 \%$, sisanya sebesar 14,6\% dijelaskan oleh variabel-variabel lain.

\section{Menguji Kecocokkan Model Regresi Linear terhadap Data dengan Uji F}

Output SPSS yang menyajikan nilai statistik dari uji $F$ disajikan pada Tabel 10.6. Berikut perumusan hipotesis untuk uji $F$.

$$
H_{0}: \beta_{1}=\beta_{2}=\cdots=\beta_{k}=0 .
$$

$H_{1}$ : Paling tidak terdapat satu koefisien regresi populasi yang tidak sama dengan nol.

Perhatikan bahwa hipotesis nol menyatakan seluruh koefisien regresi populasi bernilai nol. Dengan kata lain, variabel bebas jumlah jam belajar dalam sehari dan uang jajan dalam sehari tidak memiliki pengaruh yang signifikan secara statistikaa terhadap variabel IP. Hipotesis alternatif menyatakan bahwa paling tidak terdapat satu koefisien regresi populasi yang tidak bernilai nol. Dengan kata lain, paling tidak terdapat satu variabel bebas yang memiliki pengaruh signifikan secara statistika terhadap variabel IP.

\section{Tabel 10.6}

\begin{tabular}{|c|c|c|c|c|c|c|}
\hline \multicolumn{7}{|c|}{ ANOVA ${ }^{\mathrm{b}}$} \\
\hline Model & & $\begin{array}{c}\text { Sum of } \\
\text { Squares }\end{array}$ & df & Mean Square & $\mathrm{F}$ & Sig. \\
\hline 1 & Regression & 1.501 & 2 & .751 & 49.568 & $.000^{\mathrm{a}}$ \\
\hline & Residual & .257 & 17 & .015 & & \\
\hline & Total & 1.758 & 19 & & & \\
\hline
\end{tabular}

Berdasarkan Tabel 10.6, diketahui nilai statistik dari uji $F$ adalah 49,568. Nilai derajat bebas pembilang adalah $k-1=3-1=2$ dan nilai derajat bebas penyebut adalah $n-k=20-$ $3=17$. Nilai kritis $F$ dengan derajat bebas pembilang 2, derajat bebas penyebut 17 , dan tingkat signifikansi 5\% adalah 3,20. Berikut aturan pengambilan keputusan terhadap hipotesis berdasarkan uji $F$.

Jika nilai statistik dari uji $F \leq$ nilai kritis $F$, maka $H_{0}$ diterima dan $H_{1}$ ditolak. jika nilai statistik dari uji $F>$ nilai kritis $F$, maka $H_{0}$ ditolak dan $H_{1}$ diterima. 
Perhatikan bahwa karena nilai statistik dari uji $F$ lebih kecil dibandingkan nilai kritis $F$, maka hipotesis nol ditolak dan hipotesis alternatif diterima. Hal ini berarti paling tidak terdapat satu variabel bebas yang memiliki pengaruh signifikan secara statistika terhadap variabel IP.

Pengambilan keputusan terhadap hipotesis juga dapat dilakukan dengan menggunakan pendekatan nilai probabilitas dari uji $F$. Nilai probabilitas dari uji $F$ dibandingkan dengan tingkat signifikansi yang digunakan. Berikut aturan pengambilan keputusan terhadap hipotesis berdasarkan nilai probabilitas.

Jika nilai probabilitas $\geq$ tingkat signifikansi, maka $H_{0}$ diterima dan $H_{1}$ ditolak. Jika nilai probabilitas < tingkat signifikansi, maka $H_{0}$ ditolak dan $H_{1}$ diterima.

Berdasarkan Tabel 10.6 diketahui nilai probabilitas (Sig) 0,000. Karena nilai probabilitas tersebut lebih kecil dibandingkan $\alpha=0,05$, maka hipotesis nol ditolak dan hipotesis alternatif diterima. Hal ini berarti paling tidak terdapat satu variabel bebas yang memiliki pengaruh signifikan secara statistika terhadap variabel IP.

\section{Korelasi Parsial (Partial Correlation)}

Berikut akan ditentukan seberapa besar keeratan hubungan atau korelasi antara faktor jumlah jam belajar dalam sehari dan IP, dengan mengontrol pengaruh uang jajan dalam sehari. Pilih Analyze $=>$ Correlate $=>$ Partial, sehingga muncul kotak dialog Partial Correlation (Gambar 10.17). Masukkan variabel jumlah jam belajar dalam sehari (X1) dan IP (Y) ke dalam kotak Variables dan masukkan variabel uang jajan dalam sehari (X2) ke dalam kotak Controlling for. Kemudian pilih OK. Output SPSS untuk nilai korelasi parsial X1 dan Y, dengan mengontrol pengaruh variabel X2 disajikan pada Tabel 10.7. Perhatikan bahwa jumlah jam belajar dalam sehari memiliki keeratan hubungan terhadap IP sebesar 0,921, dengan mengontrol pengaruh dari uang jajan dalam sehari. Perhatikan bahwa nilai korelasi parsial tersebut mendekati 1 . Sehingga keeratan hubungan yang terjadi cukup kuat.

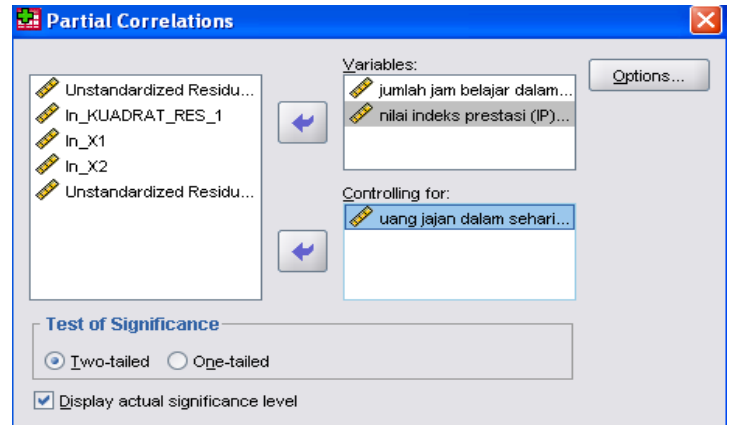

Gambar 10.17

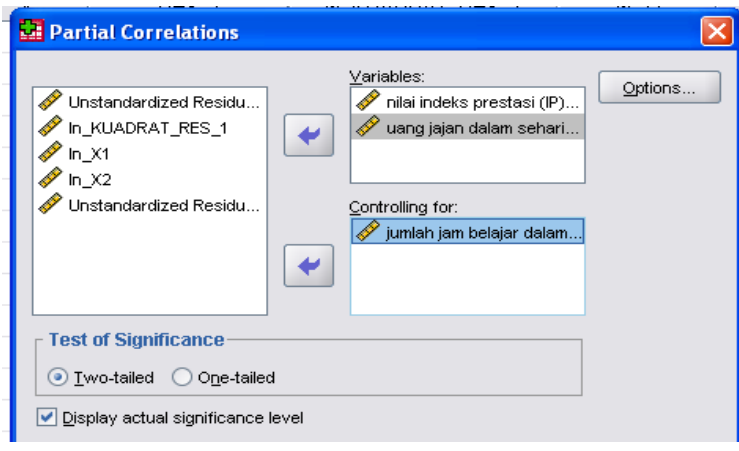

Gambar 10.18

Tabel 10.7

Correlations

\begin{tabular}{|lll|r|r|}
\hline & & $\begin{array}{c}\text { jumlah jam } \\
\text { belajar dalam } \\
\text { Sehari }\end{array}$ & $\begin{array}{c}\text { nilai indeks } \\
\text { prestasi (IP) }\end{array}$ \\
\hline Canng jajan dalam sehari Variables & jumlah jam belajar dalam & Correlation & 1.000 & .921 \\
& Sehari & & .000 \\
& & Significance (2-tailed) & & 17 \\
\cline { 2 - 5 } & df & 0 & 1.000 \\
& nilai indeks prestasi (IP) & Correlation & .921 & \\
& & Significance (2-tailed) & .000 & 0 \\
& df & 17 & \\
& & & & \\
\end{tabular}




\section{Tabel 10.8}

\begin{tabular}{|c|c|c|c|c|}
\hline \multicolumn{5}{|c|}{ Correlations } \\
\hline & & & $\begin{array}{l}\text { nilai indeks } \\
\text { prestasi }(\mathbb{P})\end{array}$ & $\begin{array}{c}\text { uang jajan } \\
\text { dalam sehari }\end{array}$ \\
\hline \multirow{6}{*}{$\begin{array}{l}\text { jumlah jam belajar dalam } \\
\text { sehari }\end{array}$} & \multirow[t]{3}{*}{ nilai indeks prestasi $(\mathbb{I P})$} & Correlation & 1.000 & .285 \\
\hline & & Significance (2-tailed) & & .236 \\
\hline & & df & 0 & 17 \\
\hline & \multirow[t]{3}{*}{ uang jajan dalam sehari } & Correlation & .285 & 1.000 \\
\hline & & Significance (2-tailed) & .236 & \\
\hline & & df & 17 & 0 \\
\hline
\end{tabular}

Selanjutnya akan ditentukan seberapa besar keeratan hubungan atau korelasi antara faktor uang jajan dalam sehari dan IP, dengan mengontrol pengaruh jumlah jam belajar dalam sehari. Pilih Analyze $\Rightarrow$ Correlate $\Rightarrow$ Partial, sehingga muncul kotak dialog Partial Correlation (Gambar 10.18). Masukkan variabel uang jajan dalam sehari (X2) dan IP (Y) ke dalam kotak Variables dan masukkan variabel jumlah jam belajar dalam sehari (X1) ke dalam kotak Controlling for. Kemudian pilih OK. Output SPSS untuk nilai korelasi parsial X2 dan $\mathbf{Y}$, dengan mengontrol pengaruh variabel X1 disajikan pada Tabel 10.8. Perhatikan bahwa uang jajan dalam sehari memiliki keeratan hubungan terhadap IP sebesar 0,285, dengan mengontrol pengaruh dari jumlah jam belajar dalam sehari. Perhatikan bahwa nilai korelasi parsial tersebut mendekati 0 , sehingga keeratan hubungan yang terjadi tidak terlalu kuat.

\section{Uji Signifikansi Koefísien Regresi Secara Individu dengan Uji t}

Berikut akan ditentukan apakah faktor jumlah jam belajar dalam sehari mempengaruhi IP secara signifikan (signifikan secara statistika), dengan mengontrol pengaruh uang jajan dalam sehari. Output SPSS untuk uji signifikansi koefisien regresi populasi secara individu dengan uji $t$ disajikan pada Tabel 10.3. Berdasarkan Tabel 10.3, nilai statistik dari uji $t$ untuk variabel jumlah jam belajar dalam sehari adalah 9,742. Nilai kritis $t$ dengan derajat bebas $n-k=$ $20-3=17$ dan tingkat signifikansi $5 \%$ adalah $\pm 2,110$. Berikut aturan pengambilan keputusan terhadap hipotesis berdasarkan uji $t$.

$$
\begin{aligned}
& \text { Jika }\left|t_{\text {hitung }}\right| \leq\left|t_{\text {kritis }}\right|, \text { maka } H_{0} \text { diterima dan } H_{1} \text { ditolak. } \\
& \text { Jika }\left|t_{\text {hitung }}\right|>\left|t_{\text {kritis }}\right| \text {, maka } H_{0} \text { ditolak dan } H_{1} \text { diterima. }
\end{aligned}
$$

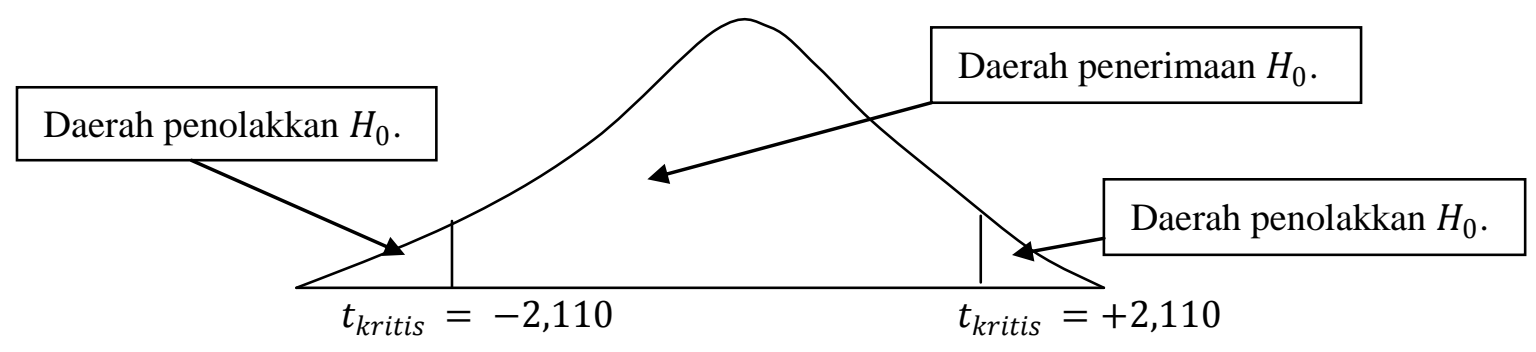

Perhatikan bahwa karena $\left|t_{\text {hitung }}\right|>\left|t_{\text {kritis }}\right|$, yakni 9,742 $>2,110$, maka disimpulkan bahwa faktor jumlah jam belajar dalam sehari mempengaruhi IP secara signifikan (signifikan secara statistika), dengan mengontrol pengaruh uang jajan dalam sehari.

Pengambilan keputusan terhadap hipotesis juga dapat dilakukan dengan menggunakan pendekatan nilai probabilitas dari uji $t$. Nilai probabilitas dari uji $t$ dibandingkan dengan tingkat signifikansi yang digunakan. Berikut aturan pengambilan keputusan terhadap hipotesis berdasarkan nilai probabilitas. 
Jika nilai probabilitas $\geq$ tingkat signifikansi, maka $H_{0}$ diterima dan $H_{1}$ ditolak. Jika nilai probabilitas $<$ tingkat signifikansi, maka $H_{0}$ ditolak dan $H_{1}$ diterima.

Nilai probabilitas (Sig) dari uji $t$ berdasarkan variabel jumlah jam belajar dalam sehari adalah 0,000 . Karena nilai probabilitas tersebut lebih kecil dibandingkan tingkat signifikansi $\alpha=$ $5 \%$, maka disimpulkan bahwa faktor jumlah jam belajar dalam sehari mempengaruhi IP secara signifikan (signifikan secara statistika), dengan mengontrol pengaruh uang jajan dalam sehari.

Diketahui nilai koefisien regresi untuk variabel jumlah jam belajar dalam sehari adalah 0,104. Nilai tersebut dapat diinterpretasikan ketika jumlah jam belajar dalam sehari ditambah satu jam, maka diharapkan (expected) nilai indeks prestasi meningkat sebesar 0,104, ketika pengaruh dari uang jajan dalam sehari dipertahankan konstan.

Selanjutnya akan ditentukan apakah faktor uang jajan dalam sehari mempengaruhi IP secara signifikan (signifikan secara statistika), dengan mengontrol pengaruh jumlah jam belajar dalam sehari. Berdasarkan Tabel 10.3, nilai statistik dari uji $t$ untuk variabel uang jajan dalam sehari adalah 1,227. Nilai kritis $t$ dengan derajat bebas $n-k=20-3=17$ dan tingkat signifikansi $5 \%$ adalah $\pm 2,110$.

Perhatikan bahwa karena $\left|t_{\text {hitung }}\right| \leq\left|t_{\text {kritis }}\right|$, yakni $1,227<2,110$, maka disimpulkan bahwa faktor uang jajan dalam sehari tidak mempengaruhi IP secara signifikan (signifikan secara statistika), dengan mengontrol pengaruh uang jajan dalam sehari. Dengan kata lain, pengaruh yang diberikan oleh faktor uang jajan dalam sehari terhadap IP sangat lemah, dengan mengontrol pengaruh jumlah jam belajar dalam sehari.

Nilai probabilitas (Sig) dari uji $t$ berdasarkan variabel uang jajan dalam sehari adalah 0,236. Karena nilai probabilitas tersebut lebih besar dibandingkan tingkat signifikansi $\alpha=5 \%$, maka disimpulkan bahwa faktor uang jajan dalam sehari tidak mempengaruhi IP secara signifikan (signifikan secara statistika), dengan mengontrol pengaruh jumlah jam belajar dalam sehari. 
Andaikan diberikan data mengenai pengeluaran per-bulan, pendapatan per-bulan, dan jumlah anak, dari 20 keluarga (Tabel 10.9).

Tabel 10.9 Data Mengenai Pengeluaran Per-Bulan, Pendapatan Per-Bulan, dan Jumlah Anak dari 20 Keluarga (Data Fiktif)

\begin{tabular}{|c|c|c|c|}
\hline Keluarga Ke & Pengeluaran (dalam jutaan) & Pendapatan (dalam jutaan) & Jumlah Anak \\
\hline 1 & 3.3 & 3.6 & 4 \\
\hline 2 & 4.2 & 4.7 & 2 \\
\hline 3 & 5.4 & 6.5 & 5 \\
\hline 4 & 5.3 & 8.4 & 3 \\
\hline 5 & 5.7 & 6.2 & 5 \\
\hline 6 & 3.5 & 4.5 & 2 \\
\hline 7 & 6.2 & 7.8 & 2 \\
\hline 8 & 3.6 & 3.9 & 5 \\
\hline 9 & 7.5 & 8.9 & 2 \\
\hline 10 & 5.4 & 6.2 & 5 \\
\hline 11 & 5.3 & 8.5 & 3 \\
\hline 12 & 4.3 & 5 & 6 \\
\hline 13 & 7.8 & 8 & 3 \\
\hline 14 & 4.2 & 6.4 & 5 \\
\hline 15 & 3.5 & 4 & 3 \\
\hline 16 & 5.3 & 8.9 & 6 \\
\hline 17 & 4.3 & 10 & 3 \\
\hline 18 & 7.8 & 8 & 3 \\
\hline 19 & 4.2 & 5 & 4 \\
\hline 20 & 3.5 & & \\
\hline
\end{tabular}

Berdasarkan data pada Tabel 10.9, diketahui pada keluarga ke-1 memiliki pendapatan perbulan sebesar 3,6 juta, 4 orang anak, dan pengeluaran per-bulan sebesar 3,3 juta. Keluarga ke19 memiliki pendapatan per-bulan sebesar 5 juta, 3 orang anak, dan pengeluaran per-bulan sebesar 4.2 juta. Misalkan variabel pengeluaran sebagai variabel tak bebas (dependent), sedangkan variabel pendapatan dan jumlah anak sebagai variabel bebas (independent). Berikut hal-hal yang ingin diketahui.

$\Rightarrow$ Membuat persamaan regresi linear berganda yang menerangkan hubungan pengeluaran terhadap pendapatan, dan jumlah anak.

$\Rightarrow$ Menentukan seberapa besar faktor pendapatan berkontribusi dalam hal naik/turunnya pengeluaran, dengan mengontrol pengaruh jumlah anak. Kemudian menentukan apakah kontribusi tersebut signifikan secara statistika.

$\Rightarrow$ Menentukan seberapa besar faktor jumlah anak berkontribusi dalam hal naik/turunnya pengeluaran, dengan mengontrol pengaruh pendapatan. Kemudian menentukan apakan kontribusi tersebut signifikan secara statistika. 
$\Rightarrow$ Menentukan faktor yang memberikan kontribusi paling besar terhadap naik/turunnya pengeluaran.

Sajikan data pada Tabel 10.9 dalam Microsoft Excel sebagai berikut (Gambar 10.19).

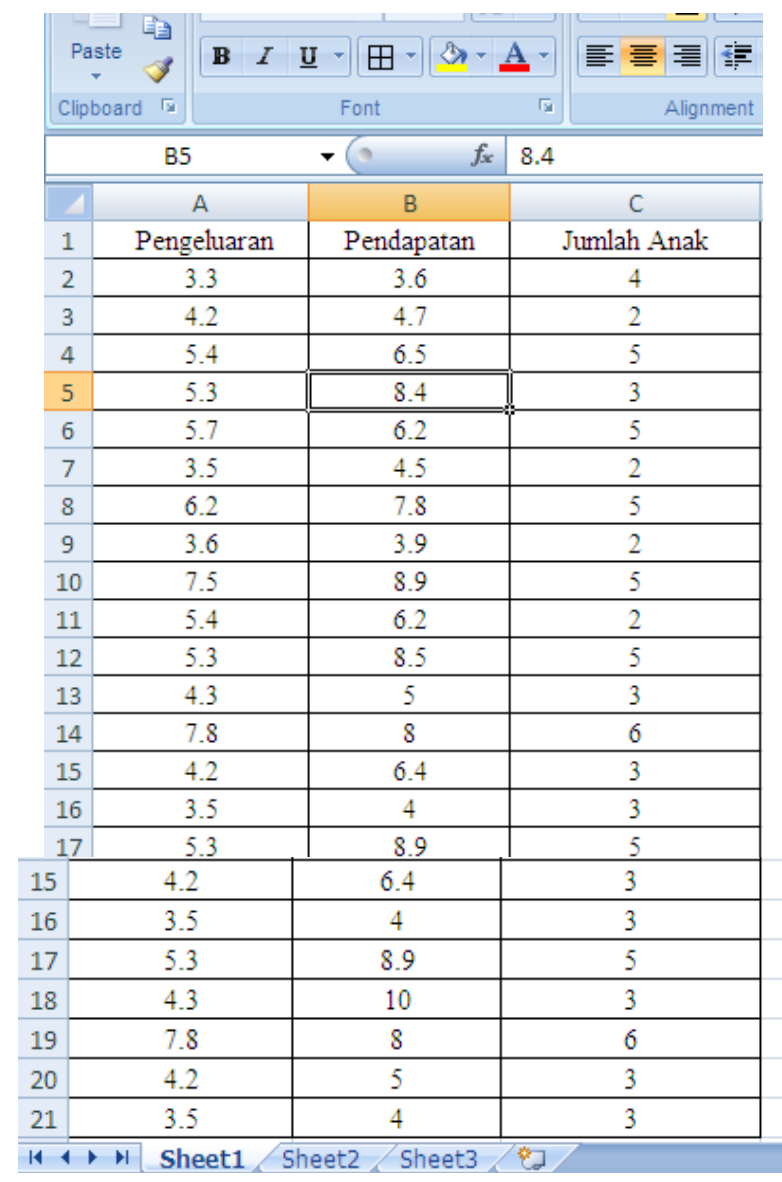

Gambar 10.19

Selanjutnya simpan dengan format Excel 97-2003 Workbook dan ketik nama file dengan data regresi ugi (Gambar 10.20). Kemudian disimpan (pilih Save), selanjutnya keluar dari program Microsoft Excel, dan aktifikan EViews 7. Pilih File $\Rightarrow>$ New $=>$ Workfile... (Gambar 10.21), sehingga muncul kotak Workfile Create (Gambar 10.22).

Pada Gambar 10.22, yakni pada Workfile structure type, atur menjadi Unstructured / Undated, dan pada Observations:, ketik 20. Dalam hal ini, jumlah keluarga yang diteliti sebanyak 20. Selanjutnya pilih OK, sehingga muncul kotakWorkfile: UNTITLED (Gambar 10.23).

Pada Gambar 10.24, pilih Proc $=>$ Import $=>$ Load Workfile Page..., sehingga muncul kotak Open (Gambar 10.25). Pada Gambar 10.25, pilih file Microsoft Excel yang telah disimpan sebelumnya, yakni dengan nama data regresi ugi, dengan Files of type: Excel 97-2003 file (*.xls). Kemudian pilih Open, sehingga muncul kotak Excel 97-2003 Read - Step 1of 3 (Gambar 10.26). 


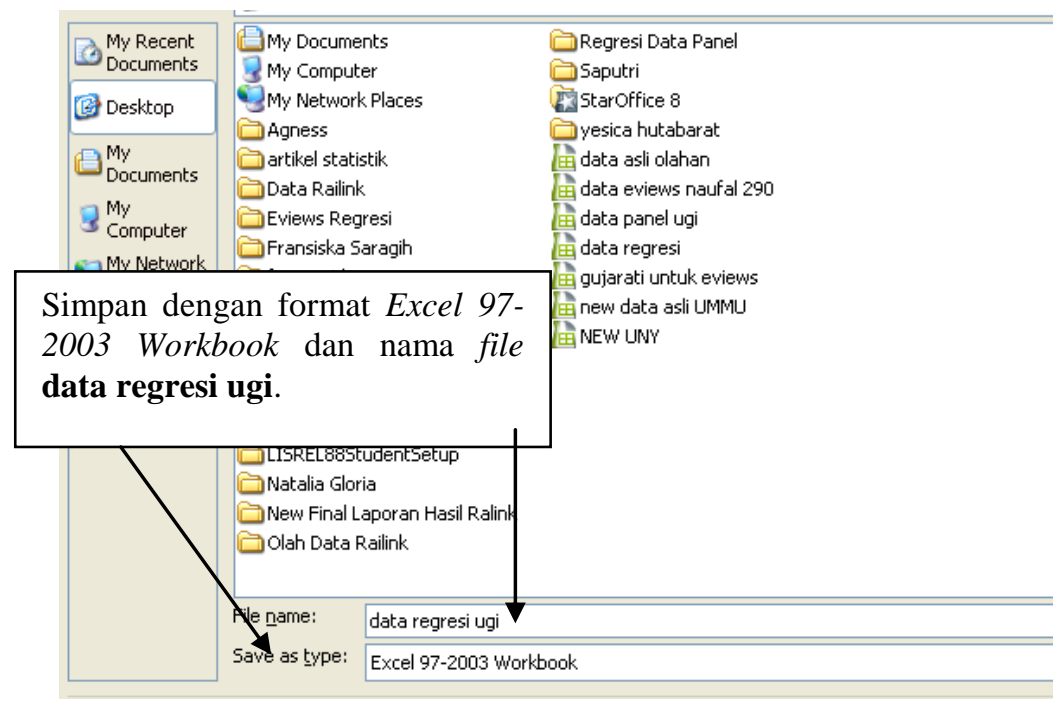

Gambar 10.20

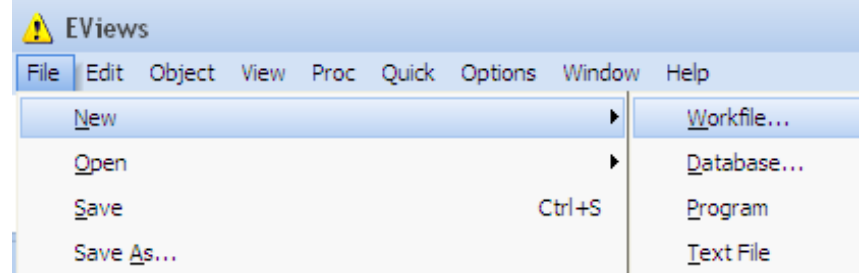

Gambar 10.21

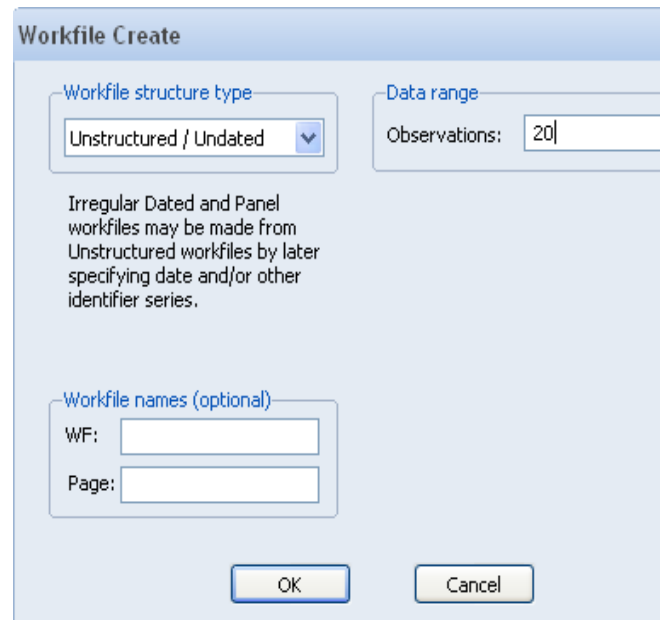

Gambar 10.22

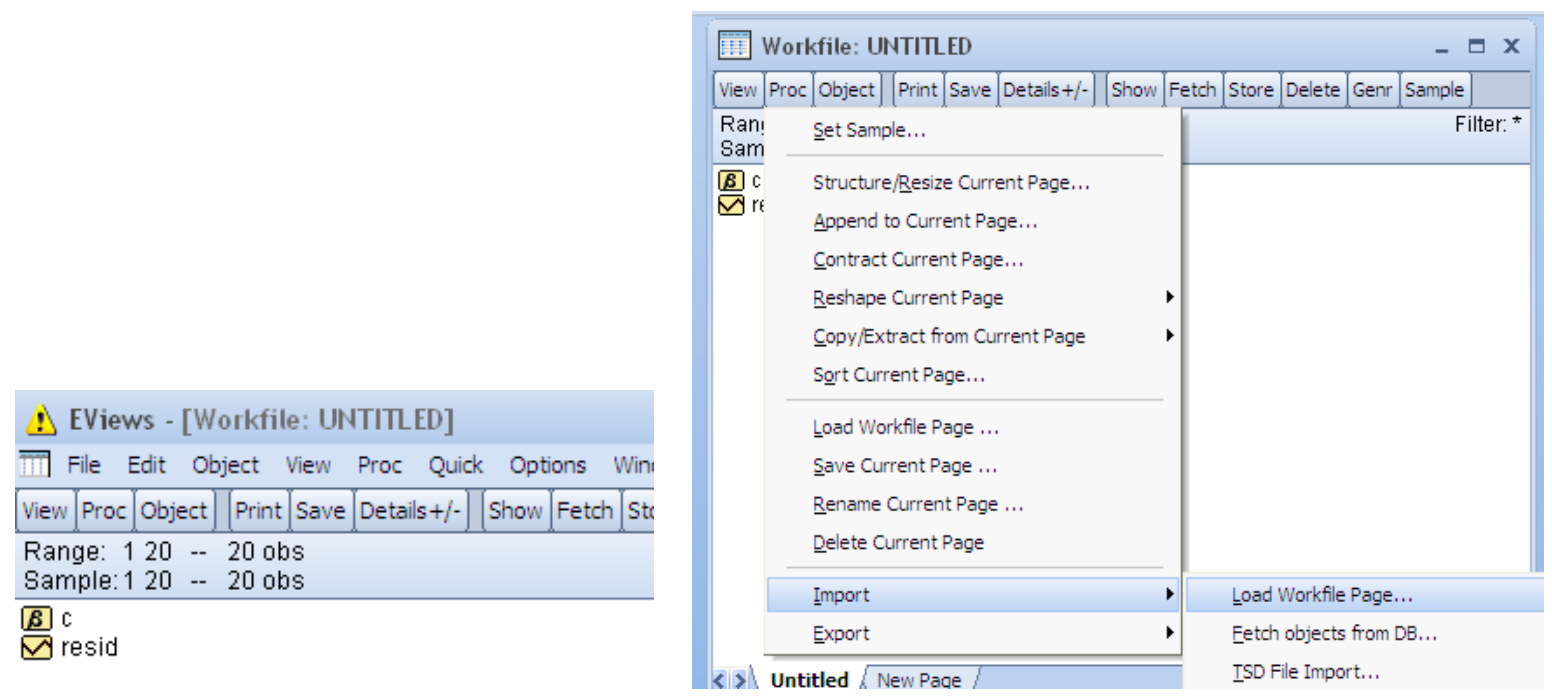

Gambar 10.23

Gambar 10.24 


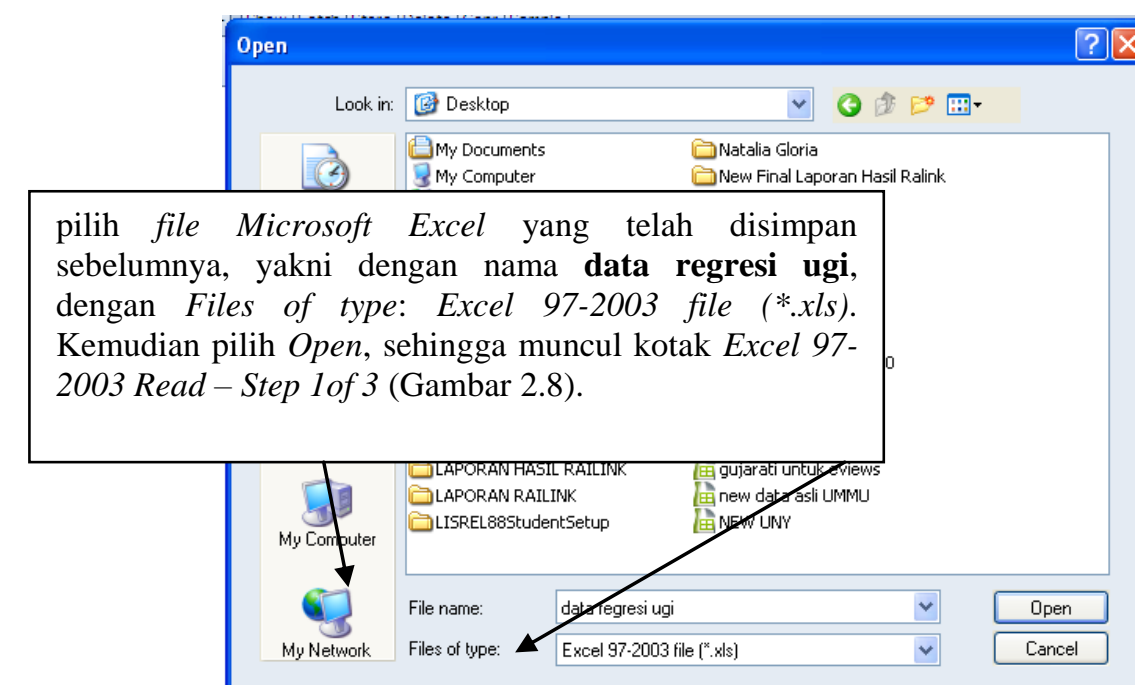

\section{Gambar 10.25}

Pada Gambar 10.26, kemudian pilih Finish, sehingga muncul kotak seperti pada Gambar 10.27 .

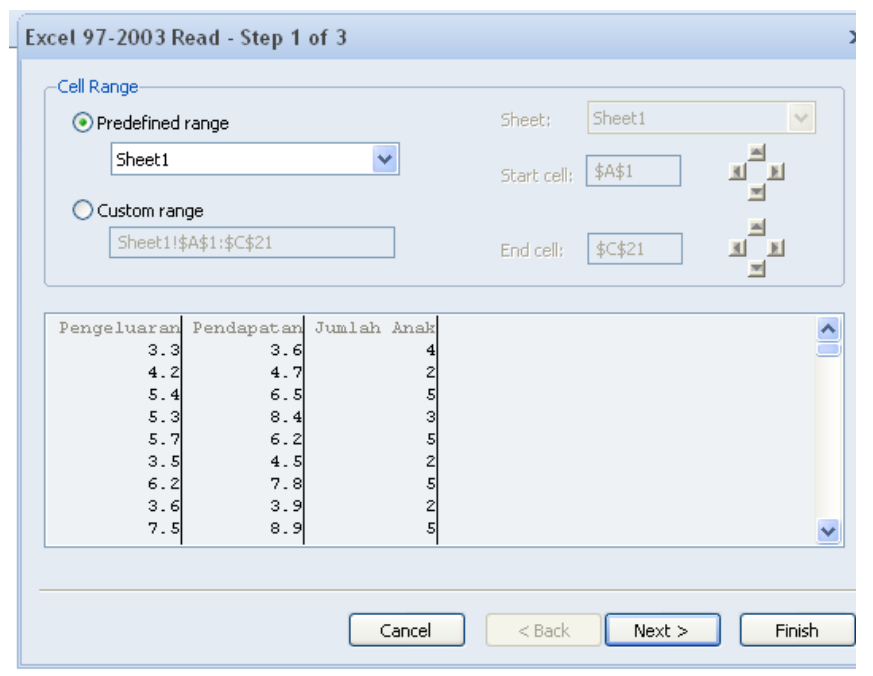

Gambar 10.26

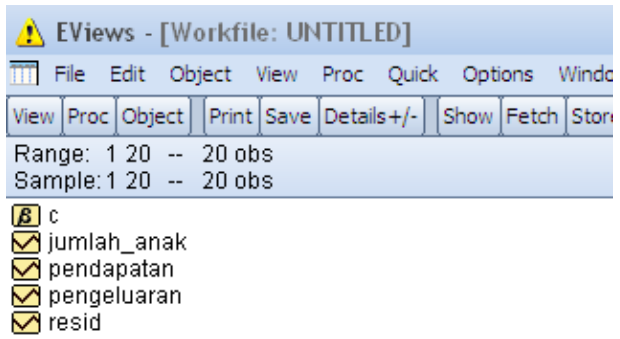

Gambar 10.27

\section{Statístik Deskriptif}

Selanjutnya pilih Quick $\Rightarrow$ Group Statistics $\Rightarrow$ Descriptive Statistics $=>$ Common sample (Gambar 10.28), sehingga muncul kotak Series List (Gambar 10.29).

Pada kotak Series List (Gambar 10.29), ketik nama-nama variabel yang dilibatkan, yakni pendapatan, pengeluaran, dan jumlah_anak. Kemudian pilih OK, sehingga diperoleh hasil statistik deskriptif, seperti pada Gambar 10.30. 


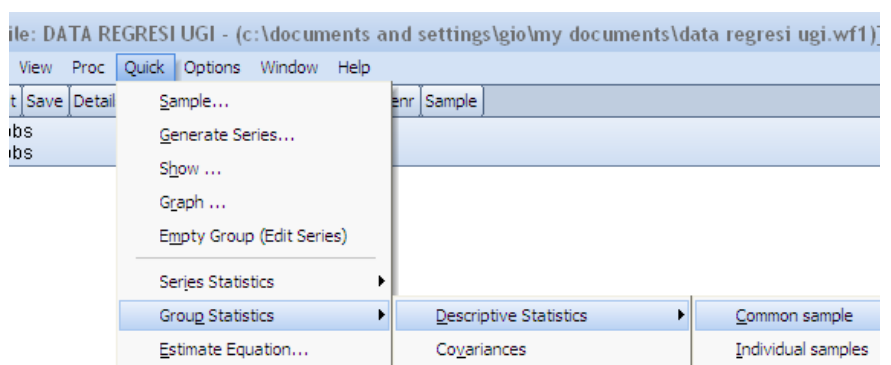

Gambar 10.28

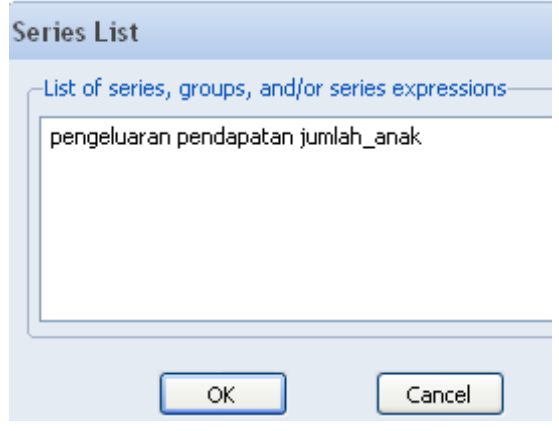

Gambar 10.29

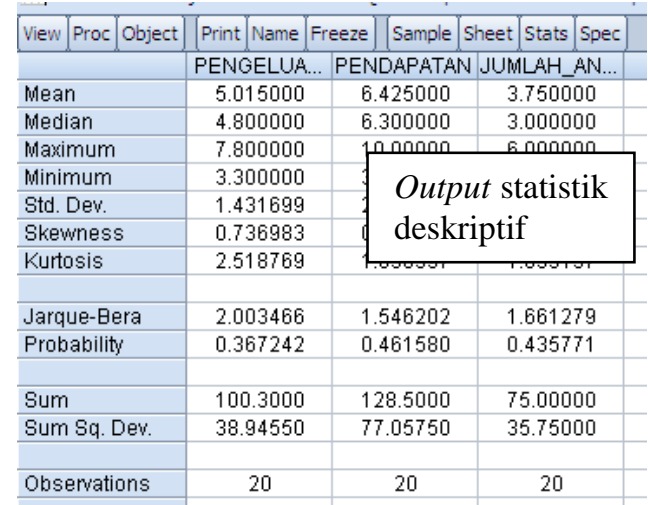

Gambar 10.30

\section{Estímasi Persamaan Regresí}

Selanjutnya pilih Quick $\Rightarrow$ Estimate Equation... (Gambar 10.31), sehingga muncul kotak Equation Estimation (Gambar 10.32).

\begin{tabular}{|c|c|c|c|c|c|c|c|c|c|}
\hline \multicolumn{6}{|c|}{$\lfloor$ EViews - [Group: UNTITLED } & \multicolumn{4}{|c|}{ Workfile: DATA REGRESI UGI } \\
\hline \multicolumn{4}{|c|}{ I77 File Edit Object } & View & Proc & Quick & Options & Window & Help \\
\hline View & Proc & Object & Print & Name & Free: & \multicolumn{4}{|c|}{ Sample... } \\
\hline \multirow{2}{*}{\multicolumn{3}{|c|}{ Mean }} & \multicolumn{3}{|c|}{ PENGELUA... PF } & \multicolumn{4}{|c|}{ Generate Series... } \\
\hline & & & \multicolumn{3}{|c|}{5.015000} & \\
\hline \multicolumn{3}{|c|}{ Median } & \multicolumn{3}{|c|}{4.800000} & \multicolumn{4}{|c|}{ Show ... } \\
\hline \multicolumn{3}{|c|}{ Maximum } & \multicolumn{3}{|c|}{7.800000} & \multicolumn{4}{|c|}{ Graph ... } \\
\hline \multicolumn{3}{|c|}{ Minimum } & \multicolumn{3}{|c|}{3.300000} & \multirow{2}{*}{\multicolumn{4}{|c|}{ Empty Group (Edit Series) }} \\
\hline \multicolumn{3}{|c|}{ Std. Dev. } & \multicolumn{3}{|c|}{1.431699} & & & & \\
\hline Ske & whes & & 0.7 & 36983 & & \multirow{2}{*}{\multicolumn{4}{|c|}{$\begin{array}{l}\text { Series Statistics } \\
\text { Groug Statistics }\end{array}$}} \\
\hline \multicolumn{3}{|c|}{ Kurtosis } & \multicolumn{3}{|c|}{2.518769} & & & & \\
\hline & & & \multirow{2}{*}{\multicolumn{3}{|c|}{2.003466}} & \multirow{2}{*}{\multicolumn{4}{|c|}{ Estimate Equation... }} \\
\hline \multicolumn{3}{|c|}{ Jarque-Bera } & & & & & & & \\
\hline \multicolumn{3}{|c|}{ Probability } & \multicolumn{3}{|c|}{0.367242} & \multicolumn{4}{|c|}{ Estimate VAR... } \\
\hline
\end{tabular}

Gambar 10.31

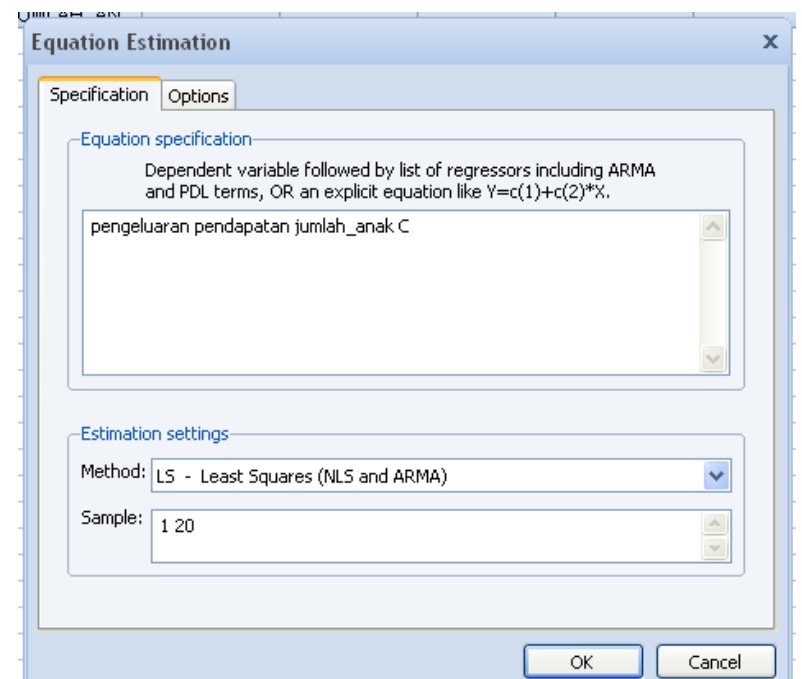

Gambar 10.32 
Pada Gambar 10.32, yakni Equation Estimation, ketik pengeluaran pendapatan jumlah_anak C, dan pilih OK. Hasilnya seperti pada Gambar 10.33.

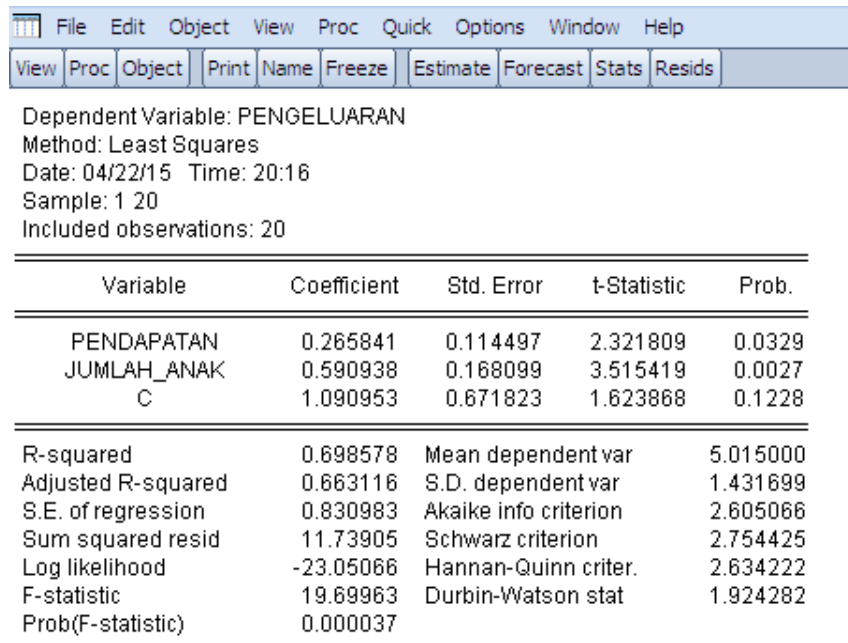

Gambar 10.33

\section{Uji Asumsi Normalitas dengan Uji Jarque-Bera}

Pilih View $\Rightarrow$ Residual Diagnostics $\Rightarrow$ Histogram - Normality Test (Gambar 10.34). Hasilnya seperti pada Gambar 10.35.

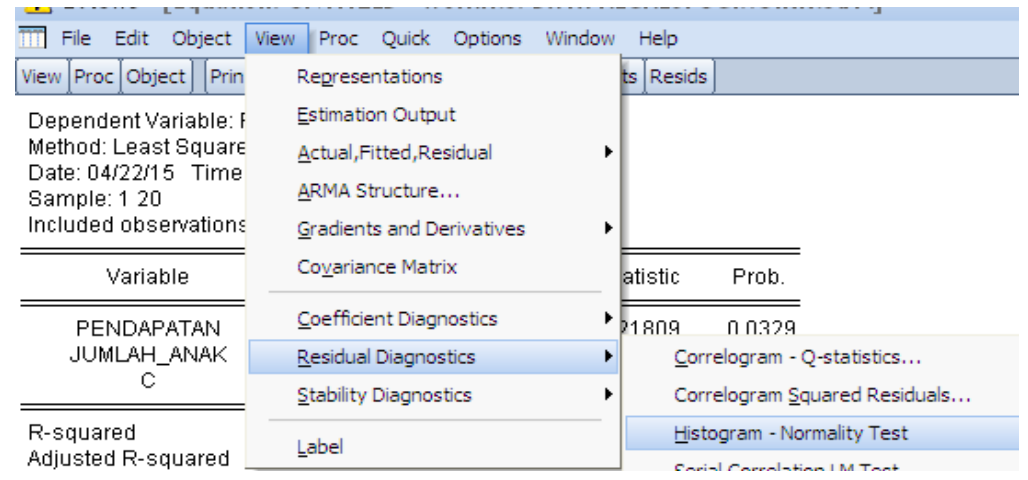

Gambar 10.34

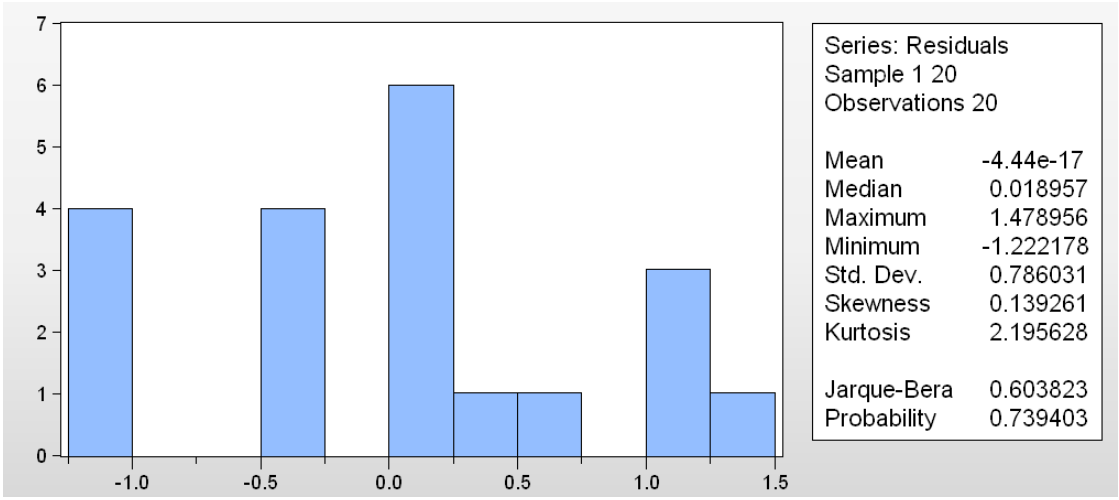

Gambar 10.35 


\section{Ují Asumsí Tídak Terjadi Multíkolinearitas}

Pilih Quick $=>$ Group Statistics $=>$ Correlations (Gambar 10.36), sehingga muncul kotak Series List (Gambar 10.37). Pada kotak Series List, ketik nama-nama variabel bebas, yakni pendapatan dan jumlah_anak. Kemudian pilih OK. Hasilnya seperti pada Gambar 10.38.

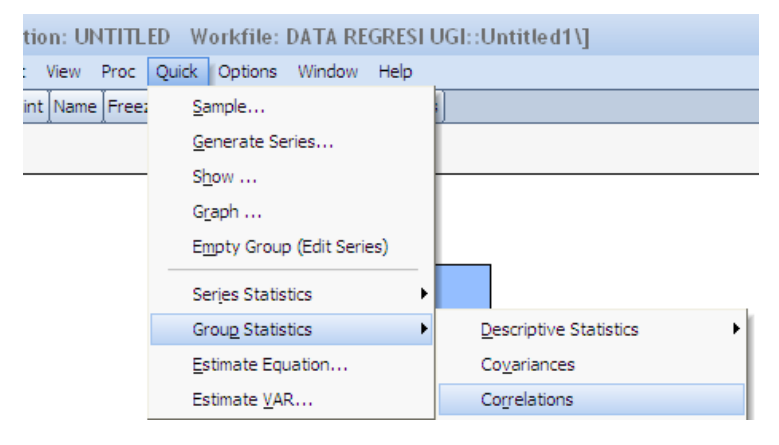

Gambar 10.36

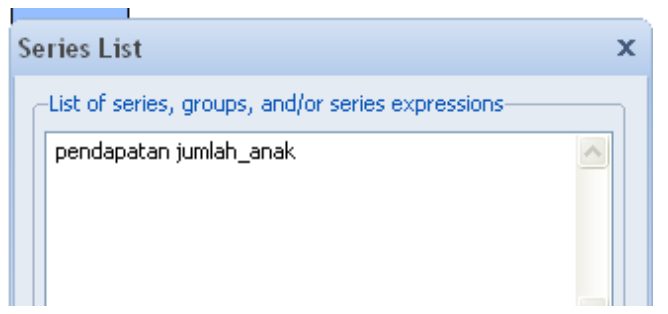

Gambar 10.37

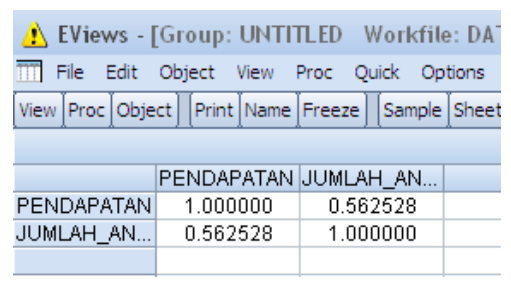

Gambar 10.38

\section{Uji Asumsi Homoskedastísitas dengan Uji Glesjer, Uji White, dan Ují} Park

Pilih View $=>$ Residual Diagnostics $=>$ Heteroskedasticity Tests...(Gambar 10.40), sehingga muncul kotak Heteroskedasticity Tests (Gambar 10.41).

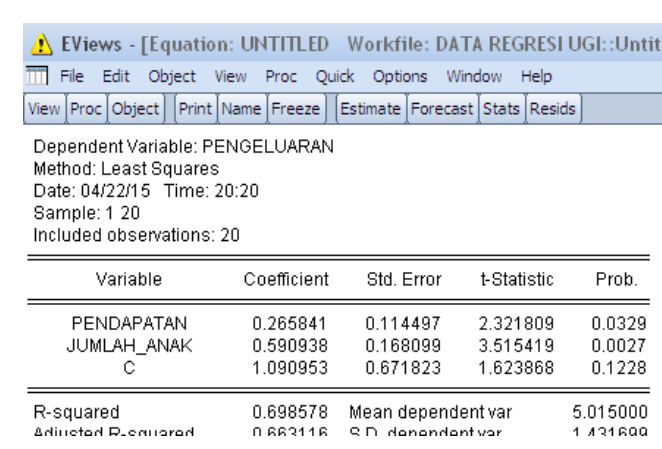

Gambar 10.39

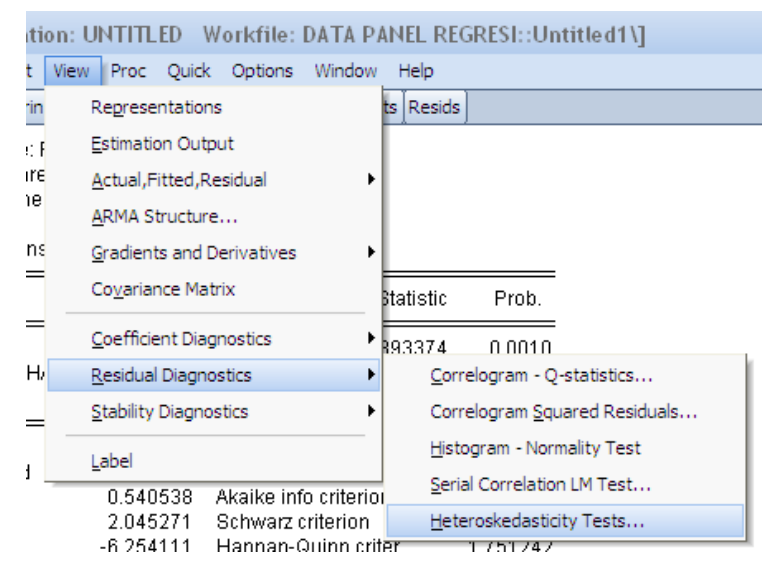

Gambar 10.40 


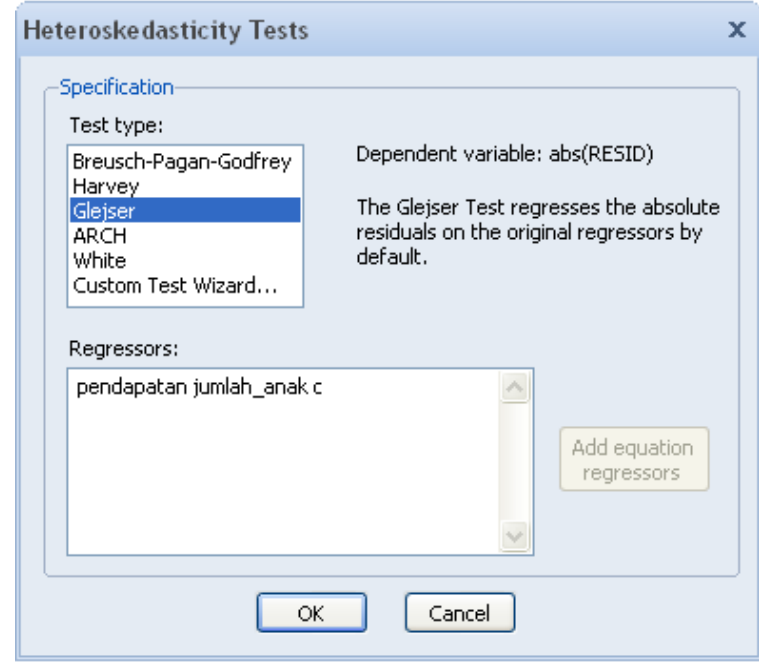

Gambar 10.41

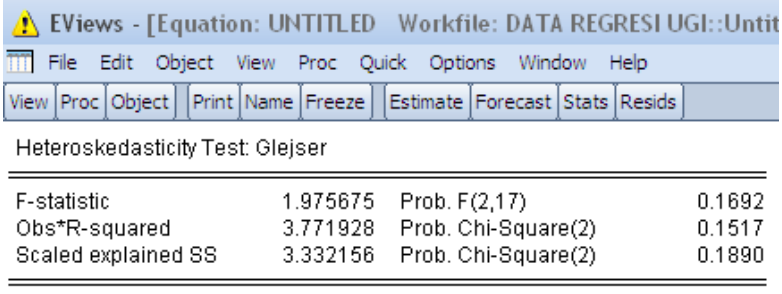

\section{Test Equation:}

Dependent Variable: ARESID

Method: Least Squares

Date: 04/22/15 Time: 20:21

Sample: 120

Included observations: 20

\begin{tabular}{crrrr}
\hline \hline Variable & Coefficient & Std. Error & t-Statistic & Prob. \\
\hline \hline C & -0.067194 & 0.371900 & -0.180678 & 0.8588 \\
PENDAPATAN & 0.103465 & 0.063382 & 1.632395 & 0.1210 \\
JUMLAH_ANAK & 0.001819 & 0.093054 & 0.019546 & 0.9846 \\
\hline \hline
\end{tabular}

Gambar 10.42

Pada Test type: pilih Glejser. Kemudian pilih OK. Hasilnya seperti pada Gambar 10.43. Gambar 10.43 merupakan hasil uji Glejser berdasarkan SPSS.

\begin{tabular}{|c|c|c|c|c|c|c|c|c|}
\hline \multicolumn{9}{|c|}{ Coefficients $^{a}$} \\
\hline \multirow[b]{2}{*}{ Mod } & & \multicolumn{2}{|c|}{ Unstandardized Coefficients } & \multirow{2}{*}{$\begin{array}{c}\begin{array}{c}\text { Standardized } \\
\text { Coefficients }\end{array} \\
\text { Beta }\end{array}$} & \multirow[b]{2}{*}{$t$} & \multirow[b]{2}{*}{ Sig. } & \multicolumn{2}{|c|}{ Collinearity Statistics } \\
\hline & & $B$ & Std. Error & & & & Tolerance & VIF \\
\hline \multirow[t]{3}{*}{1} & (Constant) & -.067 & .372 & & -.181 & .859 & & \\
\hline & Pendapatan & .103 & .063 & .431 & 1.632 & .121 & .684 & 1.463 \\
\hline & Jumlah Anak & .002 & .093 & .005 & .020 & .985 & .684 & 1.463 \\
\hline
\end{tabular}

a. Dependent Variable: abs_res

\section{Gambar 10.43}

Untuk uji asumsi homoskedastisitas dengan uji White, pilih View $=>$ Residual Diagnostics $=>$ Heteroskedasticity Tests (Gambar 10.44), sehingga muncul kotak Heteroskedasticity Tests (Gambar 10.45). Pilih White. Kemudian OK. Hasil berdasarkan uji White diperlihatkan pada Gambar 10.46 .

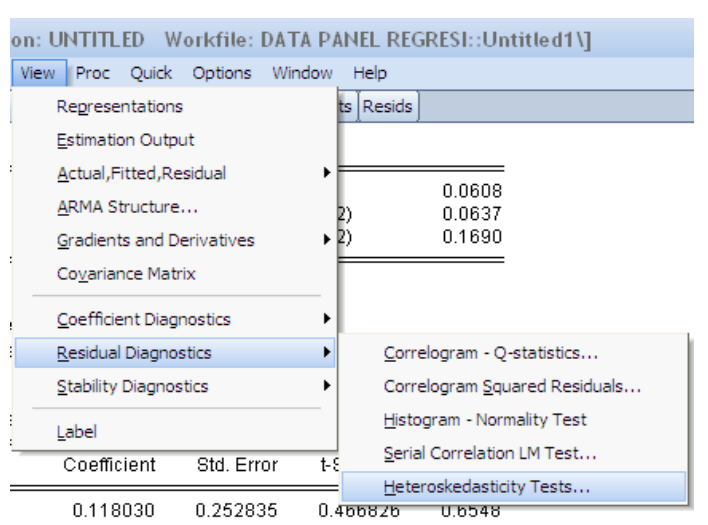

Gambar 10.44

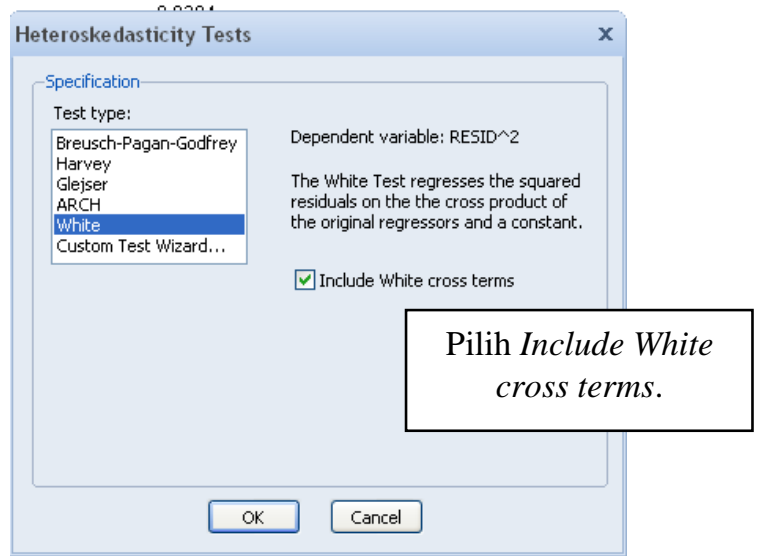

Gambar 10.45 


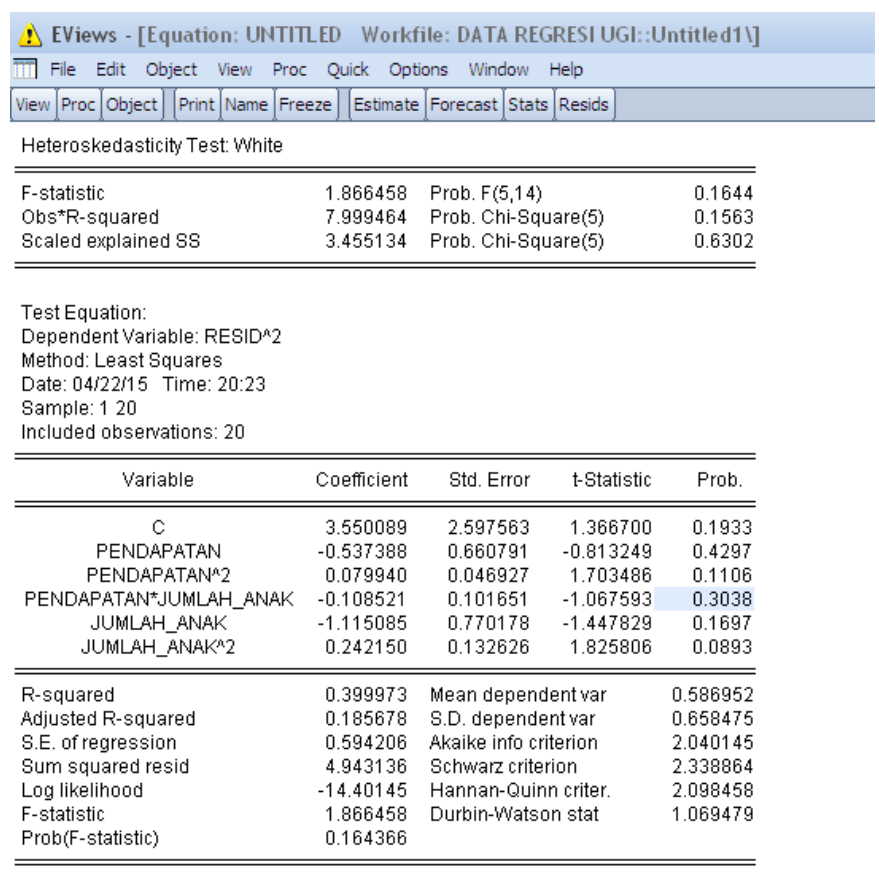

\section{Gambar 10.46}

Gambar 10.47 merupakan hasil uji White berdasarkan SPSS.

Model Summary
\begin{tabular}{|c|c|c|c|c|c|}
\hline Model & $R$ & R Square & $\begin{array}{c}\text { Adjusted R } \\
\text { Square }\end{array}$ & $\begin{array}{c}\text { Std. Error of } \\
\text { the Estimate }\end{array}$ & $\begin{array}{c}\text { Durbin- } \\
\text { Watson }\end{array}$ \\
\hline 1 & $.632^{\mathrm{a}}$ & .400 & .186 & .59421 & 1.069 \\
\hline
\end{tabular}
a. Predictors: (Constant), $\times 1 \times 2, \times 1$ _pangkat2, Jumlah Anak, Pendapatan,
x2_pangkat2
b. Dependent Variable: res_kuadrat

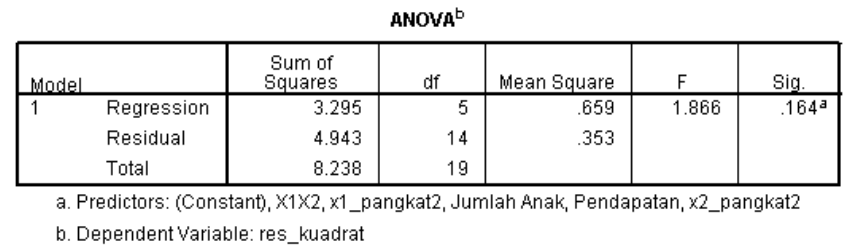

Coefficients $^{a}$

\begin{tabular}{|c|c|c|c|c|c|c|c|c|}
\hline \multirow[b]{2}{*}{ Made } & & \multicolumn{2}{|c|}{ Unstandardized Coefficients } & \multirow{2}{*}{$\begin{array}{c}\text { Standardized } \\
\text { Coefficients } \\
\text { Beta }\end{array}$} & \multirow[b]{2}{*}{ t } & \multirow[b]{2}{*}{ Siq. } & \multicolumn{2}{|c|}{ Collinearity Statistics } \\
\hline & & B & Std. Error & & & & Tolerance & VIF \\
\hline \multirow[t]{6}{*}{1} & (Constant) & 3.550 & 2.598 & & 1.367 & .193 & & \\
\hline & Pendapatan & -.537 & .661 & -1.644 & -813 & .430 & .010 & 95.295 \\
\hline & Jumlah Anak & -1.115 & .770 & -2.323 & -1.448 & .170 & .017 & 60.060 \\
\hline & x1_pangkat2 & .080 & .047 & 3.221 & 1.703 & .111 & .012 & 83.435 \\
\hline & x2_pangkat2 & .242 & .133 & 3.961 & 1.826 & .089 & .009 & 109.826 \\
\hline & $\times 1 \times 2$ & -.109 & .102 & -2.412 & -1.068 & .304 & .008 & 119.093 \\
\hline
\end{tabular}

a. Dependent Variable: res_kuadrat

\section{Gambar 10.47}

Untuk uji asumsi homoskedastisitas dengan uji Park, pilih View $=>$ Residual Diagnostics $=>$ Heteroskedasticity Tests, sehingga muncul kotak Heteroskedasticity Tests (Gambar 10.48). Pilih Harvey, pada Regressors: ketika $\log \left(\right.$ pendapatan) $\log \left(j u m l a h \_a n a k\right)$. Kemudian pilih OK. Hasilnya seperti pada Gambar 10.49 . 


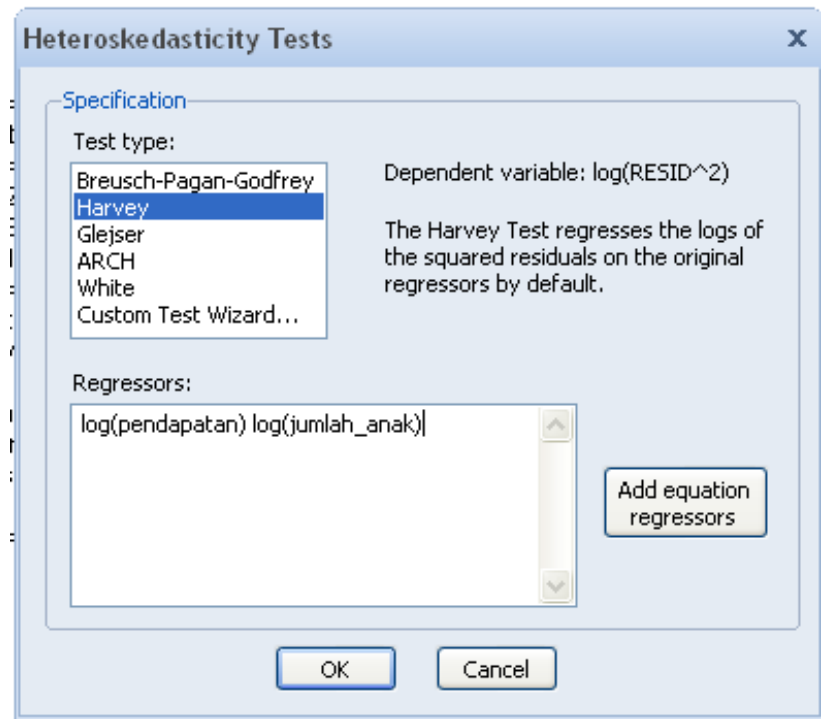

Gambar 10.48
!) EViews - [Equation: UNTITLED Workfile: DATA REGRESI UGI::Untitl 77 File Edit Object View Proc Quick Options Window Help View [Proc [Object] [Print [Name [Freeze] [Estimate [Forecast Stats ${ }^{\text {Resids }}$ Heteroskedasticity Test: Hawey

\begin{tabular}{llll}
\hline \hline F-statistic & 0.658260 & Prob. $F(2,17)$ & 0.5305 \\
Obs*R-squared & 1.437521 & Prob. Chi-Square(2) & 0.4874 \\
Scaled explained SS & 3.056733 & Prob. Chi-Square(2) & 0.2169 \\
\hline
\end{tabular}

Test Equation:

Dependent Variable: LRESID2

Method: Least Squares

Date: 04/22/15 Time: $21: 15$

Sample: 120

Included observations: 20

\begin{tabular}{lrlrr}
\hline \hline \multicolumn{1}{c}{ Variable } & Coefficient & Std. Error & t-Statistic & Prob. \\
\hline \hline C & -7.298607 & 4.370310 & -1.670043 & 0.1132 \\
LOG(PENDAPATAN) & 2.938970 & 2.878152 & 1.021131 & 0.3215 \\
LOG(JUMLAH_ANAK) & -0.355650 & 2.459170 & -0.144622 & 0.8867 \\
\hline \hline R-squared & 0.071876 & Mean dependent var & -2.422546 \\
Adjusted R-squared & -0.037315 & S.D. dependent var & 3.323493 \\
S.E. of regression & 3.384933 & Akaike info criterion & 5.414026 \\
Sum squared resid & 194.7821 & Schwarz criterion & 5.563386 \\
Log likelihood & -51.14026 & Hannan-Quinn criter. & 5.443183 \\
F-statistic & 0.658260 & Durbin-Watson stat & 1.381187 \\
Prob(F-statistic) & 0.530458 & & \\
\hline \hline
\end{tabular}

\section{Gambar 10.49}

Gambar 10.50 merupakan hasil uji Park berdasarkan SPSS.

\begin{tabular}{|c|c|c|c|c|c|c|}
\hline & & \multicolumn{5}{|c|}{ Coefficients $^{\beth}$} \\
\hline \multirow{2}{*}{\multicolumn{2}{|c|}{ Madel }} & \multicolumn{2}{|c|}{ Unstandardized Coefficients } & \multirow{2}{*}{$\begin{array}{c}\text { Standardized } \\
\text { Coefficients } \\
\text { Beta } \\
\end{array}$} & \multirow[b]{2}{*}{$t$} & \multirow[b]{2}{*}{ Sig. } \\
\hline & & $\mathrm{B}$ & Std. Error & & & \\
\hline \multirow[t]{3}{*}{1} & (Constant) & -7.299 & 4.370 & & -1.670 & .113 \\
\hline & $\ln \times 1$ & 2.939 & 2.878 & .289 & 1.021 & .322 \\
\hline & $\ln \times 2$ & -.356 & 2.459 & -.041 & -.145 & .887 \\
\hline
\end{tabular}

\section{Gambar 10.50}

\section{Uji Asumsi Normalitas dengan Q-Q Plot}

Gambar 10.51 menyajikan nilai residual. Untuk uji asumsi normalitas dengan $Q-Q$ Plot, pilih View $\Rightarrow>$ Graph...(Gambar 10.52), sehingga muncul kotak Graph Options (Gambar 10.53). Pada Gambar 10.53, pilih Quantile-Quantile dan pada $Q-Q$ graph: pilih Theoretical. Pada Gambar 10.54, atur menjadi Normal, pada Distributions:

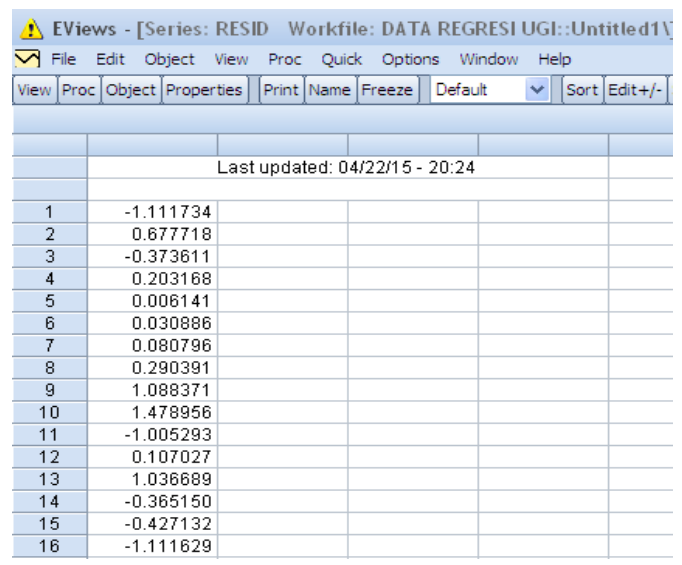

Gambar 10.51

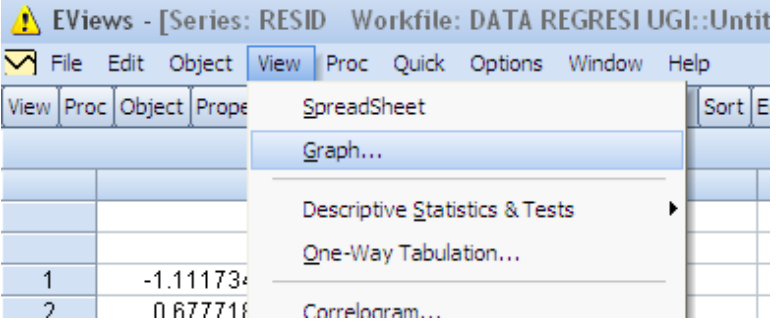

Gambar 10.52 


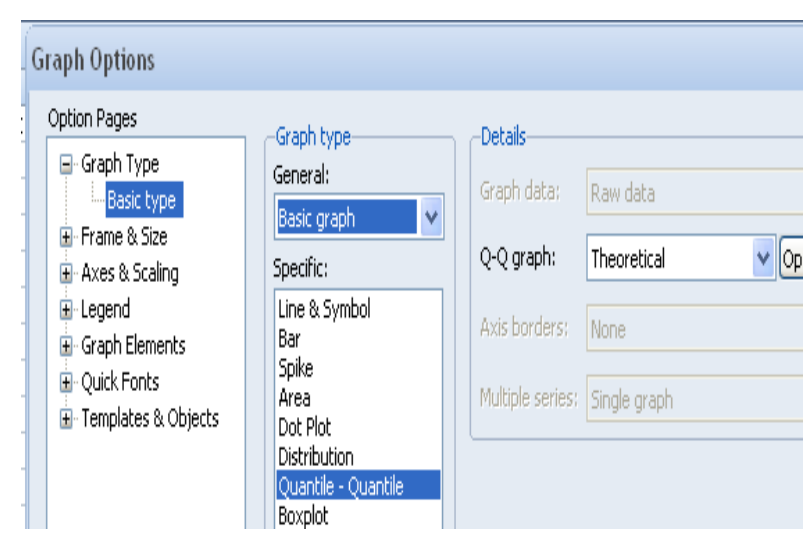

Gambar 10.53

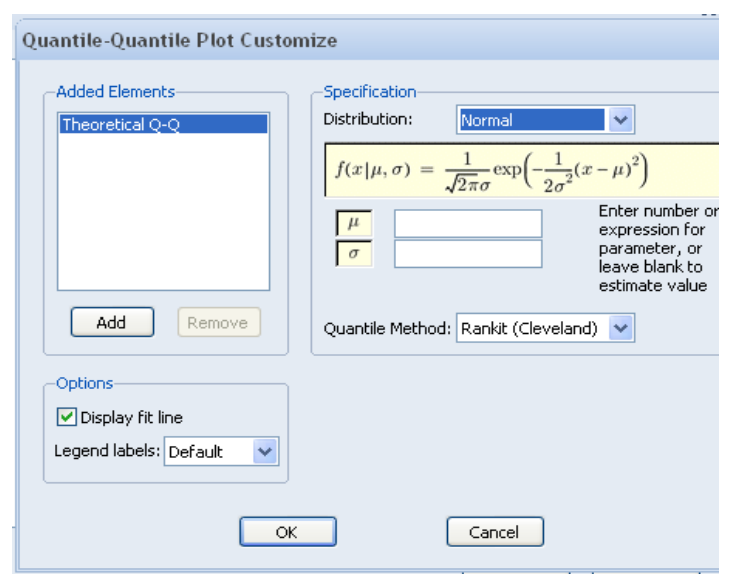

Gambar 10.54

Kemudian pilih OK. Hasilnya seperti pada Gambar 10.55.

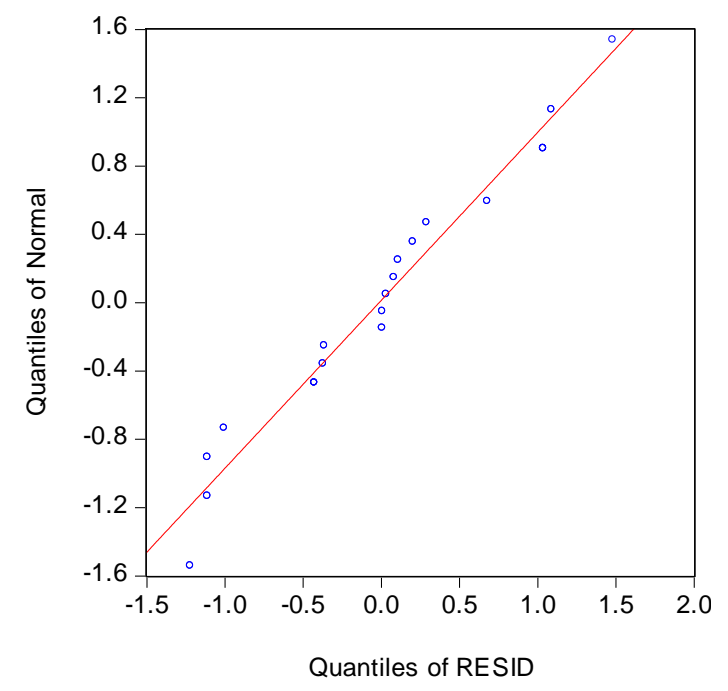

Gambar 10.55

\section{INTERPRETASI OUTPUT EVIEWS}

\section{Asumsi Normalitas Error}

Pengujian asumsi normalitas error akan diuji dengan pendekatan analisis grafik, yakni $Q-Q$ plot (Gambar 10.55). Gambar 10.55 merupakan output dari EViews. Pada $Q-Q$ plot (Gambar 10.55), titik-titik menyebar cukup dekat pada garis diagonal, maka disimpulkan bahwa asumsi normalitas dipenuhi.

Pada pengujian asumsi normalitas error dengan pendekatan analisis grafik $Q-Q$ plot, disimpulkan bahwa asumsi normalitas error dipenuhi. Berikut akan digunakan pendekatan uji Jarque-Bera untuk menguji asumsi normalitas error. Gambar 10.35 merupakan output EViews untuk uji normalitas dengan uji jarque-Bera. Diketahui nilai statistik dari uji JarqueBera adalah 0,603823. Gambar 10.56 merupakan perhitungan nilai kritis chi-kuadrat dengan bantuan Microsoft Excel. Berikut aturan pengambilan keputusan terhadap hipotesis. 
Jika nilai statistik $J B \leq \chi_{\text {kritis }}^{2}, H_{0}$ diterima dan $H_{1}$ ditolak.

Jika nilai statistik $J B>\chi_{\text {kritis }}^{2}, H_{0}$ ditolak dan $H_{1}$ diterima.

Karena nilai statistik dari uji Jarque-Bera, yakni 0,603823, lebih kecil dibandingkan nilai kritis chi-kuadrat, yakni 5,991, maka disimpulkan bahwa asumsi normalitas error dipenuhi. Dengan pendekatan probabilitas, diketahui nilai probabilitas, yakni 0,739403 lebih besar dibandingkan tingkat signifikansi, yakni 0,05. Maka disimpulkan bahwa asumsi normalitas error dipenuhi.

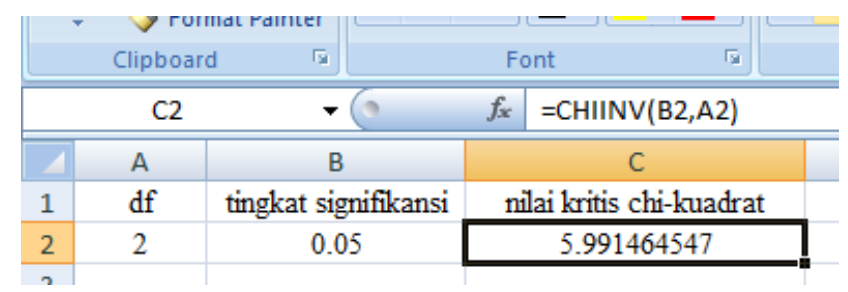

\section{Gambar 10.56}

\section{Asumsi Tídak Terjadi Multikolinearítas}

Untuk mendeteksi apakah terindikasi terjadi gejala multikolinearitas, dapat digunakan pendekatan matriks korelasi dari variabel bebas. Jika terdapat nilai korelasi di atas 0,8 antar variabel bebas, maka diindikasi terjadi multikolinearitas. Gujarati (2003:359) menyatakan sebagai berikut.

"Another suggested rule of thumb is that if the pair-wise or zero-order correlation coefficient between two regressors is high, say, in excess of 0,8 , then multicolinearity is a serious problem".

Output EViews untuk uji asumsi tidak terjadi multikolinearitas disajikan pada Gambar 10.38. Berdasarkan Gambar 10.38, dapat dilihat bahwa nilai korelasi antara Pendapatan dan Jumlah Anak adalah 0,56, yang mana tidak lebih dari 0,8.

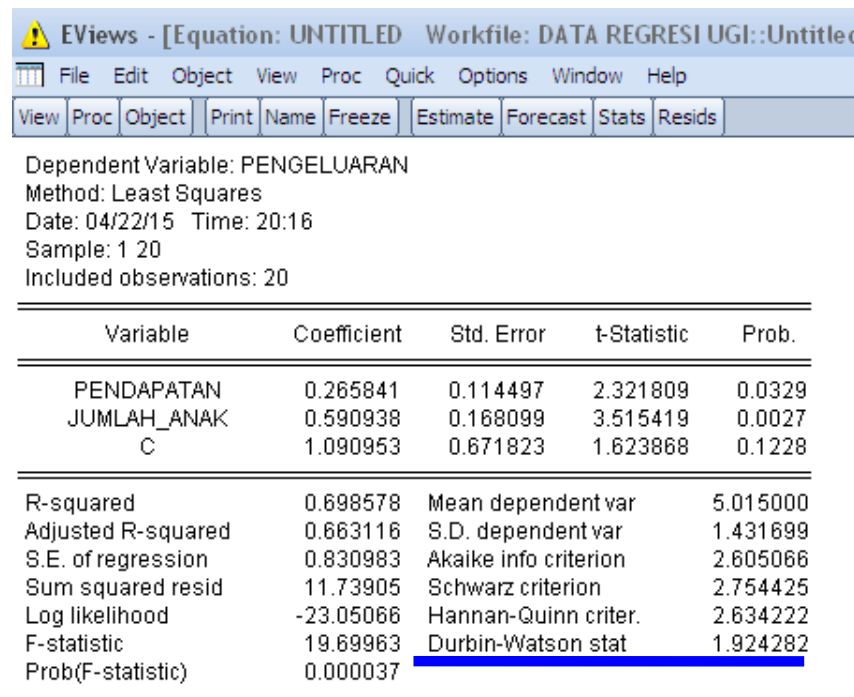

\section{Gambar 10.57}




\section{Asumsi JNon-Autokorelasí}

Untuk menguji asumsi independensi dari error atau non-autokorelasi, dapat digunakan uji Durbin-Watson. Nilai statistik dari uji Durbin-Watson yang lebih kecil dari 1 atau lebih besar dari 3 diindikasi terjadi autokorelasi. Field (2009:220-221) menyatakan sebagai berikut.

"The size of the Durbin-Watson statistic depends upon the number of predictors in the model and the number of observations. For accuracy, you should look up the exact acceptable values in Durbin and Watson's (1951) original paper. As very conservative rule of thumb, values less then 1 or greater than 3 are definitely cause for concern; however, values closer to 2 may stil be problematic depending on your sample and model”.

Gambar 10.57 merupakan output EViews yang menyajikan nilai statistik dari uji DurbinWatson. Diketahui nilai statistik dari uji Durbin-Watson adalah 1,924282, yang mana nilai tersebut berada di antara 1 dan 3. Maka disimpulkan bahwa asumsi non-autokorelasi dipenuhi atau tidak tejadi autokorelasi.

\section{Asumsi Homoskedastísitas}

Asumsi homoskedastisitas menyatakan terjadi kesamaan varians dari error (errors with constant variance) untuk setiap tingkatan atau level dari variabel-variabel bebas. Ketika asumsi homoskedastisitas tidak dipenuhi, maka peristiwa tersebut disebut heteroskedastisitas. Untuk mendeteksi terjadinya gejala heteroskedastisitas dapat dilakukan dengan menggunakan uji Park, uji Glejser, dan uji White. Gambar 10.49 merupakan output EViews untuk uji asumsi homoskedastisitas dengan uji Park. Diketahui nilai probabilitas untuk koefisien regresi LOG(PENDAPATAN) dan LOG(JUMLAH_ANAK) masing-masing adalah 0,3215 dan 0,8867, yang mana keduanya tidak signifikan secara statistik pada tingkat signifikansi 0,05 . Maka disimpulkan bahwa asumsi homoskedastisitas dipenuhi.

Gambar 10.42 merupakan output EViews untuk uji asumsi homoskedastisitas dengan uji Glejser. Diketahui nilai probabilitas untuk koefisien regresi PENDAPATAN dan JUMLAH_ANAK masing-masing adalah 0,1210 dan 0,9846, yang mana keduanya tidak signifikan secara statistik pada tingkat signifikansi 0,05. Maka disimpulkan bahwa asumsi homoskedastisitas dipenuhi.

Gambar 10.46 merupakan output EViews untuk uji asumsi homoskedastisitas dengan uji White. Berikut hasil kali antara nilai koefisien determinasi (R-Squared) dan ukuran sampel (sample size).

$$
0,399973 \times 20=7,99946
$$

Selanjutnya akan dihitung nilai kritis chi-kuadrat dengan nilai derajat bebas 5 dengan bantuan software Microsoft Excel (Gambar 10.58). Diketahui nilai kritis chi-kuadrat adalah 11,07. Perhatikan bahwa karena hasil kali antara nilai koefisien determinasi ( $R$-Squared) dan ukuran sampel (sample size), yakni 7,99946, lebih kecil dibandingkan nilai kritis chi-kuadrat, yakni 11,07 , maka disimpulkan bahwa hipotesis nol diterima, yakni tidak terjadi heteroskedastisitas. 


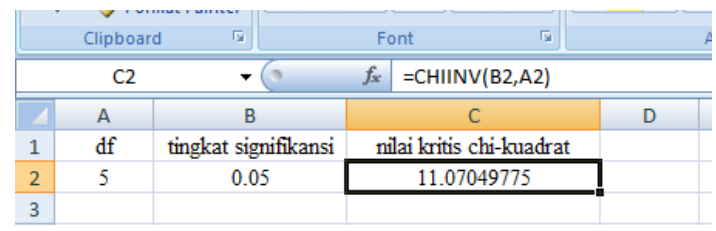

Gambar 10.58

\section{Mengukur Kecocokkan Model Regresi Linear Berganda terhadap Data dengan Koefisien Determinasi $\left(r^{2}\right)$}

Berdasarkan Gambar 10.33, diketahui nilai koefisien determinasi (R-Squared) 0,698578. Nilai tersebut dapat diinterpretasikan sebagai variabel pendapatan dan jumlah anak mampu menjelaskan atau menerangkan variation variabel pengeluaran sebesar 69,86\%, sisanya sebesar 30,14\% dijelaskan oleh variabel-variabel lain.

\section{Menguji Sígnifikansi Kecocokkan Model Regresi Linear terhadap Data dengan Uji $F$}

Berdasarkan Gambar 10.33, diketahui nilai statistik dari uji $F$ adalah 19,69.

$$
\begin{aligned}
& d f 1=\text { Derajat bebas pembilang }=k-1=3-1=2 . \\
& d f 2=\text { Derajat bebas penyebut }=n-k=20-3=17 .
\end{aligned}
$$

\begin{tabular}{|c|c|c|c|c|c|c|}
\hline \multicolumn{3}{|c|}{ Clipboard } & \multicolumn{2}{|c|}{ Font } & $\sqrt{5}$ & \\
\hline \multicolumn{3}{|c|}{ D2 } & $f_{x}$ & \multicolumn{2}{|c|}{$=F I N V(C 2, A 2, B 2)$} & \\
\hline 4 & A & B & C & & D & $E$ \\
\hline 1 & df1 & $\mathrm{df} 2$ & tingkat signif & kansi & Nilai Kritis F & \\
\hline 2 & 2 & 17 & 0.05 & & 3.591530569 & \\
\hline
\end{tabular}

Berikut perhitungan nilai kritis $F$ (F tabel) berdasarkan Microsoft Excel (Gambar 10.59).

\section{Gambar 10.59}

Perhatikan bahwa karena nilai statistik dari uji $F$, yakni 19,69 lebih besar dibandingkan nilai kritis $F$, yakni 3,591, maka disimpulkan bahwa pengaruh simultan atau bersama-sama dari variabel bebas pendapatan dan jumlah anak terhadap pengeluaran signifikan secara statistik pada tingkat signifikansi $5 \%$.

Selain pendekatan nilai kritis, dapat juga digunakan pendekatan nilai probabilitas. Berdasarkan Gambar 10.33, diketahui nilai probabilitas dari nilai statistik dari uji F (Prob) $F$ statistic)) adalah 0,000037. Karena nilai probabilitas tersebut lebih kecil dibandingkan tingkat signifikansi, yakni 0,05, maka disimpulkan bahwa pengaruh simultan atau bersama-sama dari variabel bebas pendapatan dan jumlah anak terhadap pengeluaran signifikan secara statistik pada tingkat signifikansi 5\%. 


\section{Uji Sígnífikansi Koefisien Regresí Secara Individu dengan Uji t}

Berikut akan ditentukan apakah faktor pendapatan mempengaruhi pengeluaran secara signifikan (signifikan secara statistik), dengan mengontrol pengaruh jumlah anak. Output EViews untuk uji signifikansi koefisien regresi populasi secara individu dengan uji $t$ disajikan pada Gambar 10.33. Berdasarkan Gambar 10.33, nilai statistik dari uji $t$ untuk variabel pendapatan adalah 2,3218. Nilai kritis $t$ dengan derajat bebas $n-k=20-3=17$ dan tingkat signifikansi $5 \%$ adalah $\pm 2,110$.

\begin{tabular}{|c|c|c|c|}
\hline & $\mathrm{C} 2$ & -0 & $/(\mathrm{B} 2, \mathrm{~A} 2)$ \\
\hline 4 & A & B & C \\
\hline 1 & derajat bebas & tingkat signifikansi & Nilai Kritis T \\
\hline 2 & 17 & 0.05 & 2.109815559 \\
\hline
\end{tabular}

\section{Gambar 10.60}

Berikut aturan pengambilan keputusan terhadap hipotesis berdasarkan uji $t$.

$$
\begin{aligned}
& \text { Jika }\left|t_{\text {hitung }}\right| \leq\left|t_{\text {kritis }}\right| \text {, maka } H_{0} \text { diterima dan } H_{1} \text { ditolak. } \\
& \text { Jika }\left|t_{\text {hitung }}\right|>\left|t_{\text {kritis }}\right| \text {, maka } H_{0} \text { ditolak dan } H_{1} \text { diterima. }
\end{aligned}
$$

Perhatikan bahwa karena $\left|t_{\text {hitung }}\right|>\left|t_{\text {kritis }}\right|$, yakni 2,3128 $>2,110$, maka disimpulkan bahwa faktor pendapatan mempengaruhi pengeluaran secara signifikan (signifikan secara statistik), dengan mengontrol pengaruh jumlah anak. Pengambilan keputusan terhadap hipotesis juga dapat dilakukan dengan menggunakan pendekatan nilai probabilitas dari uji $t$. Nilai probabilitas dari uji $t$ berdasarkan variabel pendapatan adalah 0,0329. Karena nilai probabilitas tersebut lebih kecil dibandingkan tingkat signifikansi $\alpha=5 \%$, maka disimpulkan bahwa faktor pendapatan mempengaruhi pengeluaran secara signifikan (signifikan secara statistik), dengan mengontrol pengaruh jumlah anak.

Diketahui nilai koefisien regresi untuk variabel pendapatan adalah 0,266. Nilai tersebut dapat diinterpretasikan ketika pendapatan bertambah Rp.1 juta, maka secara rata-rata (on average) pengeluaran meningkat sebesar Rp.266.000, ketika pengaruh dari jumlah anak dipertahankan konstan. Selanjutnya akan ditentukan apakah faktor jumlah anak mempengaruhi pengeluaran secara signifikan (signifikan secara statistik), dengan mengontrol pengaruh pendapatan. Berdasarkan Gambar 10.33, nilai statistik dari uji $t$ untuk variabel jumlah anak adalah 3,515. Nilai kritis $t$ dengan derajat bebas $n-k=20-3=17$ dan tingkat signifikansi 5\% adalah $\pm 2,110$. Perhatikan bahwa karena $\left|t_{\text {hitung }}\right|>\left|t_{\text {kritis }}\right|$, yakni 3,515 $>2,110$, maka disimpulkan bahwa faktor jumlah anak mempengaruhi pendapatan secara signifikan (signifikan secara statistik), dengan mengontrol pengaruh pendapatan. Nilai probabilitas (Sig) dari uji $t$ berdasarkan variabel jumlah anak adalah 0,0027 . Karena nilai probabilitas tersebut lebih kecil dibandingkan tingkat signifikansi $\alpha=5 \%$, maka disimpulkan bahwa faktor jumlah anak mempengaruhi pengeluaran secara signifikan (signifikan secara statistik), dengan mengontrol pengaruh pendapatan.

Diketahui nilai koefisien regresi untuk variabel jumlah anak adalah 0,59. Nilai tersebut dapat diinterpretasikan ketika jumlah anak bertambah satu, maka secara rata-rata (on average) pengeluaran meningkat sebesar Rp.590.000, ketika pengaruh dari pendapatan dipertahankan konstan. Perhatikan bahwa variabel jumlah anak memberikan kontribusi yang terbesar terhadap kenaikkan pengeluaran dalam suatu keluarga. 


\section{$S \mathcal{H A R \mathcal { R }}$}

[1] Misalkan diberikan data sebagai berikut.

\section{Tabel 10.1}

\begin{tabular}{|c|c|c|}
\hline$X_{1}$ & $X_{2}$ & $Y$ \\
\hline 10 & 9,5 & 3,01 \\
\hline 12 & 11 & 3,15 \\
\hline 9 & 9 & 2,9 \\
\hline 10 & 10 & 3,1 \\
\hline 8 & 8 & 2,7 \\
\hline 11 & 12 & 3,25 \\
\hline 15 & 13 & 3,6 \\
\hline 17 & 14 & 3,7 \\
\hline 16 & 13,5 & 3,65 \\
\hline 10 & 11 & 3,15 \\
\hline
\end{tabular}

Andaikan $X_{1}$ dan $X_{2}$ merupakan variabel bebas, sedangkan $Y$ sebagai variabel tak bebas. Bentuk umum dari persamaan regresi linear berganda (sampel) dengan dua variabel bebas sebagai berikut.

$$
\hat{Y}=\hat{\alpha}+\hat{\beta}_{1} X_{1}+\hat{\beta}_{2} X_{2}
$$

$\rightarrow$ Menghitung koefisien regresi $\hat{\alpha}, \hat{\beta}_{1}$, dan $\hat{\beta}_{2}$.

Berdasarkan data pada Tabel 10.1, berikut akan dihitung koefisien regresi $\hat{\alpha}, \hat{\beta}_{1}$, dan $\hat{\beta}_{2}$. Berikut rumus untuk menghitung nilai $\hat{\alpha}, \hat{\beta}_{1}$ dan $\hat{\beta}_{2}$.

$$
\begin{gathered}
p=n \sum X_{1} Y-\sum X_{1} \sum Y \\
q=n \sum X_{2}^{2}-\left(\sum X_{2}\right)^{2} \\
r=n \sum X_{1} X_{2}-\sum X_{1} \sum X_{2} \\
s=n \sum X_{2} Y-\sum X_{2} \sum Y \\
t=n \sum X_{1}^{2}-\left(\sum X_{1}\right)^{2} \\
u=t q-r^{2} .
\end{gathered}
$$

Sehingga $\hat{\alpha}, \hat{\beta}_{1}$, dan $\hat{\beta}_{2}$ dihitung dengan rumus 


$$
\begin{gathered}
\hat{\beta}_{1}=\frac{p q-r s}{u} \\
\hat{\beta}_{2}=\frac{s t-p r}{u} \\
\hat{\alpha}=\frac{\sum Y-\hat{\beta}_{1} \sum X_{1}-\hat{\beta}_{2} \sum X_{2}}{n}
\end{gathered}
$$

Tabel 10.2

\begin{tabular}{|c|c|c|c|c|c|c|c|c|c|}
\hline \multicolumn{1}{c|}{} & $X_{1}$ & $X_{2}$ & $Y$ & $X_{1} Y$ & $X_{2} Y$ & $X_{1} X_{2}$ & $X_{1}^{2}$ & $X_{2}^{2}$ & $Y^{2}$ \\
\cline { 2 - 10 } & 10 & 9,5 & 3,01 & 30,1 & 28,595 & 95 & 100 & 90,25 & 9,0601 \\
\hline & 12 & 11 & 3,15 & 37,8 & 34,65 & 132 & 144 & 121 & 9,9225 \\
\hline & 9 & 9 & 2,9 & 26,1 & 26,1 & 81 & 81 & 81 & 8,41 \\
\hline 10 & 10 & 3,1 & 31 & 31 & 100 & 100 & 100 & 9,61 \\
\hline & 8 & 8 & 2,7 & 21,6 & 21,6 & 64 & 64 & 64 & 7,29 \\
\cline { 2 - 10 } & 11 & 12 & 3,25 & 35,75 & 39 & 132 & 121 & 144 & 10,5625 \\
\cline { 2 - 10 } & 15 & 13 & 3,6 & 54 & 46,8 & 195 & 225 & 169 & 12,96 \\
\cline { 2 - 9 } & 17 & 14 & 3,7 & 62,9 & 51,8 & 238 & 289 & 196 & 13,69 \\
\cline { 2 - 9 } & 16 & 13,5 & 3,65 & 58,4 & 49,275 & 216 & 256 & 182,25 & 13,3225 \\
\hline Total & 10 & 11 & 3,15 & 31,5 & 34,65 & 110 & 100 & 121 & 9,9225 \\
\hline Rata-rata & 11,8 & 111 & 32,21 & 389,15 & 363,47 & 1363 & 1480 & 1268,5 & 104,75 \\
\hline
\end{tabular}

$$
\begin{gathered}
p=n \sum X_{1} Y-\sum X_{1} \sum Y=10(389,15)-(118)(32,21)=90,72 \\
q=n \sum X_{2}^{2}-\left(\sum X_{2}\right)^{2}=10(1268,5)-(111)^{2}=364 \\
r=n \sum X_{1} X_{2}-\sum X_{1} \sum X_{2}=(10)(1363)-(118)(111)=532 \\
s=n \sum X_{2} Y-\sum X_{2} \sum Y=(10)(363,47)-(111)(32,21)=59,39 \\
t=n \sum X_{1}^{2}-\left(\sum X_{1}\right)^{2}=(10)(1480)-(118)^{2}=876 \\
u=t q-r^{2}=(876)(364)-(532)^{2}=35840 \\
\hat{\beta}_{1}=\frac{p q-r s}{u} \\
\hat{\beta}_{1}=0,039804688 \text { atau } 0,04 .
\end{gathered}
$$




$$
\begin{gathered}
\hat{\beta}_{2}=\frac{s t-p r}{u} \\
\hat{\beta}_{2}=\frac{(59,39)(876)-(90,72)(532)}{35840}=0,104983259 \text { atau } 0,105 . \\
\hat{\alpha}=\frac{\sum Y-\hat{\beta}_{1} \sum X_{1}-\hat{\beta}_{2} \sum X_{2}}{n} \\
\hat{\alpha}=\frac{32,21-(0,0398)(118)-(0,105)(111)}{10} \\
\hat{\alpha}=1,585990513 \text { atau } 1,586 .
\end{gathered}
$$

Maka diperoleh persamaan regresi linear berganda

$$
\widehat{Y}=1,585990513+0,039804688 X_{1}+0,104983259 X_{2} .
$$

Tabel 10.3 menyajikan nilai $\hat{\alpha}, \hat{\beta}_{1}$, dan $\hat{\beta}_{2}$ berdasarkan perhitungan SPSS.

Tabel 10.3

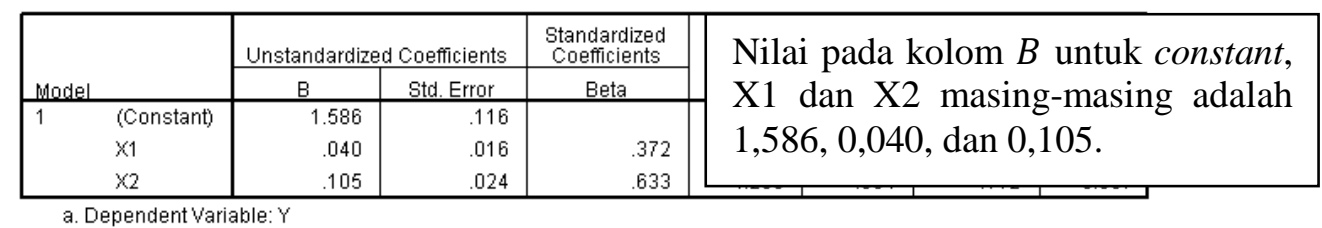

$\rightarrow$ Menghitung koefisien determinasi.

Selanjutnya akan dihitung nilai koefisien determinasi $\left(r^{2}\right)$ atau $R$-Square. Berikut rumus untuk menghitung nilai koefisien determinasi.

Tabel 10.4

\begin{tabular}{|c|c|c|c|c|c|c|}
\cline { 2 - 7 } \multicolumn{1}{c|}{} & $Y$ & $\hat{Y}$ & $\hat{Y}-\bar{Y}$ & $(\hat{Y}-\bar{Y})^{2}$ & $Y-\bar{Y}$ & $(Y-\bar{Y})^{2}$ \\
\cline { 2 - 7 } & 3,01 & 2,981378 & $-0,168621652$ & 0,057418536 & $-0,211$ & 0,044521 \\
\hline 3,15 & 3,218463 & 0,068462612 & 0,000006 & $-0,071$ & 0,005041 \\
\hline 2,9 & 2,889082 & $-0,260917969$ & 0,110169538 & $-0,321$ & 0,103041 \\
\hline & 3,1 & 3,03387 & $-0,116130022$ & 0,035017645 & $-0,121$ & 0,014641 \\
\cline { 2 - 7 } & 2,7 & 2,744294 & $-0,405705915$ & 0,22724853 & $-0,521$ & 0,271441 \\
\hline & 3,25 & 3,283641 & 0,133641183 & 0,003923918 & 0,029 & 0,000841 \\
\cline { 2 - 7 } & 3,6 & 3,547843 & 0,397843192 & 0,106826472 & 0,379 & 0,143641 \\
\cline { 2 - 7 } & 3,7 & 3,732436 & 0,582435826 & 0,261566604 & 0,479 & 0,229441 \\
\cline { 2 - 7 } & 3,65 & 3,64014 & 0,490139509 & 0,175677928 & 0,429 & 0,184041 \\
\cline { 2 - 7 } & 3,15 & 3,138853 & $-0,011146763$ & 0,006748091 & $-0,071$ & 0,005041 \\
\hline Total & 32,21 & & & 0,984603262 & & 1,00169 \\
\hline Rata-Rata & 3,221 & & & & & \\
\hline
\end{tabular}




$$
\begin{aligned}
r^{2} & =\frac{\sum(\hat{Y}-\bar{Y})^{2}}{\sum(Y-\bar{Y})^{2}} \\
r^{2} & =\frac{0,984603262}{1,00169} \\
r^{2} & =0,9829425
\end{aligned}
$$

Tabel 10.5 menyajikan nilai koefisien determinasi atau $R$-Square berdasarkan perhitungan SPSS.

\section{Tabel 10.5}

\begin{tabular}{|c|l|r|r|r|r|}
\hline Model & $\mathrm{R}$ & R Square & $\begin{array}{c}\text { Adjusted R } \\
\text { Square }\end{array}$ & $\begin{array}{c}\text { Std. Error of } \\
\text { the Estimate }\end{array}$ & $\begin{array}{c}\text { Durbin- } \\
\text { Watson }\end{array}$ \\
\hline 1 & $.991^{\mathrm{a}}$ & .983 & .978 & .04941 & 2.774 \\
\hline
\end{tabular}

$\rightarrow$ Menghitung standard error dari estimasi.

Selanjutnya akan dihitung nilai standard error dari estimasi $(s)$. Berikut rumus untuk menghitung standard error dari estimasi.

$$
s=\sqrt{\frac{\sum(Y-\hat{Y})^{2}}{n-k}} \text { atau } \sqrt{\frac{\sum(Y-\hat{Y})^{2}}{n-3}} .
$$

Perhatikan bahwa $k$ menyatakan jumlah variabel. Nilai $k$ adalah 3 , karena jumlah variabel sebanyak 3, yakni $X_{1}, X_{2}$, dan $Y$.

$$
\begin{aligned}
& s=\sqrt{\frac{0.0170863}{10-3}} \\
& s=0,04940547 .
\end{aligned}
$$

Tabel 10.6

\begin{tabular}{|c|c|c|c|c|}
\hline$Y$ & $\hat{Y}$ & $Y-\hat{Y}$ & $(Y-\hat{Y})^{2}$ \\
\cline { 2 - 5 } & 3,01 & 2,981378 & 0,028622 & 0,000819 \\
\hline 3,15 & 3,218463 & $-0,06846$ & 0,004687 \\
\hline 2,9 & 2,889082 & 0,010918 & 0,000119 \\
\hline 3,1 & 3,03387 & 0,06613 & 0,004373 \\
\hline 2,7 & 2,744294 & $-0,04429$ & 0,001962 \\
\hline 3,25 & 3,283641 & $-0,03364$ & 0,001132 \\
\hline 3,6 & 3,547843 & 0,052157 & 0,00272 \\
\hline & 3,7 & 3,732436 & $-0,03244$ & 0,001052 \\
\hline & 3,65 & 3,64014 & 0,00986 & 0,0001 \\
\hline Total & 3,15 & 3,138853 & 0,011147 & 0,000124 \\
\hline
\end{tabular}


Tabel 10.7 menyajikan nilai standard error dari estimasi berdasarkan perhitungan SPSS.

Tabel 10.7

Kolom Std. Error of the estimate menyajikan nilai standard error dari estimasi.

\begin{tabular}{|c|c|c|c|}
\multicolumn{5}{|c|}{ Model Summary } \\
\hline Square & $\begin{array}{c}\text { Adjusted R } \\
\text { Square }\end{array}$ & $\begin{array}{c}\text { Std. Error of } \\
\text { the Estimate }\end{array}$ & $\begin{array}{c}\text { Durbin- } \\
\text { Watson }\end{array}$ \\
\hline .983 & .978 & .04941 & 2.774 \\
\hline
\end{tabular}

$\rightarrow$ Menghitung standard error dari koefisien regresi.

Selanjutnya akan dihitung standard error dari koefisien regresi $\hat{\beta}_{1}$ (dilambangkan dengan $s_{\widehat{\beta}_{1}}$ ) dan $\hat{\beta}_{2}$ (dilambangkan dengan $s_{\widehat{\beta}_{2}}$ ). Berikut rumus untuk menghitung $s_{\widehat{\beta}_{1}}$ dan $s_{\widehat{\beta}_{2}}$.

$$
\begin{aligned}
& s_{\widehat{\beta}_{1}}=\frac{s \sqrt{\sum\left(X_{2}-\bar{X}_{2}\right)^{2}}}{\left[\sqrt{\left(\sum\left(X_{1}-\bar{X}_{1}\right)^{2}\right)\left(\sum\left(X_{2}-\bar{X}_{2}\right)^{2}\right)-\left(\sum\left(X_{1}-\bar{X}_{1}\right)\left(X_{2}-\bar{X}_{2}\right)\right)^{2}}\right]} \\
& s_{\widehat{\beta}_{2}}=\frac{s \quad \sqrt{\sum\left(X_{1}-\bar{X}_{1}\right)^{2}}}{\left[\sqrt{\left(\sum\left(X_{1}-\bar{X}_{1}\right)^{2}\right)\left(\sum\left(X_{2}-\bar{X}_{2}\right)^{2}\right)-\left(\sum\left(X_{1}-\bar{X}_{1}\right)\left(X_{2}-\bar{X}_{2}\right)\right)^{2}}\right]} .
\end{aligned}
$$

Berikut perhitungan nilai $s_{\widehat{\beta}_{1}}$ dan $s_{\widehat{\beta}_{2}}$.

$$
\begin{gathered}
s_{\widehat{\beta}_{1}}=\frac{s \sqrt{\sum\left(X_{2}-\bar{X}_{2}\right)^{2}}}{\left[\sqrt{\left(\sum\left(X_{1}-\bar{X}_{1}\right)^{2}\right)\left(\sum\left(X_{2}-\bar{X}_{2}\right)^{2}\right)-\left(\sum\left(X_{1}-\bar{X}_{1}\right)\left(X_{2}-\bar{X}_{2}\right)\right)^{2}}\right]} \\
s_{\widehat{\beta}_{1}}=\frac{0,04940547 \sqrt{36,4}}{\left[\sqrt{(87,6)(36,4)-(53,2)^{2}}\right]} \\
s_{\widehat{\beta}_{2}}=\frac{s_{\widehat{\beta}_{1}}=\frac{0,2980751}{18,93146}}{\left[\sqrt{\left(\sum\left(X_{1}-\bar{X}_{1}\right)^{2}\right)\left(\sum\left(X_{2}-\bar{X}_{2}\right)^{2}\right)-\left(\sum\left(X_{1}-\bar{X}_{1}\right)\left(X_{2}-\bar{X}_{2}\right)\right)^{2}}\right]} \\
s_{\widehat{\beta}_{1}}=0,015744962 . \\
0,04940547 \sqrt{87,6} \\
s_{\widehat{\beta}_{2}}=\frac{s \sqrt{\sum\left(X_{1}-\bar{X}_{1}\right)^{2}}}{\left[\sqrt{(87,6)(36,4)-(53,2)^{2}}\right]} \\
s_{\widehat{\beta}_{2}}=0,024425472 . \\
18,93146
\end{gathered}
$$


Tabel 10.9 menyajikan nilai $s_{\widehat{\beta}_{1}}$ dan $s_{\widehat{\beta}_{2}}$ berdasarkan perhitungan SPSS.

Tabel 10.8

\begin{tabular}{|c|c|c|c|c|c|}
\cline { 2 - 6 } \multicolumn{1}{c|}{} & $X_{1}$ & $X_{2}$ & $\left(X_{1}-\bar{X}_{1}\right)^{2}$ & $\left(X_{2}-\bar{X}_{2}\right)^{2}$ & $\left(\left(X_{1}-\bar{X}_{1}\right)\left(X_{2}-\bar{X}_{2}\right)\right)$ \\
\cline { 2 - 6 } & 10 & 9,5 & 3,24 & 2,56 & 2,88 \\
\cline { 2 - 6 } & 12 & 11 & 0,04 & 0,01 & $-0,02$ \\
\cline { 2 - 6 } & 9 & 9 & 7,84 & 4,41 & 5,88 \\
\cline { 2 - 6 } & 10 & 10 & 3,24 & 1,21 & 3,9204 \\
\cline { 2 - 6 } & 8 & 8 & 14,44 & 9,61 & 1,98 \\
\cline { 2 - 6 } & 11 & 12 & 0,64 & 0,81 & $-0,72$ \\
\cline { 2 - 6 } & 15 & 13 & 10,24 & 3,61 & 6,08 \\
\cline { 2 - 6 } & 16 & 14 & 27,04 & 8,41 & 15,08 \\
\cline { 2 - 6 } & 10 & 11,5 & 17,64 & 5,76 & 10,08 \\
\hline Total & 118 & 111 & 3,24 & 0,01 & 53,2 \\
\hline Rata-Rata & 11,8 & 11,1 & 87,6 & 36,4 & 5,32 \\
\hline
\end{tabular}

Tabel 10.9

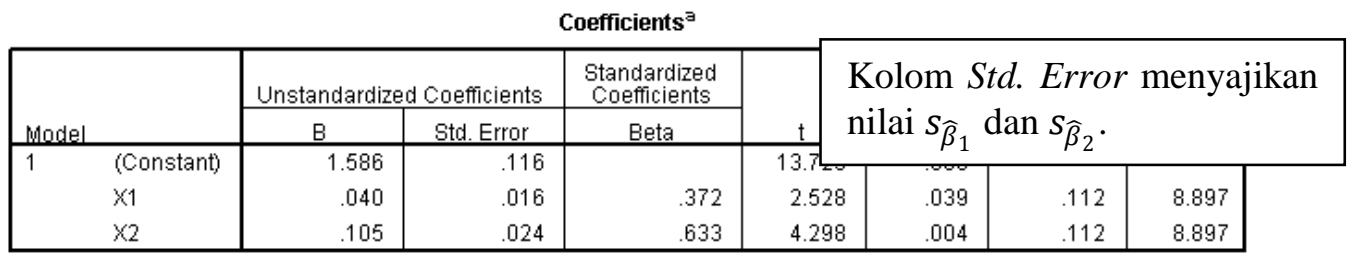

$\rightarrow$ Uji signifikansi koefisien regresi $\beta_{1}$ dan $\beta_{2}$.

Untuk menentukan apakah koefisien regresi populasi $\beta$ signifikan atau tidak, maka perlu dihitung terlebih dahulu nilai statistik dari uji $t$ berdasarkan koefisien regresi (sampel) $\hat{\beta}$. Berikut perhitungan untuk menentukan nilai statistik dari uji $t$ berdasarkan koefisien regresi $\hat{\beta}_{1}$.

$$
\begin{gathered}
t_{\widehat{\beta}_{1}}=\frac{\left(\hat{\beta}_{1}-\beta_{1}\right)}{S_{\widehat{\beta}_{1}}} \\
t_{\widehat{\beta}_{1}}=\frac{0,039804688-0}{0,015744962} \\
t_{\widehat{\beta}_{1}}=2,52809 \\
t_{\widehat{\beta}_{2}}=\frac{\left(\hat{\beta}_{2}-\beta_{2}\right)}{S_{\widehat{\beta}_{2}}} \\
t_{\widehat{\beta}_{2}}=\frac{0,104983259-0}{0,024425472}
\end{gathered}
$$




$$
t_{\widehat{\beta}_{2}}=4,298106
$$

Tabel 10.10 merupakan output SPSS yang menyajikan nilai statistik dari uji $t$ berdasarkan koefisien regresi (sampel) $\hat{\beta}$.

\section{Tabel 10.10}

\begin{tabular}{|c|c|c|c|c|c|c|}
\hline \multirow{2}{*}{\multicolumn{2}{|c|}{ Madel }} & \multicolumn{2}{|c|}{ Unstandardized Coefficients } & $\begin{array}{l}\text { Standardized } \\
\text { Coefficients }\end{array}$ & \multirow[b]{2}{*}{$t$} & \\
\hline & & $\mathrm{B}$ & Std. Error & Beta & & \multirow{3}{*}{$\begin{array}{l}\text { Kolom } t \text { menyajikan nilai } \\
t_{\widehat{\beta}_{1}} \text { dan } t_{\widehat{\beta}_{7}} \text {. }\end{array}$} \\
\hline & (Constant) & 1.586 & .116 & & \multirow{3}{*}{$\begin{array}{r}13.723 \\
2.528 \\
4.298 \\
\end{array}$} & \\
\hline & $x_{1}$ & .040 & .016 & .372 & & \\
\hline & $\times 2$ & .105 & .024 & 633 & & 8.897 \\
\hline
\end{tabular}

$\rightarrow$ Menghitung korelasi parsial antara $X_{1}$ dan $Y$, dengan mengontrol pengaruh $X_{2}$. Menghitung korelasi parsial antara $X_{2}$ dan $Y$, dengan mengontrol pengaruh $X_{1}$.

Berikut akan dihitung korelasi parsial antara $X_{1}$ dan $Y$ dengan mengontrol pengaruh $X_{2}$ dan korelasi parsial antara $X_{2}$ dan $Y$ dengan mengontrol pengaruh $X_{1}$. Namun sebelumnya akan dihitung korelasi sederhana antara $Y$ dan $X_{1}, Y$ dan $X_{2}$, serta $X_{1}$ dan $X_{2}$.

$$
\begin{gathered}
r_{Y X_{1}}=\frac{n \sum Y X_{1}-\sum Y \sum X_{1}}{\sqrt{\left[n \sum Y^{2}-\left(\sum Y\right)^{2}\right]\left[n \sum X_{1}^{2}-\left(\sum X_{1}\right)^{2}\right]}} \\
r_{Y X_{2}}=\frac{n \sum Y X_{2}-\sum Y \sum X_{2}}{\sqrt{\left[n \sum Y^{2}-\left(\sum Y\right)^{2}\right]\left[n \sum X_{2}^{2}-\left(\sum X_{2}\right)^{2}\right]}} \\
r_{X_{1} X_{2}}=\frac{n \sum X_{1} X_{2}-\sum X_{1} \sum X_{2}}{\sqrt{\left[n \sum X_{1}^{2}-\left(\sum X_{1}\right)^{2}\right]\left[n \sum X_{2}^{2}-\left(\sum X_{2}\right)^{2}\right]}} .
\end{gathered}
$$

Setelah nilai-nilai dari korelasi sederhana diperoleh, maka korelasi parsial dapat dihitung dengan rumus sebagai berikut.

$$
\begin{aligned}
& r_{Y X_{1}, X_{2}}=\frac{r_{Y X_{1}}-r_{Y X_{2}} r_{X_{1} X_{2}}}{\sqrt{\left(1-r_{Y X_{2}}^{2}\right)\left(1-r_{X_{1} X_{2}}^{2}\right)}} \\
& r_{Y X_{2}, X_{1}}=\frac{r_{Y X_{2}}-r_{Y X_{1}} r_{X_{2} X_{1}}}{\sqrt{\left(1-r_{Y X_{1}}^{2}\right)\left(1-r_{X_{2} X_{1}}^{2}\right)}} \\
& r_{X_{1} X_{2}, Y}=\frac{r_{X_{1} X_{2}}-r_{Y X_{2}} r_{Y X_{1}}}{\sqrt{\left(1-r_{Y X_{1}}^{2}\right)\left(1-r_{Y X_{2}}^{2}\right)}} .
\end{aligned}
$$

Berdasarkan Tabel 10.2 diperoleh nilai-nilai sebagai berikut. 
$\begin{array}{llll}\sum Y X_{1}=389,15 & \sum Y=32,21 & \sum X_{1}=118 & \sum Y^{2}=104,75 \\ \sum X_{1}^{2}=1480 & \sum Y X_{2}=363,47 & \sum X_{2}=111 & \sum X_{2}^{2}=1268,5\end{array}$

$\sum X_{1} X_{2}=1363$

Berikut perhitungan untuk nilai-nilai dari korelasi sederhana.

$$
\begin{aligned}
& r_{Y X_{1}}=\frac{n \sum Y X_{1}-\sum Y \sum X_{1}}{\sqrt{\left[n \sum Y^{2}-\left(\sum Y\right)^{2}\right]\left[n \sum X_{1}^{2}-\left(\sum X_{1}\right)^{2}\right]}} \\
& r_{Y X_{1}}=\frac{10 \times 389,15-32,21 \times 118}{\sqrt{\left[10 \times 104,75-32,21^{2}\right]\left[10 \times 1480-118^{2}\right]}} \\
& r_{Y X_{1}}=\frac{90,72}{\sqrt{[10,0159][876]}} \\
& r_{Y X_{1}}=0,9684658 \\
& r_{Y X_{2}}=\frac{n \sum Y X_{2}-\sum Y \sum X_{2}}{\sqrt{\left[n \sum Y^{2}-\left(\sum Y\right)^{2}\right]\left[n \sum X_{2}^{2}-\left(\sum X_{2}\right)^{2}\right]}} \\
& r_{Y X_{2}}=\frac{10 \times 363,47-32,21 \times 111}{\sqrt{\left[10 \times 104,75-32,21^{2}\right]\left[10 \times 1268,5-111^{2}\right]}} \\
& r_{Y X_{2}}=\frac{59,39}{\sqrt{[10,0159][364]}} \\
& r_{Y X_{2}}=0,9835489 \\
& r_{X_{1} X_{2}}=\frac{n \sum X_{1} X_{2}-\sum X_{1} \sum X_{2}}{\sqrt{\left[n \sum X_{1}^{2}-\left(\sum X_{1}\right)^{2}\right]\left[n \sum X_{2}^{2}-\left(\sum X_{2}\right)^{2}\right]}} \\
& r_{X_{1} X_{2}}=\frac{10 \times 1363-118 \times 111}{\sqrt{\left[10 \times 1480-118^{2}\right]\left[10 \times 1268,5-111^{2}\right]}} \\
& r_{X_{1} X_{2}}=\frac{532}{\sqrt{[876][364]}} \\
& r_{X_{1} X_{2}}=0,9421258 .
\end{aligned}
$$

Berikut perhitungan untuk nilai-nilai dari korelasi parsial.

$$
r_{Y X_{1}, X_{2}}=\frac{r_{Y X_{1}}-r_{Y X_{2}} r_{X_{1} X_{2}}}{\sqrt{\left(1-r_{Y X_{2}}^{2}\right)\left(1-r_{X_{1} X_{2}}^{2}\right)}}
$$




$$
\begin{gathered}
r_{Y X_{1}, X_{2}}=\frac{0,9684658-(0,9835489 \times 0,9421258)}{\sqrt{\left(1-(0,9835489)^{2}\right)\left(1-(0,9421258)^{2}\right)}} \\
r_{Y X_{1}, X_{2}}=0,6908474 .
\end{gathered}
$$

Berdasarkan perhitungan, nilai korelasi parsial $r_{Y X_{1}, X_{2}}$ adalah 0,691.

$$
\begin{gathered}
r_{Y X_{2}, X_{1}}=\frac{r_{Y X_{2}}-r_{Y X_{1}} r_{X_{2} X_{1}}}{\sqrt{\left(1-r_{Y X_{1}}^{2}\right)\left(1-r_{X_{2} X_{1}}^{2}\right)}} \\
r_{Y X_{2}, X_{1}}=\frac{0,9835489-(0,9684658)(0,9421258)}{\sqrt{\left(1-(0,9685)^{2}\right)\left(1-(0,9421)^{2}\right)}} \\
r_{Y X_{2}, X_{1}}=0,851590767 .
\end{gathered}
$$

Berdasarkan perhitungan, nilai korelasi parsial $r_{Y X_{2}, X_{1}}$ adalah 0,85159 .

$$
\begin{gathered}
r_{X_{1} X_{2}, Y}=\frac{r_{X_{1} X_{2}}-r_{Y X_{2}} r_{Y X_{1}}}{\sqrt{\left(1-r_{Y X_{1}}^{2}\right)\left(1-r_{Y X_{2}}^{2}\right)}} \\
r_{X_{1} X_{2}, Y}=\frac{0,9421258-(0,9835489)(0,9684658)}{\sqrt{\left(1-(0,9684658)^{2}\right)\left(1-(0,9835489)^{2}\right)}} \\
r_{X_{1} X_{2}, Y}=-0,23125166 .
\end{gathered}
$$

Berdasarkan perhitungan, nilai korelasi parsial $r_{X_{1} X_{2}, Y}$ adalah -0,23125166. Berikut disajikan nilai $r_{X_{1} Y, X_{2}}, r_{X_{2} Y, X_{1}}$, dan $r_{X_{1} X_{2}, Y}$ berdasarkan perhitungan SPSS (Tabel 10.11).

\section{Tabel 10.11}

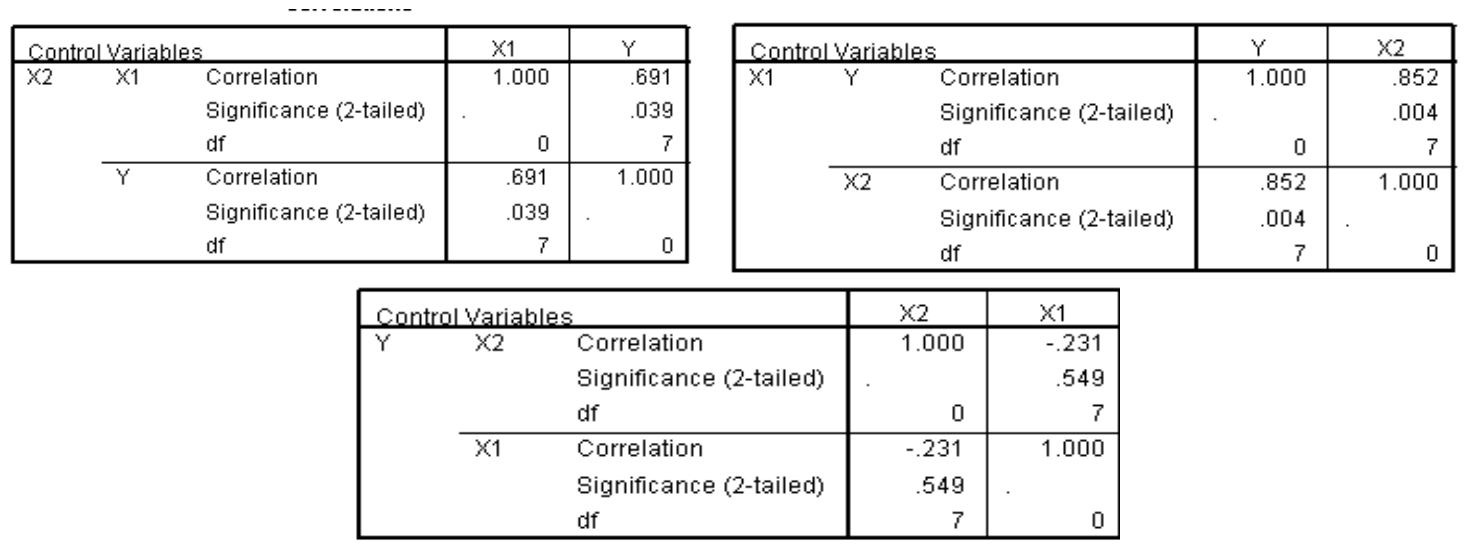

$\rightarrow$ Menghitung nilai statistik dari uji $F$ untuk uji kecocokkan model terhadap data.

Selanjutnya akan dihitung nilai statistik dari uji $F$. Berikut rumus untuk menghitung nilai statistik dari uji $F$. 


$$
F=\frac{\frac{r^{2}}{k-1}}{\frac{1-r^{2}}{n-k}}
$$

Sehingga nilai statistik dari uji $F$

$$
\begin{gathered}
F=\frac{\frac{0,982942}{3-1}}{\frac{1-0,982942}{10-3}} \\
F=201,682 .
\end{gathered}
$$

Tabel 10.12 menyajikan nilai statistik dari uji $F$.

Tabel 10.12

\begin{tabular}{|l|l|r|r|r|r|}
\hline & Sum of & & & & \\
\hline Kolom F menyajikan nilai & 2 & mean Square & F & Sig. \\
\cline { 4 - 6 } statistik dari uji $F$. & & .492 & 201.689 & $.000^{3}$ \\
\hline & & .002 & & \\
\hline
\end{tabular}

[2] Misalkan diberikan data sebagai berikut.

Tabel 10.13

\begin{tabular}{|c|c|c|}
\hline$Y$ & $X_{1}$ & $X_{2}$ \\
\hline 1 & 1 & 1 \\
\hline 2 & 2 & 3 \\
\hline 4 & 3 & 4 \\
\hline 5 & 4 & 5 \\
\hline 6 & 5 & 6 \\
\hline 8 & 6 & 8 \\
\hline 10 & 7 & 9 \\
\hline 12 & 8 & 10 \\
\hline
\end{tabular}

Berdasarkan data pada Tabel 10.13, misalkan $X_{1}$ dan $X_{2}$ merupakan variabel bebas, sedangkan $Y$ sebagai variabel tak bebas. Berikut akan dihitung nilai VIF dari variabel bebas $X_{1}$ dan $X_{2}$.

$\rightarrow$ Menghitung nilai VIF dari variabel bebas $X_{1}$.

$\Rightarrow$ Untuk menghitung nilai VIF dari variabel bebas $X_{1}$, terlebih dahulu membuat persamaan regresi linear dengan $X_{1}$ sebagai variabel tak bebas, sedangkan $X_{2}$ sebagai variabel bebas.

$$
\widehat{X}_{1}=\hat{\alpha}+\hat{\beta}_{2} X_{2}
$$


Dengan menggunakan bantuan SPSS, diperoleh persamaan regresi sebagai berikut.

$$
\hat{X}_{1}=-0,015+0,785 X_{2} \text {. }
$$

Tabel 10.14

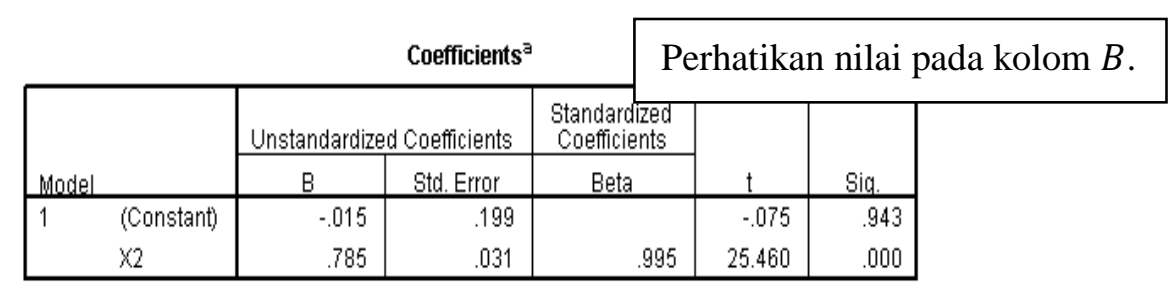

$\Rightarrow$ Kemudian hitung nilai koefisien determinasi $r_{X_{1}, X_{2}}^{2}$. Setelah diperoleh nilai koefisien determinasi $r_{X_{1}, X_{2}}^{2}$, maka nilai VIF untuk variabel bebas $X_{1}$ dihitung dengan rumus sebagai berikut.

$$
\operatorname{VIF} X_{1}=\frac{1}{\left(1-r_{X_{1}, X_{2}}^{2}\right)}
$$

Dengan menggunakan bantuan SPSS, diperoleh $r_{X_{1}, X_{2}}^{2}=0,99082892416$.

\begin{tabular}{|c|c|c|c|c|c|}
\hline Model & $\mathrm{R}$ & R Square & Adjustede & $\begin{array}{l}\text { Std. } \\
\text { the } \mathrm{E}\end{array}$ & $r_{X_{1}, X_{2}}^{2}=0,99082892416$ \\
\hline 1 & $.995^{a}$ & .991 & .989 & & .253 \\
\hline
\end{tabular}

Tabel 10.15

Nilai VIF untuk variabel bebas $X_{1}$ adalah

$$
\operatorname{VIF} X_{1}=\frac{1}{\left(1-r_{X_{1}, X_{2}}^{2}\right)}=\frac{1}{(1-0,99082892416)}=109,0384608
$$

$\rightarrow$ Menghitung nilai VIF dari variabel bebas $X_{2}$.

$\Rightarrow$ Untuk menghitung nilai VIF dari variabel bebas $X_{2}$, terlebih dahulu membuat persamaan regresi linear dengan $X_{2}$ sebagai variabel tak bebas, sedangkan $X_{1}$ sebagai variabel bebas.

$$
\hat{X}_{2}=\hat{\alpha}+\hat{\beta}_{1} X_{1}
$$

\begin{tabular}{|c|c|c|c|c|c|c|}
\hline \multirow[b]{2}{*}{ Model } & \multicolumn{2}{|c|}{ Unstandardized Coefficients } & \multirow[t]{2}{*}{$\begin{array}{r}\mathrm{Star} \\
\mathrm{CoO}\end{array}$} & \multirow{3}{*}{\multicolumn{2}{|c|}{$\begin{array}{l}\text { Perhatikan } \\
B \text {. }\end{array}$}} & \multirow[t]{3}{*}{ kolom } \\
\hline & B & Std. Error & & & & \\
\hline $1 \quad$ (Constant) & .071 & .250 & & & & \\
\hline $\mathrm{x} 1$ & 1.262 & .050 & & .995 & 25.460 & .000 \\
\hline
\end{tabular}

Dengan bantuan SPSS, diperoleh persamaan regresi sebagai berikut.

$$
\hat{X}_{2}=0,071+1,262 X_{1} .
$$

Tabel 10.16 
$\Rightarrow$ Hitung nilai koefisien determinasi $r_{X_{2}, X_{1}}^{2}$. Setelah diperoleh nilai koefisien determinasi $r_{X_{2}, X_{1}}^{2}$, maka nilai VIF untuk variabel bebas $X_{2}$ dihitung dengan rumus sebagai berikut.

$$
\operatorname{VIF} X_{2}=\frac{1}{\left(1-r_{X_{2}, X_{1}}^{2}\right)}
$$

Dengan bantuan SPSS diperoleh nilai koefisien determinasi 0,99082892416.

Tabel 10.17

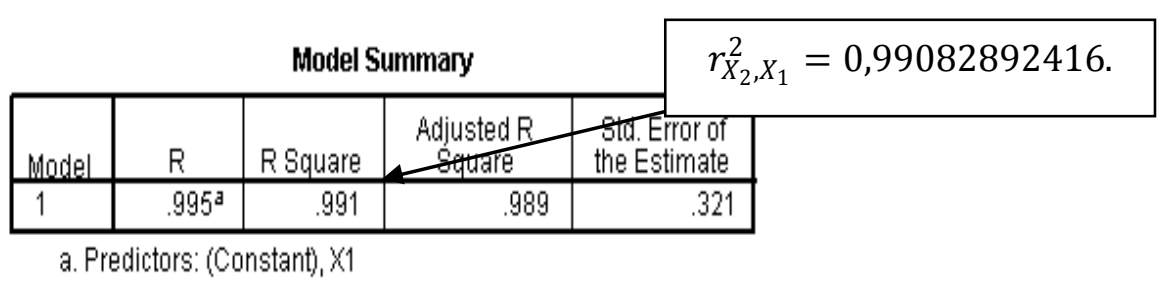

Maka nilai VIF untuk variabel bebas $X_{2}$ adalah

$$
\operatorname{VIF} X_{2}=\frac{1}{\left(1-r_{X_{2}, X_{1}}^{2}\right)}=\frac{1}{(1-0,99082892416)}=109,0384608
$$

Tabel 10.18 menyajikan nilai VIF untuk masing-masing variabel bebas berdasarkan perhitungan SPSS.

\section{Tabel 10.18}

Perhatikan nilai-nilai

\begin{tabular}{|c|c|c|c|c|c|c|c|c|}
\hline \multirow{2}{*}{\multicolumn{2}{|c|}{ Model }} & \multicolumn{2}{|c|}{ Unstandardized Coefficients } & \multirow{2}{*}{$\begin{array}{c}\begin{array}{c}\text { Standardized } \\
\text { Coefficients }\end{array} \\
\text { Beta }\end{array}$} & \multirow[b]{2}{*}{$t$} & \multirow[b]{2}{*}{ Siq. } & \multicolumn{2}{|c|}{ Collinearity Statistics } \\
\hline & & $\mathrm{B}$ & Std. Error & & & & Tolerance & VIF \\
\hline \multirow[t]{3}{*}{1} & (Constant) & -.962 & .416 & & -2.313 & .069 & & \\
\hline & $\times 1$ & 1.596 & .854 & 1.024 & 1.870 & .120 & .009 & 109.038 \\
\hline & $\times 2$ & -.038 & .673 & -.031 & -.057 & .957 & .009 & 109.038 \\
\hline
\end{tabular}
pada kolom VIF.

a. Dependent Variable: $Y$

\begin{tabular}{|c|c|c|c|c|c|c|}
\hline \multicolumn{7}{|c|}{ ANOVA ${ }^{b}$} \\
\hline \multicolumn{2}{|c|}{ Madel } & $\begin{array}{c}\text { Sum of } \\
\text { Squares }\end{array}$ & df & Mean Square & $\mathrm{F}$ & Sig. \\
\hline \multirow[t]{3}{*}{1} & Regression & 100.596 & 2 & 50.298 & 179.144 & $.000^{a}$ \\
\hline & Residual & 1.404 & 5 & .281 & & \\
\hline & Total & 102.000 & 7 & & & \\
\hline
\end{tabular}

Tabel 10.19

Perhatikan bahwa nilai VIF untuk masing-masing variabel bebas sangat tinggi, yakni lebih dari 10, sehingga diindikasi telah terjadi multikolinearitas. Berdasarkan Tabel 10.19 menunjukkan hasil uji $F$ signifikan, yang berarti bahwa paling tidak terdapat satu koefisien regresi signifikan. Namun pada Tabel 10.18 menunjukkan tidak terdapat satupun koefisien regresi yang signifikan (nilai Sig lebih besar dari 0,05). Di samping itu, hubungan antara variabel bebas $X_{2}$ dan variabel tak bebas $Y$ bersifat positif, namun pada Tabel 10.18, nilai koefisien regresi untuk variabel $X_{2}$ bernilai negatif. Hal ini justru bertentangan. Sehingga disimpulkan bahwa memang benar-benar telah terjadi multikolinearitas. 
[3] Menghitung nilai VIF untuk persamaan regresi linear berganda dengan tiga variabel bebas.

Misalkan dalam suatu persamaan regresi linear berganda terdiri dari tiga variabel bebas, yakni $X_{1}, X_{2}$, dan $X_{3}$, sedangkan $Y$ merupakan variabel tak bebas. Nilai VIF untuk variabel bebas $X_{1}, X_{2}$, dan $X_{3}$ dihitung sebagai berikut.

$\rightarrow$ Menghitung nilai VIF dari variabel bebas $X_{1}$.

$\Rightarrow$ Untuk menghitung nilai VIF dari variabel bebas $X_{1}$, terlebih dahulu membuat persamaan regresi linear dengan $X_{1}$ sebagai variabel tak bebas, sedangkan $X_{2}$ dan $X_{3}$ sebagai variabel bebas, sehingga diperoleh persamaan regresi linear berganda sebagai berikut.

$$
\hat{X}_{1}=\hat{\alpha}+\hat{\beta}_{2} X_{2}+\hat{\beta}_{3} X_{3}
$$

$\Rightarrow$ Kemudian hitung nilai koefisien determinasi $r_{X_{1}, X_{2} X_{3}}^{2}$. Setelah diperoleh nilai koefisien determinasi $r_{X_{1}, X_{2} X_{3}}^{2}$, maka nilai VIF untuk variabel bebas $X_{1}$ dihitung dengan rumus sebagai berikut.

$$
V I F X_{1}=\frac{1}{\left(1-r_{X_{1}, X_{2} X_{3}}^{2}\right)}
$$

$\rightarrow$ Menghitung nilai VIF dari variabel bebas $X_{2}$.

$\Rightarrow$ Untuk menghitung nilai VIF dari variabel bebas $X_{2}$, terlebih dahulu membuat persamaan regresi linear dengan $X_{2}$ sebagai variabel tak bebas, sedangkan $X_{1}$ dan $X_{3}$ sebagai variabel bebas, sehingga diperoleh persamaan regresi linear berganda sebagai berikut.

$$
\hat{X}_{2}=\hat{\alpha}+\hat{\beta}_{1} X_{1}+\hat{\beta}_{3} X_{3}
$$

$\Rightarrow$ Kemudian hitung nilai koefisien determinasi $r_{X_{2}, X_{1} X_{3}}^{2}$. Setelah diperoleh nilai koefisien determinasi $r_{X_{2}, X_{1} X_{3}}^{2}$, maka nilai VIF untuk variabel bebas $X_{2}$ dihitung dengan rumus sebagai berikut.

$$
V I F X_{2}=\frac{1}{\left(1-r_{X_{2}, X_{1} X_{3}}^{2}\right)}
$$

$\rightarrow$ Menghitung nilai VIF dari variabel bebas $X_{3}$.

$\Rightarrow$ Untuk menghitung nilai VIF dari variabel bebas $X_{3}$, terlebih dahulu membuat persamaan regresi linear dengan $X_{3}$ sebagai variabel tak bebas, sedangkan $X_{1}$ dan $X_{2}$ sebagai variabel bebas, sehingga diperoleh persamaan regresi linear berganda sebagai berikut.

$$
\hat{X}_{3}=\hat{\alpha}+\hat{\beta}_{1} X_{1}+\hat{\beta}_{2} X_{2}
$$

$\Rightarrow$ Kemudian hitung nilai koefisien determinasi $r_{X_{3}, X_{1} X_{2}}^{2}$. Setelah diperoleh nilai koefisien determinasi $r_{X_{3}, X_{1} X_{2}}^{2}$, maka nilai VIF untuk variabel bebas $X_{3}$ dihitung dengan rumus sebagai berikut. 


$$
V I F X_{3}=\frac{1}{\left(1-r_{X_{3}, X_{1} X_{2}}^{2}\right)}
$$

[4] Misalkan diberikan data sebagai berikut.

Tabel 10.20

\begin{tabular}{|c|c|c|}
\hline$Y$ & $X_{1}$ & $X_{2}$ \\
\hline 3.01 & 10 & 9.5 \\
\hline 3.00 & 10 & 11 \\
\hline 2.90 & 9 & 9 \\
\hline 3.09 & 11 & 10 \\
\hline 2.80 & 8 & 8 \\
\hline 3.20 & 13 & 12 \\
\hline 3.60 & 14 & 13 \\
\hline 3.70 & 16 & 14 \\
\hline 3.65 & 16 & 13.5 \\
\hline 3.15 & 10 & 11 \\
\hline 3.27 & 11.00 & 11.00 \\
\hline 3.65 & 15.00 & 14.00 \\
\hline 3.70 & 17.00 & 14.00 \\
\hline 3.66 & 16.00 & 13.50 \\
\hline 3.19 & 10.00 & 11.00 \\
\hline
\end{tabular}

Berdasarkan data pada Tabel 10.20, misalkan $Y$ merupakan variabel tak bebas, sedangkan $X_{1}$ dan $X_{2}$ merupakan variabel bebas. Berikut akan dihitung secara manual nilai statistik dari uji Durbin-Watson.

$\rightarrow$ Membuat persamaan regresi linear berganda.

Berikut akan ditentukan persamaan regresi linear berganda berdasarkan data pada Tabel 10.20. Dengan menggunakan software SPSS diperoleh persamaan regresi linear berganda sebagai berikut.

$$
\widehat{Y}=1.68301+0.04775 X_{1}+0.08851 X_{2} .
$$

$\rightarrow$ Menghitung nilai statistik dari uji Durbin-Watson.

Berikut akan dihitung nilai statistik dari uji Durbin-Watson (d).

Tabel 10.21

\begin{tabular}{|c|c|c|c|c|c|c|c|}
\hline$Y$ & $X_{1}$ & $X_{2}$ & $\hat{Y}$ & $\hat{e}=Y-\hat{Y}$ & $\hat{e}^{2}$ & $\hat{e}_{t}-\hat{e}_{t-1}$ & $\left(\hat{e}_{t}-\hat{e}_{t-1}\right)^{2}$ \\
\hline 3.01 & 10 & 9.5 & 3.001355 & 0.008645 & $7.4736 \mathrm{E}-05$ & & \\
\hline 3 & 10 & 11 & 3.13412 & -0.13412 & 0.017988174 & -0.142765 & 0.020381845 \\
\hline 2.9 & 9 & 9 & 2.90935 & -0.00935 & $8.74225 \mathrm{E}-05$ & 0.12477 & 0.015567553 \\
\hline 3.09 & 11 & 10 & 3.09336 & -0.00336 & $1.12896 \mathrm{E}-05$ & 0.00599 & $3.58801 \mathrm{E}-05$ \\
\hline 2.8 & 8 & 8 & 2.77309 & 0.02691 & 0.000724148 & 0.03027 & 0.000916273 \\
\hline 3.2 & 13 & 12 & 3.36588 & -0.16588 & 0.027516174 & -0.19279 & 0.037167984 \\
\hline 3.6 & 14 & 13 & 3.50214 & 0.09786 & 0.00957658 & 0.26374 & 0.069558788 \\
\hline 3.7 & 16 & 14 & 3.68615 & 0.01385 & 0.000191823 & -0.08401 & 0.00705768 \\
\hline
\end{tabular}




\begin{tabular}{|c|c|c|c|c|c|c|c|c|}
\multicolumn{1}{c|}{} & 3.65 & 16 & 13.5 & 3.641895 & 0.008105 & $6.5691 \mathrm{E}-05$ & -0.005745 & $3.3005 \mathrm{E}-05$ \\
\cline { 2 - 9 } & 3.15 & 10 & 11 & 3.13412 & 0.01588 & 0.000252174 & 0.007775 & $6.04506 \mathrm{E}-05$ \\
\cline { 2 - 9 } & 3.27 & 11 & 11 & 3.18187 & 0.08813 & 0.007766897 & 0.07225 & 0.005220063 \\
\cline { 2 - 9 } & 3.65 & 15 & 14 & 3.6384 & 0.0116 & 0.00013456 & -0.07653 & 0.005856841 \\
\cline { 2 - 9 } & 3.7 & 17 & 14 & 3.7339 & -0.0339 & 0.00114921 & -0.0455 & 0.00207025 \\
\cline { 2 - 9 } & 3.66 & 16 & 13.5 & 3.641895 & 0.018105 & 0.000327791 & 0.052005 & 0.00270452 \\
\cline { 2 - 9 } & 3.19 & 10 & 11 & 3.13412 & 0.05588 & 0.003122574 & 0.037775 & 0.001426951 \\
\hline Total & 49.57 & 186 & 174.5 & 49.57165 & -0.00165 & 0.068989245 & 0.047235 & 0.168058083 \\
\hline
\end{tabular}

Nilai statistik dari uji Durbin-Watson dihitung dengan rumus sebagai berikut.

$$
\begin{gathered}
d=\frac{\sum_{t=2}^{n}\left(\hat{e}_{t}-\hat{e}_{t-1}\right)^{2}}{\sum_{t=1}^{n} \hat{e}_{t}^{2}} \\
=\frac{0.168058083}{0.068989245} \\
=2,436 .
\end{gathered}
$$

Berdasarkan perhitungan, diperoleh nilai statistik dari uji Durbin-Watson 2,436. Berikut hasil perhitungan SPSS yang menyajikan nilai statistik dari uji Durbin-Watson.

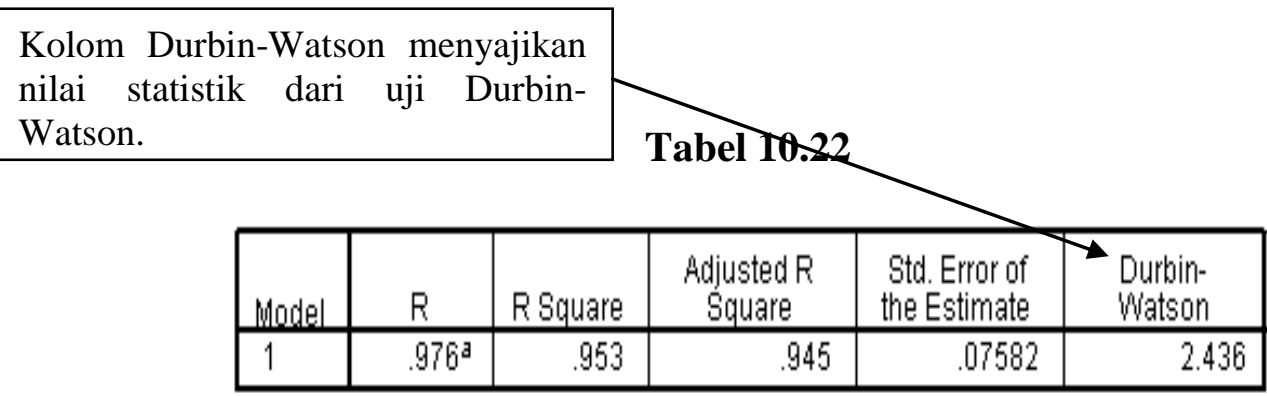

[5] Mengenai ukuran sampel, Hair (2009:172) memberikan pertimbangan sebagai berikut.

"Simple regression can be effective with a sample size of 20, but maintaining power 0,80 in multiple regression requires a minimum sample of 50 and preferably 100 observations for most research situations.

The minimum ratio of observations to variables is 5:1, but the preferred ratio is 15:1 or 20:1, which should increase when stepwise estimation is used.

Maximizing the degrees of freedom improves generalizability and addressed both model parsimony and sample size concern".

Sedangkan Field (2009:222) menyatakan sebagai berikut.

"Green (1991) makes two rules of thumb for the minimum acceptable sample size, the first based on whether you want to test the overall fit of your regression model (i.e. test the $R^{2}$ ), and the second based on whether you want to test the individual predictors within the model (i.e. test b-values of the model). If you want to test the model overall, then he recommends a minimum sample size of 50+8k, where $k$ is the number of predictors. So, with five predictors, 
you'd need a sample size of 50+40=90. If you want to test the individual predictors then he suggests a minimum sample size of 104+ $k$, so again taking the example of 5 predictors you'd need a sample size of 104+5=109. Of course, in most cases we're interested both in the overall fit and in the contribution of individual predictors, and in this situation Green recommends you calculate both of the minimum sample size I've just described, and use the one that has the largest value (so, in the five predictors example, we'd use 109 because it is bigger than 90)".

\section{Referensi}

1. Agresti, A. dan B. Finlay. 2009. Statistical Methods for the Social Sciences, $4^{\text {th }}$ Edition. United States of America: Prentice Hall.

2. Field, A. 2009. Discovering Statistics Using SPSS, $3^{\text {rd }}$ Edition. London: Sage.

3. Gio, P.U. 2013. Aplikasi Statistika dalam SPSS. Medan: USUpress.

4. Gujarati, D.N. 2003. Basic Econometrics, $4^{\text {th }}$ Edition. New York: McGraw-Hill.

5. Hair, J.F Jr., R.E. Anderson, B.J. Babin, dan W.C. Black. 2010. Multivariate Data Analysis, $7^{\text {th }}$ Edition. Pearson Prentice Hall.

6. Johnson, R.A. dan D.W. Wichern. 2007. Applied Multivariate Statistical Analysis, $6^{\text {th }}$ Edition. United States of America: Prentice Hall.

7. Malhotra, N.K. dan D.F. Birks. 2006. Marketing Research, An Applied Approach, $2^{\text {nd }}$ European Edition. London: Prentice Hall.

8. Montgomery, D.C. dan G.C. Runger. 2011. Applied Statistics and Probability for Engineers, $5^{\text {th }}$ Edition. United States of America: John Wiley \& Sons, Inc.

9. Stevens, J.P. 2009. Applied Multivariate Statistics For The Social Science, $5^{\text {th }}$ Edition. New York: Routledge.

10. Supranto, J. 2004. Ekonometri, Buku Kedua. Jakarta: Ghalia Indonesia.

11. Supranto, J. 2005. Ekonometri, Buku Kesatu. Jakarta: Ghalia Indonesia. 


\section{BAB 11}

\section{REGRESI LOGISTIK}

\section{Sekilas Regresi Logistik}

Dalam regresi linear, baik sederhana maupun berganda, variabel tak bebas bersifat metrik (interval atau rasio), sedangkan dalam regresi logistik, variabel tak bebas bersifat non-metrik (memiliki kategori). Pada regresi linear, variabel bebas bersifat metrik (interval atau rasio), sedangkan dalam regresi logistik, variabel bebas dapat bersifat metrik atau non-metrik atau kombinasi dari keduanya. Hair dkk. (2010:314) menyatakan sebagai berikut.

"Logistic regression may be described as estimating the relationship between a single nonmetric (binary) dependent variable and set of metric or non-metric independent variables, in this general form:

$$
\begin{array}{cc}
Y_{1} & =X_{1}+X_{2}+X_{3}+\cdots+X_{n} \\
\text { (binary non-metric }) & (\text { non-metric and metric }) "
\end{array}
$$

Sejalan dengan Hair, Field (2009:265) menyatakan sebagai berikut.

"Logistic regression is multiple regression but with an outcome variable that is a categorical variable and predictors variables that are continuous or categorical".

Sebagai contoh aplikasi dari regresi logistik dapat menjawab pertanyaan-pertanyaan seperti berikut.

$\Rightarrow$ Apakah seorang siswa diperkirakan memiliki peluang yang cukup besar untuk lulus ujian masuk perguruan tinggi negeri berdasarkan informasi jumlah jam belajar dalam sehari dan mengikuti kursus bimbingan belajar atau tidak di luar sekolah.

$\Rightarrow$ Apakah seorang responden diperkirakan memiliki peluang yang cukup besar untuk memilih presiden A berdasarkan informasi usia dan pekerjaannya.

$\Rightarrow$ Apakah seorang responden diperkirakan memiliki peluang yang cukup besar untuk terkena serangan jantung berdasarkan informasi jenis kelamin dan menghisap rokok atau tidak.

Pada regresi logistik, jika variabel tak bebas memiliki dua kategori, maka disebut regresi logistik biner (binary regression logistic). Namun, jika variabel tak bebas memiliki lebih dari dua kategori, maka disebut regresi logistik multinomial (multinomial/polychotomous logistic regression). Secara umum, persamaan regresi logistik sederhana (melibatkan satu variabel bebas) memiliki bentuk

$$
\ln \left[\frac{P(y=1)}{1-P(y=1)}\right]=\alpha+\beta x
$$


Perhatikan bahwa $P(y=1)$ menyatakan probabilitas terjadinya kejadian sukses (success), sedangkan $1-P(y=1)$ menyatakan probabilitas terjadinya kejadian gagal (failure). Rasio dari $\frac{P(y=1)}{1-P(y=1)}$ disebut dengan odds. Sebagai contoh misalkan $P(y=1)=0,8$, maka

$$
\frac{P(y=1)}{1-P(y=1)}=\frac{0,8}{1-0,8}=4
$$

Nilai 4 tersebut dapat diartikan kejadian untuk terjadinya sukses 4 kali lebih mungkin (as likely as) dibandingkan untuk terjadinya gagal. Misalkan diberikan data seperti pada Tabel 11.1. Berdasarkan data pada Tabel 11.1, pada variabel kelulusan, misalkan nilai 1 menyatakan lulus, sedangkan nilai 0 menyatakan tidak lulus. Probabilitas untuk lulus dengan menggunakan metode A adalah $\frac{1}{4}$, maka probabilitas untuk tidak lulus dengan menggunakan metode A adalah $1-\frac{1}{4}=\frac{3}{4}$. Nilai odds pada metode A adalah

$$
\frac{P(y=1)}{1-P(y=1)}=\frac{1 / 4}{1-1 / 4}=\frac{1 / 4}{3 / 4}=\frac{1}{3} .
$$

Nilai $\frac{1}{3}$ tersebut dapat diartikan kejadian untuk lulus dengan menggunakan metode A $\frac{1}{3}$ kali lebih mungkin dibandingkan untuk tidak lulus. Dengan kata lain, kejadian untuk tidak lulus dengan menggunakan metode A 3 kali lebih mungkin dibandingkan untuk lulus. Probabilitas untuk lulus dengan menggunakan metode $\mathrm{B}$ adalah $\frac{3}{4}$, maka probabilitas untuk tidak lulus dengan menggunakan metode B adalah $1-\frac{3}{4}=\frac{1}{4}$. Maka nilai odds pada metode B adalah

$$
\frac{P(y=1)}{1-P(y=1)}=\frac{3 / 4}{1-3 / 4}=\frac{3 / 4}{1 / 4}=3 \text {. }
$$

Nilai 3 tersebut menyatakan kejadian untuk lulus dengan menggunakan metode B 3 kali lebih mungkin dibandingkan untuk tidak lulus. Jika nilai odds pada metode B dibagi dengan nilai odds pada metode A, maka diperoleh

$$
\frac{\text { odds metode } B}{\text { odds metode } A}=\frac{3}{\frac{1}{3}}=9 .
$$

Nilai 9 dapat diinterpretasikan mahasiswa dengan menggunakan metode B untuk lulus 9 kali lebih mungkin dibandingkan dengan mahasiswa dengan menggunakan metode A. Nilai 9 tersebut disebut odds ratio.

Persamaan regresi logistik sederhana untuk probabilitas terjadinya sukses memiliki bentuk

$$
P(y=1)=\frac{e^{\alpha+\beta x}}{1+e^{\alpha+\beta x}}
$$

Persamaan regresi logistik untuk probabilitas dapat digunakan untuk mengestimasi probabilitas atau kemungkinan terjadinya suatu variabel tak bebas. 
Tabel 11.1

\begin{tabular}{|c|c|c|}
\hline Responden & Kelulusan & Metode \\
\hline 1 & 1 & $\mathrm{~A}$ \\
\hline 2 & 0 & $\mathrm{~A}$ \\
\hline 3 & 0 & $\mathrm{~A}$ \\
\hline 4 & 0 & $\mathrm{~A}$ \\
\hline 5 & 1 & $\mathrm{~B}$ \\
\hline 6 & 1 & $\mathrm{~B}$ \\
\hline 7 & 1 & $\mathrm{~B}$ \\
\hline 8 & 0 & $\mathrm{~B}$ \\
\hline
\end{tabular}

Pada bab sebelumnya telah dibahas mengenai regresi linear. Pada regresi linear mengasumsikan error $(e)$ berdistribusi normal dan memiliki nilai varians yang sama pada setiap tingkatan variabel bebas (across levels of the independent variable). Error merupakan selisih antara nilai variabel tak bebas $(y)$ dengan nilai estimasi variabel tak bebas $(\hat{y})$. Namun asumsi normalitas dan varians yang konstan dari error (homoskedastisitas) tidak berlaku ketika nilai dari variabel tak bebas hanya memiliki dua kemungkinan nilai (dichotomous outcome variable) (Hosmer dan Lemeshow, 2000:7).

Lebih lanjut Hosmer dan Lemeshow (2000:7) mengemukakan pada kondisi variabel tak bebas hanya memiliki dua kemungkinan nilai (dichotomous outcome variable), nilai dari variabel tak bebas $y$ ketika diberikan nilai variabel $x$ dapat dinyatakan ke dalam persamaan

$$
y=\pi(x)+e
$$

Berdasarkan persamaan $y=\pi(x)+e$, nilai $e$ diasumsikan dapat terjadi (may assume) pada salah satu dari dua nilai yang mungkin. Jika $y=1$ (misalkan 1 menyatakan kejadian sukses), maka

$$
\begin{aligned}
& y=\pi(x)+e \\
& 1=\pi(x)+e \\
& e=1-\pi(x),
\end{aligned}
$$

dengan probabilitas $\pi(x)$. Jika $y=0$ (misalkan 0 menyatakan kejadian gagal), maka

$$
\begin{gathered}
y=\pi(x)+e \\
0=\pi(x)+e \\
e=-\pi(x),
\end{gathered}
$$

dengan probabilitas $1-\pi(x)$. Perhatikan bahwa $e$ memiliki distribusi dengan rata-rata (mean) nol, yakni

$$
\begin{gathered}
E(x)=\sum x f(x) \\
=[(1-\pi(x))(\pi(x))]+[(-\pi(x))(1-\pi(x))]
\end{gathered}
$$




$$
\begin{gathered}
=\left[\pi(x)-\pi^{2}(x)\right]+\left[-\pi(x)+\pi^{2}(x)\right] \\
=0
\end{gathered}
$$

dan varians $\pi(x)(1-\pi(x))$, yakni

$$
\begin{gathered}
\operatorname{Var}(x)=E\left(X^{2}\right)-[E(X)]^{2}=\left[\left[(1-\pi(x))^{2}(\pi(x))\right]+\left[(-\pi(x))^{2}(1-\pi(x))\right]\right]-[0]^{2} \\
=\left[\left(1-2 \pi(x)+\pi^{2}(x)\right)(\pi(x))\right]+\left[\pi^{2}(x)-\pi^{3}(x)\right] \\
=\pi(x)-\pi^{2}(x) \\
=\pi(x)[1-\pi(x)] .
\end{gathered}
$$

Perhatikan bahwa distribusi binomial menjelaskan atau menerangkan distribusi error. Hal ini berarti asumsi mengenai distribusi normal dari error tidak dikenakan pada penggunaan regresi logistik biner. Persamaan regresi logistik biner berganda memiliki bentuk umum

$$
\ln \left(\frac{P(y=1)}{1-P(y=1)}\right)=\alpha+\beta_{1} x_{1}+\beta_{2} x_{2}+\cdots+\beta_{k} x_{k},
$$

dan persamaan regresi logistik biner berganda untuk probabilitas terjadinya sukses memiliki bentuk umum

$$
P(y=1)=\frac{e^{\alpha+\beta_{1} x_{1}+\beta_{2} x_{2}+\cdots+\beta_{k} x_{k}}}{1+e^{\alpha+\beta_{1} x_{1}+\beta_{2} x_{2}+\cdots+\beta_{k} x_{k}}} .
$$

\section{Mengukur Kecocokkan Model Regresi Logistik terhadap Data dengan Nagelkerke's $\mathbf{R}_{\mathbf{N}}^{2}$}

Dalam regresi linear, baik sederhana maupun berganda, koefisien determinasi $\left(R^{2}\right)$ digunakan untuk mengukur kemampuan model regresi linear dalam mencocokkan atau menyesuaikan (fits) data. Jika koefisien determinasi dari model regresi linear bernilai 1, maka model tersebut menyesuaikan atau mencocokkan data secara sempurna (Gambar 11.1). Jika koefisien determinasi dari model regresi linear bernilai mendekati 0 , maka model tersebut kurang baik dalam menyesuaikan atau mencocokkan data (Gambar 11.2).

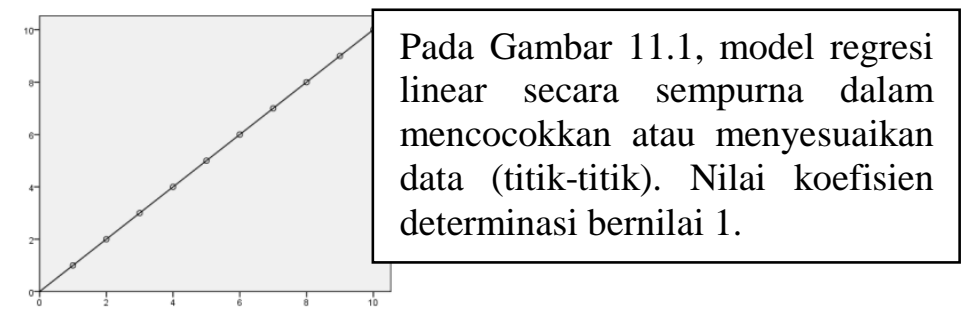

Gambar 11.1 


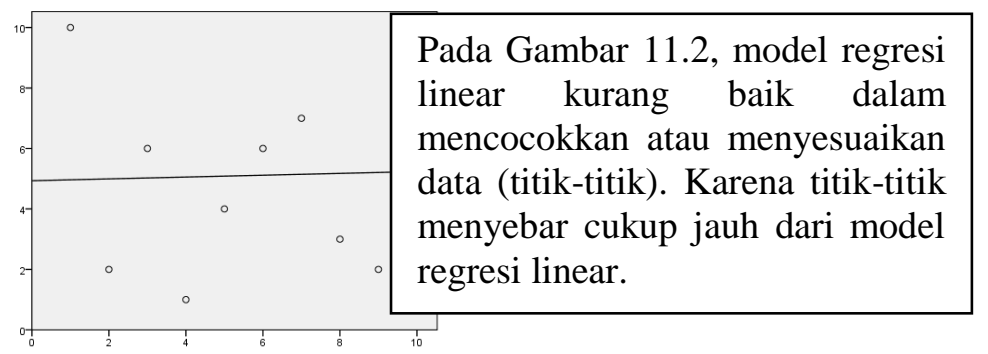

Gambar 11.2

Dalam regresi logistik, dapat digunakan statistik Nagelkerke's $R_{N}^{2}$ untuk mengukur kemampuan model regresi logistik dalam mencocokkan atau menyesuaikan data. Dengan kata lain, nilai statistik dari Nagelkerke's $R_{N}^{2}$ dapat diinterpretasikan sebagai suatu nilai yang mengukur kemampuan variabel-variabel bebas dalam menjelaskan atau menerangkan variation variabel tak bebas. Sebagaimana Hair dkk. (2010:342) menyatakan sebagai berikut.

"Just like its multiple regression counterpart, the logit $R^{2}$ value ranges from 0.0 to 1.0. As the proposed model increases model fit, the -2LL value decrease. A perfect fit has a $-2 L L$ value of 0.0 and $a R_{\text {LOGIT }}^{2}$ of 1 .

Two other measures are similar in design to the pseudo $R^{2}$ value and are generally categorized as pseudo $R^{2}$ measures as well. The Cox and Snell $R^{2}$ measure operates in the same manner, with higher values indicating greater model fit. However, this measure is limited in that it cannot reach the maximum value of 1 , so Nagelkerke proposed a modification that had the range of 0 to 1 . Both of these additional measures are interpreted as reflecting the amount of variation accounted for by the logistic model, with 1.0 indicating perfect model."

Tabel 11.2 menyajikan nilai statistik dari Nagelkerke's $R_{N}^{2}$.

Tabel 11.2

\begin{tabular}{|l|c|c|c|}
\hline \multicolumn{5}{|c|}{ Model Summary } \\
\hline $\begin{array}{l}\text { Kolom Nagelkerke } R \text { Square } \\
\text { menyajikan nilai statistik } \\
\text { dari Nagelkerke's } R_{N}^{2}\end{array}$ & $\begin{array}{c}-2 \mathrm{Log} \\
\text { likelihood }\end{array}$ & $\begin{array}{c}\text { Cox \& Snell R } \\
\text { Square }\end{array}$ & $\begin{array}{c}\text { Nagelkerke R } \\
\text { Square }\end{array}$ \\
\cline { 3 - 5 } & $63.688^{\mathrm{a}}$ & .374 & .500 \\
& & &
\end{tabular}

\section{Menguji Kecocokkan Model Regresí Logístîk terhadap Data dengan -2log-likelihood, Hosmer-Lemeshow, dan Pearson Chi-Square}

Dalam regresi logisitik, hasil selisih statistik -2log-likelihood antara model regresi logistik yang menggunakan satu set variabel bebas dan model yang lebih sederhana (simpler model) dapat digunakan untuk mengetahui apakah model regresi logistik yang menggunakan satu set variabel bebas lebih baik dalam hal mencocokkan atau menyesuaikan data dibandingkan model regresi logistik yang sederhana. Jika statistik -2log-likelihood pada model regresi logistik yang menggunakan satu set variabel bebas lebih kecil dibandingkan model yang lebih sederhana, maka model regresi logistik yang menggunakan satu set variabel bebas lebih baik dalam hal mencocokkan data dibandingkan model yang lebih sederhana tersebut (Hair dkk., 2010:342; Agresti dan Finlay, 2009:499). 
Tabel 11.3 menyajikan nilai statistik dari -2log-likelihood untuk model yang sederhana dan model yang menggunakan satu set variabel bebas.

\section{Tabel 11.3}

Block 0: Beginning Block

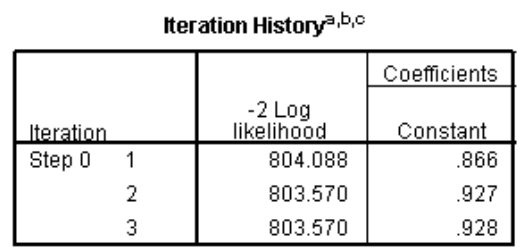

Block 1: Method = Enter

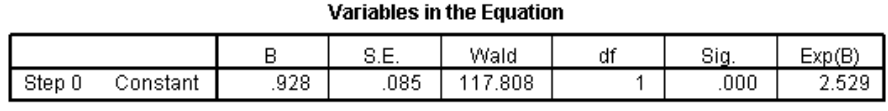

\begin{tabular}{|c|c|c|c|c|c|}
\hline \multicolumn{6}{|c|}{ Variables not in the Equation } \\
\hline & & & Score & df & Sig. \\
\hline \multirow[t]{3}{*}{ Step 0 } & Variables & Korban & 388.807 & 1 & .000 \\
\hline & & Hukuman & 1.469 & 1 & .226 \\
\hline & \multicolumn{2}{|c|}{ Overall Statistics } & 391.236 & 2 & .000 \\
\hline
\end{tabular}

Tabel 11.4

\begin{tabular}{|c|c|c|c|c|c|c|c|c|c|c|c|}
\hline \multirow{2}{*}{ Iteration } & & \multirow{2}{*}{$\begin{array}{l}-2 \log \\
\text { likelihood }\end{array}$} & \multirow{2}{*}{ Constant } & \multicolumn{2}{|l|}{ Coefficients } & \multirow{2}{*}{\multicolumn{6}{|c|}{ Omnibus Tests of Model Coefficients }} \\
\hline & & & & & & & & & & & \\
\hline \multirow[t]{5}{*}{ Step 1} & 1 & 447.908 & -1.588 & 3.261 & -.363 & & & \multicolumn{2}{|c|}{ Chi-square } & $\mathrm{df}$ & Sig. \\
\hline & 2 & 419.251 & -2.066 & 4.312 & -.707 & \multirow[t]{4}{*}{ Step 1} & Step & \multicolumn{2}{|c|}{385.584} & 2 & .000 \\
\hline & 3 & 417.991 & -2.170 & 4.578 & -.856 & & Block & \multicolumn{2}{|c|}{385.584} & 2 & .000 \\
\hline & 4 & 417.986 & -2.175 & 4.595 & -.868 & & Model & \multirow{2}{*}{\multicolumn{2}{|c|}{385.584}} & 2 & .000 \\
\hline & 5 & 417.986 & -2.175 & 4.595 & -.868 & & & & & & \\
\hline & & \multicolumn{8}{|c|}{ Variables in the Equation } & & \\
\hline & & & & $\mathrm{B}$ & S.E. & Wald & $\mathrm{df}$ & Sig. & $\operatorname{Exp}(B)$ & & \\
\hline & & \multirow[t]{3}{*}{ Step $1^{a}$} & Korban & 4.595 & .314 & 214.784 & 1 & .000 & 98.985 & & \\
\hline & & & Hukuman & -.868 & .367 & 5.589 & 1 & .018 & .420 & & \\
\hline & & & Constant & -2.175 & .264 & 67.973 & 1 & .000 & .114 & & \\
\hline
\end{tabular}

Pada Tabel 11.3 untuk Tabel Iteration History, nilai statistik -2log-likelihood pada iterasi ketiga adalah 803,570. Nilai statistik -2log-likelihood tersebut merupakan nilai untuk model sederhana (belum melibatkan variabel bebas, yakni variabel bebas korban dan hukuman). Pada Tabel 11.4 untuk Tabel Iteration History, nilai statistik -2log-likelihood pada iterasi kelima adalah 417,986. Nilai statistik -2log-likelihood tersebut merupakan nilai untuk model regresi logistik yang melibatkan variabel bebas (telah melibatkan variabel bebas korban dan hukuman). Perhatikan bahwa nilai statistik -2log-likelihood pada model regresi logistik yang menggunakan variabel bebas lebih kecil dibandingkan model yang tidak melibatkan variabel bebas, sehingga model regresi logistik yang melibakan variabel bebas lebih baik dalam hal mencocokkan data.

Selanjutnya perhatikan bahwa nilai Chi-square pada Step 1 (Step) untuk Tabel Omnibus Tests of Model Coefficients (Tabel 11.4) diperoleh berdasarkan hasil selisih 803,570$417,986=385,584$. Untuk menguji apakah model regresi logistik yang melibatkan variabel bebas signifikan secara statistika lebih baik dibandingkan model sebelumnya (model sederhana) dalam hal mencocokkan data, maka bandingkan nilai Sig. untuk Step 1 (Step) pada Tabel Omnobus Tests of Model Coefficients, yakni 0,000 terhadap tingkat signifikansi $(\alpha)$. Nilai Sig. disebut juga dengan nilai probabilitas. Jika nilai probabilitas lebih kecil dari tingkat signifikansi, maka disimpulkan bahwa model yang melibatkan variabel bebas signifikan secara statistika lebih baik dalam hal mencocokkan data dibandingkan model sederhana. 
Sementara pada uji Hosmer-Lemeshow menguji signifikansi kecocokkan antara predicted probabilities (nilai probabilitas berdasarkan hasil prediksi) dan observed probabilities (nilai probabilitas pengamatan). Hipotesis nol menyatakan tidak terdapat perbedaan yang signifikan secara statistika antara predicted probabilities dan observed probabilities. Sementara hipotesis alternatif menyatakan terdapat perbedaan yang signifikan secara statistika antara predicted probabilities dan observed probabilities. Diterimanya hipotesis nol dapat diartikan bahwa variabel-variabel bebas yang digunakan dalam model mampu memprediksi dengan baik observed probabilities. Meyers dkk. (2005:240-241) menyatakan sebagai berikut.

"The Hosmer and Lemeshow test is another absolute measure to assess whether the predicted probabilities match the observed probabilities. A researcher is seeking a non significant $p$ value for this test because the goal of the research is to derive a set of independent variables (covariates) that will accurately predict the actual probabilities. Thus, the researcher does not want to reject the null hypothesis. In this example, the goodness-of-fit statistic is 10.161, distributed as a chi-square value, with the $p$ value of 0.180 indicating an acceptable match between predicted and observed probabilities."

Untuk pengambilan keputusan terhadap hipotesis, dapat dilakukan dengan membandingkan nilai statistik dari uji Hosmer-Lemeshow terhadap nilai kritis berdasarkan tabel distribusi chikuadrat. Berikut aturan pengambilan keputusan terhadap hipotesis.

$$
\begin{aligned}
& \text { Jika } \chi_{\text {Hosmer-Lemes how }}^{2} \leq \chi_{\text {kritis }}^{2}, \text { maka } H_{0} \text { diterima dan } H_{1} \text { ditolak. } \\
& \text { Jika } \chi_{\text {Hosmer-Lemes how }}^{2}>\chi_{\text {kritis }}^{2}, \text { maka } H_{0} \text { ditolak dan } H_{1} \text { diterima. }
\end{aligned}
$$

Pada uji Pearson Chi-square menguji signifikansi mengenai kecocokan model regresi logistik terhadap data. Hipotesis nol menyatakan model regresi logistik yang dihasilkan mampu mencocokan data dengan baik (model fits the data well). Sedangkan hipotesis alternatif menyatakan model regresi logistik yang dihasilkan tidak mampu mencocokan data dengan baik (Agresti dan Finlay, 2009:508-509). Agresti dan Finlay (2009:507-508) menyatakan sebagai berikut.

"Two chi-squared statistics, having similar properties, are commonly use to do this, the Pearson statistic

$$
\chi^{2}=\sum \frac{\left(f_{o}-f_{e}\right)^{2}}{f_{e}}
$$

was introduced in Section 8.2 for testing independence. Another statistic, the likelihood-ratio statistic is

$$
G^{2}=2 \sum f_{o} \log \left(\frac{f_{o}}{f_{e}}\right)
$$

It equals the difference between the (-2log l) values for the model being tested and for the most complex model possible. Software for generalized linear models calls this statistic deviance. Both $\chi^{2}$ and $G^{2}$ statistics equal 0 when there is a perfect fit (i.e., all fo=fe). Since large values indicate a poor fit, the P-value for testing a model is the right-tail probability above the observed value." 
Untuk pengambilan keputusan terhadap hipotesis, dapat dilakukan dengan membandingkan nilai statistik dari uji Pearson Chi-square terhadap nilai kritis berdasarkan tabel distribusi chikuadrat. Berikut aturan pengambilan keputusan terhadap hipotesis.

$$
\begin{aligned}
& \text { Jika } \chi_{\text {Pearson Chi-square }}^{2} \leq \chi_{\text {kritis }}^{2}, \text { maka } H_{0} \text { diterima dan } H_{1} \text { ditolak. } \\
& \text { Jika } \chi_{\text {Pearson Chi-square }}^{2}>\chi_{\text {kritis }}^{2}, \text { maka } H_{0} \text { ditolak dan } H_{1} \text { diterima. }
\end{aligned}
$$

Pengambilan keputusan terhadap hipotesis juga dapat dilakukan dengan menggunakan pendekatan nilai probabilitas dari uji Hosmer-Lemeshow/Pearson Chi-square. Nilai probabilitas dari uji Hosmer-Lemeshow/Pearson Chi-square dibandingkan dengan tingkat signifikansi yang digunakan. Berikut aturan pengambilan keputusan terhadap hipotesis berdasarkan pendekatan nilai probabilitas.

Jika nilai probabilitas $\geq$ tingkat signifikansi, maka $H_{0}$ diterima dan $H_{1}$ ditolak. Jika nilai probabilitas < tingkat signifikansi, maka $H_{0}$ ditolak dan $H_{1}$ diterima.

Tabel 11.5 menyajikan nilai statistik dari uji Hosmer-Lemeshow dan Pearson Chi-square. Tabel 11.5 juga menyajikan nilai probabilitas dari uji Hosmer-Lemeshow dan Pearson Chisquare.

\begin{tabular}{|c|c|c|c|c|c|}
\hline \multirow{4}{*}{$\begin{array}{l}\text { Pada Tabel Hosmer and } \\
\text { Lemeshow Test, kolom Chi- } \\
\text { square menyajikan nilai statistik } \\
\text { dari uji Hosmer-Lemeshow. }\end{array}$} & \multicolumn{4}{|c|}{ Hosmer and Lemeshow Test } & \multirow{6}{*}{$\begin{array}{l}\text { Pada Tabel Goodness-of-Fit, } \\
\text { kolom Pearson menyajikan } \\
\text { nilai statistik dari uji Pearson } \\
\text { Chi-square. }\end{array}$} \\
\hline & $e n$ & i-square & df & Sig. & \\
\hline & & .198 & 2 & 906 & \\
\hline & \multicolumn{4}{|c|}{ Goodness-of-fit } & \\
\hline & earson & $\frac{\text { Chi-Square }}{8.967}$ & $\frac{\mathrm{df}}{17}$ & $\frac{\text { Sig. }}{941}$ & \\
\hline & eviance & 11.255 & 17 & .843 & \\
\hline
\end{tabular}

\section{Tabel 11.5}

\section{Uji Sígnífikansi Koefísien Regresi Logístîk Secara Indivídu (Ujî Wald)}

Dalam regresi linear, baik sederhana maupun berganda, uji $t$ digunakan untuk menguji signifikansi dari koefisien regresi populasi $\left(\beta_{i}\right)$ secara individu. Pada regresi logistik, uji signifikansi koefisien regresi populasi secara individu dapat diuji dengan uji Wald. Dalam uji Wald, statistik yang diuji adalah statistik Wald (Wald statistic). Nilai statistik dari uji Wald berdistribusi chi-kuadrat. Hipotesis nol dari uji Wald menyatakan koefisien regresi populasi signifikan secara statistika bernilai nol. Hal ini berarti pengaruh variabel bebas terhadap variabel tak bebas tidak signifikan secara statistika. Hipotesis alternatif menyatakan koefisien regresi populasi signifikan secara statistika berbeda dari nol. Dengan kata lain, pengaruh variabel bebas terhadap variabel tak bebas signifikan secara statistika (Field, 2009:269-270).

Berikut rumus untuk menghitung nilai statistik dari uji Wald.

$$
\text { Statistik Wald }=\frac{\hat{\beta}_{i}}{S_{\widehat{\beta}_{i}}} .
$$

Perhatikan bahwa $s_{\widehat{\beta}_{i}}$ menyatakan standard error dari koefisien regresi $\left(\hat{\beta}_{i}\right)$. Untuk pengambilan keputusan terhadap hipotesis, nilai statistik dari uji Wald dibandingkan dengan 
nilai kritis berdasarkan tabel distribusi chi-kuadrat. Berikut aturan pengambilan keputusan terhadap hipotesis berdasarkan uji Wald.

Jika nilai statistik dari uji Wald $\leq \chi_{\text {kritis }}^{2}, H_{0}$ diterima dan $H_{1}$ ditolak. Jika nilai statistik dari uji Wald $>\chi_{\text {kritis }}^{2}, H_{0}$ ditolak dan $H_{1}$ diterima.

Pengambilan keputusan terhadap hipotesis juga dapat dilakukan dengan menggunakan pendekatan nilai probabilitas dari uji Wald. Berikut aturan pengambilan keputusan berdasarkan pendekatan nilai probabilitas.

Jika nilai probabilitas $\geq$ tingkat signifikansi, $H_{0}$ diterima dan $H_{1}$ ditolak. Jika nilai probabilitas $<$ tingkat signifikansi, $H_{0}$ ditolak dan $H_{1}$ diterima.

Tabel 11.6

\begin{tabular}{|l|r|r|r|r|r|r|}
\multicolumn{7}{|c|}{ Variables in the Equation } \\
\hline Step 1a & \multicolumn{1}{c|}{ B } & \multicolumn{1}{c|}{ S.E. } & Wald & df & Sig. & Exp(B) \\
& & & 6.799 & 3 & .079 & \\
jam(1) & 2.929 & 1.353 & 4.685 & 1 & .030 & 18.718 \\
jam(2) & 3.253 & 1.417 & 5.272 & 1 & .022 & 25.881 \\
jam(3) & 3.476 & 1.586 & 4.804 & 1 & .028 & 32.337 \\
UTS & 1.196 & .593 & 4.062 & 1 & .044 & 3.306 \\
Constant & -8.938 & 3.661 & 5.959 & 1 & .015 & .000 \\
\hline
\end{tabular}

Tabel 11.6 menyajikan nilai statistik dari uji Wald dan nilai probabilitas dari uji Wald. Berdasarkan Tabel 11.6 dapat diperiksa koefisien-koefisien regresi $\left(\beta_{i}\right)$ manakah yang signifikan secara statistika berbeda dari 0 . Untuk menentukan koefisien-koefisien regresi $\left(\beta_{i}\right)$ yang signifikan secara statistika berbeda dari 0 , dapat dilakukan dengan membandingkan nilai Sig. untuk masing-masing koefisien regresi $\left(\hat{\beta}_{i}\right)$ dengan $\alpha=0,05$. Jika nilai Sig. lebih kecil dari 0,05 , maka koefisien regresi $\left(\beta_{i}\right)$ signifikan secara statistika berbeda dari 0. Perhatikan bahwa nilai Sig. untuk jam(1), jam(2), jam(3), dan UTS lebih kecil dari 0,05, maka koefisien-koefisien regresi dari $\mathbf{j a m}(\mathbf{1}), \mathbf{j a m}(\mathbf{2}), \mathbf{j a m}(\mathbf{3})$, dan UTS signifikan secara statistika berbeda dari 0 .

\section{Contoh Kasus dalam Regresi Logístik}

Berikut diberikan contoh kasus yang dapat diselesaikan dengan pendekatan regresi logistik.

[1] Misalkan seorang peneliti bernama Ugi ingin meneliti pengaruh jumlah jam belajar dalam sehari dan hasil ujian tengah semester (UTS) matematika terhadap kelulusan ujian akhir semester (UAS) matematika. Data yang telah dikumpulkan disajikan pada Tabel 11.7.

Berdasarkan data pada Tabel 11.7, untuk variabel Jam, nilai 1 menyatakan seorang mahasiswa menggunakan waktu untuk belajar matematika dalam sehari 4-6 jam, nilai 2 menyatakan 7-9 jam dalam sehari, nilai 3 menyatakan 10-12 jam dalam sehari, dan nilai 4 menyatakan 13-15 jam dalam sehari. Seorang mahasiswa dengan nomor urut 2 menghabiskan waktu untuk belajar matematika dalam sehari 4-6 jam, memperoleh nilai UTS matematika 5, namun tidak lulus UAS matematika. 
Tabel 11.7

\begin{tabular}{|c|c|c|c|c|c|c|c|}
\hline Mahasiswa & Kelulusan & Jam & UTS & Mahasiswa & Kelulusan & Jam & UTS \\
\hline 1 & 0 & 1 & 5 & 11 & 0 & 2 & 5 \\
\hline 2 & 0 & 1 & 5 & 12 & 0 & 2 & 5 \\
\hline 3 & 0 & 1 & 5 & 13 & 0 & 2 & 6 \\
\hline 4 & 0 & 1 & 5 & 14 & 1 & 2 & 6 \\
\hline 5 & 0 & 1 & 5 & 15 & 1 & 2 & 7 \\
\hline 6 & 0 & 1 & 5 & 16 & 1 & 2 & 7 \\
\hline 7 & 0 & 1 & 5 & 17 & 1 & 2 & 7 \\
\hline 8 & 0 & 1 & 6 & 18 & 1 & 2 & 6 \\
\hline 9 & 0 & 1 & 7 & 19 & 1 & 2 & 5 \\
\hline 10 & 1 & 1 & 6 & 20 & 1 & 2 & 5 \\
\hline
\end{tabular}

\begin{tabular}{|c|c|c|c|c|c|c|c|}
\hline Mahasiswa & Kelulusan & Jam & UTS & Mahasiswa & Kelulusan & Jam & UTS \\
\hline 21 & 0 & 3 & 5 & 31 & 0 & 4 & 6 \\
\hline 22 & 0 & 3 & 6 & 32 & 1 & 4 & 5 \\
\hline 23 & 1 & 3 & 5 & 33 & 1 & 4 & 6 \\
\hline 24 & 1 & 3 & 5 & 34 & 1 & 4 & 7 \\
\hline 25 & 1 & 3 & 6 & 35 & 1 & 4 & 7 \\
\hline 26 & 1 & 3 & 6 & 36 & 1 & 4 & 8 \\
\hline 27 & 1 & 3 & 7 & 37 & 1 & 4 & 8 \\
\hline 28 & 1 & 3 & 7 & 38 & 1 & 4 & 8 \\
\hline 29 & 1 & 3 & 8 & 39 & 1 & 4 & 6 \\
\hline 30 & 1 & 3 & 8 & 40 & 1 & 4 & 8 \\
\hline
\end{tabular}

Berikut hal-hal yang ingin diketahui oleh peneliti.

$\Rightarrow$ Peneliti ingin mengestimasi berapa kali lebih mungkin lulus UAS matematika untuk mahasiswa dengan jumlah jam belajar dalam sehari 7-9 jam dibandingkan mahasiswa dengan jumlah jam belajar dalam sehari 4-6 jam (dengan mengontrol pengaruh dari variabel bebas lain dalam model (other variables held constant)) (Gujarati, 606:2003).

$\Rightarrow$ Peneliti ingin mengestimasi berapa kali lebih mungkin lulus UAS matematika untuk mahasiswa dengan jumlah jam belajar dalam sehari 10-12 jam dibandingkan mahasiswa dengan jumlah jam belajar dalam sehari 4-6 jam (dengan mengontrol pengaruh dari variabel bebas lain).

$\Rightarrow$ Peneliti ingin mengestimasi berapa kali lebih mungkin lulus UAS matematika untuk mahasiswa dengan jumlah jam belajar dalam sehari 13-15 jam dibandingkan mahasiswa dengan jumlah jam belajar dalam sehari 4-6 jam.

$\Rightarrow$ Peneliti ingin mengestimasi probabilitas mahasiswa untuk lulus UAS matematika ketika mahasiswa tersebut menghabiskan waktu untuk belajar 4-6 jam dalam sehari dan memperoleh nilai UTS matematika 5.

$\Rightarrow$ Peneliti ingin mengestimasi probabilitas mahasiswa untuk lulus UAS matematika ketika mahasiswa tersebut menghabiskan waktu untuk belajar 7-9 jam dalam sehari dan memperoleh nilai UTS matematika 5. 
$\Rightarrow$ Peneliti ingin mengestimasi probabilitas mahasiswa untuk lulus UAS matematika ketika seorang mahasiswa menghabiskan waktu untuk belajar 10-12 jam dalam sehari dan memperoleh nilai UTS 7.

$\Rightarrow$ Peneliti ingin mengestimasi berapa kali lebih mungkin mahasiswa dengan nilai UTS matematika 7 untuk lulus UAS matematika dibandingkan mahasiswa dengan nilai UTS matematika 6 (dengan mengontrol pengaruh dari variabel bebas lain), berapa kali lebih mungkin mahasiswa dengan nilai UTS matematika 8 untuk lulus UAS matematika dibandingkan mahasiswa dengan nilai UTS. Dengan kata lain, mengestimasi berapa kali lebih mungkin seorang mahasiswa dengan nilai UTS matematika 1 satuan lebih tinggi untuk lulus UAS matematika dibandingkan mahasiswa dengan nilai UTS 1 satuan lebih rendah.

[2] Misalkan seorang mahasiswa kedokteran yang sedang menyusun tugas akhir akan meneliti pengaruh jenis kelamin dan orang yang hobi bermain game online terhadap insomnia (gangguan tidur). Berikut hal-hal yang akan diteliti oleh mahasiswa tersebut.

$\Rightarrow$ Mengukur seberapa besar faktor jenis kelamin dan bermain game online secara simultan/bersamaan menjelaskan variation dari kejadian insomnia.

$\Rightarrow$ Peneliti ingin mengestimasi berapa kali lebih mungkin terkena gejala insomnia untuk jenis kelamin pria dibandingkan jenis kelamin wanita (dengan mengontrol pengaruh dari variabel bebas lain, yakni game online).

$\Rightarrow$ Peneliti ingin mengestimasi berapa kali lebih mungkin terkena gejala insomnia untuk seseorang yang hobi bermain game online dibandingkan seseorang yang tidak hobi bermain game online.

Gambar 11.3 merupakan data yang telah dikumpulkan oleh mahasiswa tersebut. Berdasarkan data pada Gambar 11.3, jumlah responden yang diteliti sebanyak 40 responden. Variabel insomnia memiliki dua nilai, yakni 0 dan 1 . Nilai 0 menyatakan responden tidak mengalami gejala insomnia, sedangkan nilai 1 menyatakan responden mengalami gejala insomnia. Pada variabel jenis kelamin juga terdapat dua nilai, yakni 0 dan 1 . Nilai 0 menyatakan responden berjenis kelamin wanita, sedangkan nilai 1 menyatakan responden berjenis kelamin pria. Variabel game memiliki dua nilai, yakni 0 dan 1 . Nilai 0 menyatakan respoden tidak hobi bermain game online, sedangkan nilai 1 menyatakan responden hobi bermain game online. Berdasarkan data pada Gambar 11.3, responden nomor 1 hobi bermain game online, berjenis kelamin wanita dan mengalami gejala insomnia. Responden nomor 11 hobi bermain game online, berjenis kelamin pria, dan mengalami gejala insomnia.

\begin{tabular}{|c|c|c|c|c|c|c|c|c|c|c|c|}
\hline & insomnia & jenis_kelamin & game & & insomnia & jenis_kelamin & game & & & & \\
\hline 1 & 1 & 0 & 1 & 18 & 1 & 1 & 0 & & & & \\
\hline 2 & 1 & 0 & 1 & 19 & 1 & 1 & 0 & & & & \\
\hline 3 & 1 & 0[ & 1 & 20 & 1 & 1 & 0 & & & & \\
\hline 4 & 1 & 0 & 1 & 21 & 0 & 1 & 0 & & & & \\
\hline 5 & 1 & 0 & 0 & 22 & 0 & 1 & 0 & & & & \\
\hline 6 & 1 & 0 & 0 & 23 & 0 & 1 & 0 & & & & \\
\hline 7 & 1 & 0 & 0 & 24 & 0 & 1 & 1 & & & & \\
\hline 8 & 1 & 0 & 1 & 25 & 0 & 1 & 0 & & & & \\
\hline 9 & 1 & 0 & 1 & 26 & 0 & 0 & $\begin{array}{l}0 \\
0\end{array}$ & 35 & 0 & 0 & 0 \\
\hline 10 & $\begin{array}{l}1 \\
1\end{array}$ & $\begin{array}{l}0 \\
1\end{array}$ & $\begin{array}{l}1 \\
1\end{array}$ & $\begin{array}{l}27 \\
28\end{array}$ & $\begin{array}{l}0 \\
0\end{array}$ & $\begin{array}{l}0 \\
0\end{array}$ & $\begin{array}{l}0 \\
0\end{array}$ & 36 & 0 & 0 & 1 \\
\hline $\begin{array}{l}11 \\
12\end{array}$ & 1 & 1 & 1 & 29 & 0 & 0 & 0 & 37 & 0 & 0 & 1 \\
\hline 13 & 1 & 1 & 1 & 30 & 0 & 0 & 0 & & 0 & 0 & \\
\hline 14 & 1 & 1 & 1 & 31 & 0 & 0 & 0 & 36 & & & 1 \\
\hline 15 & 1 & 1 & 1 & 32 & 0 & 0 & 0 & 39 & 0 & 0 & 1 \\
\hline 16 & 1 & 1 & 1 & 33 & 0 & 0 & 0 & 40 & 0 & 0 & 1 \\
\hline 17 & 1 & 1 & 0 & 34 & 0 & 0 & 0 & & & & \\
\hline
\end{tabular}

Gambar 11.3 
Misalkan seorang peneliti bernama Ugi ingin meneliti pengaruh jumlah jam belajar dalam sehari dan hasil ujian tengah semester (UTS) matematika terhadap kelulusan dari ujian akhir semester (UAS) matematika. Berikut data yang telah dikumpulkan oleh peneliti tersebut.

Tabel 11.1

\begin{tabular}{|c|c|c|c|c|c|c|c|}
\hline Mahasiswa & Kelulusan & Jam & UTS & Mahasiswa & Kelulusan & Jam & UTS \\
\hline 1 & 0 & 1 & 5 & 11 & 0 & 2 & 5 \\
\hline 2 & 0 & 1 & 5 & 12 & 0 & 2 & 5 \\
\hline 3 & 0 & 1 & 5 & 13 & 0 & 2 & 6 \\
\hline 4 & 0 & 1 & 5 & 14 & 1 & 2 & 6 \\
\hline 5 & 0 & 1 & 5 & 15 & 1 & 2 & 7 \\
\hline 6 & 0 & 1 & 5 & 16 & 1 & 2 & 7 \\
\hline 7 & 0 & 1 & 5 & 17 & 1 & 2 & 7 \\
\hline 8 & 0 & 1 & 6 & 18 & 1 & 2 & 6 \\
\hline 9 & 0 & 1 & 7 & 19 & 1 & 2 & 5 \\
\hline 10 & 1 & 1 & 6 & 20 & 1 & 2 & 5 \\
\hline
\end{tabular}

\begin{tabular}{|c|c|c|c|c|c|c|c|}
\hline Mahasiswa & Kelulusan & Jam & UTS & Mahasiswa & Kelulusan & Jam & UTS \\
\hline 21 & 0 & 3 & 5 & 31 & 0 & 4 & 6 \\
\hline 22 & 0 & 3 & 6 & 32 & 1 & 4 & 5 \\
\hline 23 & 1 & 3 & 5 & 33 & 1 & 4 & 6 \\
\hline 24 & 1 & 3 & 5 & 34 & 1 & 4 & 7 \\
\hline 25 & 1 & 3 & 6 & 35 & 1 & 4 & 7 \\
\hline 26 & 1 & 3 & 6 & 36 & 1 & 4 & 8 \\
\hline 27 & 1 & 3 & 7 & 37 & 1 & 4 & 8 \\
\hline 28 & 1 & 3 & 7 & 38 & 1 & 4 & 8 \\
\hline 29 & 1 & 3 & 8 & 39 & 1 & 4 & 6 \\
\hline 30 & 1 & 3 & 8 & 40 & 1 & 4 & 8 \\
\hline
\end{tabular}

Berdasarkan data pada Tabel 11.1, untuk variabel Jam, nilai 1 menyatatakan seorang mahasiswa menggunakan waktu untuk belajar matematika dalam sehari 4-6 jam, nilai 2 menyatakan 7-9 jam dalam sehari, nilai 3 menyatakan 10-12 jam dalam sehari, dan nilai 4 menyatakan 13-15 jam dalam sehari. Seorang mahasiswa dengan nomor urut 2 menghabiskan waktu untuk belajar dalam sehari 4-6 jam, memperoleh nilai UTS matematika 5, namun tidak lulus UAS matematika.

Berikut hal-hal yang ingin diketahui oleh peneliti.

$\Rightarrow$ Peneliti ingin mengestimasi berapa kali lebih mungkin lulus UAS matematika untuk mahasiswa dengan jumlah jam belajar dalam sehari 7-9 jam dibandingkan mahasiswa dengan jumlah jam belajar dalam sehari 4-6 jam (dengan mengontrol pengaruh dari variabel bebas lain dalam model). 
$\Rightarrow$ Peneliti ingin mengestimasi berapa kali lebih mungkin lulus UAS matematika untuk mahasiswa dengan jumlah jam belajar dalam sehari 10-12 jam dibandingkan mahasiswa dengan jumlah jam belajar dalam sehari 4-6 jam.

$\Rightarrow$ Peneliti ingin mengestimasi berapa kali lebih mungkin lulus UAS matematika untuk mahasiswa dengan jumlah jam belajar dalam sehari 13-15 jam dibandingkan mahasiswa dengan jumlah jam belajar dalam sehari 4-6 jam.

$\Rightarrow$ Peneliti ingin mengestimasi probabilitas mahasiswa untuk lulus UAS matematika ketika mahasiswa tersebut menghabiskan waktu untuk belajar 4-6 jam dalam sehari dan memperoleh nilai UTS matematika 5.

$\Rightarrow$ Peneliti ingin mengestimasi probabilitas mahasiswa untuk lulus UAS matematika ketika mahasiswa tersebut menghabiskan waktu untuk belajar 7-9 jam dalam sehari dan memperoleh nilai UTS matematika 5.

$\Rightarrow$ Peneliti ingin mengestimasi kemungkinan mahasiswa untuk lulus UAS matematika ketika seorang mahasiswa menghabiskan waktu untuk belajar 10-12 jam dalam sehari dan memperoleh nilai UTS 7.

$\Rightarrow$ Peneliti ingin mengestimasi berapa kali lebih mungkin mahasiswa dengan nilai UTS matematika 7 untuk lulus UAS matematika dibandingkan mahasiswa dengan nilai UTS matematika 6. Berapa kali lebih mungkin mahasiswa dengan nilai UTS matematika 8 untuk lulus UAS matematika dibandingkan mahasiswa dengan nilai UTS 7. Dengan kata lain, mengestimasi berapa kali lebih mungkin seorang mahasiswa dengan nilai UTS matematika 1 satuan lebih tinggi untuk lulus UAS matematika dibandingkan mahasiswa dengan nilai UTS 1 satuan lebih rendah.

Bangun data pada Tabel 11.1 dalam SPSS (Gambar 11.1). Untuk variabel kelulusan, beri Value 1 untuk Label lulus dan Value 0 untuk Label tidak lulus. Pada variabel jam beri Value 1 untuk Label 4-6 jam, Value 2 untuk Label 7-9 jam, Value 3 untuk Label 10-12 jam, dan Value 4 untuk Label 13-15 jam. Selanjutnya pilih Analyze $\Rightarrow>$ Regression $=>$ Binary Logistic, sehingga muncul kotak dialog Logistic Regression (Gambar 11.2). Pada kotak dialog Logistics Regression, masukkan variabel kelulusan pada kotak Dependent, serta masukkan variabel jam dan UTS pada kotak Covariates (Gambar 11.2).

Kemudian pilih Categorical, sehingga muncul kotak dialog Logistic Regression: Define Categorical Variables (Gambar 11.3). Masukkan variabel jam pada kotak Categorical Covariates. Kemudian pilih First pada Reference Category dan pilih Change. Sehingga berubah menjadi jam(Indicator(first))). Hal ini berarti pada variabel jam untuk kategori 4-6 jam (Value 1) menjadi baseline category. Selanjutnya pilih Continue. Pilih Options, sehingga muncul kotak dialog Logistic Regression: Options (Gambar 11.4). Pada kotak dialog Logistic Regression: Options, pilih Hosmer-Lemeshow goodness-of-fit dan Iteration history. Kemudian pilih Continue dan OK. 


\begin{tabular}{|r|r|r|r|}
\hline \multicolumn{1}{|c|}{} & kelulusan & jam & UTS \\
\hline 1 & 0 & 1 & 5.00 \\
\hline 2 & 0 & 1 & 5.00 \\
\hline 3 & 0 & 1 & 5.00 \\
\hline 4 & 0 & 1 & 5.00 \\
\hline 5 & 0 & 1 & 5.00 \\
\hline 6 & 0 & 1 & 5.00 \\
\hline 7 & 0 & 1 & 5.00 \\
\hline 8 & 0 & 1 & 6.00 \\
\hline 9 & 0 & 1 & 7.00 \\
\hline 10 & 1 & 1 & 6.00 \\
\hline 11 & 0 & 2 & 5.00 \\
\hline 12 & 0 & 2 & 5.00 \\
\hline 13 & 0 & 2 & 6.00 \\
\hline 14 & 1 & 2 & 6.00 \\
\hline 15 & 1 & 2 & 7.00 \\
\hline 16 & 1 & 2 & 7.00 \\
\hline 17 & 1 & 2 & 7.00 \\
\hline
\end{tabular}

\begin{tabular}{|r|r|r|r|r|}
\hline & kelulusan & jam & UTS & \\
\hline \hline 18 & 1 & 2 & 6.00 \\
\hline 19 & 1 & 2 & 5.00 \\
\hline 20 & 1 & 2 & 5.00 \\
\hline 21 & 0 & 3 & 5.00 \\
\hline 22 & 0 & 3 & 6.00 \\
\hline 23 & 1 & 3 & 5.00 \\
\hline 24 & 1 & 3 & 5.00 \\
\hline 25 & 1 & 3 & 6.00 \\
\hline 26 & 1 & 3 & 6.00 \\
\hline 27 & 1 & 3 & 7.00 \\
\hline 28 & 1 & 3 & 7.00 \\
\hline 29 & 1 & 3 & 8.00 \\
\hline 30 & 1 & 3 & 8.00 \\
\hline 31 & 0 & 4 & 6.00 \\
\hline 32 & 1 & 4 & 5.00 \\
\hline 33 & 1 & 4 & 6.00 \\
\hline 34 & 1 & 4 & 7.00 \\
\hline
\end{tabular}

\begin{tabular}{|l|}
\hline 35 \\
\hline 36 \\
\hline 37 \\
\hline 38 \\
\hline 39 \\
\hline 40 \\
\hline 41 \\
\hline
\end{tabular}

7.00

8.00

8.00

6.00

8.00

\begin{tabular}{|c|c|c|c|c|c|c|}
\hline & Name & Type & Width & Decimals & Label & Values \\
\hline 1 & kelulusan & Numeric & 8 & 0 & & $\{0$, tidak lulu... \\
\hline 2 & jam & Numeric & 8 & 0 & jumlah jam bela... & $\{1,4-6$ jam $\} \ldots$ \\
\hline 3 & UTS & Numeric & 8 & 2 & nilai ujian tenga... & None \\
\hline
\end{tabular}

Gambar 11.1

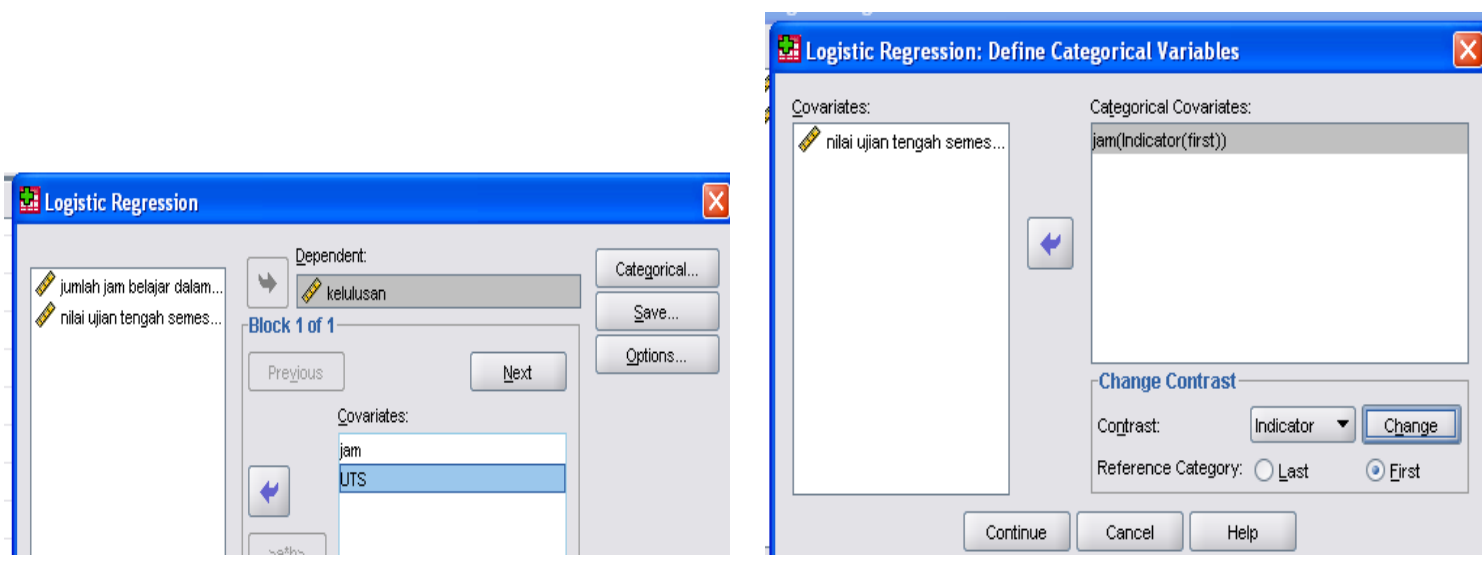

Gambar 11.2

Gambar 11.3

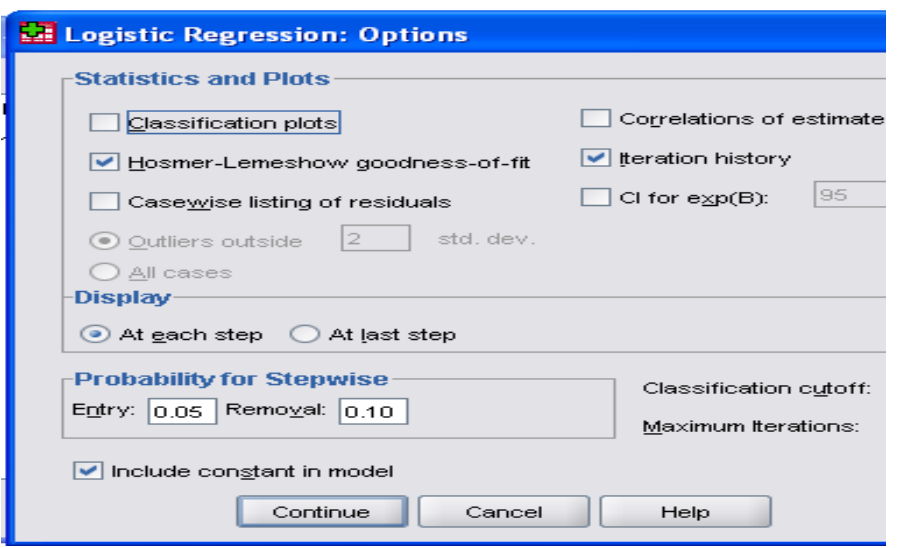

Gambar 11.4 
Berikut hasil berdasarkan perhitungan SPSS.

Tabel 11.2

Categorical Variables Codings
\begin{tabular}{|l|r|r|r|r|r|}
\hline & & \multicolumn{3}{|c|}{ Parameter coding } \\
\cline { 4 - 6 } & & Frequency & \multicolumn{1}{c|}{$(1)$} & \multicolumn{1}{c|}{$(2)$} & \multicolumn{1}{c|}{$(3)$} \\
\hline jumlah jam belajar dalam & $4-6$ jam & 10 & .000 & .000 & 000 \\
Sehari & 10 & 1.000 & .000 & .000 \\
& $7-9$ jam & 10 & .000 & 1.000 & .000 \\
& $10-12$ jam & 10 & .000 & .000 & 1.000 \\
& $13-15$ jam & 10 & .000 &
\end{tabular}

Berdasarkan Tabel 11.2, pada variabel jam untuk kategori 4-6 jam merupakan baseline category. Hal ini dapat dilihat dari nilai Parameter coding (1), (2), dan (3) bernilai 0. Jumlah mahasiswa yang menghabiskan waktu untuk belajar matematika 4-6 jam dalam sehari sebanyak 10 mahasiswa, begitu juga untuk 7-8 jam, 10-12 jam, dan 13-15 jam.

Tabel 11.3

\begin{tabular}{|c|c|c|c|c|c|c|}
\hline \multicolumn{7}{|c|}{ Variables in the Equation } \\
\hline & $\mathrm{B}$ & S.E. & Wald & df & Sig. & $\operatorname{Exp}(B)$ \\
\hline $\begin{array}{ll}\text { Step 0 } & \text { Constant }\end{array}$ & .511 & .327 & 2.446 & 1 & .118 & 1.667 \\
\hline
\end{tabular}

Block 0: Beginning Block

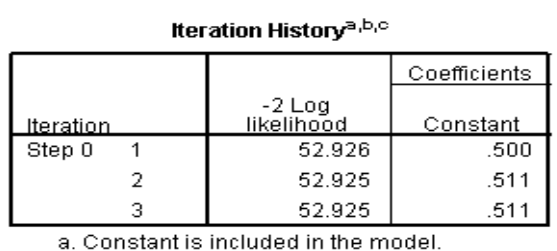

\begin{tabular}{|c|c|c|c|c|c|}
\hline \multicolumn{6}{|c|}{ Variables not in the Equation } \\
\hline & & & Score & $\mathrm{df}$ & Sig. \\
\hline \multirow[t]{6}{*}{ Step 0} & Variables & jam & 16.533 & 3 & .001 \\
\hline & & $\operatorname{jam}(1)$ & .320 & 1 & .572 \\
\hline & & $\operatorname{jam}(2)$ & 1.742 & 1 & .187 \\
\hline & & jam(3) & 4.302 & 1 & .038 \\
\hline & & UTS & 10.881 & 1 & .001 \\
\hline & Overall $\mathrm{St}$ & stics & 19.399 & 4 & .001 \\
\hline
\end{tabular}

Tabel 11.4

Block 1: Method = Enter

\begin{tabular}{|c|c|c|c|c|c|c|}
\hline \multicolumn{7}{|c|}{ Iteration History ${ }^{\mathrm{a}, \mathrm{b}, \mathrm{c}, \mathrm{d}}$} \\
\hline \multirow[b]{2}{*}{ Iteration } & \multirow[b]{2}{*}{$\begin{array}{l}-2 \log \\
\text { likelihood }\end{array}$} & \multicolumn{5}{|c|}{ Coefficients } \\
\hline & & Constant & jam(1) & $\operatorname{jam}(2)$ & $\operatorname{jam}(3)$ & UTS \\
\hline Step 1 & 32.491 & -4.623 & 2.120 & 2.296 & 2.360 & .560 \\
\hline & 30.248 & -7.385 & 2.662 & 2.940 & 3.091 & .961 \\
\hline & 29.991 & -8.697 & 2.887 & 3.205 & 3.416 & 1.159 \\
\hline & 29.985 & -8.931 & 2.928 & 3.252 & 3.475 & 1.195 \\
\hline & 29.985 & -8.938 & 2.929 & 3.253 & 3.476 & 1.196 \\
\hline & 29.985 & -8.938 & 2.929 & 3.253 & 3.476 & 1.196 \\
\hline
\end{tabular}

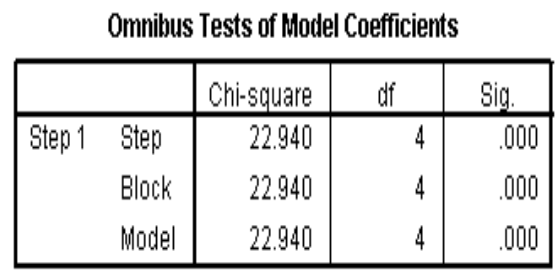

Berdasarkan Tabel 11.3, yakni pada Iteration History, untuk Step 0 iterasi ketiga, nilai 52,925 merupakan nilai statistik -2 log-likelihood tanpa melibatkan variabel bebas jam dan UTS. Kemudian pada Tabel 11.4, yakni pada Iteration History, untuk Step 1 iterasi keenam, nilai 29,985 merupakan nilai statistik -2 log-likelihood yang melibatkan variabel bebas jam dan UTS. Perhatikan bahwa nilai statistik -2log-likelihood pada model regresi logistik yang menggunakan variabel bebas jam dan UTS lebih kecil dibandingkan model yang tidak melibatkan variabel bebas, sehingga model regresi logistik yang melibakan variabel bebas jam dan UTS lebih baik dalam hal mencocokkan data dibandingkan model regresi tanpa melibatkan melibatkan variabel bebas. 
Perhatikan bahwa pada Tabel Omnibus Tests of Model Coefficients (Tabel 11.4), nilai Chisquare pada Step 1 (Step) diperoleh berdasarkan hasil selisih 52,925-29,985=22,94. Hasil selisih tersebut berdistribusi chi-kuadrat. Untuk menguji apakah model regresi logistik yang melibatkan variabel bebas jam dan UTS signifikan secara statistika lebih baik/akurat dalam hal mencocokkan data dibandingkan model sebelumnya (tanpa melibatkan variabel bebas), maka bandingkan nilai Sig. pada Tabel Omnibus Tests of Model Coefficients untuk Step 1 (Step), yakni 0,000 terhadap tingkat signifikansi. Dalam kasus ini, tingkat signifikansi yang digunakan adalah 0,05. Nilai Sig. disebut juga dengan nilai probabilitas ( $p$-value). Perhatikan bahwa karena nilai probabilitas lebih kecil dari tingkat signifikansi, maka disimpulkan bahwa model yang melibatkan variabel bebas jam dan UTS signifikan secara statistika lebih baik/akurat dalam hal mencocokkan data dibandingkan model tanpa melibatkan variabel bebas.

Cara lain adalah dengan membandingkan nilai Chi-square pada Step 1 (Step), yakni 22,940 dengan nilai kritis yang diperoleh berdasarkan tabel distribusi chi-kuadrat $\chi_{\text {kritis }}^{2}$. Diketahui nilai derajat bebas (degree of freedom) 4. Nilai $\chi_{\text {kritis }}^{2}$ dengan derajat bebas 4 dan tingkat signifikansi 0,05 adalah 9,488.

Tabel 11.5

\begin{tabular}{|c|c|c|c|c|}
\hline \multirow{2}{*}{ derajat bebas } & \multicolumn{4}{|c|}{ luas sisi kanan } \\
\hline & 0.1 & 0,05 & 0.02 & 0.01 \\
\hline 1 & 2.706 & 3. 41 & 5.412 & 6.635 \\
\hline 2 & 4.605 & 5.91 & 7.824 & 9.210 \\
\hline 3 & 6.251 & 7.15 & 9.837 & 11.345 \\
\hline 4 & 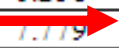 & 9.488 & 11.668 & 13.277 \\
\hline 5 & 9.236 & 11.070 & 13.388 & 15.086 \\
\hline 6 & 10.645 & 12.592 & 15.033 & 16.812 \\
\hline 7 & 12.017 & 14.067 & 16.622 & 18.475 \\
\hline 8 & 13.362 & 15.507 & 18.168 & 20.090 \\
\hline 9 & 14.684 & 16.919 & 19.679 & 21.666 \\
\hline 10 & 15.987 & 18.307 & 21.161 & 23.209 \\
\hline
\end{tabular}

Jika nilai Chi-square pada Step 1 (Step) $\leq \chi_{\text {kritis }}^{2}$, maka disimpulkan bahwa model yang melibatkan variabel bebas jam dan UTS signifikan secara statistika tidak lebih baik dalam hal mencocokkan data dibandingkan model tanpa melibatkan variabel bebas. Jika nilai Chisquare pada Step 1 (Step) $>\chi_{\text {kritis }}^{2}$, maka disimpulkan bahwa model yang melibatkan variabel bebas jam dan UTS signifikan secara statistika lebih baik dalam hal mencocokkan data dibandingkan model tanpa melibatkan variabel bebas. Perhatikan bahwa karena nilai Chi-square pada Step 1 (Step) $>\chi_{\text {kritis }}^{2}$, yakni 22,940 > 9,488, maka disimpulkan bahwa model yang melibatkan variabel bebas jam dan UTS signifikan secara statistika lebih baik dalam hal mencocokkan data dibandingkan model tanpa melibatkan variabel bebas.

\section{Tabel 11.6}

\begin{tabular}{|l|c|c|c|}
\multicolumn{4}{|c|}{ Model Summary } \\
\hline Sten & $\begin{array}{c}-2 \text { Log } \\
\text { likelihood }\end{array}$ & $\begin{array}{c}\text { Cox \& Snell R } \\
\text { Square }\end{array}$ & $\begin{array}{c}\text { Nagelkerke R } \\
\text { Square }\end{array}$ \\
\hline 1 & $29.985^{\mathrm{a}}$ & .436 & .595 \\
\hline
\end{tabular}

Nilai statistik Nagelkerke's $R_{N}^{2}$ berfungsi untuk mengukur kemampuan model regresi logistik dalam mencocokkan atau menyesuaikan (fits) data. Dengan kata lain, statistik Nagelkerke's $R_{N}^{2}$ dapat diinterpretasikan sebagai kemampuan variabel-variabel bebas dalam menjelaskan atau menerangkan variation variabel tak bebas. Berikut disajikan output SPSS yang menunjukkan nilai statistik Nagelkerke's $R_{N}^{2}$ (Tabel 11.6). Berdasarkan Tabel 11.6, nilai 
statistik Nagelkerke $R$ Square 0,595. Nilai tersebut diinterpretasikan sebagai kemampuan variabel bebas jam dan UTS untuk menjelaskan variation variabel tak bebas, yakni kelulusan sebesar 59,5\%, sisanya 40,5\% dijelaskan oleh variabel-variabel/faktor-faktor lain.

Tabel 11.7

Hosmer and Lemeshow Test

\begin{tabular}{|l|r|r|r|}
\hline Sten & Chi-square & df & Sig. \\
\hline 1 & 3.026 & 8 & .933 \\
\hline
\end{tabular}

Sementara pada uji Hosmer-Lemeshow menguji signifikansi kecocokkan antara predicted probabilities (nilai probabilitas berdasarkan hasil prediksi) dan observed probabilities (nilai probabilitas pengamatan). Hipotesis nol menyatakan tidak terdapat perbedaan yang signifikan secara statistika antara predicted probabilities dan observed probabilities. Sementara hipotesis alternatif menyatakan terdapat perbedaan yang signifikan secara statistika antara predicted probabilities dan observed probabilities. Diterimanya hipotesis nol dapat diartikan bahwa variabel-variabel bebas yang digunakan dalam model mampu memprediksi dengan baik observed probabilities. Berdasarkan Tabel 11.7, diketahui nilai Sig. atau probabilitas 0,933. Perhatikan bahwa karena nilai probabilitas, yakni 0,933 lebih besar dibandingkan tingkat signifikansi, yakni 0,05, maka hipotesis nol diterima, dan hipotesis alternatif ditolak. Hal ini berarti variabel-variabel bebas Jam dan UTS mampu memprediksi dengan baik observed probabilities dari Kelulusan.

Berdasarkan Tabel 11.8 dapat diperiksa koefisien-koefisien regresi $(\beta)$ manakah yang signifikan secara statistika berbeda dari 0. Untuk menentukan koefisien-koefisien regresi manakah yang signifikan secara statistika berbeda dari 0, dapat dilakukan dengan membandingkan nilai Sig. untuk masing-masing koefisien regresi dengan 0,05. Jika nilai Sig. lebih kecil dari 0,05, maka koefisien regresi $(\beta)$ signifikan secara statistika berbeda dari 0 . Perhatikan bahwa nilai Sig. untuk jam(1), jam(2), jam(3), dan UTS lebih kecil dari 0,05, maka koefisien-koefisien regresi dari jam(1), jam(2), jam(3), dan UTS signifikan secara statistika berbeda dari 0 .

Tabel 11. 8

\begin{tabular}{|c|r|r|r|r|r|r|}
\multicolumn{7}{|c|}{ Variables in the Equation } \\
\hline Step 1a & \multicolumn{1}{|c|}{ B } & \multicolumn{1}{c|}{ S.E. } & Wald & df & Sig. & Exp(B) \\
& & & 6.799 & 3 & .079 & \\
jam(1) & 2.929 & 1.353 & 4.685 & 1 & .030 & 18.718 \\
jam(2) & 3.253 & 1.417 & 5.272 & 1 & .022 & 25.881 \\
jam(3) & 3.476 & 1.586 & 4.804 & 1 & .028 & 32.337 \\
UTS & 1.196 & .593 & 4.062 & 1 & .044 & 3.306 \\
Constant & -8.938 & 3.661 & 5.959 & 1 & .015 & .000 \\
\hline
\end{tabular}

Selanjutnya akan dilakukan interpretasi untuk masing-masing koefisien regresi yang signifikan secara statistika berbeda dari nol.

$\Rightarrow$ Diketahui nilai $\operatorname{Exp}(\hat{\beta})$ untuk jam(1) adalah 18,718. Nilai tersebut diinterpretasikan mahasiswa dengan jumlah jam belajar dalam sehari 7-9 jam, diperkirakan berpeluang untuk lulus UAS matematika 18,718 kali lebih mungkin dibandingkan mahasiswa dengan jumlah jam belajar dalam sehari 4-6 jam. 
$\Rightarrow$ Diketahui nilai $\operatorname{Exp}(\hat{\beta})$ untuk jam(2) adalah 25,881. Nilai tersebut diinterpretasikan mahasiswa dengan jumlah jam belajar dalam sehari 10-12 jam, diperkirakan berpeluang untuk lulus UAS matematika 25,881 kali lebih mungkin dibandingkan mahasiswa dengan jumlah jam belajar dalam sehari 4-6 jam.

$\Rightarrow$ Diketahui nilai $\operatorname{Exp}(\hat{\beta})$ untuk jam(3) adalah 32,337. Nilai tersebut diinterpretasikan mahasiswa dengan jumlah jam belajar dalam sehari 13-15 jam, diperkirakan berpeluang untuk lulus UAS matematika 32,337 kali lebih mungkin dibandingkan mahasiswa dengan jumlah jam belajar dalam sehari 4-6 jam.

$\Rightarrow$ Diketahui nilai $\operatorname{Exp}(\hat{\beta})$ untuk UTS adalah 3,306. Mahasiswa dengan nilai UTS matematika 1 satuan lebih tinggi diperkirakan berpeluang untuk lulus UAS matematika 3,306 kali lebih mungkin dibandingkan mahasiswa dengan nilai UTS 1 satuan lebih rendah. Sebagai contoh mahasiswa dengan nilai UTS matematika 7 diperkirakan berpeluang untuk lulus UAS matematika 3,306 kali lebih mungkin dibandingkan mahasiswa dengan nilai UTS matematika 6. Begitu juga mahasiswa dengan nilai UTS matematika 8 diperkirakan berpeluang untuk lulus UAS matematika 3,306 kali lebih mungkin dibandingkan mahasiswa dengan nilai UTS 7.

Berdasarkan Tabel 11.8, dapat ditentukan persamaan regresi logistik untuk menentukan estimasi probabilitas/kemungkinan kelulusan UAS matematika dari mahasiswa sebagai berikut.

$$
\hat{P}(\boldsymbol{y}=\mathbf{1})=\frac{e^{-8,938+2,929 j a m(1)+3,253 \text { jam (2)+3,476 jam (3)+1,196UTS }}}{1+e^{-8,938+2,929 j a m(1)+3,253 \text { jam (2)+3,476jam (3)+1,196UTS }}}
$$

$\Rightarrow$ Estimasi probabilitas mahasiswa untuk lulus UAS matematika ketika menghabiskan waktu untuk belajar 4-6 jam dalam sehari dan memperoleh nilai UTS matematika 5 adalah

$$
\hat{P}(\boldsymbol{y}=\mathbf{1})=\frac{e^{-8,938+1,196(5)}}{1+e^{-8,938+1,196(5)}}=\frac{0,051922658}{1+0,051922658}=0,049 .
$$

$\Rightarrow$ Estimasi probabilitas mahasiswa untuk lulus UAS matematika ketika menghabiskan waktu untuk belajar 7-9 jam dalam sehari dan memperoleh nilai UTS matematika 5 adalah

$$
\hat{P}(\boldsymbol{y}=\mathbf{1})=\frac{e^{-8,938+2,929 \mathrm{jam}(1)+1,196(5)}}{1+e^{-8,938+2,929 j a m(1)+1,196(5)}}=\frac{0,971416464}{1+0,971416464}=0,49 .
$$

$\Rightarrow$ Estimasi probabilitas mahasiswa untuk lulus UAS matematika ketika menghabiskan waktu untuk belajar 10-12 jam dalam sehari dan memperoleh nilai UTS 7.

$$
\hat{P}(y=1)=\frac{e^{-8,938+3,253 \operatorname{jam}(2)+1,196(7)}}{1+e^{-8,938+3,253 \operatorname{jam}(2)+1,196(7)}}=\frac{14,68754712}{1+14,68754712}=0,94 .
$$




\section{$S \mathcal{H A R E}$}

[1] Misalkan diberikan data dalam SPSS sebagai berikut (Gambar 11.1).

\begin{tabular}{|r|r|r|r|r|}
\hline & hasil_ujian & \multicolumn{1}{|c|}{ jam } & hobi & uang_iajan \\
\hline \hline 57 & 0 & 11 & 1 & 6.1 \\
\hline 58 & 0 & 11 & 2 & 4.1 \\
\hline 59 & 0 & 11 & 2 & 3.3 \\
\hline 60 & 0 & 11 & 0 & 2.5 \\
\hline 61 & 1 & 12 & 0 & 9.9 \\
\hline 62 & 1 & 12 & 0 & 9.5 \\
\hline 63 & 1 & 12 & 0 & 5.5 \\
\hline 64 & 1 & 12 & 0 & 5.5 \\
\hline 65 & 1 & 12 & 1 & 5.5 \\
\hline 66 & 1 & 12 & 1 & 5.5 \\
\hline 67 & 1 & 12 & 1 & 5.5 \\
\hline 68 & 1 & 12 & 2 & 2.5 \\
\hline 69 & 0 & 12 & 2 & 1.6 \\
\hline 70 & 0 & 12 & 0 & 6.5 \\
\hline 74 & & & & \\
\hline
\end{tabular}

\section{Gambar 11.1}

Berdasarkan data pada Gambar 11.1, misalkan variabel hasil ujian sebagai variabel tak bebas, sedangkan variabel jam, hobi dan uang jajan sebagai variabel bebas. Berikut diberikan output SPSS dengan pendekatan regresi logistik Backward: Wald.

Tabel 11.1

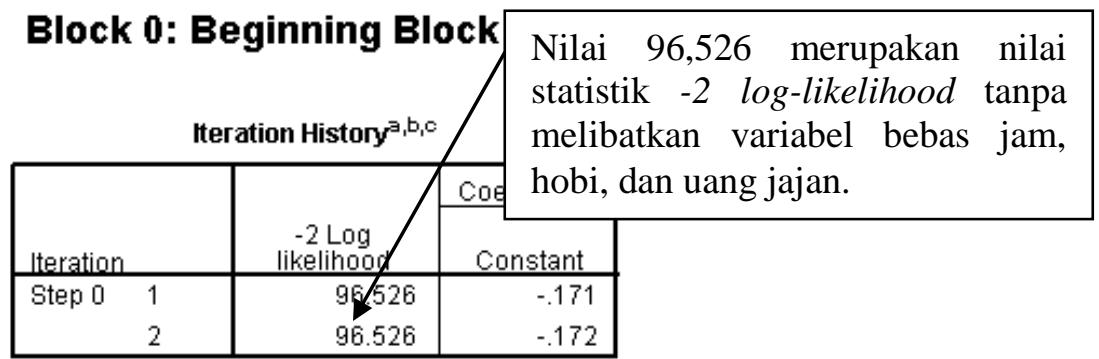

a. Constant is included in the model.

b. Initial -2 Log Likelihood: 96.526

c. Estimation terminated at iteration number 2 because parameter estimates

changed by less than .001 .

Tabel 11.2

\begin{tabular}{|c|c|c|c|c|c|}
\hline \multicolumn{6}{|c|}{ Variables not in the Equation } \\
\hline & & & Score & $\mathrm{df}$ & Sig. \\
\hline \multirow[t]{6}{*}{ Step 0} & Variables & jam & 8.995 & 1 & .003 \\
\hline & & hobi & 22.720 & 2 & .000 \\
\hline & & hobi(1) & 18.134 & 1 & .000 \\
\hline & & hobi(2) & .598 & 1 & .439 \\
\hline & & uang_jajan & 6.669 & 1 & .010 \\
\hline & Overall St & stics & 27.679 & 4 & .000 \\
\hline
\end{tabular}




\section{Tabel 11.3}

Block 1: Method = Backward Stepwise (Wald)

Pada Step 1 iterasi

keenam, nilai 63,173 merupakan nilai statistik

-2 log-likelihood melibatkan variabel bebas jam, hobi, dan uang jajan.

Pada Step 2 iterasi keenam, nilai 63,688 merupakan nilai statistik -2 log-likelihood melibatkan variabel bebas jam dan hobi.

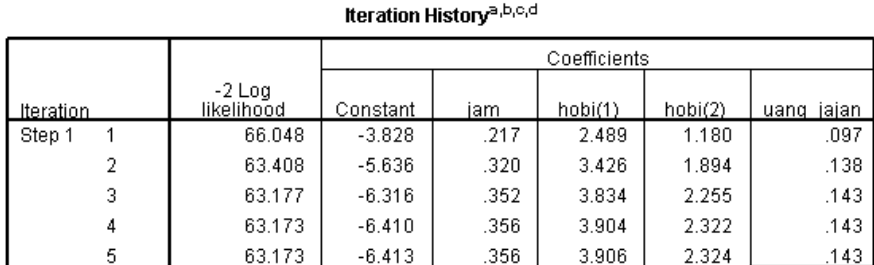

\begin{tabular}{l|l|l|l|l}
63.173 & -6.413 & 356 & 3.906 & 2.324 \\
\hline
\end{tabular}

\begin{tabular}{|l|l|l|l|l}
66.622 & -3.939 & 256 & 2564 & 1.223 \\
\hline
\end{tabular}

\begin{tabular}{|l|l|l|l|l|}
\hline 63.945 & -5.837 & .376 & 3.547 & 1.999 \\
\hline
\end{tabular}

\begin{tabular}{l|l|l|l|l}
63.693 & -6.552 & 411 & 3.980 & 2.387
\end{tabular}

\begin{tabular}{|l|l|l|l|l|}
63.688 & -6.654 & .414 & 4.056 & 2.460 \\
\hline
\end{tabular}

\begin{tabular}{|l|l|l|l|l|}
63.688 & -6.656 & .414 & 4.059 & 2.462 \\
\hline 63.688 & -6.656 & .44 & 4.059 & 2.462 \\
\hline
\end{tabular}

\begin{tabular}{l|l|l|l|l|}
\hline 63.688 & -6.656 & .414 & 4.059 & 2.462 \\
\hline
\end{tabular}

Nilai 33,353 merupakan hasil selisih antara 96,526 (-2 loglikelihood tanpa variabel bebas) dan 63,173 (-2 loglikelihood dengan tiga variabel bebas). Perbedaan kemampuan dalam hal mencocokkan (fits) data signifikan secara statistika (perhatikan nilai Sig.).

Nilai -0,515 merupakan hasil selisih antara 63,173 (-2 loglikelihood dengan tiga variabel bebas) dan 63,688 (-2 loglikelihood dengan dua variabel bebas). Perbedaan kemampuan dalam hal mencocokkan (fits) data tidak signifikan (perhatikan nilai Sig.).

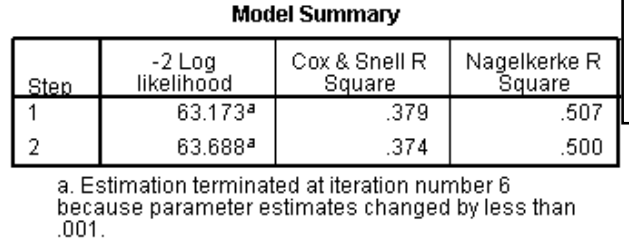

nilai Sig.)

Tabel 11.6

\begin{tabular}{|ll|r|r|r|r|r|r|}
\hline \multicolumn{7}{|c|}{ Variables in the Equation } \\
\hline Step 1 & jam & \multicolumn{1}{c|}{ B } & \multicolumn{1}{c|}{ S.E. } & \multicolumn{1}{c|}{ Wald } & \multicolumn{1}{c|}{ df } & Sig. & Exp(B) \\
& hobi & & .185 & 3.691 & 1 & .055 & 1.427 \\
& & & 13.438 & 2 & .001 & \\
& hobi(1) & 3.906 & 1.168 & 11.187 & 1 & .001 & 49.711 \\
& hobi(2) & 2.324 & 1.163 & 3.992 & 1 & .046 & 10.216 \\
& uang_jajan & .143 & .202 & .500 & 1 & .480 & 1.154 \\
& Constant & -6.413 & 1.984 & 10.451 & 1 & .001 & .002 \\
Step 2 & jam & .414 & .168 & 6.093 & 1 & .014 & 1.513 \\
& & & 14.242 & 2 & .001 & \\
& hobi & & 1.167 & 12.103 & 1 & .001 & 57.898 \\
& hobi(1) & 4.059 & 1.154 & 4.555 & 1 & .033 & 11.732 \\
& hobi(2) & 2.462 & 1.154 & 1 & .001 & .001 \\
Constant & -6.656 & 1.977 & 11.340 & 1 &
\end{tabular}

Tabel 11.7

Variables not in the Equation
\begin{tabular}{|ll|r|r|r|}
\hline & Score & df & Sig. \\
\hline Step 2 & Variables uang_jajan & .503 & 1 & .478 \\
& Overall Statistics & .503 & 1 & .478 \\
\hline
\end{tabular}

a. Variable(s) removed on step 2: uang_jajan. 
Berdasarkan Tabel 11.1, yakni Iteration History, untuk Step 0 iterasi kedua, nilai 96,526 merupakan nilai statistik -2 log-likelihood tanpa melibatkan variabel bebas jam, hobi, dan uang jajan. Kemudian pada Tabel 11.3, yakni Iteration History, untuk Step 1 iterasi keenam, nilai 63,173 merupakan nilai statistik -2 log-likelihood melibatkan variabel bebas jam, hobi, dan uang jajan. Selanjutnya pada Tabel 11.3, yakni Iteration History, untuk Step 2 iterasi keenam, nilai 63,688 merupakan nilai statistik -2 log-likelihood melibatkan variabel bebas jam dan hobi.

Nilai 33,353 merupakan hasil selisih antara 96,526 (-2 log-likelihood tanpa variabel bebas) dan 63,173 (-2 log-likelihood dengan tiga variabel bebas). Perbedaan kemampuan dalam hal mencocokkan (fits) data signifikan (perhatikan nilai Sig.). Dengan kata lain, kemampuan model regresi dengan melibatkan tiga variabel bebas signifikan secara statistika lebih baik/akurat dalam hal mencocokan data dibandingkan model tanpa melibatkan variabel bebas.

Selanjutnya nilai -0,515 merupakan hasil selisih antara 63,173 (-2 log-likelihood dengan tiga variabel bebas) dan 63,688 (-2 log-likelihood dengan dua variabel bebas). Perbedaan kemampuan dalam hal mencocokkan (fits) data tidak signifikan secara statistika (perhatikan nilai Sig.). Dengan kata lain, model regresi logistik yang melibatkan tiga variabel bebas tidak lebih baik dibandingkan model regresi logistik yang melibatkan dua variabel bebas pada tingkat signifikansi $5 \%$.

[2] Misalkan diberikan data seperti pada Gambar 11.2.

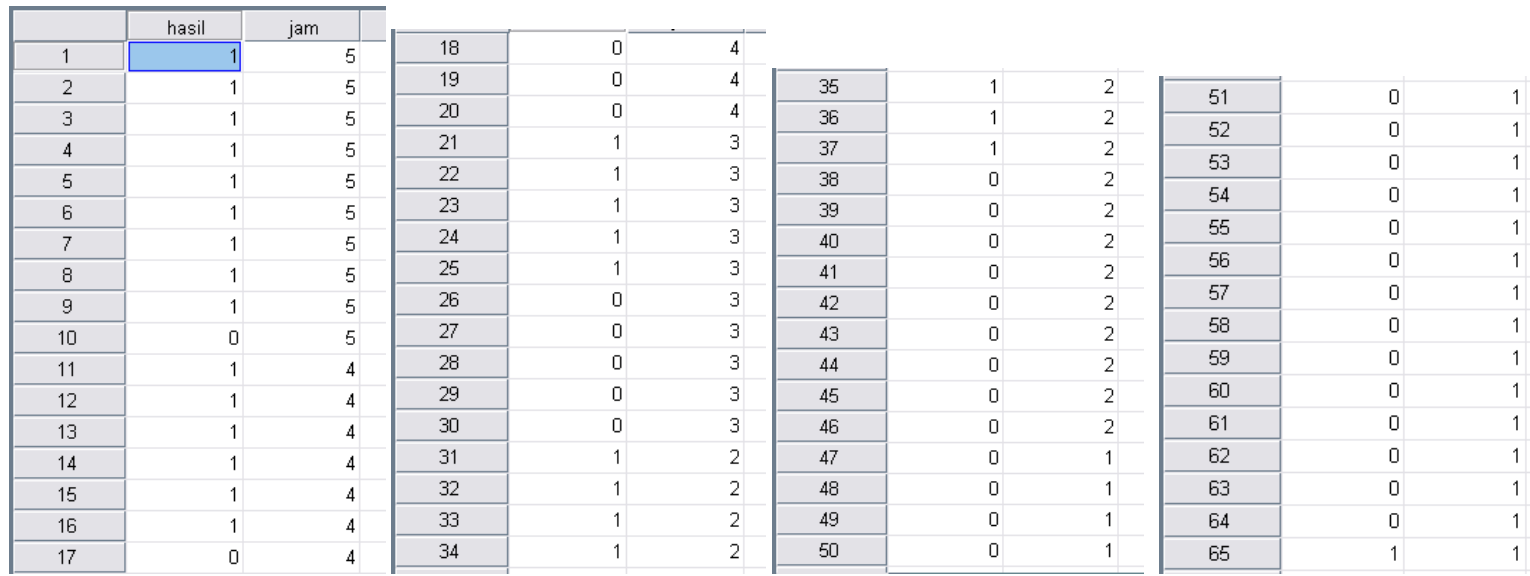

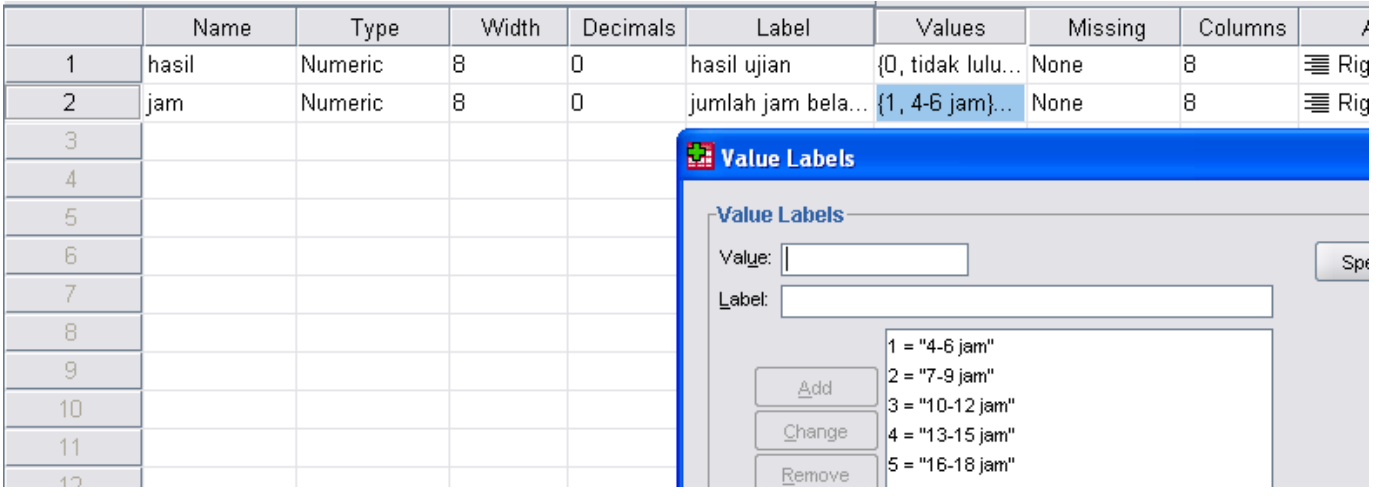

Gambar 11.2 
Berdasarkan data pada Gambar 11.2, diketahui jumlah mahasiswa yang diteliti sebanyak 65 mahasiswa. Pada variabel hasil, nilai 1 menyatakan lulus, sedangkan nilai 0 menyatakan tidak lulus. Pada variabel jam, nilai 1 menyatakan waktu yang dihabiskan untuk belajar dalam sehari 4-6 jam, nilai 2 menyatakan 7-9 jam, nilai 3 menyatakan 10-12 jam, nilai 4 menyatakan 13-15 jam, dan nilai 5 menyatakan 16-18 jam.

Perhatikan bahwa mahasiswa dengan nomor urut 2 menghabiskan waktu untuk belajar dalam kisaran 16-18 jam dalam sehari dan hasil ujian menunjukkan lulus. Mahasiswa dengan nomor urut 10 menghabiskan waktu untuk belajar dalam kisaran 16-18 jam dalam sehari dan hasil ujian menunjukkan tidak lulus. Misalkan ingin diketahui hal-hal sebagai berikut.

$\Rightarrow$ Peneliti ingin mengestimasi/memperkirakan berapa kali lebih mungkin lulus ujian untuk mahasiswa dengan jumlah jam belajar dalam sehari 7-9 jam dibandingkan mahasiswa dengan jumlah jam belajar dalam sehari 4-6 jam.

$\Rightarrow$ Peneliti ingin mengestimasi/memperkirakan berapa kali lebih mungkin lulus ujian untuk mahasiswa dengan jumlah jam belajar dalam sehari 10-12 jam dibandingkan mahasiswa dengan jumlah jam belajar dalam sehari 4-6 jam.

$\Rightarrow$ Peneliti ingin mengestimasi/memperkirakan berapa kali lebih mungkin lulus ujian untuk mahasiswa dengan jumlah jam belajar dalam sehari 13-15 jam dibandingkan mahasiswa dengan jumlah jam belajar dalam sehari 4-6 jam.

$\Rightarrow$ Peneliti ingin mengestimasi/memperkirakan berapa kali lebih mungkin lulus ujian untuk mahasiswa dengan jumlah jam belajar dalam sehari 16-18 jam dibandingkan mahasiswa dengan jumlah jam belajar dalam sehari 4-6 jam.

Perhatikan bahwa kategori jumlah jam belajar dalam sehari 4-6 jam dijadikan sebagai kategori yang dibandingkan (baseline category). Selanjutnya pilih Analyze $=>$ Regression $=>$ Binary Logistic, sehingga muncul kotak dialog Logistic Regression (Gambar 11.3). Masukkan variabel hasil pada Dependent dan masukkan variabel jam pada Covariates. Kemudian pilih Categorical, sehingga muncul kotak dialog Logistic Regression: Define Categorical Variables (Gambar 11.4).

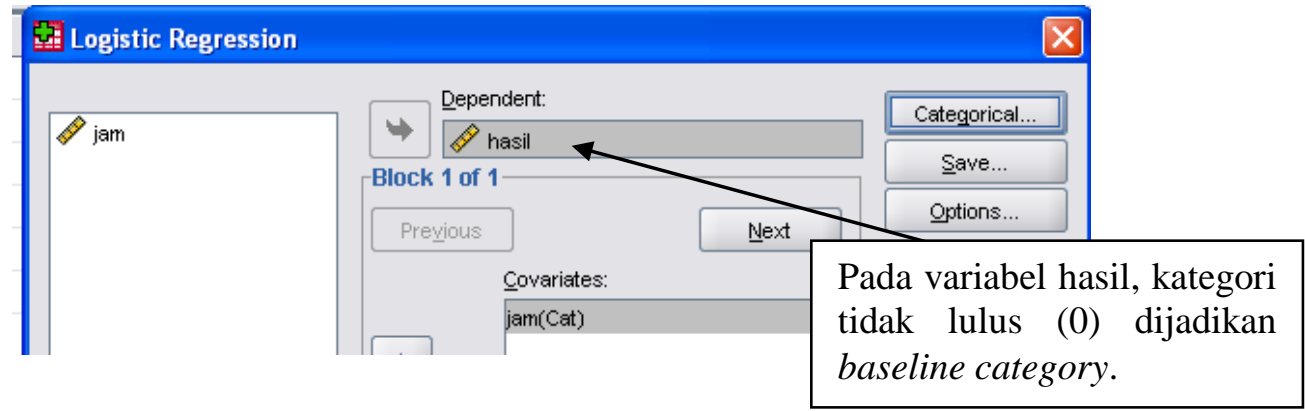

Gambar 11.3

Diketahui kategori untuk jumlah jam belajar dalam sehari 4-6 jam diberi Value 1. Value 1 merupakan nilai kategori paling rendah, sedangkan Value 6 merupakan nilai kategori paling tinggi. Karena kategori dengan Value 1 menyatakan nilai kategori paling rendah dan akan dijadikan baseline category, pada kotak dialog Logistic Regression: Define Categorical Variables (Gambar 11.4), pilih First pada Reference Category dan pilih Change, sehingga isi pada kotak Categorical Covariates menjadi jam(indicator(first)) . Kemudian pilih Continue. 
Pilih Options, sehingga muncul kotak dialog Logistic Regression: Options (Gambar 11.5). Pada Gambar 11.5 pilih Hosmer-Lemeshow goodness-of-fit dan Iteration history. Kemudian pilih Continue dan OK.

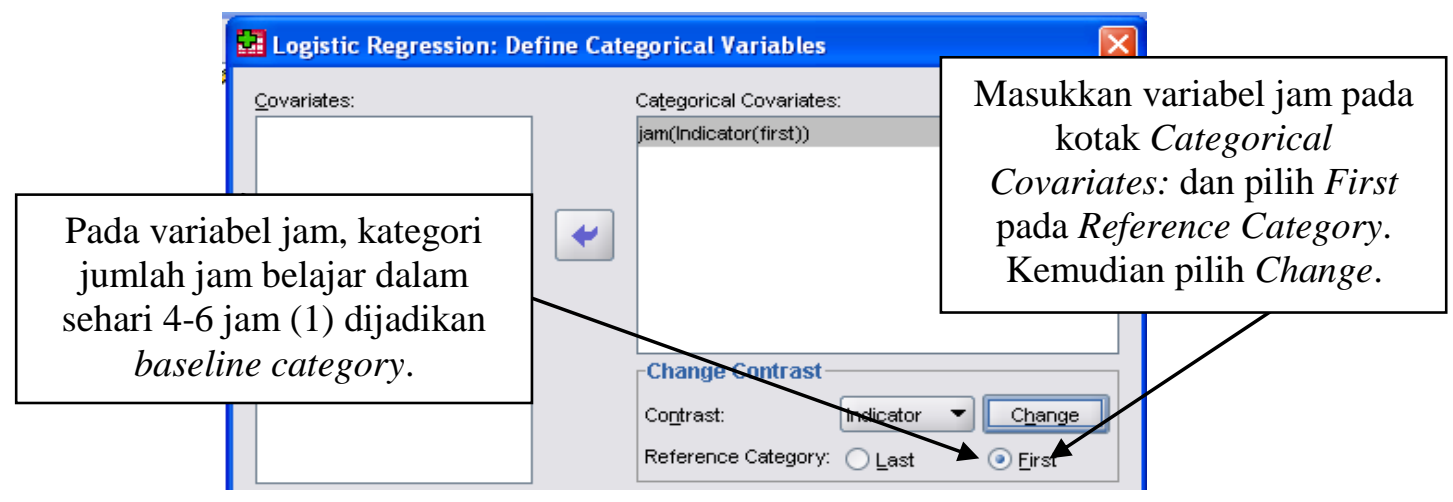

Gambar 11.4

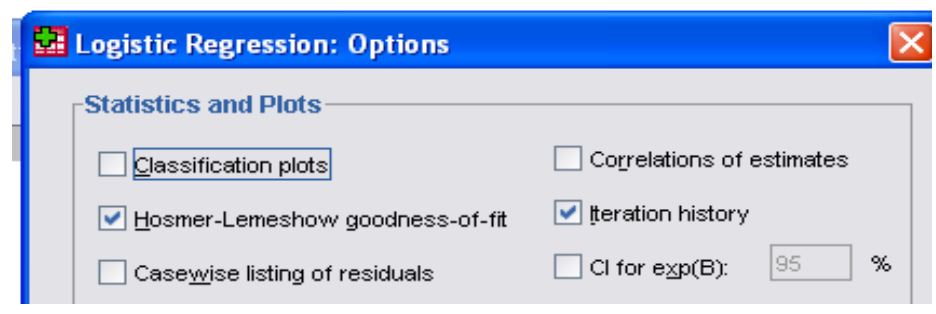

Gambar 11.5

. Berikut hasil dari perhitungan SPSS.

Tabel 11.8

\begin{tabular}{|c|c|c|c|c|c|c|}
\hline \multicolumn{7}{|c|}{ Categorical Variables Codings } \\
\hline & & \multirow[b]{2}{*}{ Frequency } & \multicolumn{4}{|c|}{ Parameter coding } \\
\hline & & & (1) & (2) & (3) & (4) \\
\hline \multirow[t]{5}{*}{ jam } & 4-6 jam & 19 & .000 & .000 & .000 & .000 \\
\hline & $7-9$ jam & 16 & 1.000 & .000 & .000 & .000 \\
\hline & 10-12 jam & 10 & .000 & 1.000 & .000 & .000 \\
\hline & 13-15 jam & 10 & .000 & .000 & 1.000 & .000 \\
\hline & 16-18 jam & 10 & .000 & .000 & .000 & 1.000 \\
\hline
\end{tabular}

Tabel 11.9

\begin{tabular}{|c|c|c|c|c|c|c|c|}
\hline \multicolumn{8}{|c|}{ Variables in the Equation } \\
\hline & & $\mathrm{B}$ & S.E. & Wald & $\mathrm{df}$ & Sig. & $\operatorname{Exp}(B)$ \\
\hline \multirow[t]{6}{*}{ Step $1^{a}$} & jam & & & 12.846 & 4 & .012 & \\
\hline & jam(1) & 2.639 & 1.144 & 5.318 & 1 & .021 & 14.000 \\
\hline & $\operatorname{jam}(2)$ & 2.890 & 1.206 & 5.740 & 1 & .017 & 18.000 \\
\hline & $\operatorname{jam}(3)$ & 3.296 & 1.213 & 7.378 & 1 & .007 & 27.000 \\
\hline & $\operatorname{jam}(4)$ & 5.088 & 1.472 & 11.946 & 1 & .001 & 162.000 \\
\hline & Constant & -2.890 & 1.027 & 7.915 & 1 & .005 & .056 \\
\hline
\end{tabular}

Berdasarkan Tabel 11.9, yakni Variables in the Equation, dapat ditarik informasi sebagai berikut. 
$\Rightarrow$ Mahasiswa dengan jumlah jam belajar dalam sehari 7-9 jam diperkirakan berpeluang untuk lulus ujian 14 kali lebih mungkin dibandingkan mahasiswa dengan jumlah jam belajar dalam sehari 4-6 jam.

$\Rightarrow$ Mahasiswa dengan jumlah jam belajar dalam sehari 10-12 jam diperkirakan berpeluang untuk lulus ujian 18 kali lebih mungkin dibandingkan mahasiswa dengan jumlah jam belajar dalam sehari 4-6 jam.

$\Rightarrow$ Mahasiswa dengan jumlah jam belajar dalam sehari 13-15 jam diperkirakan berpeluang untuk lulus ujian 27 kali lebih mungkin dibandingkan mahasiswa dengan jumlah jam belajar dalam sehari 4-6 jam.

$\Rightarrow$ Mahasiswa dengan jumlah jam belajar dalam sehari 16-18 jam diperkirakan berpeluang untuk lulus ujian 162 kali lebih mungkin dibandingkan mahasiswa dengan jumlah jam belajar dalam sehari 4-6 jam.

Alternatif lain untuk memperoleh output SPSS seperti sebelumnya sebagai berikut. Pertama, ubah urutan pengkodean untuk variabel jam. Dalam hal ini Value 5 menyatakan jumlah jam belajar 4-6 jam dalam sehari, Value 4 menyatakan jumlah jam belajar 7-9 jam dalam sehari, Value 3 menyatakan jumlah jam belajar 10-12 jam dalam sehari, Value 2 menyatakan jumlah jam belajar 13-15 jam dalam sehari, dan Value 1 menyatakan jumlah jam belajar 16-18 jam dalam sehari. Selanjutnya pilih Analyze $\Rightarrow>$ Regression $\Rightarrow>$ Multinomial Logistic, sehingga muncul kotak dialog Multinomial Logistic Regression (Gambar 11.6). Masukkan variabel hasil pada Dependent dan variabel jam pada Factor(s).

Untuk variabel hasil, kategori tidak lulus (0) dijadikan sebagai baseline category (atur dengan First).

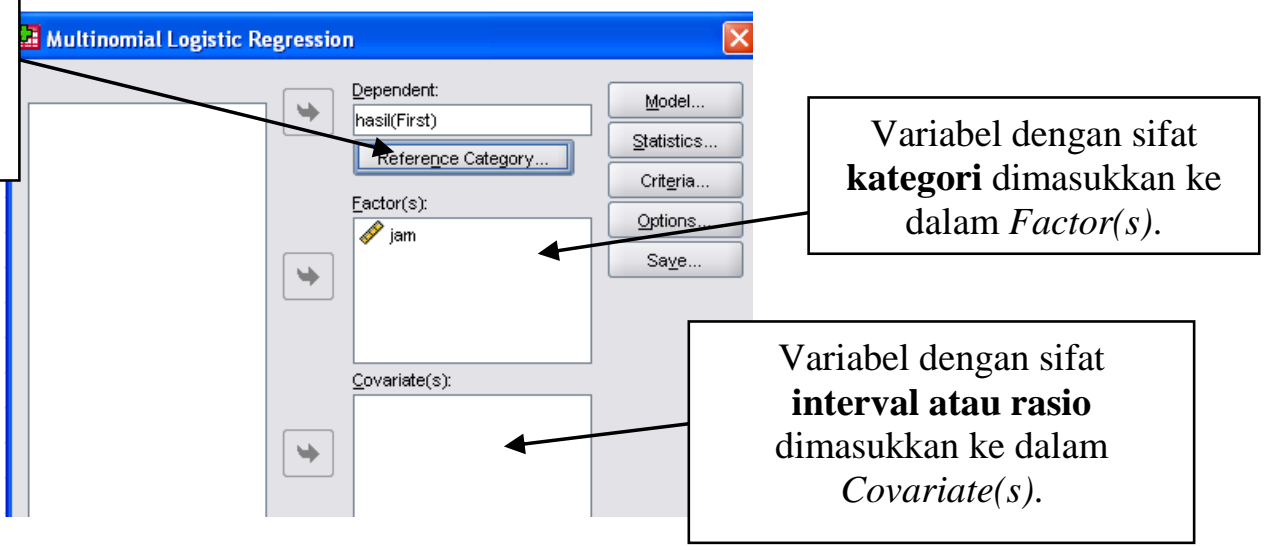

Gambar 11.6

Kemudian pilih OK. Berikut hasil berdasarkan perhitungan SPSS.

Tabel 11.10

Output SPSS yang diperoleh sama seperti output SPSS pada Tabel 11.9.

\begin{tabular}{|c|c|c|c|c|c|c|c|c|c|}
\hline \multicolumn{10}{|c|}{ Parameter Estimates } \\
\hline \multirow[b]{2}{*}{ hasila } & & \multirow[b]{2}{*}{$\mathrm{B}$} & \multirow[b]{2}{*}{ Std. Error } & \multirow[b]{2}{*}{ Wald } & \multirow[b]{2}{*}{ df } & \multirow[b]{2}{*}{ Siq. } & \multirow[b]{2}{*}{ Exp(B) } & \multicolumn{2}{|c|}{$\begin{array}{l}95 \% \text { Confidence Interval for Exp } \\
\text { (B) }\end{array}$} \\
\hline & & & & & & & & Lower Bound & Upper Bound \\
\hline Iulus & Intercept & -2.890 & 1.027 & 7.915 & 1 & .005 & & & \\
\hline & [jam=1] & 5.088 & 1.472 & 11.946 & 1 & .001 & 162.000 & 9.049 & 2900.346 \\
\hline & [jam=2] & 3.296 & 1.213 & 7.378 & 1 & .007 & 27.000 & 2.504 & 291.186 \\
\hline & [jam=3] & 2.890 & 1.206 & 5.740 & 1 & .017 & 18.000 & 1.692 & 191.521 \\
\hline & [jam=4] & 2.639 & 1.144 & 5.318 & 1 & .021 & 14.000 & 1.486 & 131.885 \\
\hline & [jam=5] & $0^{\mathrm{b}}$ & & & 0 & & & & \\
\hline
\end{tabular}


[3] Aktifkan menu Probabilities dan Group membership.

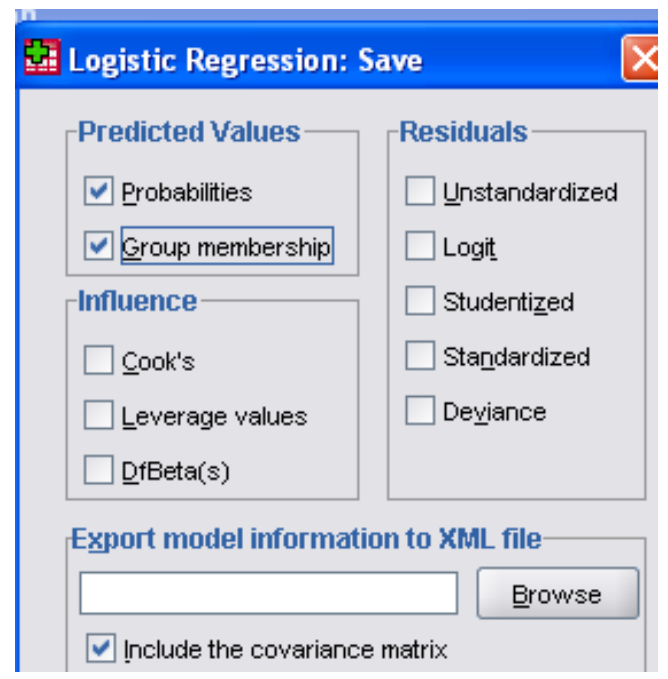

\section{Gambar 11.7}

Maka akan diperoleh output SPSS sebagai berikut.

\begin{tabular}{|c|c|c|c|c|c|c|c|c|}
\hline \multirow{3}{*}{$\begin{array}{l}\text { File Edit } \\
\text { 回 且 }\end{array}$} & \multirow{2}{*}{$\begin{array}{cl}\text { View } & \text { Data } \\
\mathbb{\Psi} & \hookrightarrow\end{array}$} & Transtorm Analyze & alyze Graphs & \multicolumn{2}{|c|}{ Untilities Add-ons Window Help } & & & \\
\hline & & 音圈屡? & H4 +1 & 畕功四 & 80 aty & & & \\
\hline & Name & Type & Width & Decimals & Label & Values & Missing & Colt \\
\hline 1 & kelulusan & Numeric & 8 & 0 & & $\{0$, tidak lulu... & None & 8 \\
\hline 2 & jam & Numeric & 8 & 0 & jumlah jam belajar dala... & $\{1,4-6$ jam $\} \ldots$ & None & 8 \\
\hline 3 & UTS & Numeric & 8 & 2 & nilai ujian tengah seme... & None & None & 8 \\
\hline 4 & PRE_1 & Numeric & 11 & 5 & Predicted probability & None & None & 13 \\
\hline 5 & PGR_1 & Numeric & 8 & 0 & Predicted group & $\{0$, tidak lulu... & None & 8 \\
\hline
\end{tabular}

\section{Gambar 11.8}

Perhatikan bahwa terbentuk variabel baru bernama PRE_1 (Predicted probability) dan PGR_1 (Predicted group). Pada variabel PRE_1 memberikan nilai estimasi probabilitas (predicted probability) mengenai kelulusan mahasiswa. Nilai probabilitas berkisar di antara 0 dan 1. Nilai probabilitas yang semakin dekat dengan 1 menunjukkan semakin besar juga peluang mahasiswa untuk lulus. Sedangkan pada variabel PGR_1 memprediksi apakah seorang mahasiswa akan lulus atau tidak.

Berdasarkan Gambar 11.9, untuk mahasiswa nomor 1, diketahui mahasiswa tersebut tidak lulus. Berdasarkan hasil prediksi diketahui mahasiswa nomor 1 juga tidak lulus (perhatikan variabel PGR_1). Berdasarkan variabel PRE_1 diketahui estimasi probabilitas mahasiswa nomor 1 untuk lulus sebesar 0,04932. Nilai tersebut dapat dihitung sebagai berikut.

$$
\begin{gathered}
\hat{P}(y=1)=\frac{e^{-8,938+2,929 j a m(1)+3,253 \mathrm{jam}(2)+3,476 \mathrm{jam}(3)+1,196 \mathrm{UTS}}}{1+e^{-8,938+2,929 j a m(1)+3,253 \mathrm{jam}(2)+3,476 \mathrm{jam}(3)+1,196 \text { UTS }}} \\
\hat{P}(y=1)=\frac{e^{-8,938+0+0+0+1,196 \text { UTS }}}{1+e^{-8,938+0+0+0+1,196 \mathrm{UTS}}}
\end{gathered}
$$




$$
\begin{gathered}
\hat{P}(y=1)=\frac{e^{-2,958}}{1+e^{-2,958}} \\
\hat{P}(y=1)=\frac{0,051923}{1+0,051923}=0,0493 .
\end{gathered}
$$

Untuk mahasiswa nomor 18, diketahui mahasiswa tersebut lulus. Berdasarkan hasil prediksi diketahui mahasiswa nomor 18 juga lulus (perhatikan variabel PGR_1). Berdasarkan variabel PRE_1 diketahui estimasi probabilitas mahasiswa nomor 18 lulus sebesar 0,76251. Nilai tersebut dapat dihitung sebagai berikut.

$$
\begin{gathered}
\hat{P}(y=1)=\frac{e^{-8,938+2,929 j a m(1)+3,253 \mathrm{jam}(2)+3,476 \mathrm{jam}(3)+1,196 \mathrm{UTS}}}{1+e^{-8,938+2,929 j a m(1)+3,253 \mathrm{jam}(2)+3,476 \mathrm{jam}(3)+1,196 \mathrm{UTS}}} \\
\hat{P}(y=1)=\frac{e^{-8,938+2,929 \mathrm{jam}(1)+1,196 \mathrm{UTS}}}{1+e^{-8,938+2,929 \mathrm{jam}(1)+1,196 \mathrm{UTS}}} \\
\hat{P}(y=1)=\frac{e^{-8,938+2,929+1,196(6)}}{1+e^{-8,938+2,929+1,196(6)}}=\frac{3,212341}{1+3,212341}=0,762 .
\end{gathered}
$$

\begin{tabular}{|c|c|c|c|c|c|}
\hline 1: PGR_1 & 0.0 & & & & \\
\hline & kelulusan & jam & UTS & PRE_1 & PGR_1 \\
\hline 1 & tidak lulus & 4-6 jam & 5.00 & 0.04932 & tidak lulus \\
\hline 2 & tidak lulus & 4-6 jam & 5.00 & 0.04932 & tidak lulus \\
\hline 3 & tidak lulus & 4-6 jam & 5.00 & 0.04932 & tidak lulus \\
\hline 4 & tidak lulus & 4-6 jam & 5.00 & 0.04932 & tidak lulus \\
\hline 5 & tidak lulus & 4-6 jam & 5.00 & 0.04932 & tidak lulus \\
\hline 6 & tidak lulus & 4-6 jam & 5.00 & 0.04932 & tidak lulus \\
\hline 7 & tidak lulus & 4-6 jam & 5.00 & 0.04932 & tidak lulus \\
\hline 8 & tidak lulus & 4-6 jam & 6.00 & 0.14642 & tidak lulus \\
\hline 9 & tidak lulus & 4-6 jam & 7.00 & 0.36189 & tidak lulus \\
\hline 10 & lulus & 4-6 jam & 6.00 & 0.14642 & tidak lulus \\
\hline 11 & tidak lulus & 7-9 jam & 5.00 & 0.49268 & tidak lulus \\
\hline 12 & tidak lulus & 7-9 jam & 5.00 & 0.49268 & tidak lulus \\
\hline 13 & tidak lulus & 7-9 jam & 6.00 & 0.76251 & lulus \\
\hline 14 & lulus & 7-9 jam & 6.00 & 0.76251 & lulus \\
\hline 15 & lulus & 7.9 jam & 7.00 & 0.91391 & lulus \\
\hline 16 & lulus & 7-9 jam & 7.00 & 0.91391 & lulus \\
\hline 17 & lulus & $7.9 \mathrm{jam}$ & 7.00 & 0.91391 & lulus \\
\hline
\end{tabular}

\begin{tabular}{|c|c|c|c|c|c|}
\hline & kelulusan & jam & UTS & PRE_1 & PGR_1 \\
\hline 18 & lulus & $7.9 \mathrm{jam}$ & 6.00 & 0.76251 & lulus \\
\hline 19 & lulus & $7.9 \mathrm{jam}$ & 5.00 & 0.49268 & tidak Iulus \\
\hline 20 & lulus & $7.9 \mathrm{jam}$ & 5.00 & 0.49268 & tidak lulus \\
\hline 21 & tidak lulus & 10-12 jam & 5.00 & 0.57316 & lulus \\
\hline 22 & tidak lulus & $10-12 \mathrm{jam}$ & 6.00 & 0.81616 & lulus \\
\hline 23 & lulus & 10-12 jam & 5.00 & 0.57316 & lulus \\
\hline 24 & lulus & 10-12 jam & 5.00 & 0.57316 & lulus \\
\hline 25 & lulus & 10-12 jam & 6.00 & 0.81616 & lulus \\
\hline 26 & lulus & 10-12 jam & 6.00 & 0.81616 & lulus \\
\hline 27 & lulus & 10-12 jam & 7.00 & 0.93621 & lulus \\
\hline 28 & lulus & 10-12 jam & 7.00 & 0.93621 & lulus \\
\hline 29 & lulus & 10-12 jam & 8.00 & 0.97981 & lulus \\
\hline 30 & lulus & 10-12 jam & 8.00 & 0.97981 & lulus \\
\hline 31 & tidak lulus & 13-15 jam & 6.00 & 0.84726 & lulus \\
\hline 32 & lulus & 13-15 jam & 5.00 & 0.62655 & lulus \\
\hline 33 & lulus & 13-15 jam & 6.00 & 0.84726 & lulus \\
\hline 34 & lulus & 13-15 jam & 7.00 & 0.94829 & lulus \\
\hline
\end{tabular}

Perhatikan bahwa apabila nilai probabilitas lebih besar dari 0,5, maka akan diprediksi masuk ke dalam kelompok (predicted group) lulus. Namun apabila nilai probabilitas lebih kecil dari 0,5, maka akan diprediksi masuk ke dalam kelompok (predicted group) tidak lulus.

\section{Gambar 11.9}

Tabel 11.11

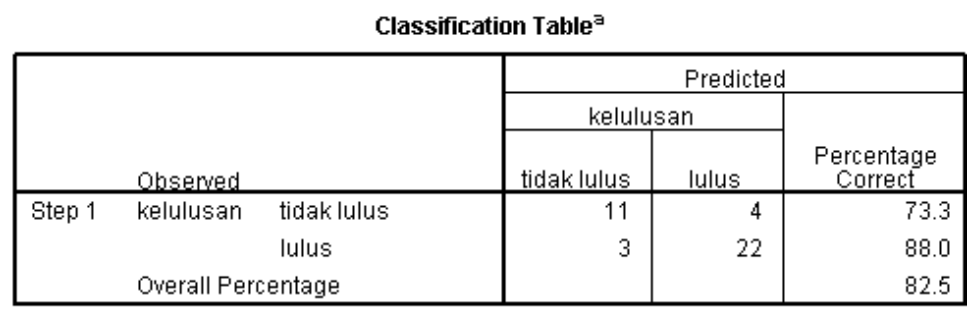

a. The cut value is .500 
Berdasarkan Classification Table, diketahui jumlah mahasiswa yang tidak lulus sebanyak 15 mahasiswa. Dari 15 mahasiswa tersebut, kemudian diprediksi 11 mahasiswa tidak lulus dan 4 mahasiswa lulus. Perhatikan bahwa hasil prediksi tidak $100 \%$ benar. 4 mahasiswa yang diprediksi lulus, pada keadaan sebenarnya tidak lulus. Diketahui juga bahwa jumlah mahasiswa yang lulus sebanyak 25 mahasiswa. Dari 25 mahasiswa tersebut, kemudian diprediksi 22 mahasiswa lulus dan 3 mahasiswa tidak lulus. Perhatikan bahwa hasil prediksi tidak $100 \%$ benar. 3 mahasiswa yang diprediksi tidak lulus, pada keadaan sebenarnya lulus. Sehingga persentase ketepatan model dapat memprediksi dengan benar sebesar

$$
\frac{11+22}{11+22+4+3} \times 100 \%=82,5 \% \text {. }
$$

[4] Aktifkan menu Classification plots (Gambar 11.10).

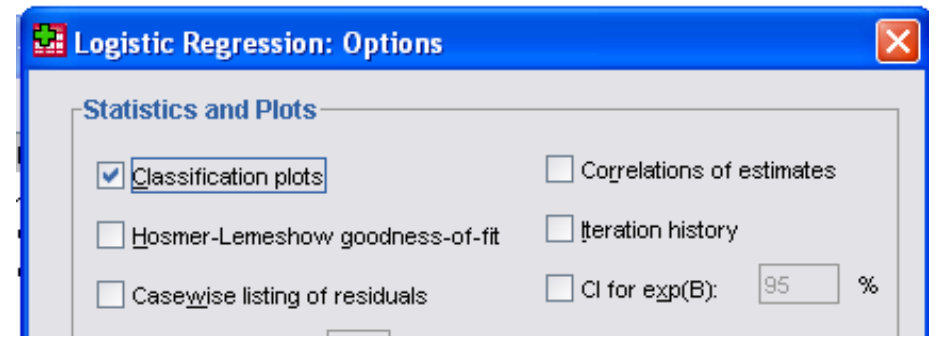

Gambar 11.10

Maka akan diperoleh output SPSS sebagai berikut.

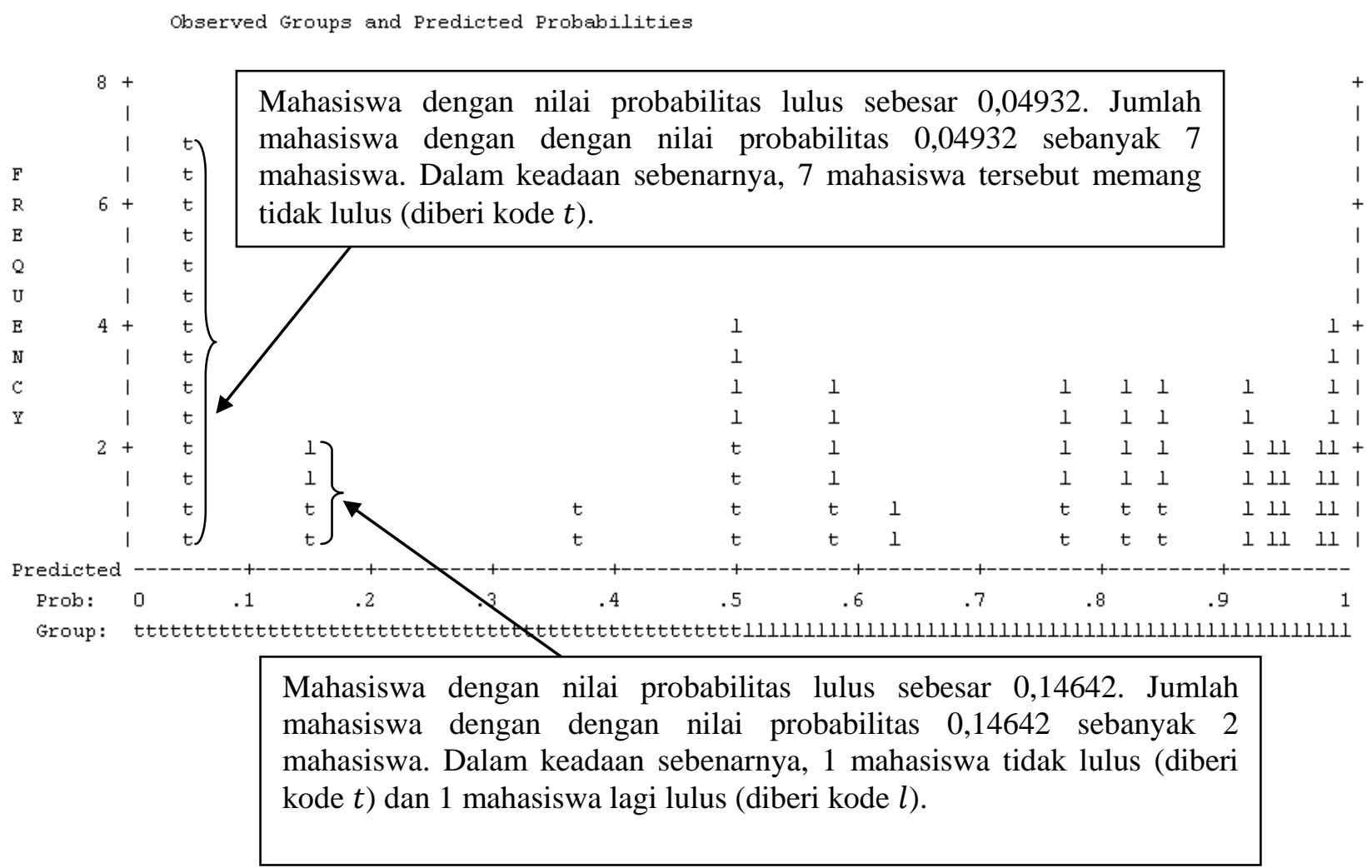

Gambar 11.11 
Berdasarkan Output SPSS pada Gambar 11.11 dapat ditarik informasi sebagai berikut.

$\Rightarrow$ Mahasiswa dengan nilai probabilitas lulus sebesar 0,04932. Jumlah mahasiswa dengan dengan nilai probabilitas 0,04932 sebanyak 7 mahasiswa. Dalam keadaan sebenarnya, 7 mahasiswa tersebut memang tidak lulus (diberi kode $t$ ).

$\Rightarrow$ Mahasiswa dengan nilai probabilitas lulus sebesar 0,14642. Jumlah mahasiswa dengan dengan nilai probabilitas 0,14642 sebanyak 2 mahasiswa. Dalam keadaan sebenarnya, 1 mahasiswa tidak lulus (diberi kode $t$ ) dan 1 mahasiswa lagi lulus (diberi kode $l$ ).

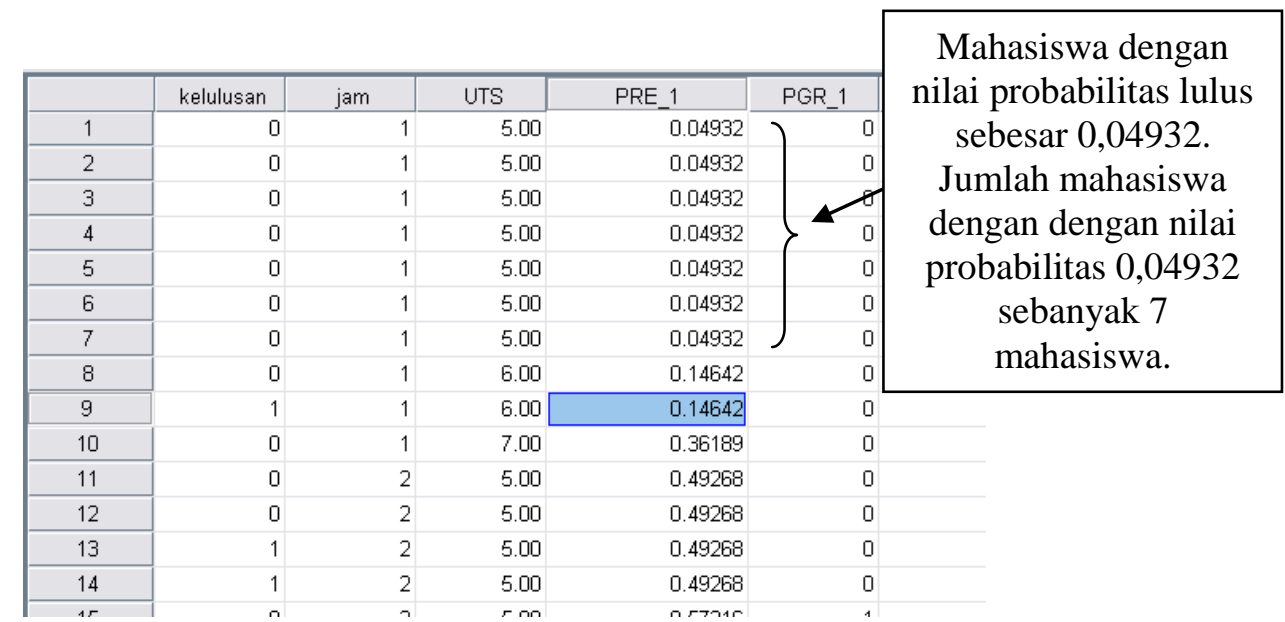

\section{Gambar 11.12}

\section{Referensi}

1. Agresti, A. dan B. Finlay. 2009. Statistical Methods for the Social Sciences, $4^{\text {th }}$ Edition. United States of America: Prentice Hall.

2. Field, A. 2009. Discovering Statistics Using SPSS, $3^{\text {rd }}$ Edition. London: Sage.

3. Gujarati, D.N. 2003. Basic Econometrics, $4^{\text {th }}$ Edition. New York: McGraw-Hill.

4. Hosmer, D.W. dan S. Lemeshow. 2000. Applied Logistic Regression, $2^{\text {nd }}$ Edition. United States of America: John Wiley \& Sons, Inc.

5. Hair, J. F Jr., R.E. Anderson, B.J. Babin, dan W.C. Black. 2010. Multivariate Data Analysis, $7^{\text {th }}$ Edition. Pearson Prentice Hall.

6. Kleinbaum, D.G. dan M. Klein. 2010. Logistic Regression, $3^{\text {rd }}$ Edition. New York: Springer.

7. Meyers, L.S., G. Gamst, dan A.J. Guarino. 2005. Applied Multivariate Research, Design and Interpretation. Sage.

8. Stevens, J.P. 2009. Applied Multivariate Statistics For The Social Science, $5^{\text {th }}$ Edition. New York: Routledge.

9. Supranto, J. 2004. Ekonometri, Buku Kedua. Jakarta: Ghalia Indonesia. 


\section{BAB 12}

\section{ANALISIS DISKRIMINAN}

\section{Sekílas Analisis Diskriminan}

Pada pembahasan sebelumnya telah dibahas mengenai regresi linear berganda (multiple regression). Dalam regresi linear berganda, variabel tak bebas bersifat metrik (interval atau rasio), sedangkan dalam analisis diskriminan variabel tak bebas bersifat non-metrik (kategori). Persamaan regresi linear berganda dapat digunakan untuk memprediksi atau mengestimasi nilai dari variabel tak bebas, sedangkan persamaan diskriminan dapat digunakan untuk memprediksi suatu objek masuk ke dalam salah satu kategori dari variabel tak bebas berdasarkan informasi dari objek tersebut. Pada analisis diskriminan, variabel bebas bersifat metrik (interval atau rasio). Hair dkk. (2010:232) menyatakan sebagai berikut.

"The basic purpose of discriminant analysis is to estimate the relationship between a single non-metric (categorical) dependent variable and a set of metric independent variables in this general form:

$$
\begin{aligned}
& Y_{1} \quad=X_{1}+X_{2}+X_{3}+\cdots+X_{n} \\
& \text { (non-metric) (metric)" }
\end{aligned}
$$

Analisis diskriminan dapat digunakan untuk menjawab pertanyaan sebagai berikut.

$\Rightarrow$ Apakah faktor jumlah jam belajar dalam sehari dan IQ mahasiswa dapat membedakan atau mengelompokkan antara mahasiswa dengan indeks prestasi kumulatif $<3$ dan $\geq 3$.

$\Rightarrow$ Apakah faktor jumlah kehadiran siswa dalam satu tahun dan rata-rata nilai pelajaran secara keseluruhan dapat membedakan atau mengelompokkan antara siswa yang naik kelas dan tinggal kelas.

Jika terdapat $k$ kategori dalam variabel tak bebas, serta terdapat $p$ variabel bebas atau prediktor, maka persamaan diskriminan yang dapat dibentuk sebanyak $\min (k-1, p)$. Sebagai contoh jika dalam variabel tak bebas terdapat 2 kategori dan melibatkan 5 variabel bebas, maka persamaan diskriminan yang dapat dibentuk sebanyak $\min (2-1,5)=$ $\min (1,5)=1$. Jika kategori dalam suatu variabel tak bebas lebih dari dua, maka disebut analisis diskriminan berganda (multiple discriminant analysis).

Analisis diskriminan dapat dilakukan dengan pendekatan direct method dan stepwise method. Pada pendekatan direct method mengestimasi persamaan diskriminan dengan cara memasukkan atau memproses seluruh variabel bebas secara bersamaan atau simultan. Dengan kata lain, pada pendekatan direct method tidak memperhatikan kekuatan untuk mendiskriminasi (discriminating power) dari masing-masing variabel bebas. Pendekatan ini cocok diterapkan jika berdasarkan penelitian atau model teori sebelumnya, peneliti ingin pengelompokkan didasarkan dengan menggunakan seluruh variabel bebas.

Pada pendekatan stepwise method, hanya variabel-variabel bebas yang memiliki discriminating power yang signifikan secara statistika dilibatkan dalam pembentukan model 
persamaan diskriminan. Pada pendekatan stepwise method menyeleksi variabel-variabel bebas manakah yang memiliki discriminating power yang cukup kuat dan lemah. Persamaan diskriminan yang dihasilkan dengan pendekatan stepwise method menggunakan variabelvariabel bebas yang memiliki discriminating power signifikan secara statistika.

\section{Uji Beda Rata-Rata berdasarkan Kategori-Kategori pada Variabel Tak Bebas dari Masing-Masing Varíabel Bebas}

Uji beda rata-rata berdasarkan kategori-kategori pada variabel tak bebas dari masing-masing variabel bebas dapat digunakan uji $F$. Untuk menentukan apakah perbedaan rata-rata berdasarkan kategori-kategori pada variabel tak bebas dari suatu variabel bebas signifikan atau tidak, dapat dilakukan dengan membandingkan nilai statistik dari uji $F$ terhadap nilai kritis berdasarkan tabel distribusi $F$. Sebelum menghitung nilai kritis $F$, terlebih dahulu menghitung nilai derajat bebas pembilang dan derajat bebas penyebut. Berikut rumus untuk menghitung nilai derajat bebas pembilang dan penyebut.

$$
\begin{aligned}
& \text { Derajat bebas pembilang }=k-1 \\
& \text { Derajat bebas penyebut }=n-k .
\end{aligned}
$$

Perhatikan bahwa $n$ menyatakan jumlah elemen dalam sampel dan $k$ menyatakan jumlah kategori pada variabel tak bebas. Andaikan pada variabel tak bebas terdiri atas 2 kategori, maka derajat bebas pembilang adalah $k-1=2-1=1$ dan derajat bebas penyebut adalah $30-2=28$. Misalkan tingkat signifikansi yang digunakan adalah $5 \%$. Maka nilai kritis $F$ dengan derajat bebas pembilang adalah 1 , derajat bebas penyebut adalah 28, dan tingkat signifikansi $5 \%$ adalah 4,196.

\section{Tabel 12.1}

\begin{tabular}{c|c|c|c|c|c|c|}
\hline$f_{\boldsymbol{x}}$ & \multicolumn{5}{|l}{$=\mathrm{FINV}(13, \mathrm{G} 3, \mathrm{H} 3)$} \\
\hline \hline $\mathrm{D}$ & $\mathrm{E}$ & $\mathrm{F}$ & $\mathrm{G}$ & $\mathrm{H}$ & $\mathrm{I}$ & \\
\hline & & & \multicolumn{2}{|c|}{ Derajat Bebas } & & \\
\cline { 4 - 7 } & & Pembilang & Penyebut & tingkat signifikansi & F Kritis/Tabel \\
\hline & & 1 & 28 & 0.05 & 4.195971707 \\
\hline
\end{tabular}

Tabel 12.1 menyajikan perhitungan nilai kritis $F$ dengan menggunakan bantuan Microsoft Excel. Berikut aturan pengambilan keputusan terhadap hipotesis berdasarkan uji $F$.

Jika nilai statistik dari uji $F \leq$ nilai kritis $F$, maka $H_{0}$ diterima dan $H_{1}$ ditolak. jika nilai statistik dari uji $F>$ nilai kritis $F$, maka $H_{0}$ ditolak dan $H_{1}$ diterima.

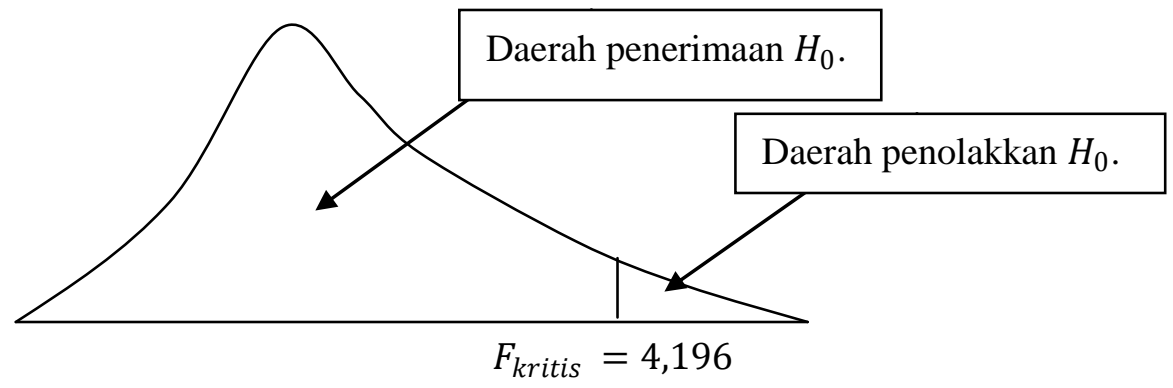


Hipotesis nol menyatakan perbedaan rata-rata berdasarkan kategori-kategori pada variabel tak bebas dari suatu variabel bebas tidak signifikan secara statistika. Pengambilan keputusan terhadap hipotesis juga dapat dilakukan dengan menggunakan pendekatan nilai probabilitas dari uji $F$. Nilai probabilitas dari uji $F$ dibandingkan dengan tingkat signifikansi yang digunakan. Berikut aturan pengambilan keputusan terhadap hipotesis berdasarkan pendekatan nilai probabilitas.

Jika nilai probabilitas $\geq$ tingkat signifikansi, maka $H_{0}$ diterima dan $H_{1}$ ditolak. Jika nilai probabilitas < tingkat signifikansi, maka $\mathrm{H}_{0}$ ditolak dan $\mathrm{H}_{1}$ diterima.

Tabel 12.2 merupakan contoh output SPSS untuk uji beda rata-rata berdasarkan kategorikategori pada variabel tak bebas dari masing-masing variabel bebas dengan uji $F$.

Tabel 12.2

\begin{tabular}{|c|c|c|c|c|c|}
\hline & $\begin{array}{l}\text { Wilks' } \\
\text { Lambda }\end{array}$ & $F$ & df1 & $\mathrm{df} 2$ & Sig. \\
\hline $\begin{array}{l}\text { Jumlah jam belajar } \\
\text { dalam sehari }\end{array}$ & .151 & 157.604 & 1 & 28 & .000 \\
\hline IQ mahasiswa & .086 & 297.897 & 1 & 28 & .000 \\
\hline Usia mahasiswa & .969 & .892 & 1 & 28 & .353 \\
\hline
\end{tabular}

Berdasarkan Tabel 12.2, perhatikan bahwa $d f 1$ merupakan derajat bebas pembilang dan $d f 2$ merupakan derajat bebas penyebut. Nilai Sig. merupakan nilai probabilitas. Jika terjadi perbedaan rata-rata yang signifikan secara statistika, maka variabel bebas tersebut diindikasi mampu mengelompokkan atau mendiskriminasi suatu pengamatan atau objek dengan baik, untuk masuk ke dalam salah satu dari kategori-kategori pada variabel tak bebas.

\section{Mengukur Kemampuan Varíabel-Varíabel Bebas yang Dígunakan pada Persamaan Dískriminan dalam Menjelaskan Varians (Variance) dari Variabel Tak Bebas}

Nilai korelasi kanonikal menyatakan suatu nilai yang mengukur keeratan hubungan (linear) antara nilai (skor) yang diperoleh berdasarkan persamaan diskriminan terhadap nilai dari variabel tak bebas (outcome) (lihat bagian share [1]). Kuadrat dari nilai korelasi kanonikal (canonical correlation) digunakan untuk mengukur kemampuan variabel-variabel bebas yang digunakan pada persamaan diskriminan dalam menjelaskan variance dari variabel tak bebas (Meyers dkk., 2005:273).

Kuadrat dari nilai korelasi kanonikal berkisar antara 0 dan 1 . Kuadrat dari korelasi kanonikal yang mendekati 1 menunjukkan variabel-variabel bebas yang digunakan pada persamaan diskriminan tersebut mampu dalam menjelaskan variance dari variabel tak bebas dengan baik. Sedangkan kuadrat dari nilai korelasi kanonikal yang mendekati 0 menunjukkan variabelvariabel bebas pada persamaan diskriminan tersebut kurang mampu dalam menjelaskan varians dari variabel tak bebas. Berdasarkan Tabel 12.3, nilai korelasi kanonikal sebesar 0,970 . 


\section{Tabel 12.3}

Eigemvalues

\begin{tabular}{|c|r|r|r|r|}
\hline Function & Eigenvalue & \% of Variance & Cumulative $\%$ & $\begin{array}{c}\text { Canonical } \\
\text { Correlation }\end{array}$ \\
\hline 1 & $15.680^{\circ}$ & 100.0 & 100.0 & .970 \\
\hline
\end{tabular}

a. First 1 canonical discriminant functions were used in the analvsis.

\section{Mengukur Kemampuan dan Menguji Signifikansi Persamaan Diskriminan dalam Pengelompokkan}

Kemampuan variabel-variabel bebas yang digunakan dalam persamaan diskriminan untuk mengelompokkan atau mendiskriminasi suatu pengamatan atau objek, untuk masuk ke dalam salah satu dari kategori-kategori pada variabel tak bebas, dapat diukur dengan nilai Wilks' Lambda. Nilai Wilk's Lambda merupakan suatu nilai yang menyatakan varians variabel tak bebas (berupa kategori-kategori/kelompok-kelompok) yang tidak terjelaskan oleh persamaan diskriminan yang melibatkan satu atau lebih variabel bebas. Nilai Wilks' Lambda berkisar di antara 0 dan 1 .

Nilai Wilks' Lambda yang mendekati 0 menunjukkan semakin baik kemampuan variabelvariabel yang digunakan dalam persamaan diskriminan untuk mengelompokkan atau mendiskriminasi suatu pengamatan atau objek, untuk masuk ke dalam salah satu dari kategori-kategori pada variabel tak bebas. Untuk menguji signifikansi dari persamaan diskriminan, dapat digunakan pendekatan uji chi-kuadrat.

Nilai statistik dari uji chi-kuadrat dibandingkan dengan nilai kritis chi-kuadrat berdasarkan tabel distribusi chi-kuadrat. Jika nilai statistik dari uji chi-kuadrat $>$ dari nilai kritis chikuadrat, maka kemampuan persamaan diskriminan dalam mengelompokkan atau mendiskriminasi suatu pengamatan atau objek, untuk masuk ke dalam salah satu dari kategori-kategori pada variabel tak bebas, signifikan secara statistika.

Pendekatan lain yang dapat digunakan adalah dengan membandingkan nilai probabilitas terhadap tingkat signifikansi $(\alpha)$. jika nilai probabilitas $<$ dari tingkat signifikansi, maka kemampuan persamaan diskriminan dalam mengelompokkan atau mendiskriminasi suatu pengamatan atau objek, untuk masuk ke dalam salah satu dari kategori-kategori pada variabel tak bebas, signifikan secara statistika. Tabel 12.4 menyajikan nilai Wilks' Lambda $(0,060)$, nilai statistik dari uji chi-kuadrat $(75,983)$ dan probabilitas atau Sig. $(0,000)$.

Tabel 12.4

Wilks' Lambda

\begin{tabular}{|c|r|r|r|r|}
\hline TestofFunction(s) & \multicolumn{1}{|c|}{$\begin{array}{c}\text { Wilks' } \\
\text { Lambda }\end{array}$} & Chi-square & \multicolumn{1}{c|}{ df } & Sig. \\
\hline 1 & .060 & 75.983 & 2 & .000 \\
\hline
\end{tabular}




\section{Contoh Kasus dalam Analisis Diskriminan}

Berikut diberikan contoh kasus yang dapat diselesaikan dengan pendekatan analisis diskriminan.

[1] Misalkan seorang guru ingin meneliti apakah jumlah ketidakhadiran ke sekolah, rata-rata nilai latihan, dan uang jajan siswa merupakan suatu faktor yang dapat membedakan atau mengelompokkan siswa masuk ke dalam kelompok siswa yang naik kelas atau tidak naik kelas. Berikut data yang telah dikumpulkan oleh guru tersebut (Tabel 12.5).

Tabel 12.5

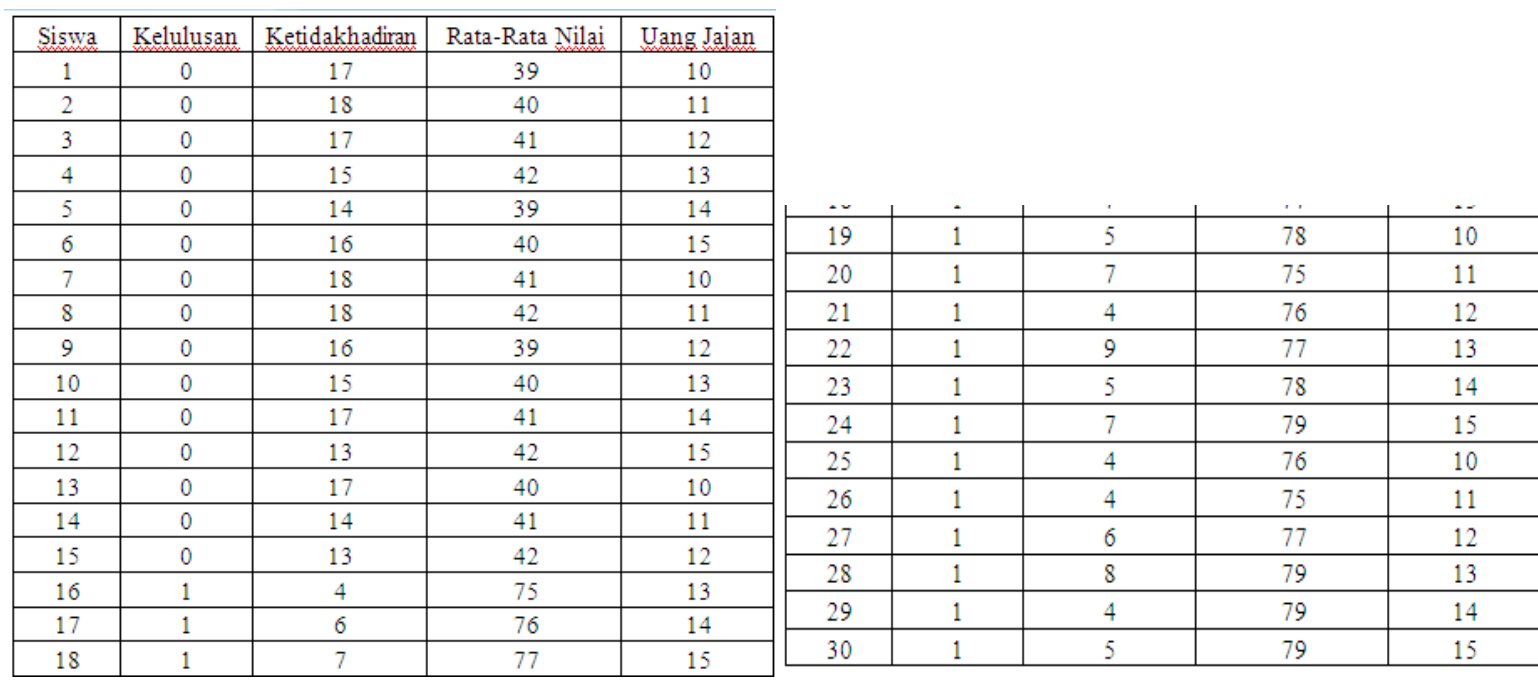

Berdasarkan data pada Tabel 12.5, jumlah siswa yang diteliti sebanyak 30 siswa. Pada Tabel 12.5 untuk variabel Kelulusan, nilai 0 menyatakan tidak naik kelas, sedangkan nilai 1 menyatakan naik kelas. Siswa dengan nomor urut 1 tidak naik kelas dengan jumlah ketidakhadiran 17 kali, rata-rata nilai latihan 39, dan uang jajan per hari Rp. 10000. Siswa dengan nomor urut 17 naik kelas dengan jumlah ketidakhadiran 6 kali, rata-rata nilai latihan 76, dan uang jajan per hari Rp. 14000.

Adapun hal-hal yang ingin diketahui guru tersebut adalah sebagai berikut.

$\Rightarrow$ Apakah jumlah ketidakhadiran merupakan faktor yang signifikan secara statistika untuk membedakan atau mengelompokkan antara siswa yang naik kelas dan yang tidak naik kelas.

$\Rightarrow$ Apakah rata-rata nilai latihan merupakan faktor yang signifikan secara statistika untuk membedakan atau mengelompokkan antara siswa yang naik kelas dan yang tidak naik kelas.

$\Rightarrow$ Apakah uang jajan merupakan faktor yang signifikan secara statistika untuk membedakan atau mengelompokkan antara siswa yang naik kelas dan yang tidak naik kelas. 


\section{Asumsi-Asumsí dalam Analisís Diskriminan}

Pada analisis analisis diskriminan (linear) terdapat beberapa asumsi yang dikenakan, antara lain asumsi normalitas multivariat dan asumsi kesamaan matriks-matriks kovarian.

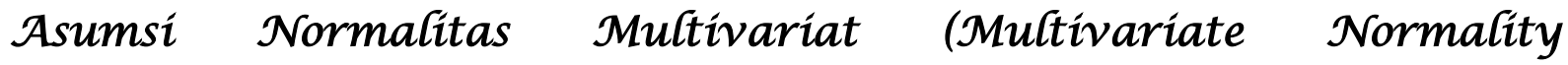 Assumption)}

Terdapat asumsi yang dikenakan pada penggunaan analisis diskriminan linear, yakni asumsi normalitas multivariat (multivariate normality assumption). Malhotra dan Birks (2006:550) menyatakan sebagai berikut.

"The assumptions in discriminant analysis are that each of the groups is a sample from a multivariate normal population and that all the populations have the same covariance matrix".

Normalitas untuk setiap variabel-variabel secara terpisah (separately) merupakan suatu syarat yang diperlukan (necessary), namun tidak cukup (but not sufficient), untuk tercapainya normalitas multivariat. Untuk setiap variabel secara individu (individual) harus berdistribusi normal (must be normally distributed) untuk mengikuti (follow) distribusi normal multivariat. Stevens (2009:222) menyatakan sebagai berikut.

"The multivariate normality assumption is a much more stringent assumption than the corresponding assumption of normality on a single variable in ANOVA. Although it is difficult to completely characterize multivariate normality, normality on each of the variables separately is a necessary, but not sufficient, condition for multivariate normality to hold. That is, each of the individual variables must be normally distributed for the variables to follow a multivariate normal distribution".

Ketika asumsi normalitas multivariat tidak terpenuhi, hal tersebut dapat menimbulkan masalah dalam estimasi/prediksi dari persamaan diskriminan. Stevens (2009:268) menyatakan sebagai berikut.

"For the classification problem, it is assumed that the two populations are multivariate normal and have the same covariance matrix".

Namun terdapat alternatif lain yang dapat digunakan sebagai pengganti analisis diskriminan, yakni regresi logistik. Dalam penggunaan regresi logistik tidak dikenakan asumsi normalitas untuk masing-masing variabel bebas.

Untuk menguji asumsi normalitas populasi dari masing-masing sampel variabel bebas, dapat digunakan uji Kolmogorov-Smirnov. Hipotesis nol menyatakan sampel yang diambil berasal dari populasi yang berdistribusi normal, sedangkan hipotesis alternatif menyatakan sampel yang diambil tidak berasal dari populasi yang berdistribusi normal. Pengambilan keputusan terhadap hipotesis dapat dilakukan dengan membandingkan nilai probabilitas dari uji Kolmogorov-Smirnov terhadap tingkat signifikansi yang digunakan. Berikut aturan pengambilan keputusan terhadap hipotesis dengan pendekatan probabilitas.

Jika nilai probabilitas $\geq$ tingkat signifikansi, maka $H_{0}$ diterima dan $H_{1}$ ditolak. Jika nilai probabilitas < tingkat signifikansi, maka $H_{0}$ ditolak dan $H_{1}$ diterima. 
Tabel 12.6 menyajikan nilai probabilitas dari uji Kolmogorov-Smirnov.

\section{Tabel 12.6}

\begin{tabular}{|ll|r|c|}
\cline { 3 - 3 } & & & Nilai Asymp. Sig. (2-tailed) \\
Most Extreme Differences & Std. Deviation & .07412 & Absolute \\
& Positive & .280 & $=0,412$ merupakan nilai \\
& Negative & .174 & probabilitas dari uji \\
Kolmogorow-Smirnov $z$ & & .280 & Kolmogorov-Smirnov. \\
Asymp. Sig. (2-tailed) & & .812 & \\
\hline
\end{tabular}

\section{Asumsi Kesamaan Matriks-Matriks Kovarian (Assumption of Equal Covariance Matrices)}

Selain asumsi normalitas multivariat, terdapat asumsi lain yang dikenakan pada penggunaan analisis diskriminan, yakni asumsi kesamaan matriks-matriks kovarian populasi (equal population covariance matrices). Untuk menguji asumsi kesaman matriks-matriks kovarian populasi dapat digunakan uji Box's M. Hipotesis nol menyatakan tidak terdapat perbedaan yang signifikan secara statistika di antara matriks-matriks kovarian populasi (equal population covariance matrices). Hipotesis alternatif menyatakan terdapat perbedaan yang signifikan secara statistika di antara matriks-matriks kovarian populasi. Pengambilan keputusan terhadap hipotesis dapat digunakan pendekatan nilai probabilitas (Sig.). Nilai probabilitas tersebut dibandingkan dengan tingkat signifikansi $(\alpha)$. Tabel 12.7 menyajikan nilai probabilitas dan nilai statistik dari uji Box’s M.

Jika nilai probabilitas $\geq$ tingkat signifikansi, maka $H_{0}$ diterima dan $H_{1}$ ditolak. Jika nilai probabilitas < tingkat signifikansi, maka $H_{0}$ ditolak dan $H_{1}$ diterima.

Tabel 12.7

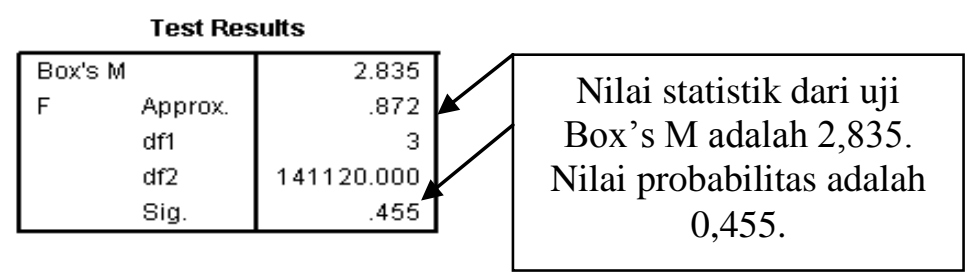




\section{PENYELESAIAN DALAM SPSS}

Misalkan seorang peneliti ingin meneliti apakah faktor jumlah jam belajar dalam sehari, intelligence quotient (IQ), dan uang jajan mahasiswa dapat membedakan atau mengelompokkan mahasiswa untuk masuk ke dalam kelompok mahasiswa dengan indeks prestasi kumulatif (IPK) $\geq 3$ atau IPK $<3$. Berikut data yang telah dikumpulkan oleh peneliti tersebut (Tabel 12.1).

\section{Tabel 12.1}

\begin{tabular}{|c|c|c|c|c|}
\hline Mahasiswa & IPK & Jam & IQ & Usia \\
\hline 1 & 0 & 7 & 95 & 20 \\
\hline 2 & 0 & 8 & 96 & 21 \\
\hline 3 & 0 & 7 & 97 & 22 \\
\hline 4 & 0 & 5 & 98 & 23 \\
\hline 5 & 0 & 4 & 95 & 24 \\
\hline 6 & 0 & 6 & 96 & 25 \\
\hline 7 & 0 & 8 & 97 & 20 \\
\hline 8 & 0 & 8 & 98 & 21 \\
\hline 9 & 0 & 6 & 95 & 22 \\
\hline 10 & 0 & 5 & 96 & 23 \\
\hline 11 & 0 & 7 & 97 & 24 \\
\hline 12 & 0 & 3 & 98 & 25 \\
\hline 13 & 0 & 7 & 96 & 20 \\
\hline 14 & 0 & 4 & 97 & 21 \\
\hline 15 & 0 & 3 & 98 & 22 \\
\hline 16 & 1 & 12 & 103 & 23 \\
\hline 17 & 1 & 14 & 104 & 24 \\
\hline 18 & 1 & 15 & 105 & 25 \\
\hline
\end{tabular}

\begin{tabular}{|l|l|l|l|l|}
\hline 19 & 1 & 13 & 106 & 20 \\
\hline 20 & 1 & 15 & 103 & 21 \\
\hline 21 & 1 & 12 & 104 & 22 \\
\hline 22 & 1 & 17 & 105 & 23 \\
\hline 23 & 1 & 13 & 106 & 24 \\
\hline 24 & 1 & 15 & 107 & 25 \\
\hline 25 & 1 & 12 & 104 & 20 \\
\hline 26 & 1 & 12 & 103 & 21 \\
\hline 27 & 1 & 14 & 105 & 22 \\
\hline 28 & 1 & 16 & 107 & 23 \\
\hline 29 & 1 & 12 & 107 & 24 \\
\hline 30 & 1 & 13 & 107 & 25 \\
\hline
\end{tabular}

Berdasarkan data pada Tabel 12.1, jumlah mahasiswa yang diteliti sebanyak 30 mahasiswa. Pada Tabel 12.1 untuk variabel IPK, nilai 0 menyatakan IPK $<3$, sedangkan nilai 1 menyatakan nilai IPK $\geq 3$. Mahasiswa dengan nomor urut 1 memperoleh IPK $<3$ dengan jumlah jam belajar dalam sehari 7 jam, memiliki IQ 95, dan berusia 20 tahun. Mahasiswa dengan nomor urut 17 memperoleh IPK $\geq 3$ dengan jumlah jam belajar dalam sehari 14 jam, memiliki IQ 104, dan berusia 24 tahun.

Berikut hal-hal yang ingin diketahui oleh peneliti.

$\Rightarrow$ Apakah jumlah jam belajar dalam sehari merupakan faktor yang signifikan secara statistika untuk mengelompokkan atau membedakan antara mahasiswa dengan IPK < 3 dan IPK $\geq 3$.

$\Rightarrow$ Apakah IQ merupakan faktor yang signifikan secara statistika untuk mengelompokkan atau membedakan antara mahasiswa dengan IPK $<3$ dan IPK $\geq 3$.

$\Rightarrow$ Apakah usia merupakan faktor yang signifikan secara statistika untuk mengelompokkan atau membedakan antara mahasiswa dengan IPK $<3$ dan IPK $\geq 3$.

$\Rightarrow$ Faktor manakah yang memiliki kontribusi paling besar dalam hal kemampuannya untuk membedakan antara mahasiswa dengan IPK $<3$ dan IPK $\geq 3$. 
Permasalahan tersebut akan diselesaikan dengan analisis diskriminan pendekatan stepwise method dalam SPSS. Pendekatan stepwise method digunakan dengan maksud untuk menyeleksi variabel-variabel bebas manakah yang memiliki kekuatan (power) yang cukup signifikan secara statistika dalam hal membedakan atau mengelompokkan ke dalam kategorikategori dari variabel tak bebas. Bangun data pada Tabel 12.1 dalam SPSS seperti pada Gambar 12.1.

\begin{tabular}{|c|c|c|c|c|c|c|c|c|c|}
\hline & IPK & Jam & 10 & Usia & & & & & \\
\hline 1 & 0 & 7 & 95 & 20 & 15 & 0 & 3 & 98 & 22 \\
\hline 2 & 0 & 8 & 96 & 21 & 16 & 1 & 12 & 103 & 23 \\
\hline 3 & 0 & 7 & 97 & 22 & 17 & 1 & 14 & 104 & 24 \\
\hline 4 & 0 & 5 & 98 & 23 & 18 & 1 & 15 & 105 & 25 \\
\hline 5 & 0 & 4 & 95 & 24 & 19 & 1 & 13 & 106 & 20 \\
\hline 6 & 0 & 6 & 96 & 25 & 20 & 1 & 15 & 103 & 21 \\
\hline 7 & 0 & 8 & 97 & 20 & 21 & 1 & 12 & 104 & 22 \\
\hline 8 & 0 & 8 & 98 & 21 & 22 & 1 & 17 & 105 & 23 \\
\hline 9 & 0 & 6 & 95 & 22 & 23 & 1 & 13 & 106 & 24 \\
\hline 10 & 0 & 5 & 96 & 23 & 24 & 1 & 15 & 107 & 25 \\
\hline 11 & 0 & 7 & 97 & 24 & 25 & 1 & 12 & 104 & 20 \\
\hline 12 & 0 & 3 & 98 & 25 & 26 & 1 & 12 & 103 & 21 \\
\hline 13 & 0 & 7 & 96 & 20 & 27 & 1 & 14 & 105 & 22 \\
\hline 14 & 0 & 4 & 97 & 21 & 28 & 1 & 16 & 107 & 23 \\
\hline 15 & 0 & 3 & 98 & 22 & 29 & 1 & 12 & 107 & 24 \\
\hline 16 & 1 & 12 & 103 & 23 & 30 & 1 & 13 & 107 & 25 \\
\hline 17 & 1 & 14 & 104 & 24 & 31 & & & & \\
\hline
\end{tabular}

\begin{tabular}{|c|c|c|c|c|c|c|c|c|c|}
\hline & IPK & Jam & $1 Q$ & Usia & & & & & \\
\hline 1 & $\mathrm{IPK}<3$ & 7 & 95 & 20 & 15 & $\mathrm{IPK}<3$ & 3 & 98 & 22 \\
\hline 2 & $\mathrm{IPK}<3$ & 8 & 96 & 21 & 16 & $\mathrm{IPK}>=3$ & 12 & 103 & 23 \\
\hline 3 & $\mathrm{IPK}<3$ & 7 & 97 & 22 & 17 & $\mid \mathrm{PK}>=3$ & 14 & 104 & 24 \\
\hline 4 & $\mathrm{IPK}<3$ & 5 & 98 & 23 & 18 & $\mathrm{IPK}>=3$ & 15 & 105 & 25 \\
\hline 5 & $\mathrm{IPK}<3$ & 4 & 95 & 24 & 19 & $\mathrm{IPK}>=3$ & 13 & 106 & 20 \\
\hline 6 & $\mathrm{IPK}<3$ & 6 & 96 & 25 & 20 & $\mid \mathrm{PK}>=3$ & 15 & 103 & 21 \\
\hline 7 & $\mathrm{IPK}<3$ & 8 & 97 & 20 & 21 & $\mathrm{IPK}>=3$ & 12 & 104 & 22 \\
\hline 8 & $\mathrm{IPK}<3$ & 8 & 98 & 21 & 22 & $\mathrm{IPK}>=3$ & 17 & 105 & 23 \\
\hline 9 & $\mathrm{IPK}<3$ & 6 & 95 & 22 & 23 & $\mid \mathrm{PK}>=3$ & 13 & 106 & 24 \\
\hline 10 & $\mathrm{IPK}<3$ & 5 & 96 & 23 & 24 & $\mathrm{IPK}>=3$ & 15 & 107 & 25 \\
\hline 11 & $\mathrm{IPK}<3$ & 7 & 97 & 24 & 25 & $\mathrm{IPK}>=3$ & 12 & 104 & 20 \\
\hline 12 & $\mathrm{IPK}<3$ & 3 & 98 & 25 & 26 & $\mid \mathrm{PK}>=3$ & 12 & 103 & 21 \\
\hline 13 & $\mathrm{IPK}<3$ & 7 & 96 & 20 & 27 & $\mathrm{IPK}>=3$ & 14 & 105 & 22 \\
\hline 14 & $\mathrm{IPK}<3$ & 4 & 97 & 21 & 28 & $\mid \mathrm{PK}>=3$ & 16 & 107 & 23 \\
\hline 15 & $\mathrm{IPK}<3$ & 3 & 98 & 22 & 29 & $\mid \mathrm{PK}>=3$ & 12 & 107 & 24 \\
\hline 16 & $\mathrm{IPK}>=3$ & 12 & 103 & 23 & 30 & $\mathrm{IPK}>=3$ & 13 & 107 & 25 \\
\hline 17 & $\mathrm{IPK}>=3$ & 14 & 104 & 24 & 31 & & & & \\
\hline
\end{tabular}

Gambar 12.1

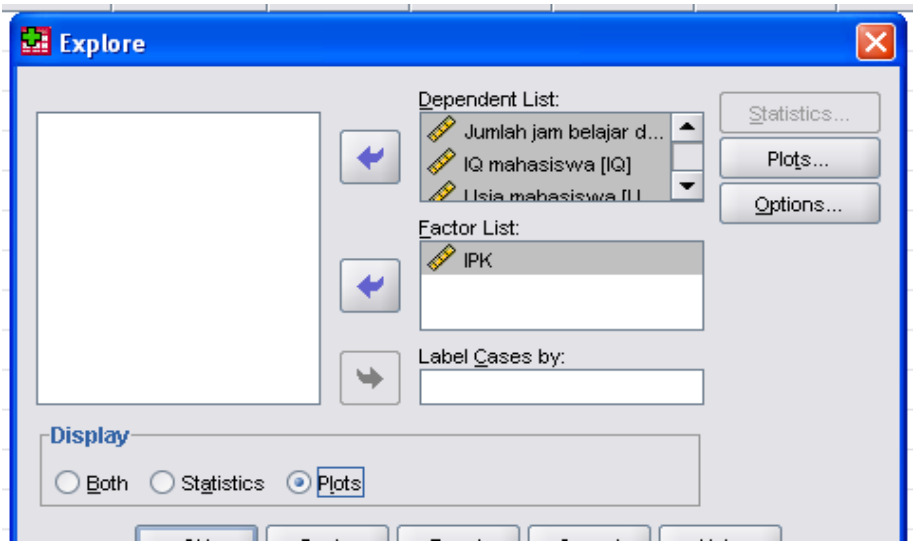

Gambar 12.2 
Pada variabel IPK, beri Value 0 untuk Label IPK $<3$ dan Value 1 untuk Label $>=3$. Sebelum menggunakan analisis diskriminan, berikut akan diuji asumsi normalitas multivariat dan kesamaan matriks-matriks kovarian populasi. Pengujian asumsi normalitas multivariat akan didekati dengan menguji normalitas populasi berdasarkan masing-masing variabel bebas untuk setiap kategori/kelompok.

Pilih Analyze $=>$ Descriptive Statistics $\Rightarrow$ Explore, sehingga muncul kotak dialog Explore (Gambar 12.2). Masukkan variabel jam, IQ, dan usia ke dalam Dependent List dan variabel IPK pada Factor List. Selanjutnya pilih Plots, sehingga muncul kotak dialog Explore: Plots. Pilih/centang Normality plots with tests. Kemudian pilih Continue. Pada Display pilih Plots. Selanjutnya pilih OK. Output SPSS terlihat pada Tabel 12.2.

\section{Tabel 12.2}

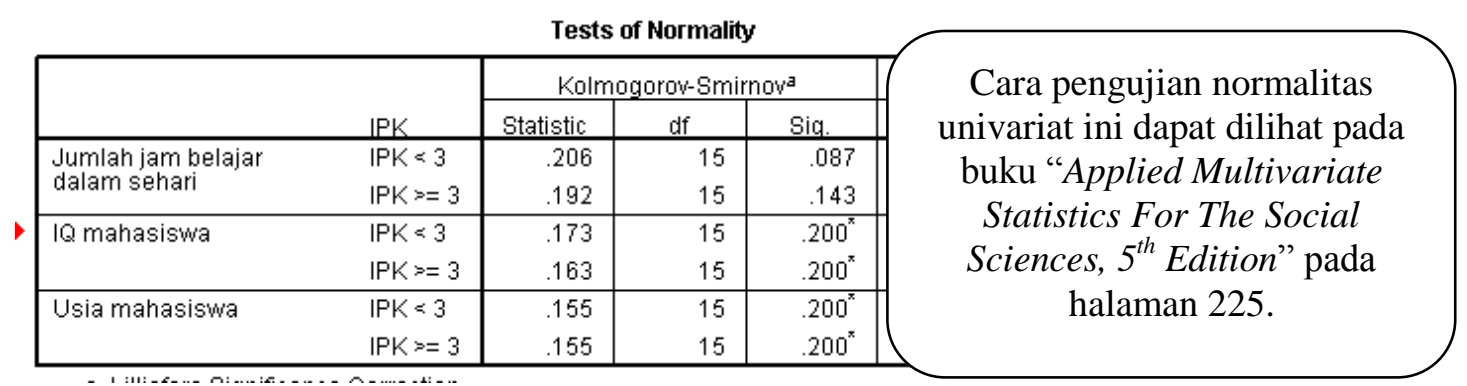

Berdasarkan informasi pada Tabel 12.2, yakni Tests of Normality, akan diperiksa apakah asumsi normalitas untuk masing-masing variabel bebas dalam setiap kelompokkelompok/kategori-kategori dipenuhi atau tidak. Untuk menentukan apakah asumsi normalitas terpenuhi atau tidak, dapat dilakukan dengan membandingkan nilai Sig. dari uji Kolmogorov-Smirnov terhadap tingkat signifikansi $(\alpha)$ yang digunakan.

Perhatikan bahwa diketahui nilai Sig. dari uji Kolmogorov-Smirnov untuk masing-masing variabel bebas dalam setiap kelompok-kelompok/kategori-kategori lebih besar dari 0,05, maka disimpulkan bahwa asumsi normalitas univariat dipenuhi.

Selanjutnya akan diperiksa asumsi kesamaan matriks-matriks kovarian populasi. Pilih Analyze $\Rightarrow$ Classify $=>$ Discriminant, sehingga muncul kotak dialog Discriminant Analysis (Gambar 12.3). Pilih Use stepwise method. Selanjutnya masukkan variabel Jam, IQ, dan Usia pada Independent, sedangkan variabel IPK pada Grouping Variable.

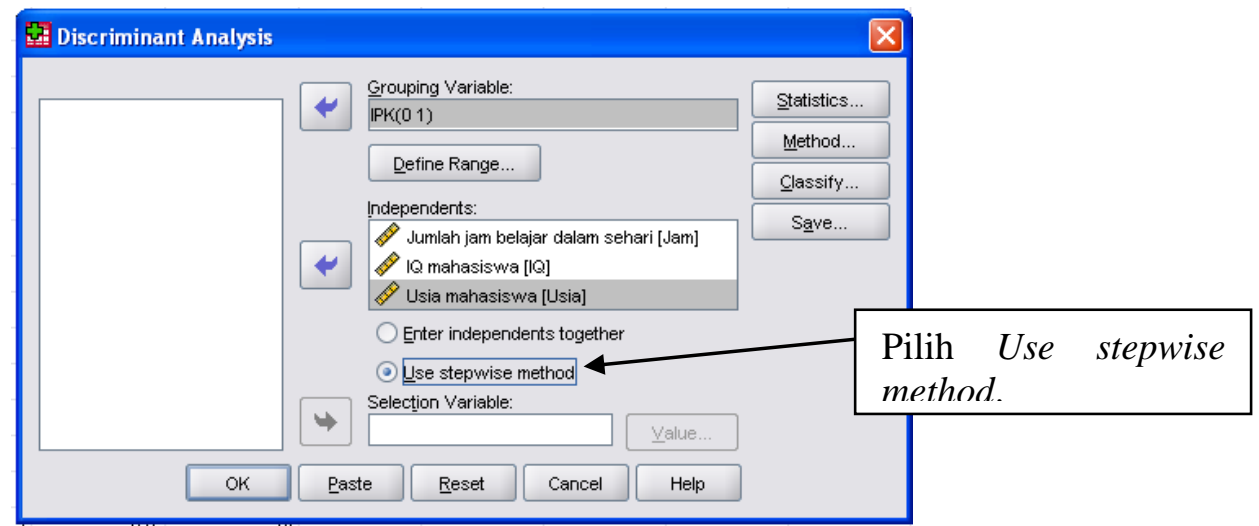

Gambar 12.3 
Kemudian pilih Define Range, sehingga muncul kotak dialog Discriminant Analysis: Define Range (Gambar 12.4). Pada kotak dialog Discriminant Analysis: Define Range (Gambar 12.4), isi 0 untuk Minimum dan isi 1 untuk Maximum. Selanjutnya pilih Continue. Kemudian pilih Statistics, sehingga muncul kotak dialog Discriminant Analysis: Statistics (Gambar 12.5). Pada kotak dialog Discriminant Analysis: Statistics (Gambar 12.5), pilih Means, Univariate ANOVAs, Box's M dan Unstandardized. Kemudian pilih Continue.

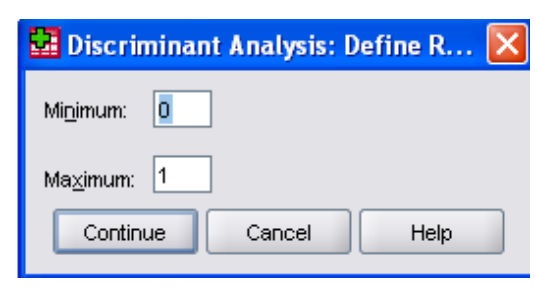

Gambar 12.4

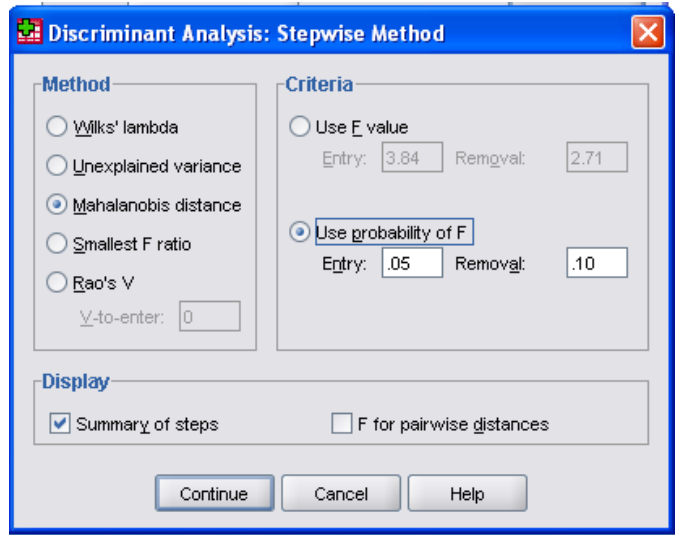

Gambar 12.6

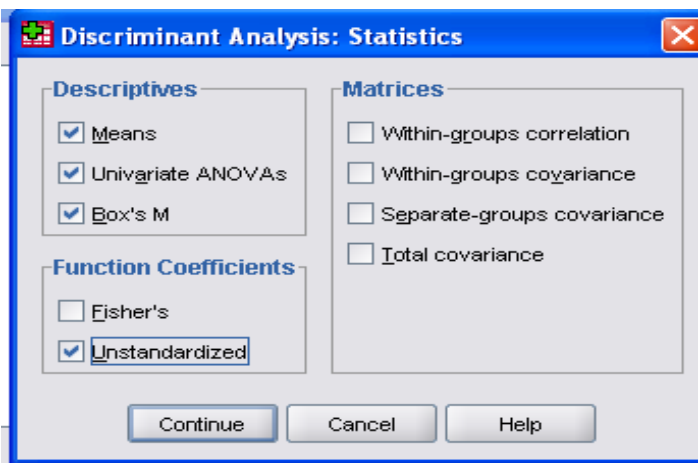

Gambar 12.5

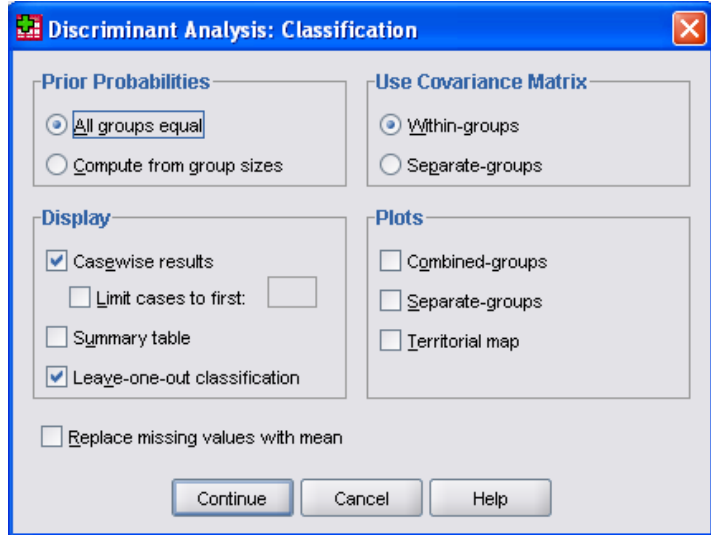

Gambar 12.7

Selanjutnya pilih Method, sehingga muncul kotak dialog Discriminant Analysis: Stepwise Method (Gambar 12.6). Pada kotak dialog Discriminant Analysis: Stepwise Method (Gambar 12.6), pilih Mahalanobis distance dan Use probability of F. Kemudian pilih Summary of steps pada Display dan Continue.

Pilih Classify, sehingga muncul kotak dialog Discriminant Analysis: Clasiffication (Gambar 12.7). Pada kotak dialog Discriminant Analysis: Classification (Gambar 12.7), pilih Casewise results dan Leave-one-out classification pada Display (Gambar 12.7). Kemudian pilih Continue dan OK. Berikut hasil berdasarkan SPSS.

Tabel 12.3

\begin{tabular}{|ll|r|}
\hline \multicolumn{3}{|c|}{ Test Results } \\
\hline Box's MI & 2.835 \\
F & Approx. & .872 \\
& df1 & 3 \\
& df2 & 141120.000 \\
Sig. & .455 \\
\hline
\end{tabular}


Berdasarkan Tabel 12.3 (Test Results), berikut akan diuji asumsi kesamaan matriks-matriks kovarian. Hipotesis nol menyatakan tidak terjadi perbedaan yang signifikan secara statistika di antara matriks-matriks kovarian populasi (equal population covariance matrices), sedangkan hipotesis alternatif menyatakan terjadi perbedaan yang signifikan secara statistika di antara matriks-matriks kovarian populasi. Pengambilan keputusan terhadap hipotesis dapat digunakan pendekatan nilai probabilitas (Sig.). Nilai probabilitas tersebut dibandingkan dengan tingkat signifikansi $(\alpha)$. Berikut aturan pengambilan keputusan terhadap hipotesis dengan pendekatan probabilitas.

Jika nilai probabilitas $\geq$ tingkat signifikansi, maka $H_{0}$ diterima dan $H_{1}$ ditolak. Jika nilai probabilitas < tingkat signifikansi, maka $\mathrm{H}_{0}$ ditolak dan $\mathrm{H}_{1}$ diterima.

Berdasarkan Tabel 12.3 diketahui nilai Sig. adalah 0,455. Karena nilai Sig. $(0,455)$ lebih besar dibandingkan tingkat signifikansi $(0,05)$, maka hipotesis nol diterima dan hipotesis alternatif ditolak. Hal ini berarti asumsi kesamaan matriks-matriks kovarian populasi dipenuhi.

\section{Tabel 12.4}

\begin{tabular}{|c|c|c|c|c|c|}
\hline \multicolumn{6}{|c|}{ Group Statistics } \\
\hline & & \multirow[b]{2}{*}{ Mean } & \multirow[b]{2}{*}{ Std. Deviation } & \multicolumn{2}{|c|}{ Valid N (listwise) } \\
\hline \multicolumn{2}{|l|}{ IPK } & & & Unweighted & Weighted \\
\hline \multirow[t]{3}{*}{$\mathrm{IPK}<3$} & $\begin{array}{l}\text { Jumlah jam belajar } \\
\text { dalam sehari }\end{array}$ & 5.87 & 1.767 & 15 & 15.000 \\
\hline & IQ mahasiswa & 96.60 & 1.121 & 15 & 15.000 \\
\hline & Usia mahasiswa & 22.20 & 1.740 & 15 & 15.000 \\
\hline \multirow[t]{3}{*}{$\mathrm{IPK}>=3$} & $\begin{array}{l}\text { Jumlah jam belajar } \\
\text { dalam sehari }\end{array}$ & 13.67 & 1.633 & 15 & 15.000 \\
\hline & IQ mahasiswa & 105.07 & 1.534 & 15 & 15.000 \\
\hline & Usia mahasiswa & 22.80 & 1.740 & 15 & 15.000 \\
\hline \multirow[t]{3}{*}{ Total } & $\begin{array}{l}\text { Jumlah jam belajar } \\
\text { dalam sehari }\end{array}$ & 9.77 & 4.305 & 30 & 30.000 \\
\hline & IQ mahasiswa & 100.83 & 4.504 & 30 & 30.000 \\
\hline & Usia mahasiswa & 22.50 & 1.737 & 30 & 30.000 \\
\hline
\end{tabular}

Berdasarkan Tabel 12.4 (Group Statistics) dapat ditarik informasi sebagai berikut.

$\Rightarrow$ Untuk variabel Jam (jumlah jam belajar dalam sehari), rata-rata jumlah jam belajar dalam sehari dari mahasiswa dengan IPK $<3$ adalah 5,87 jam per hari, sedangkan rata-rata jumlah jam belajar dalam sehari dari mahasiswa dengan IPK $\geq 3$ adalah 13,67 jam per hari. Perhatikan bahwa secara rata-rata, terlihat perbedaan yang begitu mencolok dalam hal jumlah jam belajar dalam sehari antara mahasiswa dengan IPK < 3 dan mahasiswa dengan IPK $\geq 3$. Secara rata-rata, mahasiswa dengan IPK $\geq 3$ menghabiskan waktu untuk belajar dalam sehari lebih lama, dibandingkan dengan mahasiswa dengan IPK $<3$. Perhatikan bahwa perbedaan rata-rata yang terjadi di antara dua kelompok tersebut (IPK $<3$ dan IPK $\geq 3$ ) perlu diuji untuk menentukan apakah perbedaan tersebut signifikan atau tidak secara statistika.

$\Rightarrow$ Untuk variabel IQ, rata-rata IQ mahasiswa dengan IPK $<3$ adalah 96,60, sedangkan rata-rata IQ mahasiswa dengan IPK $\geq 3$ adalah 105,07. Perhatikan bahwa secara ratarata, terlihat perbedaan yang cukup mencolok dalam hal IQ antara mahasiswa dengan IPK $<3$ dan mahasiswa dengan IPK $\geq 3$. Secara rata-rata, IQ mahasiswa dengan IPK $\geq 3$ lebih tinggi dibandingkan dengan IQ mahasiswa dengan IPK $<3$. Perhatikan bahwa perbedaan rata-rata yang terjadi di antara dua kelompok tersebut perlu diuji untuk menentukan apakah perbedaan tersebut signifikan atau tidak secara statistika. 
$\Rightarrow$ Untuk variabel Usia, rata-rata usia mahasiswa dengan IPK $<3$ adalah 22,20, sedangkan rata-rata usia mahasiswa dengan IPK $\geq 3$ adalah 22,80. Perhatikan bahwa secara rata-rata, terlihat perbedaan dalam hal usia antara mahasiswa dengan IPK $<3$ dan mahasiswa dengan IPK $\geq 3$. Secara rata-rata, usia mahasiswa dengan IPK $\geq 3$ lebih tinggi dibandingkan dengan usia mahasiswa dengan IPK $<3$. Perhatikan bahwa perbedaan rata-rata yang terjadi di antara dua kelompok tersebut perlu diuji untuk menentukan apakah perbedaan tersebut signifikan atau tidak secara statistika.

Tabel 12.5

\begin{tabular}{|c|c|c|c|c|c|c|}
\hline \multicolumn{6}{|c|}{ Tests of Equality of Group Means } & \multirow{5}{*}{$\begin{array}{c}\text { Hasil pada Tabel 12,5 } \\
\text { dapat diperoleh } \\
\text { dengan menggunakan } \\
\text { metode analisis } \\
\text { varians. }\end{array}$} \\
\hline & $\begin{array}{l}\text { Wilks' } \\
\text { Lambda }\end{array}$ & $\mathrm{F}$ & df1 & $\mathrm{df} 2$ & Sig. & \\
\hline $\begin{array}{l}\text { Jumlah jam belajar } \\
\text { dalam sehari }\end{array}$ & .151 & 157.604 & $\overline{1}$ & 28 & .000 & \\
\hline IQ mahasiswa & .086 & 297.897 & 1 & 28 & .000 & \\
\hline Usia mahasiswa & .969 & .892 & 1 & 28 & .353 & \\
\hline
\end{tabular}

Berdasarkan informasi pada Tabel 12.5 (Tests of Equality of Group Means), berikut akan diuji apakah perbedaan rata-rata dari dua kelompok, yakni kelompok mahasiswa dengan IPK < 3 dan kelompok mahasiswa dengan IPK $\geq 3$ berdasarkan masing-masing variabel bebas berbeda secara signifikan atau tidak. Untuk menentukan apakah perbedaan rata-rata dari suatu variabel bebas berdasarkan kelompok mahasiswa dengan IPK $<3$ dan IPK $\geq 3$ signifikan atau tidak (secara statistika), bandingkan nilai Sig dengan tingkat signifikansi $(\alpha)$ yang digunakan. Jika nilai $\operatorname{Sig} \geq$ tingkat signifikansi $(\alpha)$, maka perbedaan rata-rata yang terjadi signifikan secara statistika. Namun jika nilai Sig $<$ tingkat signifikansi $(\alpha)$, maka perbedaan rata-rata yang terjadi tidak signifikan secara statistika. Jika terjadi perbedaan rata-rata yang signifikan secara statistika dari suatu variabel bebas berdasarkan kelompok mahasiswa dengan IPK $<3$ dan IPK $\geq 3$, maka diindikasi variabel bebas tersebut berpengaruh dalam hal pengelompokkan.

$\Rightarrow$ Nilai Sig. untuk variabel Jam adalah 0,000. Karena nilai Sig. tersebut lebih kecil dibandingkan tingkat signifikansi, yakni $\alpha=0,05$, maka perbedaan rata-rata jumlah jam belajar dalam sehari antara mahasiswa dengan IPK $<3$ dan mahasiswa IPK $\geq 3$ signifikan secara statistika.

$\Rightarrow$ Nilai Sig. untuk variabel IQ adalah 0,000. Karena nilai Sig. tersebut lebih kecil dibandingkan tingkat signifikansi, yakni $\alpha=0,05$, maka perbedaan rata-rata IQ antara mahasiswa dengan IPK $<3$ dan mahasiswa IPK $\geq 3$ signifikan secara statistika.

$\Rightarrow$ Nilai Sig. untuk variabel Usia adalah 0,353. Karena nilai Sig. tersebut lebih besar dibandingkan tingkat signifikansi, yakni $\alpha=0,05$, maka perbedaan rata-rata usia antara mahasiswa dengan IPK $<3$ dan mahasiswa IPK $\geq 3$ tidak signifikan secara statistika.

Tabel 12.6

\begin{tabular}{|c|c|c|c|c|c|c|c|}
\hline \multirow[b]{3}{*}{ Sten } & \multirow[b]{3}{*}{ Entered } & \multicolumn{6}{|c|}{ Min. D Squared } \\
\hline & & \multirow[b]{2}{*}{ Statistic } & \multirow[b]{2}{*}{$\begin{array}{c}\text { Between } \\
\text { Grouns }\end{array}$} & \multicolumn{4}{|c|}{ Exact $F$} \\
\hline & & & & Statistic & df1 & $\mathrm{df} 2$ & Sig. \\
\hline 1 & $\begin{array}{l}\mathrm{IQ} \\
\text { mahasiswa }\end{array}$ & 39.720 & $\begin{array}{l}\text { IPK }<3 \text { and } \\
\text { IPK }>=3\end{array}$ & 297.897 & 1 & 28.000 & $1.861 \mathrm{E}-16$ \\
\hline 2 & $\begin{array}{l}\text { Jumlah jam } \\
\text { belajar dalam }\end{array}$ & 58.538 & $\begin{array}{l}\mathrm{IPK}=3 \text { and } \\
\mathrm{IPK} \gg=3\end{array}$ & 211.678 & 2 & 27.000 & $3.165 \mathrm{E}-17$ \\
\hline
\end{tabular}


Berdasarkan Tabel 12.6 (Variables Enter/Removed) dapat ditarik informasi bahwa variabel IQ dan Jam diikutsertakan untuk proses pembentukan persamaan diskriminan, sedangkan variabel Usia tidak diikutsertakan. Perhatikan bahwa berdasarkan hasil sebelumnya, yakni pada Tabel Test of Equality of Group Means, diketahui bahwa perbedaan rata-rata dari variabel IQ dan Jam berdasarkan kelompok mahasiswa dengan IPK $<3$ dan IPK $\geq 3$ signifikan secara statistika, namun tidak demikian dengan variabel Usia.

\section{Tabel 12.7}

\begin{tabular}{|c|c|c|c|c|c|}
\hline \multicolumn{6}{|c|}{ Variables in the Analysis } \\
\hline \multicolumn{2}{|c|}{ Step } & Tolerance & $\begin{array}{l}\text { Sig. of } \mathrm{F} \text { to } \\
\text { Remove }\end{array}$ & $\begin{array}{c}\text { Min. D } \\
\text { Squared }\end{array}$ & $\begin{array}{l}\text { Between } \\
\text { Groups }\end{array}$ \\
\hline 1 & $1 Q$ mahasiswa & 1.000 & .000 & & \\
\hline \multirow[t]{2}{*}{2} & $\mathrm{IQ}$ mahasiswa & .998 & .000 & 21.014 & $\begin{array}{l}\text { IPK }<3 \text { and } \\
I P K==3\end{array}$ \\
\hline & $\begin{array}{l}\text { Jumlah jam belajar } \\
\text { dalam sehari }\end{array}$ & .998 & .002 & 39.720 & $\begin{array}{l}\text { IPK }=3 \text { and } \\
I P K==3\end{array}$ \\
\hline
\end{tabular}

Berdasarkan Tabel 12.7 (Variables in the Analysis) dapat ditarik informasi sebagai berikut.

$\Rightarrow$ Dalam Tabel Variables in the Analysis, pada langkah pertama (step 1), variabel yang dipilih pertama kali untuk proses analisis adalah variabel IQ. Dalam hal ini variabel IQ menempati urutan pertama dalam hal kemampuannya untuk mengelompokkan atau membedakan antara mahasiswa dengan IPK $<3$ dan mahasiswa dengan IPK $\geq 3$.

$\Rightarrow$ Selanjutnya pada langkah kedua (step 2) variabel Jam dimasukkan untuk proses analisis. Dalam hal ini variabel Jam menempati urutan kedua dalam hal kemampuannya untuk mengelompokkan atau membedakan antara mahasiswa dengan IPK $<3$ dan mahasiswa dengan IPK $\geq 3$.

Berdasarkan Tabel 12.8 (Variables Not in the Analysis) menerangkan proses seleksi dari variabel-variabel bebas yang akan digunakan dalam proses analisis selanjutnya, yakni pembentukan persamaan diskriminan. Variabel-variabel yang tersisa pada langkah terakhir menandakan variabel-variabel tersebut tidak diikutsertakan dalam pembentukan persamaan diskriminan. Berdasarkan hasil pada Tabel Variables Not in the Analysis dapat ditarik informasi sebagai berikut.

$\Rightarrow$ Pada Step 0, nilai Mahalanobis Distance (Min. D Square) paling besar dan signifikan (Sig.<0,05) terletak pada variabel IQ. Sehingga variabel IQ dipilih untuk proses analisis selanjutnya.

$\Rightarrow$ Pada Step 1, variabel IQ sudah tidak ada. Dalam hal ini variabel IQ telah dipilih untuk proses analisis selanjutnya. Kemudian perhatikan bahwa nilai Mahalanobis Distance (Min. D Square) yang paling besar dan signifikan (Sig. <0,05) pada Step 1 terletak pada variabel Jam. Sehingga variabel Jam dipilih untuk proses analisis selanjutnya.

$\Rightarrow$ Pada Step 2, tersisa variabel Usia. Perhatikan bahwa nilai Sig. untuk variabel Usia lebih besar dari 0,05, yang menandakan variabel Usia tidak diikutsertakan untuk proses analisis selanjutnya. 
Tabel 12.8

\begin{tabular}{|c|c|c|c|c|c|c|}
\hline \multicolumn{7}{|c|}{ Variables Not in the Analysis } \\
\hline Ste & & Tolerance & $\begin{array}{c}\text { Min. } \\
\text { Tolerance }\end{array}$ & $\begin{array}{l}\text { Sig. of } F \text { to } \\
\text { Enter }\end{array}$ & $\begin{array}{c}\text { Min. D } \\
\text { Squared }\end{array}$ & $\begin{array}{l}\text { Between } \\
\text { Groups }\end{array}$ \\
\hline \multirow[t]{3}{*}{0} & $\begin{array}{l}\text { Jumlah jam belajar } \\
\text { dalam sehari }\end{array}$ & 1.000 & 1.000 & .000 & 21.014 & $\begin{array}{l}\mathrm{IPK} \approx 3 \text { and } \\
\mathrm{IPK}=3\end{array}$ \\
\hline & IQ mahasiswa & 1.000 & 1.000 & .000 & 39.720 & $\begin{array}{l}\mid \mathrm{PK}<3 \text { and } \\
\mathrm{IPK}==3\end{array}$ \\
\hline & Usia mahasiswa & 1.000 & 1.000 & .353 & .119 & $\begin{array}{l}\mathrm{IPK}=3 \text { and } \\
\mathrm{IPK}=3=3\end{array}$ \\
\hline \multirow[t]{2}{*}{1} & $\begin{array}{l}\text { Jumlah jam belajar } \\
\text { dalam sehari }\end{array}$ & & .998 & .002 & 58.538 & $\begin{array}{l}\text { IPK } \approx 3 \text { and } \\
I P K==3\end{array}$ \\
\hline & Usia mahasiswa & .883 & .883 & .140 & 43.438 & $\begin{array}{l}\mathrm{IPK} \approx 3 \text { and } \\
\mathrm{IPK}=3\end{array}$ \\
\hline 2 & Usia mahasiswa & .859 & .859 & .432 & 60.065 & $\begin{array}{l}\mathrm{IPK} \approx 3 \text { and } \\
\mathrm{IPK}=3=3\end{array}$ \\
\hline
\end{tabular}

Tabel 12.9

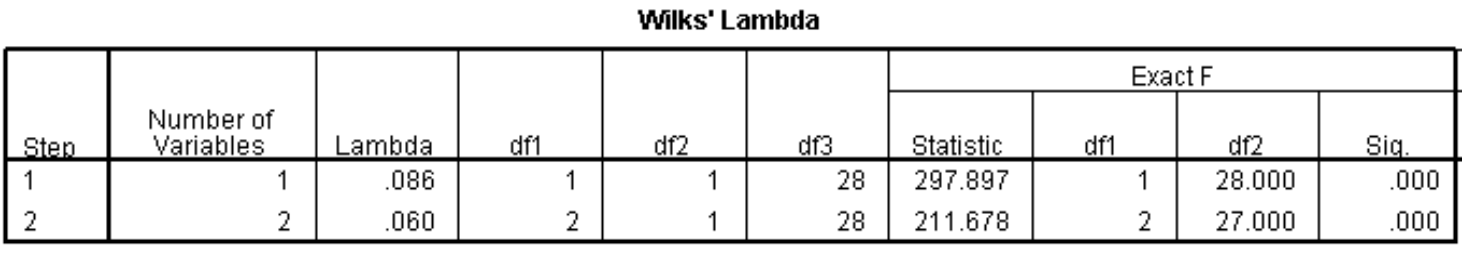

Berdasarkan Tabel 12.9 (Wilks' Lambda) dapat ditarik informasi sebagai berikut.

$\Rightarrow$ Pada Step 1, persamaan diskriminan hanya melibatkan satu variabel bebas, yakni variabel IQ (perhatikan kolom Number of Variables). Kemampuan persamaan diskriminan tersebut untuk mengelompokkan atau membedakan antara mahasiswa dengan IPK $<3$ dan IPK $\geq 3$ berdasarkan IQ signifikan secara statistika (nilai Sig. < $0,05)$.

$\Rightarrow$ Pada Step 2, persamaan diskriminan melibatkan dua variabel bebas, yakni variabel IQ dan Jam (perhatikan kolom Number of Variables). Kemampuan persamaan diskriminan tersebut untuk mengelompokkan atau membedakan antara mahasiswa dengan IPK $<3$ dan IPK $\geq 3$ berdasarkan IQ dan Jam signifikan secara statistika (nilai Sig. $<0,05$ ).

$\Rightarrow$ Namun perhatikan bahwa kemampuan persamaan diskriminan untuk mengelompokkan atau membedakan antara mahasiswa dengan IPK $<3$ dan IPK $\geq 3$, lebih unggul/baik pada persamaan diskriminan dengan melibatkan dua variabel bebas dibandingkan satu variabel bebas. Hal tersebut dapat dilihat dari nilai Lambda pada persamaan diskriminan yang melibatkan dua variabel bebas lebih kecil dibandingkan persamaan diskriminan yang hanya melibatkan satu variabel bebas.

Sehingga variabel IQ dan Jam akan diikutsertakan dalam pembentukan persamaan diskriminan untuk mengelompokkan atau membedakan antara mahasiswa dengan IPK $<3$ dan IPK $\geq 3$.

Tabel 12.10

\begin{tabular}{|c|c|r|r|r|}
\multicolumn{5}{c|}{ Eigemvalues } \\
\hline Function & Eigenvalue & $\%$ of Variance & Cumulative $\%$ & $\begin{array}{c}\text { Canonical } \\
\text { Correlation }\end{array}$ \\
\hline 1 & $15.680^{3}$ & 100.0 & 100.0 & .970 \\
\hline
\end{tabular}


Berdasarkan Tabel 12.10 (Eigenvalues), diketahui nilai korelasi kanonikal (canonical correlation) 0,970. Nilai korelasi kanonikal mengukur keeratan hubungan (dalam hal ini hubungan linear) antara nilai-nilai yang diperoleh berdasarkan persamaan diskriminan dengan nilai-nilai dari variabel tak bebas. Nilai korelasi kanonikal berkisar antara 0 dan 1 . Nilai korelasi kanonikal yang mendekati 1 menunjukkan keeratan hubungan yang kuat antara antara nilai-nilai yang diperoleh berdasarkan persamaan diskriminan dengan nilai-nilai dari variabel tak bebas. Kuadrat dari nilai korelasi kanonikal $\left(0,97^{2}=0,9401\right)$ menyatakan kemampuan persamaan diskriminan yang melibatkan variabel bebas IQ dan jumlah jam belajar dalam sehari dalam menjelaskan varians (variance) variabel tak bebas sebesar $94,01 \%$, sisanya $5,99 \%$ dijelaskan oleh faktor-faktor lain.

Berdasarkan Tabel 12.11, yakni Wilks' Lambda, diketahui nilai Sig. adalah 0.000. Karena nilai Sig. lebih kecil dari tingkat signifikansi, yakni $\alpha=0,05$, maka persamaan diskriminan yang dihasilkan dengan melibatkan variabel bebas IQ dan jumlah jam belajar dalam sehari signifikan secara statistika mampu mengelompokkan atau membedakan mahasiswa dengan kategori IPK $<3$ dan mahassiwa dengan kategori $\geq 3$.

Tabel 12.11

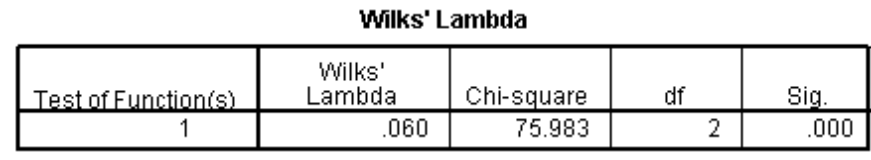

Tabel 12.12

Tabel 12.13
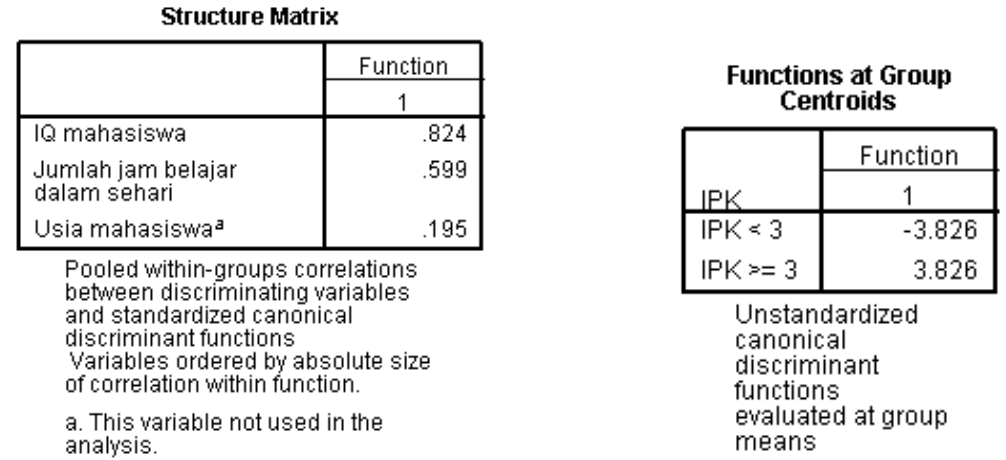

Berdasarkan Tabel 12.12, yakni Structure Matrix, menerangkan keeratan hubungan antara masing-masing variabel bebas, yakni IQ, Jam, dan Usia terhadap fungsi diskriminan. Terlihat bahwa variabel IQ memiliki keeratan hubungan paling kuat terhadap fungsi diskriminan. Kemudian disusul oleh variabel Jam dan Usia. Namun perhatikan bahwa pada variabel Usia, terdapat huruf "a" yang berarti variabel Usia tidak digunakan dalam analisis selanjutnya (This variable not used in the analysis). Dengan kata lain, variabel Usia tidak diikutsertakan dalam pembentukan persamaan diskriminan.

Berdasarkan informasi pada Tabel 12.13, yakni Functions at Group Centroids, diketahui nilai Centroids untuk kelompok mahasiswa dengan IPK $<3$ adalah $c_{0}=-3,826$, sedangkan untuk kelompok mahasiswa dengan IPK $\geq 3$ adalah $c_{1}=3,826$. Perhatikan bahwa $c_{0}$ merupakan rata-rata dari nilai-nilai diskriminan berdasarkan kelompok mahasiswa dengan IPK $<3$, sedangkan $c_{1}$ merupakan rata-rata dari nilai-nilai diskriminan berdasarkan kelompok mahasiswa dengan IPK $\geq 3$. Selanjutnya akan ditentukan nilai kritis atau nilai pemisah sebagai berikut. 


$$
\begin{gathered}
\text { nilai pemisah }=\frac{\left(n_{1} c_{0}+n_{0} c_{1}\right)}{n_{1}+n_{2}} \\
=\frac{((15)(-3,826)+(15)(3,826))}{15+15} \\
=0
\end{gathered}
$$

Maka aturan untuk pengelompokan atau pendiskriminasi sebagai berikut.

$\Rightarrow$ Jika nilai diskriminan $(\widehat{D})$ lebih besar dari nilai pemisah 0 , maka masuk ke dalam kelompok mahasiswa dengan IPK $\geq 3$.

$\Rightarrow$ Jika nilai diskriminan $(\widehat{D})$ lebih kecil dari nilai pemisah 0 , maka masuk ke dalam kelompok mahasiswa dengan IPK $<3$.

Berdasarkan Tabel 12.14, yakni Canonical Discriminant Function Coefficients, diperoleh persamaan diskriminan sebagai berikut.

$$
\widehat{D}=-63,398+0,596 I Q+0,333 \mathrm{Jam}
$$

Sebagai contoh misalkan seorang mahasiswa bernama Ugi, diketahui jumlah jam belajar dalam sehari adalah 6 jam dan memiliki IQ 101, maka diperoleh nilai/skor diskriminan sebagai berikut.

$$
\begin{gathered}
\widehat{D}=-63,398+0,596 \mathrm{IQ}+0,333 \mathrm{Jam} \\
=-63,398+0,596(101)+0,333(6) \\
=-1,204 .
\end{gathered}
$$

Perhatikan bahwa karena nilai diskriminan, yakni -1,204 lebih kecil dibandingkan dengan nilai kritis atau pemisah, yakni 0, maka Ugi diprediksi masuk ke dalam kelompok mahasiswa dengan IPK < 3. Sebagai contoh lagi misalkan seorang mahasiswa bernama Egi dengan jumlah jam belajar dalam sehari 14 jam dan IQ 102, maka diperoleh nilai diskriminan sebagai berikut.

$$
\begin{gathered}
\widehat{D}=-63,398+0,596 \mathrm{IQ}+0,333 \mathrm{Jam} \\
=-63,398+0,596(102)+0,333(14) \\
=2,056 .
\end{gathered}
$$

Perhatikan bahwa karena nilai diskriminan, yakni 2,056 lebih besar dibandingkan dengan nilai kritis, yakni 0, maka Egi diprediksi masuk ke dalam kelompok mahasiswa dengan IPK $\geq 3$. 


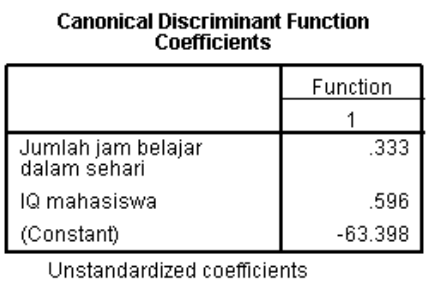

Tabel 12.15

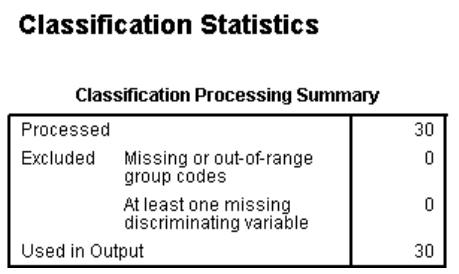

Tabel 12.16

Berdasarkan Tabel 12.15, yakni Classification Processing Sumarry, menandakan bahwa jumlah mahasiswa yang diproses sebanyak 30 mahasiswa dan tidak ada yang tidak diproses.

Berdasarkan Tabel 12.16, yakni Prior Probabilities for Groups memberikan informasi bahwa jumlah mahasiswa pada kelompok mahasiswa dengan IPK $<3$ adalah 15 siswa dan jumlah mahasiswa dengan kelompok IPK $\geq 3$ adalah 15 siswa.

Berdasarkan Tabel 12.17, yakni Classification Results memberikan informasi sebagai berikut.

$\Rightarrow$ Pada data awal (Original), jumlah mahasiswa dengan kategori IPK $<3$ sebanyak 15 mahasiswa. Kemudian, data dari 15 mahasiswa tersebut dimasukkan ke dalam persamaan diskriminan untuk dikelompokkan, apakah termasuk ke dalam kelompok mahasiswa dengan IPK $<3$ atau IPK $\geq 3$. Hasil pengelompokkan setelah digunakan persamaan diskriminan (Predicted Group Membership) menunjukkan bahwa 15 mahasiswa tersebut masuk ke dalam kelompok mahasiswa dengan IPK $<3$.

Kemudian perhatikan lagi bahwa pada data awal (Original), jumlah mahasiswa dengan kategori IPK $\geq 3$ sebanyak 15 mahasiswa. Kemudian, data dari 15 mahasiswa tersebut dimasukkan ke dalam persamaan diskriminan untuk dikelompokkan, apakah termasuk ke dalam kelompok mahasiswa dengan IPK $<3$ atau IPK $\geq 3$. Hasil pengelompokkan setelah digunakan persamaan diskriminan (Predicted Group Membership) menunjukkan bahwa 15 mahasiswa tersebut masuk ke dalam kelompok mahasiswa dengan IPK $\geq 3$.

$\Rightarrow$ Berdasarkan hasil tersebut, tidak terdapat perubahan klasifikasi untuk setiap mahasiswa. Hal ini berarti angka ketepatan prediksi dengan menggunakan data tersebut adalah

$$
\text { angka ketepatan prediksi }=\frac{(15+15)}{30}=100 \% \text {. }
$$

$\Rightarrow$ Berdasarkan informasi dari Tabel Classification Results pada bagian (b), memberikan informasi bahwa angka ketepatan prediksi sebesar $100 \%$. Hal ini berarti persamaan diskriminan yang dihasilkan layak untuk digunakan dalam memprediksi seorang 
mahasiswa apakah masuk ke dalam kelompok mahasiswa dengan IPK $<3$ atau IPK $\geq 3$ berdasarkan informasi jumlah jam belajar dalam sehari dan IQ. Dalam keadaan lapangan, sangat kecil kemungkinan untuk mendapatkan angka ketepatan prediksi $100 \%$. Data yang digunakan dalam contoh ini adalah data fiktif.

Tabel 12.17

\begin{tabular}{|c|c|c|c|c|c|}
\hline \multicolumn{6}{|c|}{ Classification Results $^{b, c}$} \\
\hline & & \multirow[b]{2}{*}{ IPK } & \multicolumn{2}{|c|}{ Predicted Group Membership } & \multirow[b]{2}{*}{ Total } \\
\hline & & & $\mathrm{IPK}<3$ & $\mathrm{IPK}>=3$ & \\
\hline \multirow[t]{4}{*}{ Original } & Count & $\mathrm{IPK}<3$ & 15 & 0 & 15 \\
\hline & & $\mathrm{IPK}>=3$ & 0 & 15 & 15 \\
\hline & $\%$ & $\mathrm{IPK}=3$ & 100.0 & .0 & 100.0 \\
\hline & & $\mathrm{IPK}>=3$ & .0 & 100.0 & 100.0 \\
\hline \multirow[t]{4}{*}{ Cross-validated $^{a}$} & Count & $\mathrm{IPK}=3$ & 15 & 0 & 15 \\
\hline & & $\mathrm{IPK}>=3$ & 0 & 15 & 15 \\
\hline & $\%$ & IPK $<3$ & 100.0 & .0 & 100.0 \\
\hline & & $\mathrm{IPK}>=3$ & .0 & 100.0 & 100.0 \\
\hline
\end{tabular}

a. Cross validation is done only for those cases in the analysis. In cross than that case.

b. $100.0 \%$ of original grouped cases correctly classified

c. $100.0 \%$ of cross-validated grouped cases correctly classified. 
[1] Korelasi kanonikal (canonical correlation) dapat diartikan sebagai suatu nilai yang mengukur keeratan hubungan (linear) antara nilai (skor) yang diperoleh berdasarkan persamaan diskriminan terhadap nilai dari variabel tak bebas (outcome). Misalkan diberikan data dalam SPSS seperti pada Gambar 12.1.

\begin{tabular}{|c|c|c|c|c|c|c|c|c|c|}
\hline & IPK & Jam & 10 & Usia & & & & & \\
\hline 1 & 0 & 7 & 95 & 20 & & & & & \\
\hline 2 & 0 & 8 & 96 & 21 & & & & & \\
\hline 3 & 0 & 7 & 97 & 22 & & & & & \\
\hline 4 & 0 & 5 & 98 & 23 & & & & & \\
\hline 5 & 0 & 4 & 95 & 24 & & & & & \\
\hline 6 & 0 & 6 & 96 & 25 & 18 & 1 & 15 & 105 & 25 \\
\hline 7 & 0 & 8 & 97 & 20 & 19 & 1 & 13 & 106 & 20 \\
\hline 8 & 0 & 8 & 98 & 21 & 20 & 1 & 15 & 103 & 21 \\
\hline 9 & 0 & 6 & 95 & 27 & 21 & 1 & 12 & 104 & 22 \\
\hline 10 & 0 & 5 & 95 & 22 & 22 & 1 & 17 & 105 & 23 \\
\hline 11 & 0 & 7 & 96 & 23 & 23 & 1 & 13 & 106 & 24 \\
\hline 11 & 0 & 7 & 97 & 24 & 24 & 1 & 15 & 107 & 25 \\
\hline 12 & 0 & 3 & 98 & 25 & 25 & 1 & 12 & 104 & 20 \\
\hline 13 & 0 & 7 & 96 & 20 & 26 & 1 & 12 & 103 & 21 \\
\hline 14 & 0 & 4 & 97 & 21 & 27 & 1 & 14 & 105 & 22 \\
\hline 15 & 0 & 3 & 98 & 22 & 28 & 1 & 16 & 107 & 23 \\
\hline 16 & 1 & 12 & 103 & 23 & 29 & 1 & 12 & 107 & 24 \\
\hline 17 & 1 & 14 & 104 & 24 & 30 & 1 & 13 & 107 & 25 \\
\hline
\end{tabular}

\begin{tabular}{|c|c|c|c|c|c|c|c|c|c|}
\hline & IPK & Jam & 10 & Usia & & & & & \\
\hline 1 & IPK $<3$ & 7 & 95 & 20 & & & & & \\
\hline 2 & $\mathrm{IPK}<3$ & 8 & 96 & 21 & & & & & \\
\hline 3 & $\mathrm{IPK}<3$ & 7 & 97 & 22 & & & & & \\
\hline 4 & $\mathrm{IPK}<3$ & 5 & 98 & 23 & & & & & \\
\hline 5 & $\mathrm{IPK}<3$ & 4 & 95 & 24 & 18 & $\mid \mathrm{PK}>>=3$ & 15 & 105 & 25 \\
\hline 6 & $\mathrm{IPK}<3$ & 6 & 96 & 25 & 19 & IPK $>=3$ & 13 & 106 & 20 \\
\hline 7 & $\mathrm{IPK}<3$ & 8 & 97 & 20 & 20 & $\mathrm{IPK}>=3$ & 15 & 103 & 21 \\
\hline 8 & $\mathrm{IPK}<3$ & 8 & 98 & 21 & 21 & IPK $>=3$ & 12 & 104 & 22 \\
\hline 9 & $\mathrm{IPK}<3$ & 6 & 95 & 22 & 22 & IPK $>=3$ & 17 & 105 & 23 \\
\hline 10 & $\mathrm{IPK}<3$ & 5 & 96 & 23 & 23 & IPK $>=3$ & 13 & 106 & 24 \\
\hline 11 & $\mathrm{IPK}<3$ & 7 & 97 & 24 & 24 & $\mathrm{IPK}>=3$ & 15 & 107 & 25 \\
\hline 12 & $\mathrm{IPK}<3$ & 3 & 98 & 25 & 25 & IPK $>=3$ & 12 & 104 & 20 \\
\hline 13 & $\mathrm{IPK}<3$ & 7 & 96 & 20 & 26 & $\mathrm{IPK}>=3$ & 12 & 103 & 21 \\
\hline 14 & $\mathrm{IPK}<3$ & 4 & 97 & 21 & 27 & IPK $>=3$ & 14 & 105 & 22 \\
\hline 15 & $\mathrm{IPK}<3$ & 3 & 98 & 22 & 28 & $\mid \mathrm{PK}>=3$ & 16 & 107 & 23 \\
\hline 16 & $\mid \mathrm{PK}>=3$ & 12 & 103 & 23 & 29 & IPK $>=3$ & 12 & 107 & 24 \\
\hline 17 & IPK $>=3$ & 14 & 104 & 24 & 30 & $\mid P K>=3$ & 13 & 107 & 25 \\
\hline
\end{tabular}

Gambar 12.1

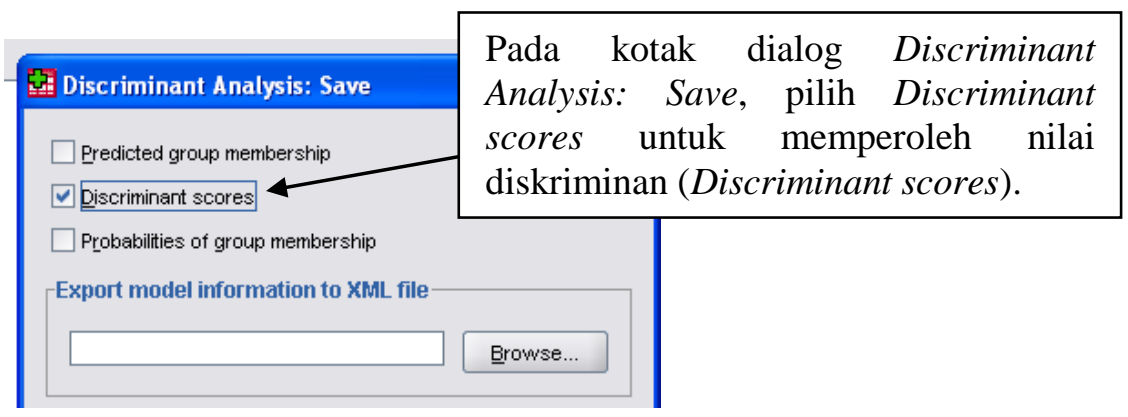

Gambar 12.2 
Dengan menggunakan analisis diskriminan pendekatan stepwise method, diperoleh nilai (skor) persamaan diskriminan sebagai berikut.

\begin{tabular}{|c|c|c|c|}
\hline & IPK & Jam & 10 \\
\hline 1 & $\mathrm{IPK}<3$ & 7 & \\
\hline 2 & $I P K<3$ & 8 & \\
\hline 3 & $I P K<3$ & 7 & \\
\hline 4 & $\mathrm{IPK}<3$ & 5 & \\
\hline 5 & $I P K<3$ & 4 & \\
\hline 6 & $\mathrm{IPK}<3$ & 6 & \\
\hline 7 & $\mathrm{IPK}<3$ & 8 & \\
\hline 8 & $\mathrm{IPK}<3$ & 8 & \\
\hline 9 & $\mathrm{IPK}<3$ & 6 & \\
\hline 10 & $\mathrm{IPK}<3$ & 5 & \\
\hline 11 & $\mathrm{IPK}<3$ & 7 & \\
\hline 12 & $I P K<3$ & 3 & \\
\hline 13 & $\mathrm{IPK}<3$ & 7 & \\
\hline 14 & $I P K<3$ & 4 & \\
\hline 15 & $\mathrm{IPK}<3$ & 3 & \\
\hline 16 & $\mid \mathrm{PK}>>=3$ & 12 & \\
\hline 17 & $\mid P K>=3$ & 14 & \\
\hline
\end{tabular}

\begin{tabular}{|r|r|}
\hline 95 & Usia \\
\hline 96 & \\
\hline 97 & \\
\hline 98 & \\
\hline 95 & \\
\hline 96 & \\
\hline 97 & \\
\hline 98 & \\
\hline 95 & \\
\hline 96 & \\
\hline 97 & \\
\hline 98 & \\
\hline 96 & \\
\hline 97 & \\
\hline 98 & \\
\hline 103 & \\
\hline 104 & \\
\hline
\end{tabular}

\begin{tabular}{l|l|l|l|}
\hline 20 & Dis1_1 \\
\hline 21 & -4.40187 & \\
\hline 22 & -3.47 & \\
\hline 23 & -3.20809 & \\
\hline 24 & -3.2795 \\
\hline 25 & -5.40231 & 18 \\
\hline 20 & -4.13891 & 19 \\
\hline 21 & -2.87551 & 20 \\
\hline 22 & -2.27907 & 21 \\
\hline 23 & -4.73535 & 22 \\
\hline 24 & -4.47239 & 23 \\
\hline 25 & -3.20899 & 24 \\
\hline 20 & -3.94647 & 25 \\
\hline 21 & -3.80543 & 26 \\
\hline 22 & -4.20943 & 27 \\
\hline 23 & -3.94647 & 28 \\
\hline 24 & 2.03706 & 29 \\
\hline & 3.30047 & \\
\hline & & \\
\hline
\end{tabular}

Perhatikan bahwa nilai-nilai pada variabel Dis_1 merupakan nilai-nilai diskriminan (discriminant scores).

$$
\begin{gathered}
\widehat{D}_{1}=0.3334813822734606(7)+0.5964409563758277(95)-63.398131268100094 \\
=-4,40187 \emptyset 736 .
\end{gathered}
$$

Tabel 12.1

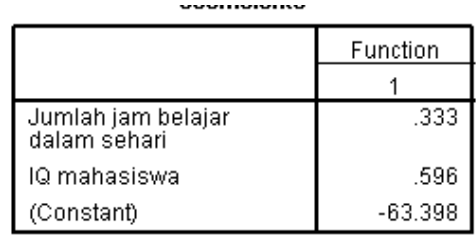

Unstandardized coefficients

Untuk memperoleh korelasi kanonikal pilih Analyze $\Rightarrow$ Correlate $\Rightarrow>$ Bivariate, sehingga muncul kotak dialog Bivariate Correlations (Gambar 12.3). Masukkan variabel IPK dan Dis1_1 ke dalam kotak Variables. Kemudian pilih OK.

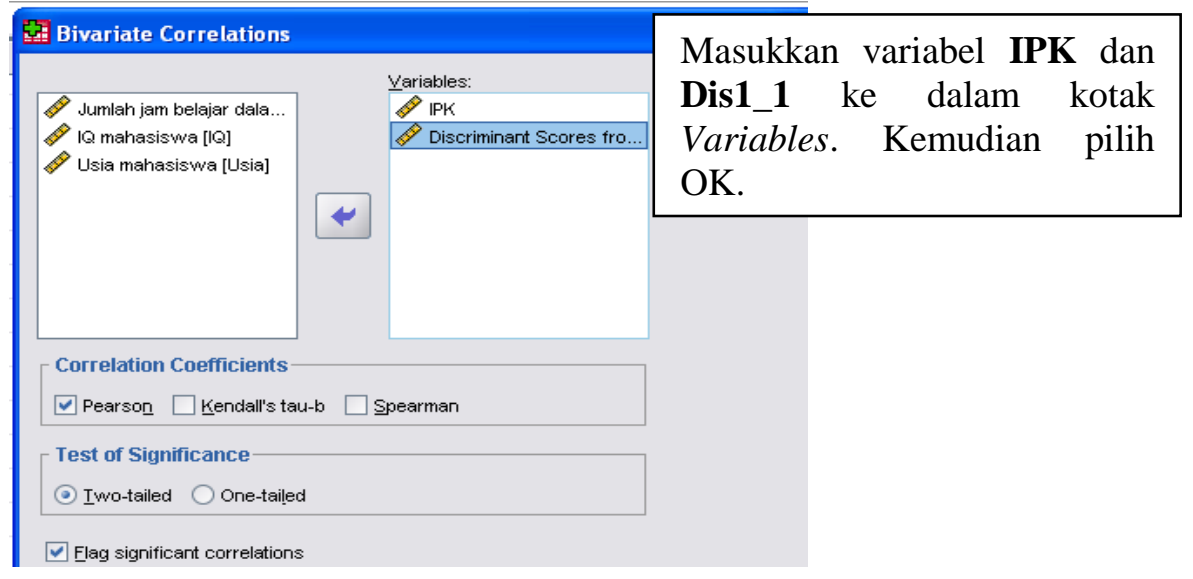

Gambar 12.3 
Berikut hasil berdasarkan SPSS.

\section{Tabel 12.2}

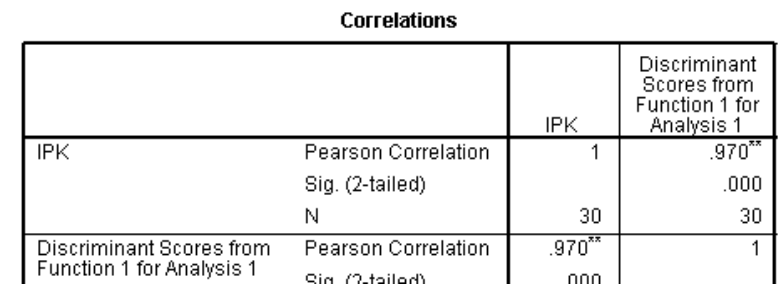

Perhatikan bahwa berdasarkan Tabel 12.2 (Correlations), nilai korelasi antara IPK dan Dis1_1 adalah 0,970. Nilai 0,970 merupakan nilai korelasi kanonikal.

\section{Tabel 12.3}

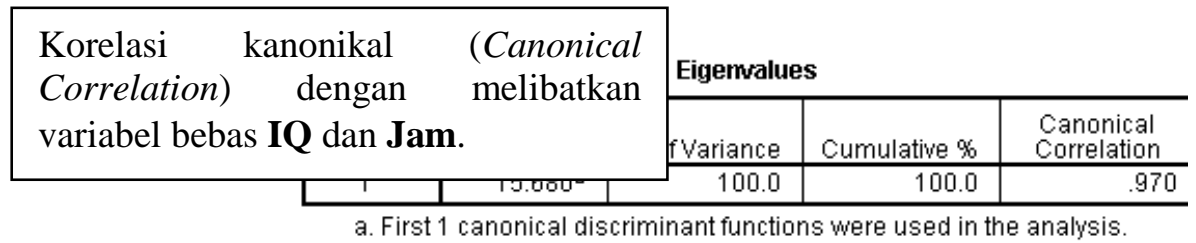

[2] Salah satu asumsi yang dikenakan pada penggunaan analisis diskriminan adalah asumsi kesamaan matriks-matriks kovarian populasi. Misalkan diberikan data seperti pada Gambar 12.1. Kemudian pilih Analyze $\Rightarrow$ Classify $\Rightarrow$ Discriminant, sehingga muncul kotak dialog Discriminant Analysis (Gambar 12.4). Masukkan variabel IPK pada Grouping Variable dan masukkan variabel Jam, IQ, dan Usia pada Independent. Pilih Enter independents together. Selanjutnya pilih Statistics, sehingga muncul kotak dialog Discriminant Analysis: Statistics (Gambar 12.5). Pada kotak dialog Discriminant Analysis: Statistics, pilih Separate-groups covariance. Kemudian pilih Continue dan OK.

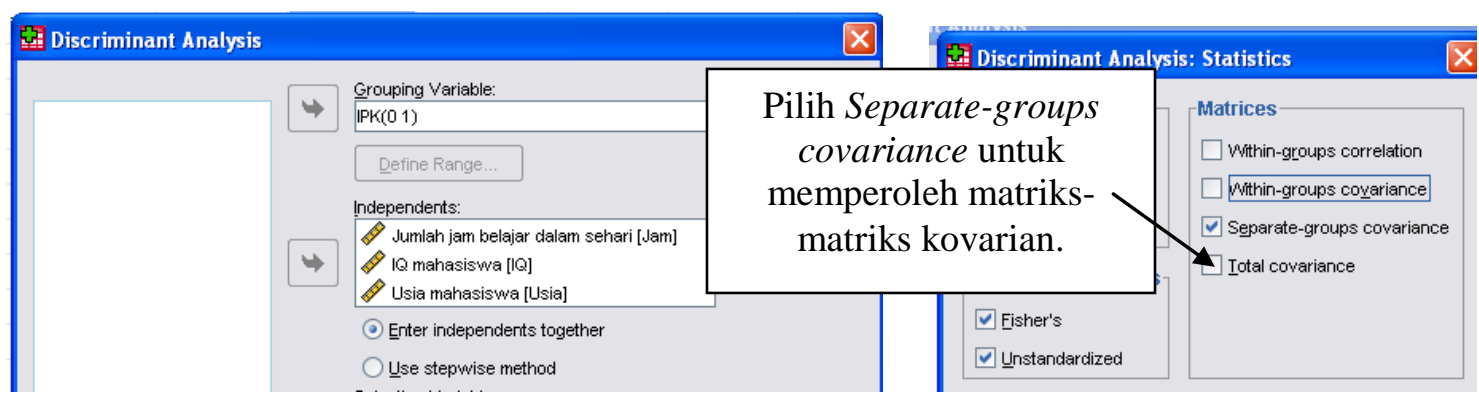

Gambar 12.4

Gambar 12.5

Berikut hasil berdasarkan SPSS.

Tabel 12.4

\begin{tabular}{|ll|r|r|r|}
\hline & $\begin{array}{c}\text { Jumlah jam } \\
\text { belajar dalam } \\
\text { Sehari }\end{array}$ & $\begin{array}{c}\text { IQ } \\
\text { mahasiswa }\end{array}$ & $\begin{array}{c}\text { Cowariance Matrices } \\
\text { mahasiswa }\end{array}$ \\
\hline IPK $<3$ & 3.124 & -.414 & -1.614 \\
& $\begin{array}{l}\text { Jumlah jam belajar } \\
\text { dalam sehari } \\
\text { IQ mahasiswa }\end{array}$ & -.414 & 1.257 & .229 \\
& Usia mahasiswa & -1.614 & .229 & 3.029 \\
\hline IPK $>=3$ & Jumlah jam belajar & 2.667 & .595 & .786 \\
& dalam sehari & .595 & 2.352 & 1.371 \\
& IQ mahasiswa & .786 & 1.371 & 3.029 \\
\hline
\end{tabular}


Berdasarkan Tabel 12.4 (Covariance Matrices), diperoleh dua matriks kovarian, yakni

$$
\begin{gathered}
C_{1}=\left[\begin{array}{ccc}
3,124 & -0,414 & -1,614 \\
-0,414 & 1,257 & 0,229 \\
-1,614 & 0,229 & 3,029
\end{array}\right] \\
C_{2}=\left[\begin{array}{lll}
2,667 & 0,595 & 0,786 \\
0,595 & 2,352 & 1,371 \\
0,786 & 1,371 & 3,029
\end{array}\right] .
\end{gathered}
$$

Berdasarkan matriks kovarian $C_{1}$, nilai 3,124, 1,257, dan 3,029 masing-masing merupakan nilai varians variabel Jam, IQ, dan Usia pada kelompok mahasiswa dengan IPK < 3 . Sedangkan nilai $-0,414,-1,614,0,229$, dan 3,029 disebut nilai-nilai kovarian pada kelompok IPK < 3. Jika asumsi kesamaan matriks-matriks kovarian dipenuhi, berarti tidak terdapat perbedaan yang signifikan secara statistika antara elemen-elemen pada $C_{1}$ dan $C_{2}$.

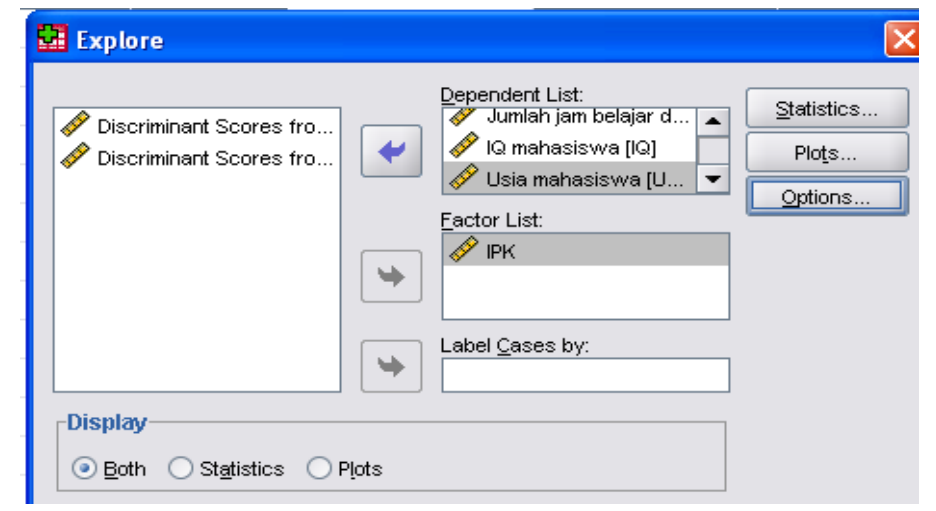

Gambar 12.6

\begin{tabular}{|c|c|c|c|c|c|c|}
\hline \multicolumn{7}{|c|}{ Descriptives } \\
\hline \multicolumn{4}{|c|}{$\mathbb{P P K}$} & Statistic & \multirow{2}{*}{\multicolumn{2}{|c|}{ Std. Errar l }} \\
\hline \multirow{25}{*}{$\begin{array}{l}\text { Jumlah jam belajar } \\
\text { dalam sehari }\end{array}$} & $\mathrm{IPK}<3$ & Mean & & 5.87 & & \\
\hline & & $95 \%$ Confidence Interval & Lower Bound & 4.89 & \multirow{6}{*}{\multicolumn{2}{|c|}{$\begin{array}{c}\text { Nilai 3,124 merupakan } \\
\text { varians dari variabel } \\
\text { Jam pada kelompok } \\
\text { IPK < } 3 \text {. }\end{array}$}} \\
\hline & & for Mean & Upper Bound & 6.85 & & \\
\hline & & $5 \%$ Trimmed Mean & & 5.91 & & \\
\hline & & Median & & 6.00 & & \\
\hline & & Variance & & 3.124 & & \\
\hline & & Std. Deviation & & 1.767 & & \\
\hline & & Minimum & & 3 & & \\
\hline & & Maximum & & 8 & & \\
\hline & & Range & & 5 & & \\
\hline & & Interquartile Range & & 3 & & \\
\hline & & Skewness & & -.395 & .580 & \\
\hline & & Kurtosis & & -1.188 & 1.121 & \\
\hline & $\mathrm{IPK} \gg=3$ & Mean & & 13.67 & .422 & \\
\hline & & $95 \%$ Confidence Interval & Lower Bound & 12.76 & \multirow{7}{*}{\multicolumn{2}{|c|}{$\begin{array}{c}\text { Nilai } 2,667 \text { merupakan } \\
\text { varians dari variabel } \\
\text { Jam pada kelompok } \\
\text { IPK } \geq 3 \text {. }\end{array}$}} \\
\hline & & for Mean & Upper Bound & 14.57 & & \\
\hline & & $5 \%$ Trimmed Mean & & 13.57 & & \\
\hline & & Median & & 130 & & \\
\hline & & Std. Deviation & & 1.633 & & \\
\hline & & Minimum & & 12 & & \\
\hline & & Maximum & & 17 & & \\
\hline & & Range & & 5 & & \\
\hline & & Interquartile Range & & 3 & & \\
\hline & & Skewness & & .622 & .580 & \\
\hline & & Kurtosis & & -.651 & 1.121 & \\
\hline
\end{tabular}

Tabel 12.5 


\begin{tabular}{|c|c|c|c|c|c|c|}
\hline IQ mahasiswa & IPK $\gg=3$ & $\begin{array}{l}\text { Mean } \\
95 \% \text { Confidence Interval } \\
\text { for Mean } \\
5 \% \text { Trimmed Mean } \\
\text { Median } \\
\text { Variance } \\
\text { Std. Deviation } \\
\text { Minimum } \\
\text { Maximum } \\
\text { Range } \\
\text { Interquartile Range } \\
\text { Skewness } \\
\text { Kurtosis } \\
\text { Mean } \\
95 \% \text { Confidence Interval } \\
\text { for Mean } \\
5 \% \text { Trimmed Mean } \\
\text { Median } \\
\text { Variance } \\
\text { Std. Deviation } \\
\text { Minimum } \\
\text { Maximum } \\
\text { Range }\end{array}$ & $\begin{array}{l}\text { Lower Bound } \\
\text { Upper Bound }\end{array}$ & $\begin{array}{r}96.60 \\
95.98 \\
97.22 \\
96.61 \\
97.00 \\
1.257 \\
1.121 \\
95 \\
98 \\
3 \\
2 \\
-.112 \\
-1.291 \\
105.07 \\
104.22 \\
105.92 \\
105.07 \\
105.00 \\
2.352 \\
1.534 \\
103 \\
107 \\
4 \\
\end{array}$ & .289 & $\begin{array}{l}\text { Vilai } 2,352 \text { merupakan } \\
\text { yarians dari variabel } \\
\text { IQ pada kelompok } \\
\text { IPK } \geq 3 .\end{array}$ \\
\hline
\end{tabular}

[3] Menu Predicted group membership dalam SPSS (Gambar 12.7) dapat digunakan untuk memprediksi suatu pengamatan atau objek masuk ke dalam salah satu kategori pada variabel tak bebas.

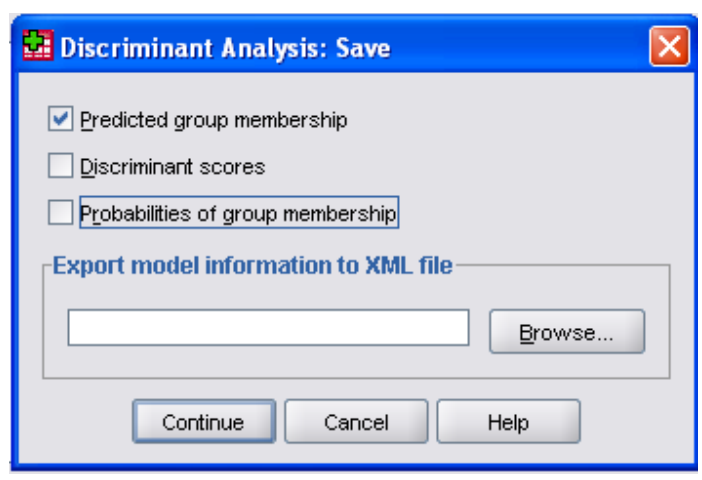

Gambar 12.7

Berikut hasil berdasarkan penggunaan menu Predicted group membership.

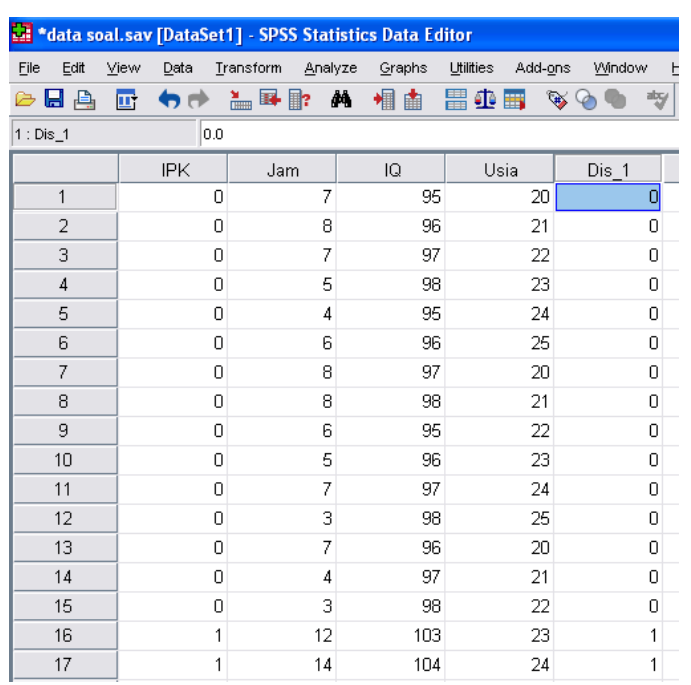

\begin{tabular}{|c|c|c|c|c|c|c|c|}
\hline \multirow{2}{*}{\multicolumn{8}{|c|}{ 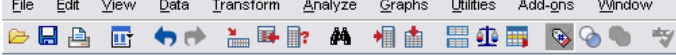 }} \\
\hline & & & & & & & \\
\hline \multicolumn{8}{|l|}{ 1: Dis_1 } \\
\hline & & IPK & Jam & & 10 & Usia & Dis_1 \\
\hline 1 & & $\mathrm{IPK}<3$ & & 7 & 95 & 20 & $\mathrm{IPK}<3$ \\
\hline 2 & & $\mathrm{IPK}<3$ & & 8 & 96 & 21 & $\mathrm{IPK}<3$ \\
\hline 3 & & $\mathrm{IPK}<3$ & & 7 & 97 & 22 & $\mathrm{IPK}<3$ \\
\hline 4 & & $\mathrm{IPK}<3$ & & 5 & 98 & 23 & $\mathrm{IPK}<3$ \\
\hline 5 & & $\mathrm{IPK}<3$ & & 4 & 95 & 24 & $\mathrm{IPK}<3$ \\
\hline 6 & & $\mathrm{IPK}<3$ & & 6 & 96 & 25 & $\mathrm{IPK}<3$ \\
\hline 7 & & $\mathrm{IPK}<3$ & & 8 & 97 & 20 & $\mathrm{IPK}<3$ \\
\hline 8 & & $\mathrm{IPK}<3$ & & 8 & 98 & 21 & $\mathrm{IPK}<3$ \\
\hline 9 & & $\mathrm{IPK}<3$ & & 6 & 95 & 22 & $\mathrm{IPK}<3$ \\
\hline 10 & & $\mathrm{IPK}<3$ & & 5 & 96 & 23 & $\mathrm{IPK}<3$ \\
\hline 11 & & $\mathrm{IPK}<3$ & & 7 & 97 & 24 & $\mathrm{IPK}<3$ \\
\hline 12 & & IPK $<3$ & & 3 & 98 & 25 & $\mathrm{IPK}<3$ \\
\hline 13 & & $\mathrm{IPK}<3$ & & 7 & 96 & 20 & $\mathrm{IPK}<3$ \\
\hline 14 & & $\mathrm{IPK}<3$ & & 4 & 97 & 21 & $\mathrm{IPK}<3$ \\
\hline 15 & & $\mathrm{IPK}<3$ & & 3 & 98 & 22 & $\mathrm{IPK}<3$ \\
\hline 16 & & IPK $>=3$ & & 12 & 103 & 23 & $\mid \mathrm{PK}>=3$ \\
\hline 17 & & $\mid P K>=3$ & & 14 & 104 & 24 & $\mid P K>>=3$ \\
\hline
\end{tabular}

Gambar 12.8 


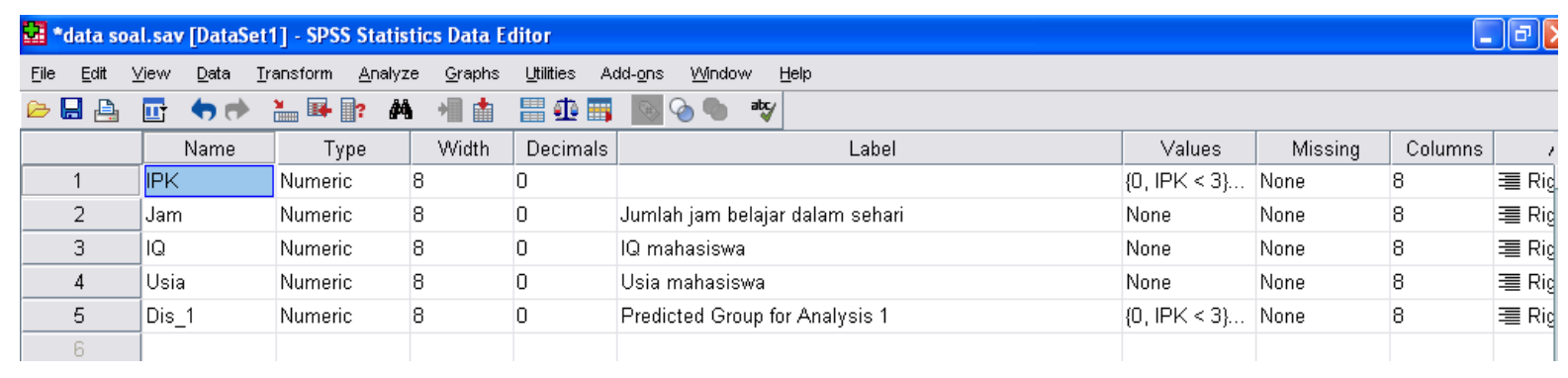

\section{Gambar 12.9}

Berdasarkan Gambar 12.8 terbentuk variabel Dis_1 dengan Label Predicted Group for Analysis 1 (Gambar 12.9). Untuk mahasiswa nomor 1, diketahui mahasiswa tersebut memiliki IPK $<3$. Berdasarkan hasil prediksi dengan fungsi diskriminan, diketahui mahasiswa nomor 1 tersebut juga memiliki IPK $<3$. Hal ini menunjukkan bahwa hasil prediksi dengan hasil sebenarnya untuk mahasiswa nomor 1 adalah sama.

[4] Pada pembahasan sebelumnya digunakan pendekatan stepwise. Pada pendekatan stepwise method, hanya variabel-variabel bebas yang memiliki discriminating power yang signifikan secara statistika dilibatkan dalam pembentukan model persamaan diskriminan.

Sekarang akan digunakan pendekatan enter atau direct method. Pada pendekatan direct method mengestimasi persamaan diskriminan dengan cara memasukkan atau memproses seluruh variabel bebas secara bersamaan atau simultan. Dengan kata lain, pada pendekatan direct method tidak memperhatikan kekuatan untuk mendiskriminasi (discriminating power) dari masing-masing variabel bebas. Aktifkan pendekatan Enter seperti pada Gambar 12.10.

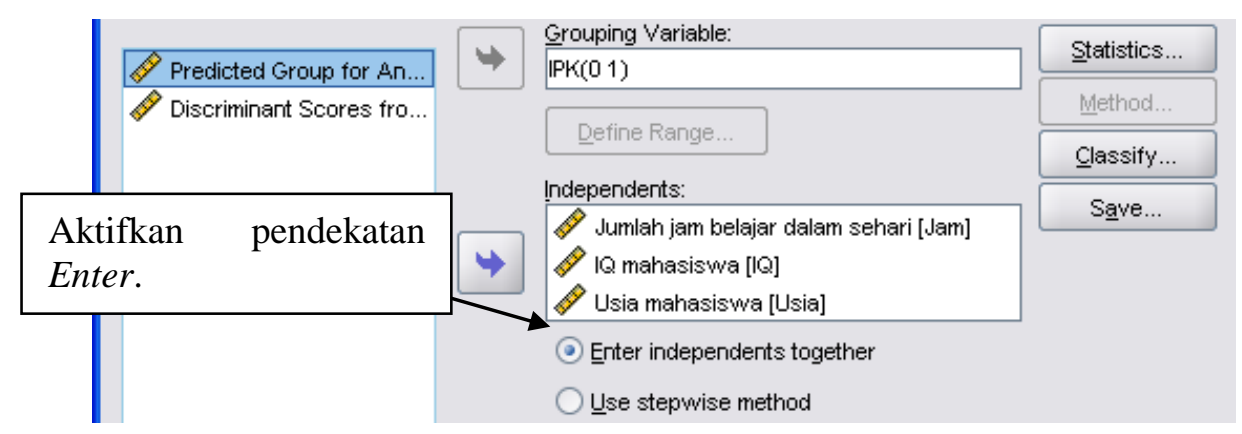

\section{Gambar 12.10}

Diperoleh Output SPSS sebagai berikut.

Tabel 12.6

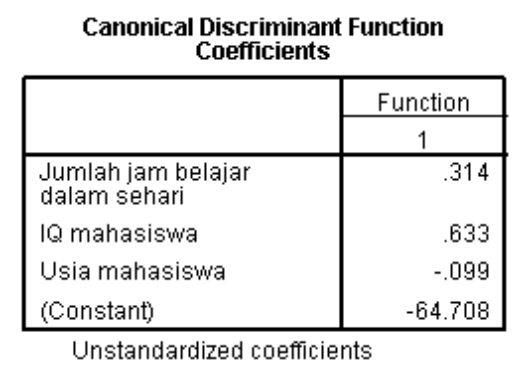


Berdasarkan Tabel 12.6, dapat dibentuk persamaan diskriminan sebagai berikut.

$$
\widehat{D}=-64,708-0,099 \text { Usia }+0,633 I Q+0,314 \mathrm{Jam}
$$

\begin{tabular}{|c|c|c|c|c|c|c|c|c|c|}
\hline Eile É Edit & Yiew & Data & Iransform & Analyze & Graphs & Untilities Add- & Mindow & $\underline{H}$ & \\
\hline 8 回苞 & 世 & कत & 总圆圆? & A & 阐为 & 睤功四 & .80 & 8 & \\
\hline 1: Dis_1 & & & 0.0 & & & & & & \\
\hline & & IPK & Jam & & 10 & Usia & Dis_1 & & Dis1_1 \\
\hline 1 & & & 0 & 7 & 95 & 20 & 0 & & -4.31558 \\
\hline 2 & & & 0 & 8 & 96 & 21 & 0 & 0 & -3.46734 \\
\hline 3 & & & 0 & 7 & 97 & 22 & 0 & 0 & -3.24646 \\
\hline 4 & & & 0 & 5 & 98 & 23 & 0 & 0 & -3.33926 \\
\hline 5 & & & 0 & 4 & 95 & 24 & 0 & 0 & -5.65199 \\
\hline 6 & & & 0 & 6 & 96 & 25 & 0 & 0 & -4.49007 \\
\hline 7 & & & 0 & 8 & 97 & 20 & 0 & & -2.73510 \\
\hline 8 & & & n & 8 & 98 & 21 & $n$ & & -2 วกПБА \\
\hline
\end{tabular}

\section{Gambar 12.11}

Berdasarkan 12.11, diketahui nilai diskriminan untuk mahasiswa nomor 1 adalah $-4,313558$. Nilai tersebut dihitung sebagai berikut.

$$
\begin{gathered}
\widehat{D}=-64,707712-0,098843 \text { Usia }+0,633402 \text { IQ }+0,313677 \mathrm{Jam} \\
\widehat{D}=-64,707712-0,098843(20)+0,633402(95)+0,313677(7)=-4,315 .
\end{gathered}
$$

Perhatikan bahwa hasil perhitungan nilai diskriminan tersebut melibatkan variabel Usia. Padahal pada variabel Usia, perbedaan rata-rata usia antara mahasiswa dengan IPK < 3 dan mahasiswa IPK $\geq 3$ tidak signifikan secara statistika (Tabel 12.7).

\section{Tabel 12.7}

\begin{tabular}{|l|r|r|r|r|r|}
\multicolumn{1}{|c|}{ Tests of Equality of Group Means } \\
\hline & \multicolumn{1}{|c|}{$\begin{array}{c}\text { Wilks' } \\
\text { Lambda }\end{array}$} & \multicolumn{1}{c|}{$\mathrm{F}$} & \multicolumn{1}{c|}{ df1 } & \multicolumn{1}{c|}{ df2 } & \multicolumn{1}{c|}{ Sig. } \\
\hline Jumlah jam belajar & .151 & 157.604 & 1 & 28 & .000 \\
dalam sehari & & & & & \\
IQ mahasiswa & .086 & 297.897 & 1 & 28 & .000 \\
Usia mahasiswa & .969 & .892 & 1 & 28 & .353 \\
\hline
\end{tabular}

\section{Referensi}

1. Hair, J.F Jr., R.E. Anderson, B.J. Babin, dan W.C. Black. 2010. Multivariate Data Analysis, $7^{\text {th }}$ Edition. Pearson Prentice Hall.

2. Johnson, R.A. dan D.W. Wichern. 2007. Applied Multivariate Statistical Analysis, $6^{\text {th }}$ Edition. United States of America: Prentice Hall.

3. Malhotra, N.K. dan D.F. Birks. 2006. Marketing Research, An Applied Approach, $2^{\text {nd }}$ European Edition. London: Prentice Hall.

4. Meyers, L.S., G. Gamst, dan A.J. Guarino. 2013. Applied Multivariate Research, Design and Interpretation, $2^{\text {nd }}$ Edition. Sage Publication.

5. Stevens, J.P. 2009. Applied Multivariate Statistics For The Social Science, $5^{\text {th }}$ Edition. New York: Routledge. 


\section{BAB 13}

\section{ANALISIS VARIANS SATU ARAH}

\section{Sekílas Analisís Varians Satu Arah}

Analisis varians (ANOVA) merupakan perluasan dari uji $t$. Uji $t$ menguji rata-rata dari dua populasi, sedangkan analisis varians menguji rata-rata dari tiga populasi atau lebih. Dalam analisis varians, variabel bebas bersifat non-metrik atau kualitatif (kategori), sedangkan variabel tak bebas bersifat metrik atau kuantitatif (interval atau rasio). Hipotesis nol yang diajukan pada analisis varians adalah seluruh rata-rata populasi bernilai sama, yakni $\mu_{1}=$ $\mu_{2}=\mu_{3}=\cdots=\mu_{k}$ (dalam hal ini jumlah populasi sebanyak $k$ ), sedangkan hipotesis alternatif menyatakan paling sedikit terdapat satu pasang rata-rata populasi yang berbeda.

Analisis varians bersifat uji global (global test), yakni hanya mendeteksi apakah terdapat perbedaan di antara rata-rata populasi atau tidak, namun tidak dapat menentukan pasangan rata-rata populasi mana saja yang berbeda nyata secara statistika. Untuk menentukan pasangan rata-rata populasi mana saja yang berbeda nyata secara statistika, maka digunakan uji perbandingan berganda (multiple comparison test). Pada uji perbandingan berganda, dapat digunakan uji Tukey HSD (honestly significance difference), uji Bonferroni, uji LSD (least square difference), uji jarak Duncan (Duncan multiple range test), dan sebagainya.

Untuk pengambilan keputusan terhadap hipotesis, dapat dilakukan dengan membandingkan nilai statistik dari uji $F\left(F_{\text {hitung }}\right)$ terhadap nilai kritis berdasarkan tabel distribusi $F\left(F_{\text {kritis }}\right)$. Untuk menentukan nilai kritis $F$, terlebih dahulu dihitung nilai derajat bebas pembilang dan derajat bebas penyebut. Berikut rumus untuk menghitung nilai derajat bebas pembilang dan derajat bebas penyebut.

$$
\begin{aligned}
& \text { Derajat bebas pembilang }=k-1 . \\
& \text { Derajat bebas penyebut }=N-k .
\end{aligned}
$$

Perhatikan bahwa $k$ menyatakan jumlah kelompok, perlakuan atau sampel yang diteliti, sedangkan $N$ menyatakan jumlah elemen dari seluruh sampel yang diteliti. Derajat bebas pembilang disebut juga dengan derajat bebas numerator, sedangkan derajat bebas penyebut disebut juga dengan derajat bebas denominator. Berikut aturan pengambilan keputusan terhadap hipotesis berdasarkan uji $F$.

Jika nilai statistik dari uji $F \leq$ nilai kritis $F$, maka $H_{0}$ diterima dan $H_{1}$ ditolak. Jika nilai statistik dari uji $F>$ nilai kritis $F$, maka $H_{0}$ ditolak dan $H_{1}$ diterima.

Pengambilan keputusan terhadap hipotesis juga dapat dilakukan dengan membandingkan nilai probabilitas ( $p$-value) dari uji $F$ terhadap tingkat signifikansi $\alpha$ (significance level). Berikut aturan pengambilan keputusan berdasarkan pendekatan nilai probabilitas.

Jika nilai probabilitas $\geq$ tingkat signifikansi, maka $H_{0}$ diterima dan $H_{1}$ ditolak. Jika nilai probabilitas < tingkat signifikansi, maka $H_{0}$ ditolak dan $H_{1}$ diterima. 


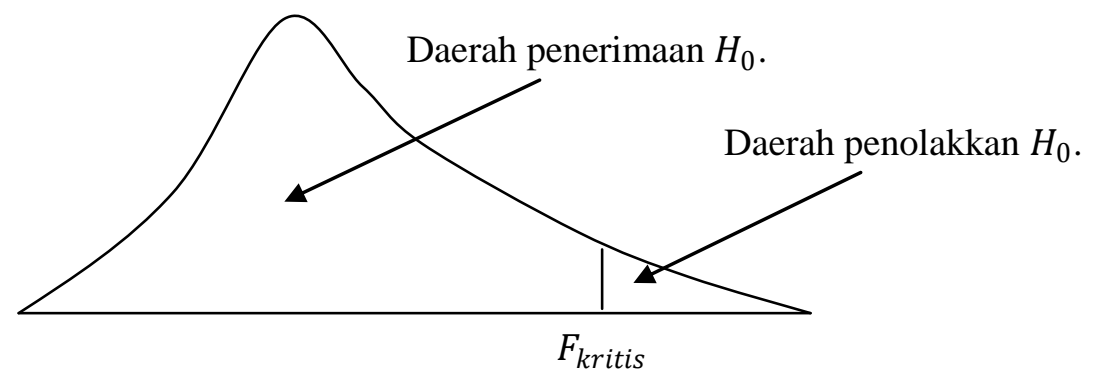

Tabel 13.1 menyajikan nilai statistik dari uji $F$, nilai probabilitas dari uji $F$, derajat bebas pembilang, dan derajat bebas penyebut.

Tabel 13.1

\begin{tabular}{|c|c|c|c|c|c|c|c|}
\hline \multirow{5}{*}{$\begin{array}{c}\mathrm{df}=3 \text { merupakan } \\
\text { derajat bebas } \\
\text { pembilang, sedangkan } \\
\mathrm{df}=36 \text { merupakan } \\
\text { derajat bebas }\end{array}$} & \multicolumn{6}{|c|}{ ANOVA } & \multirow{5}{*}{$\begin{array}{c}\text { Nilai } \text { Sig }=0,000 \\
\text { merupakan nilai } \\
\text { probabilitas dari uji } \\
\begin{array}{c}F, \text { sedangkan nilai } F \\
=117,204 \\
\text { merupakan nilai }\end{array}\end{array}$} \\
\hline & \multicolumn{6}{|c|}{ nilai indeks prestasi kumulatif mahasiswa } & \\
\hline & & $\begin{array}{l}\text { Sum of } \\
\text { squares }\end{array}$ & $d f$ & Mean Square & & & \\
\hline & Between Groups & & $\rightarrow 3$ & .955 & 117.204 & .000 & \\
\hline & $\begin{array}{l}\text { Within Groups } \\
\text { Total }\end{array}$ & $\begin{array}{r}.293 \\
3.158\end{array}$ & $\begin{array}{l}36 \\
39\end{array}$ & & & & \\
\hline
\end{tabular}

\section{Contoh Kasus dalam Analisis Varians Satu Arah}

Berikut diberikan contoh kasus yang dapat diselesaikan dengan pendekatan analisis varians satu arah.

[1] Misalkan seorang guru ingin meneliti apakah terdapat perbedaan (secara rata-rata) mengenai nilai ujian matematika siswa ketika diterapkan metode mengajar $\mathrm{A}, \mathrm{B}$, dan $\mathrm{C}$. Dalam hal ini, apakah terdapat pengaruh pada penggunaan metode mengajar yang berbedaberbeda terhadap hasil nilai ujian matematika siswa. Untuk keperluan penelitian, guru tersebut mengambil sampel sebanyak 21 siswa. Kemudian 7 siswa diterapkan metode mengajar A, 7 siswa berikutnya diterapkan metode mengajar B, dan sisanya diterapkan metode mengajar C. Berikut data yang telah dikumpulkan oleh guru tersebut (Tabel 13.2).

Tabel 13.2 Data Nilai Uji Matematika dari 21 Responden (Data Fiktif)

\begin{tabular}{|c|c|c|c|c|c|}
\hline \multicolumn{2}{|c|}{ Metode A } & \multicolumn{2}{c|}{ Metode B } & \multicolumn{2}{c|}{ Metode C } \\
\hline Nama & Nilai & Nama & Nilai & Nama & Nilai \\
\hline A & 65 & H & 80 & O & 64 \\
\hline B & 60 & I & 80 & P & 64 \\
\hline C & 62 & J & 82 & Q & 63 \\
\hline D & 65 & K & 81 & R & 62 \\
\hline E & 60 & L & 85 & S & 66 \\
\hline F & 64 & M & 82 & T & 63 \\
\hline G & 66 & N & 83 & U & 65 \\
\hline
\end{tabular}

Perhatikan bahwa nilai ujian matematika merupakan variabel tak bebas dan bersifat kuantitatif, sedangkan metode mengajar merupakan variabel bebas dan bersifat kualitatif (kategori). Dengan menggunakan pendekatan analisis varians satu arah, dapat diuji apakah 
terdapat perbedaan pengaruh yang cukup signifikan (secara statistika) di antara ketiga metode mengajar tersebut terhadap nilai ujian matematika yang dicapai siswa.

[2] Misalkan seorang petani memiliki 15 lahan jagung dengan ukuran yang sama. 5 lahan pertama diberi pupuk jenis A, 5 lahan kedua diberi pupuk jenis B, dan 5 lahan ketiga diberi pupuk jenis C. Tabel 13.3 menyajikan data hasil panen jagung. Andaikan petani tersebut ingin mengetahui apakah terdapat perbedaan (secara rata-rata) hasil panen jagung berdasarkan penggunaan jenis pupuk. Dengan kata lain, apakah penggunaan jenis pupuk yang berbedabeda berpengaruh terhadap hasil panen jagung yang diperoleh.

Tabel 13.3 Data Hasil Panen Jagung dalam kg (Data Fiktif)

\begin{tabular}{|c|c|c|}
\hline Pupuk Jenis A & Pupuk Jenis B & Pupuk Jenis C \\
\hline $100 \mathrm{~kg}$ & $120 \mathrm{~kg}$ & $140 \mathrm{~kg}$ \\
\hline $121 \mathrm{~kg}$ & $99 \mathrm{~kg}$ & $142 \mathrm{~kg}$ \\
\hline $98 \mathrm{~kg}$ & $102 \mathrm{~kg}$ & $135 \mathrm{~kg}$ \\
\hline $109 \mathrm{~kg}$ & $109 \mathrm{~kg}$ & $141 \mathrm{~kg}$ \\
\hline $104 \mathrm{~kg}$ & $115 \mathrm{~kg}$ & $144 \mathrm{~kg}$ \\
\hline
\end{tabular}

Perhatikan bahwa hasil panen jagung merupakan variabel tak bebas dan bersifat kuantitatif, sedangkan jenis pupuk merupakan variabel bebas dan bersifat kualitatif (kategori). Dengan menggunakan pendekatan analisis varians satu arah, dapat diuji apakah terdapat pengaruh yang cukup signifikan secara statistika di antara ketiga jenis pupuk tersebut terhadap hasil panen jagung yang diperoleh.

\section{Asumsi-Asumsí dalam Analisís Varíans Satu Arah}

Terdapat beberapa asumsi yang dikenakan dalam penggunaan analisis varians satu arah, antara lain asumsi normalitas, homogenitas atau kesamaan varians, serta sampel-sampel acak independen (independent random samples).

\section{Asumsi Normalitas}

Salah satu asumsi yang dikenakan dalam analisis varians satu arah adalah asumsi normalitas, yakni sampel-sampel yang diteliti berasal dari populasi-populasi yang berdistribusi normal. Untuk menguji apakah sampel-sampel yang diteliti berasal dari populasi-populasi yang berdistribusi normal, dapat digunakan uji Kolmogorov-Smirnov. Hipotesis nol menyatakan sampel yang diambil berasal dari populasi yang berdistribusi normal, sedangkan hipotesis alternatif menyatakan sampel yang diambil tidak berasal dari populasi yang berdistribusi normal. Untuk pengambilan keputusan terhadap hipotesis, dapat dibandingkan antara nilai probabilitas dari uji Kolmogorov-Smirnov dan tingkat signifikansi yang digunakan $(\alpha)$. Berikut aturan pengambilan keputusan terhadap hipotesis.

Jika nilai probabilitas $\geq$ tingkat signifikansi, $H_{0}$ diterima dan $H_{1}$ ditolak. Jika nilai probabilitas $<$ tingkat signifikansi, $H_{0}$ ditolak dan $H_{1}$ diterima.

Tabel 13.4 menyajikan nilai probabilitas dari uji Kolmogorov-Smirnov. 
Tabel 13.4

\begin{tabular}{|c|c|c|c|}
\hline & & $\begin{array}{l}\text { nilai indeks } \\
\text { prestasi } \\
\text { kumulatif } \\
\text { mahasiswa } \\
\text { jurusan } \\
\text { matematik }\end{array}$ & 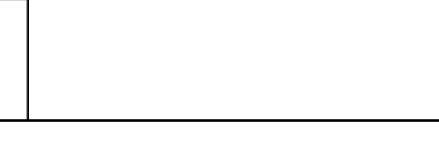 \\
\hline $\begin{array}{l}\text { Normal Parameters }{ }^{a . . b} \\
\text { Most Extreme Differences }\end{array}$ & $\begin{array}{l}\text { Mean } \\
\text { Std. Deviation } \\
\text { Absolute }\end{array}$ & $\begin{array}{r}1 \\
2.739 \\
.0741 \\
.28\end{array}$ & $\begin{array}{c}\text { Nilai Asymp. Sig. (2-tailed) } \\
=0,412 \text { merupakan nilai } \\
\text { probabilitas. }\end{array}$ \\
\hline $\begin{array}{l}\text { Kolmogorov-Smirnov } Z \\
\text { Asymp. Sig. (2-tailed) }\end{array}$ & $\begin{array}{l}\text { Positive } \\
\text { Negative }\end{array}$ & $\begin{array}{r}.174 \\
-.280 \\
.886 \\
.412 \\
\end{array}$ & 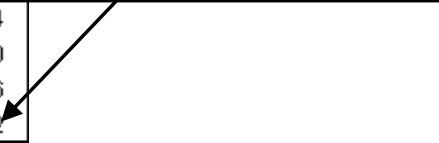 \\
\hline
\end{tabular}

\section{Asumsi Kesamaan Varians}

Selain asumsi normalitas, asumsi lain yang dikenakan dalam analisis varians adalah asumsi kesamaan varians, yakni sampel-sampel yang diteliti berasal dari populasi-populasi yang memiliki varians yang sama. Untuk menguji apakah sampel-sampel yang diteliti berasal dari populasi-populasi yang memiliki varians yang sama, dapat digunakan uji Levene. Hipotesis nol menyatakan sampel-sampel yang diambil berasal dari populasi-populasi yang memiliki varians yang sama, sedangkan hipotesis alternatif menyatakan paling tidak terdapat sepasang populasi yang memiliki varians yang berbeda.

Untuk pengambilan keputusan terhadap hipotesis, dapat dibandingkan antara nilai probabilitas dari uji Levene dan tingkat signifikansi yang digunakan $(\alpha)$. Berikut aturan pengambilan keputusan terhadap hipotesis dengan pendekatan nilai probabilitas.

Jika nilai probabilitas $\geq$ tingkat signifikansi, $H_{0}$ diterima dan $H_{1}$ ditolak. Jika nilai probabilitas $<$ tingkat signifikansi, $H_{0}$ ditolak dan $H_{1}$ diterima.

Tabel 13.5 menyajikan nilai probabilitas dari uji Levene.

Tabel 13.5

Test of Homogeneity of Variances

Kolom Sig menyajikan nilai probabilitas dari

uji Levene.

nilai indeks prestasi kumulatif mahasiswa
\begin{tabular}{|c|r|r|r|}
\hline $\begin{array}{c}\text { Levene } \\
\text { Statistic }\end{array}$ & $\mathrm{df} 1$ & $\mathrm{df2}$ & Sig. \\
\hline 2.233 & 3 & 36 & .101 \\
\hline
\end{tabular}

\section{Asumsi Sampel-Sampel Acak Independen (Independent Random Samples)}

Asumsi mengenai sampel-sampel acak independen dapat diartikan sampel-sampel yang ditarik berasal dari populasi yang berbeda-beda, serta pengambilan elemen sampel bersifat acak (random). 


\section{PENYELESAIAN DALAM SPSS}

Misalkan seorang peneliti ingin mengetahui apakah terdapat perbedaan (secara rata-rata) yang cukup signifikan secara statistika mengenai nilai indeks prestasi kumulatif di antara mahasiswa jurusan matematika, fisika, kimia dan biologi di universitas ABC pada tingkat signifikansi 5\%. Untuk keperluan penelitian, peneliti mengambil sampel sebanyak 10 responden dari masing-masing jurusan, dan menanyakan nilai indeks prestasi kumulatif saat ini. Berikut data yang telah dikumpulkan.

Tabel 13.1 Nilai Indeks Prestasi Kumulatif dari 40 Responden (Data Fiktif)

\begin{tabular}{|c|c|c|c|c|c|c|c|}
\hline \multicolumn{7}{|c|}{ Jurusan } \\
\hline Nama & Matematika & Nama & Fisika & Nama & Kimia & Nama & Biologi \\
\hline A & 2.75 & K & 2.7 & V & 3.32 & AF & 3.1 \\
\hline B & 2.65 & L & 2.66 & W & 3.3 & AG & 3.15 \\
\hline C & 2.77 & M & 2.77 & X & 3.36 & AH & 2.9 \\
\hline D & 2.76 & N & 2.68 & Y & 3.4 & AI & 2.95 \\
\hline E & 2.8 & O & 2.81 & Z & 3.45 & AJ & 3.22 \\
\hline F & 2.82 & P & 2.8 & AA & 3.2 & AK & 3.16 \\
\hline G & 2.77 & Q & 2.76 & AB & 3.52 & AL & 2.95 \\
\hline H & 2.65 & R & 2.6 & AC & 3.4 & AM & 2.99 \\
\hline I & 2.6 & S & 2.7 & AD & 3.42 & AN & 3.03 \\
\hline J & 2.78 & T & 2.65 & AE & 3.28 & AO & 3.21 \\
\hline
\end{tabular}

Berdasarkan data pada Tabel 13.1, seorang mahasiswa dari jurusan matematika bernama $\mathbf{J}$ memiliki nilai indeks prestasi kumulatif 2,78 , seorang mahasiswa dari jurusan fisika bernama $\mathrm{S}$ memiliki nilai indeks prestasi kumulatif 2,7 , dan seterusnya. Berikut hal-hal yang ingin diketahui oleh peneliti:

$\Rightarrow$ Apakah terdapat perbedaan (secara rata-rata) yang cukup signifikan secara statistikaa mengenai nilai indeks prestasi kumulatif di antara mahasiswa jurusan matematika, fisika, kimia, dan biologi pada tingkat signifikansi $5 \%$.

$\Rightarrow$ Apakah terdapat perbedaan yang signifikan secara statistika mengenai nilai indeks prestasi kumulatif antara mahasiswa matematika v/s fisika, matematika v/s kimia, matematika v/s biologi, fisika v/s kimia, fisika v/s biologi, dan kimia v/s biologi.

Berikut akan dilakukan uji asumsi normalitas terlebih dahulu, yakni akan diuji apakah sampel-sampel mengenai nilai indeks prestasi kumulatif mahasiswa jurusan matematika, fisika, kimia dan biologi berasal dari populasi-populasi yang berdistribusi normal. Bangun data pada Tabel 13.1 dalam SPSS (Gambar 13.1).

\begin{tabular}{|c|c|c|c|c|c|c|}
\hline & Name & Type & Width & Decimals & Label & \\
\hline 1 & matematika & Numeric & 8 & 2 & nilai indeks prestasi kumulatif mahasiswa jurusan ma... & No \\
\hline 2 & fisika & Numeric & 8 & 2 & nilai indeks prestasi kumulatif mahasiswa jurusan fisika & No \\
\hline 3 & kimia & Numeric & 8 & 2 & nilai indeks prestasi kumulatif mahasiswa jurusan ki... & No \\
\hline 4 & biologi & Numeric & 8 & 2 & nilai indeks prestasi kumulatif mahasiswa jurusan bio... & No \\
\hline
\end{tabular}




\begin{tabular}{|r|r|r|r|r|r}
\hline & matematika & \multicolumn{1}{|c|}{ fisika } & kimia & \multicolumn{1}{c|}{ biologi } \\
\hline 1 & 2.75 & 2.70 & 3.32 & 3.10 \\
\hline 2 & 2.65 & 2.66 & 3.30 & 3.15 \\
\hline 3 & 2.77 & 2.77 & 3.36 & 2.90 \\
\hline 4 & 2.76 & 2.68 & 3.40 & 2.95 \\
\hline 5 & 2.80 & 2.81 & 3.45 & 3.22 \\
\hline 6 & 2.82 & 2.80 & 3.20 & 3.16 \\
\hline 7 & 2.77 & 2.76 & 3.52 & 2.95 \\
\hline 8 & 2.65 & 2.60 & 3.40 & 2.99 \\
\hline 9 & 2.60 & 2.70 & 3.42 & 3.03 \\
\hline 10 & 2.78 & 2.65 & 3.28 & 3.21 \\
\hline
\end{tabular}

\section{Gambar 13.1}

Pilih Analyze $=>$ Nonparametric Tests $=>1$-Sample $K$-S, sehingga muncul kotak dialog OneSample Kolmogorov-Smirnov Test (Gambar 13.2). Masukkan variabel matematika, fisika, kimia, dan biologi ke dalam kotak Test Variable List (Gambar 13.2). Pada Test Distribution pilih Normal. Kemudian pilih OK.

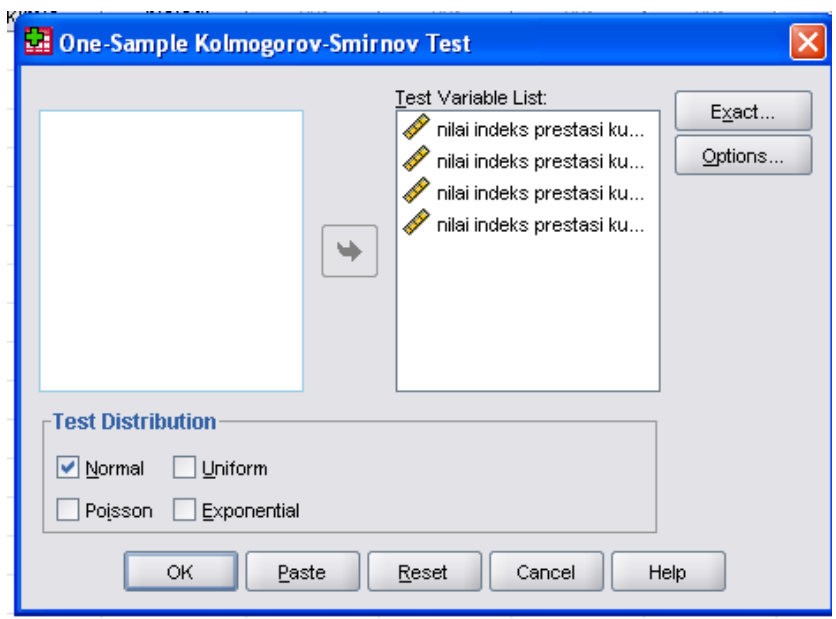

\section{Gambar 13.2}

Untuk menentukan apakah sampel-sampel mengenai nilai indeks prestasi kumulatif mahasiswa jurusan matematika, fisika, kimia dan biologi berasal dari populasi-populasi yang berdistribusi normal, bandingkan masing-masing nilai probabilitas (Asymp. Sig. (2-tailed)) terhadap tingkat signifikansi yang digunakan $(\alpha)$. Misalkan digunakan tingkat signifikansi $5 \%$. Berikut aturan pengambilan keputusan berdasarkan pendekatan nilai probabilitas.

Jika nilai probabilitas $\geq$ tingkat signifikansi, maka $H_{0}$ diterima dan $H_{1}$ ditolak. Jika nilai probabilitas < tingkat signifikansi, maka $H_{0}$ ditolak dan $H_{1}$ diterima.

Pada Tabel 13.2, nilai Asymp. Sig. (2-tailed) dari masing-masing jurusan lebih besar dari tingkat signifikansi yang digunakan, yakni 0,05, maka disimpulkan bahwa sampel-sampel mengenai nilai indeks prestasi kumulatif mahasiswa jurusan matematika, fisika, kimia dan biologi berasal dari populasi-populasi yang berdistribusi normal. Perhatikan bahwa telah diperlihatkan asumsi normalitas dipenuhi. 
Tabel 13.2

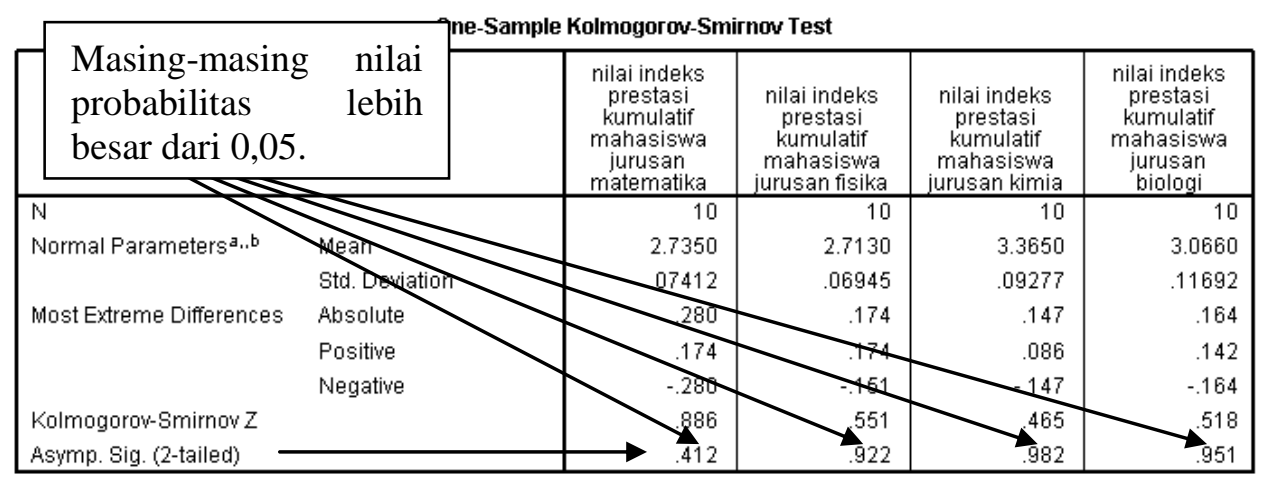

Setelah asumsi normalitas dipenuhi, selanjutnya akan dilakukan uji kesamaan varians. Bangun data pada Tabel 13.1 dalam SPSS seperti berikut (Gambar 13.3).

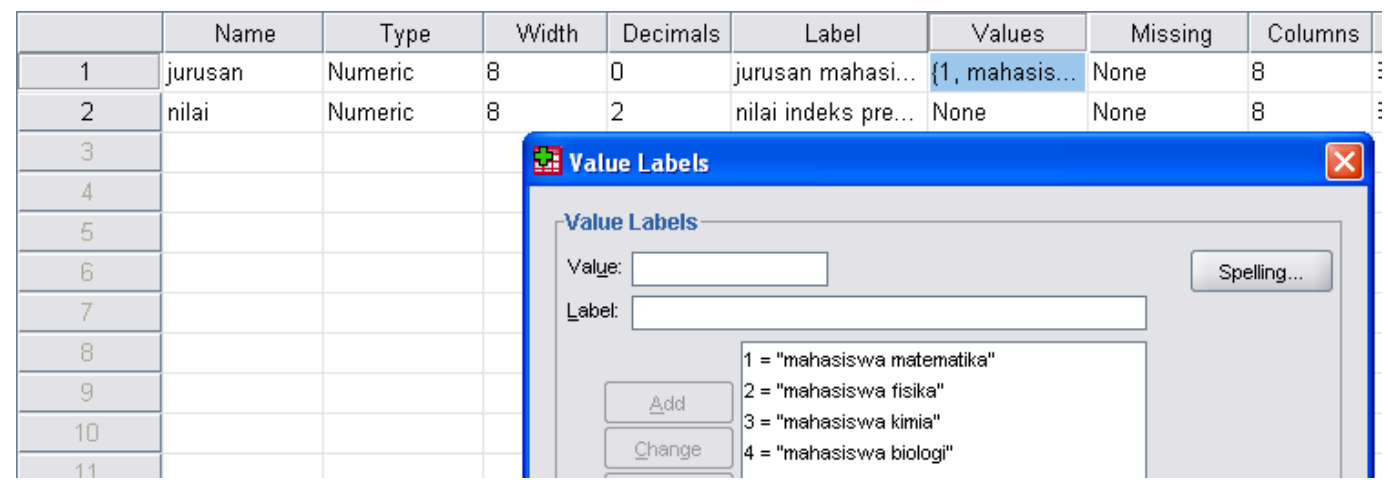

\begin{tabular}{|r|r|r|l|l|}
\hline & jurusan & nilai & var & var \\
\hline 1 & 1 & 2.75 & \\
\hline 2 & 1 & 2.65 & \\
\hline 3 & 1 & 2.77 & \\
\hline 4 & 1 & 2.76 & \\
\hline 5 & 1 & 2.80 & \\
\hline 6 & 1 & 2.82 & \\
\hline 7 & 1 & 2.77 & \\
\hline 8 & 1 & 2.65 & \\
\hline 9 & 1 & 2.60 & \\
\hline 10 & 1 & 2.78 & \\
\hline 11 & 2 & 2.70 & \\
\hline 12 & 2 & 2.66 & \\
\hline 13 & 2 & 2.77 & \\
\hline 14 & 2 & 2.68 & \\
\hline 15 & 2 & 2.81 & \\
\hline 16 & 2 & 2.80 & \\
\hline 17 & 2 & 2.76 & \\
\hline
\end{tabular}

\section{Gambar 13.3}

Pilih Analyze $=>$ Compare Means $=>$ One-Way ANOVA, sehingga muncul kotak dialog OneWay ANOVA (Gambar 13.4). Masukkan variabel nilai ke dalam Dependent List: dan masukkan variabel jurusan mahasiswa ke dalam Factor. 


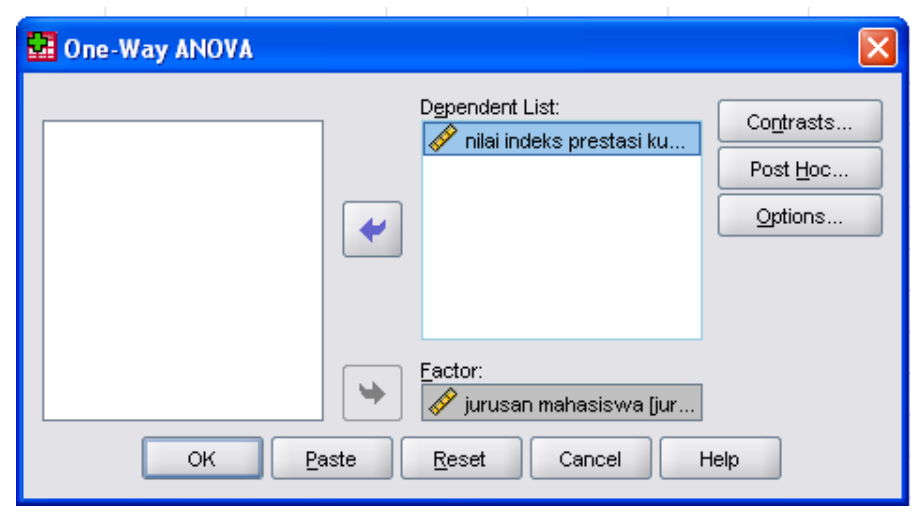

\section{Gambar 13.4}

Selanjutnya pilih Post Hoc, sehingga muncul kotak dialog One-Way ANOVA: Post Hoc Multiple Comparisons (Gambar 13.5). Pada kotak dialog One-Way ANOVA: Post Hoc Multiple Comparisons pilih Tukey dan Games Howell. Jika asumsi kesamaan varians terpenuhi, maka multiple comparisons dilakukan dengan uji Tukey, sedangkan ketika asumsi kesamaan varians tidak dipenuhi, maka multiple comparisons dilakukan dengan uji GamesHowell. Kemudian pilih Continue, sehingga kembali pada tampilan seperti pada Gambar 13.4.

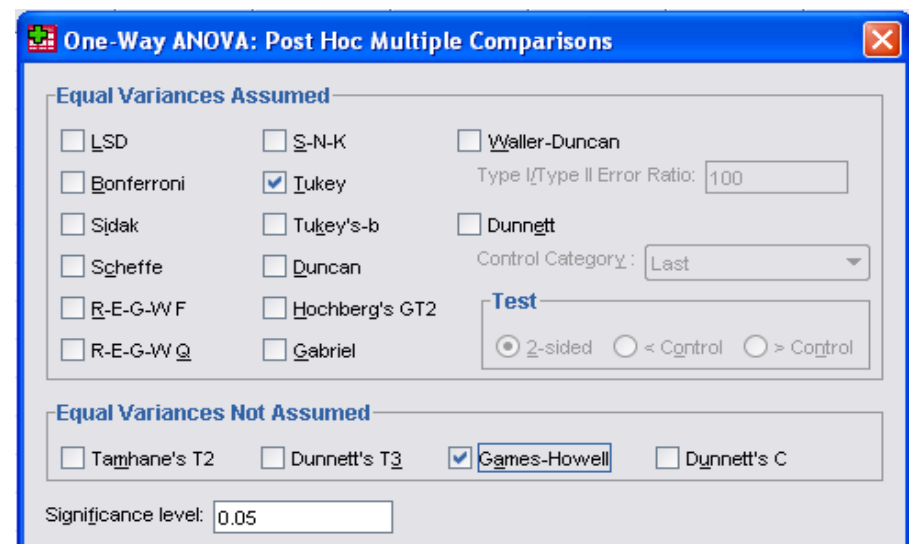

Gambar 13.5

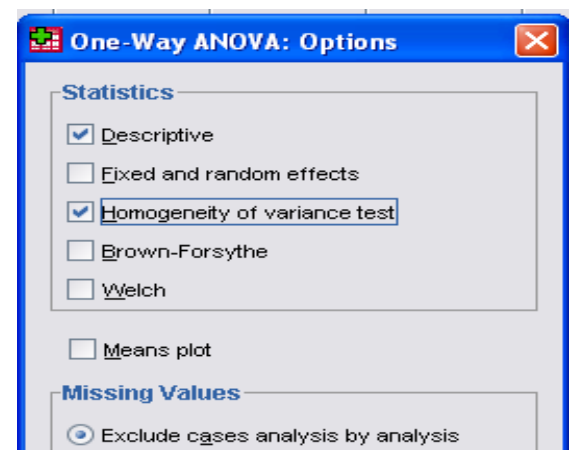

Gambar 13.6

Pada kotak dialog One-Way ANOVA (Gambar 13.4), pilih Options, sehingga muncul kotak dialog One-Way ANOVA: Options (Gambar 13.6). Pilih Descriptive dan Homogeneity of variance test. Selanjutnya pilih Continue dan OK. Berikut hasil berdasarkan SPSS dan interpretasinya.

Berdasarkan Tabel 13.3, secara rata-rata (mean), nilai indeks prestasi kumulatif mahasiswa jurusan kimia menempati urutan paling tinggi, yakni 3,3650, disusul oleh jurusan biologi 3,0660 , matematika 2,7350, dan fisika 2,7130. Nilai indeks prestasi kumulatif minimum dari jurusan matematika adalah 2,60, dan maksimum adalah 2,82. Nilai indeks prestasi kumulatif minimum tersebut merupakan nilai indeks prestasi kumulatif mahasiswa yang bernama I, sedangkan nilai indeks prestasi kumulatif maksimum merupakan nilai indeks prestasi kumulatif mahasiswa yang bernama $\mathrm{F}$. 
Tabel 13.3

\begin{tabular}{||l|} 
nilai indeks prestasi kumulatif mahasiswa \\
\hline
\end{tabular}

Tabel 13.4

Test of Homogeneity of Variances

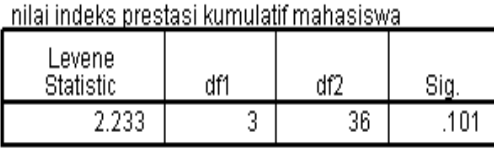

Tabel 13.5

ANOVA

nilai indeks prestasi kumulatif mahasiswa
\begin{tabular}{|l|r|r|r|r|r|}
\hline & \multicolumn{1}{c}{$\begin{array}{c}\text { Sum of } \\
\text { Squares }\end{array}$} & \multicolumn{1}{c|}{ df } & Mean Square & F & Sig. \\
\hline Between Groups & 2.865 & 3 & .955 & 117.204 & .000 \\
Within Groups & .293 & 36 & .008 & & \\
Total & 3.158 & 39 & & & \\
\hline
\end{tabular}

Selanjutnya akan diuji asumsi kesamaan varians populasi berdasarkan informasi pada Tabel 13.4. Perhatikan bahwa karena nilai probabilitas dari uji Levene $(0,101)$ lebih besar dari tingkat signifikansi $(0,05)$, maka disimpulkan bahwa varians populasi dari nilai indeks prestasi kumulatif mahasiswa jurusan matematika, fisika, kimia dan biologi adalah sama pada tingkat signifikansi 5\%. Oleh karena asumsi kesamaan varians populasi dipenuhi, maka multiple comparisons dilakukan dengan uji Tukey.

Informasi yang disajikan pada Tabel 13.5 (ANOVA) akan digunakan untuk pengambilan keputusan apakah terdapat perbedaan (secara rata-rata) yang cukup signifikan secara statistika mengenai nilai indeks prestasi kumulatif di antara mahasiswa jurusan matematika, fisika, kimia, dan biologi pada tingkat signifikansi $5 \%$.

Berdasarkan Tabel 13.5 diketahui nilai probabilitas (Sig) dari uji $F$ adalah 0,000. Oleh karena nilai probabilitas $(0,000)$ lebih kecil dibandingkan tingkat signifikansi yang digunakan $(0,05)$, maka disimpulkan bahwa terdapat perbedaan yang signifikan secara statistika mengenai nilai indeks prestasi kumulatif di antara mahasiswa jurusan matematika, fisika, kimia, dan biologi pada tingkat signifikansi $5 \%$.

\section{Tabel 13.6}

\begin{tabular}{|c|c|c|c|c|c|c|c|}
\hline & & Multiple & mparisons & & & & \\
\hline & & & & & & $95 \%$ Confid & \\
\hline & (1) iurusan mahasiswa & (J) iurusan mahasiswa & $\begin{array}{c}\text { Mean } \\
\text { Difference (1- } \\
J)\end{array}$ & Std. Error & Siq. & Lower Bound & $\mathrm{u}$ \\
\hline Tukey HSD & mahasiswa matematika & mahasiswa fisika & .02200 & .04037 & .947 & -.0867 & \\
\hline & & mahasiswa kimia & $-.63000^{\pi}$ & .04037 & .000 & -.7387 & \\
\hline & & mahasiswa biologi & $-.33100^{\pi}$ & .04037 & .000 & -.4397 & \\
\hline & mahasiswa fisika & mahasiswa matematika & -.02200 & .04037 & .947 & -.1307 & \\
\hline & & mahasiswa kimia & $-.65200^{\pi}$ & .04037 & .000 & -.7607 & \\
\hline & & mahasiswa biologi & $-.35300^{\pi}$ & .04037 & .000 & -.4617 & \\
\hline & mahasiswa kimia & mahasiswa matematika & $.63000^{x}$ & .04037 & .000 & .5213 & \\
\hline & & mahasiswa fisika & $.65200^{\pi}$ & .04037 & .000 & .5433 & \\
\hline & & mahasiswa biologi & $.29900^{\pi}$ & .04037 & .000 & .1903 & \\
\hline & mahasiswa biologi & mahasiswa matematika & $.33100^{x}$ & .04037 & .000 & .2223 & \\
\hline & & mahasiswa fisika & $.35300^{\pi}$ & .04037 & .000 & .2443 & \\
\hline & & mahasiswa kimia & $-.29900^{\pi}$ & .04037 & .000 & -.4077 & \\
\hline
\end{tabular}


Informasi yang disajikan pada Tabel 13.6 (Multiple Comparisons) akan digunakan untuk mengetahui apakah terdapat perbedaan (secara rata-rata) yang cukup signifikan secara statistika mengenai nilai indeks prestasi kumulatif antara mahasiswa: matematika $\mathrm{v} / \mathrm{s}$ fisika, matematika v/s kimia, matematika v/s biologi, fisika v/s kimia, fisika v/s biologi, dan kimia v/s biologi pada tingkat signifikansi 5\%. Dalam hal ini, cukup perhatikan pada bagian Tukey $H S D$ karena asumsi kesamaan varians populasi telah dipenuhi.

$\Rightarrow$ Perhatikan bahwa tidak terdapat perbedaan (secara rata-rata) yang cukup signifikan secara statistika mengenai nilai indeks prestasi kumulatif antara mahasiswa matematika dengan mahasiswa fisika. Hal ini dapat dilihat dari nilai Sig. yang lebih besar dari tingkat signifikansi yang digunakan $5 \%(0,947 \geq 0,05)$.

$\Rightarrow$ Terdapat perbedaan (secara rata-rata) yang cukup signifikan secara statistika mengenai nilai indeks prestasi kumulatif antara mahasiswa matematika dengan mahasiswa kimia. Hal ini dapat dilihat dari nilai Sig. yang lebih kecil dari tingkat signifikansi yang digunakan $5 \%(0,00<0,05)$.

$\Rightarrow$ Terdapat perbedaan yang cukup signifikan secara statistika mengenai nilai indeks prestasi kumulatif antara mahasiswa matematika dengan mahasiswa biologi. Hal ini dapat dilihat dari nilai Sig. yang lebih kecil dari tingkat signifikansi yang digunakan $5 \%(0,00<0,05)$.

$\Rightarrow$ Terdapat perbedaan yang cukup signifikan secara statistika mengenai nilai indeks prestasi kumulatif antara mahasiswa kimia dengan mahasiswa biologi. Hal ini dapat dilihat dari nilai Sig. yang lebih kecil dari tingkat signifikansi yang digunakan $5 \%(0,00<0,05)$.

Informasi yang disajikan pada Tabel 13.7 (Homogeneous Subsets) dapat diinterpretasikan bahwa nilai indeks prestasi kumulatif mahasiswa fisika dan matematika adalah sama (perbedaan yang terjadi tidak signifikan) pada tingkat signifikansi 5\%, namun nilai indeks prestasi kumulatif mahasiswa fisika berbeda dengan mahasiswa biologi dan kimia pada tingkat signifikansi 5\%. Perhatikan juga bahwa nilai indeks prestasi kumulatif mahasiswa biologi berbeda dengan mahasiswa fisika, matematika, dan kimia pada tingkat signifikansi 5\%. Dan terakhir, nilai indeks prestasi kumulatif mahasiswa kimia berbeda dengan mahasiswa fisika, matematika, dan biologi pada tingkat signifikansi 5\%.

Berdasarkan Tabel 13.7 (Homogeneous Subsets) terlihat bahwa nilai indeks prestasi kumulatif mahasiswa kimia berada pada kolom ketiga yang menandakan bahwa nilai indeks prestasi kumulatif mahasiswa kimia menempati urutan paling tinggi (secara rata-rata).

\section{Tabel 13.7}

\section{Homogeneous Subsets}

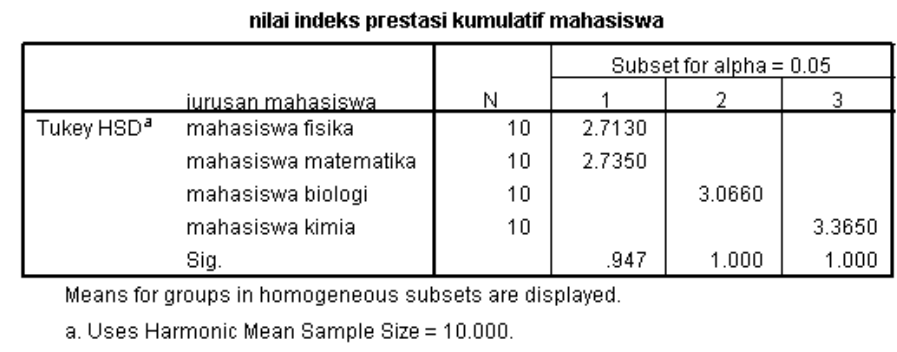




\section{Referensi}

1. Agresti, A. dan B. Finlay. 2009. Statistical Methods for the Social Sciences, $4^{\text {th }}$ Edition. United States of America: Prentice Hall.

2. Field, A. 2009. Discovering Statistics Using SPSS, $3^{\text {rd }}$ Edition. London: Sage.

3. Gamst, G., L.S. Meyers, dan A.J. Guarino. 2008. Analysis of Variance Designs, Computational Approach with SPSS and SAS. Cambridge: Cambridge University Press.

4. Gio, P.U. 2013. Aplikasi Statistika dalam SPSS. Medan: USUpress.

5. Mann, P. S. dan C.J. Lacke. 2011. Introductory Statistics, International Student Version, $7^{\text {th }}$ Edition. Asia: John Wiley \& Sons, Inc.

6. Montgomery, D.C. dan G.C. Runger. 2011. Applied Statistics and Probability for Engineers, $5^{\text {th }}$ Edition. United States of America: John Wiley \& Sons, Inc.

7. Smidth, R. K. dan D. H. Sanders. 2000. Statistics a First Course, $6^{\text {th }}$ Edition. United States of America: McGraw-Hill Companies. 


\section{BAB 14}

\section{ANALISIS VARIANS DUA ARAH}

\section{Sekílas Analisís Varíans Dua Arah}

Pada pembahasan sebelumnya telah dibahas mengenai analisis varians satu arah. Analisis varians satu arah hanya melibatkan satu variabel bebas bersifat non-metrik atau kualitatif (kategori), sedangkan pada analisis varians dua arah melibatkan dua variabel bebas bersifat non-metrik. Dalam analisis varians dua arah, variabel tak bebas juga bersifat metrik atau kuantitatif (interval atau rasio). Analisis varians melibatkan satu variabel tak bebas. Jika jumlah variabel tak bebas lebih dari satu, maka digunakan multivariate analysis of variance (MANOVA).

Dalam analisis varians dua arah dengan interaksi (interaction), dapat diuji ada tidaknya interaksi antara variabel bebas pertama dan variabel bebas kedua, terhadap pengaruhnya pada variabel tak bebas. Jika terdapat interaksi antara variabel bebas pertama dan variabel bebas kedua, maka dapat ditentukan perlakuan mana saja yang menyebabkan terjadinya interaksi.

Apabila terjadi interaksi, namun tidak signifikan secara statistika antara variabel bebas pertama dan variabel bebas kedua, maka dapat dilakukan pengujian apakah terdapat perbedaan rata-rata (mean) dari nilai variabel tak bebas berdasarkan kategori-kategori pada variabel bebas pertama dengan mengontrol (controlling) pengaruh variabel bebas kedua. Begitu juga sebaliknya dapat diuji apakah terdapat perbedaan rata-rata (mean) dari nilai variabel tak bebas untuk kategori-kategori pada variabel bebas kedua dengan mengontrol (controling) pengaruh variabel bebas pertama. Pengujian yang demikian ini dinamakan dengan pengujian pengaruh utama (main effect test).

Perlu diperhatikan bahwa sebelum melakukan pengujian pengaruh utama (main effect test), pertama lakukan pengujian apakah terjadi interaksi atau tidak antara variabel bebas pertama dan variabel bebas kedua. Ketika terjadi interaksi, maka pengujian hipotesis pada pengaruh utama menjadi tidak berarti. Agresti dan Finlay (2009:386) menyatakan sebagai berikut.

"When interaction exists, it is not meaningful to test the main effects hypotheses. When we reject $H_{0}$ : no interaction, we conclude that each variable has an effect, but the nature of that effect changes according to the category of the other variable. It's then better to compare the means for one predictor separately within categories of the other. On the other hand, if the evidence of interaction is not strong (i.e., if the p-value is not small), we then test the two main effect hypotheses".

Daniel (2005:361) menyatakan sebagai berikut.

"When hypothesis of no interaction is rejected, interest the levels of factors A dan B usually become subordinate to interest in the interaction effects. In other words, we are more interested in learning what combinations of levels are significant different."

Dalam analisis varians dua arah dengan interaksi, hipotesis nol mengenai pengujian interaksi menyatakan tidak terdapat interaksi antara variabel bebas pertama dan variabel bebas kedua terhadap pengaruhnya pada variabel tak bebas, sedangkan hipotesis alternatif menyatakan 
terdapat interaksi antara variabel bebas pertama dan variabel bebas kedua terhadap pengaruhnya pada variabel tak bebas.

Hipotesis nol untuk pengujian pengaruh utama menyatakan tidak terdapat perbedaan rata-rata (mean) dari nilai variabel tak bebas untuk kategori-kategori pada variabel bebas pertama dengan mengontrol (controlling) pengaruh variabel bebas kedua. Dengan kata lain, variabel bebas pertama tidak bepengaruh terhadap variabel tak bebas dengan mengontrol (controlling) pengaruh variabel bebas kedua. Begitu juga sebaliknya tidak terdapat perbedaan rata-rata (mean) dari nilai variabel tak bebas untuk kategori-kategori pada variabel bebas kedua dengan mengontrol (controlling) variabel bebas pertama.

\section{Contoh Kasus dalam Analisís Varians Dua Arah}

Berikut diberikan contoh kasus yang dapat diselesaikan dengan pendekatan analisis varians dua arah.

[1] Misalkan seorang petani jagung bernama Ugi ingin meneliti apakah terdapat pengaruh yang signifikan secara statistika pada penggunaan jenis bibit jagung dan jenis pupuk terhadap hasil produksi jagung. Berikut data produksi jagung yang telah dikumpulkan.

Tabel 14.1 Data Produksi Jagung dalam Satuan Kuintal (Data Fiktif)

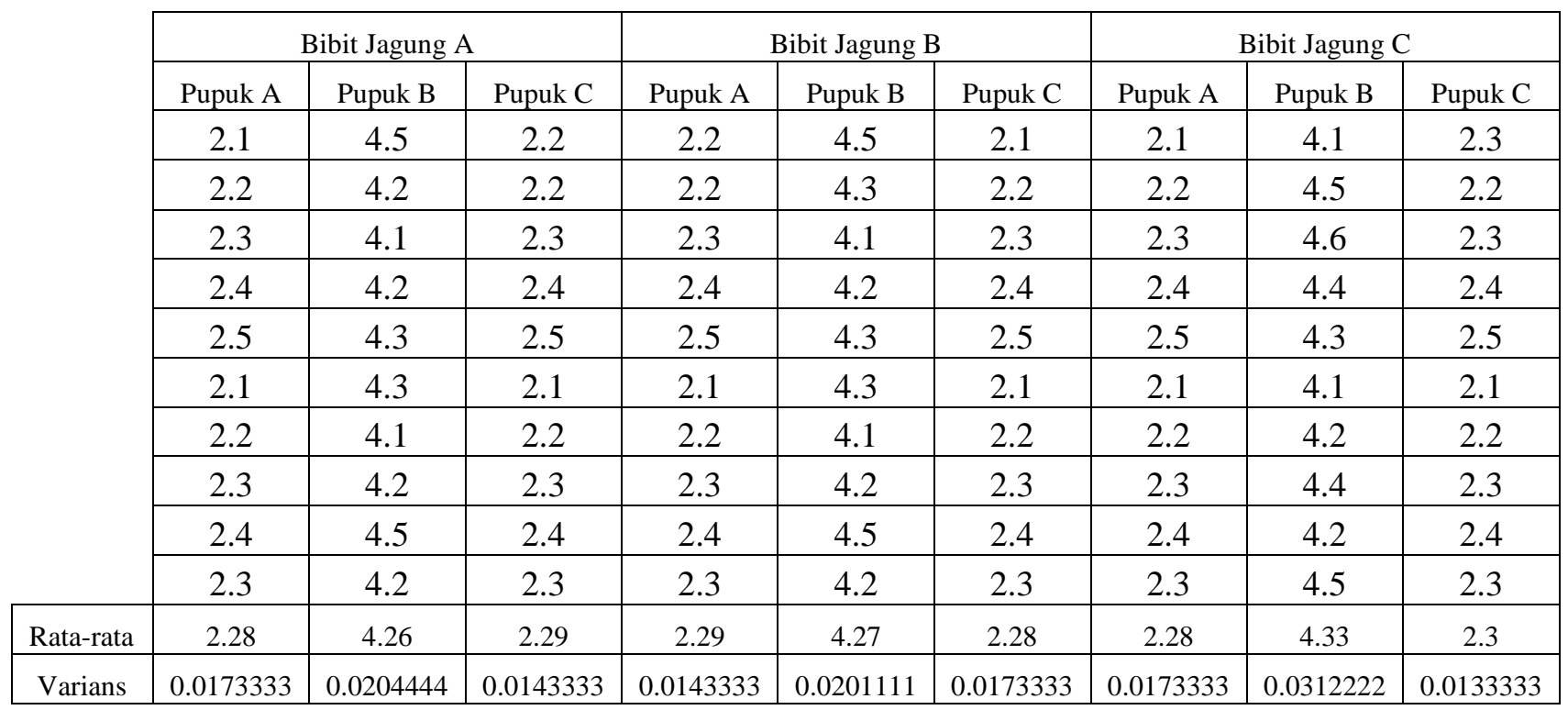

Berdasarkan data pada Tabel 14.1, diketahui terdapat tiga jenis bibit jagung, yakni jenis A, B, dan $\mathrm{C}$, sedangkan untuk jenis pupuk juga terdapat tiga jenis, yakni jenis $\mathrm{A}, \mathrm{B}$, dan $\mathrm{C}$. Perhatikan bahwa terdapat 9 kombinasi kategori, yakni (bibit jagung A \& pupuk A), (bibit jagung A \& pupuk B), (bibit jagung A \& pupuk C), (bibit jagung B \& pupuk A), dan seterusnya. Untuk masing-masing kombinasi kategori disediakan 10 lahan dengan ukuran lahan yang sama. Berikut hal-hal yang ingin diketahui oleh petani tersebut :

$\Rightarrow$ Apakah terdapat interaksi yang signifikan secara statistika antara penggunaan jenis bibit jagung dan jenis pupuk dalam pengaruhnya terhadap hasil produksi jagung.

$\Rightarrow$ Apakah penggunaan jenis pupuk berpengaruh pada hasil produksi jagung, dengan mengontrol pengaruh jenis bibit jagung. 
$\Rightarrow$ Apakah penggunaan jenis bibit jagung berpengaruh pada hasil produksi jagung, dengan mengontrol pengaruh jenis pupuk.

[2] Misalkan seorang peneliti bernama Ugi ingin meneliti apakah terdapat pengaruh yang signifikan secara statistika pada penerapan metode mengajar dan tingkat pendidikan guru terhadap nilai ujian matematika siswa. Data nilai ujian matematika dari 60 siswa disajikan dalam Tabel 14.2.

Berdasarkan data pada Tabel 14.2, diketahui terdapat dua jenis metode mengajar, yakni metode mengajar A dan B, sedangkan untuk tingkat pendidikan guru terdiri dari tiga kategori, yakni S1, S2, dan S3. Perhatikan bahwa terdapat 6 kombinasi kategori, yakni guru berpendidikan S1 yang menerapkan metode mengajar A (S1,A), (S1,B), (S2,A), (S2,B), $(\mathrm{S} 3, \mathrm{~A})$, dan $(\mathrm{S} 3, \mathrm{~B})$.

Berikut hal-hal yang ingin diketahui oleh petani tersebut :

$\Rightarrow$ Apakah terdapat interaksi yang signifikan secara statistika pada penerapan metode mengajar dan tingkat pendidikan guru dalam pengaruhnya terhadap nilai ujian matematika siswa.

$\Rightarrow$ Apakah metode mengajar guru berpengaruh pada nilai ujian matematika siswa, dengan mengontrol pengaruh tingkat pendidikan guru.

$\Rightarrow$ Apakah tingkat pendidikan guru berpengaruh pada nilai ujian matematika siswa, dengan mengontrol pengaruh metode mengajar guru.

Tabel 14.2 Data Nilai Ujian Matematika dari 60 Siswa

\begin{tabular}{|c|c|c|c|c|c|c|c|c|c|c|c|}
\hline \multicolumn{9}{|c|}{ Metode A } & \multicolumn{9}{|c|}{ Metode B } \\
\hline Siswa & S1 & Siswa & S2 & Siswa & S3 & Siswa & S1 & Siswa & S2 & Siswa & S3 \\
\hline 1 & 61 & 11 & 62 & 21 & 61 & 31 & 80 & 41 & 82 & 51 & 81 \\
\hline 2 & 62 & 12 & 62 & 22 & 62 & 32 & 81 & 42 & 81 & 52 & 81 \\
\hline 3 & 63 & 13 & 63 & 23 & 63 & 33 & 82 & 43 & 82 & 53 & 82 \\
\hline 4 & 64 & 14 & 64 & 24 & 64 & 34 & 83 & 44 & 83 & 54 & 83 \\
\hline 5 & 65 & 15 & 65 & 25 & 65 & 35 & 84 & 45 & 84 & 55 & 84 \\
\hline 6 & 61 & 16 & 61 & 26 & 61 & 36 & 85 & 46 & 85 & 56 & 85 \\
\hline 7 & 62 & 17 & 62 & 27 & 62 & 37 & 80 & 47 & 80 & 57 & 80 \\
\hline 8 & 63 & 18 & 63 & 28 & 63 & 38 & 81 & 48 & 81 & 58 & 81 \\
\hline 9 & 64 & 19 & 64 & 29 & 64 & 39 & 82 & 48 & 82 & 59 & 82 \\
\hline 10 & 65 & 20 & 65 & 30 & 65 & 40 & 83 & 50 & 83 & 60 & 83 \\
\hline $\bar{x}$ & 63 & & 63.1 & & 63 & & 82.1 & & 82.3 & & 82.2 \\
\hline$s^{2}$ & 2.222 & & 1.878 & & 2.222 & & 2.767 & & 2.233 & & 2.4 \\
\hline
\end{tabular}

\section{Asumsi-Asumsi dalam Analisís Varians Dua Arah}

Terdapat beberapa asumsi yang dikenakan dalam penggunaan analisis varians dua arah, antara lain asumsi normalitas, homogenitas atau kesamaan varians, serta sampel-sampel acak independen (independent random samples). 


\section{Asumsi Normalitas}

Salah satu asumsi yang dikenakan dalam analisis varians dua arah dengan interaksi adalah asumsi normalitas. Andaikan variabel bebas pertama memiliki $a$ kategori, sedangkan variabel bebas kedua memiliki $b$ kategori, maka terdapa $a b$ kombinasi kategori. Asumsi normalitas menyatakan masing-masing populasi dari kombinasi kategori berdistribusi normal (Daniel, 2005:356).

Untuk menguji apakah masing-masing populasi dari kombinasi kategori berdistribusi normal atau tidak, dapat digunakan uji Kolmogorov-Smirnov. Hipotesis nol menyatakan populasi dari suatu kombinasi kategori berdistribusi normal, sedangkan hipotesis alternatif menyatakan populasi dari suatu kombinasi kategori tidak berdistribusi normal.

Untuk pengambilan keputusan terhadap hipotesis, dapat dibandingkan antara nilai probabilitas dari uji Kolmogorov-Smirnov dan tingkat signifikansi yang digunakan $(\alpha)$. Berikut aturan pengambilan keputusan terhadap hipotesis.

Jika nilai probabilitas $\geq$ tingkat signifikansi, $H_{0}$ diterima dan $H_{1}$ ditolak. Jika nilai probabilitas $<$ tingkat signifikansi, $H_{0}$ ditolak dan $H_{1}$ diterima.

Tabel 14.3 menyajikan nilai probabilitas dari uji Kolmogorov-Smirnov.

\section{Tabel 14.3}

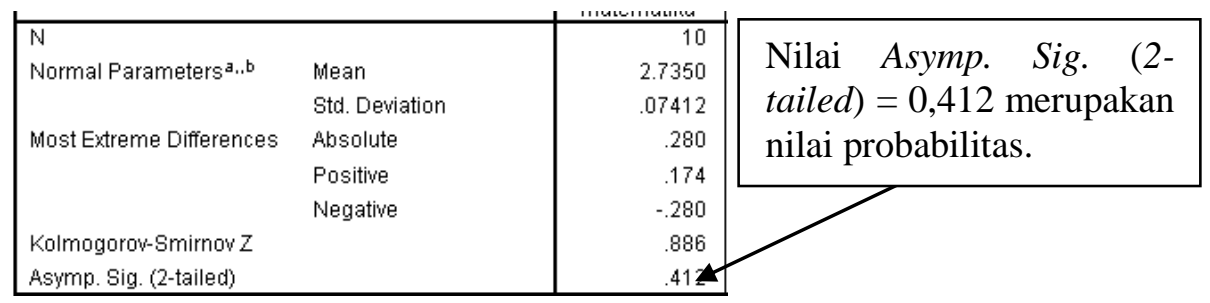

\section{Asumsí Kesamaan Varíans}

Selain asumsi normalitas, asumsi lain yang dikenakan dalam analisis varians dua arah dengan interaksi adalah asumsi kesamaan varians, yakni seluruh populasi dari kombinasi kategori memiliki varians yang sama (Daniel, 2005:356).

Untuk menguji asumsi kesamaan varians dapat digunakan uji Levene. Pada uji Levene, hipotesis nol menyatakan seluruh populasi dari kombinasi kategori memiliki varians yang sama, sedangkan hipotesis alternatif menyatakan terdapat paling sedikit sepasang populasi dari kombinasi kategori yang memiliki varians yang berbeda.

Untuk pengambilan keputusan terhadap hipotesis, dapat dibandingkan antara nilai probabilitas dari uji Levene dan tingkat signifikansi yang digunakan $(\alpha)$. Berikut aturan pengambilan keputusan terhadap hipotesis dengan pendekatan nilai probabilitas.

Jika nilai probabilitas $\geq$ tingkat signifikansi, $H_{0}$ diterima dan $H_{1}$ ditolak. Jika nilai probabilitas < tingkat signifikansi, $H_{0}$ ditolak dan $H_{1}$ diterima. 
Tabel 14.4 menyajikan nilai probabilitas dari uji Levene.

Tabel 14.4

Test of Homogeneity of Variances
nilai indeks prestasi kumulatif mahasiswa
\begin{tabular}{|c|r|r|r|c|}
\hline $\begin{array}{c}\text { Levene } \\
\text { Statistic }\end{array}$ & $\mathrm{df1}$ & $\mathrm{df} 2$ & Sig. & $\begin{array}{c}\text { Nilai Sig }=0,101 \\
\text { merupakan nilai } \\
\text { probabilitas. }\end{array}$ \\
\hline 2.233 & 3 & 36 & .101 & .
\end{tabular}

\section{Asumsi Sampel-Sampel Acak Independen (Independent Random Samples)}

Sampel-sampel dari setiap kombinasi kategori berasal dari populasi yang berbeda-beda, serta dalam pengambilan elemen sampel bersifat acak (random). Daniel (2005:356) menyatakan sebagai berikut.

"The observations in each of the ab cells constitute a random independent sample of size $n$ drawn from the population defined by the particular combination of the levels of the two factors." 


\section{PENYELESAIAN DALAM SPSS}

Misalkan seorang petani jagung bernama Ugi ingin meneliti apakah terdapat pengaruh yang signifikan secara statistika pada penggunaan jenis bibit jagung dan jenis pupuk terhadap hasil produksi jagung. Berikut data produksi jagung yang telah dikumpulkan.

Tabel 14.1 Data Produksi Jagung dalam Satuan Kuintal (Data Fiktif)

\begin{tabular}{|c|c|c|c|c|c|c|c|c|c|}
\hline & \multicolumn{3}{|c|}{ Bibit Jagung A } & \multicolumn{3}{|c|}{ Bibit Jagung B } & \multicolumn{3}{|c|}{ Bibit Jagung C } \\
\hline & Pupuk A & Pupuk B & Pupuk C & Pupuk A & Pupuk B & Pupuk C & Pupuk A & Pupuk B & Pupuk C \\
\hline & 2.1 & 4.5 & 2.2 & 2.2 & 4.5 & 2.1 & 2.1 & 4.1 & 2.3 \\
\hline & 2.2 & 4.2 & 2.2 & 2.2 & 4.3 & 2.2 & 2.2 & 4.5 & 2.2 \\
\hline & 2.3 & 4.1 & 2.3 & 2.3 & 4.1 & 2.3 & 2.3 & 4.6 & 2.3 \\
\hline & 2.4 & 4.2 & 2.4 & 2.4 & 4.2 & 2.4 & 2.4 & 4.4 & 2.4 \\
\hline & 2.5 & 4.3 & 2.5 & 2.5 & 4.3 & 2.5 & 2.5 & 4.3 & 2.5 \\
\hline & 2.1 & 4.3 & 2.1 & 2.1 & 4.3 & 2.1 & 2.1 & 4.1 & 2.1 \\
\hline & 2.2 & 4.1 & 2.2 & 2.2 & 4.1 & 2.2 & 2.2 & 4.2 & 2.2 \\
\hline & 2.3 & 4.2 & 2.3 & 2.3 & 4.2 & 2.3 & 2.3 & 4.4 & 2.3 \\
\hline & 2.4 & 4.5 & 2.4 & 2.4 & 4.5 & 2.4 & 2.4 & 4.2 & 2.4 \\
\hline & 2.3 & 4.2 & 2.3 & 2.3 & 4.2 & 2.3 & 2.3 & 4.5 & 2.3 \\
\hline Rata-rata & 2.28 & 4.26 & 2.29 & 2.29 & 4.27 & 2.28 & 2.28 & 4.33 & 2.3 \\
\hline Varians & 0.0173333 & 0.0204444 & 0.0143333 & 0.0143333 & 0.0201111 & 0.0173333 & 0.0173333 & 0.0312222 & 0.0133333 \\
\hline
\end{tabular}

Berdasarkan data pada Tabel 14.1, diketahui terdapat tiga jenis bibit jagung, yakni jenis A, B, dan $\mathrm{C}$, sedangkan untuk jenis pupuk juga terdapat tiga jenis, yakni jenis $\mathrm{A}, \mathrm{B}$, dan $\mathrm{C}$. Perhatikan bahwa terdapat 9 kombinasi kategori, yakni (bibit jagung A \& pupuk A), (bibit jagung A \& pupuk B), (bibit jagung A \& pupuk C), (bibit jagung B \& pupuk A), dan seterusnya. Untuk masing-masing kombinasi kategori disediakan 10 lahan dengan ukuran lahan yang sama. Berikut hal-hal yang ingin diketahui oleh petani tersebut :

$\Rightarrow$ Apakah terdapat interaksi yang signifikan secara statistika pada penggunaan jenis bibit jagung dan jenis pupuk dalam pengaruhnya terhadap hasil produksi jagung.

$\Rightarrow$ Apakah penggunaan jenis pupuk berdampak pada hasil produksi jagung, dengan mengontrol pengaruh jenis bibit jagung.

$\Rightarrow$ Apakah penggunaan jenis bibit jagung berdampak pada hasil produksi jagung, dengan mengontrol pengaruh jenis pupuk.

Salah satu asumsi yang dikenakan dalam analisis varians dua arah dengan interaksi adalah asumsi normalitas. Asumsi normalitas menyatakan masing-masing populasi dari kombinasi kategori berdistribusi normal. Dalam hal ini, akan diuji normalitas masing-masing populasi dari 9 kombinasi kategori berdasarkan data pada Tabel 14.1. Bangun data pada Tabel 14.1 dalam SPSS seperti berikut (Gambar 14.1). 


\begin{tabular}{|r|r|r|r|r|r|r|r|r|r|}
\hline & kombinasi1 & kombinasi2 & kombinasi3 & kombinasi4 & kombinasi5 & kombinasi6 & kombinasi7 & kombinasi8 & kombinasi9 \\
\hline 1 & 2.10 & 4.50 & 2.20 & 2.20 & 4.50 & 2.10 & 2.10 & 4.10 & 2.30 \\
\hline 2 & 2.20 & 4.20 & 2.20 & 2.20 & 4.30 & 2.20 & 2.20 & 4.50 & 2.20 \\
\hline 3 & 2.30 & 4.10 & 2.30 & 2.30 & 4.10 & 2.30 & 2.30 & 4.60 & 2.30 \\
\hline 4 & 2.40 & 4.20 & 2.40 & 2.40 & 4.20 & 2.40 & 2.40 & 4.40 & 2.40 \\
\hline 5 & 2.50 & 4.30 & 2.50 & 2.50 & 4.30 & 2.50 & 2.50 & 4.30 & 2.50 \\
\hline 6 & 2.10 & 4.30 & 2.10 & 2.10 & 4.30 & 2.10 & 2.10 & 4.10 & 2.10 \\
\hline 7 & 2.20 & 4.10 & 2.20 & 2.20 & 4.10 & 2.20 & 2.20 & 4.20 & 2.20 \\
\hline 8 & 2.30 & 4.20 & 2.30 & 2.30 & 4.20 & 2.30 & 2.30 & 4.40 & 2.30 \\
\hline 9 & 2.40 & 4.50 & 2.40 & 2.40 & 4.50 & 2.40 & 2.40 & 4.20 & 2.40 \\
\hline 10 & 2.30 & 4.20 & 2.30 & 2.30 & 4.20 & 2.30 & 2.30 & 4.50 & 2.30 \\
\hline 11 & & & & & & & & & \\
\hline
\end{tabular}

\begin{tabular}{|c|c|c|c|c|c|c|c|c|c|c|}
\hline & Name & Type & Width & Decimals & Label & Values & Missing & Columns & Align & Measure \\
\hline 1 & kombinasi1 & Numeric & 8 & 2 & kombinasi kategori 1 & None & None & 8 & Right & $\&$ Scale \\
\hline 2 & kombinasi2 & Numeric & 8 & 2 & kombinasi kategori 2 & None & None & 8 & 至 Right & $\&$ Scale \\
\hline 3 & kombinasi3 & Numeric & 8 & 2 & kombinasi kategori 3 & None & None & 8 & 軎 Right & $\&$ Scale \\
\hline 4 & kombinasi4 & Numeric & 8 & 2 & kombinasi kategori 4 & None & None & 8 & 豆 Right & $\&$ Scale \\
\hline 5 & kombinasi5 & Numeric & 8 & 2 & kombinasi kategori 5 & None & None & 8 & 善 Right & $\&$ Scale \\
\hline 6 & kombinasi6 & Numeric & 8 & 2 & kombinasi kategori 6 & None & None & 8 & 吾 Right & $\&$ Scale \\
\hline 7 & kombinasi7 & Numeric & 8 & 2 & kombinasi kategori 7 & None & None & 8 & 軎 Right & $\&$ Scale \\
\hline 8 & kombinasi8 & Numeric & 8 & 2 & kombinasi kategori 8 & None & None & 8 & 豆 Right & $\&$ Scale \\
\hline 9 & kombinasi9 & Numeric & 8 & 2 & kombinasi kategori 9 & None & None & 8 & 至 Right & \& Scale \\
\hline
\end{tabular}

\section{Gambar 14.1}

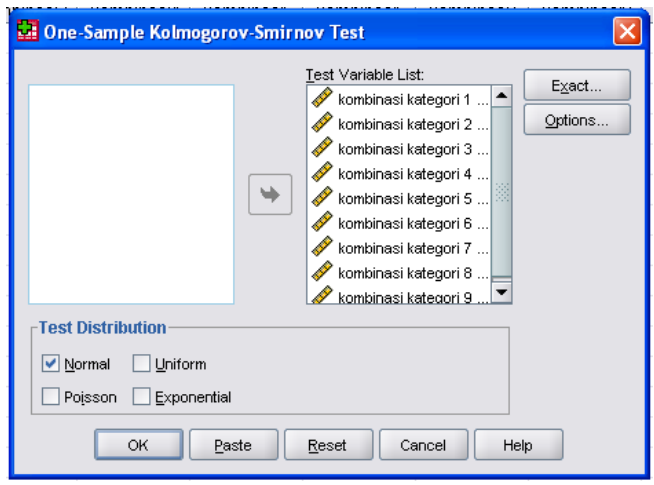

\section{Gambar 14.2}

Pilih Analyze $=>$ Nonparametric Tests $=>1$-Sample $K-S$, sehingga muncul kotak dialog OneSample Kolmogorov-Smirnov Tes (Gambar 14.2). Masukkan seluruh variabel ke dalam kotak Test Variable List (Gambar 14.2). Pada Test Distribution pilih Normal. Kemudian pilih OK. Berikut hasil berdasarkan SPSS. Berdasarkan Tabel 14.2, diketahui nilai Asymp. Sig. (2tailed) untuk masing-masing kombinasi kategori lebih besar dari tingkat signifikansi $\alpha=$ 0,05, maka disimpulkan bahwa populasi dari 9 kombinasi kategori berdistribusi normal. Perhatikan bahwa asumsi normalitas telah dipenuhi. Selanjutnya bangun data pada Tabel 14.1 dalam SPSS sebagai berikut (Gambar 14.3).

\section{Tabel 14.2}

\begin{tabular}{|c|c|c|c|c|c|}
\hline \multicolumn{6}{|c|}{ One-Sample Kolmogorov-Smirnov Test } \\
\hline & & $\begin{array}{l}\text { kombinasi } \\
\text { kategori } 1\end{array}$ & $\begin{array}{l}\text { kombinasi } \\
\text { kategori } 2\end{array}$ & $\begin{array}{l}\text { kombinasi } \\
\text { kategori } 3\end{array}$ & $\begin{array}{l}\text { kombinasi } \\
\text { kategori } 4\end{array}$ \\
\hline $\mathrm{N}$ & & 10 & 10 & 10 & 10 \\
\hline \multirow{2}{*}{ Normal Parameters ${ }^{\mathrm{a} . \mathrm{b}}$} & Mean & 2.2800 & 4.2600 & 2.2900 & 2.2900 \\
\hline & Std. Deviation & .13166 & .14298 & .11972 & .11972 \\
\hline \multirow[t]{3}{*}{ Most Extreme Differences } & Absolute & .160 & .263 & .174 & 174 \\
\hline & Positive & .140 & .263 & .174 & .174 \\
\hline & Negative & -.160 & -.153 & -.133 & -.133 \\
\hline Kolmogorow-Smirnow $Z$ & & .507 & .830 & .550 & .550 \\
\hline Asymp. Sig. (2-tailed) & & .959 & .495 & .923 & .923 \\
\hline
\end{tabular}




\begin{tabular}{|r|r|r|r|r|}
\hline $\begin{array}{c}\text { kombinasi } \\
\text { kategori } 5\end{array}$ & $\begin{array}{c}\text { kombinasi } \\
\text { kategori } 6\end{array}$ & $\begin{array}{c}\text { kombinasi } \\
\text { kategori } 7\end{array}$ & $\begin{array}{c}\text { kombinasi } \\
\text { kategori } 8\end{array}$ & $\begin{array}{c}\text { kombinasi } \\
\text { kategori } 9\end{array}$ \\
\hline 10 & 10 & 10 & 10 & 10 \\
4.2700 & 2.2800 & 2.2800 & 4.3300 & 2.3000 \\
.14181 & .13166 & .13166 & .17670 & .11547 \\
.216 & .160 & .160 & .169 & .200 \\
.216 & .140 & .140 & .169 & .200 \\
-.148 & -.160 & -.160 & -.154 & -.200 \\
.684 & .507 & .507 & .535 & .632 \\
.738 & .959 & .959 & .937 & .819 \\
\hline
\end{tabular}

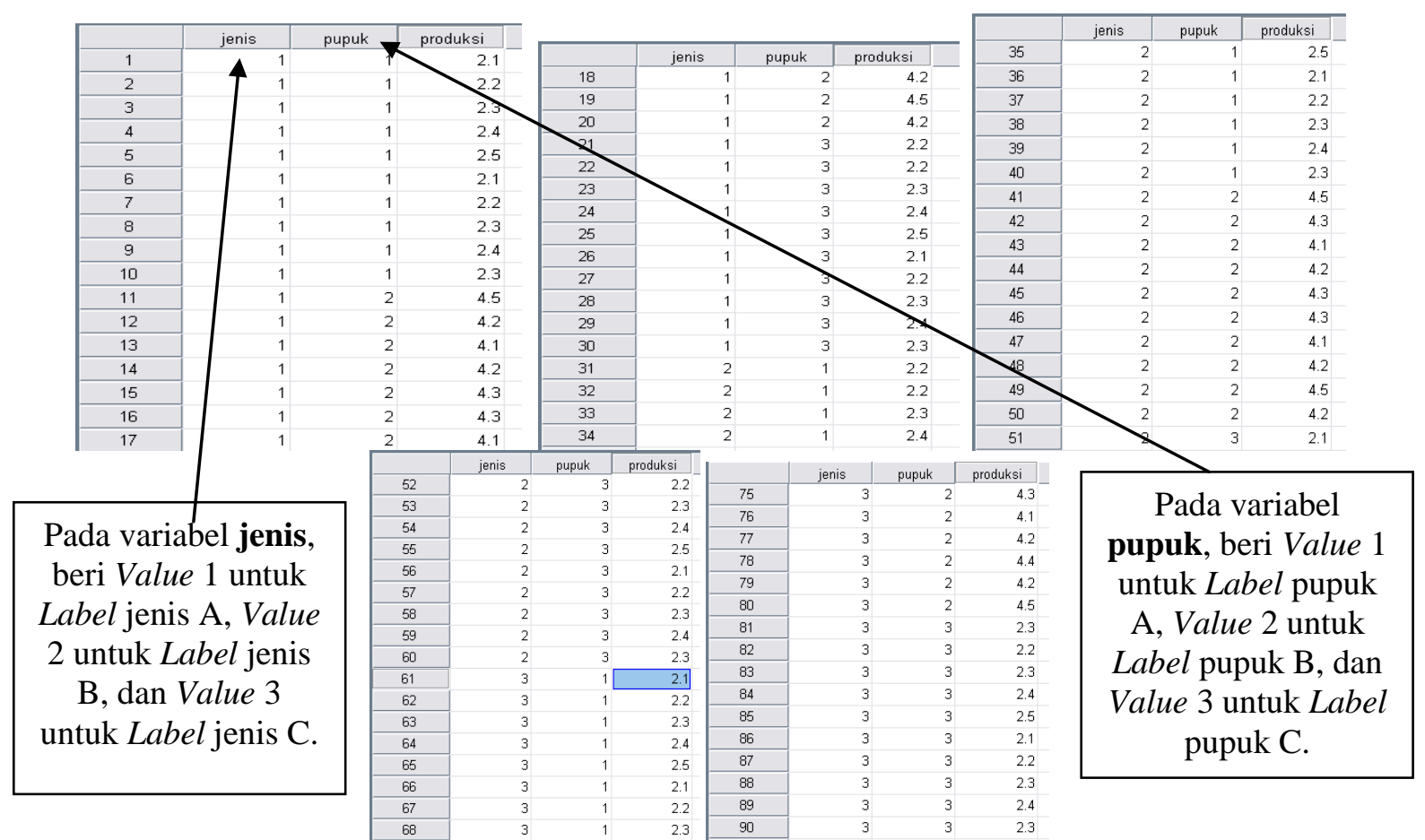

\section{Gambar 14.3}

Setelah data pada Tabel 14.1 dibangun dalam SPSS (Gambar 14.3), pilih Analyze $=>$ General Linear Model $\Rightarrow$ Univariate, sehingga muncul kotak dialog Univariate (Gambar 14.4). Masukkan variabel produksi pada kotak Dependent List dan masukkan variabel jenis dan pupuk ke dalam kotak Fixed Factor( $(s)$.

Kemudian pilih Plots, sehingga muncul kotak dialog Univariate: Profile Plots (Gambar 14.5). Masukkan variabel jenis pada kotak Horizontal Axis dan pupuk pada kotak Separate Lines. Kemudian pilih $A d d$, sehingga terbentuk variabel jenis*pupuk (Gambar 14.5). Kemudian pilih Continue.

Pilih Post Hoc, sehingga muncul kotak dialog Univariate: Post Hoc Multiple Comparisons for Observed Means (Gambar 14.6). Masukkan variabel jenis dan pupuk pada kotak Post Hoc Tests for. Pada Equal Variances Assumed, pilih Bonferroni. Kemudian pilih Continue.

Selanjutnya pilih Options, sehingga muncul kotak dialog Univariate: Options (Gambar 14.7). Masukkan variabel jenis, pupuk, dan jenis*pupuk pada kotak Display Means for. Pada Display, pilih Descriptive statistics dan Homogeneity tests. Selanjutnya pilih Continue dan OK. 


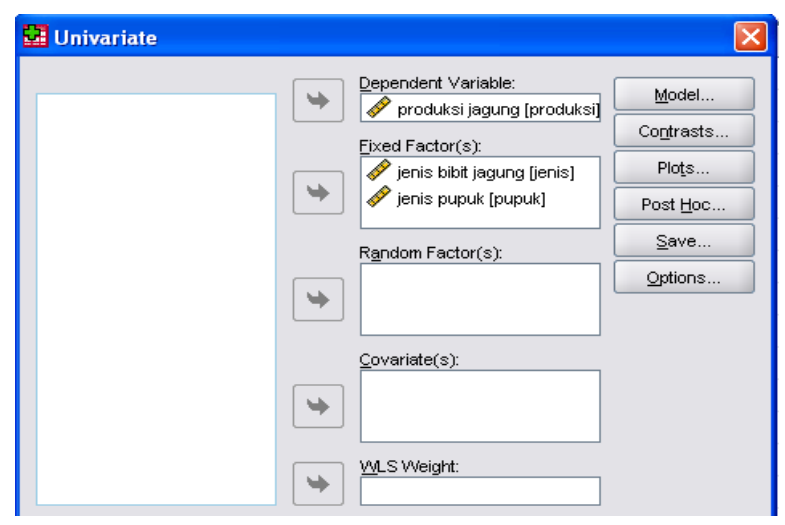

Gambar 14.4

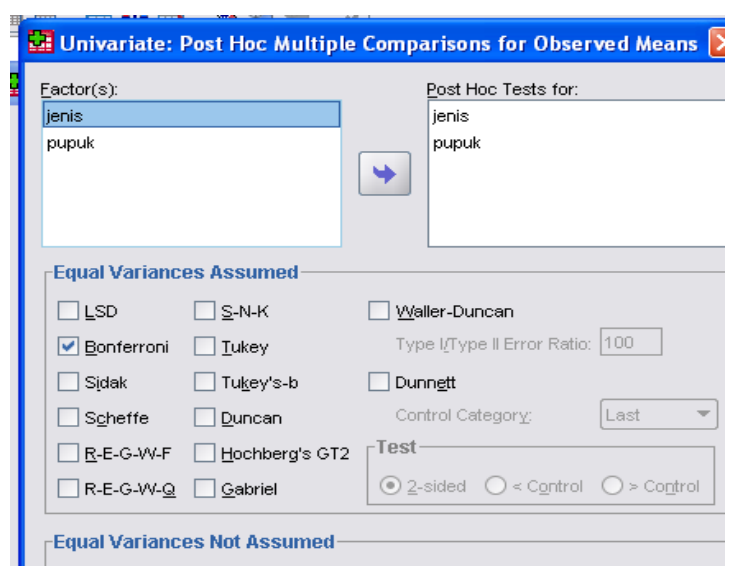

Gambar 14.6

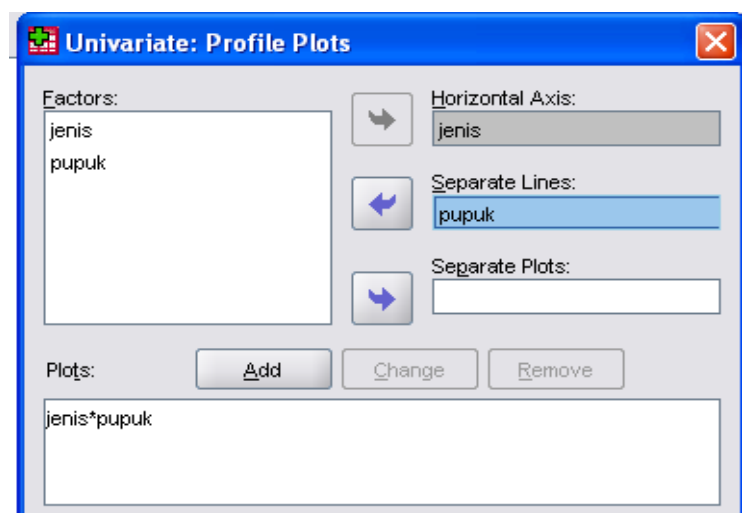

Gambar 14.5

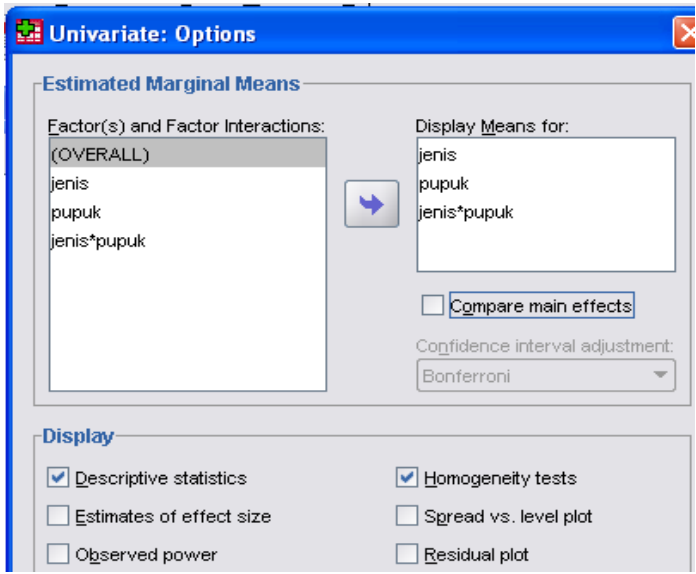

Gambar 14.7

Berikut hasil berdasarkan SPSS.

Tabel 14.3

\begin{tabular}{|c|c|c|c|}
\hline \multicolumn{4}{|c|}{$\begin{array}{c}\text { Levene's Test of Equality of Error } \\
\text { Variances }\end{array}$} \\
\hline \multicolumn{4}{|c|}{ Dependent Variable:produksi jaqu } \\
\hline $\mathrm{F}$ & df1 & $\mathrm{df} 2$ & Sig. \\
\hline .670 & 8 & 81 & .716 \\
\hline
\end{tabular}

Informasi yang disajikan pada Tabel 14.3 (Levene's Test of Equality of Error Variances) akan digunakan untuk menguji asumsi kesamaan varians, yakni akan ditentukan apakah varians populasi dari 9 kombinasi kategori adalah sama. Perhatikan bahwa nilai Sig. (probabilitas) adalah 0,716. Karena nilai probabilitas $(0,716)$ lebih besar dibandingkan tingkat signifikansi $(0,05)$, maka disimpulkan bahwa populasi dari 9 kombinasi kategori memiliki varians yang sama. Perhatikan bahwa asumsi kesamaan varians telah dipenuhi.

Berdasarkan Tabel 14.4, dapat dilihat bahwa hasil produksi jagung dengan menggunakan jenis bibit A dan pupuk A secara rata-rata adalah 2,280 kuintal. Hasil produksi jagung dengan menggunakan jenis bibit A dan pupuk B secara rata-rata adalah 4,260 kuintal. Berdasarkan Tabel 14.4, diguga bahwa penggunaan jenis pupuk B akan memberikan dampak yang positif dalam hal produksi jagung. Dengan kata lain, diduga penggunaan jenis pupuk berpengaruh terhadap hasil produksi jagung. 
Tabel 14.4

Descriptive Statistics

Dependent Variable:produksiagung
\begin{tabular}{|cc|c|r|r|}
\hline ienis bibitiagung & ienis pupuk & Mean & Std. Deviation & N \\
\hline jenis A & pupuk A & 2.280 & .1317 & 10 \\
& pupuk B & 4.260 & .1430 & 10 \\
& pupuk C & 2.290 & .1197 & 10 \\
& Total & 2.943 & .9555 & 30 \\
\hline jenis B & pupuk A & 2.290 & .1197 & 10 \\
& pupuk B & 4.270 & .1418 & 10 \\
& pupuk C & 2.280 & .1317 & 10 \\
& Total & 2.947 & .9601 & 30 \\
\hline jenis C & pupuk A & 2.280 & .1317 & 10 \\
& pupuk B & 4.330 & .1767 & 10 \\
& pupuk C & 2.300 & .1155 & 10 \\
& Total & 2.970 & .9879 & 30 \\
\hline Total & pupuk A & 2.283 & .1234 & 30 \\
& pupuk B & 4.287 & .1525 & 30 \\
& pupuk C & 2.290 & .1185 & 30 \\
& Total & 2.953 & .9571 & 90 \\
\hline
\end{tabular}

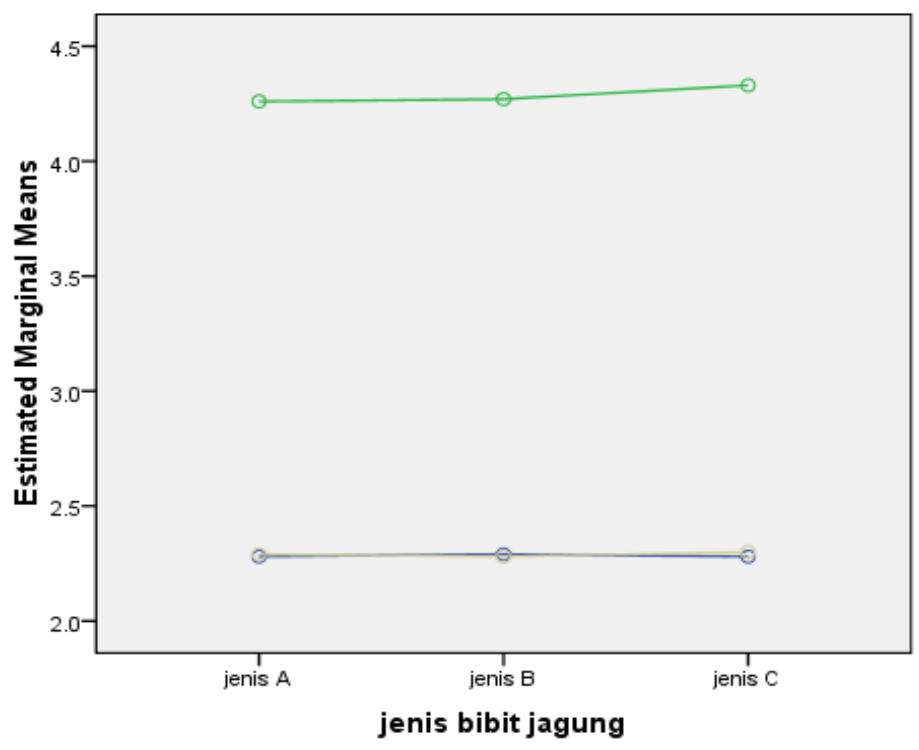

Gambar 14.8

Berdasarkan Gambar 14.8, dapat dilihat bahwa garis pupuk A dan C berhimpitan, sedangkan garis pupuk B berada paling atas. Hal tersebut dapat diartikan penggunaan pupuk jenis B secara rata-rata menghasilkan jagung lebih banyak dibandingkan penggunaan jenis pupuk lainnya. Oleh karena itu diindikasi terdapat pengaruh antara penggunaan jenis pupuk terhadap hasil produksi jagung.

Perhatikan juga bahwa ketiga garis tersebut terlihat cukup paralel. Hal tersebut dapat diartikan bahwa diindikasi tidak terjadi interaksi antara penggunaan jenis bibit jagung dan jenis pupuk dalam pengaruhnya terhadap hasil produksi jagung.

Berdasarkan Tabel 14.5 akan ditentukan hal-hal sebagai berikut.

$\Rightarrow$ Apakah terdapat interaksi yang signifikan secara statistika pada penggunaan jenis bibit jagung dan jenis pupuk dalam pengaruhnya terhadap hasil produksi jagung.

$\Rightarrow$ Apakah penggunaan jenis bibit jagung berdampak pada hasil produksi jagung, dengan mengontrol pengaruh jenis pupuk. 
$\Rightarrow$ Apakah penggunaan jenis pupuk berdampak pada hasil produksi jagung, dengan mengontrol pengaruh jenis bibit jagung.

Tabel 14.5

Tests of Between-Subjects Effects

Dependent Variable:produksi jaqung
\begin{tabular}{|l|r|r|r|r|r|}
\hline Source & $\begin{array}{c}\text { Type III Sum } \\
\text { of Squares }\end{array}$ & df & Mean Square & \multicolumn{1}{c|}{ F } & Sig. \\
\hline Corrected Model & $80.032^{\mathrm{a}}$ & 8 & 10.004 & 543.113 & .000 \\
Intercept & 784.996 & 1 & 784.996 & 42617.075 & .000 \\
jenis & .013 & 2 & .006 & .344 & .710 \\
pupuk & 80.001 & 2 & 40.000 & 2171.600 & .000 \\
jenis * pupuk & .019 & 4 & .005 & .253 & .907 \\
Error & 1.492 & 81 & .018 & & \\
Total & 866.520 & 90 & & & \\
Corrected Total & 81.524 & 89 & & & \\
\hline
\end{tabular}
a. R Squared $=.982$ (Adjusted R Squared $=.980$ )

Pada Tabel 14.5, perhatikan baris jenis*pupuk. Diketahui nilai Sig adalah 0,907. Karena nilai Sig tersebut lebih besar dari tingkat signifikansi $\alpha=0,05$, maka disimpulkan bahwa tidak terjadi interaksi yang signifikan secara statistika pada penggunaan jenis bibit jagung dan jenis pupuk dalam pengaruhnya terhadap hasil produksi jagung. Karena tidak terjadi interaksi, maka akan dilanjutkan dengan pengujian pengaruh utama (main effect test) dari masingmasing variabel bebas.

Perhatikan baris jenis. Diketahui nilai Sig adalah 0,710. Karena nilai Sig tersebut lebih besar dari tingkat signifikansi $\alpha=0,05$, maka disimpulkan bahwa penggunaan jenis bibit jagung tidak berdampak signifikan secara statistika pada hasil produksi jagung, dengan mengontrol pengaruh jenis pupuk.

Kemudian perhatikan baris pupuk. Diketahui nilai Sig adalah 0,000. Karena nilai Sig tersebut lebih kecil dari tingkat signifikansi $\alpha=0,05$, maka disimpulkan bahwa penggunaan jenis pupuk berdampak signifikan secara statistika pada hasil produksi jagung, dengan mengontrol pengaruh jenis bibit jagung.

\section{Tabel 14.6}

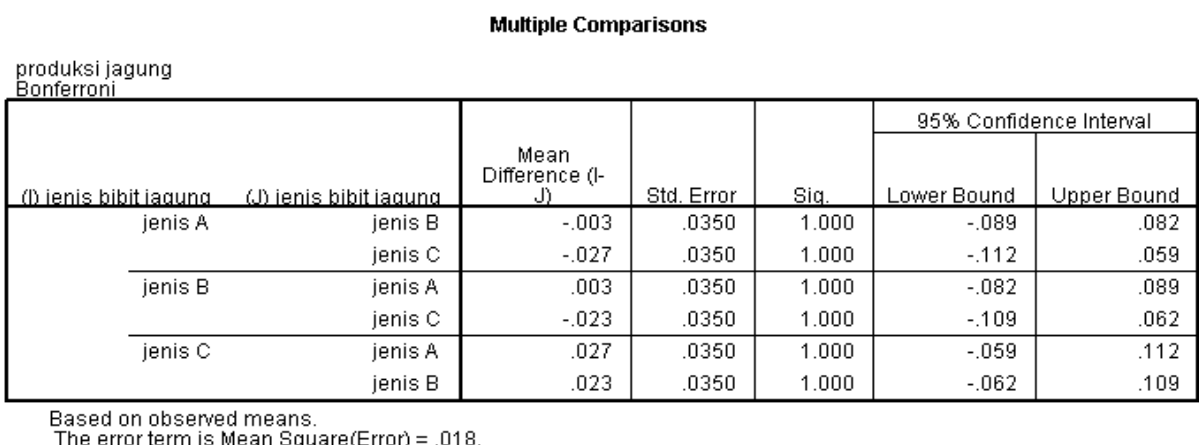

Berdasarkan Tabel 14.6 (Multiple Comparisons) untuk jenis bibit, akan ditentukan hal-hal sebagai berikut.

$\Rightarrow$ Ada tidaknya perbedaan rata-rata hasil produksi jagung antara menggunakan jenis bibit jagung A dan B.

$\Rightarrow$ Ada tidaknya perbedaan rata-rata hasil produksi jagung antara menggunakan jenis bibit jagung A dan $\mathrm{C}$. 
$\Rightarrow$ Ada tidaknya perbedaan rata-rata hasil produksi jagung antara menggunakan jenis bibit jagung $\mathrm{B}$ dan $\mathrm{C}$.

Perhatikan nilai Sig. pada baris jenis A v/s jenis B, yakni 1,000. Karena nilai Sig. lebih besar dibandingkan tingkat signifikansi $\alpha=0,05$, maka disimpulkan bahwa tidak terdapat perbedaan rata-rata yang signifikan secara statistika dari hasil produksi jagung antara menggunakan jenis bibit jagung A dan B. Kemudian perhatikan nilai Sig. pada baris jenis A v/s jenis C, yakni 1,000. Karena nilai Sig. lebih besar dibandingkan tingkat signifikansi $\alpha=0,05$, maka disimpulkan bahwa tidak terdapat perbedaan rata-rata yang signifikan secara statistika dari hasil produksi jagung antara menggunakan jenis bibit jagung $\mathrm{A}$ dan $\mathrm{C}$, dan begitu juga untuk jenis B v/s jenis $\mathrm{C}$.

Tabel 14.7

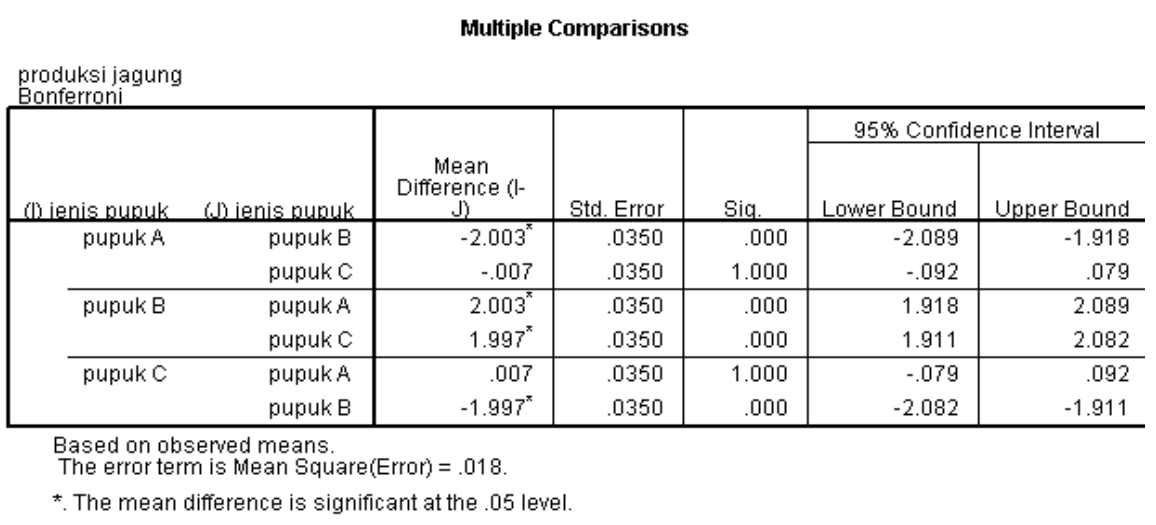

Berdasarkan Tabel 14.7 akan ditentukan hal-hal sebagai berikut.

$\Rightarrow$ Ada tidaknya perbedaan rata-rata hasil produksi jagung antara menggunakan jenis pupuk A dan B.

$\Rightarrow$ Ada tidaknya perbedaan rata-rata hasil produksi jagung antara menggunakan jenis pupuk A dan C.

$\Rightarrow$ Ada tidaknya perbedaan rata-rata produksi jagung antara menggunakan jenis pupuk B dan C.

Perhatikan nilai Sig. pada baris pupuk A v/s pupuk B, yakni 0,000. Karena nilai Sig. lebih kecil dibandingkan tingkat signifikansi $\alpha=0,05$, maka disimpulkan bahwa terdapat perbedaan rata-rata yang signifikan secara statistika dari hasil produksi jagung antara menggunakan jenis pupuk A dan B. Kemudian perhatikan nilai Sig. pada baris pupuk A v/s pupuk C, yakni 1,000. Karena nilai Sig. lebih besar dibandingkan tingkat signifikansi $\alpha=0,05$, maka disimpulkan bahwa tidak terdapat perbedaan rata-rata yang signifikan secara statistika dari hasil produksi jagung antara menggunakan jenis bibit pupuk $\mathrm{A}$ dan $\mathrm{C}$, namun terdapat perbedaan rata-rata yang signifikan secara statistika dari hasil produksi jagung antara menggunakan jenis pupuk B dan C. 


\section{Referensi}

1. Agresti, A. dan B. Finlay. 2009. Statistical Methods for the Social Sciences, $4^{\text {th }}$ Edition. United States of America: Prentice Hall.

2. Daniel, W.W. 2005. Biostatistics: A Foundation for Analysis in the Health Sciences, $8^{\text {th }}$ Edition. United States of America: John Wiley \& Sons.

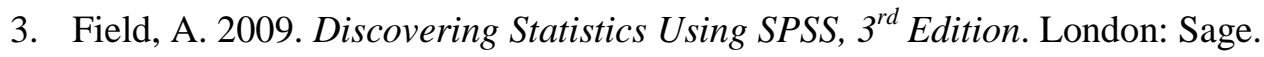

4. Gamst, G., L.S. Meyers, dan A.J. Guarino. 2008. Analysis of Variance Designs, Computational Approach with SPSS and SAS. Cambridge: Cambridge University Press.

5. Gio, P.U. 2013. Aplikasi Statistika dalam SPSS. Medan: USUpress.

6. Mann, P. S. dan C.J. Lacke. 2011. Introductory Statistics, International Student Version, $7^{\text {th }}$ Edition. Asia: John Wiley \& Sons, Inc.

7. Montgomery, D.C. dan G.C. Runger. 2011. Applied Statistics and Probability for Engineers, $5^{\text {th }}$ Edition. United States of America: John Wiley \& Sons, Inc.

8. Smidth, R. K. dan D. H. Sanders. 2000. Statistics a First Course, $6^{\text {th }}$ Edition. United States of America: McGraw-Hill Companies. 


\section{BAB 15}

\section{ANALISIS KOVARIAN}

\section{Sekílas Analisis Kovarian}

Analisis kovarian dapat dikatakan sebagai suatu alat statistika yang di dalamnya menggabungkan uji beda rata-rata dan regresi. Dalam analisis kovarian, rata-rata yang diuji adalah rata-rata yang telah disesuaikan (adjusted mean). Steven (2009:287) menyatakan sebagai berikut.

"The reader should recall that the null hypothesis being tested in ANCOVA is that the adjusted population means are equal".

Pada bab sebelumnya telah dipaparkan mengenai analisis varians. Analisis varians satu arah membandingkan rata-rata berdasarkan kategori-kategori dari suatu variabel bebas. Sementara pada analisis varians dua arah membandingkan rata-rata berdasarkan kategori-kategori pada suatu variabel bebas, dengan mengontrol variabel bebas lainnya. Dalam hal ini, variabel bebas yang dikontrol bersifat non-metrik (kualitatif). Dalam analisis varians dua arah, variabel yang dikontrol bersifat non-metrik, sementara pada analisis kovarian, variabel yang dikontrol bersifat metrik (interval atau rasio). Pada analisis kovarian, variabel yang dikontrol disebut juga dengan kovariat (covariate). Agresti dan Finlay (2009:413) menyatakan sebagai berikut.

"One-way ANOVA compares the mean of the response variable for several groups. Two-way ANOVA compares means while controlling for another categorical variable. In many applications, it's useful to compare means while controlling for a quantitative variable. The quantitative control variable is called a covariate. The use of regression for this type of comparison is often called analysis of covariance. It is one of the many statistical contributions of R.A. Fisher, the brilliant British statistician".

Kovariat dapat diartikan sebagai suatu variabel yang berkorelasi terhadap variabel tak bebas. Kovariat tidak bertindak sebagai variabel utama dalam hal mempengaruhi variabel tak bebas , namun bertindak sebagai variabel kontrol atau variabel pelengkap yang masih berkorelasi terhadap variabel tak bebas. Dalam analisis kovarian, variabel bebas (non-metrik) dapat berinteraksi dengan variabel yang dikontrol atau kovariat. Hipotesis nol untuk uji interaksi menyatakan tidak terdapat interaksi yang signifikan secara statistika antara variabel bebas (non-metrik) dan kovariat dalam pengaruhnya terhadap variabel tak bebas. Hipotesis alternatif menyatakan terdapat interaksi yang signifikan secara statistika antara variabel bebas (nonmetrik) dan kovariat dalam pengaruhnya terhadap variabel tak bebas.

Pada analisis kovarian juga dapat diuji apakah terdapat perbedaan rata-rata dari variabel tak bebas berdasarkan kategori-kategori pada variabel bebas dengan mengontrol kovariat. Hipotesis nol untuk uji ini menyatatakan tidak terdapat perbedaan rata-rata yang cukup signifikan secara statistika pada variabel tak bebas berdasarkan kategori-kategori dalam variabel bebas dengan mengontrol kovariat. Hipotesis alternatif untuk uji ini menyatatakan terdapat perbedaan rata-rata yang cukup signifikan secara statistika pada variabel tak bebas berdasarkan kategori-kategori pada variabel bebas dengan mengontrol kovariat. 
Dalam analisis kovarian juga dapat diuji apakah kovariat memiliki hubungan atau pengaruh yang signifikan secara statistika terhadap variabel tak bebas, dengan mengontrol variabel bebas (non-metrik). Hipotesis nol pada uji ini menyatakan tidak terdapat hubungan atau pengaruh yang signifikan secara statistika antara kovariat dan variabel tak bebas, dengan mengontrol variabel bebas (non-metrik). Hipotesis alternatif menyatakan terdapat pengaruh yang signifikan secara statistika antara kovariat dan variabel tak bebas, dengan mengontrol variabel bebas (non-metrik).

\section{Contoh Kasus dalam Analisis Kovarian}

Berikut diberikan contoh kasus yang dapat diselesaikan dengan pendekatan analisis kovarian.

[1] Misalkan seorang guru ingin meneliti apakah terdapat perbedaan (secara rata-rata) nilai ujian matematika siswa ketika diterapkan metode mengajar A, B, dan C. Untuk keperluan penelitian, guru tersebut mengajar 10 siswa dengan menerapkan metode A, 10 siswa berikutnya dengan metode B, dan 10 siswa yang lain dengan metode C. Setelah beberapa bulan, baru diadakan ujian matematika. Guru tersebut ingin mengetahui pengaruh secara bersih atau murni penggunaan metode mengajar terhadap nilai ujian matematika. Namun guru tersebut berfikir, bisa saja faktor IQ siswa juga memiliki pengaruh terhadap nilai ujian matematika yang dicapai oleh siswa. Maka guru tersebut melibatkan variabel IQ sebagai pengontrol. Perhatikan bahwa nilai ujian matematika merupakan variabel tak bebas (metrik), metode mengajar merupakan variabel bebas (non-metrik), dan IQ merupakan kovariat. Berikut data yang telah dikumpulkan oleh guru tersebut (Tabel 15.1).

Tabel 15.1

\begin{tabular}{|c|c|c|c|c|c|c|c|c|}
\hline \multicolumn{3}{|c|}{ Metode A } & \multicolumn{4}{c|}{ Metode B } & \multicolumn{3}{c|}{ Metode C } \\
\hline Siswa & nilai ujian & IQ & Siswa & nilai ujian & IQ & Siswa & nilai ujian & IQ \\
\hline 1 & 6.5 & 100 & 11 & 7 & 113 & 21 & 7.4 & 114 \\
\hline 2 & 6.4 & 99 & 12 & 6.5 & 98 & 22 & 8 & 97 \\
\hline 3 & 5 & 95 & 13 & 7.5 & 97 & 23 & 8.2 & 95 \\
\hline 4 & 5.5 & 96 & 14 & 6.5 & 97 & 24 & 9 & 97 \\
\hline 5 & 6 & 96 & 15 & 7.5 & 115 & 25 & 9.5 & 114 \\
\hline 6 & 6.9 & 114 & 16 & 6.9 & 95 & 26 & 8.5 & 98 \\
\hline 7 & 5.9 & 97 & 17 & 7.3 & 100 & 27 & 8 & 100 \\
\hline 8 & 5 & 94 & 18 & 8 & 111 & 28 & 8 & 111 \\
\hline 9 & 6 & 95 & 19 & 7.3 & 94 & 29 & 7.5 & 95 \\
\hline 10 & 6 & 99 & 20 & 7.1 & 100 & 30 & 9.9 & 99 \\
\hline
\end{tabular}

Dengan menggunakan pendekatan analisis kovarian, akan diteliti hal-hal sebagai berikut.

$\Rightarrow$ Apakah terdapat interaksi yang cukup signifikan secara statistika antara metode mengajar dan IQ dalam pengaruhnya terhadap nilai ujian matematika.

$\Rightarrow$ Apakah terdapat perbedaan yang cukup signifikan secara statistika mengenai rata-rata ujian matematika pada penggunaan metode mengajar A, B, dan C dengan mengontrol IQ. 
$\Rightarrow$ Apakah terdapat pengaruh atau hubungan yang cukup signifikan secara statistika antara IQ terhadap nilai ujian matematika dengan mengontrol metode mengajar.

[2] Misalkan seorang peneliti ingin meneliti apakah terdapat perbedaan yang signifikan secara statistika mengenai rata-rata gaji per-bulan $(y)$ di antara karyawan-karyawan yang bekerja pada posisi $\mathrm{A}, \mathrm{B}$, dan $\mathrm{C}$ di perusahaan XYZ pada tingkat signifikansi 5\% dengan melibatkan masa kerja sebagai kovariat $(x)$. Berikut data yang telah diperoleh peneliti tersebut (Tabel 15.2).

Tabel 15.2

\begin{tabular}{|c|c|c|c|c|c|c|c|c|}
\hline \multicolumn{2}{|c|}{ Posisi A } & \multicolumn{3}{c|}{ Posisi B } & \multicolumn{3}{c|}{ Posisi C } \\
\hline Karyawan & $y$ & $x$ & Karyawan & $y$ & $x$ & Karyawan & $y$ & $x$ \\
\hline 1 & 1,1 & 5 & 16 & 3,1 & 8 & 31 & 7,1 & 14 \\
\hline 2 & 1,2 & 5 & 17 & 3,2 & 8 & 32 & 7,2 & 14 \\
\hline 3 & 1,3 & 6 & 18 & 3,3 & 9 & 33 & 7,3 & 15 \\
\hline 4 & 1,4 & 6 & 19 & 3,4 & 9 & 34 & 7,4 & 15 \\
\hline 5 & 1,5 & 6 & 20 & 3,5 & 9 & 35 & 7,5 & 15 \\
\hline 6 & 1,6 & 7 & 21 & 3,6 & 10 & 36 & 7,6 & 16 \\
\hline 7 & 1,7 & 8 & 22 & 3,7 & 11 & 37 & 7,7 & 17 \\
\hline 8 & 1,1 & 5 & 23 & 3,1 & 8 & 38 & 7,1 & 14 \\
\hline 9 & 1,2 & 5 & 24 & 3,2 & 7 & 39 & 7,2 & 12 \\
\hline 10 & 1,3 & 5 & 25 & 3,3 & 7 & 40 & 7,3 & 12 \\
\hline 11 & 1,4 & 6 & 26 & 3,4 & 9 & 41 & 7,4 & 15 \\
\hline 12 & 1,5 & 6 & 27 & 3,5 & 9 & 42 & 7,5 & 15 \\
\hline 13 & 1,6 & 7 & 28 & 3,6 & 10 & 43 & 7,6 & 16 \\
\hline 14 & 1,7 & 7 & 29 & 3,7 & 10 & 44 & 7,7 & 16 \\
\hline 15 & 1,8 & 7 & 30 & 3,8 & 10 & 45 & 7,8 & 16 \\
\hline
\end{tabular}

Dengan menggunakan pendekatan analisis kovarian, berikut hal-hal yang ingin diteliti.

$\Rightarrow$ Apakah terdapat interaksi yang cukup signifikan secara statistika antara posisi kerja karyawan dan masa kerja karyawan dalam pengaruhnya terhadap gaji karyawan perbulan.

$\Rightarrow$ Apakah terdapat perbedaan yang cukup signifikan secara statistika mengenai rata-rata gaji per-bulan di antara karyawan-karyawan yang bekerja pada posisi A, B, dan C di perusahaan XYZ dengan mengontrol masa kerja karyawan.

$\Rightarrow$ Apakah terdapat pengaruh atau hubungan yang cukup signifikan secara statistika antara masa kerja karyawan terhadap gaji karyawan per-bulan di perusahaan XYZ dengan mengontrol posisi kerja karyawan.

\section{Asumsi-Asumsi dalam Analisis Kovarian}

Asumsi-asumsi pada analisis varians berlaku juga pada analisis kovarian. Namun pada analisis kovarian terdapat asumsi tambahan, yakni asumsi linearitas dari regresi (linearity of regression) dan homogenitas dari regresi (homogeneity of regression). 


\section{Asumsi Linearitas dari Regresi (Linearity of Regression)}

Asumsi linearitas dari regresi berarti terdapat hubungan linear yang signifikan secara statistika antara kovariat dengan variabel tak bebas. Signifikan atau tidak, dari hubungan linear tersebut dapat diuji dengan menggunakan korelasi Pearson. Hipotesis nol menyatakan bahwa tidak terdapat hubungan linear yang cukup signifikan antara kovariat dengan variabel tak bebas. Sedangkan hipotesis alternatif menyatakan terdapat hubungan linear yang cukup signifikan antara kovariat dengan variabel tak bebas.

Dasar pengambilan keputusan terhadap hipotesis dapat dilakukan dengan membandingkan nilai probabilitas ( $p$-value) dari uji korelasi Pearson dengan tingkat signifikansi yang digunakan. Jika nilai probabilitas lebih kecil dibandingkan tingkat signifikansi, maka disimpulkan bahwa terdapat hubungan linear yang cukup signifikan antara kovariat dengan variabel tak bebas. Hal ini berarti asumsi linearitas dari regresi terpenuhi.

Jika hubungan linear antara kovariat dan variabel tak bebas tidak signifikan secara statistika, prosedur pendekatan regresi linear yang melibatkan kovariat akan memberikan hasil estimasi yang tidak tepat (no viable prediction). Gamst dkk. (2008:458) menyatakan sebagai berikut.

"We discussed in Section 16.4.1 that, based on the sample as a whole, the scores on the covariate are used in a linear regression procedure to predict the scores of the dependent variable. In order to properly interpret the results of the regression procedure, it is assumed that the relationship between the two variables is linear. Technically, the linear regression procedure evaluates the predictability of the dependent measure based on a linear model incorporating the covariate; if the dependent variable and the covariate are not related linearly (even if they are strongly related in a more a complex way), the linear regression procedure will return an outcome of "no viable prediction".

Tabel 15.3 menyajikan output SPSS yang menunjukkan nilai probabilitas untuk pengambilan keputusan terhadap hipotesis.

\section{Tabel 15.3}

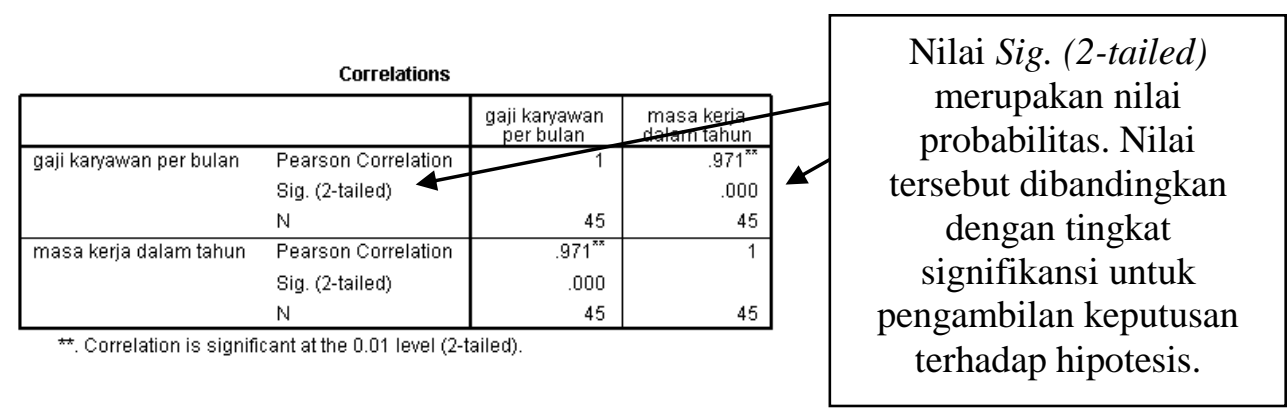

\section{Asumsi Homogenitas dari Regresi (Homogeneity of Regression)}

Uji asumsi homogenitas dari regresi berarti menguji apakah kemiringan dari garis regresi populasi bernilai sama untuk setiap kelompok atau kategori pada variabel bebas. Uji asumsi homogenitas dari regresi juga dapat berarti menguji apakah interaksi yang terjadi signifikan secara statistika antara variabel bebas (non-metrik) dan kovariat dalam pengaruhnya terhadap variabel tak bebas. Hipotesis nol pada uji ini menyatakan interaksi yang terjadi antara variabel bebas dan kovariat tidak signifikan secara statistika dalam pengarunya terhadap variabel tak bebas. Sedangkan hipotesis alternatif menyatakan terdapat interaksi yang cukup signifikan 
secara statistika antara variabel bebas dan kovariat dalam hal pengarunya terhadap variabel tak bebas.

Dasar pengambilan keputusan terhadap hipotesis dapat dilakukan dengan membandingkan nilai probabilitas dengan tingkat signifikansi. Jika nilai probabilitas lebih kecil dibandingkan tingkat signifikansi, maka disimpulkan bahwa terdapat interaksi yang cukup signifikan secara statistika antara variabel bebas dan kovariat dalam hal pengarunya terhadap variabel tak bebas. Dalam hal ini, asumsi mengenai kemiringan dari garis regresi populasi bernilai sama untuk setiap kelompok/kategori pada variabel bebas tidak terpenuhi. Stevens (2009:289) menyatakan ketika asumsi homogenitas dari regresi tidak terpenuhi, maka penggunaan analisis kovarian menjadi tidak tepat (is not appropriate).

Tabel 15.4 menyajikan output SPSS yang menunjukkan nilai probabilitas untuk pengambilan keputusan terhadap hipotesis.

Tabel 15.4

Tests of Between-Subjects Effects

Dependent Variable:gaii kanawan per bulan
\begin{tabular}{|l|r|r|r|r|r|}
\hline Source & $\begin{array}{c}\text { Type III Sum } \\
\text { of Squares }\end{array}$ & df & Mean Square & \multicolumn{1}{c|}{ F } & \multicolumn{1}{c|}{ Sig. } \\
\hline Corrected Model & $281.537^{\mathrm{a}}$ & 5 & 56.307 & 3718.599 & .000 \\
Intercept & 3.950 & 1 & 3.950 & 20.5 & .000 \\
posisi * masa & .078 & 2 & .039 & 2.560 & .090 \\
\hline posisi & 2.833 & 2 & 1.417 & 93.561 & .000 \\
masa & 1.525 & 1 & 1.525 & 100.696 & .000 \\
Error & .591 & 39 & .015 & & \\
Total & 1036.120 & 45 & & & \\
Corrected Total & 282.128 & 44 & & & \\
\hline
\end{tabular}

a. $R$ Squared $=.998$ (Adjusted $R$ Squared $=.998$ )
Nilai Sig. (probabilitas) untuk interaksi antara variabel posisi dan masa adalah 0,090. Karena probabilitas tersebut lebih kecil dibandingkan 0,05 , maka disimpulkan bahwa interaksi yang terjadi tidak signifikan. Hal ini berarti asumsi homogenitas dari regresi terpenuhi.

Ketika asumsi homogenitas dari regresi terpenuhi, maka kemiringan garis regresi untuk setiap kelompok adalah sama. perhatikan gambar 15.1. Pada Gambar 15.1, kemiringan ketiga garis regresi bernilai sama.

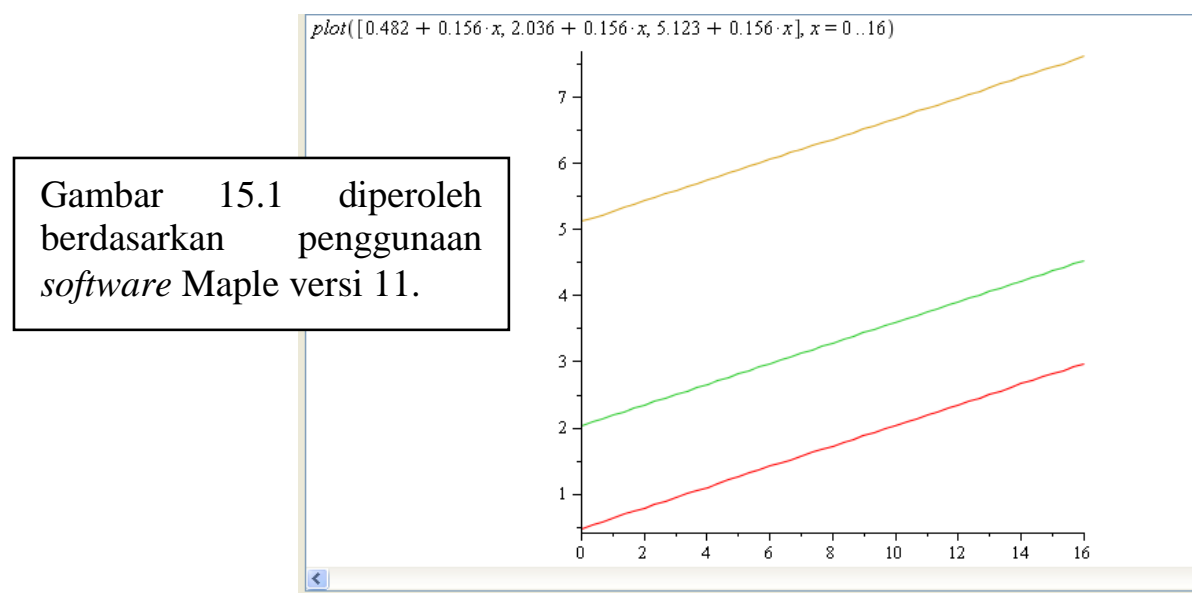

Gambar 15.1 


\section{PENYELESAIAN DALAM SPSS}

Misalkan seorang peneliti ingin meneliti apakah terdapat perbedaan yang signifikan secara statistika mengenai rata-rata gaji per-bulan di antara karyawan-karyawan yang bekerja pada posisi A, B, dan C di perusahaan XYZ pada tingkat signifikansi 5\%, dengan melibatkan masa kerja sebagai kovariat. Berikut data yang telah diperoleh peneliti tersebut (Tabel 15.1).

\section{Tabel 15.1}

\begin{tabular}{|c|c|c|c|c|c|c|c|c|}
\hline \multicolumn{2}{|c|}{ Posisi A } & \multicolumn{3}{c|}{ Posisi B } & \multicolumn{3}{c|}{ Posisi C } \\
\hline Karyawan & $y$ & $x$ & Karyawan & $y$ & $x$ & Karyawan & $y$ & $x$ \\
\hline 1 & 1,1 & 5 & 16 & 3,1 & 8 & 31 & 7,1 & 14 \\
\hline 2 & 1,2 & 5 & 17 & 3,2 & 8 & 32 & 7,2 & 14 \\
\hline 3 & 1,3 & 6 & 18 & 3,3 & 9 & 33 & 7,3 & 15 \\
\hline 4 & 1,4 & 6 & 19 & 3,4 & 9 & 34 & 7,4 & 15 \\
\hline 5 & 1,5 & 6 & 20 & 3,5 & 9 & 35 & 7,5 & 15 \\
\hline 6 & 1,6 & 7 & 21 & 3,6 & 10 & 36 & 7,6 & 16 \\
\hline 7 & 1,7 & 8 & 22 & 3,7 & 11 & 37 & 7,7 & 17 \\
\hline 8 & 1,1 & 5 & 23 & 3,1 & 8 & 38 & 7,1 & 14 \\
\hline 9 & 1,2 & 5 & 24 & 3,2 & 7 & 39 & 7,2 & 12 \\
\hline 10 & 1,3 & 5 & 25 & 3,3 & 7 & 40 & 7,3 & 12 \\
\hline 11 & 1,4 & 6 & 26 & 3,4 & 9 & 41 & 7,4 & 15 \\
\hline 12 & 1,5 & 6 & 27 & 3,5 & 9 & 42 & 7,5 & 15 \\
\hline 13 & 1,6 & 7 & 28 & 3,6 & 10 & 43 & 7,6 & 16 \\
\hline 14 & 1,7 & 7 & 29 & 3,7 & 10 & 44 & 7,7 & 16 \\
\hline 15 & 1,8 & 7 & 30 & 3,8 & 10 & 45 & 7,8 & 16 \\
\hline
\end{tabular}

Berdasarkan data pada Tabel 15.1, jumlah karyawan yang diteliti dalam sampel sebanyak 45 karyawan. Untuk setiap posisi terdiri dari 15 karyawan. Perhatikan bahwa $y$ menyatakan gaji per-bulan dalam jutaan. Karyawan dengan nomor urut 12 memiliki gaji per-bulan sebesar 1,5 juta, karyawan dengan nomor urut 40 memiliki gaji per-bulan sebesar 7,3 juta, dan seterusnya. Perhatikan juga bahwa $x$ menyatakan masa kerja dalam tahun. Sebagai contoh, karyawan dengan nomor urut 12 telah bekerja di perusahaan XYZ selama 6 tahun, karyawan dengan nomor urut 40 telah bekerja di perusahaan XYZ selama 12 tahun, dan seterusnya.

Berikut hal-hal yang ingin diketahui oleh peneliti.

$\Rightarrow$ Apakah terdapat interaksi yang cukup signifikan secara statistika antara posisi kerja karyawan dan masa kerja karyawan dalam pengaruhnya terhadap gaji karyawan perbulan.

$\Rightarrow$ Apakah terdapat perbedaan yang cukup signifikan secara statistika mengenai rata-rata gaji per-bulan di antara karyawan-karyawan yang bekerja pada posisi A, B, dan C di perusahaan XYZ dengan mengontrol masa kerja karyawan. 
$\Rightarrow$ Apakah terdapat pengaruh atau hubungan yang cukup signifikan secara statistika antara masa kerja karyawan terhadap gaji karyawan per-bulan di perusahaan XYZ dengan mengontrol posisi kerja karyawan.

Asumsi-asumsi pada analisis varians berlaku juga pada analisis kovarian. Namun pada analisis kovarian terdapat asumsi tambahan lagi yang diujikan, yakni asumsi linearitas dari regresi (linearity of regression) dan homogenitas dari regresi (homogeneity of regression).

Pada penyelesaian ini hanya akan dipaparkan untuk menguji asumsi linearitas dan homogenitas dari regresi dalam SPSS. Pertama akan diuji terlebih dahulu mengenai asumsi linearitas dari regresi. Asumsi linearitas dari regresi berarti menguji apakah terdapat hubungan linear yang signifikan secara statistika antara kovariat dengan variabel tak bebas.

Bangun data pada Tabel 15.1 dalam SPSS seperti gambar berikut (Gambar 15.1).

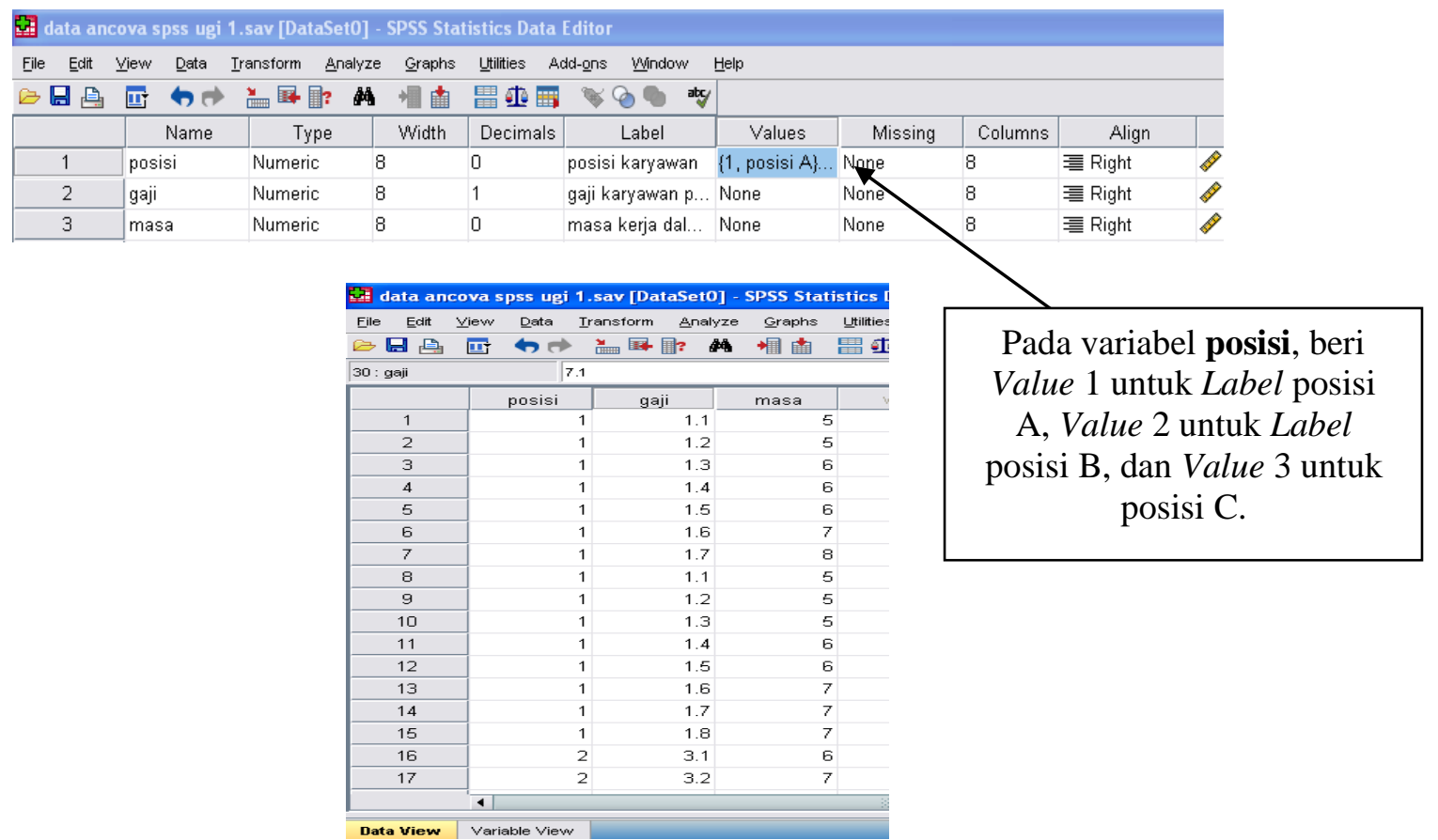

Gambar 15.1

Pada variabel posisi, beri Value 1 untuk Label posisi A, Value 2 untuk Label posisi B, dan Value 3 untuk posisi C. Selanjutnya pilih Analyze $\Rightarrow$ Correlate $\Rightarrow>$ Bivariate, sehingga muncul kotak dialog Bivariate: Correlations (Gambar 15.2). Masukkan variabel gaji dan masa ke dalam kotak Variables. Pada Correlation Coefficients pilih Pearson dan kemudian pilih Flag significant correlations. Selanjutnya pilih OK. Hasil berdasarkan SPSS diperlihatkan pada Tabel 15.2. 


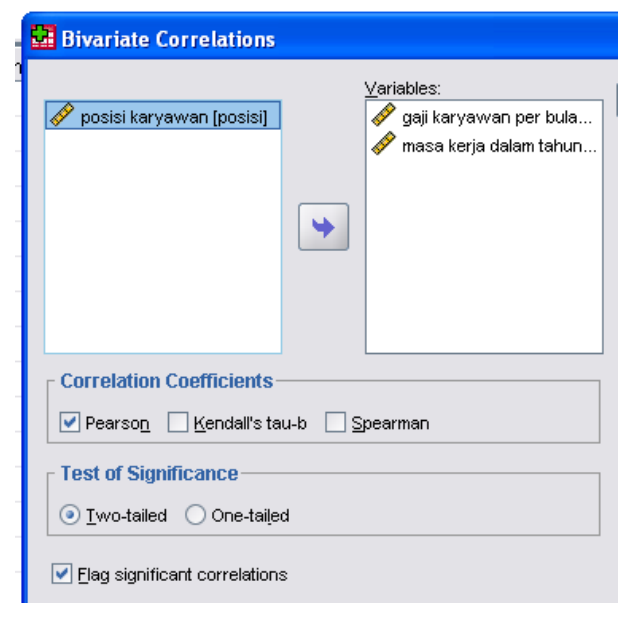

Tabel 15.2

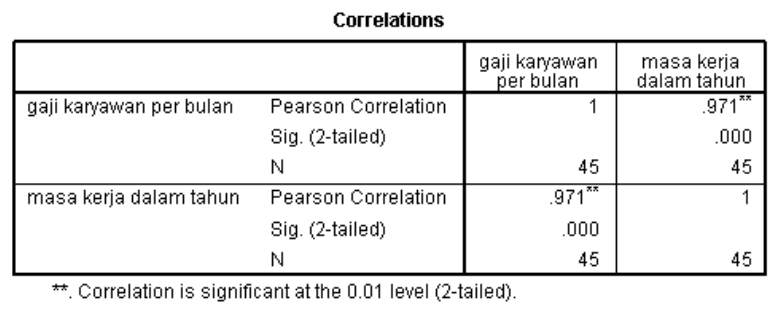

\section{Gambar 15.2}

Untuk menentukan apakah asumsi linearitas dari regresi terpenuhi atau tidak, maka dapat dilakukan dengan membandingkan nilai Sig. (2-tailed) terhadap tingkat signifikansi yang digunakan. Berdasarkan Tabel 15.2, nilai Sig. (2-tailed) adalah 0,000. Oleh karena nilai Sig. (2-tailed) lebih kecil dibandingkan tingkat signifikansi $(0,05)$, maka disimpulkan bahwa asumsi linearitas dari regresi terpenuhi. Terpenuhinya asumsi linearitas dari regresi menunjukkan terdapat alasan yang cukup kuat untuk memasukkan variabel masa kerja sebagai kovariat.

Setelah terpenuhi asumsi linearitas dari regresi, selanjutnya melakukan uji asumsi homogenitas dari regresi. Menguji asumsi homogenitas dari regresi berarti menguji apakah terjadi interaksi yang cukup signifikan secara statistika antara posisi karyawan dan masa kerja karyawan dalam pengaruhnya terhadap gaji karyawan per-bulan. Uji asumsi homogenitas dari regresi dapat juga berarti menguji apakah kemiringan dari garis regresi populasi adalah sama untuk setiap kategori pada posisi kerja karyawan.

Pilih Analyze $\Rightarrow>$ General Linear Model $\Rightarrow$ Univariate, sehingga muncul kotak dialog Univariate (Gambar 15.3). Pada kotak dialog Univariate, masukkan variabel gaji ke dalam Dependent Variable, variabel posisi ke dalam Fixed Factor(s), dan variabel masa ke dalam Covariate(s). Selanjutnya pilih Model, sehingga muncul kotak dialog Univariate: Model (Gambar 15.4).

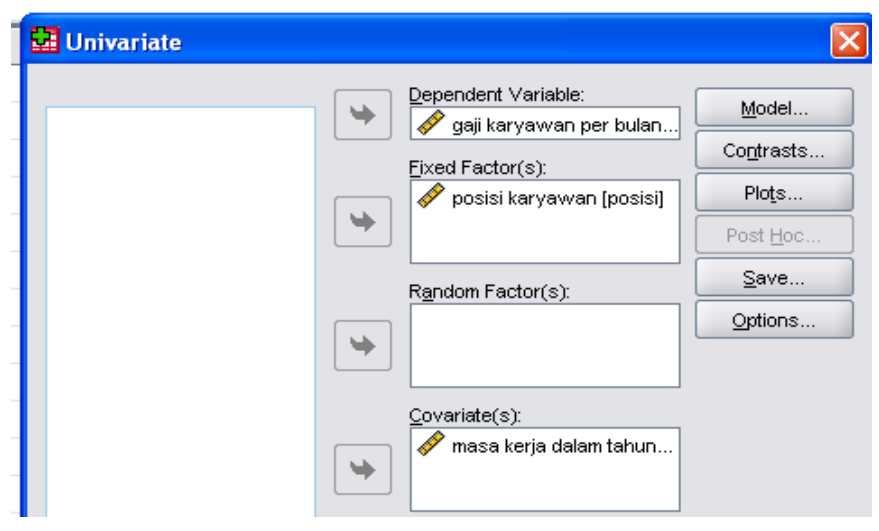

\section{Gambar 15.3}

Pada kotak dialog Univariate: Model (Gambar 15.4), pilih Custom. Kemudian pada Type pilih Interaction, dan masukkan variabel posisi dan masa ke dalam kotak Model. 


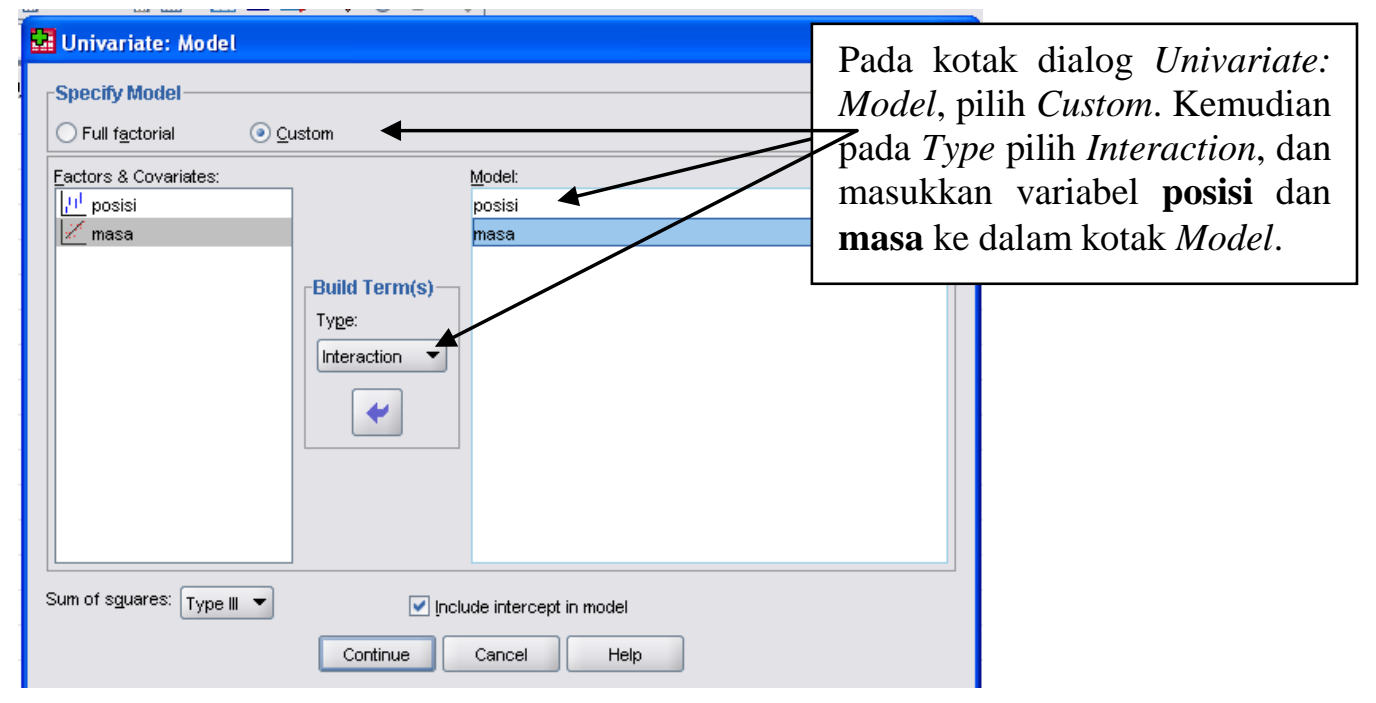

Gambar 15.4

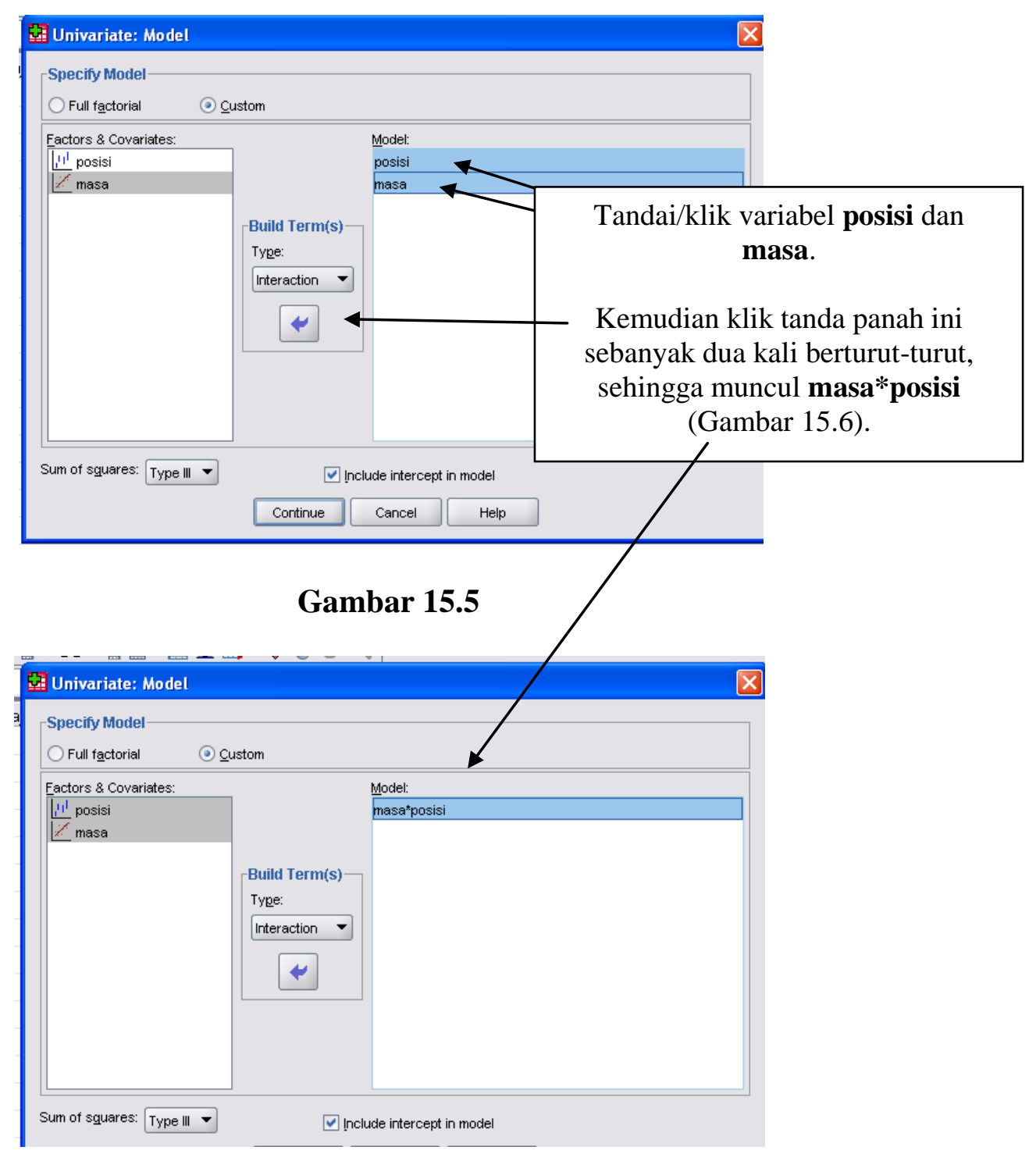

Gambar 15.6 
Setelah muncul variabel masa*posisi (Gambar 15.6) di dalam kotak Model, kemudian masukkan variabel posisi dan masa ke dalam kotak Model, seperti pada Gambar 15.7. Kemudian pilih Continue dan OK.

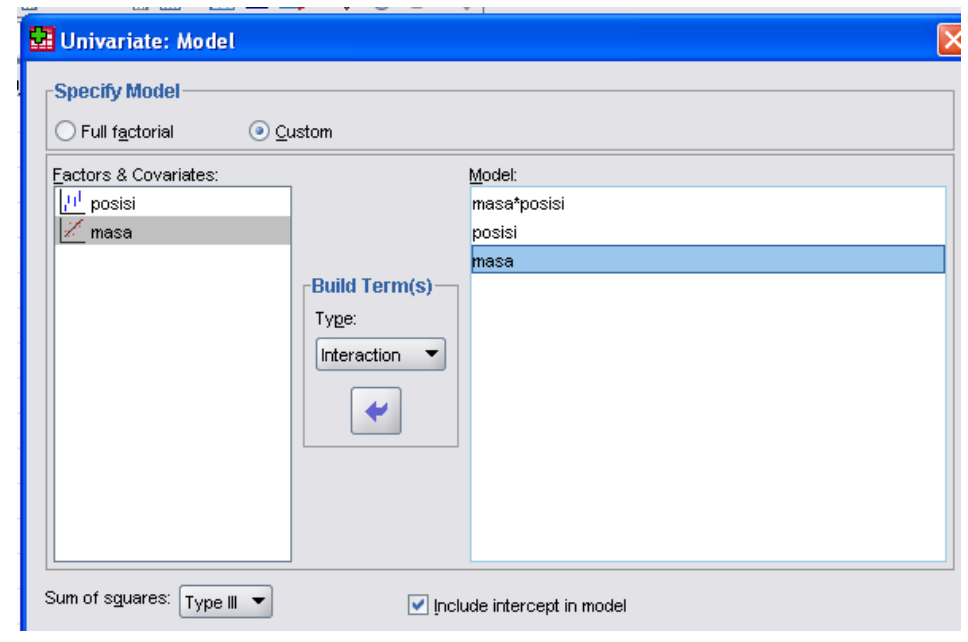

Gambar 15.7

Berikut hasil berdasarkan SPSS.

Tabel 15.3

Tests of Between-Subjects Effects

\begin{tabular}{|c|c|c|c|c|c|}
\hline Source & $\begin{array}{c}\text { Type III Sum } \\
\text { of Squares }\end{array}$ & df & Mean Square & $\mathrm{F}$ & Sig. \\
\hline Corrected Model & $281.537^{a}$ & 5 & 56.307 & 3718.599 & .000 \\
\hline Intercept & 3.950 & 1 & 3.950 & 260.845 & .000 \\
\hline posisi * masa & ه7ه. & 2 & وفجم. & 2.560 & .090 \\
\hline posisi & 2.833 & 2 & 1.417 & 93.561 & .000 \\
\hline masa & 1.525 & 1 & 1.525 & 100.696 & .000 \\
\hline Error & .591 & 39 & .015 & & \\
\hline Total & 1036.120 & 45 & & & \\
\hline Corrected Total & 282.128 & 44 & & & \\
\hline
\end{tabular}

a. R Squared $=.998$ (Adjusted R Squared $=.998$ )

Berdasarkan Tabel 15.3 (Test of Between-Subjects Effects), untuk menentukan apakah asumsi homogenitas dari regresi terpenuhi atau tidak, maka dapat dilakukan dengan membandingkan nilai Sig. pada posisi*masa terhadap tingkat signifikansi. Perhatikan bahwa karena Sig. $(0,090)$ lebih besar dibandingkan dengan tingkat signifikansi $(0,05)$, maka disimpulkan bahwa asumsi homogenitas dari regresi terpenuhi.

Terpenuhinya asumsi homogenitas berarti tidak terjadi interaksi yang begitu signifikan secara statistika antara posisi karyawan dan masa kerja karyawan dalam pengaruhnya terhadap gaji karyawan per-bulan. Dengan kata lain, asumsi mengenai kemiringan dari garis regresi populasi adalah sama untuk setiap kategori pada posisi kerja karyawan terpenuhi pada tingkat signifikansi $5 \%$.

Perhatikan bahwa asumsi linearitas dan homogenitas dari regresi telah terpenuhi. Selanjutnya akan diuji hal-hal sebagai berikut. 
$\Rightarrow$ Apakah terdapat perbedaan yang cukup signifikan secara statistika mengenai ratarata gaji per-bulan di antara karyawan-karyawan yang bekerja pada posisi $\mathrm{A}, \mathrm{B}$, dan $\mathrm{C}$ di perusahaan XYZ dengan mengontrol masa kerja karyawan.

$\Rightarrow$ Apakah terdapat pengaruh atau hubungan yang cukup signifikan secara statistika antara masa kerja karyawan terhadap gaji karyawan per-bulan di perusahaan XYZ dengan mengontrol posisi karyawan.

Pilih Analyze $\Rightarrow$ General Linear Model $\Rightarrow$ Univariate, sehingga muncul kotak dialog Univariate (Gambar 15.3). Pada kotak dialog Univariate, masukkan variabel gaji ke dalam Dependent Variable, variabel posisi ke dalam Fixed Factor(s), dan variabel masa ke dalam Covariate(s). Selanjutnya pilih Model, sehingga muncul kotak dialog Univariate: Model (Gambar 15.8). Pada kotak Univariate: Model, pilih Custom, dan masukkan variabel posisi dan masa ke dalam Model (Gambar 15.8). Selanjutnya pilih Continue.

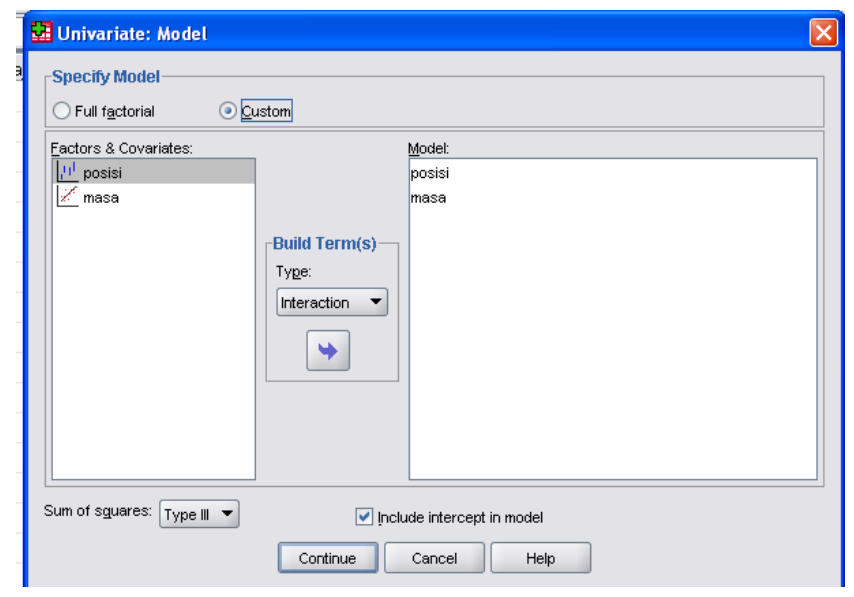

Gambar 15.8

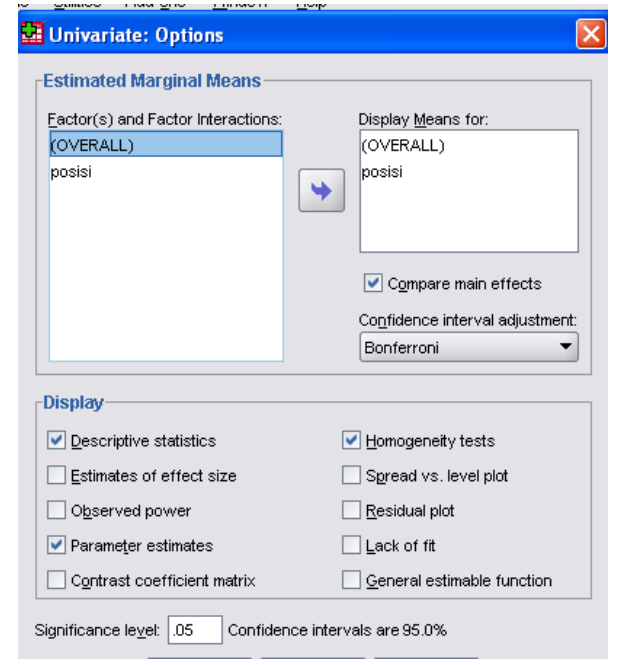

Gambar 15.9

Kemudian pilih Options, sehingga muncul kotak dialog Univariate: Options (Gambar 15.9). Pada kotak dialog Univariate: Options, masukkan OVERALL dan posisi pada kotak Display Means for. Selanjutnya pilih Compare main effects dan atur dengan Bonferroni. Pada Display, pilih Descriptive statistics, Homogeneity tests, dan Parameter estimates. Selanjutnya pilih Continue dan OK. 


\section{Tabel 15.4}

Between-Subjects Factors
\begin{tabular}{|ll|l|r|}
\hline & & Value Label & \multicolumn{1}{|c|}{ N } \\
\hline posisi karyawan & 1 & posisi A & 15 \\
& 2 & posisi B & 15 \\
& 3 & posisi C & 15 \\
\hline
\end{tabular}

Berdasarkan Tabel 15.4 (Between-Subjects Factors), diketahui jumlah karyawan yang diteliti dalam sampel sebanyak 45 karyawan. Untuk setiap posisi terdiri dari 15 karyawan.

\section{Tabel 15.5}

Descriptive Statistics

Dependent Variable: gaii karyawan per bulan
\begin{tabular}{|c|r|r|r|}
\hline posisi kawawan & Mean & Std. Deviation & \multicolumn{1}{c|}{ N } \\
\hline posisi A & 1.427 & .2251 & 15 \\
posisi B & 3.427 & .2251 & 15 \\
posisi C & 7.427 & .2251 & 15 \\
Total & 4.093 & 2.5322 & 45 \\
\hline
\end{tabular}

Berdasarkan Tabel 15.5 (Descriptive Statistics), secara rata-rata karyawan dengan posisi kerja $\mathrm{C}$ memiliki gaji yang paling tinggi dibandingkan dengan posisi kerja lain. Hal ini terlihat dari nilai Mean untuk posisi kerja $\mathrm{C}$ sebesar 7,427. Nilai Mean tersebut paling besar dibandingkan nilai Mean dari posisi kerja yang lain.

\section{Tabel 15.6}

\section{Levene's Test of Equality of Error}

Variances $^{\mathrm{a}}$

\begin{tabular}{|c|c|c|c|}
\hline $\bar{F}$ & $\mathrm{df1}$ & $\mathrm{df2}$ & Sig. \\
\hline .836 & 2 & 42 & 440 \\
\hline
\end{tabular}

Tests the null hypothesis that the error variance of the dependent variable is equal across groups.

a. Design: Intercept + posisi + masa

\section{Tabel 15.7}

Tests of Between-Subjects Effects

Dependent Variable:gai karvawan per bulan
\begin{tabular}{|l|r|r|r|r|r|}
\hline Source & $\begin{array}{c}\text { Type III Sum } \\
\text { of Squares }\end{array}$ & df & Mean Square & F & Sig. \\
\hline Corrected Model & $281.460^{a}$ & 3 & 93.820 & 5757.706 & .000 \\
Intercept & 3.910 & 1 & 3.910 & 239.963 & .000 \\
posisi & 15.415 & 2 & 7.708 & 473.014 & .000 \\
masa & 1.460 & 1 & 1.460 & 89.595 & .000 \\
Error & .668 & 41 & .016 & & \\
Total & 1036.120 & 45 & & & \\
Corrected Total & 282.128 & 44 & & & \\
\hline
\end{tabular}
a. R Squared $=.998$ (Adjusted R Squared $=.997$ )

Berdasarkan Tabel 15.6 (Levene's Test of Equality of Error Variances) dapat dilakukan pengujian asumsi mengenai kesamaan varians dari error pada setiap grup atau kelompok. Dalam hal ini, error merupakan selisih antara nilai variabel tak bebas $(y)$ dan nilai estimasi variabel tak bebas $(\hat{y})$. Untuk menentukan apakah asumsi tersebut terpenuhi atau tidak, maka dapat dilakukan dengan membandingkan nilai Sig. terhadap tingkat signifikansi. Perhatikan 
bahwa karena Sig. $(0,440)$ lebih besar dibandingkan dengan tingkat signifikansi $(0,05)$, maka disimpulkan bahwa asumsi mengenai kesamaan varians dari error terpenuhi pada tingkat signifikansi 5\%.

Berdasarkan Tabel 15.7 (Tests of Between Subjects Effects) akan diuji hal-hal sebagai berikut.

$\Rightarrow$ Apakah terdapat perbedaan yang cukup signifikan secara statistika mengenai ratarata gaji per-bulan di antara karyawan-karyawan yang bekerja pada posisi A, B, dan C di perusahaan XYZ dengan mengontrol masa kerja karyawan.

$\Rightarrow$ Apakah terdapat pengaruh atau hubungan yang cukup signifikan secara statistika antara masa kerja karyawan terhadap gaji karyawan per-bulan di perusahaan XYZ dengan mengontrol posisi kerja karyawan.

Berdasarkan Tabel 15.7, nilai Sig. atau probabilitas untuk variabel posisi adalah 0,000 . Karena nilai probabilitas untuk variabel posisi $(0,000)$ lebih kecil dibandingkan tingkat signifikansi $(0,05)$, maka disimpulkan bahwa terdapat perbedaan yang cukup signifikan secara statistika mengenai rata-rata gaji per-bulan di antara karyawan-karyawan yang bekerja pada posisi A, B, dan C di perusahaan XYZ dengan mengontrol masa kerja karyawan.

Selanjutnya perhatikan nilai Sig. atau probabilitas untuk variabel masa, yakni 0,000. Karena nilai probabilitas untuk variabel masa $(0,000)$ lebih kecil dibandingkan tingkat signifikansi $(0,05)$, maka disimpulkan bahwa terdapat pengaruh atau hubungan yang cukup signifikan secara statistika antara masa kerja karyawan terhadap gaji karyawan per-bulan di perusahaan $\mathrm{XYZ}$ dengan mengontrol posisi kerja karyawan. Dengan kata lain, semakin lama masa kerja karyawan, maka gaji karyawan tersebut juga semakin cenderung meningkat.

\section{Tabel 15.8}

Parameter Estimates

\begin{tabular}{|c|c|c|c|c|c|c|}
\hline \multirow[b]{2}{*}{ Parameter } & \multirow[b]{2}{*}{$B$} & \multirow[b]{2}{*}{ Std. Error } & \multirow[b]{2}{*}{$\mathrm{t}$} & \multirow[b]{2}{*}{ Siq. } & \multicolumn{2}{|c|}{$95 \%$ Confidence Interval } \\
\hline & & & & & Lower Bound & Upper Bound \\
\hline Intercept & 5.123 & .246 & 20.862 & .000 & 4.627 & 5.619 \\
\hline [posisi=1] & -4.641 & .151 & -30.738 & .000 & -4.946 & -4.336 \\
\hline [posisi=2] & -3.087 & 107 & -28.813 & .000 & -3.303 & -2.871 \\
\hline [posisi=3] & $0^{a}$ & & & & & . \\
\hline masa & .156 & .016 & 9.465 & .000 & .122 & .189 \\
\hline
\end{tabular}

a. This parameter is set to zero because it is redundant.

Berdasarkan Tabel 15.8 (Parameter Estimates) diperoleh persamaan regresi linear sebagai berikut.

$$
\hat{y}=5,123+0,156 x-4,641 z_{1}-3,087 z_{2} \text {. }
$$

Perhatikan bahwa pada persamaan regresi tersebut, nilai kemiringan (slope) dari variabel masa adalah positif, yakni 0,156 . Hal ini menandakan bahwa terjadi hubungan yang bersifat positif antara masa kerja karyawan terhadap gaji karyawan per-bulan. Persamaan regresi untuk karyawan dengan posisi kerja A adalah

$$
\begin{gathered}
\hat{y}_{A}=5,123+0,156 x-4,641(1)-3,087(0) \\
\hat{y}_{A}=0,482+0,156 x .
\end{gathered}
$$


Persamaan regresi untuk karyawan dengan posisi kerja B adalah

$$
\begin{gathered}
\hat{y}_{B}=5,123+0,156 x-4,641(0)-3,087(1) \\
\hat{y}_{B}=2,036+0,156 x .
\end{gathered}
$$

Persamaan regresi untuk karyawan dengan posisi kerja $\mathrm{C}$ adalah

$$
\begin{gathered}
\hat{y}_{C}=5,123+0,156 x-4,641(0)-3,087(0) \\
\hat{y}_{C}=5,123+0,156 x .
\end{gathered}
$$

Berikut disajikan dalam grafik dari ketiga garis regresi tersebut.

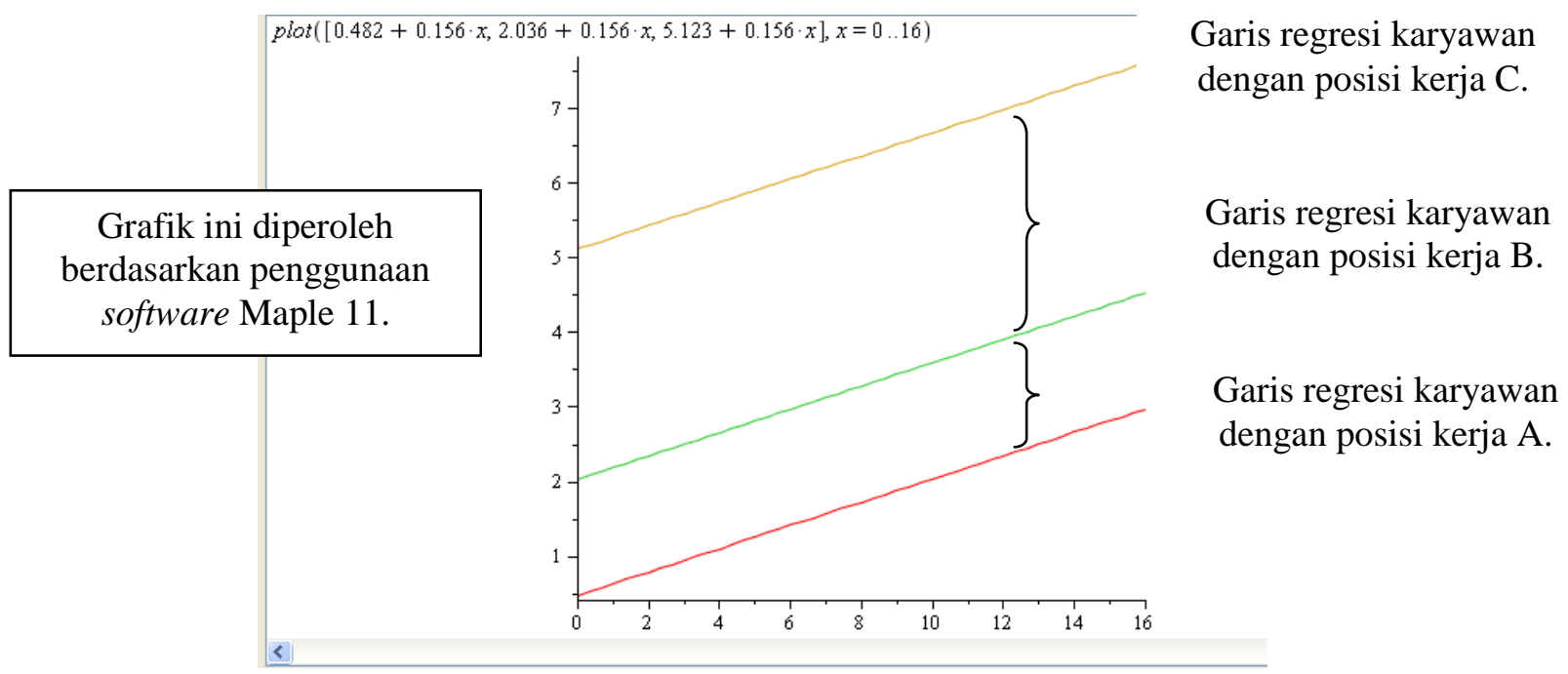

Perhatikan bahwa ketiga garis regresi tersebut memiliki kemiringan (slope) yang sama, yakni 0,156 . Kemiringan yang bernilai positif berarti semakin lama masa kerja karyawan, maka akan semakin meningkat gaji karyawan per-bulan. Berdasarkan grafik tersebut, terlihat bahwa garis regresi untuk karyawan dengan posisi $\mathrm{C}$ kerja menempati posisi paling tinggi

\begin{tabular}{|c|c|c|c|c|c|c|}
\hline \multirow[b]{2}{*}{ (1) nosisikamawan } & \multirow[b]{2}{*}{ (J) nosisi kawawan } & \multirow[b]{2}{*}{$\begin{array}{l}\text { Mean } \\
\text { Difference (I- } \\
\text { J) }\end{array}$} & \multirow[b]{2}{*}{ Std. Error } & \multirow[b]{2}{*}{ Sig. ${ }^{a}$} & \multicolumn{2}{|c|}{$\begin{array}{c}95 \% \text { Confidence Interval for } \\
\text { Difference }\end{array}$} \\
\hline & & & & & Lower Bound & Upper Bound \\
\hline \multirow[t]{2}{*}{ posisi $\mathrm{A}$} & posisi B & $-1.554^{x}$ & .066 & .000 & -1.719 & -1.388 \\
\hline & posisi C & $-4.641^{x}$ & .151 & .000 & -5.018 & -4.264 \\
\hline \multirow[t]{2}{*}{ posisi B } & posisi A & $1.554^{x}$ & .066 & .000 & 1.388 & 1.719 \\
\hline & posisi C & $-3.087^{\pi}$ & .107 & .000 & -3.354 & -2.819 \\
\hline \multirow[t]{2}{*}{ posisi C } & posisi A & $4.641^{\pi}$ & .151 & .000 & 4.264 & 5.018 \\
\hline & posisi B & $3.087^{\pi}$ & .107 & .000 & 2.819 & 3.354 \\
\hline
\end{tabular}
dibandingkan yang lain.

\section{Tabel 15.9}

Pairwise Comparisons

Based on estimated marginal means

*. The mean difference is significant at the .05 level.

a. Adjustment for multiple comparisons: Bonferroni.

Berdasarkan Tabel 15.9 (Pairwise Comparisons) akan diuji hal-hal sebagai berikut. 
$\Rightarrow$ Apakah terdapat perbedaan yang cukup signifikan mengenai rata-rata (adjusted mean) gaji per-bulan antara karyawan posisi A dan $\mathrm{B}$, dengan mengontrol masa kerja karyawan.

$\Rightarrow$ Apakah terdapat perbedaan yang cukup signifikan mengenai rata-rata (adjusted mean) gaji per-bulan antara karyawan posisi $\mathrm{A}$ dan $\mathrm{C}$, dengan mengontrol masa kerja karyawan.

$\Rightarrow$ Apakah terdapat perbedaan yang cukup signifikan mengenai rata-rata (adjusted mean) gaji per-bulan antara karyawan posisi $\mathrm{B}$ dan $\mathrm{C}$, dengan mengontrol masa kerja karyawan.

Perhatikan bahwa rata-rata yang dibandingkan bukan lagi rata-rata dari tiap-tiap kelompok, melainkan rata-rata yang sudah disesuaikan (adjusted mean). Untuk menentukan apakah terdapat perbedaan yang cukup signifikan mengenai rata-rata gaji per-bulan antara karyawan posisi A dan B, dengan mengontrol masa kerja karyawan, perhatikan nilai Sig. untuk posisi A v/s posisi B, yakni 0,000. Karena nilai Sig. lebih kecil dibandingkan tingkat signifikansi, yakni 0,05, maka disimpulkan bahwa terdapat perbedaan yang cukup signifikan mengenai rata-rata gaji per-bulan antara karyawan posisi $\mathrm{A}$ dan $\mathrm{B}$, dengan mengontrol masa kerja karyawan. Perhatikan juga bahwa terdapat perbedaan yang cukup signifikan mengenai ratarata gaji per-bulan antara karyawan posisi A dan $\mathrm{C}$, dengan mengontrol masa kerja karyawan, $\mathrm{B}$ dan $\mathrm{C}$, dengan mengontrol masa kerja karyawan. 


\section{$S \mathcal{H A R \mathcal { E }}$}

[1] Pada pembahasan sebelumnya diperoleh hasil SPSS sebagai berikut.

\section{Tabel 15.1}

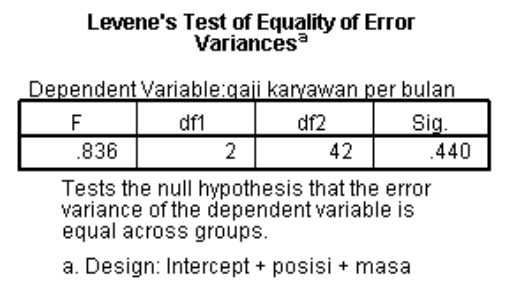

Informasi pada Tabel Levene's Test of Equality of ErrorVariances dapat digunakan untuk menguji asumsi kesamaan dari varians error. Dalam hal ini, error merupakan selisih antara nilai variabel tak bebas $(y)$ dan nilai estimasi variabel tak bebas $(\hat{y})$. Akan diperlihatkan cara lain untuk memperoleh hasil SPSS pada Tabel 15.1. Diketahui persamaan regresi untuk karyawan dengan posisi A, B, dan C sebagai berikut.

$$
\begin{gathered}
\hat{y}_{A}=0,482+0,156 x ; \quad \hat{y}_{B}=2,036+0,156 x . \\
\hat{y}_{C}=5,123+0,156 x .
\end{gathered}
$$

Buat tabel perhitungan seperti berikut (Tabel 15.2).

Tabel 15.2

\begin{tabular}{|c|c|c|c|c|c|c|c|c|c|c|c|}
\hline \multicolumn{9}{|c|}{ Kelompok A } & \multicolumn{4}{c|}{ Kelompok B } & \multicolumn{4}{|c|}{ Kelompok C } \\
\hline$y$ & $x$ & $\hat{y}$ & $y-\hat{y}$ & $y$ & $x$ & $\hat{y}$ & $y-\hat{y}$ & $y$ & $x$ & $\hat{y}$ & $y-\hat{y}$ \\
\hline 1.1 & 5 & 1.262 & -0.162 & 3.1 & 8 & 3.284 & -0.184 & 7.1 & 14 & 7.307 & -0.207 \\
\hline 1.2 & 5 & 1.262 & -0.062 & 3.2 & 8 & 3.284 & -0.084 & 7.2 & 14 & 7.307 & -0.107 \\
\hline 1.3 & 6 & 1.418 & -0.118 & 3.3 & 9 & 3.44 & -0.14 & 7.3 & 15 & 7.463 & -0.163 \\
\hline 1.4 & 6 & 1.418 & -0.018 & 3.4 & 9 & 3.44 & -0.04 & 7.4 & 15 & 7.463 & -0.063 \\
\hline 1.5 & 6 & 1.418 & 0.082 & 3.5 & 9 & 3.44 & 0.06 & 7.5 & 15 & 7.463 & 0.037 \\
\hline 1.6 & 7 & 1.574 & 0.026 & 3.6 & 10 & 3.596 & 0.004 & 7.6 & 16 & 7.619 & -0.019 \\
\hline 1.7 & 8 & 1.73 & -0.03 & 3.7 & 11 & 3.752 & -0.052 & 7.7 & 17 & 7.775 & -0.075 \\
\hline 1.1 & 5 & 1.262 & -0.162 & 3.1 & 8 & 3.284 & -0.184 & 7.1 & 14 & 7.307 & -0.207 \\
\hline 1.2 & 5 & 1.262 & -0.062 & 3.2 & 7 & 3.128 & 0.072 & 7.2 & 12 & 6.995 & 0.205 \\
\hline 1.3 & 5 & 1.262 & 0.038 & 3.3 & 7 & 3.128 & 0.172 & 7.3 & 12 & 6.995 & 0.305 \\
\hline 1.4 & 6 & 1.418 & -0.018 & 3.4 & 9 & 3.44 & -0.04 & 7.4 & 15 & 7.463 & -0.063 \\
\hline 1.5 & 6 & 1.418 & 0.082 & 3.5 & 9 & 3.44 & 0.06 & 7.5 & 15 & 7.463 & 0.037 \\
\hline 1.6 & 7 & 1.574 & 0.026 & 3.6 & 10 & 3.596 & 0.004 & 7.6 & 16 & 7.619 & -0.019 \\
\hline 1.7 & 7 & 1.574 & 0.126 & 3.7 & 10 & 3.596 & 0.104 & 7.7 & 16 & 7.619 & 0.081 \\
\hline 1.8 & 7 & 1.574 & 0.226 & 3.8 & 10 & 3.596 & 0.204 & 7.8 & 16 & 7.619 & 0.181 \\
\hline
\end{tabular}


Kemudian bangun data dalam SPSS seperti berikut (Gambar 15.1).

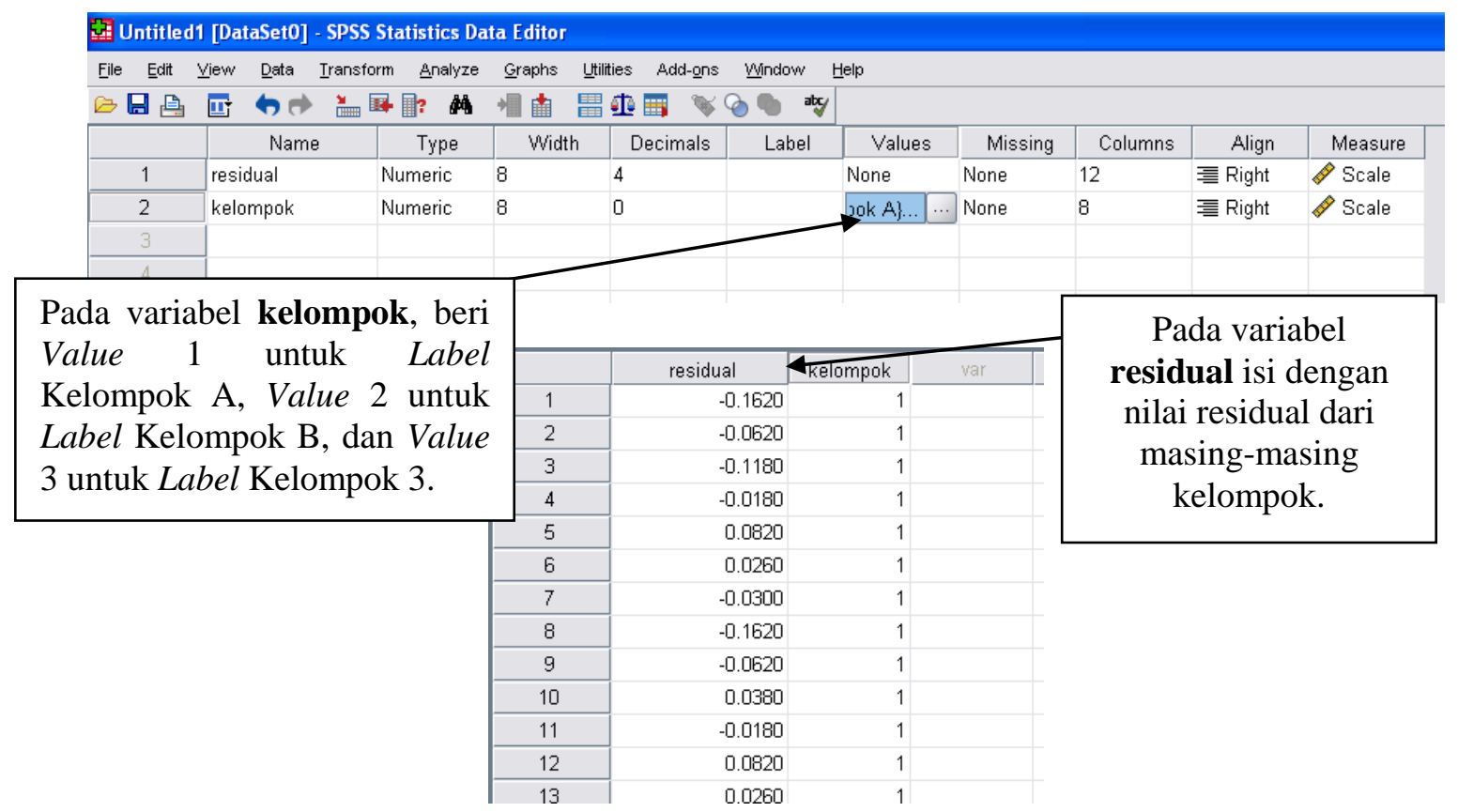

Gambar 15.1

Selanjutnya pilih Analyze $\Rightarrow$ Compare Means $\Rightarrow$ One-Way ANOVA (Gambar 15.2). Pada kotak dialog One-Way ANOVA (Gambar 15.3), masukkan variabel residual pada kotak Dependent List dan masukkan variabel kelompok pada kotak Factor. Kemudian pilih Options, sehingga muncul kotak dialog One Way ANOVA: Options (Gambar 15.4).

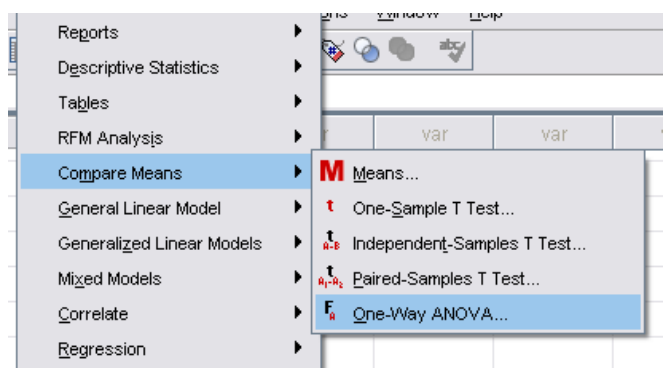

Gambar 15.2

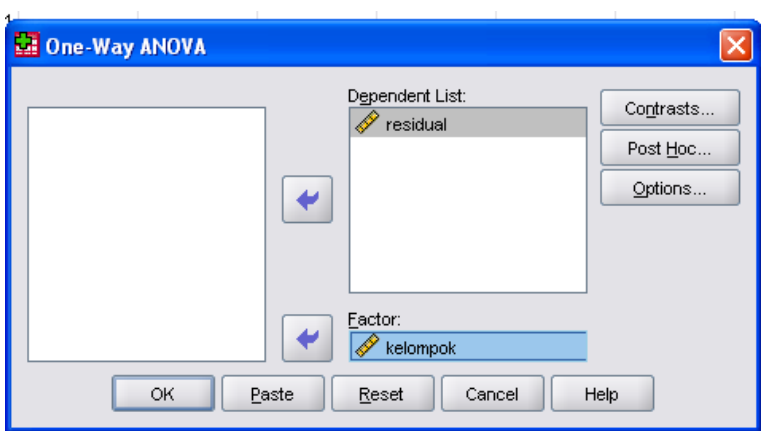

Gambar 15.3

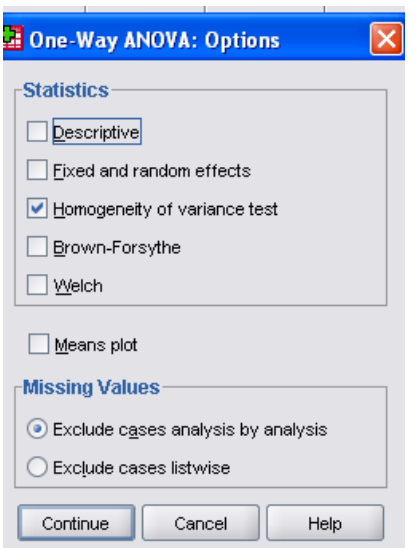

Gambar 15.4 
Pada kotak dialog One-Way ANOVA: Options (Gambar 15.4), pilih Homogeneity of variance test. Kemudian pilih Continue dan OK. Berikut hasil berdasarkan SPSS.

Test of Homogeneity of Variances

residual
\begin{tabular}{|r|r|r|c|}
\hline $\begin{array}{c}\text { Levene } \\
\text { Statistic }\end{array}$ & df1 & df 2 & Sig. \\
\hline .849 & 2 & 42 & .435 \\
\hline
\end{tabular}

Perhatkan bahwa hasil yang diperoleh sedikit berbeda. Hal ini hanya mengenai permasalahan tingkat ketelitian desimal yang digunakan.

[2] Pada pembahasan sebelumnya diperoleh hasil SPSS sebagai berikut.

Tabel 15.3

Pairwise Comparisons

\begin{tabular}{|c|c|c|c|c|c|c|}
\hline \multirow[b]{2}{*}{ (1) nosisikanawan } & \multirow[b]{2}{*}{ (J) nosisi kawawan } & \multirow[b]{2}{*}{$\begin{array}{c}\text { Mean } \\
\text { Difference (1- } \\
\mathrm{J})\end{array}$} & \multirow[b]{2}{*}{ Std. Error } & \multirow[b]{2}{*}{$\mathrm{Siq}^{\mathrm{a}}$} & \multicolumn{2}{|c|}{$\begin{array}{c}95 \% \text { Confidence Interval for } \\
\text { Difference }\end{array}$} \\
\hline & & & & & Lower Bound & Upper Bound \\
\hline \multirow[t]{2}{*}{ posisi A } & posisi B & $-1.554^{x}$ & .066 & .000 & -1.719 & -1.388 \\
\hline & posisic & $-4.641^{\pi}$ & .151 & .000 & -5.018 & -4.264 \\
\hline \multirow[t]{2}{*}{ posisi B } & posisi A & $1.554^{x}$ & .066 & .000 & 1.388 & 1.719 \\
\hline & posisi C & $-3.087^{\pi}$ & .107 & .000 & -3.354 & -2.819 \\
\hline \multirow[t]{2}{*}{ posisi $\mathrm{C}$} & posisi A & $4.641^{x}$ & .151 & .000 & 4.264 & 5.018 \\
\hline & posisi B & $3.087^{x}$ & .107 & .000 & 2.819 & 3.354 \\
\hline
\end{tabular}

Berdasarkan Tabel 15.3 (Pairwise Comparisons), Mean Difference untuk posisi A dan B adalah $-1,554$, untuk posisi $\mathrm{A}$ dan $\mathrm{C}$ adalah $-4,641$, dan untuk posisi $\mathrm{B}$ dan $\mathrm{C}$ adalah -3,097. Nilai Mean tersebut merupakan nilai rata-rata yang telah disesuaikan (adjusted mean). Pada analisis kovarian, rata-rata populasi yang diuji merupakan rata-rata yang telah disesuaikan (adjusted means). Berikut akan diperlihatkan cara untuk memperoleh adjusted mean.

Diketahui bahwa persamaan regresi untuk karyawan dengan posisi $\mathrm{A}, \mathrm{B}$, dan $\mathrm{C}$ sebagai berikut.

$$
\begin{aligned}
& \hat{y}_{A}=0,482+0,156 x . \\
& \hat{y}_{B}=2,036+0,156 x . \\
& \hat{y}_{C}=5,123+0,156 x .
\end{aligned}
$$

Diketahui nilai rata-rata secara keseluruhan (grand mean) dari $x$ adalah 9,9333. Maka adjusted mean gaji karyawan per-bulan untuk posisi $\mathrm{A}, \mathrm{B}$, dan $\mathrm{C}$ adalah

$$
\begin{aligned}
& \hat{y}_{A}=0,482+0,156 x=0,482+0,156(9,9333)=2,0315948 \\
& \hat{y}_{B}=2,036+0,156 x=2,036+0,156(9,9333)=3,5855948 \\
& \hat{y}_{C}=5,123+0,156 x=5,123+0,156(9,9333)=6,6725948 .
\end{aligned}
$$


Sehingga selisih adjusted mean gaji karyawan per-bulan antara posisi A dan B (Mean Difference) sebesar

$$
\begin{gathered}
\hat{y}_{A}-\hat{y}_{B}=2,0315948-3,5855948=-1,1554 \\
\hat{y}_{A}-\hat{y}_{C}=2,0315948-6,6725948=-4,641 .
\end{gathered}
$$

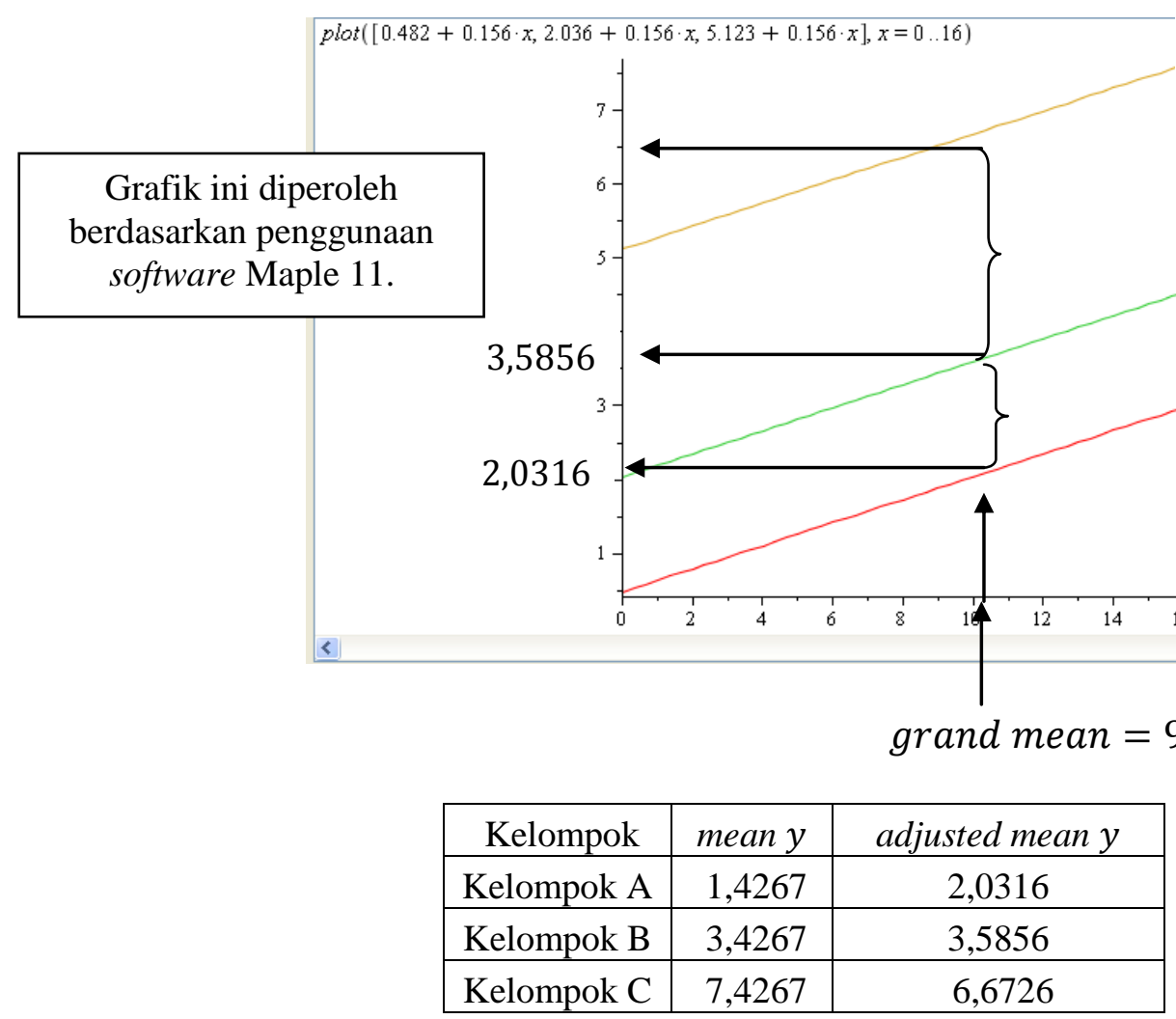

Jadi pada multiple comparison untuk analisis kovarian, yang diuji adalah adjusted mean, bukan nilai mean dari masing-masing kelompok.

[3] Pada analisis kovarian juga dikenakan asumsi independensi antara kovariat dan pengaruh perlakuan (variabel bebas) (independence of the covariate and treatment effect). Berikut akan diperlihatkan langkah-langkah untuk melakukan uji asumsi independensi (independence assumption) berdasarkan data pada Tabel 15.2. Pertama, bangun data pada Tabel 15.2 dalam SPSS (Gambar 15.5).

Setelah data pada Tabel 15.2 dibangun dalam SPSS (Gambar 15.5), selanjutnya pilih Analyze $\Rightarrow$ Compare Means => One-Way ANOVA. Pada kotak dialog One-Way ANOVA, masukkan variabel masa pada kotak Dependent List dan masukkan variabel posisi pada kotak Factor (Gambar 15.6). Selanjutnya pilih OK.

Tabel 15.4 merupakan hasil berdasarkan SPSS. Perhatikan bahwa berdasarkan Tabel 15.4 (ANOVA), diketahui nilai Sig. atau probabilitas adalah 0,000. Nilai probabilitas tersebut kemudian dibandingkan dengan tingkat signifikansi. Jika nilai probabilitas $\geq$ tingkat signifikansi, maka disimpulkan bahwa asumsi independensi terpenuhi. Jika nilai probabilitas $<$ tingkat signifikansi, maka disimpulkan bahwa asumsi independensi tidak terpenuhi. Misalkan tingkat signifikansi yang digunakan adalah 0,05. Perhatikan bahwa karena nilai probabilitas $(0,000)$ lebih kecil dibandingkan tingkat signifikansi $(0,05)$, maka asumsi independensi tidak terpenuhi. Field (2009:400) menyarankan sebelum menggunakan atau 
menetapkan kovariat dalam analisis, periksa terlebih dahulu bahwa asumsi independensi terpenuhi antara kovariat dan pengaruh perlakuan (variabel bebas).

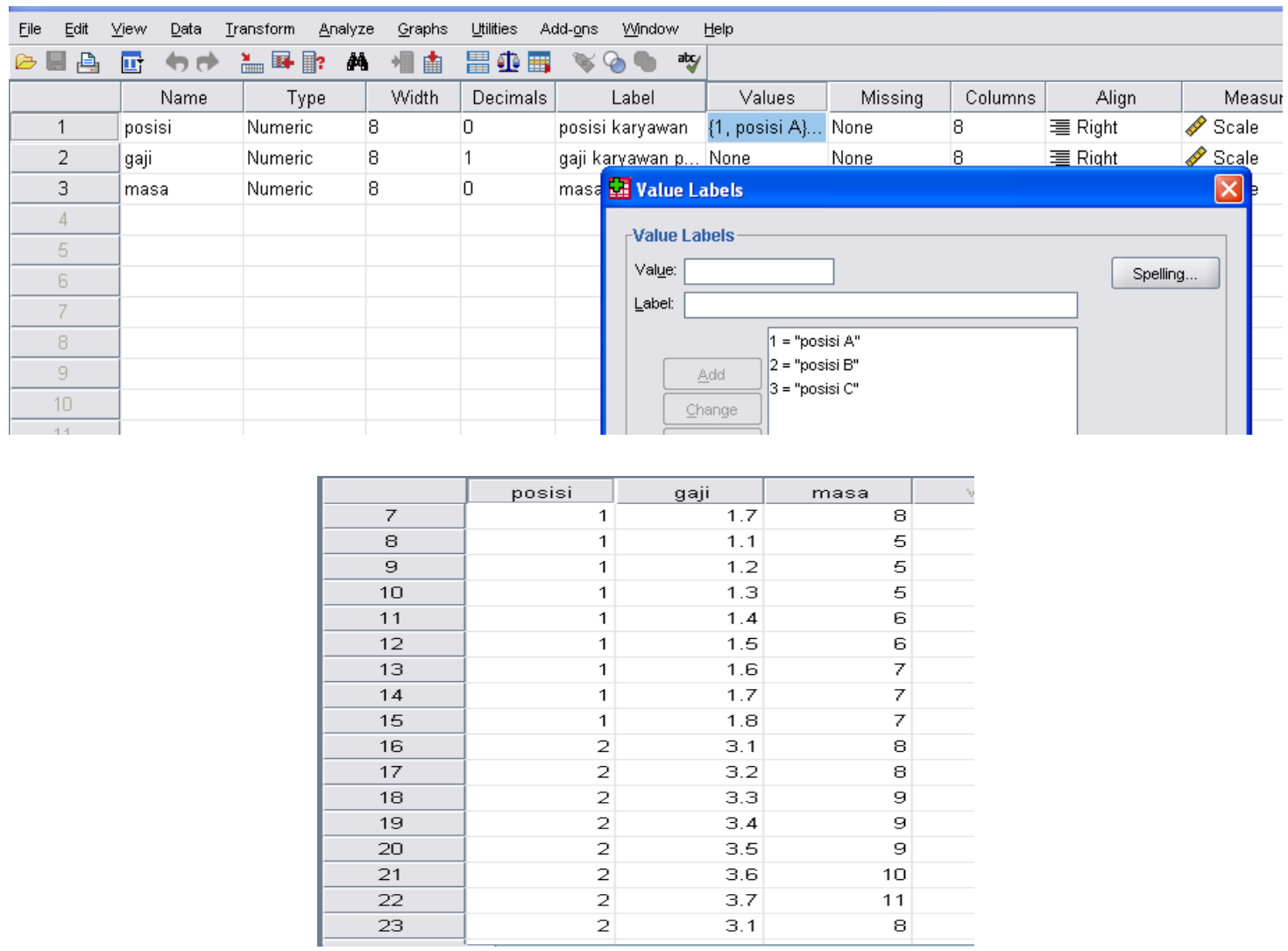

Gambar 15.5

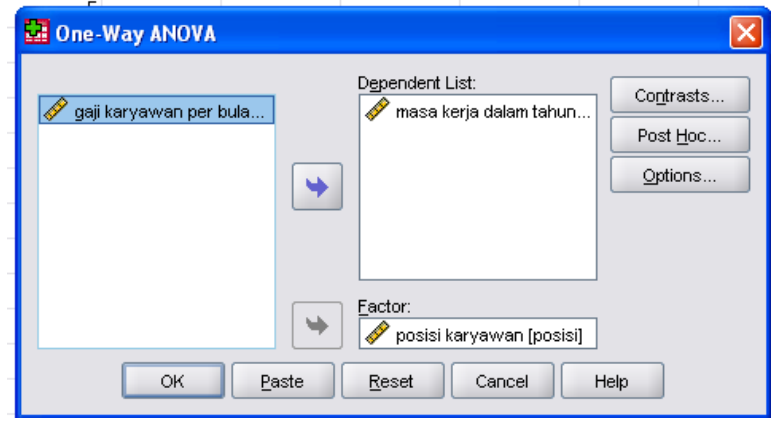

Gambar 15.6

Tabel 15.4

\begin{tabular}{|c|c|c|c|c|c|c|}
\hline \multirow{2}{*}{ masa keria dalam } & & ANOVA & & & & \multirow[b]{2}{*}{ Analyze $\Rightarrow$ Compare } \\
\hline & $\begin{array}{c}\text { Sum of } \\
\text { Squares }\end{array}$ & $\mathrm{df}$ & Mean Square & $\mathrm{F}$ & Sig. & \\
\hline Between Groups & 594.533 & 2 & 297.267 & $\frac{r}{207.166}$ & .000 & Means $\Rightarrow>$ One-Way \\
\hline Within Groups & 60.267 & 42 & 1.435 & & & $A N O V A$ \\
\hline Total & 654.800 & 44 & & & & \\
\hline
\end{tabular}


Tabel 15.5

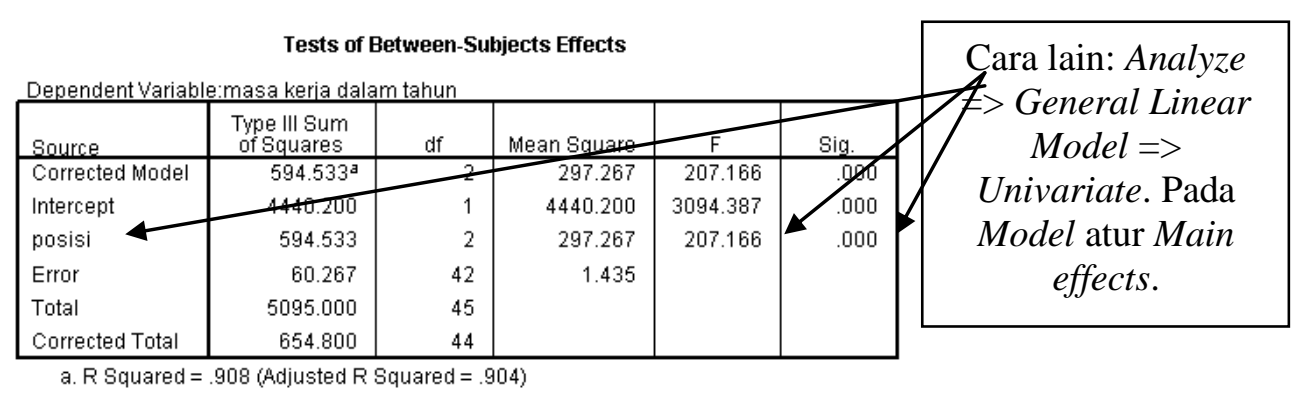

Field (2009:400-401) menyatakan sebagai berikut.

"In section 11.3.1, I mentioned that before including a covariate in an analysis we should check that it is independent from the experimental manipulation. In this case, the proposed covariate is partner's libido, and we need to check that this variable was roughly equal across levels of our independent variable. In other words, is the mean level of partner's libido roughly equal across our three Viagra groups? We can test this by running an ANOVA with Partner_Libido as the outcome and Dose as the predictor.

SPSS Output 11.1 shows the results of such an ANOVA. The main effect of dose is not significant, $F(2,27)=1.98, p=.16$, which shows that the average level of partner's libido was roughly the same in the three Viagra groups. In other words, the means for partner's libido in Table 11.2 are not significantly different in the placebo, low-and high-dose groups. This result means that it is appropriate to use partner's libido as a covariate in the analysis."

\section{Referensí}

1. Agresti, A. dan B. Finlay. 2009. Statistical Methods for the Social Sciences, $4^{\text {th }}$ Edition. United States of America: Prentice Hall.

2. Daniel, W.W. 2005. Biostatistics: A Foundation for Analysis in the Health Sciences, $8^{\text {th }}$ Edition. United States of America: John Wiley \& Sons.

3. Field, A. 2009. Discovering Statistics Using SPSS, $3^{\text {rd }}$ Edition. London: Sage.

4. Gamst, G., L.S. Meyers, dan A.J. Guarino. 2008. Analysis of Variance Designs, Computational Approach with SPSS and SAS. Cambridge: Cambridge University Press.

5. Montgomery, D.C. dan G.C. Runger. 2011. Applied Statistics and Probability for Engineers, $5^{\text {th }}$ Edition. United States of America: John Wiley \& Sons, Inc.

6. Smidth, R. K. dan D. H. Sanders. 2000. Statistics a First Course, $6^{\text {th }}$ Edition. United States of America: McGraw-Hill Companies.

7. Stevens, J.P. 2009. Applied Multivariate Statistics For The Social Science, $5^{\text {th }}$ Edition. New York: Routledge. 


\section{BAB 16}

\section{UJI INDEPENDENSI UNTUK VARIABEL-VARIABEL KATEGORI}

\section{Sekilas Ují Independensi untuk Variabel-Variabel Kategori}

Beberapa contoh dari variabel-variabel kategori seperti jenis kelamin (terdiri dari dua kategori, yakni laki-laki dan perempuan), warga negara (WNI dan WNA), hobi (suka memasak atau tidak suka memasak), kelulusan (lulus atau tidak lulus), kebahagiaan (tidak terlalu bahagia, bahagia, sangat bahagia) dan sebagainya. Uji independensi untuk variabelvariabel kategori merupakan suatu uji untuk menguji ada tidaknya hubungan di antara variabel-variabel kategori. Berikut diberikan beberapa contoh kasus yang dapat diselesaikan dengan pendekatan uji independensi untuk variabel-variabel kategori.

$\Rightarrow$ Menentukan ada tidaknya hubungan antara tingkat usia terhadap acara TV yang disukai. Misalkan untuk variabel tingkat usia terdiri dari tiga kategori, yakni anakanak, remaja, dan dewasa, sedangkan untuk variabel acara TV terdiri dari tiga kategori, yakni kartun, musik, dan berita.

$\Rightarrow$ Menentukan ada tidaknya hubungan antara tingkat pendapatan keluarga terhadap kebahagiaan. Misalkan untuk variabel tingkat pendapatan terdiri dari tiga kategori, yakni di bawah rata-rata, rata-rata, dan di atas rata-rata, sedangkan untuk variabel kebahagiaan terdiri dari tiga kategori, yakni tidak terlalu bahagia, bahagia, dan sangat bahagia.

Hipotesis nol yang diajukan pada uji independensi untuk variabel-variabel kategori adalah variabel-variabel kategori signifikan secara statistika tidak berhubungan (statistically independent), sedangkan hipotesis alternatif menyatakan variabel-variabel kategori signifikan secara statistika berhubungan (statistically dependent).

\section{Tabel Kontingensi (Contingency Table)}

Dalam uji independensi untuk dua variabel kategori, data disajikan dalam tabel kontingensi (contingency table). Tabel kontingensi menyajikan jumlah subjek yang diamati dari seluruh kombinasi kejadian yang mungkin. Sebagai contoh diberikan dua variabel kategori, yakni variabel jenis kelamin dan variabel hobi. Dari variabel jenis kelamin memiliki dua kategori, yakni laki-laki dan perempuan, sedangkan pada variabel hobi, misalkan memiliki tiga kategori, yakni membaca, memasak, dan berolahraga. Pada tabel kontingensi menyajikan jumlah subjek yang diamati (observed) untuk seluruh kombinasi yang mungkin dari dua variabel kategori tersebut. Berikut adalah seluruh kombinasi yang mungkin dari dua variabel kategori tersebut.

$\Rightarrow$ Jenis kelamin laki-laki dengan hobi membaca.

$\Rightarrow$ Jenis kelamin laki-laki dengan hobi memasak.

$\Rightarrow$ Jenis kelamin laki-laki dengan hobi berolahraga.

$\Rightarrow$ Jenis kelamin perempuan dengan hobi membaca. 
$\Rightarrow$ Jenis kelamin perempuan dengan hobi memasak.

$\Rightarrow$ Jenis kelamin perempuan dengan hobi berlolahraga.

Misalkan diajukan beberapa pertanyaan sebagai berikut.

$\Rightarrow$ Apakah antara laki-laki dan perempuan cenderung berbeda dalam hal pemilihan hobi?

$\Rightarrow$ Apakah laki-laki cenderung memilih hobi olahraga, sedangkan perempuan cenderung memilih hobi membaca dan memasak?

$\Rightarrow$ Apakah terdapat hubungan antara jenis kelamin dan hobi?

Misalkan diberikan data mengenai jenis kelamin dan hobi dari 3000 mahasiswa (Tabel 16.1).

Tabel 16.1

\begin{tabular}{ccccc}
\hline & \multicolumn{3}{c}{ Hobi } & \\
\cline { 2 - 4 } Jenis Kelamin & Membaca & Memasak & Olahraga & Total \\
\hline Laki-Laki & 100 & 300 & 900 & 1300 \\
Perempuan & 900 & 700 & 100 & 1700 \\
\cline { 2 - 4 } Total & 1000 & 1000 & 1000 & 3000 \\
\hline
\end{tabular}

Tabel 16.1 merupakan tabel kontingensi (contingency table) berukuran $2 \times 3$. Tabel kontingensi tersebut memiliki 2 baris dan 3 kolom. Berdasarkan Tabel 16.1, dari 1300 mahasiswa laki-laki, 100 mahasiswa hobi membaca, 300 mahasiswa hobi memasak, dan 900 mahasiswa hobi olah raga. Dari 1700 mahasiswa perempuan, 900 mahasiswa hobi membaca, 700 mahasiswa hobi memasak, dan 100 mahasiswa hobi olahraga. Berdasarkan Tabel 16.1 terlihat bahwa mahasiswa dengan jenis kelamin laki-laki cenderung lebih menyukai olahraga dibandingkan membaca dan memasak. Perhatikan bahwa total untuk baris-baris pada variabel jenis kelamin, yakni $(1300,1700)$ disebut distribusi marjinal sampel untuk jenis kelamin, sedangkan total untuk kolom-kolom pada variabel hobi, yakni $(1000,1000,1000)$ disebut distribusi marjinal sampel untuk hobi.

Untuk mempelajari bagaimana hobi bergantung (depend on) terhadap jenis kelamin, maka terlebih dahulu frekuensi yang disajikan pada Tabel 16.1 dikonversi dalam bentuk persentase (percentage) dalam setiap baris (within each row). Perhatikan Tabel 16.2.

Tabel 16.2

\begin{tabular}{cccccc}
\hline & \multicolumn{4}{c}{ Hobi } & \\
\cline { 2 - 4 } Jenis Kelamin & Membaca & Memasak & Olahraga & Total & $n$ \\
\hline Laki-Laki & $7.692308 \%$ & $23.07692 \%$ & $69.23077 \%$ & $100 \%$ & 1300 \\
Perempuan & $52.94118 \%$ & $41.17647 \%$ & $5.882353 \%$ & $100 \%$ & 1700 \\
\hline
\end{tabular}

Berdasarkan Tabel 16.2, 7,692308\% dari mahasiswa laki-laki hobi membaca. Dengan kata lain, dari 1300 mahasiswa laki-laki, sebanyak 100 mahasiswa hobi membaca.

$$
\frac{100}{1300} \times 100 \%=7,692308 \% \text {. }
$$

Dua himpunan dari persentase untuk laki-laki, yakni $(7,692308 ; 23,07692 ; 69,23077)$ dan perempuan, yakni $(52,94118 ; 41,17647 ; 5,882353)$ disebut distribusi-distribusi bersyarat pada hobi (conditional distributions on hobby). Distribusi-distribusi tersebut merupakan distribusi 
data sampel dari hobi, bergantung pada (conditional on) jenis kelamin. Distribusi bersyarat perempuan pada hobi merupakan himpunan dari persentase $(52,94118 ; 41,17647 ; 5,882353)$ untuk (membaca, memasak, dan olahraga). Dengan cara yang sama, dapat juga dibuat distribusi-distribusi bersyarat pada jenis kelamin, untuk masing-masing hobi. Perhatikan Tabel 16.3.

Tabel 16.3

\begin{tabular}{cccc}
\hline & \multicolumn{3}{c}{ Hobi } \\
\cline { 2 - 4 } Jenis Kelamin & Membaca & Memasak & Olahraga \\
\hline Laki-Laki & $10 \%$ & $30 \%$ & $90 \%$ \\
Perempuan & $90 \%$ & $70 \%$ & $10 \%$ \\
Total & $100 \%$ & $100 \%$ & $100 \%$ \\
\hline$n$ & 1000 & 1000 & 1000 \\
\hline
\end{tabular}

Berdasarkan Tabel 16.3, 10\% dari mahasiswa yang hobi membaca adalah mahasiswa lakilaki. Dengan kata lain, dari 1000 mahasiswa yang hobi membaca, terdapat 100 mahasiswa laki-laki.

$$
\frac{100}{1000} \times 100 \%=10 \% \text {. }
$$

Dalam prakteknya, dapat dibentuk distribusi bersyarat untuk variabel tak bebas, dalam kategori-kategori dari variabel bebas. Dalam hal ini, hobi sebagai variabel tak bebas. Jadi, pada Tabel 16.2 menyajikan persentase dalam baris, yang menerangkan persentase dari (membaca, memasak, dan olahraga) untuk setiap jenis kelamin (variabel bebas).

\section{Uji Chi Kuadrat Pearson (Pearson's Chi-Square Test) dan Contoh Perhitungan}

Uji chi-kuadrat Pearson dapat digunakan untuk menguji apakah terdapat hubungan yang signifikan secara statistika di antara dua variabel kategori. Pada uji chi-kuadrat Pearson membandingkan antara frekuensi pengamatan (observed frequency) yang tersaji dalam tabel kontingensi dengan nilai-nilai yang memenuhi hipotesis nol mengenai independensi (independence).

Tabel 16.4

\begin{tabular}{ccccc}
\hline & \multicolumn{3}{c}{ Hobi } & \\
\cline { 2 - 4 } Jenis Kelamin & Membaca & Memasak & Olahraga & Total \\
\hline Perempuan & $573(522,9)$ & $516(540,4)$ & $422(447,7)$ & 1511 \\
Laki-Laki & $386(436,1)$ & $475(450,6)$ & $399(373,3)$ & 1260 \\
\cline { 2 - 4 } Total & 959 & 991 & 821 & 2771 \\
\hline
\end{tabular}

Berdasarkan Tabel 16.4, perhatikan bahwa nilai yang tidak diberi tanda kurung disebut frekuensi pengamatan (observed frequency), sedangkan nilai yang diberi tanda kurung disebut frekuensi harapan (expected frequency), di mana nilai-nilai tersebut merupakan nilai-nilai hipotesis nol. Perhatikan bahwa setiap nilai dari hipotesis nol memiliki total baris dan total kolom yang sama sebagaimana juga pada frekuensi pengamatan. 


$$
\begin{gathered}
522,9+540,4+447,7=1511 \\
436,1+450,6+373,3=1260 \\
522,9+436,1=959 \\
540,4+450,6=991 \\
447,7+373,3=821 .
\end{gathered}
$$

Misalkan $f_{o}$ (observed frequency) menotasikan frekuensi pengamatan, sedangkan $f_{e}$ (expected frequency) menotasikan frekuensi harapan. Frekuensi harapan dalam suatu cell dihitung dengan mengalikan total suatu baris dan total suatu kolom pada cell tersebut dan kemudian dibagi dengan jumlah elemen sampel seluruhnya (dalam Tabel 16.4, jumlah elemen dalam sampel seluruhnya sebanyak 2771).

Perhatikan bahwa pada cell bagian paling atas-kiri menyatakan mahasiswa perempuan yang hobi membaca dengan frekuensi pengamatan $f_{o}=573$, sedangkan frekuensi harapannya adalah

$$
f_{e}=\frac{(1511)(959)}{(2771)}=522,9
$$

Perhatikan bahwa nilai 522,9 diperoleh dengan cara mengalikan total baris dan total kolom dari cell mahasiswa perempuan dengan hobi membaca, dan kemudian dibagi dengan jumlah elemen sampel seluruhnya. Dalam jumlah elemen sampel seluruhnya (in the entire sample), 959 dari 2771 mahasiswa (34,6\%) masuk ke dalam kelompok mahasiswa yang hobi membaca. Jika variabel jenis kelamin dan hobi saling bebas atau tidak berhubungan (independent), maka diharapkan 34,6\% (522,9) dari laki-laki dan 34,6\% (436) dari perempuan masuk ke dalam mahasiswa yang hobi membaca (perhatikan bahwa persentasenya sama, bukan jumlah subjeknya yang sama!!). Sebagai contoh, 34,6\% mahasiswa perempuan diharapkan termasuk ke dalam mahasiswa yang hobi membaca. Frekuensi harapan untuk cell tersebut adalah

$$
f_{e}=\left(\frac{959}{2771}\right) \times 1511=(0,346)(1511)=522,9,
$$

sedangkan 34,6\% mahasiswa laki-laki diharapkan termasuk ke dalam mahasiswa yang hobi membaca. Maka frekuensi harapan untuk cell tersebut adalah

$$
f_{e}=\left(\frac{959}{2771}\right) \times 1260=(0,346)(1260)=436,1
$$

Nilai statistik dari uji chi-kuadrat Pearson dinotasikan dengan lambang $\chi^{2}$, dihitung dengan rumus

$$
\chi^{2}=\sum \frac{\left(f_{o}-f_{e}\right)^{2}}{f_{e}}
$$

Penjumalahan dilakukan untuk seluruh cell dalam tabel kontingensi. Untuk setiap cell, dikuadratkan (squared) hasil dari selisih antara frekuensi pengamatan dengan frekuensi harapan, dan kemudian dibagi dengan frekuensi harapan. Uji chi-kuadrat Pearson diperkenalkan oleh seorang statistikawan Inggris, yakni Karl Pearson sekitar tahun 1900. 
Ketika $H_{0}$ diterima/benar, $f_{o}$ dan $f_{e}$ cenderung dekat untuk setiap cell, dan $\chi^{2}$ (berdasarkan perhitungan) bernilai relatif kecil. Jika $H_{0}$ tidak diterima/salah, paling tidak beberapa dari nilai $f_{o}$ dan $f_{e}$ tidak cenderung dekat, yakni nilai-nilai $\left(f_{o}-f_{e}\right)^{2}$ cenderung besar dan statistik $\chi^{2}$ relatif besar. Semakin besar statistik $\chi^{2}$, semakin kuat bukti dalam hal menolak $H_{0}$. Dengan mensubstitusikan $f_{o}$ dan $f_{e}$ ke dalam rumus $\chi^{2}$ (data Tabel 16.4), diperoleh

$$
\begin{gathered}
\chi^{2}=\sum \frac{\left(f_{o}-f_{e}\right)^{2}}{f_{e}} \\
=\frac{(573-522,9)^{2}}{522,9}+\frac{(516-540,4)^{2}}{540,4}+\frac{(422-447,7)^{2}}{447,7}+\frac{(386-436,1)^{2}}{436,1} \\
+\frac{(475-450,6)^{2}}{450,6}+\frac{(399-373,3)^{2}}{373,3} \\
=4,8+\cdots+1,8 \approx 16,2 .
\end{gathered}
$$

Nilai dari 16,2 merupakan nilai statistik dari uji chi-kuadrat Pearson ( $\chi^{2}$ berdasarkan perhitungan). Untuk menentukan apakah hipotesis nol ditolak atau diterima, terlebih dahulu dihitung nilai kritis chi-kuadrat berdasarkan tabel distribusi chi-kuadrat. Untuk menentukan nilai kritis chi-kuadrat, terlebih dahulu menghitung derajat bebas (degree of freedom). Derajat bebas dihitung dengan rumus

$$
d f=(r-1)(c-1),
$$

di mana $r$ dan $c$ masing-masing menyatakan jumlah baris dan kolom dalam tabel kontingensi. Untuk tabel kontingensi dengan ukuran $2 \times 3, r=2$ dan $c=3$, maka diperoleh $d f=$ $(2-1)(3-1)=2$. Jumlah baris dan kolom yang semakin banyak, menghasilkan nilai $d f$ yang semakin besar. Berikut disajikan tabel distribusi chi-kuadrat.

\section{Tabel 16.5}

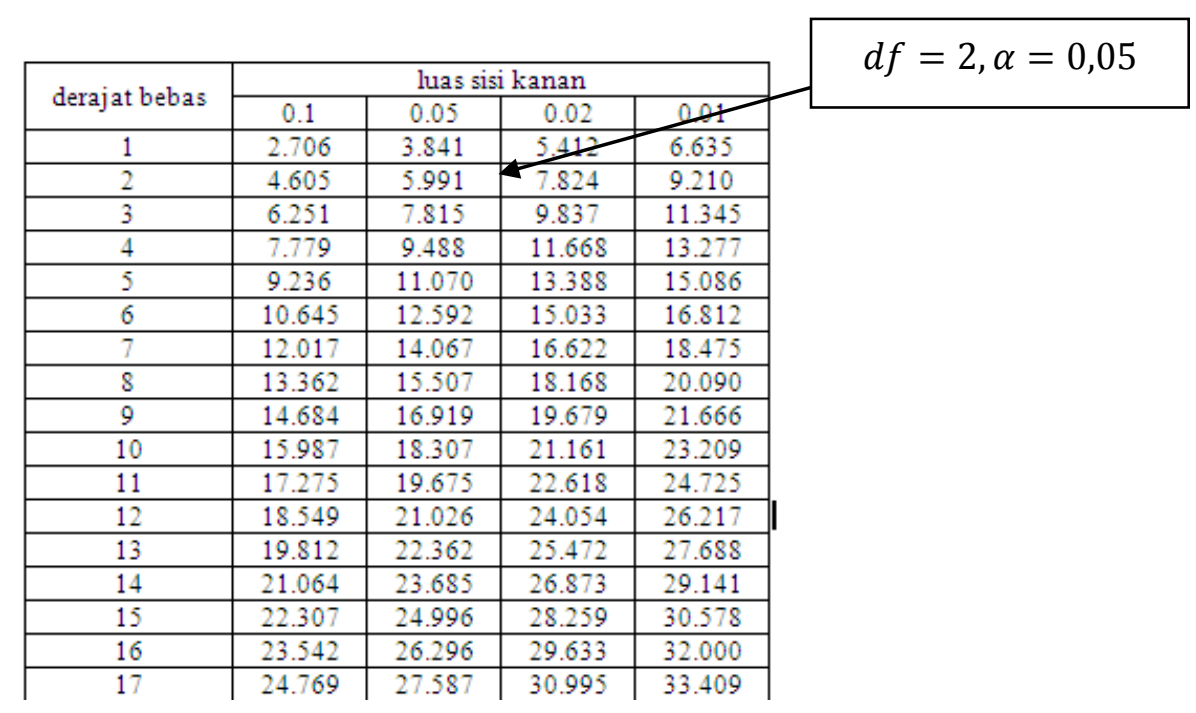

Berdasarkan Tabel 16.5, nilai kritis chi-kuadrat dengan derajat bebas 2 dan tingkat signifikansi $\alpha=0,05$ adalah 5,991. 
Terima $H_{0}$ ketika $\chi^{2}$ hitung $\leq$ nilai kritis $\chi^{2}$. Perhatikan bahwa nilai kritis $\chi^{2}$ diperoleh berdasarkan tabel distribusi chikuadrat.

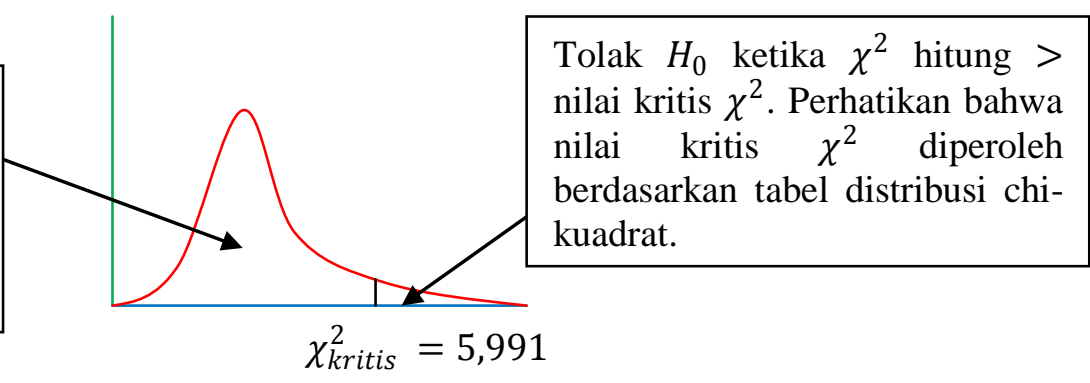

Gambar 16.1

Berikut disajikan perumusan hipotesis.

$H_{0}$ : Jenis kelamin dan hobi signifikan secara statistika tidak berhubungan (statistically independent). Dengan kata lain tidak terdapat hubungan yang signifikan secara statistika jenis kelamin terhadap hobi.

$H_{0}$ : Jenis kelamin dan hobi signifikan secara statistika berhubungan (statistically dependent). Dengan kata lain terdapat hubungan yang signifikan secara statistika jenis kelamin terhadap hobi.

Diketahui nilai $\chi^{2}$ hitung adalah 16,2. Karena nilai $\chi^{2}$ hitung, yakni 16,2 lebih besar dibandingkan nilai kritis $\chi^{2}$, yakni 5,991, maka hipotesis nol ditolak, dan hipotesis alternatif diterima. Hal ini berarti terdapat hubungan yang signifikan (dalam populasi) secara statistika jenis kelamin terhadap pemilihan hobi, pada tingkat signifikansi $5 \%$.

\section{Uji Eksak Fisher (Fisher's Exact Test)}

Terdapat suatu permasalahan yang timbul pada uji chi-kuadrat, yang mana distribusi sampling dari statistik suatu uji (test statistic) memiliki suatu pendekatan distribusi chi-kuadrat. Semakin besar ukuran suatu sampel, maka akan semakin baik pendekatan tersebut. Dalam ukuran sampel yang kecil, pendekatan distribusi chi-kuadrat menjadi tidak cukup baik, yakni membuat uji signifikansi dari distribusi chi-kuadrat tidak akurat (Field, 2009:690).

\section{Tabel 16.6}

\begin{tabular}{|c|c|c|c|c|c|c|}
\hline \multicolumn{6}{|c|}{ Chi-Square Tests } & \multirow{9}{*}{$\begin{array}{c}\text { Huruf “a” } \\
\text { menunjukkan bahwa } \\
\text { tidak terdapat cell } \\
\text { yang memiliki nilai } \\
\text { frekuensi harapan < } 5 \\
\text { pada tabel kontingensi } \\
\text { dalam perhitungan } \\
\text { nilai statistik dari uji } \\
\text { Pearson Chi-Square. }\end{array}$} \\
\hline & Value & $\mathrm{df}$ & $\begin{array}{l}\text { Asymp. Sig. } \\
\text { (2-sided) }\end{array}$ & $\begin{array}{l}\text { Exact Sig. (2- } \\
\text { sided) }\end{array}$ & Exa & \\
\hline Pearson Chi-Square & $10.989^{\mathrm{a}}$ & & $\frac{01}{0101}$ & \multirow{6}{*}{.002} & & \\
\hline Continuity Correction & 8.901 & 1 & .003 & & & \\
\hline Likelihood Ratio & 11.872 & 1 & 001 & & & \\
\hline Fisher's Exact Test & & & \multirow{3}{*}{001} & & & \\
\hline $\begin{array}{l}\text { Linear-by-Linear } \\
\text { Association }\end{array}$ & 10.714 & & & & & \\
\hline N of Valid Cases & 40 & & & & & \\
\hline $\begin{array}{l}\text { a. } \\
\text { b. Computed only fo }\end{array}$ & d cou & & & & & \\
\hline
\end{tabular}

Berdasarkan output SPSS Tabel 16.6 dan Tabel 16.7, dapat dilihat bahwa pada penggunaan uji chi-kuadrat Pearson, frekuensi harapan (expected frequency) untuk setiap cell harus lebih besar dari 5. Field (2009:690) menyatakan ketika frekuensi harapan (expected frequency) lebih besar dari 5 untuk setiap cell pada tabel kontingensi, distribusi sampling akan mendekati 
distribusi chi-kuadrat. Apabila frekuensi harapan sangat kecil, dengan kata lain jumlah sampel relatif sangat sedikit, hal tersebut mengakibatkan distribusi sampling statistik dari suatu uji (chi-kuadrat Pearson) akan menyimpang dari distribusi chi-kuadrat. Hal tersebut membuat uji signifikansi dari distribusi chi kuadrat tidak akurat.

\section{Tabel 16.7}

\begin{tabular}{|c|c|c|c|c|c|c|}
\hline \multicolumn{6}{|c|}{ Chi-Square Tests } & \multirow{9}{*}{$\begin{array}{c}\text { Huruf "a" } \\
\text { menunjukkan bahwa } \\
\text { terdapat satu cell yang } \\
\text { memiliki nilai } \\
\text { frekuensi harapan }<5 \\
\text { pada tabel kontingensi } \\
\text { dalam perhitungan } \\
\text { nilai statistik dari uji } \\
\text { Pearson Chi-Square. }\end{array}$} \\
\hline & Value & df & $\frac{\text { Asymp. Sig }}{(z-\text { sided })}$ & $\begin{array}{l}\text { Exact sig. (2- } \\
\text { sided) }\end{array}$ & $\begin{array}{r}\text { Exact Sif } \\
\text { sided }\end{array}$ & \\
\hline Pearson Chi-Square & $31.837^{\mathrm{a}}$ & 1 & .000 & \multirow{6}{*}{\multicolumn{2}{|c|}{ Solued }} & \\
\hline Continuity Correction ${ }^{b}$ & 27.886 & 1 & .000 & & & \\
\hline Likelihood Ratio & 37.386 & 1 & .000 & & & \\
\hline Fisher's Exact Test & & & & & & \\
\hline $\begin{array}{l}\text { Linear-by-Linear } \\
\text { Association }\end{array}$ & 31.041 & 1 & .000 & & & \\
\hline$N$ of Valid Cases & 40 & & & & & \\
\hline \multicolumn{6}{|c|}{$\begin{array}{l}\text { a. } 1 \text { cells }(25.0 \%) \text { have expected count less than } 5 \text {. The minimum expected count is } 4.20 \text {. } \\
\text { b. Computed only for a } 2 \times 2 \text { table }\end{array}$} & \\
\hline
\end{tabular}

Senada dengan Field, Agresti dan Finlay (2009:227) menyatakan sebagai berikut.

"The chi-squared distribution is the sampling distribution of the $\chi^{2}$ test statistic only if the sample size is large. A rough guideline for this requirement is that the expected frequency $f_{e}$ should exceed 5 in each cell. Otherwise, the chi-squared distribution may be poorly approximately the actual distribution of the $\chi^{2}$ statistic".

Terdapat alternatif lain sebagai pengganti uji chi-kuadrat Pearson, yakni uji eksak Fisher (Fisher's exact test). Uji eksak Fisher akurat digunakan ketika ukuran sampel relatif kecil. Field (2009:690) menyatakan sebagai berikut.

"Fisher came up with a method for computing the exact probability of the chi-square statistic that is accurate when sample sizes are small. This method is called Fisher's exact test. This procedure is normally used on $2 \times 2$ contingency tables and with small samples. However, it can be used on larger contingency tables and with large samples, but on larger contingency tables it becomes computationally intensive and you might find SPSS taking a long time to give you an answer".

Pada Tabel 16.6 dan Tabel 16.7 tersaji nilai statistik dari uji eksak Fisher (Fisher's Exact Test).

\section{Uji Likelihood Ratio dan Contoh Perhitungan}

Alternatif lain dari uji chi-kuadrat Pearson adalah uji Likelihood Ratio. Berikut rumus untuk menghitung statistik dari uji Likelihood Ratio.

$$
L_{\chi^{2}}=2 \sum f_{o_{i j}} \ln \left(\frac{f_{o_{i j}}}{f_{e_{i j}}}\right)
$$

Perhatikan bahwa $f_{o_{i j}}$ merupakan frekuensi pengamatan pada baris ke- $i$ dan kolom ke- $j$ (dalam tabel kontingensi), sedangkan $f_{e_{i j}}$ merupakan frekuensi harapan pada baris ke- $i$ dan kolom ke-j. Sebagaimana pada uji chi-kuadrat Pearson, untuk menentukan apakah hipotesis nol diterima atau ditolak pada uji Likelihood Ratio, nilai statistik dari uji Likelihood Ratio 
dibandingkan terhadap nilai kritis berdasarkan tabel distribusi chi-kuadrat. Jika nilai statistik dari uji Likelihood Ratio $\leq$ nilai kritis berdasarkan tabel distribusi chi-kuadrat, maka hipotesis nol diterima dan hipotesis alternatif ditolak. Jika nilai statistik dari uji Likelihood Ratio > nilai kritis berdasarkan tabel distribusi chi-kuadrat, maka hipotesis nol ditolak dan hipotesis alternatif diterima. Berdasarkan data pada Tabel 16.4, berikut akan dihitung nilai statistik dari uji Likelihood Ratio.

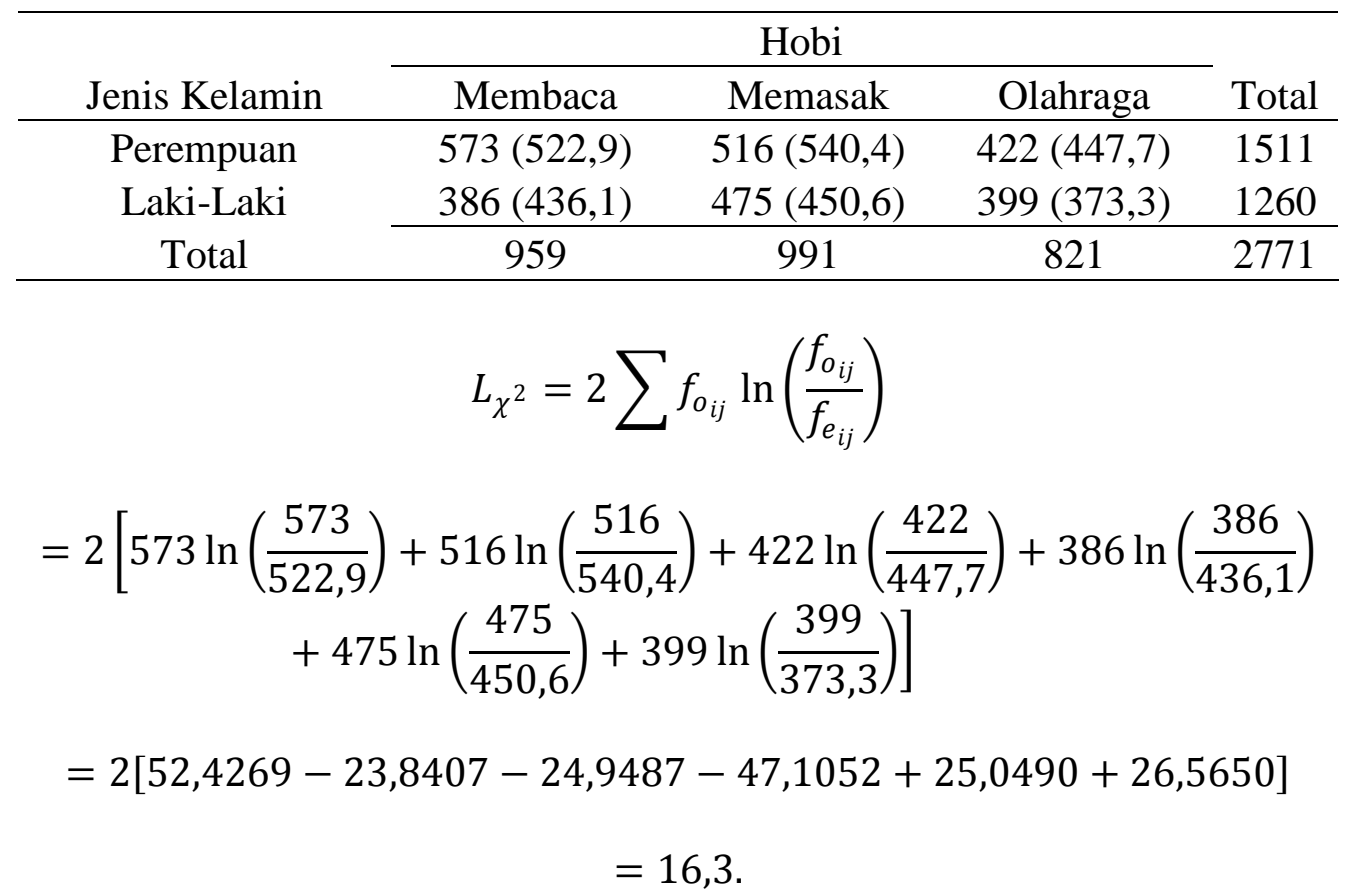

Berikut diberikan output SPSS yang menyajikan nilai statistik dari uji Likelihood Ratio. Field (2009:691) menyatakan nilai statistik dari uji Likelihood Ratio akan mendekati (will be roughly) nilai statistik dari uji chi-kuadrat Pearson, namun demikian uji Likelihood Ratio lebih disukai (is preferred) ketika ukuran sampel kecil.

\section{Tabel 16.8}

\begin{tabular}{|c|c|c|c|c|}
\hline \multicolumn{4}{|c|}{ Chi-Square Tests } & \multirow{3}{*}{$\begin{array}{l}\text { Berdasarkan perhitungan } \\
\text { SPSS, nilai } L_{\chi^{2}}=16,273 \text {. }\end{array}$} \\
\hline & Value & df & $\underset{(2-\text { sid }}{\text { Asymp }}$ & \\
\hline Pearson Chi-Square & $16.202^{\mathrm{a}}$ & 2 & & \\
\hline Likelihood Ratio & 16.273 & 2 & & .000 \\
\hline $\begin{array}{l}\text { Linear-by-Linear } \\
\text { Association }\end{array}$ & 13.047 & 1 & & .000 \\
\hline$N$ of Valid Cases & 2771 & & & \\
\hline
\end{tabular}




\section{PENYELESAIAN DALAM SPSS}

Andaikan seorang peneliti bernama Ugi ingin meneliti ada tidaknya hubungan (association) antara jenis kelamin terhadap pemilihan hobi. Misalkan untuk variabel hobi terdiri dari tiga kategori, yakni membaca, memasak, dan olahraga. Andaikan penelitian dilakukan pada siswa di sekolah XYZ. Berikut data yang telah dikumpulkan.

Tabel 16.1 (Data Fiktif)

\begin{tabular}{ccccc}
\hline & \multicolumn{3}{c}{ Hobi } & \\
\cline { 2 - 4 } Jenis Kelamin & Membaca & Memasak & Olahraga & Total \\
\hline Perempuan & 573 & 516 & 422 & 1511 \\
Laki-Laki & 386 & 475 & 399 & 1260 \\
\cline { 2 - 4 } Total & 959 & 991 & 821 & 2771 \\
\hline
\end{tabular}

Berdasarkan Tabel 16.1, jumlah siswa yang diteliti 2771, yang terdiri dari 1511 perempuan dan 1260 laki-laki. Jumlah siswa perempuan yang diteliti 1511, 573 di antaranya hobi membaca, 516 hobi memasak, dan 422 hobi olahraga. Bangun data pada Tabel 16.1 dalam SPSS sebagai berikut (Gambar 16.1).

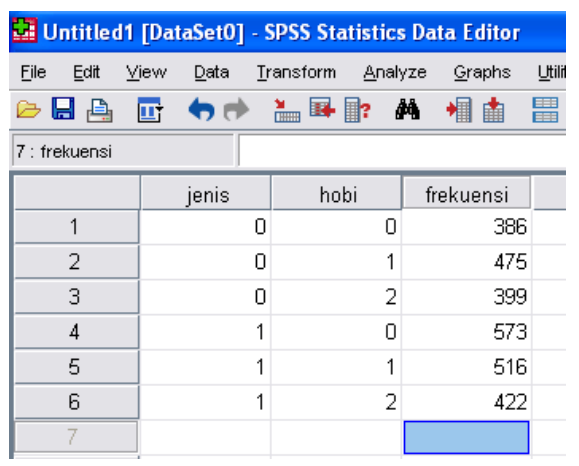

\begin{tabular}{|c|c|c|c|c|c|}
\hline \multicolumn{6}{|c|}{ F Untitled1 [DataSet0] - SPSS Statistics Data Editor } \\
\hline File Edit & liew & Data Ir & ransform Analyz & ze Graphs & Untilities \\
\hline 回回曷 & $\Phi$ & $\phi \boldsymbol{\theta}$ & 盖国国? & 阐丽 & 畫过 \\
\hline \multicolumn{6}{|l|}{7 : trekuensi } \\
\hline & & jenis & hobi & frekuensi & \\
\hline 1 & & laki-laki & membaca & 386 & \\
\hline 2 & & laki-laki & memasak & 475 & \\
\hline 3 & & laki-laki & olah raga & 399 & \\
\hline 4 & & erempuan & membaca & 573 & \\
\hline 5 & & erempuan & memasak & 516 & \\
\hline 6 & & erempuan & olah raga & 422 & \\
\hline 7 & & & & & \\
\hline
\end{tabular}

\section{Gambar 16.1}

Setelah data pada Tabel 16.1 dibangun dalam SPSS, pilih Data $\Rightarrow$ Weight Cases, sehingga muncul kotak dialog Weight Cases (Gambar 16.2). Pada Gambar 16.2, aktifkan Weight cases by, kemudian masukkan variabel frekuensi ke dalam kotak Frequency Variable dan pilih OK. Selanjutnya pilih Analyze => Descriptive Statistics $\Rightarrow$ Crosstabs, sehingga muncul kotak dialog Crosstabs (Gambar 16.3). Pada Gambar 16.3, masukkan variabel jenis pada kotak Row (s), variabel hobi pada kotak Column(s), dan pilih Statistics, sehingga muncul kotak dialog Crosstabs: Statistics (Gambar 16.4). Pada kotak dialog Crosstabs: Statistics, pilih Chisquare, kemudian pilih Continue. Selanjutnya pilih Cells, sehingga muncul kotak dialog Cell Display (Gambar 16.5). Pada kotak dialog Cells Display, pilih Observed dan Expected pada Counts. Kemudian pilih Row, Column, dan Total pada Percentages. Kemudian pilih Continue dan OK. 


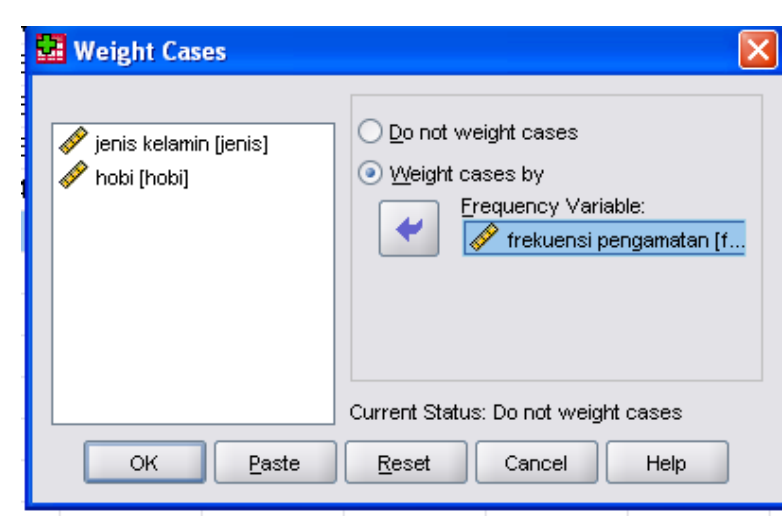

Gambar 16.2

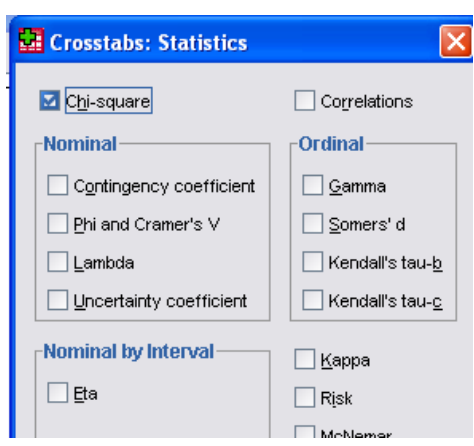

Gambar 16.4

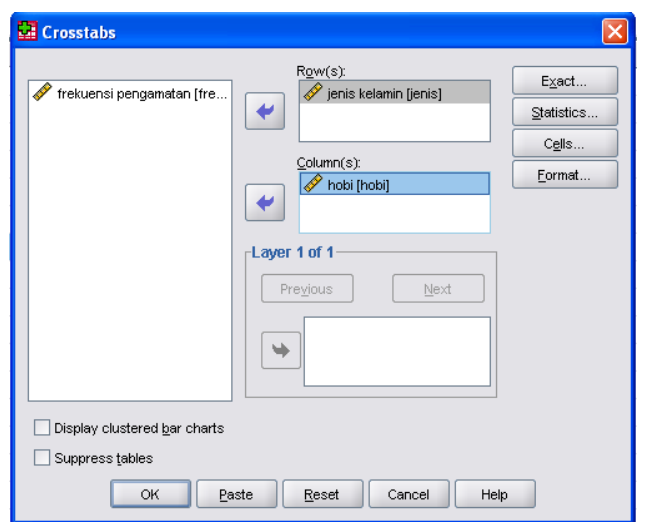

Gambar 16.3

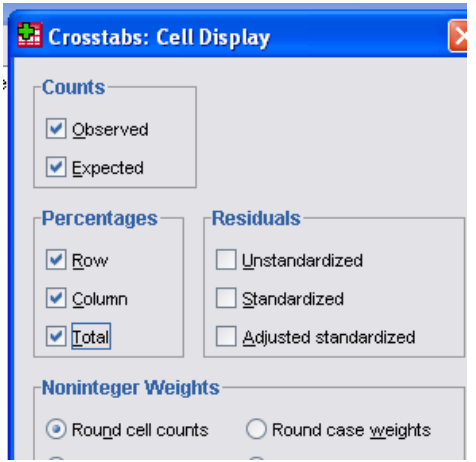

Gambar 16.5

Berikut hasil berdasarkan SPSS.

Tabel 16.2

\begin{tabular}{|l|c|c|r|r|r|r|}
\hline \multirow{2}{*}{ Case Processing Summary } \\
\cline { 2 - 8 } & \multicolumn{9}{|c|}{ Valid } & \multicolumn{2}{c|}{ Cases } \\
\cline { 2 - 8 } & $\mathrm{N}$ & Percent & $\mathrm{N}$ & Percent & $\mathrm{N}$ & Percent \\
\hline jenis kelamin * hobi & 2771 & $100.0 \%$ & 0 & $0 \%$ & 2771 & $100.0 \%$ \\
\hline
\end{tabular}

Berdasarkan Tabel 16.2, yakni Case Processing Summary, diketahui jumlah responden yang diteliti (kolom Total) sebanyak $N=2771$ siswa. Pada kolom Missing, $N=0$ berarti tidak terdapat data yang tidak diproses. Dengan kata lain, seluruh data diproses. Berdasarkan Tabel 16.3, yakni jenis kelamin * hobi Crosstabulation, dapat ditarik informasi sebagai berikut.

$\Rightarrow$ Dari 1260 siswa laki-laki, 386 siswa hobi membaca, 475 siswa hobi memasak, dan 399 siswa hobi olahraga (frekuensi pengamatan).

$\Rightarrow$ Dari 1551 siswa perempuan, 573 siswa hobi membaca, 516 siswa hobi memasak, dan 422 siswa hobi olahraga (frekuensi pengamatan).

$\Rightarrow$ Dari 2771 siswa, 959 siswa hobi membaca, 991 siswa hobi memasak, dan 821 siswa hobi olahraga. 
Tabel 16.3

\begin{tabular}{|c|c|c|c|c|c|c|}
\hline & & & \multicolumn{3}{|c|}{ hobi } & \multirow[b]{2}{*}{ Total } \\
\hline & & & membaca & memasak & olah raga & \\
\hline \multirow[t]{10}{*}{ jenis kelamin } & laki-laki & Count & 386 & 475 & 399 & 1260 \\
\hline & & Expected Count & 436.1 & 450.6 & 373.3 & 1260.0 \\
\hline & & $\%$ within jenis kelamin & $30.6 \%$ & $37.7 \%$ & $31.7 \%$ & $100.0 \%$ \\
\hline & & $\%$ within hobi & $40.3 \%$ & $47.9 \%$ & $48.6 \%$ & $45.5 \%$ \\
\hline & & $\%$ of Total & $13.9 \%$ & $17.1 \%$ & $14.4 \%$ & $45.5 \%$ \\
\hline & perempuan & Count & 573 & 516 & 422 & 1511 \\
\hline & & Expected Count & 522.9 & 540.4 & 447.7 & 1511.0 \\
\hline & & $\%$ within jenis kelamin & $37.9 \%$ & $34.1 \%$ & $27.9 \%$ & $100.0 \%$ \\
\hline & & $\%$ within hobi & $59.7 \%$ & $52.1 \%$ & $51.4 \%$ & $54.5 \%$ \\
\hline & & $\%$ of Total & $20.7 \%$ & $18.6 \%$ & $15.2 \%$ & $54.5 \%$ \\
\hline \multirow{5}{*}{\multicolumn{2}{|c|}{ Total }} & Count & 959 & 991 & 821 & 2771 \\
\hline & & Expected Count & 959.0 & 991.0 & 821.0 & 2771.0 \\
\hline & & $\%$ within jenis kelamin & $34.6 \%$ & $35.8 \%$ & $29.6 \%$ & $100.0 \%$ \\
\hline & & $\%$ within hobi & $100.0 \%$ & $100.0 \%$ & $100.0 \%$ & $100.0 \%$ \\
\hline & & $\%$ of Total & $34.6 \%$ & $35.8 \%$ & $29.6 \%$ & $100.0 \%$ \\
\hline
\end{tabular}

Tabel 16.4

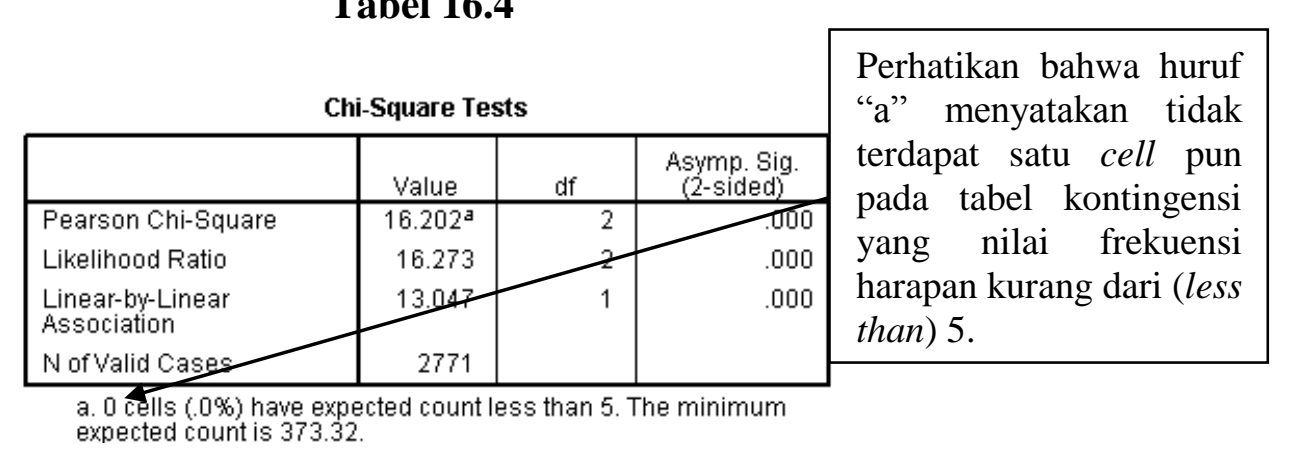

Berdasarkan Tabel 16.4, yakni Chi-Square Tests, akan ditentukan ada tidak hubungan yang signifikan secara statistika antara variabel jenis kelamin terhadap hobi. Namun sebelumnya perhatikan bahwa tidak terdapat satu cell pun pada tabel kontingensi yang nilai frekuensi harapan kurang dari (less than) 5, sehingga akan digunakan pendekatan uji chi-kuadrat Pearson (Pearson Chi-Square). Perhatikan bahwa diketahui nilai statistik dari uji chi-kuadrat Pearson adalah 16,202 ( $\chi^{2}$ hitung). Nilai kritis chi-kuadrat dengan derajat bebas $(d f) 2$ pada tingkat signifikansi 5\% adalah 5,991.

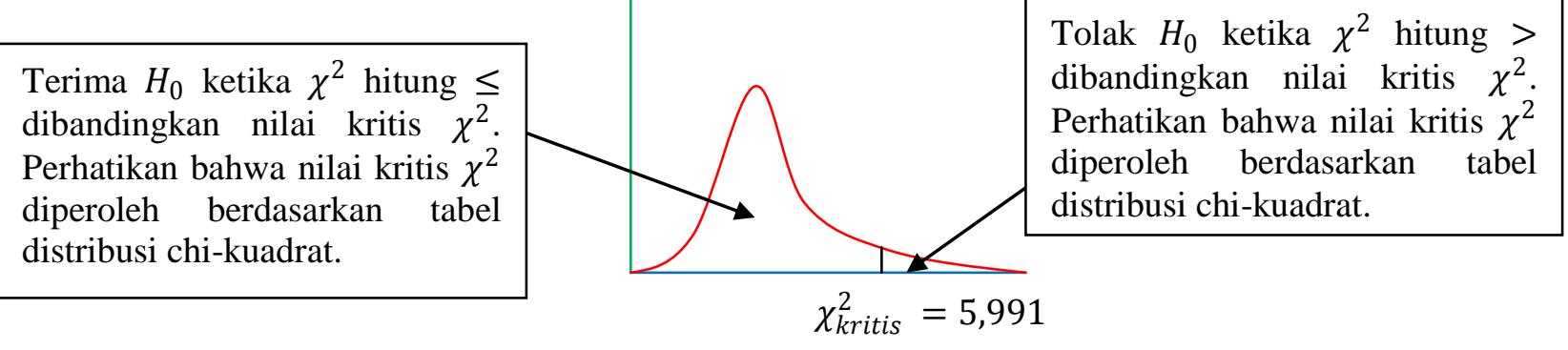

Gambar 16.1

Berikut disajikan perumusan hipotesis.

$H_{0}$ : Jenis kelamin dan hobi secara signifikan statistik tidak berhubungan (statistically independent). Dengan kata lain tidak terdapat hubungan yang signifikan secara statistika jenis kelamin terhadap hobi. 
$H_{0}$ : Jenis kelamin dan hobi signifikan secara statistika berhubungan (statistically dependent). Dengan kata lain terdapat hubungan yang signifikan secara statistika jenis kelamin terhadap hobi.

Diketahui nilai $\chi^{2}$ hitung adalah 16,202. Karena nilai $\chi^{2}$ hitung, yakni 16,2 lebih besar dibandingkan nilai kritis $\chi^{2}$, yakni 5,991, maka hipotesis nol ditolak, dan hipotesis alternatif diterima. Hal ini berarti terdapat hubungan yang signifikan (dalam populasi) secara statistika jenis kelamin terhadap pemilihan hobi, pada tingkat signifikansi $5 \%$.

\section{Referensí}

1. Agresti, A. dan B. Finlay. 2009. Statistical Methods for the Social Sciences, $4^{\text {th }}$ Edition. United States of America: Prentice Hall.

2. Field, A. 2009. Discovering Statistics Using SPSS, $3^{\text {rd }}$ Edition. London: Sage.

3. Gamst, G., L.S. Meyers, dan A.J. Guarino. 2008. Analysis of Variance Designs, Computational Approach with SPSS and SAS. Cambridge: Cambridge University Press.

4. Gio, P.U. 2013. Aplikasi Statistika dalam SPSS. Medan: USUpress.

5. Mann, P. S. dan C.J. Lacke. 2011. Introductory Statistics, International Student Version, $7^{\text {th }}$ Edition. Asia: John Wiley \& Sons, Inc.

6. Montgomery, D.C. dan G.C. Runger. 2011. Applied Statistics and Probability for Engineers, $5^{\text {th }}$ Edition. United States of America: John Wiley \& Sons, Inc.

7. Smidth, R. K. dan D. H. Sanders. 2000. Statistics a First Course, $6^{\text {th }}$ Edition. United States of America: McGraw-Hill Companies. 


\section{BAB 17}

\section{ANALISIS VARIANS MULTIVARIAT (MANOVA)}

\section{Sekílas $\mathcal{M} \mathcal{A} \mathcal{N O}$ VA}

Pada bab sebelumnya telah dibahas mengenai analisis varians atau analysis of variance (ANOVA). Multivariate analysis of variance (MANOVA) merupakan perluasan dari ANOVA. Dalam ANOVA hanya terbatas pada penggunaan satu variabel tak bebas yang bersifat metrik (interval atau rasio), sedangkan pada MANOVA dapat melibatkan dua atau lebih variabel tak bebas yang bersifat metrik. Hair dkk. (2010:341) menyatakan sebagai berikut.

"Multivariate analysis of variance (MANOVA) is an extension of analysis of variance (ANOVA) to accommodate more than one dependent variable. It is a dependence technique that measures the differences for two or more metric dependent variables based on a set of categorical (nonmetric) variables acting as independent variables. ANOVA dan MANOVA can be stated in the following general forms:

$$
\begin{aligned}
& \text { Analysis of Variance } \\
& \begin{array}{cc}
Y_{1} & =X_{1}+X_{2}+X_{3}+\cdots+X_{n} \\
\text { metric } & \text { nonmetric }
\end{array} \\
& \text { Multivariate Analysis of Variance } \\
& Y_{1}+Y_{2}+Y_{3}+\cdots+Y_{6}=X_{1}+X_{2}+X_{3}+\cdots+X_{n} \\
& \text { metric nonmetric". }
\end{aligned}
$$

MANOVA menguji ada tidaknya perbedaan rata-rata dari dua atau lebih variabel tak bebas secara simultan (simultaneously) berdasarkan kelompok-kelompok pada variabel bebas. Perlu diperhatikan bahwa pada MANOVA, variabel bebas (independent variable) bersifat non-metrik (terdiri dari beberapa kelompok/kategori), sedangkan variabel bebas bersifat metrik (interval atau rasio). Field (2009:585) menyatakan sebagai berikut.

"ANOVA can be used only in situations in which there is one dependent variable (or outcome) and so is known as a univariate test (univariate quite obviously means 'one variable'); MANOVA is designed to look at several dependent variables (outcomes) simultaneously and so is a multivariate test (multivariate means 'many variables')'”.

Sebagai contoh kasus pada ANOVA, ingin diuji apakah penerapan metode mengajar yang berbeda-beda berpengaruh pada nilai ujian matematika siswa. Perhatikan contoh data berikut.

Berdasarkan data pada Tabel 17.1, dari 36 siswa, 12 siswa diterapkan metode mengajar A, 12 siswa berikutnya diterapkan metode mengajar B, dan siswa lainnya diterapkan metode mengajar $\mathrm{C}$. Perhatikan bahwa metode mengajar merupakan variabel bebas yang terdiri dari tiga kategori, yakni metode $\mathrm{A}, \mathrm{B}$, dan $\mathrm{C}$, sedangkan nilai ujian matematika siswa merupakan variabel tak bebas. Berdasarkan data pada Tabel 17.1, ANOVA dapat digunakan untuk menguji apakah terdapat perbedaan rata-rata nilai ujian matematika berdasarkan kategorikategori pada variabel bebas. 
Tabel 17.1

\begin{tabular}{|c|c|c|c|c|c|}
\hline \multicolumn{2}{|c|}{ Metode A } & \multicolumn{2}{c|}{ Metode B } & \multicolumn{2}{c|}{ Metode C } \\
\hline Siswa Ke & Nilai Matematika & Siswa Ke & Nilai Matematika & Siswa Ke & Nilai Matematika \\
\hline 1 & 60 & 13 & 61 & 25 & 60 \\
\hline 2 & 61 & 14 & 61 & 26 & 61 \\
\hline 3 & 62 & 15 & 62 & 27 & 62 \\
\hline 4 & 63 & 16 & 63 & 28 & 63 \\
\hline 5 & 64 & 17 & 64 & 29 & 64 \\
\hline 6 & 65 & 18 & 65 & 30 & 65 \\
\hline 7 & 60 & 19 & 60 & 31 & 60 \\
\hline 8 & 61 & 20 & 61 & 32 & 61 \\
\hline 9 & 62 & 22 & 62 & 33 & 63 \\
\hline 10 & 63 & 23 & 63 & 34 & 64 \\
\hline 11 & 64 & 24 & 64 & 35 & 65 \\
\hline 12 & 65 & & 65 & 36 & \\
\hline
\end{tabular}

Contoh kasus sebelumnya pada ANOVA akan dikembangkan menjadi contoh kasus MANOVA. Andaikan ingin diuji apakah penerapan metode mengajar yang berbeda-beda berpengaruh pada nilai ujian matematika dan bahasa inggris siswa secara simultan (simultaneously). Perhatikan contoh data berikut.

Tabel 17.2

\begin{tabular}{|c|c|c|c|c|c|c|}
\hline & \multicolumn{2}{|c|}{ Metode A } & \multicolumn{2}{|c|}{ Metode B } & \multicolumn{2}{|c|}{ Metode C } \\
\hline & Matematika & B. Inggris & Matematika & B. Inggris & Matematika & B. Inggris \\
\hline & 60 & 61 & 61 & 61 & 60 & 67 \\
\hline & 61 & 61 & 61 & 63 & 61 & 68 \\
\hline & 62 & 62 & 62 & 64 & 62 & 69 \\
\hline & 63 & 63 & 63 & 65 & 63 & 70 \\
\hline & 64 & 64 & 64 & 66 & 64 & 71 \\
\hline & 65 & 65 & 65 & 67 & 65 & 72 \\
\hline & 60 & 60 & 60 & 62 & 60 & 67 \\
\hline & 61 & 61 & 61 & 63 & 61 & 68 \\
\hline & 62 & 62 & 62 & 64 & 62 & 69 \\
\hline & 63 & 63 & 63 & 65 & 63 & 70 \\
\hline & 64 & 64 & 64 & 66 & 64 & 71 \\
\hline & 65 & 65 & 65 & 67 & 65 & 72 \\
\hline Rata-Rata & 62.5 & 62.58333333 & 62.5833333 & 64.41666667 & 62.5 & 69.5 \\
\hline
\end{tabular}

Berdasarkan data pada Tabel 17.2, dari 36 siswa, 12 siswa diterapkan metode mengajar A, 12 siswa berikutnya diterapkan metode mengajar B, dan siswa lainnya diterapkan metode mengajar C. Setelah satu bulan kemudian, diadakan ujian matematika dan bahasa inggris dari seluruh siswa tersebut. Perhatikan bahwa metode mengajar merupakan variabel bebas, sedangkan nilai ujian matematika dan bahasa inggris merupakan variabel tak bebas. Dalam contoh kasus ini, jumlah variabel tak bebas sebanyak dua, yakni nilai ujian matematika dan bahasa inggris. Dengan menggunakan MANOVA dapat diuji ada tidaknya pengaruh (effect) 
yang signifikan secara statistika pada penggunaan metode mengajar terhadap nilai ujian matematika dan bahasa inggris secara bersamaan (simultaneously).

Misalkan dalam suatu kasus permasalahan MANOVA melibatkan sebuah variabel bebas yang terdiri dari 3 kelompok, perlakuan atau kategori dan 4 variabel tak bebas. Maka perumusan hipotesis nol sebagai berikut.

$$
H_{0}:\left[\begin{array}{l}
\mu_{11} \\
\mu_{21} \\
\mu_{31} \\
\mu_{41}
\end{array}\right]=\left[\begin{array}{l}
\mu_{12} \\
\mu_{22} \\
\mu_{32} \\
\mu_{42}
\end{array}\right]=\left[\begin{array}{l}
\mu_{13} \\
\mu_{23} \\
\mu_{33} \\
\mu_{43}
\end{array}\right] . \begin{aligned}
& \text { Tiga vektor rata-rata populasi } \\
& \text { dari empasing-masing terdiri }
\end{aligned}
$$

Hipotesis nol pada MANOVA menyatakan vektor rata-rata populasi dari seluruh kelompok (all the group mean vectors) sama. Sedangkan hipotesis alternatif menyatakan paling tidak terdapat sepasang vektor rata-rata populasi yang signifikan berbeda secara statistika. Perhatikan bahwa $\mu_{i k}$ menyatakan rata-rata dari variabel tak bebas ke- $i$, kelompok/perlakuan ke- $k$.

Dalam ANOVA, nilai statistik dari uji $F$ digunakan untuk pengambilan keputusan terhadap hipotesis. Pada MANOVA, terdapat beberapa statistik yang dapat digunakan untuk pengambilan keputusan terhadap hipotesis, antara lain Pillai's Trace, Wilks's Lambda, Hotelling's Trace, dan Roy's Largest Root. Untuk pengambilan keputusan terhadap hipotesis pada MANOVA, Field (2009:614) merekomendasikan untuk menggunakan nilai statistik dari Pillai's Trace.

Hasil penelitian Olson dan Stevens membawa (led) Bray dan Maxwell (1985) untuk menyimpulkan bahwa ketika ukuran-ukuran sampel sama (sample sizes are equal), statistik Pillai's Trace merupakan statistik yang paling tahan/kuat (is most robust) terhadap pelanggaran asumsi-asumsi. Ketika ukuran sampel tidak sampel tidak sama (sizes are unequal), periksa asumsi homogenitas dari matriks-matriks kovarian (homogeneity of covariance matrices) dengan menggunakan uji Box. Jika hasil pengujian tersebut menunjukkan tidak signifikan (asumsi homogenitas dari matriks-matriks kovarian dipenuhi) dan jika asumsi normalitas multivariat dipenuhi, maka statistik dari Pillai's Trace akurat (Field, 2009:605).

\section{Contoh Kasus dalam $\mathcal{M} \mathcal{A} \mathcal{N}$ OV $\mathcal{A}$}

Berikut diberikan contoh kasus yang dapat diselesaikan dengan pendekatan MANOVA.

[1] Andaikan dalam suatu sekolah direncanakan akan diterapkan salah satu dari tiga metode mengajar. Adapun ketiga metode mengajar tersebut adalah metode mengajar A, B, dan C. Kepala sekolah tersebut ingin mengetahui, metode mengajar manakah yang dapat membuat rata-rata nilai ujian matematika atau bahasa inggris atau kedua-duanya tinggi. Untuk itu, kepala sekolah tersebut akan melakukan penelitian. Berikut hal-hal yang akan diteliti.

$\Rightarrow$ Meneliti apakah ketiga metode mengajar tersebut memiliki kemampuan yang sama dalam mempengaruhi nilai ujian matematika dan bahasa inggris secara simultan (simultaneously) (mempengaruhi secara rata-rata). Jika tidak, berarti terdapat metode mengajar yang memiliki kemampuan berbeda dalam hal mempengaruhi nilai ujian matematika dan bahasa inggris secara simultan (simultaneously). 
$\Rightarrow$ Seandainya terdapat metode mengajar yang memiliki kemampuan berbeda dalam hal mempengaruhi nilai ujian matematika dan bahasa inggris secara simultan (simultaneously), akan diselidiki lebih dalam sebagai berikut.

- Apakah penerapan dari ketiga metode mengajar tersebut berpengaruh terhadap nilai ujian matematika (secara rata-rata).

- Jika terdapat pengaruh pada penggunaan metode mengajar terhadap nilai ujian matematika, metode mengajar manakah yang membuat nilai rata-rata ujian matematika tinggi. Maka akan dilakukan hal sebagai berikut.

- Membandingkan nilai rata-rata ujian matematika antara: metode A v/s metode $\mathrm{B}$, metode $\mathrm{A} \mathrm{v} / \mathrm{s}$ metode $\mathrm{C}$, dan metode $\mathrm{B} \mathrm{v} / \mathrm{s}$ metode $\mathrm{C}$.

- Apakah penerapan dari ketiga metode mengajar tersebut berpengaruh terhadap ujian bahasa inggris.

- Jika terdapat pengaruh pada penggunaan metode mengajar terhadap nilai ujian bahasa inggris, metode mengajar manakah yang membuat nilai rata-rata ujian bahasa inggris tinggi. Maka akan dilakukan hal sebagai berikut.

- Membandingkan nilai rata-rata ujian bahasa inggris antara: metode $\mathrm{A}$ v/s metode $\mathrm{B}$, metode $\mathrm{A}$ v/s metode $\mathrm{C}$, dan metode $\mathrm{B}$ v/s metode $\mathrm{C}$.

Berikut data yang telah dikumpulkan oleh kepala sekolah tersebut (Tabel 17.3).

Tabel 17.3

\begin{tabular}{|c|c|c|c|c|c|c|}
\hline & \multicolumn{2}{|c|}{ Metode A } & \multicolumn{2}{|c|}{ Metode B } & \multicolumn{2}{|c|}{ Metode C } \\
\hline & Matematika & B. Inggris & Matematika & B. Inggris & Matematika & B. Inggris \\
\hline & 60 & 61 & 61 & 61 & 60 & 67 \\
\hline & 61 & 61 & 61 & 63 & 61 & 68 \\
\hline & 62 & 62 & 62 & 64 & 62 & 69 \\
\hline & 63 & 63 & 63 & 65 & 63 & 70 \\
\hline & 64 & 64 & 64 & 66 & 64 & 71 \\
\hline & 65 & 65 & 65 & 67 & 65 & 72 \\
\hline & 60 & 60 & 60 & 62 & 60 & 67 \\
\hline & 61 & 61 & 61 & 63 & 61 & 68 \\
\hline & 62 & 62 & 62 & 64 & 62 & 69 \\
\hline & 63 & 63 & 63 & 65 & 63 & 70 \\
\hline & 64 & 64 & 64 & 66 & 64 & 71 \\
\hline & 65 & 65 & 65 & 67 & 65 & 72 \\
\hline Rata-Rata & 62.5 & 62.58333333 & 62.5833333 & 64.41666667 & 62.5 & 69.5 \\
\hline Varians & 3.18181818 & 2.810606061 & 2.81060606 & 3.71969697 & 3.181818182 & 3.181818182 \\
\hline
\end{tabular}


Berdasarkan data pada Tabel 17.3, dari 36 siswa, 12 siswa diterapkan metode mengajar A, 12 siswa berikutnya diterapkan metode mengajar B, dan siswa lainnya diterapkan metode mengajar C. Setelah satu bulan kemudian, diadakan ujian matematika dan bahasa inggris dari seluruh siswa tersebut. Data nilai ujian matematika dan bahasa inggris dari 36 siswa tersaji pada Tabel 17.3. Perhatikan bahwa metode mengajar merupakan variabel bebas, sedangkan nilai ujian matematika dan bahasa inggris merupakan variabel tak bebas. Dalam hal ini, terdapat sebuah variabel bebas yang terdiri dari tiga kelompok/kategori, dan dua variabel tak bebas yang bersifat metrik (rasio).

Dugaan: $\quad$ Berdasarkan data pada Tabel 17.3, nilai rata-rata ujian matematika dari penggunaan metode $A$ adalah 62,5 , metode $B$ adalah 62,58 , dan metode $C$ adalah 62,5 . Dari sini dapat diduga bahwa tidak terdapat pengaruh pada penggunaan metode mengajar terhadap nilai ujian matematika. Dapat dilihat bahwa secara rata-rata, penggunaan metode mengajar $A, B$, dan $C$ menghasilkan nilai rata-rata ujian matematika yang tidak jauh berbeda.

Dugaan: Berdasarkan data pada Tabel 17.3, nilai rata-rata ujian bahasa inggris dari penggunaan metode $A$ adalah 62,58 , metode $B$ adalah 64,42 , dan metode $C$ adalah 69,5. Dari sini dapat diduga bahwa terdapat pengaruh pada penggunaan metode mengajar terhadap nilai ujian bahasa inggris. Dapat dilihat bahwa secara rata-rata, penggunaan metode mengajar $A, B$, dan $C$ menghasilkan nilai rata-rata ujian matematika yang cukup berbeda.

Dugaan: Berdasarkan kedua dugaan sebelumnya, maka diduga pertanyaan "metode mengajar tersebut memiliki kemampuan yang sama dalam mempengaruhi nilai ujian matematika dan bahasa inggris secara simultan (simultaneously) (mempengaruhi secara rata-rata)" akan ditolak. Dengan kata lain, diduga $H_{0}$ ditolak dan $H_{1}$ diterima.

[2] Andaikan seorang psikolog akan meneliti apakah terdapat perbedaan IQ (intelligent quotient) dan indeks prestasi kumulatif (IPK) antara mahasiswa pria dan wanita di Universitas ABCDE. Berikut hal-hal yang akan diteliti oleh psikolog tersebut.

$\Rightarrow$ Meneliti apakah terdapat perbedaan IQ dan IPK secara simultan (simultaneously) antara mahasiswa pria dan wanita. Jika terdapat perbedaan, selanjutnya akan ditentukan hal-hal sebagai berikut.

- Apakah terdapat perbedaan (secara rata-rata) IQ antara mahasiswa pria dan wanita. Jika terdapat perbedaan, akan ditentukan apakah mahasiswa pria atau wanita yang memiliki IQ lebih tinggi (secara rata-rata).

- Apakah terdapat perbedaan (secara rata-rata) IQ antara mahasiswa pria dan wanita. Jika terdapat perbedaan, akan ditentukan apakah mahasiswa pria atau wanita yang memiliki IQ lebih tinggi (secara rata-rata). 
Berikut data yang telah dikumpulkan oleh psikolog tersebut (Tabel 17.4).

Tabel 17.4

\begin{tabular}{|c|c|c|c|c|c|}
\hline \multirow{2}{*}{ Responden Ke- } & \multicolumn{2}{|c|}{ Pria } & \multirow{2}{*}{ Responden Ke- } & \multicolumn{2}{|c|}{ Wanita } \\
\cline { 2 - 3 } & IQ & IPK & & IQ & IPK \\
\hline 1 & 104 & 2.9 & 16 & 96 & 3.12 \\
\hline 2 & 104 & 2.75 & 17 & 96 & 3.3 \\
\hline 3 & 105 & 2.8 & 18 & 97 & 3.25 \\
\hline 4 & 105 & 2.85 & 19 & 97 & 3.22 \\
\hline 5 & 105 & 2.9 & 20 & 97 & 3.17 \\
\hline 6 & 106 & 2.9 & 21 & 98 & 3 \\
\hline 7 & 106 & 3.02 & 22 & 98 & 3.5 \\
\hline 8 & 106 & 2.9 & 23 & 98 & 3.45 \\
\hline 9 & 106 & 2.75 & 24 & 98 & 3.36 \\
\hline 10 & 107 & 2.8 & 25 & 99 & 3.3 \\
\hline 11 & 107 & 2.85 & 26 & 99 & 3.3 \\
\hline 12 & 107 & 2.9 & 27 & 99 & 3.31 \\
\hline 13 & 108 & 2.9 & 28 & 100 & 3 \\
\hline 14 & 108 & 3.02 & 29 & 100 & 3.3 \\
\hline 15 & 109 & 3 & 30 & 100 & 3.4 \\
\hline Rata-Rata & 106.2 & 2.882667 & Rata-Rata & 98.13333 & 3.265333 \\
\hline
\end{tabular}

Berdasarkan data pada Tabel 17.4, psikolog tersebut mengambil sampel sebanyak 30 mahasiswa, yang terdiri dari 15 mahasiswa pria dan 15 mahasiswa wanita. Tabel 17.4 menyajikan IQ dan IPK dari masing-masing mahasiswa yang sedang diteliti. Perhatikan bahwa variabel jenis kelamin merupakan variabel bebas, sedangkan IQ dan IPK merupakan variabel tak bebas. Dalam hal ini, terdapat sebuah variabel bebas yang terdiri dari dua kelompok/kategori, dan dua variabel tak bebas yang bersifat metrik (rasio).

\section{Asumsi-Asumsi dalam $\mathcal{A}$ nalisis $\mathcal{M} \mathcal{A} \mathcal{N} O \mathcal{V} \mathcal{A}$}

Terdapat beberapa asumsi yang dikenakan pada penggunaan MANOVA, antara lain asumsi normalitas multivariat (multivariate normality assumption) dan asumsi kesamaan matriksmatriks kovarian populasi (equal covariance matrices atau homogeneity of covariance matrices).

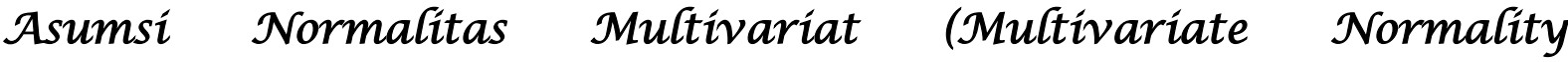 Assumption)}

ANOVA dan MANOVA sama-sama dikenakan asumsi normalitas. Namun asumsi normalitas pada ANOVA merupakan asumsi normalitas univariat, sedangkan pada MANOVA merupakan asumsi normalitas multivariat. Pada ANOVA, pengamatan-pengamatan (observations) pada variabel tak bebas (dependent variable) diasumsikan berdistribusi normal untuk setiap kelompok pada variabel bebas. Sedangkan pada MANOVA pengamatanpengamatan pada variabel-variabel tak bebas (dependent variables) diasumsikan secara 
bersamaan (collectively) mengikuti (follow) distribusi normal multivariat (multivariate normal distribution) untuk setiap kelompok.

Pengujian normalitas multivariat tidak dapat diuji dengan menggunakan SPSS dan sebagai alternatif adalah menguji asumsi normalitas univariat untuk setiap variabel tak bebas. Field (2009:604) menyatakan sebagai berikut.

"The assumption normality of multivariate normality cannot be tested on SPSS and so the only practical solution is to check the assumption of univariate normality for each dependent variable in turn".

Normalitas untuk setiap variabel-variabel secara terpisah (separately) merupakan suatu syarat yang diperlukan (necessary), namun tidak cukup (but not sufficient), untuk tercapainya normalitas multivariat. Untuk setiap variabel secara individu (individual) harus berdistribusi normal (must be normally distributed) untuk mengikuti (follow) distribusi normal multivariat. Stevens (2009:222) menyatakan sebagai berikut.

"The multivariate normality assumption is a much more stringent assumption than the corresponding assumption of normality on a single variable in ANOVA. Although it is difficult to completely characterize multivariate normality, normality on each of the variables separately is a necessary, but not sufficient, condition for multivariate normality to hold. That is, each of the individual variables must be normally distributed for the variables to follow a multivariate normal distribution".

\section{Asumsi Kesamaan Matríks-Matriks Kovarian (Assumption of Equal Covariance Matrices)}

Selain asumsi normalitas multivariat, terdapat asumsi lain yang dikenakan pada penggunaan MANOVA, yakni asumsi kesamaan matriks-matriks kovarian populasi (equal population covariance matrices). Untuk menguji asumsi kesaman matriks-matriks kovarian populasi dapat digunakan uji Box. Namun Stevens (2009) menyatakan uji Box sangat sensitif/rentan terhadap ketidaknormalan. Lebih lanjut Field (2009) menyatakan uji Box rentan terhadap penyimpangan dari normalitas multivariat dan dapat menjadi tidak signifikan (nonsignificant) bukan karena matriks-matriks kovarian sama (similar), namun karena asumsi normalitas multivariat tidak dipenuhi (is not tenable). Oleh karena itu, sebelum menggunakan uji Box, perlu diketahui terlebih dahulu apakah asumsi normalitas multivariat telah dicapai.

Selain itu, nilai statistik dari uji chi-kuadrat $\chi^{2}$ dan $F$ dapat digunakan sebagai pendekatan (approximation) terhadap nilai statistik dari uji Box. Stevens (2009:230) memberi aturan (rule), ketika seluruh ukuran-ukuran kelompol (all group sizes) 20 dan jumlah variabel tak bebas sebanyak 6 , maka pendekatan yang baik adalah nilai statistik dari uji chi-kuadrat $\chi^{2}$. Jika tidak memenuhi aturan tersebut, maka pendekatan nilai statistik dari uji $F$ lebih akurat dan seharusnya digunakan.

Hipotesis nol menyatakan tidak terdapat perbedaan yang signifikan secara statistika di antara matriks-matriks kovarian populasi (equal population covariance matrices). Hipotesis alternatif menyatakan terdapat perbedaan yang signifikan secara statistika di antara matriksmatriks kovarian populasi. Berikut aturan pengambilan keputusan jika digunakan pendekatan nilai statistik dari uji chi-kuadrat $\chi^{2}$. 
Jika $\chi^{2} \leq \chi_{\text {kritis }}^{2}$, maka $H_{0}$ diterima dan $H_{1}$ ditolak. Jika $\chi^{2}>\chi_{\text {kritis }}^{2}$, maka $H_{0}$ ditolak dan $H_{1}$ diterima.

Berikut aturan pengambilan keputusan jika digunakan pendekatan nilai statistik dari uji $F$.

Jika nilai statistik dari uji $F \leq$ nilai kritis $F$, maka $H_{0}$ diterima dan $H_{1}$ ditolak. jika nilai statistik dari uji $F>$ nilai kritis $F$, maka $H_{0}$ ditolak dan $H_{1}$ diterima.

Pengambilan keputusan terhadap hipotesis juga dapat digunakan pendekatan nilai probabilitas (Sig.). Nilai probabilitas tersebut dibandingkan dengan tingkat signifikansi $(\alpha)$. Berikut aturan pengambilan keputusan terhadap hipotesis dengan pendekatan probabilitas.

Jika nilai probabilitas $\geq$ tingkat signifikansi, maka $H_{0}$ diterima dan $H_{1}$ ditolak. Jika nilai probabilitas < tingkat signifikansi, maka $H_{0}$ ditolak dan $H_{1}$ diterima.

Tabel 17.5 menyajikan nilai statistik dari uji Box, nilai statistik dari uji $F$, dan nilai probabilitas (Sig.).

\section{Tabel 17.6}

$\begin{aligned} & \text { Box's Test of Equality } \\
& \text { of Covariance } \\
& \text { Matrices }^{\mathrm{a}}\end{aligned}$
\begin{tabular}{|l|r|}
\hline Box's M & 8.321 \\
$\mathrm{~F}$ & 2.500 \\
df1 & 3 \\
df2 & 87120.000 \\
Sig. & .058 \\
\hline
\end{tabular}




\section{PENYELESAIAN DALAM SPSS}

Andaikan dalam suatu sekolah direncanakan akan diterapkan salah satu dari tiga metode mengajar. Adapun ketiga metode mengajar tersebut adalah metode mengajar A, B, dan C. Kepala sekolah tersebut ingin mengetahui, metode mengajar manakah yang dapat membuat rata-rata nilai ujian matematika atau bahasa inggris atau kedua-duanya tinggi. Untuk itu, kepala sekolah tersebut akan melakukan penelitian. Berikut hal-hal yang akan diteliti.

$\Rightarrow$ Meneliti apakah ketiga metode mengajar tersebut memiliki kemampuan yang sama dalam mempengaruhi nilai ujian matematika dan bahasa inggris secara simultan (simultaneously) (mempengaruhi secara rata-rata). Jika tidak, berarti terdapat metode mengajar yang memiliki kemampuan berbeda dalam hal mempengaruhi nilai ujian matematika dan bahasa inggris secara simultan (simultaneously).

$\Rightarrow$ Seandainya terdapat metode mengajar yang memiliki kemampuan berbeda dalam hal mempengaruhi nilai ujian matematika dan bahasa inggris secara simultan (simultaneously), akan diselidiki lebih dalam sebagai berikut.

- Apakah penerapan dari ketiga metode mengajar tersebut berpengaruh terhadap nilai ujian matematika (secara rata-rata). Dengan kata lain, dari tiga metode mengajar tersebut, apakah terdapat metode mengajar yang memiliki kemampuan yang berbeda dalam hal mempengaruhi nilai ujian matematika.

- Jika terdapat pengaruh pada penggunaan metode mengajar terhadap nilai ujian matematika, metode mengajar manakah yang membuat nilai rata-rata ujian matematika tinggi. Maka akan dilakukan hal sebagai berikut.

- Membandingkan nilai rata-rata ujian matematika antara: metode A v/s metode $\mathrm{B}$, metode $\mathrm{A}$ v/s metode $\mathrm{C}$, dan metode $\mathrm{B} \mathrm{v} / \mathrm{s}$ metode $\mathrm{C}$.

- Apakah penerapan dari ketiga metode mengajar tersebut berpengaruh terhadap ujian bahasa inggris. Dengan kata lain, dari tiga metode mengajar tersebut, apakah terdapat metode mengajar yang memiliki kemampuan yang berbeda dalam hal mempengaruhi nilai ujian bahasa inggris.

- Jika terdapat pengaruh pada penggunaan metode mengajar terhadap nilai ujian bahasa inggris, metode mengajar manakah yang membuat nilai rata-rata ujian bahasa inggris tinggi. Maka akan dilakukan hal sebagai berikut.

- Membandingkan nilai rata-rata ujian bahasa inggris antara: metode $\mathrm{A}$ v/s metode $\mathrm{B}$, metode $\mathrm{A}$ v/s metode $\mathrm{C}$, dan metode $\mathrm{B}$ v/s metode $\mathrm{C}$.

Berikut data yang telah dikumpulkan oleh kepala sekolah tersebut (Tabel 17.1). 
Tabel 17.1

\begin{tabular}{|c|c|c|c|c|c|c|}
\hline & \multicolumn{2}{|c|}{ Metode A } & \multicolumn{2}{|c|}{ Metode B } & \multicolumn{2}{|c|}{ Metode C } \\
\hline & Matematika & B. Inggris & Matematika & B. Inggris & Matematika & B. Inggris \\
\hline & 60 & 61 & 61 & 61 & 60 & 67 \\
\hline & 61 & 61 & 61 & 63 & 61 & 68 \\
\hline & 62 & 62 & 62 & 64 & 62 & 69 \\
\hline & 63 & 63 & 63 & 65 & 63 & 70 \\
\hline & 64 & 64 & 64 & 66 & 64 & 71 \\
\hline & 65 & 65 & 65 & 67 & 65 & 72 \\
\hline & 60 & 60 & 60 & 62 & 60 & 67 \\
\hline & 61 & 61 & 61 & 63 & 61 & 68 \\
\hline & 62 & 62 & 62 & 64 & 62 & 69 \\
\hline & 63 & 63 & 63 & 65 & 63 & 70 \\
\hline & 64 & 64 & 64 & 66 & 64 & 71 \\
\hline & 65 & 65 & 65 & 67 & 65 & 72 \\
\hline Rata-Rata & 62.5 & 62.58333333 & 62.5833333 & 64.41666667 & 62.5 & 69.5 \\
\hline varians & 3.18181818 & 2.810606061 & 2.81060606 & 3.71969697 & 3.181818182 & 3.181818182 \\
\hline
\end{tabular}

Berdasarkan data pada Tabel 17.1, dari 36 siswa, 12 siswa diterapkan metode mengajar A, 12 siswa berikutnya diterapkan metode mengajar B, dan siswa lainnya diterapkan metode mengajar C. Setelah satu bulan kemudian, diadakan ujian matematika dan bahasa inggris dari seluruh siswa tersebut. Data nilai ujian matematika dan bahasa inggris dari 36 siswa tersaji pada Tabel 17.1. Perhatikan bahwa metode mengajar merupakan variabel bebas, sedangkan nilai ujian matematika dan bahasa inggris merupakan variabel tak bebas. Dalam hal ini, terdapat sebuah variabel bebas yang terdiri dari tiga kelompok/kategori, dan dua variabel tak bebas yang bersifat metrik (rasio).

Permasalahan tersebut akan diselesaikan dengan pendekatan MANOVA. Beberapa asumsi yang dikenakan pada penggunaan MANOVA adalah asumsi normalitas multivariat dan kesamaan matriks-matriks kovarian populasi. Pengujian asumsi normalitas multivariat didekati dengan pengujian normalitas univariat untuk masing-masing variabel tak bebas dalam setiap kelompok-kelompok/kategori-kategori.

Bangun data pada Tabel 17.1 dalam SPSS seperti berikut (Gambar 17.1). Selanjutnya pilih Analyze $\Rightarrow$ Descriptive Statistics $\Rightarrow$ Explore, sehingga muncul kotak dialog Explore (Gambar 17.2). Masukkan variabel nilai ujian matematika dan nilai bahasa inggris ke dalam Dependent List dan variabel metode mengajar pada Factor List. Selanjutnya pilih Plots, sehingga muncul kotak dialog Explore: Plots. Pilih/centang Normality plots with tests. Kemudian pilih Continue. Pada Display pilih Plots. Selanjutnya pilih OK. Output SPSS terlihat pada Tabel 17.2. 


\begin{tabular}{|c|c|c|c|c|c|c|c|c|}
\hline & metode & matematika & bahasa_inggris & \multirow{4}{*}{$\begin{array}{c}\text { Untuk variabel } \\
\text { metode,beri }\end{array}$} & & & & \\
\hline 1 & metode $\mathrm{A}$ & 60 & 61 & & & & & \\
\hline 2 & metode $\mathrm{A}$ & 61 & 61 & & tode & matematika & bahasa inggris & var \\
\hline 3 & metode A & 62 & 62 & & tode $\mathrm{B}$ & 64 & 66 & \\
\hline 4 & metode $\mathrm{A}$ & 63 & 63 & kode angka 1 & tode B & 65 & 67 & \\
\hline 5 & metode A & 64 & 64 & \multirow{7}{*}{$\begin{array}{l}\text { untuk metode } \\
\text { A, kode angka } \\
2 \text { untuk metode } \\
\text { B, dan kode } \\
\text { angka } 3 \text { untuk }\end{array}$} & tode C & 60 & 67 & \\
\hline 6 & metode $\mathrm{A}$ & 65 & 65 & & tode C & 61 & 68 & \\
\hline 7 & metode $\mathrm{A}$ & 60 & 60 & & tode C & 62 & 69 & \\
\hline 8 & metode $\mathrm{A}$ & 61 & 61 & & tode C & 63 & 70 & \\
\hline 9 & metode $\mathrm{A}$ & 62 & 62 & & tode C & 64 & 71 & \\
\hline 10 & metode $\mathrm{A}$ & 63 & 63 & & tode C & 65 & 72 & \\
\hline 11 & metode $\mathrm{A}$ & 64 & 64 & & tode C & 60 & 67 & \\
\hline 12 & metode $\mathrm{A}$ & 65 & 65 & metode C. & tode C & 61 & 68 & \\
\hline 13 & metode $\mathrm{B}$ & 61 & 61 & Ju & Thetode C & 62 & 69 & \\
\hline 14 & metode $\mathrm{B}$ & 61 & 63 & 34 & metode $\mathrm{C}$ & 63 & 70 & \\
\hline 15 & metode $\mathrm{B}$ & 62 & 64 & 35 & metode $\mathrm{C}$ & 64 & 71 & \\
\hline 16 & metode $\mathrm{B}$ & 63 & 65 & 36 & metode $\mathrm{C}$ & 65 & 72 & \\
\hline 17 & metode $B$ & 64 & 66 & 37 & & & & \\
\hline
\end{tabular}

\begin{tabular}{|c|c|c|c|c|c|c|c|c|c|}
\hline & metode & matematika & bahasa_inggris & var & & & & & \\
\hline 1 & 1 & 60 & 61 & & & & & & \\
\hline 2 & 1 & 61 & 61 & & & metode & matematika & bahasa_inggris & var \\
\hline 3 & 1 & 62 & 62 & & 22 & 2 & 63 & 65 & \\
\hline 4 & 1 & 63 & 63 & & 23 & 2 & 64 & 66 & \\
\hline 5 & 1 & 64 & 64 & & 24 & 2 & 65 & 67 & \\
\hline 6 & 1 & 65 & 65 & & 25 & 3 & 60 & 67 & \\
\hline 7 & 1 & 60 & 60 & & 26 & 3 & 61 & 68 & \\
\hline 8 & 1 & 61 & 61 & & 27 & 3 & 62 & 69 & \\
\hline 9 & 1 & 62 & 62 & & 28 & 3 & 63 & 70 & \\
\hline 10 & 1 & 63 & 63 & & 29 & 3 & 64 & 71 & \\
\hline 11 & 1 & 64 & 64 & & 30 & 3 & 65 & 72 & \\
\hline 12 & 1 & 65 & 65 & & 31 & 3 & 60 & 67 & \\
\hline 13 & 2 & 61 & 61 & & 32 & 3 & 61 & 68 & \\
\hline 14 & 2 & 61 & 63 & & 33 & 3 & 62 & 69 & \\
\hline 15 & 2 & 62 & 64 & & 34 & 3 & 63 & 70 & \\
\hline 16 & 2 & 63 & 65 & & 35 & 3 & 64 & 71 & \\
\hline 17 & 2 & 64 & 66 & & 36 & 3 & 65 & 72 & \\
\hline
\end{tabular}

\section{Gambar 17.1}

Cara pengujian normalitas univariat ini dapat dilihat pada buku "Applied Multivariate Statistics For The Social Sciences, $5^{\text {th }}$ Edition" pada halaman 225.

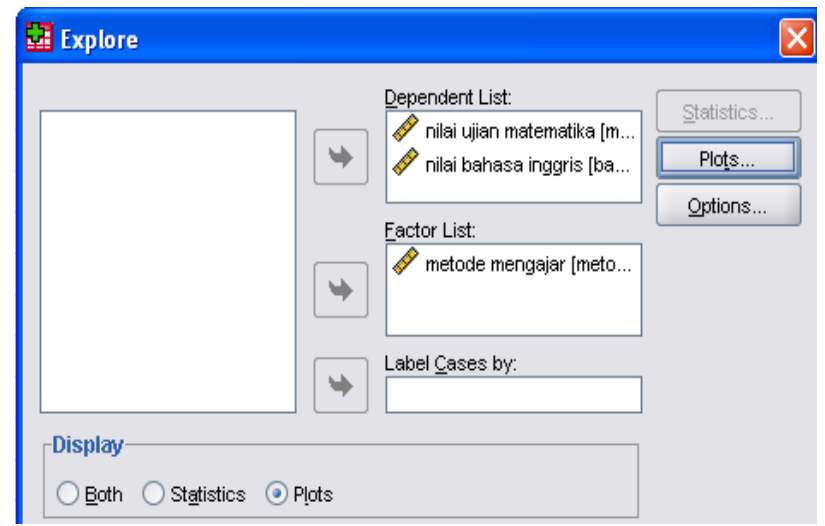

Gambar 17.2 
Tabel 17.2

\begin{tabular}{|c|c|c|c|c|c|c|c|}
\hline & \multirow[b]{2}{*}{ metode mengaiar } & \multicolumn{3}{|c|}{ Kolmogorov-Smirnov ${ }^{a}$} & \multicolumn{3}{|c|}{ Shapiro-Wilk } \\
\hline & & Statistic & $\mathrm{df}$ & Siq. & Statistic & $\mathrm{df}$ & Siq. \\
\hline \multirow[t]{3}{*}{ nilai ujian matematika } & metode A & .133 & 12 & $.200^{x}$ & .929 & 12 & .372 \\
\hline & metode B & .161 & 12 & $.200^{\pi}$ & .933 & 12 & .412 \\
\hline & metode $\mathrm{C}$ & .133 & 12 & $.200^{x}$ & .929 & 12 & .372 \\
\hline \multirow[t]{3}{*}{ nilai bahasa inggris } & metode A & .161 & 12 & $.200^{x}$ & .933 & 12 & .412 \\
\hline & metode B & .127 & 12 & $.200^{\pi}$ & .955 & 12 & .708 \\
\hline & metode $\mathrm{C}$ & .133 & 12 & $.200^{\pi}$ & .929 & 12 & .372 \\
\hline
\end{tabular}

Berdasarkan informasi pada Tabel 17.2, yakni Tests of Normality, akan diperiksa apakah asumsi normalitas untuk masing-masing variabel tak bebas dalam setiap kelompokkelompok/kategori-kategori dipenuhi atau tidak. Untuk menentukan apakah asumsi normalitas terpenuhi atau tidak, dapat dilakukan dengan membandingkan nilai Sig. terhadap tingkat signifikansi $(\alpha)$ yang digunakan.

Perhatikan bahwa diketahui nilai Sig. dari uji Kolmogorov-Smirnov untuk masing-masing variabel tak bebas dalam setiap kelompok-kelompok/kategori-kategori lebih besar dari 0,05, maka disimpulkan bahwa asumsi normalitas univariat dipenuhi.

Selanjutnya pilih Analyze $=>$ General Linear Model $=>$ Multivariate, sehingga muncul kotak dialog Multivariate (Gambar 17.3). Masukkan variabel nilai ujian matematika dan nilai bahasa inggris ke dalam Dependent Variables, dan metode mengajar pada Fixed Factor(s). Kemudian pilih Post Hoc, sehingga muncul kotak dialog Multivariate: Post Hoc Multiple Comparison for Observed Means (Gambar 17.4). Masukkan variabel metode mengajar pada kotak Post Hoc Tests for (Gambar 17.4). Kemudian pilih Bonferroni pada Equal Variances Assumed dan pilih Continue. Selanjutnya pilih Options, sehingga muncul kotak dialog Multivariate: Options (Gambar 17.5). Masukkan variabel (OVERALL) dan metode mengajar pada kotak Display Means for. Kemudian aktifkan Compare mean effect dan pilih Bonferroni. Pada Display, pilih Descriptive statistics dan Homogeneity tests. Selanjutnya pilih Continue dan $\mathrm{OK}$.

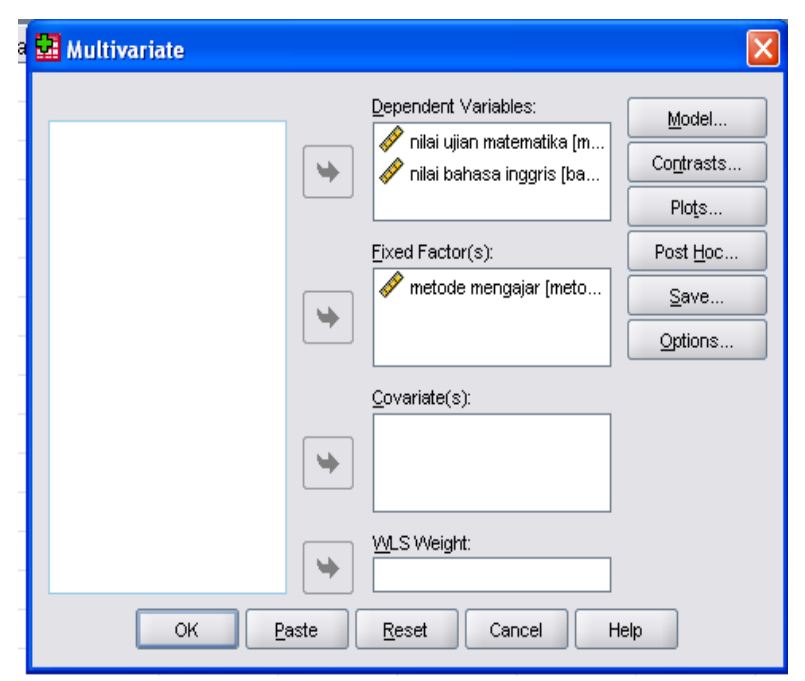

Gambar 17.3

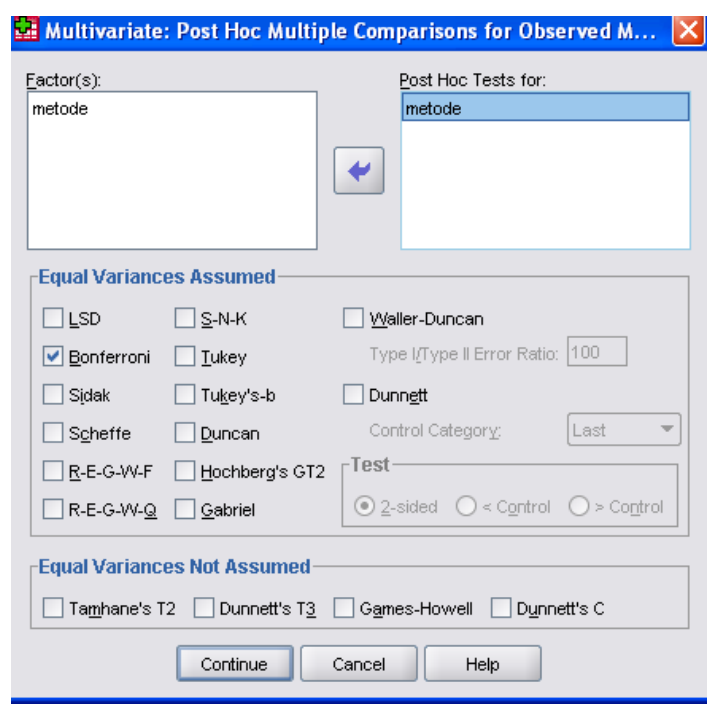

Gambar 17.4 


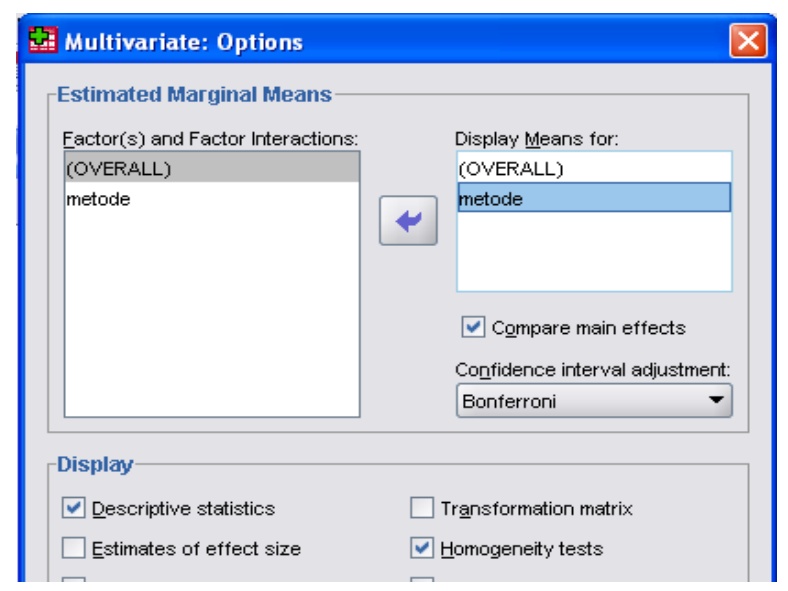

Gambar 17.5

Berikut hasil berdasarkan SPSS.

\section{Tabel 17.3}

$\begin{gathered}\text { Box's Test of Equality } \\
\text { of Cowariance } \\
\text { Matrices }\end{gathered}$
\begin{tabular}{|l|r|}
\hline Box's M1 & 8.321 \\
F & 2.500 \\
df1 & 3 \\
df2 & 87120.000 \\
Sig. & .058 \\
\hline
\end{tabular}

Berdasarkan Tabel 17.3, yakni Box's M Test of Equality of Covariance Matrices, berikut akan diuji asumsi kesamaan matriks-matriks kovarian populasi. Hipotesis nol menyatakan tidak terjadi perbedaan yang signifikan secara statistik di antara matriks-matriks kovarian populasi (equal population covariance matrices). Sedangkan hipotesis alternatif menyatakan terjadi perbedaan yang signifikan secara statistik di antara matriks-matriks kovarian populasi. Pengambilan keputusan terhadap hipotesis dapat digunakan pendekatan nilai Sig. Nilai Sig disebut juga dengan nilai probabilitas ( $p$-value). Nilai probabilitas tersebut dibandingkan dengan tingkat signifikansi $(\alpha)$. Berikut aturan pengambilan keputusan terhadap hipotesis.

Jika nilai probabilitas $\geq \alpha$, maka $H_{0}$ diterima dan $H_{1}$ ditolak. Jika nilai probabilitas $<\alpha$, maka $H_{0}$ ditolak dan $H_{1}$ diterima.

Berdasarkan Tabel 17.3 diketahui nilai probabilitas (Sig.) 0,058. Perhatikan bahwa karena nilai probabilitas lebih besar dibandingkan tingkat signifikansi $\alpha=0,05$, maka hipotesis nol diterima dan hipotesis alternatif ditolak. Hal ini berarti asumsi kesamaan matriks-matriks kovarian populasi dipenuhi. Pengambilan keputusan terhadap hipotesis juga dapat dilakukan dengan pendekatan nilai statistik dari uji $F$. Berdasarkan Tabel 17.3, diketahui derajat bebas pembilang $(d f 1)$ adalah 3 dan derajat bebas penyebut $(d f 2)$ adalah 87120 . Nilai kritis $F$ dengan derajat bebas pembilang adalah 3 , derajat bebas penyebut adalah 87120 , dan tingkat signifikansi yang digunakan $\alpha=0,05$ adalah 2,605 (lihat Gambar 17.6). Berdasarkan Tabel 17.3, diketahui nilai statistik dari uji $F$ adalah 2,5. 


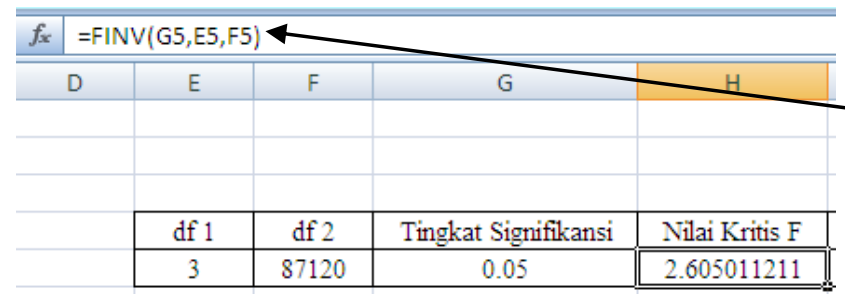

Menentukan nilai kritis $F$ dengan Microsoft Excel.

Gambar 17.6

Berikut aturan pengambilan keputusan berdasarkan uji $F$.

Jika nilai statistik dari uji $F \leq$ nilai kritis $F$, maka $H_{0}$ diterima dan $H_{1}$ ditolak. jika nilai statistik dari uji $F>$ nilai kritis $F$, maka $H_{0}$ ditolak dan $H_{1}$ diterima.

Perhatikan bahwa karena nilai nilai statistik dari uji $F$ lebih kecil dibandingkan nilai kritis $F$, maka hipotesis nol diterima dan hipotesis alternatif ditolak. Hal ini berarti asumsi kesamaan matriks-matriks kovarian populasi dipenuhi.

Tabel 17.4

Tabel 17.5

Descriptive Statistics

Between-Subjects Factors

\begin{tabular}{|ll|l|r|}
\hline & & Value Label & \multicolumn{1}{|c|}{$\mathrm{N}$} \\
\hline metode mengajar & 1 & metode A & 12 \\
& 2 & metode B & 12 \\
& 3 & metode C & 12 \\
\hline
\end{tabular}

\begin{tabular}{|lr|r|r|r|}
\hline & metode mencaiar & \multicolumn{1}{c|}{ Mean } & Std. Deviation & \multicolumn{1}{|c|}{$\mathrm{N}$} \\
\hline nilai ujian matematika & metode A & 62.50 & 1.784 & 12 \\
& metode B & 62.58 & 1.676 & 12 \\
& metode C & 62.50 & 1.784 & 12 \\
& Total & 62.53 & 1.699 & 36 \\
\hline nilai bahasa inggris & metode A & 62.58 & 1.676 & 12 \\
& metode B & 64.42 & 1.929 & 12 \\
& metode C & 69.50 & 1.784 & 12 \\
& Total & 65.50 & 3.443 & 36 \\
\hline
\end{tabular}

Berdasarkan Tabel 17.4, yakni Between-Subjects Factors, diketahui jumlah responden (siswa) yang diteliti sebanyak 36 siswa. Berdasarkan Tabel 17.5, yakni Descriptive Statistics, nilai rata-rata ujian matematika dengan metode B $(62,58)$ lebih tinggi dibandingkan metode A $(62,50)$ dan $C(62,50)$. Diketahui juga bahwa nilai rata-rata ujian bahasa inggris dengan metode $\mathrm{C}(69,50)$ lebih tinggi dibandingkan metode A $(62,58)$ dan B $(64,42)$.

Tabel 17.6

\begin{tabular}{|c|c|c|c|c|c|c|c|}
\hline \multicolumn{7}{|c|}{ Multivariate Tests ${ }^{\circ}$} & \multirow{3}{*}{ Cukup } \\
\hline Effect & & Value & $\mathrm{F}$ & Hypothesis df & Error df & Sig. & \\
\hline \multirow[t]{4}{*}{ Intercept } & Pillai's Trace & .999 & $23139.304^{a}$ & 2.000 & 32.000 & .000 & \\
\hline & Wilks' Lambda & .001 & $23139.304^{a}$ & 2.000 & 32.000 & سمחم & \multirow{5}{*}{$\begin{array}{l}\text { perhatikan } \\
\text { nilai-nilai } \\
\text { pada bagian } \\
\text { metode. }\end{array}$} \\
\hline & Hotelling's Trace & 1446.207 & $23139.304^{a}$ & 2000 & 32.000 & .000 & \\
\hline & Roy's Largest Root & 1446.207 & $23139.304^{a}$ & 2.000 & 32.000 & .000 & \\
\hline \multirow[t]{4}{*}{ metode } & FाIal's Trace & .986 & 16.043 & 4.000 & 66.000 & .000 & \\
\hline & Wilks' Lambda & .015 & $116.737^{a}$ & 4.000 & 64.000 & .000 & \\
\hline & Hotelling's Trace & 67.790 & 525.374 & 4.000 & 62.000 & .000 & \\
\hline & Roy's Largest Root & 67.790 & $1118.530^{\mathrm{b}}$ & 2.000 & 33.000 & .000 & \\
\hline
\end{tabular}

Berdasarkan Tabel 17.6, yakni Multivariate Tests, akan ditentukan apakah ketiga metode mengajar tersebut memiliki kemampuan yang sama dalam mempengaruhi nilai ujian matematika dan bahasa inggris secara simultan (simultaneously) (mempengaruhi secara ratarata) atau tidak. Untuk menentukan apakah ketiga metode mengajar tersebut memiliki kemampuan yang sama dalam mempengaruhi nilai ujian matematika dan bahasa inggris secara simultan (simultaneously) (mempengaruhi secara rata-rata) atau tidak, dapat dilakukan 
dengan membandingkan nilai Sig. dari Pillai's Trace, Wlks' Lambda, Hotelling's Trace, atau Roy's Largest Root terhadap tingkat signifikansi. Perhatikan bahwa, karena keempat nilai Sig. tersebut lebih kecil dibandingkan tingkat signifikansi $\alpha=0,05$, maka disimpulkan bahwa terdapat metode mengajar yang memiliki kemampuan berbeda dalam hal mempengaruhi nilai ujian matematika dan bahasa inggris secara simultan (simultaneously).

\section{Tabel 17.7}

\begin{tabular}{|c|c|c|c|c|c|}
\hline \multicolumn{5}{|c|}{ Levene's Test of Equality of Error Variances ${ }^{\Xi}$} & \multirow{4}{*}{$\begin{array}{l}\text { Output pada Tabel } 17.6 \\
\text { juga dapat diperoleh } \\
\text { dengan fasilitas One-Way } \\
\text { ANOVA (Univariate Test } \\
\text { Statistics). }\end{array}$} \\
\hline & $\mathrm{F}$ & df1 & $\mathrm{df2}$ & Sig. & \\
\hline nilai ujian matematika & .040 & 2 & 33 & .961 & \\
\hline nilai bahasa inggris & .107 & 2 & 33 & .899 & \\
\hline
\end{tabular}

a. Design: Intercept + metode

Berdasarkan informasi Tabel 17.7, yakni Levene's Test of Equality of Error Variances, nilai Sig. dari variabel nilai ujian matematika adalah 0,961. Karena nilai Sig. tersebut lebih besar dibandingkan tingkat signifikansi $\alpha=0,05$, maka asumsi kesamaan varians populasi nilai ujian matematika berdasarkan kategori-kategori pada metode mengajar dipenuhi. Nilai Sig. dari variabel nilai ujian bahasa inggris adalah 0,899. Karena nilai Sig. tersebut lebih besar dibandingkan tingkat signifikansi $\alpha=0,05$, maka asumsi kesamaan varians populasi nilai ujian bahasa inggris berdasarkan kategori-kategori pada metode mengajar dipenuhi.

\section{Tabel 17.8}

\begin{tabular}{|c|c|c|c|c|c|c|c|}
\hline & \multicolumn{7}{|c|}{ Tests of Between-Subjects Effects } \\
\hline \multirow{11}{*}{$\begin{array}{c}\text { Nilai } 0,991 \\
\text { dan 0,000 juga } \\
\text { dapat } \\
\text { diperoleh } \\
\text { dengan } \\
\text { fasilitas One- } \\
\text { Way ANOVA } \\
\text { (Univariate } \\
\text { Test }\end{array}$} & Source & Dependent Variable & $\begin{array}{c}\text { Type III Sum } \\
\text { of Squares }\end{array}$ & df & Mean Square & $\mathrm{F}$ & Sig. \\
\hline & \multirow[t]{2}{*}{ octed Model } & nilai ujian matematika & $.056^{a}$ & 2 & .028 & .009 & .991 \\
\hline & & Tingagis & $308.167^{b}$ & 2 & 154.083 & 47.595 & .000 \\
\hline & \multirow[t]{2}{*}{ Intercept } & nilai ujian matematika & क्याग 00.028 & 1 & 140750.028 & 46025.608 & .000 \\
\hline & & nilai bahasa inggris & 154449.000 & 1 & 154449000 & 47708.115 & .000 \\
\hline & \multirow[t]{2}{*}{ metode } & nilai ujian matematika & .056 & 2 & .028 & 009 & .991 \\
\hline & & nilai bahasa inggris & 308.167 & 2 & 154.083 & 47.595 & .000 \\
\hline & \multirow[t]{2}{*}{ Error } & nilai ujian matematika & 100.917 & 33 & 3.058 & & \\
\hline & & nilai bahasa inggris & 106.833 & 33 & 3.237 & & \\
\hline & \multirow[t]{2}{*}{ Total } & nilai ujian matematika & 140851.000 & 36 & & & \\
\hline & & nilai bahasa inggris & 154864.000 & 36 & & & \\
\hline \multirow{2}{*}{ Statistics). } & \multirow[t]{2}{*}{ Corrected Total } & nilai ujian matematika & 100.972 & 35 & & & \\
\hline & & nilai bahasa inggris & 415.000 & 35 & & & \\
\hline
\end{tabular}

Berdasarkan Tabel 17.8, yakni Tests of Between-Subjects Effects, selanjutnya akan diperiksa hal-hal sebagai berikut.

$\Rightarrow$ Apakah penerapan dari ketiga metode mengajar tersebut berpengaruh terhadap nilai ujian matematika (secara rata-rata). Dengan kata lain, dari tiga metode mengajar tersebut, apakah terdapat metode mengajar yang memiliki kemampuan yang berbeda dalam hal mempengaruhi nilai ujian matematika.

$\Rightarrow$ Apakah penerapan dari ketiga metode mengajar tersebut berpengaruh terhadap ujian bahasa inggris. Dengan kata lain, dari tiga metode mengajar tersebut, apakah terdapat 
metode mengajar yang memiliki kemampuan yang berbeda dalam hal mempengaruhi nilai ujian bahasa inggris.

Perhatikan pada baris metode, nilai Sig. dari variabel tak bebas nilai ujian matematika adalah 0,991. Karena nilai Sig. lebih besar dibandingkan tingkat signifikansi $\alpha=0,05$, maka disimpulkan bahwa penerapan dari ketiga metode mengajar tersebut tidak berpengaruh terhadap nilai ujian matematika (secara rata-rata). Selanjutnya perhatikan pada baris metode, nilai Sig. dari variabel tak bebas nilai ujian bahasa inggris adalah 0,000. Karena nilai Sig. lebih kecil dibandingkan tingkat signifikansi $\alpha=0,05$, maka disimpulkan bahwa penerapan dari ketiga metode mengajar tersebut berpengaruh terhadap ujian bahasa inggris.

Perhatikan bahwa karena terdapat pengaruh yang signifikan secara statistik pada penggunaan metode mengajar terhadap nilai ujian bahasa inggris, maka akan ditentukan metode mengajar manakah yang membuat nilai rata-rata ujian bahasa inggris tinggi. Maka akan dilakukan hal sebagai berikut.

$\Rightarrow$ Membandingkan nilai rata-rata ujian bahasa inggris antara: metode $\mathrm{A}$ v/s metode $\mathrm{B}$, metode $\mathrm{A}$ v/s metode $\mathrm{C}$, dan metode $\mathrm{B}$ v/s metode $\mathrm{C}$.

Selanjutnya akan dilakukan uji perbandingan berganda (multiple comparison test) dengan maksud untuk mengetahui metode mengajar manakah yang membuat nilai rata-rata ujian bahasa inggris tinggi. Berdasarkan Tabel 17.9, yakni Multiple Comparisons, dapat ditarik informasi sebagai berikut.

$\Rightarrow$ Perhatikan bahwa tidak terdapat perbedaan (secara rata-rata) yang signifikan secara statistik mengenai nilai ujian matematika ketika diterapkan metode mengajar A dan B. Hal ini dapat dilihat dari nilai Sig. yang lebih besar dari tingkat signifikansi yang digunakan $5 \%(1 \geq 0,05)$.

$\Rightarrow$ Perhatikan bahwa tidak terdapat perbedaan yang signifikan secara statistik mengenai nilai ujian matematika ketika diterapkan metode mengajar A dan C. Hal ini dapat dilihat dari nilai Sig. yang lebih besar dari tingkat signifikansi yang digunakan $5 \%(1 \geq 0,05)$.

$\Rightarrow$ Perhatikan bahwa tidak terdapat perbedaan yang signifikan secara statistik mengenai nilai ujian bahasa inggris ketika diterapkan metode mengajar A dan B. Hal ini dapat dilihat dari nilai Sig. yang lebih besar dari tingkat signifikansi yang digunakan $5 \%(0,053 \geq 0,05)$.

$\Rightarrow$ Perhatikan bahwa terdapat perbedaan yang signifikan secara statistik mengenai nilai ujian bahasa inggris ketika diterapkan metode mengajar A dan C. Hal ini dapat dilihat dari nilai Sig. yang lebih kecil dari tingkat signifikansi yang digunakan $5 \%(0,000<0,05)$.

$\Rightarrow$ Perhatikan bahwa terdapat perbedaan yang signifikan secara statistik mengenai nilai ujian bahasa inggris ketika diterapkan metode mengajar metode B dan C. Hal ini dapat dilihat dari nilai Sig. yang lebih kecil dari tingkat signifikansi yang digunakan $5 \%(0,000 \geq 0,05)$.

Berdasarkan uraian tersebut, maka disimpulkan bahwa metode mengajar $\mathrm{C}$ memberikan pengaruh yang signifikan secara statistik dalam hal membuat nilai ujian bahasa inggris tinggi (secara rata-rata). 


\section{Tabel 17.9}

Multiple Comparisons

\begin{tabular}{|c|c|c|c|c|c|c|c|}
\hline \multirow[b]{2}{*}{ Dependent Variable } & \multirow[b]{2}{*}{ (1) metode menqaiar } & \multirow[b]{2}{*}{ (1) metode menqaiar } & \multirow[b]{2}{*}{$\begin{array}{c}\text { Mean } \\
\text { Difference (I- } \\
\mathrm{J})\end{array}$} & \multirow[b]{2}{*}{ Std. Error } & \multirow[b]{2}{*}{ Siq. } & \multicolumn{2}{|c|}{$95 \%$ Confidence In } \\
\hline & & & & & & Lower Bound & Uppe \\
\hline \multirow[t]{6}{*}{ nilai ujian matematika } & metode $\mathrm{A}$ & metode B & -.08 & .714 & 1.000 & -1.88 & \\
\hline & & metode $\mathrm{C}$ & .00 & .714 & 1.000 & -1.80 & \\
\hline & metode $\mathrm{B}$ & metode A & .08 & .714 & 1.000 & -1.72 & \\
\hline & & metode C & .08 & .714 & 1.000 & -1.72 & \\
\hline & metode C & metode A & .00 & .714 & 1.000 & -1.80 & \\
\hline & & metode B & -.08 & .714 & 1.000 & -1.88 & \\
\hline \multirow[t]{6}{*}{ nilai bahasa inggris } & metode $\mathrm{A}$ & metode B & -1.83 & .735 & .053 & -3.69 & \\
\hline & & metode $\mathrm{C}$ & $-6.92^{x}$ & .735 & .000 & -8.77 & \\
\hline & metode B & metode A & 1.83 & .735 & .053 & -.02 & \\
\hline & & metode $\mathrm{C}$ & $-5.08^{\pi}$ & .735 & .000 & -6.94 & \\
\hline & metode C & metode A & $6.92^{x}$ & .735 & .000 & 5.06 & \\
\hline & & metode B & $5.08^{\pi}-1+2-1$ & .735 & .000 & 3.23 & \\
\hline
\end{tabular}

\section{Referensi}

1. Field, A. 2009. Discovering Statistics Using SPSS, $3^{\text {rd }}$ Edition. London: Sage.

2. Hair, J.F Jr., R.E. Anderson, B.J. Babin, dan W.C. Black. 2010. Multivariate Data Analysis, $7^{\text {th }}$ Edition. Pearson Prentice Hall.

3. Stevens, J.P. 2009. Applied Multivariate Statistics For The Social Science, $5^{\text {th }}$ Edition. New York: Routledge. 


\section{BAB 18}

\section{DISTRIBUSI PROBABILITAS}

\section{Distríbusi Binomial, Contoh Perhitungan, dan Penyelesaían dalam $\mathcal{M}$ ícrosoft Excel dan $\mathcal{R}$}

Distribusi binomial merupakan salah satu distribusi probabilitas diskrit. Hal ini karena variabel acak (random variable) bersifat terhitung (countable). Andaikan sebuah koin dilemparkan sebanyak $n$ kali dan tertarik untuk mengamati banyaknya kemunculan sisi angka. Misalkan banyaknya kemunculan sisi angka dalam $n$ kali percobaan melemparkan sebuah koin dilambangkan dengan $X$. Sebagai contoh misalkan sebuah koin dilambungkan sebanyak $n=2$ kali, banyaknya kemunculan sisi angka yang mungkin $X=0,1,2$.

Selanjutnya andaikan $p$ menyatakan probabilitas kemunculan sisi angka dan $q$ menyatakan probabilitas gagal muncul sisi angka dalam sekali percobaan melemparkan sebuah koin. Andaikan sebuah koin dilempar sebanyak dua kali, maka probabilitas pada pelemparan pertama sama dengan probabilitas pada pelemparan kedua. Dalam hal ini, probabilitas muncul sisi angka pada pelemparan pertama $\left(p=\frac{1}{2}\right)$ sama dengan probabilitas muncul sisi angka pada pelemparan kedua $\left(p=\frac{1}{2}\right)$. Percobaan Bernoulli merupakan suatu percobaan yang hanya memiliki dua hasil (outcome) yang mungkin terjadi, yakni "sukses" atau "gagal", serta probabilitas pada percobaan pertama dengan probabilitas pada percobaan selanjutnya tidak berubah-ubah atau sama. Berikut rumus untuk menghitung probabilitas kemunculan sisi angka tepat $x$ kali dalam $n$ percobaan.

$$
P(X=x)=f(x)=\left(\begin{array}{l}
n \\
x
\end{array}\right) p^{x} q^{n-x}=\frac{n !}{(n-x) ! x !} p^{x} q^{n-x} .
$$

Keterangan : $p$ merupakan probabilitas kejadian sukses dalam satu kali percobaan.

$q$ merupakan probabilitas kejadian gagal dalam satu kali percobaan.

$n$ merupakan jumlah percobaan yang dilakukan.

$X$ merupakan banyaknya kejadian sukses yang terjadi dalam $n$ kali percobaan.

Misalkan sebuah koin dilemparkan sebanyak 4 kali. Andaikan tertarik untuk mengamati banyaknya sisi angka yang muncul dalam pelemparan sebuah koin sebanyak 4 kali. Misalkan $X$ merupakan suatu variabel acak yang menyatakan banyaknya sisi angka yang muncul dalam 4 kali pelemparan sebuah koin. Nilai-nilai $X$ yang mungkin adalah $0,1,2,3,4$. Nilai $X=1$ berarti banyaknya sisi angka yang muncul dalam 4 kali pelemparan sebuah koin sebanyak 1 kali, $X=0$ berarti dalam pelemparan sebuah koin sebanyak 4 kali, tidak ada muncul sisi angka sekalipun. Berikut akan dihitung probabilitas untuk setiap kejadian yang mungkin terjadi. 


\section{Tabel 18.1 Distribusi Probabilitas Variabel Acak $X$}

\begin{tabular}{|c|c|}
\hline$X=x$ & $P(X=x)$ \\
\hline 0 & 0,0625 \\
\hline 1 & 0,25 \\
\hline 2 & 0,375 \\
\hline 3 & 0,25 \\
\hline 4 & 0,0625 \\
\hline Jumlah & 1 \\
\hline
\end{tabular}

Menghitung probabilitas untuk $X=0, X=1, X=2, X=3$, dan $X=4$.

$$
\begin{array}{ll}
P(X=0)=\left(\begin{array}{l}
4 \\
0
\end{array}\right)(0,5)^{0}(0,5)^{4-0} & P(X=2)=\left(\begin{array}{l}
4 \\
2
\end{array}\right)(0,5)^{2}(0,5)^{4-2} \\
P(X=0)=\frac{4 !}{(4-0) ! 0 !}(0,5)^{0}(0,5)^{4-0} & P(X=2)=0,375 \\
P(X=0)=0,0625 & P(X=3)=\left(\begin{array}{l}
4 \\
3
\end{array}\right)(0,5)^{3}(0,5)^{4-3} \\
P(X=1)=\left(\begin{array}{l}
4 \\
1
\end{array}\right)(0,5)^{1}(0,5)^{4-1} & P(X=3)=0,25 \\
P(X=1)=0,25 & P(X=4)=\left(\begin{array}{l}
4 \\
4
\end{array}\right)(0,5)^{4}(0,5)^{4-4} \\
& P(X=4)=0,0625 .
\end{array}
$$

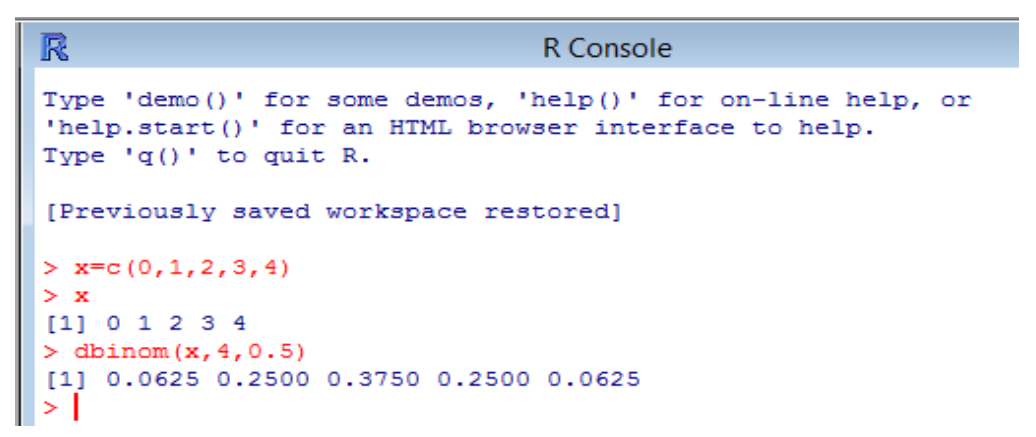

Gambar 18.1

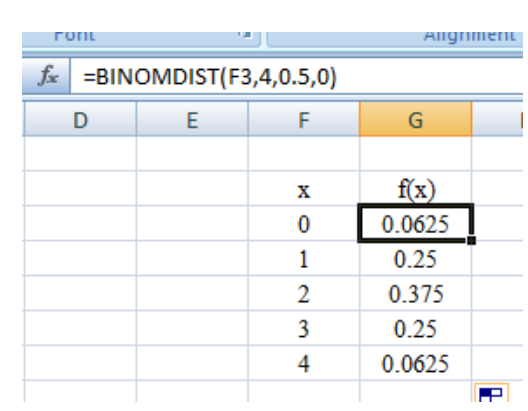

Gambar 18.2

Gambar 18.1 merupakan penyelesaian dalam R, sementara Gambar 18.2 merupakan penyelesaian dalam Microsoft Excel.

\section{Dístríbusi Poísson, Contoh Perhitungan, dan Penyelesaian dalam Mícrosoft Excel dan $\mathcal{R}$}

Distribusi Poisson juga merupakan salah satu distribusi probabilitas diskrit. Hal ini karena variabel acak bersifat terhitung (countable). Seorang ilmuwan matematika dari Prancis memperkenalkan distribusi Poisson bernama Siméon-Dennis Poisson. Berikut diberikan fungsi probabilitas dari distribusi Poisson. 


$$
P(X=x)=f(x)=\frac{\lambda^{x} e^{-\lambda}}{x !}
$$

Keterangan : $X$ merupakan banyaknya suatu kejadian yang sedang diamati, $X=0,1,2, \ldots$ $\lambda$ merupakan nilai rata-rata atau harapan $(\lambda=n p)$.

$e$ merupakan nilai dari bilangan eksponensial, yakni didekati dengan bilangan 2,71828 .

Distribusi binomial dapat didekati atau diaproksimasi dengan pendekatan distribusi Poisson ketika $n \geq 50$ dan $n p<5$ dengan nilai $p$ kecil, yakni mendekati 0 . Sebagai contoh misalkan diketahui probabilitas sebuah bola lampu akan rusak ketika diproduksi di suatu pabrik bola lampu sebesar 0,0005. Dari 4000 bola lampu yang diproduksi di suatu pabrik tertentu, tentukan probabilitas:

$\Rightarrow$ Terdapat tepat 1 bola lampu yang rusak.

$\Rightarrow$ Terdapat tepat 2 bola lampu yang rusak.

$\Rightarrow$ Terdapat 3 bola lampu yang rusak.

Berikut penyelesaian dari permasalahan tersebut.

Tabel 18.2 Probabilitas untuk $X=1, X=2$, dan $X=3$

\begin{tabular}{|c|c|}
\hline$X=x$ & $P(X=x)$ \\
\hline 1 & 0,270671 \\
\hline 2 & 0,270671 \\
\hline 3 & 0,180447 \\
\hline
\end{tabular}

Diketahui $n=4000$ dan $p=0,0005$ sehingga $\lambda=(4000)(0,0005)=2$. Berikut akan dihitung probabilitas untuk $X=1, X=2, X=3$.

$P(X=1)=\frac{2^{1} 2,71828^{-2}}{1 !}$

$$
P(X=2)=0,270671
$$

$P(X=1)=\frac{(1)(0,135335)}{1}$

$$
P(X=3)=\frac{2^{3} 2,71828^{-2}}{3 !}
$$

$P(X=1)=0,27067$

$P(X=3)=0,180447$.

$P(X=2)=\frac{2^{2} 2,71828^{-2}}{2 !}$

Perhatikan bahwa dari 4000 bola lampu yang diproduksi di suatu pabrik tertentu, probabilitas terdapat tepat 1 bola lampu rusak sebesar 0,27067, tepat 2 bola lampu yang rusak sebesar 0,270671, dan terdapat tepat 3 bola lampu yang rusak sebesar 0,180447. 


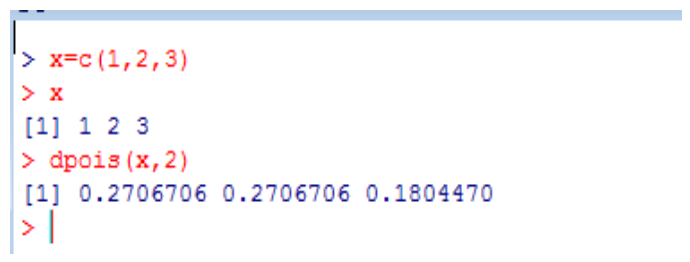

Gambar 18.3

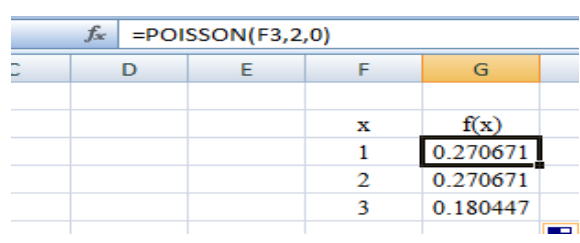

Gambar 18.4

Gambar 18.3 merupakan penyelesaian dalam R, sementara Gambar 18.4 merupakan penyelesaian dalam Microsoft Excel.

\section{Distríbusi $\mathcal{N o r m a l , ~ C o n t o h ~ P e r h i t u n g a n , ~ d a n ~ P e n y e l e s a i a n ~ d a l a m ~}$ Mícrosoft Excel dan $\mathcal{R}$}

Beberapa fenomena dalam kehidupan mendekati kurva dari distribusi normal. Sebagai contoh fenomena-fenoma yang mendekati kurva dari distribusi normal seperti fenomena mengenai nilai IQ manusia, tinggi badan, berat badan, dan sebagainya. Distribusi normal termasuk ke dalam salah satu distribusi probabilitas nondiskrit. Dalam distribusi normal, variabel acak dinyatakan dalam interval dan bersifat tidak dapat dihitung (uncountable). Sebagai contoh variabel acak $X$ dinyatakan dalam interval $0 \leq X \leq 1$, dengan $X \in \mathbb{R}$. Berikut diberikan fungsi probabilitas dari distribusi normal.

$$
P(X=x)=f(x)=\frac{1}{\sigma \sqrt{2 \pi}} e^{-\frac{(x-\mu)^{2}}{2 \sigma^{2}}}
$$

Perhatikan bahwa $\mu$ merupakan rata-rata populasi, sedangkan $\sigma$ merupakan standar deviasi populasi. Gambar 18.5 merupakan contoh dari kurva distribusi normal.

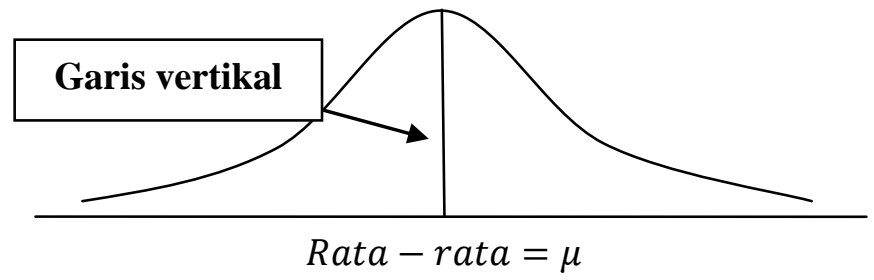

Gambar 18.5

Dalam kurva distribusi normal, garis vertikal yang di tarik dari rata-rata $(\mu)$ membuat luas daerah sisi kiri sama dengan luas daerah sisi kanan, sehingga distribusi normal bersifat simetri. Luas di bawah kurva dari distribusi normal adalah 1, sehingga luas bagian kiri dan luas bagian kanan terhadap rata-rata, masing-masing adalah 0,5 (Gambar 18.6).

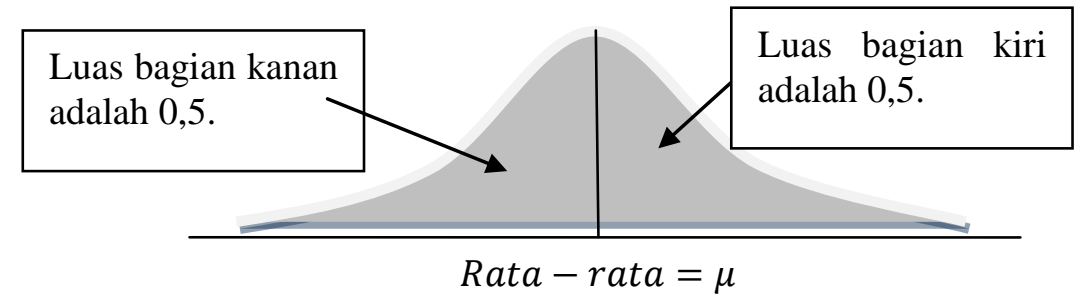

Gambar 18.6 
Dalam distribusi normal terdapat dua parameter, yakni rata-rata $(\mu)$ dan standar deviasi $(\sigma)$. Nilai standar deviasi selalu lebih besar dari 0 atau $\sigma>0$. Suatu distribusi normal dikatakan distribusi normal standar (standard normal distribution) jika $\mu=0$ dan $\sigma=1$. Luas daerah di bawah kurva dari distribusi normal standar dapat dihitung dengan menggunakan tabel distribusi normal standar. Jika dalam distribusi normal $\mu \neq 0$ dan $\sigma \neq 1$, maka distribusi normal tersebut dapat ditransformasi atau diubah ke dalam distribusi normal standar (standardizing a normal distribution).

Andaikan variabel acak dari distribusi normal dilambangkan dengan $X$. Berikut rumus untuk mentransformasi variabel acak normal $X$ menjadi variabel acak normal $Z$ terstandarisasi.

$$
Z=\frac{X-\mu}{\sigma}
$$

Variabel acak normal $Z$ terstandarisasi yang merupakan hasil transformasi dari variabel acak normal $X$, mempunyai $\mu=0$ dan $\sigma=1$. Tabel distribusi normal standar menunjukkan luas daerah antara $Z=0$ sampai $Z=z_{0}$ atau $P\left(0<Z<z_{0}\right)$. Andaikan $X$ merupakan variabel acak yang berdistribusi normal dengan rata-rata 40 dan standar deviasi 5. Berikut akan dikonversi atau ditransformasi $X=42$ dan $X=30$ menjadi nilai-nilai variabel acak normal terstandarisasi.

$$
Z=\frac{42-40}{5}=0,4
$$
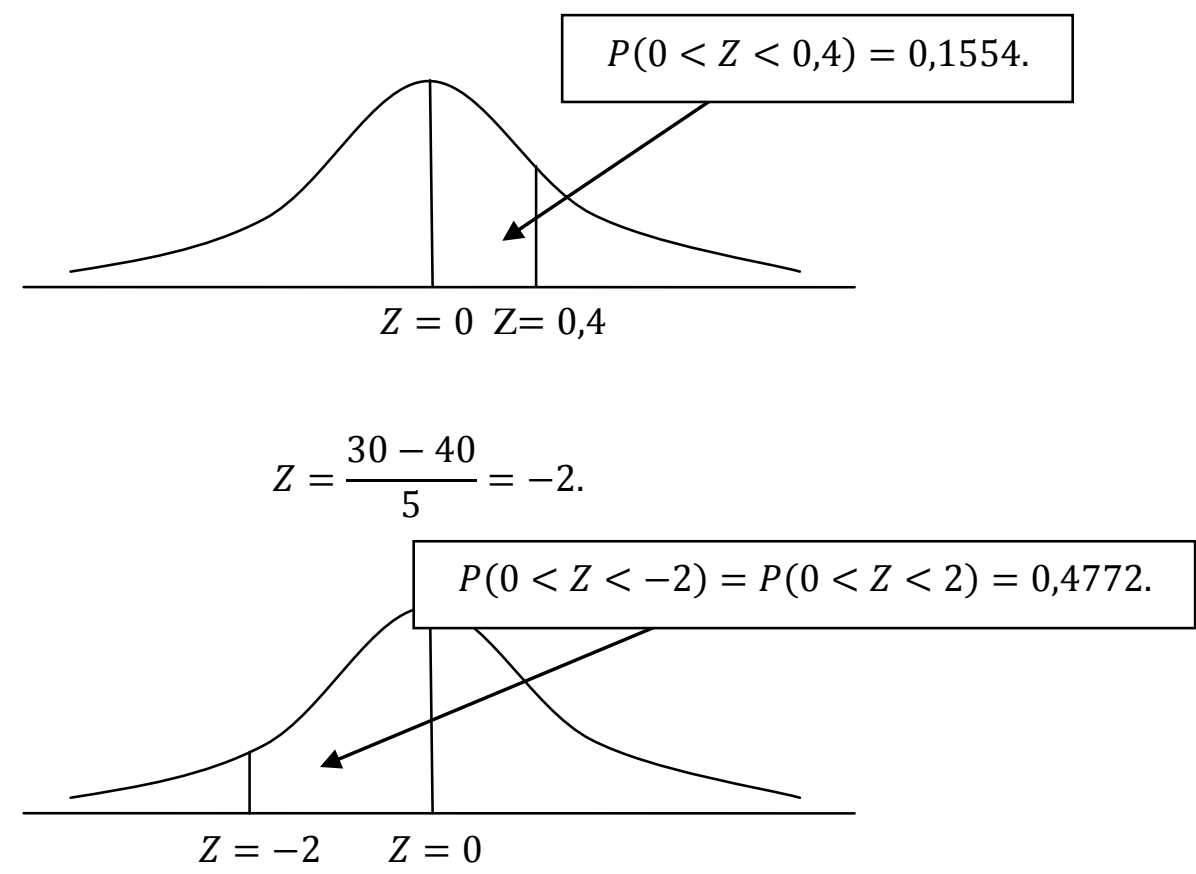

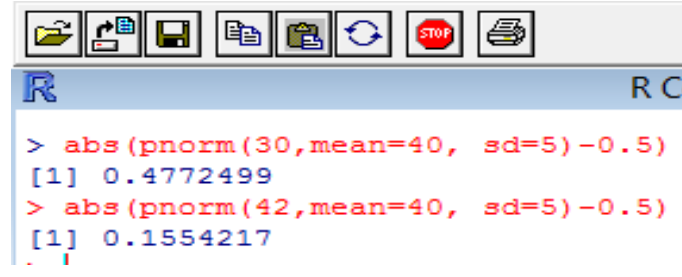

Gambar 18.7

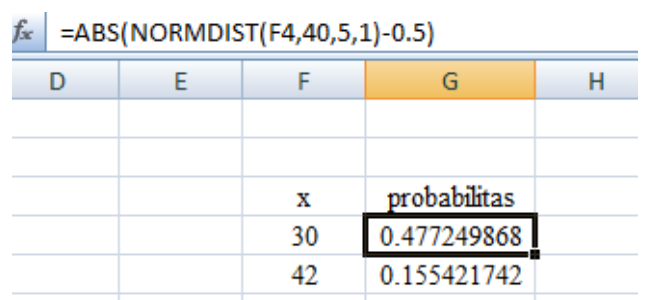

Gambar 18.8 
Gambar 18.7 merupakan penyelesaian dalam R, sementara Gambar 18.8 merupakan penyelesaian dalam Microsoft Excel.

\section{Distríbusi Geometri, Contoh Perhitungan, dan Penyelesaian dalam $\mathcal{R}$}

Andaikan percobaan yang saling bebas (percobaan Bernoulli) dilakukan berulang kali. Misalkan $p$ menyatakan probabilitas terjadinya sukses dan $q=1-p$ menyatakan probabilitas terjadinya gagal untuk sekali percobaan. Misalkan $X$ merupakan variabel acak yang menyatakan banyaknya percobaan yang dilakukan sampai terjadi sukses pertama kali. Maka $X$ disebut variabel acak geometri (geometric random variable) dengan fungsi probabilitas sebagai berikut.

$$
P(X=x)=f(x)=(1-p)^{x-1} p \quad ; x=1,2, \ldots
$$

Sebagai contoh berikut akan dihitung peluang/probabilitas seorang melemparkan sekeping koin yang setimbang memerlukan 4 lemparan sampai diperolehnya sisi gambar. Diketahui peluang untuk muncul sisi gambar $(p)$ dalam sekali pelemparan sekeping koin yang setimbang adalah 0,5 . Maka

$$
P(X=4)=(1-0,5)^{4-1}(0,5)=0,0625
$$

Terdapat 16 kejadian yang mungkin, yakni :

$\begin{array}{lll}\text { AAAA } & \text { AAGG } & \text { AGGG } \\ \text { AAAG } & \text { AGAG } & \text { GAGG } \\ \text { AAGA } & \text { AGGA } & \text { GGAG } \\ \text { AGAA } & \text { GGAA } & \text { GGGA } \\ \text { GAAA } & \text { GAAG } & \text { GGGG } \\ & \text { GAGA } & \end{array}$

Kejadian yang diinginkan, yakni pada saat pelemparan keempat terjadi kejadian sukses pertama kali.

Peluang seseorang melemparkan sekeping koin yang setimbang memerlukan 4 lemparan sampai diperolehnya sisi gambar pertama kali adalah

$$
P(A A A G)=\frac{1}{16}=0,0625
$$

Andaikan memerlukan 3 lemparan sampai diperolehnya sisi gambar pertama kali, maka

$$
P(X=3)=(1-0,5)^{3-1}(0,5)=0,125
$$

Terdapat 8 kejadian yang mungkin, yakni :

Kejadian yang diinginkan, yakni pada saat pelemparan ketiga terjadi kejadian sukses pertama kali.
AAA

AAG

AGA

GAA
GAG

AGG

GGG

Peluang seseorang melemparkan sekeping koin yang setimbang memerlukan 3 lemparan sampai diperolehnya sisi gambar pertama kali adalah 


$$
P(A A G)=\frac{1}{8}=0,125
$$

Andaikan memerlukan 2 lemparan sampai diperolehnya sisi gambar pertama kali, maka

$$
P(X=3)=(1-0,5)^{2-1}(0,5)=0,25 \text {. }
$$

Andaikan memerlukan 1 lemparan sampai diperolehnya sisi gambar pertama kali, maka

$$
P(X=3)=(1-0,5)^{2-1}(0,5)=0,5 \text {. }
$$

Berikut disajikan hasil perhitungan dan grafik berdasarkan SPSS (Gambar 18.9 dan Gambar 18.10).

\begin{tabular}{|r|r|r|r}
\hline & $x$ & $f x$ & \\
\hline 1 & 1 & 0.5000000 & \\
\hline 2 & 2 & 0.2500000 & \\
\hline 3 & 3 & 0.1250000 & \\
\hline 4 & 4 & 0.0625000 & \\
\hline 5 & 5 & 0.0312500 & \\
\hline 6 & 6 & 0.0156250 & \\
\hline 7 & 7 & 0.0078125 & \\
\hline 8 & 8 & 0.0039063 & \\
\hline 9 & 9 & 0.0019531 & \\
\hline 10 & 10 & 0.0009766 & \\
\hline
\end{tabular}

\section{Gambar 18.9}

Dalam distribusi geometri, probabilitas dari nilai variabel acak $x$ adalah $(1-p)$ kali dari probabilitas nilai variabel acak $x-1$. Sebagai contoh misalkan probabilitas terjadinya sukses dalam sekali percobaan adalah $p=0,1$. Maka

$$
\begin{gathered}
P(X=2)=(1-p)^{2-1}(0,1) \\
=(1-0,1)^{2-1}(0,1) \\
=(0,9)(0,1) .
\end{gathered}
$$

Sama saja dengan

$$
\begin{gathered}
P(X=1)=(1-p)^{1-1}(0,1) \\
=0,1 \\
P(X=2)=(1-p)(P(X=1)) \\
=(1-p)(0,1) \\
P(X=2)=(0,9)(0,1) .
\end{gathered}
$$




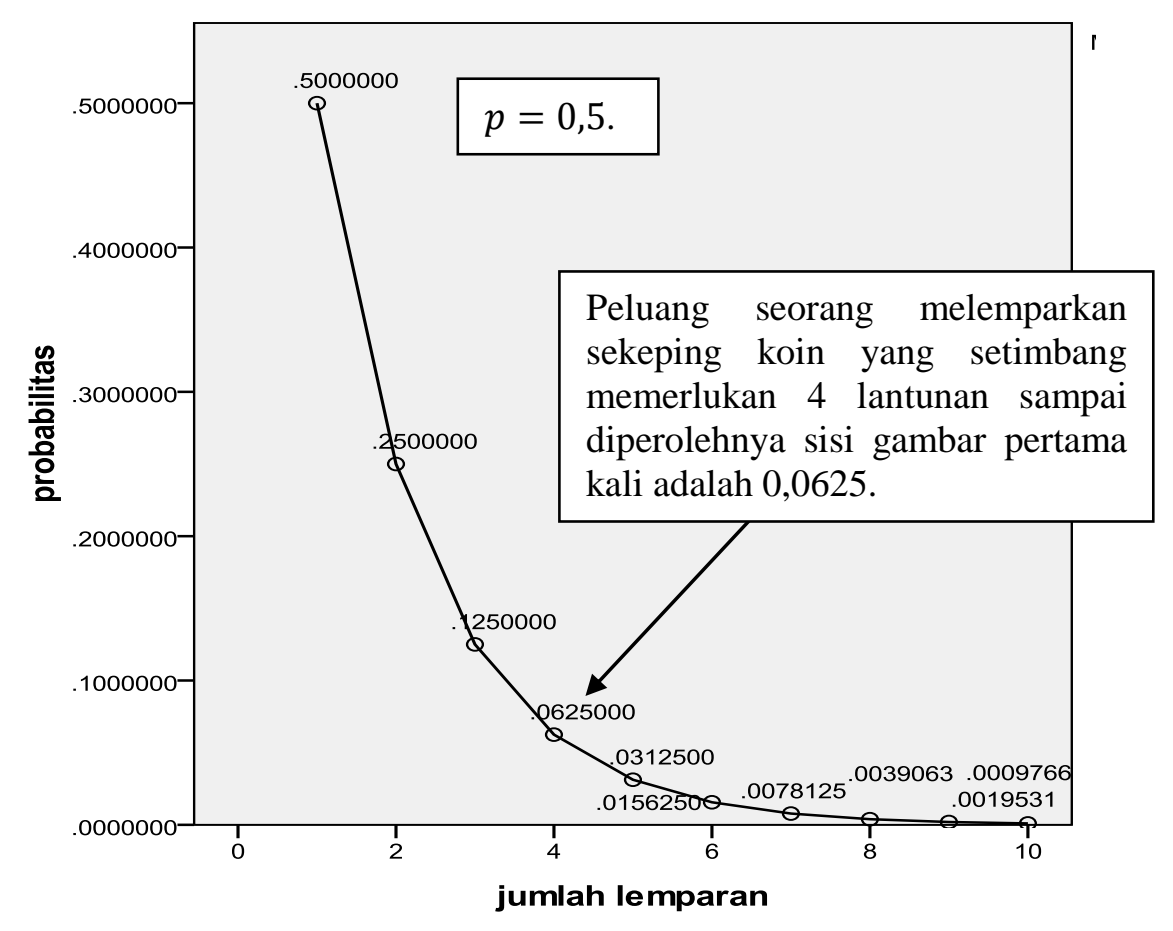

Gambar 18.10

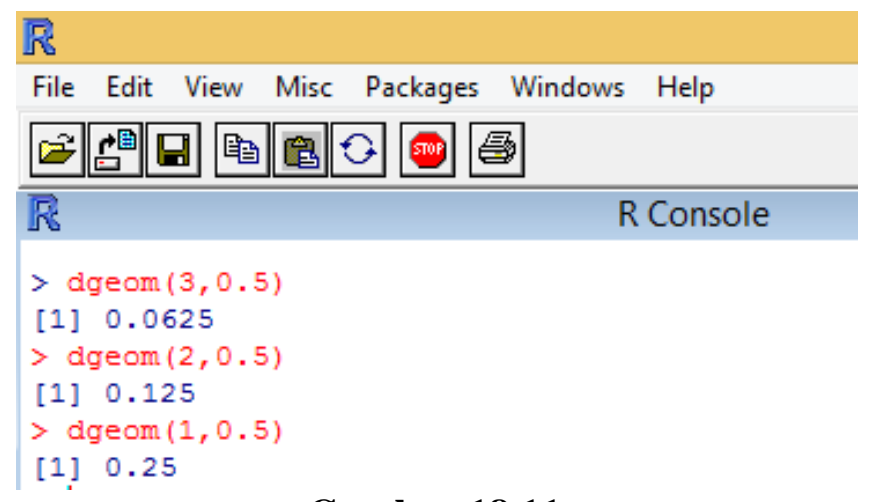

Gambar 18.11

Gambar 18.11 merupakan penyelesaian dalam R.

\section{Distríbusi Binomial Negatíf, Contoh Perhitungan, dan Penyelesaian dalam $\mathcal{R}$}

Andaikan percobaan yang saling bebas (percobaan Bernoulli) dilakukan berulang kali. Misalkan $p$ menyatakan probabilitas terjadinya sukses dan $q=1-p$ menyatakan probabilitas terjadinya gagal untuk sekali percobaan. Misalkan $X$ merupakan variabel acak yang menyatakan banyaknya percobaan yang dibutuhkan sampai sukses ke- $k$ terjadi. Maka $X$ disebut variabel acak binomial negatif (binomial negative random variable) dengan fungsi probabilitas sebagai berikut.

$$
P(X=x)=f(x)=\left(\begin{array}{l}
x-1 \\
r-1
\end{array}\right)(1-p)^{x-r} p^{r} \quad ; x=r, r+1, r+2, \ldots
$$


Sebagai contoh berikut akan dihitung peluang bahwa seseorang yang melemparkan sebuah uang logam akan mendapat sisi gambar untuk kedua kalinya pada lemparan ketiga. Diketahui probabilitas muncul sisi gambar $(p)$ dalam sekali pelemparan sebuah uang logam adalah $p=\frac{1}{2}$. Maka

$$
\begin{gathered}
P(X=x)=f(x)=\left(\begin{array}{l}
x-1 \\
r-1
\end{array}\right)(1-p)^{x-r} p^{r} \\
P(X=3)=\left(\begin{array}{l}
3-1 \\
2-1
\end{array}\right)\left(1-\frac{1}{2}\right)^{3-2}\left(\frac{1}{2}\right)^{2}=2\left(\frac{1}{2}\right)\left(\frac{1}{2}\right)^{2}=\frac{2}{8}=\frac{1}{4}=0,25 .
\end{gathered}
$$

Terdapat $2^{3}=8$ kejadian yang mungkin, yakni :

$\begin{array}{ll}\text { AAA } & \text { GGG } \\ \text { AAG } & \text { GGA } \\ \text { AGA } & \text { GAG } \\ \text { GAA } & \text { AGG }\end{array}$

Peluang seseorang melemparkan sebuah uang logam akan mendapat sisi gambar untuk kedua kalinya pada lantunan ketiga adalah

$$
P(A G G)+P(G A G)=\frac{1}{8}+\frac{1}{8}=\frac{2}{8}=\frac{1}{4}=0,25 .
$$

Contoh lain berikut akan dihitung peluang seseorang yang melemparkan dua uang logam sekaligus akan mendapat semuanya sisi gambar untuk kedua kalinya pada lantunan ketiga. Diketahui probabilitas muncul semuanya sisi gambar $(p)$ dalam sekali pelemparan dua uang logam adalah

$$
\begin{aligned}
& \text { AA } \quad \text { GA } \\
& \text { AG } \\
& p=\frac{1}{4} .
\end{aligned}
$$

Maka peluang seseorang yang melemparkan dua uang logam sekaligus akan mendapat semuanya sisi gambar untuk kedua kalinya pada lemparan ketiga adalah

$$
\begin{gathered}
P(X=x)=f(x)=\left(\begin{array}{l}
x-1 \\
r-1
\end{array}\right)(1-p)^{x-r} p^{r} \\
P(X=3)=\left(\begin{array}{l}
3-1 \\
2-1
\end{array}\right)\left(1-\frac{1}{4}\right)^{3-2}\left(\frac{1}{4}\right)^{2}=2\left(\frac{3}{4}\right)\left(\frac{1}{4}\right)^{2}=\frac{6}{64}=0,09375 .
\end{gathered}
$$

Pelemparan I Pelemparan II Pelemparan III

$\begin{array}{lll}\text { AA } & \text { AA } & \text { AA } \\ \text { AG } & \text { AG } & \text { AG } \\ \text { GA } & \text { GA } & \text { GA } \\ \text { GG } & \text { GG } & \text { GG }\end{array}$


Terdapat $4^{3}=64$ kejadian yang mungkin, yakni :

$$
\begin{aligned}
& \mathrm{AA} \rightarrow \mathrm{AA} \rightarrow \mathrm{AA} \\
& \mathrm{AA} \rightarrow \mathrm{AA} \rightarrow \mathrm{AG} \\
& \mathrm{AA} \rightarrow \mathrm{AA} \rightarrow \mathrm{GA} \\
& \mathrm{AA} \rightarrow \mathrm{AA} \rightarrow \mathrm{GG} \\
& \mathrm{AA} \rightarrow \mathrm{AG} \rightarrow \mathrm{AA} \\
& \mathrm{AA} \rightarrow \mathrm{AG} \rightarrow \mathrm{AG} \\
& \mathrm{AA} \rightarrow \mathrm{AG} \rightarrow \mathrm{GA} \\
& \mathrm{AA} \rightarrow \mathrm{AG} \rightarrow \mathrm{GG}
\end{aligned}
$$

dan seterusnya. Kejadian yang diinginkan sebagai berikut.

$\left.\begin{array}{lll}\text { AA } & \text { GG } & \text { GG } \\ \text { AG } & \text { GG } & \text { GG } \\ \text { GA } & \text { GG } & \text { GG } \\ \text { GG } & \text { AA } & \text { GG } \\ \text { GG } & \text { AG } & \text { GG }\end{array}\right\} \begin{array}{llll}\text { Terdapat } & 6 & \text { kejadian } & \text { yang } \\ \text { diinginkan. } & & \\ \text { GG } & \text { GA } & \text { GG }\end{array}$

Peluang seseorang yang melemparkan dua uang logam sekaligus akan mendapat semuanya sisi gambar untuk kedua kalinya pada lantunan ketiga adalah

$$
\frac{6}{64}=0,09375
$$

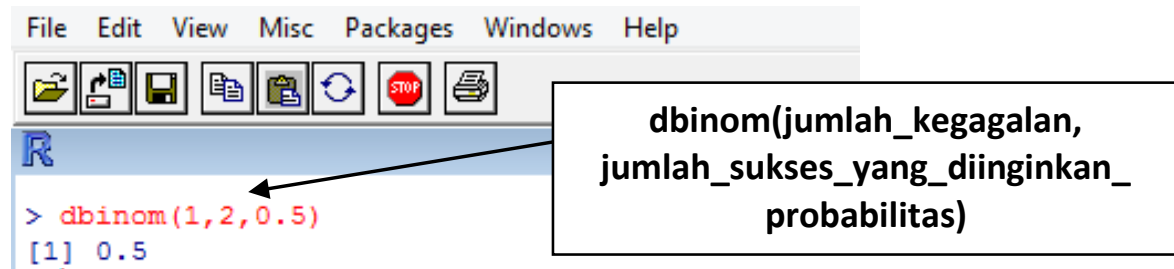

|

Gambar 18.12

Gambar 18.12 merupakan penyelesaian dalam R.

\section{Distribusi Hipergeometrí, Contoh Perhitungan, dan Penyelesaian dalam $\mathcal{R}$}

Andaikan suatu kotak berisi $p$ bola putih kecil dan $h$ bola hitam kecil. Kemudian misalkan dilakukan $n$ percobaan pengambilan suatu bola kecil di dalam kotak tersebut secara acak, warnanya dicatat, namun bola tersebut tidak dikembalikan ke dalam kotak. Misalkan $X$ merupakan variabel acak yang menyatakan jumlah bola putih kecil yang terpilih dalam $n$ percobaan. Maka $X$ disebut variabel acak hipergeometri (hypergeometric random variable) dengan fungsi probabilitas sebagai berikut. 


$$
P(X=x)=\frac{\left(\begin{array}{l}
p \\
x
\end{array}\right)\left(\begin{array}{c}
h \\
n-x
\end{array}\right)}{\left(\begin{array}{c}
p+h \\
n
\end{array}\right)}, X=\max (0, n-h), \ldots, \min (n, p)
$$

Andaikan sebuah kotak berisi $p=3$ bola putih kecil dan $h=1$ bola kecil hitam. Suatu percobaan dilakukan di mana satu bola kecil dipilih secara acak dan warnanya diamati, namun bola kecil tersebut tidak diganti/dikembalikan. Berikut akan dihitung probabilitas bahwa dalam $n=3$ kali percobaan, $X=2$ bola putih kecil akan terpilih.

$$
\begin{gathered}
P(X=x)=\frac{\left(\begin{array}{l}
p \\
x
\end{array}\right)\left(\begin{array}{c}
h \\
n-x
\end{array}\right)}{\left(\begin{array}{c}
p+h \\
n
\end{array}\right)} \\
P(X=2)=\frac{\left(\begin{array}{l}
3 \\
2
\end{array}\right)\left(\begin{array}{c}
1 \\
3-2
\end{array}\right)}{\left(\begin{array}{c}
3+1 \\
3
\end{array}\right)} \\
P(X=2)=f(2)=\frac{\left(\begin{array}{l}
3 \\
2
\end{array}\right)\left(\begin{array}{l}
1 \\
1
\end{array}\right)}{\left(\begin{array}{l}
4 \\
3
\end{array}\right)}=\frac{3 \times 1}{4}=\frac{3}{4}=0,75 .
\end{gathered}
$$

Kejadian-kejadian yang mungkin adalah sebagai berikut.

$$
P, P, H ; \quad P, H, P ; \quad H, P, P ; \quad P, P, P .
$$

Kejadian yang diinginkan atau diharapkan

$$
P, P, H ; \quad P, H, P ; \quad H, P, P \text {. }
$$

Probabilitas bahwa dalam $n=3$ kali percobaan, $x=2$ bola putih kecil akan terpilih adalah

$$
\frac{3}{4}=0,75
$$

Gambar 18.13 merupakan penyelesaian dalam R.

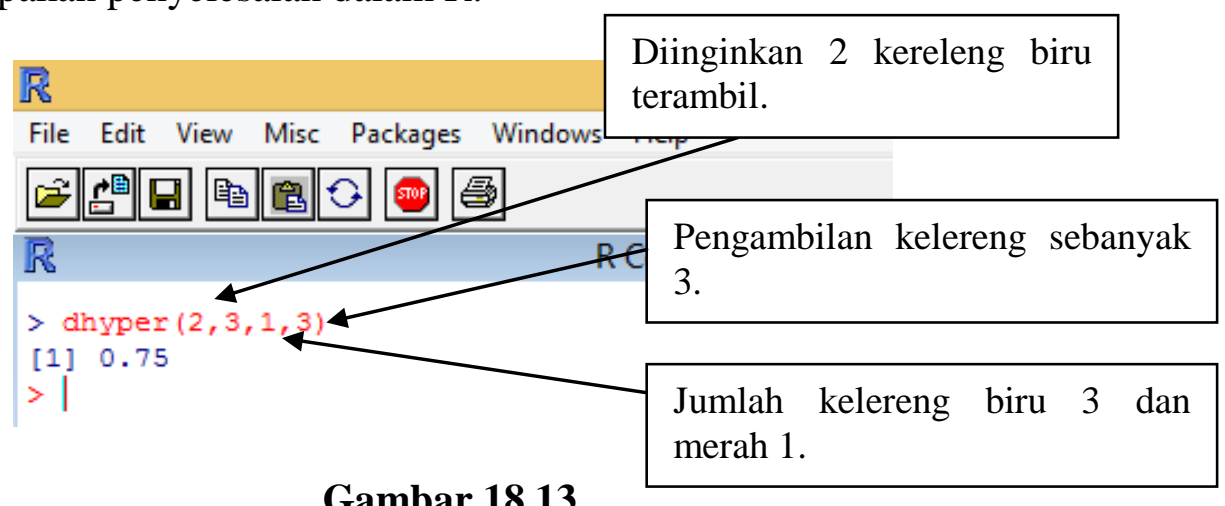

Gambar 18.13 


\section{BAB 19}

\section{REGRESI NONLINEAR SEDERHANA}

\section{Sekilas Regresi Nonlinear Sederhana}

Pada Bab 10 telah dibahas mengenai regresi linear berganda. Regresi linear digunakan apabila hubungan antara variabel bebas dengan variabel tak bebas bersifat linear. Namun, regresi yang digunakan jika hubungan antara variabel bebas dengan variabel tak bebas bersifat tak linear adalah regresi nonlinear. Regresi nonlinear yang telah dibahas adalah regresi logistik (Bab 11).

Misalkan diberikan data seperti pada Tabel 19.1.

\section{Tabel 19.1}

\begin{tabular}{|c|c|c|c|c|c|}
\hline$X$ & $Y$ & $X$ & $Y$ & $X$ & $Y$ \\
\hline 1 & 1,5 & 6 & 34,9 & 11 & 120 \\
\hline 2 & 4.2 & 7 & 50,65 & 12 & 144,9 \\
\hline 3 & 8,6 & 8 & 63,6 & 13 & 169,8 \\
\hline 4 & 17 & 9 & 80 & 14 & 198 \\
\hline 5 & 26 & 10 & 102 & 15 & 227 \\
\hline
\end{tabular}

Berdasarkan data pada Tabel 19.1, misalkan $X$ merupakan variabel bebas, dan $Y$ merupakan variabel tak bebas. Perhatikan Gambar 19.1.

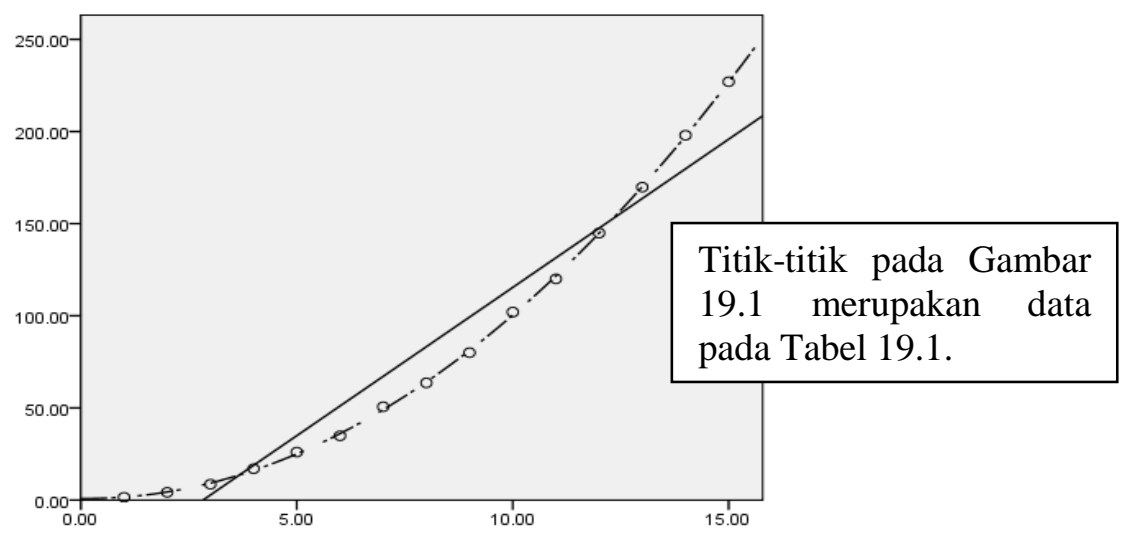

\section{Gambar 19.1}

Pada Gambar 19.1, setiap titik menyatakan data pada Tabel 19.1. Kemudian titik-titik tersebut didekati atau dihampiri oleh dua persamaan regresi, yakni persamaan regresi linear yang berupa garis lurus, dan persamaan regresi nonlinear yang berupa garis putus-putus. Perhatikan bahwa persamaan regresi yang cocok digunakan untuk mengestimasi variabel tak bebas $Y$ berdasarkan data pada Tabel 19.1 adalah persamaan regresi nonlinear. Hal ini karena pada persamaan regresi nonlinear hampir mengenai seluruh titik-titik secara tepat pada Gambar 19.1. Dengan kata lain, nilai standard error dari estimasi pada persamaan regresi nonlinear lebih kecil dibandingkan nilai standard error dari estimasi pada persamaan regresi linear. 
Dalam bab ini akan dipaparkan tujuh jenis dari regresi nonlinear sederhana, yakni:

$\Rightarrow$ Regresi nonlinear sederhana kuadratik.

$\Rightarrow$ Regresi nonlinear sederhana power.

$\Rightarrow$ Regresi nonlinear sederhana eksponensial.

$\Rightarrow$ Regresi nonlinear sederhana inverse.

$\Rightarrow$ Regresi nonlinear sederhana logaritma.

$\Rightarrow$ Regresi nonlinear sederhana compound.

$\Rightarrow$ Regresi nonlinear sederhana kubik.

\section{Regresi Nonlinear Sederhana Kuadratik dan Contoh Perhitungan}

Regresi nonlinear sederhana kuadratik merupakan suatu teknik statistika untuk membuat persamaan yang menjelaskan hubungan antara variabel bebas dan variabel tak bebas, di mana persamaan yang dihasilkan berupa persamaan kuadratik. Pada persamaan regresi sederhana hanya menggunakan satu variabel bebas. Secara umum, persamaan regresi nonlinear sederhana kuadratik memiliki bentuk

$$
\widehat{Y}=a X^{2}+b X+c .
$$

Nilai $a, b$, dan $c$ dihitung dengan menyelesaikan sistem persamaan berikut.

$$
\begin{gathered}
\sum Y=a n+b \sum X+c \sum X^{2} \\
\sum X Y=a \sum X+b \sum X^{2}+c \sum X^{3} \\
\sum X^{2} Y=a \sum X^{2}+b \sum X^{3}+c \sum X^{4} .
\end{gathered}
$$

Berikut diberikan contoh gambar dari kurva persamaan kuadratik (Gambar 19.2).
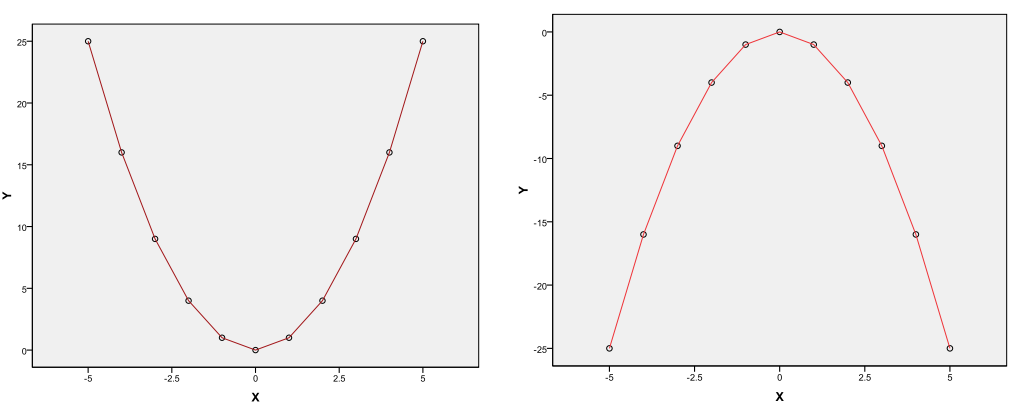

Gambar 19.2

Perhatikan data pada Tabel 19.2. Berdasarkan data pada Tabel 19.2, misalkan $Y$ merupakan variabel tak bebas dan $X$ merupakan variabel bebas. Data pada Tabel 19.2 disajikan dalam grafik seperti pada Gambar 19.3. Pada Gambar 19.3, sebaran titik-titik berpola kuadratik, sehingga hubungan antara variabel bebas $X$ dan variabel tak bebas $Y$ berdasarkan data Tabel 19.2 akan didekati dengan kurva persamaan kuadratik. 


\section{Tabel 19.2}

\begin{tabular}{|c|c|}
\hline$X$ & $Y$ \\
\hline-5 & 23 \\
\hline-4 & 15 \\
\hline-3 & 10 \\
\hline-2 & 4,9 \\
\hline-1 & 2 \\
\hline 0 & 1 \\
\hline 1 & 1,5 \\
\hline 2 & 3,5 \\
\hline 3 & 10,9 \\
\hline 4 & 17,4 \\
\hline 5 & 23,7 \\
\hline
\end{tabular}

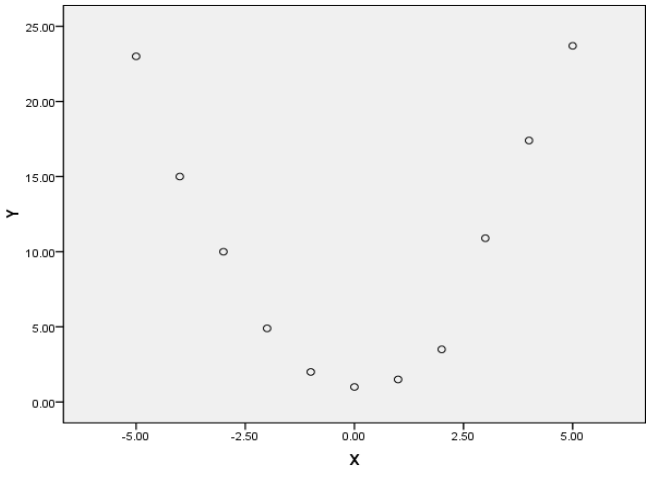

Gambar 19.3

Berikut akan dihitung nilai $a, b$, dan $c$ untuk persamaan regresi nonlinear sederhana kuadratik.

\section{Tabel 19.3}

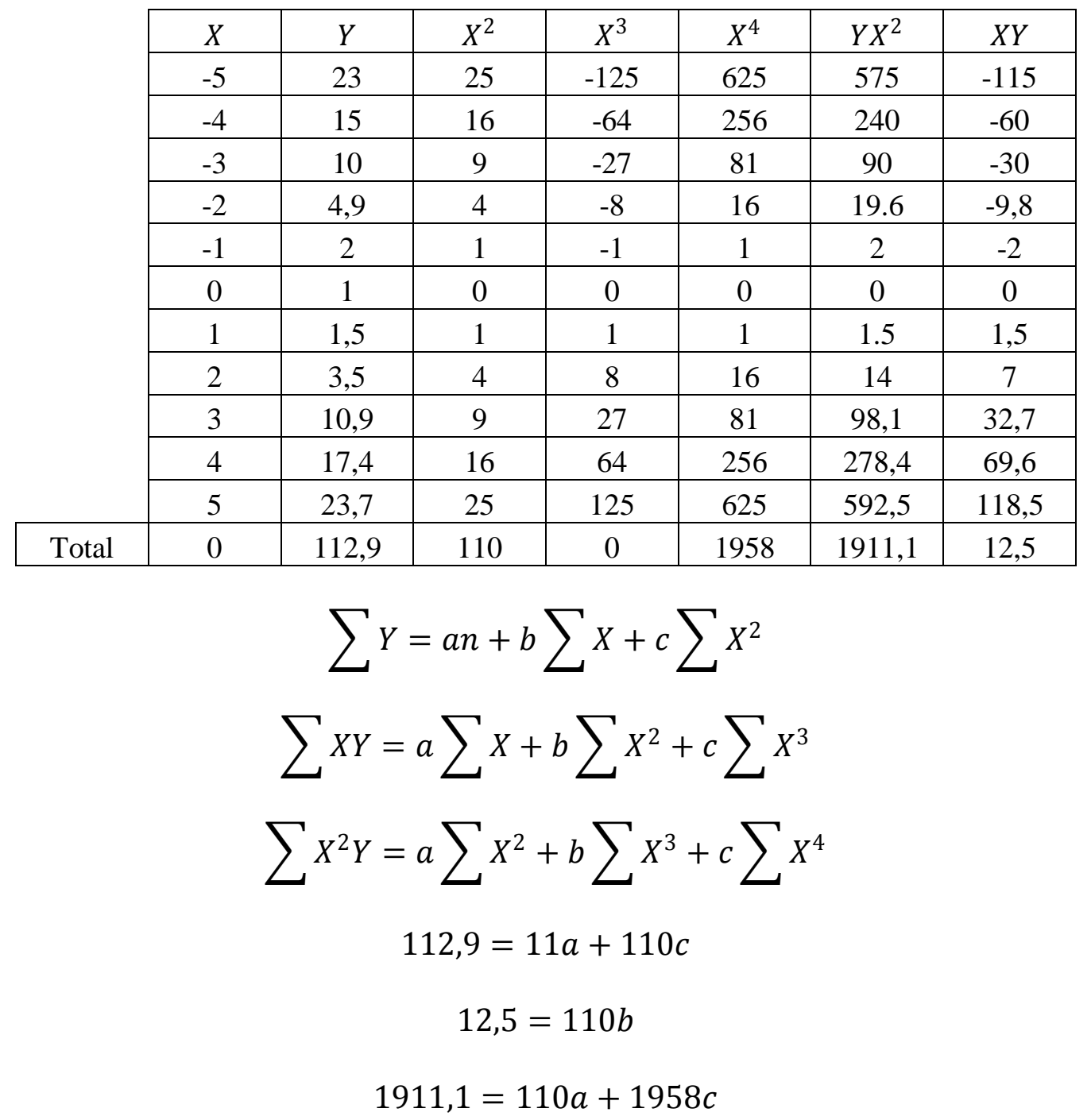


Dengan menyelesaian sistem persamaan tersebut, maka diperoleh nilai $a=1,1483, b=$ 0,1136 , dan $c=0,9115$. Persamaan regresi nonlinear sederhana kuadratik diperoleh

$$
\widehat{Y}=1,1483 X^{2}+0,1136 X+0,9115 .
$$

Gambar 19.4 merupakan grafik dari persamaan regresi nonlinear $\hat{Y}=1,1483 X^{2}+$ $0,1136 X+0,9115$.

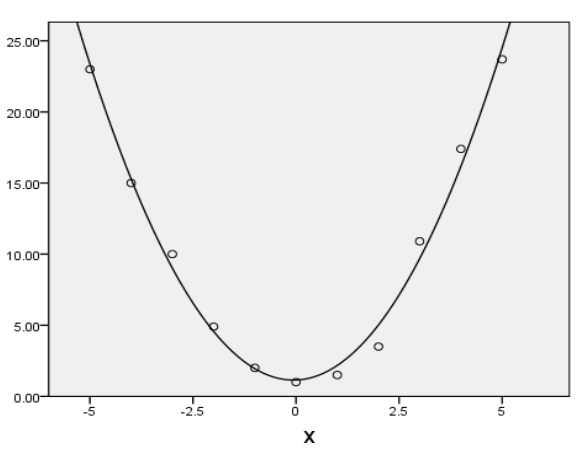

Gambar 19.4

\section{Regresi JNonlinear Sederhana Power dan Contoh Perhitungan}

Regresi nonlinear sederhana power merupakan suatu teknik statistika untuk membuat suatu persamaan yang menerangkan hubungan antara variabel bebas dan variabel tak bebas, di mana persamaan yang dihasilkan berupa persamaan power. Pada persamaan regresi sederhana hanya menggunakan satu variabel bebas. Secara umum, persamaan regresi nonlinear sederhana power memiliki bentuk

$$
\widehat{Y}=a X^{b}
$$

Untuk menghitung nilai $a$ dan $b$, terlebih dahulu mentransformasi bentuk power ke bentuk linear. Berikut transformasi dari bentuk power ke bentuk linear.

$$
\begin{gathered}
Y=a X^{b} \\
\ln Y=\ln \left(a X^{b}\right) \\
\ln Y=\ln a+\ln X^{b} \\
\ln Y=\ln a+b \ln X .
\end{gathered}
$$

Misalkan $y=\ln Y$ dan $x=\ln X$, maka

$$
\begin{gathered}
\ln Y=\ln a+b \ln X \\
y=\ln a+b x .
\end{gathered}
$$


Perhatikan bahwa $y=\ln a+b x$ merupakan bentuk linear. Berikut diberikan contoh gambar dari kurva persamaan power.
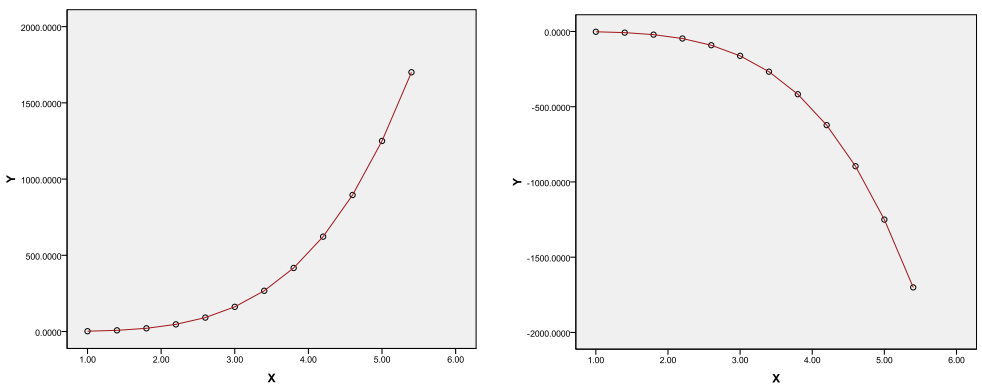

\section{Gambar 19.5}

Misalkan diberikan data seperti pada Tabel 19.4.

\section{Tabel 19.4}

\begin{tabular}{|c|c|c|c|}
\hline$X$ & $Y$ & $X$ & $Y$ \\
\hline 1 & 1 & 5 & 1100 \\
\hline 2 & 28 & 6 & 1900 \\
\hline 3 & 129 & 7 & 3680 \\
\hline 4 & 390 & 8 & 6150 \\
\hline
\end{tabular}

Berdasarkan data pada Tabel 19.4, misalkan $Y$ adalah variabel tak bebas dan $X$ adalah variabel bebas. Data pada Tabel 19.4 disajikan dalam grafik seperti pada Gambar 19.6.

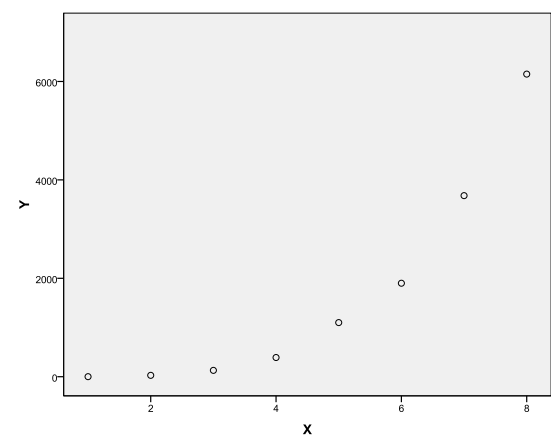

Gambar 19.6

Pada Gambar 19.6, pola sebaran dari titik-titik menyerupai kurva persamaan power, sehingga hubungan antara variabel bebas $X$ dan variabel tak bebas $Y$ pada data Tabel 19.4 akan didekati dengan kurva persamaan power. Berikut akan dihitung nilai $a$ dan $b$ dari persamaan regresi nonlinear sederhana power.

$$
\begin{gathered}
b=\frac{n\left(\sum x y\right)-\left(\sum x\right)\left(\sum y\right)}{n\left(\sum x^{2}\right)-\left(\sum x\right)^{2}} \\
b=\frac{(8)(74,83638)-(10,6046)(45,64571)}{(8)(17,52055)-(10,6046)^{2}} \\
b=4,1375383
\end{gathered}
$$




$$
\begin{aligned}
\ln a & =\frac{\left(\sum y\right)-b\left(\sum x\right)}{n} \\
\ln a=\frac{45,64571-(1,826935415)(10,6046)}{8} & \\
\ln a= & 0,221170823 \\
a & =e^{0,221170823} \\
a & =1,2475 .
\end{aligned}
$$

Tabel 19.5

\begin{tabular}{|c|c|c|c|c|c|c|c|}
\hline$X$ & $Y$ & $x=\ln X$ & $y=\ln Y$ & $x y$ & $x^{2}$ & $y^{2}$ \\
\cline { 2 - 8 } & 1 & 1 & 0 & 0 & 0 & 0 & 0 \\
\hline 2 & 28 & 0,693147 & 3,332205 & 2,309708 & 0,480453 & 11,10359 \\
\hline 3 & 129 & 1,098612 & 4,859812 & 5,33905 & 1,206949 & 23,61778 \\
\hline 4 & 390 & 1,386294 & 5,966147 & 8,270836 & 1,921812 & 35,59491 \\
\hline & 5 & 1100 & 1,609438 & 7,003065 & 11,271 & 2,59029 & 49,04293 \\
\hline & 6 & 1900 & 1,791759 & 7,549609 & 13,52708 & 3,210402 & 56,9966 \\
\hline & 7 & 3680 & 1,94591 & 8,210668 & 15,97722 & 3,786566 & 67,41507 \\
\hline & 8 & 6150 & 2,079442 & 8,724207 & 18,14148 & 4,324077 & 76,11179 \\
\hline Total & 36 & 13378 & 10,6046 & 45,64571 & 74,83638 & 17,52055 & 319,8827 \\
\hline
\end{tabular}

Y

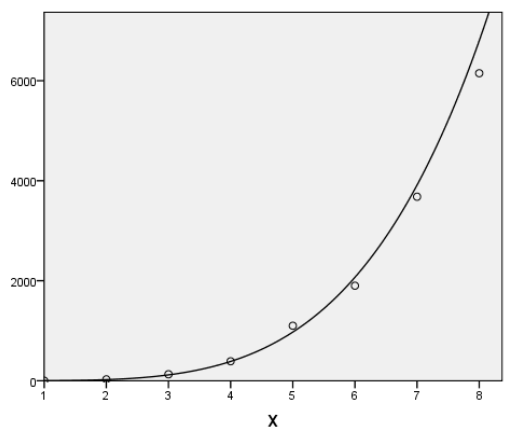

Gambar 19.7

Berdasarkan perhitungan diperoleh nilai $a$ dan $b$ masing-masing 1,2475 dan 4,1375, sehingga persamaan regresi nonlinear sederhana power adalah

$$
\widehat{Y}=1,2475 X^{4,1375} \text {. }
$$

Gambar 19.7 merupakan grafik dari persamaan regresi nonlinear $\widehat{Y}=1,2475 X^{4,1375}$

\section{Regresi Nonlinear Sederhana Eksponensial dan Contoh Perhitungan}

Regresi nonlinear sederhana eksponensial merupakan suatu teknik statistika untuk membuat persamaan yang menjelaskan hubungan antara variabel bebas dan variabel tak bebas, di mana 
persamaan yang dihasilkan berupa persamaan eksponensial. Berikut merupakan bentuk umum persamaan regresi nonlinear sederhana eksponensial.

$$
\widehat{Y}=a e^{b X} .
$$

Untuk menghitung nilai $a$ dan $b$, terlebih dahulu mentransformasi bentuk eksponensial ke bentuk linear. Berikut transformasi dari bentuk eksponensial ke bentuk linear.

$$
\begin{gathered}
Y=a e^{b X} \\
\ln Y=\ln \left(a e^{b X}\right) \\
\ln Y=\ln a+\ln \left(e^{b X}\right) \\
\ln Y=\ln a+b X \ln (e) \quad ;(\ln (e)=1) \\
\ln Y=\ln a+b X
\end{gathered}
$$

Misalkan $y=\ln Y$, maka

$$
\begin{gathered}
\ln Y=\ln a+b X \\
\mathrm{y}=\ln a+b X
\end{gathered}
$$

Perhatikan bahwa $\mathrm{y}=\ln a+b X$ merupakan bentuk linear. Berikut diberikan contoh gambar dari kurva persamaan eksponensial (Gambar 19.8).
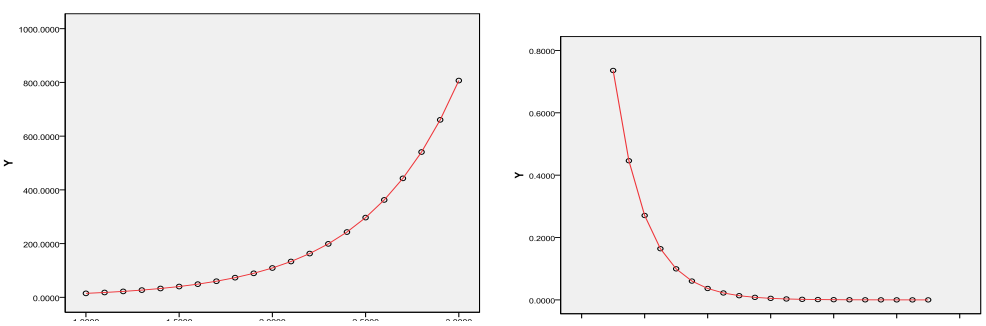

\section{Gambar 19.8}

Tabel 19.6

\begin{tabular}{|c|c|}
\hline$X$ & $Y$ \\
\hline 1 & 19,16717 \\
\hline 1,1 & 30,07504 \\
\hline 1,2 & 29,06953 \\
\hline 1,3 & 36,39122 \\
\hline 1,4 & 45,33395 \\
\hline 1,5 & 55,25662 \\
\hline 1,6 & 73,59761 \\
\hline 1,7 & 92,89232 \\
\hline 1,8 & 101,7947 \\
\hline 1,9 & 129,1036 \\
\hline 2 & 169,7945 \\
\hline
\end{tabular}

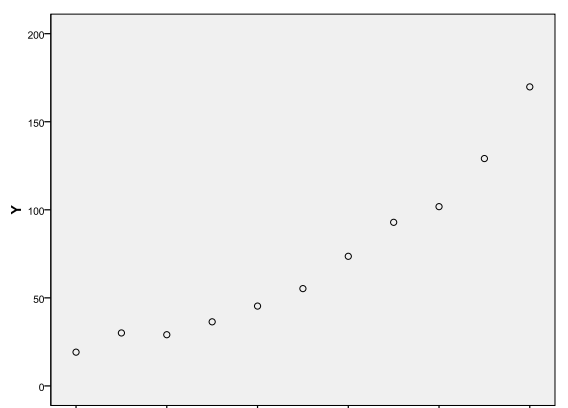

Gambar 19.9 
Misalkan diberikan data seperti pada Tabel 19.6. Berdasarkan data pada Tabel 19.6, misalkan $Y$ adalah variabel tak bebas dan $X$ adalah variabel bebas. Gambar 19.9 merupakan penyajian data pada Tabel 19.6 dalam grafik.

Pada Gambar 19.9, pola sebaran dari titik-titik menyerupai kurva persamaan eksponensial, sehingga hubungan antara variabel bebas $X$ dan variabel tak bebas $Y$ pada data Tabel 19.6 akan didekati dengan kurva persamaan eksponensial. Berikut akan dihitung nilai $a$ dan $b$ untuk persamaan regresi nonlinear sederhana eksponensial.

Tabel 19.7

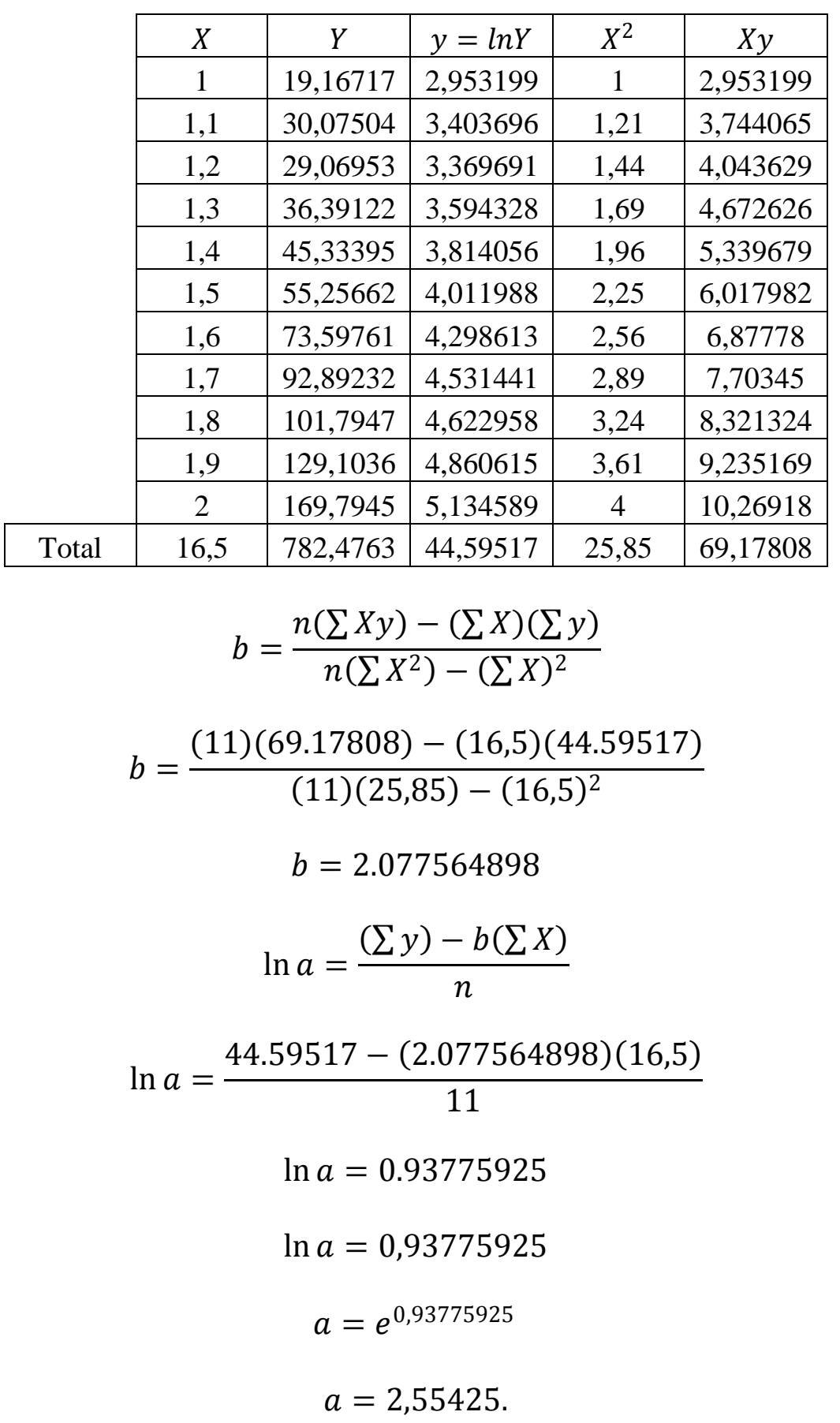

Berdasarkan perhitungan diperoleh nilai $a$ dan $b$ masing-masing 2,55425 dan 2.077564898, sehingga persamaan regresi nonlinear sederhana eksponensial adalah 


$$
\widehat{Y}=2,55425 e^{2.077564898 X} \text {. }
$$

Gambar 19.10 merupakan grafik dari persamaan regresi nonlinear $\hat{Y}=$ $2,55425 e^{2.077564898 X}$.

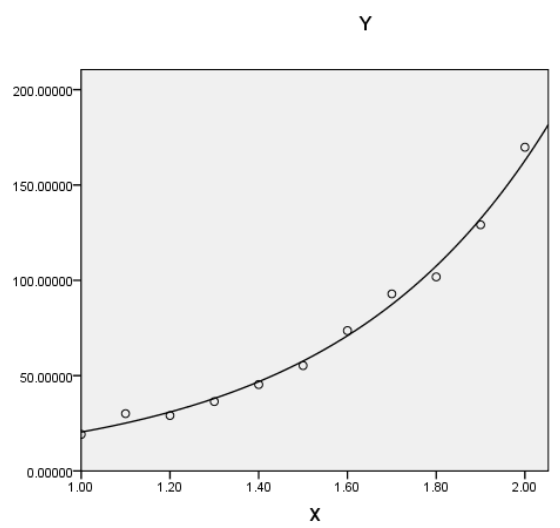

Gambar 19.10

\section{Regresi Nonlinear Sederhana Inverse dan Contoh Perhitungan}

Regresi nonlinear sederhana inverse merupakan suatu alat statistika untuk membuat suatu persamaan yang menerangkan hubungan antara variabel bebas dan variabel tak bebas, di mana persamaan yang dihasilkan berupa persamaan inverse. Berikut merupakan bentuk umum persamaan regresi nonlinear sederhana inverse.

$$
\widehat{Y}=a+\frac{b}{X}
$$

Untuk menghitung nilai $a$ dan $b$, terlebih dahulu mentransformasi bentuk inverse ke bentuk linear. Berikut transformasi dari bentuk inverse ke bentuk linear.

$$
\begin{gathered}
Y=a+\frac{b}{X} \\
Y=a+b x \quad ; x=\frac{1}{X}
\end{gathered}
$$

Perhatikan bahwa bentuk $Y=a+b x$ merupakan bentuk linear. Gambar 19.11 merupakan contoh dari kurva persamaan inverse. Misalkan diberikan data seperti pada Tabel 19.8. Berdasarkan data pada Tabel 19.8, misalkan $Y$ adalah variabel tak bebas dan $X$ adalah variabel bebas. Gambar 19.12 merupakan penyajian data pada Tabel 19.8 dalam grafik.

Pada Gambar 19.12, pola sebaran dari titik-titik menyerupai kurva persamaan inverse, sehingga hubungan antara variabel bebas $X$ dan variabel tak bebas $Y$ pada data Tabel 19.8 akan didekati dengan kurva persamaan inverse. Berikut akan dihitung nilai $a$ dan $b$ untuk persamaan regresi nonlinear sederhana inverse. 
Tabel 19.8

\begin{tabular}{|c|c|}
\hline$X$ & $Y$ \\
\hline 1 & 3 \\
\hline 5 & 1,35 \\
\hline 10 & 1,2 \\
\hline 20 & 1,09 \\
\hline 50 & 1,05 \\
\hline 100 & 1,02 \\
\hline 150 & 1,013 \\
\hline 200 & 1,06 \\
\hline 250 & 1,008 \\
\hline 300 & 1,0067 \\
\hline
\end{tabular}

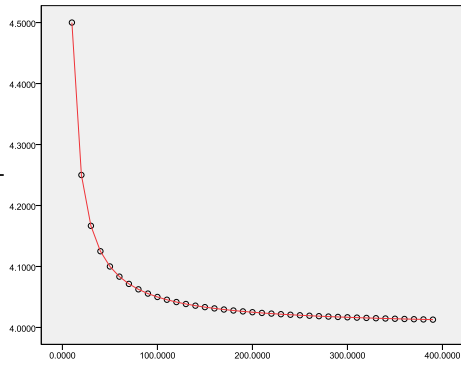

Gambar 19.11

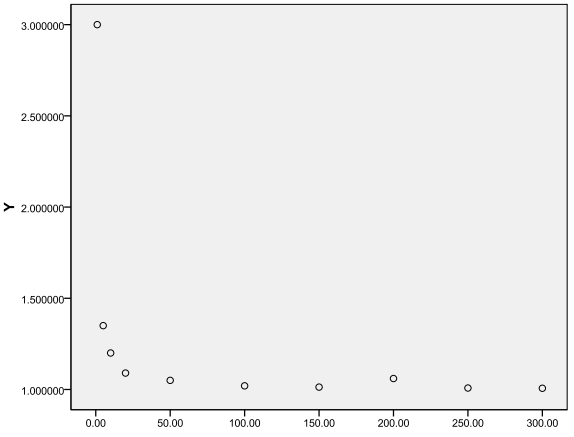

Gambar 19.12

Tabel 19.9

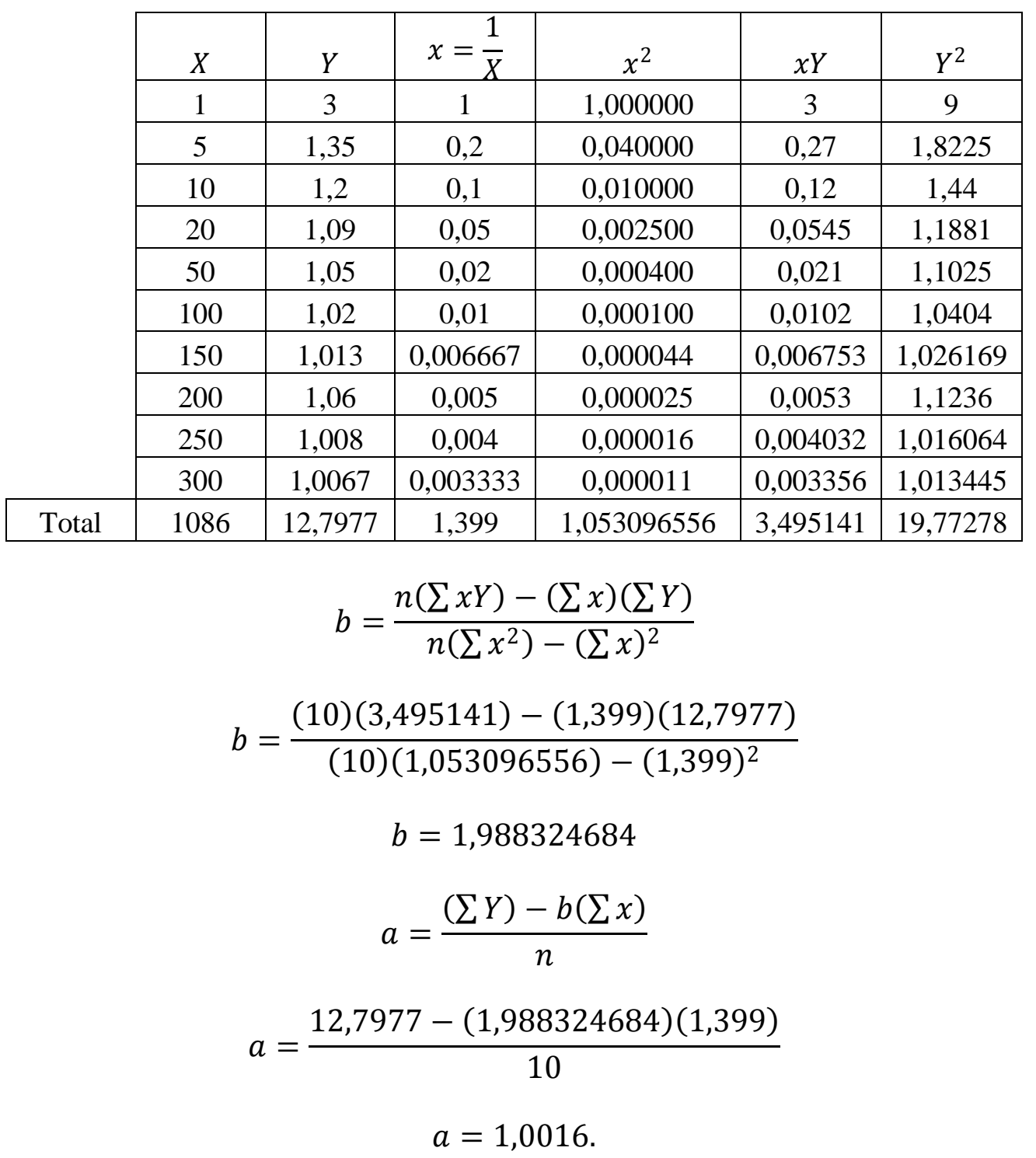




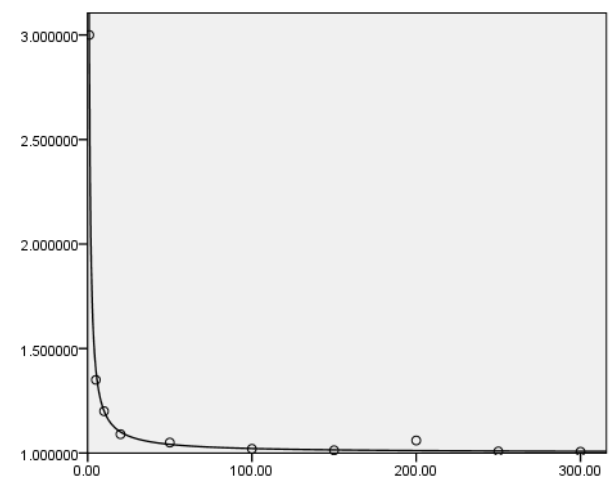

Gambar 19.13

Berdasarkan perhitungan diperoleh nilai $a$ dan $b$ masing-masing 1,0016 dan 1.988324684, sehingga persamaan regresi nonlinear sederhana inverse

$$
\widehat{Y}=1,0016+\frac{1.988324684}{X} \text {. }
$$

Gambar 19.13 merupakan grafik dari persamaan regresi nonlinear $\hat{Y}=1,0016+\frac{1.988324684}{X}$.

\section{Regresi Nonlinear Sederhana Logaritma dan Contoh Perhitungan}

Regresi nonlinear sederhana logaritma merupakan suatu alat statistika untuk membuat persamaan yang menerangkan hubungan antara variabel bebas dan variabel tak bebas, di mana persamaan yang dihasilkan berupa persamaan logaritma. Berikut merupakan bentuk umum persamaan regresi nonlinear sederhana logaritma.

$$
\widehat{Y}=a+b \ln X
$$

Untuk menghitung nilai $a$ dan $b$, terlebih dahulu mentransformasi bentuk logaritma ke bentuk linear. Berikut transformasi dari bentuk logaritma ke bentuk linear.

$$
\begin{gathered}
Y=a+b \ln X \\
Y=a+b x \quad ; x=\ln X .
\end{gathered}
$$

Perhatikan bahwa bentuk $Y=a+b x$ merupakan bentuk linear. Gambar 19.14 merupakan contoh gambar dari kurva persamaan logaritma. Misalkan diberikan data seperti pada Tabel 19.10 .

Berdasarkan data pada Tabel 19.10, misalkan $Y$ adalah variabel tak bebas dan $X$ adalah variabel bebas. Gambar 19.15 merupakan penyajian data pada Tabel 19.10 dalam grafik.

Pada Gambar 19.15, pola sebaran dari titik-titik menyerupai kurva persamaan logaritma, sehingga hubungan antara variabel bebas $X$ dan variabel tak bebas $Y$ pada data Tabel 19.10 akan didekati dengan kurva persamaan logaritma. Berikut akan dihitung nilai $a$ dan $b$ dari persamaan regresi nonlinear sederhana logaritma. 
Tabel 19.10

\begin{tabular}{|c|c|}
\hline$X$ & $Y$ \\
\hline 1 & 2 \\
\hline 2 & 4,089 \\
\hline 3 & 5,195 \\
\hline 4 & 6,158 \\
\hline 5 & 6,928 \\
\hline 6 & 7,175 \\
\hline 7 & 7,837 \\
\hline 8 & 8,538 \\
\hline 9 & 8,591 \\
\hline 10 & 8,507 \\
\hline
\end{tabular}
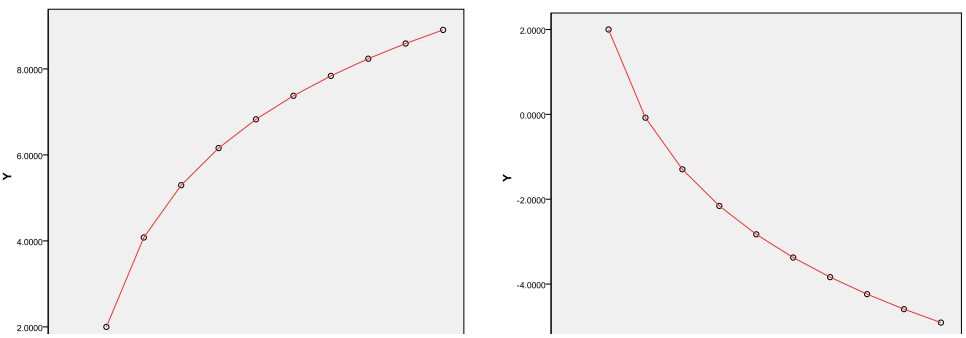

Gambar 19.14

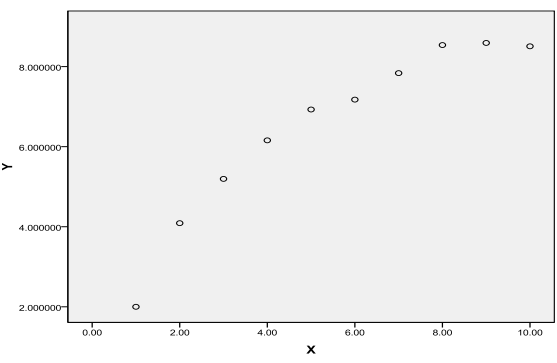

Gambar 19.15

Tabel 19.11

\begin{tabular}{|c|c|c|c|c|c|}
\hline & $X$ & $Y$ & $x=\ln X$ & $x^{2}$ & $x Y$ \\
\hline & 1 & 2 & 0 & 0 & 0 \\
\hline & 2 & 4,089 & 0,693147 & 0,480453 & 2,834279 \\
\hline & 3 & 5,195 & 1,098612 & 1,206949 & 5,707291 \\
\hline & 4 & 6,158 & 1,386294 & 1,921812 & 8,536801 \\
\hline & 5 & 6,928 & 1,609438 & 2,59029 & 11,15019 \\
\hline & 6 & 7,175 & 1,791759 & 3,210402 & 12,85587 \\
\hline & 7 & 7,837 & 1,94591 & 3,786566 & 15,2501 \\
\hline & 8 & 8,538 & 2,079442 & 4,324077 & 17,75427 \\
\hline & 9 & 8,591 & 2,197225 & 4,827796 & 18,87636 \\
\hline & 10 & 8,507 & 2,302585 & 5,301898 & 19,58809 \\
\hline Total & 55 & 65,018 & 15,10441 & 27,65024 & 112,5532 \\
\hline & \multicolumn{5}{|c|}{$b=\frac{n\left(\sum x Y\right)-\left(\sum x\right)\left(\sum Y\right)}{n\left(\sum x^{2}\right)-\left(\sum x\right)^{2}}$} \\
\hline & \multirow{2}{*}{\multicolumn{5}{|c|}{$b=\frac{(10)(112,5532)-(15,10441)(65,018)}{(10)(27,65024)-(15,10441)^{2}}$}} \\
\hline & & & & & \\
\hline & \multicolumn{5}{|c|}{$b=2,966837823$} \\
\hline & & \multicolumn{3}{|c|}{$\left(\sum Y\right)-b\left(\sum x\right)$} & \\
\hline
\end{tabular}




$$
\begin{gathered}
a=\frac{65,018-(2,966837823)(15,10441)}{10} \\
a=2,020565748
\end{gathered}
$$

Berdasarkan perhitungan diperoleh nilai $a$ dan $b$ masing-masing 2,020565748 dan 2,966837823 , sehingga persamaan regresi nonlinear sederhana logaritma adalah

$$
\widehat{Y}=2,0206+2,9668 \ln X \text {. }
$$

Gambar 19.16 merupakan grafik dari persamaan regresi nonlinear $\hat{Y}=2,0206+2,9668 \ln X$.

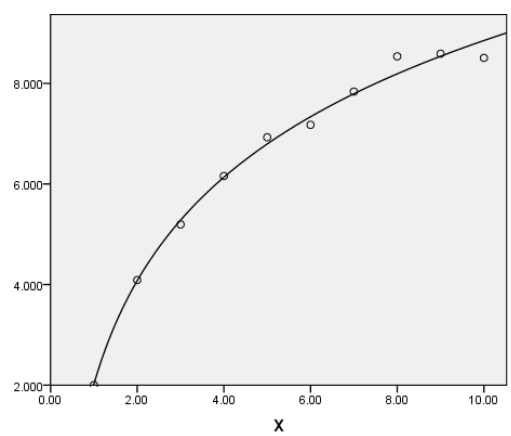

Gambar 19.16

\section{Regresi Nonlinear Sederhana Compound dan Contoh Perhitungan}

Regresi nonlinear sederhana compound merupakan suatu teknik statistika untuk membuat persamaan yang menjelaskan hubungan antara variabel bebas dan variabel tak bebas, di mana persamaan yang dihasilkan berupa persamaan compound. Berikut merupakan bentuk umum persamaan regresi nonlinear sederhana compound.

$$
\widehat{Y}=a b^{X}
$$

Untuk menghitung nilai $a$ dan $b$, terlebih dahulu mentransformasi bentuk compound ke bentuk linear. Berikut transformasi dari bentuk compound ke bentuk linear.

$$
\begin{gathered}
Y=a b^{X} \\
\ln Y=\ln \left(a b^{X}\right) \\
\ln Y=\ln a+\ln \left(b^{X}\right) \\
\ln Y=\ln a+\ln b X .
\end{gathered}
$$

Misalkan $y=\ln Y$, maka

$$
\begin{gathered}
\ln Y=\ln a+\ln b X \\
y=\ln a+\ln b X .
\end{gathered}
$$


Perhatikan bahwa bentuk $y=\ln a+\ln b X$ merupakan bentuk linear. Gambar 19.17 merupakan contoh gambar dari kurva persamaan compound.

Tabel 19.12

\begin{tabular}{|c|c|}
\hline$X$ & $Y$ \\
\hline 1 & 3 \\
\hline 2 & 9 \\
\hline 3 & 16 \\
\hline 4 & 39 \\
\hline 5 & 59 \\
\hline 6 & 110 \\
\hline 7 & 300 \\
\hline 8 & 520 \\
\hline 9 & 1050 \\
\hline 10 & 2048 \\
\hline
\end{tabular}
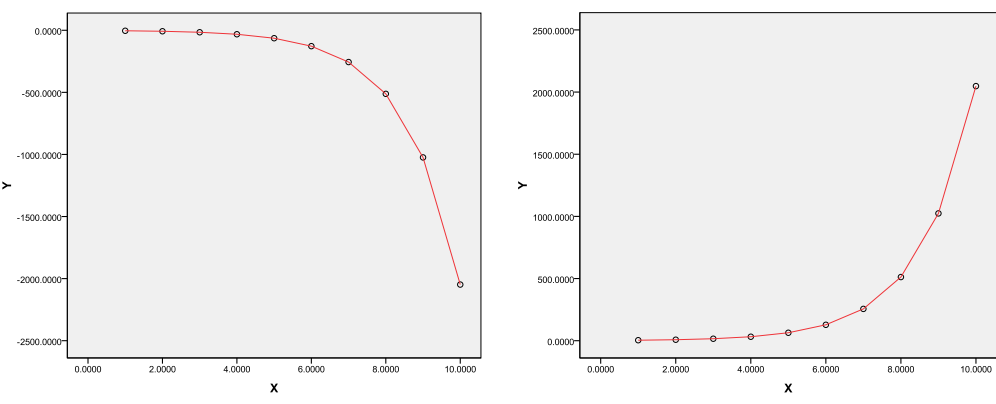

Gambar 19.17

Misalkan diberikan data sebagai berikut (Tabel 19.12). Berdasarkan data pada Tabel 19.12, misalkan $Y$ adalah variabel tak bebas dan $X$ adalah variabel bebas. Gambar 19.18 merupakan penyajian data pada Tabel 19.12 dalam grafik.

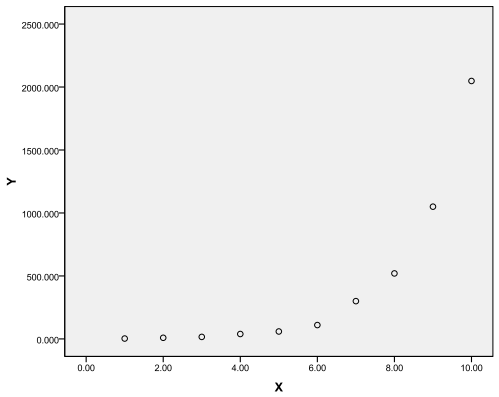

Gambar 19.18

Pada Gambar 19.18, pola sebaran dari titik-titik menyerupai kurva persamaan compound, sehingga hubungan antara variabel bebas $X$ dan variabel tak bebas $Y$ pada data Tabel 19.12 akan didekati dengan kurva persamaan compound. Berikut akan dihitung nilai $a$ dan $b$ untuk persamaan regresi nonlinear sederhana compound.

$$
\begin{gathered}
\ln b=\frac{n\left(\sum X y\right)-\left(\sum X\right)\left(\sum y\right)}{n\left(\sum X^{2}\right)-\left(\sum X\right)^{2}} \\
\ln b=\frac{(10)(305,8679)-(55)(45,04878)}{(10)(385)-(55)^{2}} \\
\ln b=0,704237044 \\
\ln a=\frac{\left(\sum y\right)-\ln b\left(\sum X\right)}{n} \\
\ln a=\frac{45,04878-(0,704237044)(55)}{10}
\end{gathered}
$$




$$
\ln a=0,631574336
$$

Sehingga diperoleh nilai $a$ dan $b$

$$
\begin{gathered}
\ln b=0,704237044 \\
b=e^{0,704237044} \\
b=2,0223 \\
\ln a=0,631574336 \\
a=e^{0,631574336} \\
a=1,88016 .
\end{gathered}
$$

\begin{tabular}{|c|c|c|c|c|c|}
\hline & $X$ & $Y$ & $y=\ln Y$ & $X y$ & $X^{2}$ \\
\hline & 1 & 3 & 1,098612 & 1,098612 & 1 \\
\hline & 2 & 9 & 2,197225 & 4,394449 & 4 \\
\hline & 3 & 16 & 2,772589 & 8,317766 & 9 \\
\hline & 4 & 39 & 3,663562 & 14,65425 & 16 \\
\hline & 5 & 59 & 4,077537 & 20,38769 & 25 \\
\hline & 6 & 110 & 4,70048 & 28,20288 & 36 \\
\hline & 7 & 300 & 5,703782 & 39,92648 & 49 \\
\hline & 8 & 520 & 6,253829 & 50,03063 & 64 \\
\hline & 9 & 1050 & 6,956545 & 62,60891 & 81 \\
\hline & 10 & 2048 & 7,624619 & 76,24619 & 100 \\
\hline Total & 55 & 4154 & 45,04878 & 305,8679 & 385 \\
\hline
\end{tabular}

Tabel 19.13

Berdasarkan perhitungan diperoleh nilai $a$ dan $b$ masing-masing 1,88016 dan 2,0223, sehingga persamaan regresi nonlinear sederhana compound adalah $\widehat{Y}=(1,88016)(2,0223)^{X}$. Gambar 19.19 merupakan grafik dari persamaan regresi nonlinear $(1,88016)(2,0223)^{X}$.

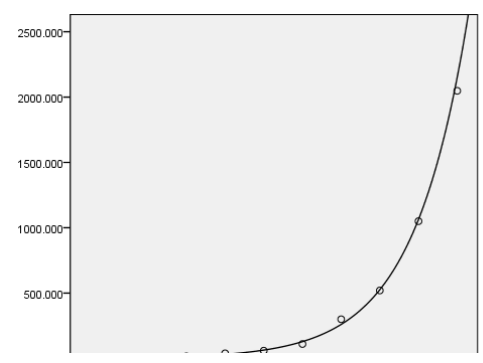

Gambar 19.19 


\section{Regresi $\mathcal{N}$ onlinear Sederhana Kubik dan Contoh Perhitungan}

Regresi nonlinear sederhana kubik merupakan suatu teknik statistika untuk membuat persamaan yang menerangkan hubungan antara variabel bebas dan variabel tak bebas, di mana persamaan yang dihasilkan berupa persamaan kubik. Berikut merupakan bentuk umum persamaan regresi nonlinear sederhana kubik.

$$
\hat{Y}=a+b X+c X^{2}+d X^{3}
$$

Nilai $a, b, c$, dan $d$, diperoleh dengan menyelesaiakan sistem persamaan berikut.

$$
\begin{gathered}
\sum Y=a n+b \sum X+c \sum X^{2}+d \sum X^{3} \\
\sum X Y=a \sum X+b \sum X^{2}+c \sum X^{3}+d \sum X^{4} \\
\sum X^{2} Y=a \sum X^{2}+b \sum X^{3}+c \sum X^{4}+d \sum X^{5} \\
\sum X^{3} Y=a \sum X^{3}+b \sum X^{4}+c \sum X^{5}+d \sum X^{6}
\end{gathered}
$$

Berikut diberikan contoh gambar dari kurva persamaan kubik.

Tabel 19.14

\begin{tabular}{|c|c|}
\hline$X$ & $Y$ \\
\hline-5 & 16 \\
\hline-4 & -7 \\
\hline-3 & -14 \\
\hline-2 & -11 \\
\hline-1 & -4 \\
\hline 0 & 1 \\
\hline 1 & -2 \\
\hline 2 & -19 \\
\hline 3 & -56 \\
\hline 4 & -119 \\
\hline 5 & -214 \\
\hline 6 & -347 \\
\hline
\end{tabular}
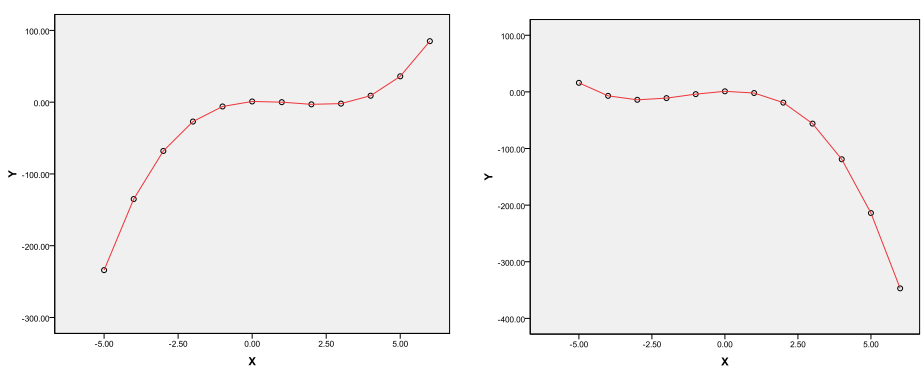

\section{Gambar 19.20}

Misalkan diberikan data sebagai berikut (Tabel 19.14). Berdasarkan data pada Tabel 19.14, misalkan $Y$ adalah variabel tak bebas dan $X$ adalah variabel bebas. Gambar 19.21 merupakan penyajian data pada Tabel 19.14 dalam grafik.

Pada Gambar 19.21, pola sebaran dari titik-titik menyerupai kurva persamaan kubik, sehingga hubungan antara variabel bebas $X$ dan variabel tak bebas $Y$ pada data Tabel 19.14 akan didekati dengan kurva persamaan kubik. Berikut akan dihitung nilai $a, b, c$, dan $d$ dari persamaan regresi nonlinear sederhana kubik. 


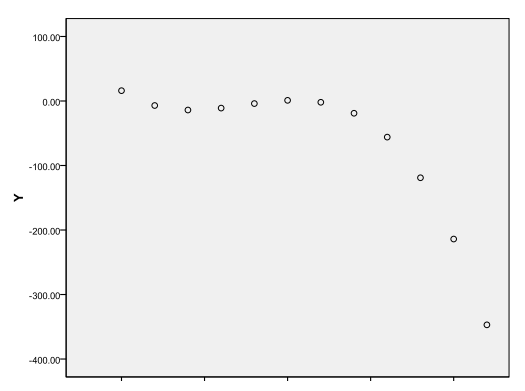

Gambar 19.21

Tabel 19.15

\begin{tabular}{|c|c|c|c|c|c|c|c|c|}
\hline & $X$ & $Y$ & $X^{2}$ & $X^{3}$ & $X^{4}$ & $X^{5}$ & $X^{6}$ & $X Y$ \\
\hline & -5 & 16 & 25 & -125 & 625 & -3125 & 15625 & -80 \\
\hline & -4 & -7 & 16 & -64 & 256 & -1024 & 4096 & 28 \\
\hline & -3 & -14 & 9 & -27 & 81 & -243 & 729 & 42 \\
\hline & -2 & -11 & 4 & -8 & 16 & -32 & 64 & 22 \\
\hline & -1 & -4 & 1 & -1 & 1 & -1 & 1 & 4 \\
\hline & 0 & 1 & 0 & 0 & 0 & 0 & 0 & 0 \\
\hline & 1 & -2 & 1 & 1 & 1 & 1 & 1 & -2 \\
\hline & 2 & -19 & 4 & 8 & 16 & 32 & 64 & -38 \\
\hline & 3 & -56 & 9 & 27 & 81 & 243 & 729 & -168 \\
\hline & 4 & -119 & 16 & 64 & 256 & 1024 & 4096 & -476 \\
\hline & 5 & -214 & 25 & 125 & 625 & 3125 & 15625 & -1070 \\
\hline & 6 & -347 & 36 & 216 & 1296 & 7776 & 46656 & -2082 \\
\hline Jumlah & 6 & -776 & 146 & 216 & 3254 & 7776 & 87686 & -3820 \\
\hline
\end{tabular}

Dengan menyelesaikan sistem persamaan tersebut, maka akan diperoleh nilai $a=1, b=$ $2, c=-4$, dan $d=-1$, sehingga diperoleh persamaan regresi nonlinear sederhana kubik $\hat{Y}=1+b X-4 X^{2}-X^{3}$. 


\section{PENYELESAIAN DALAM SPSS}

\section{Regresi Nonlinear Sederhana Kuadratik dalam SPSS}

Bangun data dalam SPSS seperti pada Gambar 19.1.

\begin{tabular}{|c|c|c|c|c|}
\hline & Name & Type & Width & Decimals \\
\hline 1 & $x$ & Numeric & 8 & 0 \\
\hline 2 & $Y$ & Numeric & 8 & 2 \\
\hline 3 & & & & \\
\hline
\end{tabular}

\begin{tabular}{|r|r|r|}
\hline & $X$ & \multicolumn{1}{|c|}{$Y$} \\
\hline 1 & -5 & 23.00 \\
\hline 2 & -4 & 15.00 \\
\hline 3 & -3 & 10.00 \\
\hline 4 & -2 & 4.90 \\
\hline 5 & -1 & 2.00 \\
\hline 6 & 0 & 1.00 \\
\hline 7 & 1 & 1.50 \\
\hline 8 & 2 & 3.50 \\
\hline 9 & 3 & 10.90 \\
\hline 10 & 4 & 17.40 \\
\hline 11 & 5 & 23.70 \\
\hline
\end{tabular}

\section{Gambar 19.1}

Kemudian pilih Analyze $=>$ Regression $=>$ Curve Estimation, sehingga muncul kotak dialog Curve Estimation (Gambar 19.2).

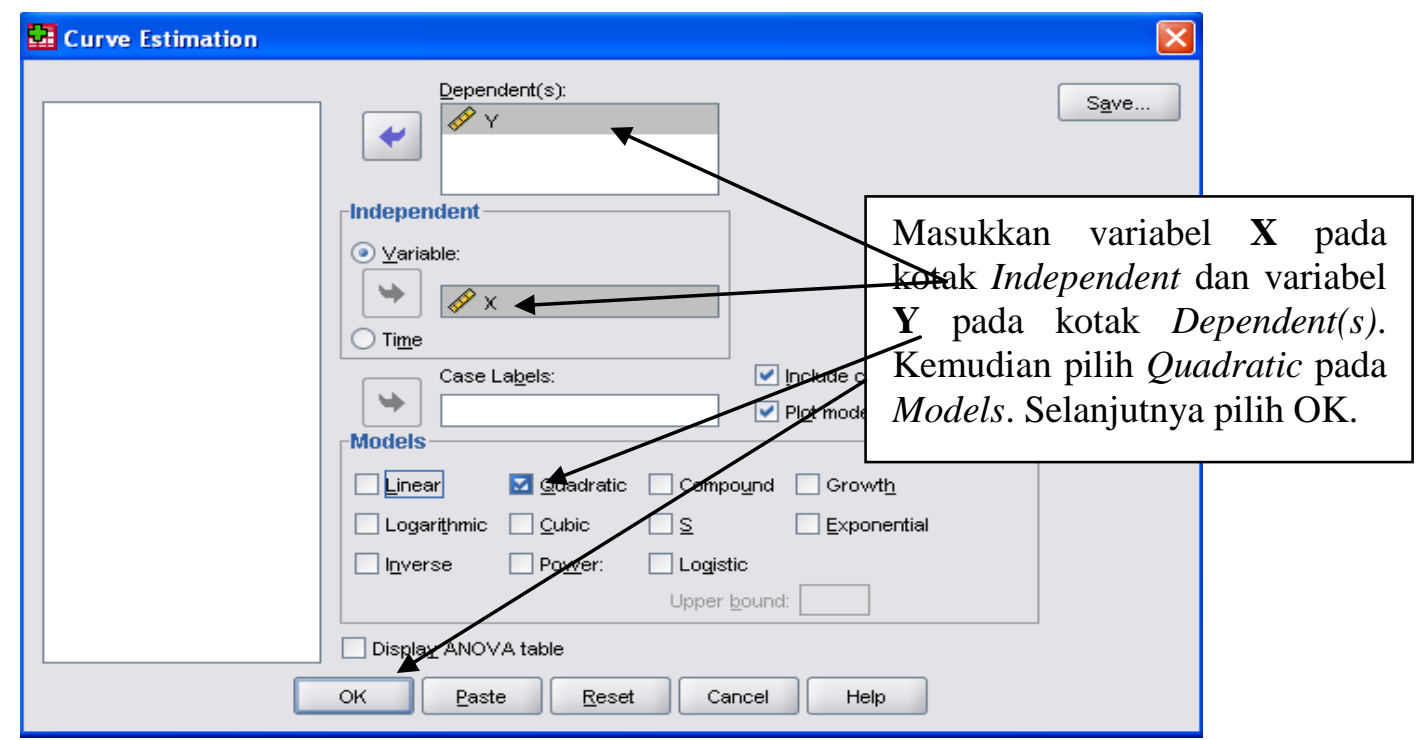

Gambar 19.2

Pada Gambar 19.2, masukkan variabel X pada kotak Independent dan variabel Y pada kotak Dependent(s). Pada Models pilih Quadratic. Kemudian pilih OK. Hasil berdasarkan SPSS disajikan pada Tabel 19.1. 


\section{Tabel 19.1}

Model Summary and Parameter Estimates

Dependent (ariable:Y

\begin{tabular}{|c|c|c|c|c|c|c|c|c|}
\hline \multirow[b]{2}{*}{ Equation } & \multicolumn{5}{|c|}{ Model Summary } & \multicolumn{3}{|c|}{ Parameter Estimates } \\
\hline & R Square & $\mathrm{F}$ & df1 & $\mathrm{df} 2$ & Sig. & Constant & b1 & b2 \\
\hline Quadratic & .989 & 372.497 & 2 & 8 & .000 & 1.148 & .114 & .912 \\
\hline
\end{tabular}

The independent variable is $X$.

Tabel 19.1 memberikan informasi bahwa nilai koefisien determinasi atau $R$ Square adalah 0,989 . Perhatikan juga bawa nilai $a, b$, dan $c$ masing-masing adalah $1,148,0,114$, dan 0,912 , sehingga diperoleh persamaan regresi nonlinear sederhana kuadratik $\hat{Y}=1,148 X^{2}+$ $0,114 X+0,912$.

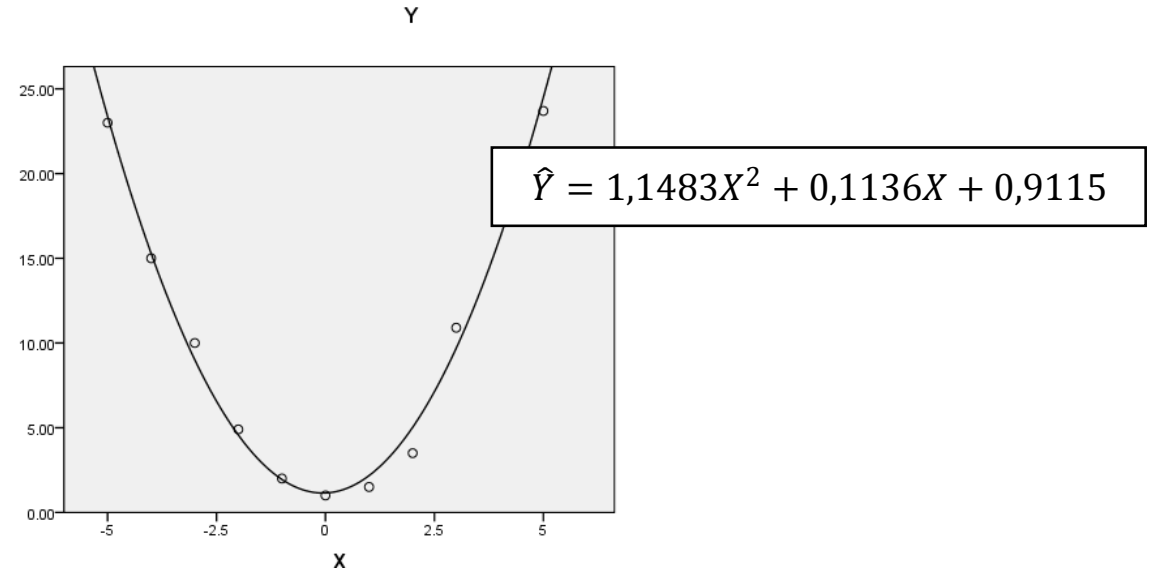

Gambar 19.3

\section{Regresi JNonlinear Sederhana Power dalam SPSS}

Bangun data dalam SPSS seperti pada Gambar 19.4. Kemudian pilih Analyze $=>$ Regression $\Rightarrow$ Curve Estimation, sehingga muncul kotak dialog Curve Estimation. Masukkan variabel $\mathbf{X}$ pada kotak Independent dan variabel Y pada kotak Dependent(s). Pada Models pilih Power. Selanjutnya pilih OK. Hasil berdasarkan SPSS disajikan pada Tabel 19.2.

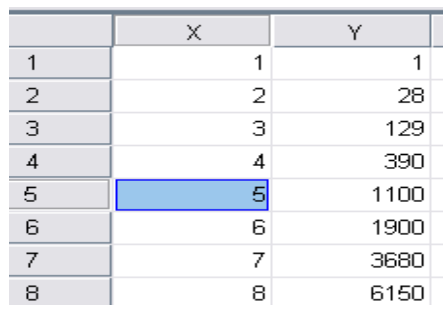

\section{Tabel 19.2}

\begin{tabular}{|c|c|c|c|c|c|c|c|}
\hline \multirow[b]{2}{*}{ Equation } & \multicolumn{5}{|c|}{ Model Summary } & \multicolumn{2}{|c|}{ Parameter Estimates } \\
\hline & R Square & $\mathrm{F}$ & $\mathrm{df1}$ & $\mathrm{d} f 2$ & Siq. & Constant & $b 1$ \\
\hline Power & .997 & 2324.432 & 1 & 6 & .000 & 1.248 & 4.137 \\
\hline
\end{tabular}

\section{Gambar 19.4}

Pada Tabel 19.2 memberikan informasi bahwa koefisien determinasi atau $R$ Square bernilai 0,997. Perhatikan juga bawa nilai $a$ dan $b$ masing-masing adalah 1,248 dan 4,137, sehingga diperoleh persamaan regresi nonlinear sederhana power $\widehat{Y}=1,248 X^{4,137}$. 


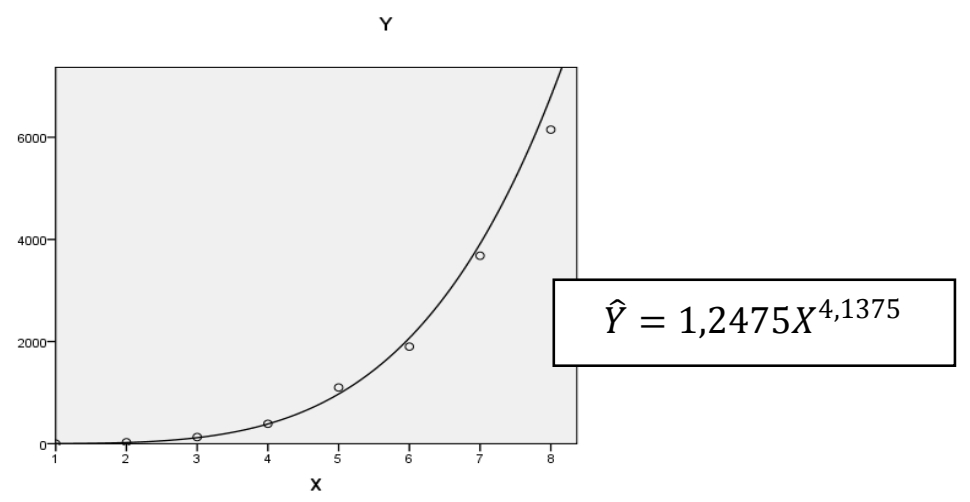

Gambar 19.5

\section{Regresi Nonlinear Sederhana ERsponensial dalam SPSS}

Bangun data dalam SPSS seperti pada Gambar 19.6. Kemudian pilih Analyze $=>$ Regression $=>$ Curve Estimation, sehingga muncul kotak dialog Curve Estimation. Masukkan variabel $\mathbf{X}$ pada kotak Independent dan variabel Y pada kotak Dependent(s). Pada Models pilih Exponential. Selanjutnya pilih OK. Hasil berdasarkan SPSS disajikan pada Tabel 19.3.

\begin{tabular}{|r|r|r|}
\hline & $X$ & \multicolumn{1}{|c|}{$Y$} \\
\hline 1 & 1.00 & 19.17 \\
\hline 2 & 1.10 & 30.08 \\
\hline 3 & 1.20 & 29.07 \\
\hline 4 & 1.30 & 36.39 \\
\hline 5 & 1.40 & 45.33 \\
\hline 6 & 1.50 & 55.26 \\
\hline 7 & 1.60 & 73.60 \\
\hline 8 & 1.70 & 92.89 \\
\hline 9 & 1.80 & 101.79 \\
\hline 10 & 1.90 & 129.10 \\
\hline 11 & 2.00 & 169.79 \\
\hline
\end{tabular}

Tabel 19.3

\begin{tabular}{|c|c|c|c|c|c|c|c|}
\hline \multirow[b]{2}{*}{ Equation } & \multicolumn{5}{|c|}{ Model Summay } & \multicolumn{2}{|c|}{ Parameter Estimates } \\
\hline & R Square & $\mathrm{F}$ & df1 & $\mathrm{d} f 2$ & Siq. & Constant & b1 \\
\hline Exponential & .988 & 770.343 & 1 & 9 & .000 & 2.554 & 2.078 \\
\hline
\end{tabular}

\section{Gambar 19.6}

Tabel 19.3 memberikan informasi bahwa koefisien determinasi atau $R$ Square bernilai 0,988. Perhatikan juga bawa nilai $a$ dan $b$ masing-masing adalah 2,554 dan 2,078, sehingga diperoleh persamaan regresi nonlinear sederhana eksponensial $\hat{Y}=2,554 e^{2.078 X}$.

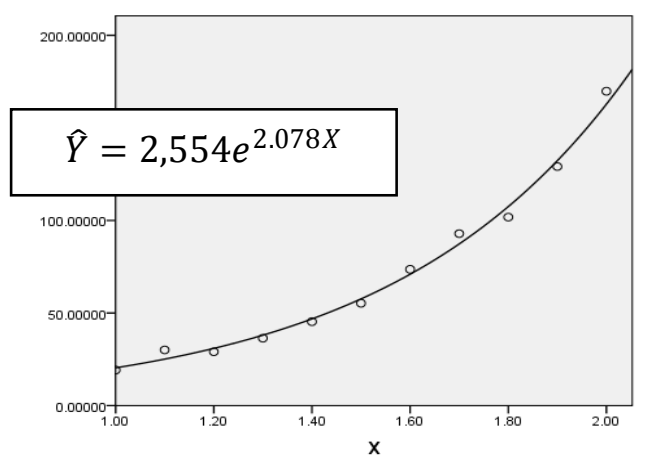

Gambar 19.7 


\section{Regresi JNonlinear Sederhana Inverse dalam SPSS}

Bangun data dalam SPSS seperti pada Gambar 19.8. Kemudian pilih Analyze $=>$ Regression $\Rightarrow$ Curve Estimation, sehingga muncul kotak dialog Curve Estimation. Masukkan variabel $\mathbf{X}$ pada kotak Independent dan variabel Y pada kotak Dependent(s). Pada Models pilih Inverse. Selanjutnya pilih OK. Hasil berdasarkan SPSS disajikan pada Tabel 19.4.

\begin{tabular}{|r|r|r|}
\hline \multicolumn{1}{|l|}{} & \multicolumn{1}{|c|}{$X$} & \multicolumn{1}{|l|}{$Y$} \\
\hline 1 & 1.00 & 3.0000 \\
\hline 2 & 5.00 & 1.3500 \\
\hline 3 & 10.00 & 1.2000 \\
\hline 4 & 20.00 & 1.0900 \\
\hline 5 & 50.00 & 1.0500 \\
\hline 6 & 100.00 & 1.0200 \\
\hline 7 & 150.00 & 1.0130 \\
\hline 8 & 200.00 & 1.0600 \\
\hline 9 & 250.00 & 1.0080 \\
\hline 10 & 300.00 & 1.0067 \\
\hline
\end{tabular}

Tabel 19.4

\begin{tabular}{|c|c|c|c|c|c|c|c|}
\hline \multirow[b]{2}{*}{ Equation } & \multicolumn{5}{|c|}{ Model Summary } & \multicolumn{2}{|c|}{ Parameter Estimates } \\
\hline & R Square & $\mathrm{F}$ & df1 & df2 & Siq. & Constant & b1 \\
\hline Inverse & 999 & 5334.531 & 1 & 8 & 000 & 1.002 & 1.988 \\
\hline
\end{tabular}

\section{Gambar 19.8}

Pada Tabel 19.4 memberikan informasi bahwa koefisien determinasi atau $R$ Square bernilai 0,999 . Perhatikan juga bawa nilai $a$ dan $b$ masing-masing adalah 1,002 dan 1,988, sehingga diperoleh persamaan regresi nonlinear sederhana inverse $\hat{Y}=1,002+\frac{1.988}{X}$.

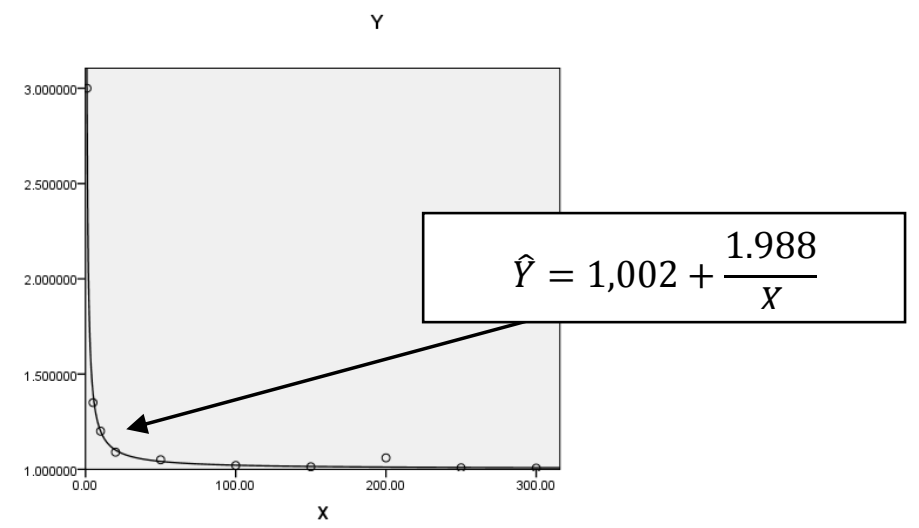

Gambar 19.9

\section{Regresi Nonlinear Sederhana Logaritma dalam SPSS}

Bangun data dalam SPSS seperti pada Gambar 19.10. Kemudian pilih Analyze $=>$ Regression $\Rightarrow>$ Curve Estimation, sehingga muncul kotak dialog Curve Estimation. Masukkan variabel $\mathbf{X}$ pada kotak Independent dan variabel Y pada kotak Dependent(s). Pada Models pilih Logarithmic. Selanjutnya pilih OK. Hasil berdasarkan SPSS disajikan pada Tabel 19.5.

Pada Tabel 19.5 memberi informasi bahwa koefisien determinasi atau $R$ Square bernilai 0,993 . Perhatikan juga bawa nilai $a$ dan $b$ masing-masing adalah 2,021 dan 2,967, sehingga diperoleh persamaan regresi nonlinear sederhana logaritma $\hat{Y}=2,021+2,967 \ln X$. 


\begin{tabular}{|c|c|c|}
\hline & $x$ & $Y$ \\
\hline 1 & 1.00 & 2.0000 \\
\hline 2 & 2.00 & 4.0890 \\
\hline 3 & 3.00 & 5.1950 \\
\hline 4 & 4.00 & 6.1580 \\
\hline 5 & 5.00 & 6.9280 \\
\hline 6 & 6.00 & 7.1750 \\
\hline 7 & 7.00 & 7.8370 \\
\hline 8 & 8.00 & 8.5380 \\
\hline 9 & 9.00 & 8.5910 \\
\hline 10 & 10.00 & 8.507 \\
\hline
\end{tabular}

Tabel 19.5

Gambar 19.10

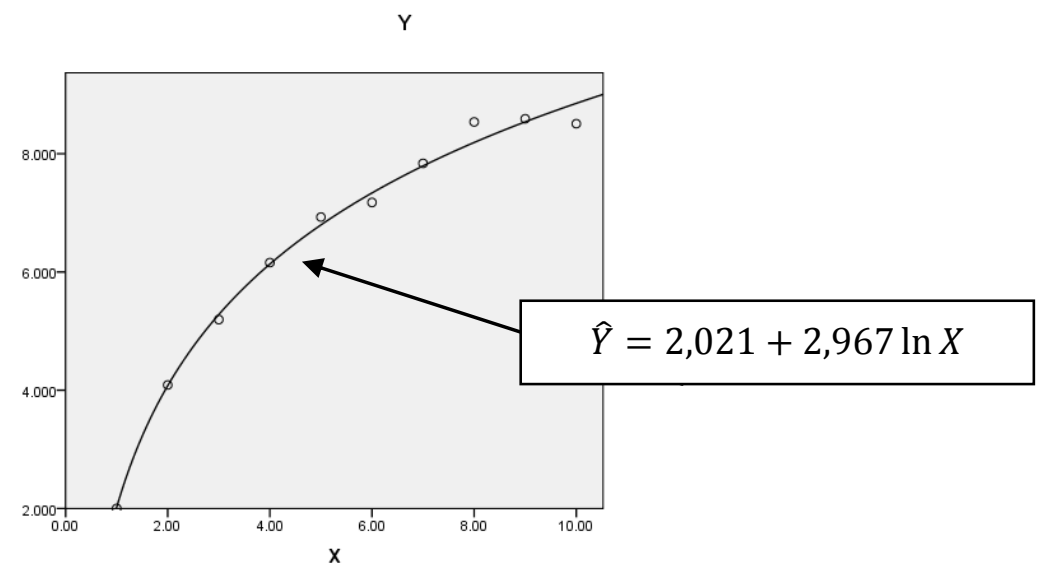

Gambar 19.11 


\section{BAB 20}

\section{STATISTIKA NONPARAMETRIK}

\section{Uji Tanda dan Contoh Perhitungan}

Uji tanda merupakan uji nonparametrik yang digunakan untuk menguji ada tidaknya perbedaan dari dua buah populasi yang saling berpasangan. Misalkan diberikan data mengenai berat badan sebelum mengkonsumsi obat penambah berat badan merek $X Y Z$ dan sesudah mengkonsumsi obat penambah berat badan merek $X Y Z$ selama satu minggu.

Tabel 20.1 (Data Fiktif)

\begin{tabular}{|c|c|c|c|c|c|c|c|c|c|}
\hline Nama & A & B & C & D & E & F & G & H & I \\
\hline$P$ & $45 \mathrm{~kg}$ & $50 \mathrm{~kg}$ & $35 \mathrm{~kg}$ & $45 \mathrm{~kg}$ & $54 \mathrm{~kg}$ & $44 \mathrm{~kg}$ & $41 \mathrm{~kg}$ & $44 \mathrm{~kg}$ & $35 \mathrm{~kg}$ \\
\hline$Q$ & $44 \mathrm{~kg}$ & $50 \mathrm{~kg}$ & $37 \mathrm{~kg}$ & $50 \mathrm{~kg}$ & $57 \mathrm{~kg}$ & $48 \mathrm{~kg}$ & $45 \mathrm{~kg}$ & $44 \mathrm{~kg}$ & $35 \mathrm{~kg}$ \\
\hline Tanda & - & 0 & + & + & + & + & + & 0 & 0 \\
\hline
\end{tabular}

Berdasarkan data pada Tabel 20.1, misalkan $P$ menyatakan sampel mengenai data berat badan sebelum mengkonsumsi obat penambah berat badan merek $X Y Z$, sedangkan $Q$ menyatakan sampel mengenai data berat badan setelah mengkonsumsi obat penambah berat badan merek $X Y Z$ selama satu minggu. Berdasarkan data pada Tabel 20.1, jumlah responden yang diteliti sebanyak 9 responden. Perhatikan bahwa $(45,44),(50,50),(35,37)$, dan seterusnya merupakan pasangan-pasangan nilai berdasarkan sampel $P$ dan sampel $Q$.

Seorang yang bernama $A$ sebelum mengkonsumsi obat penambah berat badan merek $X Y Z$ memiliki berat badan $45 \mathrm{~kg}$ dan setelah mengkonsumsi obat penambah berat badan merek $X Y Z$ selama satu minggu memiliki berat badan $44 \mathrm{~kg}$, yang dinyatakan dengan $(45,44)$. Seorang yang bernama $B$ sebelum mengkonsumsi obat penambah berat badan merek $X Y Z$ memiliki berat badan $50 \mathrm{~kg}$ dan setelah mengkonsumsi obat penambah berat badan merek $X Y Z$ selama satu minggu memiliki berat badan $50 \mathrm{~kg}$ yang dinyatakan dengan $(50,50)$, dan seterusnya.

Pada uji tanda, jika selisih dari pasangan nilai data bernilai positif $(Q>P)$, maka diberi tanda positif $(+)$. Berdasarkan data pada Tabel 20.1, tanda positif $(+)$ diberikan kepada C, D, E, F, dan G. Jika selisih dari pasangan nilai data bernilai negatif $(Q<P)$, maka diberi tanda negatif $(-)$. Berdasarkan data pada Tabel 20.1, tanda negatif $(-)$ diberikan kepada A. Namun jika selisih dari pasangan nilai data bernilai $0(Q=P)$, maka diberi nilai 0 . Berdasarkan data pada Tabel 20.1, nilai 0 diberikan kepada B, H, dan I.

Data dalam uji tanda bersifat ordinal, yakni data yang dianalisis pada uji tanda berupa tanda positif $(+)$ dan tanda negatif $(-)$, sedangkan nilai 0 tidak diikutsertakan dalam analisis. Nilai 0 berarti tidak terdapat perubahan sebelum dan sesudah perlakuan. Misalkan $n$ menyatakan jumlah tanda positif (+) dan tanda negatif (-). Berdasarkan data pada Tabel 20.1, jumlah tanda positif $(+)$ sebanyak 5 , sedangkan jumlah tanda negatif $(-)$ sebanyak 1 , sehingga nilai $n$ adalah $5+1=6$. 
Misalkan $X$ menyatakan jumlah tanda yang paling sedikit, yakni antara jumlah tanda positif $(+)$ atau jumlah tanda negatif $(-)$. Berdasarkan data pada Tabel 20.1, diketahui jumlah tanda positif $(+)$ sebanyak 5 , sedangkan jumlah tanda negatif $(-)$ sebanyak 1 , sehingga nilai $X$ adalah 1. Hipotesis nol yang diuji pada uji tanda pada dasarnya menyatakan tidak dapat pengaruh sebelum dan sesudah perlakuan. Dengan kata lain, probabilitas untuk memperoleh tanda positif $(+)$ sama dengan probabilitas untuk memperoleh tanda negatif $(-)$, yakni

$$
H_{0}: P(+)=P(-)
$$

Hipotesis alternatif menyatakan terdapat pengaruh sebelum dan sesudah perlakuan (dalam hal ini uji dua arah). Dengan kata lain, probabilitas untuk memperoleh tanda positif $(+)$ tidak sama dengan probabilitas untuk memperoleh tanda negatif $(-)$, yakni

$$
H_{1}: P(+)=P(-) \text {. }
$$

Untuk pengambilan keputusan terhadap hipotesis, perlu dihitung nilai probabilitas kumulatif ( $p$-value) dari nilai $X$. Jika dilakukan pengujian hipotesis dua arah (terdapat dua daerah penolakan hipotesis nol), maka rumus untuk menghitung nilai pobabilitas kumulatif dari nilai $X$ adalah

$$
2\left[\sum_{i=0}^{X}\left(\begin{array}{c}
n \\
i
\end{array}\right)\left(\frac{1}{2}\right)^{i}\left(\frac{1}{2}\right)^{n-i}\right]
$$

Jika dilakukan pengujian hipotesis satu arah (terdapat satu daerah penolakan hipotesis nol), maka rumus untuk menghitung nilai pobabilitas kumulatif dari nilai $X$ adalah

$$
\sum_{i=0}^{X}\left(\begin{array}{l}
n \\
i
\end{array}\right)\left(\frac{1}{2}\right)^{i}\left(\frac{1}{2}\right)^{n-i}
$$

Jika nilai probabilitas kumulatif dari nilai $X$ lebih besar atau sama dengan tingkat signifikansi $(\alpha)$, maka hipotesis nol diterima dan hipotesis alternatif ditolak. Namun jika nilai probabilitas kumulatif dari nilai $X$ lebih kecil dibandingkan tingkat signifikansi $(\alpha)$, maka hipotesis nol ditolak dan hipotesis alternatif diterima.

Jika nilai probabilitas kumulatif dari $X(p-$ value $) \geq \alpha, H_{0}$ diterima, $H_{1}$ ditolak.

\begin{tabular}{|c|c|c|}
\hline \multicolumn{2}{|c|}{ Test Statistics $^{\mathbf{b}}$} & \multirow{4}{*}{$\begin{array}{l}\text { "2-Tailed" berarti pengujian } \\
\text { hipotesis berlaku dua arah. } \\
\text { Nilai } 0,013 \text { merupakan nilai } \\
\text { probabilitas kumulatif yang } \\
\text { dihitung berdasarkan rumus } \\
\text { binomial. }\end{array}$} \\
\hline & $\begin{array}{l}\text { sesudah - } \\
\text { sebełtrm }\end{array}$ & \\
\hline Exact Sig. (2-tailed) & $.013^{\mathrm{a}}$ & \\
\hline a. Binomial d & & \\
\hline b. Sign Test & & \\
\hline
\end{tabular}
Jika nilai probabilitas kumulatif dari $X(p-$ value $)<\alpha, H_{0}$ ditolak, $H_{1}$ diterima.

Tabel 20.2 menyajikan nilai probabilitas kumulatif.

Tabel 20.2 
Sebagai contoh misalkan seorang ahli farmasi ingin mengetahui ada tidaknya pengaruh terhadap perubahan berat badan sebelum mengkonsumsi obat penambah berat badan merek $\mathrm{XYZ}$ dan sesudah mengkonsumsi obat penambah berat badan merek XYZ selama satu minggu.

Tabel 20.3 (Data Fiktif)

\begin{tabular}{||c|c|c|c|c|c|c|c|c|c|c|c|c|c|c|c||}
\hline \hline Nama & A & B & C & D & E & F & G & H & I & J & K & L & M & N & 0 \\
\hline $\mathrm{X}$ & 45 & 55 & 57 & 54 & 65 & 72 & 80 & 44 & 67 & 60 & 65 & 75 & 67 & 66 & 62 \\
\hline $\mathrm{Y}$ & 50 & 60 & 60 & 65 & 63 & 80 & 90 & 50 & 65 & 60 & 75 & 80 & 85 & 70 & 65 \\
\hline
\end{tabular}

Misalkan $X$ menyatakan berat badan sebelum mengkonsumsi obat penambah berat badan merek $X Y Z$, sedangkan $Y$ menyatakan berat badan sesudah mengkonsumsi obat penambah berat badan merek $X Y Z$ selama satu minggu. Dengan menggunakan tingkat signifikansi 5\%, berikut akan diuji apakah terdapat perbedaan berat badan yang signifikan secara statistika, sebelum mengkonsumsi obat penambah berat badan merek $X Y Z$ dan sesudah mengkonsumsi obat penambah berat badan merek $X Y Z$ selama satu minggu.

\section{Tahap Pertama}

Tahap pertama adalah perumusan hipotesis. Berikut perumusan hipotesis.

$H_{0}$ : Tidak terdapat perbedaan berat badan sebelum mengkonsumsi obat penambah berat badan merek $A$ dan sesudah mengkonsumsi obat penambah berat badan merek $A$ selama satu minggu atau dapat dinyatakan $P(+)=P(-)$.

$H_{1}$ : Terdapat perbedaan berat badan sebelum mengkonsumsi obat penambah berat badan merek $A$ dan sesudah mengkonsumsi obat penambah berat badan merek $A$ selama satu minggu atau dapat dinyatakan $P(+) \neq P(-)$.

\section{Tahap Kedua}

Tahap kedua adalah menentukan tingkat signifikansi yang nantinya akan dibandingkan dengan nilai probabilitas kumulatif dari nilai $X$. Tingkat signifikansi yang digunakan dalam kasus ini adalah $\alpha=5 \%$ atau $\alpha=0,05$.

\section{Tahap Ketiga}

Tahap ketiga adalah menghitung nilai probabilitas kumulatif dari nilai $X$.

Tabel 20.4

\begin{tabular}{|c|c|c|c|c|c|c|c|c|c|c|c|c|c|c|c|}
\hline Nama & $\mathrm{A}$ & $\mathrm{B}$ & $\mathrm{C}$ & $\mathrm{D}$ & $\mathrm{E}$ & $\mathrm{F}$ & $\mathrm{G}$ & $\mathrm{H}$ & $\mathrm{I}$ & $\mathrm{J}$ & $\mathrm{K}$ & $\mathrm{L}$ & $\mathrm{M}$ & $\mathrm{N}$ & 0 \\
\hline $\mathrm{X}$ & 45 & 55 & 57 & 54 & 65 & 72 & 80 & 44 & 67 & 60 & 65 & 75 & 67 & 66 & 62 \\
\hline $\mathrm{Y}$ & 50 & 60 & 60 & 65 & 63 & 80 & 90 & 50 & 65 & 60 & 75 & 80 & 85 & 70 & 65 \\
\hline Tanda & + & + & + & + & - & + & + & + & - & 0 & + & + & + & + & + \\
\hline
\end{tabular}

$\Rightarrow$ Pertama akan ditentukan tanda untuk setiap pasangan nilai data. Berdasarkan data pada Tabel 1.4 , pasangan nilai data $(45,50)$ diberi tanda positif $(+)$ karena $50-$ 
$45>0$, pasangan nilai data $(67,65)$ diberi tanda negatif $(-)$ karena $65-67<0$, dan seterusnya.

$\Rightarrow$ Selanjutnya akan ditentukan nilai dari $n$. Perhatikan bahwa $n$ menyatakan jumlah dari tanda positif $(+)$ dan tanda negatif $(-)$. Berdasarkan Tabel 20.4, tanda positif $(+)$ berjumlah 12 dan tanda negatif $(-)$ berjumlah 2 , sehingga nilai $n$ adalah $12+2=$ 14.

$\Rightarrow$ Kemudian akan dihitung nilai probabilitas kumulatif dari nilai $X$. Perhatikan bahwa nilai $X$ menyatakan jumlah tanda yang paling sedikit, yakni antara tanda positif $(+)$ atau tanda negatif $(-)$. Diketahui jumlah tanda positif sebanyak 12 dan jumlah tanda negatif (-) sebanyak 2, sehingga nilai $X$ adalah 2. Berikut akan dihitung nilai probabilitas kumulatif ( $p$-value) dari nilai $X=2$.

$$
\begin{aligned}
2\left[\sum_{i=0}^{x}\left(\begin{array}{c}
n \\
i
\end{array}\right)\left(\frac{1}{2}\right)^{i}\left(\frac{1}{2}\right)^{n-i}\right] & =2\left[\left(\begin{array}{c}
14 \\
0
\end{array}\right)\left(\frac{1}{2}\right)^{0}\left(\frac{1}{2}\right)^{14}+\left(\begin{array}{c}
14 \\
1
\end{array}\right)\left(\frac{1}{2}\right)^{1}\left(\frac{1}{2}\right)^{13}+\left(\begin{array}{c}
14 \\
2
\end{array}\right)\left(\frac{1}{2}\right)^{2}\left(\frac{1}{2}\right)^{12}\right] \\
= & 2[0,000061+0,000855+0,005554] \\
= & 0,013 .
\end{aligned}
$$

\section{Tahap Keempat}

Tahap keempat adalah pengambilan keputusan terhadap hipotesis.

Jika nilai probabilitas kumulatif dari $X \geq \alpha$, maka $H_{0}$ diterima, $H_{1}$ ditolak. Jika nilai probabilitas kumulatif dari $X<\alpha$, maka $H_{1}$ diterima, $H_{0}$ ditolak.

Berdasarkan perhitungan, diperoleh nilai probabilitas kumulatif untuk $X=2$ adalah 0,013 , dan tingkat signifikansi yang akan dibandingkan adalah 0,05. Karena nilai probabilitas kumulatif untuk $X=2$, yakni 0,013 , lebih kecil dari nilai tingkat signifikansi, yakni 0,05 , maka hipotesis nol ditolak dan hipotesis alternatif diterima. Ini berarti pernyataan mengenai "terdapat perbedaan berat badan sebelum mengkonsumsi obat penambah berat badan merek XYZ dan sesudah mengkonsumsi obat penambah berat badan merek XYZ selama satu minggu" dapat diterima pada tingkat signifikansi 5\%. Dengan kata lain, terdapat pengaruh yang signifikan secara statistika mengenai berat badan, sebelum dan setelah mengkonsumsi obat penambah berat badan merek XYZ selama satu minggu.

\section{Uji Wilcoxon dan Contoh Perhitungan}

Uji peringkat bertanda Wilcoxon dikembangkan oleh Frank Wilcoxon. Uji peringkat bertanda Wilcoxon dan uji tanda sama-sama menguji dua buah populasi berpasangan. Pada uji tanda hanya memperhatikan arah (direction) dari selisih untuk setiap pasangan nilai data, sedangkan pada uji Wilcoxon, selain memperhatikan arah (tanda positif $(+)$ atau tanda negatif $(-)$ ) dari selisih untuk setiap pasangan nilai data, juga mengukur jarak atau besar (magnitude) dari selisih untuk setiap pasangan nilai data. Oleh karena itu, uji peringkat bertanda Wilcoxon lebih banyak memberikan informasi dibandingkan uji tanda. Misalkan diberikan data mengenai berat badan sebelum mengkonsumsi obat penambah berat badan merek $X Y Z$ dan sesudah mengkonsumsi obat penambah berat badan merek $X Y Z$ selama satu minggu. 


\section{Tabel 20.5}

\begin{tabular}{|c|c|c|c|c|c|c|c|c|c|c|}
\hline Nama & A & B & C & D & E & F & G & H & I & Total \\
\hline$P$ & $45 \mathrm{~kg}$ & $50 \mathrm{~kg}$ & $35 \mathrm{~kg}$ & $45 \mathrm{~kg}$ & $54 \mathrm{~kg}$ & $44 \mathrm{~kg}$ & $41 \mathrm{~kg}$ & $44 \mathrm{~kg}$ & $35 \mathrm{~kg}$ & \\
\hline$Q$ & $44 \mathrm{~kg}$ & $50 \mathrm{~kg}$ & $37 \mathrm{~kg}$ & $50 \mathrm{~kg}$ & $57 \mathrm{~kg}$ & $48 \mathrm{~kg}$ & $45 \mathrm{~kg}$ & $44 \mathrm{~kg}$ & $35 \mathrm{~kg}$ & \\
\hline$Q-P$ & -1 & 0 & +2 & +5 & +3 & +4 & +4 & 0 & 0 & \\
\hline$|Q-P|$ & 1 & & 2 & 5 & 3 & 4 & 4 & & & \\
\hline Ranking & 1 & & 2 & 6 & 3 & 4,5 & 4,5 & & & \\
\hline Tanda + & & & 2 & 6 & 3 & 4,5 & 4,5 & & & 20 \\
\hline Tanda - & 1 & & & & & & & & & 1
\end{tabular}

Pada uji peringkat bertanda Wilcoxon, pertama dihitung selisih untuk setiap pasangan nilai data. Perhatikan bahwa pada Tabel 20.5 untuk baris $Q-P$, dihitung selisih untuk setiap pasangan nilai data. Pada uji tanda, selisih untuk pasangan nilai data hanya dinyatakan oleh tanda positif $(+)$, tanda negatif $(-)$, atau nilai 0 , sedangkan pada uji peringkat bertanda Wilcoxon, selain memperhatikan tanda dari selisih untuk untuk pasangan nilai data, uji peringkat bertanda Wilcoxon juga mengukur jarak atau besar (magnitude) dari selisih untuk pasangan nilai data. Selanjutnya, nilai selisih untuk setiap pasangan nilai data diabsolutkan, seperti pada baris $|Q-P|$ pada Tabel 20.5. Pada uji peringkat bertanda Wilcoxon, nilai $Q-P=0$ tidak diikutsertakan dalam analisis lebih lanjut. Kemudian, nilai absolut dari selisih untuk setiap pasangan nilai data diberi ranking atau peringkat, seperti pada baris Ranking pada Tabel 20.5. Selanjutnya nilai ranking tersebut dikelompokkan berdasarkan tanda positif $(+)$ atau tanda negatif $(-)$, seperti pada baris Tanda + dan Tanda - pada Tabel 20.5. Perhatikan bahwa, berdasarkan Tabel 20.5, jumlah ranking untuk tanda positif $(+)$ sebanyak 20, sedangkan jumlah ranking untuk tanda negatif (-) sebanyak 1.

Uji statistik yang digunakan pada uji peringkat bertanda Wilcoxon adalah uji statistik Wilcoxon $\left(W_{\text {hitung }}\right)$. Nilai statistik dari uji Wilcoxon merupakan nilai dari jumlah ranking yang paling kecil, yakni antara jumlah ranking untuk tanda positif $(+)$ atau jumlah ranking untuk tanda negatif $(-)$. Berdasarkan Tabel 20.5, nilai statistik dari uji Wilcoxon adalah $W_{\text {hitung }}=\min (20 ; 1)=1$. Setelah diperoleh nilai statistik dari uji Wilcoxon $\left(W_{\text {hitung }}\right)$, kemudian menentukan nilai kritis Wilcoxon $\left(W_{\text {kritis }}\right)$ yang diperoleh berdasarkan tabel distribusi Wilcoxon. Berikut aturan pengambilan keputusan terhadap hipotesis.

$$
\begin{aligned}
& \text { Jika } W_{\text {hitung }} \leq W_{\text {kritis }}, H_{1} \text { diterima dan } H_{0} \text { ditolak. } \\
& \text { Jika } W_{\text {hitung }}>W_{\text {kritis }}, H_{0} \text { diterima dan } H_{1} \text { ditolak. }
\end{aligned}
$$

Selain itu, penyelesaian pada uji peringkat bertanda Wilcoxon dapat diselesaikan dengan pendekatan normal atau uji statistik $Z$. jika ukuran sampel cukup besar (moderately large), yakni ukuran sampel lebih dari 20, maka pendekatan normal dapat digunakan. Montgomery dan Runger (2014:364) menyatakan sebagai berikut.

"If the sample size is moderately large, say, $n>20$, it can be shown that $W^{+}\left(\right.$or $\left.W^{-}\right)$has approximately a normal distribution with mean

$$
\mu_{W^{+}}=\frac{n(n+1)}{4}, \text { and variance } \sigma_{W^{+}}^{2}=\frac{n(n+1)(2 n+1)}{24} .
$$

Nilai statistik dari uji Wilcoxon terlebih dahulu ditransformasi ke dalam bentuk nilai normal $Z$ terstandarisasi. Berikut rumus untuk mentransformasi nilai statistik dari uji Wilcoxon ke dalam bentuk nilai normal $Z$ terstandarisasi. 


$$
Z=\frac{W_{\text {hitung }}-\left[\frac{(n)(n+1)}{4}\right]}{\sqrt{\frac{(n)(n+1)(2 n+1)}{24}}}
$$

Setelah memperoleh nilai normal $Z$ terstandarisasi, kemudian pengambilan keputusan terhadap hipotesis dapat ditentukan dengan cara membandingkan probabilitas kumulatif dari nilai normal $Z$ terstandarisasi terhadap tingkat signifikansi $(\alpha)$ yang digunakan.

Jika nilai probabilitas kumulatif dari $Z \geq \alpha$, maka $H_{0}$ diterima, $H_{1}$ ditolak. Jika nilai probabilitas kumulatif dari $Z<\alpha$, maka $H_{1}$ diterima, $H_{0}$ ditolak.

Tabel 20.6 menyajikan nilai probabilitas kumulatif dari nilai normal $Z$.

Tabel 20.6

\begin{tabular}{|c|c|c|}
\hline \multirow{2}{*}{\multicolumn{2}{|c|}{ Test Statistics $^{b}$}} & \multirow{5}{*}{$\begin{array}{l}\text { Nilai } Z=-3,113 \text { merupakan } \\
\text { hasil transformasi dari nilai } \\
\text { statistik dari uji Wilcoxon. } \\
\text { Asymp. Sig. }(2 \text {-tailed) merupakan } \\
\text { nilai probabilitas kumulatif } Z \text {. }\end{array}$} \\
\hline & & \\
\hline & $\begin{array}{l}\text { sesudah - } \\
\text { Sebelum }\end{array}$ & \\
\hline $\bar{Z}$ & $-3.113^{a}$ & \\
\hline Asymp. Sig. (2-tailed) & .002 & \\
\hline
\end{tabular}

Contoh yang sama pada uji tanda akan diselesaikan dengan uji peringkat bertanda Wilcoxon. Misalkan seorang ahli farmasi ingin mengetahui ada tidaknya pengaruh yang signifikan secara statistika mengenai berat badan, sebelum mengkonsumsi obat penambah berat badan merek $X Y Z$ dan sesudah mengkonsumsi obat penambah berat badan merek $X Y Z$ selama satu minggu.

\section{Tahap Pertama}

Tahap pertama adalah perumusan hipotesis. Berikut perumusan hipotesis.

$H_{0}$ : Tidak terdapat perbedaan berat badan sebelum mengkonsumsi obat penambah berat badan merek $X Y Z$ dan sesudah mengkonsumsi obat penambah berat badan merek $X Y Z$ selama satu minggu atau dapat dinyatakan $\mu_{X}=\mu_{Y}$.

$H_{1}$ : Terdapat perbedaan berat badan sebelum mengkonsumsi obat penambah berat badan merek $X Y Z$ dan sesudah mengkonsumsi obat penambah berat badan merek $X Y Z$ selama satu minggu atau dapat dinyatakan $\mu_{X} \neq \mu_{Y}$.

\section{Tahap Kedua}

Tahap kedua adalah menghitung nilai kritis Wilcoxon $\left(W_{\text {kritis }}\right)$ berdasarkan tabel distribusi Wilcoxon. Diketahui banyaknya nilai $Q-P$ yang bertanda positif dan negatif, yakni $n$ adalah 14 (lihat Tabel 20.7). Nilai kritis Wilcoxon dengan tingkat signifikansi 5\% dan $n=14$ adalah 21 (lihat tabel distribusi Wilcoxon untuk menentukan nilai kritis Wilcoxon). 


\section{Tahap Ketiga}

Tahap ketiga adalah menghitung nilai statistik dari uji Wilcoxon $\left(W_{\text {hitung }}\right)$.

Tabel 20.7

\begin{tabular}{|c|c|c|c|c|c|c|c|c|}
\hline & & Ber & dan & & & & \multicolumn{2}{|c|}{ Tanda } \\
\hline Nomor & Nama & $X$ & $Y$ & $Y-X$ & $|Y-X|$ & Ranking & + & - \\
\hline 1 & $\mathrm{~A}$ & 45 & 50 & +5 & 5 & 7 & 7 & \\
\hline 2 & B & 55 & 60 & +5 & 5 & 7 & 7 & \\
\hline 3 & $\mathrm{C}$ & 57 & 60 & +3 & 3 & 3,5 & 3,5 & \\
\hline 4 & $\mathrm{D}$ & 54 & 65 & +11 & 11 & 13 & 13 & \\
\hline 5 & $E$ & 65 & 63 & -2 & 2 & 1,5 & & 1,5 \\
\hline 6 & $\mathrm{~F}$ & 72 & 80 & +8 & 8 & 10 & 10 & \\
\hline 7 & $\mathrm{G}$ & 80 & 90 & +10 & 10 & 11,5 & 11,5 & \\
\hline 8 & $\mathrm{H}$ & 44 & 50 & +6 & 6 & 9 & 9 & \\
\hline 9 & I & 67 & 65 & -2 & 2 & 1,5 & & 1,5 \\
\hline 10 & $\mathbf{J}$ & 60 & 60 & 0 & & & & \\
\hline 11 & $\mathrm{~K}$ & 65 & 75 & +10 & 10 & 11,5 & 11,5 & \\
\hline 12 & $\mathrm{~L}$ & 75 & 80 & 5 & 5 & 7 & 7 & \\
\hline 13 & $\mathrm{M}$ & 67 & 85 & +18 & 18 & 14 & 14 & \\
\hline 14 & $\mathrm{~N}$ & 66 & 70 & +4 & 4 & 5 & 5 & \\
\hline 15 & $\mathrm{O}$ & 62 & 65 & +3 & 3 & 3,5 & 3,5 & \\
\hline & & & JU & LAH & & 105 & 102 & 3 \\
\hline
\end{tabular}

$\Rightarrow$ Nilai absolut dari selisih untuk setiap pasangan data diberi ranking atau peringkat. Berdasarkan data pada Tabel 2.3, data $|Y-X|$ secara berurutan adalah 5, 5, 3, 11, 2, $8,10,6,2,10,5,18,4$, dan 3 . Data $|Y-X|$ yang bernilai 0 tidak diikutkan dalam analisis. Selanjutnya data tersebut diurutkan dari yang paling kecil sampai yang paling besar (lihat Tabel 20.8).

Tabel 20.8 Data $|Y-X|$ setelah Diurutkan

\begin{tabular}{|c|c|c|c|}
\hline Urutan ke & $|Y-X|$ & Urutan ke & $|Y-X|$ \\
\hline 1 & 2 & 8 & 5 \\
\hline 2 & 2 & 9 & 7 \\
\hline 3 & 3 & 10 & 8 \\
\hline 4 & 3 & 11 & 10 \\
\hline 5 & 4 & 12 & 10 \\
\hline 6 & 5 & 13 & 11 \\
\hline 7 & 5 & 14 & 18 \\
\hline
\end{tabular}

Data $|Y-X|$ dengan nilai 2 terdapat dua buah, yakni berada pada urutan ke-1 dan urutan ke-2. Data $|Y-X|$ dengan nilai 18 berada pada urutan terakhir, yakni urutan ke-14.

Nilai ranking untuk data $|Y-X|$ dengan nilai 2 adalah 1,5. Nilai ranking tersebut merupakan rata-rata dari nilai urutan data $|Y-X|$ dengan nilai 2.

$$
\frac{1+2}{2}=1,5
$$


Data $|Y-X|$ dengan nilai 5 terdapat tiga buah, yakni berada pada urutan 6,7, dan 8 . Nilai ranking untuk data $|Y-X|$ dengan nilai 5 adalah 7 . Nilai ranking tersebut merupakan rata-rata dari urutan data $|Y-X|$ dengan nilai 5.

$$
\frac{6+7+8}{3}=7
$$

$\Rightarrow$ Selanjutnya nilai ranking dikelompokkan berdasarkan tanda positif $(+)$ atau tanda negatif $(-)$. Jika $(Y-X)$ bernilai negatif, maka nilai ranking dikelompokkan ke dalam kelompok tanda negatif $(-)$. Jika $(Y-X)$ bernilai positif, maka nilai ranking dikelompokkan ke dalam kelompok tanda positif $(+)$. Sebagai contoh $(Y-X)=-2$ memiliki nilai ranking 1,5 . Karena $(Y-X)$ bernilai negatif, yakni -2 , maka nilai ranking 1,5 dikelompokkan ke dalam kelompok tanda negatif $(-)$. Perhatikan juga bahwa $(Y-X)=11$ memiliki ranking 13. Karena $(Y-X)$ bernilai positif, yakni 11, maka nilai ranking 13 dikelompokkan ke dalam kelompok tanda positif $(+)$.

$\Rightarrow$ Kemudian menentukan nilai $n$. Perhatikan bahwa $n$ merupakan banyaknya nilai $Y-X$ yang bertanda positif $(+)$ atau negatif $(-)$. Berdasarkan data pada Tabel 20.7, nilai selisih $Y-X>0$ berjumlah 12, sedangkan nilai selisih $Y-X<0$ berjumlah 2, sehingga nilai $n$ adalah $2+12=14$.

$\Rightarrow$ Selanjutnya menjumlahkan ranking berdasarkan tanda positif $(+)$ dan tanda negatif $(-)$. Berdasarkan data pada Tabel 20.7, jumlah ranking untuk tanda positif $(+)$ adalah 102 dan jumlah ranking untuk tanda negatif $(-)$ adalah 3. Nilai statistik dari uji Wilcoxon merupakan nilai dengan jumlah ranking yang paling kecil, yakni antara jumlah ranking untuk tanda positif $(+)$ atau jumlah ranking untuk tanda negatif $(-)$. Berdasarkan Tabel 2.3, nilai statistik dari uji Wilcoxon adalah $W_{\text {hitung }}=$ $\min (102 ; 3)=3$.

\section{Tahap Keempat}

Tahap keempat adalah pengambilan keputusan terhadap hipotesis. Berikut aturan dalam pengambilan keputusan terhadap hipotesis.

$$
\begin{gathered}
\text { Jika } W_{\text {hitung }} \leq W_{\text {kritis }}, H_{1} \text { diterima dan } H_{0} \text { ditolak. } \\
\text { Jika } W_{\text {hitung }}>W_{\text {kritis }}, H_{0} \text { diterima dan } H_{1} \text { ditolak. }
\end{gathered}
$$

Diketahui nilai statistik dari uji Wilcoxon adalah 3 dan nilai kritis Wilcoxon adalah 21. Karena nilai statistik dari uji Wilcoxon, yakni 3 lebih kecil dari nilai kritis Wilcoxon, yakni 21, maka hipotesis nol ditolak dan hipotesis alternatif diterima. Ini berarti pernyataan mengenai "terdapat perbedaan yang signifikan (secara statistika) mengenai berat badan, sebelum mengkonsumsi obat penambah berat badan merek $X Y Z$ dan sesudah mengkonsumsi obat penambah berat badan merek $X Y Z$ selama satu minggu" dapat diterima pada tingkat signifikansi 5\%.

\section{Penyelesaian dengan Pendekatan Normal}

Lakukan transformasi terhadap nilai statistik dari uji Wilcoxon menjadi nilai normal $Z$ terstandarisasi. Berikut rumus untuk mentransformasi nilai statistik dari uji Wilcoxon menjadi nilai normal $Z$ terstandarisasi. 


$$
Z=\frac{W_{\text {hitung }}-\left[\frac{(n)(n+1)}{4}\right]}{\sqrt{\frac{(n)(n+1)(2 n+1)}{24}}}
$$

Berdasarkan perhitungan sebelumnya, nilai statistik dari uji Wilcoxon adalah 3, sehingga

$$
\begin{gathered}
Z=\frac{3-\left[\frac{(14)(14+1)}{4}\right]}{\sqrt{\frac{(14)(14+1)(2 \times 14+1)}{24}}} \\
Z=\frac{-49,5}{15,92953232} \\
Z=-3,108 \text { atau }-3,11 .
\end{gathered}
$$

Nilai normal $Z$ terstandarisasi adalah $-3,11$. Nilai probabilitas kumulatif dari $Z=-3,11$ berdasarkan tabel distribusi normal kumulatif adalah 0,0009. Dengan Microsoft Excel dapat dihitung sebagai berikut (Gambar 20.1).

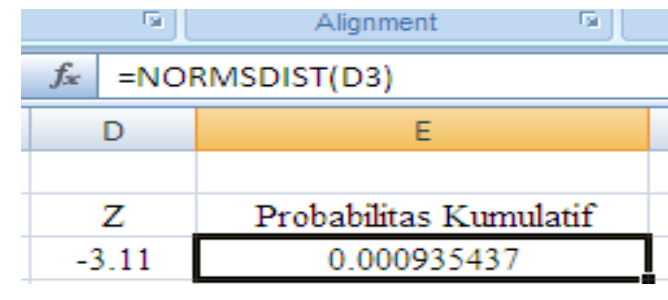

\section{Gambar 20.1}

Karena pengujian hipotesis dua arah, maka nilai probabilitas kumulatif yang akan dibandingkan dengan tingkat signifikansi adalah

$$
2 \times 0,0009=0,0018 \text { atau } 0,002 \text {. }
$$

Perhatikan bahwa karena nilai probabilitas kumulatif $0,002<\alpha=0,05$, maka hipotesis nol ditolak dan hipotesis alternatif diterima. Ini berarti pernyataan mengenai "terdapat perbedaan yang signifikan secara statistika mengenai berat badan, sebelum mengkonsumsi obat penambah berat badan merek $X Y Z$ dan sesudah mengkonsumsi obat penambah berat badan merek $X Y Z$ selama satu minggu" dapat diterima pada tingkat signifikansi $5 \%$.

\section{Uji Mann-Whitney dan Contoh Perhitungan}

Uji Mann-Whitney merupakan uji nonparametrik yang digunakan untuk menguji ada tidaknya perbedaan dari dua populasi yang saling independen. Uji Mann-Whitney merupakan alternatif dari uji $t$ untuk dua populasi independen ketika asumsi normalitas populasi tidak terpenuhi.

Sebagai contoh kasus, andaikan seorang dosen ingin meneliti mengenai ada tidaknya perbedaan yang signifikan secara statistika pada nilai ujian matakuliah kalkulus antara mahasiswa jurusan matematika dan mahasiswa jurusan statistika. Untuk keperluan penelitian, dosen tersebut mengambil sampel sebanyak 8 nilai ujian matakuliah kalkulus yang terdiri dari 396 
4 nilai ujian matakuliah kalkulus mahasiswa jurusan matematika dan 4 nilai ujian matakuliah kalkulus mahasiswa jurusan statistika. Data disajikan pada Tabel 20.9.

Tabel 20.9 (Data Fiktif)

\begin{tabular}{|c|c|c|c|c|c|}
\hline Nama & $X$ & $R(X)$ & Nama & $Y$ & $R(Y)$ \\
\hline Ugi & 65 & 2 & Andi & 80 & 5,5 \\
\hline Mifdhal & 68 & 3 & Firdaus & 90 & 7 \\
\hline Iqbal & 70 & 4 & Joko & 95 & 8 \\
\hline Alan & 80 & 5,5 & Mamat & 50 & 1 \\
\hline \multicolumn{2}{|r|}{ Total $R(X)$} & & 14,5 & \multicolumn{3}{c|}{ Total $R(Y)$} & 21,5 \\
\hline
\end{tabular}

Berdasarkan data pada Tabel 20.9, misalkan $X$ merupakan sampel nilai ujian matakuliah kalkulus mahasiswa jurusan matematika, sedangkan $Y$ merupakan sampel nilai ujian matakuliah kalkulus mahasiswa jurusan statistika. Pada uji Mann-Whitney perlu ditentukan nilai ranking untuk masing-masing nilai data dari kedua sampel. Untuk menentukan nilai ranking dari masing-masing nilai data dari kedua sampel, gabungkan seluruh nilai data dari kedua sampel. Selanjutnya, sajikan nilai-nilai tersebut dimulai dari nilai yang paling kecil hingga nilai yang paling besar. Perhatikan Tabel 20.10.

Tabel 20.10

\begin{tabular}{|c|c|c|c|c|c|c|c|c|}
\hline Urutan & 1 & 2 & 3 & 4 & 5 & 6 & 7 & 8 \\
\hline Nilai & 50 & 65 & 68 & 70 & 80 & 80 & 90 & 95 \\
\hline Ranking & 1 & 2 & 3 & 4 & 5,5 & 5,5 & 7 & 8 \\
\hline
\end{tabular}

Berdasarkan data pada Tabel 20.10, nilai 50 berada pada urutan pertama karena nilai tersebut merupakan nilai paling kecil, sedangkan nilai 80 berada pada urutan kelima dan keenam. Selanjutnya, untuk setiap nilai data dari kedua sampel diberi ranking. Untuk nilai data 50 diberi ranking 1 , karena terletak pada urutan pertama. Namun perhatikan bahwa untuk nilai data 80 diberi ranking 5,5. Perhatikan bahwa nilai data 80 terletak pada urutan kelima dan keenam, sehingga

$$
\text { nilai ranking } 80=\frac{5+6}{2}=5,5 \text {. }
$$

Setelah masing-masing nilai data dari kedua sampel diberi ranking, maka jumlahkan ranking untuk masing-masing sampel. Berdasarkan Tabel 20.9, jumlah ranking nilai ujian matakuliah kalkulus untuk sampel mahasiswa jurusan matematika $(R(X))$ adalah 14,5, sedangkan jumlah ranking nilai ujian matakuliah kalkulus untuk sampel mahasiswa jurusan statistika $(R(Y))$ adalah 21,5. Setelah menghitung jumlah ranking untuk masing-masing nilai data dari kedua sampel, maka akan ditentukan nilai statistik dari uji Mann-Whitney $\left(U_{\text {hitung }}\right)$.

$$
\begin{aligned}
& U_{1}=n_{1} n_{2}+\frac{\left(n_{1}\right)\left(n_{1}+1\right)}{2}-R_{1} \\
& U_{2}=n_{1} n_{2}+\frac{\left(n_{2}\right)\left(n_{2}+1\right)}{2}-R_{2} .
\end{aligned}
$$


Perhatikan bahwa $n_{1}$ menyatakan jumlah elemen atau pengamatan pada sampel pertama, $n_{2}$ menyatakan jumlah elemen atau pengamatan pada sampel kedua, $R_{1}$ menyatakan jumlah ranking pada sampel pertama, dan $R_{2}$ menyatakan jumlah ranking pada sampel kedua. Nilai statistik dari uji Mann-Whitney merupakan $U_{\text {hitung }}=\operatorname{minimum}\left(U_{1}, U_{2}\right)$. Setelah memperoleh nilai statistik dari uji Mann-Whitney, kemudian dibandingkan dengan nilai kritis Mann-Whitney $\left(U_{\text {kritis }}\right)$ berdasarkan tabel distribusi Mann-Whitney. Berikut aturan pengambilan keputusan terhadap hipotesis.

$$
\begin{aligned}
& U_{\text {hitung }} \leq U_{\text {kritis }}, H_{1} \text { diterima, } H_{0} \text { ditolak. } \\
& U_{\text {hitung }}>U_{\text {kritis }}, H_{0} \text { diterima, } H_{1} \text { ditolak. }
\end{aligned}
$$

Selain itu, penyelesaian pada uji uji Mann-Whitney dapat diselesaikan dengan pendekatan normal atau uji statistik $Z$. Jika ukuran sampel cukup besar (moderately large), yakni $n_{1}$ dan $n_{2}$ lebih besar dari 8, maka pendekatan normal dapat digunakan. Montgomery dan Runger (2014:398) menyatakan sebagai berikut.

"When both $n_{1}$ and $n_{2}$ are moderately large, say, more than eight, the distribution of $w_{1}$ can be well approximated by normal distribution with mean

$$
\mu_{w_{1}}=\frac{n_{1}\left(n_{1}+n_{2}+1\right)}{2}
$$

and variance

$$
\sigma_{w_{1}}^{2}=\frac{n_{1} n_{2}\left(n_{1}+n_{2}+1\right)}{12}
$$

Therefore, for $n_{1}$ and $n_{2}>8$, we could use $Z_{0}=\frac{W_{1}-\mu_{w_{1}}}{\sigma_{w_{1}}}$."

Nilai statistik dari uji Mann-Whitney terlebih dahulu ditransformasi ke dalam bentuk nilai normal $Z$ terstandarisasi. Berikut rumus untuk mentransformasi nilai statistik dari uji MannWhitney ke dalam bentuk nilai normal $Z$ terstandarisasi.

$$
Z=\frac{U-\left[\frac{n_{1} n_{2}}{2}\right]}{\sqrt{\frac{\left(n_{1}\right)\left(n_{2}\right)\left(n_{1}+n_{2}+1\right)}{12}}}
$$

Setelah memperoleh nilai normal $Z$ terstandarisasi, kemudian pengambilan keputusan terhadap hipotesis dapat ditentukan dengan cara membandingkan probabilitas kumulatif dari nilai normal $Z$ terstandarisasi terhadap tingkat signifikansi yang digunakan. Tabel 20.11 menyajikan nilai probabilitas kumulatif dari nilai normal $Z$ terstandarisasi.

Tabel 20.11

\begin{tabular}{|l|r|}
\multicolumn{2}{|c|}{ Test Statistics $^{\mathrm{b}}$} \\
\hline \multicolumn{2}{|c|}{} \\
\hline Mann-Whitney U & \multicolumn{1}{|c|}{ nilai } \\
Wilcoxon W & 17.500 \\
$Z$ & 72.500 \\
Asymp. Sig. (2-tailed) & -2.497 \\
Exact Sig. [2*(1-tailed & .013 \\
Sig.)] & $.011^{a}$ \\
\hline
\end{tabular}

Mann-Whitney $U$ merupakan nilai statistik dari uji MannWhitney. Asymp. Sig. (2tailed) merupakan nilai probabilitas dari nilai normal $Z=-2,497$ terstandarisasi. 
Sebagai contoh kasus, misalkan seorang dosen ingin meneliti mengenai ada tidaknya perbedaan yang signifikan secara statistika pada nilai ujian matakuliah kalkulus antara mahasiswa jurusan matematika dan mahasiswa jurusan statistika. Untuk keperluan penelitian, dosen tersebut mengambil sampel sebanyak 20 nilai ujian matakuliah kalkulus yang terdiri dari 10 nilai ujian matakuliah kalkulus mahasiswa jurusan matematika dan 10 nilai ujian matakuliah kalkulus mahasiswa jurusan statistika. Data yang telah dikumpulkan disajikan pada Tabel 20.12.

Tabel 20.12 (Data Fiktif)

\begin{tabular}{|c|c|c|c|}
\hline $\begin{array}{c}\text { Nama Siswa Jurusan } \\
\text { Matematika }\end{array}$ & $X$ & $\begin{array}{c}\text { Nama Siswa Jurusan } \\
\text { Statistika }\end{array}$ & $Y$ \\
\hline Ugi & 65 & Andi & 85 \\
\hline Mifdhal & 68 & Firdaus & 75 \\
\hline Iqbal & 70 & Joko & 75 \\
\hline Alan & 80 & Mamat & 75 \\
\hline John & 75 & Dani & 75 \\
\hline Andre & 72 & Darma & 75 \\
\hline Ridho & 65 & Febri & 80 \\
\hline Hanafi & 60 & Oman & 90 \\
\hline Romi & 88 & Wily & 85 \\
\hline Hasoloan & 70 & Wawan &
\end{tabular}

Berdasarkan data pada Tabel 20.12, misalkan $X$ merupakan sampel nilai ujian matakuliah kalkulus mahasiswa jurusan matematika, sedangkan $Y$ merupakan sampel nilai ujian matakuliah kalkulus mahasiswa jurusan statistika. Dalam hal ini, Uji Mann-Whitney digunakan untuk menguji apakah terdapat perbedaan yang signifikan secara statistika mengenai nilai ujian matakuliah kalkulus antara mahasiswa jurusan matematika dengan jurusan statistika.

\section{Tahap Pertama}

Tahap pertama adalah perumusan hipotesis. Berikut perumusan hipotesis.

$H_{0}$ : Tidak terdapat perbedaan yang signifikan secara statistika mengenai nilai ujian matakuliah kalkulus antara mahasiswa jurusan matematika dan mahasiswa jurusan statistika.

$H_{1}$ : Terdapat perbedaan yang signifikan secara statistika mengenai nilai ujian matakuliah kalkulus antara mahasiswa jurusan matematika dan mahasiswa jurusan statistika.

\section{Tahap Kedua}

Tahap kedua adalah menentukan nilai kritis Mann-Whitney $\left(U_{\text {kritis }}\right)$ berdasarkan tabel distribusi Mann-Whitney. Diketahui jumlah nilai data dalam sampel nilai ujian matakuliah kalkulus jurusan matematika $\left(n_{1}\right)$ adalah 10 , jurusan statistika $\left(n_{2}\right)$ adalah 10 , dan tingkat signifikansi 0,05, sehingga nilai kritis Mann-Whitney berdasarkan tabel distribusi MannWhitney adalah 23.

\section{Tahap Ketiga}

Tahap ketiga adalah menghitung nilai statistik dari uji Mann-Whitney $\left(U_{\text {hitun }}\right)$. 
Tabel 20.13

\begin{tabular}{|c|l|l|l|l|l|l|l|l|l|l|l|}
\hline Nama & Ugi & Mifdhal & Iqbal & Alan & John & Andre & Ridho & Hanafi & Romi & Hasoloan & \\
\hline$X$ & 65 & 68 & 70 & 80 & 75 & 72 & 65 & 60 & 88 & 70 & \\
\hline$R(X)$ & 2,5 & 4 & 5,5 & 15 & 10,5 & 7 & 2,5 & 1 & 19 & 5,5 & 72,5 \\
\hline Nama & Andi & Firdaus & Joko & Mamat & Dani & Darma & Febri & Oman & Wily & Wawan & \\
\hline$Y$ & 85 & 75 & 75 & 80 & 75 & 75 & 75 & 80 & 90 & 85 & \\
\hline$R(Y)$ & 17,5 & 10,5 & 10,5 & 15 & 10,5 & 10,5 & 10,5 & 15 & 20 & 17,5 & 137,5 \\
\hline
\end{tabular}

$\Rightarrow$ Gabungkan seluruh nilai ujian matakuliah kalkulus antara mahasiswa jurusan matematika dan mahasiswa jurusan statistika (Tabel 20.14).

Tabel 20.14

\begin{tabular}{|l|l|l|l|l|l|l|l|l|l|l|}
\hline Nama & Ugi & Mifdhal & Iqbal & Alan & John & Andre & Ridho & Hanafi & Romi & Hasoloan: \\
\hline Nilai & 65 & 68 & 70 & 80 & 75 & 72 & 65 & 60 & 88 & 70 \\
\hline Nama & Andi & Firdaus & Joko & Mamat & Dani & Darma & Febri & Oman & Wily & Wawan \\
\hline Nilai & 85 & 75 & 75 & 80 & 75 & 75 & 75 & 80 & 90 & 85 \\
\hline
\end{tabular}

$\Rightarrow$ Urutkan nilai ujian matakuliah kalkulus dari yang paling kecil sampai yang paling besar (Tabel 20.15).

Nilai Hanafi adalah 60. Nilai 60 merupakan nilai yang paling kecil, sehingga nilai 60 berada pada urutan pertama (Tabel 20.15). Nilai Ugi dan Ridho adalah sama, yakni 65. Nilai 65 berada pada urutan kedua dan ketiga. Nilai Wily adalah 90. Nilai 90 adalah nilai yang paling besar, sehingga nilai 90 terletak pada urutan terakhir, yakni urutan keduapuluh.

$\Rightarrow$ Selanjutnya beri ranking untuk setiap nilai ujian matakuliah kalkulus. Nilai ujian matakuliah kalkulus 65 terdapat dua buah nilai, yakni pada urutan kedua dan urutan ketiga, sehingga ranking untuk nilai ujian matakuliah kalkulus 65 adalah

$$
\frac{2+3}{2}=2,5
$$

Jadi, nilai ujian matakuliah kalkulus 60 diberi ranking 2,5. Untuk nilai ujian matakuliah kalkulus 75 terdapat enam buah nilai, yakni pada urutan kedelapan sampai dengan urutan ketigabelas, sehingga ranking untuk nilai ujian matakuliah kalkulus 75 adalah

$$
\frac{8+9+10+11+12+13}{6}=\frac{63}{3}=10,5 \text {, }
$$

dan seterusnya.

Tabel 20.15

\begin{tabular}{|c|c|c|c|c|c|c|c|c|c|c|}
\hline Urutan ke & 1 & 2 & 3 & 4 & 5 & 6 & 7 & 8 & 9 & 10 \\
\hline Nama & Hanafi & Ugi & Ridho & Mifdhal & Iqbal & Hasoloan & Andre & John & Firdaus & Joko \\
\hline Nilai & 60 & 65 & 65 & 68 & 70 & 70 & 72 & 75 & 75 & 75 \\
\hline Urutan ke & 11 & 12 & 13 & 14 & 15 & 16 & 17 & 18 & 19 & 20 \\
\hline Nama & Dani & Darma & Febri & Alan & Mamat & Oman & Andi & Wawan & Romi & Wily \\
\hline Nilai & 75 & 75 & 75 & 80 & 80 & 80 & 85 & 85 & 88 & 90 \\
\hline
\end{tabular}


$\Rightarrow$ Jumlahkan ranking berdasarkan masing-masing jurusan. Berdasarkan Tabel 20.13, jumlah ranking nilai ujian matakuliah kalkulus mahasiswa jurusan matematika $R(X)$ adalah 72,5 dan jumlah ranking nilai ujian matakuliah kalkulus mahasiswa jurusan statistika $R(Y)$ adalah 137,5. Selanjutnya menghitung nilai $U_{1}$ dan $U_{2}$.

$$
\begin{gathered}
U_{1}=n_{1} n_{2}+\frac{\left(n_{1}\right)\left(n_{1}+1\right)}{2}-R_{1} \\
U_{2}=n_{1} n_{2}+\frac{\left(n_{2}\right)\left(n_{2}+1\right)}{2}-R_{2} \\
U_{1}=(10)(10)+\frac{(10)(10+1)}{2}-72,5=82,5 \\
U_{2}=(10)(10)+\frac{(10)(10+1)}{2}-137,5=17,5 .
\end{gathered}
$$

Sehingga nilai statistik dari uji Mann-Whitney adalah $U_{\text {hitung }}=\min (82,5: 17,5)=$ 17,5 .

\section{Tahap Keempat}

Tahap keempat adalah pengambilan keputusan terhadap hipotesis. Berikut aturan pengambilan keputusan terhadap hipotesis.

$$
\begin{aligned}
& U_{\text {hitung }} \leq U_{\text {kritis }}, H_{1} \text { diterima }, H_{0} \text { ditolak. } \\
& U_{\text {hitung }}>U_{\text {kritis }}, H_{0} \text { diterima, } H_{1} \text { ditolak. }
\end{aligned}
$$

Diketahui nilai statistik dari uji Mann-Whitney adalah 17,5, sedangkan nilai kritis MannWhitney adalah 23. Karena nilai dari statistik dari uji Mann-Whitney, yakni 17,5 lebih kecil dari nilai kritis Mann-Whitney, yakni 23, maka hipotesis nol ditolak dan hipotesis alternatif diterima. Ini berarti pernyataan mengenai "terdapat perbedaan yang signifikan secara statistika mengenai nilai ujian matakuliah kalkulus antara mahasiswa jurusan matematika dan mahasiswa jurusan statistika" dapat diterima pada tingkat signifikansi 5\%.

\section{Penyelesaian dengan Pendekatan Normal}

Lakukan transformasi nilai statistik dari uji Mann-Whitney menjadi nilai normal $Z$ terstandarisasi. Berikut rumus untuk mentransformasi nilai statistik dari uji Mann-Whitney menjadi nilai normal $Z$ terstandarisasi.

$$
Z=\frac{U_{\text {hitung }}-\left[\frac{n_{1} n_{2}}{2}\right]}{\sqrt{\frac{\left(n_{1}\right)\left(n_{2}\right)\left(n_{1}+n_{2}+1\right)}{12}}}
$$

Berdasarkan perhitungan sebelumnya, nilai statistik dari uji Mann-Whitney adalah 17,5, sehingga

$$
Z=\frac{17,5-\left[\frac{(10)(10)}{2}\right]}{\sqrt{\frac{(10)(10)(10+10+1)}{12}}}
$$




$$
\begin{gathered}
Z=\frac{-32,5}{13,22876} \\
Z=-2,456 \text { atau }-2,46 .
\end{gathered}
$$

Berdasarkan perhitungan diperoleh nilai normal $Z$ terstandarisasi adalah $-2,46$. Nilai probabilitas kumulatif dari $Z=-2,46$ berdasarkan tabel distribusi normal kumulatif adalah 0,0069. Diketahui pengujian hipotesis dua arah, sehingga probabilitas kumulatif yang akan dibandingkan dengan tingkat signifikansi adalah

$$
2 \times 0,0069=0,0138 \text { atau } 0,014 \text {. }
$$

Karena nilai probabilitas kumulatif, yakni $0,014<\alpha=0,05$, maka hipotesis nol ditolak dan hipotesis alternatif diterima. Ini berarti pernyataan "terdapat perbedaan nilai ujian matakuliah kalkulus antara mahasiswa jurusan statistika dan mahasiswa jurusan matematika" dapat diterima pada tingkat signifikansi 5\%.

\section{Uji $\mathcal{M} c \mathcal{N}$ emar dan Contoh Perhitungan}

Uji McNemar merupakan uji nonparametrik yang digunakan untuk menguji dua buah populasi yang saling berpasangan. Pada uji McNemar, sekelompok subjek penelitian (misalkan sekelompok orang) memberikan suatu penilaian sebelum dan sesudah perlakuan. Masing-masing subjek penelitian hanya memiliki dua macam penilaian (dichotomous outcomes) untuk setiap perlakuan yang diberikan. Dua penilaian tersebut bersifat saling berlawanan atau dikotomi. Contoh dari dua penilaian yang bersifat saling berlawanan, yakni "benar atau salah", "sukses atau gagal", "ikut atau tidak ikut", "datang atau tidak datang", "sulit atau tidak sulit", dan sebagainya. Misalkan "1" menyatakan kejadian "sukses", sedangkan " 0 " menyatakan kejadian "gagal". Kemudian misalkan $(X, Y)$ menyatakan pasangan pengamatan/kejadian, dengan $X$ menyatakan kejadian sebelum perlakuan, sedangkan $Y$ menyatakan kejadian setelah perlakuan, maka $(X=1, Y=0)$ berarti kejadian sebelum perlakuan adalah sukses, sedangkan setelah perlakuan gagal, $(X=0, Y=0)$ berarti kejadian sebelum perlakuan adalah gagal dan setelah perlakuan juga gagal, dan seterusnya.

Hipotesis nol pada uji McNemar menyatakan tidak terdapat perbedaan efek atau pengaruh sebelum dan sesudah perlakuan. Dengan kata lain, probabilitas dari kejadian $(X=1, Y=0)$ atau $P(X=1, Y=0)$ sama dengan probabilitas untuk kejadian $(X=0, Y=1)$ atau $P(X=$ $0, Y=1$.

Hipotesis alternatif menyatakan terdapat perbedaan efek atau pengaruh sebelum dan sesudah perlakuan. Dengan kata lain, probabilitas dari kejadian $(X=1, Y=0)$ atau $P(X=1, Y=0)$ berbeda dengan probabilitas untuk kejadian $(X=0, Y=1)$ atau $P(X=0, Y=1)$. Dalam uji McNemar, data disajikan dalam tabel kontingensi $2 \times 2$. Berikut disajikan tabel kontingensi $2 \times 2$.

Tabel 20.16

\begin{tabular}{|c|c|c|c|}
\cline { 3 - 4 } \multicolumn{2}{c|}{} & \multicolumn{2}{c|}{$\begin{array}{c}\text { Sesudah } \\
\text { Perlakuan }\end{array}$} \\
\cline { 3 - 4 } \multicolumn{2}{c|}{} & 0 & 1 \\
\hline Sebelum & 0 & $a$ & $b$ \\
\cline { 3 - 4 } Perlakuan & 1 & $c$ & $d$ \\
\hline
\end{tabular}


Berdasarkan tabel kontingensi (Tabel 20.16), a merupakan jumlah subjek penelitian yang memberikan respon " 0 " sebelum perlakuan dan sesudah perlakuan, yang dinyatakan $(0,0), b$ merupakan jumlah subjek penelitian yang memberikan respon " 0 " sebelum perlakuan dan respon " 1 " setelah perlakuan, yang dinyatakan $(0,1)$, dan seterusnya. Conover (1999), Kvam dan Vidakovic (2007) mengemukakan ketika $b+c>20$, maka nilai statistik dari uji McNemar $\left(T_{1}\right)$ dihitung dengan rumus

$$
T_{1}=\frac{(b-c)^{2}}{b+c}
$$

Lebih lanjut, Conover (1999) menyatakan $T_{1}$ semakin mendekati distribusi chi-kuadrat ketika $(b+c)$ semakin besar, dengan derajat bebas 1 . Untuk pengambilan keputusan terhadap hipotesis, nilai statistik dari uji McNemar $\left(T_{1}\right)$ kemudian dibandingkan dengan nilai kritis chikuadrat $\left(\chi_{\text {kritis }}^{2}\right)$.

$$
\begin{aligned}
& \text { Jika } T_{1} \leq \chi_{\text {kritis }}^{2}, H_{0} \text { diterima dan } H_{1} \text { ditolak. } \\
& \text { Jika } T_{1}>\chi_{\text {kritis }}^{2}, H_{0} \text { ditolak dan } H_{1} \text { diterima. }
\end{aligned}
$$

Pengambilan keputusan terhadap hipotesis juga dapat digunakan dengan pendekatan nilai probabilitas dari $T_{1}$. Nilai probabilitas dari $T_{1}$ dibandingkan dengan tingkat signifikansi yang digunakan $(\alpha)$. Berikut aturan pengambilan keputusan terhadap hipotesis berdasarkan pendekatan nilai probabilitas.

Jika nilai probabilitas $T_{1} \geq \alpha$, maka $H_{0}$ diterima dan $H_{1}$ ditolak. Jika nilai probabilitas $T_{1}<\alpha$, maka $H_{1}$ diterima dan $H_{0}$ ditolak.

Rumus untuk menghitung nilai statistik dari uji McNemar $\left(T_{2}\right)$, ketika $b+c \leq 20$ adalah sebagai berikut.

$$
T_{2}=2\left[\sum_{i=0}^{X}\left(\begin{array}{l}
n \\
i
\end{array}\right) p^{i} q^{n-i}\right]
$$

Perhatikan bahwa $n=b+c$, sedangkan $X=\min (b, c)$. Berikut aturan pengambilan keputusan terhadap hipotesis.

$$
\begin{aligned}
& \text { Jika } T_{2} \geq \alpha, \text { maka } H_{0} \text { diterima dan } H_{1} \text { ditolak. } \\
& \text { Jika } T_{2}<\alpha, \text { maka } H_{1} \text { diterima. dan } H_{0} \text { ditolak. }
\end{aligned}
$$

Sebagai contoh kasus, misalkan seorang peneliti sedang meneliti apakah dengan adanya tayangan iklan yang mempromosikan bumbu masakan merek A, terjadi pengaruh yang cukup signifikan terhadap penggunaan bumbu masakan merek A. Data yang telah dikumpulkan oleh peneliti disajikan pada Tabel 20.17 .

Berdasarkan data pada Tabel 20.17, seorang yang bernama Hanafi tidak menggunakan bumbu masakan merek A sebelum ada iklan di televisi mengenai promosi bumbu masakan merek A. Namun setelah ada iklan di televisi mengenai bumbu masakan merek A, ia menggunakan bumbu masakan merek A. Perhatikan bahwa kejadian tersebut dapat dilambangkan dengan $(0,1)$. Seorang yang bernama Ugi menggunakan bumbu masakan merek A sebelum ada iklan di televisi mengenai promosi bumbu masakan merek A. Namun, setelah ada iklan di televisi 
mengenai promosi bumbu masakan merek A, ia tidak lagi menggunakan bumbu masakan merek A. Perhatikan bahwa kejadian tersebut dapat dilambangkan dengan $(1,0)$.

Tabel 20.17 (Data Fiktif)

\begin{tabular}{|c|c|c|c|c|c|}
\hline & & \multicolumn{4}{|c|}{ Pemberian Motivasi } \\
\hline No. & Nama & \multicolumn{2}{|c|}{ Sebelum Ada Iklan } & \multicolumn{2}{|c|}{ Sesudah Ada Iklan } \\
\hline 1 & Hanafi & 0 & Tidak Menggunakan & 1 & Menggunakan \\
\hline 2 & Ridho & 0 & Tidak Menggunakan & 1 & Menggunakan \\
\hline 3 & Niar & 0 & Tidak Menggunakan & 1 & Menggunakan \\
\hline 4 & Fitri & 0 & Tidak Menggunakan & 1 & Menggunakan \\
\hline 5 & Ugi & 1 & Menggunakan & 0 & Tidak Menggunakan \\
\hline 6 & Romi & 1 & Menggunakan & 1 & Menggunakan \\
\hline 7 & Mifdal & 1 & Menggunakan & 1 & Menggunakan \\
\hline 8 & Iqbal & 1 & Menggunakan & 1 & Menggunakan \\
\hline 9 & Suci & 1 & Menggunakan & 1 & Menggunakan \\
\hline 10 & Melda & 0 & Tidak Menggunakan & 1 & Menggunakan \\
\hline 11 & Evelin & 0 & Tidak Menggunakan & 1 & Menggunakan \\
\hline 12 & Hasoloan & 0 & Tidak Menggunakan & 1 & Menggunakan \\
\hline 13 & John & 0 & Tidak Menggunakan & 0 & Tidak Menggunakan \\
\hline 14 & sri & 0 & Tidak Menggunakan & 0 & Tidak Menggunakan \\
\hline 15 & alan & 0 & Tidak Menggunakan & 1 & Menggunakan \\
\hline
\end{tabular}

Dengan menggunakan tingkat signifikansi 5\%, berikut akan digunakan uji McNemar untuk mengetahui apakah terdapat pengaruh yang signifikan secara statistika terhadap penggunaan bumbu masakan merek A, setelah adanya iklan promosi.

\section{Tahap Pertama}

Tahap pertama adalah perumusan hipotesis. Berikut perumusan hipotesis.

$H_{0}: P(0,1)=P(1,0)$ atau tidak terdapat pengaruh yang signifikan secara statistika pada penggunaan bumbu masakan mereka $\mathrm{A}$, setelah adanya iklan promosi.

$H_{1}: P(0,1) \neq P(1,0)$ atau terdapat pengaruh yang signifikan secara statistika pada penggunaan bumbu masakan mereka $\mathrm{A}$, setelah adanya iklan promosi.

\section{Tahap Kedua}

Tahap kedua adalah menghitung nilai kritis chi-kuadrat $\left(\chi_{\text {kritis }}^{2}\right)$ berdasarkan tabel distribusi chi-kuadrat. Untuk menghitung nilai kritis chi-kuadrat, terlebih dahulu menghitung nilai derajat bebas.

$$
\text { Derajat bebas }=k-1 \text {. }
$$

Perhatikan bahwa $k$ merupakan jumlah sampel. Dalam hal ini, nilai $k=2$, sehingga derajat bebas $2-1=1$. Nilai kritis chi-kuadrat dengan derajat bebas 1 dan tingkat signifikansi 5\% berdasarkan tabel distribusi chi-kuadrat adalah 3,841. 


\section{Tahap Ketiga}

Tahap ketiga adalah menghitung nilai statistik dari uji McNemar. Berikut disajikan data dalam tabel kontingensi $2 \times 2$.

Tabel 20.18

\begin{tabular}{|c|c|c|c|}
\cline { 3 - 4 } \multicolumn{2}{c|}{} & \multicolumn{2}{c|}{ Sesudah Ada Iklan } \\
\cline { 3 - 4 } \multicolumn{2}{c|}{} & 0 & 1 \\
\hline \multirow{3}{*}{ Sebelum Ada Iklan } & 0 & 2 & 8 \\
\cline { 2 - 4 } & 1 & 1 & 4 \\
\hline
\end{tabular}

Berdasarkan Tabel 20.18, "0" menyatakan tidak menggunakan bumbu masakan merek A, sedangkan "1" menyatakan menggunakan bumbu masakan merek A. Diketahui terdapat 4 orang menggunakan bumbu masakan merek A sebelum dan setelah adanya iklan promosi. Terdapat 8 orang yang tidak menggunakan bumbu masakan merek A sebelum ada iklan promosi. Namun, setelah ada iklan promosi, maka 8 orang tersebut beralih untuk menggunakan bumbu masakan merek A.

Perhatikan bahwa $b+c \leq 20$, yakni $1+8 \leq 20$, maka nilai statistik dari uji McNemar $\left(T_{2}\right)$ dihitung dengan rumus sebagai berikut.

$$
T_{2}=2\left[\sum_{i=0}^{X}\left(\begin{array}{l}
n \\
i
\end{array}\right) p^{i} q^{n-i}\right]
$$

Diketahui $n=1+8=9$ dan $X=\min (1,8)=1$, sehingga

$$
\begin{gathered}
T_{2}=2\left[\sum_{i=0}^{X}\left(\begin{array}{l}
n \\
i
\end{array}\right) p^{i} q^{n-i}\right]=2[P(X=0)+P(X=1)] \\
=2\left[\left(\begin{array}{l}
9 \\
0
\end{array}\right)\left(\frac{1}{2}\right)^{0}\left(\frac{1}{2}\right)^{9}+\left(\begin{array}{c}
9 \\
1
\end{array}\right)\left(\frac{1}{2}\right)^{1}\left(\frac{1}{2}\right)^{8}\right] \\
=2[0,001953+0,017578]=0,039 .
\end{gathered}
$$

Berikut aturan pengambilan keputusan terhadap hipotesis.

Jika $T_{2} \geq \alpha$, maka $H_{0}$ diterima dan $H_{1}$ ditolak. Jika $T_{2}<\alpha$, maka $H_{1}$ diterima. dan $H_{0}$ ditolak.

Karena nilai $T_{2}$ lebih kecil dari tingkat signifikansi $\alpha=0,05$, maka hipotesis nol ditolak dan hipotesis alternatif diterima. Hal ini berarti terdapat pengaruh yang signifikan secara statistika pada penggunaan bumbu masakan mereka A, setelah adanya iklan promosi pada tingkat signifikansi $5 \%$.

\section{Korelasi Berperingkat Spearman dan Contoh Perhitungan}

Korelasi berperingkat Spearman merupakan suatu nilai yang mengukur keeratan suatu hubungan antara dua buah variabel, di mana nilai tersebut dihitung berdasarkan data ranking 
yang diperoleh berdasarkan data asli dari masing-masing variabel. Pada korelasi Pearson, nilai korelasi dihitung dengan menggunakan data asli, sedangkan nilai korelasi berperingkat Spearman dihitung dengan menggunakan data ranking yang diperoleh berdasarkan data aslinya. Berikut rumus untuk menghitung korelasi berperingkat Spearman $\left(r_{s}\right)$.

$$
r_{s}=1-\frac{6 \sum_{i=1}^{n} D_{i}^{2}}{(n)\left(n^{2}-1\right)}
$$

Perhatikan bahwa $r_{s}$ menyatakan nilai korelasi berperingkat Spearman, $D_{i}$ menyatakan nilai selisih dari pasangan nilai data ranking ke- $i$, dan $n$ menyatakan jumlah elemen dalam sampel. Setelah diperoleh nilai korelasi berperingkat Spearman (sampel), maka perlu diuji signifikansi dari korelasi berperingkat Spearman populasi $\left(\rho_{s}\right)$. Untuk menguji signifikansi dari korelasi berperingkat Spearman populasi, digunakan uji $t$. Berikut rumus untuk menghitung nilai statistik dari uji $t$.

$$
t=\frac{r_{s} \sqrt{n-2}}{\sqrt{1-r_{s}^{2}}}
$$

Nilai statistik dari uji $t$ kemudian dibandingkan dengan dengan nilai kritis $t$ berdasarkan tabel distribusi $t$ untuk pengambilan keputusan terhadap hipotesis. Hipotesis nol menyatakan tidak terdapat hubungan yang signifikan secara statistika antara variabel pertama dan variabel kedua. Secara matematis dinyatakan

$$
H_{0}: \rho_{s}=0
$$

Hipotesis alternatif menyatakan terdapat hubungan yang signifikan secara statistika antara variabel pertama dan variabel kedua. Secara matematis dinyatakan

$$
H_{1}: \rho_{s} \neq 0
$$

Pengambilan keputusan terhadap hipotesis juga dapat dilakukan dengan pendekatan nilai probabilitas dari uji $t$. Nilai probabilitas dari uji $t$ dibandingkan dengan tingkat signifikansi yang digunakan $(\alpha)$. Berikut aturan pengambilan keputusan terhadap hipotesis berdasarkan pendekatan nilai probabilitas.

$$
\begin{aligned}
& \text { Jika nilai probabilitas } \geq \alpha, \text { maka } H_{0} \text { diterima dan } H_{1} \text { ditolak. } \\
& \text { Jika nilai probabilitas }<\alpha, \text { maka } H_{0} \text { ditolak dan } H_{1} \text { diterima. }
\end{aligned}
$$

Sebagai contoh, misalkan seorang peneliti ingin mengukur keeratan hubungan antara jumlah jam belajar di luar waktu kuliah dalam sehari dan nilai indeks prestasi mahasiswa. Peneliti tersebut mengambil sampel sebanyak 12 orang mahasiswa dan kemudian melakukan interview untuk mengetahui informasi mengenai jumlah jam belajar di luar waktu kuliah dalam sehari dan nilai indeks prestasi mahasiswa. Data yang telah diperoleh disajikan pada Tabel 20.19.

Berdasarkan Tabel 20.19, $X$ menyatakan jumlah jam belajar dalam sehari di luar waktu kuliah, sedangkan $Y$ menyatakan nilai indeks prestasi mahasiswa. Berikut akan diuji apakah terdapat hubungan yang signifikan antara jumlah jam belajar dalam sehari di luar waktu kuliah terhadap nilai indeks prestasi mahasiswa pada tingkat signifikansi 5\%. 
Tabel 20.19 (Data Fiktif)

\begin{tabular}{|c|c|c|c|c|c|c|c|c|c|c|c|c|}
\hline Mahasiswa & 1 & 2 & 3 & 4 & 5 & 6 & 7 & 8 & 9 & 10 & 11 & 12 \\
\hline$X$ & 2 & 4 & 0 & 5 & 7 & 7 & 9 & 8 & 6 & 5 & 2 & 9 \\
\hline$Y$ & 1,5 & 2,8 & 1,2 & 2,9 & 3,3 & 3,25 & 3,7 & 3,8 & 3,1 & 3,3 & 2 & 3,9
\end{tabular}

\section{Tahap Pertama}

Tahap pertama adalah perumusan hipotesis. Berikut perumusan hipotesis.

$H_{0}: \rho_{s}=0$ atau tidak terdapat hubungan yang signifikan secara statistika antara jumlah jam belajar di luar waktu kuliah dalam sehari terhadap nilai indeks prestasi mahasiswa.

$H_{1}: \rho_{s} \neq 0$ atau terdapat hubungan yang signifikan secara statistika antara jumlah jam belajar di luar waktu kuliah dalam sehari terhadap nilai indeks prestasi mahasiswa.

\section{Tahap Kedua}

Tahap kedua adalah menghitung nilai kritis $t$ berdasarkan tabel distribusi $t$. Sebelum menghitung nilai kritis $t$, terlebih dahulu menghitung nilai derajat bebas. Berikut rumus untuk menghitung nilai derajat bebas.

$$
\text { Derajat bebas }=n-2 \text {. }
$$

Perhatikan bahwa $n$ merupakan jumlah elemen dalam sampel, sehingga derajat bebas adalah $12-2=10$. Nilai kritis $t$ dengan derajat bebas 10 dan tingkat signifikansi $5 \%$ adalah $\pm 2,228$.

\section{Tahap Ketiga}

Tahap ketiga adalah menghitung nilai statistik dari uji $t$.

Tabel 20.20

\begin{tabular}{|c|c|c|c|c|c|c|c|c|c|c|c|c|}
\hline Mahasiswa & 1 & 2 & 3 & 4 & 5 & 6 & 7 & 8 & 9 & 10 & 11 & 12 \\
\hline$X$ & 2 & 4 & 0 & 5 & 7 & 7 & 9 & 8 & 6 & 5 & 2 & 9 \\
\hline$Y$ & 1,5 & 2,8 & 1,2 & 2,9 & 3,3 & 3,25 & 3,7 & 3,8 & 3,1 & 3,3 & 2 & 3,9 \\
\hline$R(X)$ & 2,5 & 4 & 1 & 5,5 & 8,5 & 8,5 & 11,5 & 10 & 7 & 5,5 & 2,5 & 11,5 \\
\hline$R(Y)$ & 2 & 4 & 1 & 5 & 8,5 & 7 & 10 & 11 & 6 & 8,5 & 3 & 12 \\
\hline$D=R(X)-R(Y)$ & 0,5 & 0 & 0 & 0,5 & 0 & 1,5 & 1,5 & -1 & 1 & -3 & $-0,5$ & $-0,5$ \\
\hline$D^{2}$ & 0,25 & 0 & 0 & 0,25 & 0 & 2,25 & 2,25 & 1 & 1 & 9 & 0,25 & 0,25 \\
\hline
\end{tabular}

Berdasarkan Tabel 20.20, $R(X)$ merupakan ranking dari nilai $X$, sedangkan $R(Y)$ merupakan ranking dari nilai $Y$.

$$
\sum_{i=1}^{n} D_{i}^{2}=0,25+0+0+\cdots+9+0,25+0,25=16,5
$$

$\Rightarrow$ Urutkan nilai-nilai $X$ dan $Y$ dari yang terkecil hingga terbesar (Tabel 20.21). 


\begin{tabular}{|c|c|c|c|c|c|c|c|c|c|c|c|c|}
\hline Urutan & 1 & 2 & 3 & 4 & 5 & 6 & 7 & 8 & 9 & 10 & 11 & 12 \\
\hline$X$ & 0 & 2 & 2 & 4 & 5 & 5 & 6 & 7 & 7 & 8 & 9 & 9
\end{tabular}

Berdasarkan Tabel 20.21, nilai $X=0$ atau mahasiswa yang tidak pernah belajar berada pada urutan pertama. Mahasiswa yang belajar selama 6 jam atau $X=6$ berada pada urutan ketujuh. Terdapat dua orang mahasiswa yang belajar selama 5 jam atau $X=5$, yakni pada urutan kelima dan urutan keenam. Terdapat dua orang mahasiswa yang belajar selama 9 jam atau $X=9$, yakni pada urutan kesebelas dan urutan keduabelas, dan seterusnya.

\section{Tabel 20.22}

\begin{tabular}{|c|c|c|c|c|c|c|c|c|c|c|c|c|}
\hline Urutan & 1 & 2 & 3 & 4 & 5 & 6 & 7 & 8 & 9 & 10 & 11 & 12 \\
\hline$Y$ & 1,2 & 1,5 & 2 & 2,8 & 2,9 & 3,1 & 3,25 & 3,3 & 3,3 & 3,7 & 3,8 & 3,9 \\
\hline
\end{tabular}

Berdasarkan Tabel 20.22, mahasiswa dengan indeks prestasi 1,2 berada pada urutan pertama karena nilai tersebut paling kecil. Mahasiswa dengan indeks prestasi 3,9 terletak pada urutan keduabelas dengan urutan paling besar.

$\Rightarrow$ Selanjutnya memberi ranking untuk setiap nilai $X$ dan nilai $Y$. Nilai $X=2$ terdapat dua nilai, yakni pada urutan kedua dan urutan ketiga, sehingga ranking untuk nilai $X=2$ adalah

$$
\frac{2+3}{2}=2,5
$$

Nilai $X=7$ terdapat dua nilai, yakni pada urutan kedelapan dan urutan kesembilan, sehingga ranking untuk nilai $X=7$ adalah

$$
\frac{8+9}{2}=8,5
$$

Nilai $Y=3,3$ terdapat dua nilai, yakni urutan kedelapan dan urutan kesembilan, sehingga ranking untuk nilai $Y=3,3$ adalah

$$
\frac{8+9}{2}=8,5
$$

$\Rightarrow$ Kemudian menentukan nilai selisih untuk setiap pasangan nilai berdasarkan data ranking $X$ dan ranking $Y$. Nilai selisih tersebut misalkan dilambangkan dengan $D$. Sebagai contoh nilai $D$ untuk mahasiswa nomor 2 adalah $4-4=0$. Nilai $D$ untuk mahasiswa nomor 8 adalah $10-11=-1$, dan seterusnya.

$\Rightarrow$ Menentukan nilai $D^{2}$. Sebagai contoh nilai $D^{2}$ dari mahasiswa nomor 8 adalah $(-1)^{2}=1$, nilai $D^{2}$ dari mahasiswa nomor 7 adalah $(1,5)^{2}=2,25$, dan seterusnya.

$\Rightarrow$ Menghitung koefisien korelasi berperingkat Spearman $\left(r_{s}\right)$. 


$$
\begin{gathered}
r_{s}=1-\frac{6 \sum_{i=1}^{n} D_{i}^{2}}{(n)\left(n^{2}-1\right)} \\
=1-\frac{(6)(15,5)}{(12)\left(12^{2}-1\right)} \\
=0,9458 .
\end{gathered}
$$

Nilai korelasi berperingkat Spearman $\left(r_{s}\right)$ berdasarkan perhitungan adalah 0,9458. Nilai tersebut dapat diinterpretasikan terdapat hubungan positif antara jumlah jam belajar dalam sehari di luar waktu kuliah dengan nilai indeks prestasi mahasiswa. Perhatikan bahwa nilai korelasi berperingat Spearman $\left(r_{s}\right)$ berkisar dari -1 sampai 1 .

$\Rightarrow$ Menghitung nilai statistik dari uji $t$.

$$
\begin{gathered}
t=\frac{r_{s} \sqrt{n-2}}{\sqrt{1-r_{s}^{2}}} \\
t=\frac{0,9458 \sqrt{12-2}}{\sqrt{1-0,9458^{2}}} \\
t=9,2098
\end{gathered}
$$

Nilai statistik dari uji $t$ berdasarkan perhitungan adalah 9,2098.

\section{Tahap Keempat}

Tahap keempat adalah pengambilan keputusan terhadap hipotesis. Berikut daerah keputusan dengan nilai kritis $t= \pm 2,228$.

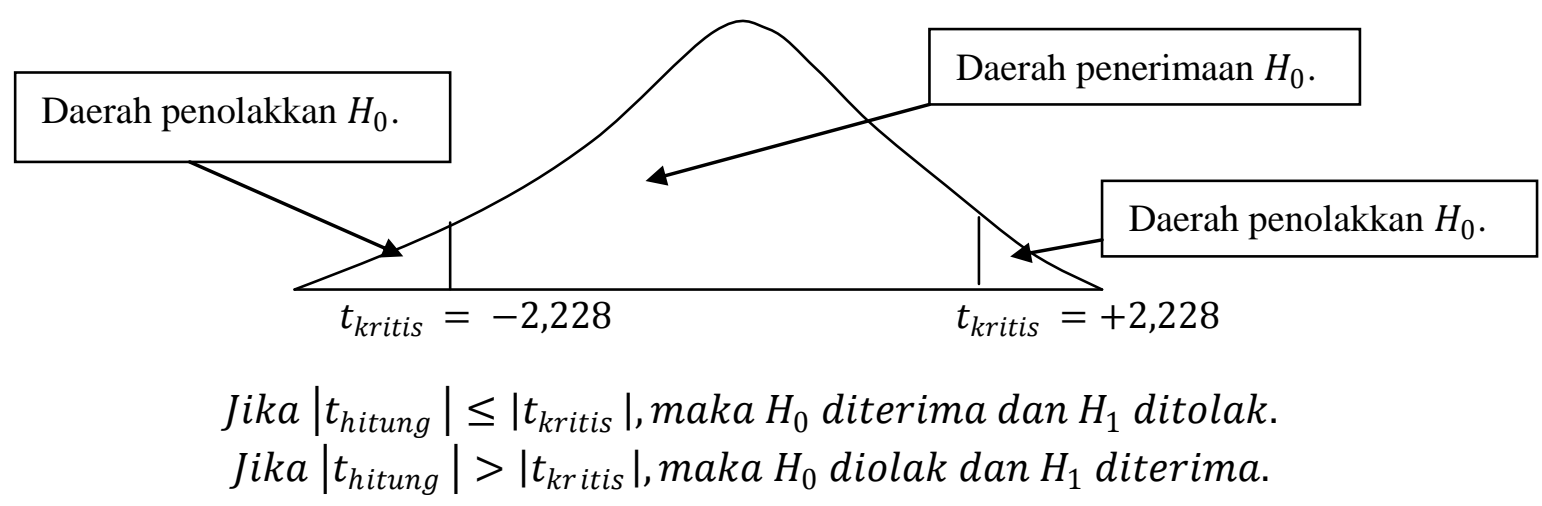

Berdasarkan perhitungan, nilai statistik dari uji $t$ adalah 9,2098. Karena nilai statistik dari uji $t$ berada di luar daerah penerimaan hipotesis nol, maka hipotesis nol ditolak dan hipotesis alternatif. Hal ini berarti terdapat hubungan yang signifikan secara statistika antara jumlah jam belajar di luar waktu kuliah dalam sehari dengan nilai indeks prestasi mahasiswa pada tingkat signifikansi 5\%. 


\section{Uji Kruskal-Wallis dan Contoh Perhitungan}

Pada uji Mann-Whitney hanya menguji dua populasi independen, sedangkan pada uji Kruskal-Wallis menguji tiga atau lebih populasi independen. Tiga atau lebih sampel independen diuji apakah berasal dari populasi-populasi yang memiliki kesamaan rata-rata atau tidak. Uji Kruskal-Wallis merupakan alternatif dari analisis varians satu arah jika asumsi normalitas dari populasi-populasi yang diteliti tidak dipenuhi.

Hipotesis nol pada uji Kruskal-Wallis menyatakan tiga atau lebih sampel independen berasal dari populasi-populasi yang memiliki kesamaan rata-rata. Hipotesis alternatif menyatakan terdapat paling sedikit sepasang rata-rata populasi yang berbeda. Berikut rumus untuk menghitung nilai statistik dari uji Kruskal-Wallis $(H)$.

$$
H=\frac{12}{N(N+1)}\left[\frac{R_{1}^{2}}{n_{1}}+\frac{R_{2}^{2}}{n_{2}}+\cdots+\frac{R_{k}^{2}}{n_{k}}\right]-3(N+1) .
$$

Perhatikan bahwa $n_{i}$ menyatakan jumlah elemen sampel ke- $i, N$ menyatakan jumlah elemen dari seluruh sampel, yakni $N=n_{1}+n_{2}+\cdots+n_{k}$, dan $R_{i}$ menyatakan jumlah ranking dari sampel ke- $i$. Untuk pengambilan keputusan terhadap hipotesis, dapat dilakukan dengan membandingkan nilai statistik dari uji Kruskal-Wallis terhadap nilai kritis chi-kuadrat $\left(\chi_{\text {kritis }}^{2}\right)$. Berikut aturan pengambilan keputusan terhadap hipotesis.

$$
\begin{aligned}
& \text { Jika } H \leq \chi_{\text {kritis }}^{2} H_{0} \text { diterima dan } H_{1} \text { ditolak. } \\
& \text { Jika } H>\chi_{\text {kritis }}^{2}, H_{0} \text { ditolak dan } H_{1} \text { diterima. }
\end{aligned}
$$

Sebagai contoh kasus, misalkan seorang peneliti ingin meneliti kualitas (dalam penelitian ini, kualitas diukur berdasarkan jumlah siswa yang lulus PTN) dari tiga bimbingan belajar, yakni bimbingan belajar A, B, dan, C. Untuk keperluan penelitian, peneliti tersebut melakukan observasi untuk memperoleh data mengenai jumlah siswa yang lulus untuk masuk perguruan tinggi negeri selama 6 tahun terakhir. Berikut data mengenai jumlah siswa yang lulus untuk masuk perguruan tinggi negeri dari ketiga bimbingan belajar A,B, dan $C$ selama 6 tahun terakhir.

\section{Tabel 20.23 (Data Fiktif)}

\begin{tabular}{|c|c|c|c|c|c|c|}
\hline Tahun & 2000 & 2001 & 2002 & 2003 & 2004 & 2005 \\
\hline Bimbe1 A & 50 & 70 & 65 & 60 & 70 & 45 \\
\hline Bimbe1 B & 80 & 69 & 50 & 65 & 65 & 45 \\
\hline Bimbe1 C & 80 & 85 & 90 & 120 & 150 & 200
\end{tabular}

Berdasarkan data pada Tabel 20.23, misalkan diasumsikan jumlah siswa yang belajar dari masing-masing bimbingan belajar adalah sama (misalkan 300 siswa) untuk setiap tahun. Jadi, pada tahun 2000, siswa yang lulus untuk masuk perguruan tinggi negeri dari bimbingan belajar A sebanyak 50 siswa dari 300 siswa, bimbingan belajar B sebanyak 80 siswa dari 300 siswa, dan bimbingan belajar $\mathrm{C}$ sebanyak 80 siswa dari 300 siswa.

Pada tahun 2005, siswa yang lulus untuk masuk perguruan tinggi negeri dari bimbingan belajar A sebanyak 45 siswa dari 300 siswa, bimbingan belajar B sebanyak 45 siswa dari 300 siswa, dan bimbingan belajar $\mathrm{C}$ sebanyak 200 siswa dari 300 siswa. Berikut akan diuji apakah terdapat perbedaan yang signifikan secara statistika mengenai kualitas di antara bimbingan belajar A, B, dan C pada tingkat signifikansi 5\%. 


\section{Tahap Pertama}

Tahap pertama adalah perumusan hipotesis. Berikut perumusan hipotesis.

$H_{0}: \mu_{1}=\mu_{2}=\mu_{3}$ atau rata-rata jumlah siswa yang lulus dari ketiga bimbingan belajar adalah sama atau ketiga bimbingan belajar mempunyai kualitas yang sama.

$H_{1}$ : Terdapat perbedaan rata-rata mengenai jumlah siswa yang lulus di antara ketiga bimbingan belajar atau terdapat perbedaan kualitas di antara ketiga bimbingan belajar.

\section{Tahap Kedua}

Tahap kedua adalah menghitung nilai kritis chi-kuadrat berdasarkan tabel distribusi chikuadrat. Sebelum menghitung nilai kritis chi-kuadrat, terlebih dahulu menghitung nilai derajat bebas. Berikut rumus untuk menghitung nilai derajat bebas.

\section{Derajat bebas $=k-1$.}

Perhatikan bahwa $k$ merupakan jumlah sampel, sehingga nilai derajat bebas adalah $3-1=$ 2. Nilai kritis chi-kuadrat dengan derajat bebas 2 dan tingkat signifikansi 5\% adalah 5,991. Nilai kritis chi-kuadrat dapat dihitung dengan Microsoft Excel sebagai berikut.

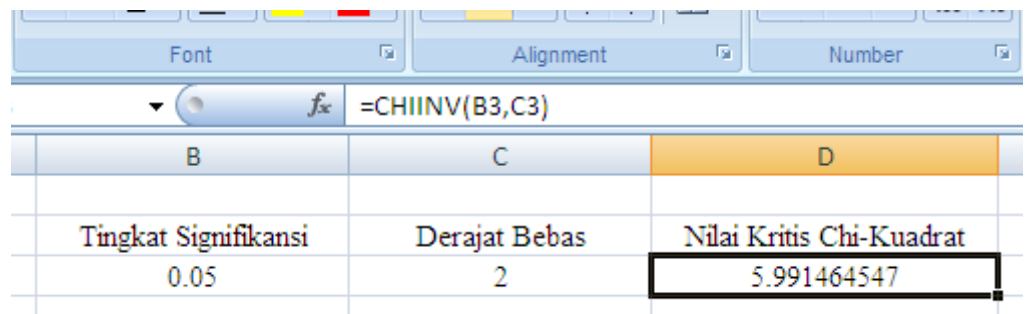

\section{Gambar 20.2}

\section{Tahap Ketiga}

Tahap ketiga adalah menghitung nilai statistik dari uji Kruskal-Wallis $(H)$.

Tabel 20.24

\begin{tabular}{|c|c|c|c|c|c|c|c|c|}
\hline Tahum & 2000 & 2001 & 2002 & 2003 & 2004 & 2005 & Total Ranking & $\begin{array}{c}\text { Rata-Rata } \\
\text { Ranking }\end{array}$ \\
\hline Ranking Bimbel A & 3,5 & 10,5 & 7 & 5 & 10,5 & 1,5 & 38 & 6,33 \\
\hline Ranking Bimbel B & 12,5 & 9 & 3,5 & 7 & 7 & 1,5 & 40,5 & 6,75 \\
\hline Ranking Bimbel C & 12,5 & 14 & 15 & 16 & 17 & 18 & 92,5 & 15,42 \\
\hline
\end{tabular}

$\Rightarrow$ Gabungkan nilai data dari seluruh sampel (Tabel 20.25).

Tabel 20.25

\begin{tabular}{|c|c|c|c|c|c|}
\hline 50 & 70 & 65 & 60 & 70 & 45 \\
\hline 80 & 69 & 50 & 65 & 65 & 45 \\
\hline 80 & 85 & 90 & 120 & 150 & 200 \\
\hline
\end{tabular}


$\Rightarrow$ Urutkan nilai data dari yang paling kecil sampai yang paling besar (Tabel 20.26).

Tabel 20.26

\begin{tabular}{|c|c|c|c|c|c|c|c|c|c|}
\hline Urutan & 1 & 2 & 3 & 4 & 5 & 6 & 7 & 8 & 9 \\
\hline Jumlah Mahasiswa & 45 & 45 & 50 & 50 & 60 & 65 & 65 & 65 & 69 \\
\hline Urutan & 10 & 11 & 12 & 13 & 14 & 15 & 16 & 17 & 18 \\
\hline Jumlah Mahasiswa & 70 & 70 & 80 & 80 & 85 & 90 & 120 & 150 & 200 \\
\hline
\end{tabular}

Perhatikan bahwa nilai 45 merupakan nilai yang paling kecil. Karena nilai 45 terdapat 2 nilai, maka nilai 45 berada pada urutan pertama dan urutan kedua.

$\Rightarrow$ Beri ranking untuk setiap nilai. Sebagai contoh, nilai 45 terdapat dua nilai, yakni pada urutan pertama dan urutan kedua, sehingga ranking untuk nilai 45 adalah

$$
\frac{1+2}{2}=1,5
$$

Nilai 65 terdapat tiga nilai, yakni pada urutan keenam, ketujuh, dan kedelapan, sehingga ranking untuk nilai 65 adalah

$$
\frac{6+7+8}{3}=7
$$

$\Rightarrow$ Selanjutnya menghitung nilai statistik dari uji Kruskal-Wallis $(H)$.

$$
\begin{gathered}
H=\frac{12}{N(N+1)}\left[\frac{R_{1}^{2}}{n_{1}}+\frac{R_{2}^{2}}{n_{2}}+\cdots+\frac{R_{k}^{2}}{n_{k}}\right]-3(N+1) \\
H=\frac{12}{18(18+1)}\left[\frac{38^{2}}{6}+\frac{40,5^{2}}{6}+\frac{92,5^{2}}{6}\right]-3(18+1) \\
H=11,073 .
\end{gathered}
$$

\section{Tahap Keempat}

Tahap keempat adalah pengambilan keputusan terhadap hipotesis. Berikut aturan dalam pengambilan keputusan terhadap hipotesis.

$$
\begin{aligned}
& \text { Jika } H \leq \chi_{\text {kritis }}^{2}, H_{0} \text { diterima dan } H_{1} \text { ditolak. } \\
& \text { Jika } H>\chi_{\text {kritis }}^{2}, H_{0} \text { ditolak dan } H_{1} \text { diterima. }
\end{aligned}
$$

Diketahui nilai statistik dari uji Kruskal-Wallis adalah 11,073 dan nilai kritis chi-kuadrat adalah 5,991. Karena nilai statistik dari uji Kruskal-Wallis lebih besar dari nilai kritis chikuadrat, maka hipotesis nol ditolak dan hipotesis alternatif diterima. Hal ini berarti terdapat perbedaan kualitas di antara ketiga bimbingan belajar tersebut pada tingkat signifikansi $5 \%$. 


\section{Uji Cochran dan Contoh Perhitungan}

Uji Cochran merupakan perluasan dari uji McNemar. Pada uji McNemar hanya menguji dua populasi berpasangan, sedangkan pada uji Cochran dapat menguji tiga atau lebih populasi berhubungan. Pada uji Cochran, sekelompok subjek penelitian (misalkan sekelompok orang) dikenai tiga atau lebih perlakuan yang berbeda. Masing-masing subjek penelitian hanya memiliki dua macam penilaian (dichotomous outcomes) untuk setiap perlakuan yang diberikan. Dua penilaian tersebut bersifat saling berlawanan atau dikotomi. Contoh dari dua penilaian yang bersifat saling berlawanan, yakni "benar atau salah", "sukses atau gagal", "ikut atau tidak ikut", "datang atau tidak datang", "sulit atau tidak sulit", dan sebagainya (Conover, 1999:250-251).

Hipotesis nol pada uji Cochran menyatakan seluruh perlakuan memberikan efek atau pengaruh yang sama (tidak terdapat perbedaan yang signifikan secara statistika). Hipotesis alternatif menyatakan terdapat perbedaan efek atau pengaruh di antara perlakuan-perlakuan yang diberikan (terdapat perbedaan yang signifikan secara statistika). Berikut rumus untuk menghitung nilai statistik dari uji Cochran $(Q)$.

$$
Q=\frac{k(k-1) \sum_{j=1}^{k} C_{j}^{2}-(k-1)\left(\sum_{j=1}^{k} C_{j}\right)^{2}}{k\left(\sum_{j=1}^{k} C_{j}\right)-\sum_{i=1}^{n} R_{i}^{2}}
$$

Perhatikan bahwa $k$ menyatakan jumlah perlakuan, $C_{j}$ menyatakan banyak nilai 1 pada perlakuan ke- $j$, dan $R_{i}$ menyatakan banyaknya nilai 1 pada subjek penelitian ke- $i$ (lihat Tabel 20.28). Untuk pengambilan keputusan terhadap hipotesis, dapat dilakukan dengan membandingkan nilai statistik dari uji Cochran terhadap nilai kritis chi-kuadrat $\left(\chi_{\text {kritis }}^{2}\right)$. Berikut aturan dalam pengambilan keputusan terhadap hipotesis.

$$
\begin{aligned}
& \text { Jika } Q \leq \chi_{\text {kritis }}^{2}, H_{0} \text { diterima dan } H_{1} \text { ditolak. } \\
& \text { Jika } Q>\chi_{\text {kritis }}^{2}, H_{0} \text { ditolak dan } H_{1} \text { diterima. }
\end{aligned}
$$

Pengambilan keputusan terhadap hipotesis juga dapat dilakukan dengan pendekatan nilai probabilitas dari uji Cochran. Nilai probabilitas dari uji Cochran dibandingkan dengan tingkat signifikansi yang digunakan $(\alpha)$. Berikut aturan pengambilan keputusan terhadap hipotesis berdasarkan nilai probabilitas.

Jika nilai probabilitas $\geq \alpha$, maka $H_{0}$ diterima dan $H_{1}$ ditolak. Jika nilai probabilitas $<\alpha$, maka $H_{0}$ ditolak dan $H_{1}$ diterima.

Sebagai contoh kasus, misalkan seorang produsen kerupuk ingin memasarkan kerupuk dengan empat rasa, yakni rasa ayam, daging, ikan, dan udang ke kota B. Sebelum memasarkan kerupuk-kerupuk tersebut ke kota $\mathrm{B}$, produsen tersebut ingin mengetahui respon atau penilaian dari masyarakat yang tinggal di sekitar rumahnya terhadap keempat rasa kerupuk tersebut. Misalkan respon yang digunakan berupa "suka" atau "tidak suka". Untuk keperluan penelitian, produsen tersebut mempersilahkan 11 orang untuk mencicipi keempat rasa kerupuk tersebut dan memberikan penilaian atau respon terhadap keempat rasa kerupuk tersebut. Berikut data yang telah dikumpulkan oleh produsen kerupuk tersebut (Tabel 20.27). 
Tabel 20.27

\begin{tabular}{|c|c|c|c|c|c|}
\hline \multirow{2}{*}{ No } & \multirow{2}{*}{ Nama } & \multicolumn{4}{|c|}{ Kerupuk rasa } \\
\cline { 3 - 6 } & & Ayam & Daging & Ikan & Udang \\
\hline 1 & ugi & 1 & 0 & 0 & 0 \\
\hline 2 & ulan & 1 & 1 & 1 & 1 \\
\hline 3 & evelin & 0 & 0 & 0 & 0 \\
\hline 4 & hasoloan & 0 & 1 & 1 & 1 \\
\hline 5 & fitri & 1 & 1 & 1 & 1 \\
\hline 6 & suci & 1 & 0 & 0 & 1 \\
\hline 7 & mifdhal & 1 & 0 & 1 & 1 \\
\hline 8 & hanafi & 1 & 0 & 0 & 1 \\
\hline 9 & iqbal & 1 & 0 & 0 & 0 \\
\hline 10 & ridho & 1 & 0 & 0 & 0 \\
\hline 11 & romi & 1 & 1 & 1 & 1
\end{tabular}

Berdasarkan Tabel 20.27, respon 0 menyatakan tidak suka, sedangkan respon 1 menyatakan suka.Diketahui seorang subjek yang bernama Ugi hanya menyukai kerupuk rasa ayam. Subjek yang bernama Ulan menyukai keempat rasa kerupuk. Subjek yang bernama Suci hanya menyukai kerupuk rasa ayam dan udang. Berikut akan diuji apakah keempat rasa kerupuk tersebut memberikan kepuasan yang sama bagi responden.

\section{Tahap Pertama}

Tahap pertama adalah perumusan hipotesis. Berikut perumusan hipotesis.

$H_{0}$ : Keempat jenis kerupuk memberikan kepuasan rasa yang sama.

$H_{1}$ : Paling tidak terdapat satu rasa kerupuk yang memberikan kepuasan rasa berbeda di antara rasa kerupuk lainnya.

\section{Tahap Kedua}

Tahap kedua adalah menghitung nilai kritis chi-kuadrat berdasarkan tabel distribusi chikuadrat. Sebelum menghitung nilai kritis chi-kuadrat, terlebih dahulu menghitung nilai derajat bebas. Berikut rumus untuk menghitung nilai derajat bebas.

$$
\text { Derajat bebas }=k-1 \text {. }
$$

Perhatikan bahwa $k$ merupakan jumlah perlakuan, sehingga derajat bebas adalah $4-1=3$. Nilai kritis chi-kuadrat dengan derajat bebas 3 dan tingkat signifikansi 5\% adalah 7,815. Perhitungan nilai kritis chi-kuadrat juga dapat dihitung dengan Microsoft Excel sebagai berikut.

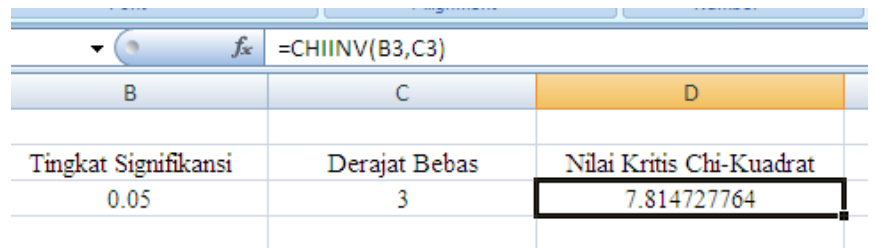

Gambar 20.3 


\section{Tahap Ketiga}

Tahap ketiga adalah menghitung nilai statistik dari uji Cochran $(Q)$.

$\Rightarrow$ Subjek yang memberikan penilaian yang sama terhadap keempat rasa kerupuk tidak diikutkan dalam analisis (lihat Tabel 20.28). Sebagai contoh pada baris ketiga, subjek yang bernama Evelin (lihat Tabel 20.28) memberikan penilaian yang sama terhadap empat jenis rasa kerupuk, yakni 0,0,0,0, sehingga subjek tersebut tidak diikutkan dalam analisis. Begitu juga dengan subjek yang bernama Fitri memberikan penilaian yang sama terhadap empat jenis rasa kerupuk, yakni 1,1,1,1, sehingga subjek tersebut tidak diikutkan dalam analisis. Subjek nomor 2,3, dan 5 tidak diikutsertakan dalam analisis, karena memberikan penilaian yang sama terhadap empat jenis rasa kerupuk, yakni $(1,1,1,1)$ atau $(0,0,0,0)$.

Tabel 20.28

\begin{tabular}{|c|c|c|c|c|c|c|c|}
\hline \multirow[b]{2}{*}{ No } & \multirow[b]{2}{*}{ Nama } & \multicolumn{4}{|c|}{ Kerupuk rasa } & \multirow[b]{2}{*}{$R$} & \multirow[b]{2}{*}{$R^{2}$} \\
\hline & & Ayam & Daging & Ikan & Udang & & \\
\hline 1 & Ugi & 1 & 0 & 0 & 0 & 1 & 1 \\
\hline 4 & Hasoloan & 0 & 1 & 1 & 1 & 3 & 9 \\
\hline 6 & Suci & 1 & 0 & 0 & 1 & 2 & 4 \\
\hline 7 & Mifdhal & 1 & 0 & 1 & 1 & 3 & 9 \\
\hline 8 & Hanafi & 1 & 0 & 0 & 1 & 2 & 4 \\
\hline 9 & Iqbal & 1 & 0 & 0 & 0 & 1 & 1 \\
\hline 10 & Ridho & 1 & 0 & 0 & 0 & 1 & 1 \\
\hline total & & $C_{1}=6$ & $C_{2}=1$ & $C_{2}=2$ & $C_{4}=4$ & 13 & 29 \\
\hline
\end{tabular}

$\Rightarrow$ Menghitung nilai statistik dari uji Cochran $(Q)$.

$$
\begin{gathered}
Q=\frac{k(k-1) \sum_{j=1}^{k} C_{j}^{2}-(k-1)\left(\sum_{j=1}^{k} C_{j}\right)^{2}}{k\left(\sum_{j=1}^{k} C_{j}\right)-\sum_{i=1}^{n} R_{i}^{2}} \\
Q=\frac{4(4-1)\left(6^{2}+1^{2}+2^{2}+4^{2}\right)-(4-1)(13)^{2}}{(4)(13)-(29)}=7,695 \text { atau } 7,70
\end{gathered}
$$

\section{Tahap Keempat}

Tahap keempat adalah pengambilan keputusan terhadap hipotesis. Berikut aturan dalam pengambilan keputusan terhadap hipotesis.

Jika $Q \leq \chi_{\text {kritis }}^{2}, H_{0}$ diterima dan $H_{1}$ ditolak.

Jika $Q>\chi_{\text {kritis }}^{2}, H_{0}$ ditolak dan $H_{1}$ diterima.

Perhatikan bahwa karena nilai statistik dari uji Cochran, yakni 7,70, lebih kecil dari nilai kritis chi-kuadrat, yakni, 7,815, maka hipotesis nol diterima dan hipotesis alternatif ditolak. Hal ini berarti keempat jenis kerupuk memberikan kepuasan rasa yang sama pada tingkat signifikansi $5 \%$. 


\section{Uji Fríedman dan Contoh Perhitungan}

Pada pembahasan sebelumnya telah dibahas mengenai uji Wilcoxon. Uji Wilcoxon hanya dapat menguji dua populasi berpasangan, sedangkan pada uji Friedman dapat menguji tiga atau lebih populasi berpasangan (Conover, 1999:368). Dalam uji Friedman, sekelompok subjek penelitian dikenai tiga atau lebih perlakuan yang berbeda. Masing-masing subjek penelitian memberikan penilaian terhadap masing-masing perlakuan yang diberikan. Selanjutnya penilaian dari masing-masing subjek diberi ranking. Pemberian ranking dimulai dari 1 sampai $k$, di mana $k$ merupakan banyaknya perlakuan. Perhatikan bahwa karena data yang dianalisis berupa data ranking, maka data tersebut termasuk data ordinal. Hipotesis nol pada uji Friedman menyatakan tidak terdapat perbedaan atau pengaruh (yang signifikan secara statistika) di antara perlakuan-perlakuan (treatment) yang diberikan. Hipotesis alternatif menyatakan terdapat paling tidak satu perlakuan yang memberikan pengaruh berbeda (signifikan secara statistika) dari perlakuan lainnya. Berikut rumus untuk menghitung nilai statistik dari uji Friedman $S$.

$$
S=\left[\frac{12}{b k(k+1)} \sum_{i=1}^{k}\left(R_{i}^{2}\right)\right]-3 b(k+1)
$$

Perhatikan bahwa $b$ menyatakan jumlah subjek atau jumlah baris, dan $k$ menyatakan jumlah perlakuan atau jumlah kolom. Untuk pengambilan keputusan terhadap hipotesis, dapat dibandingkan nilai statistik dari dari uji Friedman terhadap nilai kritis chi-kuadrat $\left(\chi_{\text {kritis }}^{2}\right)$. Berikut aturan pengambilan keputusan terhadap hipotesis.

$$
\begin{aligned}
& \text { Jika } S \leq \chi_{\text {kritis }}^{2}, H_{0} \text { diterima dan } H_{1} \text { ditolak. } \\
& \text { Jika } S>\chi_{\text {kritis }}^{2}, H_{0} \text { ditolak dan } H_{1} \text { diterima. }
\end{aligned}
$$

Sebagai contoh kasus, misalkan seorang produsen kerupuk ingin memasarkan kerupuk dengan empat rasa, yakni rasa ayam, daging, ikan, dan udang ke kota B. Sebelum memasarkan kerupuk-kerupuk tersebut, produsen tersebut ingin mengetahui respon dari masyarakat yang tinggal di sekitar rumahnya, terhadap keempat rasa kerupuk tersebut.

\begin{tabular}{|c|c|c|c|c|c|}
\hline \multirow[b]{2}{*}{ No. } & \multirow[b]{2}{*}{ Nama } & \multicolumn{4}{|c|}{ Kerupuk rasa } \\
\hline & & Ayam & Daging & Ikan & Udang \\
\hline 1 & ugi & 90 & 85 & 83 & 70 \\
\hline 2 & ulan & 90 & 70 & 77 & 65 \\
\hline 3 & evelin & 75 & 70 & 60 & 85 \\
\hline 4 & hasoloan & 80 & 70 & 75 & 90 \\
\hline 5 & fitri & 90 & 85 & 60 & 89 \\
\hline 6 & suci & 60 & 65 & 70 & 85 \\
\hline 7 & mifdhal & 65 & 85 & 70 & 90 \\
\hline 8 & hanafi & 65 & 100 & 60 & 85 \\
\hline 9 & iqbal & 80 & 70 & 75 & 90 \\
\hline 10 & ridho & 90 & 70 & 80 & 75 \\
\hline 11 & Romi & 75 & 65 & 70 & 64 \\
\hline 12 & alan & 80 & 70 & 75 & 90 \\
\hline
\end{tabular}
Respon tersebut berupa nilai yang diberikan oleh masyarakat.

Tabel 20.29 (Data Fiktif)

Nilai tersebut berkisar dari 10 sampai 100. Produsen tersebut mempersilahkan 12 orang responden untuk mencicipi keempat rasa kerupuk tersebut dan memberikan penilaian atau respon dari keempat rasa kerupuk tersebut. Data diberikan pada Tabel 20.29. Berdasarkan data pada Tabel 20.29, subjek bernama Ugi memberi nilai 90 terhadap kerupuk rasa ayam, nilai 85 terhadap kerupuk rasa daging, nilai 83 terhadap kerupuk rasa ikan, dan nilai 70 
terhadap kerupuk rasa udang. Pada tingkat signifikansi 5\%, berikut akan diuji apakah keempat rasa kerupuk tersebut memberikan kepuasan yang sama.

\section{Tahap Pertama}

Tahap pertama adalah perumusan hipotesis. Berikut perumusan hipotesis.

$H_{0}$ : Keempat jenis kerupuk memberikan kepuasan rasa yang sama (perbedaan yang terjadi tidak signifikan secara statistika).

$H_{1}$ : Paling tidak terdapat satu rasa kerupuk yang memberikan kepuasan rasa berbeda di antara rasa kerupuk lainnya (terdapat perbedaan yang signifikan secara statistika)

\section{Tahap Kedua}

Tahap kedua adalah menghitung nilai kritis chi-kuadrat $\left(\chi_{\text {kritis }}^{2}\right)$ berdasarkan tabel distribusi chi-kuadrat. Sebelum menghitung nilai kritis chi-kuadrat, terlebih dahulu menghitung nilai derajat bebas. Berikut rumus untuk menghitung nilai derajat bebas.

$$
\text { Derajat bebas }=k-1 \text {. }
$$

Perhatikan bahwa $k$ merupakan jumlah perlakuan, sehingga derajat bebas adalah $4-1=$ 3. Nilai kritis chi-kuadrat dengan derajat bebas 3 dan tingkat signifikansi $5 \%$ adalah 7,815 . Perhitungan nilai kritis juga dapat dihitung dengan Microsoft Excel sebagai berikut.

\begin{tabular}{|c|c|c|}
\hline \multicolumn{1}{|c|}{$f_{x}$} & $=C H I I N V(B 3, C 3)$ \\
\hline \hline B & $\mathrm{C}$ & \\
\hline & & \\
\hline Tingkat Signifikansi & Derajat Bebas & Nilai Kritis Chi-Kuadrat \\
\hline 0.05 & 3 & 7.814727764 \\
\hline
\end{tabular}

\section{Gambar 20.4}

\section{Tahap Ketiga}

Tahap ketiga adalah menghitung nilai statistik dari uji Friedman $(S)$.

Tabel 20.30

\begin{tabular}{|c|c|c|c|c|c|}
\hline \multirow{2}{*}{ No. } & \multirow{2}{*}{ Nama } & \multicolumn{5}{|c|}{ Kerupuk rasa } \\
\cline { 3 - 6 } & Ayam & Daging & Ikan & Udang \\
\hline 1 & ugi & 4 & 3 & 2 & 1 \\
\hline 2 & ulan & 4 & 2 & 3 & 1 \\
\hline 3 & evelin & 3 & 2 & 1 & 4 \\
\hline 4 & hasoloan & 3 & 1 & 2 & 4 \\
\hline 5 & fitri & 4 & 2 & 1 & 3 \\
\hline 6 & suci & 1 & 2 & 3 & 4 \\
\hline 7 & mifdhal & 1 & 3 & 2 & 4 \\
\hline 8 & hanafi & 2 & 4 & 1 & 3 \\
\hline 9 & iqbal & 3 & 1 & 2 & 4 \\
\hline 10 & ridho & 4 & 1 & 3 & 2 \\
\hline 11 & Romi & 4 & 2 & 3 & 1 \\
\hline 12 & alan & 3 & 1 & 2 & 4 \\
\hline jumlah ranking & 36 & 24 & 25 & 35 \\
\hline \\
rata-rata ranking & 3 & 2 & 2,083333 & 2,916667 \\
\hline
\end{tabular}


$\Rightarrow$ Berdasarkan data pada Tabel 20.30, setiap subjek atau orang dikenai empat perlakuan, yakni setiap subjek harus mencicipi empat rasa kerupuk. Kemudian subjek tersebut memberi nilai terhadap empat rasa kerupuk tersebut. Sebagai contoh nilai-nilai yang diberikan Ugi terhadap empat rasa kerupuk tersebut adalah 90, 85, 83, 70. Kemudian nilai-nilai tersebut diberi ranking. Karena jumlah perlakuan sebanyak 4, maka nilai ranking dimulai dari 1 sampai 4 . Nilai yang paling kecil diberi ranking 1 dan nilai yang paling besar diberi ranking 4. Nilai-nilai yang diberikan oleh Ugi adalah 90,85, 83 , dan 70 . Nilai yang paling kecil adalah 70 , sehingga nilai 70 diberi nilai ranking 1 , 83 diberi nilai ranking 2, nilai 85 diberi nilai ranking 3, dan nilai 90 diberi nilai ranking 4 .

$\Rightarrow$ Jika terdapat nilai-nilai yang sama, misalkan Ugi memberi nilai 70,80,70, dan 90, maka nilai 70 diberi ranking 1,5 , nilai 80 diberi ranking 3, dan nilai 90 diberi ranking 4. Nilai 70 merupakan nilai paling kecil, disusul dengan nilai 80, dan nilai 90.

Tabel 20.31

\begin{tabular}{|c|c|c|c|}
\hline Urutan ke-1 & Urutan ke-2 & Urutan ke-3 & Urutan ke-4 \\
\hline 70 & 70 & 80 & 90 \\
\hline
\end{tabular}

Nilai 70 terdapat dua nilai, yakni pada urutan pertama dan urutan kedua, sehingga ranking untuk nilai 70 adalah

$$
\frac{1+2}{2}=1,5
$$

Contoh lain misalkan Ugi memberi nilai 80,70,80, dan 90. Maka nilai 70 diberi ranking 1, nilai 80 diberi ranking 2,5, dan nilai 90 diberi ranking 4. Nilai 70 merupakan nilai paling kecil, disusul dengan nilai 80, dan nilai 90.

Tabel 20.32

\begin{tabular}{|c|c|c|c|}
\hline Urutan ke-1 & Urutan ke-2 & Urutan ke-3 & Urutan ke-4 \\
\hline 70 & 80 & 80 & 90
\end{tabular}

Nilai 80 terdapat dua nilai, yakni pada urutan kedua dan urutan ketiga, sehingga ranking untuk nilai 80 adalah

$$
\frac{2+3}{2}=2,5
$$

$\Rightarrow$ Menjumlahkan nilai ranking dari masing-masing perlakuan. Berdasarkan data pada Tabel 19.27, jumlah ranking untuk perlakuan kerupuk rasa ayam adalah 36, jumlah ranking untuk perlakuan kerupuk rasa daging adalah 24, jumlah ranking untuk perlakuan kerupuk rasa ikan adalah 25, dan jumlah ranking untuk perlakuan kerupuk rasa udang 35 .

$\Rightarrow$ Menghitung nilai statistik dari uji Friedman $(S)$. 


$$
\begin{gathered}
S=\left[\frac{12}{b k(k+1)} \sum_{i=1}^{k}\left(R_{i}^{2}\right)\right]-3 b(k+1) \\
=\left[\frac{12}{(12 \times 4)(4+1)}\left(36^{2}+24^{2}+25^{2}+35^{2}\right)\right]-(3 \times 12)(4+1) \\
=6,1 .
\end{gathered}
$$

\section{Tahap Keempat}

Tahap keempat adalah pengambilan keputusan terhadap hipotesis. Berikut aturan dalam pengambilan keputusan terhadap hipotesis.

$$
\begin{aligned}
& \text { Jika } S \leq \chi_{\text {kritis }}^{2}, H_{0} \text { diterima dan } H_{1} \text { ditolak. } \\
& \text { Jika } S>\chi_{\text {kritis }}^{2}, H_{0} \text { ditolak dan } H_{1} \text { diterima. }
\end{aligned}
$$

Perhatikan bahwa jarena nilai statistik dari uji Friedman, yakni 6,1, lebih kecil dari nilai kritis chi-kuadrat, yakni 7,815, maka hipotesis nol diterima dan hipotesis alternatif ditolak. Hal ini berarti keempat jenis kerupuk memberikan kepuasan rasa yang sama.

\section{Ují Chi-Kuadrat dan Contoh Perhitungan}

Uji chi-kuadrat (goodness of fit) merupakan suatu uji yang digunakan untuk menguji kesesuaian atau kecocokkan antara distribusi data berdasarkan pengamatan dengan distribusi data berdasarkan teoritis. Dengan kata lain, uji chi-kuadrat menguji kesesuaian antara frekuensi pengamatan dengan frekuensi harapan. Hipotesis nol pada uji chi-kuadrat menyatakan terjadi kesesuaian antara frekuensi pengamatan dengan frekuensi harapan. Sedangkan hipotesis alternatif menyatakan frekuensi pengamatan berbeda dengan frekuensi harapan. Berikut rumus untuk menghitung nilai statistik dari uji chi-kuadrat $\left(\chi_{\text {hitung }}^{2}\right)$.

$$
\chi_{\text {hitung }}^{2}=\frac{\sum\left(f_{p}-f_{h}\right)^{2}}{f_{h}} .
$$

Perhatikan bahwa $f_{p}$ merupakan frekuensi pengamatan (observed frequency), sedangkan $f_{h}$ merupakan frekuensi harapan (expected frequency). Untuk pengambilan keputusan terhadap hipotesis, dapat dilakukan dengan membandingkan nilai statistik dari uji chi-kuadrat terhadap nilai kritis chi-kuadrat $\left(\chi_{\text {kritis }}^{2}\right)$. Berikut aturan pengambilan keputusan terhadap hipotesis.

$$
\begin{aligned}
& \text { Jika } \chi_{\text {hitung }}^{2} \leq \chi_{\text {kritis }}^{2}, H_{0} \text { diterima dan } H_{1} \text { ditolak } . \\
& \text { Jika } \chi_{\text {hitung }}^{2}>\chi_{\text {kritis }}^{2}, H_{0} \text { ditolak dan } H_{1} \text { diterima. }
\end{aligned}
$$

Pengambilan keputusan terhadap hipotesis juga dapat dilakukan dengan pendekatan nilai probabilitas dari uji chi-kuadrat. Nilai probabilitas tersebut dibandingkan dengan tingkat signifikansi yang digunakan $\left(\chi_{\text {kritis }}^{2}\right)$. Berikut aturan pengambilan keputusan terhadap hipotesis berdasarkan nilai probabilitas.

Jika nilai probabilitas $\geq \chi_{\text {kritis }}^{2}$, maka $H_{0}$ diterima dan $H_{1}$ ditolak. Jika nilai probabilitas $<\chi_{\text {kritis }}^{2}$, maka $H_{0}$ ditolak dan $H_{1}$ diterima. 


\section{Contoh Kasus 1}

Sekeping koin terdiri dari dua sisi, yakni angka dan gambar. Misalkan koin tersebut dilempar sebanyak 100 kali. Secara teoritis, probabilitas untuk muncul sisi angka adalah $\frac{1}{2}$ dan probabilitas untuk muncul sisi gambar adalah $\frac{1}{2}$, sehingga dalam 100 kali lemparan, diharapkan muncul sisi angka sebanyak 50 kali dan muncul sisi gambar sebanyak 50 kali. Ternyata hasil pelemparan menunjukkan sisi gambar muncul sebanyak 15 kali dan sisi angka muncul sebanyak 85 kali. Pada tingkat signifikansi 5\%, berikut akan diuji apakah terjadi keselarasan, yakni dalam 100 kali lemparan menghasilkan angka dan gambar dalam proporsi yang sama (dengan kata lain, koin tidak berat sebelah).

\section{Tahap Pertama}

Tahap pertama adalah perumusah hipotesis. Berikut perumusan hipotesis.

$H_{0}$ : Proporsi/frekuensi kemunculan sisi angka dan gambar untuk pengamatan sama dengan proporsi/frekuensi kemunculan sisi angka dan gambar secara teoritis.

$H_{1}$ : Proporsi/frekuensi kemunculan sisi angka dan gambar untuk pengamatan berbeda dengan proporsi/frekuensi kemunculan sisi angka dan gambar secara teoritis.

\section{Tahap Kedua}

Tahap kedua adalah menghitung nilai kritis chi-kuadrat $\left(\chi_{\text {kritis }}^{2}\right)$ berdasarkan tabel distribusi chi-kuadrat. Sebelum menghitung nilai kritis chi-kuadrat, terlebih dahulu menghitung nilai derajat bebas. Berikut rumus untuk menghitung nilai derajat bebas.

$$
\text { Derajat bebas }=k-1 \text {. }
$$

Perhatikan bahwa $k$ merupakan jumlah kategori, yakni angka dan gambar, sehingga derajat bebas bernilai $2-1=1$. Nilai kritis chi-kuadrat dengan derajat bebas 1 dan tingkat signifikansi 5\% adalah 3,841. Nilai kritis chi-kuadrat juga dapat ditentukan dengan bantuan Microsoft Excel sebagai berikut.

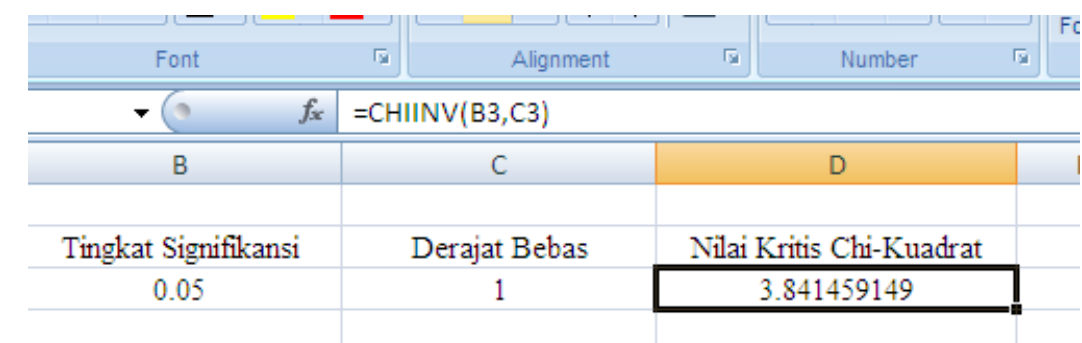

\section{Gambar 20.5}

\section{Tahap Ketiga}

Tahap ketiga adalah menghitung nilai statistik dari uji chi-kuadrat $\left(\chi_{\text {hitung }}^{2}\right)$.

$\Rightarrow$ Sajikan informasi frekuensi harapan dan frekuensi pengamatan dalam tabel seperti berikut. 
Tabel 20.33

\begin{tabular}{|c|c|c|}
\hline Sisi Koin & Angka & Gambar \\
\hline Frekuensi Harapan (teoritis) & 50 & 50 \\
\hline Frekuensi Pengamatan & 85 & 15
\end{tabular}

Secara teoritis, probabilitas untuk muncul sisi angka dan sisi gambar pada koin adalah $\frac{1}{2}$, sehingga frekuensi harapan dalam pelemparan sekeping koin sebanyak 100 kali untuk masing-masing sisi adalah

$$
\begin{aligned}
\text { frekuensi harapan angka } & =\frac{1}{2} \times(100 \text { kali lemparan })=50 \text { kali muncul angka, } \\
\text { frekuensi harapan gambar } & =\frac{1}{2} \times(100 \text { kali lemparan })=50 \text { kali muncul gambar. }
\end{aligned}
$$

Jadi, diharapkan dalam 100 kali lemparan sebuah koin, akan muncul sisi angka sebanyak 50 kali dan muncul sisi gambar sebanyak 50 kali.

$\Rightarrow$ Menghitung nilai statistik dari uji chi-kuadrat.

Tabel 20.34

\begin{tabular}{|c|c|c|c|c|}
\hline Kejadian & $E_{1}$ & $E_{2}$ & $\cdots$ & $E_{k}$ \\
\hline Frekuensi Harapan & $f_{H_{1}}$ & $f_{H_{2}}$ & $\cdots$ & $f_{H_{k}}$ \\
\hline Frekuensi Pengamatan & $f_{p_{1}}$ & $f_{p_{2}}$ & $\cdots$ & $f_{P_{k}}$
\end{tabular}

Berdasarkan Tabel 20.34, $E_{1}, E_{2}, \ldots, E_{k}$ merupakan kejadian-kejadian yang mungkin terjadi dari suatu percobaan, $f_{H_{1}}, f_{H_{2}}, \ldots, f_{H_{k}}$ berturut-turut merupakan frekuensi harapan (expected) dari $E_{1}, E_{2}, \ldots, E_{k}$, dan $f_{p_{1}}, f_{P_{2}}, \ldots, f_{P_{k}}$ berturut-turut merupakan frekuensi pengamatan (observed) dari $E_{1}, E_{2}, \ldots, E_{k}$.

Dalam percobaan pelemparan sekeping koin sebanyak satu kali, kejadian-kejadian yang mungkin terjadi adalah muncul sisi angka atau muncul sisi gambar, sehingga

$$
\begin{gathered}
E_{1}=\text { kejadian muncul angka } \\
E_{2}=\text { kejadian muncul gambar } .
\end{gathered}
$$

Berikut rumus untuk menghitung nilai statistik dari uji chi-kuadrat $\left(\chi_{\text {hitung }}^{2}\right)$.

$$
\begin{gathered}
\chi_{\text {hitung }}^{2}=\frac{\left(f_{P_{1}}-f_{H_{1}}\right)^{2}}{f_{H_{1}}}+\frac{\left(f_{P_{2}}-f_{H_{2}}\right)^{2}}{f_{H_{2}}}+\cdots+\frac{\left(f_{P_{k}}-f_{H_{k}}\right)^{2}}{f_{H_{k}}} \\
=\frac{(85-50)^{2}}{50}+\frac{(15-50)^{2}}{50} \\
=24,5+24,5 \\
=49 .
\end{gathered}
$$




\section{Tahap Keempat}

Tahap keempat adalah pengambilan keputusan terhadap hipotesis. Berikut aturan dalam pengambilan keputusan terhadap hipotesis.

$$
\begin{aligned}
& \text { Jika } \chi_{\text {hitung }}^{2} \leq \chi_{\text {kritis }}^{2}, H_{0} \text { diterima dan } H_{1} \text { ditolak } . \\
& \text { Jika } \chi_{\text {hitung }}^{2}>\chi_{\text {kritis }}^{2}, H_{0} \text { ditolak dan } H_{1} \text { diterima. }
\end{aligned}
$$

Diketahui nilai statistik dari uji chi-kuadrat adalah 49, dan nilai kritis chi-kuadrat adalah 3,841. Karena nilai statistik dari uji chi-kuadrat lebih besar dibandingkan nilai kritis chikuadrat, maka hipotesis nol ditolak dan hipotesis alternatif diterima. Hal ini berarti proporsi/frekuensi kemunculan sisi angka dan gambar untuk pengamatan berbeda dengan proporsi/frekuensi kemunculan sisi angka dan gambar secara teoritis pada tingkat signifikansi $5 \%$.

\section{Contoh Soal 2}

Misalkan sebuah mesin pencampur adonan kue menghasilkan perbandingan tepung, susu, telur, dan gula secara berturut-turut adalah 5:2:2:1. Seorang pembuat kue mengambil adonan yang dihasilkan oleh mesin tersebut $500 \mathrm{~kg}$, ternyata dalam adonan kue tersebut mengandung $275 \mathrm{~kg}$ tepung, $95 \mathrm{~kg}$ susu, $70 \mathrm{~kg}$ telur, dan $60 \mathrm{~kg}$ gula. Pada tingkat signifikansi 1\%, ujilah hipotesis apakah proporsi adonan kue yang telah dihasilkan sesuai dengan proporsi adonan yang telah ditetapkan pada mesin pencampur kue.

\section{Tahap Pertama}

Tahap pertama adalah perumusan hipotesis. Berikut perumusan hipotesis.

$H_{0}$ : Proporsi adonan kue yang telah dihasilkan sama dengan proporsi adonan kue yang telah ditetapkan pada mesin pencampur adonan kue.

$H_{1}$ : Proporsi adonan kue yang telah dihasilkan tidak sama dengan proporsi adonan kue yang telah ditetapkan pada mesin pencampur adonan kue.

\section{Tahap Kedua}

Tahap kedua adalah menentukan nilai kritis chi-kuadrat berdasarkan tabel distribusi chikuadrat. Diketahui nilai tingkat signifikansi adalah 1\%. Untuk menentukan nilai kritis chikuadrat, terlebih dahulu menentukan nilai derajat bebas. Berikut rumus dari derajat bebas.

$$
\text { Derajat bebas }=k-1 \text {. }
$$

Perhatikan bahwa $k$ merupakan jumlah kategori. Diketahui jumlah kategori sebanyak 4, yakni tepung, susu, telur, dan gula, sehingga derajat bebas adalah $4-1=3$. Nilai kritis chikuadrat dengan derajat bebas 3 dan tingkat signifikansi $1 \%$ adalah 11,345 . Nilai kritis chikuadrat juga dapat ditentukan dengan Microsoft Excel sebagai berikut. 


\begin{tabular}{|c|c|c|c|}
\hline$\rightarrow f_{x}$ & $=\mathrm{CHIINV}(\mathrm{B} 3, \mathrm{C} 3)$ & & \\
\hline B & $\mathrm{C}$ & D & $\mathrm{E}$ \\
\hline Tingkat Signifikansi & Derajat Bebas & Nilai Kritis Chi-Kuadrat & \\
\hline 0.01 & 3 & 11.34486668 & \\
\hline
\end{tabular}

\section{Gambar 20.6}

\section{Tahap Ketiga}

Tahap ketiga adalah menghitung nilai statistik dari uji chi-kuadrat $\left(\chi_{\text {hitung }}^{2}\right)$.

$\Rightarrow$ Sajikan informasi antara proporsi adonan harapan dan proporsi adonan yang dihasilkan mesin dalam tabel berikut.

Tabel 20.35

\begin{tabular}{|c|c|c|c|c|}
\hline Adonan & Tepung & Susu & Telur & Gula \\
\hline Adonan Harapan & $250 \mathrm{~kg}$ & $100 \mathrm{~kg}$ & $100 \mathrm{~kg}$ & $50 \mathrm{~kg}$ \\
\hline Adonan yang Dihasilkan & $275 \mathrm{~kg}$ & $95 \mathrm{~kg}$ & $70 \mathrm{~kg}$ & $60 \mathrm{~kg}$ \\
\hline
\end{tabular}

Diharapkan dalam $500 \mathrm{~kg}$ adonan, kue tersebut mengandung:

$$
\begin{aligned}
& \frac{5}{10} \times 500 \mathrm{~kg}=250 \mathrm{~kg} \text { tepung } \\
& \frac{2}{10} \times 500 \mathrm{~kg}=100 \mathrm{~kg} \text { susu } \\
& \frac{2}{10} \times 500 \mathrm{~kg}=100 \mathrm{~kg} \text { telur } \\
& \frac{1}{10} \times 500 \mathrm{~kg}=50 \mathrm{~kg} \text { gula } .
\end{aligned}
$$

$\Rightarrow$ Menghitung nilai statistik dari uji chi-kuadrat.

$$
\begin{gathered}
\chi_{\text {hitung }}^{2}=\frac{\left(f_{P_{1}}-f_{H_{1}}\right)^{2}}{f_{H_{1}}}+\frac{\left(f_{P_{2}}-f_{H_{2}}\right)^{2}}{f_{H_{2}}}+\cdots+\frac{\left(f_{P_{k}}-f_{H_{k}}\right)^{2}}{f_{H_{k}}} \\
=\frac{(275-250)^{2}}{250}+\frac{(95-100)^{2}}{100}+\frac{(70-100)^{2}}{100}+\frac{(60-50)^{2}}{50} \\
=2,5+0,25+9+2 \\
=13,75 .
\end{gathered}
$$

\section{Tahap Keempat}

Tahap keempat adalah pengambilan keputusan terhadap hipotesis. Berikut aturan pengambilan keputusan terhadap hipotesis. 


$$
\begin{aligned}
& \text { Jika } \chi_{\text {hitung }}^{2} \leq \chi_{\text {kritis }}^{2}, H_{0} \text { diterima dan } H_{1} \text { ditolak. } \\
& \text { Jika } \chi_{\text {hitung }}^{2}>\chi_{\text {kritis }}^{2}, H_{0} \text { ditolak dan } H_{1} \text { diterima. }
\end{aligned}
$$

Diketahui nilai statistik dari uji chi-kuadrat adalah 13,75, dan nilai kritis chi-kuadrat adalah 11,345. Karena nilai statistik dari uji chi-kuadrat lebih besar dibandingkan nilai kritis chikuadrat, maka hipotesis nol ditolak dan hipotesis alternatif diterima. Hal ini berarti proporsi adonan kue yang telah dihasilkan tidak sama dengan proporsi adonan kue yang telah ditetapkan pada mesin pencampur adonan kue pada tingkat signifikansi $1 \%$. 


\section{PENYELESAIAN DALAM SPSS (UJI TANDA)}

Bangun data dalam SPSS seperti pada Gambar 20.1. Pada Variable View, bentuk variabel Sebelum dan Sesudah. Kemudian atur tipe data (Type) dengan Numeric. Pada Data View, isi data berat badan sebelum mengkonsumsi obat penambah berat badan merek $X Y Z$, dan data berat badan sesudah mengkonsumsi obat penambah berat badan merek $X Y Z$ selama satu minggu.

Kemudian pilih Analyze $=>$ Nonparametric Tests $\Rightarrow>2$ Related Samples (Gambar 20.2). Pindahkan variabel Sebelum pada bagian Variable1, sedangkan variabel Sesudah dipindahkan pada bagian Variable2 (Gambar 20.3). Pada bagian Test Type pilih Sign (Gambar 20.3). Kemudian pilih OK.

\begin{tabular}{||r|r|r|}
\hline 1 : Sebelum & \multicolumn{3}{|c}{$\mid 45.0$} \\
\hline & Sebelum & Sesudah \\
\hline 1 & 45 & 50 \\
\hline 2 & 55 & 60 \\
\hline 3 & 57 & 60 \\
\hline 4 & 54 & 65 \\
\hline 5 & 65 & 63 \\
\hline 6 & 72 & 80 \\
\hline 7 & 80 & 90 \\
\hline 8 & 44 & 50 \\
\hline 9 & 67 & 65 \\
\hline 10 & 60 & 60 \\
\hline 11 & 65 & 75 \\
\hline 12 & 75 & 80 \\
\hline 13 & 67 & 85 \\
\hline 14 & 66 & 70 \\
\hline 15 & 62 & 65 \\
\hline 16 & & \\
\hline
\end{tabular}

Gambar 20.1

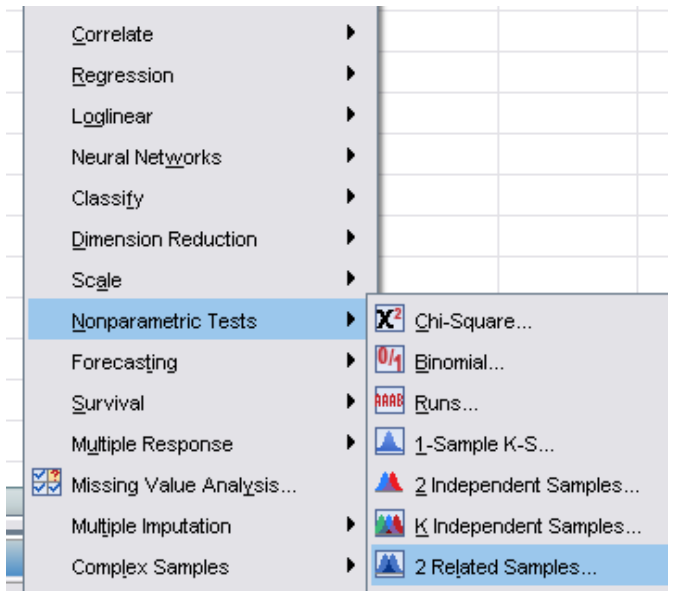

Gambar 20.2

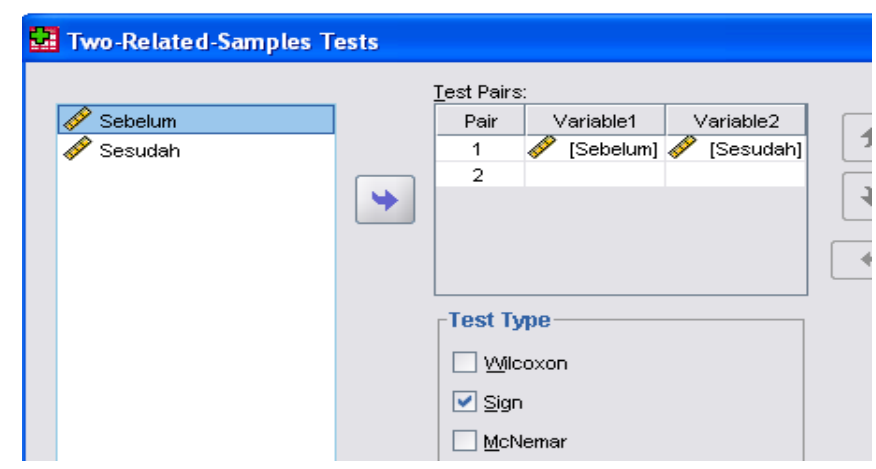

Gambar 20.3

Tabel 20.1, yakni Tabel Frequencies merupakan hasil berdasarkan SPSS. Berdasarkan Tabel 20.1, diketahui selisih dari pasangan nilai data yang bernilai negatif (Negative Differences) sebanyak 2, selisih dari pasangan nilai data yang bernilai positif (Positive Differences) sebanyak 12, dan selisih dari pasangan nilai data yang bernilai nol (Ties) sebanyak 1. Jumlah responden dalam sampel (Total) sebanyak 15. 


\section{Tabel 20.1}

\begin{tabular}{|c|c|c|}
\hline \multicolumn{3}{|c|}{ Frequencies } \\
\hline & & $\mathrm{N}$ \\
\hline \multirow[t]{4}{*}{ Sesudah - Sebelum } & Negative Differences $^{a}$ & 2 \\
\hline & Positive Differences $^{\mathrm{b}}$ & 12 \\
\hline & Ties $^{c}$ & 1 \\
\hline & Total & 15 \\
\hline \multicolumn{3}{|l|}{ a. Sesudah < Sebelum } \\
\hline \multicolumn{3}{|l|}{ b. Sesudah $>$ Sebelum } \\
\hline \multicolumn{3}{|l|}{ c. Sesudah = Sebelum } \\
\hline
\end{tabular}

Tabel 20.2

Test Statistics ${ }^{\mathrm{b}}$

\begin{tabular}{|l|c|}
\hline & $\begin{array}{l}\text { Sesudah - } \\
\text { Sebelum }\end{array}$ \\
\hline Exact Sig. (2-tailed) & $.013^{\mathrm{a}}$ \\
\hline
\end{tabular}

a. Binomial distribution used.

b. Sign Test

Tabel 20.2, yakni Tabel Test Statistics merupakan hasil berdasarkan SPSS. Berdasarkan Tabel 20.2, diketahui nilai Exact Sig. (2-tailed) adalah 0,013, yang mana merupakan nilai probabilitas kumulatif dari $X=2$. Perhatikan bahwa karena nilai Exact Sig. (2-tailed) atau probabilitas kumulatif untuk $X=2$, yakni 0,013 , lebih kecil dari nilai tingkat signifikansi, yakni 0,05 , maka hipotesis nol ditolak dan hipotesis alternatif diterima. Ini berarti pernyataan "terdapat perbedaan yang signifikan (secara statistika) mengenai berat badan sebelum dan sesudah mengkonsumsi obat penambah berat badan merek XYZ" dapat diterima pada tingkat signifikansi 5\%.

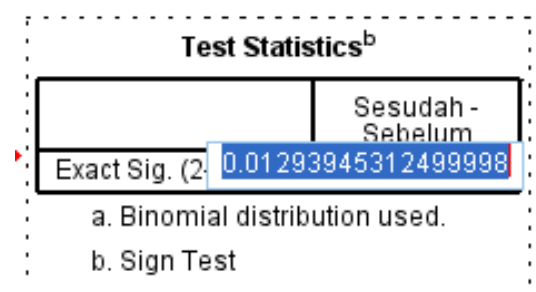

Gambar 20.4

Pada Gambar 20.4 menyajikan nilai nilai probabilitas kumulatif dari $X=2$ yang lebih detail (17 angka di belakang koma). 


\section{PENYELESAIAN DALAM Minitab (UJI TANDA)}

Bangun data dalam Minitab seperti pada Gambar 20.5. Pilih Cal $=>$ Calculator (Gambar 20.6).

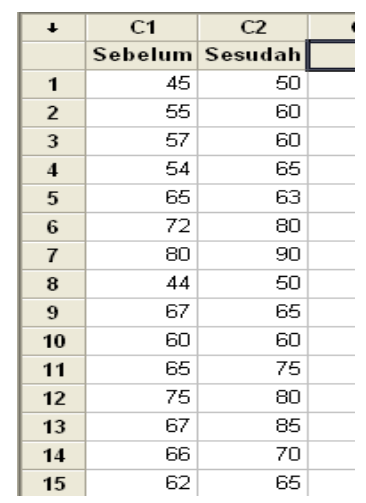

Gambar 20.5

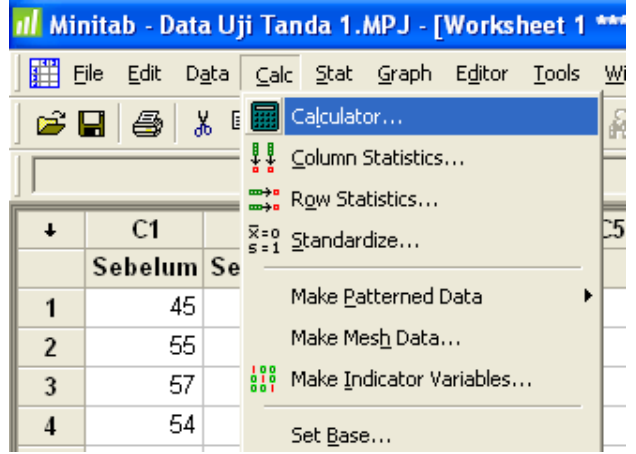

Gambar 20.6

Pada Gambar 20.7, ketik Selisih pada bagian Store result in variable:. Kemudian pada bagian Expression; atur menjadi 'Sesudah' - 'Sebelum'. Selanjutnya pilih OK, hasilnya seperti pada Gambar 20.8, di mana telah terbentuk varaibel Selisih.

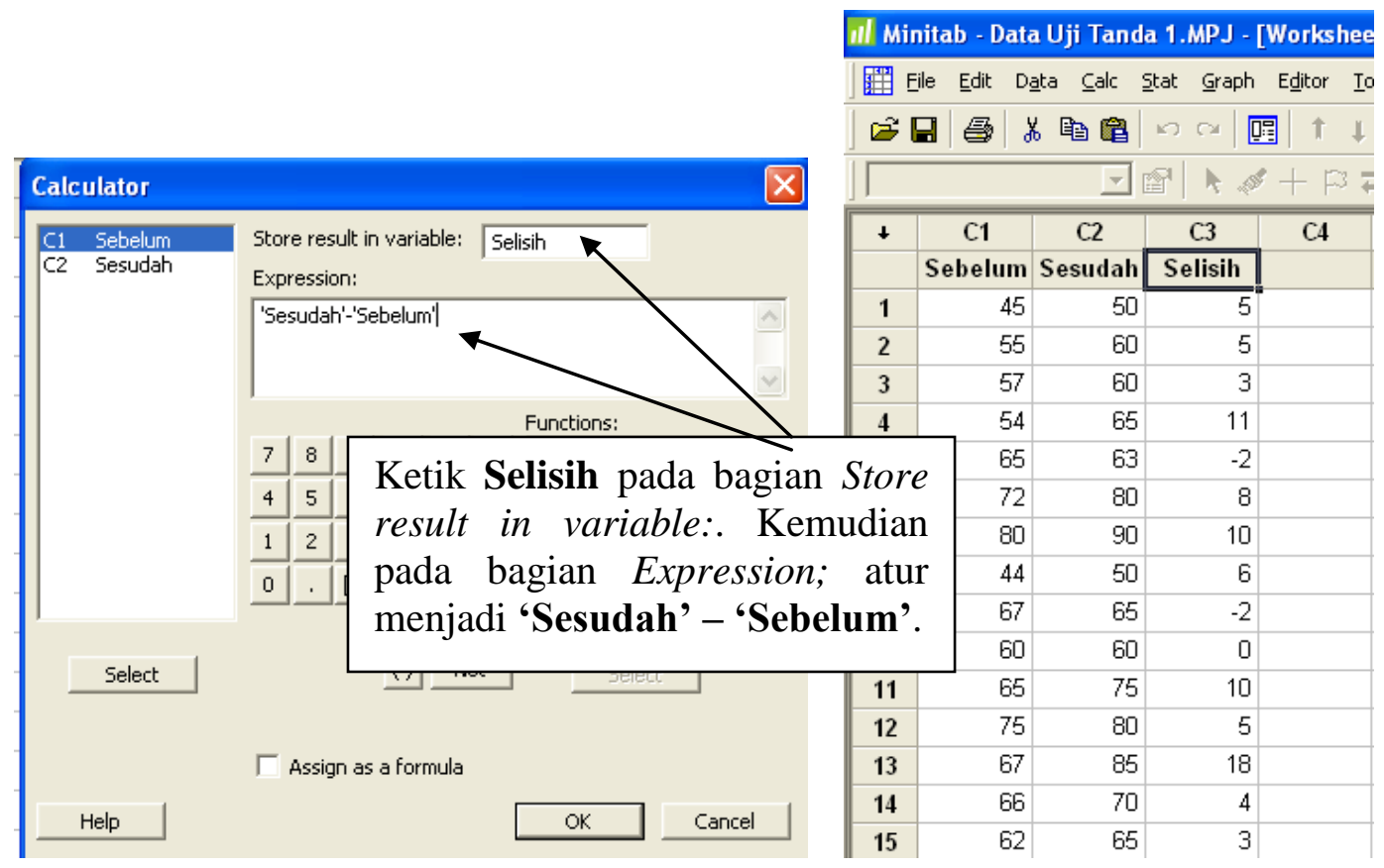

Gambar 20.7

Gambar 20.8

Selanjutnya pilih Stat $=>$ Nonparametrics $\Rightarrow>$ 1-sample Sign (Gambar 20.9). Pada Gambar 20.10, masukkan variabel Selisih pada bagian Variables:. Kemudian aktifkan/bulatkan bagian Test median dan pada Alternative: pilih not equal dengan maksud untuk pengujian dua arah. Kemudian pilih OK. 


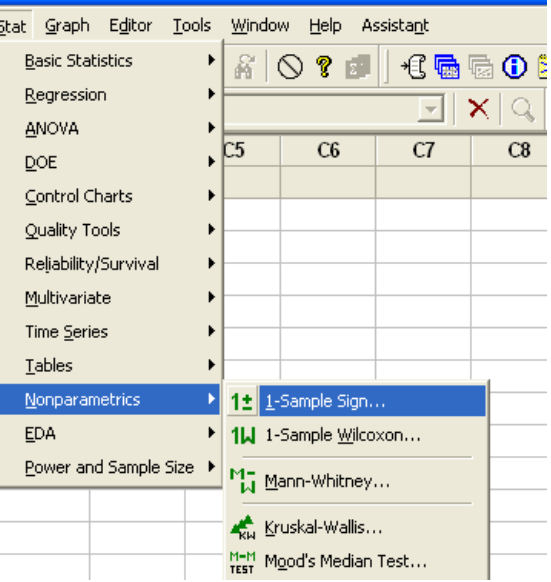

Gambar 20.9

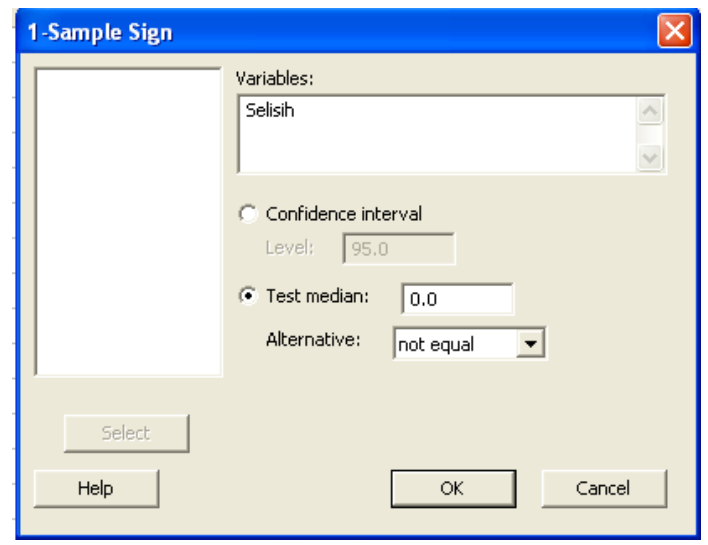

Gambar 20.10

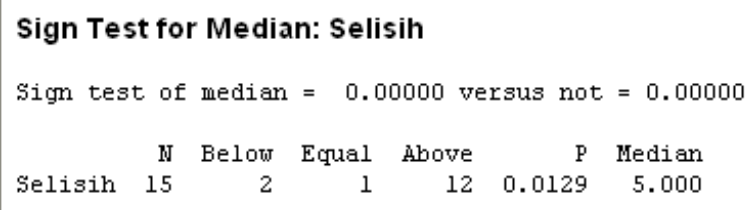

\section{Gambar 20.11}

Berdasarkan Gambar 20.11, diketahui nilai $P$ adalah 0,0129, di mana nilai tersebut merupakan nilai probabilitas kumulatif dari $X=2$. Perhatikan bahwa karena nilai probabilitas kumulatif untuk $X=2$, yakni 0,0129 , lebih kecil dari nilai tingkat signifikansi, yakni 0,05 , maka hipotesis nol ditolak dan hipotesis alternatif diterima. Ini berarti pernyataan "terdapat perbedaan yang signifikan (secara statistika) mengenai berat badan sebelum dan sesudah mengkonsumsi obat penambah berat badan merek XYZ" dapat diterima pada tingkat signifikansi 5\%. 


\section{PENYELESAIAN DALAM R (UJI TANDA)}

Aktifkan RStudio terlebih dahulu. Kemudian pilih New File $\Rightarrow R$ Script (Gambar 20.12). Pada Gambar 20.13, ketik perintah binom.test(2, 14, 0.5, alternative="two.sided").

\section{binom.test $(2,14,0.5$, alternative $="$ two.sided" $)$.}

$\Rightarrow$ Nilai 2 berarti jumlah tanda paling sedikit, yakni jumlah tanda negatif.

$\Rightarrow$ Nilai 14 berarti jumlah seluruh tanda, yakni tanda positif dan tanda negatif.

$\Rightarrow$ Two.sided berarti pengujian dua arah.

$\Rightarrow$ Perhitungan nilai probabilitas kumulatif $X=2$ dihitung dengan rumus binomial.

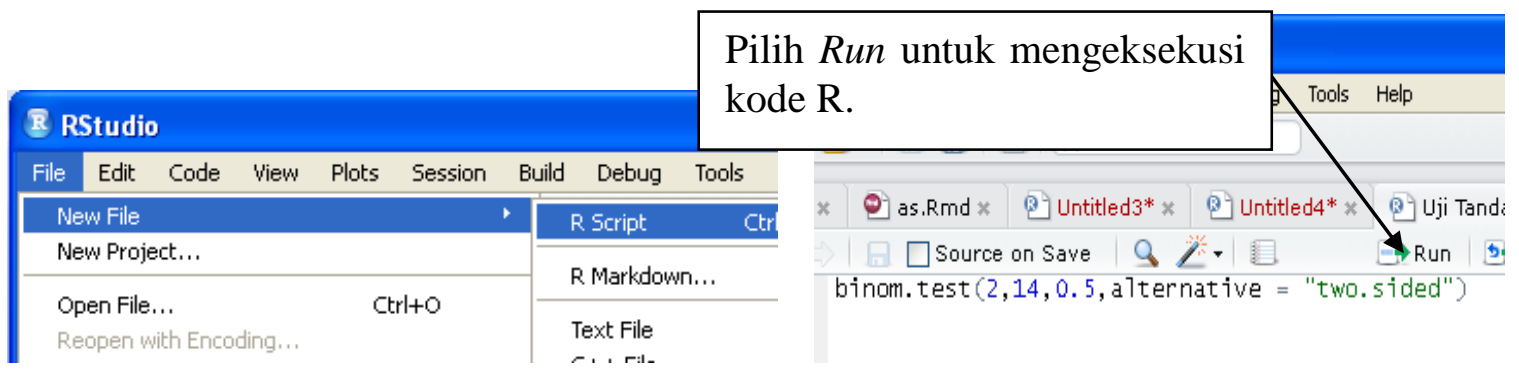

Gambar 20.12

Gambar 20.13

Gambar 20.14 merupakan hasil berdasarkan R. Diketahui nilai probabilitas kumulatif dari $X=2$ atau $p$-value $=0,01294$. Perhatikan bahwa karena nilai probabilitas kumulatif untuk $X=2$, yakni 0,01294, lebih kecil dari nilai tingkat signifikansi, yakni 0,05, maka hipotesis nol ditolak dan hipotesis alternatif diterima. Ini berarti pernyataan "terdapat perbedaan yang signifikan (secara statistik) mengenai berat badan sebelum dan sesudah mengkonsumsi obat penambah berat badan merek XYZ" dapat diterima pada tingkat signifikansi 5\%.

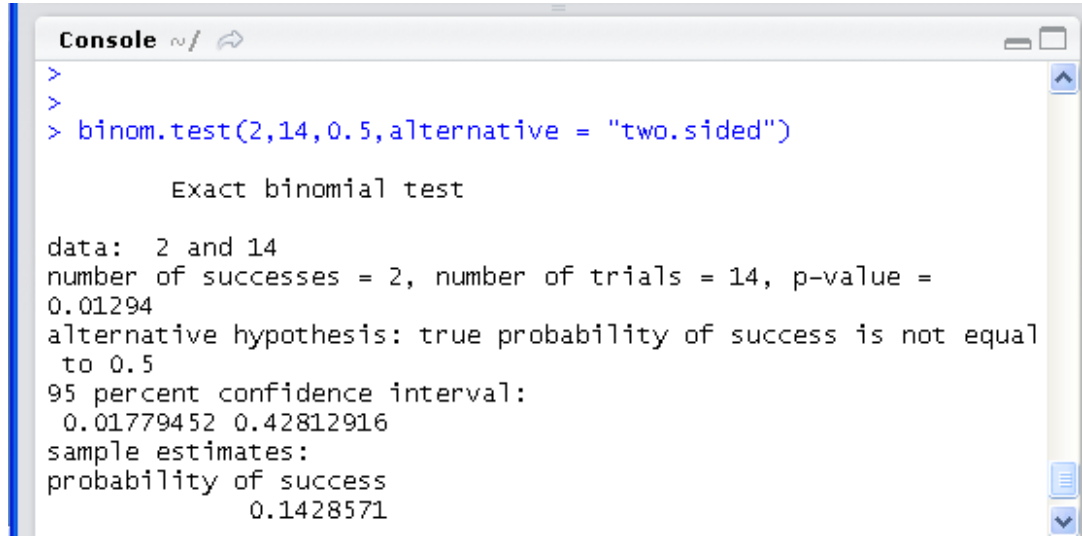

Gambar 20.14 


\section{PENYELESAIAN DALAM SPSS (UJI WILCOXON)}

Bangun data dalam SPSS seperti pada Gambar 20.15. Pada Variable View, bentuk variabel Sebelum dan Sesudah. Kemudian atur tipe data (Type) dengan Numeric. Pada Data View, isi data berat badan sebelum mengkonsumsi obat penambah berat badan merek $X Y Z$, dan data berat badan sesudah mengkonsumsi obat penambah berat badan merek $X Y Z$ selama satu minggu.

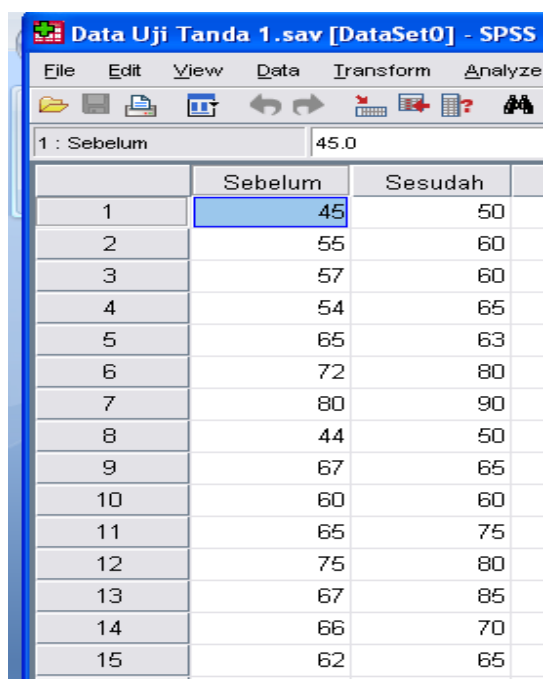

Gambar 20.15

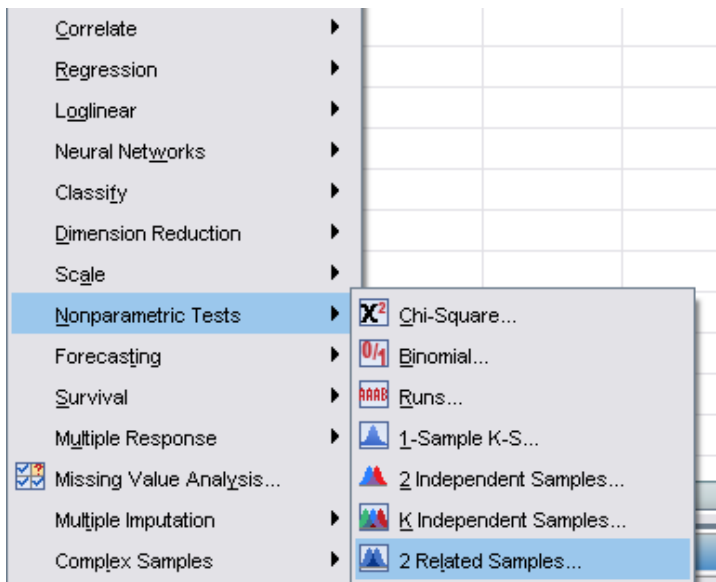

Gambar 20.16

Kemudian pilih Analyze $\Rightarrow$ Nonparametric Tests $\Rightarrow>2$ Related Samples (Gambar 20.16). Pindahkan variabel Sebelum pada bagian Variable1, sedangkan variabel Sesudah dipindahkan pada bagian Variable2 (Gambar 20.17). Pada bagian Test Type pilih Wilcoxon (Gambar 20.17). Kemudian pilih OK.

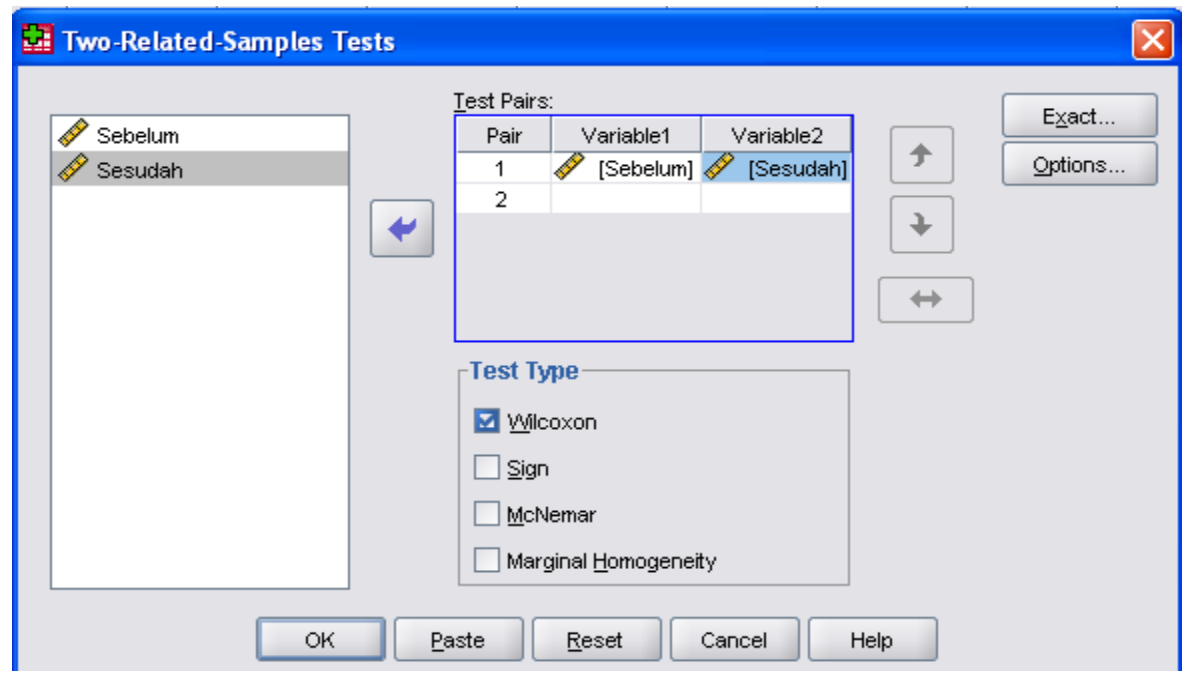

Gambar 20.17

Tabel 20.3, yakni Tabel Ranks merupakan hasil berdasarkan SPSS. Berdasarkan Tabel 20.3, diketahui selisih dari pasangan nilai data yang bernilai negatif atau pengamatan ranking yang 
negatif (Negative Ranks) sebanyak 2, selisih dari pasangan nilai data yang bernilai positif atau pengamatan ranking yang positif (Positive Ranks) sebanyak 12, dan selisih dari pasangan nilai data yang bernilai nol (Ties) sebanyak 1. Jumlah responden dalam sampel (Total) sebanyak 15. Diketahui jumlah ranking untuk kelompok tanda positif $(+)$ adalah 102, sedangkan jumlah ranking untuk kelompok tanda negatif (-) adalah 3. Hasil pada Tabel Ranks tersebut sesuai dengan hasil dengan perhitungan secara manual.

\section{Tabel 20.3}

Ranks

\begin{tabular}{|c|c|c|c|c|}
\hline & & $\mathrm{N}$ & Mean Rank & Sum of Ranks \\
\hline \multirow[t]{4}{*}{ Sesudah - Sebelum } & Negative Ranks & $2^{\mathrm{a}}$ & 1.50 & 3.00 \\
\hline & Positive Ranks & $12^{\mathrm{b}}$ & 8.50 & 102.00 \\
\hline & Ties & $1^{\mathrm{c}}$ & & \\
\hline & Total & 15 & & \\
\hline \multicolumn{5}{|c|}{ a. Sesudah < Sebelum } \\
\hline \multicolumn{5}{|c|}{ b. Sesudah > Sebelum } \\
\hline c. Sesudah $=$ Sebeluı & & & & \\
\hline
\end{tabular}

Tabel 20.4

Test Statistics ${ }^{\mathrm{b}}$

\begin{tabular}{l|r|}
\hline & \multicolumn{1}{|c|}{$\begin{array}{c}\text { Sesudah - } \\
\text { Sebelum }\end{array}$} \\
\hline$Z$ & $-3.113^{\mathrm{a}}$ \\
Asymp. Sig. (2-tailed) & .002 \\
a. Based on negative ranks. \\
b. Wilcoxon Signed Ranks Test
\end{tabular}

Tabel 20.4, yakni Tabel Test Statistics merupakan hasil berdasarkan SPSS. Berdasarkan Tabel 20.4, diketahui nilai normal $Z$ terstandarisasi adalah $-3,113$, sedangkan nilai probabilitas kumulatif dari $Z$ (Asymp. Sig. (2-tailed)) adalah 0,002. Karena nilai probabilitas 0,002< $\alpha=0,05$, maka hipotesis nol ditolak dan hipotesis alternatif diterima. Ini berarti pernyataan "terdapat perbedaan yang signifikan secara statistika mengenai berat badan, sebelum dan sesudah mengkonsumsi obat penambah berat badan merek XYZ" dapat diterima pada tingkat signifikansi 5\%. Perhatikan bahwa "(2-tailed)" berarti pengujian dilakukan secara dua arah.

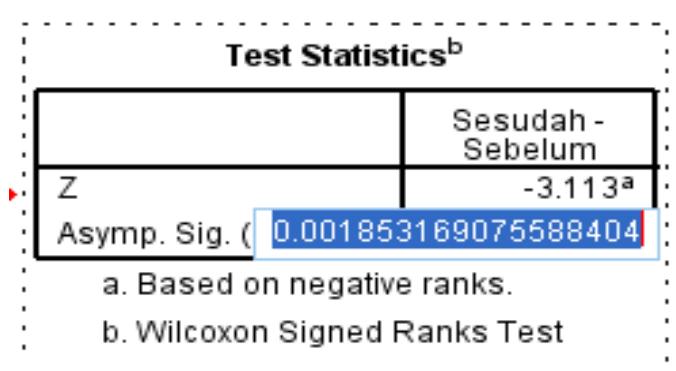

\section{Gambar 20.18}

Pada Gambar 20.18 menyajikan nilai nilai probabilitas kumulatif dari $Z$ yang lebih detail (18 angka di belakang koma). 


\section{PENYELESAIAN DALAM Minitab (UJI WILCOXON)}

Bangun data dalam Minitab seperti pada Gambar 2.19. Pilih Cal $\Rightarrow$ Calculator (Gambar 20.20).

\begin{tabular}{|c|r|r|r}
\hline+ & C1 & \multicolumn{1}{c|}{ C2 } & C \\
\cline { 4 - 5 } & Sebelum & Sesudah & \\
\hline $\mathbf{1}$ & 45 & 50 & \\
\hline $\mathbf{2}$ & 55 & 60 & \\
\hline $\mathbf{3}$ & 57 & 60 & \\
\hline $\mathbf{4}$ & 54 & 65 & \\
\hline $\mathbf{5}$ & 65 & 63 & \\
\hline $\mathbf{6}$ & 72 & 80 & \\
\hline $\mathbf{7}$ & 80 & 90 & \\
\hline $\mathbf{8}$ & 44 & 50 & \\
\hline $\mathbf{9}$ & 67 & 65 & \\
\hline $\mathbf{1 0}$ & 60 & 60 & \\
\hline $\mathbf{1 1}$ & 65 & 75 & \\
\hline $\mathbf{1 2}$ & 75 & 80 & \\
\hline $\mathbf{1 3}$ & 67 & 85 & \\
\hline $\mathbf{1 4}$ & 66 & 70 & \\
\hline $\mathbf{1 5}$ & 62 & 65 & \\
\hline & & &
\end{tabular}

Gambar 20.19

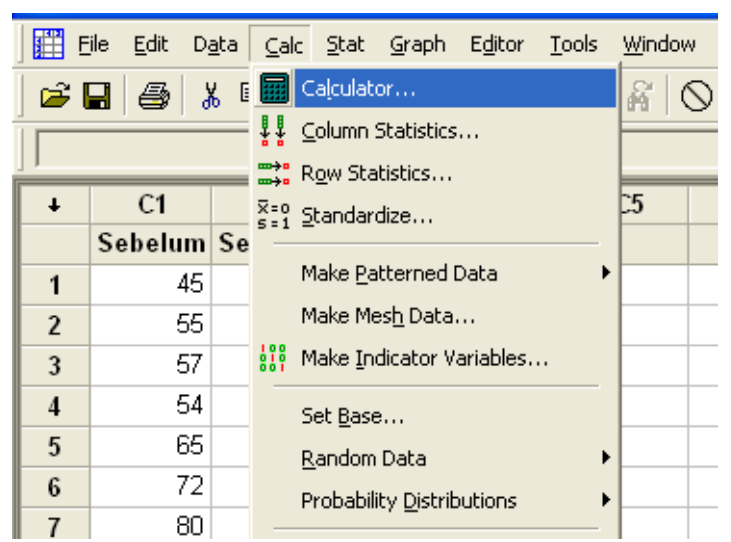

Gambar 20.20

Pada Gambar 20.21, ketik Selisih pada bagian Store result in variable: Kemudian pada bagian Expression; atur menjadi 'Sesudah' - 'Sebelum'. Selanjutnya pilih OK, hasilnya seperti pada Gambar 20.22, di mana telah terbentuk varaibel Selisih.

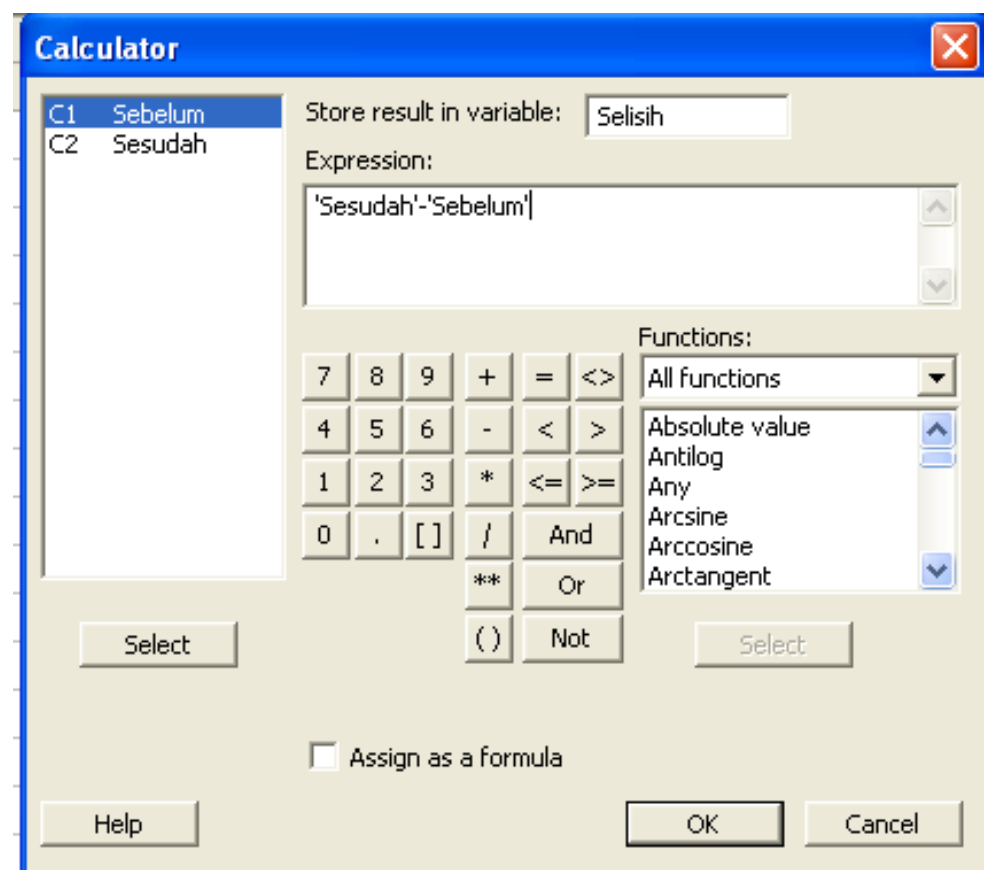

Gambar 20.21

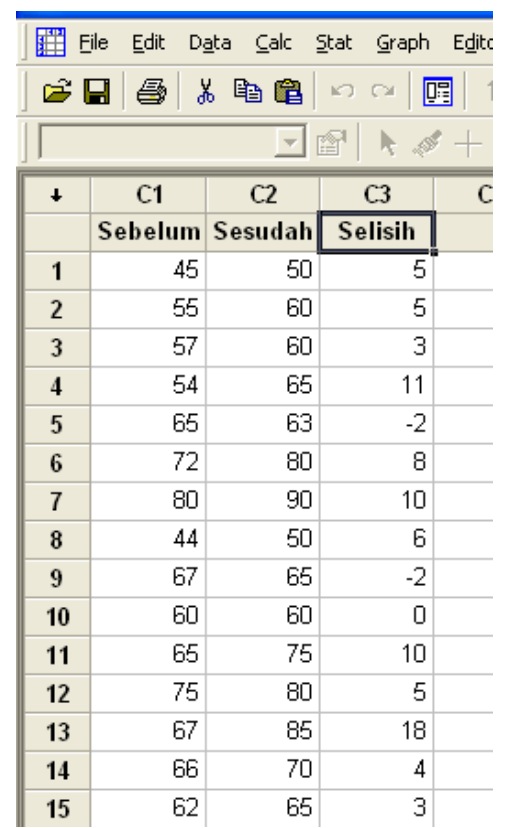

Gambar 20.22

Selanjutnya pilih Stat $=>$ Nonparametrics $=>$ 1-sample Wilcoxon (Gambar 20.23). 


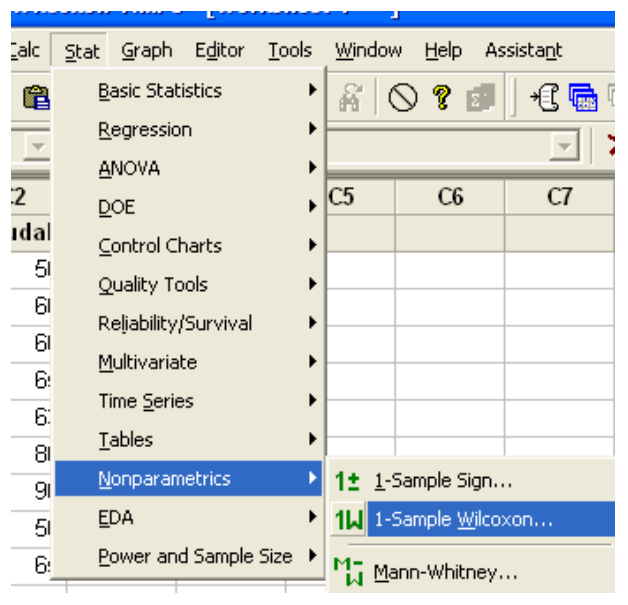

Gambar 20.23

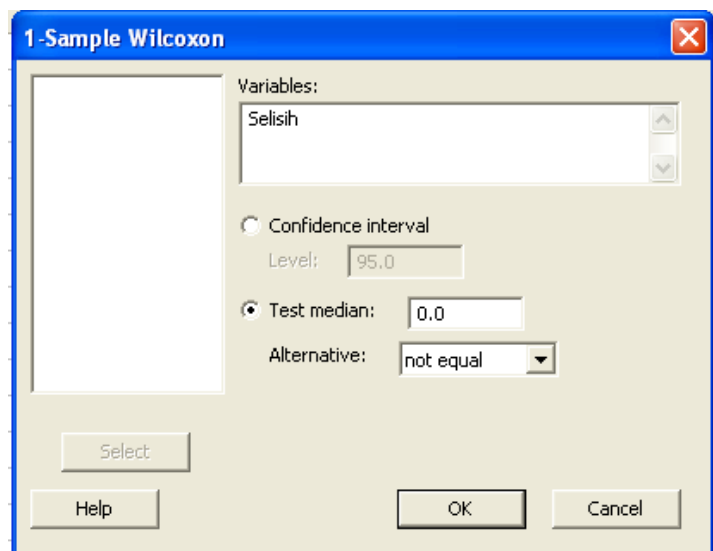

Gambar 20.24

Pada Gambar 2.24, masukkan variabel Selisih pada bagian Variables: Kemudian aktifkan/bulatkan bagian Test median dan pada Alternative: pilih not equal dengan maksud untuk pengujian dua arah. Kemudian pilih OK.

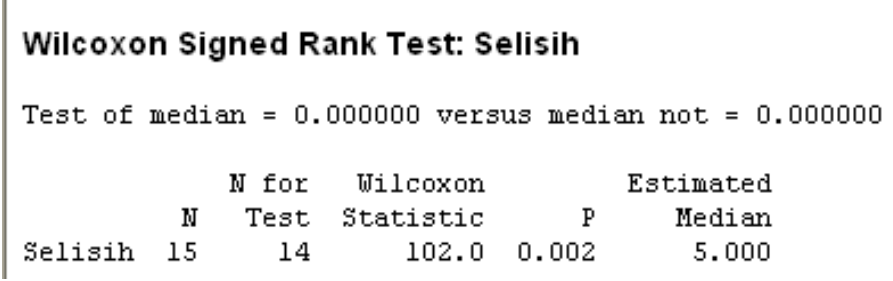

Gambar 20.25

Berdasarkan Gambar 20.25, diketahui nilai $P$ adalah 0,002, di mana nilai tersebut merupakan nilai probabilitas kumulatif nilai normal $Z$ terstandarisasi, yakni $Z=-3,11$. Karena nilai probabilitas $0,002<\alpha=0,05$, maka hipotesis nol ditolak dan hipotesis alternatif diterima. Ini berarti pernyataan "terdapat perbedaan yang signifikan secara statistika mengenai berat badan, sebelum dan sesudah mengkonsumsi obat penambah berat badan merek XYZ" dapat diterima pada tingkat signifikansi 5\%. Perhatikan bahwa "(2-tailed)" berarti pengujian dilakukan secara dua arah. 


\section{PENYELESAIAN DALAM R (UJI WILCOXON)}

Data terlebih dahulu disimpan dalam Microsoft Excel dengan tipe .CSV (Comma Separeted Values) (Gambar 20.26 dan Gambar 20.27).

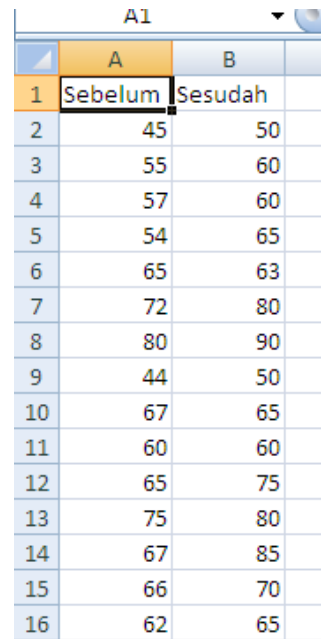

Gambar 20.26

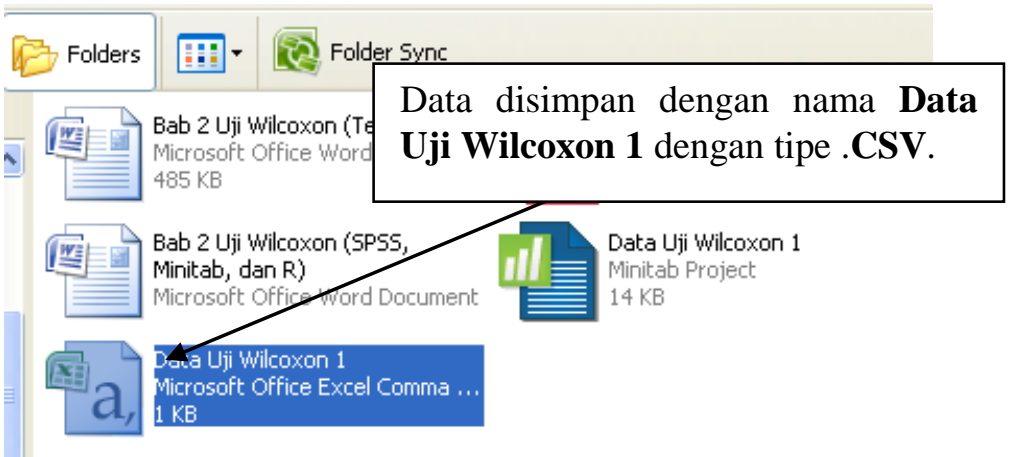

Gambar 20.27

Aktifkan RStudio, kemudian pilih File $=>R$ Script. Ketik perintah R seperti pada Gambar 20.28 .

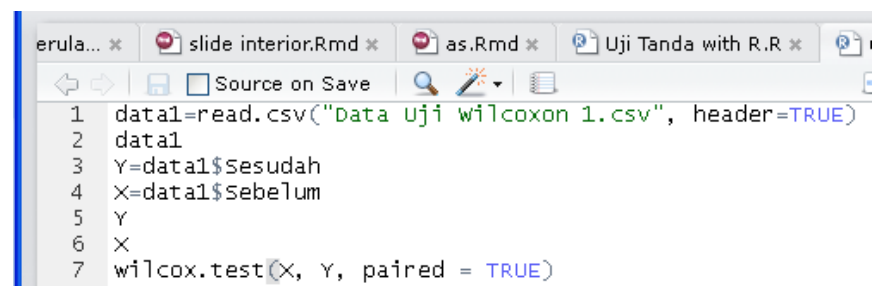

\section{Gambar 20.28}

Selanjutnya pilih Compile, pilih MS Word pada Notebook output format, dan Compile. Berikut hasil berdasarkan berdasarkan R.

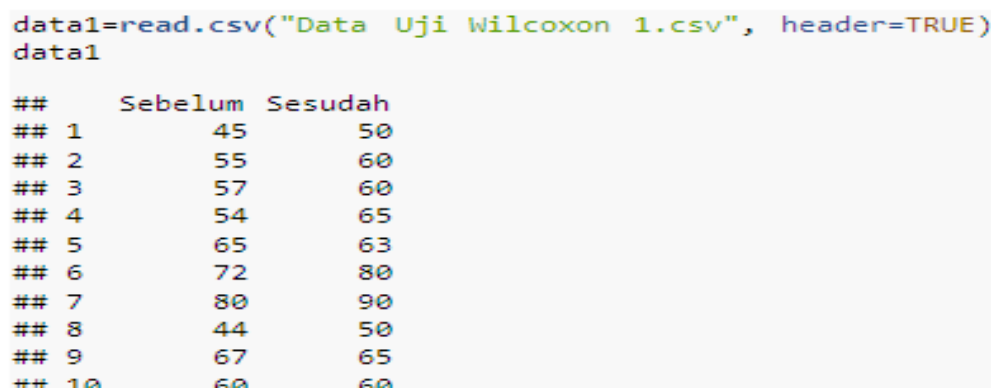

Gambar 20.29 


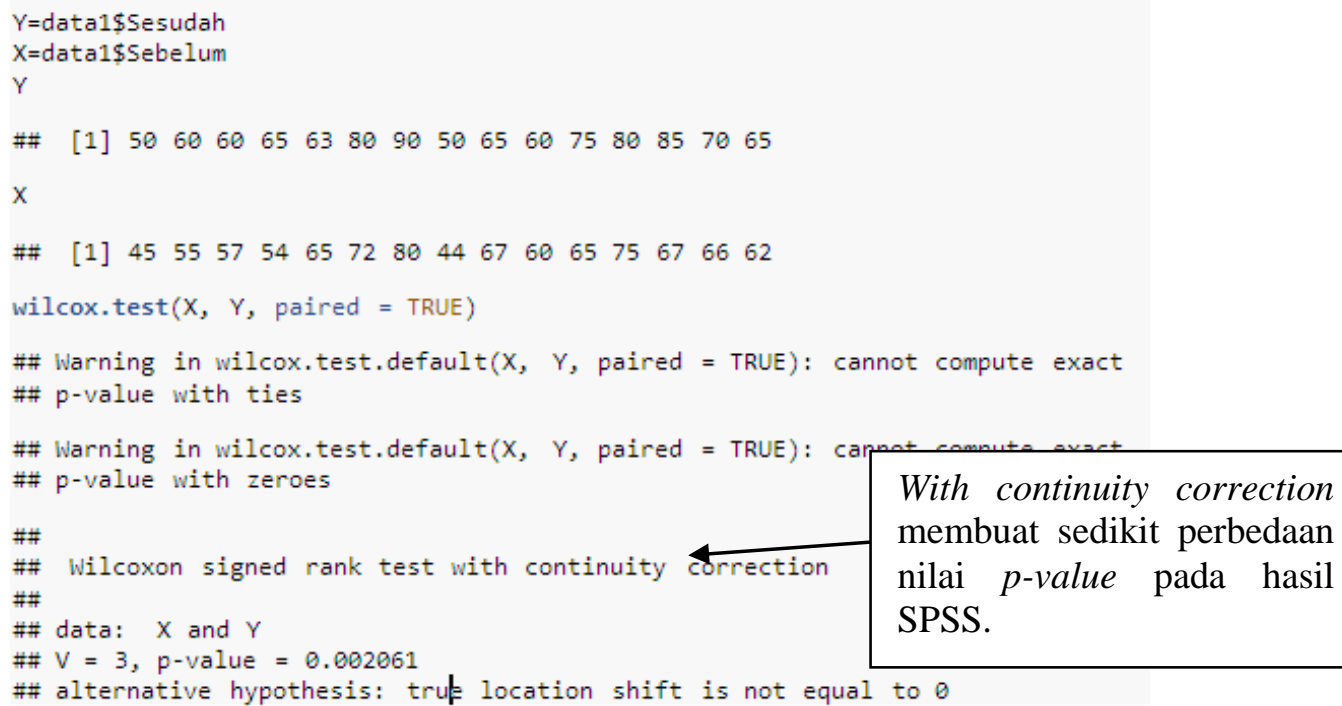

With continuity correction membuat sedikit perbedaan nilai $p$-value pada hasil SPSS.

\section{Gambar 20.30}

Perhatikan bahwa berdasarkan Gambar 20.30, nilai V =3, di mana nilai tersebut merupakan nilai statistik dari uji Wilcoxon. Karena nilai statistik dari uji Wilcoxon, yakni 3 lebih kecil dari nilai kritis Wilcoxon, yakni 21, maka hipotesis nol ditolak dan hipotesis alternatif diterima. Ini berarti pernyataan mengenai "terdapat perbedaan yang signifikan (secara statistika) mengenai berat badan, sebelum mengkonsumsi obat penambah berat badan merek $X Y Z$ dan sesudah mengkonsumsi obat penambah berat badan merek $X Y Z$ selama satu minggu" dapat diterima pada tingkat signifikansi $5 \%$.

Berdasarkan Gambar 20.30 juga diketahui nilai p-value (setelah koreksi) adalah 0,002061. Karena nilai probabilitas $0,002061<\alpha=0,05$, maka hipotesis nol ditolak dan hipotesis alternatif diterima. Ini berarti pernyataan "terdapat perbedaan yang signifikan secara statistika mengenai berat badan, sebelum dan sesudah mengkonsumsi obat penambah berat badan merek XYZ" dapat diterima pada tingkat signifikansi 5\%. Perhatikan bahwa "(2-tailed)" berarti pengujian dilakukan secara dua arah. Pada Gambar 20.31 menyajikan kode R untuk uji Wilcoxon tanpa koreksi.

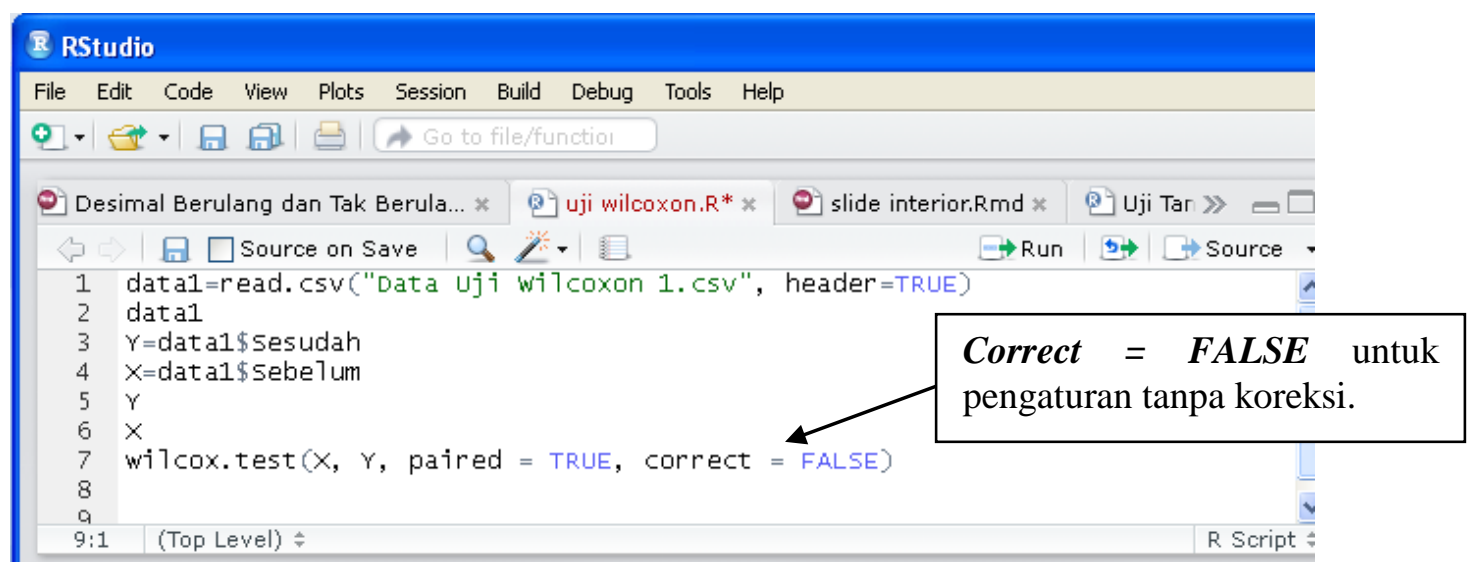

\section{Gambar 20.31}

Dengan melakukan compile kode R pada Gambar 20.31, diperoleh hasil seperti pada Gambar 20.32. Berdasarkan Gambar 20.32, diketahui nilai p-value (sebelum koreksi) adalah 0,001853, di mana nilai tersebut merupakan nilai probabilitas kumulatif nilai normal $Z$ terstandarisasi, 
yakni $Z=-3,11$. Karena nilai probabilitas $0,001853<\alpha=0,05$, maka hipotesis nol ditolak dan hipotesis alternatif diterima. Ini berarti pernyataan "terdapat perbedaan yang signifikan secara statistika mengenai berat badan, sebelum dan sesudah mengkonsumsi obat penambah berat badan merek XYZ" dapat diterima pada tingkat signifikansi 5\%. Perhatikan bahwa "(2tailed)" berarti pengujian dilakukan secara dua arah.

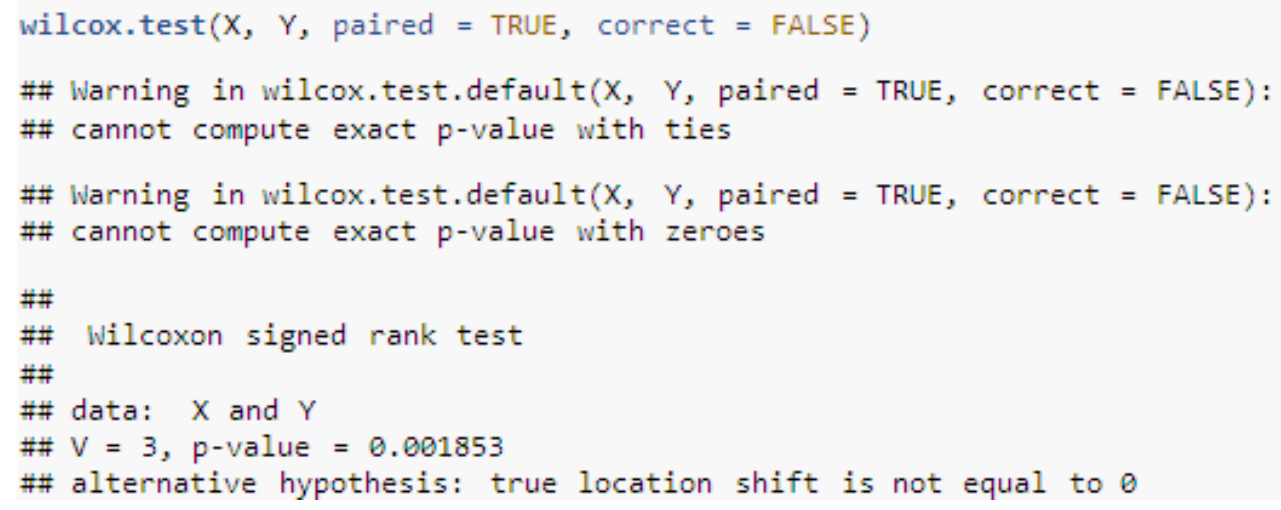

Gambar 20.32 
Bangun data dalam SPSS seperti pada Gambar 20.33. Pada Variable View, bentuk variabel Jurusan dan Nilai. Kemudian atur tipe data (Type) dengan Numeric. Untuk variabel Jurusan, beri Value 0 untuk Label "Matematika", dan Value 1 untuk Label "Statistika" (lihat Gambar 3.1). Kemudian aktifkan Data View. Ketik data seperti pada Gambar 20.33. Berdasarkan Gambar 20.33, diketahui masing-masing jurusan diamati 10 mahasiswa. Pada kolom Jurusan, nilai 0 menyatakan jurusan matematika, sedangkan nilai 1 menyatakan jurusan statistika.

\begin{tabular}{|c|r|r|}
\hline \multicolumn{1}{|c|}{} & Jurusan & \multicolumn{1}{|c|}{ Nilai } \\
\hline 1 & 0 & 65 \\
\hline 2 & 0 & 68 \\
\hline 3 & 0 & 70 \\
\hline 4 & 0 & 80 \\
\hline 5 & 0 & 75 \\
\hline 6 & 0 & 72 \\
\hline 7 & 0 & 65 \\
\hline 8 & 0 & 60 \\
\hline 9 & 0 & 88 \\
\hline 10 & 0 & 70 \\
\hline 11 & 1 & 85 \\
\hline 12 & 1 & 75 \\
\hline 13 & 1 & 75 \\
\hline 14 & 1 & 80 \\
\hline 15 & 1 & 75 \\
\hline 16 & 1 & 75 \\
\hline 17 & 1 & 75 \\
\hline
\end{tabular}

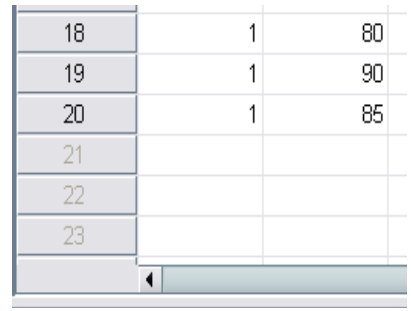

Gambar 20.33

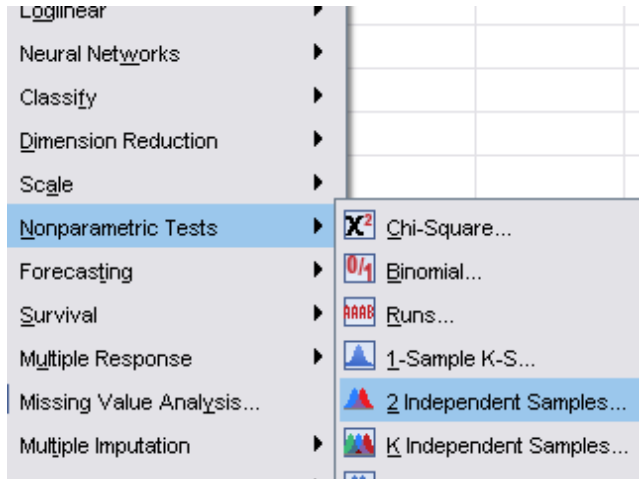

Gambar 20.34

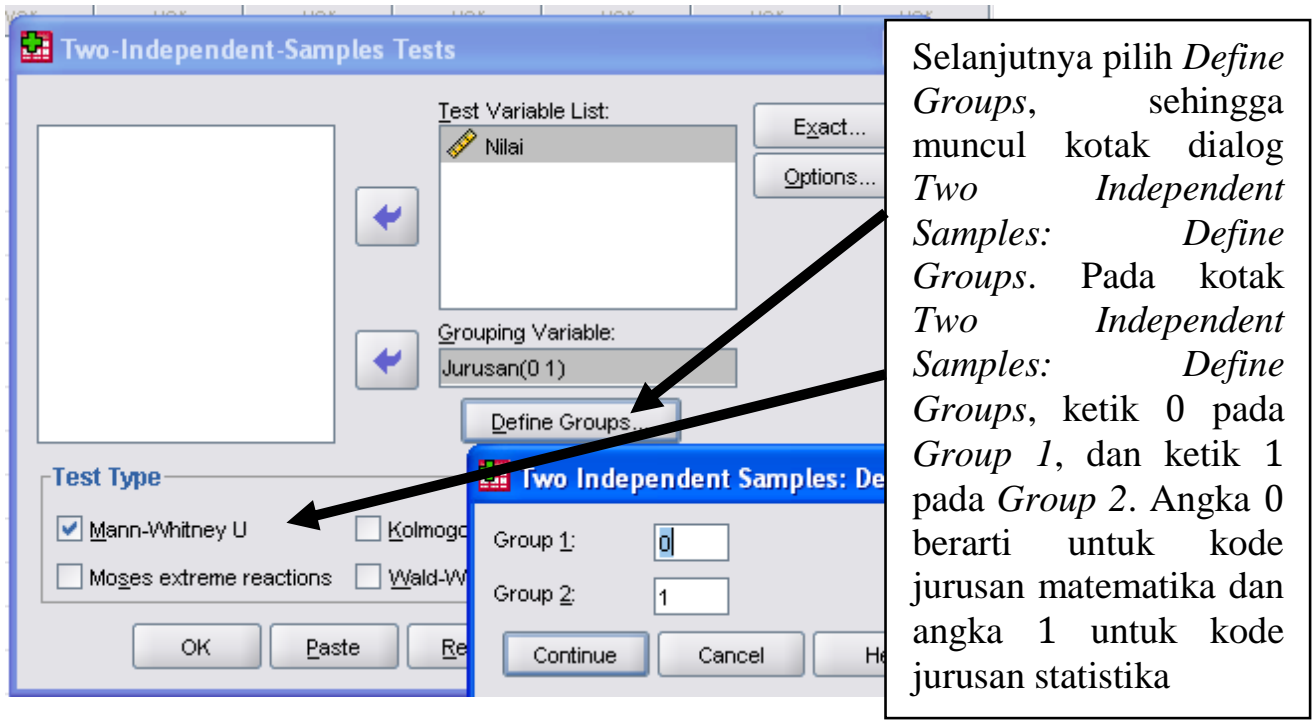

Gambar 20.35

Pilih Analyze $=>$ Nonparametric Tests $=>2$ Independent Samples (Gambar 20.34), sehingga muncul kotak dialog Two Independent Samples Test (Gambar 20.35). Pada Gambar 20.35, variabel Nilai dimasukkan pada kotak Test Variable List dan variabel Jurusan dimasukkan pada kotak Grouping Variable. Pada Test Type, pilih Mann-Whitney U. Selanjutnya pilih Define Groups, sehingga muncul kotak dialog Two Independent Samples: Define Groups. 
Pada kotak Two Independent Samples: Define Groups, ketik 0 pada Group 1, dan ketik 1 pada Group 2. Angka 0 berarti untuk kode jurusan matematika dan angka 1 untuk kode jurusan statistika. Kemudian pilih Continue dan $O K$.

Tabel 20.5, yakni Tabel Rank merupakan hasil berdasarkan SPSS. Pada kolom Sum of Ranks, diketahui jumlah ranking nilai ujian matakuliah kalkulus mahasiswa jurusan matematika adalah 72,5 dan jumlah ranking nilai ujian matakuliah kalkulus mahasiswa jurusan statistika adalah 137,5. Pada kolom Mean Rank merupakan nilai rata-rata dari ranking nilai ujian matakuliah kalkulus berdasarkan masing-masing jurusan.

\section{Tabel 20.5}

\begin{tabular}{|ll|r|r|r|}
\hline \multicolumn{5}{|c|}{ Ranks } \\
\hline Nilai & Jurusan & N & Mean Rank & \multicolumn{1}{c|}{ Sum of Ranks } \\
& Statistika & 10 & 7.25 & 72.50 \\
& Total & 10 & 13.75 & 137.50 \\
& 20 & & \\
\hline
\end{tabular}

Pada Tabel 20.6 (Tabel Test Statistics) diketahui nilai statistik uji Mann-Whitney adalah 17,5. Nilai kritis Mann-Whitney adalah 23. Karena nilai dari statistik dari uji Mann-Whitney, yakni 17,5 lebih kecil dari nilai kritis Mann-Whitney, yakni 23, maka hipotesis nol ditolak dan hipotesis alternatif diterima. Ini berarti pernyataan mengenai "terdapat perbedaan yang signifikan secara statistika mengenai nilai ujian matakuliah kalkulus antara mahasiswa jurusan matematika dan mahasiswa jurusan statistika" dapat diterima pada tingkat signifikansi 5\%. Perhatikan juga bahwa diketahui nilai Asymp. Sig. (2-tailed) adalah 0,013. Nilai tersebut merupakan:

$2 \times($ nilai probabilitas kumulatif dari nilai normal $Z=-2,497)=2 \times 0,0062=0,013$.

Karena nilai probabilitas kumulatif $0,013<\alpha=0,05$, maka hipotesis nol ditolak dan hipotesis alternatif diterima. Ini berarti pernyataan mengenai "nilai ujian matakuliah kalkulus mahasiswa jurusan statistika berbeda signifikan secara statistika dengan nilai ujian matakuliah kalkulus mahasiswa jurusan matematika" dapat diterima pada tingkat signifikansi 5\%. Perhatikan bahwa "(2-tailed)" berarti pengujian dilakukan secara dua arah.

Tabel 20.6

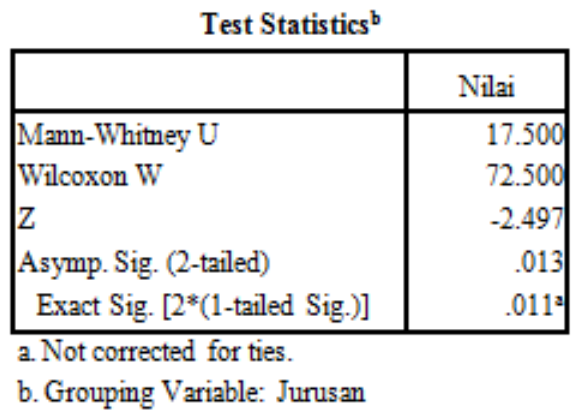

Tabel 20.7

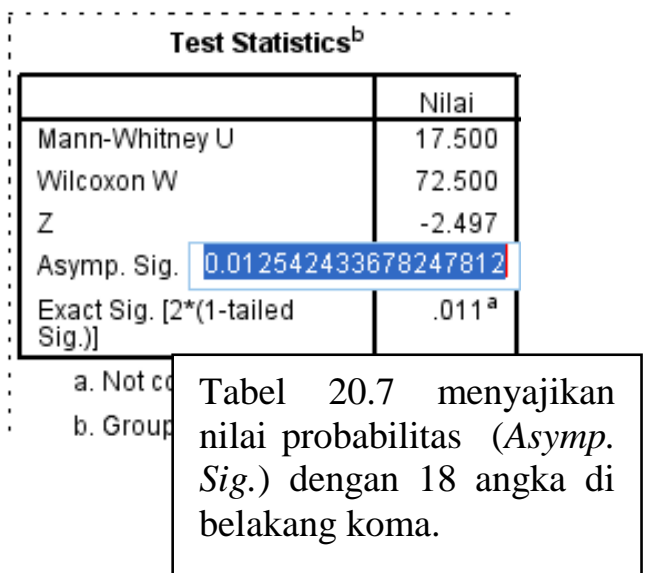




\section{PENYELESAIAN DALAM Minitab (UJI MANN- WHITNEY)}

Bangun data dalam Minitab seperti pada Gambar 20.36. Pilih Stat $\Rightarrow$ Nonparametrics $\Rightarrow$ Mann-Whitney (Gambar 20.37).

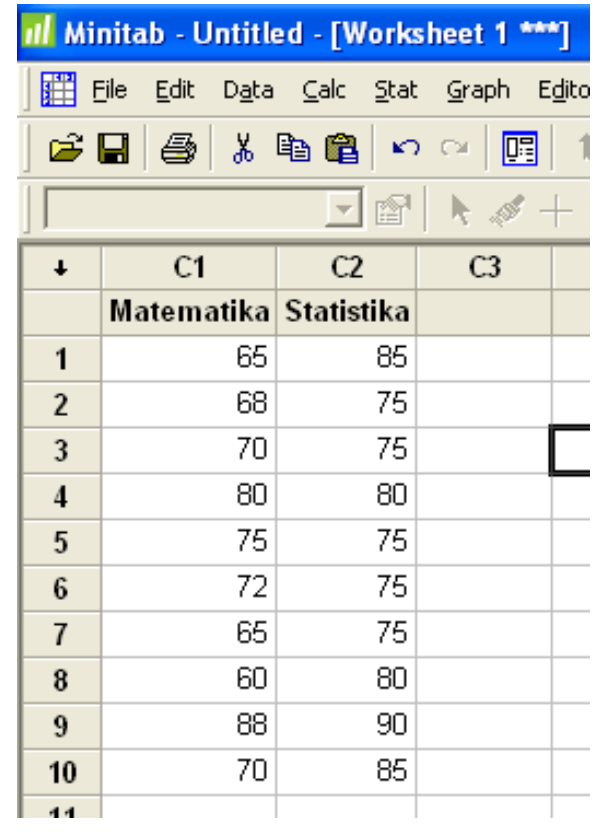

Gambar 20.36

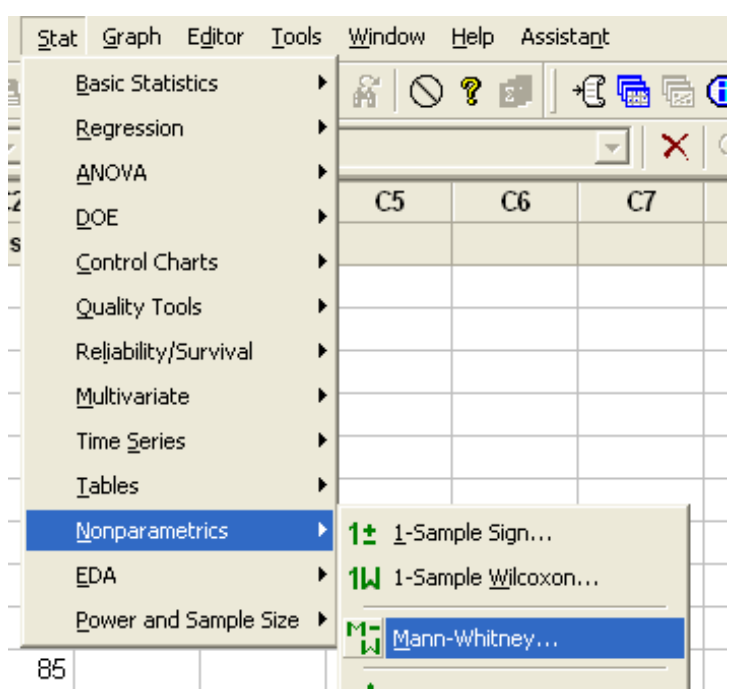

Gambar 20.37

Pada Gambar 20.38, pindahkan variabel Matematika pada First Sample, dan pindahkan variabel Statistika pada Second Sample. Kemudian pilih OK.

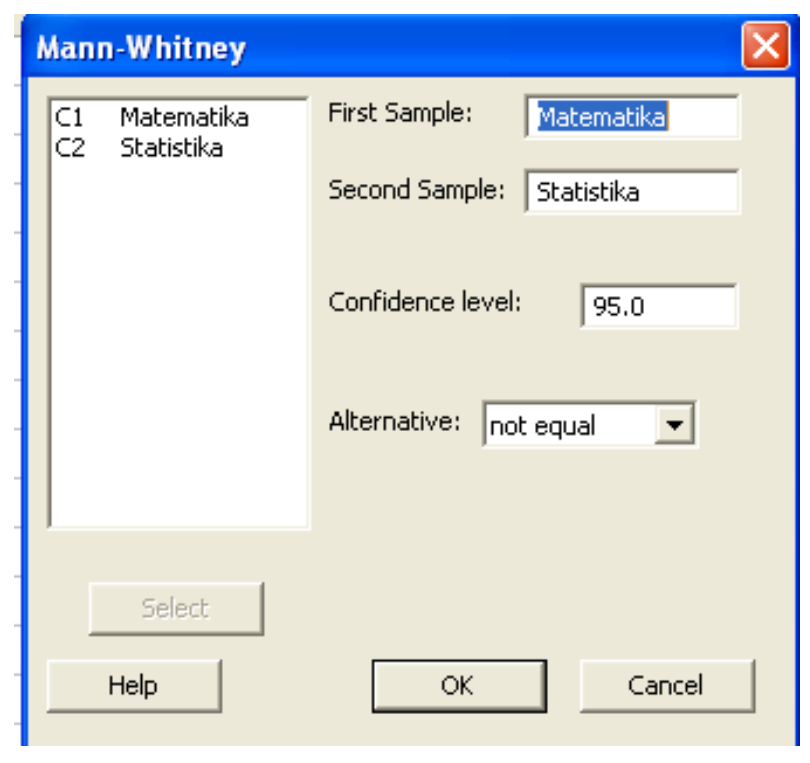

Gambar 20.38 


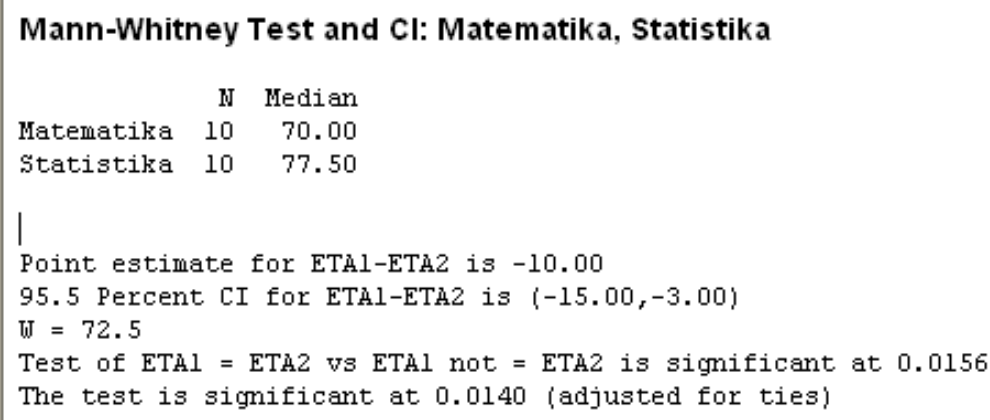

\section{Gambar 20.39}

Berdasarkan Gambar 20.39, diketahui nilai $W=72,5$, di mana nilai tersebut merupakan jumlah ranking nilai ujian matakuliah kalkulus mahasiswa jurusan matematika. Diketahui berdasarkan perhitungan sebelumnya, jumlah ranking nilai ujian matakuliah kalkulus mahasiswa jurusan matematika $R(X)$ adalah 72,5 dan jumlah ranking nilai ujian matakuliah kalkulus mahasiswa jurusan statistika $R(Y)$ adalah 137,5, maka $W=\operatorname{minimum}(72,5 ; 137,5)=72,5$.

Perhatikan juga bahwa diketahui nilai probabilitas (adjusted for ties) adalah $0,014<\alpha=$ 0,05, maka hipotesis nol ditolak dan hipotesis alternatif diterima. Ini berarti pernyataan mengenai "nilai ujian matakuliah kalkulus mahasiswa jurusan statistika berbeda signifikan secara statistika dengan nilai ujian matakuliah kalkulus mahasiswa jurusan matematika" dapat diterima pada tingkat signifikansi 5\%. 


\section{PENYELESAIAN DALAM R (UJI MANN-WHITNEY)}

Data terlebih dahulu disimpan dalam Microsoft Excel dengan tipe .CSV (Comma Separeted Values) (Gambar 20.40 dan Gambar 20.41).

\begin{tabular}{|c|c|c|c|}
\hline A & B & \multirow{7}{*}{\multicolumn{2}{|c|}{$\begin{array}{l}\begin{array}{l}3 \text { Uji Mann-Whitney (SPSS, } \\
\text { :ab, dan R) } \\
\text { Jsoft Office Word Document }\end{array} \\
\begin{array}{l}\text { I uji mann whitney } \\
\text { :ab Project } \\
\text { B }\end{array}\end{array}$}} \\
\hline NilaiJurusanMatematika & NilaiJurusanStatistika & & \\
\hline 65 & 85 & & \\
\hline 68 & 75 & & \\
\hline 70 & 75 & & \\
\hline 80 & 80 & & \\
\hline 75 & 75 & \multirow{6}{*}{$\begin{array}{l}\text { Data disimpan dengan } \\
\text { nama data uji mann } \\
\text { whitney } \mathbf{R} \text { dengan } \\
\text { tipe.CSV. }\end{array}$} & \\
\hline 72 & 75 & & \multirow{5}{*}{$\begin{array}{l}\text { uji_mann_whitney_R } \\
\text { Microsoft Office Word Document } \\
10 \mathrm{~KB}\end{array}$} \\
\hline 65 & 75 & & \\
\hline 60 & 80 & & \\
\hline 88 & 90 & & \\
\hline 70 & 85 & & \\
\hline
\end{tabular}

Gambar 20.40

Gambar 20.41

Aktifkan RStudio, kemudian pilih File $=>R$ Script. Ketik perintah R seperti pada Gambar 20.42 .

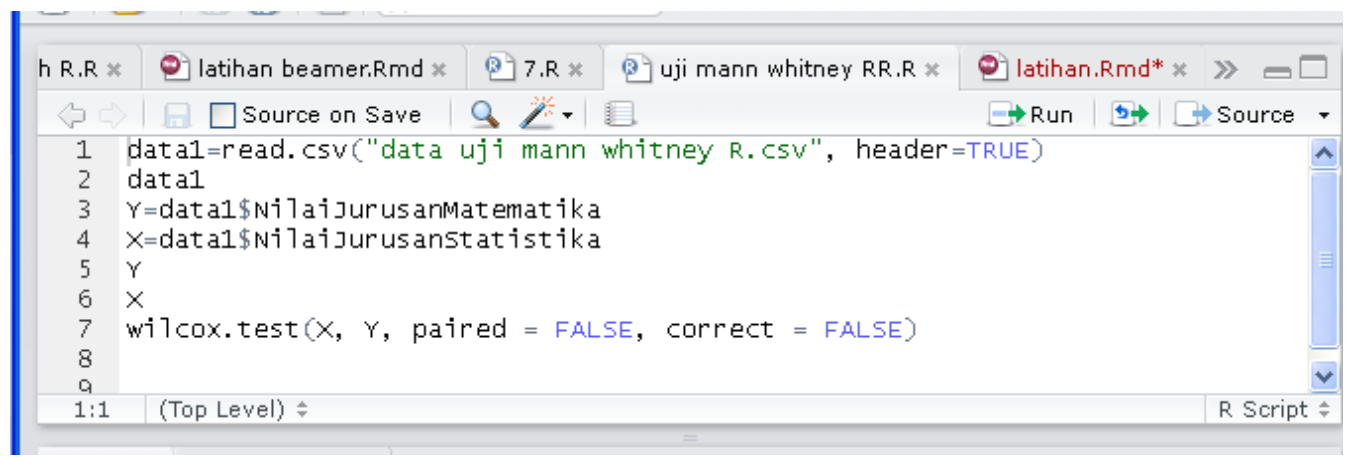

\section{Gambar 20.42}

Selanjutnya pilih Compile, pilih MS Word pada Notebook output format, dan Compile. Berikut hasil berdasarkan berdasarkan R.

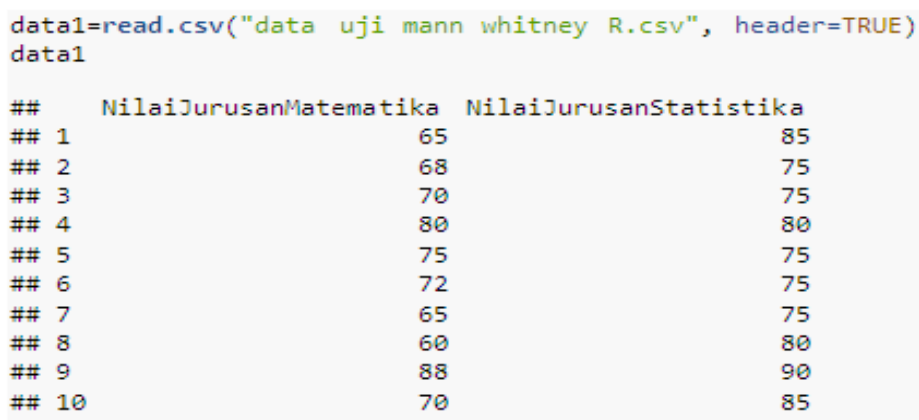

Gambar 20.43 
\#\# [1] $65 \begin{array}{llllllllll}65 & 68 & 70 & 80 & 75 & 72 & 65 & 60 & 88 & 70\end{array}$

$\mathrm{x}$

\#\# [1] $\quad 85 \quad 75 \quad 75 \quad 80 \quad 75 \quad 75 \quad 75 \quad 80 \quad 90 \quad 85$

wilcox.test $(X, Y$, paired $=$ FALSE, correct $=$ FALSE $)$

\#\# Warning in wilcox.test.default $(X, Y$, paired $=$

\#\# cannot compute exact p-value with ties

$\#$

\#\#ilcoxon rank sum test

\#\# data: $X$ and $Y$

$\# W=82.5$, p-value $=0.01254$

\#\# alternative hypothesis: true location shift is not equal to $\theta$
"Correct = FALSE" berarti

Perhitungan tanpa menggunakan rumus koreksi, menghasilkan nilai probabilitas ( $p$-value) 0,01254. Hasil dalam SPSS diperoleh 0,01254 .

Gambar 20.44

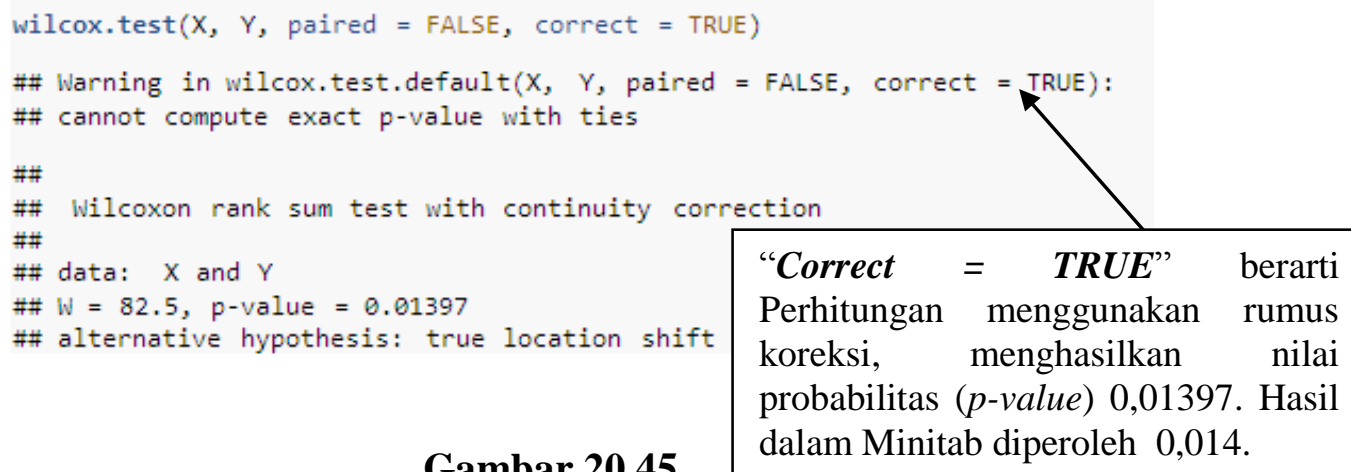
probabilitas ( $p$-value) 0,01397. Hasil dalam Minitab diperoleh 0,014.

Gambar 20.45 


\section{PENYELESAIAN DALAM SPSS (UJI McNEMAR)}

Bangun data dalam SPSS seperti pada Gambar 20.46. Pada Variable View, bentuk variabel Sebelum dan Sesudah. Kemudian atur tipe data (Type) dengan Numeric. Untuk variabel Sebelum, beri Value 0 untuk Label "tidak menggunakan bumbu masakan A", dan Value 1 untuk Label "menggunakan bumbu masakan A". Begitu juga pada variabel Sesudah, beri Value 0 untuk Label "tidak menggunakan bumbu masakan A", dan Value 1 untuk Label "menggunakan bumbu masakan A". Kemudian aktifkan Data View. Input data pada Data View seperti pada Gambar 20.46. Pilih Analyze $\Rightarrow$ Nonparametric Tests $=>2$ Related Samples (Gambar 20.47), sehingga muncul kotak dialog Two Related Samples Test (Gambar 20.48). Variabel Sebelum dimasukkan pada Variablel dan variabel Sesudah dimasukkan pada Variable2. Pada Test Type pilih McNemar dan kemudian pilih OK.

\begin{tabular}{|c|r|r|}
\hline \multicolumn{1}{|c|}{} & Sebelum & Sesudah \\
\hline 1 & 0 & 1 \\
\hline 2 & 0 & 1 \\
\hline 3 & 0 & 1 \\
\hline 4 & 0 & 1 \\
\hline 5 & 1 & 0 \\
\hline 6 & 1 & 1 \\
\hline 7 & 1 & 1 \\
\hline 8 & 1 & 1 \\
\hline 9 & 1 & 1 \\
\hline 10 & 0 & 1 \\
\hline 11 & 0 & 1 \\
\hline 12 & 0 & 1 \\
\hline 13 & 0 & 0 \\
\hline 14 & 0 & 0 \\
\hline 15 & 0 & 1 \\
\hline
\end{tabular}

Gambar 20.46

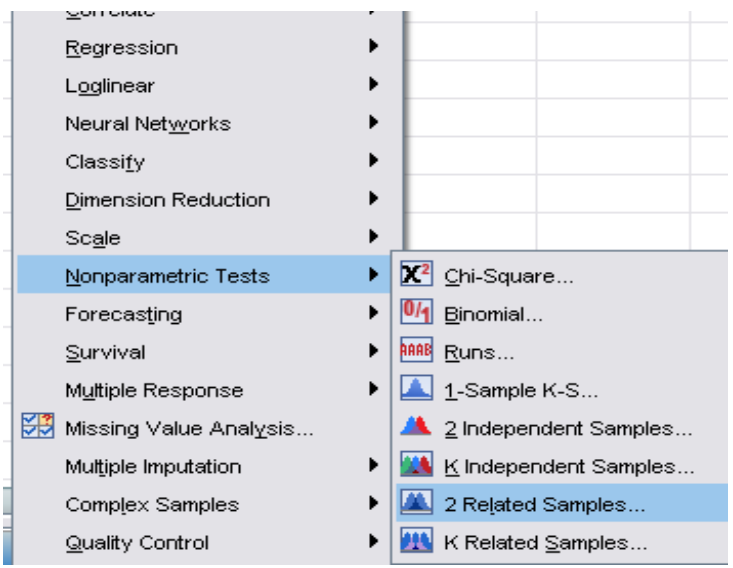

Gambar 20.47

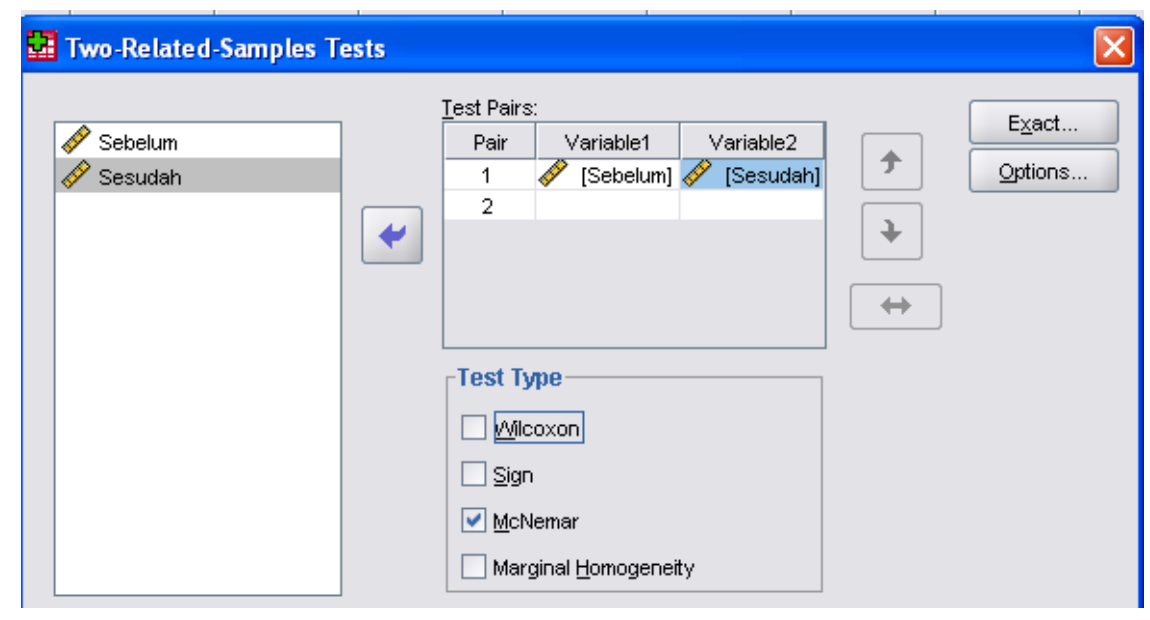

Gambar 20.48

Berdasarkan Tabel 20.8 (Tabel Sebelum \& Sesudah), Diketahui terdapat 4 orang menggunakan bumbu masakan merek A sebelum dan setelah adanya iklan promosi. Terdapat 8 orang yang tidak menggunakan bumbu masakan merek A sebelum ada iklan promosi. Namun, setelah ada iklan promosi, maka 8 orang tersebut beralih untuk menggunakan bumbu masakan merek A. Tabel tersebut merupakan tabel kontingensi berukuran $2 \times 2$ (dua baris dan dua kolom). 


\section{Tabel 20.8}

\begin{tabular}{|c|c|c|}
\hline \multicolumn{3}{|c|}{ Sebelum \& Sesudah } \\
\hline \multirow[b]{2}{*}{ Sebelum } & \multicolumn{2}{|c|}{ Sesudah } \\
\hline & $\begin{array}{c}\text { tidak } \\
\text { menggunakan } \\
\text { bumbu masakan A }\end{array}$ & $\begin{array}{c}\text { menggunakan } \\
\text { bumbu masakan A }\end{array}$ \\
\hline $\begin{array}{l}\text { tidak menggunakan bumbu } \\
\text { masakan A }\end{array}$ & 2 & 8 \\
\hline $\begin{array}{l}\text { menggunakan bumbu masakan } \\
\text { A }\end{array}$ & 1 & 4 \\
\hline
\end{tabular}

Berdasarkan Tabel 20.9 (Tabel Test Statistics) diketahui nilai Exact Sig. (2-tailed) 0,039. Nilai tersebut merupakan nilai statistik dari uji $\operatorname{McNemar}\left(T_{2}\right)$ yang dihitung dengan rumus

$$
T_{2}=2\left[\sum_{i=0}^{X}\left(\begin{array}{c}
n \\
i
\end{array}\right) p^{i} q^{n-i}\right]
$$

Karena nilai Exact Sig. (2-tailed), yakni 0,039, lebih kecil dari tingkat signifikansi $\alpha=0,05$, maka hipotesis nol ditolak dan hipotesis alternatif diterima. Hal ini berarti terdapat pengaruh yang signifikan secara statistika pada penggunaan bumbu masakan mereka A, setelah adanya iklan promosi pada tingkat signifikansi $5 \%$.

Tabel 20.9

Test Statistics ${ }^{\mathrm{b}}$

\begin{tabular}{|l|r|}
\hline & \multicolumn{2}{|c|}{$\begin{array}{c}\text { Sebelum \& } \\
\text { Sesudah }\end{array}$} \\
\hline $\mathrm{N}$ & 15 \\
Exact Sig. (2-tailed) & $.039^{\mathrm{a}}$ \\
\hline
\end{tabular}

Perhitungan dengan menggunakan rumus binomial.

a. Binomial distribution used.

b. McNemar Test 


\section{PENYELESAIAN DALAM Minitab (UJI McNEMAR)}

Aktifkan terlebih dahulu software Minitab (Gambar 20.49). Kemudian pilih Calc $\Rightarrow$ Probability Distributions $=>$ Binomial (Gambar 20.50).

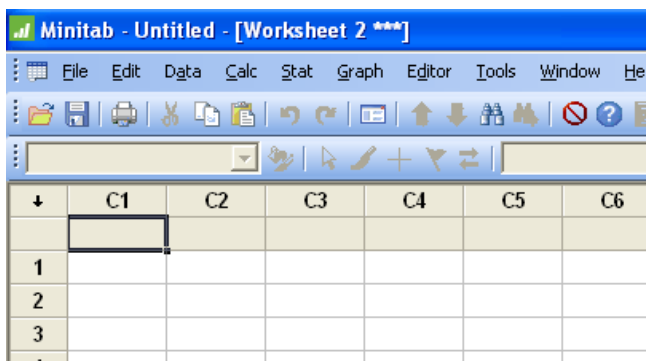

Gambar 20.49

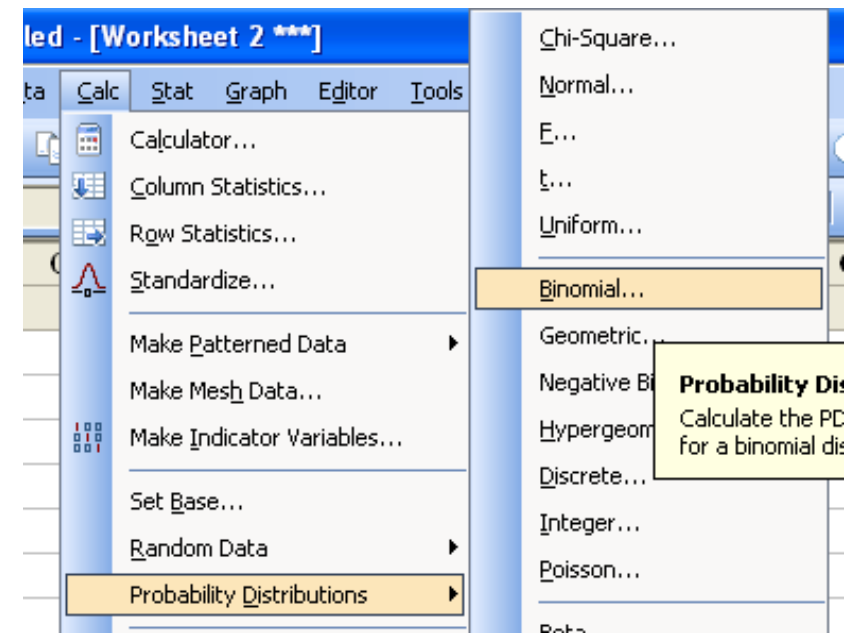

Gambar 20.50

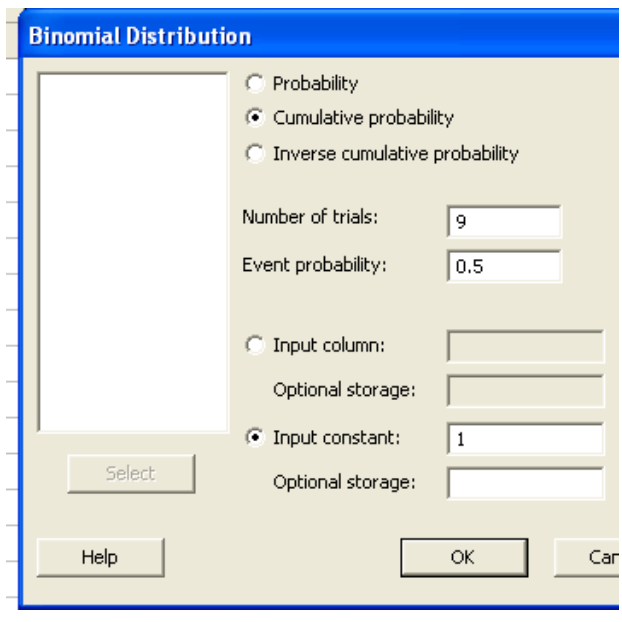

Gambar 20.51

\section{Gambar 20.52}

$$
2 \times 0,0195312=0,0390624 .
$$

Berdasarkan perhitungan di atas diperoleh nilai probabilitas ( $p$-value) 0,03906, yakni lebih kecil dari tingkat signifikansi yang digunakan $\alpha=0,05$, maka hipotesis nol ditolak, dan hipotesis alternatif diterima. Nilai p-value, yakni 0,03906 diperoleh dari perhitungan berikut (ingat rumus $T_{2}$ ). 


\section{PENYELESAIAN DALAM R (UJI MCNEMAR)}

Aktifkan RStudio, kemudian pilih File $=>R$ Script. Ketik perintah R seperti pada Gambar 20.53 .

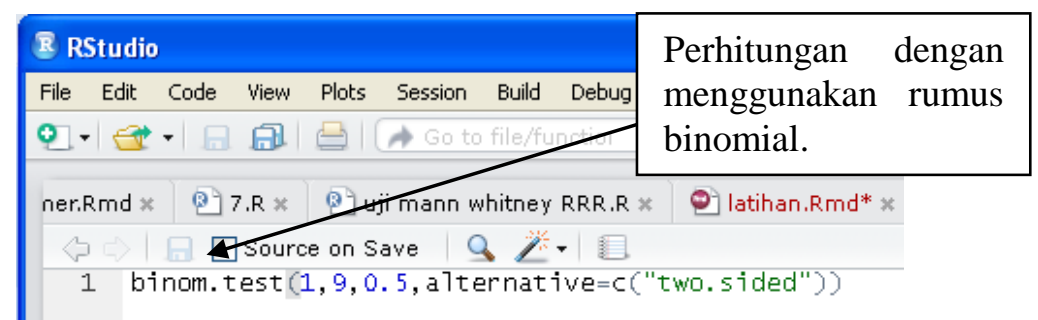

Gambar 20.53

Selanjutnya pilih Compile, pilih MS Word pada Notebook output format, dan Compile. Berikut hasil berdasarkan berdasarkan $\mathrm{R}$.

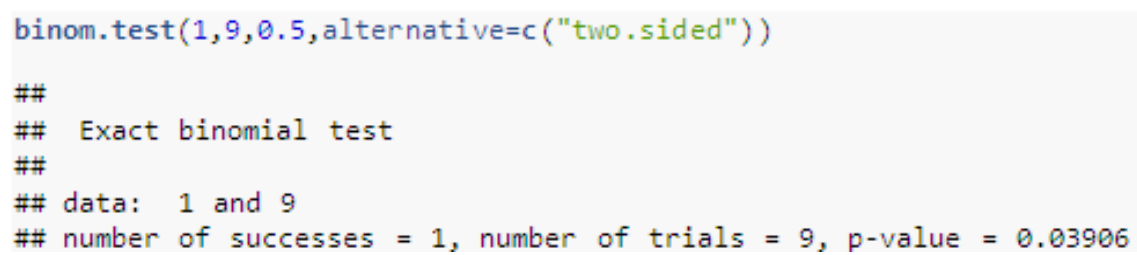

Gambar 20.54

Berdasarkan Gambar 20.54, diperoleh nilai probabilitas ( $p$-value) 0,03906, yakni lebih kecil dari tingkat signifikansi yang digunakan $\alpha=0,05$, maka hipotesis nol ditolak, dan hipotesis alternatif diterima. Nilai $p$-value, yakni 0,03906 diperoleh dari perhitungan berikut (ingat rumus $T_{2}$ ).

$$
\begin{gathered}
2\left[\sum_{i=0}^{X}\left(\begin{array}{c}
n \\
i
\end{array}\right) p^{i} q^{n-i}\right]=2[P(X=0)+P(X=1)] \\
=2\left[\left(\begin{array}{l}
9 \\
0
\end{array}\right)\left(\frac{1}{2}\right)^{0}\left(\frac{1}{2}\right)^{9}+\left(\begin{array}{l}
9 \\
1
\end{array}\right)\left(\frac{1}{2}\right)^{1}\left(\frac{1}{2}\right)^{8}\right] \\
=2[0,001953+0,017578] \\
=0,039 .
\end{gathered}
$$


Bangun data dalam SPSS seperti pada Gambar 5.1. Pada Variable View, bentuk variabel Jam dan IP. Kemudian atur tipe data (Type) dengan Numeric. Untuk variabel IP, atur Decimals dengan 1, karena terdapat 1 angka di belakang koma. Kolom Label berfungsi untuk memberi keterangan.

\begin{tabular}{|r|r|r|}
\hline \multicolumn{1}{|c|}{} & Jam & \multicolumn{1}{|c|}{ IP } \\
\hline 1 & 2 & 1.5 \\
\hline 2 & 4 & 2.8 \\
\hline 3 & 0 & 1.2 \\
\hline 4 & 5 & 2.9 \\
\hline 5 & 7 & 3.3 \\
\hline 6 & 7 & 3.3 \\
\hline 7 & 9 & 3.7 \\
\hline 8 & 8 & 3.8 \\
\hline 9 & 6 & 3.1 \\
\hline 10 & 5 & 3.3 \\
\hline 11 & 2 & 2.0 \\
\hline 12 & 9 & 3.9 \\
\hline
\end{tabular}

Gambar 20.55

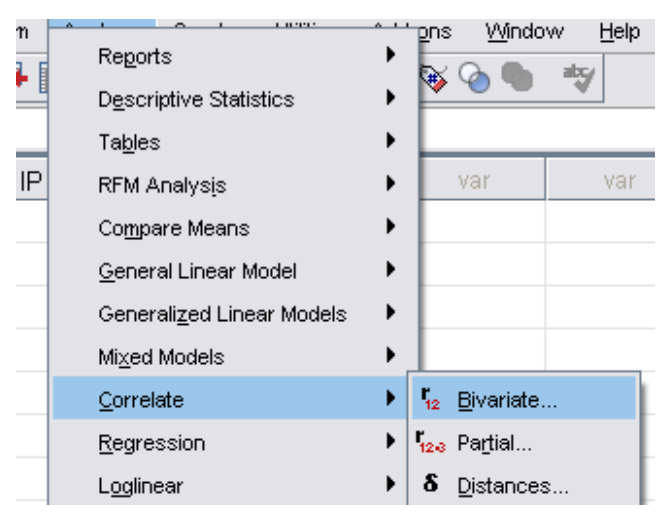

Gambar 20.56

Pilih Analyze => Correlate $=>$ Bivariate (Gambar 20.56), sehingga muncul kotak dialog Bivariate Correlations (Gambar 20.57). Variabel Jam dan IP dimasukkan pada kotak Variables. Pada Correlation Coefficients, pilih Spearman. Pada Test of Significance, pilih Two-Tailed, karena pengujian hipotesis dilakukan dua arah. Kemudian pilih Flag Significant Correlations dan pilih OK.

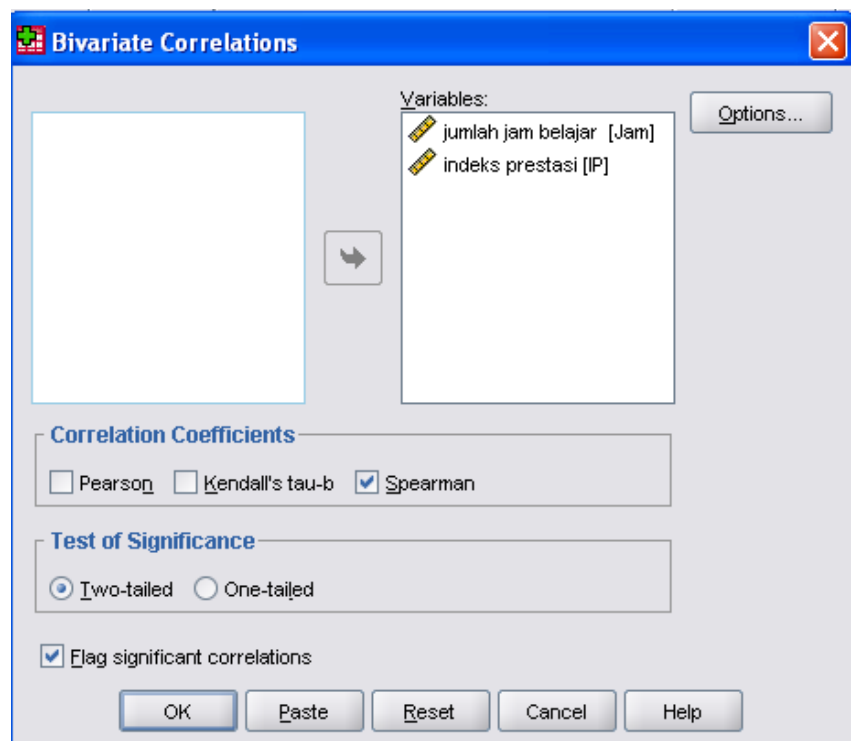

Gambar 20.57

Berdasarkan Tabel 20.10 (Tabel Correlation), diketahui nilai korelasi berperingkat Spearman adalah 0,942. Diketahui juga bahwa nilai probabilitas dari uji $t$ atau Sig.(2-tailed) adalah 0,000. Karena nilai probabilitas lebih kecil dari nilai tingkat signifikansi, yakni 0,05, maka hipotesis nol ditolak dan hipotesis alternatif diterima. Hal ini berarti terdapat hubungan yang 
signifikan secara statistika antara jumlah jam belajar di luar waktu kuliah dalam sehari dengan nilai indeks prestasi mahasiswa pada tingkat signifikansi $5 \%$.

Tabel 20.10

\begin{tabular}{|c|c|c|c|c|}
\hline \multicolumn{5}{|c|}{ Correlations } \\
\hline & & & $\begin{array}{c}\text { jumlah jam belajar } \\
\text { dalam sehari }\end{array}$ & indeks prestasi \\
\hline \multirow[t]{6}{*}{ Spearman's rho } & \multirow[t]{3}{*}{ jumlah jam belajar dalam sehari } & Correlation Coefficient & 1.000 & $.942^{\text {*** }}$ \\
\hline & & Sig. (2-tailed) & & .000 \\
\hline & & $\mathrm{N}$ & 12 & 12 \\
\hline & \multirow[t]{3}{*}{ indeks prestasi } & Correlation Coefficient & $.942^{* * *}$ & 1.000 \\
\hline & & Sig. (2-tailed) & .000 & \\
\hline & & $\mathrm{N}$ & 12 & 12 \\
\hline
\end{tabular}

**. Correlation is significant at the 0.01 level (2-tailed).

Tabel 20.11

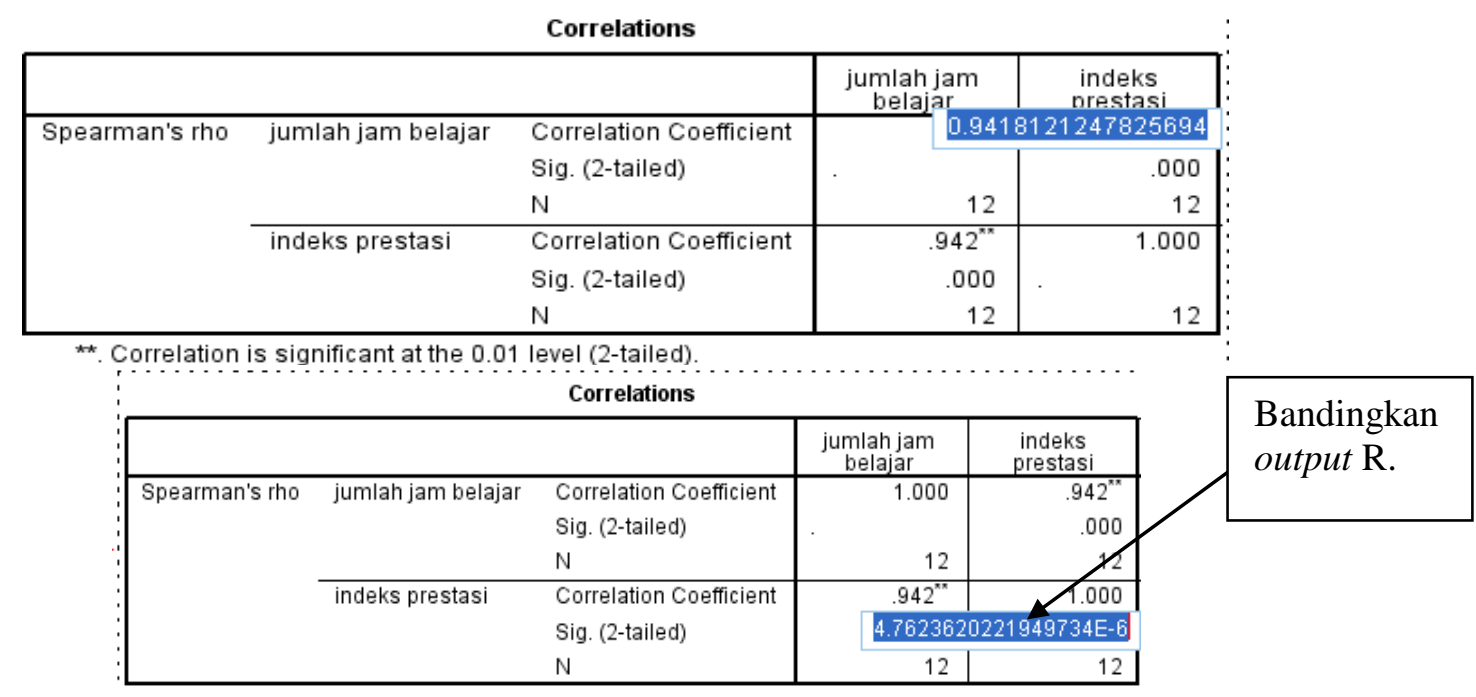




\section{PENYELESAIAN DALAM R (KORELASI SPEARMAN)}

Data terlebih dahulu disimpan dalam Microsoft Excel dengan tipe .CSV (Comma Separeted Values) (Gambar 20.58 dan Gambar 20.59).

\begin{tabular}{|c|c|c|}
\hline 4 & A & B \\
\hline 1 & Jam & IP \\
\hline 2 & 2 & 1.5 \\
\hline 3 & 4[ & 2.8 \\
\hline 4 & 0 & 1.2 \\
\hline 5 & 5 & 2.9 \\
\hline 6 & 7 & 3.3 \\
\hline 7 & 7 & 3.25 \\
\hline 8 & 9 & 3.7 \\
\hline 9 & 8 & 3.8 \\
\hline 10 & 6 & 3.1 \\
\hline 11 & 5 & 3.3 \\
\hline 12 & 2 & 2 \\
\hline 13 & 9 & 3.9 \\
\hline
\end{tabular}

Gambar 20.58 э... 노요 Microsoft Office Excel Worksh...

nent $\quad$ min $9 \mathrm{~KB}$

Xi. Jata spearman

a. Microsoft Office Excel Comma ...

nent $\quad$ spearman RR

R. File
$1 \mathrm{~KB}$

紧目 spearman_RRR

Data disimpan dengan nama data spearman dengan tipe .CSV.

Aktifkan RStudio, kemudian pilih File $=>R$ Script. Ketik perintah R seperti pada Gambar 20.60 .

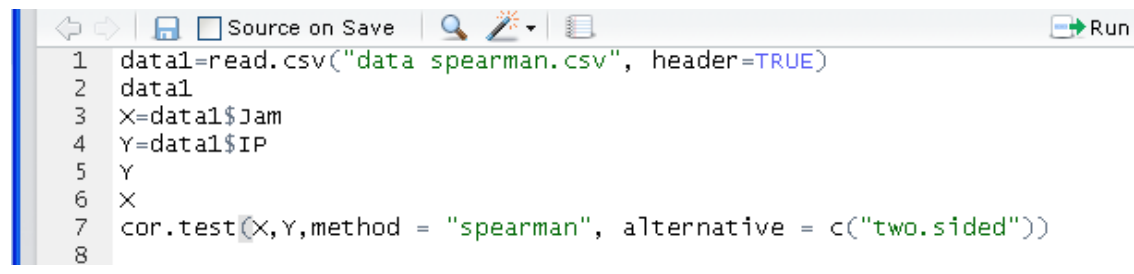

\section{Gambar 20.60}

Selanjutnya pilih Compile, dan pilih MS Word pada Notebook output format. Gambar 20.61 dan Gambar 20.62 merupakan hasil berdasarkan R. Berdasarkan Tabel 20.11 diketahui nilai korelasi berperingkat Spearman (rho) adalah 0,9418121. Diketahui juga bahwa nilai probabilitas dari uji $t$ ( $p$-value) adalah $\frac{4.762}{10^{6}}=0,000004762$. Karena nilai probabilitas lebih kecil dari nilai tingkat signifikansi, yakni 0,05, maka hipotesis nol ditolak dan hipotesis alternatif diterima.

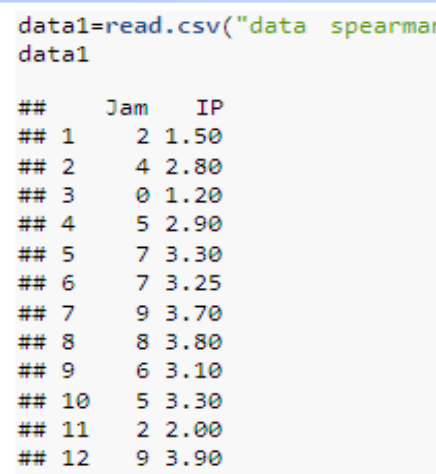

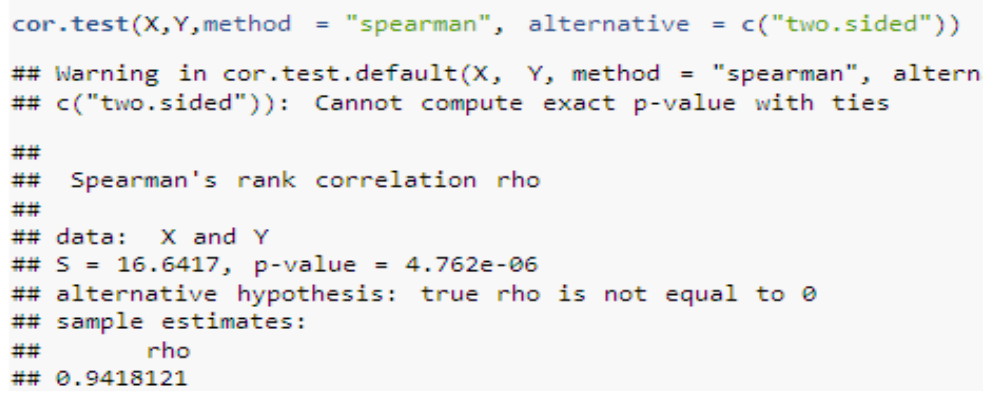

Gambar 20.61 
Bangun data dalam SPSS seperti pada Gambar 20.63. Pada Variable View, bentuk variabel Jumlah dan Bimbel (bimbingan belajar). Untuk variabel Bimbel, beri Value 1 untuk Label "bimbingan belajar A", beri Value 2 untuk Label "bimbingan belajar B", dan beri Value 3 untuk Label "bimbingan belajar C". Kemudian aktifkan Data View. Input data pada Data View seperti pada Gambar 20.63. Pilih Analyze $=>$ Nonparametric Tests $=>K$ Independent Samples (Gambar 20.64), sehingga muncul kotak dialog Test for Several Independent Samples (Gambar 20.65).
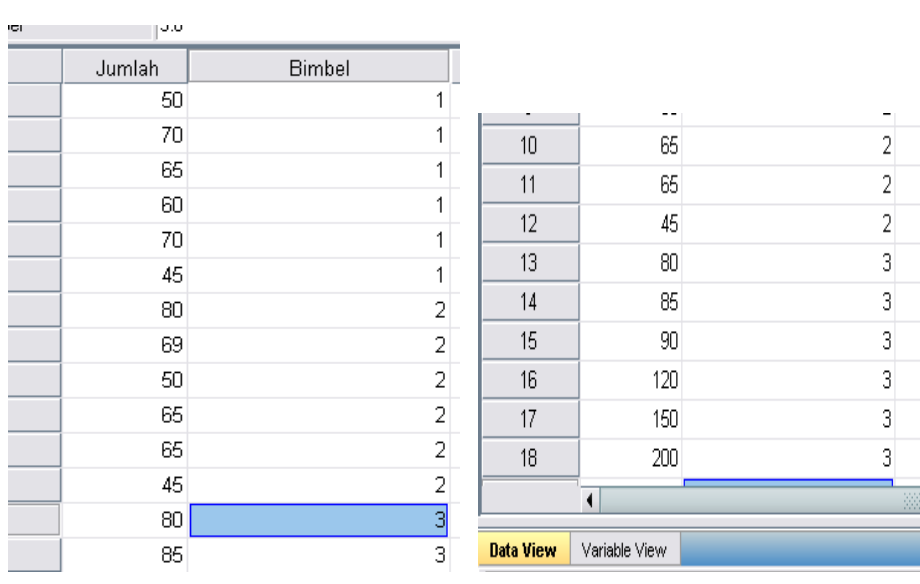

\begin{tabular}{|r|r|r|}
\hline & Jumlah & \multicolumn{1}{|c|}{ Bimbel } \\
\hline 1 & 50 & bimbingan belajar A \\
\hline 2 & 70 & bimbingan belajar A \\
\hline 3 & 65 & bimbingan belajar A \\
\hline 4 & 60 & bimbingan belajar A \\
\hline 5 & 70 & bimbingan belajar A \\
\hline 6 & 45 & bimbingan belajar A \\
\hline 7 & 80 & bimbingan belajar B \\
\hline 8 & 69 & bimbingan belajar B \\
\hline 9 & 50 & bimbingan belajar B \\
\hline 10 & 65 & bimbingan belajar B \\
\hline 11 & 65 & bimbingan belajar B \\
\hline 12 & 45 & bimbingan belajar B \\
\hline 13 & 80 & bimbingan belajar C \\
\hline 14 & 85 & bimbingan belajar C \\
\hline 15 & 90 & bimbingan belajar C \\
\hline 16 & 120 & bimbingan belajar C \\
\hline 17 & 150 & bimbingan belajar C \\
\hline & &
\end{tabular}

Gambar 20.63

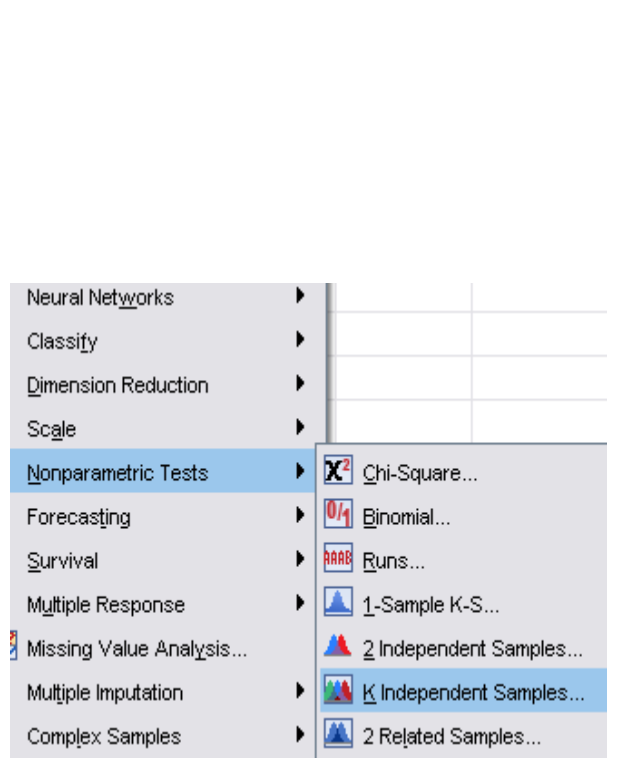

Gambar 20.64

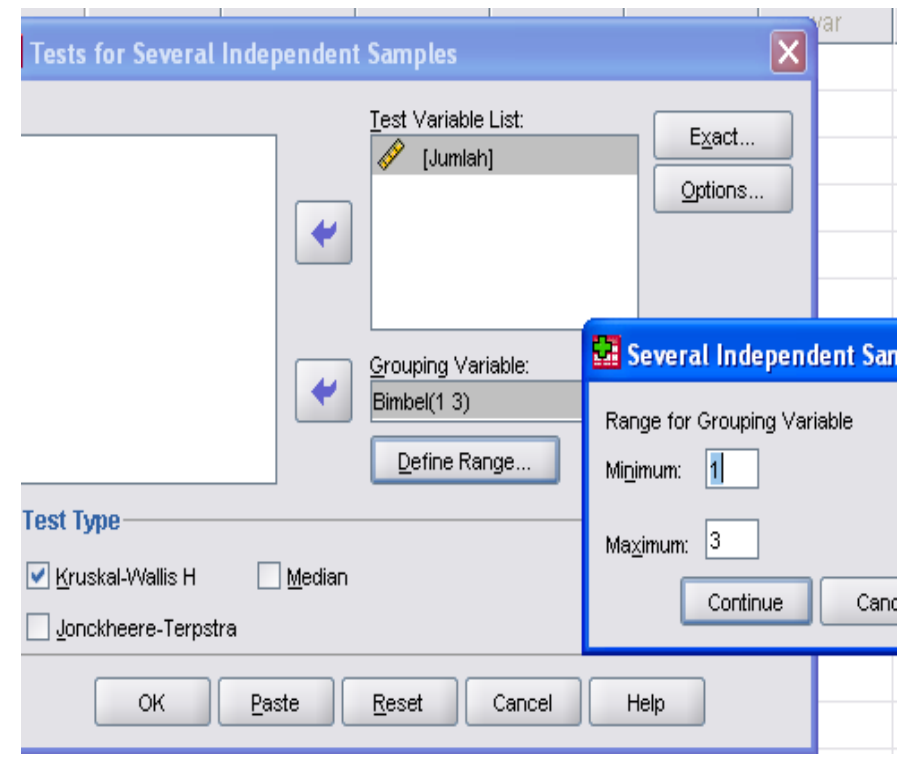

Gambar 20.65

Pada Gambar 20.65, pilih Kruskal-Wallis $H$ pada Test Type. Kemudian variabel jumlah dimasukkan pada Test Variable List dan variabel Bimbel dimasukkan pada Grouping Variable. Selanjutnya pilih Define Group. Isi Minimum dengan nilai 1 dan Maximum dengan nilai 3. Perhatikan bahwa nilai 1 (nilai Value yang paling minimum) berarti Label untuk 
bimbingan belajar A, sedangkan nilai 3 (nilai Value yang paling maksimum) berarti Label untuk bimbingan belajar $\mathbf{C}$. Selanjutnya pilih Continue dan $\mathrm{OK}$.

Hasil berdasarkan SPSS disajikan pada Tabel 20.11 (Tabel Ranks). Berdasarkan Tabel 20.11 untuk kolom Mean Rank, diketahui rata-rata ranking dari bimbingan belajar A adalah 6,33. Nilai tersebut merupakan hasil bagi antara jumlah ranking pada bimbingan belajar A, yakni 38 dengan banyaknya elemen sampel bimbingan belajar A yakni, 6 .

Pada Tabel 20.12 (Tabel Test Statistics), diketahui nilai statistik dari Kruskal-Wallis $(H)$ atau Chi Square adalah 11,165 dan nilai probabilitas dari uji Kruskal-Wallis (Asymp. Sig.) adalah 0,004. Oleh karena nilai probabilitas, yakni 0,004, lebih kecil dibandingkan tingkat signifikansi $\alpha=0,05$, maka hipotesis nol ditolak dan hipotesis alternatif diterima. Hal ini berarti terdapat perbedaan kualitas yang signifikan secara statistika di antara ketiga bimbingan belajar tersebut pada tingkat signifikansi $5 \%$.

Tabel 20.11

\begin{tabular}{|l|r|r|}
\hline \multicolumn{2}{|c|}{ Ranks } \\
\hline Bimbel & $\mathrm{N}$ & Mean Rank \\
\hline bimbingan belajar A & 6 & 6.33 \\
bimbingan belajar B & 6 & 6.75 \\
bimbingan belajar C & 6 & 15.42 \\
Total & 18 & \\
\hline
\end{tabular}

Tabel 20.12

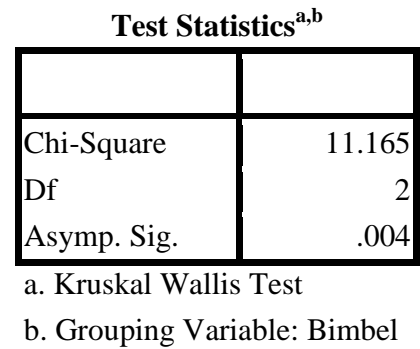

Lihat pada output Minitab. Nilai statistik dari uji Kruskal-Wallis sebelum koreksi adalah 11,07, dan setelah dikoreksi (adjusted for ties) menjadi 11,17. 


\section{PENYELESAIAN DALAM Minitab (UJI KRUSKAL- WALLIS)}

Bangun data dalam Minitab seperti pada Gambar 20.66. Pilih Stat $=>$ Nonparametrics $=>$ Kruskal-Wallis (Gambar 20.67).

\begin{tabular}{|r|r|r|r}
\hline+ & C1 & \multicolumn{1}{c|}{ C2 } & \\
\hline & Jumlah & Bimbel & \\
\hline $\mathbf{2}$ & 70 & 1 & \\
\hline $\mathbf{3}$ & 65 & 1 & \\
\hline $\mathbf{4}$ & 60 & 1 & \\
\hline $\mathbf{5}$ & 70 & 1 & \\
\hline $\mathbf{6}$ & 45 & 1 & \\
\hline $\mathbf{7}$ & 80 & 2 & \\
\hline $\mathbf{8}$ & 69 & 2 & \\
\hline $\mathbf{9}$ & 50 & 2 & \\
\hline $\mathbf{1 0}$ & 65 & 2 & \\
\hline $\mathbf{1 1}$ & 65 & 2 & \\
\hline $\mathbf{1 2}$ & 45 & 2 & \\
\hline $\mathbf{1 3}$ & 80 & 3 & \\
\hline $\mathbf{1 4}$ & 85 & 3 & \\
\hline $\mathbf{1 5}$ & 90 & 3 & \\
\hline $\mathbf{1 6}$ & 120 & 3 & \\
\hline $\mathbf{1 7}$ & 150 & 3 & \\
\hline $\mathbf{1 8}$ & 200 & 3 & \\
\hline $\mathbf{1 9}$ & & & \\
\hline & & & \\
\hline
\end{tabular}

Gambar 20.66

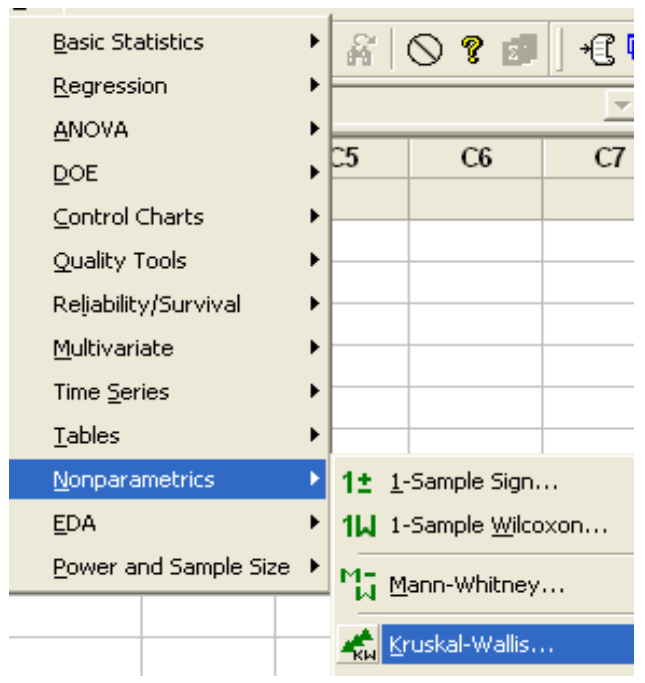

Gambar 20.67

Pada Gambar 20.68, pindahkan variabel Jumlah pada Response, dan pindahkan variabel Factor pada Factor. Kemudian pilih OK. Gambar 20.69 merupakan hasil berdasarkan Minitab. Diketahui nilai statistik dari uji Kruskal-Wallis (H) adalah 11,17, derajat bebas (DF) adalah 2, dan probabilitas $(\mathrm{P})$ adalah 0,004 . Oleh karena nilai probabilitas, yakni 0,004, lebih kecil dibandingkan tingkat signifikansi $\alpha=0,05$, maka hipotesis nol ditolak dan hipotesis alternatif diterima. Hal ini berarti terdapat perbedaan kualitas yang signifikan secara statistika di antara ketiga bimbingan belajar tersebut pada tingkat signifikansi 5\%.

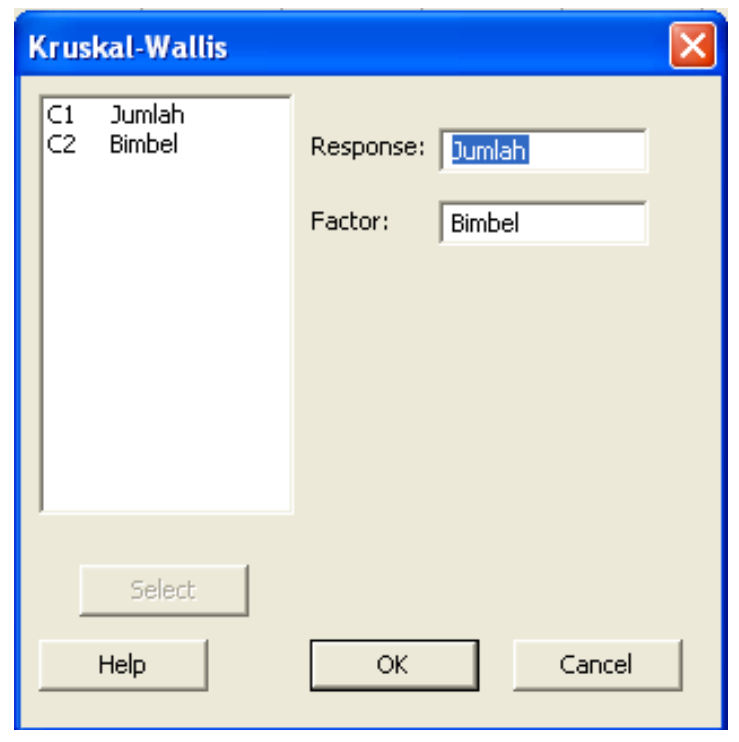

Gambar 20.68

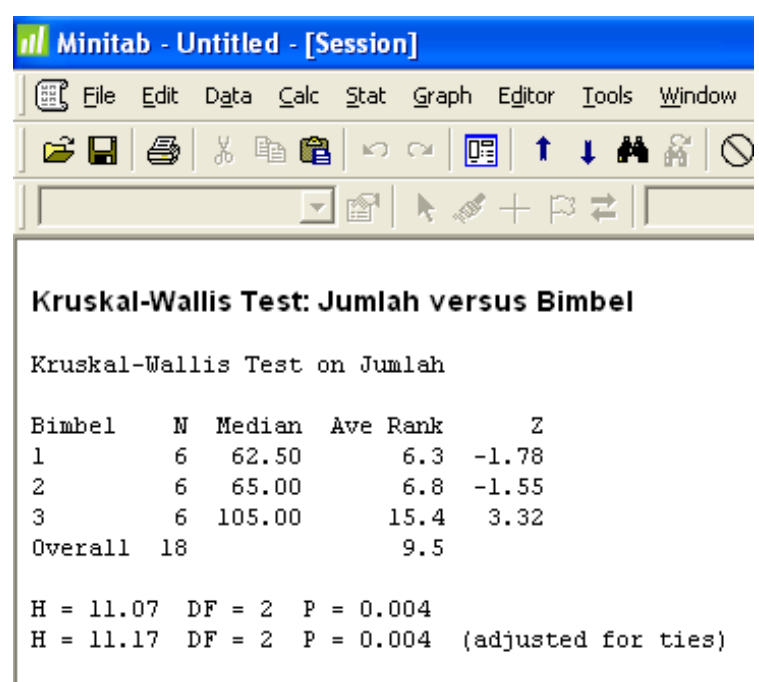

Gambar 20.69 


\section{PENYELESAIAN DALAM R (UJI KRUSKAL-WALLIS)}

Data terlebih dahulu disimpan dalam Microsoft Excel dengan tipe .CSV (Comma Separeted Values) (Gambar 20.70 dan Gambar 20.71).

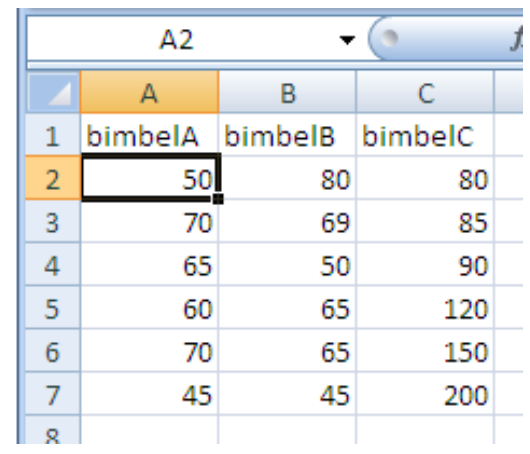

Gambar 20.70

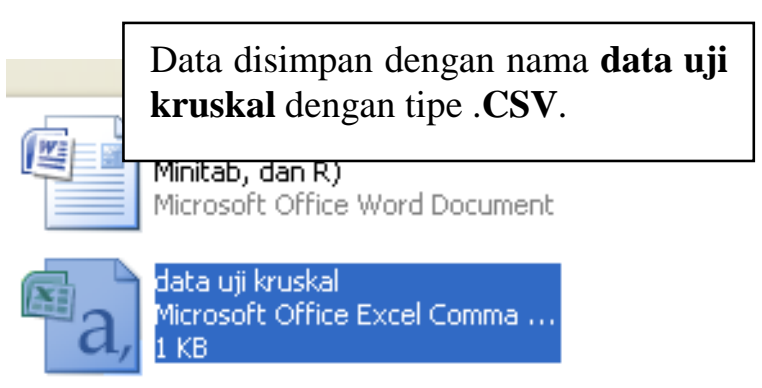

Gambar 20.71

Aktifkan RStudio, kemudian pilih File $\Rightarrow R$ Script Ketik perintah R seperti pada Gambar 20.72 .

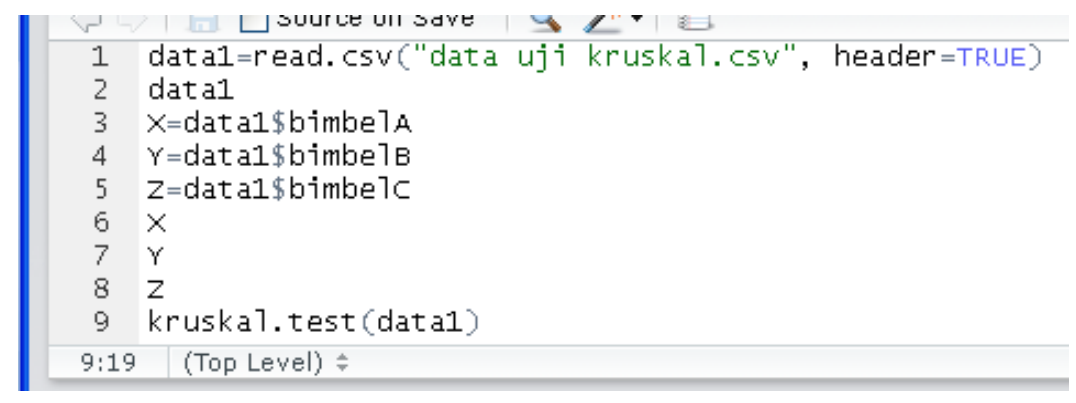

\section{Gambar 20.72}

Selanjutnya pilih Compile, pilih MS Word pada Notebook output format, dan Compile. Berikut hasil berdasarkan berdasarkan R.

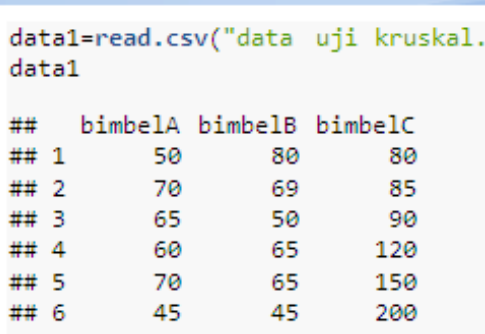

Gambar 20.73
Lihat pada output Minitab. Nilai statistik dari uji Kruskal-Wallis sebelum koreksi adalah 11,07, dan setelah dikoreksi (adjusted for ties) menjadi 11,17.

\#\# Kruskal-Wallis chi-squared $=11.1653, \mathrm{df}=2, \mathrm{p}$-value $=0.003763$

$\# \#$

$\# \#$

\#\#

\#\#[1] $\quad 80 \quad 85 \quad 90 \quad 120 \quad 150 \quad 200$

kruskal.test(data1)

ruskal-wallis rank sum tes

Berdasarkan Gambar 6.16, Diketahui nilai statistik dari uji Kruskal-Wallis adalah 11,1653, derajat bebas (df) adalah 2, dan probabilitas ( $p$-value) adalah 0,003763 . Oleh karena nilai probabilitas, yakni 0,003763 , lebih kecil dibandingkan tingkat signifikansi $\alpha=0,05$, maka hipotesis nol ditolak dan hipotesis alternatif diterima. 


\section{PENYELESAIAN DALAM SPSS (UJI COCHRAN)}

Bangun data dalam SPSS seperti pada Gambar 20.75. Pada Variable View, bentuk variabel ayam, daging, ikan, dan udang. Kemudian aktifkan Data View. Input data pada Data View seperti pada Gambar 20.75 .

\begin{tabular}{|r|r|r|r|r|}
\hline 11 : udang & \multicolumn{1}{|c|}{1.0} & & \\
\hline & ayam & daging & ikan & udang \\
\hline 1 & 1 & 0 & 0 & 0 \\
\hline 2 & 1 & 1 & 1 & 1 \\
\hline 3 & 0 & 0 & 0 & 0 \\
\hline 4 & 0 & 1 & 1 & 1 \\
\hline 5 & 1 & 1 & 1 & 1 \\
\hline 6 & 1 & 0 & 0 & 1 \\
\hline 7 & 1 & 0 & 1 & 1 \\
\hline 8 & 1 & 0 & 0 & 1 \\
\hline 9 & 1 & 0 & 0 & 0 \\
\hline 10 & 1 & 0 & 0 & 0 \\
\hline 11 & 1 & 1 & 1 & 1 \\
\hline
\end{tabular}

Gambar 20.75

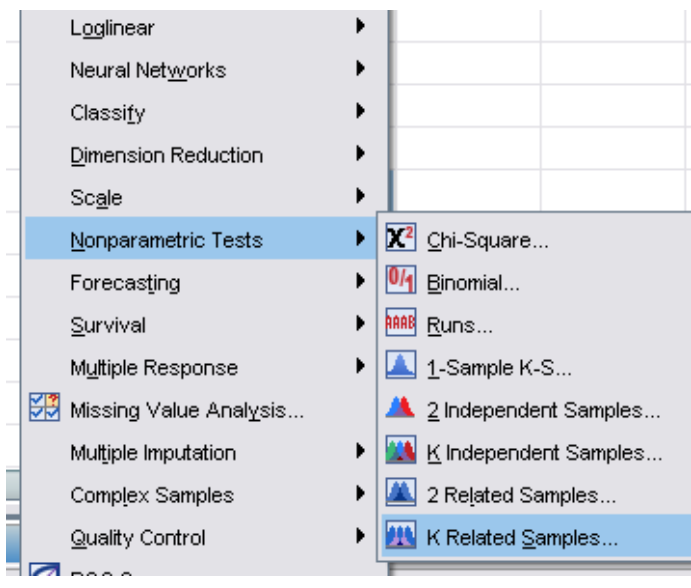

Gambar 20.76

Pilih Analyze $\Rightarrow>$ Nonparametric Tests $\Rightarrow$ K Related Samples (Gambar 20.76), sehingga muncul kotak dialog Test for Several Related Samples (Gambar 20.77). Masukkan variabel ayam, daging, ikan dan udang pada kotak Test Variables. Pada Test Type pilih Cochran's $Q$ dan kemudian pilih OK.

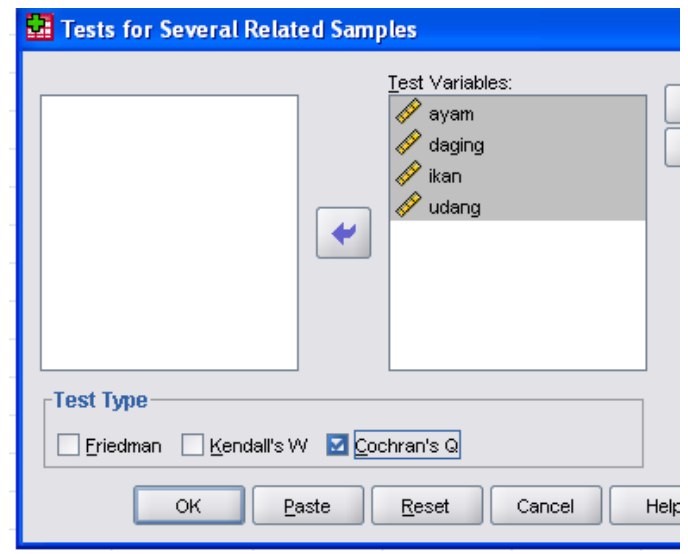

Gambar 20.77

Berdasarkan Tabel 20.13 (Tabel Frequencies) diketahui responden yang suka terhadap kerupuk rasa ayam sebanyak 9 responden, dan responden yang tidak suka rasa ayam sebanyak 2 orang. Responden yang tidak suka terhadap kerupuk rasa daging sebanyak 7 orang dan responden yang suka rasa daging sebanyak 4 orang.

Berdasarkan Tabel 20.14 (Tabel Test Statistics) diketahui nilai statistik dari uji Cochran atau Cochran's $Q$ adalah 7,696 atau dibulatkan menjadi 7,70. Diketahui kritis chi-kuadrat $\left(\chi_{\text {kritis }}^{2}\right)$ adalah 7,815. Perhatikan bahwa karena nilai statistik dari uji Cochran, yakni 7,70, lebih kecil dari nilai kritis chi-kuadrat, yakni 7,815, maka hipotesis nol diterima dan hipotesis alternatif 
ditolak. Hal ini berarti keempat jenis kerupuk memberikan kepuasan rasa yang sama pada tingkat signifikansi $5 \%$.

Tabel 20.13

\begin{tabular}{|c|c|c|c|}
\hline \multicolumn{4}{|c|}{ Frequencies } \\
\hline & \multicolumn{3}{|c|}{ Value } \\
\hline & 0 & 1 & \\
\hline ayam & & & 9 \\
\hline daging & & & 4 \\
\hline ikan & & & 5 \\
\hline udang & & & 7 \\
\hline
\end{tabular}

Nilai atau Value 0 menyatakan tidak suka, sedangkan nilai atau Value 1 menyatakan suka.

Tabel 20.14

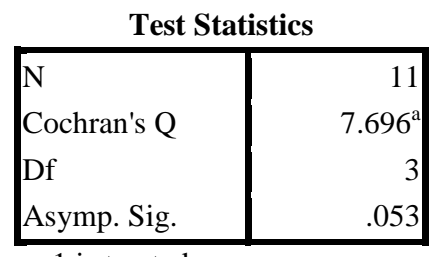

Selain itu, pengambilan keputusan terhadap hipotesis juga dapat dilakukan dengan membandingkan nilai Asymp. Sig. terhadap tingkat signifikansi. Perhatikan bahwa karena nilai probabilitas (Asymp. Sig.), yakni 0,053, lebih besar dari tingkat signifikansi $\alpha=0,05$, maka hipotesis nol diterima dan hipotesis alternatif ditolak. 


\section{PENYELESAIAN DALAM R (UJI COCHRAN)}

Data terlebih dahulu disimpan dalam Microsoft Excel dengan tipe .CSV (Comma Separeted Values) (Gambar 20.78 dan Gambar 20.79).

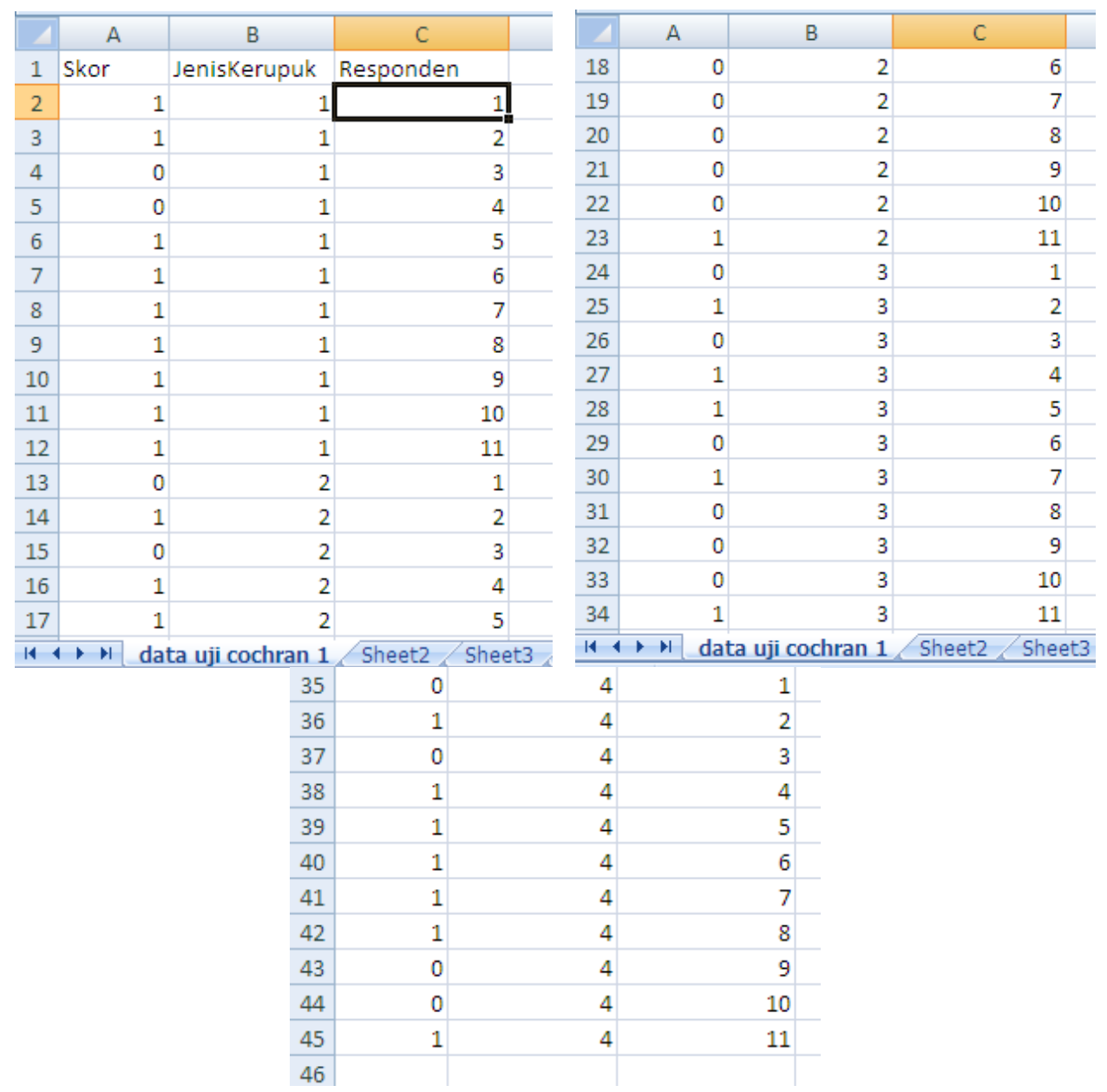

Gambar 20.78

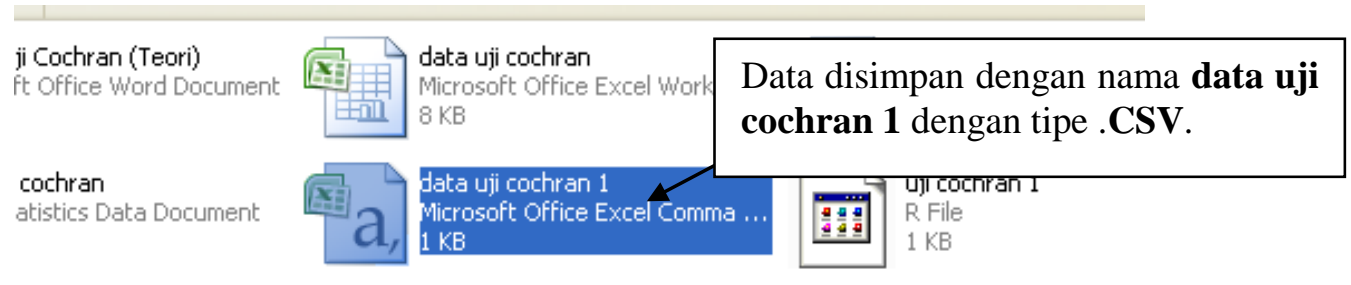

Gambar 20.79

Aktifkan RStudio, kemudian pilih File $\Rightarrow R$ Script. Ketik perintah R seperti pada Gambar 20.80 . 


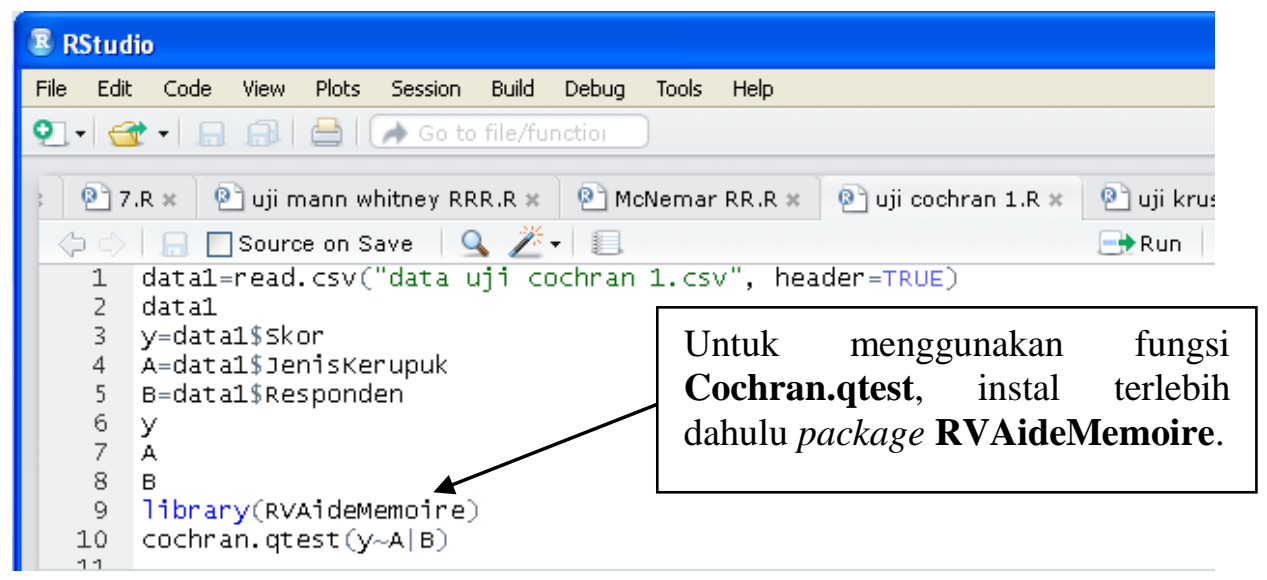

Gambar 20.80

Selanjutnya pilih Compile, dan pilih MS Word pada Notebook output format, dan Compile. Gambar 20.81 merupakan hasil berdasarkan R. Diketahui nilai statistik dari uji Cochran (Q) adalah 7,6957, derajat bebas (df) adalah 3, dan nilai probabilitas ( $p$-value) adalah 0,05274 . Perhatikan bahwa karena nilai probabilitas, yakni 0,05274, lebih besar dari tingkat signifikansi $\alpha=0,05$, maka hipotesis nol diterima dan hipotesis alternatif ditolak.

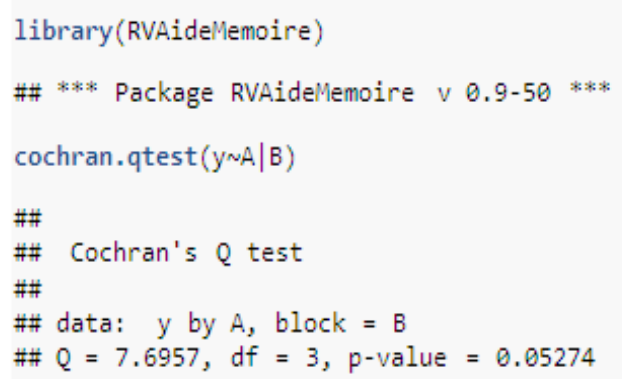

Gambar 20.81 
PENYELESAIAN DALAM SPSS (UJI FRIEDMAN)

Bangun data dalam SPSS seperti pada Gambar 20.82. Pada Variable View, bentuk variabel ayam, daging, ikan, dan udang. Kemudian aktifkan Data View. Input data pada Data View seperti pada Gambar 20.82 .

\begin{tabular}{r|r|r|r|r|}
\hline \multicolumn{1}{|c|}{} & \multicolumn{1}{c|}{ ayam } & \multicolumn{1}{c|}{ daging } & \multicolumn{1}{c|}{ ikan } & \multicolumn{1}{c|}{ udang } \\
\hline 1 & 90 & 85 & 83 & 70 \\
\hline 2 & 90 & 70 & 77 & 65 \\
\hline 3 & 75 & 70 & 60 & 85 \\
\hline 4 & 80 & 70 & 75 & 90 \\
\hline 5 & 90 & 85 & 60 & 89 \\
\hline 6 & 60 & 65 & 70 & 85 \\
\hline 7 & 65 & 85 & 70 & 90 \\
\hline 8 & 65 & 100 & 60 & 85 \\
\hline 9 & 80 & 70 & 75 & 90 \\
\hline 10 & 90 & 70 & 80 & 75 \\
\hline 11 & 75 & 65 & 70 & 64 \\
\hline 12 & 80 & 70 & 75 & 90 \\
\hline
\end{tabular}

Gambar 20.82

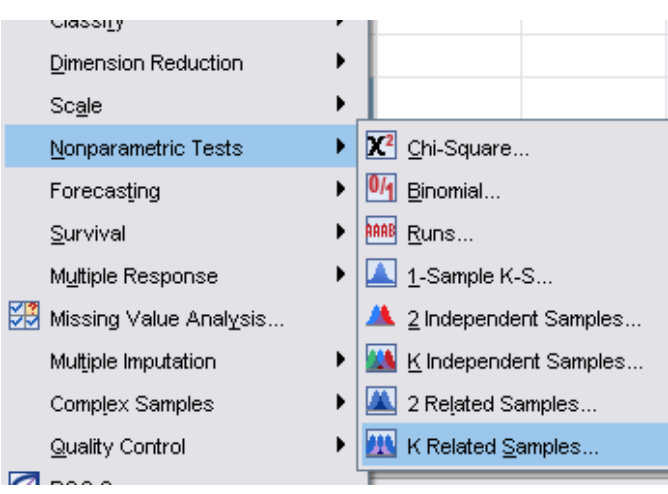

Gambar 20.83

Pilih Analyze $\Rightarrow>$ Nonparametric Tests $\Rightarrow$ K Related Samples (Gambar 20.83), sehingga muncul kotak dialog Test for Several Related Samples (Gambar 20.84). Variabel ayam, daging, ikan, dan udang dimasukkan pada Test Variables. Pada Test Type pilih Friedman dan kemudian pilih OK.

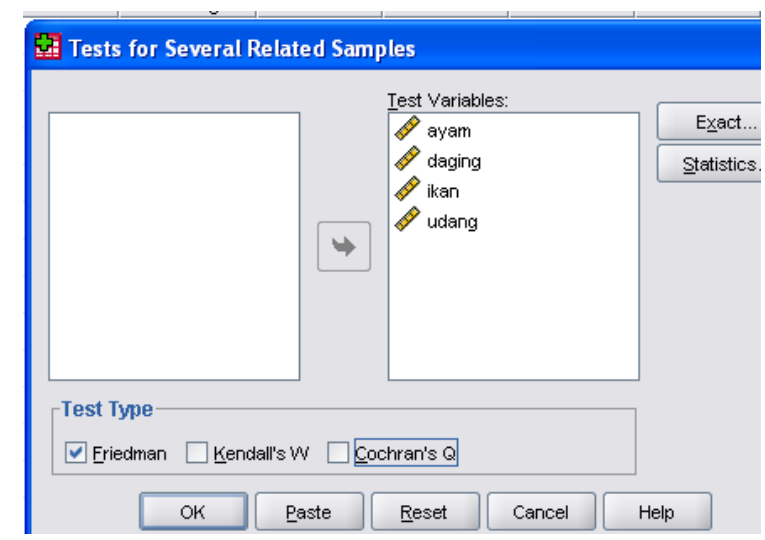

Gambar 20.84

Berdasarkan Tabel 20.15 (Tabel Ranks), pada rata-rata ranking untuk rasa ayam adalah 3, rata-rata ranking untuk rasa daging 2 , rata-rata ranking untuk rasa ikan 2,08, dan rata-rata ranking untuk rasa udang 2,92. Hasil perhitungan berdasarkan SPSS sama dengan hasil dengan perhitungan manual sebelumnya.

Berdasarkan Tabel 20.16 (Tabel Test Statistics), diketahui nilai statistik dari uji Friedman atau Chi-Square adalah 6,1. Perhatikan bahwa karena nilai statistik dari uji Friedman, yakni 6,1, lebih kecil dari nilai kritis chi-kuadrat $\left(\chi_{\text {kritis }}^{2}\right)$, yakni 7,815, maka hipotesis nol diterima dan hipotesis alternatif ditolak. Hal ini berarti perbedaan kepuasan di antara keempat jenis kerupuk tidak signifikan secara statistik pada tingkat signifikansi $5 \%$. 
Selain itu, pengambilan keputusan terhadap hipotesis juga dapat dilakukan dengan membandingkan nilai Asymp. Sig. (nilai probabilitas) terhadap tingkat signifikansi. Perhatikan bahwa karena nilai Asymp. Sig., yakni 0,107, lebih besar dari tingkat signifikansi $\alpha=0,05$, maka hipotesis nol diterima dan hipotesis alternatif ditolak.

Tabel 20.15

\begin{tabular}{|l|r|}
\hline \multicolumn{2}{|c}{ Ranks } \\
\hline & Mean Rank \\
\hline Ayam & 3.00 \\
Daging & 2.00 \\
Ikan & 2.08 \\
Udang & 2.92 \\
\hline
\end{tabular}

Tabel 20.16

\begin{tabular}{|l|r|}
\multicolumn{2}{|c|}{ Test Statistics $^{\mathbf{a}}$} \\
\hline $\mathrm{N}$ & 12 \\
Chi-Square & 6.100 \\
Df & 3 \\
Asymp. Sig. & .107 \\
\hline
\end{tabular}


PENYELESAIAN DALAM Minitab (UJI FRIEDMAN)

Bangun data dalam Minitab seperti pada Gambar 20.85. Bentuk variabel Nilai, Jenis Kerupuk, dan Responden Ke-. Pilih Stat $\Rightarrow>$ Nonparametrics $\Rightarrow>$ Friedman (Gambar 20.86).

\begin{tabular}{|c|r|r|r|}
+ & C1 & C2 & C3 \\
\hline & Nilai & Jenis Kerupuk Responden Ke-[ \\
\hline $\mathbf{1}$ & 90 & 1 & 1 \\
\hline $\mathbf{2}$ & 90 & 1 & 2 \\
\hline $\mathbf{3}$ & 75 & 1 & 3 \\
\hline $\mathbf{4}$ & 80 & 1 & 4 \\
\hline $\mathbf{5}$ & 90 & 1 & 5 \\
\hline $\mathbf{6}$ & 60 & 1 & 6 \\
\hline $\mathbf{7}$ & 65 & 1 & 7 \\
\hline $\mathbf{8}$ & 65 & 1 & 8 \\
\hline $\mathbf{9}$ & 80 & 1 & 9 \\
\hline $\mathbf{1 0}$ & 90 & 1 & 10 \\
\hline $\mathbf{1 1}$ & 75 & 1 & 11 \\
\hline $\mathbf{1 2}$ & 80 & 1 & 12 \\
\hline $\mathbf{1 3}$ & 85 & 2 & 1 \\
\hline $\mathbf{1 4}$ & 70 & 2 & 2 \\
\hline $\mathbf{1 5}$ & 70 & 2 & 3 \\
\hline $\mathbf{1 6}$ & 70 & 2 & 4 \\
\hline $\mathbf{1 7}$ & 85 & 2 & 5 \\
\hline $\mathbf{1 8}$ & 65 & 2 & 6 \\
\hline
\end{tabular}

\begin{tabular}{|r|r|r|r|r}
\hline+ & C1 & C2 & C3 \\
\hline & Nilai & Jenis Kerupuk Responden Ke- \\
\hline $\mathbf{1 9}$ & 85 & 2 & 7 \\
\hline $\mathbf{2 0}$ & 100 & 2 & 8 \\
\hline $\mathbf{2 1}$ & 70 & 2 & 9 \\
\hline $\mathbf{2 2}$ & 70 & 2 & 10 \\
\hline $\mathbf{2 3}$ & 65 & 2 & 11 \\
\hline $\mathbf{2 4}$ & 70 & 2 & 12 \\
\hline $\mathbf{2 5}$ & 83 & 3 & 1 \\
\hline $\mathbf{2 6}$ & 77 & 3 & 2 \\
\hline $\mathbf{2 7}$ & 60 & 3 & 3 \\
\hline $\mathbf{2 8}$ & 75 & 3 & 4 \\
\hline $\mathbf{2 9}$ & 60 & 3 & 5 \\
\hline $\mathbf{3 0}$ & 70 & 3 & 6 \\
\hline $\mathbf{3 1}$ & 70 & 3 & 7 \\
\hline $\mathbf{3 2}$ & 60 & 3 & 8 \\
\hline $\mathbf{3 3}$ & 75 & 3 & 9 \\
\hline $\mathbf{3 4}$ & 80 & 3 & 10 \\
\hline $\mathbf{3 5}$ & 70 & 3 & 11 \\
\hline $\mathbf{3 6}$ & 75 & 3 & 12 \\
\hline & & & \\
\hline
\end{tabular}

\begin{tabular}{|r|r|r|r|}
\hline \hline+ & \multicolumn{1}{|c|}{ C1 } & \multicolumn{1}{c|}{ C2 } & \multicolumn{1}{c|}{ C3 } \\
\hline & Nilai & Jenis Kerupuk & Responden Ke-[ \\
\hline 37 & 70 & 4 & 1 \\
\hline $\mathbf{3 8}$ & 65 & 4 & 2 \\
\hline $\mathbf{3 9}$ & 85 & 4 & 3 \\
\hline $\mathbf{4 0}$ & 90 & 4 & 4 \\
\hline $\mathbf{4 1}$ & 89 & 4 & 5 \\
\hline $\mathbf{4 2}$ & 85 & 4 & 6 \\
\hline $\mathbf{4 3}$ & 90 & 4 & 7 \\
\hline $\mathbf{4 4}$ & 85 & 4 & 8 \\
\hline $\mathbf{4 5}$ & 90 & 4 & 9 \\
\hline $\mathbf{4 6}$ & 75 & 4 & 10 \\
\hline $\mathbf{4 7}$ & 64 & 4 & 11 \\
\hline $\mathbf{4 8}$ & 90 & 4 & 12 \\
\hline $\mathbf{4 0}$ & & & \\
\hline
\end{tabular}

Gambar 20.85

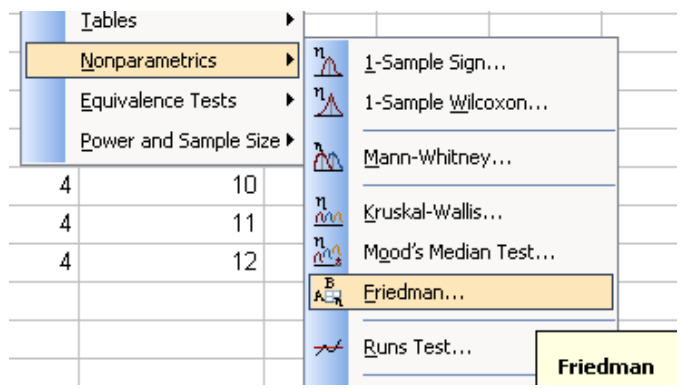

Gambar 20.86
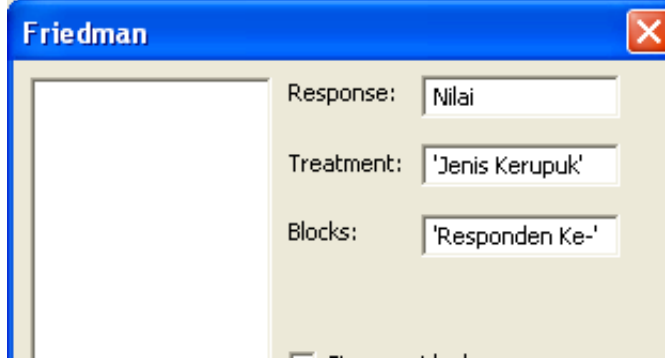

Gambar 20.87

Pada Gambar 20.87, pindahkan variabel Nilai pada kotak Response, variabel Jenis Kerupuk pada kotak Treatment, dan variabel Responden Ke- pada kotak Blocks. Kemudian pilih OK. Gambar 20.88 menyajikan hasil perhitungan berdasarkan Minitab. Diketahui nilai statistik dari uji Friedman (S) adalah 6,10, derajat bebas (DF) adalah 3, dan nilai probabilitas (P) adalah 0,107 .

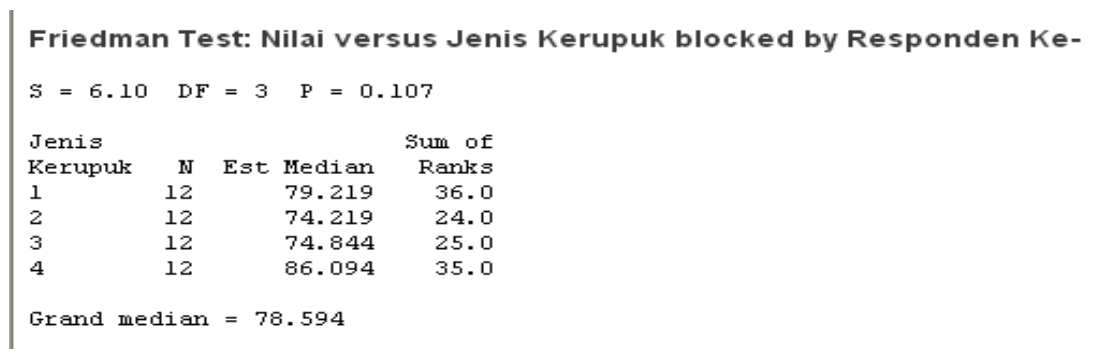

Gambar 20.88 


\section{PENYELESAIAN DALAM R (UJI FRIEDMAN)}

Data terlebih dahulu disimpan dalam Microsoft Excel dengan tipe .CSV (Comma Separeted Values) (Gambar 20.89 dan Gambar 20.90).

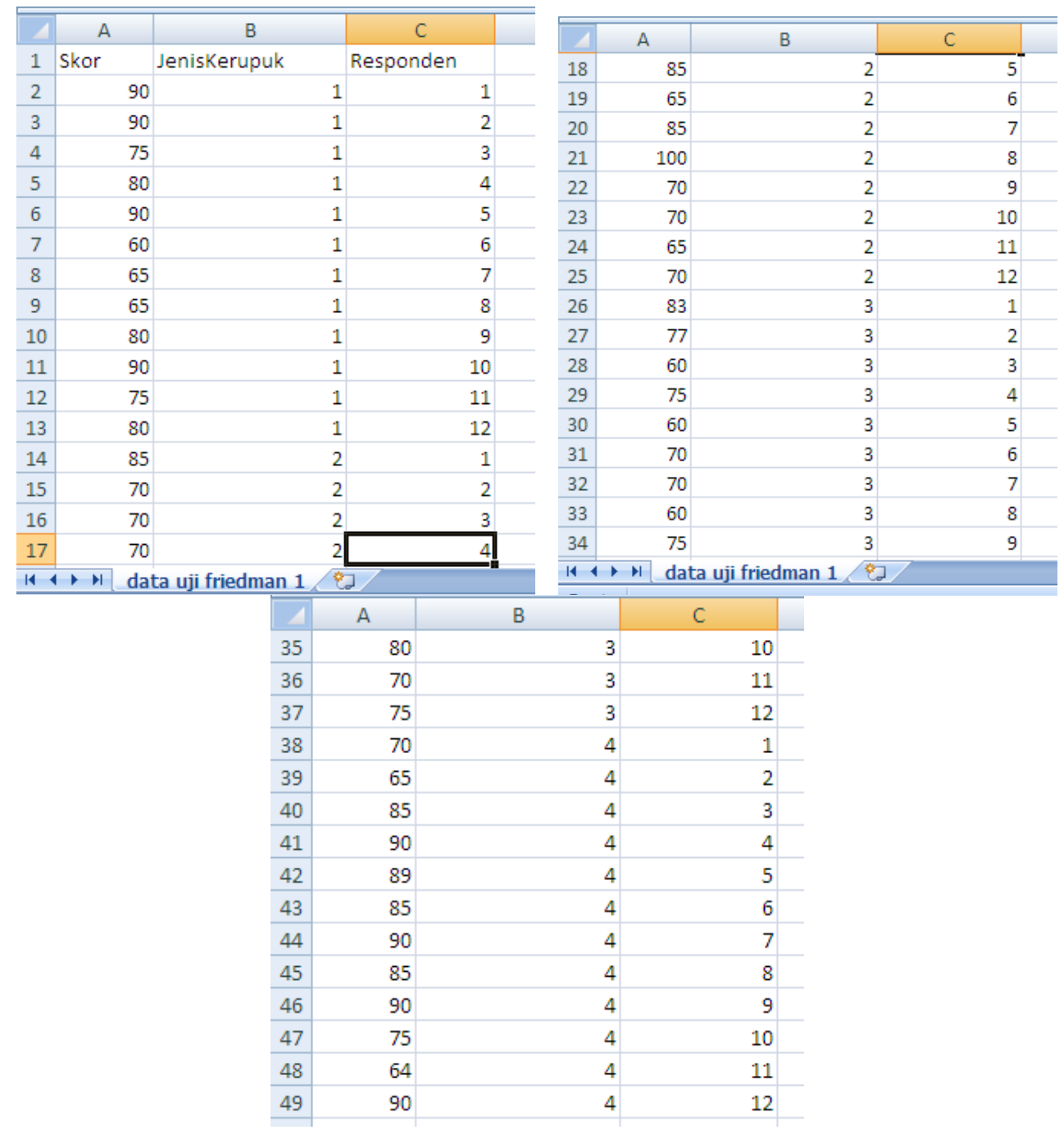

Gambar 20.89

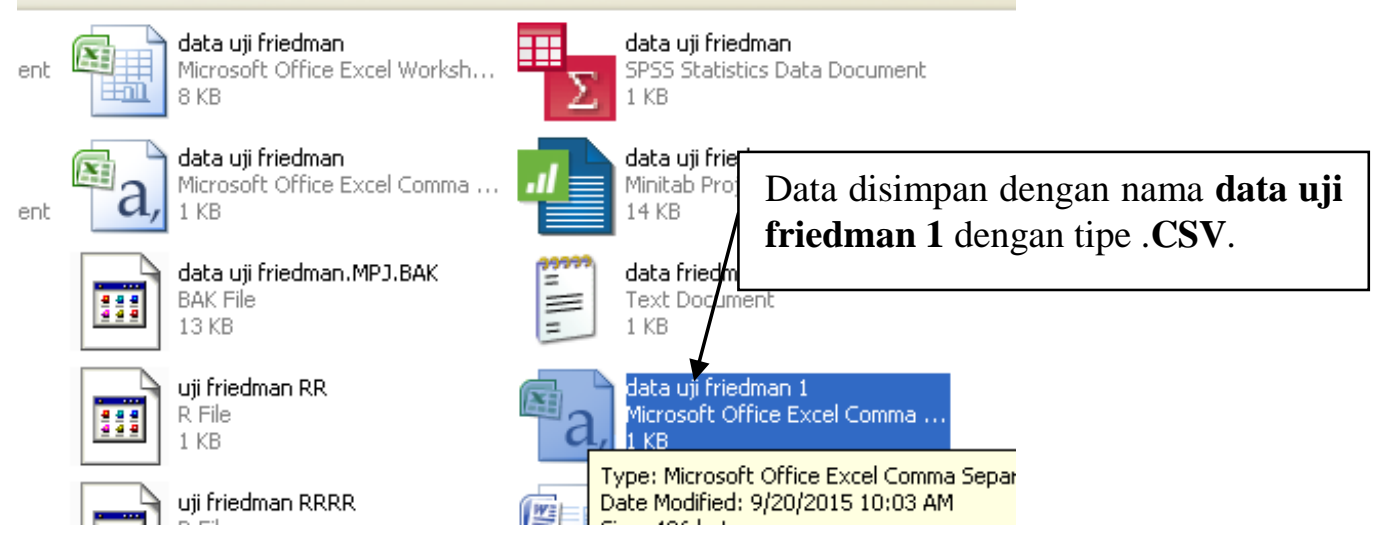

Gambar 20.90 
Aktifkan RStudio, kemudian pilih File $\Rightarrow R$ Script. Ketik perintah R seperti pada Gambar 20.91 .

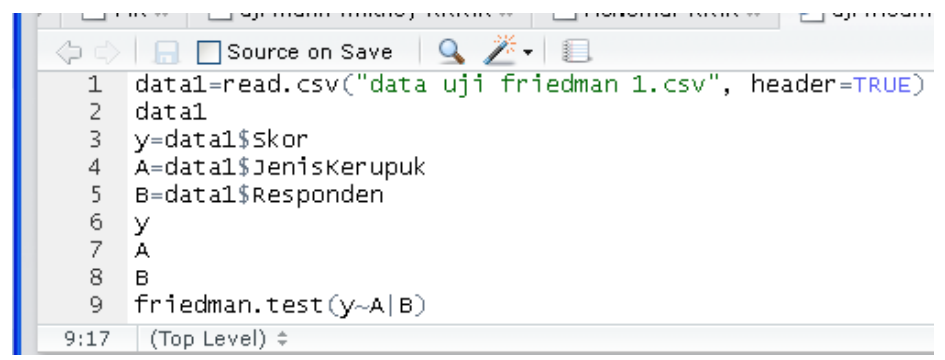

\section{Gambar 20.91}

Selanjutnya pilih Compile, dan pilih MS Word pada Notebook output format, dan Compile. Berikut hasil berdasarkan R.

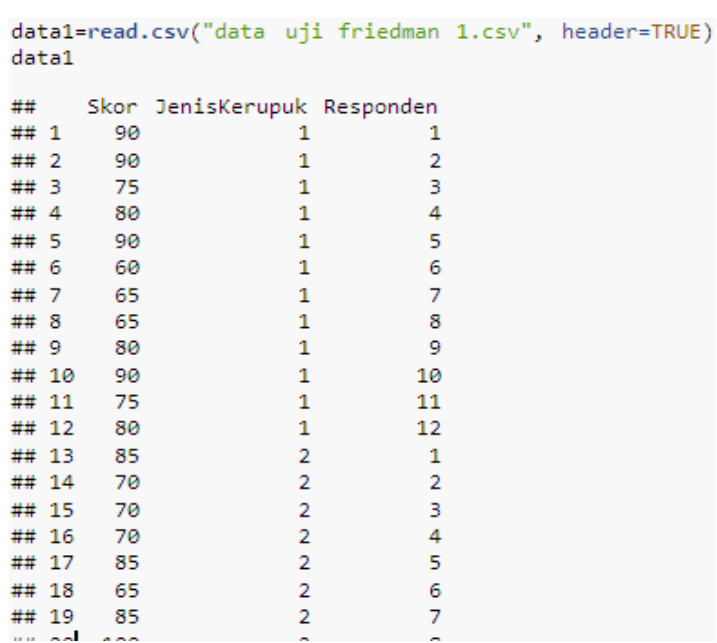

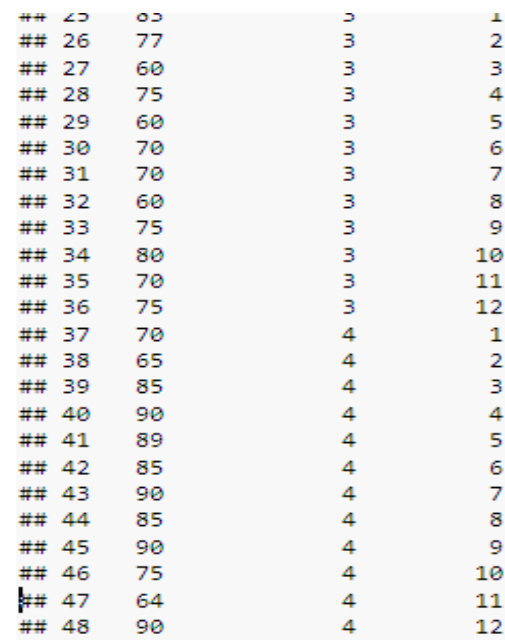

Gambar 20.92

Berdasarkan Gambar 20.93, diketahui nilai statistik dari uji Friedman adalah 6,1, derajat bebas (df) adalah 3, dan nilai probabilitas ( $p$-value) adalah 0,1068. Perhatikan bahwa karena nilai statistik dari uji Friedman, yakni 6,1, lebih kecil dari nilai kritis chi-kuadrat $\left(\chi_{\text {kritis }}^{2}\right)$, yakni 7,815, maka hipotesis nol diterima dan hipotesis alternatif ditolak. Hal ini berarti perbedaan kepuasan di antara keempat jenis kerupuk tidak signifikan secara statistik pada tingkat signifikansi 5\%. Selain itu, pengambilan keputusan terhadap hipotesis juga dapat dilakukan dengan membandingkan nilai probabilitas ( $p$-value) terhadap tingkat signifikansi. Perhatikan bahwa karena nilai Asymp. Sig., yakni 0,1068, lebih besar dari tingkat signifikansi $\alpha=0,05$, maka hipotesis nol diterima dan hipotesis alternatif ditolak.

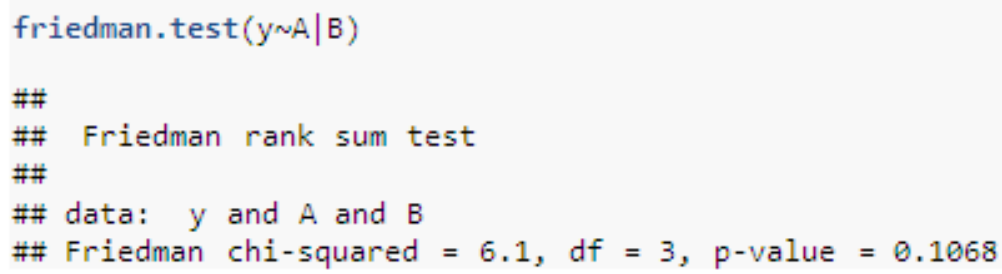

Gambar 20.93 


\section{PENYELESAIAN DALAM SPSS (CHI-KUADRAT 1)}

Bangun data dalam SPSS seperti pada Gambar 20.94. Pada Variable View, bentuk variabel frekuensi dan sisi_angka. Beri Value 1 untuk Label "angka", dan beri Value 0 untuk Label "gambar" (Gambar 20.94). Kemudian aktifkan Data View (Gambar 20.95). Input data pada Data View seperti pada Gambar 20.95. Pilih Data $\Rightarrow$ Weight Cases (Gambar 20.96). Pada Gambar 20.97, aktifkan/bulatkan Weight cases by, kemudian pindahkan variabel frekuensi pada bagian Frequency Variable: dan pilih OK.
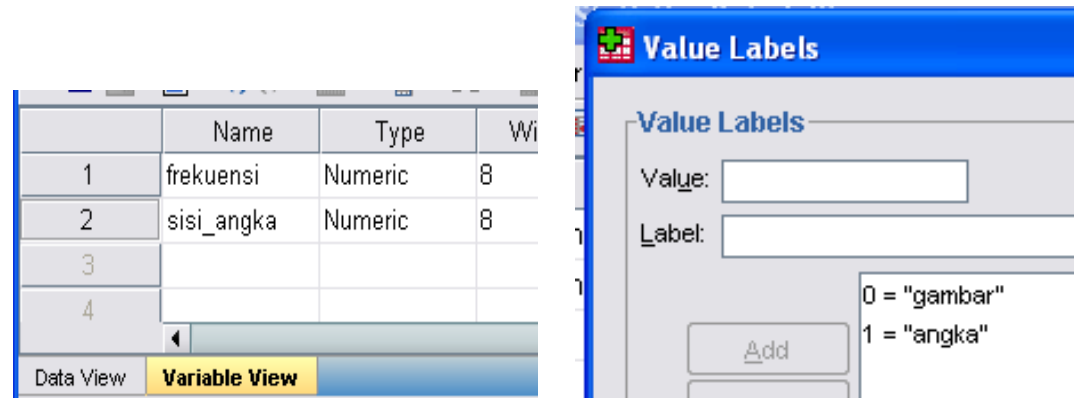

Gambar 20.94
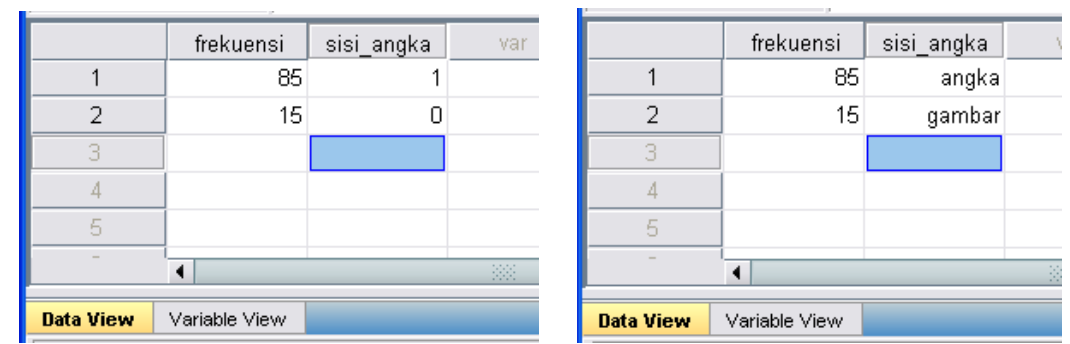

Gambar 20.95

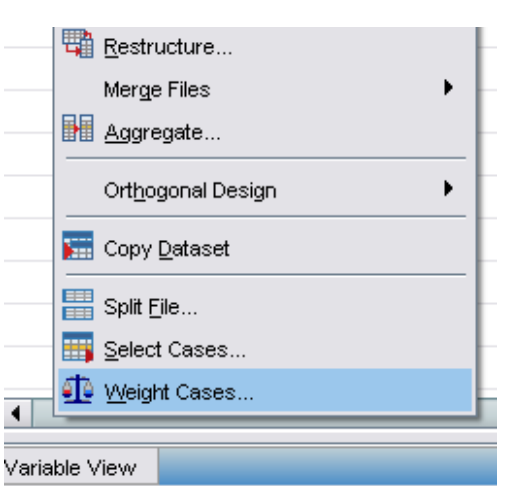

Gambar 20.96

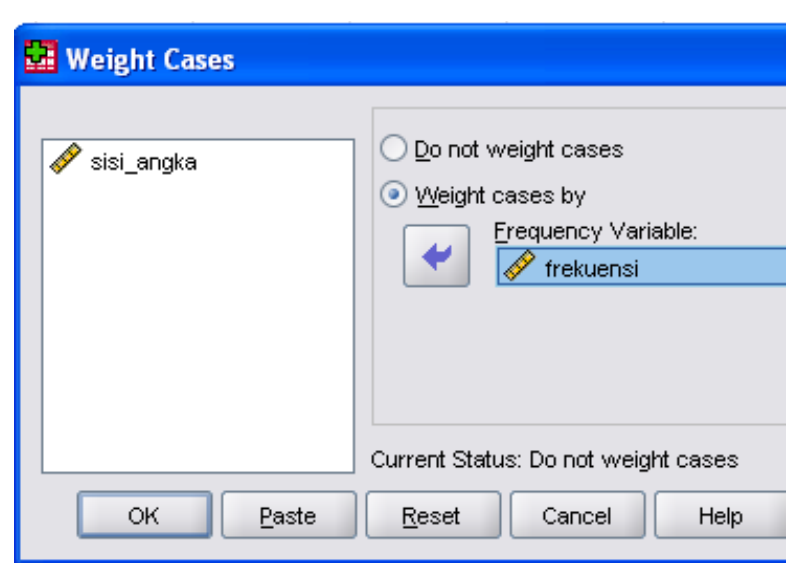

Gambar 20.97

Pilih Analyze $=>$ Nonparametric Test $=>$ Chi Square (Gambar 20.98), sehingga muncul kotak dialog Chi Square Test (Gambar 20.99). Masukkan variabel frekuensi dan sisi_angka pada kotak Test Variable List (Gambar 20.99). Kemudian pilih OK. 


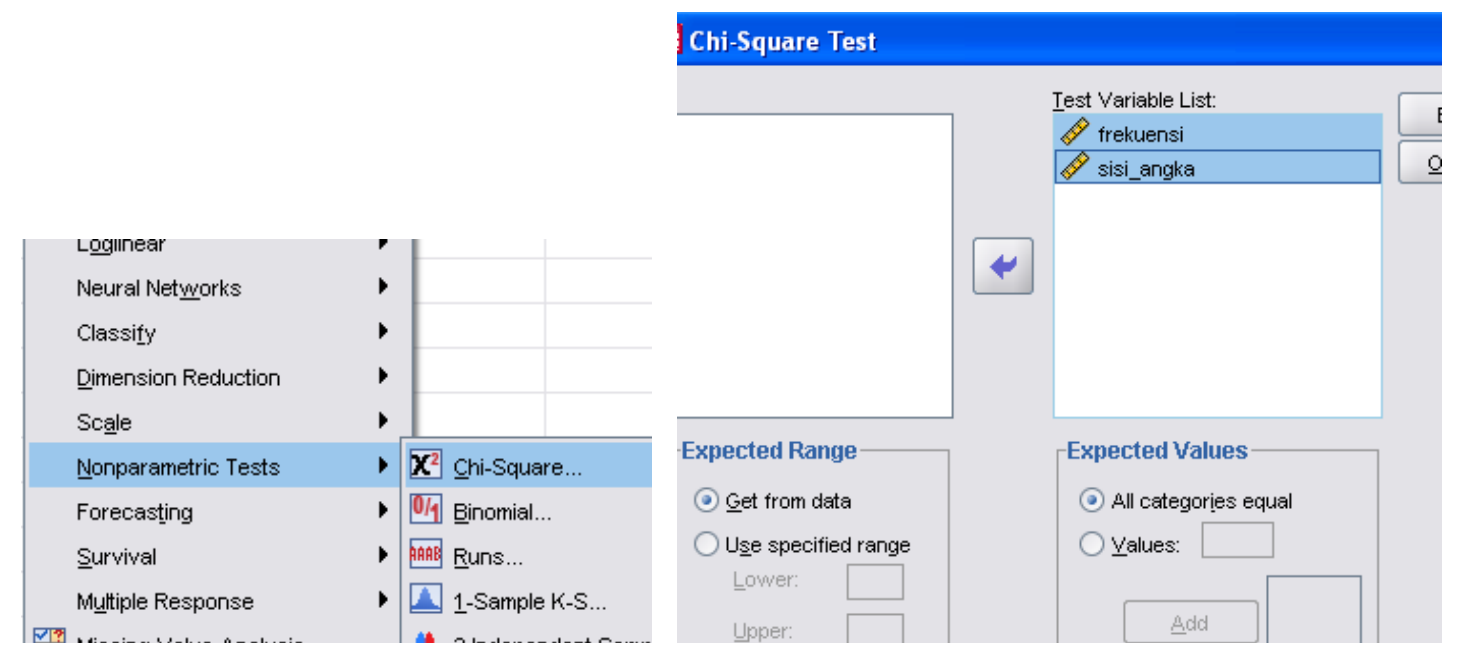

Gambar 20.98

Gambar 20.99

Berdasarkan Tabel 20.17 (Tabel frekuensi), pada kolom Observed $N$ menyajikan frekuensi pengamatan, yakni untuk sisi angka muncul sebanyak 85 kali dan untuk sisi gambar sebanyak 15 kali. Pada kolom Expected $N$ merupakan frekuensi harapan, yakni untuk sisi angka dan gambar masing-masing sebanyak 50 kali muncul. Pada kolom Residual merupakan nilai selisih antara frekuensi pengamatan dan frekuensi harapan.

Tabel 20.17

Frekuensi

\begin{tabular}{|l|r|r|r|}
\hline & Observed N & Expected N & Residual \\
\hline 15 & 15 & 50.0 & -35.0 \\
85 & 85 & 50.0 & 35.0 \\
Total & 100 & & \\
\hline
\end{tabular}

Tabel 20.18

\begin{tabular}{|l|r|r|}
\hline & Frekuensi & sisi angka \\
\hline Chi-Square & $49.000^{2}$ & $49.000^{2}$ \\
Df & 1 & 1 \\
Asymp. Sig. & .000 & .000 \\
\hline
\end{tabular}
a. 0 cells $(.0 \%)$ have expected frequencies less
than 5. The minimum expected cell frequency is
5n 0

Berdasarkan Tabel 20.18 (Tabel Test Statistics), diketahui nilai statistik dari uji chi-kuadrat atau Chi-Square adalah 49. Diketahui nilai kritis chi-kuadrat $\left(\chi_{\text {kritis }}^{2}\right)$ dengan derajat bebas $(\mathrm{Df}=$ degree of freedom) 1 dan tingkat signifikansi 5\% adalah 3,841 (silahkan lihat tabel distribusi chi-kuadrat atau cari menggunakan Microsoft Excel). Karena nilai statistik dari uji chi-kuadrat, yakni 49, lebih besar dibandingkan nilai kritis chi-kuadrat, yakni 3,841, maka hipotesis nol ditolak dan hipotesis alternatif diterima. Hal ini berarti proporsi/frekuensi kemunculan sisi angka dan gambar untuk pengamatan berbeda signifikan secara statistik dengan proporsi/frekuensi kemunculan sisi angka dan gambar secara teoritis pada tingkat signifikansi 5\%. Selain itu, pengambilan keputusan terhadap hipotesis juga dapat digunakan nilai Asymp. Sig. atau probabilitas. Diketahui nilai probabilitas adalah 0,000. Karena nilai probabilitas lebih kecil dari tingkat signifikansi $\alpha=0,05$, maka hipotesis nol ditolak dan hipotesis alternatif diterima. 


\section{PENYELESAIAN DALAM SPSS (CHI-KUADRAT 2)}

Bangun data dalam SPSS seperti Gambar 20.100. Pada variabel adonan, Beri Value 1 untuk Label "tepung", Value 2 untuk Label "susu", Value 3 untuk Label "telur", dan Value 4 untuk Label "gula". Kemudian aktifkan Data View. Input data pada Data View seperti pada Gambar 20.100. Pilih Data $\Rightarrow$ Weight Cases (Gambar 20.101). Kemudian bulatkan Weight cases by. Masukkan variabel proporsi_pengamatan pada kotak Frequency Variable (Gambar 20.102) dan pilih OK.

Selanjutnya pilih Analyze $\Rightarrow>$ Nonparametric Test $\Rightarrow$ Chi Square, sehingga muncul kotak dialog Chi Square Test (Gambar 20.103). Masukkan variabel adonan dan proporsi_pengamatan pada kotak Test Variable List. Kemudian aktifkan/bulatkan Values pada Expected Values. Diketahui, harapan untuk adonan yang dihasilkan mengandung 250 gram tepung, $100 \mathrm{ml}$ susu, 100 gram telur, dan 50 gram gula, sehingga pada Values isi 250, kemudian pilih Add. Isi lagi Values 100, kemudian pilih $A d d$, sampai dengan 50. Setelah itu pilih OK.
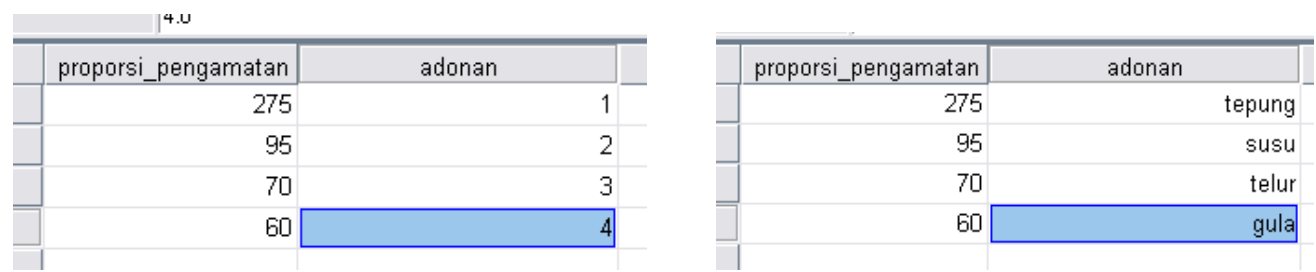

Gambar 20.100

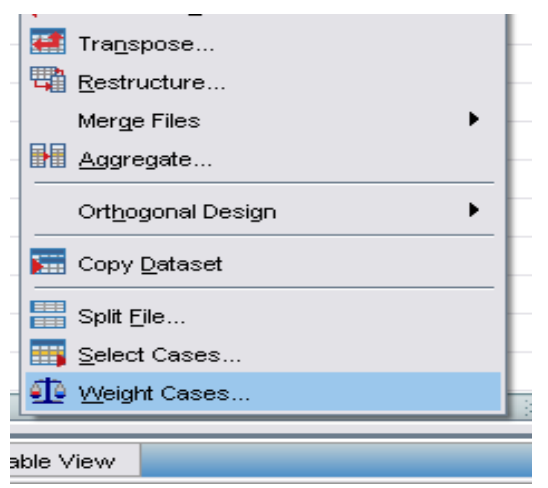

Gambar 20.101

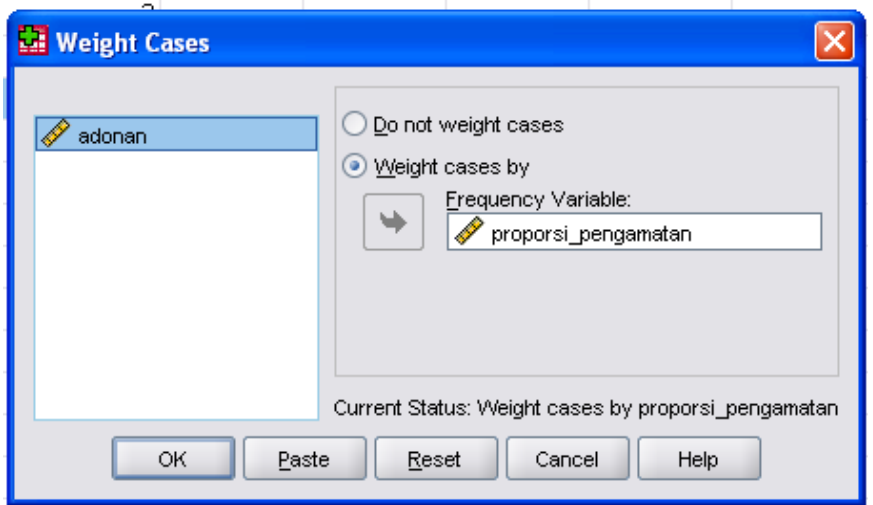

Gambar 20.102

Berdasarkan Tabel 20.19 (Tabel adonan), pada kolom Observed $N$ merupakan proporsi adonan pengamatan untuk tepung, susu, telur, dan gula yang masing-masing 275, 95, 70, dan 60. Kolom Expected $N$ merupakan proporsi adonan harapan untuk tepung, susu, telur, dan gula yang masing-masing 250, 100, 100, dan 50.

Pada Tabel 20.20 (Tabel Test Statistics), diketahui nilai statistik dari uji chi-kuadrat atau ChiSquare adalah 13,750. Diketahui nilai kritis chi-kuadrat $\left(\chi_{\text {kritis }}^{2}\right)$ dengan derajat bebas (Df $=$ degree of freedom) 3 dan tingkat signifikansi $1 \%$ adalah 11,345. Oleh karena nilai statistik dari uji chi-kuadrat lebih besar dari nilai kritis chi-kuadrat, maka hipotesis nol ditolak dan hipotesis alternatif diterima. Hal ini berarti proporsi adonan kue yang telah dihasilkan berbeda 
signifikan secara statistik dengan proporsi adonan kue yang telah ditetapkan pada mesin pencampur adonan kue pada tingkat signifikansi $1 \%$.

Selain itu, pengambilan keputusan terhadap hipotesis juga dapat digunakan nilai Asymp. Sig. atau probabilitas. Diketahui nilai probabilitas adalah 0,003. Karena nilai probabilitas lebih kecil dari tingkat signifikansi $\alpha=0,01$, maka hipotesis nol ditolak dan hipotesis alternatif diterima.

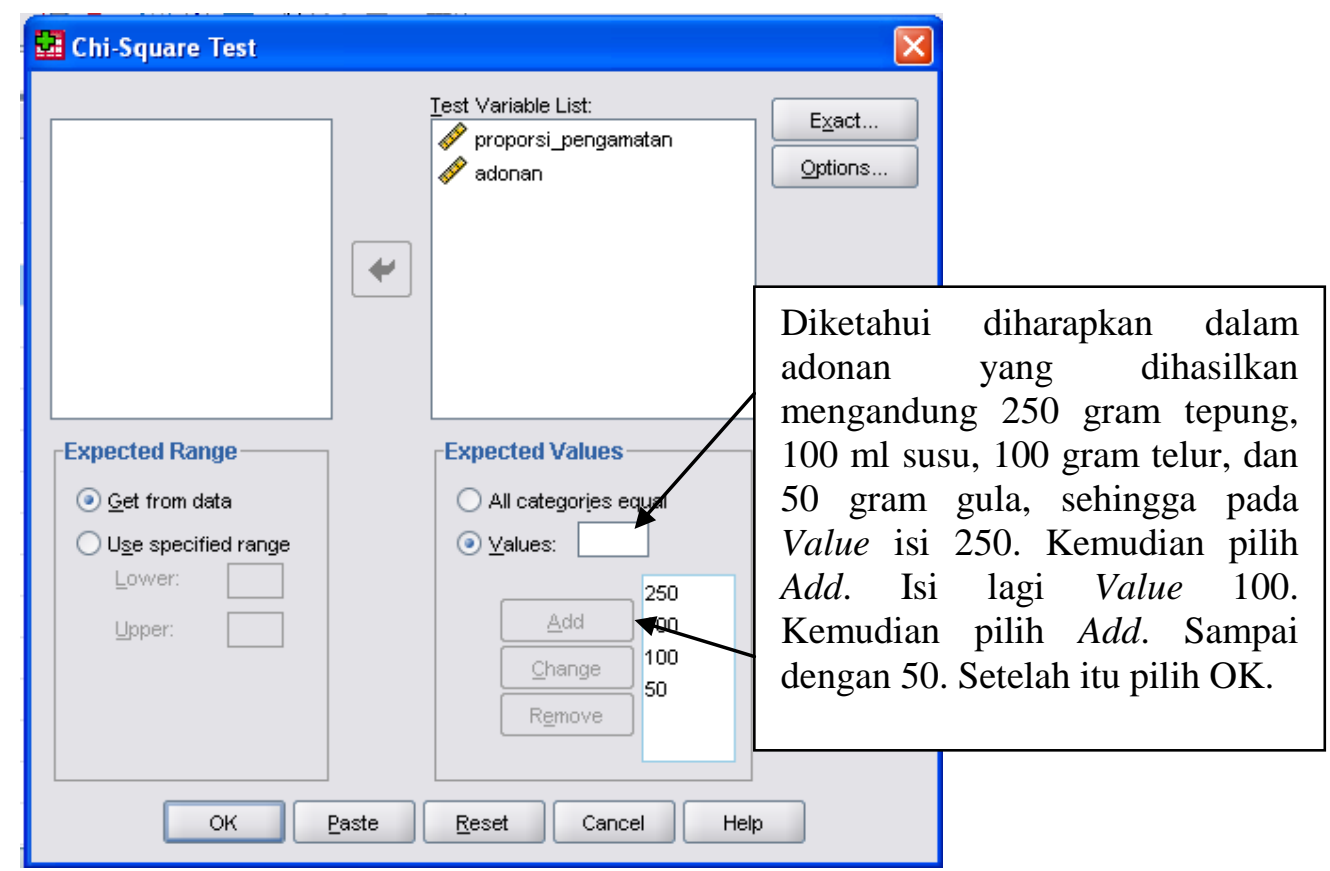

Gambar 20.103

Tabel 20.19

\begin{tabular}{|l|r|r|r|}
\hline \multicolumn{4}{|c|}{ Adonan } \\
\hline Tepung & Observed N & Expected N & Residual \\
Susu & 275 & 250.0 & 25.0 \\
Telur & 95 & 100.0 & -5.0 \\
Gula & 70 & 100.0 & -30.0 \\
Total & 60 & 50.0 & 10.0 \\
\hline
\end{tabular}

Tabel 20.20

\begin{tabular}{|l|r|r|}
\hline \multicolumn{1}{|c}{ Test Statistics } \\
\hline proporsi_pengamatan & adonan \\
\hline Chi-Square & $1166.150^{\mathrm{a}}$ & $13.750^{\mathrm{a}}$ \\
Df & 3 & 3 \\
Asymp. Sig. & .000 & .003 \\
\hline
\end{tabular}

a. 0 cells $(.0 \%)$ have expected frequencies less than 5 . The minimum expected cell frequency is 50.0. 


\section{PENYELESAIAN DALAM Minitab (CHI-KUADRAT 1)}

Bangun data dalam Minitab seperti pada Gambar 20.104. Bentuk variabel frekuensi dan sisi (Gambar 20.104). Pilih Stat $=>$ Tables $=>$ Chi-Square Goodness-of-Fit Test (One Variable) (Gambar 20.105).

\begin{tabular}{|c|c|c|}
\hline+ & C1 & $C 2$ \\
\hline & frekuensi & \multicolumn{2}{c|}{ sisi } \\
\hline 1 & 85 & 1 \\
\hline 2 & 15 & 0 \\
\hline
\end{tabular}

Gambar 20.104

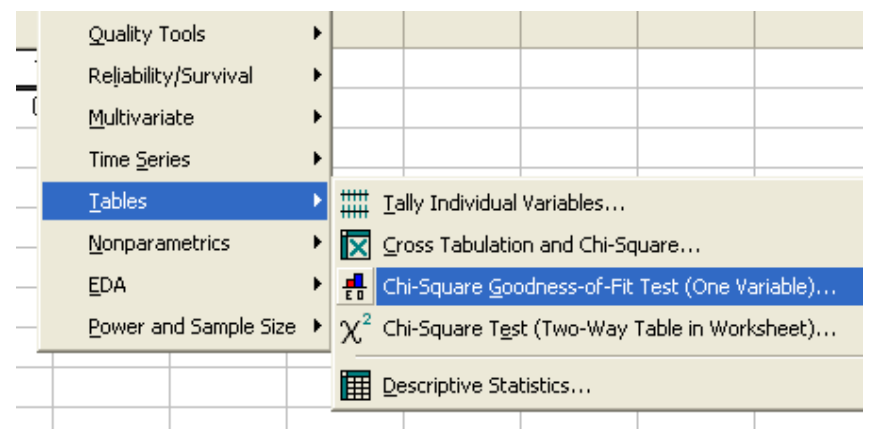

Gambar 20.105

Pada Gambar 20.106, pindahkan variabel frekuensi pada Observed counts, dan pindahkan variabel sisi (kategori) pada Category names (optional). Kemudian pilih OK.

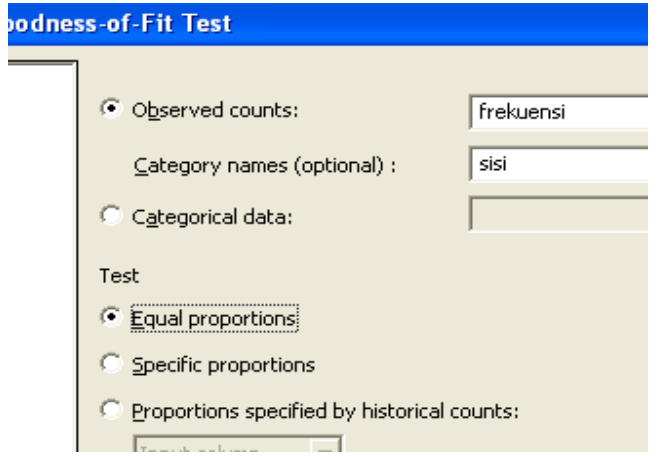

Gambar 20.106

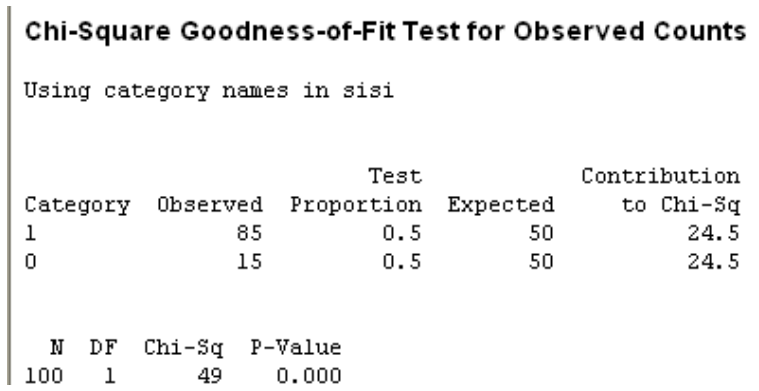

Gambar 20.107

Gambar 20.107 menyajikan hasil berdasarkan Minitab. Diketahui nilai statistik dari uji chikuadrat (Chi-sq) adalah 49, dan nilai probabilitas ( $P$-value) adalah 0,000 . Diketahui nilai kritis chi-kuadrat $\left(\chi_{\text {kritis }}^{2}\right)$ dengan derajat bebas $(\mathrm{Df}=$ degree of freedom) 3 dan tingkat signifikansi $1 \%$ adalah 11,345 . Oleh karena nilai statistik dari uji chi-kuadrat lebih besar dari nilai kritis chi-kuadrat, maka hipotesis nol ditolak dan hipotesis alternatif diterima. Hal ini berarti proporsi adonan kue yang telah dihasilkan berbeda signifikan secara statistik dengan proporsi adonan kue yang telah ditetapkan pada mesin pencampur adonan kue pada tingkat signifikansi $1 \%$. Diketahui nilai probabilitas adalah 0,000. Karena nilai probabilitas lebih kecil dari tingkat signifikansi $\alpha=0,01$, maka hipotesis nol ditolak dan hipotesis alternatif diterima. 
PENYELESAIAN DALAM Minitab (CHI-KUADRAT 2)

Bangun data dalam Minitab seperti pada Gambar 20.108. Bentuk variabel pengamatan, adonan, dan proporsi harapan (Gambar 20.108). Pilih Stat $\Rightarrow$ Tables $\Rightarrow$ Chi-Square Goodness-of-Fit Test (One Variable) (Gambar 20.109).

\begin{tabular}{|r|r|r|r|}
\hline+ & C1 & C2 & \multicolumn{1}{c|}{ C3 } \\
\hline & pengamatan & adonan & proporsi harapan [ \\
\hline $\mathbf{1}$ & 275 & 1 & 0.5 \\
\hline $\mathbf{2}$ & 95 & 2 & 0.2 \\
\hline $\mathbf{3}$ & 70 & 3 & 0.2 \\
\hline $\mathbf{4}$ & 60 & 4 & 0.1 \\
\hline $\mathbf{5}$ & & & \\
\hline
\end{tabular}

Gambar 20.108

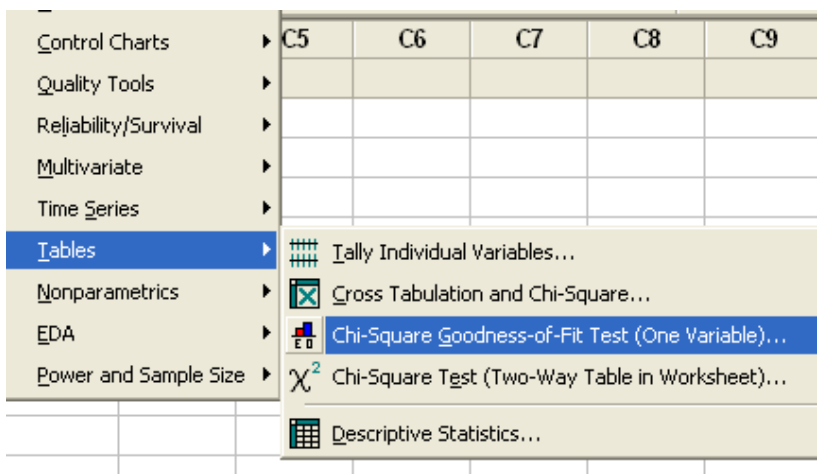

Gambar 20.109

Pada Gambar 20.110, pindahkan variabel pengamatan pada Observed counts, dan variabel adonan pada Category names (optional). Kemudian aktifkan/bulatkan Specific proportions, dan masukkan variabel proporsi harapan (Gambar 20.110). Pilih OK.

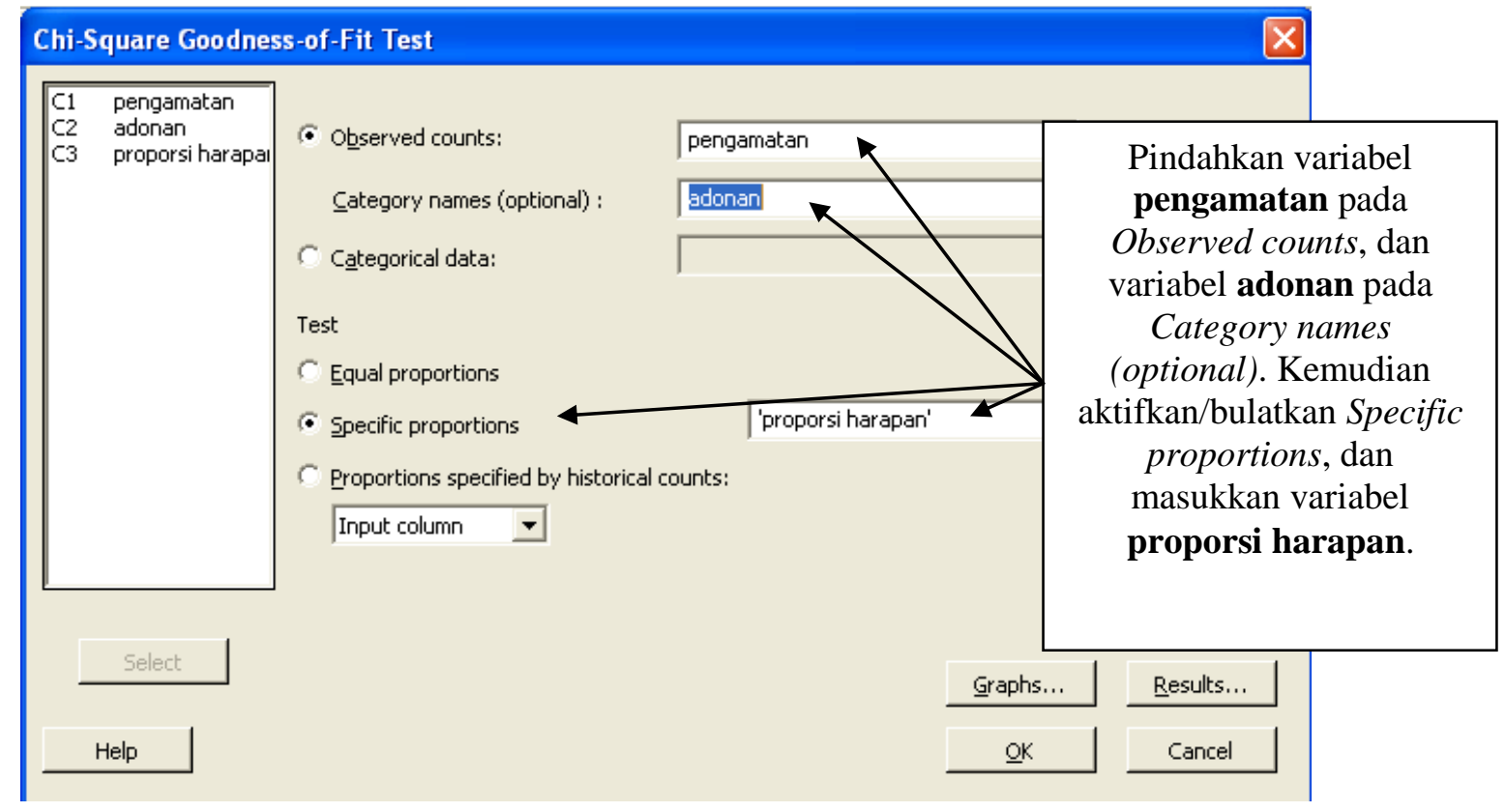

Gambar 20.110

Gambar 20.111 merupakan hasil berdasarkan Minitab. Diketahui nilai statistik dari uji chikuadrat $(C h i-S q)$ adalah 13,75 , dan nilai probabilitas ( $P$-Value) adalah 0,003 . 


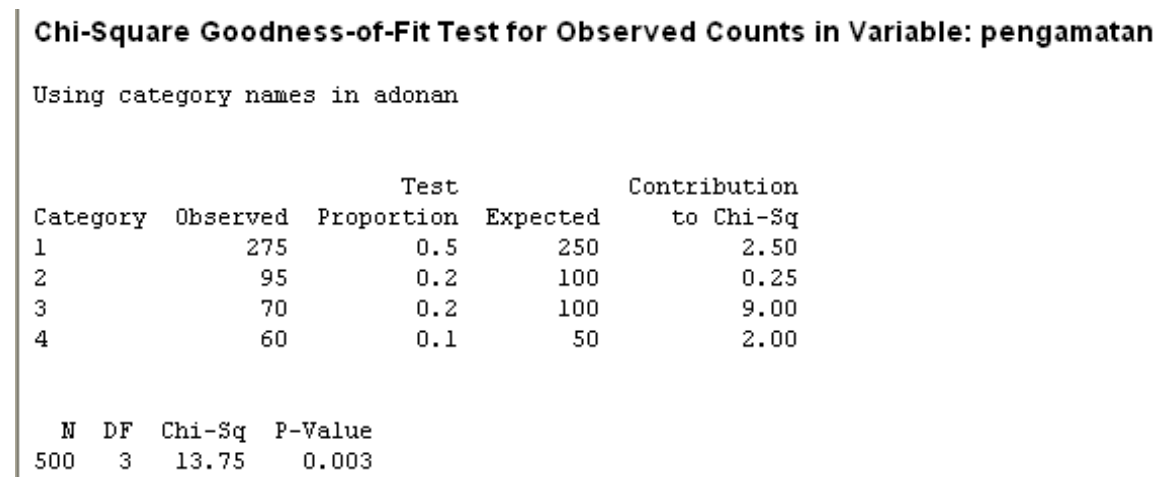

Gambar 20.111

\section{PENYELESAIAN DALAM R (CHI-KUADRAT 1)}

Ketik kode R seperti pada Gambar 20.112. Selanjutnya pilih Compile, dan pilih MS Word pada Notebook output format. Gambar 20.113. menyajikan hasil berdasarkan R.

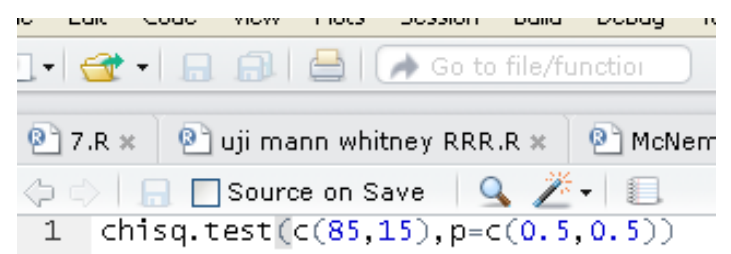

Gambar 20.112

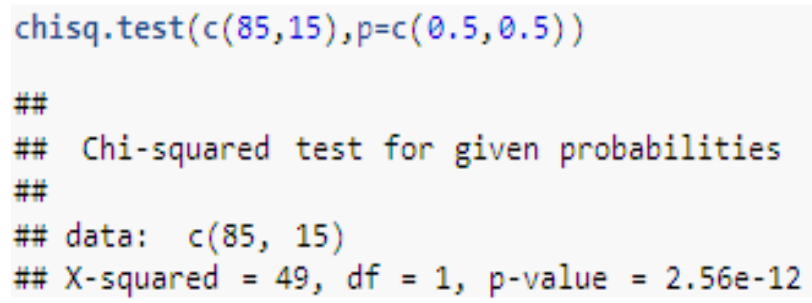

Diketahui nilai statistik dari uji chi-kuadrat ( $X$-squared) adalah 49, dan nilai probabilitas ( $p$ value) adalah $\frac{2.56}{10^{12}}=0,00000000000256$.

\section{PENYELESAIAN DALAM R (CHI-KUADRAT 2)}

Ketik kode R seperti pada Gambar 20.114. Selanjutnya pilih Compile, dan pilih MS Word pada Notebook output format. Gambar 20.115 menyajikan hasil berdasarkan R. Diketahui nilai statistik dari uji chi-kuadrat ( $X$-squared) adalah 13,75 , dan nilai probabilitas ( $p$-value) adalah 0,003266 .

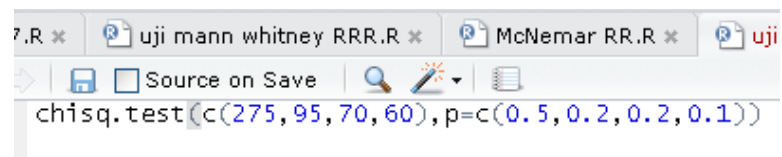

Gambar 20.114
Chi-squared test for given probabilities

data: $c(275,95,70,60)$

$X$-squared $=13.75, d f=3, p$-value $=0.003266$

\section{Gambar 20.115}




\section{BAB 21}

\section{ANALISIS FAKTOR}

\section{Sekilas Analisis Faktor}

Berikut pemaparan singkat mengenai analisis faktor menurut Hair dkk. (2010:92-94).

"The starting point in factor analysis, as with other statistical technique, is the research problem. The general purpose of factor analytic techniques is to find a way to condense (summarize) the information contained in a number of a original variables into a smaller set of new, composite dimensions or variates (factor) with a minimum loss of information-that is, to search for and define the fundamental constructs or dimensions assumed to underlie the original variables (Gorsuch, 1983, Gorsuch, 1990)...We should note at this point that factor analytic techniques can achieve their purpose from either an exploratory or confirmatory perspective."

Field (2009:628-629) menyatakan sebagai berikut.

"If we measure several variables, or ask someone several questions about themselves, the correlation between each pair of variables (or questions) can be arranged in what's known as an R-matrix. An R-matrix is just a correlation matrix: a table of correlation coefficients between variables (in fact, we saw small versions of these matrices in Chapter 6). The diagonal elements of an R-matrix are all ones because each variable will correlate perfectly with itself. The off diagonal elements are the correlation coefficients between pairs of variables, or questions. The existence of clusters of large correlation coefficients between subsets of variables suggests that those variables could be measuring aspects of the same underlying dimension. These underlying dimensions are known as factors (or latent variables). By reducing a data set from a group of interrelated variables to a smaller set of factors, factor analysis achieves parsimony by explaining the maximum amount of common variance in a correlation matrix using the smallest number of explanatory constructs."

Berdasarkan uraian di atas, analisis faktor merupakan suatu metode yang dapat mereduksi sekumpulan variabel-variabel asli (original variables) menjadi beberapa variabel baru, yang disebut dengan faktor atau dimensi. Analisis faktor berusaha menghasilkan faktor dengan jumlah seminimal mungkin, yang mana faktor-faktor tersebut mampu menjelaskan jumlah maksimal dari variance (explaining the maximum amount of common variance in a correlation matrix) dalam matriks korelasi atau matriks $\mathrm{R}$ (keseluruhan variabel).

Misalkan diberikan data seperti pada Tabel 21.1. Berdasarkan data pada Tabel 21.1, terdapat tujuh variabel, yakni X1, X2, X3, X4, X5, X6, dan X7. Tabel 21.2 menyajikan matriks korelasi (matriks R), yakni menyajikan nilai korelasi (korelasi Pearson) antar dua variabel. Berdasarkan Tabel 21.2, nilai korelasi (korelasi Pearson) antara X1 dan X2 adalah -0,271, korelasi antara X1 dan X5 adalah -0,301, dan seterusnya. Perhatikan bahwa berdasarkan Tabel 21.2:

$$
\begin{aligned}
& \Rightarrow \text { Terdapat korelasi yang tinggi antara X1 dan X6 (nilai korelasi 0,8992). } \\
& \Rightarrow \text { Terdapat korelasi yang tinggi antara X2 dan X5. } \\
& \Rightarrow \text { Terdapat korelasi yang tinggi di antara X3, X4, dan X7. }
\end{aligned}
$$


Sehingga diduga akan terbentuk tiga faktor, yakni faktor pertama meliputi X1 dan X6, faktor kedua meliputi X2 dan X5, dan faktor ketiga meliputi X3, X4, dan X7.

Tabel 21.1

\begin{tabular}{|c|c|c|c|c|c|c|c|}
\hline No & $\mathrm{X} 1$ & $\mathrm{X} 2$ & $\mathrm{X} 3$ & $\mathrm{X} 4$ & $\mathrm{X} 5$ & $\mathrm{X} 6$ & $\mathrm{X} 7$ \\
\hline 1 & 1 & 5 & 1 & 1 & 5 & 4 & 1 \\
\hline 2 & 2 & 6 & 4 & 4 & 10 & 2 & 4 \\
\hline 3 & 3 & 7 & 2 & 2 & 7 & 3 & 2 \\
\hline 4 & 4 & 8 & 3 & 3 & 8 & 1 & 3 \\
\hline 5 & 5 & 9 & 3 & 3 & 9 & 5 & 3 \\
\hline 6 & 6 & 4 & 2 & 2 & 6 & 6 & 2 \\
\hline 7 & 7 & 1 & 3 & 3 & 1 & 7 & 3 \\
\hline 8 & 8 & 2 & 3 & 3 & 2 & 8 & 3 \\
\hline 9 & 9 & 3 & 1 & 1 & 3 & 9 & 1 \\
\hline 10 & 8 & 4 & 2 & 2 & 4 & 10 & 2 \\
\hline 11 & 1 & 5 & 1 & 1 & 5 & 1 & 1 \\
\hline 12 & 2 & 1 & 1 & 1 & 1 & 2 & 1 \\
\hline 13 & 3 & 2 & 2 & 4 & 2 & 3 & 3 \\
\hline 14 & 4 & 3 & 3 & 2 & 3 & 4 & 3 \\
\hline 15 & 5 & 4 & 4 & 3 & 4 & 5 & 1 \\
\hline
\end{tabular}

Tabel 21.2

\begin{tabular}{|c|c|c|c|c|c|c|c|}
\hline Korelasi & $\mathrm{X} 1$ & $\mathrm{X} 2$ & $\mathrm{X} 3$ & $\mathrm{X} 4$ & $\mathrm{X} 5$ & $\mathrm{X} 6$ & $\mathrm{X} 7$ \\
\hline $\mathrm{X} 1$ & 1 & -0.271 & 0.1653 & 0.087 & -0.301 & 0.8992 & 0.0916 \\
\hline $\mathrm{X} 2$ & & 1 & 0.215 & 0.1309 & 0.9214 & -0.347 & 0.1794 \\
\hline $\mathrm{X} 3$ & & & 1 & 0.8043 & 0.3278 & -0.008 & 0.673 \\
\hline $\mathrm{X} 4$ & & & & 1 & 0.2559 & -0.08 & 0.8076 \\
\hline $\mathrm{X} 5$ & & & & & 1 & -0.368 & 0.3218 \\
\hline $\mathrm{X} 6$ & & & & & & 1 & -0.074 \\
\hline $\mathrm{X} 7$ & & & & & & & 1 \\
\hline
\end{tabular}

Dalam proses analisis faktor, tiap-tiap variabel atau indikator akan diuji kelayakannya, apakah suatu variabel tersebut layak untuk diikutsertakan dalam proses pembentukan faktor atau tidak, dalam analisis faktor. Nilai atau ukuran Kaiser-Meyer-Olkin Measure of Sampling Adequacy dari suatu variabel di bawah 0,5 menandakan variabel tersebut dapat dipertimbangkan untuk dibuang (Should consider excluding them from the analysis) (Field, 2009:659). 


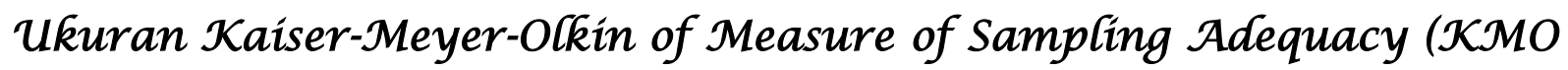 $\mathcal{M S A})$}

Nilai atau ukuran Kaiser-Meyer-Olkin Measure of Sampling Adequacy atau disingkat KMO MSA, digunakan untuk mengetahui apakah proses analisis faktor dapat dilakukan atau tidak (appropriateness of factor analysis). Nilai KMO MSA di atas 0,5 menunjukkan proses analisis faktor dapat dilakukan (factor analysis is appropriate), sementara nilai KMO MSA di bawah 0,5 menunjukkan proses analisis faktor tidak dapat dilakukan (factor analysis may not be appropriated) (Malhotra dan Birks, 2006:574). Tabel 21.3 menyajikan nilai KMO MSA.

\section{Tabel 21.3}

\section{KMO and Bartlett's Test}

\begin{tabular}{|l|r|}
\hline Kaiser-Meyer-Olkin Measure of Sampling Adequacy. & .600 \\
Bartlett's Test of Sphericity $\quad$ Approx. Chi-Square & 68.801 \\
& df \\
Sig. & .000 \\
\hline
\end{tabular}

Berdasarkan Tabel 21.3, diketahui nilai KMO MSA adalah 0,666. Karena nilai KMO MSA > 0,5 , hal ini berarti proses analisis faktor dapat dilakukan.

\section{Bartlett's Test of Sphericity}

Nilai atau ukuran Bartlett's Test of Sphericity digunakan untuk menguji apakah korelasi antar variabel cukup besar atau tidak untuk analisis faktor (principal component analysis) (Field, 2009:671). Sejalan dengan Field, Malhotra dan Birks (2006:574) menyatakan Bartlett's test of sphericity merupakan suatu uji untuk menguji suatu hipotesis (hipotesis nol) yang menyatakan bahwa variabel-variabel dalam populasi penelitian tidak berkorelasi. Dengan kata lain, matriks korelasi populasi merupakan matriks identitas, yang mana tiap-tiap variabel berkorelasi sempurna hanya pada dirinya atau variabel itu sendiri (nilai korelasi 1), namun tidak berkorelasi dengan variabel lainnya (nilai korelasi 0 ).

Untuk mengetahui apakah korelasi antar variabel cukup besar atau tidak, dapat dibandingkan nilai Sig. (probabilitas) dari Bartlett's of Sphericity terhadap tingkat signifikansi yang digunakan $(\alpha)$. Jika nilai Sig. (probabilitas) dari Bartlett's of Sphericity < tingkat signifikansi $(\alpha)$, hal ini menunjukkan korelasi yang terjadi antar variabel cukup besar. Berdasarkan Tabel 21.3, diketahui nilai Sig. dari Bartlett's of Sphericity adalah 0,000 < 0,05, maka hipotesis mengenai variabel-variabel dalam populasi penelitian tidak berkorelasi tidak diterima. Dengan kata lain, korelasi antar variabel cukup besar untuk analisis faktor.

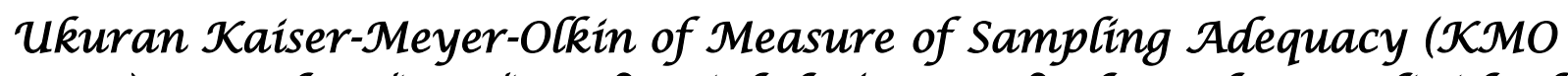
$\mathcal{M S A})$ untuk Tiap-Tiap Variabel (KMMO Values for Individual Variables)

Selanjutnya memeriksa nilai KMO MSA untuk tiap-tiap variabel (the KMO values for individual variables). Nilai KMO MSA untuk tiap-tiap variabel terletak pada nilai-nilai diagonal dari matriks korelasi anti-image (Field, 2009:659). Nilai KMO MSA dari suatu variabel di bawah 0,5 seharusnya dipertimbangkan untuk dibuang, kemudian lakukan kembali proses analisis faktor tanpa melibatkan variabel yang telah dibuang, dan periksa kembali nilai 472 
KMO MSA untuk tiap-tiap variabel, apakah telah memenuhi syarat (di atas 0,5) atau tidak. (Field, 2009:659). Tabel 21.4 menyajikan nilai KMO MSA untuk tiap-tiap variabel.

Berdasarkan Tabel 21.4, diketahui nilai KMO MSA untuk variabel X1 adalah 0,501, nilai KMO MSA untuk variabel X2 adalah 0,534, dan seterusnya. Perhatikan bahwa karena nilai KMO MSA dari setiap variabel di atas 0,5, maka seluruh variabel layak untuk dipertahankan, untuk masuk dalam proses analisis faktor (proses pembentukkan faktor).

Tabel 21.4

Anti-image Matrices

\begin{tabular}{|c|c|c|c|c|c|c|c|c|}
\hline & & $\mathrm{X} 1$ & $\mathrm{X} 2$ & $\mathrm{X} 3$ & $\mathrm{X} 4$ & $\mathrm{X} 5$ & $\mathrm{X} 6$ & $\mathrm{X} 7$ \\
\hline \multirow[t]{7}{*}{ Anti-image Covariance } & $\mathrm{X} 1$ & .148 & -.033 & -.044 & .002 & .033 & -.136 & -.037 \\
\hline & $\mathrm{X} 2$ & -.033 & .127 & .014 & .003 & -.110 & .031 & .040 \\
\hline & $\mathrm{X} 3$ & -.044 & .014 & .311 & -.157 & -.032 & .023 & .008 \\
\hline & $\mathrm{X} 4$ & .002 & .003 & -.157 & .215 & .008 & .009 & -.155 \\
\hline & $\mathrm{X} 5$ & .033 & -.110 & -.032 & .008 & .113 & -.022 & -.050 \\
\hline & X6 & -.136 & .031 & .023 & .009 & -.022 & .152 & .029 \\
\hline & $\mathrm{X} 7$ & -.037 & .040 & .008 & -.155 & -.050 & .029 & .314 \\
\hline \multirow[t]{7}{*}{ Anti-image Correlation } & $\mathrm{X} 1$ & $.501^{\mathrm{a}}$ & -.240 & -.205 & .012 & .257 & -.904 & -.173 \\
\hline & $\mathrm{X} 2$ & -.240 & $.534^{\mathrm{a}}$ & .072 & .019 & -.918 & .219 & .199 \\
\hline & X3 & -.205 & .072 & $.738^{\mathrm{a}}$ & -.606 & -.173 & .107 & .026 \\
\hline & $\mathrm{X} 4$ & .012 & .019 & -.606 & $.657^{\mathrm{a}}$ & .052 & .051 & -.596 \\
\hline & X5 & .257 & -.918 & -.173 & .052 & $.565^{\mathrm{a}}$ & -.168 & -.264 \\
\hline & X6 & -.904 & .219 & .107 & .051 & -.168 & $.538^{\mathrm{a}}$ & .133 \\
\hline & X7 & -.173 & .199 & .026 & -.596 & -.264 & .133 & $.710^{\mathrm{a}}$ \\
\hline
\end{tabular}

a. Measures of Sampling Adequacy(MSA)

\section{Ekstraksi Faktor (Factor Extraction): Fígenvalues}

Setelah terpenuhi persyaratan untuk nilai KMO MSA (nilai KMO MSA baik secara keseluruhan atau masing-masing variabel/indikator di atas 0,5) dan uji signifikansi dari Bartlett's Test of Sphericity menunjukkan hasil yang signifikan secara statistika (nilai Sig. < tingkat signifikansi $\alpha$ ), selanjutnya adalah ekstraksi faktor, yakni mereduksi variabelvariabel atau indikator-indikator (dalam contoh kasus ini terdapat 7 variabel) menjadi beberapa faktor (yang jumlahnya lebih sedikit).

Eigenvalues (nilai-nilai eigen) merupakan salah satu pendekatan yang dapat digunakan untuk menentukan jumlah faktor yang akan dipertahankan dalam analisis. (selain pendekatan eigenvalues, terdapat pendekatan scree plot). Pada Tabel 21.5 terdapat 7 faktor atau component yang terbentuk (diketahui jumlah variabel juga 7), namun tidak semua faktor akan dipertahankan dalam analsis selanjutnya. Pada Tabel 21.5, dari 7 faktor yang terbentuk, hanya 3 faktor yang dipertahankan dalam analisis selanjutnya, yakni faktor atau component 1, 2, dan 3. Sebagaimana Field (2009:639) menyatakan sebagai berikut.

"Not all factors are retained in an analysis, and there is debate over the criterion used to decide whether a factor is statistically important. I mentioned above that eigenvalues associated with a variate indicate the substantive importance of that factor. Therefore, it seems logical that we should retain only factors with large eigenvalues... Typically there will 
be a few factors with quite high eigenvalues, and many factors with relatively low eigenvalues, ..."

Lebih lanjut, Field (2009:640) menyatakan sebagai berikut.

"Although scree plots are very useful, factor selection should not be based on this criterion alone. Kaiser (1960) recommended retaining all factors with eigenvalues greater than 1. This criterion is based on the idea that the eigenvalues represent the amount of variation explained by a factor and that an eigenvalue of 1 represents a substantial amount of variation."

Berdasarkan uraian di atas, Kaiser (1960) memberi rekomendasi bahwa eigenvalue dari suatu faktor yang lebih besar dari 1, agar dipertahankan dalam proses analisis. Perhatikan bahwa berdasarkan Tabel 21.5, eigenvalues untuk faktor atau component 1, 2, dan 3 adalah 2,988, 2,277, dan 1,126, di mana lebih besar dari 1, sehingga faktor 1, 2, dan 3 dipertahankan untuk analisis selanjutnya (terbentuk tiga faktor).

Berdasarkan Tabel 21.5, diketahui faktor atau component pertama mampu menjelaskan $42,679 \%$ dari total variance, faktor atau component kedua mampu menjelaskan $32,531 \%$ dari total variance dan faktor atau component ketiga mampu menjelaskan 16,082\% dari total variance. Jadi, ketiga faktor tersebut mampu menjelaskan $91,293 \%$ dari total variance. Perhatikan bahwa faktor atau component keempat sampai ketujuh tidak disajikan kemampuannya dalam menjelaskan total variance. Hal ini dikarenakan karena nilai initial Eigenvalues pada kolom Total untuk faktor atau component 4 sampai 7 tidak lebih dari 1.

Tabel 21.5

Total Variance Explained

\begin{tabular}{|c|c|c|c|c|c|c|c|c|c|}
\hline \multirow[b]{2}{*}{ Component } & \multicolumn{3}{|c|}{ Initial Eigenvalues } & \multicolumn{3}{|c|}{$\begin{array}{c}\text { Extraction Sums of Squared } \\
\text { Loadings }\end{array}$} & \multicolumn{3}{|c|}{ Rotation Sums of Squared Loadings } \\
\hline & Total & $\begin{array}{c}\% \text { of } \\
\text { Variance }\end{array}$ & $\begin{array}{c}\text { Cumulative } \\
\%\end{array}$ & Total & $\begin{array}{c}\% \text { of } \\
\text { Variance }\end{array}$ & $\begin{array}{c}\text { Cumulative } \\
\%\end{array}$ & Total & $\begin{array}{c}\% \text { of } \\
\text { Variance }\end{array}$ & $\underset{\%}{\text { Cumulative }}$ \\
\hline 1 & 2.988 & 42.679 & 42.679 & 2.988 & 42.679 & 42.679 & 2.557 & 36.532 & 36.532 \\
\hline 2 & 2.277 & 32.531 & 75.210 & 2.277 & 32.531 & 75.210 & 1.921 & 27.447 & 63.980 \\
\hline 3 & 1.126 & 16.082 & 91.293 & 1.126 & 16.082 & 91.293 & 1.912 & 27.313 & 91.293 \\
\hline 4 & .322 & 4.606 & 95.899 & & & & & & \\
\hline 5 & .139 & 1.990 & 97.888 & & & & & & \\
\hline 6 & .094 & 1.337 & 99.226 & & & & & & \\
\hline 7 & .054 & .774 & 100.000 & & & & & & \\
\hline
\end{tabular}

Extraction Method: Principal Component Analysis.

\section{Communalities}

Perhatikan Tabel 21.6 (Communalities). Nilai communalities untuk variabel X1 (lihat kolom Extraction, baris X1) adalah 0,976. Nilai tersebut dapat diartikan faktor-faktor yang telah terbentuk (berdasarkan metode principal component analysis, disingkat PCA) dapat menjelaskan variance dari variabel X1 sebesar 95,9\%, faktor-faktor yang telah terbentuk dapat menjelaskan variance dari variabel X2 sebesar 96,8\%, dan seterusnya. 
Tabel 21.6

\begin{tabular}{|c|c|c|}
\hline \multicolumn{3}{|c|}{ Communalities } \\
\hline & Initial & Extraction \\
\hline $\mathrm{X} 1$ & 1.000 & .959 \\
\hline $\mathrm{X} 2$ & 1.000 & .968 \\
\hline X3 & 1.000 & .814 \\
\hline $\mathrm{X} 4$ & 1.000 & .914 \\
\hline X5 & 1.000 & .964 \\
\hline X6 & 1.000 & .957 \\
\hline X7 & 1.000 & .815 \\
\hline
\end{tabular}

Berikut pemaparan singkat mengenai communalities menurut Hair dkk. (2010:134).

"Communalities, show the amount of variance in a variable that is accounted for by the two factors taken together. The size of the communality is a useful index for assessing how much variance in a particular variable is accounted for by the factor solution. Higher communality values indicate that a large amount of the variance in a variable has been extracted by the factor solution. Small communalities show that a substantial portion of the variable's variance is not accounted for by the factors. Although no statistical guidelines indicate exactly what is "large" or "small", practical considerations dictate a lower level of 0,5 for communalities in this analysis."

Field (2009:642) menyatakan sebagai berikut.

"The closer communalities are to 1, the better our factors are at explaining the original data. It is logical that the more factor retained, the greater communalities will be (because less information is discarded); therefore, the communalities are good indices of whether to few factors have been retained. In fact, with generalized least-squares factor analysis and maximum-likelihood factor analysis you can get a statistical measure of the goodness of fit the factor solution. This basically measures the proportion of variance that the factor solution explains."

Nilai communalities pada Tabel 21.6 dari tiap-tiap variabel dapat dihitung dengan menggunakan regresi linear. Perhatikan Gambar 21.1. Pada Gambar 21.1, variabel FAC1_1, FAC2_1, dan FAC3_1, merupakan faktor-faktor yang dihasilkan dengan metode PCA tanpa rotasi, sementara variabel FAC1_2, FAC2_2, dan FAC3_2, merupakan faktor-faktor yang dihasilkan dengan metode PCA dengan rotasi, metode varimax. Gambar 21.2 merupakan langkah melakukan regresi linear, di mana X1 sebagai variabel tak bebas, sementara FAC1_1, FAC2_1, dan FAC3_1 sebagai variabel bebas. Hasilnya ditunjukkan pada Tabel 21.7.

Perhatikan bahwa nilai $R$-Square berdasarkan Tabel 21.7 adalah 0,959 , di mana, sama dengan nilai communalites untuk variabel X1, seperti pada Tabel 21.6. Gambar 21.3 merupakan langkah melakukan regresi linear, di mana X1 sebagai variabel tak bebas, sementara FAC1_2, FAC2_2, dan FAC3_2 sebagai variabel bebas. Hasilnya ditunjukkan pada Tabel 21.8. 


\begin{tabular}{|c|c|c|c|c|c|c|c|c|c|c|}
\hline$\times 3$ & $X_{4}$ & $\times 5$ & $\times 6$ & $x 7$ & FAC1_1 & FAC2_1 & FAC3_1 & FAC1_2 & $\mathrm{FAC}_{2} 2$ & FAC3_2 \\
\hline 1 & 1 & 5 & 4 & 1 & -0.66285 & -1.46464 & 0.21571 & -1.41600 & 0.29366 & -0.73470 \\
\hline 4 & 4 & 10 & 2 & 4 & 2.11172 & 0.02289 & -0.44762 & 1.73698 & 0.91180 & -0.90100 \\
\hline 2 & 2 & 7 & 3 & 2 & 0.40351 & -0.92035 & 0.60364 & -0.42578 & 1.00607 & -0.42517 \\
\hline 3 & 3 & 8 & 1 & 3 & 1.37561 & -0.49730 & 0.32943 & 0.63525 & 1.22779 & -0.58061 \\
\hline 3 & 3 & 9 & 5 & 3 & 1.31071 & -0.03718 & 1.42846 & 0.50242 & 1.81855 & 0.44756 \\
\hline 2 & 2 & 6 & 6 & 2 & -0.23415 & 0.11506 & 0.70602 & -0.33425 & 0.33123 & 0.58744 \\
\hline 3 & 3 & 1 & 7 & 3 & -0.33917 & 1.50550 & -0.89547 & 0.90725 & -1.39021 & 0.65395 \\
\hline 3 & 3 & 2 & 8 & 3 & -0.24490 & 1.62675 & -0.23333 & 0.83642 & -0.89951 & 1.11893 \\
\hline 1 & 1 & 3 & 9 & 1 & -1.58795 & 0.46662 & 1.42771 & -1.37411 & -0.07094 & 1.69837 \\
\hline 2 & 2 & 4 & 10 & 2 & -0.70199 & 0.95194 & 1.28702 & -0.38407 & 0.17416 & 1.69634 \\
\hline 1 & 1 & 5 & 1 & 1 & -0.50368 & -1.80351 & -0.22118 & -1.35398 & 0.19360 & -1.29789 \\
\hline 1 & 1 & 1 & 2 & 1 & -1.32862 & -1.03217 & $-1,38315$ & -1.15157 & -1.41078 & -1.19469 \\
\hline 2 & 4 & 2 & 3 & 3 & 0.20780 & 0.37185 & -1.88416 & 0.97429 & -1.37439 & -0.94515 \\
\hline 3 & 2 & 3 & 4 & 3 & 0.05797 & 0.27280 & -0.81494 & 0.46257 & -0.65362 & -0.31737 \\
\hline 4 & 3 & 4 & 5 & 1 & 0.13599 & 0.42174 & -0.11814 & 0.38459 & -0.15740 & 0.19399 \\
\hline
\end{tabular}

Gambar 21.1 Skor Faktor tanpa Rotasi dan dengan Rotasi (Metode Varimax)

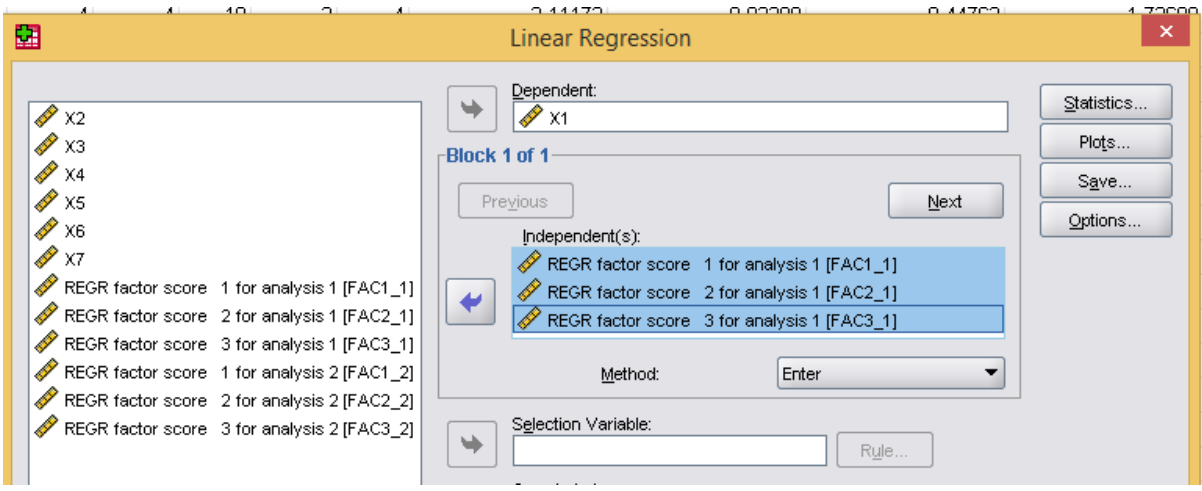

\section{Gambar 21.2}

\section{Tabel 21.7}

\begin{tabular}{|l|r|r|r|r|}
\hline Model & \multicolumn{1}{|c|}{ Model Summary } & \multicolumn{1}{c|}{$\begin{array}{c}\text { Std. Error of the } \\
\text { Estimate }\end{array}$} \\
\hline 1 & $.979^{\mathrm{a}}$ & \multicolumn{1}{c|}{ R Square } & Adjusted R Square & .599 \\
\hline
\end{tabular}

a. Predictors: (Constant), REGR factor score 3 for analysis 1, REGR factor score 2 for analysis 1, REGR factor score 1 for analysis 1

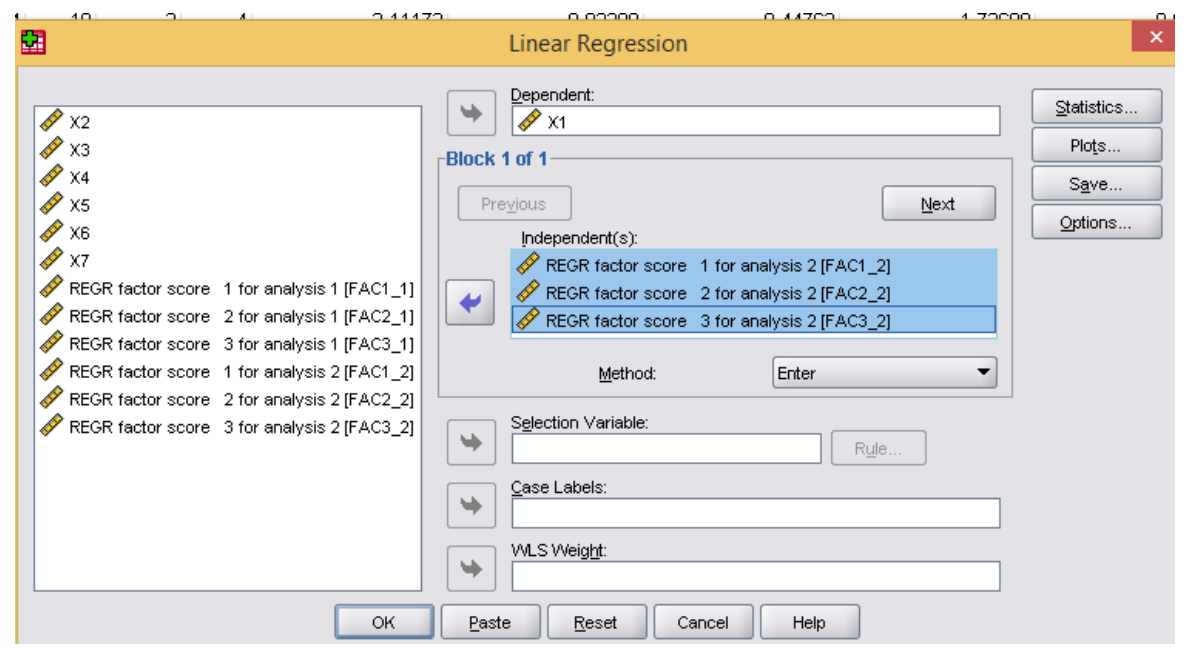

Gambar 21.3 
Tabel 21.8

\begin{tabular}{|l|r|r|r|r|}
\hline Model & \multicolumn{1}{|c|}{ Rodel Summary } & $\begin{array}{c}\text { Std. Error of the } \\
\text { Estimate }\end{array}$ \\
\hline 1 & $.979^{\mathrm{a}}$ & \multicolumn{1}{|c|}{ R Square } & Adjusted R Square & .959 \\
\hline
\end{tabular}

a. Predictors: (Constant), REGR factor score 3 for analysis 2, REGR factor

score 2 for analysis 2, REGR factor score 1 for analysis 2

Perhatikan bahwa nilai $R$-Square berdasarkan Tabel 21.8 adalah 0,959 , di mana sama dengan nilai communalites untuk variabel X1, seperti pada Tabel 21.6.

Faktor-faktor yang terbentuk, baik sebelum dan setelah rotasi (rotasi dengan metode varimax) (lihat Gambar 21.1), memiliki kemampuan yang sama dalam menjelaskan variance dari variabel X1 (lihat Tabel 21.7 dan Tabel 21.8).

\section{Component Matrix (Before Rotation)}

Perhatikan Tabel 21.9 (Component Matrix). Pada Tabel 21.9, telah terbentuk tiga faktor atau component dengan metode PCA, tanpa rotasi. Jika dilihat pada Gambar 21.1, ketiga faktor tersebut adalah FAC1_1, FAC2_1, dan FAC3_1. Nilai-nilai yang tersaji pada Tabel 21.9 merupakan nilai korelasi antara variabel dan faktor (faktor yang terbentuk dengan metode PCA, tanpa rotasi). Sebagai contoh nilai korelasi (korelasi Pearson) antara variabel X1 dan FAC1_1 (faktor atau component pertama) adalah $-0,285$, nilai korelasi antara variabel X1 dan FAC2_1 (faktor atau component kedua) adalah 0,824 , dan nilai korelasi antara variabel X1 dan FAC3_1 (faktor atau component ketiga) adalah 0,447. Nilai korelasi antara variabel dan faktor disebut dengan factor loading. Gambar 21.4 merupakan tampilan untuk menghitung korelasi antara variabel X1 dengan masing-masing faktor (FAC1_1, FAC2_1, dan FAC3_1). Hasilnya ditunjukkan pada Tabel 21.10. Informasi pada Tabel 21.9 memberikan informasi korelasi tiap-tiap variabel terhadap tiap-tiap faktor, di mana dapat digunakan untuk menentukan suatu variabel akan masuk ke dalam faktor pertama, kedua atau ketiga. Diketahui sebelumnya bahwa korelasi antara suatu variabel dan faktor disebut factor loading.

Tabel 21.9

\begin{tabular}{|l|r|r|r|}
\multicolumn{4}{|c|}{ Component Matrix ${ }^{\mathbf{a}}$} \\
\cline { 2 - 4 } & \multicolumn{3}{|c|}{ Component } \\
\cline { 2 - 4 } X1 & \multicolumn{1}{|c|}{2} & \multicolumn{1}{c|}{3} \\
X2 & -.285 & .824 & .447 \\
X3 & .673 & -.420 & .582 \\
X4 & .733 & .518 & -.093 \\
X5 & .748 & .522 & -.286 \\
X6 & .776 & -.351 & .488 \\
X7 & -.451 & .732 & .466 \\
\hline
\end{tabular}

Extraction Method: Principal Component Analysis.

a. 3 components extracted. 


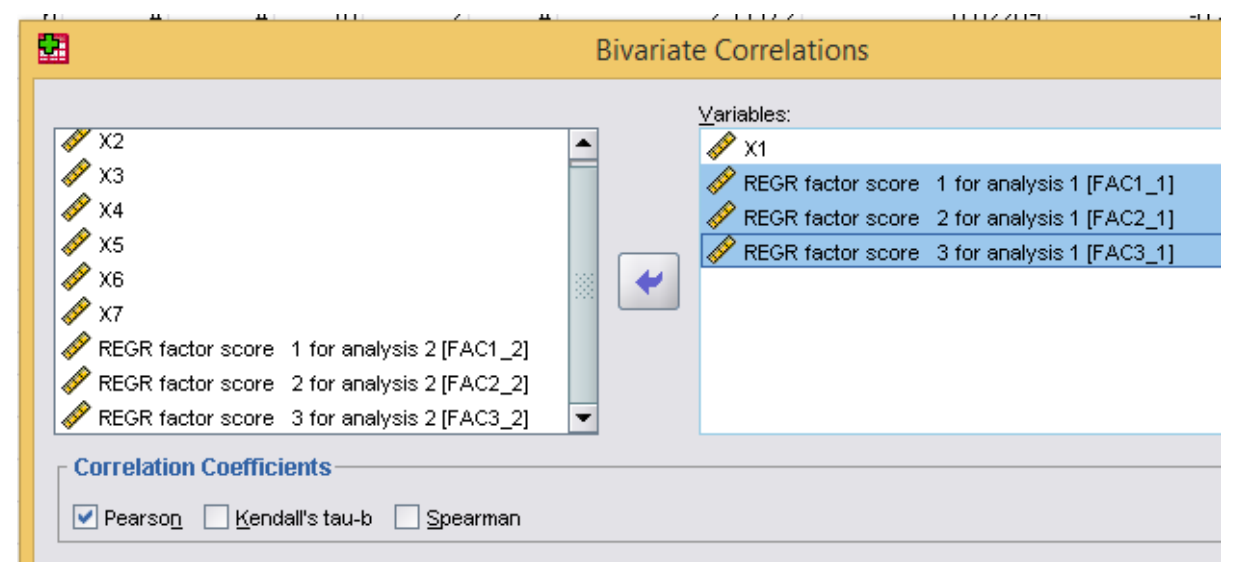

Gambar 21.4

Tabel 21.10

\begin{tabular}{|c|c|c|c|c|c|}
\hline \multicolumn{6}{|c|}{ Correlations } \\
\hline & & $\mathrm{X} 1$ & \begin{tabular}{|c|} 
REGR factor score \\
1 for analysis 1 \\
\end{tabular} & \begin{tabular}{|c|} 
REGR factor score \\
2 for analysis 1
\end{tabular} & $\begin{array}{c}\text { REGR factor score } \\
3 \text { for analysis } 1 \\
\end{array}$ \\
\hline \multirow[t]{3}{*}{$\mathrm{X} 1$} & Pearson Correlation & 1 & -.285 & $.824^{* * *}$ & .447 \\
\hline & Sig. (2-tailed) & & .303 & .000 & .095 \\
\hline & $\mathrm{N}$ & 15 & 15 & 15 & 15 \\
\hline
\end{tabular}

**. Correlation is significant at the 0.01 level (2-tailed).

Hair dkk. (2010:134) menyatakan sebagai berikut.

"As anticipated, the first factor accounts for the largest amount of variance in Table 7. The second factor is somewhat of a general factor, with half of the variables having a high loading (high loading is defined as greater than 0,4). The third factor has two high loadings, whereas the fourth factor only has one high loading. Based on this factor-loading pattern with a relatively large number of high loadings on factor 2 and only one high loading on factor 4, interpretation would be difficult and theoretically less meaningful. Therefore, the researcher should process to rotate the factor matrix to redistribute the variance from the earlier factors to the later factors. However, before proceeding with rotation process, we must examine the communalities to see whether any variables have communalities so low that they should be eliminated."

Berdasarkan uraian di atas, nilai factor loading dikatakan tinggi apabila di atas 0,4. Diketahui nilai korelasi antara variabel X1 dan faktor kedua adalah 0,824 , sementara korelasi antara variabel X1 dan faktor ketiga adalah 0,447. Karena kedua nilai factor loading termasuk tinggi, maka akan sulit untuk ditentukan, apakah variabel X1 akan masuk ke dalam faktor kedua atau ketiga. Begitu juga diketahui nilai korelasi antara variabel X2 dan faktor pertama adalah 0,673, korelasi antara variabel X2 dan faktor kedua adalah -0,420, sementara korelasi antara variabel X2 dan faktor ketiga adalah 0,582. Karena ketiga nilai factor loading termasuk tinggi, maka akan sulit untuk ditentukan, apakah variabel X2 akan masuk ke dalam faktor pertama, kedua atau ketiga. Oleh karena itu Hair dkk. (2010:134) menyarankan agar dilakukan proses rotasi. 


\section{Rotated Component Matrix (After Rotation)}

Perhatikan Tabel 21.11 (Rotated Component Matrix). Pada Tabel 21.11 juga menyajikan nilai factor loading, namun telah melalui proses rotasi. Pada Tabel 21.11, proses untuk menentukan apakah suatu variabel masuk ke dalam faktor pertama, kedua, atau ketiga terlihat lebih mudah. Hal ini dikarenakan suatu variabel hanya memiliki nilai korelasi yang tinggi, pada salah satu faktor saja. Sebagai contoh, untuk variabel X1 hanya memiliki nilai korelasi yang tinggi pada faktor yang ketiga $(0,961>0,4)$, sementara nilai korelasi antara variabel X1 dan faktor pertama adalah $0,122(0,122<0,4)$, dan nilai korelasi antara variabel $\mathrm{X} 1$ dan faktor kedua adalah $-0,142(|-0,142|<0,4)$, sehingga dapat ditentukan variabel X1 masuk ke dalam faktor ketiga.

Perhatikan bahwa metode rotasi yang digunakan adalah metode rotasi varimax. Jika dilihat pada Gambar 21.1, ketiga faktor tersebut adalah FAC1_2, FAC2_2, dan FAC3_2. Nilai-nilai yang tersaji pada Tabel 21.11 merupakan nilai korelasi antara variabel dan faktor (faktor yang terbentuk dengan metode PCA, dengan metode rotasi varimax). Sebagai contoh nilai korelasi (korelasi Pearson) antara variabel X1 dan FAC1_2 (faktor atau component pertama) adalah 0,122, nilai korelasi antara variabel X1 dan FAC2_2 (faktor atau component kedua) adalah 0,142, dan nilai korelasi antara variabel X1 dan FAC3_2 (faktor atau component ketiga) adalah 0,961 . Nilai korelasi antara variabel dan faktor disebut dengan factor loading. Gambar 21.5 merupakan tampilan untuk menghitung korelasi antara variabel X1 dengan masingmasing faktor (FAC1_2, FAC2_2, dan FAC3_2). Hasilnya ditunjukkan pada Tabel 21.12.

Gambar 21.6 merupakan modifikasi dari Tabel 21.11, di mana hanya menyajikan nilai factor loading yang lebih besar dari 0,4. Berdasarkan Gambar 21.6 dapat ditarik informasi sebagai berikut.

$\Rightarrow$ Variabel X1 dan X6 masuk ke dalam faktor ketiga.

$\Rightarrow$ Variabel X2 dan X5 masuk ke dalam faktor kedua.

$\Rightarrow$ Variabel X3, X4, dan X7 masuk ke dalam faktor pertama.

Tabel 21.11

\begin{tabular}{|l|r|r|r|}
\multicolumn{4}{c|}{ Rotated Component Matrix } \\
\hline \multirow{2}{*}{} & \multicolumn{3}{|c|}{ Component } \\
\cline { 2 - 4 } & 1 & 2 & \multicolumn{1}{c|}{3} \\
\hline X1 & .122 & -.142 & .961 \\
X2 & .073 & .969 & -.156 \\
X3 & .879 & .178 & .098 \\
X4 & .954 & .046 & -.022 \\
X5 & .220 & .937 & -.194 \\
X6 & -.062 & -.192 & .957 \\
X7 & .895 & .120 & -.006 \\
\hline
\end{tabular}

Extraction Method: Principal Component Analysis.

Rotation Method: Varimax with Kaiser

Normalization.

a. Rotation converged in 5 iterations. 


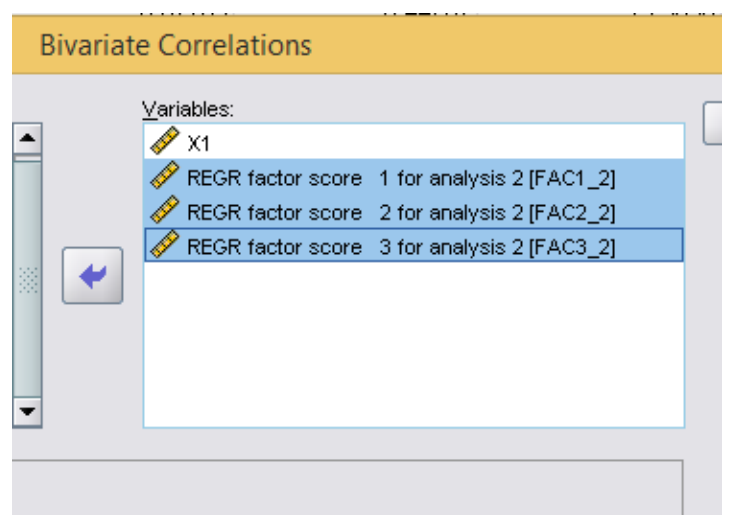

Gambar 21.5

\begin{tabular}{|l|r|r|r|}
\hline \multicolumn{5}{|c|}{ Rotated Component Matrix } \\
\hline & \multicolumn{3}{|c|}{ Component } \\
\cline { 2 - 4 } & \multicolumn{1}{|c|}{1} & \multicolumn{1}{c|}{2} & \multicolumn{1}{c|}{3} \\
\hline $\mathrm{X} 1$ & & .969 & \\
$\mathrm{X} 2$ & & .961 \\
$\mathrm{X} 3$ & .879 & & \\
$\mathrm{X} 4$ & .954 & & \\
$\mathrm{X} 5$ & & .937 & \\
$\mathrm{X} 6$ & & & \\
$\mathrm{X} 7$ & & & \\
\hline
\end{tabular}

Gambar 21.6

Tabel 21.12

\begin{tabular}{|c|c|c|c|c|c|}
\hline \multicolumn{6}{|c|}{ Correlations } \\
\hline & & $\mathrm{X} 1$ & $\begin{array}{c}\text { REGR factor score } \\
1 \text { for analysis } 2\end{array}$ & $\begin{array}{c}\text { REGR factor score } \\
2 \text { for analysis } 2\end{array}$ & $\begin{array}{c}\text { REGR factor score } \\
3 \text { for analysis } 2\end{array}$ \\
\hline \multirow[t]{3}{*}{$\mathrm{X} 1$} & Pearson Correlation & 1 & .122 & -.142 & $.961^{* * *}$ \\
\hline & Sig. (2-tailed) & & .665 & .614 & .000 \\
\hline & $\mathrm{N}$ & 15 & 15 & 15 & 15 \\
\hline
\end{tabular}

**. Correlation is significant at the 0.01 level (2-tailed). 


\section{PENYELESAIAN DALAM SPSS}

Bangun data dalam SPSS, seperti pada Gambar 21.1. Selanjutnya pilih Analyze $=>$ Dimension Reduction $\Rightarrow$ Factor (Gambar 21.2), sehingga muncul tampilan Factor Analysis (Gambar 21.3). Pada Gambar 21.3, pindahkan ketujuh variabel ke dalam kotak Variables. Kemudian pilih Descriptive, sehingga muncul tampilan Factor Analysis: Descriptives (Gambar 21.4). Pada Gambar 21.4, pilih Initial Solution, Anti-image, dan KMO and Bartlett's test of sphericity. Selanjutnya pilih Continue. Kemudian pilih Extraction (Gambar 21.3), sehingga muncul tampilan Factor Analysis: Extraction (Gambar 21.5). Pada Gambar 21.5, pilih Principal Components pada bagian Method, bulatkan Based on Eigenvalue, dan isi 1 pada Eigenvalues greater than: Selanjutnya pilih Continue. Kemudian pilih Rotation (Gambar 21.3), sehingga muncul tampilan Factor Analysis: Rotation (Gambar 21.6). Pilih Varimax, kemudian pilih Continue. Selanjutnya pilih Scores (Gambar 21.3), sehingga muncul tampilan Factor Analysis: Factor Scores (Gambar 21.7). Pada Gambar 21.7, pilih Save as variables, dan bulatkan Regression. Kemudian pilih Continue dan OK.

\begin{tabular}{|c|c|c|c|c|c|c|c|}
\hline & $\mathrm{X} 1$ & $\times 2$ & $\times 3$ & $\times 4$ & $\times 5$ & $\times 6$ & $\times 7$ \\
\hline 1 & 1 & 5 & 1 & 1 & 5 & 4 & 1 \\
\hline 2 & 2 & 6 & 4 & 4 & 10 & 2 & 4 \\
\hline 3 & 3 & 7 & 2 & 2 & 7 & 3 & 2 \\
\hline 4 & 4 & 8 & 3 & 3 & 8 & 1 & 3 \\
\hline 5 & 5 & 9 & 3 & 3 & 9 & 5 & 3 \\
\hline 6 & 6 & 4 & 2 & 2 & 6 & 6 & 2 \\
\hline 7 & 7 & 1 & 3 & 3 & 1 & 7 & 3 \\
\hline 8 & 8 & 2 & 3 & 3 & 2 & 8 & 3 \\
\hline 9 & 9 & 3 & 1 & 1 & 3 & 9 & 1 \\
\hline 10 & 8 & 4 & 2 & 2 & 4 & 10 & 2 \\
\hline 11 & 1 & 5 & 1 & 1 & 5 & 1 & 1 \\
\hline 12 & 2 & 1 & 1 & 1 & 1 & 2 & 1 \\
\hline 13 & 3 & 2 & 2 & 4 & 2 & 3 & 3 \\
\hline 14 & 4 & 3 & 3 & 2 & 3 & 4 & 3 \\
\hline 15 & 5 & 4 & 4 & 3 & 4 & 5 & 1 \\
\hline
\end{tabular}

Gambar 21.1

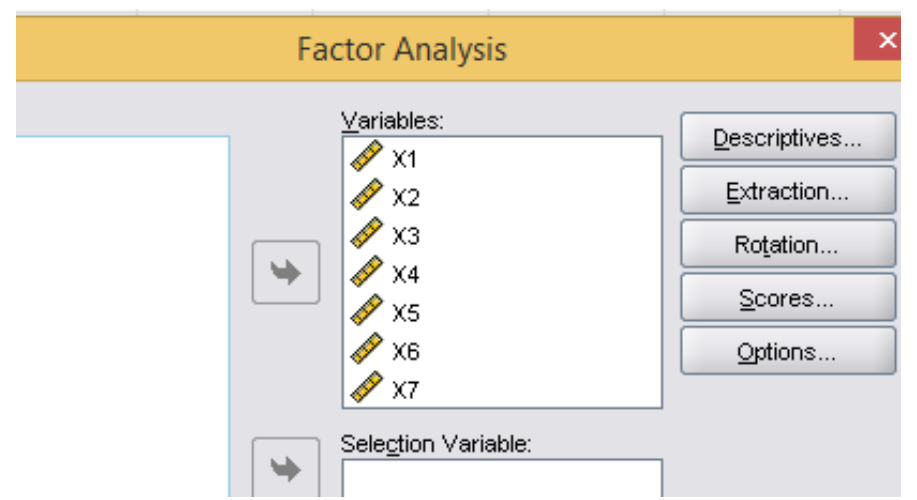

Gambar 21.3

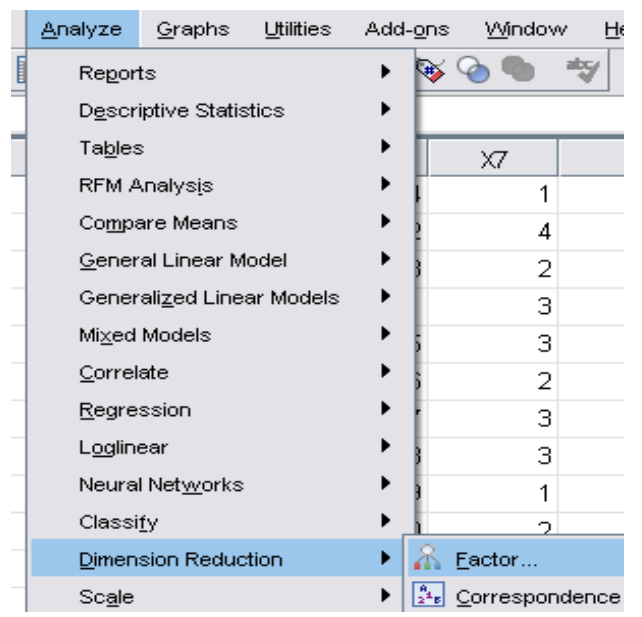

Gambar 21.2

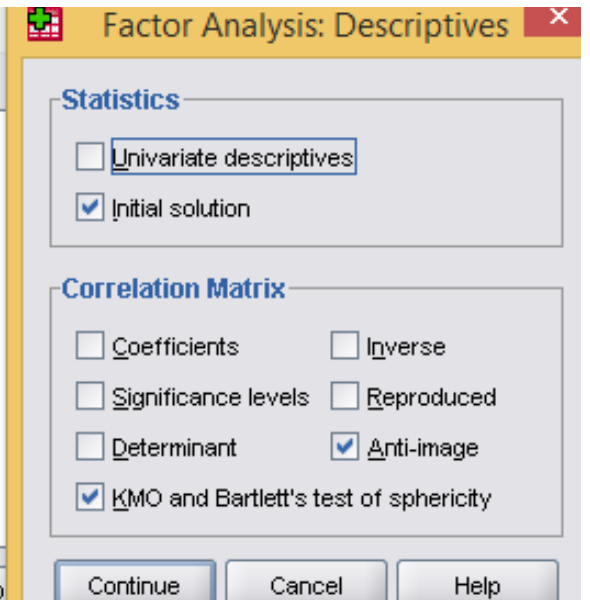

Gambar 21.4 


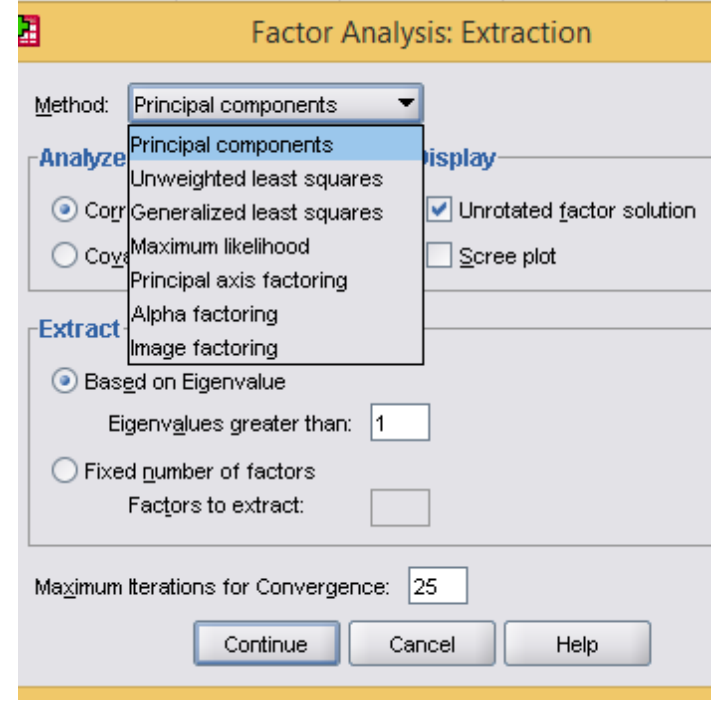

Gambar 21.5

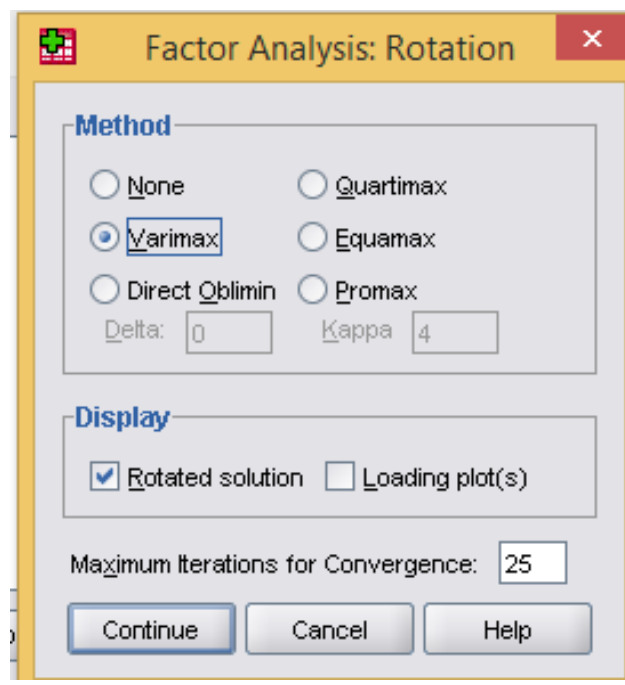

Gambar 21.6

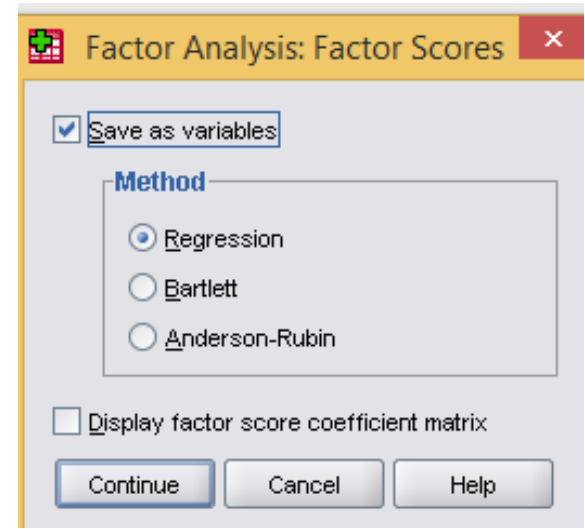

\section{Gambar 21.7}

Untuk interpretasi dari output SPSS ini, telah dibahas pada pembahasan teori analisis faktor sebelumnya. 


\section{$S \mathcal{H A R E}$}

[1] Perhatikan Tabel 21.1 (Communalities). Nilai communalities untuk variabel X1 (lihat kolom Extraction, baris X1) adalah 0,976. Nilai tersebut dapat diartikan faktor-faktor yang telah terbentuk (berdasarkan metode principal component analysis, disingkat PCA, metode rotasi Varimax) dapat menjelaskan variance dari variabel X1 sebesar 97,6\%, faktor-faktor yang telah terbentuk dapat menjelaskan variance dari variabel X2 sebesar $96 \%$, dan seterusnya.

\section{Tabel 21.1}

\begin{tabular}{|c|c|c|}
\hline \multicolumn{3}{|c|}{ Communalities } \\
\hline & Initial & Extraction \\
\hline $\mathrm{X} 1$ & 1.000 & .976 \\
\hline $\mathrm{X} 2$ & 1.000 & .960 \\
\hline X3 & 1.000 & .908 \\
\hline $\mathrm{X} 4$ & 1.000 & .906 \\
\hline $\mathrm{X} 5$ & 1.000 & .967 \\
\hline X6 & 1.000 & .971 \\
\hline $\mathrm{X} 7$ & 1.000 & .919 \\
\hline
\end{tabular}

Field (2009:637) menyatakan sebagai berikut.

"The second approach is to estimate the amount of common variance by estimating communality values for each variable. There are various methods of estimating communalities but the most widely used (including alpha factoring) is to use the squared multiple correlation (SMC) of each variable with all others. So, for the popularity data, imagine you ran a multiple regression using one measure (Selfish) as the outcome and the other five measures as predictors: the resulting multiple $R^{2}$ (see section 7.5.2) would be used as an estimate of the communality for the variable Selfish. This second approach is used in factor analysis. These estimates allow the factor analysis to be done. Once the underlying factors have been extracted, new communalities can be calculated that represent the multiple correlation between each variable and the factors extracted. Therefore, the communality is a measure of the proportion of variance explained by the extracted factors."

Gambar 21.1 menyajikan tiga faktor yang telah terbentuk, yakni FAC1_1, FAC2_1, dan FAC3_1 (faktor-faktor tersebut dibentuk dengan metode PCA, kemudian dirotasi dengan metode Varimax). 


\begin{tabular}{|c|c|c|c|c|c|c|c|c|c|c|c|c|c|c|}
\hline File É Edit & View & Dat & $\underline{\operatorname{Ir}}$ & ansform & enalyz & Graphs & Uيtilities Add- & -ons Windo & $w$ & elp & & & & \\
\hline 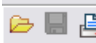 & 画 & 6 & & 盖圆娄? & \$4 & 㥜典 & 畫里四 & $\Leftrightarrow 80$ & $\operatorname{dyg}$ & & & & & \\
\hline $1: \times 4$ & & & 3.0 & & & & & & & & & & & Visible: 10 \\
\hline & & $\mathrm{x}_{1}$ & & $\times 2$ & & $\times 3$ & $\times 4$ & $\times 5$ & & $\times 6$ & $x 7$ & FAC1_1 & FAC2_1 & FAC3_1 \\
\hline 1 & & & 3 & & 3 & 3 & 3 & & 2 & 3 & 3 & $0 . \overline{2} 3182$ & $0 . \overline{5} 1313$ & $0 . \overline{4} 1486$ \\
\hline 2 & & & 2 & & 2 & 3 & 2 & & 2 & 2 & 3 & 0.27123 & -0.00388 & -0.96580 \\
\hline 3 & & & 2 & & 1 & 2 & 3 & & 1 & 2 & 3 & 0.25571 & -1.33827 & -0.80386 \\
\hline 4 & & & 2 & & 2 & 3 & 3 & & 2 & 2 & 2 & 0.28095 & 0.17837 & -0.99605 \\
\hline 5 & & & 2 & & 2 & 3 & 3 & & 2 & 2 & 3 & 0.68722 & -0.01478 & -1.04728 \\
\hline 6 & & & 4 & & 1 & 2 & 4 & & 1 & 4 & 4 & 0.22691 & -1.58708 & 1.97357 \\
\hline 7 & & & 3 & & 2 & 3 & 3 & & 2 & 4 & 3 & 0.05057 & -0.05115 & 1.10507 \\
\hline 8 & & & 2 & & 2 & 3 & 4 & & 2 & 2 & 4 & 1.50947 & -0.21884 & -1.17999 \\
\hline 9 & & & 3 & & 4 & 4 & 4 & & 4 & 3 & 2 & 0.64139 & 2.60679 & 0.12547 \\
\hline 10 & & & 2 & & 1 & 2 & 2 & & 1 & 2 & 2 & -0.56655 & -1.13421 & -0.67115 \\
\hline 11 & & & ? & & 2 & 1 & 1 & & 2 & 2 & 1 & -1 ดАว२7 & ก กวว77 & ח31ว3ว \\
\hline
\end{tabular}

\section{Gambar 21.1}

Selanjutnya melakukan regresi linear (linear regression), dengan $\mathrm{X} 1$ sebagai variabel tak bebas, sedangkan FAC1_1, FAC2_1, dan FAC3_1 sebagai variabel bebas (perhatikan Gambar 21.2). Hasilnya seperti pada Tabel 21.2.

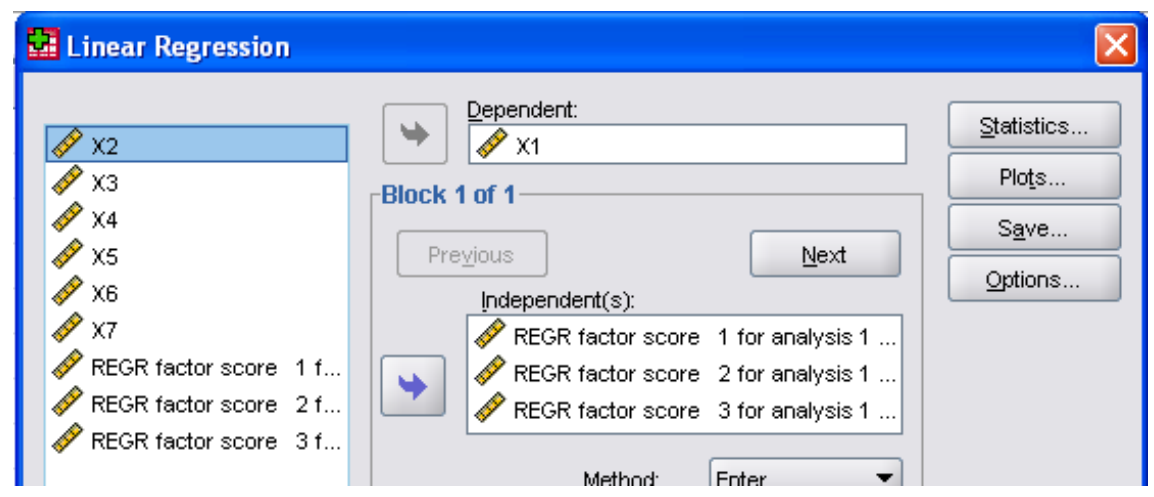

Gambar 21.2

Tabel 21.2

Variables Entered/Removed

\begin{tabular}{|l|l|l|l|}
\hline Model & \multicolumn{1}{|c|}{ Variables Entered } & Variables Removed & Method \\
\hline 1 & $\begin{array}{l}\text { REGR factor score 3 for analysis 1, } \\
\text { REGR factor score 2 for analysis 1, } \\
\text { REGR factor score 1 for analysis 1 }\end{array}$ & & Enter \\
\hline
\end{tabular}

a. All requested variables entered.

\begin{tabular}{|l|r|r|r|r|}
\hline Model & \multicolumn{1}{|c|}{ R } & \multicolumn{1}{|c|}{ R Square } & Adjusted R Square & $\begin{array}{l}\text { Std. Error of the } \\
\text { Estimate }\end{array}$ \\
\hline 1 & $.988^{\mathrm{a}}$ & .976 & .970 & .128 \\
\hline
\end{tabular}

a. Predictors: (Constant), REGR factor score 3 for analysis 1, REGR factor score 2 for analysis 1 , REGR factor score 1 for analysis 1

Berdasarkan Tabel 21.2, diketahui nilai $R$-Square adalah 0,976. Nilai tersebut dapat diartikan variabel FAC1_1, FAC2_1, dan FAC3_1 mampu menjelaskan variance dari variabel X1 sebesar $97,6 \%$. Nilai $R$-square tersebut sama dengan nilai communalities variabel X1 pada 
Tabel 21.1. Gambar 21.3 menyajikan skor dari masing-masing faktor dengan metode PCA, metode rotasi Varimax dan Equamax. Gambar 21.4 menyajikan berbagai metode rotasi.

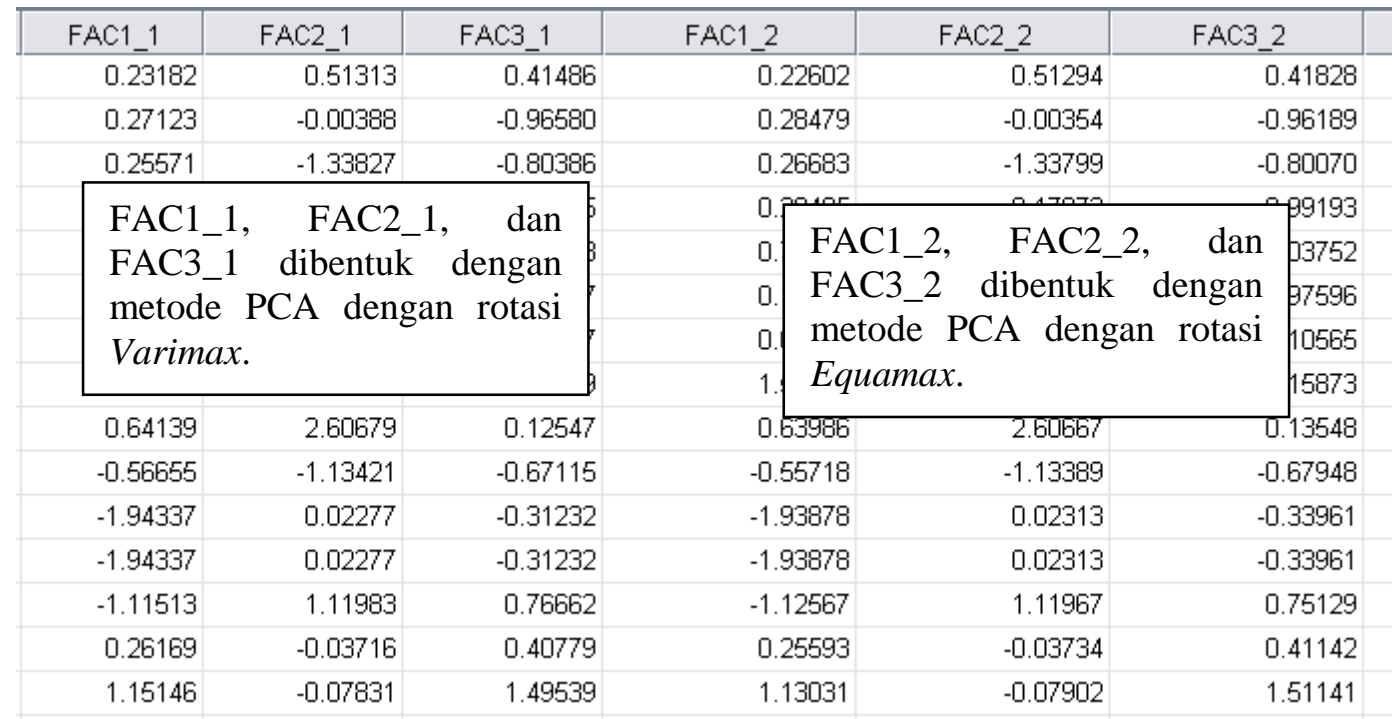

Gambar 21.3

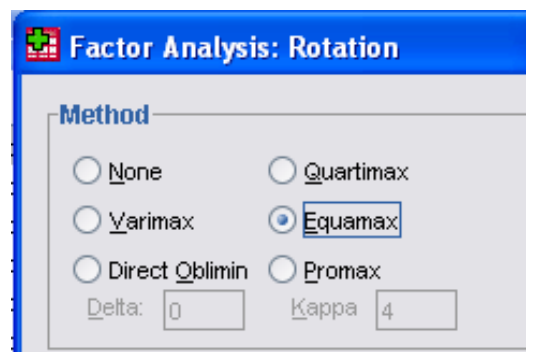

Gambar 21.4

Pada Gambar 21.5, faktor FAC_1, FAC2_1, dan FAC3_1 dibentuk dengan metode PCA, metode rotasi Varimax, sedangkan faktor FAC1_3, FAC2_3, dan FAC3_3 dibentuk dengan metode Maximum Likelihood, metode rotasi Varimax. Gambar 21.6 menyajikan metodemetode ekstraksi, yakni berbagai metode untuk membentuk suatu faktor.

\begin{tabular}{|c|c|c|c|c|c|c|c|c|}
\hline FAC1_1 & FAC2_1 & FAC3_1 & FAC1_2 & FAC2_2 & FAC3_2 & FAC1_3 & $\mathrm{FAC}_{2} 33$ & FAC3_3 \\
\hline 0.23182 & 0.51313 & 0.41486 & 0.22602 & 0.51294 & 0.41828 & 0.21752 & 0.19960 & 0.48652 \\
\hline 0.27123 & -0.00388 & -0.96580 & 0.28479 & -0.00354 & -0.96189 & 0.19259 & 0.01348 & -0.90746 \\
\hline 0.25571 & -1.33827 & -0.80386 & 0.26683 & -1.33799 & -0.80070 & 0.26237 & -1.29866 & -0.81846 \\
\hline 0.28095 & 0.17837 & -0.99605 & 0.29495 & 0.17872 & -0.99193 & 0.17806 & 0.06470 & -0.90770 \\
\hline 0.68722 & -0.01478 & -1.04728 & 0.70188 & -0.01446 & -1.03752 & 0.63918 & 0.01269 & -1.03613 \\
\hline 0.22691 & -1.58708 & 1.97357 & 0.19895 & -1.58786 & 1.97596 & 0.30054 & -1.45983 & 2.01589 \\
\hline 0.05057 & -0.05115 & 1.10507 & 0.03501 & -0.05158 & 1.10565 & 0.20537 & -0.04362 & 0.52191 \\
\hline 1.50947 & -0.21884 & -1.17999 & 1.52589 & -0.21857 & -1.15873 & 1.54689 & -0.04010 & -1.29322 \\
\hline 0.64139 & 2.60679 & 0.12547 & 0.63986 & 2.60667 & 0.13548 & 0.60292 & 2.59841 & 0.17619 \\
\hline-0.56655 & -1.13421 & -0.67115 & -0.55718 & -1.13389 & -0.67948 & -0.64534 & -1.24586 & -0.56137 \\
\hline-1.94337 & 0.02277 & -0.31232 & -1.93878 & 0.02313 & -0.33961 & -1.85740 & 0.05026 & -0.31760 \\
\hline-1.94337 & 0.02277 & -0.31232 & -1.93878 & 0.02313 & -0.33961 & -1.85740 & 0.05026 & -0.31760 \\
\hline-1.11513 & 1.11983 & 0.76662 & -1.12567 & 1.11967 & 0.75129 & -1.00765 & 1.25463 & 0.75337 \\
\hline 0.26169 & -0.03716 & 0.40779 & 0.25593 & -0.03734 & 0.41142 & 0.20441 & -0.04149 & 0.50960 \\
\hline 1.15146 & -0.07831 & 1.49539 & 1.13031 & -0.07902 & 1.51141 & 1.01793 & -0.11446 & 1.69606 \\
\hline
\end{tabular}

Gambar 21.5 


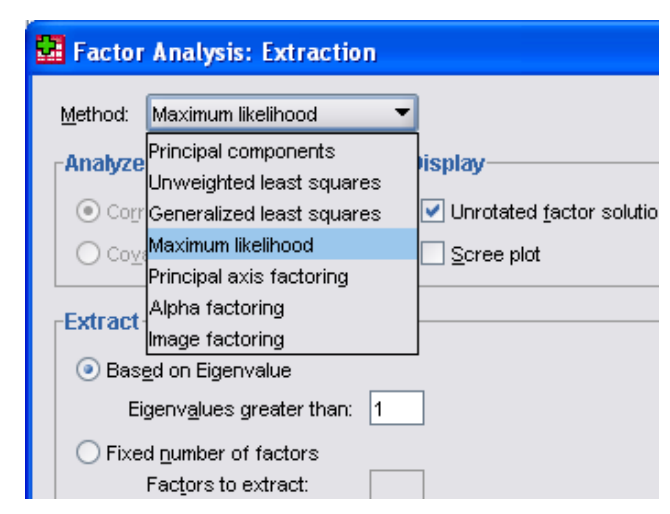

\section{Gambar 21.6}

[2] Eigenvalues merupakan salah satu pendekatan yang dapat digunakan untuk menentukan jumlah faktor yang akan dipertahankan dalam analisis. (selain pendekatan eigenvalues, terdapat pendekatan scree plot). Pada Tabel 21.3 terdapat 7 faktor atau component yang terbentuk (diketahui jumlah variabel juga 7), namun tidak semua faktor akan dipertahankan dalam analsis selanjutnya. Pada Tabel 21.3, dari 7 faktor yang terbentuk, hanya 3 faktor yang dipertahankan dalam analisis, yakni faktor atau component 1, 2, dan 3. Sebagaimana Field (2009:639) menyatakan sebagai berikut.

"Not all factors are retained in an analysis, and there is debate over the criterion used to decide whether a factor is statistically important. I mentioned above that eigenvalues associated with a variate indicate the substantive importance of that factor. Therefore, it seems logical that we should retain only factors with large eigenvalues... Typically there will be a few factors with quite high eigenvalues, and many factors with relatively low eigenvalues, ..."

Pperhatikan Gambar 21.7 (Factor Analysis: Extraction). Pada Gambar 21.7, bagian Based on Eigenvalues, Eigenvalues greater than: diisi dengan 1. Hal ini berarti suatu faktor akan terbentuk (akan dipertahankan dalam analisis selanjutnya), jika faktor tersebut memiliki eigenvalue (nilai eigen) lebih besar dari 1. Berdasarkan Tabel 21.3, diketahui eigenvalue untuk faktor atau component pertama adalah 3,44, eigenvalue untuk faktor atau component kedua adalah 2,150, dan eigenvalue untuk faktor atau component ketiga adalah 1,1018. Pada Tabel 21.4 (Component Matrix), hanya tiga faktor atau component yang dianalsis.

Tabel 21.3

Total Variance Explained

\begin{tabular}{|l|r|r|r|r|r|r|}
\hline \multirow{2}{*}{$\begin{array}{l}\text { Compon } \\
\text { ent }\end{array}$} & \multicolumn{3}{|c|}{ Initial Eigenvalues } & \multicolumn{2}{|c|}{ Extraction Sums of Squared Loadings } \\
\cline { 2 - 7 } & Total & \% of Variance & Cumulative \% & Total & \% of Variance & Cumulative \% \\
\hline 1 & 3.440 & 49.136 & 49.136 & 3.440 & 49.136 & 49.136 \\
2 & 2.150 & 30.709 & 79.845 & 2.150 & 30.709 & 79.845 \\
3 & 1.018 & 14.540 & 94.385 & 1.018 & 14.540 & 94.385 \\
4 & .166 & 2.364 & 96.749 & & & \\
5 & .133 & 1.896 & 98.644 & & & \\
6 & .054 & .766 & 99.410 & & & \\
7 & .041 & .590 & 100.000 & & & \\
\hline
\end{tabular}

Extraction Method: Principal Component Analysis. 


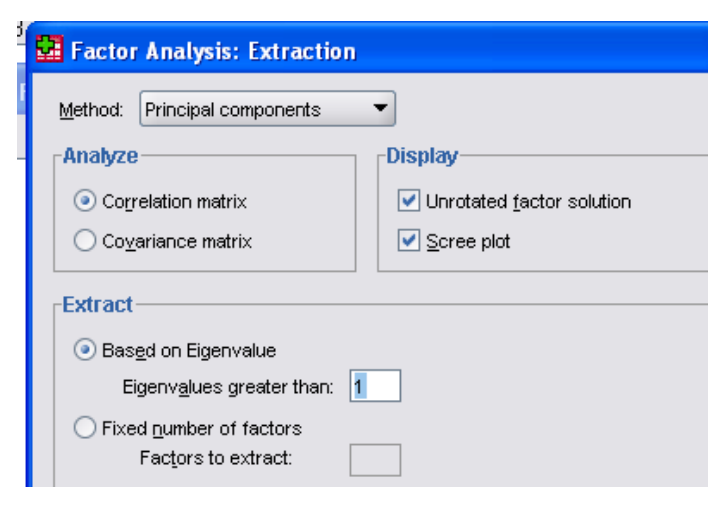

\section{Gambar 21.7}

Tabel 21.4

\begin{tabular}{|c|c|c|c|}
\hline \multicolumn{4}{|c|}{ Component Matrix ${ }^{a}$} \\
\hline & \multicolumn{3}{|c|}{ Component } \\
\hline & 1 & 2 & 3 \\
\hline $\mathrm{X} 1$ & .823 & -.112 & -.535 \\
\hline $\mathrm{X} 2$ & .325 & .924 & -.008 \\
\hline X3 & .801 & .218 & .468 \\
\hline $\mathrm{X} 4$ & .868 & -.184 & .343 \\
\hline $\mathrm{X} 5$ & .291 & .940 & .006 \\
\hline X6 & .806 & -.120 & -.554 \\
\hline X7 & .726 & -.552 & .296 \\
\hline
\end{tabular}

Extraction Method: Principal Component Analysis.

a. 3 components extracted.

Tabel 21.5

\begin{tabular}{l|r|r|}
\hline & \multicolumn{1}{|c|}{ Communalities } \\
\hline In1 & Extraction \\
X2 & 1.000 & .976 \\
X3 & 1.000 & .960 \\
X4 & 1.000 & .908 \\
X5 & 1.000 & .906 \\
X6 & 1.000 & .967 \\
X7 & 1.000 & .971 \\
Extraction Method: Principal \\
Component Analysis.
\end{tabular}

Field (2009:640) menyatakan sebagai berikut.

"Although scree plots are very useful, factor selection should not be based on this criterion alone. Kaiser (1960) recommended retaining all factors with eigenvalues greater than 1. This criterion is based on the idea that the eigenvalues represent the amount of variation explained by a factor and that an eigenvalue of 1 represents a substantial amount of variation."

Berdasarkan uraian di atas, Kaiser (1960) memberi rekomendasi bahwa eigenvalue dari suatu faktor yang lebih besar dari 1, agar dipertahankan dalam proses analisis. 


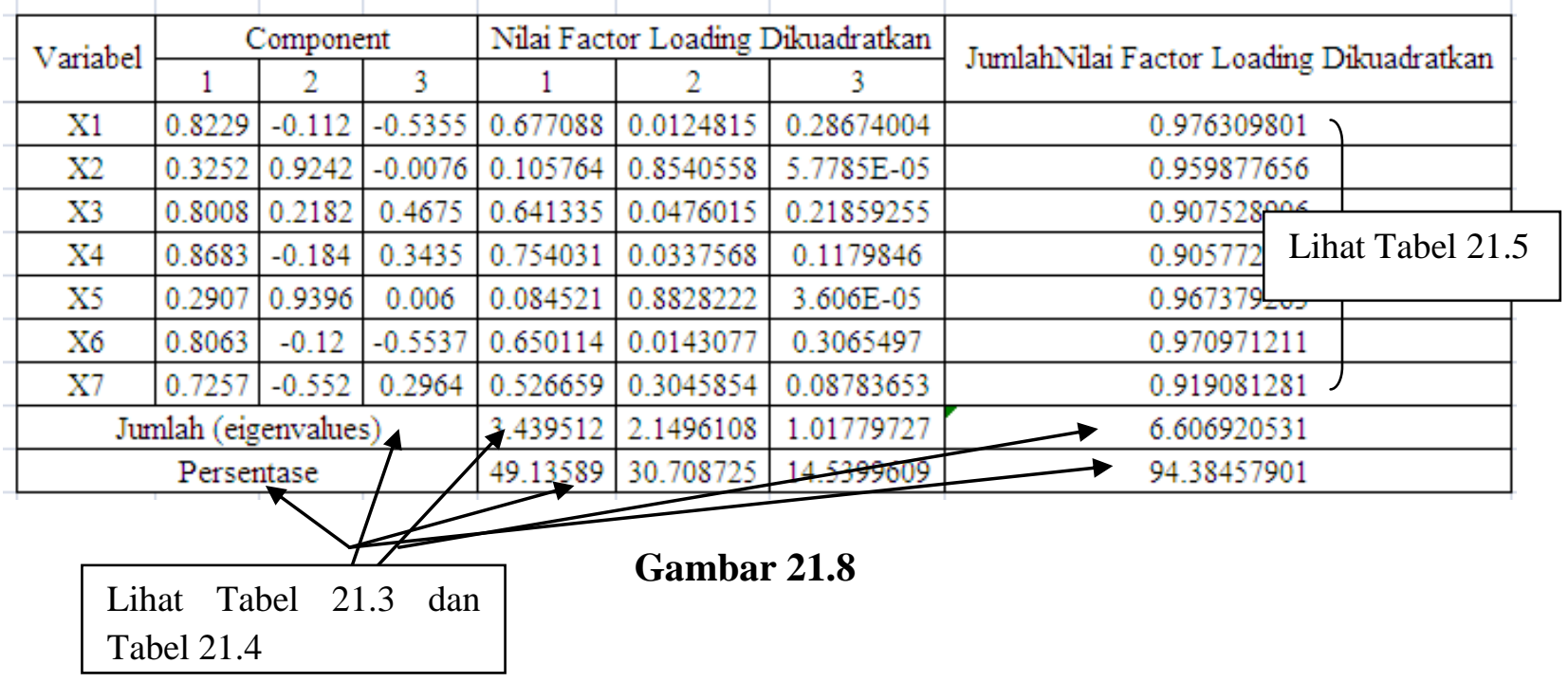

[3] Perhatikan Tabel 21.6 (Anti-image Matrices), pada bagian Anti-image Correlation. Nilainilai pada posisi diagonal, yakni $0,617^{\mathrm{a}}, 0,582^{\mathrm{a}}$, dan seterusnya merupakan nilai-nilai measures of sampling adequacy (atau disebut juga Kaiser-Meyer-Olkin Measure of Sampling Adequacy, disingkat KMO MSA). Diketahui nilai KMO MSA untuk variabel X1 adalah 0,617, nilai KMO MSA untuk variabel X2 adalah 0,582, dan seterusnya. Sementara nilai-nilai selain pada posisi diagonal merupakan nilai korelasi parsial negatif (negative partial correlations) antar variabel (partial correlation among variables). Gambar 21.9 dan Gambar 21.10 merupakan langkah-langkah dalam SPSS untuk menentukan nilai korelasi antara X1 dan X3, dengan mengontrol pengaruh dari X2, X4, X5, X6, dan X7.

Tabel 21.6

Anti-image Matrices

\begin{tabular}{|ll|r|r|r|r|r|r|r|}
\hline & & \multicolumn{1}{c|}{$\mathrm{X} 1$} & \multicolumn{1}{c|}{$\mathrm{X} 2$} & \multicolumn{1}{c|}{$\mathrm{X} 3$} & \multicolumn{1}{c|}{$\mathrm{X} 4$} & \multicolumn{1}{c|}{$\mathrm{X} 5$} & \multicolumn{1}{c|}{$\mathrm{X} 6$} & \multicolumn{1}{c|}{$\mathrm{X} 7$} \\
\hline Anti-image Covariance & $\mathrm{X} 1$ & .084 & -.016 & .036 & -.030 & .006 & -.082 & -.011 \\
& $\mathrm{X} 2$ & -.016 & .097 & -.027 & .021 & -.082 & .013 & -.002 \\
& $\mathrm{X} 3$ & .036 & -.027 & .245 & -.096 & -.022 & -.027 & -.077 \\
& $\mathrm{X} 4$ & -.030 & .021 & -.096 & .199 & -.025 & .021 & -.103 \\
& $\mathrm{X} 5$ & .006 & -.082 & -.022 & -.025 & .090 & -.007 & .046 \\
& $\mathrm{X} 6$ & -.082 & .013 & -.027 & .021 & -.007 & .093 & -.002 \\
& $\mathrm{X} 7$ & -.011 & -.002 & -.077 & -.103 & .046 & -.002 & .195 \\
\hline Anti-image Correlation & $\mathrm{X} 1$ & $.617^{\mathrm{a}}$ & -.181 & .253 & -.234 & .072 & -.928 & -.088 \\
& $\mathrm{X} 2$ & -.181 & $.582^{\mathrm{a}}$ & -.176 & .154 & -.870 & .132 & -.013 \\
& $\mathrm{X} 3$ & .253 & -.176 & $.770^{\mathrm{a}}$ & -.436 & -.148 & -.176 & -.353 \\
& $\mathrm{X} 4$ & -.234 & .154 & -.436 & $.751^{\mathrm{a}}$ & -.183 & .154 & -.522 \\
& $\mathrm{X} 5$ & .072 & -.870 & -.148 & -.183 & $.558^{\mathrm{a}}$ & -.079 & .344 \\
& $\mathrm{X} 6$ & -.928 & .132 & -.176 & .154 & -.079 & $.627^{\mathrm{a}}$ & -.013 \\
& $\mathrm{X} 7$ & -.088 & -.013 & -.353 & -.522 & .344 & -.013 & $.749^{\mathrm{a}}$ \\
\hline
\end{tabular}

a. Measures of Sampling Adequacy(MSA) 


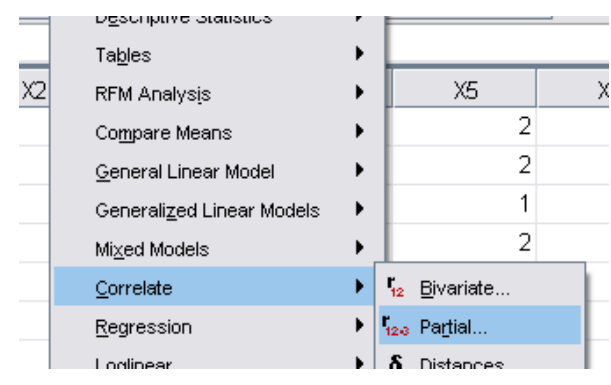

Gambar 21.9

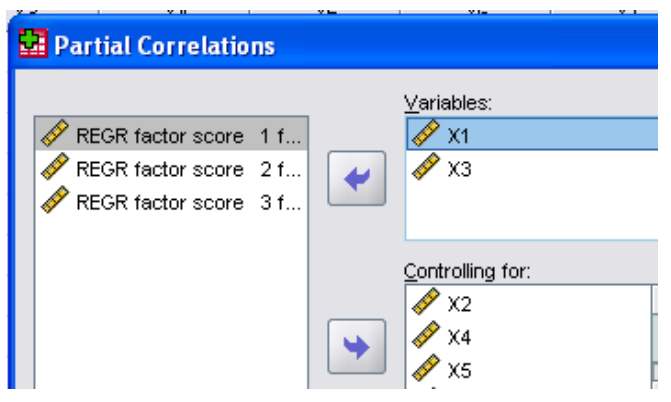

Gambar 21.10

Tabel 21.7 menyajikan nilai korelasi antara X1 dan X3, dengan mengontrol pengaruh dari X2, X4, X5, X6, dan X7, yakni bernilai -0,253. Maka korelasi parsial negatifnya adalah $-1 \times-$ $0,253=0,253$. Bandingkan hasilnya pada Tabel 21.6.

Tabel 21.7

\begin{tabular}{|lll|r|r|}
\hline Control Variables & & \multicolumn{1}{|c|}{ Correlations } & \multicolumn{1}{|c|}{ X3 } \\
\hline X2 \& X4 \& X5 \& X6 \& X7 & X1 & Correlation & 1.000 & -.253 \\
& & Significance (2-tailed) &. & .481 \\
& & df & 0 & 8 \\
\cline { 2 - 5 } & X3 & Correlation & -.253 & 1.000 \\
& Significance (2-tailed) & .481 &. \\
& df & 8 & 0 \\
& &
\end{tabular}

[4] Perhatikan Tabel 21.8 (Rotated Component Matrix). Pada Tabel 21.8, telah terbentuk tiga faktor atau component dengan metode PCA, metode rotasi varimax. Nilai-nilai yang tersaji pada Tabel 21.8 merupakan nilai korelasi antara variabel dan faktor (faktor yang terbentuk dengan metode PCA, metode rotasi varimax). Sebagai contoh nilai korelasi (korelasi Pearson) antara X1 dan faktor 1 adalah 0,274, nilai korelasi antara X1 dan faktor 2 adalah 0,080, dan nilai korelasi antara X1 dan faktor 3 adalah 0,946. Nilai korelasi antara variabel dan faktor disebut dengan factor loading. Gambar 21.11 merupakan tampilan untuk menghitung korelasi antara variabel X1 dengan masing-masing faktor. Hasilnya ditunjukkan pada Tabel 21.9.

Tabel 21.8

\begin{tabular}{|l|r|r|r|}
\multicolumn{4}{c|}{ Rotated Component Matrix } \\
\hline \multirow{2}{*}{} & \multicolumn{3}{|c|}{ Component } \\
\cline { 2 - 4 } & 1 & 2 & 3 \\
\hline X1 & .274 & .080 & .946 \\
X2 & .043 & .975 & .084 \\
X3 & .845 & .422 & .126 \\
X4 & .895 & .046 & .319 \\
X5 & .024 & .982 & .049 \\
X6 & .252 & .067 & .950 \\
X7 & .836 & -.347 & .316 \\
\hline
\end{tabular}

Extraction Method: Principal Component Analysis.

Rotation Method: Varimax with Kaiser Normalization.

a. Rotation converged in 4 iterations. 


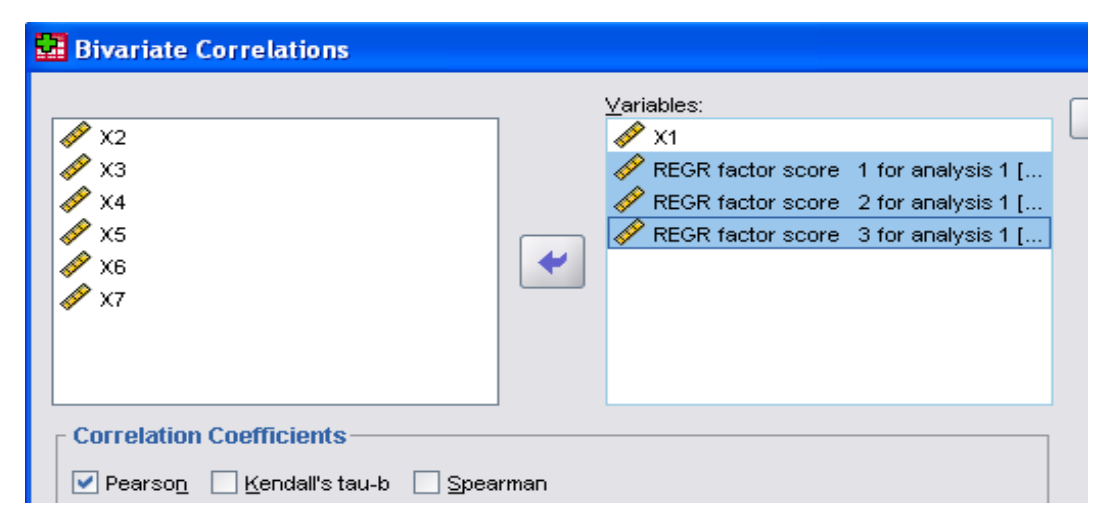

\section{Gambar 21.11}

Tabel 21.9

\begin{tabular}{|c|c|c|c|c|c|}
\hline \multicolumn{6}{|c|}{ Correlations } \\
\hline & & $\mathrm{X} 1$ & $\begin{array}{l}\text { REGR factor } \\
\text { score } 1 \text { for } \\
\text { analysis } 1\end{array}$ & $\begin{array}{l}\text { REGR factor } \\
\text { score } 2 \text { for } \\
\text { analysis } 1\end{array}$ & $\begin{array}{l}\text { REGR factor } \\
\text { score } 3 \text { for } \\
\text { analysis } 1\end{array}$ \\
\hline \multirow[t]{3}{*}{$\mathrm{X} 1$} & Pearson Correlation & 1 & .274 & .080 & $.946^{* *}$ \\
\hline & Sig. (2-tailed) & & .323 & .778 & .000 \\
\hline & $\mathrm{N}$ & 15 & 15 & 15 & 15 \\
\hline
\end{tabular}

**. Correlation is significant at the 0.01 level (2-tailed).

Pada Gambar 21.12, telah terbentuk tiga faktor atau component, yakni FAC1_2, FAC2_2, dan FAC3_2, dengan metode PCA, tanpa menggunakan metode rotasi (lihat Gambar 21.13). Nilai-nilai yang tersaji pada Tabel 21.10 (Component Matrix) merupakan nilai korelasi antara variabel dan faktor. Sebagai contoh nilai korelasi (korelasi Pearson) antara X1 dan faktor 1 (FAC1_2) adalah 0,823, nilai korelasi antara X1 dan faktor 2 (FAC2_2) adalah -0,112, dan nilai korelasi antara X1 dan faktor 3 (FAC3_2) adalah -0,535. Nilai korelasi antara variabel dan faktor disebut dengan factor loading. Gambar 21.14 merupakan tampilan untuk menghitung korelasi antara variabel X1 dengan masing-masing faktor. Hasilnya ditunjukkan pada Tabel 21.11.

\begin{tabular}{|c|c|c|c|c|c|c|c|}
\hline & $\times 7$ & FAC1_1 & FAC2__1 & FAC3_1 & FAC1_2 & FAC2 _2 & FAC3_2 \\
\hline 3 & 3 & 0.23182 & 0.51313 & 0.41486 & 0.56023 & 0.39144 & -0.14856 \\
\hline 2 & 3 & 0.27123 & -0.00388 & -0.96580 & -0.41888 & 0.07621 & 0.90834 \\
\hline 2 & 3 & 0.25571 & -1.33827 & -0.80386 & -0.65592 & -1.23599 & 0.73800 \\
\hline 2 & 2 & 0.28095 & 0.17837 & -0.99605 & -0.38615 & 0.25501 & 0.94272 \\
\hline 2 & 3 & 0.68722 & -0.01478 & -1.04728 & -0.16995 & -0.00807 & 1.24110 \\
\hline 4 & 4 & 0.22691 & -1.58708 & 1.97357 & 1.03283 & -1.86073 & -1.39149 \\
\hline 4 & 3 & 0.05057 & -0.05115 & 1.10507 & 0.72897 & -0.21491 & -0.80546 \\
\hline 2 & 4 & 1.50947 & -0.21884 & -1.17999 & 0.29519 & -0.35543 & 1.87225 \\
\hline 3 & 2 & 0.64139 & 2.60679 & 0.12547 & 1.19074 & 2.37639 & 0.39673 \\
\hline 2 & 2 & -0.56655 & -1.13421 & -0.67115 & -1.12105 & -0.88864 & 0.10685 \\
\hline 2 & 1 & -1.94337 & 0.02277 & -0.31232 & -1.61179 & 0.46364 & -1.03049 \\
\hline
\end{tabular}

Gambar 21.12 


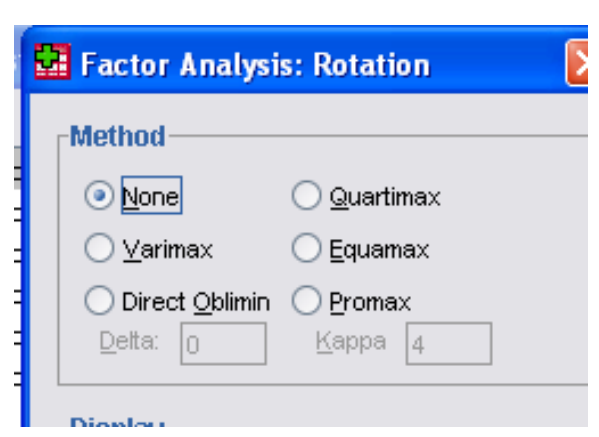

Gambar 21.13

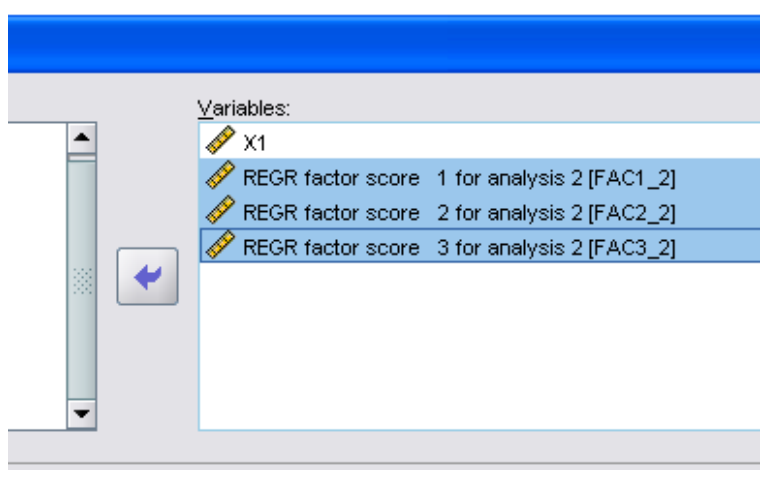

Gambar 21.14

Tabel 21.10

\begin{tabular}{|c|c|c|c|}
\hline \multicolumn{4}{|c|}{ Component Matrix $^{a}$} \\
\hline & \multicolumn{3}{|c|}{ Component } \\
\hline & 1 & 2 & 3 \\
\hline $\mathrm{X} 1$ & .823 & -.112 & -.535 \\
\hline $\mathrm{X} 2$ & .325 & .924 & -.008 \\
\hline X3 & .801 & .218 & .468 \\
\hline X4 & .868 & -.184 & .343 \\
\hline$X 5$ & .291 & .940 & .006 \\
\hline X6 & .806 & -.120 & -.554 \\
\hline $\mathrm{X7}$ & .726 & -.552 & .296 \\
\hline
\end{tabular}

Extraction Method: Principal Component Analysis.

a. 3 components extracted.

\section{Tabel 21.11}

\begin{tabular}{|c|c|c|c|c|c|}
\hline \multicolumn{6}{|c|}{ Correlations } \\
\hline & & $\mathrm{X} 1$ & $\begin{array}{c}\text { REGR factor score } \\
1 \text { for analysis } 2\end{array}$ & $\begin{array}{c}\text { REGR factor score } \\
2 \text { for analysis } 2\end{array}$ & \begin{tabular}{|c} 
REGR factor score \\
3 for analysis 2
\end{tabular} \\
\hline \multirow[t]{3}{*}{$\mathrm{X} 1$} & Pearson Correlation & 1 & $.823^{* * *}$ & -.112 & $-.535^{*}$ \\
\hline & Sig. (2-tailed) & & .000 & .692 & .040 \\
\hline & $\mathrm{N}$ & 15 & 15 & 15 & 15 \\
\hline
\end{tabular}

**. Correlation is significant at the 0.01 level (2-tailed).

*. Correlation is significant at the 0.05 level (2-tailed).

Kuadrat dari factor loading merupakan persentase variance dari suatu variabel yang dijelaskan oleh suatu faktor.

Field (2009:644-645) menyatakan sebagai berikut.

"Once a factor structure has been found, it is important to decide which variables make up (membentuk) which factors. Earlier I said that the factor loadings were a gauge of the substantive importance of a given variable to a given factor. Therefore, it makes sense that we use these values to place variables with factors... This value can be found by squaring the factor loading to give an estimate of the amount of variance in a factor accounted for by a variable (like $\boldsymbol{R}^{\mathbf{2}}$ ). In this respect Stevens (2002) recommends interpreting only factor loadings with an absolute value greater than 0.4 (which explain around $16 \%$ of the variance in the variable)." 
Berdasarkan uraian di atas, kuadrat dari loading factor merupakan jumlah (persentase) variance dari suatu variabel yang dijelaskan oleh suatu faktor. Diketahui berdasarkan Tabel 2.10, faktor 1 menjelaskan variance dari variabel X1 sebesar $(0,823)^{2}=0,677$ atau $67,7 \%$, faktor 2 menjelaskan variance dari variabel X1 sebesar $(-0,112)^{2}=0,0125$ atau $1,25 \%$, dan faktor 3 menjelaskan variance dari variabel X1 sebesar $(-0,535)^{2}=0,286$ atau $28,6 \%$.

Tabel 21.12

\begin{tabular}{|c|c|}
\hline Korelasi X1 dan Tiap-Tiap Faktor & Kuadrat dari Korelasi X1 dan Tiap-Tiap Faktor \\
\hline 0.822853756 & 0.677088304 \\
\hline-0.111720439 & 0.012481456 \\
\hline-0.53548113 & 0.286740041 \\
\hline Jumlah & $\mathbf{0 . 9 7 6 3 0 9 8 0 1}$ (Perhatikan Nilai Communalities X1, \\
& Tabel 21.13) \\
\hline
\end{tabular}

Tabel 21.13

\begin{tabular}{|l|r|r|}
\hline & \multicolumn{2}{|c|}{ Communalities } \\
\hline Xnitial & Extraction \\
X2 & 1.000 & $\mathbf{9 7 6}$ \\
X3 & 1.000 & .960 \\
X4 & 1.000 & .908 \\
X5 & 1.000 & .906 \\
X6 & 1.000 & .967 \\
X7 & 1.000 & .971 \\
Extraction Method: Principal \\
Component Analysis.
\end{tabular}

\section{Referensi}

1. Field, A. 2009. Discovering Statistics Using SPSS, $3^{\text {rd }}$ Edition. London: Sage.

2. Hair, J.F Jr., R.E. Anderson, B.J. Babin, dan W.C. Black. 2010. Multivariate Data Analysis, $7^{\text {th }}$ Edition. Pearson Prentice Hall.

3. Malhotra, N.K. dan D.F. Birks. 2006. Marketing Research, An Applied Approach, $2^{\text {nd }}$ European Edition. London: Prentice Hall.

4. Stevens, J.P. 2009. Applied Multivariate Statistics For The Social Science, $5^{\text {th }}$ Edition. New York: Routledge. 


\section{BAB 22}

\section{ANALISIS KLASTER}

\section{Sekilas Analisis Klaster}

Berikut pemaparan singkat mengenai analisis klaster menurut Hair dkk. (2010:477).

"Cluster analysis groups individuals or objects into clusters so that objects in the same cluster are more similar to one another than they are to objects in other clusters. The attempt is to maximize the homogeneity of objects within the clusters while also maximizing the heterogeneity between clusters."

Malhotra dan Birks (2006:597) menyatakan sebagai berikut.

"Cluster analysis is a class of techniques used to classify objects or cases into relatively homogeneous groups called clusters. Objects in each cluster tend to be similar to each other and dissimilar to objects in the other clusters. Cluster analysis is also called classification analysis or numerical taxonomy ${ }^{3}$. Both cluster analysis and discriminant analysis are concerned with classification. Discriminant analysis, however, requires prior knowledge of the cluster or group membership for each object or case included, to develop the classification rule. In contrast, in cluster analysis there is no a priori information about the group or cluster membership for any of the objects. Groups or clusters are suggested by the data, not defined a priori ${ }^{5}$.

Janssens dkk. (2008:317) menyatakan sebagai berikut.

"The objective of cluster analysis is to take a sample of $n$ individuals or objects, each of which is measured for $p$ variables, and group it into $g$ classes, where $g$ is less than $n$. In other words, the goal is to sort cases (individuals, products, brands, stimuli) into groups so that a high degree of similarity exists between cases in the same group, and a low degree of similarity between cases belonging to different groups. This similarity is evaluated on the basis of the value of each case (individual, product, etc.) for the variables (characteristics, attributes) upon which the cluster analysis is performed."

Berdasarkan uraian di atas, analisis klaster (cluster analysis) merupakan suatu teknik statistika yang digunakan untuk mengelompokkan (group) sekumpulan objek (manusia, produk, tanaman, dan sebagainya) ke dalam beberapa klaster. Perhatikan bahwa suatu objek hanya bisa masuk atau tergabung dalam satu klaster. Beberapa objek yang berada dalam satu klaster cenderung saling mirip, namun cenderung berbeda terhadap objek-objek yang berada dalam klaster lainnya. Sebagai contoh perhatikan data pada Tabel 22.1. Berdasarkan data pada Tabel 22.1, objek yang diteliti adalah batu, sebanyak 15 batu. Masing-masing batu memiliki kadar $\mathrm{X}$ dan kadar Y. Gambar 22.1 memberikan gambaran yang cukup jelas untuk pengelompokkan (cluster). Berdasarkan Gambar 22.2, jika dibentuk klaster sebanyak 3, maka:

$\Rightarrow$ Batu A, B, C, D, dan E berada dalam satu klaster, misalkan klaster pertama.

$\Rightarrow$ Batu F, G, H, I, dan J berada dalam satu klaster, misalkan klaster kedua.

$\Rightarrow$ Batu K, L, M, N, dan O berada dalam satu klaster, misalkan klaster ketiga. 
Perhatikan bahwa batu A, B, C, D, dan E cenderung mirip, karena berada di dalam satu klaster, yakni klaster pertama, namun cenderung berbeda terhadap batu-batu yang berada dalam klaster yang berbeda. Tiga klaster yang tersaji dalam Gambar 22.1 melibatkan dua variabel klaster, yakni variabel kadar X (sumbu horizontal) dan kadar Y (sumbu vertikal).

Tabel 22.1

\begin{tabular}{|c|c|c|}
\hline Batu & kadar X & kadar Y \\
\hline A & 1.1 & 2.1 \\
\hline B & 1.1 & 2.2 \\
\hline C & 1.2 & 2.25 \\
\hline D & 1.3 & 2.1 \\
\hline E & 1.3 & 2.3 \\
\hline F & 3.5 & 1.2 \\
\hline G & 3.5 & 1.3 \\
\hline H & 3.6 & 1 \\
\hline I & 3.7 & 1.1 \\
\hline J & 3.7 & 1.2 \\
\hline K & 6.1 & 3.1 \\
\hline L & 6.1 & 3.2 \\
\hline M & 6.2 & 3.25 \\
\hline N & 6.3 & 3.2 \\
\hline O & 6.3 & 3.1 \\
\hline
\end{tabular}

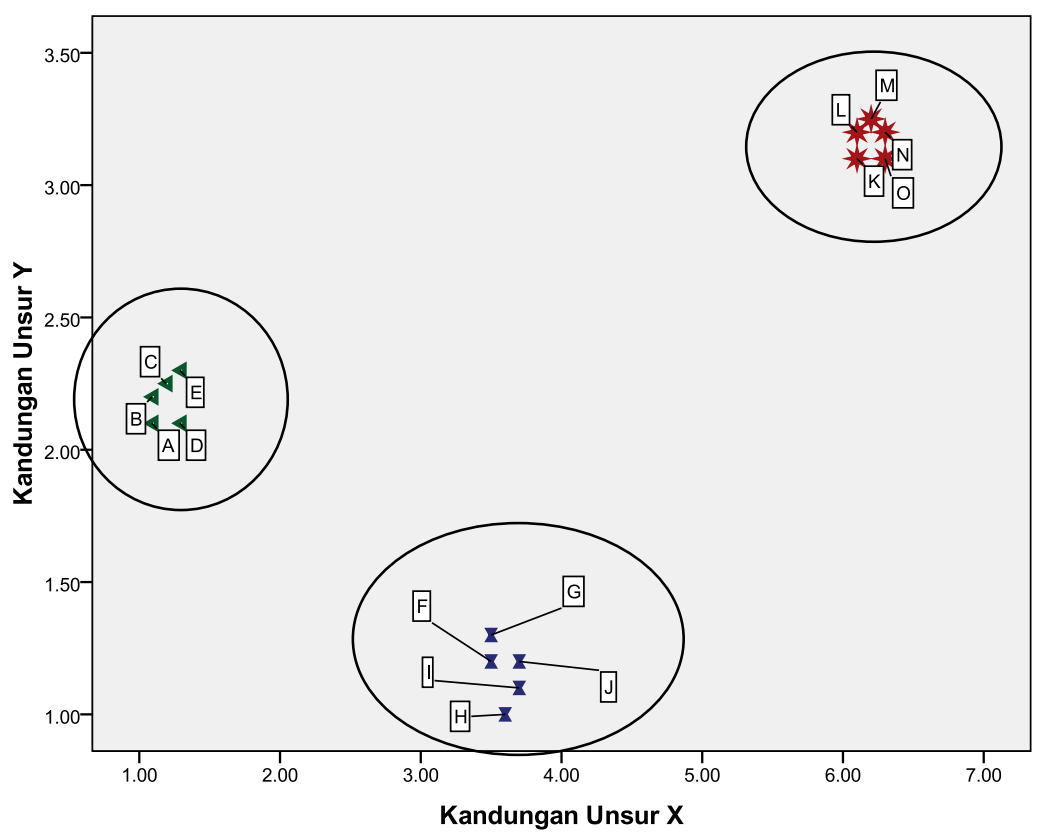

Gambar 22.2 


\section{UKuran Kemiripan (Measure of Simílarity)}

Gambar 22.3 merupakan tampilan SPSS yang menyediakan beberapa ukuran kemiripan, yakni di antaranya adalah Euclidean distance dan Squared Euclidean distance. Gambar 22.4 menyajikan Euclidean distance (jarak Euclidean) untuk tiap-tiap pasang objek (batu). Berdasarkan Gambar 22.2, suatu objek akan semakin mirip dengan objek yang lain, jika posisinya semakin berdekatan. Dengan kata lain, jarak di antara objek tersebut semakin kecil (nilai Euclidean distance semakin kecil).

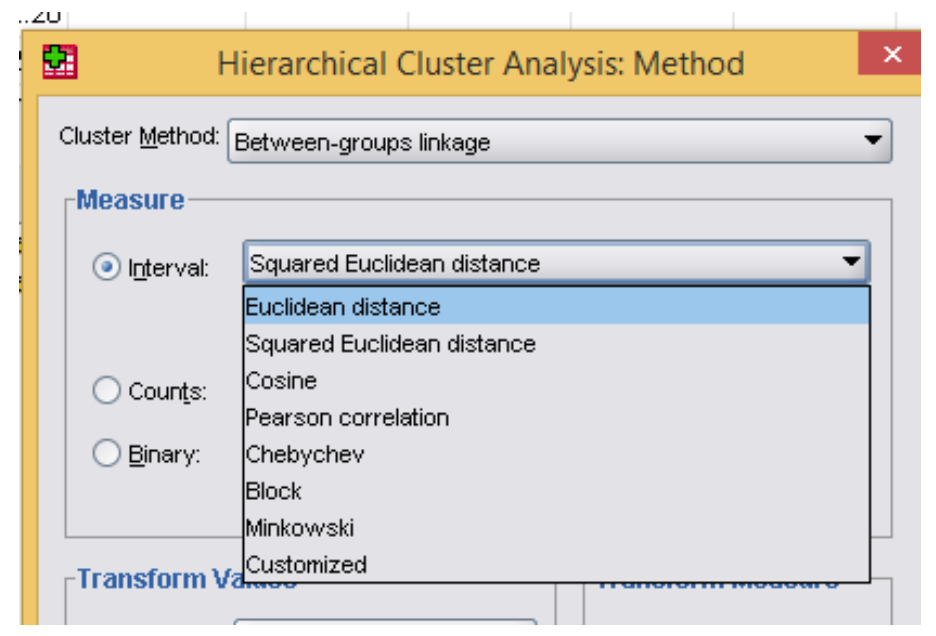

Gambar 22.3 Berbagai Ukuran Kemiripan dalam SPSS

\begin{tabular}{l|r|r|r|r|r|r|r|r|r|r|r|r|r|r|r}
\multicolumn{10}{c|}{ Proximity Matrix } \\
\hline
\end{tabular}

\section{Gambar 22.4 Euclidean Distance untuk Tiap-Tiap Pasang Objek (Batu)}

Berdasarkan Gambar 22.4, diketahui Euclidean distance untuk objek A dan objek C adalah 0,180 . Nilai ini dihitung sebagai berikut.

$$
\sqrt{(1,2-1,1)^{2}+(2,25-2,1)^{2}}=0,180277 \text { atau dibulatkan } 0,180
$$


Diketahui Euclidean distance untuk objek A dan objek O adalah 5,295. Nilai ini dihitung sebagai berikut.

$$
\sqrt{(6,3-1,1)^{2}+(3,1-2,1)^{2}}=5,295280 \text { atau dibulatkan } 5,295 \text {. }
$$

\begin{tabular}{l|r|r|r|r|r|r|r|r|r|r|r|r|r|r|r|r}
\multicolumn{10}{c}{ Proximity Matrix } \\
\hline
\end{tabular}

\section{Gambar 22.5 Squared Euclidean Distance untuk Tiap-Tiap Pasang Objek (Batu)}

Gambar 22.5 menyajikan Squared Euclidean distance (jarak Euclidean yang dikuadratkan) untuk tiap-tiap pasang objek (batu). Berdasarkan Gambar 22.5, diketahui Squared Euclidean distance untuk objek A dan objek $\mathrm{C}$ adalah 0,032. Nilai ini dihitung sebagai berikut.

$$
(1,2-1,1)^{2}+(2,25-2,1)^{2}=0,0325 .
$$

Diketahui Squared Euclidean distance untuk objek A dan objek O adalah 28,040. Nilai ini dihitung sebagai berikut.

$$
(6,3-1,1)^{2}+(3,1-2,1)^{2}=28,04 .
$$

Malhotra dan Birks (2006:600) menyatakan sebagai berikut

"Because the objective of clustering is to group similar objects together, some measure is needed to assess how similar or different the objects are. The most common approach is to measure similarity in terms of distance between pairs of objects. Objects with smaller distances between them are more similar to each other than are those at larger distances. There are several ways to compute the distance between two objects ${ }^{9}$. The most commonly used measure of similarity is the euclidean distance or its square ${ }^{10}$. The euclidean distance is the square root of the sum of the squared differences in values for each variable. Other distance measures are also available. The city-block or Manhattan distance between two objects is the sum of the absolute differences in values for each variable. The Chebychev distance between two objects is the maximum absolute difference in values for any variable. For our example, we use the squared euclidean distance." 
Berdasarkan uraian di atas, secara umum, ukuran kemiripan yang umum digunakan adalah Euclidean distance atau Squared Euclidean distance. Lebih lanjut Malhotra dan Birks (2006:600) dan Hair dkk. (2010:496-497) menganjurkan untuk melakukan standarisasi data (data ditransormasi ke dalam bentuk normal, dengan rata-rata 0 , dan standar deviasi 1) untuk tiap-tiap variabel klaster, apabila data pada variabel-variabel kluster memiliki satuan yang berbeda-beda. Di sisi lain, data yang termasuk outlier juga dianjurkan untuk dihapus (Malhotra dan Birks, 2006:601).

Selanjutnya Malhotra dan Birks (2006:601) menyatakan penggunaan ukuran kemiripan (measure of similarity) yang berbeda-beda, dapat mempengaruhi hasil klaster, sehingga disarankan untuk menggunakan berbagai ukuran kemiripan dan hasil klaster tersebut diperbandingkan.

Sejalan dengan Malhotra dan Birks, Hair dkk. (2010:496) menyatakan sebagai berikut.

"Which Distance Measures is Best? In attempting to select a particular distance measure, the researcher should remember the following caveats: Difference distance measures or a change in the scales of the variables may lead to different cluster solutions. Thus, it is advisable to use several measures and compare the results with theoretical or know patterns. When the variables are correlated (either positively or negatively) the Mahalanobis distance measure is likely to be the most appropriate because it adjusts for correlations and weights all variable equally. Alternatively, the researcher may wish to avoid using highly redundant variables as input to cluster analysis."

Selain ukuran kemiripan Euclidean distance dan Squared Euclidean distance, terdapat ukuran lain, yakni city-block distance (atau sering disebut dengan jarak Manhattan), dan Chebychev distance. Gambar 22.6 menyajikan city-block distance untuk tiap-tiap pasang objek.

\begin{tabular}{|c|c|c|c|c|c|c|c|c|c|c|c|c|c|c|c|}
\hline \multicolumn{16}{|c|}{ Proximity Matrix } \\
\hline \multirow[b]{2}{*}{ Case } & \multicolumn{15}{|c|}{ City Block Distance } \\
\hline & 1 & 2 & 3 & 4 & 5 & 6 & 7 & 8 & 9 & 10 & 11 & 12 & 13 & 14 & 15 \\
\hline 1 & .000 & .100 & .250 & .200 & .400 & 3.300 & 3.200 & 3.600 & 3.600 & 3.500 & 6.000 & 6.100 & 6.250 & 6.300 & 6.200 \\
\hline 2 & .100 & .000 & .150 & .300 & .300 & 3.400 & 3.300 & 3.700 & 3.700 & 3.600 & 5.900 & 6.000 & 6.150 & 6.200 & 6.100 \\
\hline 3 & .250 & .150 & .000 & .250 & .150 & 3.350 & 3.250 & 3.650 & 3.650 & 3.550 & 5.750 & 5.850 & 6.000 & 6.050 & 5.950 \\
\hline 4 & .200 & .300 & .250 & .000 & .200 & 3.100 & 3.000 & 3.400 & 3.400 & 3.300 & 5.800 & 5.900 & 6.050 & 6.100 & 6.000 \\
\hline 5 & .400 & .300 & .150 & .200 & .000 & 3.300 & 3.200 & 3.600 & 3.600 & 3.500 & 5.600 & 5.700 & 5.850 & 5.900 & 5.800 \\
\hline 6 & 3.300 & 3.400 & 3.350 & 3.100 & 3.300 & .000 & .100 & .300 & .300 & .200 & 4.500 & 4.600 & 4.750 & 4.800 & 4.700 \\
\hline 7 & 3.200 & 3.300 & 3.250 & 3.000 & 3.200 & .100 & .000 & .400 & .400 & .300 & 4.400 & 4.500 & 4.650 & 4.700 & 4.600 \\
\hline 8 & 3.600 & 3.700 & 3.650 & 3.400 & 3.600 & .300 & .400 & .000 & .200 & .300 & 4.600 & 4.700 & 4.850 & 4.900 & 4.800 \\
\hline 9 & 3.600 & 3.700 & 3.650 & 3.400 & 3.600 & .300 & .400 & .200 & .000 & .100 & 4.400 & 4.500 & 4.650 & 4.700 & 4.600 \\
\hline 10 & 3.500 & 3.600 & 3.550 & 3.300 & 3.500 & .200 & .300 & .300 & .100 & .000 & 4.300 & 4.400 & 4.550 & 4.600 & 4.500 \\
\hline 11 & 6.000 & 5.900 & 5.750 & 5.800 & 5.600 & 4.500 & 4.400 & 4.600 & 4.400 & 4.300 & .000 & .100 & .250 & .300 & .200 \\
\hline 12 & 6.100 & 6.000 & 5.850 & 5.900 & 5.700 & 4.600 & 4.500 & 4.700 & 4.500 & 4.400 & .100 & .000 & .150 & .200 & .300 \\
\hline 13 & 6.250 & 6.150 & 6.000 & 6.050 & 5.850 & 4.750 & 4.650 & 4.850 & 4.650 & 4.550 & .250 & .150 & .000 & .150 & .250 \\
\hline 14 & 6.300 & 6.200 & 6.050 & 6.100 & 5.900 & 4.800 & 4.700 & 4.900 & 4.700 & 4.600 & .300 & .200 & .150 & .000 & .100 \\
\hline 15 & 6.200 & 6.100 & 5.950 & 6.000 & 5.800 & 4.700 & 4.600 & 4.800 & 4.600 & 4.500 & .200 & .300 & .250 & 100 & 000 \\
\hline
\end{tabular}

\section{Gambar 22.6 City-Block Distance untuk Tiap-Tiap Pasang Objek (Batu)}

Berdasarkan Gambar 22.6, diketahui city-block distance antara objek A dan C adalah 0,250. Nilai tersebut dihitung sebagai berikut.

$$
|2,25-2,1|+|1,2-1,1|=0,15+0,1=0,25
$$


Diketahui juga bahwa city-block distance antara objek B dan $\mathrm{G}$ adalah 3,3. Nilai tersebut dihitung sebagai berikut.

$$
|1,3-2,2|+|3,5-1,1|=0,9+2,4=3,3 .
$$

Pada Gambar 22.7 menyajikan Chebychev distance untuk tiap-tiap pasang objek. Berdasarkan Gambar 22.7, diketahui Chebychev distance antara objek A dan C adalah 0,150. Nilai tersebut dihitung sebagai berikut.

$$
\max (|2,25-2,1|+|1,2-1,1|)=\max (0,15+0,1)=0,150 .
$$

\begin{tabular}{|c|c|c|c|c|c|c|c|c|c|c|c|c|c|c|c|}
\hline \multicolumn{16}{|c|}{ Proximity Matrix } \\
\hline \multirow[b]{2}{*}{ Case } & \multicolumn{15}{|c|}{ Chebychev Distance } \\
\hline & 1 & 2 & 3 & 4 & 5 & 6 & 7 & 8 & 9 & 10 & 11 & 12 & 13 & 14 & 15 \\
\hline 1 & .000 & .100 & .150 & .200 & .200 & 2.400 & 2.400 & 2.500 & 2.600 & 2.600 & 5.000 & 5.000 & 5.100 & 5.200 & 5.200 \\
\hline 2 & .100 & .000 & .100 & .200 & .200 & 2.400 & 2.400 & 2.500 & 2.600 & 2.600 & 5.000 & 5.000 & 5.100 & 5.200 & 5.200 \\
\hline 3 & .150 & .100 & .000 & .150 & .100 & 2.300 & 2.300 & 2.400 & 2.500 & 2.500 & 4.900 & 4.900 & 5.000 & 5.100 & 5.100 \\
\hline 4 & .200 & .200 & .150 & .000 & .200 & 2.200 & 2.200 & 2.300 & 2.400 & 2.400 & 4.800 & 4.800 & 4.900 & 5.000 & 5.000 \\
\hline 5 & .200 & .200 & .100 & .200 & .000 & 2.200 & 2.200 & 2.300 & 2.400 & 2.400 & 4.800 & 4.800 & 4.900 & 5.000 & 5.000 \\
\hline 6 & 2.400 & 2.400 & 2.300 & 2.200 & 2.200 & .000 & .100 & .200 & .200 & .200 & 2.600 & 2.600 & 2.700 & 2.800 & 2.800 \\
\hline 7 & 2.400 & 2.400 & 2.300 & 2.200 & 2.200 & .100 & .000 & .300 & .200 & .200 & 2.600 & 2.600 & 2.700 & 2.800 & 2.800 \\
\hline 8 & 2.500 & 2.500 & 2.400 & 2.300 & 2.300 & .200 & .300 & .000 & .100 & .200 & 2.500 & 2.500 & 2.600 & 2.700 & 2.700 \\
\hline 9 & 2.600 & 2.600 & 2.500 & 2.400 & 2.400 & .200 & .200 & .100 & .000 & 100 & 2.400 & 2.400 & 2.500 & 2.600 & 2.600 \\
\hline 10 & 2.600 & 2.600 & 2.500 & 2.400 & 2.400 & .200 & .200 & .200 & .100 & .000 & 2.400 & 2.400 & 2.500 & 2.600 & 2.600 \\
\hline 11 & 5.000 & 5.000 & 4.900 & 4.800 & 4.800 & 2.600 & 2.600 & 2.500 & 2.400 & 2.400 & 000 & .100 & .150 & .200 & .200 \\
\hline 12 & 5.000 & 5.000 & 4.900 & 4.800 & 4.800 & 2.600 & 2.600 & 2.500 & 2.400 & 2.400 & 100 & .000 & .100 & .200 & .200 \\
\hline 13 & 5.100 & 5.100 & 5.000 & 4.900 & 4.900 & 2.700 & 2.700 & 2.600 & 2.500 & 2.500 & .150 & 100 & .000 & 100 & .150 \\
\hline 14 & 5.200 & 5.200 & 5.100 & 5.000 & 5.000 & 2.800 & 2.800 & 2.700 & 2.600 & 2.600 & .200 & .200 & .100 & .000 & .100 \\
\hline 15 & 5.200 & 5.200 & 5.100 & 5.000 & 5.000 & 2.800 & 2.800 & 2.700 & 2.600 & 2.600 & .200 & .200 & .150 & .100 & .000 \\
\hline
\end{tabular}

Gambar 22.7 Chebychev Distance untuk Tiap-Tiap Pasang Objek (Batu)

Diketahui juga bahwa Chebychev distance antara objek B dan G adalah 2,4. Nilai tersebut dihitung sebagai berikut.

$$
\max (|1,3-2,2|+|3,5-1,1|)=\max (0,9+2,4)=2,4 .
$$

\section{Mendeteksi Outlier (Multivariate Outlier)}

Outlier merupakan suatu pengamatan yang berbeda atau tidak mirip dari pengamatan lainnya. Dalam analisis klaster, pemeriksaan outlier yang dimaksudkan bukan merupakan pemeriksaan univariate outlier, melainkan multivariate outlier. Hal ini karena dalam proses analisis klaster menyertakan (include) seluruh variabel klaster yang terpilih dalam mengidentifikasi klaster-klaster yang menunjukkan kemiripan di dalam kelompok. Hair dkk. (2010:514) menyatakan sebagai berikut.

"The first issue is to identify any outliers in the sample before partitioning begins. Univariate procedures do not identify any potential indicates for designation as outliers. Multivariate procedures are used because cluster analysis includes all of the selected clustering variables in identifying clusters that exhibit similarity within groups. Outliers are observations that are different or dissimilar. In our example, we will refer to the term dissimilarity, because larger distance mean less similar observations. Moreover, because we 
are looking for outliers, the focus is squarely on finding observations that are potentially quite different than the outliers."

Salah satu cara yang dapat digunakan untuk melakukan deteksi multivariate outlier adalah dengan pendekatan menghitung average dissimilarity untuk setiap objek, meskipun terdapat cara lain, yakni dengan memeriksa Euclidean distance dari suatu objek ke objek yang lain. Nilai Euclidean distance yang relatif besar dapat menjadi kandidat outlier. Namun pemeriksaan outlier dengan pendekatan Euclidean distance memiliki kelemahan, jika jumlah objek semakin banyak, andaikan 100 objek. Maka akan terdapat 100 baris dan 100 kolom untuk matriks ketidaksamaan (dissimilarity matrix). Pada Gambar 22.5 hanya menggunakan 15 objek, maka terdapat 15 baris dan 15 kolom, pemeriksaan Euclidean distance tidak terlalu sulit (Hair dkk., 2010:514).

Berikut perhitungan untuk menentukan average dissimilarity untuk tiap-tiap objek (batu) pada data Tabel 22.1.

Tabel 22.2 Statistik Deskriptif untuk Masing-Masing Variabel Klaster

\begin{tabular}{|c|c|c|c|c|c|}
\hline Variabel Kluster & $\mathrm{N}$ & Minimum & Maximum & Mean & Std. Deviation \\
\hline Kadar X & 15 & 1.1 & 6.3 & 3.666667 & 2.115475856 \\
\hline Kadar Y & 15 & 1 & 3.25 & 2.173333 & 0.85374525 \\
\hline
\end{tabular}

Tabel 22.3 Perhitungan Average Dissimilarity untuk Deteksi Multivariate Outlier (2 Variabel Klaster)

\begin{tabular}{|c|c|c|c|c|c|c|}
\hline Batu & Kadar X & Kadar Y & $a=(X-\bar{X})^{2}$ & $b=(Y-\bar{Y})^{2}$ & $a+b$ & $\begin{array}{c}\text { Average Dissimilarity } \\
\sqrt{\boldsymbol{a}+\boldsymbol{b}}\end{array}$ \\
\hline 1 & 1.1 & 2.1 & 6.587778 & 0.005378 & 6.593155556 & 2.567714072 \\
\hline 2 & 1.1 & 2.2 & 6.587778 & 0.000711 & 6.588488889 & 2.566805191 \\
\hline 3 & 1.2 & 2.25 & 6.084444 & 0.005878 & 6.090322222 & 2.467857821 \\
\hline 4 & 1.3 & 2.1 & 5.601111 & 0.005378 & 5.606488889 & 2.367802544 \\
\hline 5 & 1.3 & 2.3 & 5.601111 & 0.016044 & 5.617155556 & 2.370053914 \\
\hline 6 & 3.5 & 1.2 & 0.027778 & 0.947378 & 0.975155556 & 0.987499648 \\
\hline 7 & 3.5 & 1.3 & 0.027778 & 0.762711 & 0.790488889 & 0.889094421 \\
\hline 8 & 3.6 & 1 & 0.004444 & 1.376711 & 1.381155556 & 1.175225747 \\
\hline 9 & 3.7 & 1.1 & 0.001111 & 1.152044 & 1.153155556 & 1.073850807 \\
\hline 10 & 3.7 & 1.2 & 0.001111 & 0.947378 & 0.948488889 & 0.973903942 \\
\hline 11 & 6.1 & 3.1 & 5.921111 & 0.858711 & 6.779822222 & 2.603809175 \\
\hline 12 & 6.1 & 3.2 & 5.921111 & 1.054044 & 6.975155556 & 2.641051979 \\
\hline 13 & 6.2 & 3.25 & 6.417778 & 1.159211 & 7.576988889 & 2.752633083 \\
\hline 14 & 6.3 & 3.2 & 6.934444 & 1.054044 & 7.988488889 & $\mathbf{2 . 8 2 6 3 9 1 4 9 6}$ \\
\hline 15 & 6.3 & 3.1 & 6.934444 & 0.858711 & 7.793155556 & 2.791622388 \\
\hline
\end{tabular}

\section{Prosedur Pengklasteran}

Gambar 22.8 menyajikan prosedur pengklasteran dalam analisis klaster (Malhotra dan Birks, 2006:601). Berdasarkan Gambar 22.8, prosedur pengklasteran dapat menggunakan metode hierarchical atau metode non-hierarchical. Pada metode hierarchical, jumlah klaster belum atau tidak diketahui sebelumnya, sementara pada metode non-hierarchical jumlah klaster 
ditetapkan terlebih dahulu, sebelum melakukan pengklasteran objek. Dengan kata lain, pada metode non-hierarchical, tahap awal ialah menentukan jumlah klaster yang diinginkan, kemudian tiap-tiap objek pengamatan digabungkan ke dalam salah satu klaster yang telah ditetapkan.

Selanjutnya, Dalam metode hierarchical terdiri dari dua metode, yakni metode agglomerative dan metode divisive. Metode agglomerative dimulai dengan menganggap tiap-tiap objek sebagai klaster-klaster yang berbeda atau terpisah. Kemudian dua klaster/objek paling dekat digabung menjadi satu klaster. Proses ini terus berlanjut, sampai seluruh objek bergabung menjadi satu klaster. Sementara pada metode divisive merupakan kebalikan dari metode agglomerative, yakni dimulai dengan menganggap tiap-tiap objek berasal dalam satu klaster, kemudian dipecah atau dipisahkan sampai setiap objek berada dalam klaster-klaster yang terpisah (Malhotra dan Birks, 2006:601).

Metode agglomerative terdiri dari 3 metode, yakni metode linkage, variance, dan centroid. Metode linkage terdiri dari metode single linkage, complete linkage, dan average linkage, sementara pada metode variance terdiri dari metode ward. Pada metode non-hierarchical terdiri dari metode sequential threshold, optimising partitioning, dan parallel threshold. Metode non-hierarchical sering disebut dengan istilah k-means clustering.

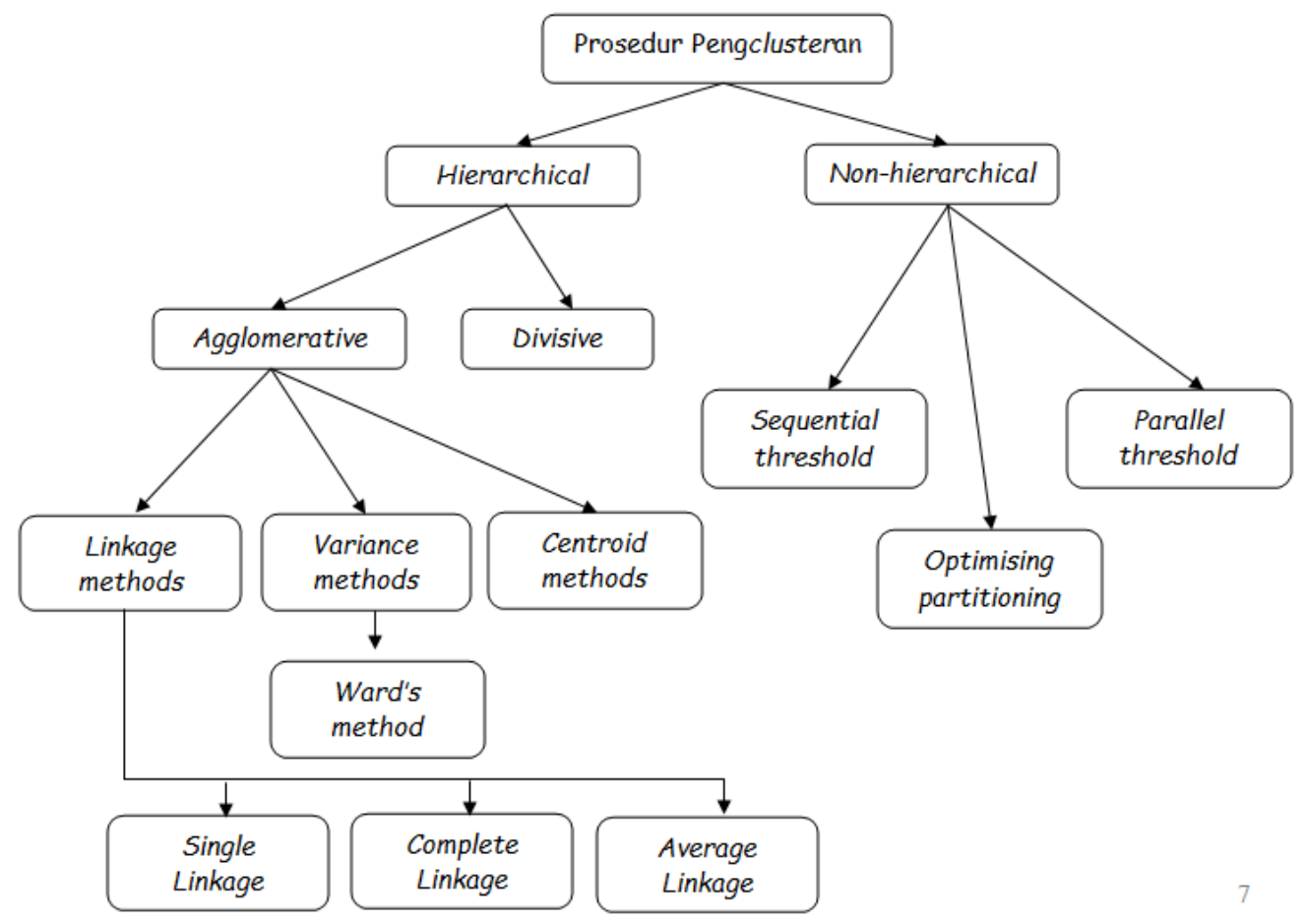

Gambar 22.8 Prosedur Pengklasteran (Malhotra dan Birks, 2006:601)

\section{Contoh Perhitungan Average Linkage}

Berikut diberikan contoh penggunaan analisis klaster metode average linkage. Diberikan data seperti pada Gambar 22.9. Data pada Gambar 22.9 disajikan dalam grafik seperti pada Gambar 22.10. Berikut akan digunakan analisis klaster metode average linkage untuk pengklasteran. Gambar 22.11 menyajikan Squared Euclidean distance (matriks jarak / distance matrix). 


\begin{tabular}{|r|r|r|r|}
\hline \multicolumn{1}{|c|}{} & \multicolumn{1}{|c|}{ Batu } & \multicolumn{1}{c|}{ A } & \multicolumn{1}{|c|}{ B } \\
\hline 1 & A & 1.10 & 1.10 \\
\hline \hline 2 & B & 1.20 & .85 \\
\hline \hline 3 & C & 1.30 & .97 \\
\hline \hline 5 & D & 1.40 & .90 \\
\hline \hline 5 & E & 1.35 & 1.00 \\
\hline \hline
\end{tabular}

Gambar 22.9

Berdasarkan Gambar 22.11, diketahui Squared Euclidean distance untuk objek A dan objek C adalah 0,057. Nilai tersebut dihitung sebagai berikut.

$$
(1,1-0,97)^{2}+(1,1-1,3)^{2}=0,0569 \text { atau dibulatkan } 0,057 .
$$

Diketahui Squared Euclidean distance untuk objek B dan objek F adalah 0,023. Nilai tersebut dihitung sebagai berikut.

$$
(0,85-1)^{2}+(1,2-1,2)^{2}=0,0225 \text { atau dibulatkan } 0,023 .
$$

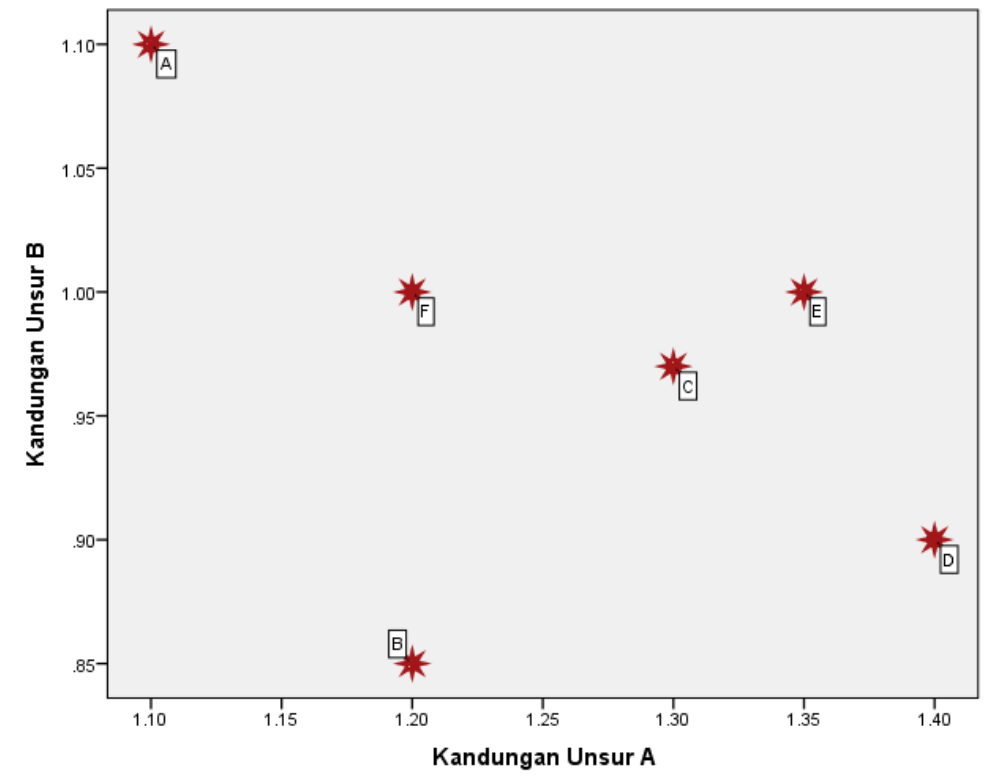

\begin{tabular}{|c|c|c|c|c|c|c|}
\hline \multicolumn{7}{|c|}{ Proximity Matrix } \\
\hline \multirow[b]{2}{*}{ Case } & \multicolumn{6}{|c|}{ Squared Euclidean Distance } \\
\hline & $1: \mathrm{A}$ & $2: \mathrm{B}$ & $3: C$ & $4: D$ & $5: E$ & $6: F$ \\
\hline 1:A & .000 & .073 & .057 & .130 & .073 & .020 \\
\hline $2: B$ & .073 & .000 & .024 & .042 & .045 & .023 \\
\hline $3: C$ & .057 & .024 & .000 & .015 & .003 & .011 \\
\hline $4: D$ & .130 & .042 & .015 & .000 & .012 & .050 \\
\hline $5: E$ & .073 & .045 & .003 & .012 & .000 & .023 \\
\hline $6: F$ & .020 & .023 & .011 & .050 & .023 & .000 \\
\hline
\end{tabular}

Gambar 22.10

Gambar 22.11 Squared Euclidean Distance (Matriks Jarak) 
Gambar 22.11 menyajikan Squared Euclidean distance (matriks jarak / distance matrix). Berdasarkan Gambar 22.11, diketahui nilai Squared Euclidean distance paling kecil berada pada pasangan objek $\mathrm{C}$ dan objek $\mathrm{E}$ (pasangan objek yang berbeda), yakni bernilai 0,003 (Perhatikan Gambar 22.11). Maka objek C dan objek E bergabung menjadi cluster (C,E). Pada Gambar 22.12, terlihat bahwa pada Stage 1, objek C (3) dan objek E (5) bergabung menjadi cluster (C,E). Perhatikan juga bahwa nilai coefficient $\mathbf{0 , 0 0 3}$, yang merupakan jarak antara objek C dan objek E.

\section{Average Linkage (Between Groups)}

\begin{tabular}{|l|r|r|r|r|r|r|}
\hline \multicolumn{7}{|c|}{ Agglomeration Schedule } \\
\hline \multirow{3}{*}{ Stage } & \multicolumn{2}{|c|}{ Cluster Combined } & & \multicolumn{2}{|c|}{ Stage Cluster First Appears } & \\
\cline { 2 - 3 } \cline { 5 - 6 } & Cluster 1 & Cluster 2 & Coefficients & Cluster 1 & \multicolumn{1}{c|}{ Cluster 2 } & Next Stage \\
\hline 1 & 3 & 5 & .003 & 0 & 0 & 2 \\
2 & 3 & 4 & .014 & 1 & 0 & 4 \\
3 & 1 & 6 & .020 & 0 & 0 & 5 \\
4 & 2 & 3 & .037 & 0 & 2 & 5 \\
5 & 1 & 2 & .055 & 3 & 4 & 0 \\
\hline
\end{tabular}

\section{Gambar 22.12 Output SPSS untuk Analisis Klaster Metode Average Linkage}

Selanjutnya menghitung jarak antara cluster (C,E) terhadap objek lainnya.

$\Rightarrow$ Menghitung jarak antara cluster (C,E) terhadap objek A.

$$
d_{(C, E) A}=\frac{d_{(C, A)}+d_{(E, A)}}{N_{(C, E)} \times N_{(A)}}=\frac{0,0569+0,0725}{2 \times 1}=0,0647 .
$$

Perhatikan bahwa $N_{(C, E)}$ dan $N_{A}$ masing-masing menyatakan jumlah objek dalam klaster (C,E) dan A.

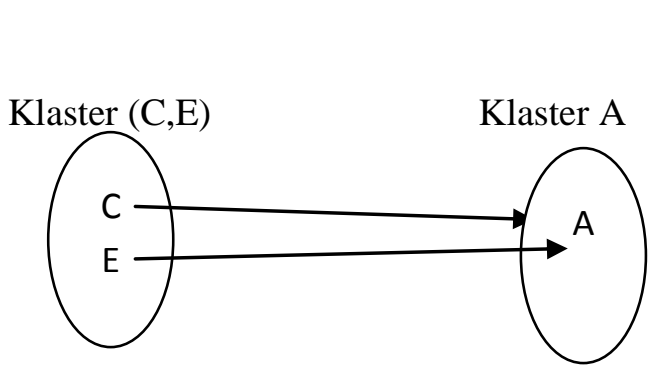

Menentukan jarak antara klaster (C,E) dan klaster $\mathbf{A}$ adalah hitung jarak dar C ke A, dan jarak dari $\mathrm{E}$ ke A. Kemudian jumlahkan dan bagi 2. 2 dalam hal ini $2 \times 1=2.2$ menyatakan jumlah anggota klaster (C,E) dan 1 menyatakan jumlah anggota klaster A.

$\Rightarrow$ Menghitung jarak antara cluster $(\mathrm{C}, \mathrm{E})$ terhadap objek B.

$$
d_{(C, E) B}=\frac{d_{(C, B)}+d_{(E, B)}}{N_{(C,)} \times N_{(B)}}=\frac{0,0244+0,045}{2 \times 1}=0,0347 .
$$

Gambar 22.13 menyajikan jarak antara cluster (C,E) terhadap masing-masing objek. 


\begin{tabular}{|c|c|c|c|c|c|c|}
\hline & A & B & C & D & E & F \\
\hline A & 0.000000 & 0.072500 & 0.056900 & 0.130000 & 0.072500 & 0.020000 \\
\hline B & 0.072500 & 0.000000 & 0.024400 & 0.042500 & 0.045000 & 0.022500 \\
\hline C & 0.056900 & 0.024400 & 0.000000 & 0.014900 & 0.003400 & 0.010900 \\
\hline D & 0.130000 & 0.042500 & 0.014900 & 0.000000 & 0.012500 & 0.050000 \\
\hline E & 0.072500 & 0.045000 & 0.003400 & 0.012500 & 0.000000 & 0.022500 \\
\hline F & 0.020000 & 0.022500 & 0.010900 & 0.050000 & 0.022500 & 0.000000 \\
\hline Jarak & 0.0647 & 0.0347 & & 0.0137 & & 0.0167 \\
\hline
\end{tabular}

\section{Gambar 22.13}

Sehingga diperoleh matriks jarak yang baru seperti pada Gambar 22.14.

\begin{tabular}{c|c|c|c|c|c}
\hline & C,E & A & B & D & F \\
\hline C,E & 0 & 0.0647 & 0.0347 & 0.0137 & 0.0167 \\
\hline A & 0.0647 & 0 & 0.072500 & 0.130000 & 0.020000 \\
\hline B & 0.0347 & 0.072500 & 0 & 0.042500 & 0.022500 \\
\hline D & 0.0137 & 0.130000 & 0.042500 & 0 & 0.050000 \\
\hline F & 0.0167 & 0.020000 & 0.022500 & 0.050000 & 0
\end{tabular}

Gambar 22.14 Matriks Jarak

Berdasarkan Gambar 22.14, diketahui nilai jarak paling kecil berada pada pasangan (C,E) dan D (pasangan objek yang berbeda), yakni bernilai 0,0137, maka (C,E) dan D bergabung menjadi cluster (C,E,D). Pada Gambar 22.12, terlihat bahwa pada Stage 2, objek C (3) dan objek D (4) bergabung. Perhatikan juga bahwa nilai coefficient 0,014 (pembulatan dari 0,0137).

Selanjutnya menghitung jarak antara cluster (C,E,D) terhadap objek lainnya.

$\Rightarrow$ Menghitung jarak antara cluster (C,E,D) terhadap objek A.

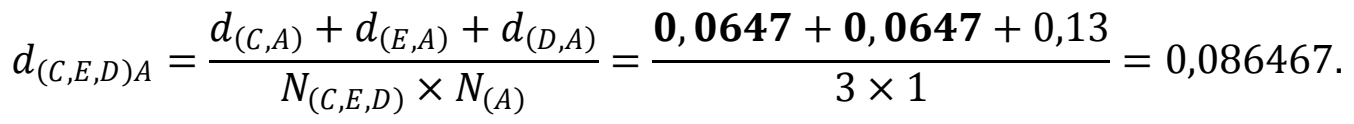

$\Rightarrow$ Menghitung jarak antara cluster (C,E,D) terhadap objek B.

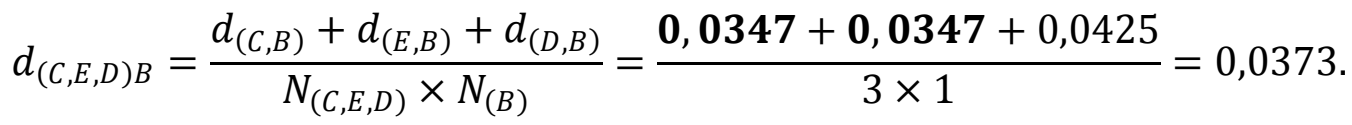

$\Rightarrow$ Menghitung jarak antara cluster (C,E,D) terhadap objek F.

$$
d_{(C, E, D) F}=\frac{d_{(C, F)}+d_{(E, F)}+d_{(D, F)}}{N_{(C, E, D)} \times N_{(B)}}=\frac{\mathbf{0 , 0 1 6 7 + 0 , 0 1 6 7 + 0 , 0 5}}{3 \times 1}=0,0278 .
$$

Gambar 22.15 menyajikan jarak antara cluster (C,E,D) terhadap masing-masing objek. 


\begin{tabular}{c|c|c|c|c|c|}
\hline & C,E & A & B & D & F \\
\hline C,E & 0 & 0.0647 & 0.0347 & 0.0137 & 0.0167 \\
\hline A & 0.0647 & 0 & 0.0725 & 0.13 & 0.02 \\
\hline B & 0.0347 & 0.0725 & 0 & 0.0425 & 0.0225 \\
\hline D & 0.0137 & 0.13 & 0.0425 & 0 & 0.05 \\
\hline F & 0.0167 & 0.02 & 0.0225 & 0.05 & 0 \\
\hline Jarak & & 0.086467 & 0.0373 & & 0.0278 \\
\hline
\end{tabular}

Gambar 22.15

Sehingga diperoleh matriks jarak yang baru seperti pada Gambar 22.16.

\begin{tabular}{c|c|c|c|c}
\hline & C,E,D & A & B & F \\
\hline C,E,D & 0 & 0.086467 & 0.0373 & 0.0278 \\
\hline A & 0.086467 & 0 & 0.0725 & 0.02 \\
\hline B & 0.0373 & 0.0725 & 0 & 0.0225 \\
\hline F & 0.0278 & 0.02 & 0.0225 & 0
\end{tabular}

\section{Gambar 22.16}

Berdasarkan Gambar 22.16, diketahui nilai jarak paling kecil berada pada pasangan objek A dan objek F, yakni bernilai 0,02, maka objek A dan objek $\mathbf{F}$ bergabung menjadi cluster (A,F). Pada Gambar 22.12, terlihat bahwa pada Stage 3, objek 1 (A) dan objek 6 (F). Perhatikan juga bahwa nilai coefficient 0,02.

Selanjutnya menghitung jarak antara cluster $(\mathrm{A}, \mathrm{F})$ terhadap objek lainnya.

$\Rightarrow$ Menghitung jarak antara cluster (A,F) terhadap objek B.

$$
d_{(A, F) B}=\frac{d_{(A, B)}+d_{(F, B)}}{N_{(A, F)} \times N_{(B)}}=\frac{0,0725+0,0225}{2 \times 1}=0,0475 .
$$

$\Rightarrow$ Menghitung jarak antara cluster $(\mathrm{A}, \mathrm{F})$ terhadap cluster $(\mathrm{C}, \mathrm{E}, \mathrm{D})$.

$$
\begin{aligned}
& d_{(A, F)(C, E, D)}=\frac{d_{(A, C)}+d_{(A, E)}+d_{(A, D)}+d_{(F, C)}+d_{(F, E)}+d_{(F, D)}}{6} \\
& d_{(A, F)(C, E, D)}=\frac{(\mathbf{3} \times \mathbf{0}, \mathbf{0 8 6 4 6 7})+(\mathbf{3} \times \mathbf{0 , 0 2 7 8})}{6}=0,057133 .
\end{aligned}
$$

Gambar 22.17 menyajikan jarak antara cluster (A,F) terhadap masing-masing objek.

\begin{tabular}{|c|c|c|c|c|}
\hline & C,E,D & A & B & F \\
\hline C,E,D & 0 & 0.086467 & 0.0373 & 0.0278 \\
\hline A & 0.086467 & 0 & 0.0725 & 0.02 \\
\hline B & 0.0373 & 0.0725 & 0 & 0.0225 \\
\hline F & 0.0278 & 0.02 & 0.0225 & 0 \\
\hline Jarak & 0.057133 & & 0.0475 & \\
\hline
\end{tabular}

Gambar 22.17 
Sehingga diperoleh matriks jarak yang baru seperti pada Gambar 22.18.

\begin{tabular}{c|c|c|c}
\hline & A,F & C,E,D & B \\
\hline A,F & 0 & 0.057133 & 0.0475 \\
\hline C,E,D & 0.057133 & 0 & 0.0373 \\
\hline B & 0.0475 & 0.0373 & 0 \\
\hline
\end{tabular}

Gambar 22.18

Berdasarkan Gambar 22.18, diketahui nilai jarak paling kecil berada pada pasangan (C,E,D) dan B, yakni bernilai 0,0373, maka (C,E,D) dan B bergabung menjadi cluster (C,E,D,B). Pada Gambar 22.12, terlihat bahwa pada Stage 4, objek 2 dan objek 3. Perhatikan juga bahwa nilai coefficient 0,037 .

Selanjutnya menghitung jarak antara cluster (C,E,D,B) terhadap objek lainnya.

$\Rightarrow$ Menghitung jarak antara cluster $(\mathrm{C}, \mathrm{E}, \mathrm{D}, \mathrm{B})$ terhadap cluster $(\mathrm{A}, \mathrm{F})$.

$$
\begin{gathered}
d_{(C, E, D, B)(A, F)}=\frac{d_{(A, C)}+d_{(A, E)}+d_{(A, D)}+d_{(A, B)}+d_{(F, C)}+d_{(F, E)}+d_{(F, D)}+d_{(F, B)}}{N_{(C, E, D, B)} \times N_{(A, F)}} \\
d_{(C, E, D, B)(A, F)}=\frac{(6 \times 0,057133)+(2 \times 0,0475)}{8}=0,054725 .
\end{gathered}
$$

Gambar 22.19 menyajikan jarak antara cluster (A,F) terhadap cluster (A,F).

\begin{tabular}{c|c|c|c}
\hline & A,F & C,E,D & B \\
\hline A,F & 0 & 0.057133 & 0.0475 \\
\hline C,E,D & 0.057133 & 0 & 0.0373 \\
\hline B & 0.0475 & 0.0373 & 0 \\
\hline Jarak & 0.054725 & & \\
\hline
\end{tabular}

\section{Gambar 22.19}

Sehingga diperoleh matriks jarak yang baru seperti pada Gambar 22.20.

\begin{tabular}{c|c|c}
\hline & A,F & C,E,D,B \\
\hline A,F & 0 & 0.054725 \\
\hline C,E,D,B & 0.054725 & 0
\end{tabular}

\section{Gambar 22.20}

Gambar 22.20 menyajikan jarak antara cluster (C,E,F,D,B) terhadap cluster (A,F). Diketahui jarak antara cluster (C,E,F,D,B) dan cluster (A,F)adalah 0,054725. Pada Gambar 22.12, yakni Stage 5 (objek 1 dan objek 2 bergabung). Diketahui nilai coefficient adalah 0,054725. Berdasarkan hasil perhitungan diketahui:

$\Rightarrow$ Berdasarkan Gambar 22.20, jika dibentuk dua klaster, maka klaster-klaster tersebut adalah $\{\mathrm{A}, \mathrm{F}\}$ dan $\{\mathrm{C}, \mathrm{E}, \mathrm{D}, \mathrm{B}\}$.

$\Rightarrow$ Berdasarkan Gambar 22.18, jika dibentuk tiga klaster, maka klaster-klaster tersebut adalah $\{\mathrm{A}, \mathrm{F}\},\{\mathrm{C}, \mathrm{E}, \mathrm{D}\}$, dan $\{\mathrm{B}\}$. 
Hasil tersebut sesuai dengan hasil SPSS seperti pada Gambar 22.21. Gambar 22.21 merupakan hasil berdasarkan SPSS untuk analisis klaster metode average linkage.

Cluster Membership
\begin{tabular}{|l|r|r|}
\hline Case & 3 Clusters & 2 Clusters \\
\hline $1: A$ & 1 & 1 \\
$2: B$ & 2 & 2 \\
$3: C$ & 3 & 2 \\
$4: D$ & 3 & 2 \\
$5: E$ & 3 & 2 \\
$6: F$ & 1 & 1 \\
\hline
\end{tabular}

\section{Gambar 22.21}

Jadi, pada metode average linkage memperlakukan jarak di antara dua klaster sebagai jarak rata-rata antara seluruh objek dalam klaster pertama terhadap seluruh objek dalam klaster kedua. Gambar 22.22 menyajikan dendogram. Dendogram menyajikan proses pengklasteran mulai dari Stage 1 hingga Stage 6.

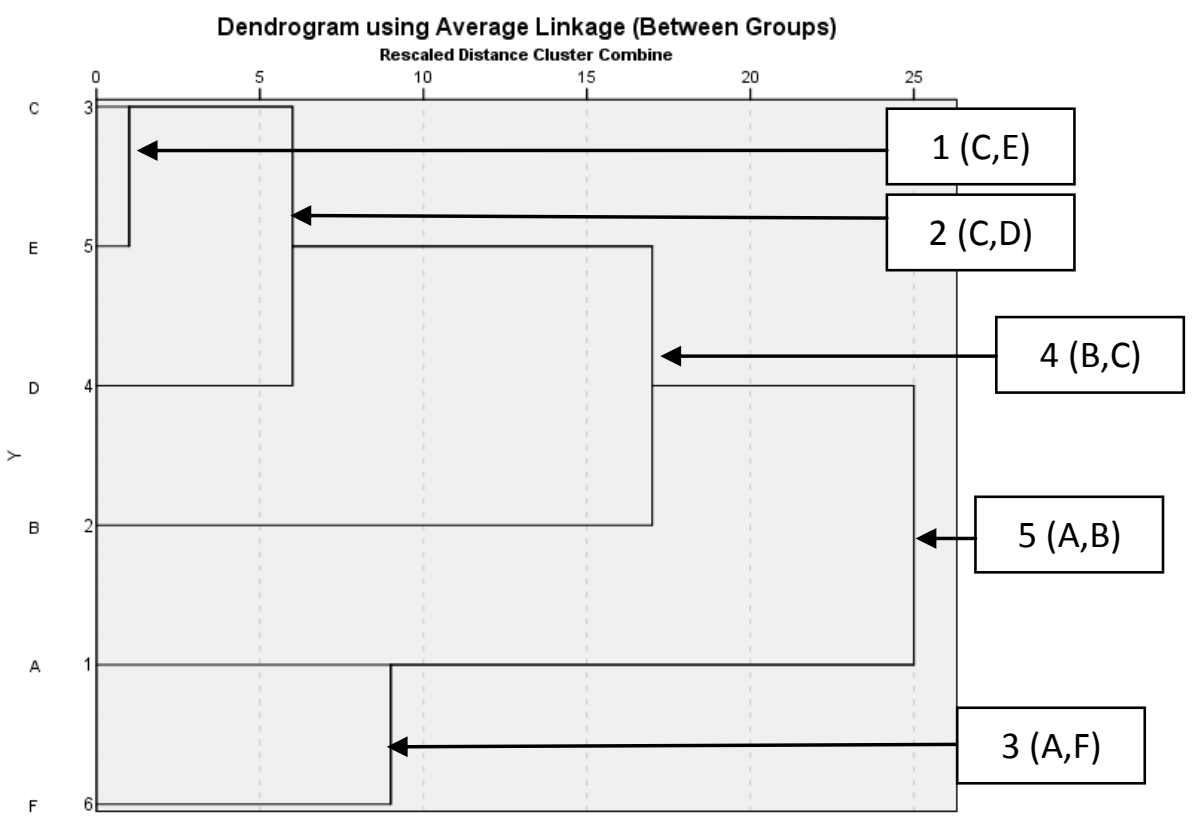

Gambar 22.22

\section{Contoh Perhitungan Single Linkage}

Berdasarkan Gambar 22.11, diketahui nilai Squared Euclidean distance paling kecil berada pada pasangan objek $\mathrm{C}$ dan objek $\mathrm{E}$ (pasangan objek yang berbeda), yakni bernilai 0,003 (Perhatikan Gambar 22.23). Maka objek $\mathbf{C}$ dan objek $\mathbf{E}$ bergabung menjadi cluster (C,E). Pada Gambar 22.24, terlihat bahwa pada Stage 1, objek C dan objek E bergabung menjadi cluster (C,E). Perhatikan juga bahwa nilai coefficient $\mathbf{0 , 0 0 3}$, yang merupakan jarak antara objek C dan objek E. 


\begin{tabular}{|c|c|c|c|c|c|c|}
\hline & A & B & $\mathrm{C}$ & D & $E$ & $\mathrm{~F}$ \\
\hline $\mathrm{A}$ & 0 & 0.073 & 0.057 & 0.13 & 0.073 & 0.02 \\
\hline B & 0.073 & 0 & 0.024 & 0.042 & 0.045 & 0.023 \\
\hline $\mathrm{C}$ & 0.057 & 0.024 & 0 & 0.015 & 0.003 & 0.011 \\
\hline $\mathrm{D}$ & 0.13 & 0.042 & 0.015 & 0 & 0.012 & 0.05 \\
\hline $\mathrm{E}$ & 0.073 & 0.045 & 0.003 & 0.012 & 0 & 0.023 \\
\hline $\mathrm{F}$ & 0.02 & 0.023 & 0.011 & 0.05 & 0.023 & 0 \\
\hline
\end{tabular}

Gambar 22.23 Squared Euclidean Distance (Matriks Jarak)

\begin{tabular}{|c|c|c|c|c|c|c|}
\hline \multicolumn{5}{|c|}{ Single Linkage } & \multicolumn{2}{|c|}{$\begin{array}{l}3 \text { dalam hal ini adalah } \\
\text { objek } C \text {, dan } 5 \text { dalam ha } \\
\text { ini adalah objek } E \text {. }\end{array}$} \\
\hline \multirow[b]{2}{*}{ Stage } & \multicolumn{2}{|c|}{ Cluster Combined } & & \multicolumn{2}{|c|}{ Stage Cluster Eirs } & \multirow[b]{2}{*}{ Next Stage } \\
\hline & Cluster 1 & Cluster 2 & Coefficients & Eluster 1 & Cluster 2 & \\
\hline 1 & $\overline{3}$ & $\overline{5}$ & .003 & & & 2 \\
\hline 2 & 3 & 6 & .011 & & & 3 \\
\hline 3 & 3 & 4 & .012 & & & 4 \\
\hline 4 & 1 & 3 & .020 & & & 5 \\
\hline 5 & 1 & 2 & .023 & & & 0 \\
\hline
\end{tabular}

Gambar 22.24

Selanjutnya menghitung jarak antara cluster (C,E) terhadap objek lainnya.

$\Rightarrow$ Menghitung jarak antara cluster (C,E) terhadap objek A.

$$
d_{(C, E) A}=\min \left\{d_{(C, A)} ; d_{(E, A)}\right\}=\min \{0,057 ; 0,073\}=0,057 .
$$

Dapat diartikan bahwa jarak antara objek $\mathrm{C}$ ke objek A lebih dekat, dibandingkan jarak antara objek E ke objek A.

$\Rightarrow$ Menghitung jarak antara cluster $(\mathrm{C}, \mathrm{E})$ terhadap objek B.

$$
d_{(C, E) B}=\min \left\{d_{(C, B)} ; d_{(E, B)}\right\}=\min \{0,024 ; 0,045\}=0,024 .
$$

Dapat diartikan bahwa jarak antara objek C ke objek B lebih dekat, dibandingkan jarak antara objek E ke objek B.

$\Rightarrow$ Menghitung jarak antara cluster $(\mathrm{C}, \mathrm{E})$ terhadap objek D.

$$
d_{(C, E) D}=\min \left\{d_{(C, D)} ; d_{(E, D)}\right\}=\min \{0,015 ; 0,012\}=0,012 \text {. }
$$

$\Rightarrow$ Menghitung jarak antara cluster (C,E) terhadap objek F.

$$
d_{(C, E) F}=\min \left\{d_{(C, F)} ; d_{(E, F)}\right\}=\min \{0,011 ; 0,023\}=0,011 .
$$

Gambar 22.25 menyajikan jarak antara cluster (C,E) terhadap masing-masing objek. 


\begin{tabular}{|c|c|c|c|c|c|c|}
\hline & $\mathrm{A}$ & $\mathrm{B}$ & $\mathrm{C}$ & $\mathrm{D}$ & $\mathrm{E}$ & $\mathrm{F}$ \\
\hline $\mathrm{A}$ & 0 & 0.073 & 0.057 & 0.13 & 0.073 & 0.02 \\
\hline $\mathrm{B}$ & 0.073 & 0 & 0.024 & 0.042 & 0.045 & 0.023 \\
\hline $\mathrm{C}$ & 0.057 & 0.024 & 0 & 0.015 & 0.003 & 0.011 \\
\hline $\mathrm{D}$ & 0.13 & 0.042 & 0.015 & 0 & 0.012 & 0.05 \\
\hline $\mathrm{E}$ & 0.073 & 0.045 & 0.003 & 0.012 & 0 & 0.023 \\
\hline $\mathrm{F}$ & 0.02 & 0.023 & 0.011 & 0.05 & 0.023 & 0 \\
\hline Minimum & 0.057 & 0.024 & & 0.012 & & 0.011 \\
\hline
\end{tabular}

Gambar 22.25

Sehingga diperoleh matriks jarak yang baru seperti pada Gambar 22.26.

\begin{tabular}{c|c|c|c|c|c} 
& C,E & A & B & D & F \\
\hline C,E & 0 & 0.057 & 0.024 & 0.012 & 0.011 \\
\hline A & 0.057 & 0 & 0.073 & 0.13 & 0.02 \\
\hline B & 0.024 & 0.073 & 0 & 0.042 & 0.023 \\
\hline D & 0.012 & 0.13 & 0.042 & 0 & 0.05 \\
\hline F & 0.011 & 0.02 & 0.023 & 0.05 & 0 \\
\hline
\end{tabular}

\section{Gambar 22.26 Matriks Jarak}

Sampai pada tahap ini, telah terbentuk 5 klaster, yakni $\{C, E\},\{A\},\{B\},\{D\}$, dan $\{F\}$. Gambar 22.27 disajikan output SPSS.

\begin{tabular}{|c|c|c|c|c|c|}
\hline \multirow{5}{*}{$\begin{array}{l}\text { Jika dibentuk } 5 \\
\text { klaster, maka } \\
\text { diperoleh klaster } \\
\{C, E\},\{A\},\{B\}, \\
\{D\}, \operatorname{dan}\{F\} .\end{array}$} & \multicolumn{5}{|c|}{ Cluster Membership } \\
\hline & Case & 5 Clusters & 4 Clusters & 3 Clusters & 2 Clusters \\
\hline & $1: A$ & 1 & 1 & 1 & 1 \\
\hline & $2: B$ & 2 & 2 & 2 & 2 \\
\hline & $3: C$ & 3 & 3 & 3 & 1 \\
\hline & $4: D$ & 4 & 4 & 3 & 1 \\
\hline & $5: E$ & 3 & 3 & 3 & 1 \\
\hline & $6: F$ & 5 & 3 & 3 & 1 \\
\hline
\end{tabular}

\section{Gambar 22.27 Output SPSS untuk Analisis Klaster Metode Single Linkage}

Berdasarkan Gambar 22.26, diketahui nilai jarak paling kecil berada pada pasangan (C,E) dan F, yakni bernilai 0,011. Maka (C,E) dan F bergabung menjadi cluster (C,E,F). Pada Gambar 22.24, yakni Stage 2 (objek 3 dan objek 6 bergabung). Diketahui nilai coefficient adalah 0,011 (lihat juga nilai coefficient pada Gambar 22.24, Stage 2).

Selanjutnya menghitung jarak antara cluster (C,E,F) terhadap objek lainnya.

$\Rightarrow$ Menghitung jarak antara cluster (C,E,F) terhadap objek A.

$$
d_{(C, E, F) A}=\min \left\{d_{(C, E) A} ; d_{(F, A)}\right\}=\min \{0,057 ; 0,02\}=0,02 .
$$

$\Rightarrow$ Menghitung jarak antara cluster (C,E,F) terhadap objek B.

$$
d_{(C, E, F) B}=\min \left\{d_{(C, E) B} ; d_{(F, B)}\right\}=\min \{0,024 ; 0,023\}=0,023 .
$$


$\Rightarrow$ Menghitung jarak antara cluster $(\mathrm{C}, \mathrm{E}, \mathrm{F})$ terhadap objek D.

$$
d_{(C, E, F) D}=\min \left\{d_{(C, E) D} ; d_{(F, D)}\right\}=\min \{0,012 ; 0,05\}=0,012 .
$$

Gambar 22.28 menyajikan jarak antara cluster (C,E,F) terhadap masing-masing objek.

\begin{tabular}{|c|c|c|c|c|c|}
\hline & $\mathrm{C}, \mathrm{E}$ & $\mathrm{A}$ & $\mathrm{B}$ & $\mathrm{D}$ & $\mathrm{F}$ \\
\hline $\mathrm{C}, \mathrm{E}$ & 0 & 0.057 & 0.024 & 0.012 & 0.011 \\
\hline $\mathrm{A}$ & 0.057 & 0 & 0.073 & 0.13 & 0.02 \\
\hline $\mathrm{B}$ & 0.024 & 0.073 & 0 & 0.042 & 0.023 \\
\hline $\mathrm{D}$ & 0.012 & 0.13 & 0.042 & 0 & 0.05 \\
\hline $\mathrm{F}$ & 0.011 & 0.02 & 0.023 & 0.05 & 0 \\
\hline Minimum & & 0.02 & 0.023 & 0.012 & \\
\hline
\end{tabular}

Gambar 22.28

Sehingga diperoleh matriks matriks jarak yang baru seperti pada Gambar 22.29.

\begin{tabular}{|c|c|c|c|c|}
\hline & $\mathrm{C}, \mathrm{E}, \mathrm{F}$ & $\mathrm{A}$ & $\mathrm{B}$ & $\mathrm{D}$ \\
\hline $\mathrm{C}, \mathrm{E}, \mathrm{F}$ & 0 & 0.02 & 0.023 & 0.012 \\
\hline $\mathrm{A}$ & 0.02 & 0 & 0.073 & 0.13 \\
\hline $\mathrm{B}$ & 0.023 & 0.073 & 0 & 0.042 \\
\hline $\mathrm{D}$ & 0.012 & 0.13 & 0.042 & 0 \\
\hline
\end{tabular}

Gambar 22.29

Berdasarkan Gambar 22.29, diketahui nilai jarak paling kecil berada pada pasangan (C,E,F) dan D, yakni bernilai 0,012. Maka (C,E,F) dan D bergabung menjadi cluster (C,E,F,D). Pada Gambar 22.24, yakni Stage 3 (objek 3 dan objek 4 bergabung). Diketahui nilai coefficient adalah 0,012 (lihat juga nilai coefficient pada Gambar 22.24, Stage 3).

Selanjutnya menghitung jarak antara cluster (C,E,F,D) terhadap objek lainnya.

$\Rightarrow$ Menghitung jarak antara cluster (C,E,F,D) terhadap objek A.

$$
d_{(C, E, F, D) A}=\min \left\{d_{(C, E, F) A} ; d_{(D, A)}\right\}=\min \{0,02 ; 0,13\}=0,02
$$

$\Rightarrow$ Menghitung jarak antara cluster (C,E,F,D) terhadap objek B.

$$
d_{(C, E, F, D) B}=\min \left\{d_{(C, E, F) B} ; d_{(D, B)}\right\}=\min \{0,023 ; 0,042\}=0,023 .
$$

Gambar 22.30 menyajikan jarak antara cluster (C,E,F,D) terhadap masing-masing objek.

\begin{tabular}{c|c|c|c|c}
\hline & $\mathrm{C}, \mathrm{E}, \mathrm{F}$ & $\mathrm{A}$ & $\mathrm{B}$ & $\mathrm{D}$ \\
\hline $\mathrm{C}, \mathrm{E}, \mathrm{F}$ & 0 & 0.02 & 0.023 & 0.012 \\
\hline $\mathrm{A}$ & 0.02 & 0 & 0.073 & 0.13 \\
\hline $\mathrm{B}$ & 0.023 & 0.073 & 0 & 0.042 \\
\hline $\mathrm{D}$ & 0.012 & 0.13 & 0.042 & 0 \\
\hline Minimum & & 0.02 & 0.023 & \\
\cline { 5 - 5 } & & &
\end{tabular}

Gambar 22.30 
Sehingga diperoleh matriks jarak yang baru seperti pada Gambar 22.31.

\begin{tabular}{c|c|c|c|}
\hline & $\mathrm{C}_{3}, \mathrm{E}_{7} \mathrm{D}$ & $\mathrm{A}$ & $\mathrm{B}$ \\
\hline $\mathrm{C}, \mathrm{E}, \mathrm{F}, \mathrm{D}$ & 0 & 0.02 & 0.023 \\
\hline $\mathrm{A}$ & 0.02 & 0 & 0.073 \\
\hline $\mathrm{B}$ & 0.023 & 0.073 & 0 \\
\hline
\end{tabular}

Gambar 22.31

Berdasarkan Gambar 22.31, diketahui nilai jarak paling kecil berada pada pasangan (C,E,F,D) dan A, yakni bernilai 0,002. Maka (C,E,F,D) dan A bergabung menjadi cluster (C,E,F,D,A). Pada Gambar 22.24, yakni Stage 4 (objek 3 dan objek 1 bergabung). Diketahui nilai coefficient adalah 0,02 (lihat juga nilai coefficient pada Gambar 22.24, Stage 4).

Selanjutnya menghitung jarak antara cluster (C,E,F,D,A) terhadap objek lainnya.

$\Rightarrow$ Menghitung jarak antara cluster $(\mathrm{C}, \mathrm{E}, \mathrm{F}, \mathrm{D}, \mathrm{A})$ terhadap objek $\mathrm{B}$.

$$
d_{(C, E, F, D, A) B}=\min \left\{d_{(C, E, F, D) B} ; d_{(A, B)}\right\}=\min \{0,023 ; 0,073\}=0,023 .
$$

Gambar 22.32 menyajikan jarak antara cluster (C,E,F,D,A) terhadap objek B. diketahui jarak antara cluster (C,E,F,D,A) dan B adalah 0,023. Pada Gambar 22.24, yakni Stage 5 (objek 1 dan objek 2 bergabung). Diketahui nilai coefficient adalah 0,023 (lihat juga nilai coefficient pada Gambar 22.24, Stage 5).

\begin{tabular}{|c|c|c|}
\hline & $\mathrm{C}_{2} \mathrm{D}, \mathrm{E}, \mathrm{F}, \mathrm{A}$ & $\mathrm{B}$ \\
\hline $\mathrm{C}, \mathrm{D}, \mathrm{E}, \mathrm{F}, \mathrm{A}$ & 0 & 0.023 \\
\hline B & 0.023 & 0 \\
\hline
\end{tabular}

Gambar 22.32

Dari hasil yang telah diperoleh, dapat disimpulkan bahwa:

$\Rightarrow$ Jika dibentuk 3 klaster, maka $\{\mathrm{C}, \mathrm{E}, \mathrm{F}, \mathrm{D}\},\{\mathrm{A}\}$, dan $\{\mathrm{B}\}$ (lihat Gambar 22.31).

$\Rightarrow$ Jika dibentuk 2 klaster, maka $\{\mathrm{C}, \mathrm{E}, \mathrm{F}, \mathrm{D}, \mathrm{A}\}$ dan $\{\mathrm{B}\}$ (lihat Gambar 22.32).

Hasil pengklasteran tersebut sesuai dengan hasil yang diperoleh dengan SPSS, seperti pada Gambar 22.33. Berdasarkan Gambar 22.33, jika dibentuk 3 klaster, maka diperoleh klaster $\{A\},\{B\}$, dan $\{C, D, E, F\}$, dan jika dibentuk dua klaster, maka diperoleh klaster $\{A, C, D, E, F\}$ dan $\{\mathrm{B}\}$. Gambar 22.34 menyajikan dendogram dengan menggunakan metode single linkage. Berdasarkan dendogram tersebut, dapat ditarik informasi:

$\Rightarrow$ Pertama, objek $3(\mathrm{C})$ dan objek 5 (E) bergabung menjadi cluster $(3,5)$.

$\Rightarrow$ Selanjutnya, cluster $(3,5)$ bergabung dengan objek $6(\mathrm{~F})$ membentuk cluster $(3,5,6)$.

$\Rightarrow$ Kemudian cluster $(3,5,6)$ bergabung dengan objek 4 (D) membentuk cluster $(3,5,6,4)$.

$\Rightarrow$ Cluster $(3,5,6,4)$ bergabung dengan objek 1 (A) membentuk cluster $(3,5,6,4,1)$.

$\Rightarrow$ Dan terakhir cluster $(3,5,6,4,1)$ bergabung dengan objek 2 (B) membentuk cluster $(3,5,6,4,1,2)$. 


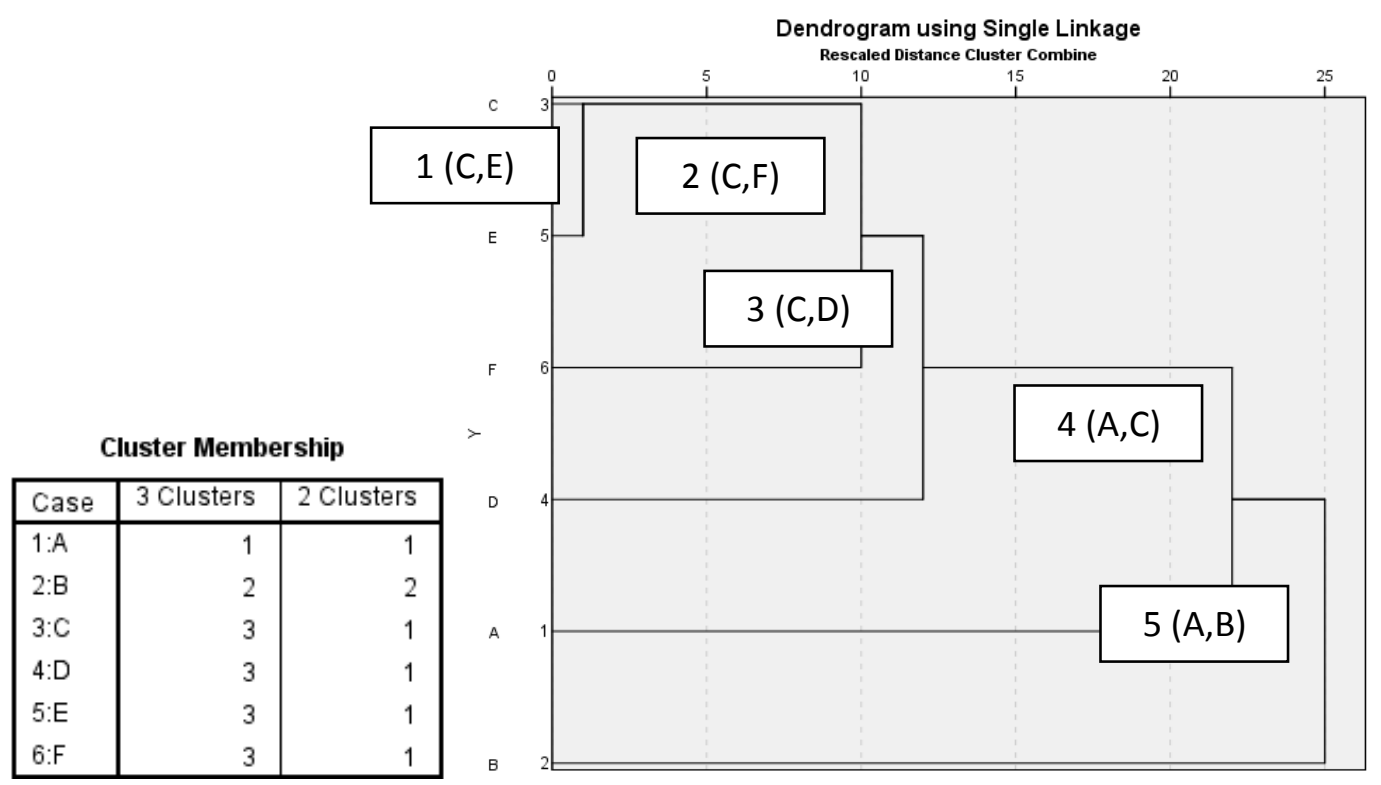

Gambar 22.33

Gambar 22.34

Jadi, pada metode average linkage, pertama menentukan jarak paling minimum antara dua objek. Misalkan objek $i$ dan objek $k$ memiliki jarak yang paling minimum, maka objek $i$ dan objek $k$ bergabung menjadi suatu klaster $(i, k)$. Langkah selanjutnya menghitung jarak antara klaster $(i, k)$ terhadap klaster/objek lainnya (misalkan klaster $l$ ), dengan rumus sebagai berikut.

$$
d_{(i, k), l}=\min \left(d_{(i, k)} ; d_{(i, l)}\right) .
$$

\section{Contoh Perhitungan Metode Ward}

Berikut akan digunakan analisis klaster metode average ward untuk pengklasteran. Data yang digunakan tetap sama, seperti pada Gambar 22.9. Tabel 22.4 menyajikan perhitungan error sum of squares (ESS) untuk tiap pasang klaster.

Tabel 22.4 Error Sum of Squares (ESS) untuk Setiap Pasangan Klaster

\begin{tabular}{|c|c|c|c|c|c|}
\hline Klaster & $A$ & $B$ & $c=\left(A-\bar{X}_{A}\right)^{2}$ & $d=\left(B-\bar{X}_{B}\right)^{2}$ & $c+d$ \\
\hline $\mathrm{E}$ & 1.35 & 1 & 0.005625 & 0 & 0.005625 \\
\hline $\mathrm{F}$ & 1.2 & 1 & 0.005625 & 0 & 0.005625 \\
\hline Rata-Rata & 1.275 & 1 & \multicolumn{2}{|c|}{ Jumlah } & 0.01125 \\
\hline $\mathrm{A}$ & 1.1 & 1.1 & 0.0025 & 0.015625 & 0.018125 \\
\hline $\mathrm{B}$ & 1.2 & 0.85 & 0.0025 & 0.015625 & 0.018125 \\
\hline Rata-Rata & 1.15 & 0.975 & \multicolumn{2}{|c|}{ Jumlah } & 0.03625 \\
\hline A & 1.1 & 1.1 & 0.01 & 0.004225 & 0.014225 \\
\hline $\mathrm{C}$ & 1.3 & 0.97 & 0.01 & 0.004225 & 0.014225 \\
\hline Rata-Rata & 1.2 & 1.035 & \multicolumn{2}{|c|}{ Jumlah } & 0.02845 \\
\hline
\end{tabular}




\begin{tabular}{|c|c|c|c|c|c|}
\hline $\mathrm{A}$ & 1.1 & 1.1 & 0.0225 & 0.01 & 0.0325 \\
\hline $\mathrm{D}$ & 1.4 & 0.9 & 0.0225 & 0.01 & 0.0325 \\
\hline Rata-Rata & 1.25 & 1 & \multicolumn{2}{|c|}{ Jumlah } & 0.065 \\
\hline $\mathrm{A}$ & 1.1 & 1.1 & 0.015625 & 0.0025 & 0.018125 \\
\hline $\mathrm{E}$ & 1.35 & 1 & 0.015625 & 0.0025 & 0.018125 \\
\hline Rata-Rata & 1.225 & 1.05 & \multicolumn{2}{|c|}{ Jumlah } & 0.03625 \\
\hline $\mathrm{A}$ & 1.1 & 1.1 & 0.0025 & 0.0025 & 0.005 \\
\hline $\mathrm{F}$ & 1.2 & 1 & 0.0025 & 0.0025 & 0.005 \\
\hline Rata-Rata & 1.15 & 1.05 & \multicolumn{2}{|c|}{ Jumlah } & 0.01 \\
\hline $\mathrm{B}$ & 1.2 & 0.85 & 0.0025 & 0.0036 & 0.0061 \\
\hline $\mathrm{C}$ & 1.3 & 0.97 & 0.0025 & 0.0036 & 0.0061 \\
\hline Rata-Rata & 1.25 & 0.91 & \multicolumn{2}{|c|}{ Jumlah } & 0.0122 \\
\hline $\mathrm{B}$ & 1.2 & 0.85 & 0.01 & 0.000625 & 0.010625 \\
\hline $\mathrm{D}$ & 1.4 & 0.9 & 0.01 & 0.000625 & 0.010625 \\
\hline Rata-Rata & 1.3 & 0.875 & \multicolumn{2}{|c|}{ Jumlah } & 0.02125 \\
\hline B & 1.2 & 0.85 & 0.005625 & 0.005625 & 0.01125 \\
\hline $\mathrm{E}$ & 1.35 & 1 & 0.005625 & 0.005625 & 0.01125 \\
\hline Rata-Rata & 1.275 & 0.925 & \multicolumn{2}{|c|}{ Jumlah } & 0.0225 \\
\hline $\mathrm{B}$ & 1.2 & 0.85 & 0 & 0.005625 & 0.005625 \\
\hline $\mathrm{F}$ & 1.2 & 1 & 0 & 0.005625 & 0.005625 \\
\hline Rata-Rata & 1.2 & 0.925 & \multicolumn{2}{|c|}{ Jumlah } & 0.01125 \\
\hline $\mathrm{C}$ & 1.3 & 0.97 & 0.0025 & 0.001225 & 0.003725 \\
\hline $\mathrm{D}$ & 1.4 & 0.9 & 0.0025 & 0.001225 & 0.003725 \\
\hline Rata-Rata & 1.35 & 0.935 & \multicolumn{2}{|c|}{ Jumlah } & 0.00745 \\
\hline $\mathrm{C}$ & 1.3 & 0.97 & 0.000625 & 0.000225 & 0.00085 \\
\hline $\mathrm{E}$ & 1.35 & 1 & 0.000625 & 0.000225 & 0.00085 \\
\hline Rata-Rata & 1.325 & 0.985 & \multicolumn{2}{|c|}{ Jumlah } & 0.0017 \\
\hline $\mathrm{C}$ & 1.3 & 0.97 & 0.0025 & 0.000225 & 0.002725 \\
\hline $\mathrm{F}$ & 1.2 & 1 & 0.0025 & 0.000225 & 0.002725 \\
\hline Rata-Rata & 1.25 & 0.985 & \multicolumn{2}{|c|}{ Jumlah } & 0.00545 \\
\hline $\mathrm{D}$ & 1.4 & 0.9 & 0.000625 & 0.0025 & 0.003125 \\
\hline $\mathrm{E}$ & 1.35 & 1 & 0.000625 & 0.0025 & 0.003125 \\
\hline Rata-Rata & 1.375 & 0.95 & \multicolumn{2}{|c|}{ Jumlah } & 0.00625 \\
\hline $\mathrm{D}$ & 1.4 & 0.9 & 0.01 & 0.0025 & 0.0125 \\
\hline
\end{tabular}




\begin{tabular}{|c|c|c|c|c|c|}
\hline F & 1.2 & 1 & 0.01 & 0.0025 & 0.0125 \\
\hline Rata-Rata & 1.3 & 0.95 & \multicolumn{2}{|c|}{ Jumlah } & 0.025 \\
\hline \multicolumn{7}{|c|}{} \\
\hline E & 1.35 & 1 & 0.005625 & 0 & 0.005625 \\
\hline F & 1.2 & 1 & 0.005625 & 0 & 0.005625 \\
\hline Rata-Rata & 1.275 & 1 & \multicolumn{2}{|c|}{ Jumlah } & 0.01125 \\
\hline
\end{tabular}

Berdasarkan Tabel 22.4, diketahui $E S S_{(A, B)}=0,01125, E S S_{(A, C)}=0,03625$, dan seterusnya. Diketahui $E S S$ paling kecil adalah $\operatorname{ESS}_{(C, E)}=0,0017$. Maka klaster C dan E bergabung. Tabel 22.5 menyajikan secara ringkas nilai ESS untuk setiap pasangan klaster.

Gambar 22.35 merupakan output SPSS untuk analisis klaster metode ward, yang menyajikan proses penggabungan klaster untuk tiap-tiap tahap (stage). Berdasarkan Gambar 22.35, diketahui pada Stage 1, klaster 3 (C) dan 5 (E) bergabung, dengan nilai Coefficients $\left(E S S_{(A, B)}\right)$ adalah 0,002 (hasil pembulatan 0,0017, lihat Gambar 22.36).

Tabel 22.5 Error Sum of Squares (ESS) untuk Setiap Pasangan Klaster

\begin{tabular}{|c|c|c|}
\hline \multicolumn{2}{|c|}{ Klaster } & ESS \\
\hline C & E & $\mathbf{0 . 0 0 1 7}$ \\
\hline C & F & 0.00545 \\
\hline D & E & 0.00625 \\
\hline C & D & 0.00745 \\
\hline A & F & 0.01 \\
\hline B & F & 0.01125 \\
\hline E & F & 0.01125 \\
\hline B & C & 0.0122 \\
\hline B & D & 0.02125 \\
\hline B & E & 0.0225 \\
\hline D & F & 0.025 \\
\hline A & C & 0.02845 \\
\hline A & B & 0.03625 \\
\hline A & E & 0.03625 \\
\hline A & D & 0.065 \\
\hline
\end{tabular}

\begin{tabular}{|l|r|r|r|r|r|r|}
\hline \multicolumn{2}{|c|}{ Agglomeration Schedule } \\
\hline \multirow{3}{*}{ Stage } & \multicolumn{2}{|c|}{ Cluster Combined } & & \multicolumn{2}{|c|}{ Stage Cluster First Appears } & \\
\cline { 2 - 3 } \cline { 5 - 6 } & Cluster 1 & Cluster 2 & Coefficients & \multicolumn{1}{c|}{ Cluster 1 } & \multicolumn{1}{c|}{ Cluster 2 } & Next Stage \\
\hline 1 & 3 & 5 & .002 & 0 & 0 & 2 \\
2 & 3 & 4 & .010 & 1 & 0 & 4 \\
3 & 1 & 6 & .020 & 0 & 0 & 5 \\
4 & 2 & 3 & .046 & 0 & 2 & 5 \\
5 & 1 & 2 & .100 & 3 & 4 & 0 \\
\hline
\end{tabular}

Gambar 22.35 
Ward Linkage

\begin{tabular}{|c|c|c|c|c|c|c|}
\hline \multicolumn{7}{|c|}{ Agglomeration Schedule } \\
\hline \multirow[b]{2}{*}{ Stage } & \multicolumn{2}{|c|}{ Cluster Combined } & \multirow[b]{2}{*}{ Coefficients } & \multicolumn{2}{|c|}{ Stage Cluster First Appears } & \multirow[b]{2}{*}{ Next Stage } \\
\hline & Cluster 1 & Cluster 2 & & Cluster 1 & Cluster 2 & \\
\hline 1 & 3 & 5 & 0.001700 & 0 & 0 & 2 \\
\hline 2 & 3 & 4 & .010 & 1 & 0 & 4 \\
\hline 3 & 1 & 6 & .020 & 0 & 0 & 5 \\
\hline 4 & 2 & 3 & .046 & 0 & 2 & 5 \\
\hline 5 & 1 & 2 & .100 & 3 & 4 & 0 \\
\hline
\end{tabular}

Gambar 22.36

Tabel 22.7 Error Sum of Squares (ESS) antara Klaster (C,E) dengan Klaster Lainnya

\begin{tabular}{|c|c|c|c|c|c|}
\hline Klaster & $A$ & $B$ & $c=\left(A-\bar{X}_{A}\right)^{2}$ & $d=\left(B-\bar{X}_{B}\right)^{2}$ & $c+d$ \\
\hline $\mathrm{C}$ & 1.3 & 0.97 & 0.0025 & 0.002844 & 0.005344 \\
\hline $\mathrm{E}$ & 1.35 & 1 & 0.01 & 0.000544 & 0.010544 \\
\hline $\mathrm{A}$ & 1.1 & 1.1 & 0.0225 & 0.005878 & 0.028378 \\
\hline Rata-Rata & 1.25 & 1.023333 & \multicolumn{2}{|c|}{ Jumlah } & 0.044267 \\
\hline $\mathrm{C}$ & 1.3 & 0.97 & 0.000278 & 0.0009 & 0.001178 \\
\hline $\mathrm{E}$ & 1.35 & 1 & 0.004444 & 0.0036 & 0.008044 \\
\hline B & 1.2 & 0.85 & 0.006944 & 0.0081 & 0.015044 \\
\hline Rata-Rata & 1.283333 & 0.94 & \multicolumn{2}{|c|}{ Jumlah } & 0.024267 \\
\hline $\mathrm{C}$ & 1.3 & 0.97 & 0.0025 & 0.000178 & 0.002678 \\
\hline $\mathrm{E}$ & 1.35 & 1 & $4.93 \mathrm{E}-32$ & 0.001878 & 0.001878 \\
\hline $\mathrm{D}$ & 1.4 & 0.9 & 0.0025 & 0.003211 & 0.005711 \\
\hline Rata-Rata & 1.35 & 0.956667 & \multicolumn{2}{|c|}{ Jumlah } & 0.010267 \\
\hline $\mathrm{C}$ & 1.3 & 0.97 & 0.000278 & 0.0004 & 0.000678 \\
\hline $\mathrm{E}$ & 1.35 & 1 & 0.004444 & 0.0001 & 0.004544 \\
\hline $\mathrm{F}$ & 1.2 & 1 & 0.006944 & 0.0001 & 0.007044 \\
\hline Rata-Rata & 1.283333 & 0.99 & \multicolumn{2}{|c|}{ Jumlah } & 0.012267 \\
\hline
\end{tabular}

Berdasarkan Tabel 22.7, diketahui $\operatorname{ESS}_{(C, E, A)}=0,044267, \operatorname{ESS}_{(C, E, B)}=0,024267$, dan seterusnya. Tabel 22.8 menyajikan secara ringkas nilai ESS untuk setiap pasangan klaster pada Tabel 22.7.

Tabel 22.8 Error Sum of Squares (ESS) antara Klaster (C,E) dengan Klaster Lainnya

\begin{tabular}{|c|c|c|c|}
\hline \multicolumn{3}{|c|}{ Klaster } & EES \\
\hline C & E & D & $\mathbf{0 . 0 1 0 2 6 7}$ \\
\hline C & E & F & 0.012267 \\
\hline C & E & B & 0.024267 \\
\hline C & E & A & 0.044267 \\
\hline
\end{tabular}


Berdasarkan Tabel 22.8, diketahui ESS paling kecil adalah $\operatorname{ESS}_{(C, E, D)}=0,010267$. Maka klaster (C,E) dan D bergabung menjadi klaster (C,E,D). Berdasarkan Gambar 22.37, diketahui pada Stage 2, klaster $3(\mathrm{C})$ dan 4 (D) bergabung, dengan nilai Coefficients $\left(E S S_{(C, E, D)}\right)$ adalah 0,010 (hasil pembulatan 0,010267, lihat Gambar 22.37).

\begin{tabular}{|l|r|r|r|r|r|r|} 
Stage & Cluster 1 & Cluster 2 & Coefficients & Cluster 1 & Cluster 2 & Next Stage \\
\hline 1 & 3 & 5 & .002 & 0 & 0 & 2 \\
2 & 3 & 4 & 0.010267 & 1 & 0 & 4 \\
3 & 1 & 6 & .020 & 0 & 0 & 5 \\
4 & 2 & 3 & .046 & 0 & 2 & 5 \\
5 & 1 & 2 & .100 & 3 & 4 & 0 \\
\hline
\end{tabular}

\section{Gambar 22.37}

Berdasarkan Gambar 22.37, diketahui nilai Coefficients pada Stage 3 adalah 0,020 (sebelum dibulatkan 0,020267). Nilai tersebut diperoleh

$$
E E S_{(A, F)}+E E S_{(C, E, D)}=0,01+0,010267=0,020267
$$

Berdasarkan Gambar 22.37, diketahui nilai Coefficients pada Stage 4 adalah 0,046 (sebelum dibulatkan 0.045675). Nilai tersebut diperoleh

$$
\operatorname{ESS}_{(B, C, D, E)}+\operatorname{ESS}_{(A, F)}=0,035675+0,01=0,045675 .
$$

Tabel 22.9

\begin{tabular}{|c|c|c|c|c|c|}
\hline Klaster & $A$ & $B$ & $c=\left(A-\bar{X}_{A}\right)^{2}$ & $d=\left(B-\bar{X}_{B}\right)^{2}$ & $c+d$ \\
\hline B & 1.2 & 0.85 & 0.012656 & 0.0064 & 0.019056 \\
\hline C & 1.3 & 0.97 & 0.000156 & 0.0016 & 0.001756 \\
\hline D & 1.4 & 0.9 & 0.007656 & 0.0009 & 0.008556 \\
\hline E & 1.35 & 1 & 0.001406 & 0.0049 & 0.006306 \\
\hline Rata-Rata & 1.3125 & 0.93 & \multicolumn{3}{|c|}{ Jumlah } \\
\hline
\end{tabular}

Berdasarkan Gambar 22.37, diketahui nilai Coefficients pada Stage 5 adalah 0,001 (sebelum dibulatkan 0.100083). Nilai tersebut diperoleh

$$
E S S_{A, B, C, D, E, F}=0,100083
$$

Tabel 22.10

\begin{tabular}{|c|c|c|c|c|c|}
\hline Klaster & $A$ & $B$ & $c=\left(A-\bar{X}_{A}\right)^{2}$ & $d=\left(B-\bar{X}_{B}\right)^{2}$ & $c+d$ \\
\hline A & 1.1 & 1.1 & 0.025069 & 0.0169 & 0.041969 \\
\hline B & 1.2 & 0.85 & 0.003403 & 0.0144 & 0.017803 \\
\hline C & 1.3 & 0.97 & 0.001736 & $1.23 \mathrm{E}-32$ & 0.001736 \\
\hline D & 1.4 & 0.9 & 0.020069 & 0.0049 & 0.024969 \\
\hline E & 1.35 & 1 & 0.008403 & 0.0009 & 0.009303 \\
\hline F & 1.2 & 1 & 0.003403 & 0.0009 & 0.004303 \\
\hline Rata-Rata & 1.258333 & 0.97 & \multicolumn{7}{|c|}{ Jumlah } & 0.100083 \\
\hline
\end{tabular}




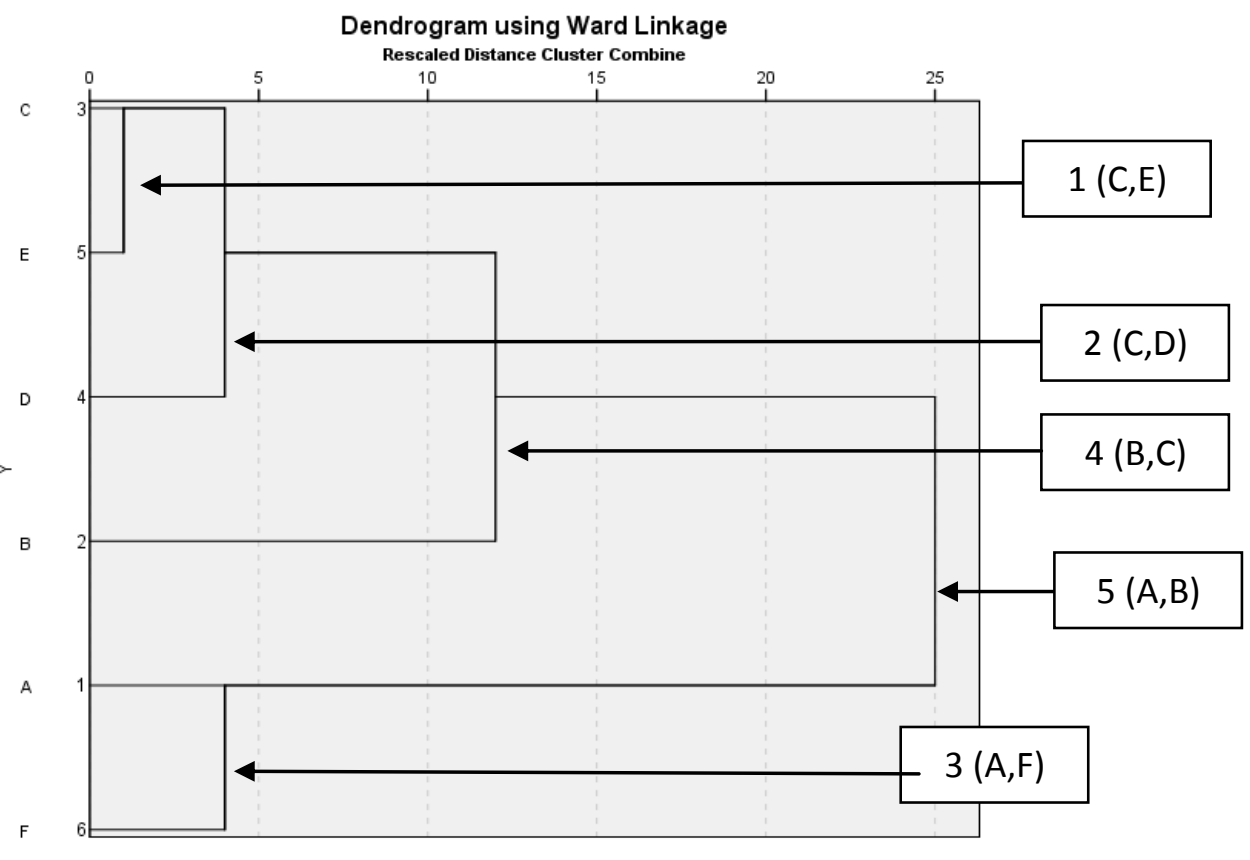

Gambar 22.38

Cluster Membership

\begin{tabular}{|l|r|r|}
\hline Case & 3 Clusters & 2 Clusters \\
\hline $1: A$ & 1 & 1 \\
$2: B$ & 2 & 2 \\
$3: C$ & 3 & 2 \\
$4: D$ & 3 & 2 \\
$5: E$ & 3 & 2 \\
$6: F$ & 1 & 1 \\
\hline
\end{tabular}

Gambar 22.39 


\section{PENYELESAIAN DALAM SPSS}

Bangun data dalam SPSS, seperti pada Gambar 22.1. Kemudian pilih Analyze $=>$ Classify $=>$ Hierarchical (Gambar 22.2), sehingga muncul tampilan seperti pada Gambar 22.3. Pada Gambar 22.3, masukkan variabel A dan B ke dalam kotak Variable(s):, sedangkan variabel Batu dimasukkan ke dalam kotak Label Cases by: Pada Gambar 22.3 pilih Statistics, sehingga muncul tampilan seperti pada Gambar 22.4. Pada Gambar 22.4, pilih Agglomeration schedule, Proximity matrix, serta bulatkan Range of solutions, kemudian isi 2 pada Minimum number of clusters: dan isi 5 pada Maximum number of clusters:. Pilih Continue. Selanjutnya pilih Plots, sehingga muncul tampilan seperti pada Gambar 22.5. Pada Gambar 22.5, pilih Dendogram, kemudian pilih Continue. Selanjutnya pilih Method, sehingga muncul tampilan seperti pada Gambar 22.6. Pada Cluster Method:

1. Between-groups linkage berarti average linkage.

2. Nearest neighbor berarti single linkage.

3. Ward's method berarti metode Ward.

Sementara pada Gambar 22.7 menyajikan berbagai jenis ukuran jarak. Andaikan pada Cluster Method: dipilih Between-groups linkage, sementara untuk ukuran jarak dipilih Squared Euclidean distance. Kemudian pilih Continue dan OK. Untuk interpretasi dari output SPSS ini, telah dibahas pada pembahasan teori analisis klaster.

\begin{tabular}{|c|c|c|c|}
\hline & Batu & $A$ & B \\
\hline 1 & A & 1.10 & 1.10 \\
\hline 2 & $B$ & 1.20 & .85 \\
\hline 3 & C & 1.30 & .97 \\
\hline 4 & $D$ & 1.40 & .90 \\
\hline 5 & $E$ & 1.35 & 1.00 \\
\hline 6 & $\mathrm{~F}$ & 1.20 & 1.00 \\
\hline 7 & & & \\
\hline
\end{tabular}

\begin{tabular}{|c|c|c|c|c|c|c|}
\hline$\oplus$ & & & & & ${ }^{\star}$ data spss & $2 \mathrm{sh}$ \\
\hline File Edit & View Data & Transform & Analyze & Direct Marketin & Graphs & $\mathrm{Ac}$ \\
\hline$E$ 岏 & $\underline{\square}$ & 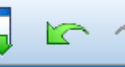 & & 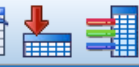 & 블 & 国 \\
\hline & Name & Type & Width & Decimals & Label & \\
\hline 1 & Batu & String & 24 & 0 & & No \\
\hline 2 & A & Numeric & 8 & 2 & Kandungan Unsur A & No \\
\hline 3 & $B$ & Numeric & 8 & 2 & Kandungan Unsur B & No \\
\hline 4 & & & & & & \\
\hline
\end{tabular}

Gambar 22.1

\begin{tabular}{|c|c|c|c|}
\hline I aples & ? & & valuco \\
\hline Compare Means & $>$ & & None \\
\hline General Linear Model & $>$ & sur A & None \\
\hline Generalized Linear Models & $\rightarrow$ & sur B & None \\
\hline Mixed Models & $>$ & & \\
\hline Correlate & $>$ & & \\
\hline Regression & $>$ & & \\
\hline Logglinear & $>$ & & \\
\hline Neural Networks & $>$ & & \\
\hline Classify & $>$ & \multicolumn{2}{|c|}{ TwoStep Cluster... } \\
\hline Dimension Reduction & $>$ & \multicolumn{2}{|c|}{ K-Means Cluster... } \\
\hline Scale & $>$ & \multicolumn{2}{|c|}{ 面 Hierarchical Cluster.. } \\
\hline Nonparametric Tests & 1 & \multicolumn{2}{|c|}{ [ros } \\
\hline
\end{tabular}

Gambar 22.2

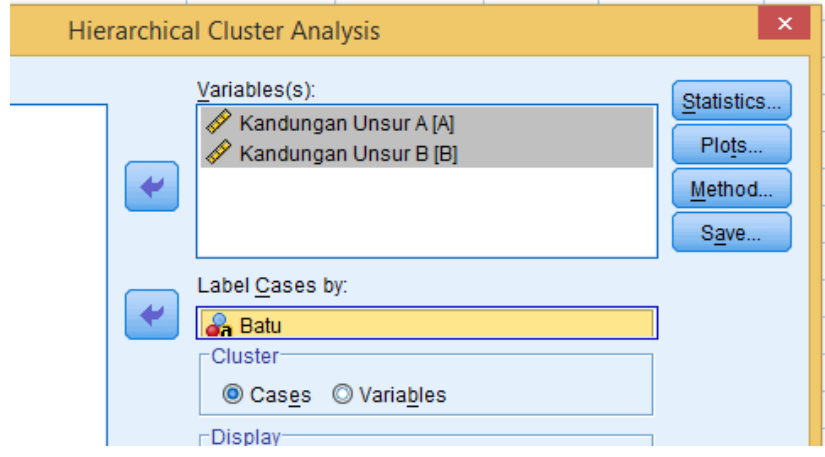

Gambar 22.3 


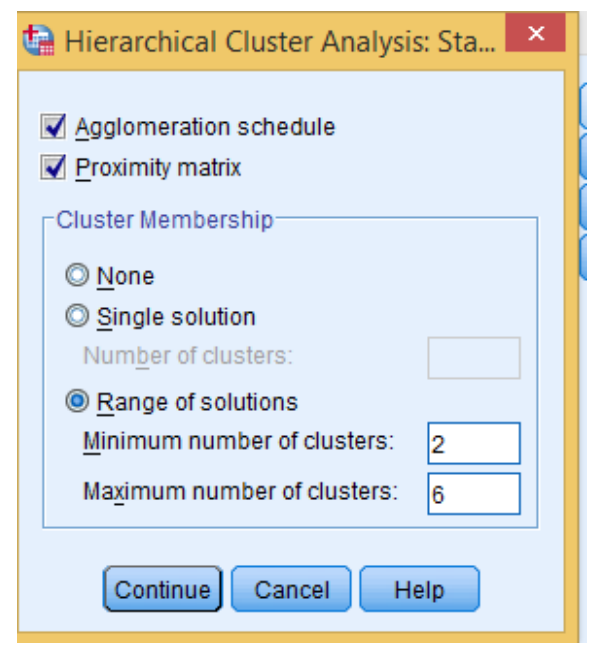

Gambar 22.4

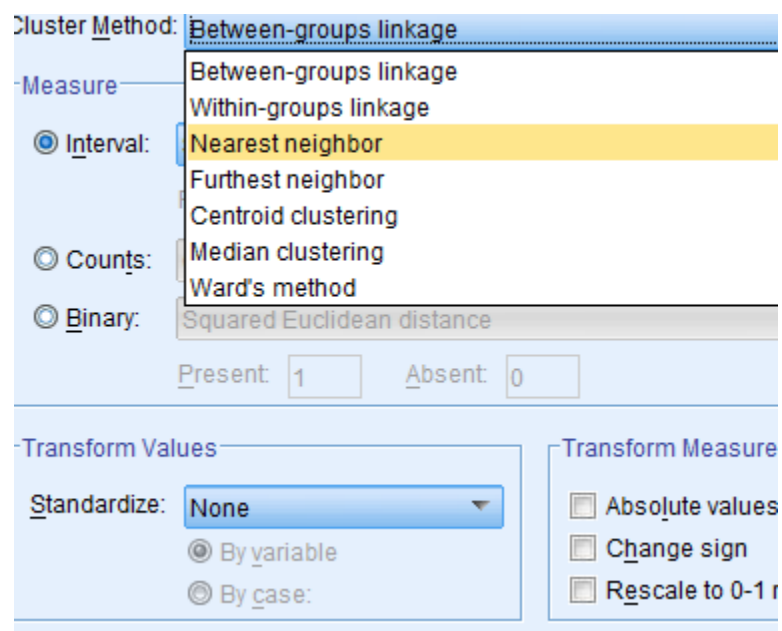

Gambar 22.6

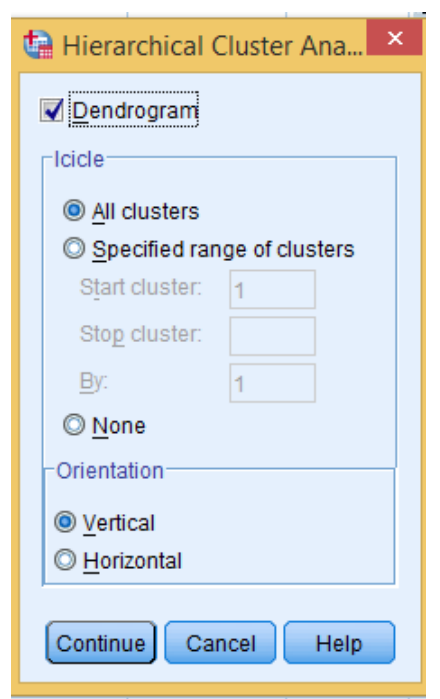

Gambar 22.5

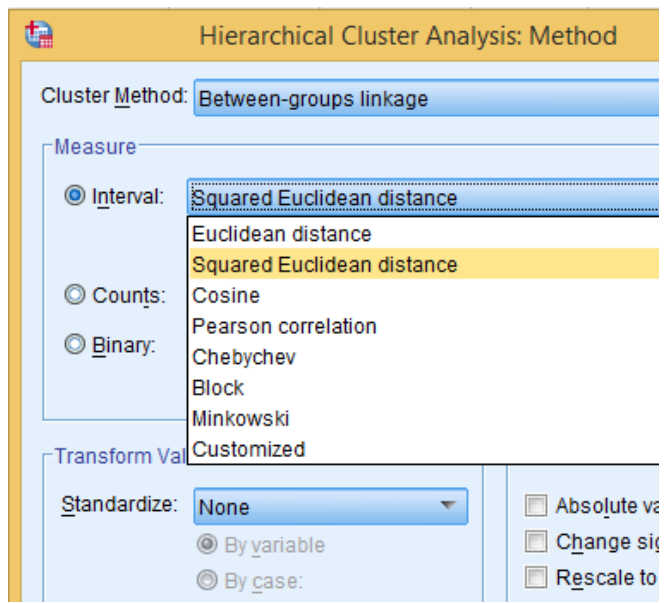

Gambar 22.7

\section{Referensi}

1. Field, A. 2009. Discovering Statistics Using SPSS, $3^{\text {rd }}$ Edition. London: Sage.

2. Hair, J.F Jr., R.E. Anderson, B.J. Babin, dan W.C. Black. 2010. Multivariate Data Analysis, $7^{\text {th }}$ Edition. Pearson Prentice Hall.

3. Janssens, W., K. Wijnen, P.D. Pelsmacker, dan P.V. Kenhove. 2008. Marketing Research with SPSS. Pearson Prenticel Hall.

4. Johnson, R.A. dan D.W. Wichern. 2007. Applied Multivariate Statistical Analysis, $6^{\text {th }}$ Edition. Pearson Prentice Hall.

5. Malhotra, N.K. dan D.F. Birks. 2006. Marketing Research, An Applied Approach, $2^{\text {nd }}$ European Edition. London: Prentice Hall.

6. Stevens, J.P. 2009. Applied Multivariate Statistics For The Social Science, $5^{\text {th }}$ Edition. New York: Routledge. 


\section{BAB 23}

ANALISIS KONJOIN

\section{Sekílas Analisis Konjoin}

Andaikan seorang pengusaha sepatu, akan merancang suatu produk sepatu baru. Untuk itu, pengusaha sepatu tersebut ingin mengetahui hal-hal sebagai berikut.

$\Rightarrow$ Hal-hal apa yang secara umum diinginkan atau disukai oleh masyarakat dalam membeli suatu sepatu.

$\Rightarrow$ Kemudian hal-hal apa yang secara umum dianggap penting oleh masyarakat, dari suatu sepatu.

Selanjutnya, pengusaha sepatu tersebut mempertimbangkan menggunakan atribut sol, bagian atas, dan harga, untuk mengetahui atribut mana yang dianggap penting oleh masyarakat.

Seorang pengusaha mempertimbangkan menggunakan atribut warna, bahan, dan harga, untuk mengetahui atribut mana yang dianggap penting oleh masyarakat.

Kemudian, pengusaha sepatu tersebut mempertimbangkan untuk menetapkan level/tingkatan dari masing-masing atribut sebagai berikut.

$\Rightarrow$ Atribut warna sepatu dipertimbangkan memiliki tiga level, yakni sepatu berwarna hitam, putih, dan abu-abu.

$\Rightarrow$ Atribut bahan dipertimbangkan memiliki tiga level, yakni sepatu dengan bahan jenis $\mathbf{A}, \mathbf{B}$, dan $\mathbf{C}$.

$\Rightarrow$ Atribut harga sepatu dipertimbangkan memiliki tiga level, Rp.70.000, Rp.100.000, dan Rp.150.000.

Pengusaha sepatu tersebut ingin mengetahui secara umum keinginan masyarakat dalam memilih atau membeli suatu sepatu. Berikut diberikan beberapa contoh kemungkinan yang secara umum diinginkan oleh masyarakat dari suatu sepatu.

$\Rightarrow$ Bisa saja secara umum masyarakat menginginkan sepatu berwarna hitam, dengan bahan jenis A, dan harga Rp. 70.000 .

$\Rightarrow$ Bisa saja secara umum masyarakat menginginkan sepatu berwarna hitam, dengan bahan jenis B, dan harga Rp. 70.000 . 
$\Rightarrow$ Bisa saja secara umum masyarakat menginginkan sepatu berwarna abu-abu, dengan bahan jenis C, dan harga Rp. 100.000, dan sebagainya.

Diketahui jumlah atribut sebanyak tiga, yakni warna, bahan, dan harga. Untuk atribut warna terdapat tiga level, yakni hitam, putih, dan abu-abu. Atribut bahan dan harga, juga masingmasing memiliki tiga level. Maka total seluruh stimulus sebanyak 27 stimulus, yakni

\section{Jumlah Level Warna $\times$ Jumlah Level Bahan $\times$ Jumlah Level Harga $=3 \times 3 \times$ $3=27$.}

Misalkan:

$\Rightarrow$ Untuk atribut warna, level warna hitam diberi kode angka 1, level warna putih diberi kode angka 2, dan level warna abu-abu diberi kode angka 3.

$\Rightarrow$ Untuk atribut bahan, level bahan A diberi kode angka 1, level bahan B diberi kode angka 2, dan level bahan $\mathrm{C}$ diberi kode angka 3.

$\Rightarrow$ Untuk atribut harga, level harga Rp. 70.000 diberi kode angka 1, level harga Rp. 100.000 diberi kode angka 2, dan level harga Rp. 150.000 diberi kode angka 3.

Berikut disajikan tabel dari total seluruh stimulus.

\section{Tabel 23.1 Total Seluruh Stimulus}

\begin{tabular}{|c|c|c|c|}
\hline Stimulus & Wama & Bahan & Harga \\
\hline 1 & 1 & 1 & 1 \\
\hline 2 & 1 & 1 & 2 \\
\hline 3 & 1 & 1 & 3 \\
\hline 4 & 1 & 2 & 1 \\
\hline 5 & 1 & 2 & 2 \\
\hline 6 & 1 & 2 & 3 \\
\hline 7 & 1 & 3 & 1 \\
\hline 8 & 1 & 3 & 2 \\
\hline 9 & 1 & 3 & 3 \\
\hline 10 & 2 & 1 & 1 \\
\hline 11 & 2 & 1 & 2 \\
\hline 12 & 2 & 1 & 3 \\
\hline 13 & 2 & 2 & 1 \\
\hline 14 & 2 & 2 & 2 \\
\hline 15 & 2 & 2 & 3 \\
\hline 16 & 2 & 3 & 1 \\
\hline 17 & 2 & 3 & 2 \\
\hline 18 & 2 & 3 & 3 \\
\hline 19 & 3 & 1 & 1 \\
\hline 20 & 3 & 1 & 2 \\
\hline
\end{tabular}

\begin{tabular}{|l|l|l|l|}
\hline 21 & 3 & 1 & 3 \\
\hline 22 & 3 & 2 & 1 \\
\hline 23 & 3 & 2 & 2 \\
\hline 24 & 3 & 2 & 3 \\
\hline 25 & 3 & 3 & 1 \\
\hline 26 & 3 & 3 & 2 \\
\hline 27 & 3 & 3 & 3 \\
\hline
\end{tabular}

Berdasarkan Tabel 23.1, diketahui stimulus 1 bernilai 1,1,1. Hal ini berarti sepatu berwarna hitam, dengan bahan jenis A, dan harga Rp. 70.000. Diketahui stimulus 27 bernilai 3,3,3. Hal ini berarti sepatu berwarna abu-abu, dengan bahan jenis C, dan harga Rp. 150.000, dan seterusnya. Kemudian seorang pengusaha sepatu tersebut membuat kuesioner penilaian terhadap 27 stimulus tersebut. Andaikan penilaian responden pertama dari 27 stimulus disajikan dalam Tabel 23.2. Pada penilaian stimulus pada Tabel 23.2, responden pertama diminta untuk memberikan nilai ranking untuk setiap stimulus, untuk stimulus yang paling tidak disukai diberi nilai ranking 1, sampai stimulus stimulus yang paling disukai diberi nilai 
ranking 27. Perhatikan bahwa tidak terdapat nilai ranking yang sama dari penilaian yang diberikan oleh responden pertama.

Seorang pengusaha sepatu ingin mengetahui stimulus mana yang secara umum diinginkan oleh masyarakat. Mungkin saja secara umum, masyarakat menginginkan sepatu berwarna abu-abu, dengan jenis bahan $C$, dan harga Rp. 150.000 (stimulus 27), atau mungkin saja secara umum, masyarakat menginginkan sepatu berwarna hitam, dengan bahan jenis A, dan harga Rp. 70.000 (stimulus 1), dan seterusnya.

Tabel 23.2 Penilaian Responden Pertama

\begin{tabular}{|c|c|c|c|c|}
\hline Stimulus & Warna & Bahan & Harga & Penilaian Responden 1 \\
\hline 1 & 1 & 1 & 1 & 27 \\
\hline 2 & 1 & 1 & 2 & 19 \\
\hline 3 & 1 & 1 & 3 & 11 \\
\hline 4 & 1 & 2 & 1 & 26 \\
\hline 5 & 1 & 2 & 2 & 18 \\
\hline 6 & 1 & 2 & 3 & 10 \\
\hline 7 & 1 & 3 & 1 & 25 \\
\hline 8 & 1 & 3 & 2 & 17 \\
\hline 9 & 1 & 3 & 3 & 9 \\
\hline 10 & 2 & 1 & 1 & 24 \\
\hline 11 & 2 & 1 & 2 & 16 \\
\hline 12 & 2 & 1 & 3 & 8 \\
\hline 13 & 2 & 2 & 1 & 23 \\
\hline 14 & 2 & 2 & 2 & 15 \\
\hline 15 & 2 & 2 & 3 & 7 \\
\hline 16 & 2 & 3 & 1 & 22 \\
\hline 17 & 2 & 3 & 2 & 14 \\
\hline 18 & 2 & 3 & 3 & 6 \\
\hline 19 & 3 & 1 & 1 & 21 \\
\hline 20 & 3 & 1 & 2 & 13 \\
\hline 21 & 3 & 1 & 3 & 5 \\
\hline 22 & 3 & 2 & 1 & 20 \\
\hline 23 & 3 & 2 & 2 & 12 \\
\hline 24 & 3 & 2 & 3 & 5 \\
\hline 25 & 3 & 3 & 1 & 3 \\
\hline 26 & 3 & 3 & 2 & 2 \\
\hline 27 & 3 & 3 & 3 & 1 \\
\hline
\end{tabular}

Tabel 23.3 juga merupakan alternatif lain dalam pemberian penilaian terhadap 27 stimulus oleh responden pertama. 
Tabel 23.3 Penilaian Responden Pertama

\begin{tabular}{|c|c|c|c|c|}
\hline Stimulus & Warna & Bahan & Harga & Penilaian Responden 1 \\
\hline 1 & 1 & 1 & 1 & 9 \\
\hline 2 & 1 & 1 & 2 & 7 \\
\hline 3 & 1 & 1 & 3 & 6 \\
\hline 4 & 1 & 2 & 1 & 8 \\
\hline 5 & 1 & 2 & 2 & 7 \\
\hline 6 & 1 & 2 & 3 & 4 \\
\hline 7 & 1 & 3 & 1 & 8 \\
\hline 8 & 1 & 3 & 2 & 8 \\
\hline 9 & 1 & 3 & 3 & 8 \\
\hline 10 & 2 & 1 & 1 & 9 \\
\hline 11 & 2 & 1 & 2 & 9 \\
\hline 12 & 2 & 1 & 3 & 8 \\
\hline 13 & 2 & 2 & 1 & 6 \\
\hline 14 & 2 & 2 & 2 & 6 \\
\hline 15 & 2 & 2 & 3 & 5 \\
\hline 16 & 2 & 3 & 1 & 7 \\
\hline 17 & 2 & 3 & 2 & 7 \\
\hline 18 & 2 & 3 & 3 & 7 \\
\hline 19 & 3 & 1 & 1 & 9 \\
\hline 20 & 3 & 1 & 2 & 7 \\
\hline 21 & 3 & 1 & 3 & 5 \\
\hline 22 & 3 & 2 & 1 & 5 \\
\hline 23 & 3 & 2 & 2 & 7 \\
\hline 24 & 3 & 2 & 3 & 5 \\
\hline 25 & 3 & 3 & 1 & 3 \\
\hline 26 & 3 & 3 & 2 & 2 \\
\hline 27 & 3 & 3 & 3 & 1 \\
\hline
\end{tabular}

Pada penilaian stimulus pada Tabel 23.3, responden pertama diminta untuk memberikan nilai untuk setiap stimulus. Skala nilai dimulai dari 1 sampai 9, dengan nilai 1 menyatakan yang paling tidak disukai (not preferred) dan nilai 9 menyatakan yang paling disukai (greatly preferred). Pada sistem penilaian ini, nilai yang diberikan untuk stimulus pertama, boleh sama dengan nilai yang diberikan untuk stimulus kedua. Sebagai contoh, berdasarkan Tabel 23.3, penilaian responden dari stimulus 1 sama dengan penilaian stimulus 10, dan 11, yakni diberi nilai 9.

\section{Contoh Jenís Data Metrik dan Nonmetrîk}

Mengenai jenis data pada variabel tak bebas dalam analisis konjoin, Malhotra dan Birks (2006:632) menyatakan sebagai berikut.

"As in the case of MDS, conjoint analysis input data can be either non-metric or metric. For non-metric data, respondents are typically required to provide rank-order evaluations. For the pairwise approach, respondents rank all the cells of each matrix in terms of their 
desirability. For the full-profile approach, they rank all the stimulus profiles. Rankings involve relative evaluations of the attribute levels. Proponents of ranking data believe that such data accurately reflect the behavior of consumers in the market place."

Lebih lanjut, Malhotra dan Birks (2006:632) menyatakan sebagai berikut.

"In the metric form, respondents provide ratings, rather than rankings. In this case, the judgements are typically made independently. Advocates of rating data believe they are more convenient for the respondents and easier to analyze than rankings. In recent years, the use of ratings has become increasingly common. In conjoint analysis, the dependent variable is usually preference or intention to buy. In other words, respondents provide ratings or rankings in terms of their preference or intentions to buy. The conjoint methodology, however, is flexible and can accommodate a range of other dependent variables, including actual purchase or choice. In evaluating boot profiles, respondents were required to provide preference ratings for the boots described by the nine profiles in the estimation set. These ratings were obtained using a nine-point Likert scale $(1=$ not preferred, $9=$ greatly preferred)."

Dari pernyataan tersebut, dapat ditarik informasi sebagai berikut.

$\Rightarrow$ Ketika data dari variabel tak bebas bersifat nonmetrik, maka seorang responden akan memberikan nilai ranking untuk tiap-tiap stimulus. Sebagai contoh, andaikan terdapat $k$ stimulus, maka seorang responden memberikan nilai ranking 1 untuk stimulus yang paling tidak disukai, dan memberikan nilai ranking $k$ untuk stimulus yang paling disukai. Contoh penilaian stimulus dengan cara ranking ditunjukkan pada Tabel 23.2. Para pengguna atau penggagas (proponents) cara ini meyakini data yang diperoleh secara akurat mencerminkan perilaku konsumen pasar.

$\Rightarrow$ Di sisi lain, ketika data dari variabel tak bebas bersifat metrik, maka seorang responden akan memberikan penilaian (nilai rating) untuk tiap-tiap stimulis. Pemberian rating dapat menggunakan skala Likert yang dimulai dari 1 sampai 9 . Dengan nilai 1 menyatakan yang paling tidak disukai (not preferred) dan nilai 9 menyatakan yang paling disukai (preferred). Para penggagas (advocates) cara ini meyakini bahwa proses penilaian untuk tiap-tiap stimulus dengan cara rating lebih mudah dibandingkan dengan cara ranking dikarenakan tidak terlalu membutuhkan banyak pertimbangan. Contoh penilaian dengan cara rating disajikan pada Tabel 23.3.

Menurut anda, cara mana yang lebih praktis atau tidak terlalu membutuhkan banyak pertimbangan dalam memberikan penilaian terhadap stimulus, apakah cara ranking atau rating?

Jika jumlah atribut sebanyak 5, dan masing-masing atribut memiliki 4 level, maka jumlah stimulus yang dapat dibentuk sebanyak

$$
4 \times 4 \times 4 \times 4 \times 4=1024 \text { stimulus. }
$$

Mungkin responden akan jenuh dalam memberikan penilaian terhadap masing-masing stimulus. 
Pada contoh kasus sebelumnya, diketahui jumlah atribut sebanyak tiga, dan masing-masing atribut tersebut memiliki tiga level, sehingga jumlah stimulus yang dapat dibentuk sebanyak 27.

\section{Pairwise Approach dan Full-Profile Approach}

Malhotra dan Birks (2006:630) menyatakan terdapat dua pendekatan (approach) dalam pembentukan stimulus, yakni:

$\Rightarrow$ Pairwise approach. Untuk ilustrasi dari pendekatan ini, perhatikan kembali contoh kasus sebelumnya. Diketahui jumlah atribut sebanyak 3, yakni warna, bahan, dan harga. Dengan menggunakan pendekatan pairwise approach, maka akan dibentuk stimulus untuk tiap-tiap pasangan atribut. Jadi akan dibentuk stimulus pada pasangan atribut (warna, bahan), (warna, harga), dan (bahan, harga). Perhatikan bahwa terdapat 3 pasang atribut.

Banyaknya pasangan atribut $=C_{2}^{\text {jumla hatribut }}=C_{2}^{3}=3$ pasang atribut .

Tabel 23.4 menyajikan stimulus untuk pasangan atribut warna dan bahan.

Tabel 23.4 Stimulus untuk Pasangan Atribut Warna dan Bahan

\begin{tabular}{|c|c|c|c|}
\hline \multirow{2}{*}{ Bahan } & \multicolumn{3}{|c|}{ Warna } \\
\cline { 2 - 4 } & hitam & putih & abu-abu \\
\hline A & & & \\
\hline B & & & \\
\hline C & & & \\
\hline
\end{tabular}

Tabel 23.5 menyajikan stimulus untuk pasangan atribut warna dan harga.

Tabel 23.5 Stimulus untuk Pasangan Warna dan Harga

\begin{tabular}{|c|c|c|c|}
\hline \multirow{2}{*}{ Harga } & \multicolumn{3}{|c|}{ Warna } \\
\cline { 2 - 4 } & hitam & putih & abu-abu \\
\hline Rp. 70.000 & & & \\
\hline Rp. 100.000 & & & \\
\hline Rp. 150.000 & & & \\
\hline
\end{tabular}

Tabel 23.6 menyajikan stimulus untuk pasangan atribut bagian atas dan harga.

Tabel 23.6 Stimulus untuk Pasangan Atribut Bahan dan Harga

\begin{tabular}{|c|c|c|c|}
\hline \multirow{2}{*}{ Harga } & \multicolumn{3}{|c|}{ Bahan } \\
\cline { 2 - 4 } & A & B & C \\
\hline Rp. 70.000 & & & \\
\hline Rp. 100.000 & & & \\
\hline Rp. 150.000 & & & \\
\hline
\end{tabular}


Tabel 23.7 menyajikan contoh penilaian stimulus dari responden pertama untuk pasangan atribut bahan dan harga. Berdasarkan Tabel 23.7, diketahui yang paling diinginkan responden pertama adalah sepatu dengan harga Rp. 70.000 dan bahan jenis C (nilai ranking 9). Sementara yang paling tidak diinginkan responden pertama adalah sepatu dengan harga $\mathrm{Rp}$. 150.000 dan bahan jenis B (nilai ranking 1).

Tabel 23.7 Stimulus untuk Pasangan Atribut Bahan dan Harga

\begin{tabular}{|c|c|c|c|}
\hline \multirow{2}{*}{ Harga } & \multicolumn{3}{|c|}{ Bahan } \\
\cline { 2 - 4 } & A & B & C \\
\hline Rp. 70.000 & 7 & 8 & 9 \\
\hline Rp. 100.000 & 5 & 6 & 3 \\
\hline Rp. 150.000 & 2 & 1 & 4 \\
\hline
\end{tabular}

$\Rightarrow$ Full-profile approach. Pendekatan full-profile disebut juga dengan istilah multiplefactor evaluation atau complete profiles. Ilustrasi dari pendekatan ini sudah dilakukan, yakni pada pembentukan stimulus seperti pada Tabel 23.1.

\begin{tabular}{|r|r|r|r|r|r|}
\hline & warna & \multicolumn{1}{c|}{ bahan } & \multicolumn{1}{c|}{ harga } & \multicolumn{1}{l|}{ STATUS_ } & \multicolumn{1}{c|}{ CARD_ } \\
\hline 1 & 1.00 & 1.00 & 1.00 & 0 & 1 \\
\hline 2 & 1.00 & 2.00 & 2.00 & 0 & 2 \\
\hline 3 & 1.00 & 3.00 & 3.00 & 0 & 3 \\
\hline 4 & 2.00 & 1.00 & 2.00 & 0 & 4 \\
\hline 5 & 2.00 & 2.00 & 3.00 & 0 & 5 \\
\hline 6 & 2.00 & 3.00 & 1.00 & 0 & 6 \\
\hline 7 & 3.00 & 1.00 & 3.00 & 0 & 7 \\
\hline 8 & 3.00 & 2.00 & 1.00 & 0 & 8 \\
\hline 9 & 3.00 & 3.00 & 2.00 & 0 & 9 \\
\hline
\end{tabular}

Gambar 23.1

\begin{tabular}{r|r|r|r|r|}
\hline warna & bahan & \multicolumn{1}{c|}{ harga } & STATUS_ & CARD_ \\
\hline Hitam & Jenis A & Rp. 70.000 & Design & 1 \\
\hline Hitam & Jenis B & Rp. 100.000 & Design & 2 \\
\hline Hitam & Jenis C & Rp. 150.000 & Design & 3 \\
\hline Putih & Jenis A & Rp. 100.000 & Design & 4 \\
\hline Putih & Jenis B & Rp. 150.000 & Design & 5 \\
\hline Putih & Jenis C & Rp. 70.000 & Design & 6 \\
\hline Abu-Abu & Jenis A & Rp. 150.000 & Design & 7 \\
\hline Abu-Abu & Jenis B & Rp. 70.000 & Design & 8 \\
\hline Abu-Abu & Jenis C & Rp. 100.000 & Design & 9
\end{tabular}

Gambar 23.2 Stimulus Setelah Direduksi

Malhotra dan Birks (2006:631) menyatakan sebagai berikut.

"It is not necessary to evaluate all the possible combinations, nor is it feasible in all cases. In the pairwise approach, it is possible to reduce the number of paired comparisons by using cyclical designs. Likewise, in the full-profile approach, the number of stimulus profiles can be greatly reduced by means of fractional factorial designs. A special class of fractional designs, orthogonal arrays, allows for the efficient estimation of all main effects. Orthogonal arrays permit the measurement of all main effects of interest on an uncorrelated basis. These designs assume that all interactions are negligible. Orthogonal arrays are constructed from basic full factorial designs by substituting a new factor for selected interaction effects that are presumed to be negligible ${ }^{25}$. Generally, two sets of data are obtained. One, the estimation set, is used to calculate the part-worth functions for the attribute levels. The other, the holdout set, is used to assess reliability and validity."

Dari pernyataan tersebut, dapat dikatakan bahwa jika jumlah stimulus cukup banyak, maka jumlah stimulus tersebut dapat direduksi atau dikurangkan. Pada pendekatan pairwise approach, jumlah stimulus dapat direduksi dengan menggunakan pendekatan cyclical designs, sementara pada pendekatan full-profile approach, jumlah stimulus dapat direduksi dengan menggunakan pendekatan fractional factorial design. Diketahui pembentukan stimulus pada Tabel 23.1 dengan menggunakan pendekatan full-profile approach, yakni sebanyak 27. Dengan menggunakan software SPSS, yang semula jumlah stimulus sebanyak 27, secara otomatis SPSS mereduksi menjadi 9 stimulus. Perhatikan Gambar 23.1 dan Gambar 23.2. 


\section{PENYELESAIAN DALAM SPSS}

Aktifkan SPSS, seperti pada Gambar 23.1. Kemudian pilih Data $\Rightarrow$ Orthogonal Design $=>$ Generate (Gambar 23.2). Pada Gambar 23.3, didefinisikan/dibentuk aribut warna. Pada Gambar 23.4 telah didefinisikan/dibentuk atribut warna, bahan, dan harga. Pada Gambar 23.6, didefinisikan level untuk atribut warna (pilih Define Values untuk mendefinisikan level). Level untuk atribut bahan dan harga telah didefinisikan pada Gambar 23.8.

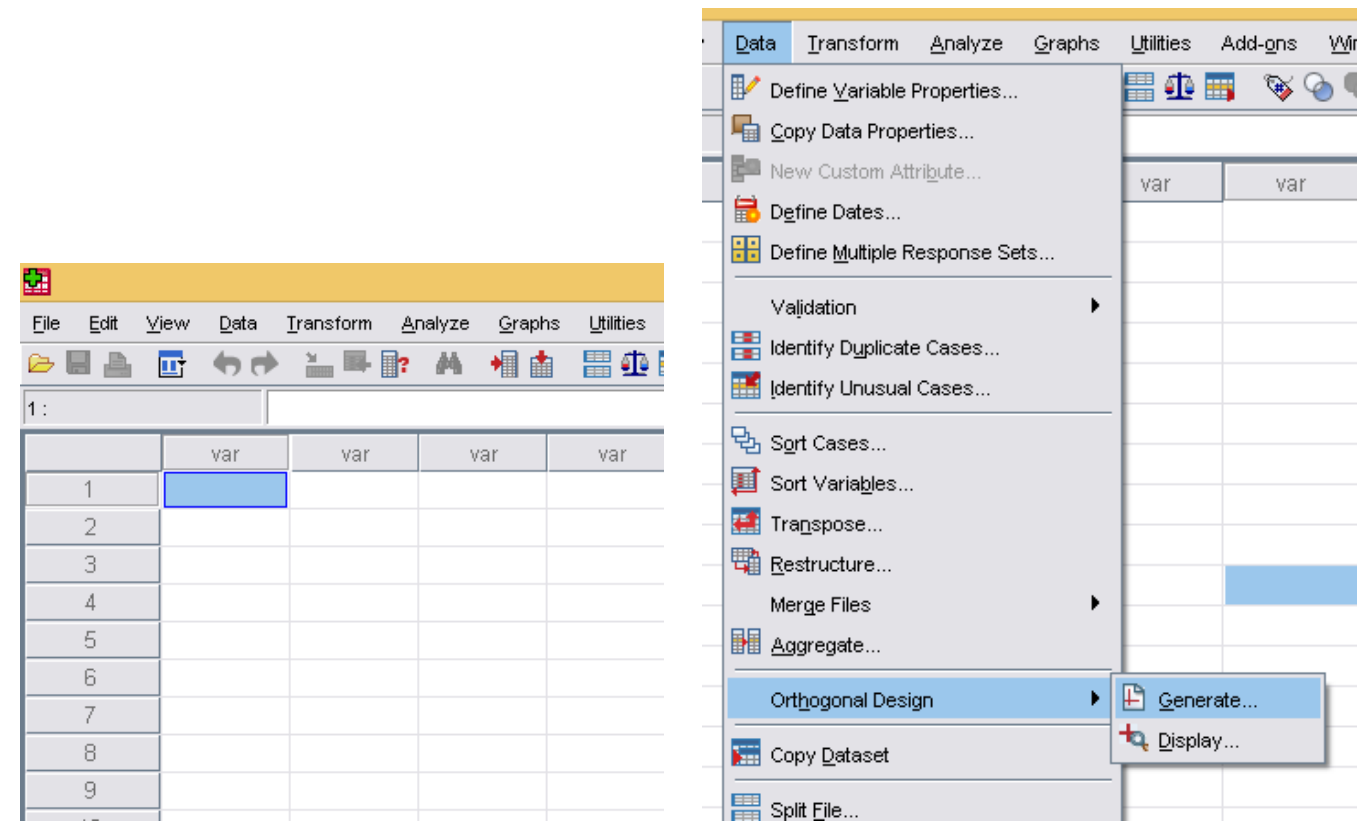

Gambar 23.1

Gambar 23.2

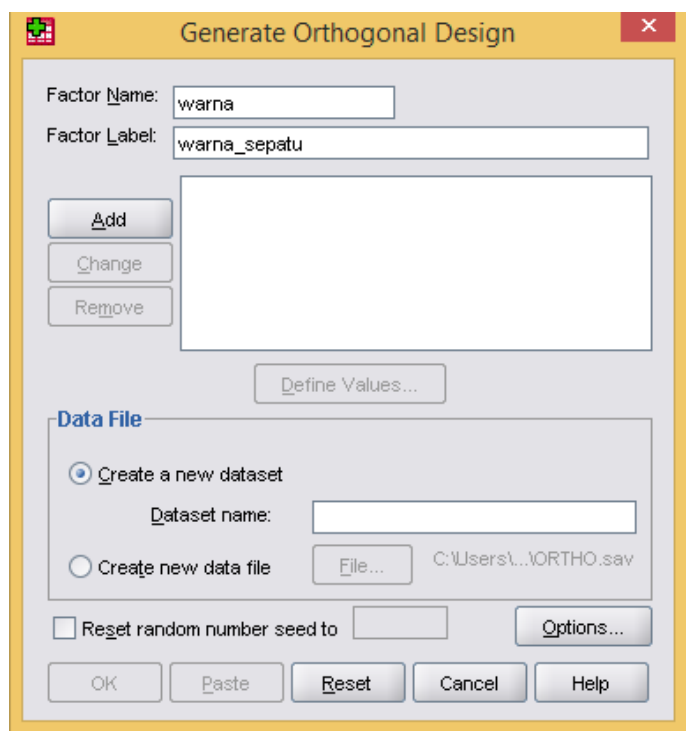

Gambar 23.3

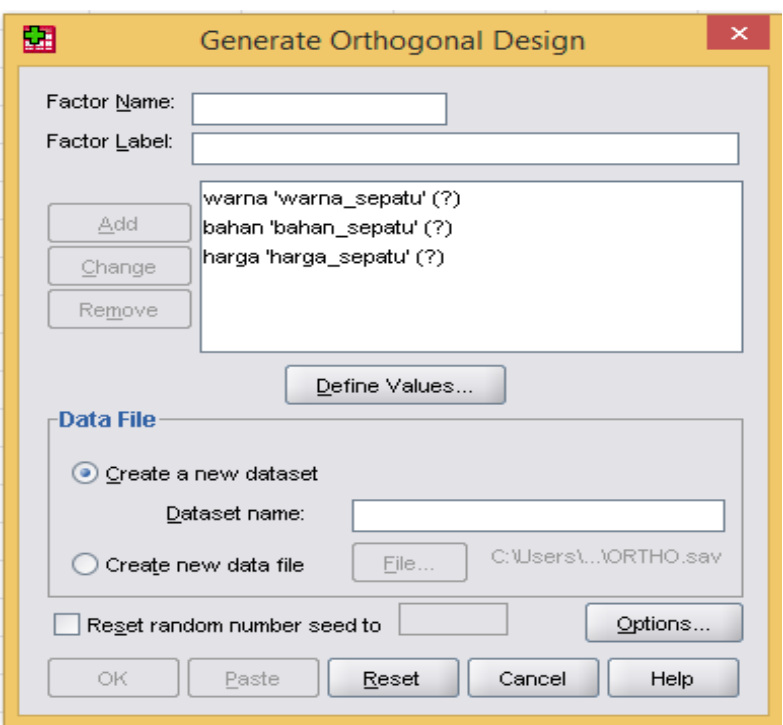

Gambar 23.4

Setelah mendefinisikan seluruh atribut beserta levelnya, selanjutnya pilih Create new data file dan pilih file (Gambar 23.9), sehingga muncul seperti pada Gambar 23.10. Pada Gambar 
23.10, beri nama file dengan stimulus. Kemudian pilih Save. Perhatikan Gambar 23.11!!!! Selanjutnya pilih OK, sehingga muncul tampilan seperti pada Gambar 23.12.

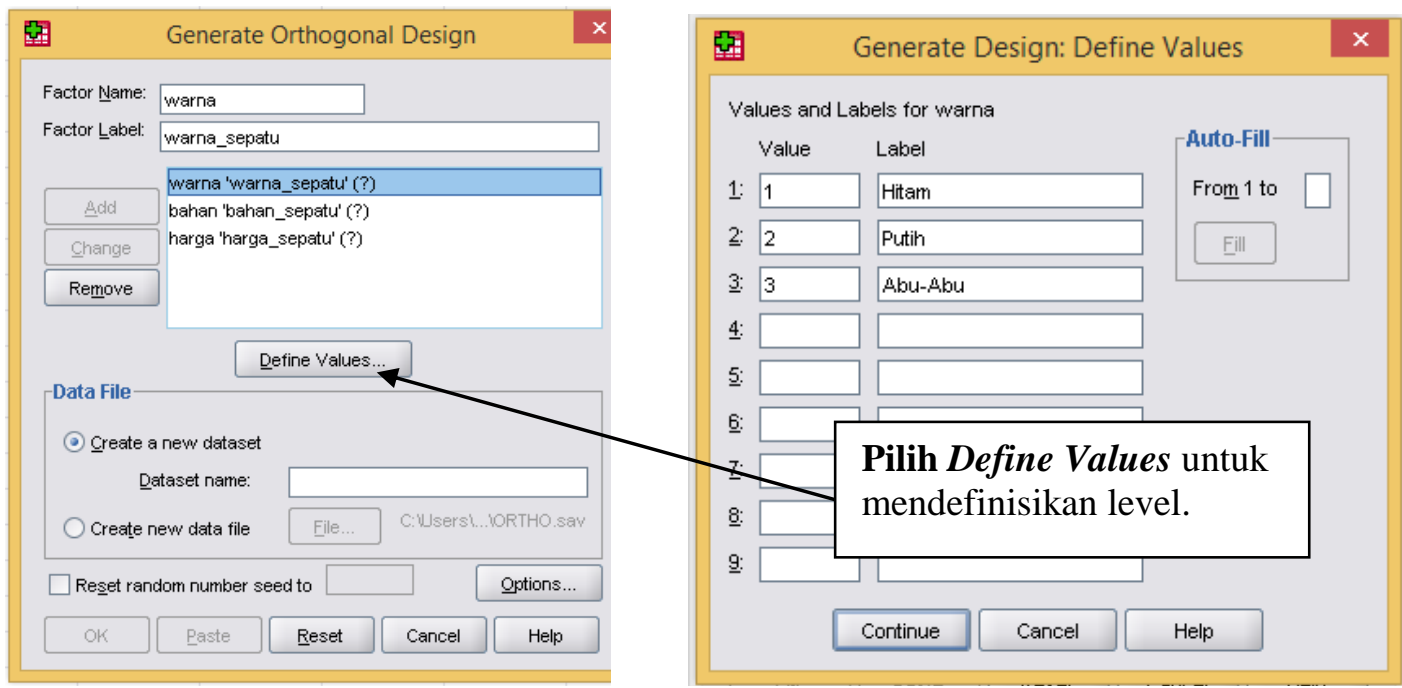

Gambar 23.5

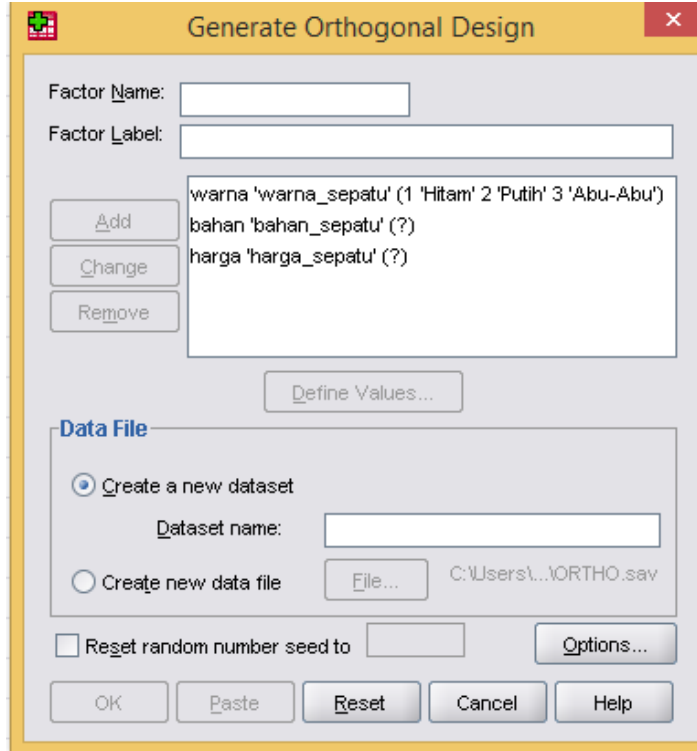

Gambar 23.7

Gambar 23.6

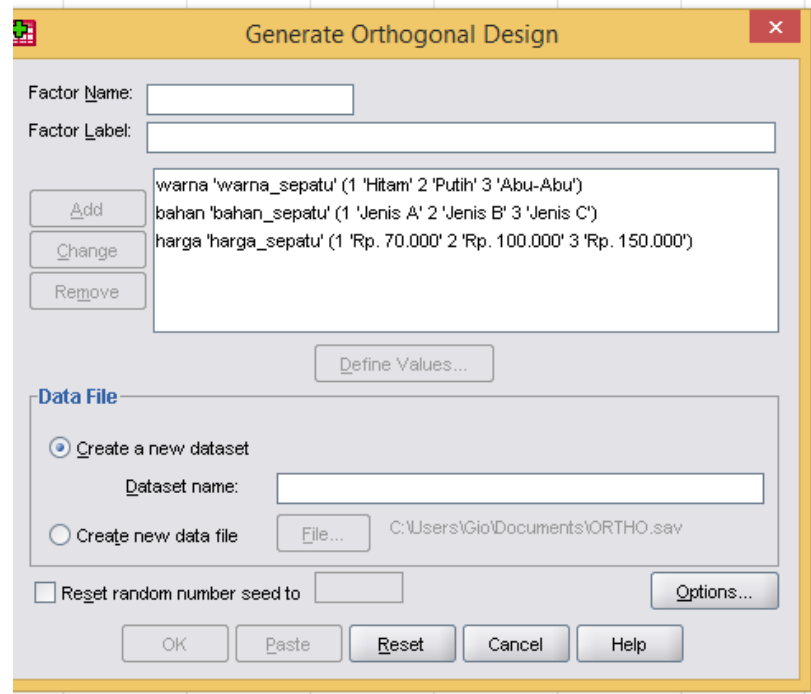

Gambar 23.8

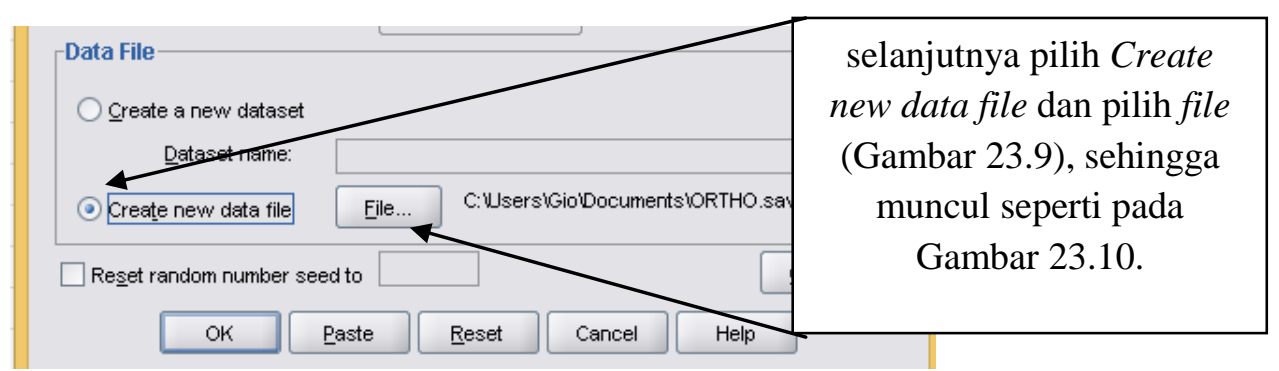

Gambar 23.9 


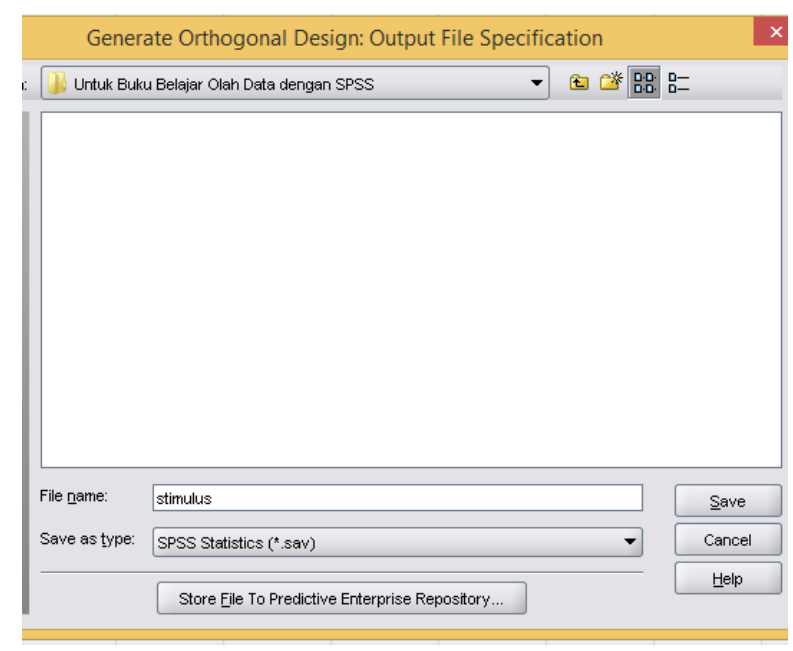

Gambar 23.10
File yang bernama stimulus disimpan pada alamat:

D:\ANALISIS KONJOIN\Untuk Buku Belajar Qlah Data dengan SPSS

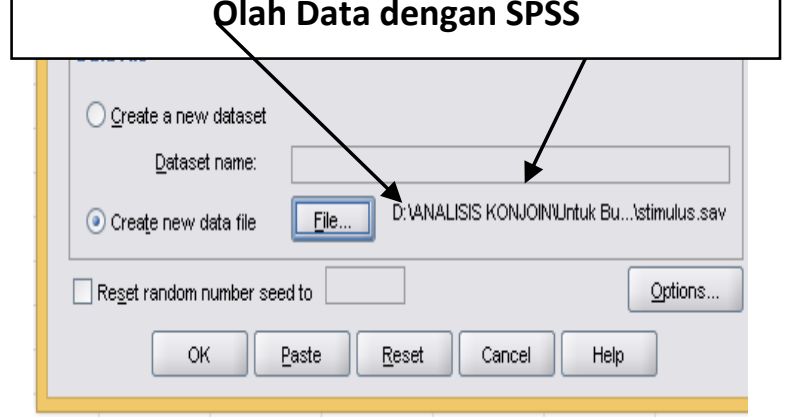

Gambar 23.11

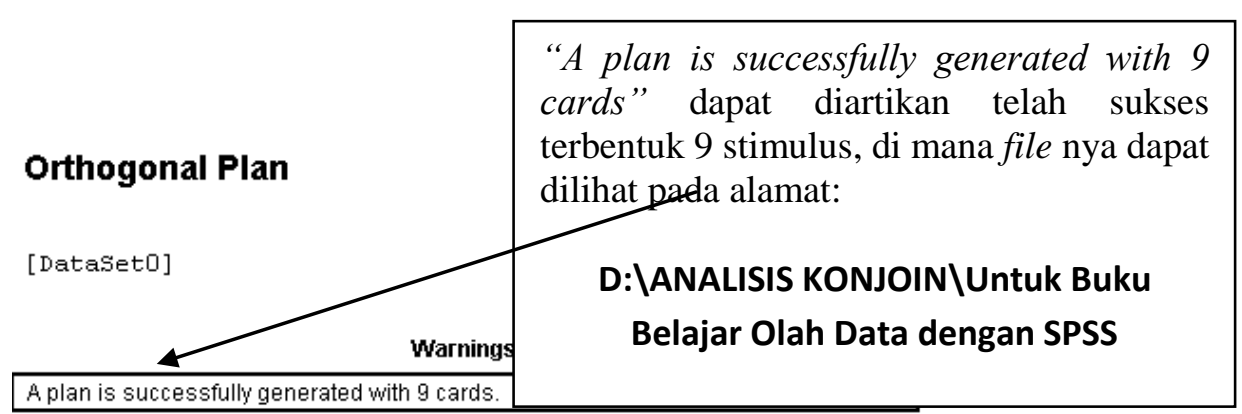

Gambar 23.12

*Output1 [Document1] - SPSS Statistics Viewer

Insert Fơrmat Analyze Graphs Lيtilities Add-ons Window Help

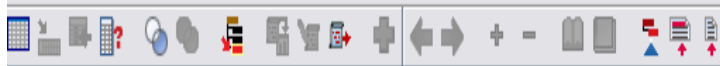

*Generate Orthogonal Design.

ORTHOPLSW

/FACTORS=warna 'warna sepatu' (1 'Hitam' 2 'Putih' 3 'Abu-abu') bahan 'bahan_sepatu' (1 'Jenis A' 2 'Jenis B' 3 'Jenis C') harga harga sepatu' (1 'Rp. 70.000' 2 'Rp. 100.000' 3 'Rp. 150.000')

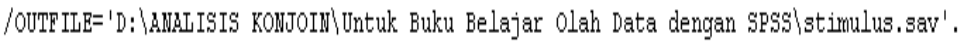

Gambar 23.13

\begin{tabular}{l} 
View \\
\hline S PC \& Data (D:) + ANALISIS KONJOIN * Untuk Buku Belajar Olah Data dengan SPSS \\
\hline Name
\end{tabular}

Gambar 23.14 
Selanjutnya buka file stimulus tersebut. Perhatikan Gambar 23.15 dan Gambar 23.16. Gambar 23.17 dan Gambar 23.18 menyajikan isi dari file stimulus.

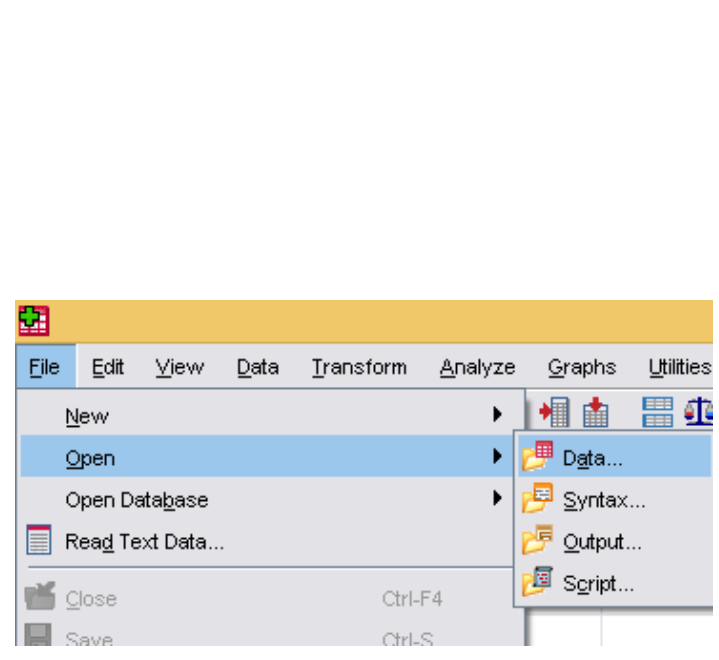

Gambar 23.15

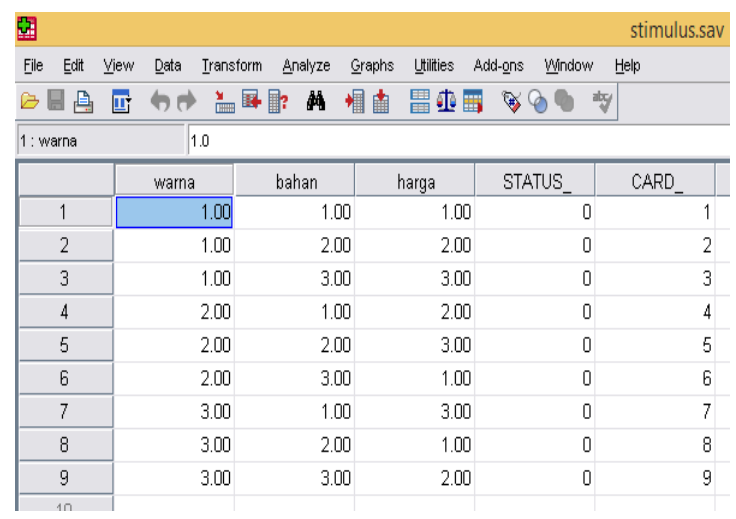

Gambar 23.17

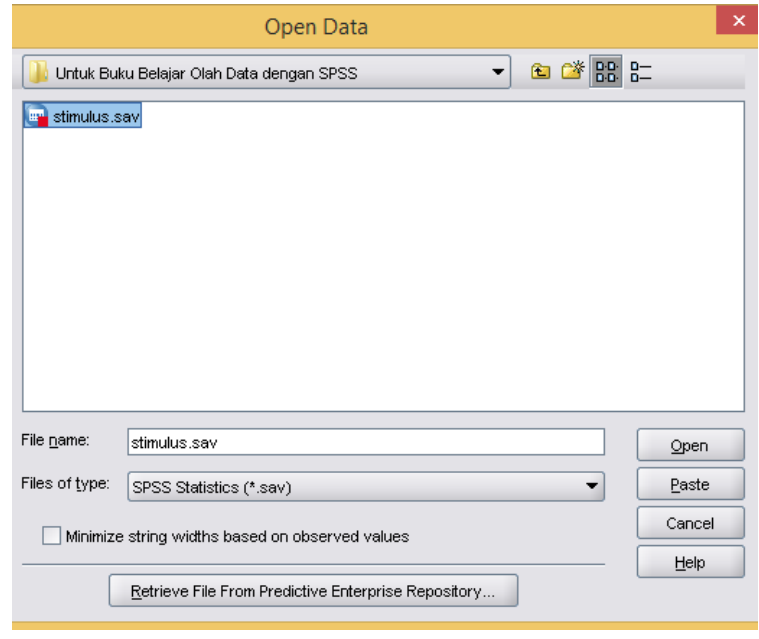

Gambar 23.16

\begin{tabular}{|c|c|c|c|c|c|c|}
\hline 四 & & & & & stimulus & av [D \\
\hline Elle Edih & Data Irans & Analyze $\underline{G}$ & ohs untilities A & d-ons Mindow & telp & \\
\hline B & hत & 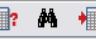 & 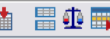 & (2) 80 th & & \\
\hline 1: warna & 1.0 & & & & & \\
\hline & warna & bahan & harga & STATUS_ & CARD_ & \\
\hline 1 & Hitam & Jenis A & Rp. 70.000 & Design & & 1 \\
\hline 2 & Hitam & Jenis B & Rp. 100.000 & Design & & 2 \\
\hline 3 & Hitam & Jenis C & Rp. 150.000 & Design & & 3 \\
\hline 4 & Putih & Jenis A & Rp. 100.000 & Design & & 4 \\
\hline 5 & Putih & Jenis B & Rp. 150.000 & Design & & 5 \\
\hline 6 & Putih & Jenis C & Rp. 70.000 & Design & & 6 \\
\hline 7 & Abu-Abu & Jenis A & Rp. 150.000 & Design & & 7 \\
\hline 8 & Abu-Abu & Jenis B & Rp. 70.000 & Design & & 8 \\
\hline 9 & Abu-Abu & Jenis C & Rp. 100.000 & Design & & 9 \\
\hline
\end{tabular}

Gambar 23.18

Berdasarkan Gambar 23.17, baris pertama terdiri dari stimulus $(1,1,1)$, yang berarti sepatu berwarna hitam, dengan jenis bahan A, dan harga Rp. 70.000. Sementara baris kedua terdiri dari stimulus $(1,2,2)$, yang berarti sepatu berwarna hitam, dengan jenis bahan $\mathrm{B}$, dan harga Rp. 100.000, dan seterusnya.

Jika dilakukan proses ulang dari Gambar 23.1 sampai Gambar 23.11, stimulus-stimulus yang terbentuk bisa berbeda dari Gambar 23.17. Bisa saja pada baris pertama: warna $=3$, bahan $=2$, dan harga $=1$. Lihat share bagian 1.

Berdasarkan stimulus-stimulus yang telah dibentuk pada Gambar 23.18, kemudian 2 orang responden diminta untuk memberi penilaian. Penilaian yang telah diberikan disajikan pada Gambar 23.19. 


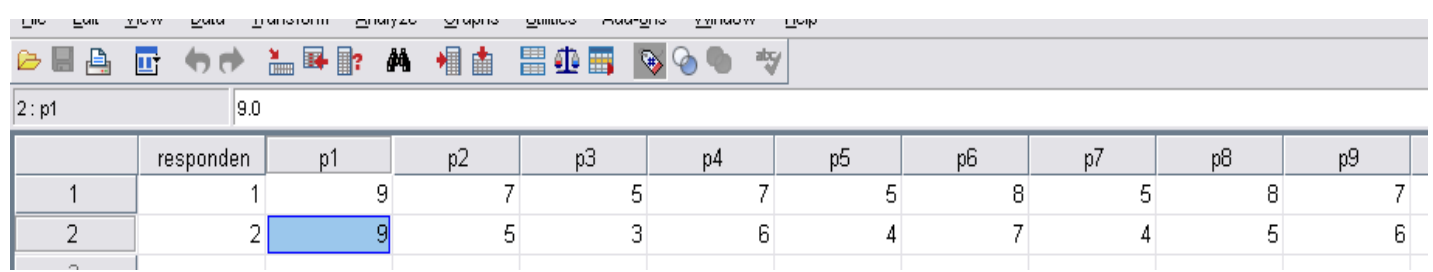

Gambar 23.19

Berdasarkan Gambar 23.19, diketahui:

$\Rightarrow$ Responden pertama memberi penilaian 9 terhadap stimulus pertama (p1), yakni $(1=$ hitam, $1=$ jenis $A, 1=$ Rp. 70.000), memberi penilaian 7 terhadap stimulus kedua (p2), yakni $(1=$ hitam, $2=$ jenis $B, 2=$ Rp. 100.000), dan seterusnya.

$\Rightarrow$ Responden kedua memberi penilaian 9 terhadap stimulus pertama $(\mathrm{p} 1)$, yakni $(1=$ hitam, $1=$ jenis $A, 1=$ Rp. 70.000), memberi penilaian 5 terhadap stimulus kedua (p2), yakni $(1=$ hitam, $2=$ jenis $B, 2=$ Rp. 100.000), dan seterusnya.

\begin{tabular}{|c|c|c|c|}
\hline & Name & Datg & \\
\hline Desktop & (뜰 Bab 23 Analisis Konjoin (Share) & $12 / 1$ & Data penilaian pada Gambar 23.19 \\
\hline Downloads & WWily Bab 23 Analisis Konjoin (Software SPSS, dII) & $12 /$ & kemudian disimpan pada lokasi \\
\hline 9国 Recent places & $\begin{array}{l}\text { 땜 Bab } 23 \text { Analisis Konjoin } \\
\text { 삘 data }\end{array}$ & $12 /$ & yang sama, yakni \\
\hline This PC & ini generate1 & & ONIOI \\
\hline Hesktop & ini generate2 & 120 & Buku Belajar Olah Data dengan \\
\hline $\begin{array}{l}\text { Documents } \\
\text { Downloads }\end{array}$ & $\begin{array}{l}\text { IIIII) generate3 } \\
\text { vode }\end{array}$ & $12 / 1$ & SPSS. \\
\hline (1) Music & iㅔ preferensi & $12 /$ & \\
\hline F Pictures & inin stimulus & $12 / 1$ & Nama file adalah nreforenci untuk \\
\hline Videos & uji coba regresi stimulus 2 & $12 /$ & data node Cambar 2310 \\
\hline 典 OS (C:) & inivi uji coba regresi stimulus & $12 / 1$ & \\
\hline
\end{tabular}

Gambar 23.20

Berdasarkan penilaian pada Gambar 23.19, dapat dilihat bahwa responden pertama dan kedua memberi penilaian paling tinggi terhadap stimulus p1, sehingga mayoritas (secara umum) responden diduga menginginkan/menyukai sepatu dengan harga Rp. 70.000, berwarna hitam, dengan bahan jenis A.

Data penilaian pada Gambar 23.19 kemudian disimpan pada lokasi yang sama, yakni

\section{D:\ANALISIS KONJOINIUntuk Buku Belajar Olah Data dengan SPSS.}

Setelah disimpan data penilaian pada Gambar 23.19, pilih File $=>$ New $=>$ Syntax (Gambar 23.21), sehingga muncul tampilan SPSS Statistics Syntax Editor (Gambar 23.22).

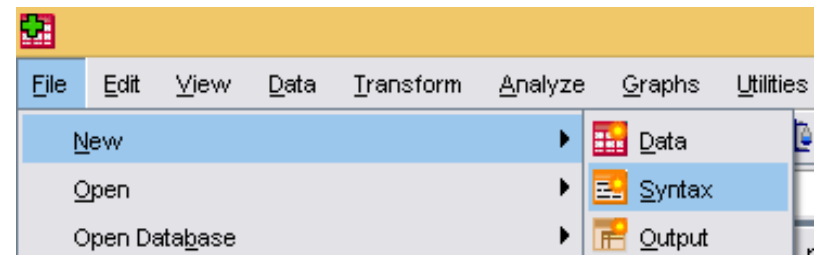

Gambar 23.21 


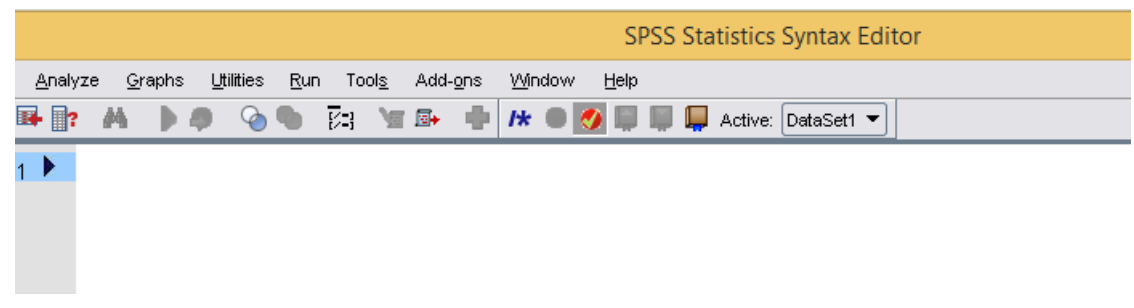

Gambar 23.22

Pada Gambar 23.22, ketik kode program berikut (lihat Gambar 23.23). Setelah kode program selesai diketik, pilih $R u n=>$ All (Gambar 23.24), sehingga diperoleh output SPSS.

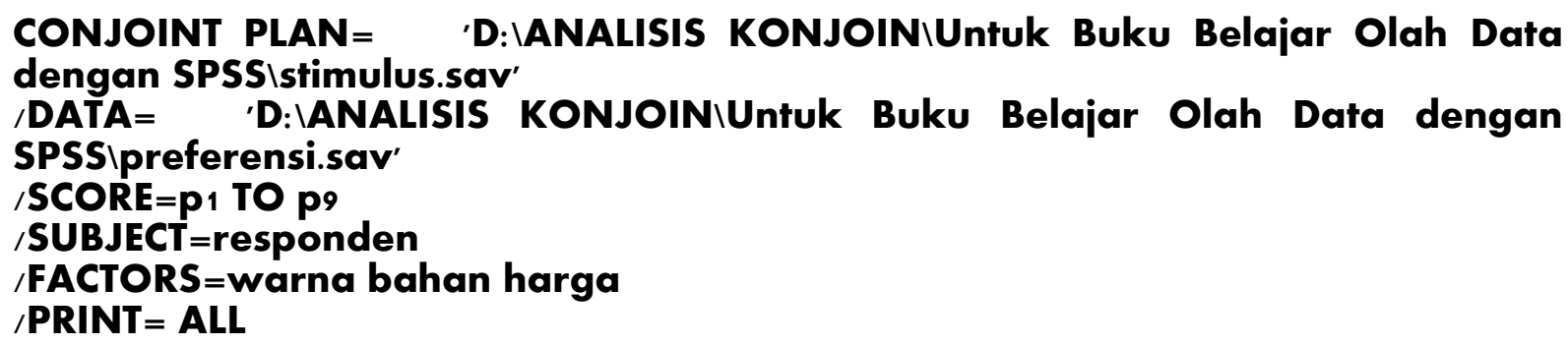

Gambar 23.23

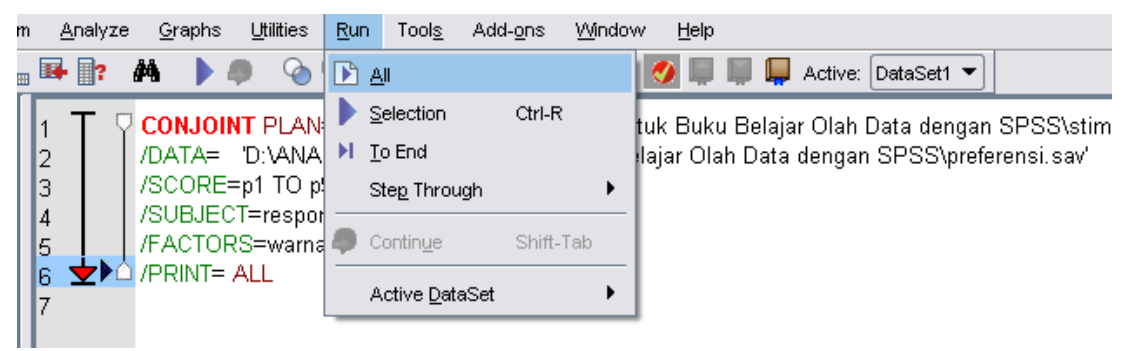

Gambar 23.24

Tabel 23.1

\begin{tabular}{|l|l|l|}
\hline \multicolumn{2}{|c|}{ Model Description } \\
\hline & N of Levels & $\begin{array}{c}\text { Relation to Ranks or } \\
\text { Scores }\end{array}$ \\
\hline warna & 3 & Discrete \\
bahan & 3 & Discrete \\
harga & 3 & Discrete \\
\hline
\end{tabular}

All factors are orthogonal. 
Berdasarkan Tabel 23.1, diketahui atribut warna memiliki tiga level atau tingkatan, yakni hitam, putih, dan abu-abu, sementara pada atribut bahan juga memiliki tiga level, yakni bahan jenis A, B, dan C. Begitu juga dengan harga memiliki tiga level, yakni Rp. 70.000, Rp. 100.000, dan Rp. 150.000.

\section{Interpretasi Responden Pertama}

Gambar 23.25 menyajikan output SPSS untuk responden pertama. Perhatikan Tabel Utilities. Berdasarkan informasi pada Tabel Utilities, dapat ditentukan kesukaan responden terhadap suatu level dari masing-masing atribut.

$\Rightarrow$ Untuk atribut warna, diketahui nilai utilities estimate hitam adalah 0,222 , nilai utilities estimate putih adalah $-0,111$, dan nilai utilities estimate abu-abu adalah -0,111. Perhatikan bahwa karena nilai utilities estimate hitam adalah yang tertinggi, maka responden pertama cenderung lebih menyukai sepatu berwarna hitam.

$\Rightarrow$ Untuk atribut bahan, diketahui nilai utilities estimate jenis A adalah 0,222, nilai utilities estimate jenis B adalah -0,111, dan nilai utilities estimate jenis $\mathrm{C}$ adalah 0,111. Perhatikan bahwa karena nilai utilities estimate jenis A adalah yang tertinggi, maka responden pertama cenderung lebih menyukai sepatu berbahan jenis A.

$\Rightarrow$ Untuk atribut harga, diketahui nilai utilities estimate Rp. 70.000 adalah 1,556, nilai utilities estimate Rp. 100.000 adalah 0,222, dan nilai utilities estimate Rp. 150.000 adalah $-1,778$. Perhatikan bahwa karena nilai utilities estimate Rp. 70.000 adalah yang tertinggi, maka responden pertama cenderung lebih menyukai harga sepatu Rp. 70.000 .

Berdasarkan uraian di atas, maka responden pertama cenderung menginginkan sepatu dengan warna hitam, dengan bahan jenis A, dan harga Rp.70.000. Diketahui nilai utilities estimate tertinggi pertama berada pada atribut harga Rp. 70.000, yakni 1,556, nilai utilities estimate tertinggi kedua berada pada atribut warna hitam dan bahan jenis A, yakni 0,222. Hal ini berarti responden pertama memiliki tingkat keinginan paling tinggi terhadap harga sepatu Rp. 70.000, kemudian disusul dengan bahan jenis A dan warna hitam.

Sekarang perhatikan informasi pada Tabel Importance Values. Berdasarkan informasi pada Tabel Importance Values, dapat ditentukan atribut mana yang paling dianggap paling penting oleh responden. Berdasarkan Tabel Importance Values, diketahui atribut harga memiliki tingkat kepentingan paling tinggi, yakni dengan nilai kepentingan 83,333. Responden pertama menganggap harga merupakan aspek yang paling penting pertama, disusul warna dan bahan.

Selanjutnya perhatikan informasi pada Tabel Correlations. Pada Tabel Correlations menyajikan nilai korelasi Pearson's $R$ dan Kendall's tau. Nilai korelasi tersebut merupakan nilai korelasi antara penilaian aktual dan penilaian berdasarkan hasil estimasi. Nilai korelasi tersebut dapat digunakan untuk mengukur ketepatan prediksi (predictive ability).

Malhotra dan Birks (2006:637) menyatakan sebagai berikut.

"In running a regression analysis on the data of Table 24.5, an $R^{2}$ of 0.934 was obtained, indicating a good fit. The preference ratings for the nine validation profiles were predicted from the utilities reported in Table 24.6. These were correlated with the input ratings for 
these profiles obtained from the respondent. The correlation coefficient was 0.95 , indicating a good predictive ability. This correlation coefficient is significant at $\alpha=0.05$."

Berdasarkan Tabel Correlations, diketahui nilai korelasi Pearson's $R$ dan Kendall's tau masing-masing cukup tinggi, yakni 0,994 dan 0,937 (mendekati 1), dan signifikan secara statistik (nilai Sig. < 0,05). Hal ini berarti penilaian aktual dan penilaian berdasarkan hasil estimasi memiliki hubungan linear yang kuat (signifikan) untuk responden pertama. Dengan kata lain, penilaian bedasarkan hasil estimasi memiliki tingkat keakuratan yang tinggi (tidak berbeda jauh) terhadap penilaian aktual untuk responden pertama.

\section{Subject 1: 1}

\begin{tabular}{|ll|r|r|}
\hline \multicolumn{5}{|c|}{ Utilities } \\
\hline warna & Hitam & $\begin{array}{c}\text { Utility } \\
\text { Estimate }\end{array}$ & Std. Error \\
& Putih & .222 & .157 \\
& Abu-Abu & -.111 & .157 \\
bahan & -.111 & .157 \\
& Jenis A & .222 & .157 \\
& Jenis B & -.111 & .157 \\
& Jenis C & -.111 & .157 \\
harga & Rp. 70.000 & 1.556 & .157 \\
& Rp. 100.000 & .222 & .157 \\
& Rp. 150.000 & -1.778 & .157 \\
(Constant) & 6.778 & .111 \\
\hline
\end{tabular}

Importance Values
\begin{tabular}{|l|r|}
\hline warna & 8.333 \\
bahan & 8.333 \\
harga & 83.333 \\
\hline
\end{tabular}

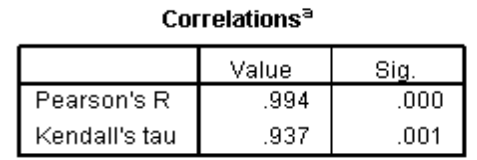

a. Correlations between observed and estimated preferences

Gambar 23.25
Subject 2: 2

\begin{tabular}{|ll|r|r|}
\hline \multicolumn{5}{|c|}{ Utilities } \\
\hline warna & Hitam & $\begin{array}{c}\text { Utility } \\
\text { Estimate }\end{array}$ & Std. Error \\
& Putih & .222 & .685 \\
& Abu-Abu & .222 & .685 \\
bahan & Jenis A & -.444 & .685 \\
& Jenis B & .889 & .685 \\
& Jenis C & -.778 & .685 \\
harga & -.111 & .685 \\
& Rp. 70.000 & 1.556 & .685 \\
& Rp. 100.000 & .222 & .685 \\
& Rp. 150.000 & -1.778 & .685 \\
(Constant) & 5.444 & .484 \\
\hline
\end{tabular}

\section{Importance Values}

\begin{tabular}{|l|l|}
\hline warna & 11.765 \\
bahan & 29.412 \\
harga & 58.824 \\
\hline
\end{tabular}

\begin{tabular}{|l|c|c|}
\hline & Correlations ${ }^{\Xi}$ \\
\hline & Value & \multicolumn{1}{c|}{ Sig. } \\
\hline Pearson's R & .916 & .000 \\
Kendall's tau & .824 & .001 \\
\hline
\end{tabular}

Gambar 23.26

\section{Interpretasi Responden Kedua}

Gambar 23.26 menyajikan output SPSS untuk responden kedua.

$\Rightarrow$ Untuk atribut warna, diketahui nilai utilities estimate hitam adalah 0,222, nilai utilities estimate putih adalah 0,222, dan nilai utilities estimate abu-abu adalah -0,444. Perhatikan bahwa karena nilai utilities estimate hitam dan putih adalah yang tertinggi, maka responden kedua cenderung lebih menyukai sepatu berwarna hitam dan putih.

$\Rightarrow$ Untuk atribut bahan, diketahui nilai utilities estimate jenis A adalah 0,889 , nilai utilities estimate jenis B adalah $-0,778$, dan nilai utilities estimate jenis $\mathrm{C}$ adalah 0,111 . Perhatikan bahwa karena nilai utilities estimate jenis A adalah yang tertinggi, maka responden kedua cenderung lebih menyukai sepatu berbahan jenis A.

$\Rightarrow$ Untuk atribut harga, diketahui nilai utilities estimate Rp. 70.000 adalah 1,556, nilai utilities estimate Rp. 100.000 adalah 0,222, dan nilai utilities estimate Rp. 150.000 
adalah -1,778. Perhatikan bahwa karena nilai utilities estimate Rp. 70.000 adalah yang tertinggi, maka responden kedua cenderung lebih menyukai harga sepatu Rp. 70.000.

Berdasarkan uraian di atas, maka responden kedua cenderung menginginkan sepatu dengan warna hitam atau putih, dengan bahan jenis A, dan harga Rp.70.000. Diketahui nilai utilities estimate tertinggi pertama berada pada atribut harga Rp. 70.000 , yakni 1,556 , nilai utilities estimate tertinggi kedua berada pada atribut bahan jenis A, dan nilai utilities estimate tertinggi ketiga berada pada atribut warna hitam atau putih. Hal ini berarti responden kedua memiliki tingkat keinginan paling tinggi terhadap harga sepatu Rp. 70.000 (pertama), kemudian disusul dengan bahan jenis A (kedua) dan warna hitam atau putih (ketiga).

Berdasarkan Tabel Importance Values, diketahui atribut harga memiliki tingkat kepentingan paling tinggi oleh responden kedua, yakni dengan nilai kepentingan 58,824. Responden kedua menganggap harga merupakan aspek yang paling penting pertama, disusul bahan dan warna.

Berdasarkan Tabel Correlations, diketahui nilai korelasi Pearson's $R$ dan Kendall's tau masing-masing cukup tinggi, yakni 0,916 dan 0,824 (mendekati 1), dan signifikan secara statistik (nilai Sig. < 0,05). Hal ini berarti penilaian aktual dan penilaian berdasarkan hasil estimasi untuk responden kedua memiliki hubungan linear yang kuat (signifikan). Dengan kata lain, penilaian bedasarkan hasil estimasi memiliki tingkat keakuratan yang tinggi (tidak berbeda jauh) terhadap penilaian aktual untuk responden kedua.

\section{Interpretasi Responden Secara Rata-Rata (Secara Umum)}

Gambar 23.27 menyajikan output SPSS untuk penilaian secara rata-rata (umum).

$\Rightarrow$ Untuk atribut warna, diketahui nilai utilities estimate hitam adalah 0,222 , nilai utilities estimate putih adalah 0,056, dan nilai utilities estimate abu-abu adalah -0,278. Perhatikan bahwa karena nilai utilities estimate hitam adalah yang tertinggi, maka secara umum responden cenderung lebih menyukai sepatu berwarna hitam.

$\Rightarrow$ Untuk atribut bahan, diketahui nilai utilities estimate jenis A adalah 0,556, nilai utilities estimate jenis B adalah -0,444, dan nilai utilities estimate jenis C adalah 0,111 . Perhatikan bahwa karena nilai utilities estimate jenis A adalah yang tertinggi, maka secara umum responden cenderung lebih menyukai sepatu berbahan jenis A.

$\Rightarrow$ Untuk atribut harga, diketahui nilai utilities estimate Rp. 70.000 adalah 1,556, nilai utilities estimate Rp. 100.000 adalah 0,222, dan nilai utilities estimate Rp. 150.000 adalah -1,778. Perhatikan bahwa karena nilai utilities estimate Rp. 70.000 adalah yang tertinggi, maka secara umum responden cenderung lebih menyukai harga sepatu Rp. 70.000 .

Berdasarkan uraian di atas, maka secara umum responden cenderung menginginkan sepatu dengan warna hitam, dengan bahan jenis A, dan harga Rp.70.000. Diketahui nilai utilities estimate tertinggi pertama berada pada atribut harga Rp. 70.000 , yakni 1,556 , nilai utilities estimate tertinggi kedua berada pada atribut bahan jenis A, dan nilai utilities estimate tertinggi ketiga berada pada atribut warna hitam. Hal ini berarti secara umum responden memiliki tingkat keinginan paling tinggi terhadap harga sepatu Rp. 70.000 (pertama), kemudian disusul dengan bahan jenis A (kedua) dan warna hitam (ketiga). 
Berdasarkan Tabel Importance Values, diketahui atribut harga memiliki tingkat kepentingan paling tinggi, yakni dengan nilai kepentingan 71,078. Secara umum responden menganggap harga merupakan aspek yang paling penting pertama, disusul bahan dan warna.

Berdasarkan Tabel Correlations, diketahui nilai korelasi Pearson's $R$ dan Kendall's tau masing-masing cukup tinggi, yakni 0,961 dan 0,837 (mendekati 1), dan signifikan secara statistik (nilai Sig. < 0,05). Hal ini berarti penilaian aktual dan penilaian berdasarkan hasil estimasi memiliki hubungan linear yang kuat (signifikan). Dengan kata lain, penilaian bedasarkan hasil estimasi memiliki tingkat keakuratan yang tinggi (tidak berbeda jauh) terhadap penilaian aktual.

\section{Overall Statistics}

\begin{tabular}{|ll|r|r|}
\hline \multicolumn{1}{|c|}{ Utilities } \\
\hline warna & Hitam & $\begin{array}{c}\text { Utility } \\
\text { Estimate }\end{array}$ & Std. Error \\
& Putih & .222 & .416 \\
& Abu-Abu & .056 & .416 \\
bahan & -.278 & .416 \\
& Jenis A & .556 & .416 \\
& Jenis B & -.444 & .416 \\
& Jenis C & -.111 & .416 \\
harga & Rp. 70.000 & 1.556 & .416 \\
& Rp. 100.000 & .222 & .416 \\
& Rp. 150.000 & -1.778 & .416 \\
(Constant) & 6.111 & .294 \\
\hline
\end{tabular}

Importance Values

\begin{tabular}{|l|r|}
\hline warna & 10.049 \\
bahan & 18.873 \\
harga & 71.078 \\
\hline \multicolumn{2}{|c|}{$\begin{array}{l}\text { Averaged } \\
\text { Importance } \\
\text { Score }\end{array}$}
\end{tabular}

Correlations $^{\Xi}$

\begin{tabular}{|c|c|c|}
\hline \multicolumn{3}{|c|}{ Correlations $^{\Xi}$} \\
\hline & Value & Sig. \\
\hline Pearson's R & .961 & .000 \\
\hline Kendall's tau & .837 & .001 \\
\hline
\end{tabular}

a. Correlations between

observed and estimated

preferences

Gambar 23.27 
[1] Perhatikan bahwa pembentukan stimulus dalam SPSS dengan menggunakan menu Orthogonal Design cenderung akan diperoleh hasil yang berbeda-beda, jika dicoba beberapa kali. Perhatikan percobaan berikut.

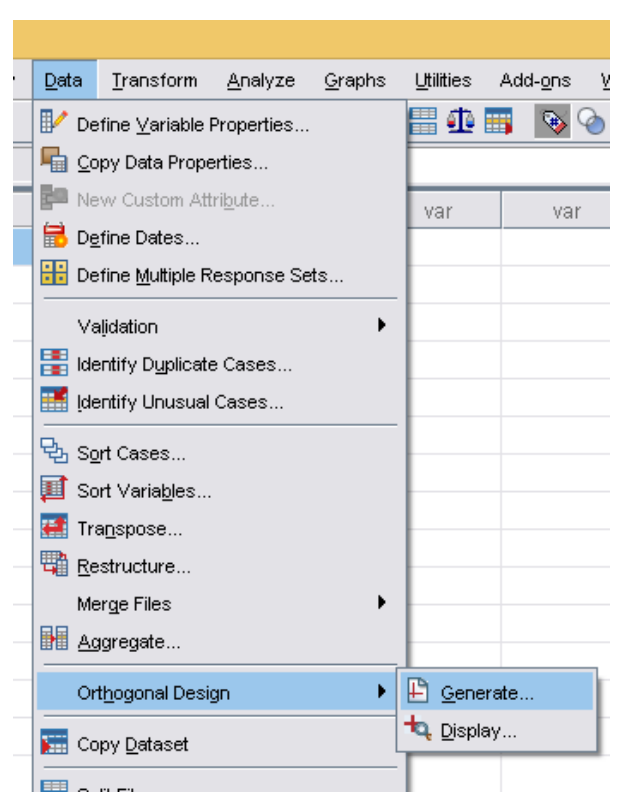

Gambar 23.1

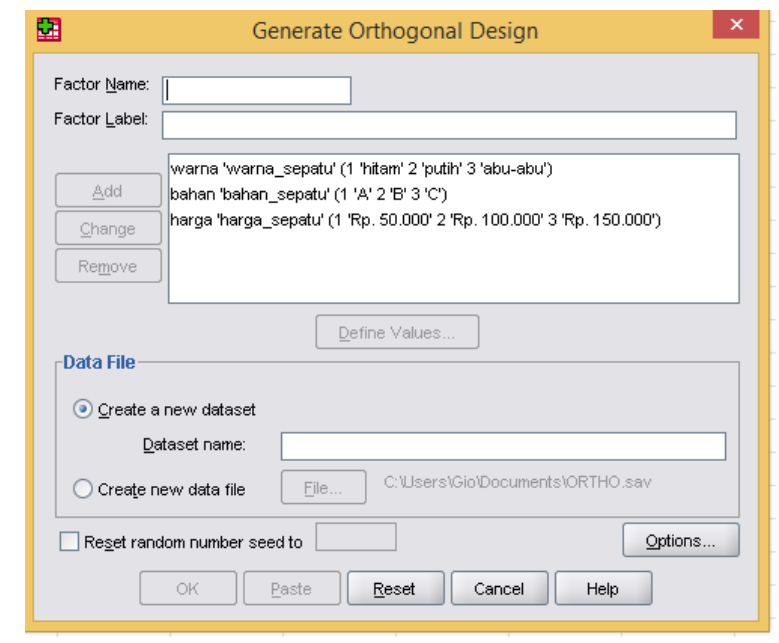

Gambar 23.2

\begin{tabular}{|c|c|c|c|c|c|}
\hline 1: warna & 2.0 & & & & \\
\hline & warna & bahan & harga & STATUS_ & $\mathrm{CARD}_{-}$ \\
\hline 1 & 2.00 & 1.00 & 2.00 & 0 & 1 \\
\hline 2 & 3.00 & 1.00 & 3.00 & 0 & 2 \\
\hline 3 & 1.00 & 3.00 & 2.00 & 0 & 3 \\
\hline 4 & 2.00 & 3.00 & 3.00 & 0 & 4 \\
\hline 5 & 1.00 & 1.00 & 1.00 & 0 & 5 \\
\hline 6 & 2.00 & 2.00 & 1.00 & 0 & 6 \\
\hline 7 & 1.00 & 2.00 & 3.00 & 0 & 7 \\
\hline 8 & 3.00 & 3.00 & 1.00 & 0 & 8 \\
\hline 9 & 3.00 & 2.00 & 2.00 & 0 & 9 \\
\hline
\end{tabular}

\section{Gambar 23.3}

Lakukan langkah yang sama, diperoleh hasil seperti pada Gambar 23.4. Lakukan langkah yang sama, diperoleh hasil seperti pada Gambar 23.5. Perhatikan bahwa stimulus yang terbentuk cenderung berbeda-beda antara Gambar 23.3, Gambar 23.4, dan Gambar 23.5. 


\begin{tabular}{|r|r|r|r|r|r|r|}
\hline \multicolumn{1}{|c|}{} & warna & bahan & \multicolumn{1}{c|}{ harga } & \multicolumn{1}{r|}{ STATUS_ } & \multicolumn{1}{c|}{ CARD_ } \\
\hline 1 & 3.00 & 1.00 & 2.00 & 0 & 1 \\
\hline 2 & 2.00 & 3.00 & 2.00 & 0 & 2 \\
\hline 3 & 1.00 & 3.00 & 3.00 & 0 & 3 \\
\hline 4 & 1.00 & 2.00 & 2.00 & 0 & 4 \\
\hline 5 & 3.00 & 3.00 & 1.00 & 0 & 5 \\
\hline 6 & 1.00 & 1.00 & 1.00 & 0 & 6 \\
\hline 7 & 3.00 & 2.00 & 3.00 & 0 & 7 \\
\hline 8 & 2.00 & 1.00 & 3.00 & 0 & 8 \\
\hline 9 & 2.00 & 2.00 & 1.00 & 0 & 9 \\
\hline 10 & & & & & & \\
\hline
\end{tabular}

Gambar 23.4

\begin{tabular}{|r|r|r|r|r|r|r|}
\hline \multicolumn{1}{|c|}{} & warna & bahan & harga & STATUS_ & CARD_ \\
\hline 1 & 1.00 & 3.00 & 3.00 & 0 & 1 \\
\hline 2 & 3.00 & 2.00 & 3.00 & 0 & 2 \\
\hline 3 & 1.00 & 1.00 & 1.00 & 0 & 3 \\
\hline 4 & 2.00 & 1.00 & 3.00 & 0 & 4 \\
\hline 5 & 2.00 & 2.00 & 1.00 & 0 & 5 \\
\hline 6 & 1.00 & 2.00 & 2.00 & 0 & 6 \\
\hline 7 & 2.00 & 3.00 & 2.00 & 0 & 7 \\
\hline 8 & 3.00 & 3.00 & 1.00 & 0 & 8 \\
\hline 9 & 3.00 & 1.00 & 2.00 & 0 & 9 \\
\hline
\end{tabular}

Gambar 23.5

[2]

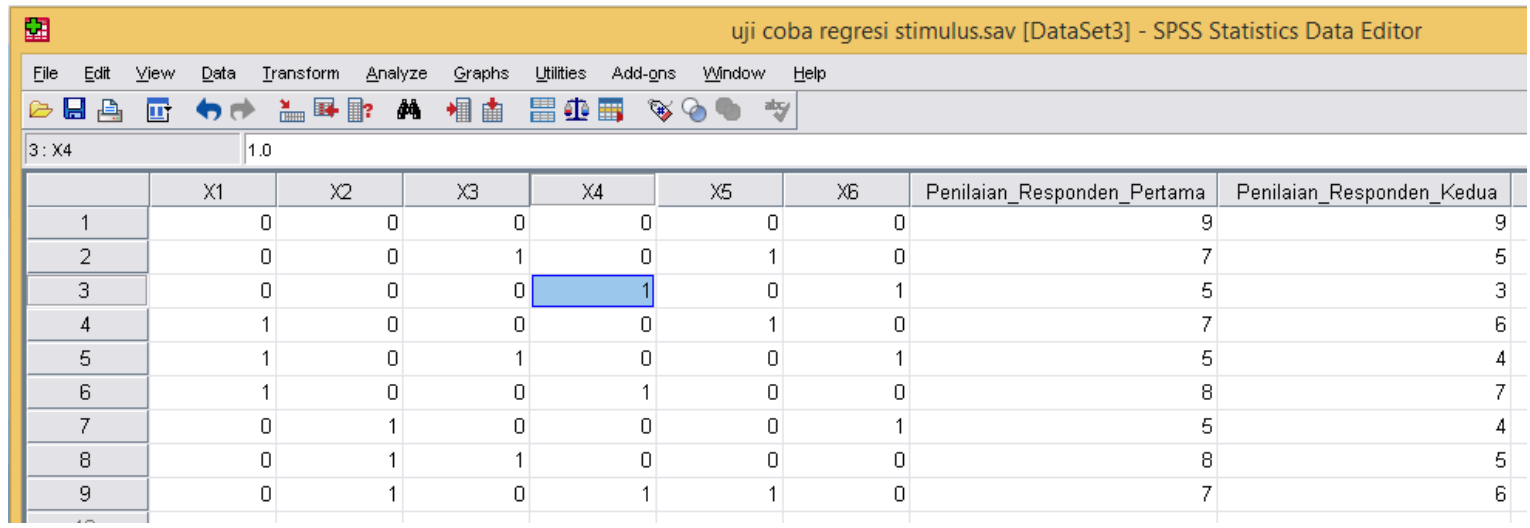

Gambar 23.6

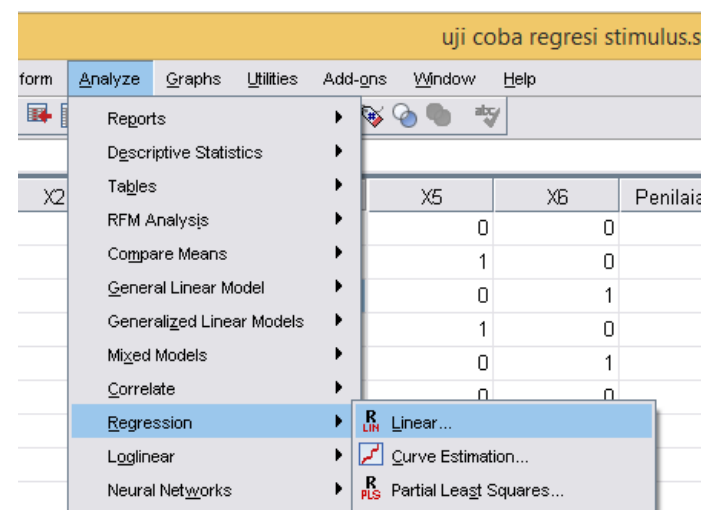

Gambar 23.7 


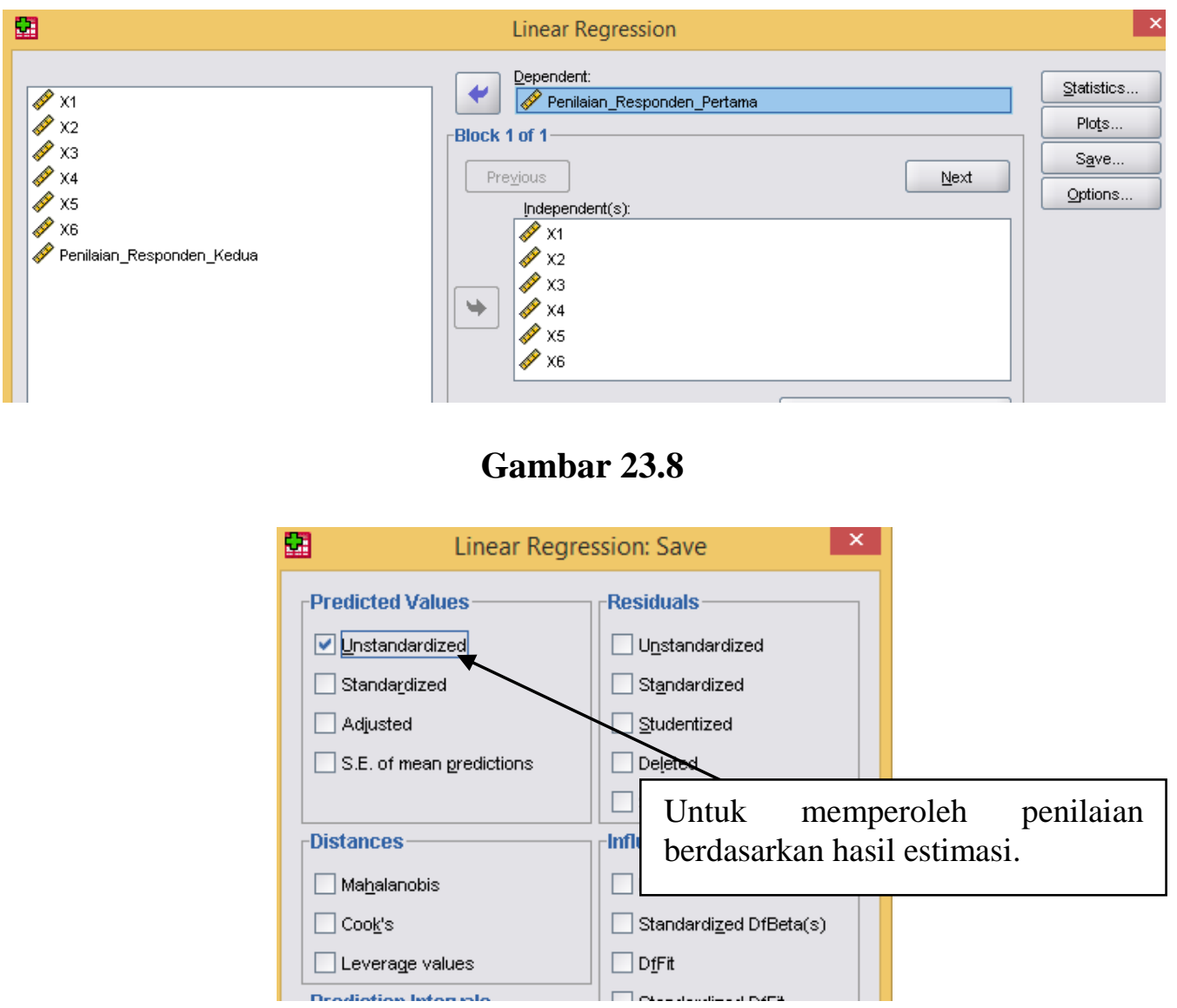

Gambar 23.9

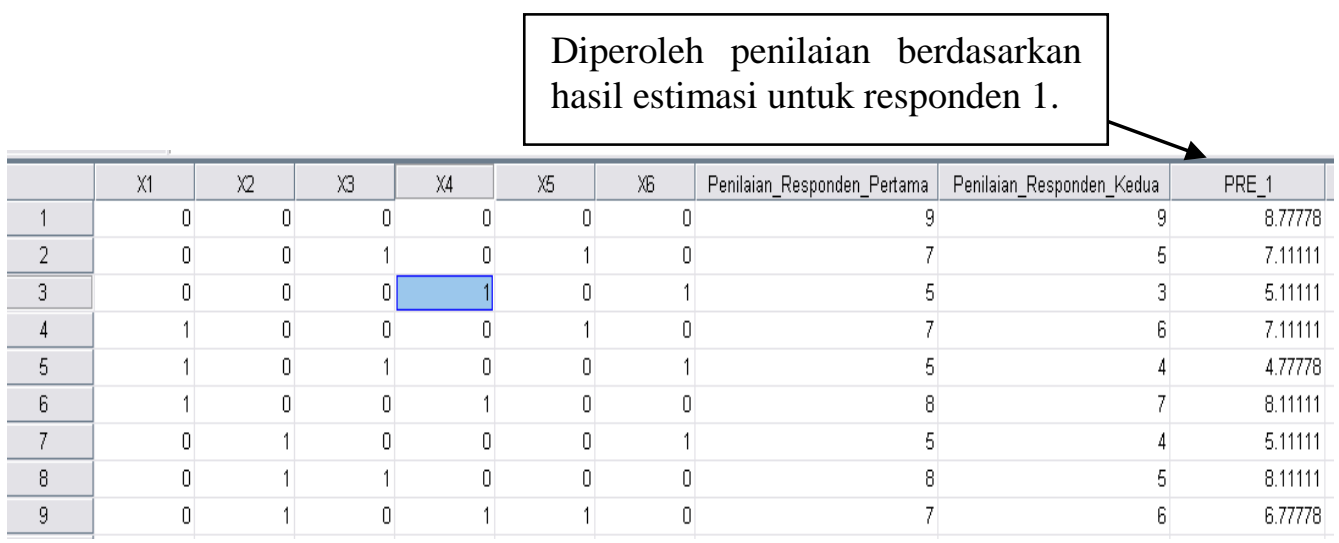

Gambar 23.10

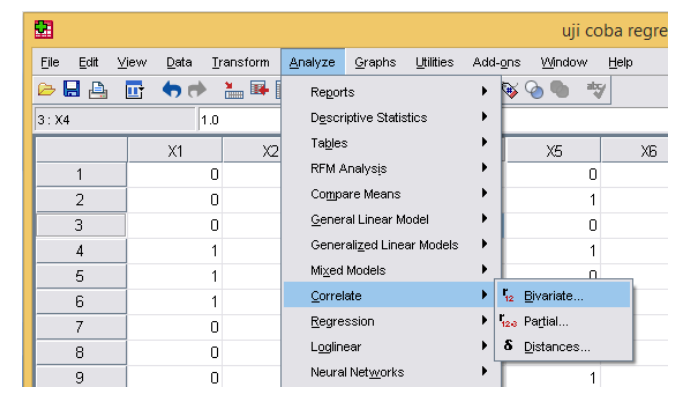

Gambar 23.11 


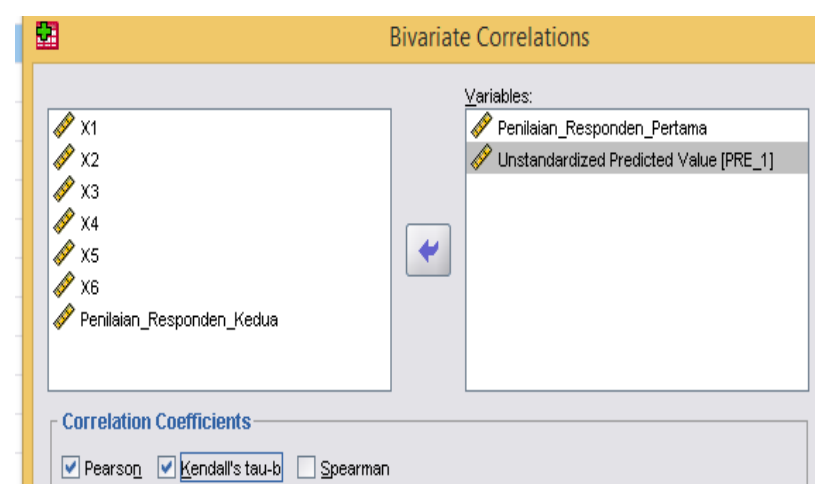

Gambar 23.12

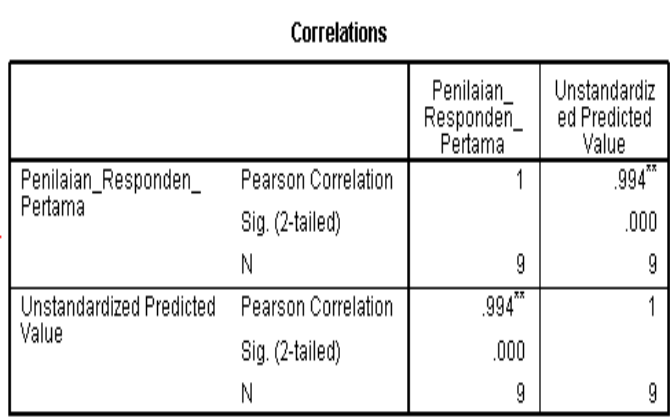

*. Correlation is significant at the 0.01 level (2-tailed).

Gambar 23.13

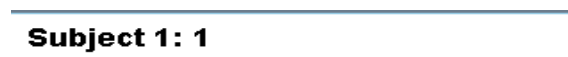

\begin{tabular}{|ll|r|r|}
\multicolumn{4}{c|}{ Utilities } \\
\hline \multicolumn{1}{|c|}{} & \multicolumn{1}{c|}{$\begin{array}{c}\text { Utility } \\
\text { Estimate }\end{array}$} & Std. Error \\
\hline warna & Hitam & .222 & .157 \\
& Putih & -.111 & .157 \\
& Abu-Abu & -.111 & .157 \\
hanan & Jenis A & .222 & .157 \\
& Jenis B & -.111 & .157 \\
& Jenis C & -.111 & .157 \\
harga & Rp. 70.000 & 1.556 & .157 \\
& Rp. 100.000 & .222 & .157 \\
& Rp. 150.000 & -1.778 & .157 \\
(Constant) & 6.778 & .111 \\
\hline
\end{tabular}

Importance values

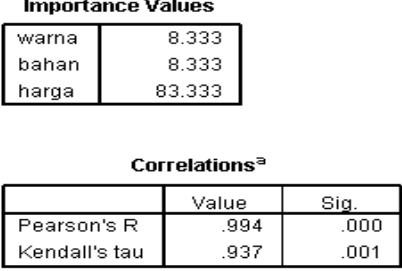

Gambar 23.15

Gambar 23.14

\section{Referensi}

1. Field, A. 2009. Discovering Statistics Using SPSS, $3^{\text {rd }}$ Edition. London: Sage.

2. Hair, J.F Jr., R.E. Anderson, B.J. Babin, dan W.C. Black. 2010. Multivariate Data Analysis, $7^{\text {th }}$ Edition. Pearson Prentice Hall.

3. Janssens, W., K. Wijnen, P.D. Pelsmacker, dan P.V. Kenhove. 2008. Marketing Research with SPSS. Pearson Prenticel Hall.

4. Johnson, R.A. dan D.W. Wichern. 2007. Applied Multivariate Statistical Analysis, $6^{\text {th }}$ Edition. Pearson Prentice Hall.

5. Malhotra, N.K. dan D.F. Birks. 2006. Marketing Research, An Applied Approach, $2^{\text {nd }}$ European Edition. London: Prentice Hall.

6. Stevens, J.P. 2009. Applied Multivariate Statistics For The Social Science, $5^{\text {th }}$ Edition. New York: Routledge. 


\section{BAB 24}

\section{MULTIDIMENSIONAL SCALING (MDS)}

\section{Sekilas Multidimensional Scaling (MDS)}

Teknik multidimensional scaling (MDS) atau disebut juga dengan nama perceptual mapping merupakan suatu teknik yang dapat mentransformasi penilaian responden mengenai kemiripan (similarity) atau preferensi (preference) dari sekumpulan objek yang diteliti (misalnya merek mobil: Toyota, Honda, Suzuki, Daihatsu, atau minyak goreng: minyak goreng A, B, C, D, dan E, dan sebagainya) ke dalam ruang multidimensi (multidimensional space) atau disebut juga dengan nama peta spasial (spatial map), di mana berdasarkan peta spasial yang didapatkan dari penggunaan MDS, dapat dilihat kemiripan antar objek berdasarkan jarak (distance) antar objek. Jadi, kemiripan antar objek dapat dilihat berdasarkan letak atau jarak antar objek dalam peta spasial. Objek-objek yang letaknya atau jaraknya semakin berdekatan dalam peta spasial dapat diinterpretasi bahwa objek-objek tersebut semakin mirip.

Ilustrasi contoh kasus berikut memodifikasi dari contoh kasus yang bersumber dari buku "Multivariate Data Analysis, $7^{\text {th }}$ Edition", yang ditulis oleh Hair dkk, halaman 542, tahun 2010. Andaikan seorang responden bernama Ugi, diminta untuk mencoba enam jenis permen, katakanlah permen A, B, C, D, E, dan F. Setelah mencoba keenam jenis permen tersebut, kemudian Ugi diminta untuk memberikan ranking mengenai kemiripan untuk setiap pasangan permen yang berbeda. Andaikan ranking 1 menyatakan pasangan permen yang paling mirip (most similar), sementara ranking 15 menyatakan pasangan permen yang paling tidak mirip. Tabel 24.1 menyajikan data ranking yang diberikan oleh Ugi.

Tabel 24.1 Data Ranking mengenai Kemiripan untuk Setiap Pasangan Permen

\begin{tabular}{ccccccc}
\hline Jenis Permen & A & B & C & D & E & F \\
\hline A & - & & & & & \\
B & 2 & - & & & & \\
C & 13 & 12 & - & & & \\
D & 4 & 6 & 9 & - & & \\
E & 3 & 5 & 10 & 1 & - & \\
F & 8 & 7 & 11 & 14 & 15 & - \\
\hline
\end{tabular}

Berdasarkan data ranking pada Tabel 24.1, Ugi memberi ranking 1 untuk pasangan permen E dan D (pasangan permen E dan D, atau D dan E sama saja). Hal ini berarti permen E dan D dianggap Ugi paling mirip yang pertama, sedangkan pasangan permen B dan A, dianggap Ugi paling mirip yang kedua, dan seterusnya, sampai pasangan permen $\mathrm{F}$ dan $\mathrm{E}$, yang dianggap Ugi paling tidak mirip (nilai ranking 15).

Perhatikan bahwa dari enam jenis permen, terdapat lima belas pasangan permen berbeda yang dapat dibentuk, yakni (A,B), (A,C), (A,D), (A,E), (A,F), (B,C), (B,D), (B,E), (B,F), (C,D), $(\mathrm{C}, \mathrm{E}),(\mathrm{C}, \mathrm{F}),(\mathrm{D}, \mathrm{E}),(\mathrm{D}, \mathrm{F})$, dan $(\mathrm{E}, \mathrm{F})$. Perhatikan Gambar 24.1. 
Perhatikan Gambar 24.1. Gambar 24.1 merupakan contoh peta spasial 2 dimensi (terdiri dari sumbu horizontal dan sumbu vertikal). Jarak dari $E$ ke $D$ (nilai ranking 1) lebih dekat dibandingkan jarak dari $B$ ke $A$ (nilai ranking 2). Begitu juga, jarak dari B ke $A$ (nilai ranking 2) lebih dekat dari pada jarak dari $E$ ke $A$ (nilai ranking 3 ). Begitu juga jarak dari $E$ ke $A$ (nilai ranking 3 ) lebih dekat dari pada jarak dari $D$ ke $A$ (nilai ranking 4 ), dan seterusnya.

$E D$ (ranking 1) < BA (ranking 2) < EA (ranking 3) <... $<F E$ (ranking 15, paling jauh jaraknya).

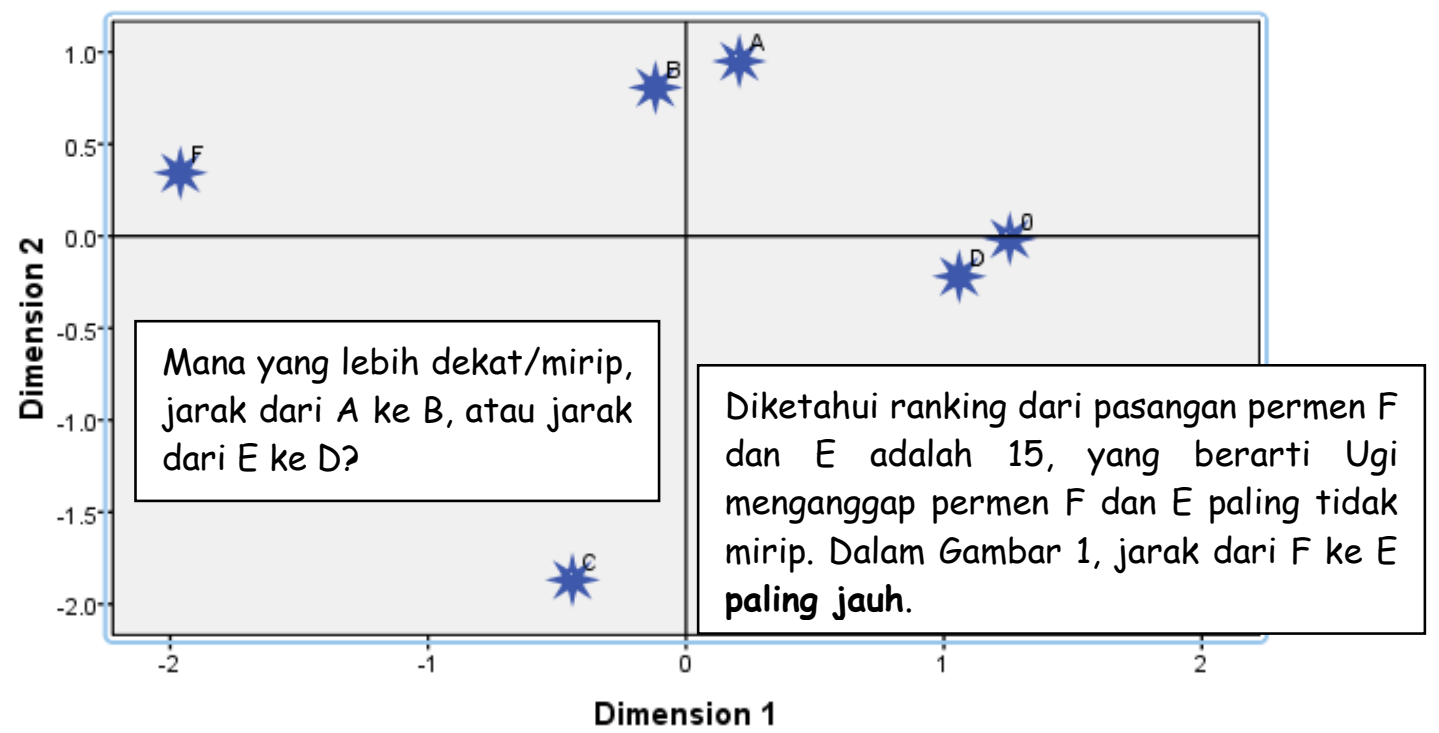

Gambar 24.1 Contoh Peta Spasial Dua Dimensi

Gambar 24.1 merupakan contoh dari peta spasial dengan jumlah dimensi sebanyak 2 (ada dua sumbu, sumbu horizontal dan sumbu vertikal). Pada Gambar 24.1, permen D lebih mirip (more similar) terhadap permen E, dibandingkan permen A. Hal ini terlihat jarak dari D ke E lebih dekat, dibandingkan jarak dari D ke A.

Perhatikan bahwa permen $E$ dan $D$ dianggap Ugi paling mirip. Namun belum diketahui atribut atau kriteria apa yang digunakan Ugi dalam penilaian kemiripan tersebut. Bisa saja penilaian kemiripannya (atribut) berdasarkan rasa, atau harga, atau ukuran permen, dan sebagainya.

Perhatikan Gambar 24.2. Berdasarkan Gambar 24.2, misalkan dimensi 1 diinterpretasi sebagai harga permen, sementara dimensi 2 diinterpretasi sebagai ukuran permen. Berdasarkan interpretasi kedua dimensi tersebut, maka dapat ditarik informasi sebagai berikut.

$\Rightarrow$ Objek A, B, dan C dalam Gambar 24.2, cenderung terletak dekat dengan sumbu vertikal (dimensi atribut ukuran permen). Kemiripan antara permen A dan B 
dinilai berdasarkan atribut atau kriteria ukuran permen. Dalam hal ini, ukuran permen A dan B cenderung sama besar, namun ukuran permen A dan B, berbeda dengan ukuran permen $\mathrm{C}$.

$\Rightarrow$ Objek $\mathrm{D}$, E, dan $\mathrm{F}$ dalam Gambar 2, cenderung terletak dekat dengan sumbu horizontal (dimensi atribut harga). Kemiripan antara permen D dan E dinilai berdasarkan atribut atau kriteria harga. Dalam hal ini, harga permen D dan E cenderung tidak berbeda jauh, namun harga permen $\mathrm{D}$ dan $\mathrm{E}$, berbeda jauh dengan harga permen $\mathrm{F}$.

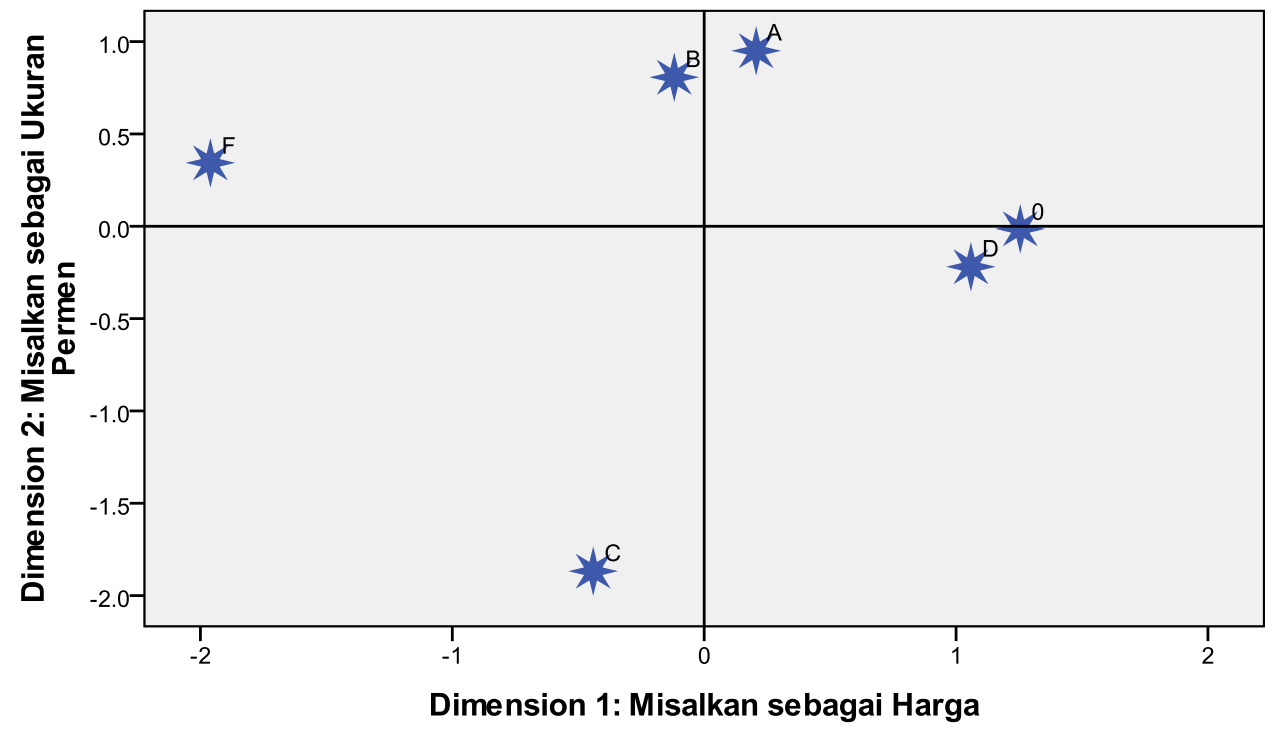

Gambar 24.2 Interpretasi dari Dimensi 1 dan Dimensi 2

Ketika peta spasial telah dibentuk, hal yang perlu dilakukan adalah memberi label untuk tiap-tiap dimensi. Dengan kata lain, mengidentifikasi atribut atau kriteria apa yang digunakan oleh responden dalam penilaian kemiripan tersebut.

Pada Gambar 24.2, dimensi 1 (sumbu horizontal) diinterpretasi atau diberi label harga, sementara pada dimensi 2 (sumbu vertikal) diinterpretasi atau diberi label ukuran permen.

Hair dkk. (2010:558) menyatakan sebagai berikut.

"The researcher typically makes a subjective evaluation of the perceptual maps and determines whether the configuration looks reasonable. This evaluation is important because at a later stage the dimensions will need to be interpreted and explained."

Berdasarkan pernyataan di atas dapat dipahami bahwa hal yang perlu dilakukan setelah peta spasial dibentuk ialah memberi label untuk tiap-tiap dimensi. Dengan kata lain, mengidentifikasi atribut atau kriteria apa yang digunakan oleh responden dalam penilaian kemiripan tersebut. Seoarang peneliti biasanya membuat evaluasi subjektif dalam hal 
mengidentifikasi tiap-tiap dimensi. Tentunya dalam evaluasi subjektif tersebut perlu diperhatikan aspek kewajaran (mencerminkan keadaan lapangan).

Hair dkk. (2010:538) menyatakan sebagai berikut.

"Dimensions Features of an object. A particular object can be thought of as possessing both perceived/subjective dimensions (e.g., expensive, fragile) and objective dimensions (e.g., color, price, features)."

Janssens dkk. (2008:368) menyatakan terdapat dua cara pengumpulan data, yakni pengumpulan data langsung (direct data collection) dan pengumpulan data tak langsung (indirect data collection). Pengumpulan data tak langsung disebut juga dengan istilah pengumpulan data berbasis atribut.

\section{Pengumpulan Data Langsung (Direct Data Collection)}

Berikut diberikan contoh pengumpulan data langsung. Contoh berikut ini memodifikasi dari contoh kasus pada buku "Marketing Research with SPSS" yang ditulis oleh Janssens dkk, halaman 398, tahun 2008. Andaikan Ugi seorang manajer pemasaran permen A. Diketahui saat ini terdapat 10 jenis permen yang telah beredar di pasar, yakni permen A, B, C, D, E, F, G, H, I, dan J. Tentunya terdapat persaingan penjualan di antara 10 jenis produk permen tersebut. Untuk itu manajer pemasaran tersebut akan meneliti posisi (position) permen A terhadap produk-produk permen lainnya. Dengan kata lain, ingin mengetahui produk permen manakah yang dianggap masyarakat mirip terhadap permen A.

Misalkan berdasarkan hasil penelitian diketahui permen $A$ dan permen $E$ dianggap mirip berdasarkan penilaian masyarakat. Maka akan terjadi persaingan penjualan antara permen $A$ dan permen $E$. Dengan diketahuinya hal ini, maka pihak manajer pemasaran permen $A$ dapat melakukan inovasi untuk memenangkan persaingan penjualan. MDS akan digunakan untuk mengetahui hal tersebut.

Selanjutnya manajer pemasaran tersebut merancang kuesioner seperti berikut.

\section{Contoh Kuesioner}

Untuk setiap pasangan permen berikut, berikan penilaian saudara. Skor penilaian dimulai dari 1 sampai 9. Skor 1 menyatakan pasangan permen tersebut sangat mirip (very similar), sedangkan skor 9 menyatakan pasangan permen tersebut sangat tidak mirip (very different). 
Tabel 24.2 Penilaian Responden Pertama

\begin{tabular}{|c|c|c|c|}
\hline No & \multicolumn{2}{|c|}{ Perbandingan Kemiripan Permen } & Penilaian Kemiripan \\
\hline 1 & $A$ & $B$ & 8 \\
\hline 2 & A & $c$ & 7 \\
\hline 3 & $A$ & $D$ & 6 \\
\hline 4 & A & $E$ & 7 \\
\hline 5 & A & $\mathrm{F}$ & 1 \\
\hline 6 & $A$ & $G$ & 7 \\
\hline 7 & A & $H$ & 8 \\
\hline 8 & A & I & 2 \\
\hline 9 & A & $\mathrm{J}$ & 7 \\
\hline 10 & $B$ & C & 6 \\
\hline 11 & $B$ & $D$ & 7 \\
\hline 12 & B & $E$ & 8 \\
\hline 13 & $B$ & $\mathrm{~F}$ & 7 \\
\hline 14 & $B$ & $G$ & 8 \\
\hline 15 & B & $H$ & 9 \\
\hline 16 & $B$ & I & 7 \\
\hline 17 & $B$ & $\mathrm{~J}$ & 2 \\
\hline 18 & $c$ & $D$ & 9 \\
\hline 19 & $c$ & $E$ & 1 \\
\hline 20 & $c$ & $\mathrm{~F}$ & 8 \\
\hline 21 & $c$ & $G$ & 7 \\
\hline 22 & $c$ & $\mathrm{H}$ & 8 \\
\hline 23 & c & I & 9 \\
\hline 24 & $c$ & $\mathrm{~J}$ & 6 \\
\hline 25 & $D$ & $E$ & 7 \\
\hline 26 & $D$ & $\mathrm{~F}$ & 8 \\
\hline 27 & $D$ & $G$ & 2 \\
\hline 28 & $D$ & $\mathrm{H}$ & 1 \\
\hline 29 & $D$ & $I$ & 7 \\
\hline 30 & $D$ & $\mathrm{~J}$ & 8 \\
\hline 31 & $E$ & $F$ & 7 \\
\hline 32 & $E$ & $G$ & 6 \\
\hline 33 & $E$ & $\mathrm{H}$ & 9 \\
\hline 34 & $E$ & I & 8 \\
\hline 35 & $E$ & $\mathrm{~J}$ & 7 \\
\hline 36 & $F$ & $G$ & 7 \\
\hline 37 & $F$ & $H$ & 9 \\
\hline 38 & $F$ & $I$ & 2 \\
\hline 39 & $F$ & $\mathrm{~J}$ & 7 \\
\hline 40 & $G$ & $H$ & 2 \\
\hline 41 & $G$ & I & 7 \\
\hline 42 & $G$ & $\mathrm{~J}$ & 8 \\
\hline 43 & $H$ & I & 7 \\
\hline 44 & $\mathrm{H}$ & $\mathrm{J}$ & 8 \\
\hline 45 & $I$ & $\mathrm{~J}$ & 8 \\
\hline
\end{tabular}


Perhatikan bahwa jumlah pasangan permen berbeda yang dapat dibentuk sebanyak 45, yakni

$$
C_{2}^{10}=\frac{10 !}{(10-2) !(2 !)}=\frac{90}{2}=45 \text {. }
$$

Tabel 24.2 merupakan hasil penilaian dari responden pertama. Berdasarkan Tabel 24.2, diketahui:

$\Rightarrow$ Permen A dianggap mirip terhadap permen $F$ (skor 1), dan juga permen A dianggap cukup mirip terhadap permen I (skor 2).

$\Rightarrow$ Permen B dianggap mirip terhadap permen $\mathrm{J}$ (skor 2).

$\Rightarrow$ Permen $\mathrm{C}$ dianggap mirip terhadap permen $\mathrm{E}$ (skor 1)

$\Rightarrow$ Permen D dianggap mirip terhadap permen $\mathrm{G}$ (skor 2), dan juga permen D dianggap mirip terhadap permen $\mathrm{H}$ (skor 1).

$\Rightarrow$ Permen F dianggap mirip terhadap permen I (skor 2).

$\Rightarrow$ Permen $\mathrm{G}$ dianggap mirip terhadap permen $\mathrm{H}$ (skor 2).

Hasil penilaian responden pertama pada Tabel 24.2 dapat diringkas seperti pada Tabel 24.3.

Tabel 24.3 Penilaian Responden Pertama

\begin{tabular}{|c|c|c|c|c|c|c|c|c|c|c|}
\hline Permen & A & B & C & D & E & F & G & H & I & J \\
\hline A & 0 & & & & & & & & & \\
\hline B & 8 & 0 & & & & & & & & \\
\hline C & 7 & 6 & 0 & & & & & & & \\
\hline D & 6 & 7 & 9 & 0 & & & & & & \\
\hline E & 7 & 8 & 1 & 7 & 0 & & & & & \\
\hline F & 1 & 7 & 8 & 8 & 7 & 0 & & & & \\
\hline G & 7 & 8 & 7 & 2 & 6 & 7 & 0 & & & \\
\hline H & 8 & 9 & 8 & 1 & 9 & 9 & 2 & 0 & & \\
\hline I & 2 & 7 & 9 & 7 & 8 & 2 & 7 & 7 & 0 & \\
\hline J & 7 & 2 & 6 & 8 & 7 & 7 & 8 & 8 & 8 & 0 \\
\hline
\end{tabular}

Berdasarkan Tabel 24.3, pasangan untuk permen yang sejenis diberi nilai 0, yang menandakan bahwa kedua permen tersebut adalah sama (hal ini akan diterapkan saat menggunakan MDS dalam SPSS). Ilustrasi pengumpulan data yang telah dilakukan merupakan pengumpulan data langsung. Pada pengumpulan data langsung, setiap pasangan objek yang berbeda dibandingkan (dalam kasus ini dibandingkan kemiripannya), tanpa diketahui kriteria atau atribut penilaian kemiripannya. Janssens dkk. (2008:368) menyatakan sebagai berikut mengenai pengumpulan data langsung.

"The respondent is presented with a set of objects and is asked to compare each with one another (see Example 2, 'question 1'; Table 10.4), and is thus not required to answer on the basis of criteria which were determined by the researcher beforehand. After an analysis of 'directly' collected data, the researcher does not know immediately however which 
attributes played a role in the comparison of the objects. The importance of the attributes may only be determined indirectly after the map has been drawn up; for example, this may be done by finding out which stimuli occupy extreme positions on the dimensions of the map, or by examining related groups of objects. The respondent may be asked additional questions to simplify the interpretation of the axes, for example by using them as input for an external analysis. The method of direct data collection is moreover limited in terms of the number of objects to be studied: at least 7 or 8 objects are required to construct a perceptual map in two or three dimensions; if the number of objects to be studied is greater than 20, then it will be nearly impossible for the consumer to compare all of the objects."

\section{Pengumpulan Data Tak Langsung (Indirect Data Collection)}

Tabel 24.4 merupakan contoh pengumpulan data tidak langsung.

Tabel 24,4 Data Penilaian secara Rata-Rata mengenai Kesukaan/Kepuasan terhadap 8 Merek Kopi dari 100 Responden

\begin{tabular}{|c|c|c|c|c|c|c|c|c|}
\hline \multirow{2}{*}{ Atribut } & \multicolumn{9}{|c|}{ Merek Kopi } \\
\cline { 2 - 9 } & $\mathrm{A}$ & $\mathrm{B}$ & $\mathrm{C}$ & $\mathrm{D}$ & $\mathrm{E}$ & $\mathrm{F}$ & $\mathrm{G}$ & $\mathrm{H}$ \\
\hline Harga & 9.12 & 2.32 & 2.76 & 9.21 & 1.98 & 1.54 & 2.12 & 1.98 \\
\hline Aroma & 1.87 & 9.65 & 1.32 & 2.12 & 9.75 & 2.23 & 1.89 & 1.52 \\
\hline Kemasan & 2.31 & 2.12 & 8.76 & 3.21 & 1.86 & 8.02 & 2.24 & 2.18 \\
\hline Kekentalan & 1.43 & 1.63 & 2.13 & 1.54 & 1.42 & 2.13 & 8.89 & 9.02 \\
\hline
\end{tabular}

Berbeda dengan pengumpulan data langsung (Vdirect data collection) yang tidak menentukan atributnya terlebih dahulu, pada pengumpulan data tak langsung (indirect data collection) telah menetapkan atributnya terlebih dahulu. Sebagaimana Janssens dkk. (2008:369) memaparkan mengenai pengumpulan data secara tidak langsung sebagai berikut.

"With indirect measurement, the respondent is asked for example to evaluate every car make on the basis of twenty items about the bodywork, the price, the motor performance, the prestige, the usage, etc. and this is done using one or more scale methods (e.g., Semantic differential, Likert scale or Stapel scale). The scores collected in this manner may then be used directly as input for a rectangular matrix which places the makes in the columns and the attributes in the rows ('two-mode' data), however they may also be converted into associations between the makes themselves and this will serve indirectly as input for a square matrix ('one-mode' data)."

Berdasarkan Tabel 24.4, diketahui terdapat 4 atribut, yakni harga, aroma, kemasan, dan kekentalan. Berdasarkan Tabel 24.4 diketahui untuk atribut harga, kopi merek A dan kopi merek D memiliki tingkat kepuasan/kesukaan yang paling tinggi berdasarkan penilaian ratarata dari 10 responden. Diketahui untuk atribut aroma, kopi merek B dan kopi merek E memiliki tingkat kepuasan/kesukaan yang paling tinggi berdasarkan penilaian rata-rata dari 10 responden, dan seterusnya. Perhatikan Gambar 24.3. Berdasarkan Gambar 24.3, dapat dilihat bahwa kopi merek $\mathrm{H}$ dan kopi merek $\mathrm{G}$ saling bersaing dalam hal kekentalan, sementara kopi merek A dan kopi merek D bersaing dalam hal harga. Kopi merek $\mathrm{C}$ dan kopi merek $\mathrm{F}$ bersaing dalam hal kemasan, sementara kopi merek E dan kopi merek B bersaing dalam hal aroma. 


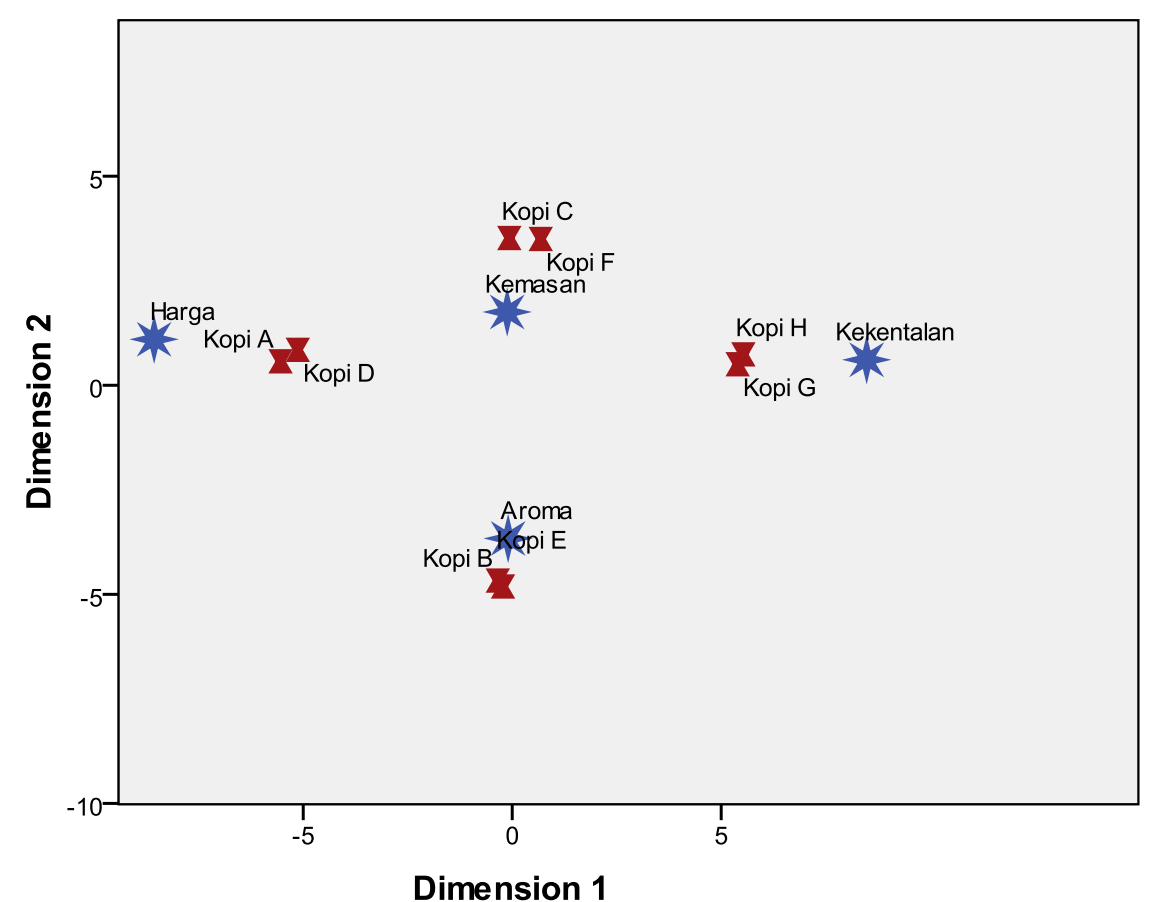

Dimension 1

Gambar 24.3 


\section{PENYELESAIAN DALAM SPSS}

[1] Berikut disajikan kembali data contoh kasus pada pemaparan sebelumnya beserta peta spasialnya.

Tabel 24.1 Data Ranking mengenai Kemiripan untuk Setiap Pasangan Permen

\begin{tabular}{ccccccc}
\hline Jenis Permen & A & B & C & D & E & F \\
\hline A & - & & & & & \\
B & 2 & - & & & & \\
C & 13 & 12 & - & & & \\
D & 4 & 6 & 9 & - & & \\
E & 3 & 5 & 10 & 1 & - & - \\
F & 8 & 7 & 11 & 14 & 15 & - \\
\hline
\end{tabular}

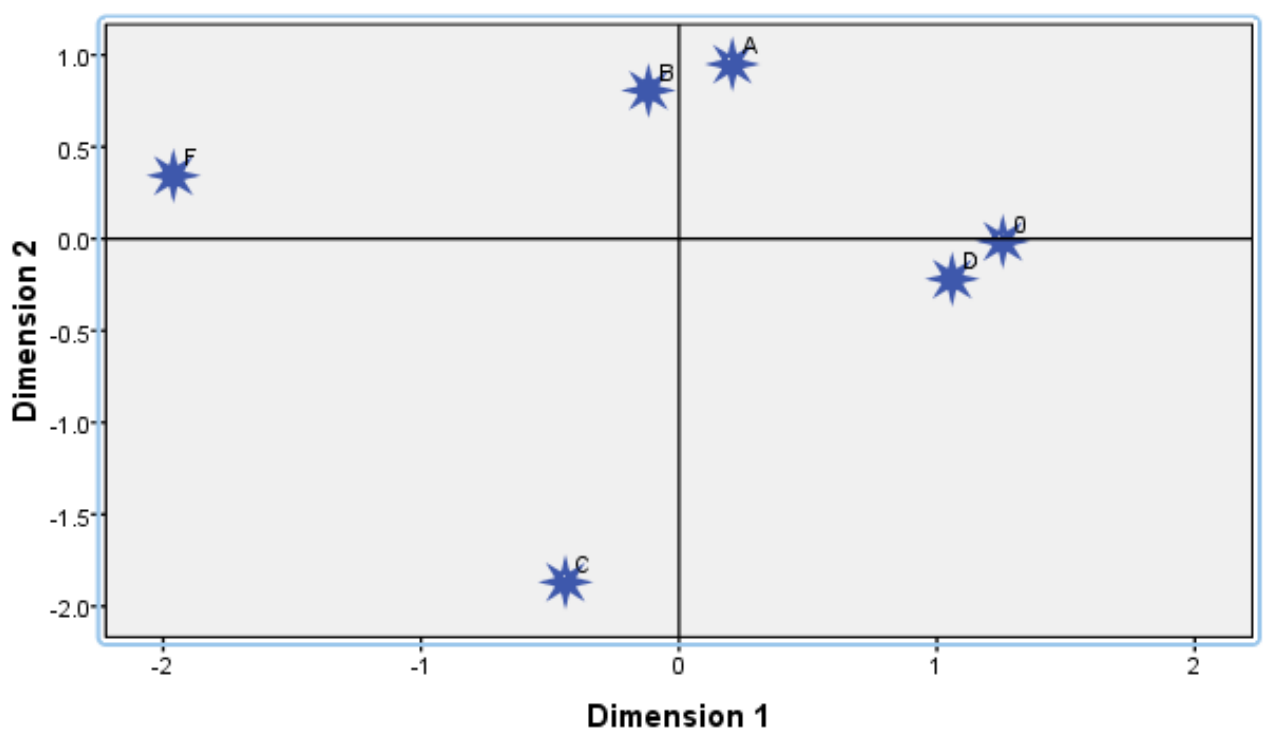

\section{Gambar 24.1 Contoh Peta Spasial Dua Dimensi}

Berikut langkah-langkah dalam SPSS untuk memperoleh peta spasial pada Gambar 24.1. Bangun data dalam SPSS, seperti pada Gambar 24.1 dan Gambar 24.2. Pilih Analyze $=>$ Scale $\Rightarrow$ Multidimensional Scaling (ALSCAL), seperti pada Gambar 24.3, sehingga muncul tampilan seperti pada Gambar 24.4. Pada Gambar 24.4, pindahkan seluruh variabel pada kotak Variables, kemudian pilih Model, sehingga muncul tampilan Multidimensional Scaling: Model (Gambar 24.5). Pada Gambar 24.5, jenis data diperlakukan Ratio, oleh karena itu pilih Ratio, kemudian pilih Matrix dan Euclidean. Pilih Continue, sehingga tampilan kembali seperti pada Gambar 24.4. Selanjutnya pilih Options, sehingga muncul tampilan seperti pada Gambar 24.6. Pada Gambar 24.6, pilih Group plots. Selanjutnya pilih Continue dan OK. Maka hasilnya seperti pada Gambar 24.7. 


\begin{tabular}{|c|c|c|c|c|c|c|c|c|}
\hline & Name & Type & Width & Decimals & Label & Values & Missing & $\mathrm{Co}_{0}$ \\
\hline 1 & A & Numeric & 8 & 0 & & None & None & 8 \\
\hline 2 & $\mathrm{~B}$ & Numeric & 8 & 0 & & None & None & 8 \\
\hline 3 & C & Numeric & 8 & 0 & & None & None & 8 \\
\hline 4 & $D$ & Numeric & 8 & 0 & & None & None & 8 \\
\hline 5 & $E$ & Numeric & 8 & 0 & & None & None & 8 \\
\hline 6 & $\mathrm{~F}$ & Numeric & 8 & 0 & & None & None & 8 \\
\hline
\end{tabular}

Gambar 24.1

\begin{tabular}{|c|c|c|c|c|c|c|}
\hline & A & $B$ & C & $D$ & $E$ & $\mathrm{~F}$ \\
\hline 1 & 0 & . & . & . & . & \\
\hline 2 & 2 & 0 & . & . & . & \\
\hline 3 & 13 & 12 & 0 & . & . & \\
\hline 4 & 4 & 6 & 9 & 0 & . & \\
\hline 5 & 3 & 5 & 10 & 1 & 0 & \\
\hline 6 & 8 & 7 & 11 & 14 & 15 & \\
\hline
\end{tabular}

Gambar 24.2

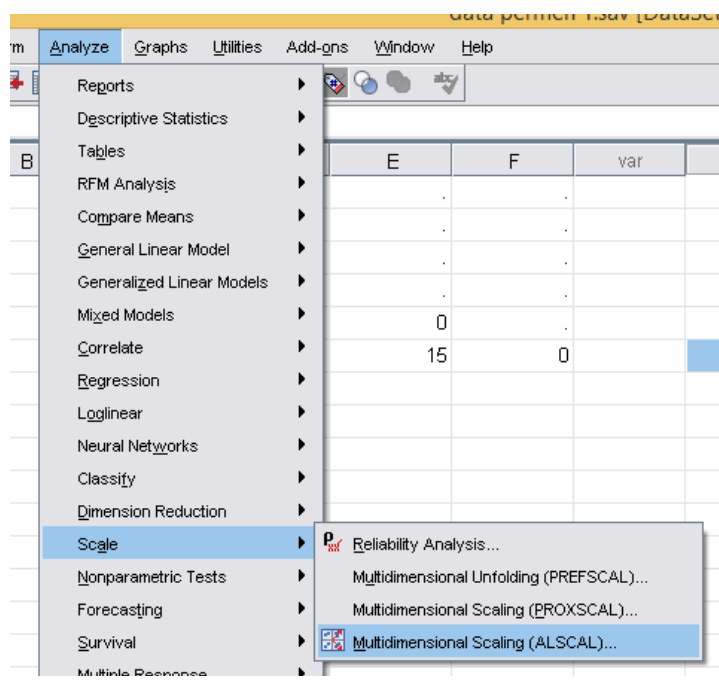

Gambar 24.3

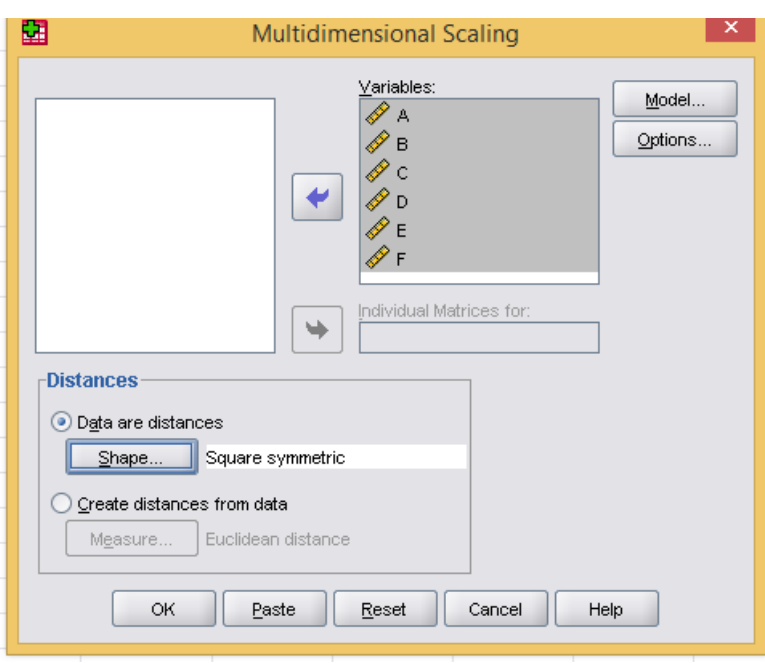

Gambar 24.4

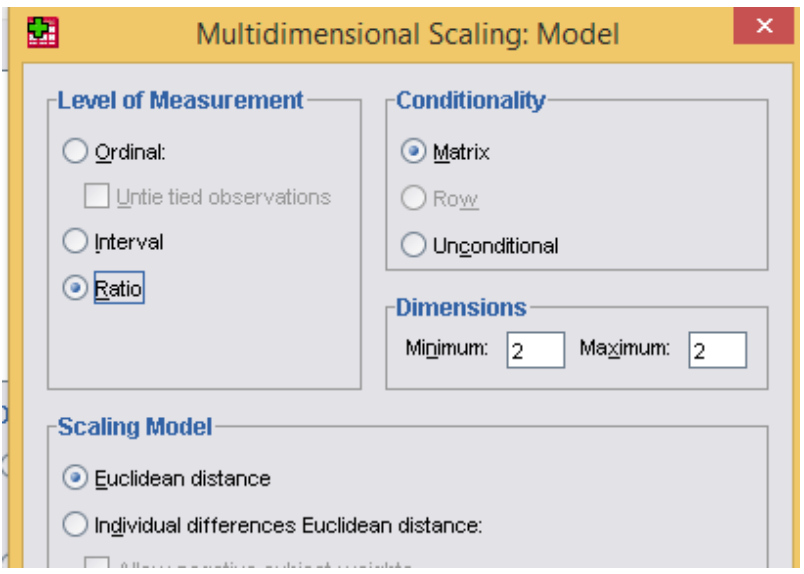

Gambar 24.5

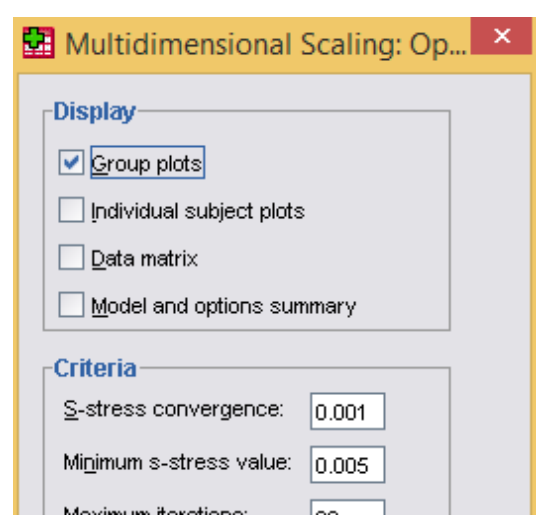

Gambar 24.6 


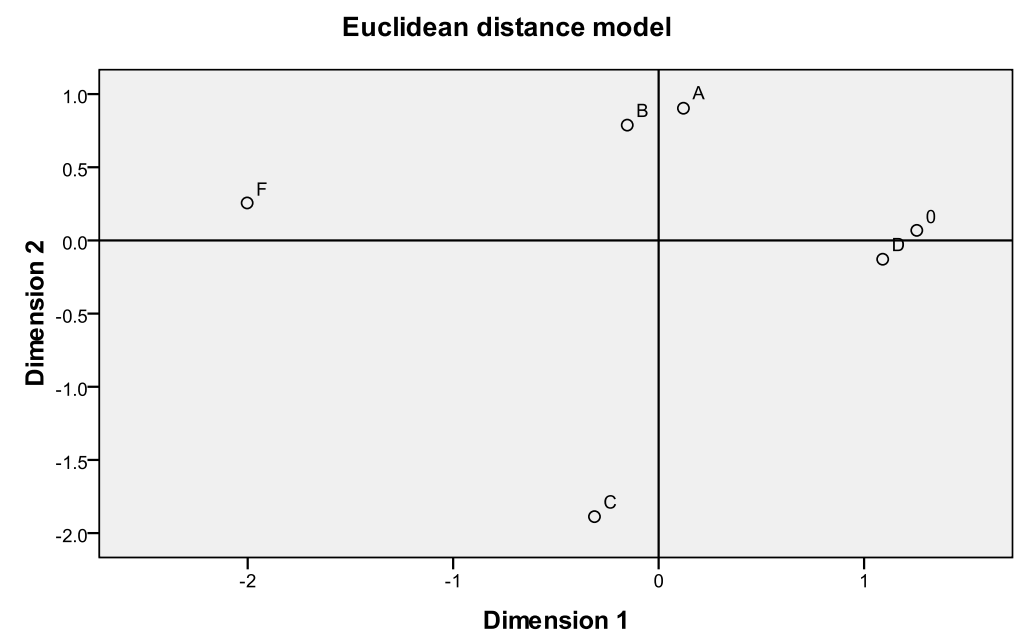

Gambar 24.7

[2] Berikut disajikan kembali data contoh kasus pada pemaparan sebelumnya beserta peta spasialnya.

Tabel 24,2 Data Penilaian secara Rata-Rata mengenai Kesukaan/Kepuasan terhadap 8 Merek Kopi dari 100 Responden

\begin{tabular}{|c|c|c|c|c|c|c|c|c|}
\hline \multirow{2}{*}{ Atribut } & \multicolumn{9}{|c|}{ Merek Kopi } \\
\cline { 2 - 9 } & $\mathrm{A}$ & $\mathrm{B}$ & $\mathrm{C}$ & $\mathrm{D}$ & $\mathrm{E}$ & $\mathrm{F}$ & $\mathrm{G}$ & $\mathrm{H}$ \\
\hline Harga & 9.12 & 2.32 & 2.76 & 9.21 & 1.98 & 1.54 & 2.12 & 1.98 \\
\hline Aroma & 1.87 & 9.65 & 1.32 & 2.12 & 9.75 & 2.23 & 1.89 & 1.52 \\
\hline Kemasan & 2.31 & 2.12 & 8.76 & 3.21 & 1.86 & 8.02 & 2.24 & 2.18 \\
\hline Kekentalan & 1.43 & 1.63 & 2.13 & 1.54 & 1.42 & 2.13 & 8.89 & 9.02 \\
\hline
\end{tabular}

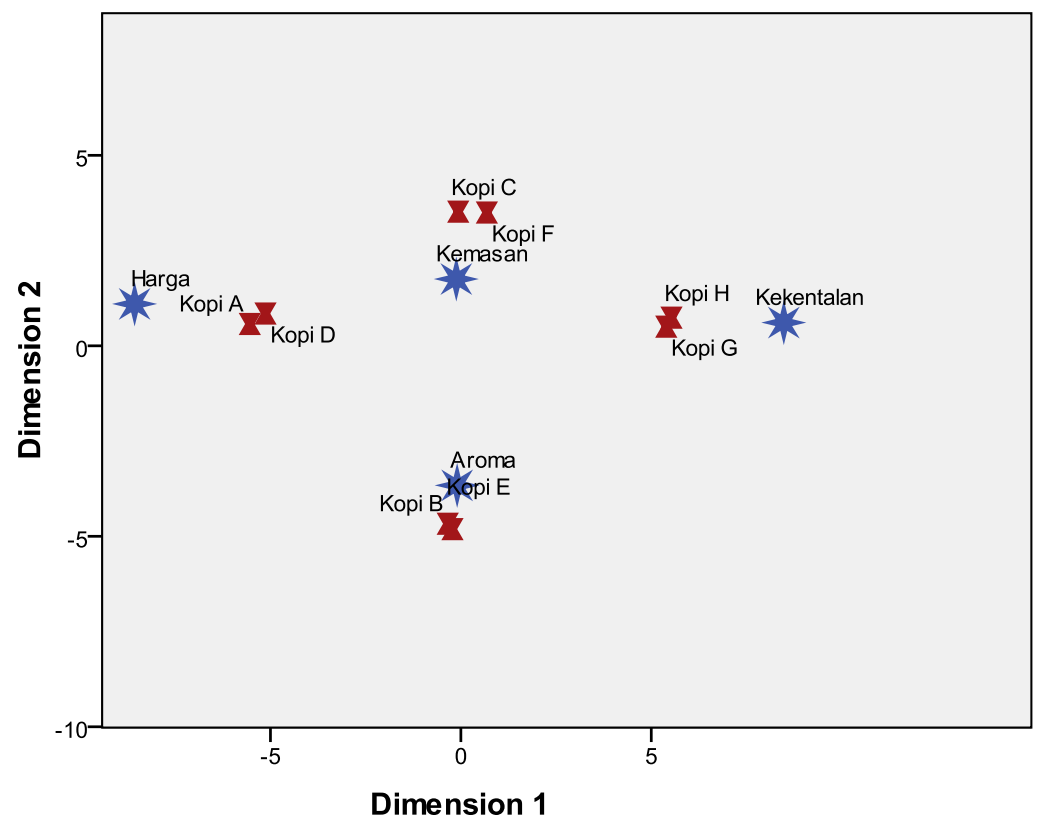

Gambar 24.8 Contoh Peta Spasial Dua Dimensi 
Berikut langkah-langkah dalam SPSS untuk memperoleh peta spasial pada Gambar 24.8. Bangun data dalam SPSS, seperti pada Gambar 24.9 hingga Gambar 24.12. Pilih Analyze => Scale $=>$ Multidimensional Unfolding (PREFSCAL), seperti pada Gambar 24.13, sehingga muncul tampilan seperti pada Gambar 24.14. Pada Gambar 24.14, pindahkan seluruh variabel (variabel A hingga H) pada kotak Proximities, dan pindahkan variabel Atribut pada kotak Rows, kemudian pilih Model, sehingga muncul tampilan Multidimensional Unfolding: Model (Gambar 24.15). Pada Gambar 24.15, pilih Linear dan Similarities, kemudian pilih Continue, sehingga tampilan kembali seperti pada Gambar 24.14. Selanjutnya pilih Options, sehingga muncul tampilan seperti pada Gambar 24.16. Pada Gambar 24.16, pilih Spearman. Selanjutnya pilih Continue dan OK. Maka hasilnya seperti pada Gambar 24.17.

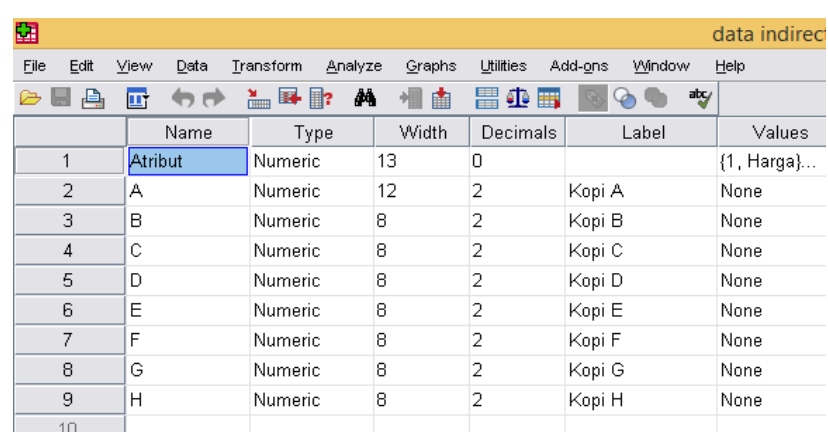

Gambar24.9

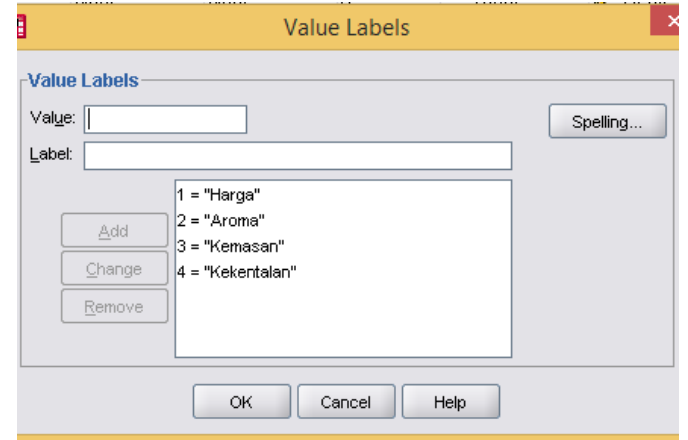

Gambar 24.10

\begin{tabular}{|c|c|c|c|c|c|c|c|c|c|}
\hline & Atribut & A & $B$ & c & D & $E$ & $\mathrm{~F}$ & G & $\mathrm{H}$ \\
\hline 1 & 1 & 9.12 & 2.32 & 2.76 & 9.21 & 1.98 & 1.54 & 2.12 & 1.98 \\
\hline 2 & 2 & 1.87 & 9.65 & 1.32 & 2.12 & 9.75 & 2.23 & 1.89 & 1.52 \\
\hline 3 & 3 & 2.31 & 2.12 & 8.76 & 3.21 & 1.86 & 8.02 & 2.24 & 2.18 \\
\hline 4 & 4 & 1.43 & 1.63 & 2.13 & 1.54 & 1.42 & 2.13 & 8.89 & 9.02 \\
\hline
\end{tabular}

\section{Gambar 24.11}

\begin{tabular}{|c|c|c|c|c|c|c|c|c|c|}
\hline & Atribut & A & $B$ & C & D & $E$ & $\mathrm{~F}$ & G & $\mathrm{H}$ \\
\hline 1 & Harga & 9.12 & 2.32 & 2.76 & 9.21 & 1.98 & 1.54 & 2.12 & 1.98 \\
\hline 2 & Aroma & 1.87 & 9.65 & 1.32 & 2.12 & 9.75 & 2.23 & 1.89 & 1.52 \\
\hline 3 & Kemasan & 2.31 & 2.12 & 8.76 & 3.21 & 1.86 & 8.02 & 2.24 & 2.18 \\
\hline 4 & Kekentalan & 1.43 & 1.63 & 2.13 & 1.54 & 1.42 & 2.13 & 8.89 & 9.02 \\
\hline
\end{tabular}

\section{Gambar 24.12}

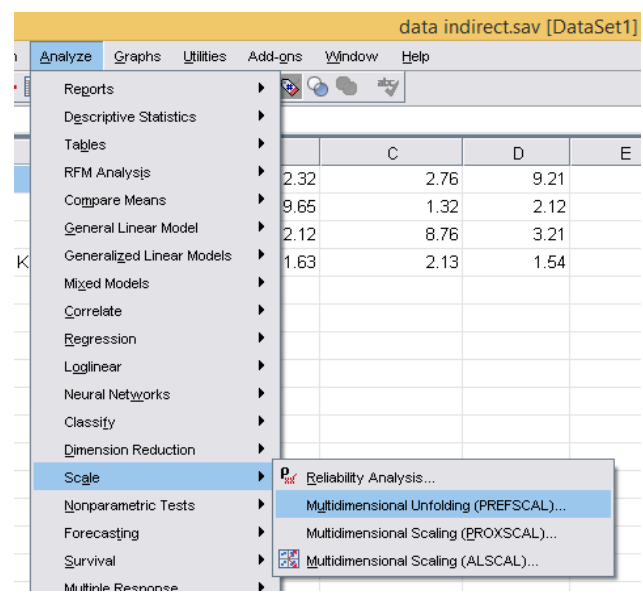

Gambar 24.13

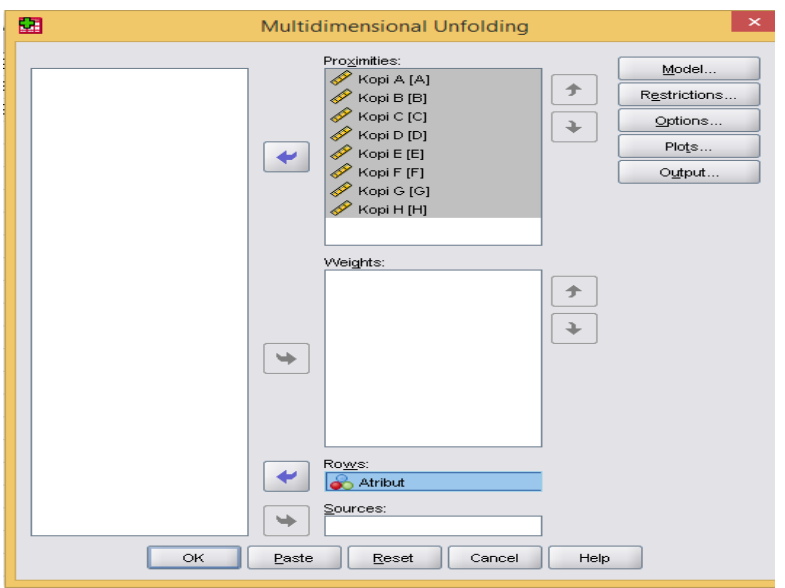

Gambar 24.14 


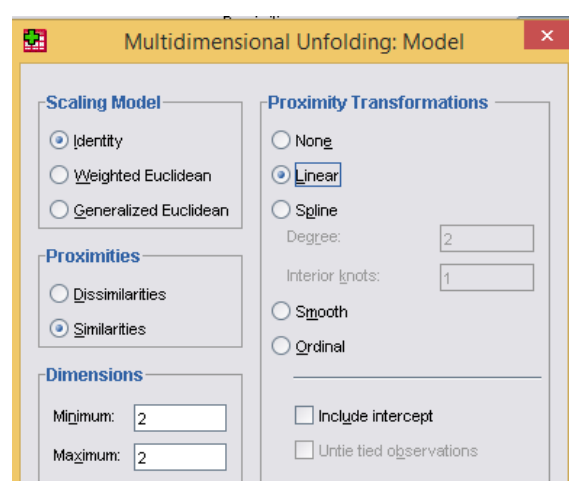

Gambar 24.15

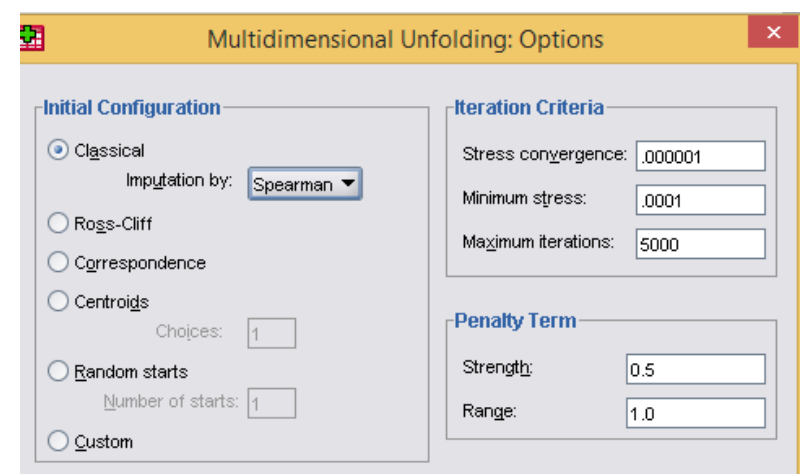

Gambar 24.16

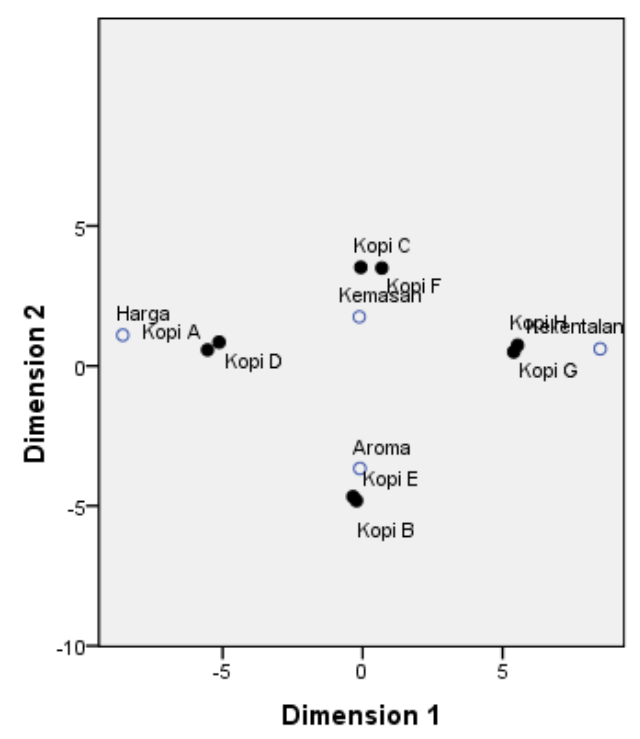

Gambar 24.17

\section{Referensí}

1. Field, A. 2009. Discovering Statistics Using SPSS, $3^{\text {rd }}$ Edition. London: Sage.

2. Hair, J.F Jr., R.E. Anderson, B.J. Babin, dan W.C. Black. 2010. Multivariate Data Analysis, $7^{\text {th }}$ Edition. Pearson Prentice Hall.

3. Janssens, W., K. Wijnen, P.D. Pelsmacker, dan P.V. Kenhove. 2008. Marketing Research with SPSS. Pearson Prenticel Hall.

4. Johnson, R.A. dan D.W. Wichern. 2007. Applied Multivariate Statistical Analysis, $6^{\text {th }}$ Edition. Pearson Prentice Hall.

5. Malhotra, N.K. dan D.F. Birks. 2006. Marketing Research, An Applied Approach, $2^{\text {nd }}$ European Edition. London: Prentice Hall.

6. Stevens, J.P. 2009. Applied Multivariate Statistics For The Social Science, $5^{\text {th }}$ Edition. New York: Routledge. 


\section{ANALISIS JALUR (PATH ANALYSIS)}

\section{Sekilas Analisís Jalur}

Schumacker dan Lomax (2010:143) menyatakan berkaitan tentang analisis jalur sebagai berikut.

"In this chapter we consider path models, the logical extension of multiple regression models. Although path analysis still uses models involving multiple observed variables, there may be any number of independent and dependent variables and any number of equations. Thus, as we shall see, path models require the analysis of several multiple regression equations using observed variables.

Sewall Wright is credited with the development of path analysis as a method for studying the direct and indirect effects of variables (Wright, 1921, 1934, 1960). Path analysis is not actually a method for discovering causes; rather, it tests theoretical relationships, which historically has been termed causal modeling."

Berdasarkan uraian di atas, dapat ditarik informasi bahwa model analisis jalur (path models) merupakan perluasan dari model regresi linear berganda. Dalam model regresi linear berganda, variabel tak bebas yang dilibatkan hanya satu (hanya terdapat satu persamaan), sementara pada model analisis jalur terdapat kemungkinan memiliki variabel tak bebas lebih dari satu, sehingga terdapat beberapa persamaan. Model analisis jalur yang melibatkan variabel tak bebas lebih dari satu, melibatkan penggunaan teknik regresi berganda lebih dari satu kali, untuk mengestimasi koefisien jalur. Jadi dalam hal ini, teknik regresi berganda dapat digunakan untuk menentukan koefisien jalur. Selanjutnya, metode analisis jalur dapat diartikan juga sebagai suatu metode untuk mempelajari pengaruh/efek langsung (direct effect) dan pengaruh tidak langsung (indirect effect) antara satu variabel dengan variabel lainnya.

Preacher dan Hayes dalam jurnal Behavior Research Methods, Instruments, \& Computers 2004, 36(4), 717-731, dengan judul "SPSS and SAS procedures for estimating indirect effects in simple mediation" menyatakan sebagai berikut.

"Researchers often conduct mediation analysis in order to indirectly assess the effect of a proposed cause on some outcome through a proposed mediator. The utility of mediation analysis stems from its ability to go beyond the merely descriptive to a more functional understanding of the relationships among variables. A necessary component of mediation is a statistically and practically significant indirect effect. Although mediation hypotheses are frequently explored in psychological research, formal significance tests of indirect effects are rarely conducted. After a brief overview of mediation, we argue the importance of directly testing the significance of indirect effects and provide SPSS and SAS macros that facilitate estimation of the indirect effect with a normal theory approach and a bootstrap approach to obtaining confidence intervals, as well as the traditional approach advocated by Baron and Kenny (1986). We hope that this discussion and the macros will enhance the frequency of formal mediation tests in the psychology literature." 
Berdasarkan uraian oleh Preacher dan Hayes dapat ditarik informasi bahwa pengujian signifikansi dari efek tidak langsung (indirect effect) dapat dilakukan dengan menggunakan SPSS dan SAS macros yang memfasilitasi pengujian signifikansi dari efek tidak langsung dengan pendekatan normal theory approach dan bootstrap approach untuk memperoleh interval keyakinan (perhatikan Gambar 25.1 dan Gambar 25.2), dan juga pendekatan tradisional yang dianjurkan (advocated) oleh Baron dan Kenny.

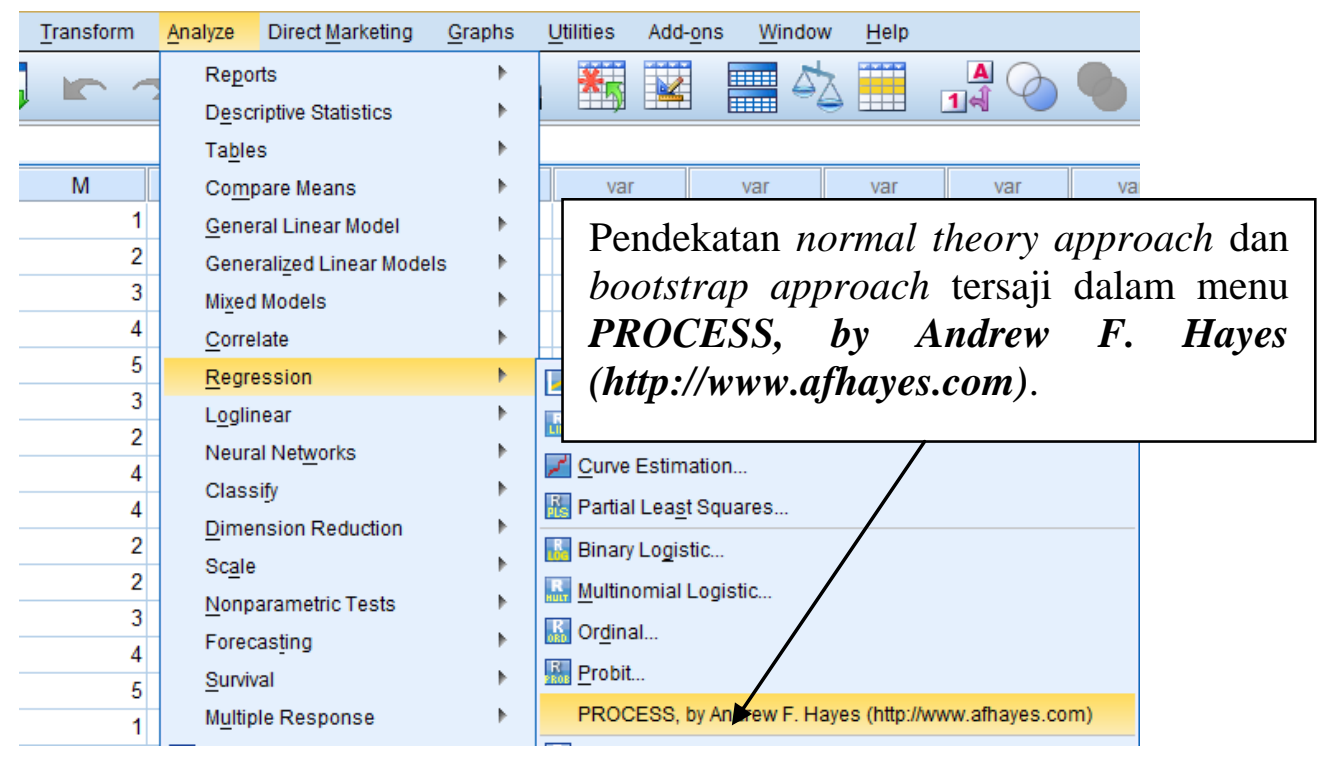

Gambar 25.1

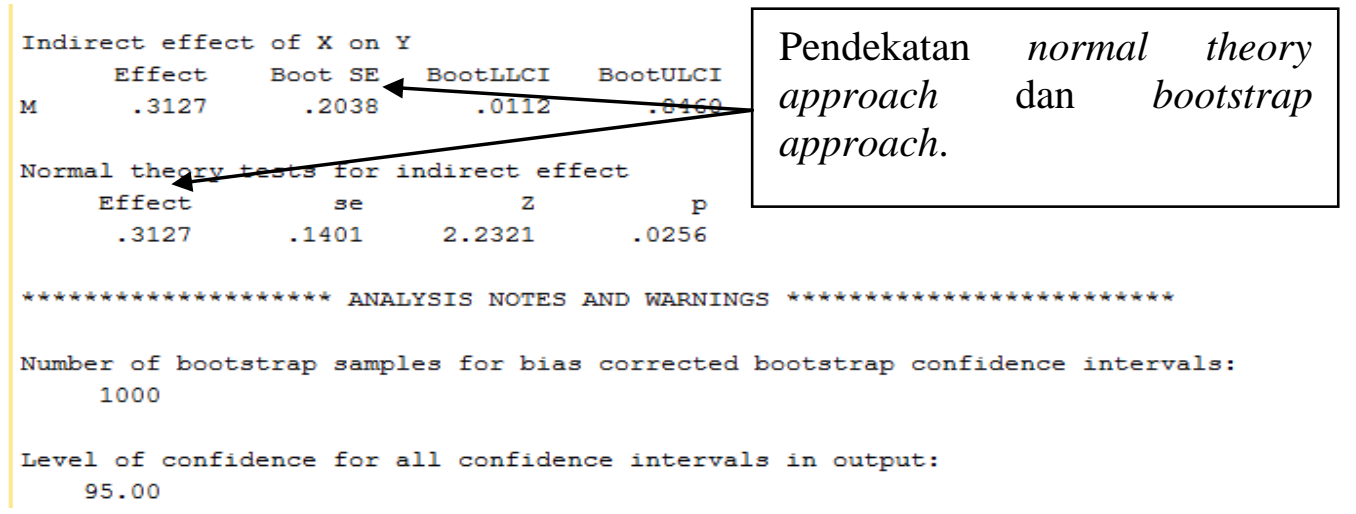

\section{Gambar 25.2}

\section{Model Mediasi dengan Satu Varíabel Mediator}

Misalkan diberikan diagram jalur (path diagram) dan persamaan untuk model regresi (Gambar 25.3), serta diagram jalur dan persamaan untuk model mediasi dengan satu variabel mediator (Gambar 25.4) (Mackinon, 2008:48-49).

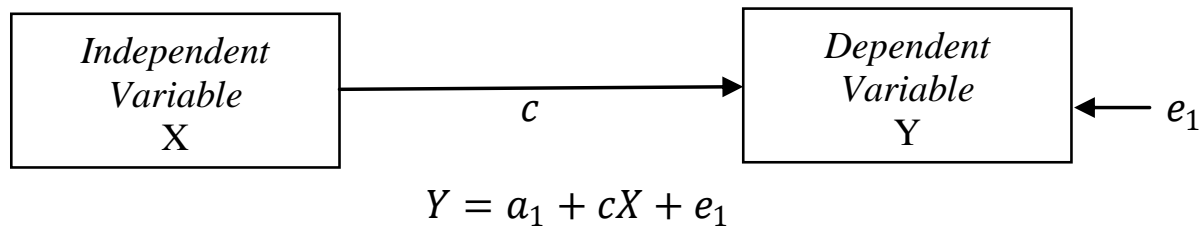




\section{Gambar 25.3 Diagram Jalur dan Persamaan untuk Model Regresi}

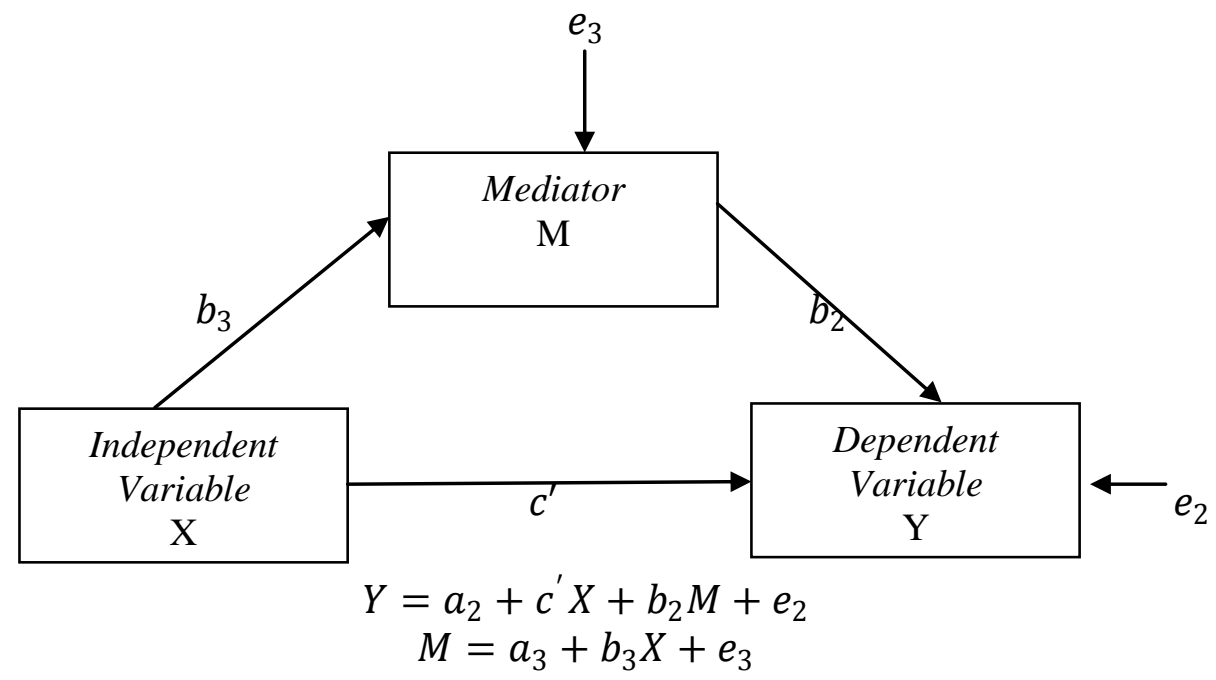

\section{Gambar 25.4 Diagram Jalur dan Persamaan untuk Model Mediasi dengan Satu Variabel Mediator}

Berdasarkan Gambar 25.3 dan Gambar 25.4, diperoleh 3 persamaan, yakni

$$
\begin{gathered}
Y=a_{1}+c X+e_{1} \quad[25.1] \\
Y=a_{2}+c^{\prime} X+b_{2} M+e_{2} \quad[25.2] \\
M=a_{3}+b_{3} X+e_{3}
\end{gathered}
$$

MacKinnon (2008:50) menyatakan sebagai berikut.

"The intercepts are not involved in the estimation of mediated effects and could be left out of the equations. However, they are included here because intercepts are important for other aspects of mediation such as plotting the mediated effect. Note that both $c$ and $c^{\prime}$ are parameters relating the independent variable to the dependent variable, but $c^{\prime}$ is a partial effect, adjusted for the effects of the mediator. The parameters of this model can be estimated by multiple regression. Equation 3.1 defines the total effect model in figure 3.1, and Equations 3.2 and 3.3 define the mediation model in figure 3.2."

Berdasarkan uraian oleh Mackinnon, intersep-intersep tidak dilibatkan untuk mengestimasi efek mediasi (mediated effects). Namun, intersep-intersep tersebut berguna untuk aspek yang lain dari mediasi, yakni memplot (grafik) efek mediasi. Nilai-nilai parameter dari model tersebut $\left(b_{3}, c, b_{2}, c^{\prime}\right.$, dan seterusnya) dapat diestimasi dengan menggunakan regresi berganda (multiple regression).

Perhatikan bahwa pengaruh tak langsung atau pengaruh mediasi (indirect effect atau mediated effect) dari variabel $\mathrm{X}$ terhadap variabel $\mathrm{Y}$, melalui variabel $\mathrm{M}$, merupakan hasil perkalian $b_{3} \times b_{2}$. Pengaruh langsung variabel $\mathrm{X}$ terhadap variabel $\mathrm{Y}$, dengan mengontrol variabel $\mathrm{M}$ adalah $c^{\prime}$. Parameter-parameter seperti $b_{3}, b_{2}, c$, dan $c^{\prime}$ dapat diestimasi dengan menggunakan metode ordinary least squares regression (metode ordinary least squares regression tersedia dalam beberapa software, seperti SPSS, SAS, EViews, Minitab, dan sebagainya) (MacKinnon, 2008:50-51). 
Uji signifikansi pengaruh mediasi untuk model mediasi dengan satu variabel mediator (significance tests of indirect effect) dengan pendekatan Baron dan Kenny (1986) ialah dengan mengestimasi persamaan [25.1] hingga persamaan [25.3] terlebih dahulu. Variabel M merupakan variabel mediator jika memenuhi persyaratan berikut.

$\Rightarrow$ Pengaruh variabel $\mathrm{X}$ terhadap variabel $\mathrm{Y}$ signifikan $(c \neq 0)$. (i)

$\Rightarrow$ Pengaruh variabel $\mathrm{X}$ terhadap variabel $\mathrm{M}$ signifikan $\left(b_{3} \neq 0\right)$. (ii)

$\Rightarrow$ Pengaruh variabel $\mathrm{M}$ terhadap variabel $\mathrm{Y}$ signfikan, dengan mengontrol variabel $\mathrm{X}$ $\left(c^{\prime} \neq 0\right)$. (iii)

Jadi, ketika $c^{\prime}$ signifikan, dan $c^{\prime}<c$, maka variabel M memediasi parsial. Namun ketika $c^{\prime}$ tidak signifikan, dan $c^{\prime}<c$, maka variabel $\mathrm{M}$ memediasi sempurna (Preacher and Hayes, 2004; Hair dkk., 2014:219; Sholihin dan Ratmono, 2013:56-57).

\section{Uji Signifikansi Pengaruh Mediasi untuk Model Mediasi dengan Satu} Variabel Mediator (Significance Tests of Indirect Iffect) dengan Pendekatan Uji Sobel dan Bootstrapping

Selain pendekatan Baron dan Kenny dalam menguji signfikansi pengaruh mediasi, terdapat pendekatan lain, yakni pendekatan uji Sobel (versi Aroian). Pada pendekatan uji Sobel, terlebih dahulu dihitung nilai standard error $b_{3} * b_{2}\left(s_{b_{3} b_{2}}\right)$ dengan rumus sebagai berikut (Sholihin dan Ratmono, 2013:80; Preacher and Hayes, 2004; MacKinnon, 2008:73).

$$
s_{b_{3} b_{2}}=\sqrt{\left(b_{3}^{2}\right)\left(s_{b_{2}}^{2}\right)+\left(b_{2}^{2}\right)\left(s_{b_{3}}^{2}\right)+\left(s_{b_{2}}^{2}\right)\left(s_{b_{3}}^{2}\right)}
$$

Selanjutnya nilai statistik dari uji Sobel $\left(z_{\text {Sobel }}\right)$ (versi Aroian) dihitung dengan rumus sebagai berikut.

$$
z_{\text {Sobel }}=\frac{b_{3} \times b_{2}}{s_{b_{3} b_{2}}}
$$

Untuk menentukan signifikansi hubungan mediasi, dapat dibandingkan nilai $z_{\text {Sobel }}$ terhadap nilai kritis $z$ dengan tingkat signifikansi $5 \%$, yakni $z_{\text {kritis }}= \pm 1,96$. Jika $\left|z_{\text {sobel }}\right|>\left|z_{\text {kritis }}\right|$, maka pengaruh tak langsung atau mediasi signifikan secara statistika (statistically significant) pada tingkat signifikansi 5\% (Preacher and Hayes, 2004).

Pada uji Sobel menetapkan asumsi bahwa distribusi sampling dari $\boldsymbol{b}_{\mathbf{3}} \times \boldsymbol{b}_{\mathbf{2}}$ berdistribusi normal, di mana asumsi ini sering kali tidak terpenuhi. Lebih lanjut, pada uji Sobel memerlukan unstandardized path coefficient (koefisien-koefisien jalur yg tidak baku) sebagai input untuk menghitung nilai statistik dari uji Sobel $\left(z_{\text {Sobel }}\right)$ dan lacks statistical power, 556 
khususnya ketika jumlah elemen sampel kecil (Hair dkk., 2014:223; Preacher and Hayes, 2004). Hair dkk. (2014:223) menyatakan sebagai berikut.

"A commonly used approach for testing mediating effects is the Sobel (1982) test, which examines the relationship between the independent variable and the dependent variable compared with the relationship between the independent variable and dependent variable, including the mediation construct (Helm, Eggert, \& Garnefeld, 2010). However, this test relies on distributional assumptions, which usually do not hold for the indirect effect p12*p23 (specifically, the multiplication of two normally distributed coefficients results in a nonnormal distribution of their product). Furthermore, the Sobel test requires unstandardized path coefficients as input for the test statistic and lacks statistical power, especially when applied to small sample sizes."

Sejalan dengan Hair dkk., Preacher dan Hayes (2004) menyatakan sebagai berikut.

"In order to conduct the test (Sobel test), ab is divided by $s_{a b}$ to yield a critical ratio that is traditionally compared with the critical value from the standard normal distribution appropriate for a given alpha level. One of the assumptions necessary for the Sobel test is that the sample size is large, so the rough critical value for the two-tailed version of the test, assuming that the sampling distribution of $a b$ is normal and that $\alpha=0,05$, is \pm 1.96 . As sample size becomes smaller, the Sobel test becomes less conservative."

Oleh karena itu sebagai alternatif dapat digunakan pendekatan yang dikembangkan oleh Preacher dan Hayes $(2004,2008)$ dan bootstrap distribusi sampling dari koefisien pengaruh tak langsung. Pada pendekatan bootstrapping tidak memerlukan asumsi bentuk distribusi dari suatu variabel atau distribusi sampling dari suatu statistik, serta dapat diterapkan untuk ukuran sampel yang kecil (Hair dkk., 2014:223). Hair dkk (2014:223) menyatakan sebagai berikut.

"When testing mediating effects, researchers should rather follow Preacher and Hayes (2004, 2008) and bootstrap the sampling distribution of the indirect effect, which works for simple and multiple mediator models (please note that we do not cover the latter case in this book; see Preacher \& Hayes, 2008). Bootstrapping makes no assumptions about the shape of the variables' distribution or the sampling distribution of the statistics and can be applied to small sample sizes with more confidence. The approach is therefore perfectly suited for the PLS-SEM method. In addition, the approach exhibits higher levels of statistical power compared with the Sobel test."

\section{Analisis Jalur: Dalam Mengestimasi Koefisien Jalur (Path Coefficient), Dapat Menggunakan Software (AMMOS, LISREL) atau software (SPSS, SAS, EViews, Minitab). Di mana Letak Perbedaannya?}

Schumacker dan Lomax (2010:152-153) menyatakan sebagai berikut.

"In chapter 4, we presented the problem of estimation in general. Parameters can be estimated by different estimation procedures, such as maximum likelihood (ML), generalized least squares (GLS), and unweighted least squares (ULS), which are all unstandardized types of estimates, as well as standardized estimates (the path coefficients previously described in this chapter were standardized estimates). In addition to different methods of estimation of the parameter estimates, full versus limited information estimation 
functions are invoked based on the software chosen for the analysis. Full information estimation computes all of the parameters simultaneously, whereas limited information estimation computes parameters for each equation separately. The parameters estimated in structural equation modeling software (LISREL) use full information estimation and therefore differ from parameter estimates computed in SPSS or SAS, where each equation in the path model is estimated separately (limited information estimation). In limited information estimation, the parameter estimates are determined uniquely in each separate equation to meet the least squares criterion of minimized residuals."

Dari pernyataan tersebut, dapat ditarik informasi bahwa terkait estimasi parameter dari koefisien jalur, software seperti LISREL dan Amos termasuk ke dalam full information estimation, yakni menghitung seluruh koefisien jalur secara simultan (simultaneously), sementara untuk software seperti SPSS, Minitab, EViews, dan SAS, termasuk ke dalam limited information estimation, yakni menghitung koefisien-koefisien jalur untuk setiap persamaan secara terpisah (separately).

Lebih lanjut, Meyers dkk. (2005:594) menyatakan sebagai berikut.

"There are two ways to analyze path models: (a) multiple regression analysis or (b) estimation with a model-fitting program (Kline, 1998). The multiple regression option employs the ordinary least squares method, whereas model-fitting programs typically use maximum likelihood (discussed in Chapter 6A) to calculate the path coefficients. These two options generally produce similar but not necessarily identical results. Later, we will discuss some of the additional benefits of using model-fitting program."

Berdasarkan pernyataan tersebut, diketahui terdapat dua pendekatan dalam menganalisis model jalur (path models), yakni pendekatan analisis regresi berganda, yakni menggunakan metode estimasi parameter ordinary least square (OLS), atau pendekatan model-fitting programs yang secara default menggunakan metode estimasi parameter Maximum likelihood (ML). Kedua metode estimasi parameter tersebut, yakni OLS dan ML bertujuan untuk menghitung atau mengestimasi koefisien jalur. Secara umum, hasil estimasi parameter dari OLS dan ML cenderung mirip, namun tidak sama persis (Meyers dkk, 2005:594).

Meyers dkk. (2005:597) menyatakan mengenai keunggulan model-fitting program sebagai berikut.

"Kline (1998) encourages researchers to use a model-fitting program because these programs provide the following: (a) an overall fit of the model, (b) the indirect and total effects of the predictors' variables, and (c) estimates of the path coefficients for latent variables model (as opposed to measured or observed variables). The overall fit of the model is how well the model explains the data, an outcome not available in multiple regression. The best a researcher can do in regression analysis is to compare the observed correlation with the hypothesized correlations. The If the two correlation matrixes are within 0,05 of the observed correlation matrix, then the researcher has some evidence of a proper fit (Agresti \& Finlay, 1997). If multiple models are used, then the model that most closely resembles the observed model is consider "best".

Lebih lanjut Meyers dkk. (2005:604) menyatakan perbedaan antara regresi dan model-fitting analysis sebagai berikut.

"We have discussed the differences between regression and model-fitting analysis. Among the differences are the following: (1) multiple regression is solved by ordinary least squares, 
whereas model-fitting programs estimate the parameters through the maximum likelihood technique, (2) least squares achieves the solution in one shot, whereas maximum likelihood uses an iterative strategy, (3) multiple regression solves the regression equation for each endogenous variable independently, whereas model-fitting procedures simultaneously assess all the paths of the entire model."

Berdasarkan uraian pernyataan tersebut, diketahui beberapa perbedaan antara pendekatan model-fitting program (seperti LISREL, Amos) dan pendekatan regresi berganda (seperti pada SPSS, SAS, Minitab) adalah sebagai berikut.

$\Rightarrow$ Pada pendekatan model-fitting program menyajikan informasi mengenai overall fit of the model (kelayakan model secara keseluruhan), sementara pada regresi berganda (seperti pada SPSS, SAS, Minitab) tidak menyajikan informasi mengenai overall fit of the model.

$\Rightarrow$ Pada pendekatan model-fitting program, selain menyajikan informasi mengenai overall fit of the model, juga menyajikan informasi total effect, direct effect, dan indirect effect, sementara pada regresi berganda (seperti pada SPSS, SAS, Minitab), perlu dihitung secara manual terlebih dahulu.

$\Rightarrow$ Pada pendekatan regresi berganda menggunakan metode estimasi parameter ordinary least squares (OLS) (seperti pada SPSS, SAS, Minitab), sementara pada pendekatan model-fitting program menggunakan metode estimasi parameter maximum likelihood (ML).

$\Rightarrow$ Pada pendekatan metode estimasi parameter OLS menghasilkan estimasi parameter secara one shot (tanpa iterasi atau pengulangan), sementara pada pendekatan metode estimasi parameter ML menghasilkan estimasi parameter melalui proses iterasi (iterative strategy).

$\Rightarrow$ Pada pendekatan regresi berganda mengestimasi parameter (koefisien jalur) dengan menyelesaikan persamaan untuk setiap variabel tak bebas (endogen) secara independen (independently), sementara pada pendekatan model-fitting program mengestimasi parameter (koefisien jalur) secara simultan (simultaneously) (all the paths of the entire model).

Bagaimanapun, Meyers dkk. (2005:559) menegaskan bahwa hasil yang diperoleh berdasarkan dua pendekatan, yakni model-fitting program dan regresi berganda sering kali sangat mirip. Meyers dkk (2005:559) menyatakan sebagai berikut.

\section{"However, we should note that the path analysis results produced by the two approaches are very often similar."}

Dalam software LISREL atau Amos, secara default menggunakan metode estimasi parameter Maximum likelihood (ML) (lihat Gambar 25.5 dan Gambar 25.6). Selain metode estimasi parameter ML, terdapat metode estimasi parameter seperti Generalized least square (GLS), Unweighted least squares (ULS), dan sebagainya (Gambar 25.3 dan Gambar 25.4).

Mindrila dalam jurnalnya (2010) yang berjudul "Maximum Likelihood (ML) and Diagonally Weighted Least Squares (DWLS) Estimation Procedures: A Comparison of Estimation Bias with Ordinal and Multivariate Non-Normal Data" dalam International Journal of Digital 
Society mengemukakan metode-metode estimasi parameter tersebut digunakan dengan tujuan yang berbeda-beda, dan juga menetapkan asumsi-asumsi yang berbeda (Mindrila, 2010).

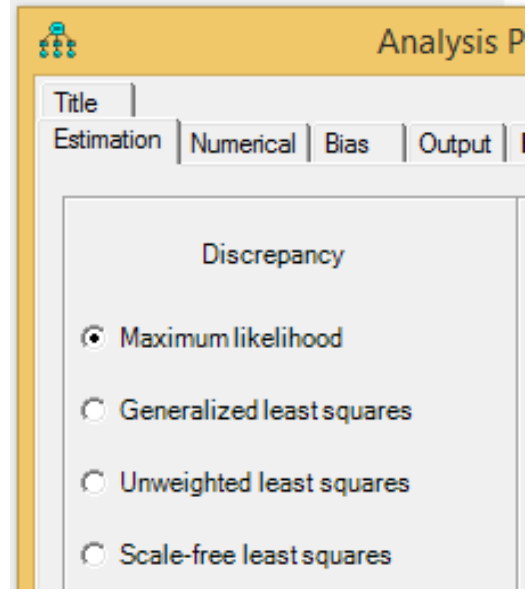

Gambar 25.5 Tampilan Amos

\begin{tabular}{|c|c|}
\hline & Estimations \\
\hline \multicolumn{2}{|l|}{ - Method of Estimation- } \\
\hline (- Maximum Likelihood & $C$ Generalized Least Squares \\
\hline$C$ Two-stage Least Squares & $C$ Unweighted Least Squares \\
\hline \multirow[t]{2}{*}{$C$ Instrument Variables } & $C$ Weighted Least Squares \\
\hline & $C$ Diagonally Weighted Least Squares \\
\hline \multicolumn{2}{|l|}{-Estimate options- } \\
\hline Г Ridge Option & Significance Level 1 \\
\hline
\end{tabular}

Gambar 25.6 Tampilan LISREL

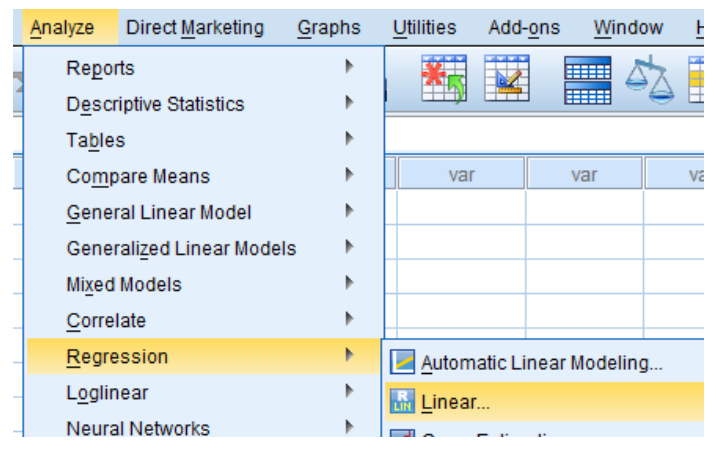

Gambar 25.7 Tampilan SPSS

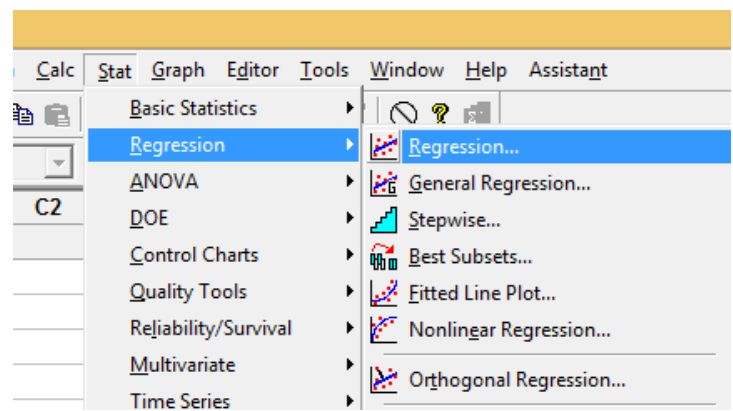

Gambar 25.8 Tampilan Minitab

Partial Least Squares Algorithm

The PLS path modeling method was developed by Wold (1982) and the PLS algorithm is essentially a sequence of regressions in terms of weight vectors. The weight vectors obtained at convergence satisfy fixed point equations (see Dijkstra, 2010, for a general analysis of such equations and

\begin{tabular}{|c|c|c|c|}
\hline 泫etup & & & \\
\hline — Basic Settings & 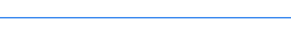 & \multirow{2}{*}{$\begin{array}{l}\text { Basic Settings } \\
\text { Weighting Scheme }\end{array}$} & ^ \\
\hline Weighting Scheme & $\bigcirc$ Centroid $\bigcirc$ Factor Path & & \\
\hline Maximum Iterations: & 300 & \multirow{2}{*}{$\begin{array}{l}\text { PLS-SEM allows the user to apply three structural model weighting } \\
\text { schemes: }\end{array}$} & \\
\hline Stop Criterion $\left(10^{\wedge}-X\right)$ : & $\div$ & & \\
\hline \multicolumn{2}{|c|}{ - Advanced Settings } & \multirow{2}{*}{$\begin{array}{l}\text { (1) centroid weighting scheme, } \\
\text { (2) factor weighting scheme, and } \\
\text { (3) path weighting scheme (default). }\end{array}$} & \\
\hline \multirow[t]{5}{*}{ Initial Weights } & $\begin{array}{l}\square \text { Use Lohmoeller Settings } \\
\text { or configure individual initial weights }\end{array}$ & & \\
\hline & & $\begin{array}{l}\text { While the results differ little for the alternative weighting schemes, path } \\
\text { weighting is the recommmended approach. This weighting scheme provides } \\
\text { the highest } \mathrm{R}^{2} \text { value for endegenous latent variables and is generally } \\
\text { applicable for all kinds of } \mathrm{PLS} \text { path model specifications and estimations. } \\
\text { Moreoover, when the path model includes higher-order constructs (offten } \\
\text { called second-order models), researchers should usually not use the } \\
\text { centroid weighting scheme. }\end{array}$ & \\
\hline & & Maximum Iterations & \\
\hline & & 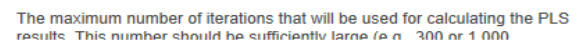 & $\checkmark$ \\
\hline & & fter Calculation: Open Full Report & \\
\hline
\end{tabular}

Gambar 25.9 Tampilan SmartPLS 


\section{PENYELESAIAN DALAM SPSS, Minitab, R, LISREL, Amos, dan SmartPLS}

Misalkan diberikan data sebagai berikut (Gambar 25.1). Kemudian diberikan diagram jalur seperti pada Gambar 52.2. Pada Gambar 25.2 menyajikan diagram jalur untuk model mediasi dengan satu variabel mediator, yakni variabel $\mathrm{M}$. Berikut akan diuji apakah variabel $\mathrm{M}$ signifikan dalam memediasi hubungan antara variabel $\mathrm{X}$ terhadap variabel $\mathrm{Y}$.

\begin{tabular}{|c|c|c|c|c|c|}
\hline \multicolumn{6}{|l|}{$\uplus$} \\
\hline File Edit & View & Data & Iransform & Analyze & Dire \\
\hline \multicolumn{6}{|c|}{$\rightleftarrows$ 比 } \\
\hline \multicolumn{6}{|l|}{ 6: } \\
\hline & & K & M & $Y$ & \\
\hline 1 & & 1 & & 1 & 1 \\
\hline 2 & & 2 & & 2 & 2 \\
\hline 3 & & 3 & & 3 & 3 \\
\hline 4 & & 4 & & + & 4 \\
\hline 5 & & 5 & & 5 & 5 \\
\hline 6 & & 1 & & & 1 \\
\hline 7 & & 2 & & ? & 2 \\
\hline 8 & & 3 & & + & 4 \\
\hline 9 & & 4 & & + & 5 \\
\hline 10 & & 5 & & 2 & 3 \\
\hline 11 & & 1 & & & 1 \\
\hline 12 & & 2 & & & 2 \\
\hline 13 & & 3 & & + & 4 \\
\hline 14 & & 4 & & & 4 \\
\hline 15 & & 5 & & 1 & 4 \\
\hline 16 & & 1 & & & 2 \\
\hline 17 & & 2 & & & 4 \\
\hline 18 & & 3 & & & 4 \\
\hline 19 & & 4 & & & 6 \\
\hline 20 & & 5 & & & 7 \\
\hline
\end{tabular}

Gambar 25.1

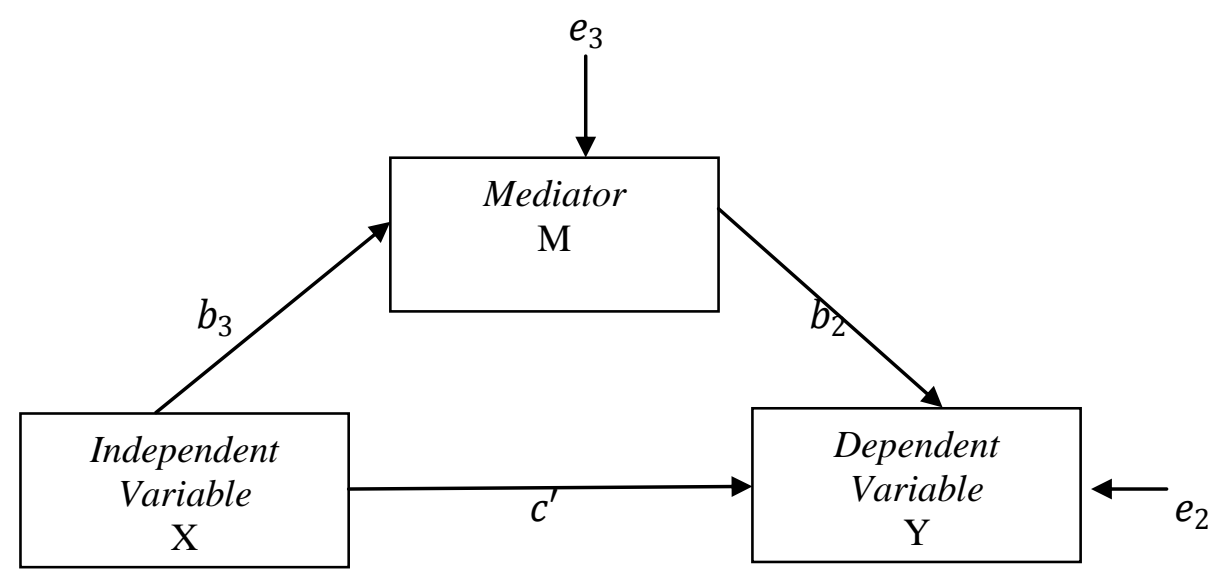

Gambar 25.2 Diagram Jalur untuk Model Mediasi dengan Satu Variabel Mediator 
Uji Signifikansi Pengaruh Mediasi untuk Model Mediasi dengan Satu Variabel Mediator (Significance Tests of Indirect Iffect) dengan Pendekatan Baron dan Kenny (Output: SPSS, Minitab, $R$, LISREL, Amos, dan SmartPLS)

\section{Dengan SPSS}

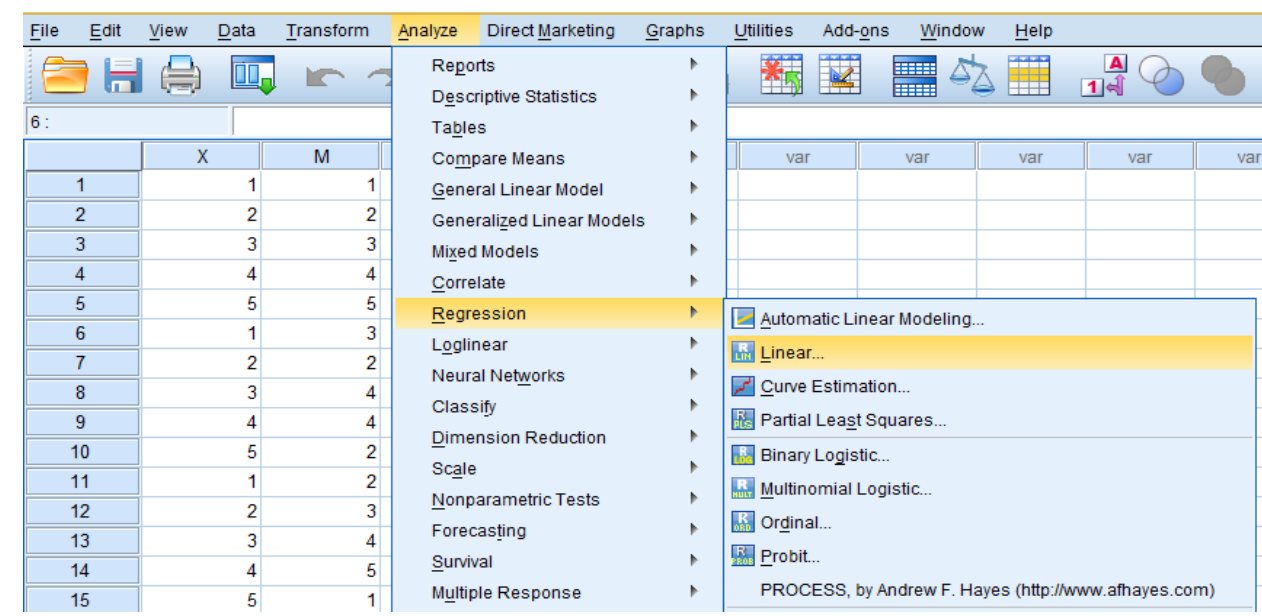

Melakukan regresi dengan $\mathrm{X}$ sebagai variabel bebas, sementara $\mathrm{Y}$ sebagai variabel tak bebas.

Coefficients $^{\mathrm{a}}$

\begin{tabular}{|c|c|c|c|c|c|c|}
\hline \multirow{2}{*}{\multicolumn{2}{|c|}{ Model }} & \multicolumn{2}{|c|}{ Unstandardized Coefficients } & \multirow{2}{*}{$\begin{array}{c}\text { Standardized } \\
\text { Coefficients }\end{array}$} & \multirow[b]{2}{*}{$\mathrm{t}$} & \multirow[b]{2}{*}{ Sig. } \\
\hline & & B & Std. Error & & & \\
\hline 1 & (Constant) & .625 & .533 & & 1.173 & .256 \\
\hline & $\mathrm{X}$ & .925 & .161 & .805 & 5.759 & .000 \\
\hline
\end{tabular}

a. Dependent Variable: Y

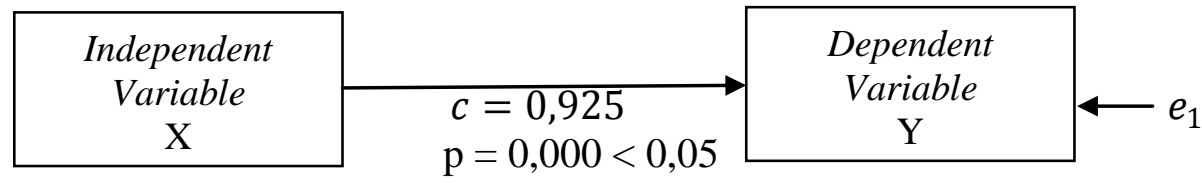

(signifikan)

Melakukan regresi dengan $\mathrm{X}$ sebagai variabel bebas, sementara $\mathrm{M}$ sebagai variabel tak bebas.

\begin{tabular}{|c|c|c|c|c|c|c|}
\hline \multicolumn{7}{|c|}{ Coefficients $^{\mathrm{a}}$} \\
\hline \multirow{2}{*}{\multicolumn{2}{|c|}{ Model }} & \multicolumn{2}{|c|}{ Unstandardized Coefficients } & $\begin{array}{c}\text { Standardized } \\
\text { Coefficients }\end{array}$ & \multirow[b]{2}{*}{$\mathrm{t}$} & \multirow[b]{2}{*}{ Sig. } \\
\hline & & B & Std. Error & Beta & & \\
\hline 1 & (Constant) & 1.650 & .700 & & 2.356 & .030 \\
\hline & $\mathrm{X}$ & .550 & .211 & .523 & 2.605 & .018 \\
\hline
\end{tabular}

a. Dependent Variable: $\mathrm{M}$ 


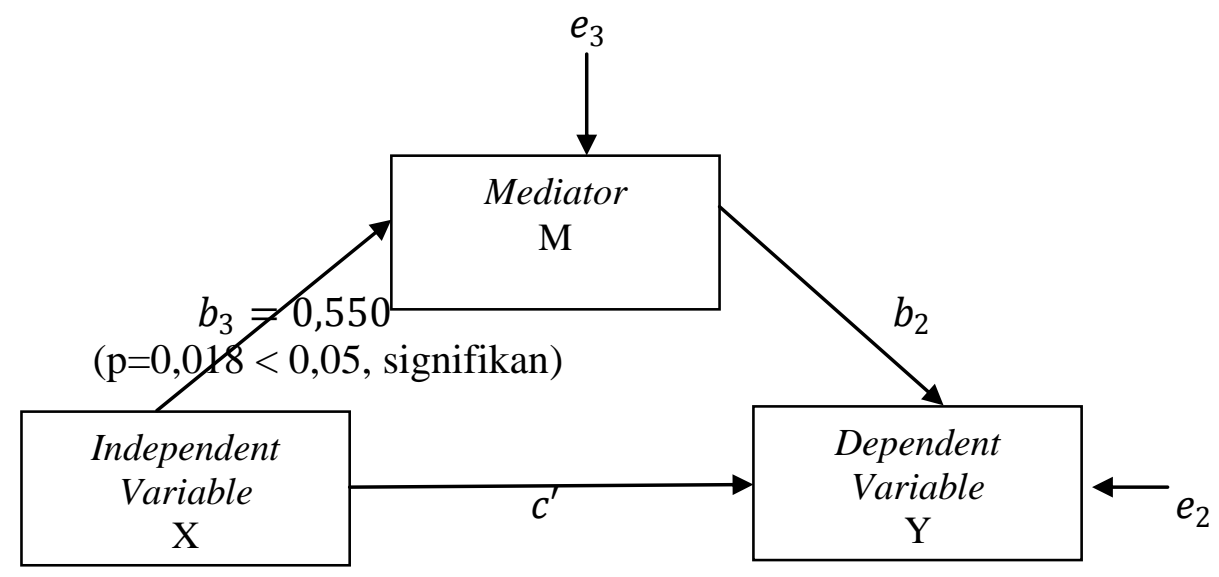

Melakukan regresi dengan X dan M sebagai variabel bebas, sementara Y sebagai variabel tak bebas.

\begin{tabular}{|c|c|c|c|c|c|c|}
\hline \multicolumn{7}{|c|}{ Coefficients $^{\mathbf{a}}$} \\
\hline \multirow{2}{*}{\multicolumn{2}{|c|}{ Model }} & \multicolumn{2}{|c|}{ Unstandardized Coefficients } & \multirow{2}{*}{$\begin{array}{c}\text { Standardized } \\
\text { Coefficients }\end{array}$} & \multirow[b]{2}{*}{$\mathrm{t}$} & \multirow[b]{2}{*}{ Sig. } \\
\hline & & B & Std. Error & & & \\
\hline 1 & (Constant) & -.313 & .417 & & -.752 & .463 \\
\hline & $\mathrm{X}$ & .612 & .129 & .533 & 4.752 & .000 \\
\hline & M & .569 & .123 & .520 & 4.638 & .000 \\
\hline
\end{tabular}

a. Dependent Variable: Y

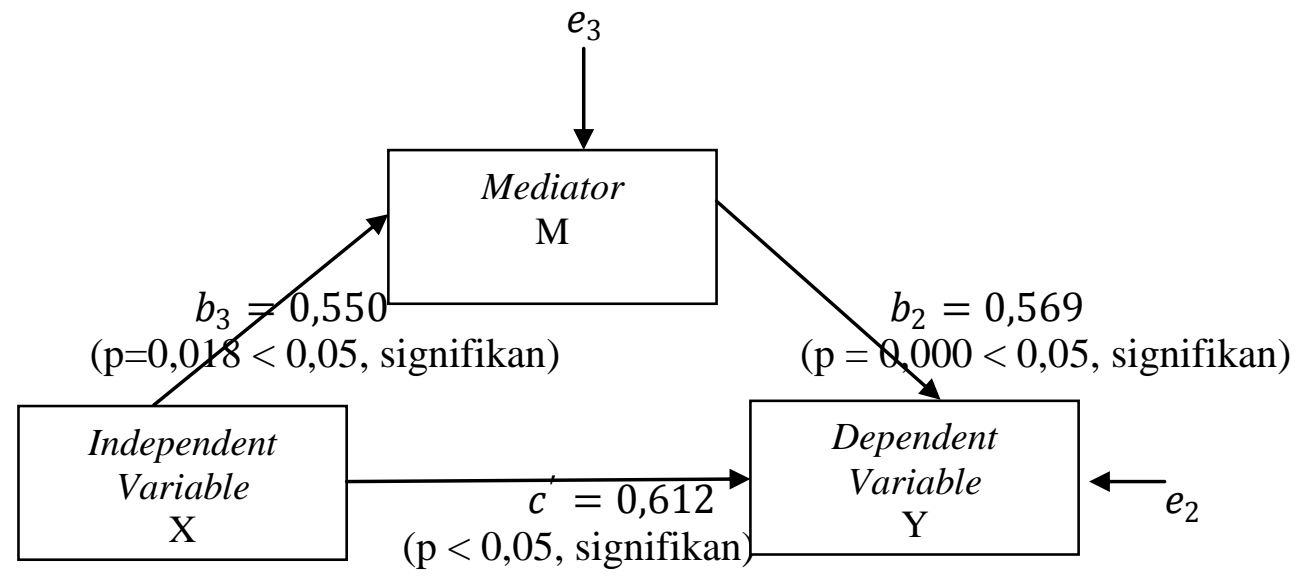

Perhatikan bahwa:

$\Rightarrow$ Pengaruh variabel $X$ terhadap variabel Y signifikan $(p=0,000<0,05)$.

$\Rightarrow$ Pengaruh variabel $X$ terhadap variabel M signifikan $(\mathrm{p}=0,018<0,05)$.

$\Rightarrow$ Pengaruh variabel $\mathrm{M}$ terhadap variabel $\mathrm{Y}$ signfikan, dengan mengontrol variabel $\mathrm{X}(\mathrm{p}$ $=0,000<0,05)$

Diketahui $c^{\prime}$ signifikan $(\mathrm{p}=0,000<0,05)$, dan $c^{\prime}=0,612<c=0,925$, maka variabel $\mathrm{M}$ signifikan dalam memediasi parsial hubungan variabel $\mathrm{X}$ terhadap variabel $\mathrm{Y}$. 


\section{Dengan Minitab}

\begin{tabular}{|c|c|c|c|c|c|c|c|}
\hline \multicolumn{8}{|l|}{1} \\
\hline 囯国 & $\underline{\underline{E} \text { dit }}$ & Dạt & ta Calc & Stat & t $\underline{G}$ & aph & $\mathrm{E}$ \\
\hline \multirow[t]{2}{*}{ है। } & 昌 & \multicolumn{2}{|c|}{ 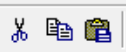 } & \multicolumn{2}{|c|}{$n c$} & \multicolumn{2}{|c|}{ 回 } \\
\hline & & & & 7 橉 & \multicolumn{3}{|c|}{$x<+$} \\
\hline \multirow[t]{2}{*}{+} & $\mathrm{C} 1$ & & $\mathrm{C} 2$ & & $\mathrm{C} 3$ & & \\
\hline & $\bar{X}$ & & M & & $Y$ & & \\
\hline 1 & & $\overline{11}$ & & 1 & & 1 & \\
\hline 2 & & 2 & 2 & 2 & & 2 & \\
\hline 3 & & 3 & 3 & 3 & & 3 & \\
\hline 4 & & 4 & 4 & 4 & & 4 & \\
\hline 5 & & 5 & 5 & 5 & & 5 & \\
\hline 6 & & 1 & 3 & 3 & & 1 & \\
\hline 7 & & 2 & 2 & 2 & & 2 & \\
\hline 8 & & 3 & 4 & 4 & & 4 & \\
\hline 9 & & 4 & 4 & 4 & & 5 & \\
\hline 10 & & 5 & 2 & 2 & & 3 & \\
\hline 11 & & 1 & 2 & 2 & & 1 & \\
\hline 12 & & 2 & 3 & 3 & & 2 & \\
\hline 13 & & 3 & 4 & 4 & & 4 & \\
\hline 14 & & 4 & 5 & 5 & & 4 & \\
\hline 15 & & 5 & 1 & 1 & & 4 & \\
\hline 16 & & 1 & 2 & 2 & & 2 & \\
\hline 17 & & 2 & 3 & 3 & & 4 & \\
\hline 18 & & 3 & 4 & 4 & & 4 & \\
\hline 19 & & 4 & 5 & 5 & & 6 & \\
\hline 20 & & 5 & 7 & 7 & & 7 & \\
\hline
\end{tabular}

\begin{tabular}{|c|c|c|c|c|c|}
\hline 䀯 Eile & Edit & Dạt & Calc & Stat Graph Editor Ioo & ols Window Help Assistant \\
\hline 急回 & 昌 & & 䠝 目 & Basic Statistics & - $\mid$ Q \\
\hline & & & & Regression & . Regression... \\
\hline & & & 1 & ANOVA & - General Regression... \\
\hline$\downarrow$ & C1 & & C2 & DOE & - Stepwise... \\
\hline & $\mathrm{X}$ & & M & Control Charts & 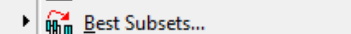 \\
\hline 1 & & 1 & & Quality Tools & - Fitted Line Plot... \\
\hline 2 & & 2 & : & Reliability/Survival & - Nonlinear Regression... \\
\hline 3 & & 3 & & Multivariate & E Toninear negression... \\
\hline 4 & & 4 & c & Multivariate & Orthogonal Regression... \\
\hline 5 & & 5 & ! & lime sei & F Partial Least Squares... \\
\hline 6 & & 1 & : & $\underline{I} \mathrm{ab}$ & \\
\hline 7 & & 2 & : & Nonparametrics & - $L_{B}$ Binary Logistic Regression... \\
\hline 8 & & 3 & 4 & $\underline{E} \mathrm{DA}$ & 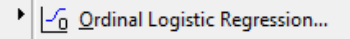 \\
\hline 9 & & 4 & & Power and Sample Size & $=-L_{N}$ Nominal Logistic Regression... \\
\hline
\end{tabular}

$\rightarrow$ Melakukan regresi dengan $\mathrm{X}$ sebagai variabel bebas, sementara $\mathrm{Y}$ sebagai variabel tak bebas.
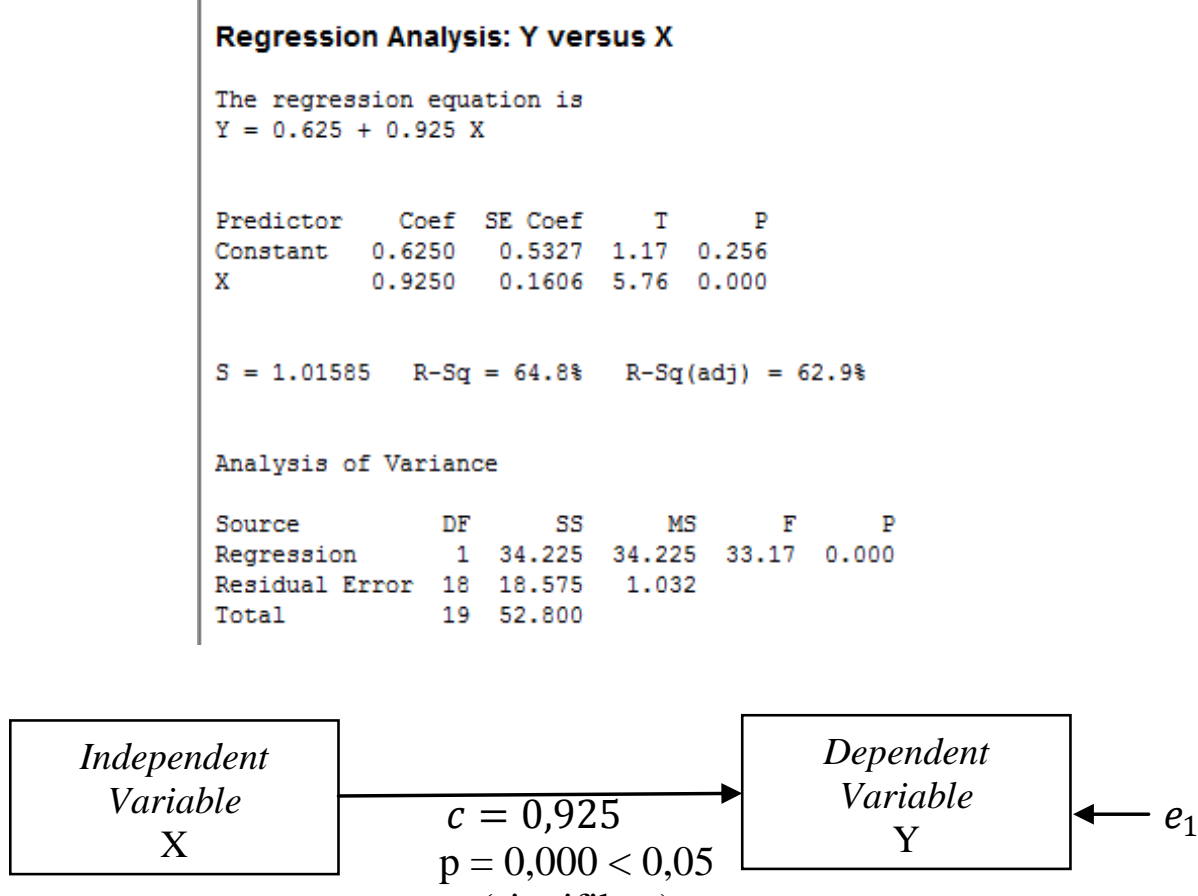

(signifikan) 
Melakukan regresi dengan $\mathrm{X}$ sebagai variabel bebas, sementara $\mathrm{M}$ sebagai variabel tak bebas.
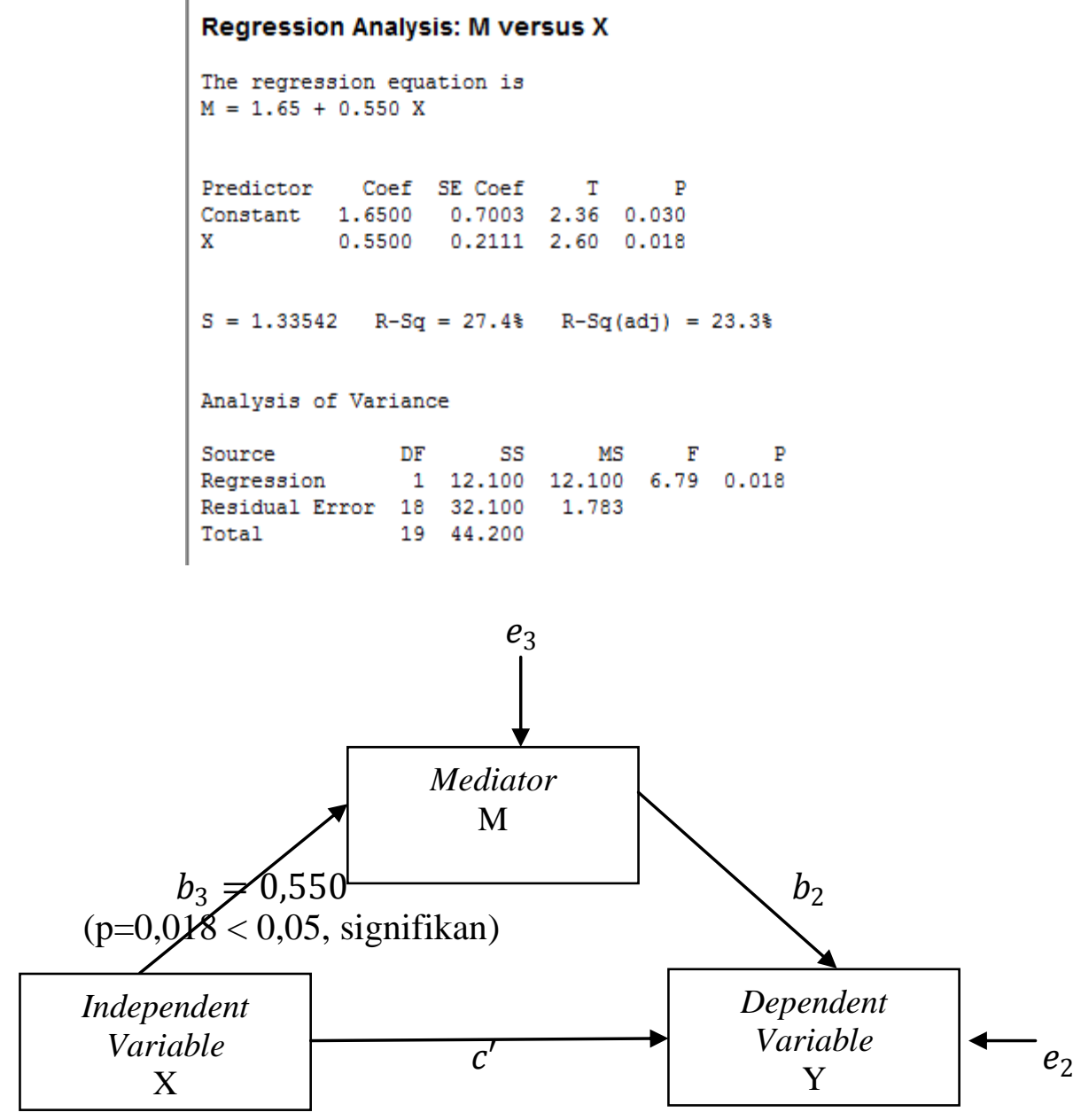

$\rightarrow$ Melakukan regresi dengan X dan M sebagai variabel bebas, sementara Y sebagai variabel tak bebas.

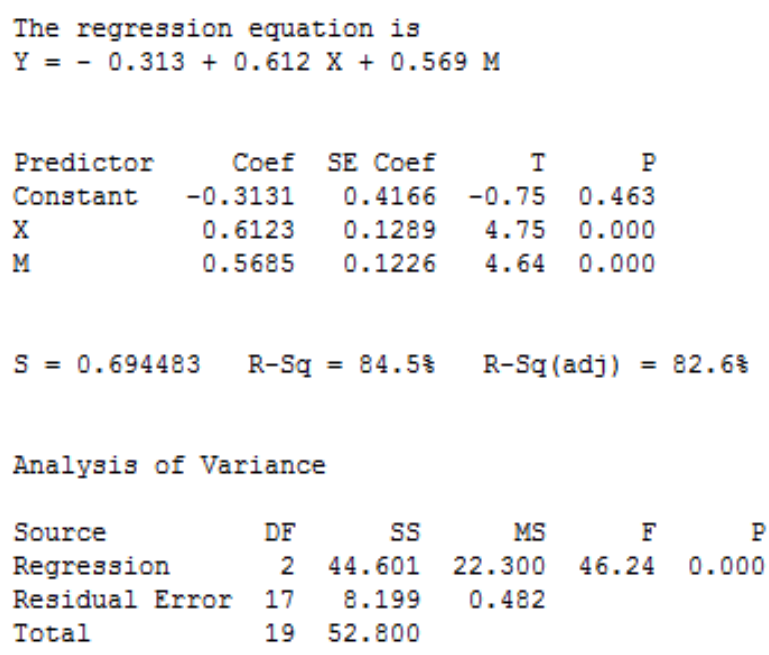




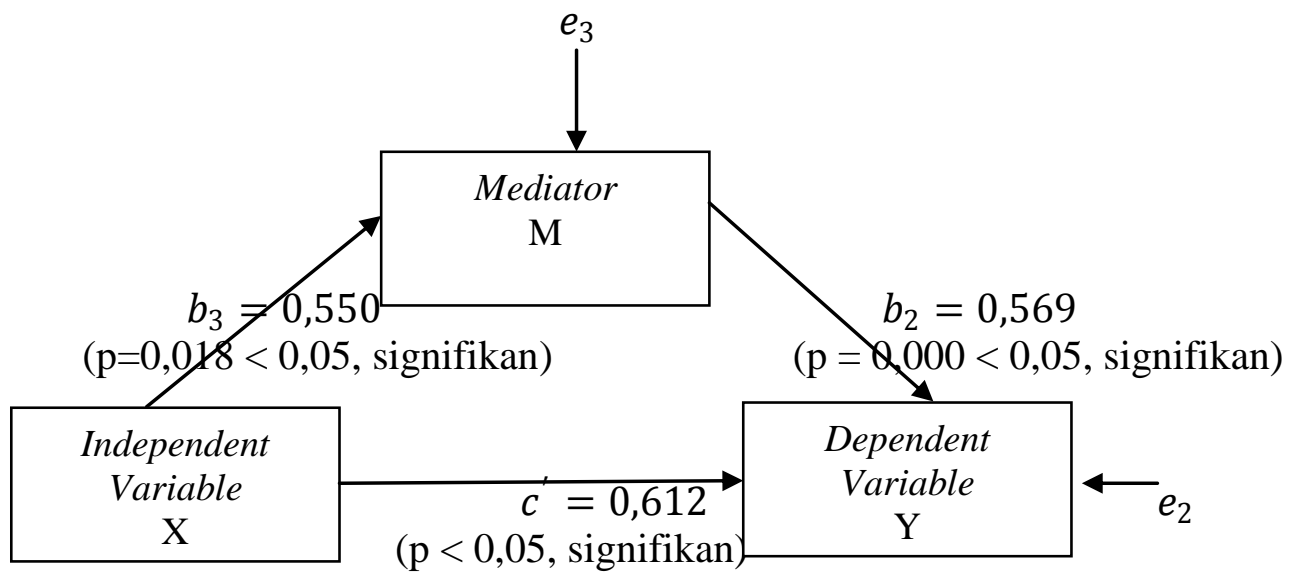

Perhatikan bahwa:

$\Rightarrow$ Pengaruh variabel X terhadap variabel Y signifikan $(\mathrm{p}=0,000<0,05)$.

$\Rightarrow$ Pengaruh variabel $X$ terhadap variabel $M$ signifikan $(\mathrm{p}=0,018<0,05)$.

$\Rightarrow$ Pengaruh variabel $M$ terhadap variabel $Y$ signfikan, dengan mengontrol variabel $X(p$ $=0,000<0,05)$

Diketahui $c^{\prime}$ signifikan $(\mathrm{p}=0,000<0,05)$, dan $c^{\prime}=0,612<c=0,925$, maka variabel $\mathrm{M}$ signifikan dalam memediasi parsial hubungan variabel $\mathrm{X}$ terhadap variabel $\mathrm{Y}$.

\section{Dengan $\mathcal{R}$}
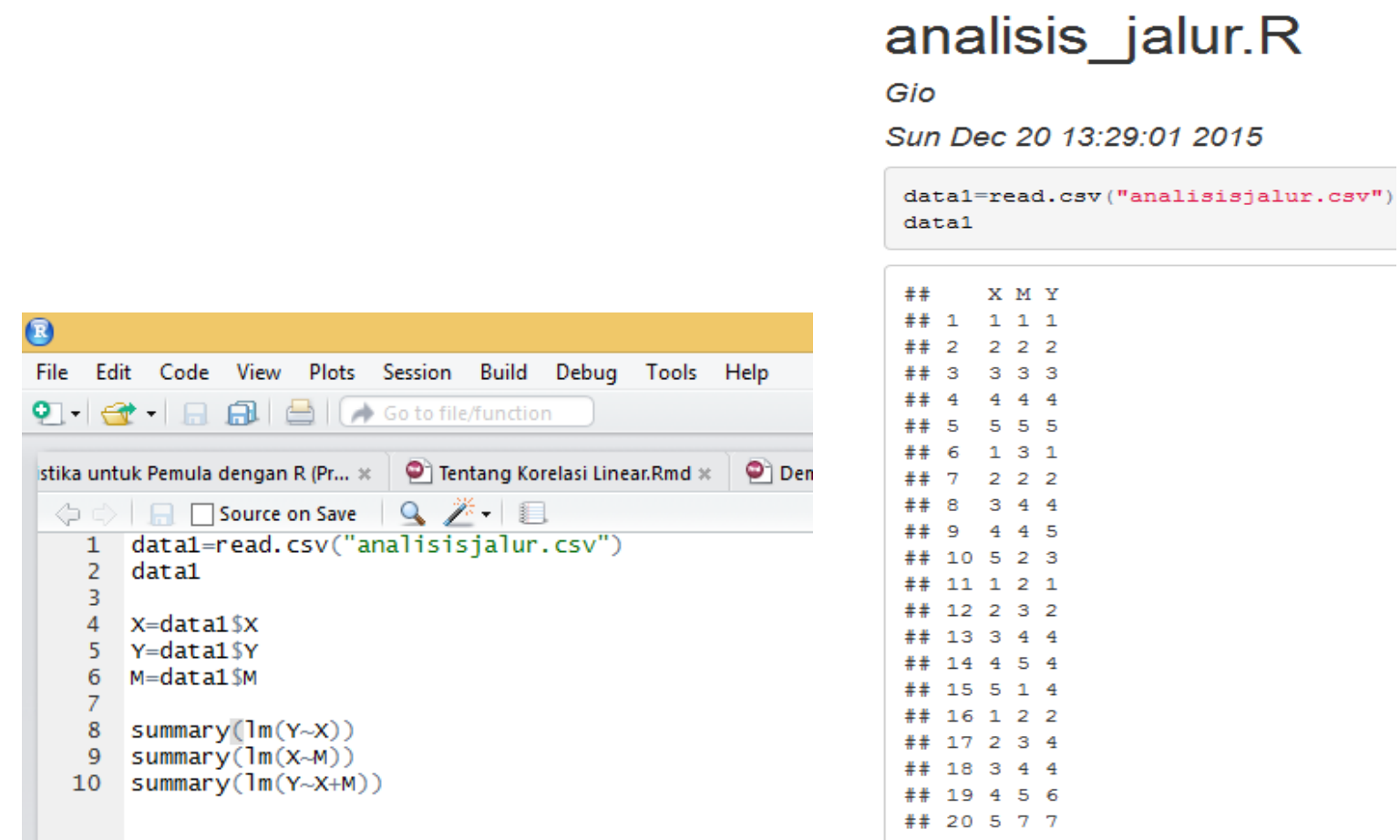

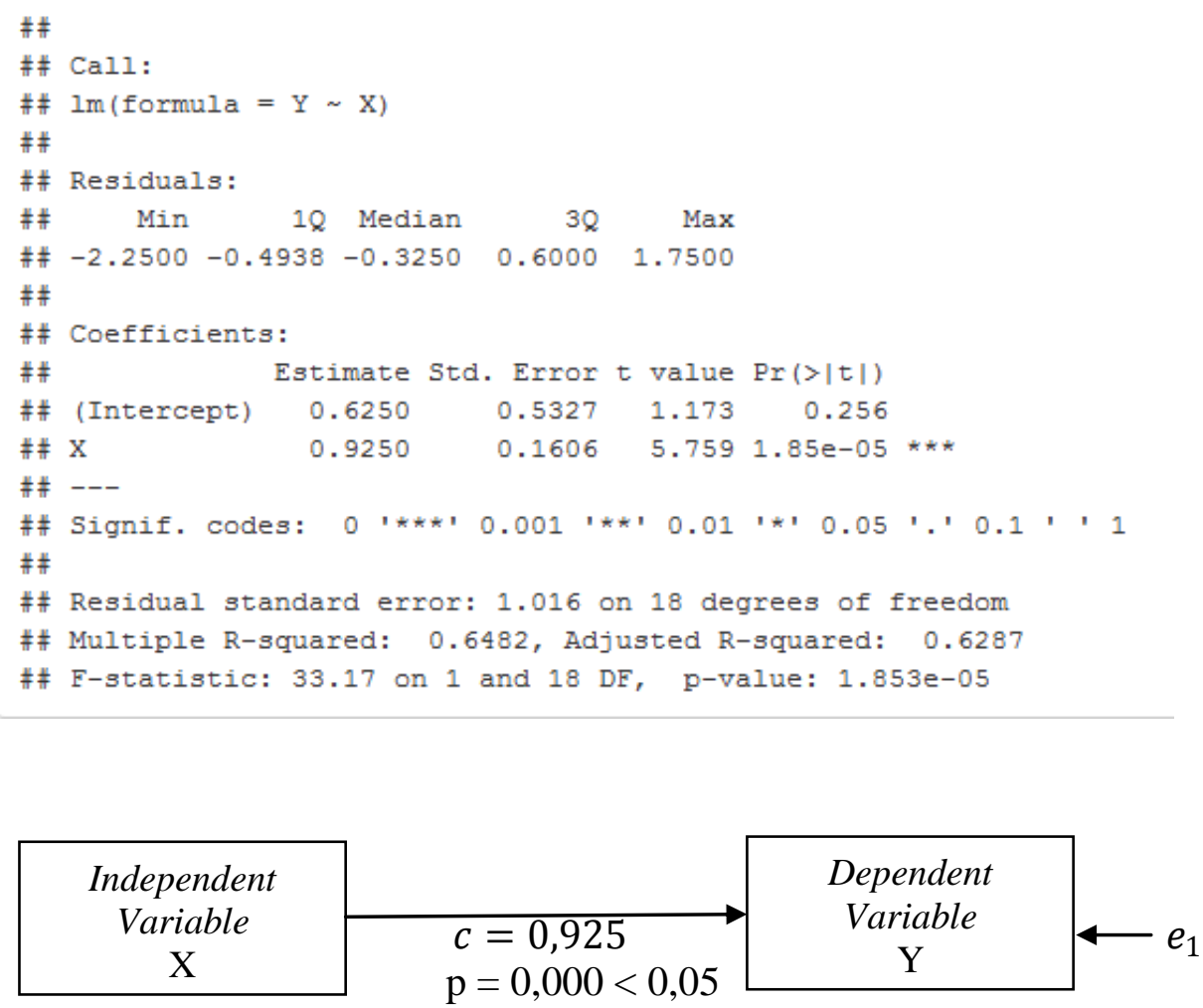

(signifikan)
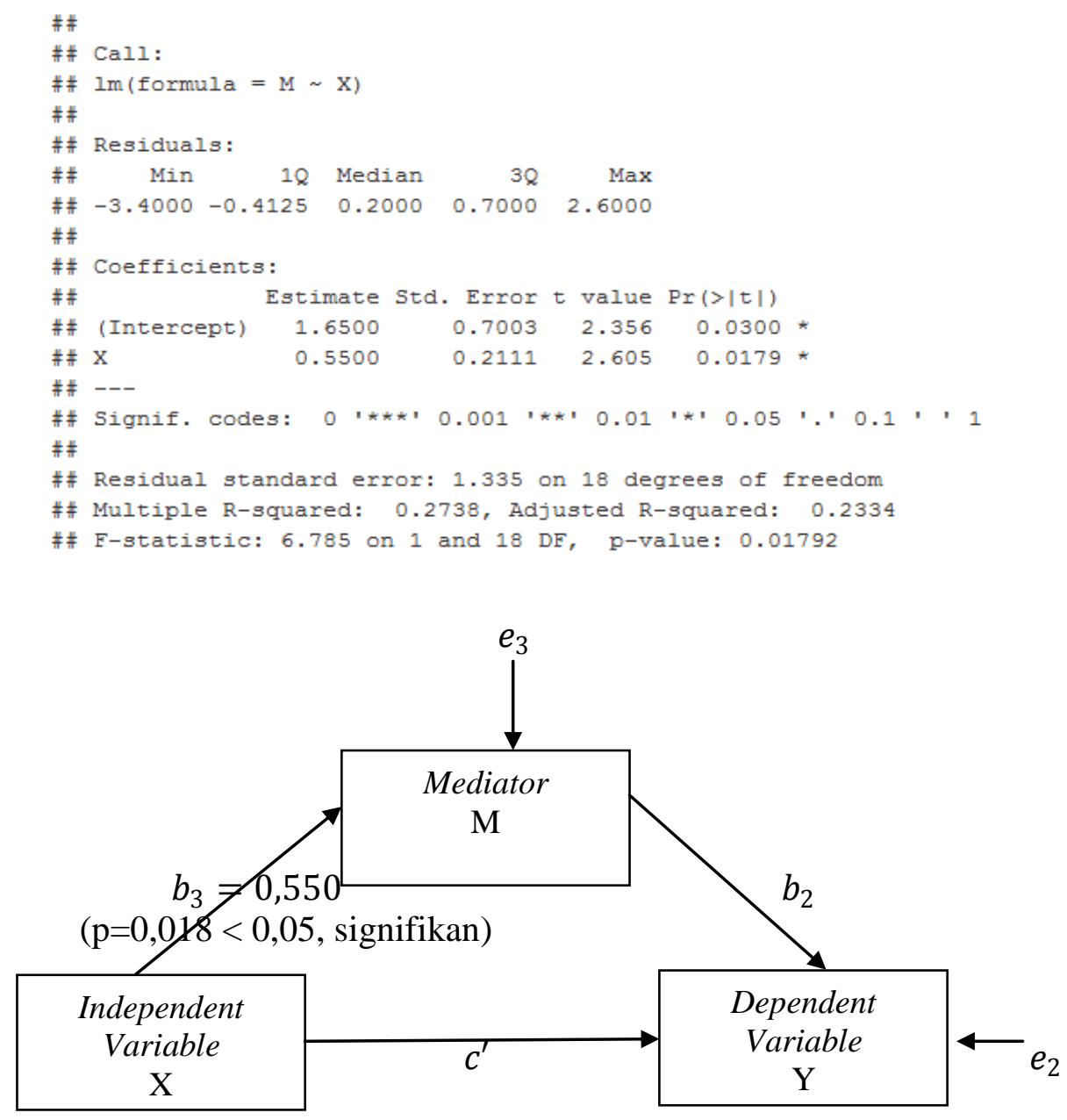

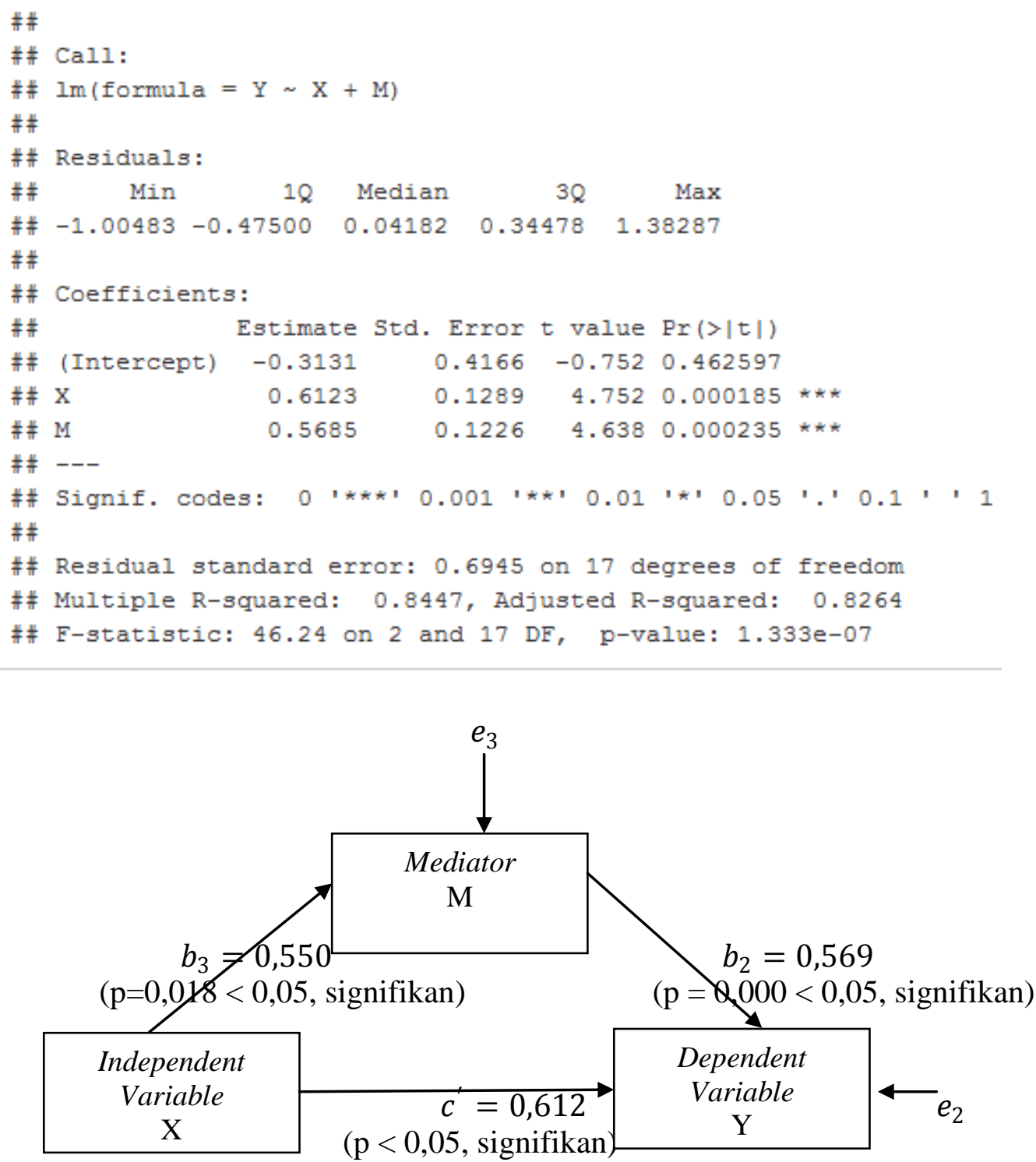

Perhatikan bahwa:

$\Rightarrow$ Pengaruh variabel $X$ terhadap variabel $Y$ signifikan $(\mathrm{p}=0,000<0,05)$.

$\Rightarrow$ Pengaruh variabel X terhadap variabel M signifikan $(\mathrm{p}=0,018<0,05)$.

$\Rightarrow$ Pengaruh variabel M terhadap variabel Y signfikan, dengan mengontrol variabel X (p $=0,000<0,05)$

Diketahui $c^{\prime}$ signifikan ( $\mathrm{p}=0,000<0,05$ ), dan $c^{\prime}=0,612<c=0,925$, maka variabel M signifikan dalam memediasi parsial hubungan variabel $\mathrm{X}$ terhadap variabel $\mathrm{Y}$. 


\section{Dengan $\mathcal{L}$ ISRE $\mathcal{L}$}

\begin{tabular}{|c|c|c|c|c|}
\hline \multicolumn{5}{|c|}{ 間 } \\
\hline \multicolumn{5}{|c|}{ 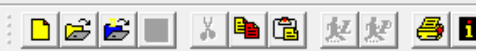 } \\
\hline & & $x$ & $M$ & $Y$ \\
\hline 1 & & 1.00 & 1.00 & 1.00 \\
\hline 2 & & 2.00 & 2.00 & 2.00 \\
\hline 3 & & 3.00 & 3.00 & 3.00 \\
\hline 4 & & 4.00 & 4.00 & 4.00 \\
\hline 5 & & 5.00 & 5.00 & 5.00 \\
\hline 6 & & 1.00 & 3.00 & 1.00 \\
\hline 7 & & 2.00 & 2.00 & 2.00 \\
\hline 8 & & 3.00 & 4.00 & 4.00 \\
\hline 9 & & 4.00 & 4.00 & 5.00 \\
\hline 10 & & 5.00 & 2.00 & 3.00 \\
\hline 11 & & 1.00 & 2.00 & 1.00 \\
\hline 12 & & 2.00 & 3.00 & 2.00 \\
\hline 13 & & 3.00 & 4.00 & 4.00 \\
\hline 14 & & 4.00 & 5.00 & 4.00 \\
\hline 15 & & 5.00 & 1.00 & 4.00 \\
\hline 16 & & 1.00 & 2.00 & 2.00 \\
\hline 17 & & 2.00 & 3.00 & 4.00 \\
\hline 18 & & 3.00 & 4.00 & 4.00 \\
\hline 19 & & 4.00 & 5.00 & 6.00 \\
\hline 20 & & 5.00 & 7.00 & 7.00 \\
\hline
\end{tabular}

国

File Edit Options Window Help

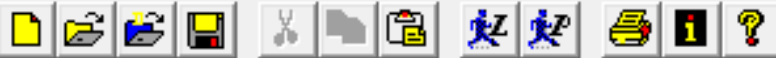

OBSERVED VARIABLE

$\mathrm{X} M \mathrm{Y}$

COVARIANCE MaTRIX FROM FILE D:\latihanlisrel\data.COV

SAMPLE SIZE 20

RELATIONSHIP

$\mathrm{Y}=\mathrm{X}$

OPTIONS: $\mathrm{SC} \mathrm{ND}=4$

PATH DIAGRAM

END OE PROGRAM

$\exists$ Models: 5 Structural Model $\quad \square$ Estimates: Estimates

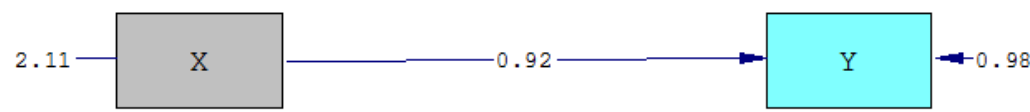

Chi-Square $=0.00, d f=0, P-$ value $=1.00000$, RMSEA $=0.000$

Number of Iterations $=0$

LISREL Estimates (Maximum Likelihood)

Structural Equations

$\mathrm{Y}=0.9250^{4} \mathrm{X}$, Errorvar $=0.9776, \mathrm{R}^{2}=0.6482$

Standerr (0.1563) (0.3172)

z-values $5.9170 \quad 3.0822$

$\begin{array}{lll}\text { P-values } 0.000 & 0.002\end{array}$

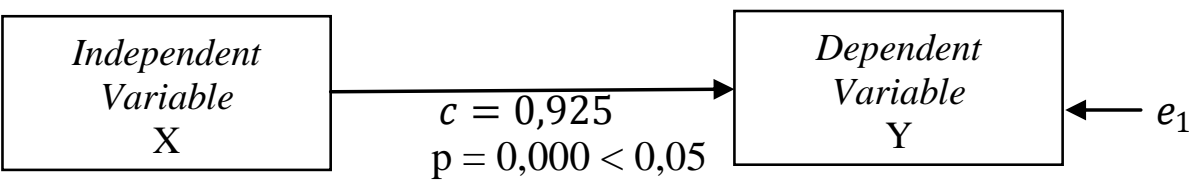

(signifikan) 


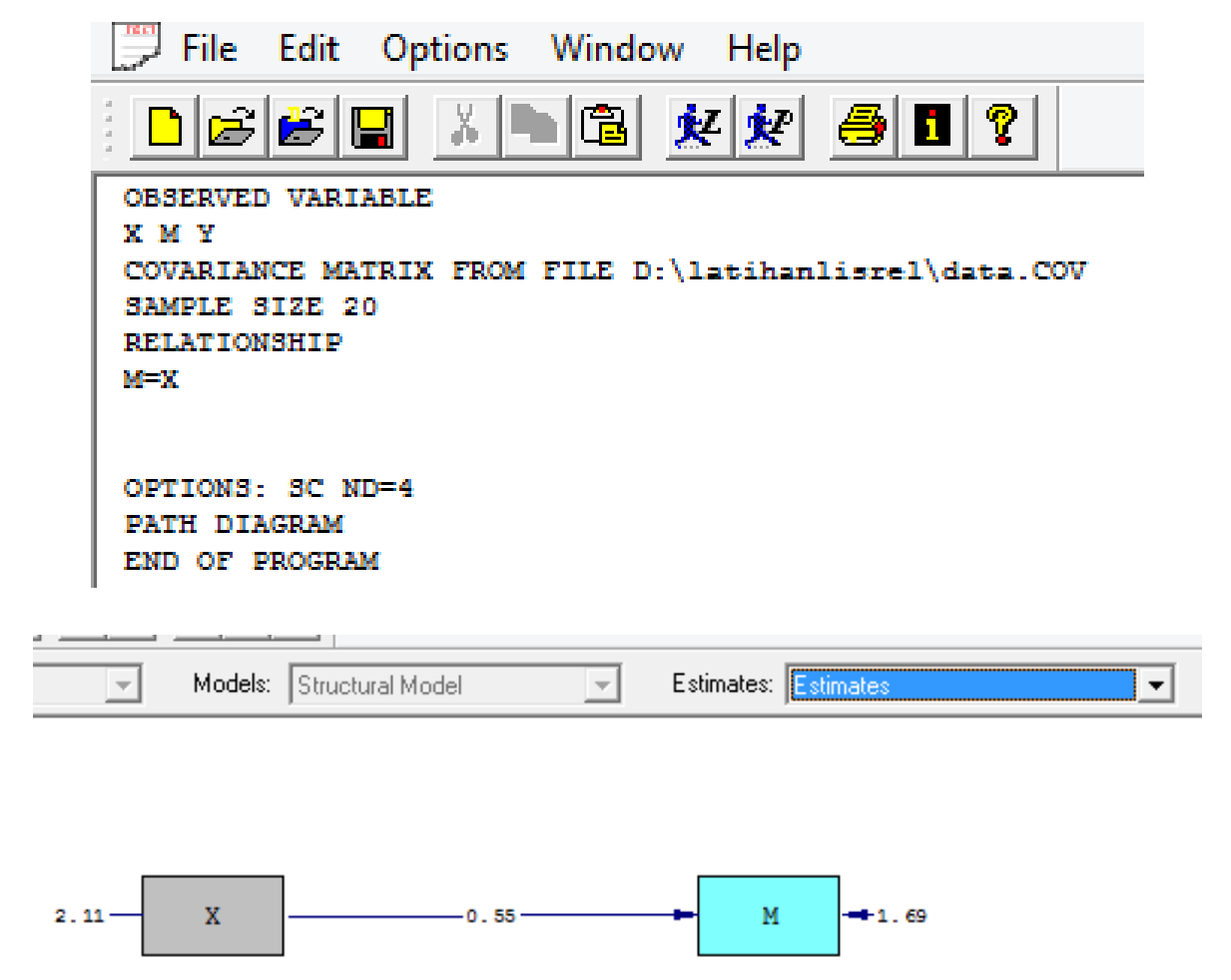

Chi-Square=0.00, df =0, P-value=1.00000, RMSEA $=0.000$
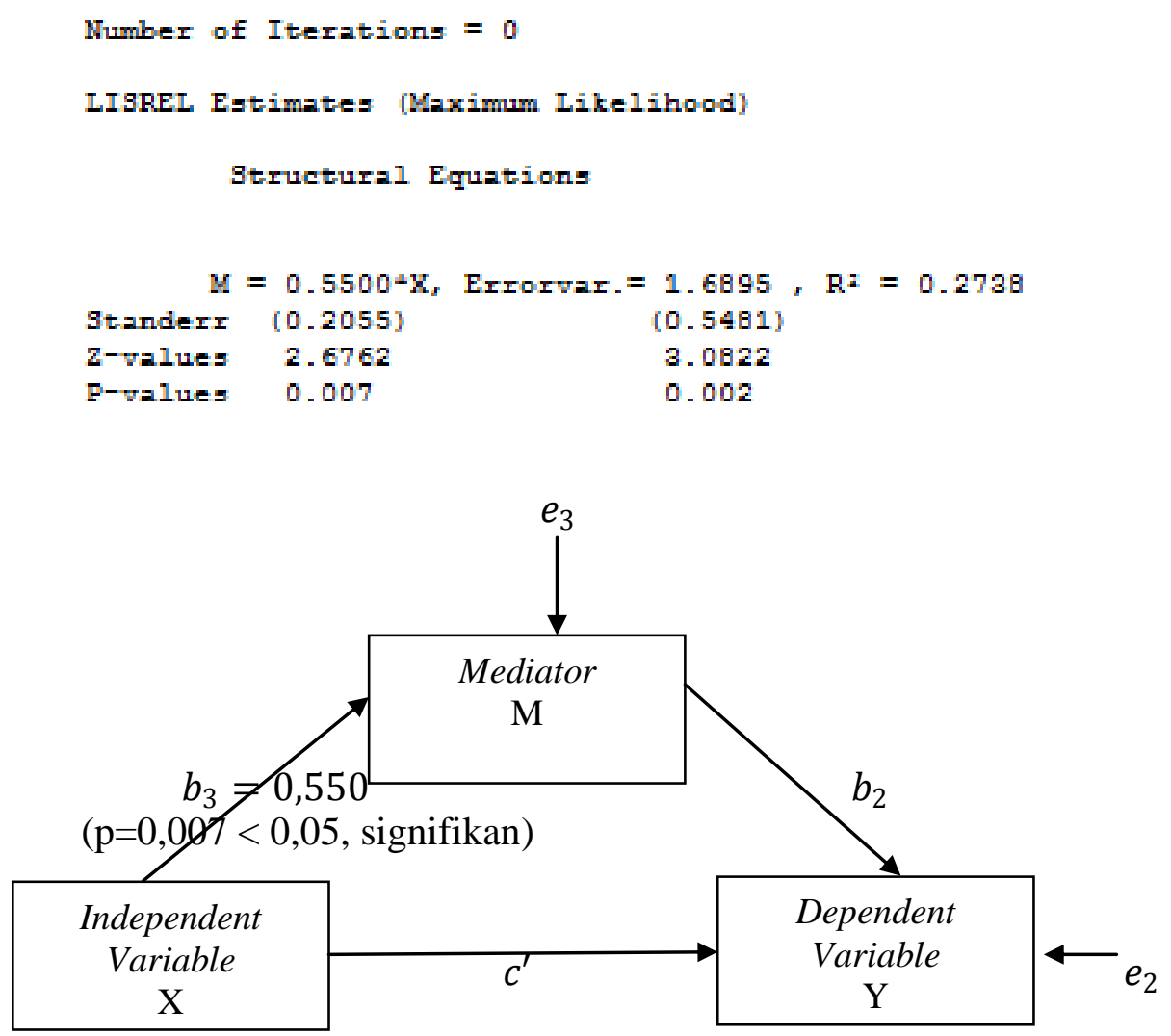

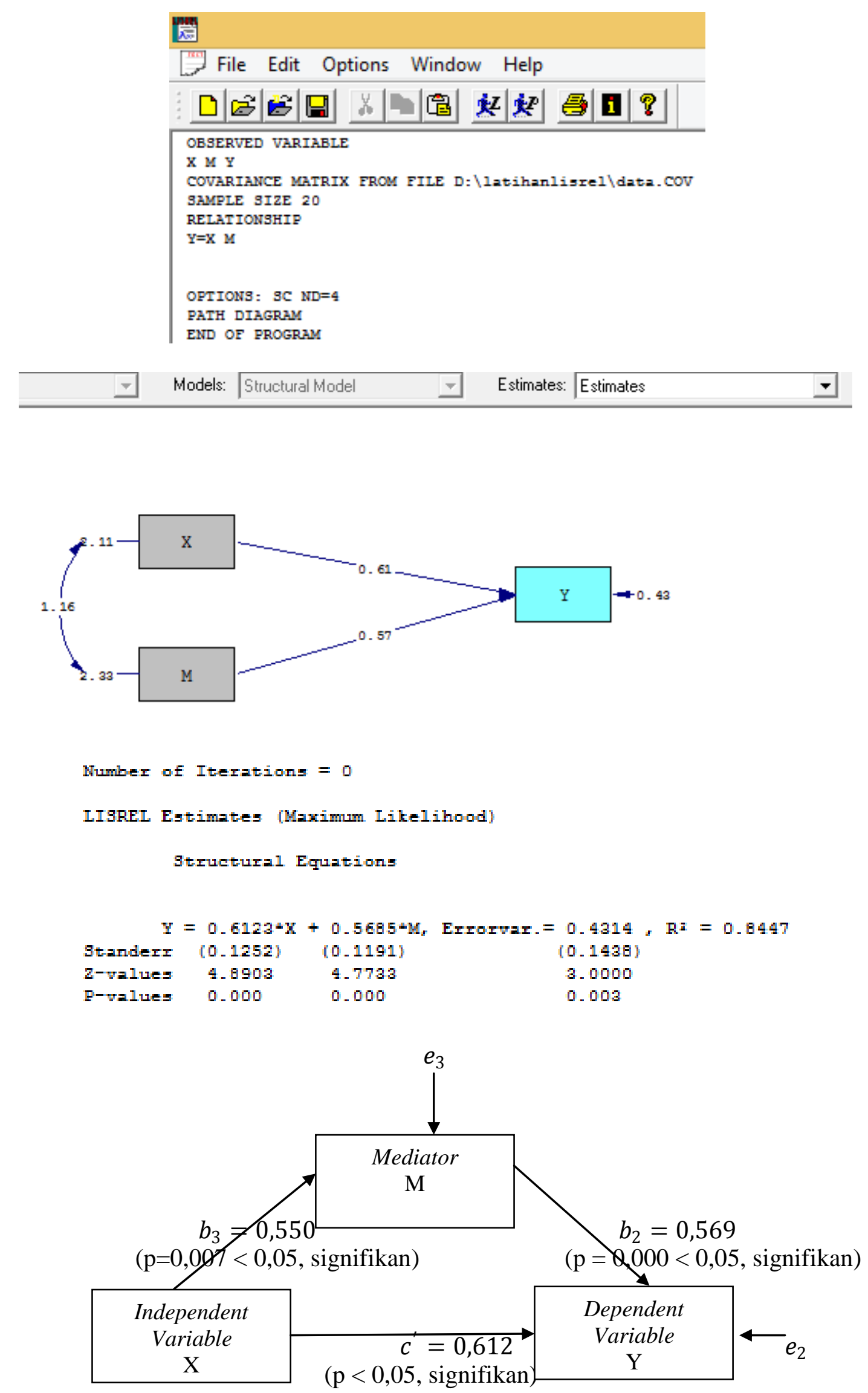


\section{Dengan Amos}

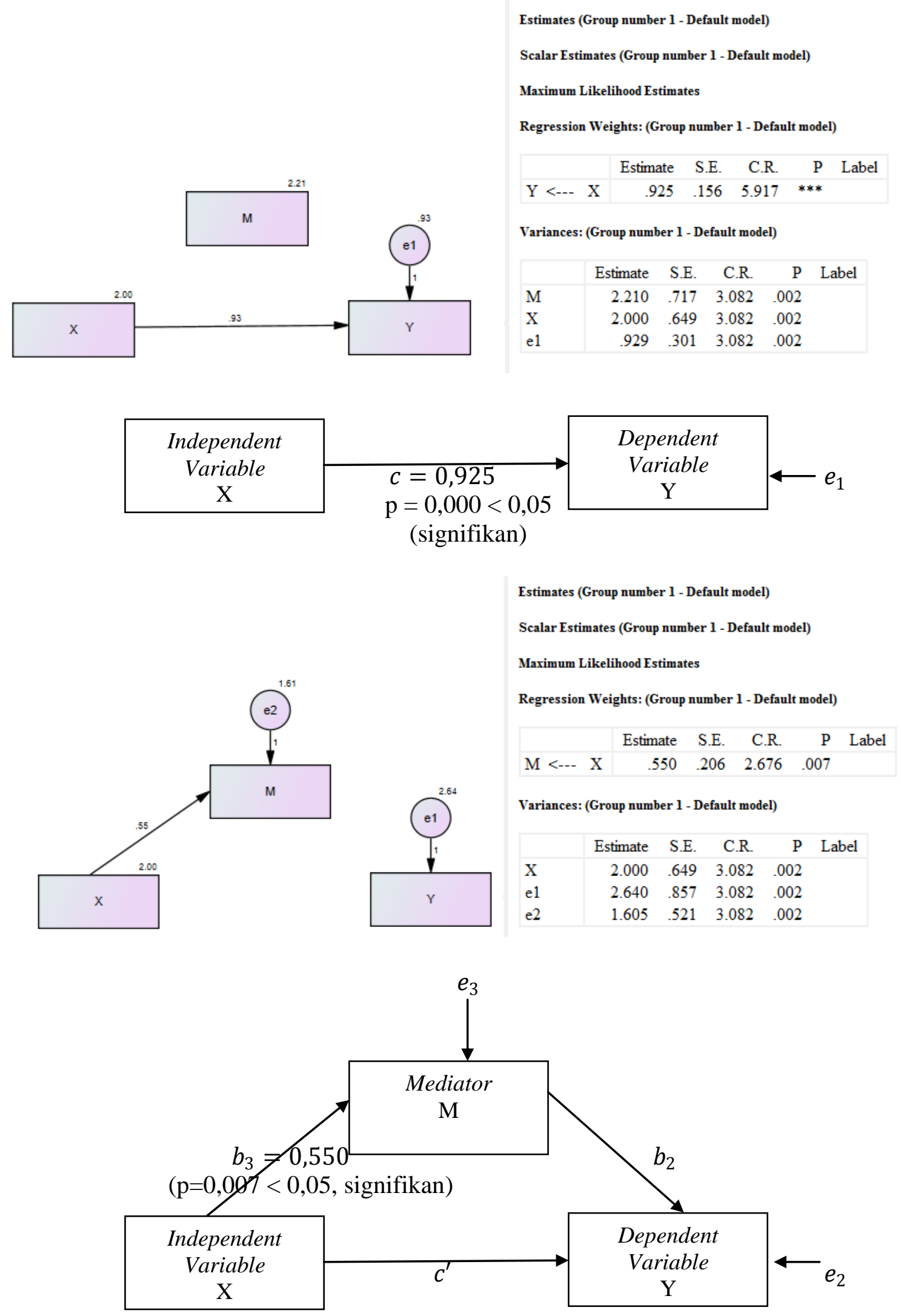




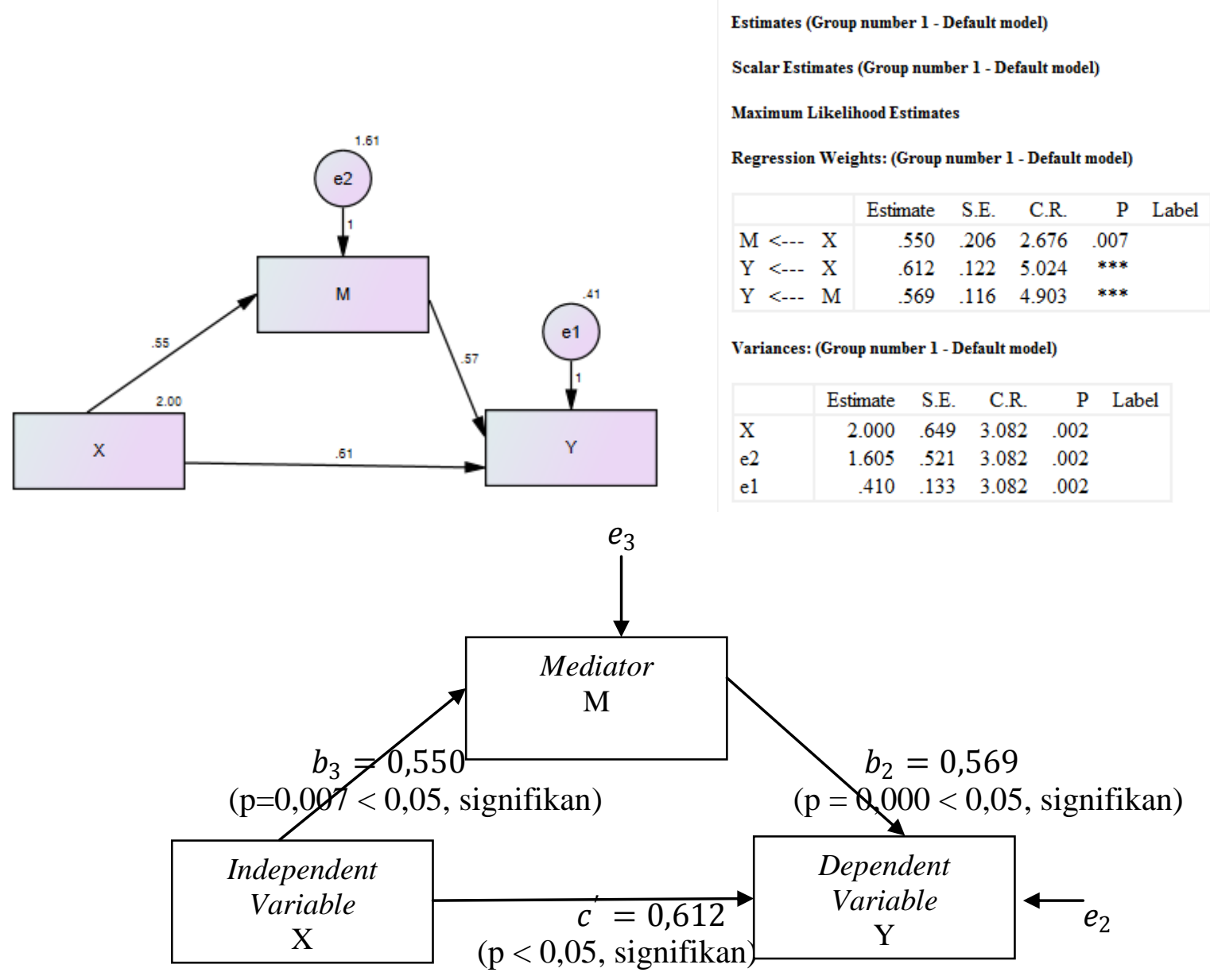

Perhatikan bahwa:

$\Rightarrow$ Pengaruh variabel $X$ terhadap variabel Y signifikan $(\mathrm{p}=0,000<0,05)$.

$\Rightarrow$ Pengaruh variabel $X$ terhadap variabel $M$ signifikan $(\mathrm{p}=0,007<0,05)$.

$\Rightarrow$ Pengaruh variabel $\mathrm{M}$ terhadap variabel $\mathrm{Y}$ signfikan, dengan mengontrol variabel $\mathrm{X}(\mathrm{p}$ $=0,000<0,05)$

Diketahui $c^{\prime}$ signifikan $(\mathrm{p}=0,000<0,05)$, dan $c^{\prime}=0,612<c=0,925$, maka variabel M signifikan dalam memediasi parsial hubungan variabel $\mathrm{X}$ terhadap variabel $\mathrm{Y}$.

\section{Dengan SmartPLS}

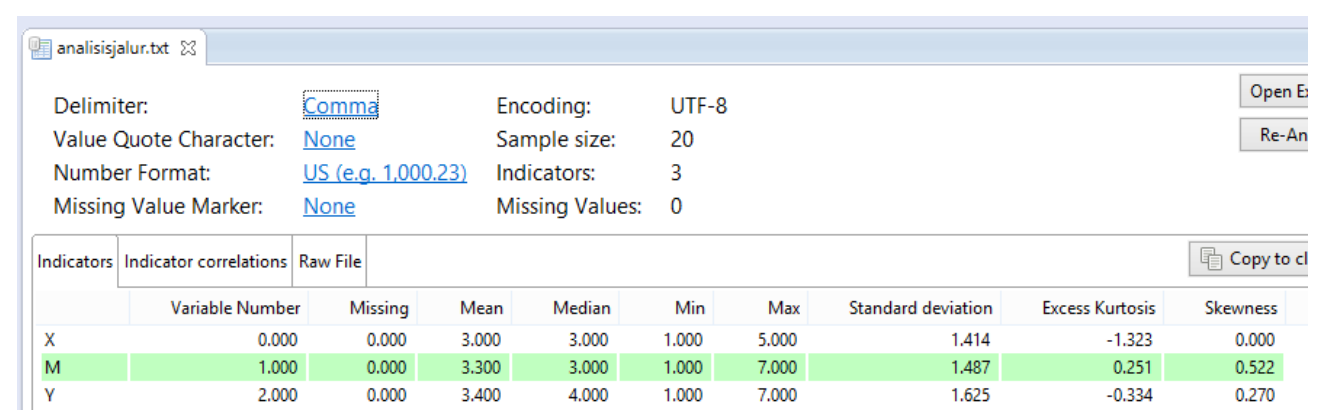




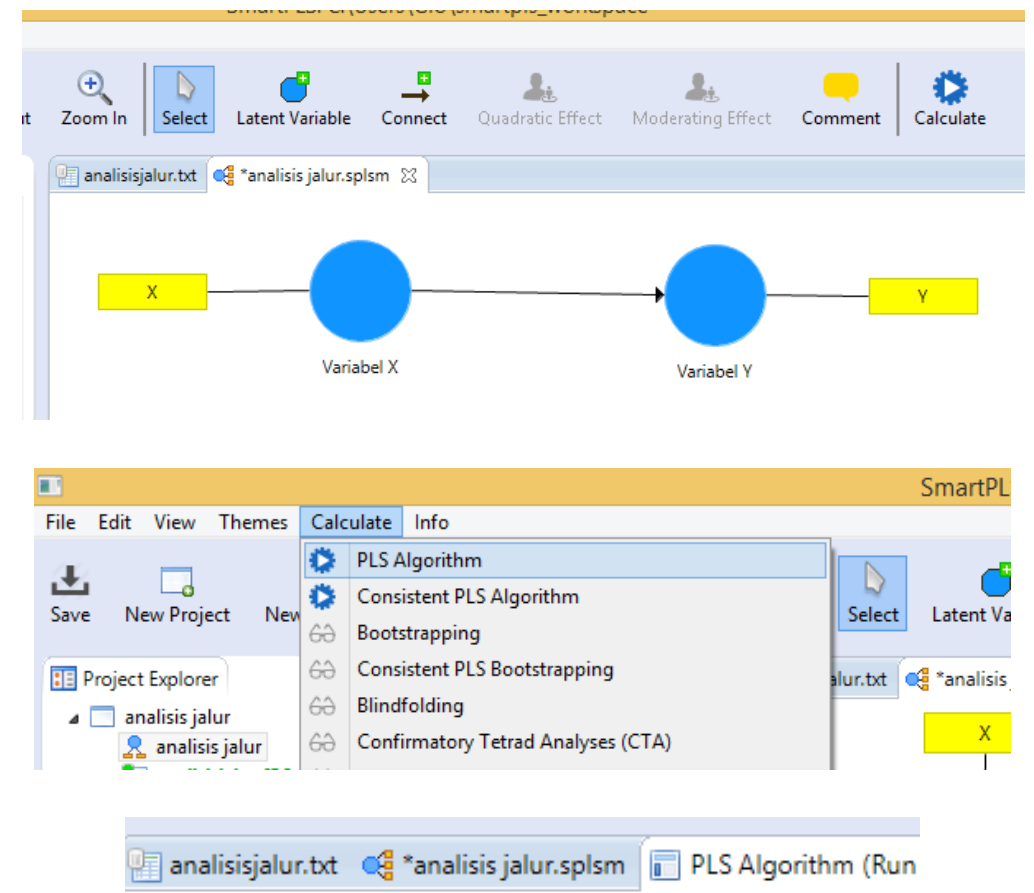

\section{Path Coefficients}

\begin{tabular}{|c|c|c|}
\hline \multirow[t]{2}{*}{ Matrix } & 接亲 Path Coefficients & \\
\hline & Variabel X & Variabel Y \\
\hline \multicolumn{2}{|l|}{ Variabel X } & 0.805 \\
\hline \multicolumn{2}{|l|}{ Variabel Y } & \\
\hline
\end{tabular}

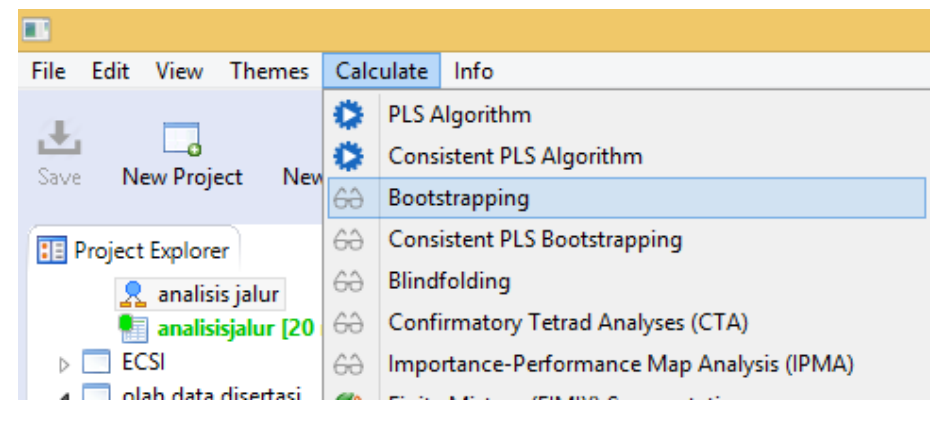

\section{Path Coefficients}

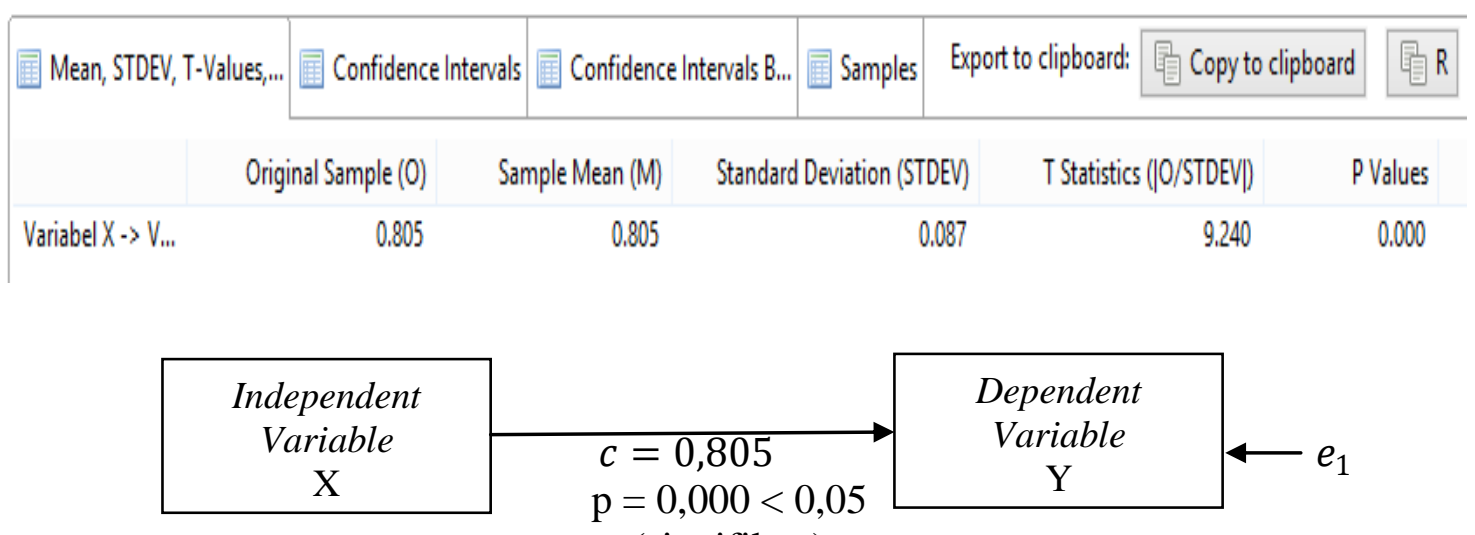

(signifikan) 


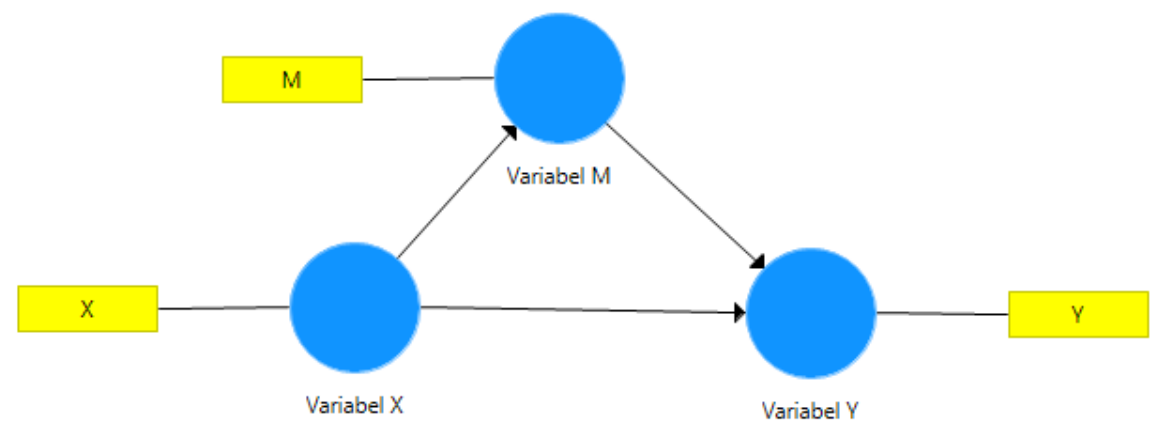

Path Coefficients

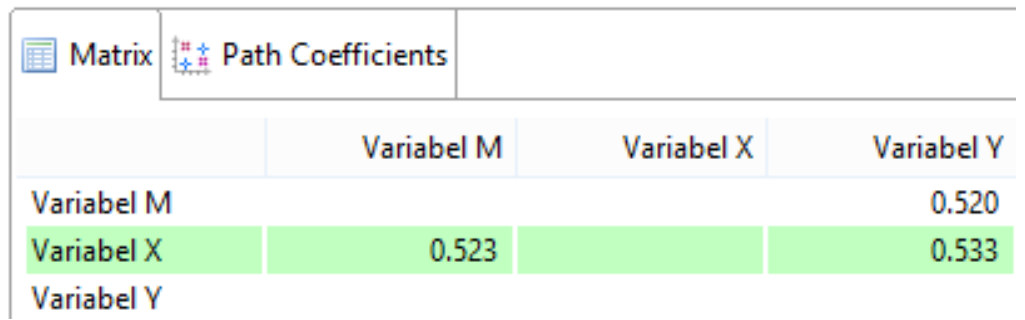

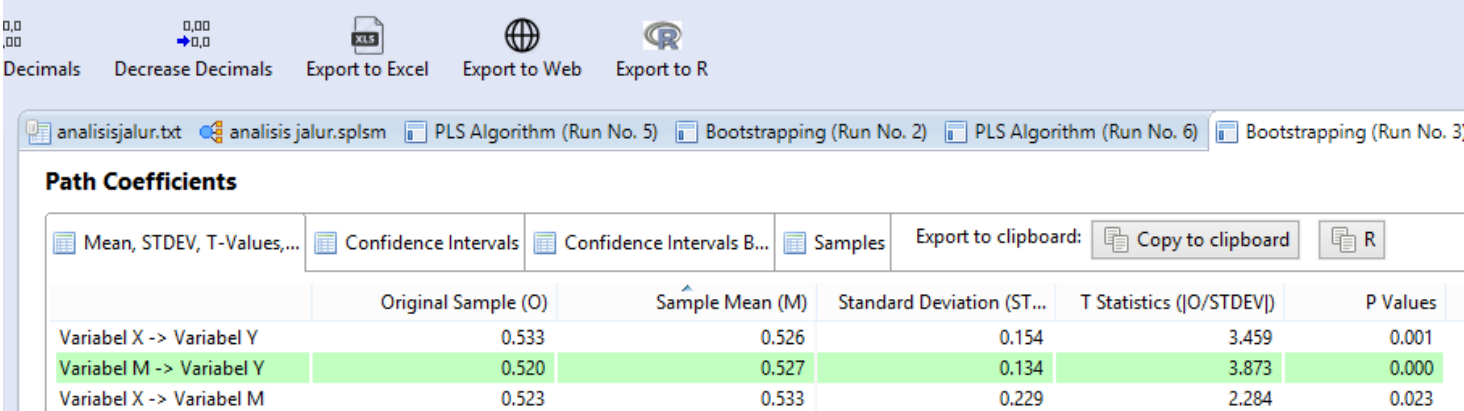

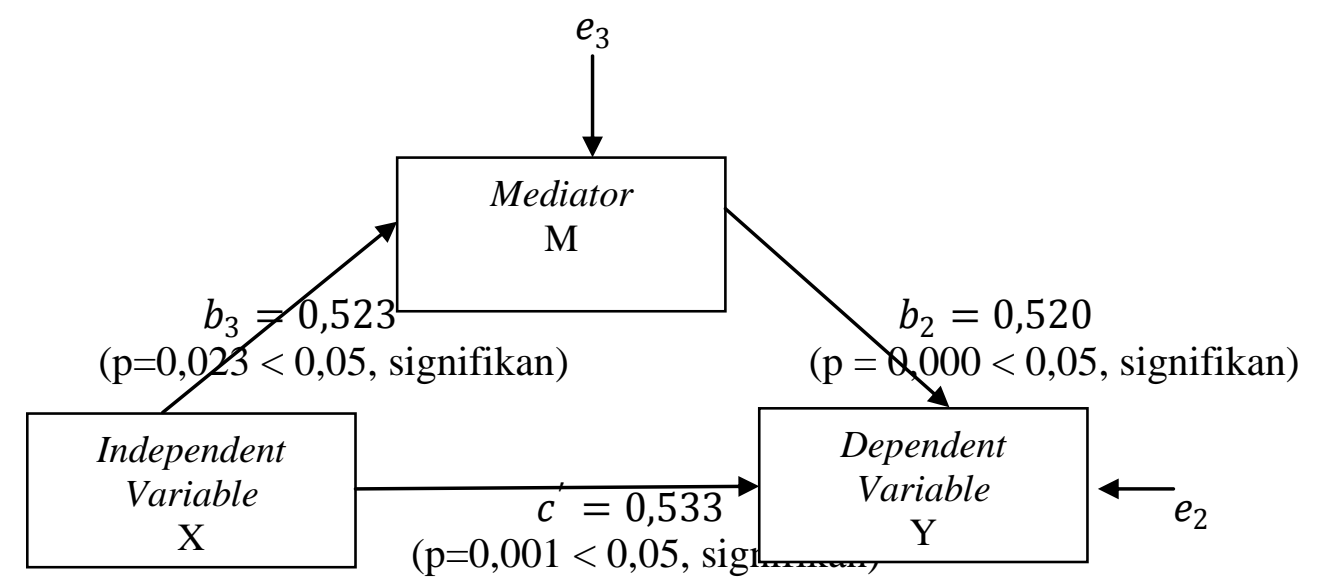

Perhatikan bahwa:

$\Rightarrow$ Pengaruh variabel $X$ terhadap variabel Y signifikan $(\mathrm{p}=0,000<0,05)$.

$\Rightarrow$ Pengaruh variabel $X$ terhadap variabel $M$ signifikan $(p=0,023<0,05)$. 
$\Rightarrow$ Pengaruh variabel $\mathrm{M}$ terhadap variabel $\mathrm{Y}$ signfikan, dengan mengontrol variabel $\mathrm{X}(\mathrm{p}$ $=0,000<0,05)$

Diketahui $c^{\prime}$ signifikan $(\mathrm{p}=0,001<0,05)$, dan $c^{\prime}=0,533<c=0,805$, maka variabel M signifikan dalam memediasi parsial hubungan variabel $\mathrm{X}$ terhadap variabel $\mathrm{Y}$.

\begin{tabular}{|c|c|c|c|c|c|c|c|c|}
\hline \multirow{2}{*}{ Software } & \multicolumn{4}{|c|}{ Koefisien Jalur } & \multicolumn{4}{c|}{ Standard Error Koefisien Jalur } \\
\cline { 2 - 9 } & $c$ & $c^{\prime}$ & $b_{2}$ & $b_{3}$ & $s_{c}$ & $s_{c^{\prime}}$ & $s_{b 2}$ & $s_{b 3}$ \\
\hline SPSS & 0.925 & 0.612 & 0.569 & 0.55 & 0.161 & 0.129 & 0.123 & 0.211 \\
\hline Minitab & 0.925 & 0.6123 & 0.5685 & 0.55 & 0.1606 & 0.1289 & 0.1226 & 0.2111 \\
\hline R & 0.925 & 0.6123 & 0.5685 & 0.55 & 0.1606 & 0.1289 & 0.1226 & 0.2111 \\
\hline LISREL & 0.925 & 0.6123 & 0.5685 & 0.55 & 0.1563 & 0.1252 & 0.1191 & 0.2055 \\
\hline AMOS & 0.925 & 0.612 & 0.569 & 0.55 & 0.156 & 0.122 & 0.116 & 0.206 \\
\hline SmartPLS & 0.805 & 0.533 & 0.522 & 0.523 & 0.087 & 0.154 & 0.134 & 0.229 \\
\hline
\end{tabular}

Berdasarkan Tabel di atas terlihat bahwa nilai-nilai dari koefisien jalur berdasarkan SPSS, Minitab, R, LISREL, AMOS, dan SmartPLS tidak berbeda jauh.

$\Rightarrow$ Penghitungan nilai-nilai dari koefisien jalur dalam SPSS, Minitab, R menggunakan metode estimasi parameter ordinary least squares (OLS).

$\Rightarrow$ Penghitungan nilai-nilai dari koefisien jalur dalam LISREL dan Amos menggunakan metode estimasi parameter Maximum likelihood (ML).

$\Rightarrow$ Penghitungan nilai-nilai dari koefisien jalur dalam SmartPLS menggunakan PLS Algorithm.

Ují Sígnífikansí Pengaruh Mediasi untuk Model Mediasí dengan Satu Variabel Mediator (Significance Tests of Indirect Iffect) dengan Pendekatan Uji Sobel dan Bootstrapping dengan Macro PROCESS oleh Andrew F. Hayes (dengan SPSS)

\section{Pendekatan Sobel}

Diketahui $b_{3}=0,550, s_{b_{3}}=0,211, b_{2}=0,569$, dan $s_{b_{2}}=0,123$, maka

$$
\begin{gathered}
s_{b_{3} b_{2}}=\sqrt{\left(b_{3}^{2}\right)\left(s_{b_{2}}^{2}\right)+\left(b_{2}^{2}\right)\left(s_{b_{3}}^{2}\right)+\left(s_{b_{2}}^{2}\right)\left(s_{b_{3}}^{2}\right)} . \\
s_{b_{3} b_{2}}=\sqrt{(0,550)^{2}(0,123)^{2}+(0,569)^{2}(0,211)^{2}+(0,123)^{2}(0,211)^{2}} . \\
s_{b_{3} b_{2}}=0,140229 .
\end{gathered}
$$


Sehingga

$$
z_{\text {Sobel }}=\frac{b_{3} \times b_{2}}{s_{b_{3} b_{2}}}=\frac{0,31295}{0,140229}=2,231703 .
$$

Berikut penggunaan kalkulator hitung interaktif untuk uji signifikansi mediasi dengan uji Sobel.

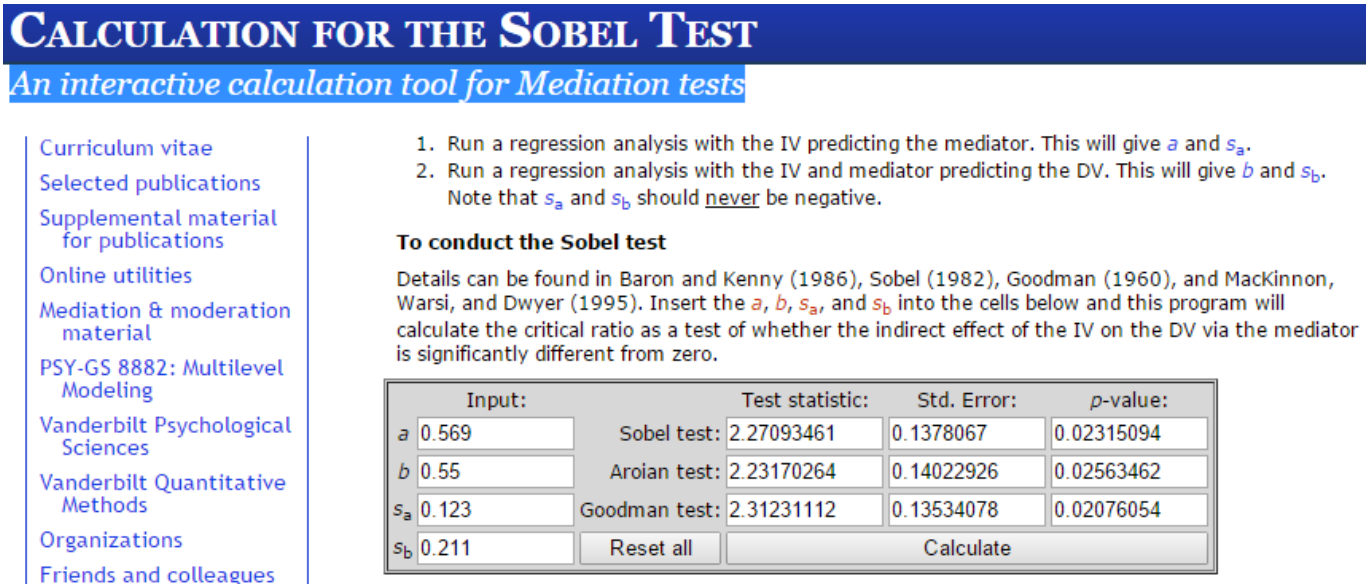

Berdasarkan gambar di atas diketahui nilai statistik dari uji Sobel (versi Aroian) adalah $2,2317>\left|z_{\text {kritis }}=1,96\right|$, serta $p$-value $=0,0256<0,05$, maka variabel M signifikan dalam memediasi hubungan variabel $\mathrm{X}$ terhadap variabel Y.

\section{Pendekatan Bootstrapping}

Pengujian signifikansi untuk pengaruh mediasi dengan pendekatan bootstrapping menggunakan macro yang dibuat oleh Andrew F. Hayes. Macro yang dibuat oleh Andrew F. Hayes dapat ditemukan di http://www.afhayes.com/.

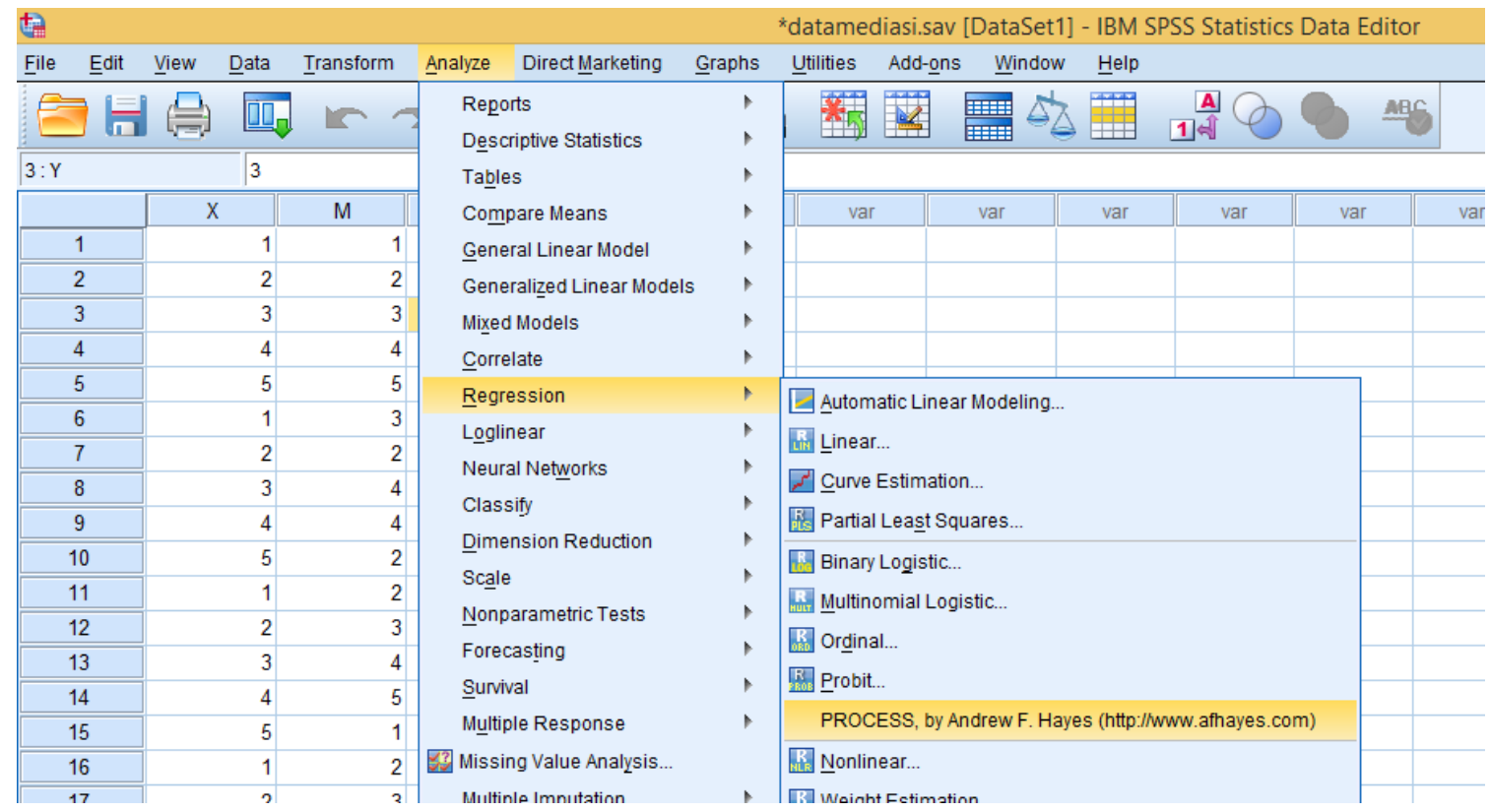



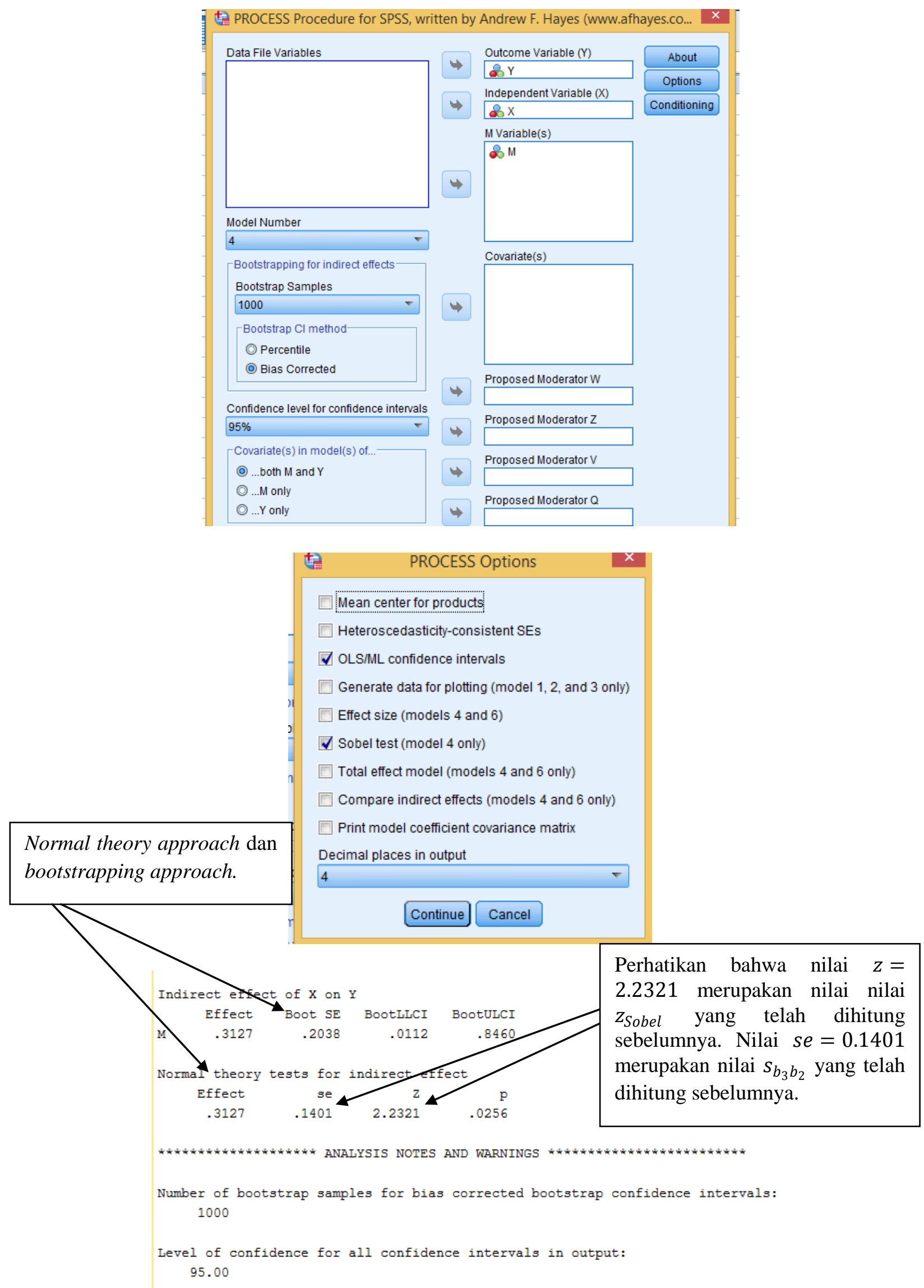

Berdasarkan hasil bootstrapping, perhatikan nilai BootLLCI dan BootULCI. Diketahui nilai nilai BootLLCI adalah 0,0112 dan nilai BootULCI adalah 0,8460. Karena di antara nilai BootLLCI dan BootULCI tidak terkandung angka 0, maka dapat disimpulkan bahwa pengaruh mediasi signifikan pada tingkat signifikansi $5 \%$. 


\section{Referensi}

1. Baron, R. M dan Kenny, D. A., 1986. The Moderator-Mediator Variable Distinction in Social Psychological Research: Conceptual, Strategic, and Statistical Considerations. Journal of Personality and Social Psychology. Vol. 51, No. 6, 11731182. American Psychological Association, Inc.

2. Hair, J.F Jr., R.E. Anderson, B.J. Babin, dan W.C. Black. 2010. Multivariate Data Analysis, $7^{\text {th }}$ Edition. Pearson Prentice Hall.

3. Hair, J.F Jr., G.T.M. Hult, C.M. Ringle, dan M. Sarstedt. 2014. A Primer on Partial Least Squares Structural Equation Modeling (PLS-SEM). Sage.

4. MacKinnon, D.P. 2008. Introduction to Statistical Mediation Analysis. Lawrence Erlbaum Associates.

5. Meyers, L.S., G. Gamst, dan A.J. Guarino. 2005. Applied Multivariate Research, Design and Interpretation. Sage.

6. Mindrila, D. 2010, Maximum Likelihood (ML) and Diagonally Weighted Least Squares (DWLS) Estimation Procedures: A Comparison of Estimation Bias with Ordinal and Multivariate Non-Normal Data, International Journal of Digital Society (IJDS), Volume 1, Issue 1.

7. Preacher, K. J dan Hayes, A. F., 2004. SPSS and SAS Procedures for Estimating Indirect Effects in Simple Mediation Models. Behavior Research Methods, Instruments, \& Computers, 36 (4), 717-731. Psychonomic Society, Inc.

8. Preacher, K. J dan Leonardelli, G. J., 2006. Calculation for the Sobel Test: An Interactive Calculation Tool for Mediation Tests. www.psych.ku.edu/ preacher/sobel/sobel.htm.

9. Schumacker, R.E. dan R.G. Lomax. 2010. A Beginner's Guide to Structural Equation Modeling, $3^{\text {rd }}$ Edition. Rouletdge.

10. Sholihin, M. dan D. Ratmono. 2013. Analisis SEM-PLS dengan WarpPLS 3.0 untuk Hubungan Nonlinear dalam Penelitian Sosial dan Bisnis. Penerbit ANDI. 